\title{
MUROS INTRAMUROS \\ El ladrillo en las fábircas del centro histórico de Valencia. Análisis cronotipológico y propuesta de conservación
}

VALENTINA CRISTINI 

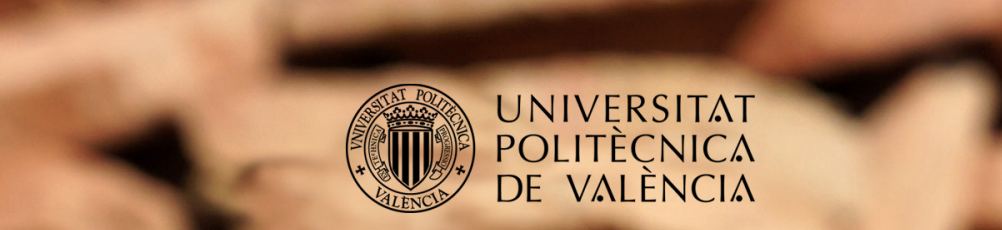

$\frac{n}{2}$

Tesis Doctoral

El ladrillo en las fábricas del centro histórico de Valencia. Análisis cronotipológico y propuesta de conservación

Autora: Valentina Cristini

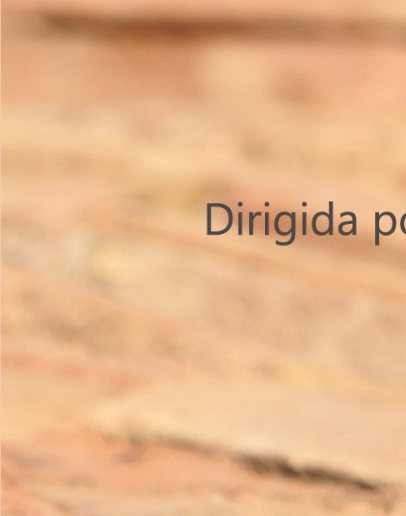

Dirigida por: Dr. F. Vegas López-Manzanares, Dra. C. Mileto
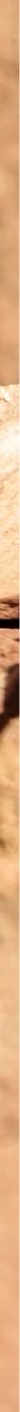

a
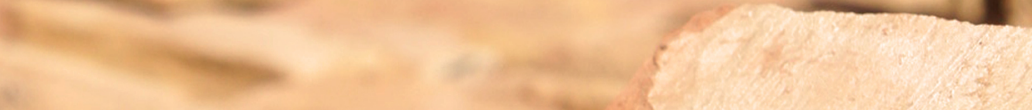
Colección Tesis Doctorales

(c) Valentina Cristini

(C) 2014, de la presente edición: Editorial Universitat Politècnica de València

Telf.: 963877012 / www.lalibreria.upv.es

ISBN: 978-84-9048-217-9 (versión CD)

Queda prohibida la reproducción, distribución, comercialización, transformación, y en general, cualquier otra forma de explotación, por cualquier procedimiento, de todo o parte de los contenidos de esta obra sin autorización expresa y por escrito de sus autores. 


\section{TOMO I/II}

\section{MUROSINTRAMUROS}

El ladrillo en las fábricas del centro histórico de Valencia. Análisis cronotipológico y propuesta de conservación 


\section{TESIS DOCTORAL}

Autora: Valentina Cristini

Directores: Fernando Vegas López-Manzanares, Camilla Mileto

Programa de doctorado

"Patrimonio Arquitectónico: historia, composición, estudios gráficos"

Depto. Composición Arquitectónica

Escuela Superior de Arquitectura, Universitat Politècnica de Vàlencia

Valencia, Febrero 2012 
A mis puntos cardinales Lucia, Maurizio, Elsa, José 

...utilizaba el ladrillo, algo eterno, que sólo muy lentamente vuelve a la tierra de la cual ha nacido y cuyo lento desmoronamiento e imperceptible desgaste se cumplen de modo tal que el edificio sigue siendo sólido aun cuando haya dejado de ser visiblemente una fortaleza, un circo o una tumba...

(M. Yourcenar, Memorias de Adriano) 



\section{mUROSINTRAMUROS}

\section{Resumen}

En el presente estudio se indican los resultados y la trayectoria de investigación de la autora referente al estudio de las técnicas constructivas propias de las fábricas de ladrillo en la zona de intramuros de la ciudad de Valencia (España), concretamente en los barrios de Velluters, la Seu-Xerea, el Carmen, el Mercat y San Francesc.

El estudio se fundamenta en el trazado de un perfil socio, económico, cultural y técnico vinculado a la producción preindustrial del ladrillo y a su puesta en obra en Valencia. Se establecen los rasgos principales que vinculan la manufactura y el empleo de ladrillos preindustriales referidos a un entorno cronológico y geográfico determinado, desde la fundación de la ciudad hasta la llegada de producciones cerámicas industriales.

En este marco, el registro pormenorizado de fábricas históricas de ladrillo refleja una serie de datos métricos y técnicos específicos. Por ello la investigación se ha concentrado en el estudio de 84 edificios históricos, tanto residenciales como monumentales. De esta manera, se han podido seleccionar 95 fábricas de ladrillo (cara a vista, agramilado, fingido, enlucido, tapia valenciana, aplantillado o vidriado). Todo ello ha generado una recopilación exhaustiva de fichas, que reflejan los aspectos técnicos, diagnósticos y analíticos de los ladrillos, con un estudio paralelo de fuentes arqueológicas, ordenadas en 19 registros de ladrillos romanos y medievales.

A través de los resultados obtenidos con el estudio pormenorizado de fábricas, la recopilación de datos arqueológicos y el análisis de laboratorio de algunas muestras de ladrillo y mortero, se propone extraer una serie de datos estadísticos y reflexiones. A lo largo del estudio se describen sincronías, diacronías, pervivencia de técnicas vigentes en las fábricas que conducen a una propuesta cronotipológica para las fábricas urbanas y sus detalles (zócalos, vanos, dinteles, aleros entre los principales). Con todos estos datos se ha llegado a la definición de una curva mensiocronológica para la zona intramuros de la ciudad de Valencia, recogiendo variaciones dimensionales y productivas de los ladrillos preindustriales lo largo de los siglos (principalmente XV-XIX).

Para finalizar, se plantea una posible línea guía de intervención sobre fábricas históricas de ladrillo, recomendando una serie de pasos operativos y metodológicos que permitan garantizar su conservación. 


\section{MUROSINTRAMUIOS}

\section{Resum}

En aquest estudi es presenten els resultats i la trajectòria d'investigació de l'autora pel que fa a l'estudi de les tècniques constructives pròpies de les fàbriques de rajola a la zona d'intramurs de la ciutat de València (Espanya), i concretament als barris de Velluters, la Seu-la Xerea, el Carme, el Mercat i Sant Francesc.

L'estudi es fonamenta en el traçat d'un perfil socioeconòmic, cultural i tècnic de la producció preindustrial de la rajola i la utilització d'aquesta a València. S'hi estableixen els trets principals que vinculen la manufactura i l'ús de rajoles preindustrials a un entorn cronològic i geogràfic determinat, des de la fundació de la ciutat fins que hi arribaren les primeres produccions ceràmiques industrials.

En aquest marc, el registre detallat de fàbriques històriques de rajola reflecteix una sèrie de dades mètriques i tècniques específiques. Per això la investigació s'ha centrat en l'estudi de 84 edificis històrics, tant residencials com monumentals. D'aquesta manera, s'han pogut seleccionar 95 fàbriques de rajola (de cara vista, retallada, fingida, enlluïda, de tàpia valenciana, aplantillada o vidriada). Tot això ha generat una recopilació exhaustiva de fitxes, que reflecteixen els aspectes tècnics, diagnòstics i analítics de les rajoles, amb un estudi paral·lel de fonts arqueològiques, ordenades en 19 registres relatius a rajoles romanes i medievals.

A través dels resultats obtinguts per l'estudi detallat de fàbriques, la recopilació de dades arqueològiques i l'anàlisi de laboratori d'algunes mostres de rajola i morter, es pretén extraure una sèrie de dades estadístiques i reflexions. Al llarg de l'estudi es descriuen sincronies, diacronies i pervivència de tècniques vigents a les fàbriques, que condueixen a una proposta cronotipològica per a les fàbriques urbanes i els detalls (entre els principals: sòcols, obertures, llindes i ràfecs) d'aquestes. Amb totes aquestes dades s'ha arribat a la definició d'una corba mensiocronològica per a la zona intramurs de la ciutat de València, que recull variacions dimensionals i productives de les rajoles preindustrials al Ilarg dels segles (principalment xv-xix).

Per finalitzar, es planteja una possible línia guia conduent a la intervenció sobre fàbriques històriques de rajola, i es recomana una sèrie de passos operatius i metodològics que permeten garantir la conservació d'aquestes fàbriques històriques urbanes. 


\section{mUROSINTRAMUROS}

\section{Abstract}

This text will present the results and the course of the research taken by the author in the study of the brick masonries in Valencia's historical city centre (Spain), in particular in the neighbourhoods of Velluters, Seu-Xerea, Carmen, Mercat and San Francesc.

The research is based on the tracing of a socio-economic and cultural technique joined to preindustrial brick production and its implementation in the city of Valencia. It establishes the main features that join the manufacture and employment of preindustrial bricks, to a specific chronological and geographical environment, from the foundation of the city to the arrival of industrial ceramic productions.

Within this framework, a detailed record of historical brick structures will reflect specific metric and technical information. To do this the research has focused on the study of 84 historical buildings, both residential and monumental, and 95 brick masonries have been selected (exposed walls, repointed, painted, or rendered surfaces, rammed earth walls, gauged or glazed masonries). All this has generated a comprehensive collection of information which reflects the technical, diagnostic and analytical aspects of the bricks, accompanied by a study of archaeological sources, arranged in 19 records relating to Roman and Medieval bricks.

Thanks to the results obtained by the study of the masonries, along with the collation of archaeological information and the analysis of brick and mortar samples, it is possible to extract statistical information and reflections. Through the analysis of technical features it's possible to see the synchrony of the masonries through the centuries, or the lack of chronological coordination between them. In particular, elements like basements, openings, lintels, eaves and brickwork contribute to the understanding of the evolution of brick masonries in Valencia's historical city centre. Consequently it's possible to design an archaeometric curve, specifically for the city, defining dimensional and productive variations in preindustrial bricks throughout the centuries.

Finally intervention guidelines, specifically designed for these brick masonries, are proposed, recommending a set of operative and methodological steps that ensure the conservation of these historical urban structures. 


\section{MUROSINTRAMUROS}

\section{Riassunto}

Questo scritto presenta i risultati della ricerca dell'autrice sviluppata sulle murature in laterizi del centro di Valencia (Spagna), in particolare nei quartieri storici di Velluters, Seu-Xerea, Carmen, Mercate San Francesc.

La ricerca si basa sul tracciato di un profilo socio-economico, culturale e tecnico, vincolato alla produzione pre industriale dei mattoni e al loro utilizzo nelle murature della cittá "intramuros". Per questo si definiscono i profili delle manifatture e delle maestranze in un contesto geografico e cronologico definito, dalla fondazione della cittá sino allo sviluppo di produzioni ceramiche industriali.

In questa linea lo studio delle murature contribuisce a definire un quadro di riflessioni, apportando dati metrici e informazioni tecniche specifiche, vincolati a 84 edifici, sia residenziali che monumentali. Per questo negli edifici sono state selezionate 95 murature storiche (con mattoni faccia vista, rigiuntati, con trame dipinte, associati a murature in terra-tapia valenciana-sagomati, smaltati) ordinate in una serie di schede di analisi. Grazie a questa base di dati, pertanto, si possono definire aspetti tecnici, diagnostici e analitici delle murature, completati inoltre da una indagine relativa a 19 tipi di laterizi-romani e medievali-documentati in scavi acheologici del centro storico.

Incrociando I'analisi diretta delle murature, con dati archeologici e analitici, procedenti da risultati di laboratorio effettuati su campioni di laterizi e malte, è possibile estrarre una serie di conclusioni statistiche e riflessioni sulle murature valenciane in mattoni. Nel corso dello studio si definiscono sincronie, diacronie, permanenze delle differenti tecniche costruttive, aspetti che contribuiscono a delineare una proposta cronotipologica per le murature e per i principali dettagli costruttivi ad esse associate (come per esempio basamenti, aperture e architravi, aggetti di gronda...). Grazie a questi contributi, inoltre, si traccia una curva mensiocronologica, per il centro storico della cittá, considerando cosí le possibili variazioni dimensionali e produttive dei laterizi preindustriali (principalmente per i sec. XV- XIX).

Per completare la ricerca, si disegna una possibile linea-guida operativa, specifica per le murature storiche analizzate, prescrivendo cosí una serie di passi metodologici, cruciali per la conservazione degli esempi studiati. 


\section{ÍNDICE GENERAL}

\section{TOMO I}

Resumen/Resum/Abstract/Riassunto

p.1

Índice general

1. INTRODUCCIÓN

1.1. Razón de ser de la investigación

p.13

1.1.1. "Especular CON el ladrillo" vs.

"Especular SOBRE el ladrillo"

1.1.2. Por qué nace "muros intramuros"

1.2. Temas de la investigación

p.21

1.2.1. Contenido material

p.22

1.2.2. Límites geográficos y temporales

p.26

1.3. Propósitos de la investigación

p.31

1.3.1. Interés

p.31

1.3.2. Objetivos

p.32

2. MÉTODO

p.35

2.1. Proceso de formación de un método

p.37

2.1.1. Estancias de investigación en el marco del

p.38 estudio

2.1.2. Trayectoria de investigación y primeros p.40 resultados

2.2. Definición de un planeamiento metodológico

p.45

2.2.1. La mensiocronología

p. 47

2.2.2. El estudio de la cultura material

p.53

2.2.3. La cronotipología

p.56

2.2.4. Diagnóstico y estudios analíticos

p. 59

2.3. Propuesta metodológica descriptiva y analítica

p.61 
2.3.1. Fuentes directas p.61

2.3.2. Fuentes indirectas p.63

3. LA IDENTIDAD DEL CENTRO HISTÓRICO DE VALENCIA p.67

3.1. Perfil geomorfológico y geológico p.69

3.1.2 La mirada histórica hacia la p.72

edafología de Valencia

$\begin{array}{ll}\text { 3.2 Perfil histórico y cultural } & \text { p.77 }\end{array}$

4. LAS FÁBRICAS EN VALENCIA: HACIA UNA INTERPRETACIÓN p.89

4.1. Una cuestión de roles $\quad$ p.91

4.2. Alfareros y ladrilleros: producción y cocción p.93

4.2.1. El ladrillar/rajolar p.103

4.3. Vendedores y controladores: mercado y comercio p.109

4.3.1. Instituciones p.109

4.3.2. Cuerpo normativo y legal p.114

4.3.3. Rúbrica de la rajola e teula p.118

4.3.4. Els Rajolers $\quad$ p.125

4.4. Tratados y manuales: de lateribus p.131

4.4.1. El siglo XIX, maduración de manuales técnicos p.135 sobre el ladrillo

4.4.2. Prácticas de albañilería en los manuales p.139 de arquitectura

5. "MUROS INTRAMUROS": ESTUDIO DE LAS FÁBRICAS p.147

5.1. Hacia la evolución de las técnicas constructivas en arcilla p.149

5.2. Fábricas con ladrillo p.153

5.2.1. Tapia valenciana p.153

5.2.2. Posibles antecedentes históricos: fábricas p.156 de ladrillo en el mundo bizantino 
5.2.3. Posibles antecedentes históricos: fábricas de tapia en Al-Andalus

5.2.4. Posible propulsor de la difusión de la técnica: La p.161 Fábrica Vella, dita de Murs y Valls

5.3 Fábricas de ladrillo

p.169

5.3.1. Ladrillo visible

p.169

5.3.2. Ladrillo visto

p.175

5.3.3. Ladrillo oculto

p.188

6. FÁBRICAS: HACIA UNA PROPUESTA DE CONSERVACIÓN

6.1 Análisis diagnóstico de las fábricas analizadas

p.199

6.1.2. ¿Qué patologías?

p.202

6.2 Líneas guía para una posible intervención

p.211

6.2.1. Procesos de limpieza general

p.212

6.2.2. Consolidación

p.237

6.2.3. Hidrofugación

p. 240

6.2.4. Complementación de piezas

p.242

6.2.5. Sustitución de piezas

p. 243

6.2.6. Reparación de juntas

p.245

6.2.7. Reparación de fisuras

p. 247

6.2.8. Protección final

p.249

6.3 Núcleo, conectores y costra: intervenir en

p.251 fábricas de tapia valenciana

7. CONCLUSIONES

7.1. Sincronías y diacronías técnico/tipológicas p.263

7.2. Elaboración de una curva mensiocronológica p.269

7.3. Fábricas monumentales y residenciales: interpretación del p.285 registro de fichas

7.4. Futuras investigaciones p.303

8. VERSIÓN ITALIANA REDUCIDA p.307

8.1. Motivazioni alla base della ricerca p.309 
8.1.1. Introduzione p.309

8.1.2. Perchè nasce "muros intramuros" p.312

8.2. Tematiche presenti nella ricerca p.315

8.2.1. Contenuto materiale p.316

8.2.2. Limiti geografici e temporali p.320

8.3. Finalità della ricerca $\quad$ p.323

8.3.1. Interesse p.323

8.3.2. Obiettivi p.324

8.4. Conclusioni: sincronie e diacronie tecnico/tipologiche p.327

8.5. Definizione di una curva mensiocronologica p.333

8.6. Murature monumentali e residenziali: interpretazione p.345 del registro di schede

8.7. Future ricerche p.355

\section{TOMO II}

Índice general

p.1

ANEJO I: REGISTRO PORMENORIZADO DE FÁBRICAS ESTUDIADAS

p.7

I.1. Criterios para la redacción de un registro de fichas

p.9

I.2. Base de datos

p.19

I.2.1. Fábricas históricas: Barrio del Carmen

p.21

I.2.2. Fábricas históricas: Barrio de Mercat

p.153

I.2.3. Fábricas históricas: Barrio de S. Francesc

p. 225

I.2.4. Fábricas históricas: Barrio de Velluters

p.265

I.2.5. Fábricas históricas: Barrio de la Xeu/Serea

p.333

I.3. Ábaco de detalles de fábricas históricas de ladrillo

p.421

ANEJO II: RECOPILACIÓN DE DATOS ARQUEOLÓGICOS

p. 433

II.1. Criterios para la consulta de informes arqueológicos

p.435

II.1.1. Extractos de informes arqueológicos

p. 436 
II.2. Base de datos p.445

II.2.1. Ladrillos procedentes del depósito SIAM p.447

ANEJO III: CARACTERIZACIÓN Y ANALISIS DE LAS FÁBRICAS p.469

III.1. Propiedades químicas, físicas, mecánicas de ladrillos p.471

III.1.1. Características mineralógicas p.472

III.1.2. Propiedades físicas p.474

III.1.3. Propiedades hídricas p.478

III.1.4. Propiedades mecánicas p.482

III.1.5. Propiedades de durabilidad p.484

III.2. Criterios para el estudio de ladrillos y morteros p.485

III.3. Informe analítico: selección de ladrillos y morteros (FT-IR) p.523

III.4. Informe analítico: selección de ladrillos y morteros p.539

$\begin{array}{lr}\text { Glosario } & \text { p.589 }\end{array}$

Bibliografía p.603

Abreviaciones p.625

Índice de imágenes Tomo I/II $\quad$ p.626

Índice de imágenes Tomo II/II p.629

Agradecimiento p.643 

murOSINTRAMUIOS

1. Introducción 



\subsection{Razón de ser de la investigación}

\subsection{1"Especular CON el ladrillo" vs "Especular SOBRE el ladrillo"}

Desde que a finales de 2004 me planteé la realización del trabajo que debería presentar al finalizar la carrera ${ }^{1}$, me cautivó la idea de documentar de alguna forma las técnicas constructivas en el centro de Valencia. Ésa era la ciudad que empecé a conocer durante el año de intercambio académico, tan diferente de los núcleos históricos de la ciudades del Norte de Italia, donde transcurrieron principalmente mis años de estudio. Me llamó la atención esa densa trama urbana tejida a lo largo de los años, que era objeto de derribos, especulaciones, promociones e intervenciones más o menos violentas. El centro histórico enseñaba "sus tripas", en un bullicio de andamios, sustitución de pieles y scraping autorizado.

Simultáneamente era una oportunidad, una sombría ocasión para conocer cómo se había construido la ciudad a lo largo de los siglos.

Cómo se habían aparejado los muros, con qué técnicas, con qué materiales y características. Y cada derribo, se convertía en una ocasión para desvelar una sección constructiva. Cada fachada/fantasma/pantalla, camuflada tras un sistema de apuntalamiento, defendía su razón de ser y sus caracteres constructivos. La sustitución de edificios que, de forma gratuita o

\footnotetext{
${ }^{1}$ CRISTINI V., Valencia, ciudad vella, ladrillos cara a vista, agramilados, fingidos y enlucidos. Analisi delle murature in laterizio: prassi costruttiva ed evoluzione archeometrica, Tutores: Bellini A., Mileto C., Pertot G., Politecnico di Milano, diciembre 2005 (inédito)
} 
justificada, salpicaba el centro histórico urbano, era una circunstancia auténtica para conocer y analizar de forma rotunda y global algunas características histórico-constructivas del centro de Valencia.

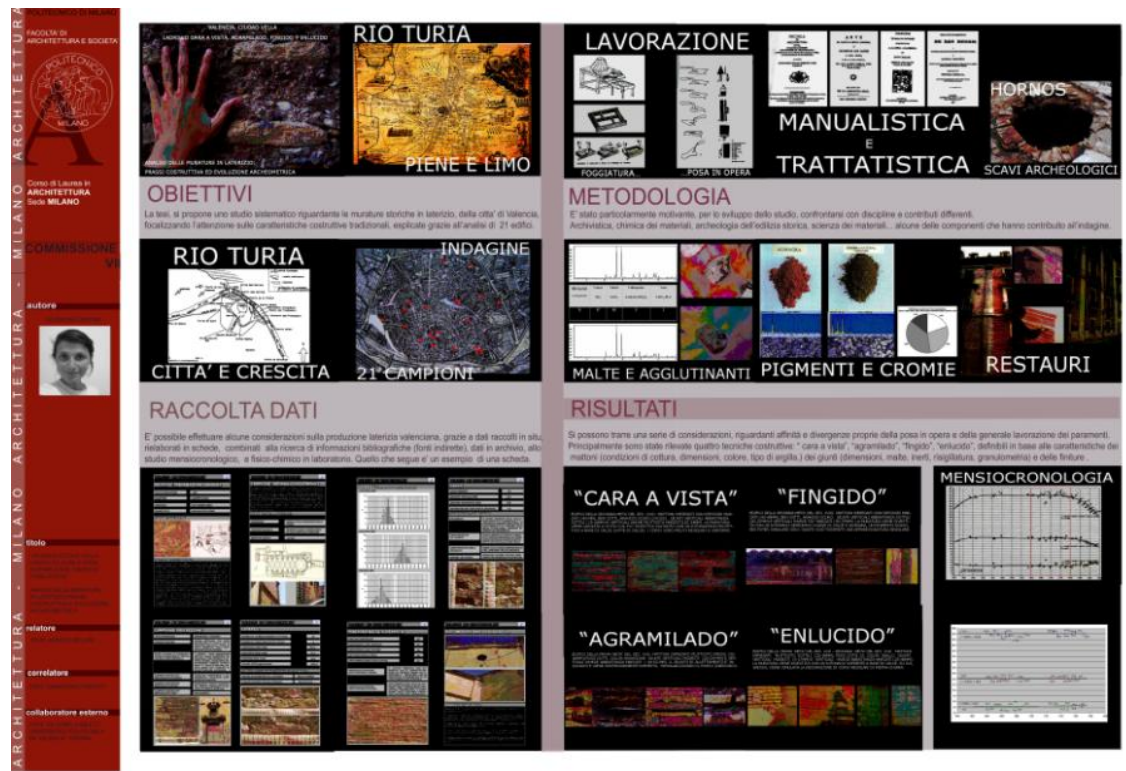

FIG.1 Làmina realizada por la autora en el marco de su proyecto de PFC, exponiendo los resultados iniciales de su estudio sobre fábricas de ladrillo en Valencia, 2005 (CRISTINI)

Había un estudio que me parecía sugestivo e interesante, un tema aparentemente anodino, banal y obvio, que paradójicamente apenas había sido objeto de estudios sistemáticos realizados. Las fábricas de ladrillo poseían un carácter sumamente insípido, al menos en mi primera lectura, pero que cobró profundidad y solidez conforme avancé en su estudio. Así, una vez se concretó y acotó el análisis a la zona intramuros de la ciudad de Valencia'², se fueron desvelando

\footnotetext{
${ }^{2}$ Siguiendo el orden cronológico de desarrollo del Proyecto final de Carrera de la Autora se estudiaron los siguientes edificios: Iglesia del Patriarca (alzado lateral); Iglesia de los Santos Juanes (fachada de la Capilla de la Comunión y muro con nicho en la nave lateral);

Iglesia de Santa Úrsula (fachada principal); Iglesia de la Virgen de los Desamparados (tambor); Catedral (alzados de la Sacristía); Iglesia de San Nicolás (alzado de la capilla lateral); Iglesia del Carmen (fachada Capilla Nuestra Señora del Carmen y muro entre la fachada de la Iglesia y el campanario); Iglesia de San Martín (alzado lateral de la Capilla de la Comunión); Convento del
} 


\section{murOSINTRAMUIOS}

detalles. Aquellas características iniciales evidentes se sustituyeron por aspectos constructivos destacados.

Adentrandome en el estudio, los edificios iban desvelando su razón constructiva nacida de sus contextos culturales. De esta manera fueron apareciendo los lenguajes compositivos y constructivos con los que fueron concebidos y así se iban tejiendo sutiles soluciones técnicas, hasta entonces afortunadamente ajenas a los ojos de los promotores.

El estudio de fábricas de ladrillo trataba uno de los sistemas constructivos que mantenía íntegra su vigencia a lo largo de toda la historia urbana. Y sin duda, el ladrillo, era y es uno de los materiales más antiguos, presente en la ciudad. De allí, el interés de investigar su presencia histórica, visible en el centro de Valencia desde los albores hasta la llegada de la revolución industrial en la ciudad.

Partiendo de esta idea, concreté la elaboración del proyecto final de carrera en un muestreo de edificios valencianos, tanto palacios nobles como iglesias, en los que estuvieran documentadas, fechadas y presentes las fábricas de ladrillo ${ }^{3}$.

Este trabajo poseía una clara finalidad: estudiar las técnicas, su evolución, los materiales utilizados, las características de los mismos y su evolución mensiocronológica ${ }^{4}$.

Pilar (fachada principal); Iglesia de San Esteban (alzado de la Capilla de la Comunión); Iglesia de San Tomás y Felipe Neri (alzado lateral); Palacio Pineda (fachada principal); Iglesia de San Andrés (alzado lateral); Palacio de los Català (fachada lateral); Palacio Cerveró (fachada principal); Palacio de la Aduana (fachada principal); Iglesia de los Genoveses (fachada principal); Iglesia de las Escuelas Pías (fachada principal); Casa Vestuario (fachada principal). Esta selección se basó en la existencia de documentación que arrojaba datos de sus diversas fases constructivas. Al mismo tiempo, la observación directa permitió identificar áreas homogéneas bien definidas, evaluando el empleo de materiales diferentes y posibles intervenciones tardías ${ }^{3}$ CRISTINI V., "Estudio de fabricas de ladrillos en Valencia: análisis mensiocronológico y técnicas de acabados "en Arqueología de la Arquitectura n.5, Universidad del País Vasco CSIC Ed.,2008 ${ }^{4}$ Ibidem 
Pero, una vez acotado el ámbito de las fabricas de ladrillos documentables en la ciutat vella, había un vacío importante que invitaba a investigar, como era el caso, de las fábricas de ladrillo en edificios residenciales, de los cuales apenas se habían realizados estudios técnicos.
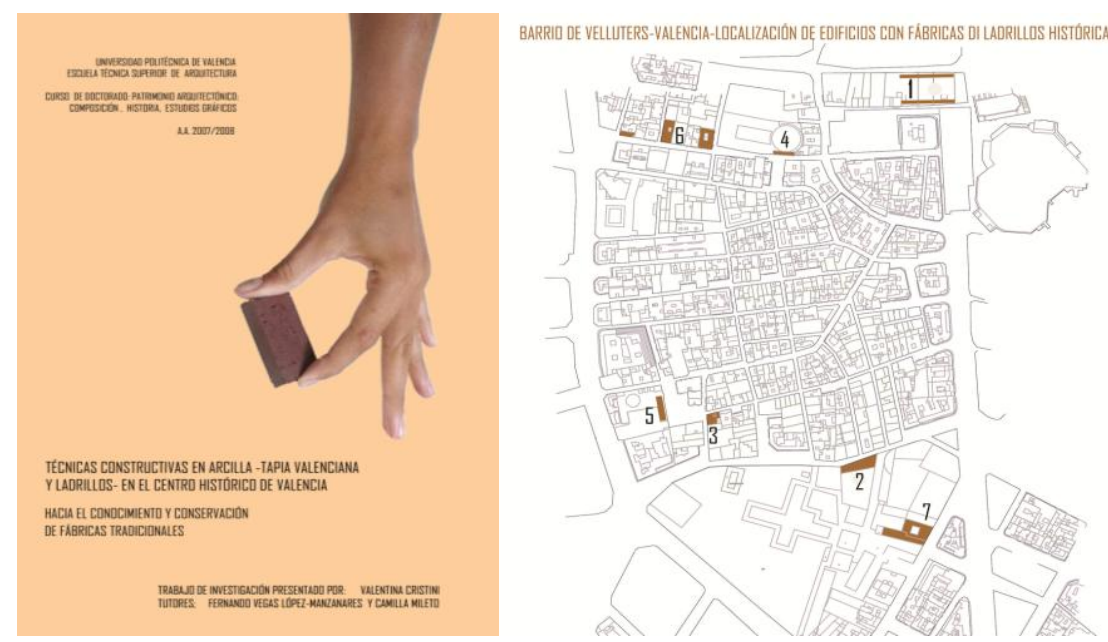

FIG. 2 Detalles del trabajo de investigación/DEA, realizado por la autora, centrado en las fábricas de ladrillo, en el barrio de Velluters, Valencia, 2008 (CRISTINI)

Esta labor, que se comenzó con el trabajo de investigación del DEA ${ }^{5}$ (Diploma de Estudios Avanzados), en 2008, fue el primer paso hacia un estudio más profundo, que se ciñó a un ámbito específico, concretamente el barrio de Velluters.

En este caso, se decidió profundizar más en los aspectos técnicos y analíticos de las fábricas de ladrillo, dirigiendo la atención hacia la diagnosis de su patología y la posterior formulación de unas adecuadas propuestas de intervención.

En el presente marco, la tesis doctoral, trata de completar el estudio, con el análisis de la totalidad el centro histórico de Valencia, mediante la lectura muraría de 95 fábricas de ladrillos de Barrio de S.

\footnotetext{
${ }^{5}$ CRISTINI V., Técnicas constructivas en arcilla: tapia valenciana y ladrillos en el centro histórico de Valencia, hacia el conocimiento y conservación de fábricas tradicionales. Trabajo de investigación, programa de doctorado: Patrimonio Arquitectónico: historia, conservación, estudios gráficos, Universidad Politécnica de Valencia, noviembre 2008, (inédito)
} 
Francesc, Barrio del Carmen, Barrio de la Xeu-Serea, junto al barrio de Velluters, en parte previamente analizado.
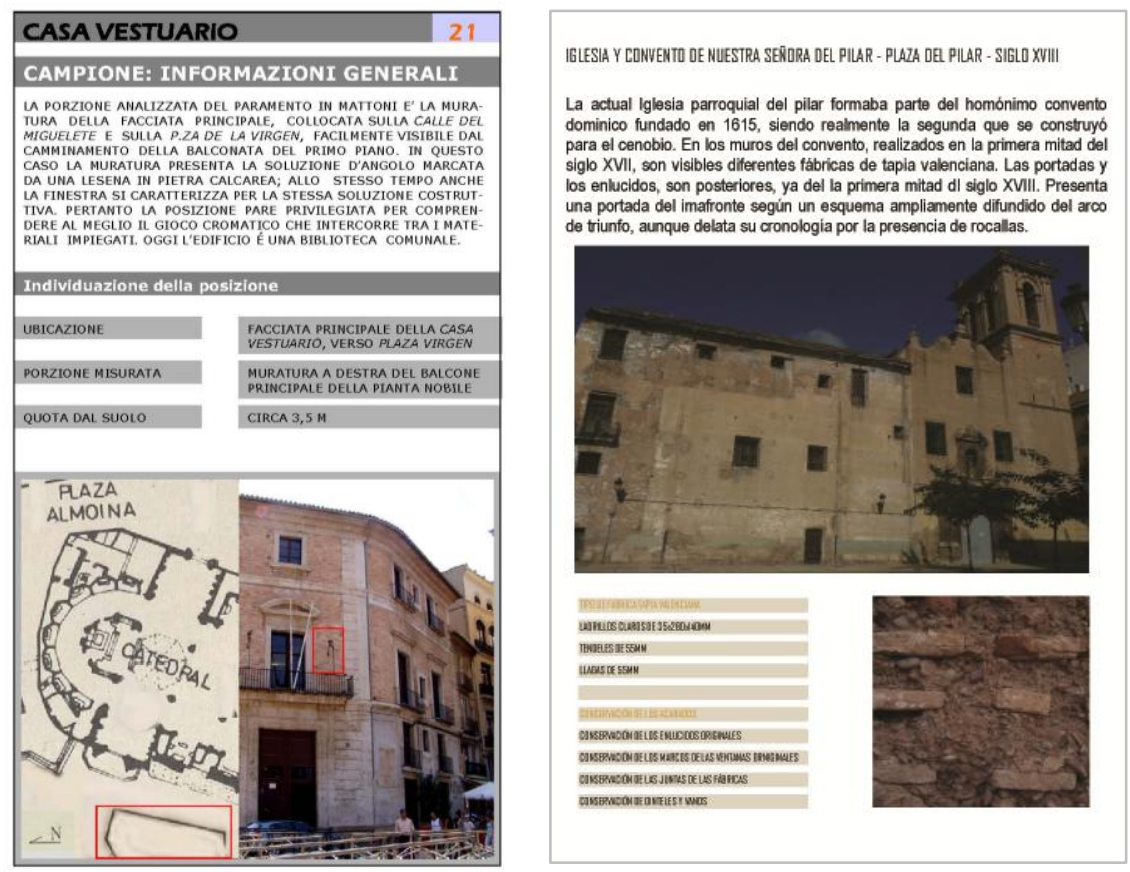

FIG. 3 Ejemplos de fichas de estudio de fábricas de ladrillo histórico, perfeccionadas a lo largo de los trabajos de investigación, 2005-2008 (CRISTINI)

Con este estudio, se ha propuesto también mejorar el conocimiento de la producción pre-industrial de ladrillos en Valencia. Los actores del proceso, como ladrilleros, vendedores, controladores de venta, albañiles...desempeñan un papel importante a la hora de comprender y analizar las fábricas. No en vano, las cuestiones de la producción, regulación, venta y puesta en obra de los ladrillos en la ciudad de Valencia completan el análisis de los casos de estudio visibles en la zona intramuros de la ciudad.

La especulación ${ }^{6}$ en el centro histórico de Valencia paradójicamente ha sido, en este marco, una ocasión única y a la vez agridulce para

${ }^{6}$ RAE: "int. Comerciar, traficar, procurar provecho o ganancia fuera del tráfico mercantil" 
reflexionar sobre algunos aspectos constructivos de los "muros intramuros" de la ciudad.

De todo ello, surge otro intento de especulación ${ }^{7}$, que se presenta en las páginas siguientes, como potencial oportunidad de reflexión sobre la riqueza de estratos y complejidad de la arquitectura del centro urbano de Valencia.

\subsubsection{Por qué nace "muros intramuros"}

Por todo esto "muros intramuros" es una investigación lenta, pero incesante, que me ha acompañado en el progresivo control de un idioma nuevo, que ha crecido conmigo, que ha sido compartida primero con padres atentos, luego con ojos curiosos y finalmente con un compañero de vida y de profesión. Se ha redactado en domicilios de varios países y de heterogéneos barrios valencianos, ha tenido altibajos, alimentándose en autobuses, trenes, aviones, así como en diferentes mesas de trabajo y bibliotecas.

Se ha reforzado con mi madurez, se ha nutrido de fotografías ingenuas al principio y críticas al final. Ha sufrido etapas grises, pero también ha florecido y madurado en momentos redondos de mi vida. Es realmente un reflejo de mis inquietudes y de mi curiosidad, siendo parte del gran bagaje de vida que ha acompañado una chica de veintitantos en una apasionante trayectoria profesional.

Por lo tanto, lo que se presenta a continuación es una investigación personal, empapada de interés por la cultura material más autóctona de mi ciudad adoptiva. Con este texto se llega a una estación de destino. Una etapa que ha sido posible gracias a un largo trabajo aditivo, pero sobretodo de filtrado. Los capítulos se han pulido, los términos refinado, los datos empíricos clarificados. Por esto no se trata de la presentación resumida y mecánica de unas investigaciones

${ }^{7}$ RAE: "trans. meditar, reflexionar con hondura, teorizar, intr. registrar, mirar con atención algo para reconocerlo y examinarlo" 
previas, sino al revés, más bien se presenta el fruto de una maduración de ideas, de su decantación y su revisión.

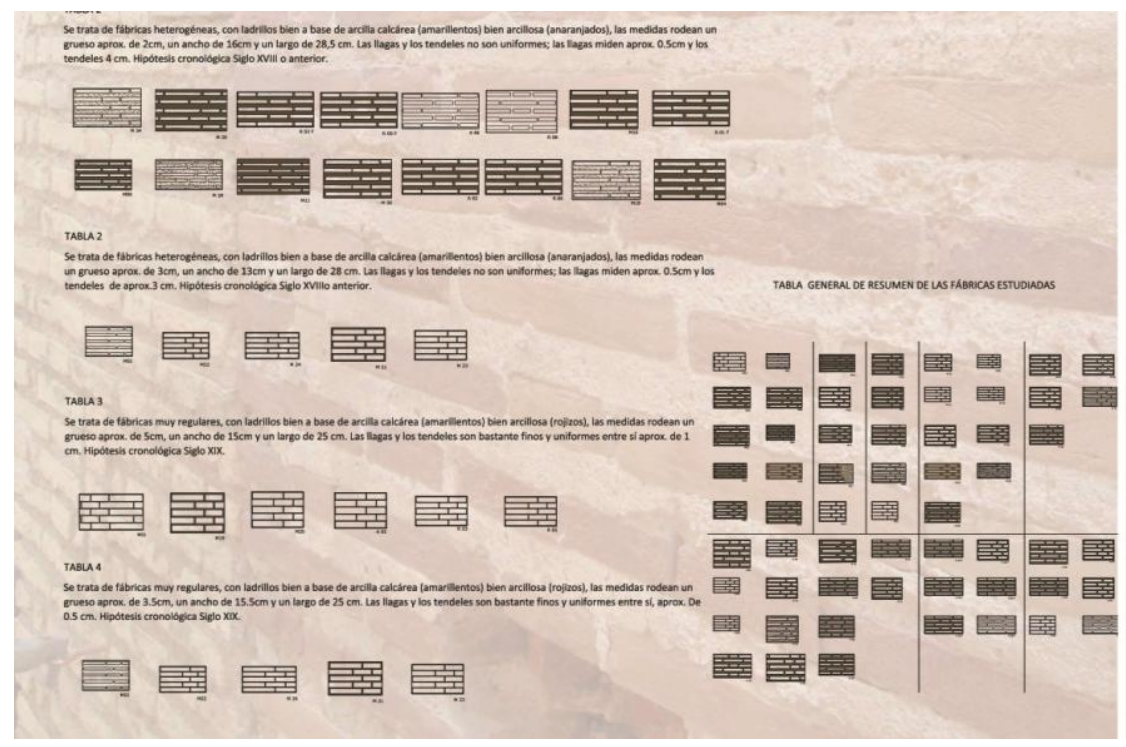

FIG.4 Detalle de las tablas de comparación entre distintas fábricas de ladrillo histórico, definidas en el trabajo de investigación/DEA, realizado por la autora (CRISTINI)

Por otro lado, sin embargo, estas páginas son también una partida para despegar hacia próximas labores vinculadas a estas cuestiones. Siempre según esta lógica, el estudio espera reforzarse en futuro, con otras experiencias, mejoras metodológicas, puntos de vistas de diferentes disciplinas.

Por esto espero puedan contribuir al próximo corpus de este estudio distintas investigaciones analíticas, pautas históricas, datos técnicos, relaciones con otros entornos geográficos, regionales, nacionales, o internacionales. Siempre para seguir, así, en esta labor de "refinado" que hace tan apasiónate la investigación en una disciplina como arquitectura. 


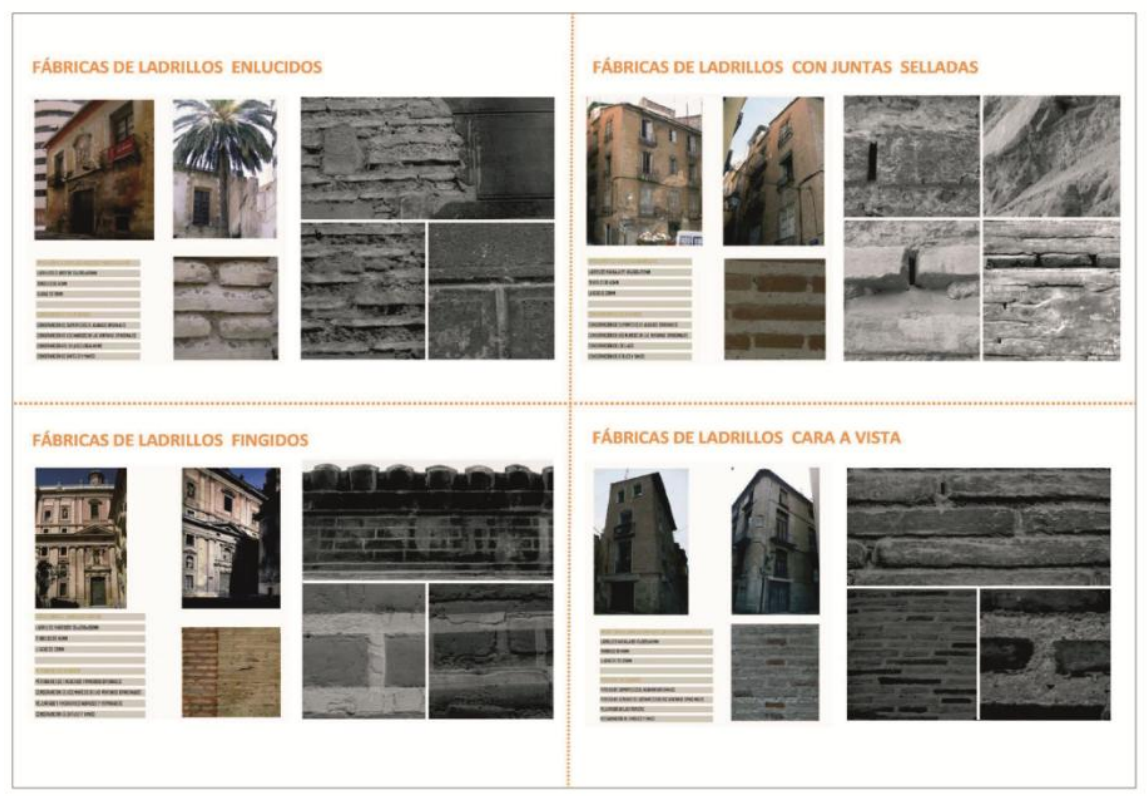

FIG. 5 Algunas de las conclusiones del trabajo de investigación/DEA, realizado por la autora, donde se definen las principales características de fábricas de ladrillos históricos del barrio de Velluters, Valencia (CRISTINI)

Me hace sonreír ver como lo que empezó de forma íntima y fortuita, ha crecido, ha cambiado de registro, vocabulario y ha fraguado en un estudio que aspira a ser riguroso, integro y porqué no, precursor de otras actitudes curiosas y flâneur hacia las entrañas de los caracteres constructivos valencianos más auténticos. 


\subsection{Temas de la investigación}

La investigación propone la elaboración de un registro de información, destinado a documentar, catalogar y analizar las características de las fábricas históricas de ladrillo. Y para ello, el tejido residencial y monumental de la zona intramuros de Valencia, se constituye como objeto del análisis y de las reflexiones presentadas en estas páginas.

Se propone así profundizar en una línea de investigación que ha ido madurando en los años, decantada en una serie de estudios realizados recientemente por la autora ${ }^{1}$. Todos estos resultados se tratan de plantear una serie de reflexiones relativas a las fábricas históricas urbanas. ¿Qué desvelan los muros de ladrillo?... No se trata de una simple metáfora, sino de la cuestión central de la tesis ¿Qué realidades tecnológicas, productivas, sociales, materiales, económicas se pueden identificar a lo largo de la historia urbana vinculadas a las fábricas? ¿Qué nexos hay entre todas ellas?

Es complejo penetrar en esta urdimbre, ya que el riesgo de perderse entre los hilos de disciplinas cercanas a la arquitectura (la sociología, la economía, la antropología, etc...) es patente.

Pero todo ello forma parte del desafío planteado al inicio del estudio, esto es, poder filtrar informaciones heterogéneas, poderse empapar de disciplinas variadas y tratar de fraguar estas aportaciones en un diseño personal, nítido y referenciado sobre la evolución de las fábricas urbanas del centro histórico de Valencia.

${ }^{1}$ CRISTINI V., op. Cit., (2005/2008) 


\subsubsection{Contenido material}

El estudio es posible tras una definición de apartados específicos, articulados en base a los diversos enfoques de análisis y reflexión (tomo I):

\section{LA IDENTIDAD DEL CENTRO HISTÓRICO DE VALENCIA}

Perfil geomorfológico y geológico

La mirada histórica hacia la edafología de Valencia

Perfil histórico y cultural

\section{LAS FÁBRICAS EN VALENCIA: HACIA UNA INTERPRETACIÓN}

Una cuestión de roles

Alfareros y ladrilleros: producción y cocción

El ladrillar/rajolar

Vendedores y controladores: mercado y comercio

Instituciones

Cuerpo normativo y legal

Rúbrica de la rajola e teula

Els Rajolers

Tratados y manuales: de lateribus

El siglo XIX, maduración de manuales

técnicos sobre el ladrillo

Prácticas de albañilería en los

manuales de arquitectura

\section{"MUROS INTRAMUROS": ESTUDIO DE LAS FÁBRICAS}

Hacia la evolución de las técnicas constructivas en arcilla 
Fábricas con ladrillo

Tapia valenciana

Posibles antecedentes históricos:

fábricas de ladrillo en el mundo bizantino

Posibles antecedentes históricos:

fábricas de tapia en Al-Andalus

Posible propulsor de la difusión de la técnica:

la Fábrica Vella, dita de Murs y Valls

Fábricas de ladrillo

Ladrillo visible

Ladrillo visto

Ladrillo oculto

\section{FÁBRICAS: HACIA UNA PROPUESTA DE CONSERVACIÓN}

Análisis diagnóstico de las fábricas analizadas

¿Qué patologías?

Líneas guía para una posible intervención

Procesos de limpieza general

Consolidación

Hidrofugación

Complementación de piezas

Sustitución de piezas

Reparación de juntas

Reparación de fisuras

Protección final

Núcleo, conectores y costra: intervenir en fábricas

de tapia valenciana 
Por otro lado el trabajo propuesto cuenta con una fase de análisis empírico, recopilado en tres anejos al texto base, identificando un registro pormenorizado de fichas y datos de estudio (tomo II):

\section{ANEJO I: REGISTRO PORMENORIZADO DE FÁBRICAS ESTUDIADAS}

Criterios para la redacción de un registro de fichas

Base de datos

Fábricas históricas: Barrio del Carmen

Fábricas históricas: Barrio de Mercat

Fábricas históricas: Barrio de S. Francesc

Fábricas históricas: Barrio de Velluters

Fábricas históricas: Barrio de la Xeu/Serea

Ábaco de detalles de fábricas históricas de ladrillo

\section{ANEJO II: RECOPILACIÓN DE DATOS ARQUEOLÓGICOS}

Criterios para la consulta de informes arqueológicos

Extractos de informes arqueológicos

Base de datos

Ladrillos procedentes del depósito SIAM

\section{ANEJO III: CARACTERIZACIÓN Y ANALISIS DE LAS FÁBRICAS}

Propiedades químicas, físicas, mecánicas de los ladrillos históricos

Características mineralógicas

Propiedades físicas

Propiedades hídricas

Propiedades mecánicas

Propiedades de durabilidad 
Criterios para el estudio de ladrillos y morteros Informe analítico: selección de ladrillos y morteros (FT-

IR)

Informe analítico: selección de ladrillos y morteros (SEM/EDX/MO)

El capítulo inicial, relativo a la "Identidad del centro histórico de Valencia" propone un enfoque de introducción al estudio, para poder relacionar de forma clara los caracteres constructivos en un determinado entorno urbano. Por lo tanto, conocer el perfil geomorfológico, geológico, histórico o, en sentido más amplio, cultural de la ciudad de Valencia es un paso indispensable para comprender el empleo del ladrillo en ámbito urbano. Este capítulo, bastante sintético es realmente la base teórica que cimenta una reflexión más en detalle, desarrollada en otro apartados posteriores, relativos a los diferentes actores vinculados al mundo de las fábricas urbanas. Profesiones diferentes toman forma en la descripción de este perfil urbano, presentando su historia, evolución u ocaso. Alfareros, ladrilleros, vendedores y controladores, así como contribuciones teóricas o manualísticas, suponen una gran aportación al conocimiento de los aspectos más profundos de la construcción en ladrillo.

Con estos conocimientos previos podemos lograr afinar el análisis y aproximarnos a la escala arquitectónica, procediendo en el capitulo "muros intramuros, estudio de las fábricas" a averiguar la sutil distinción entre fábricas con ladrillo y fábricas de ladrillo. Además, se propone la definición de una serie de variantes específicas. Entre ellas se separan aparejos de ladrillo visible, visto, u oculto, a través de secuencias y solapes temporales que delinean la evolución de las fábricas del centro histórico.

Una vez definidas estas posibles combinaciones técnicas, el estudio procede también a identificar un posible cuadro patológico específico, relacionado con los muros analizados. 
Por lo tanto, en el capitulo "fábricas: hacia una propuesta de conservación" trata de la identificación de posibles patologías diagnosticadas en los casos de estudio, así como de organizar una propuesta de excursus operativo para la intervención.

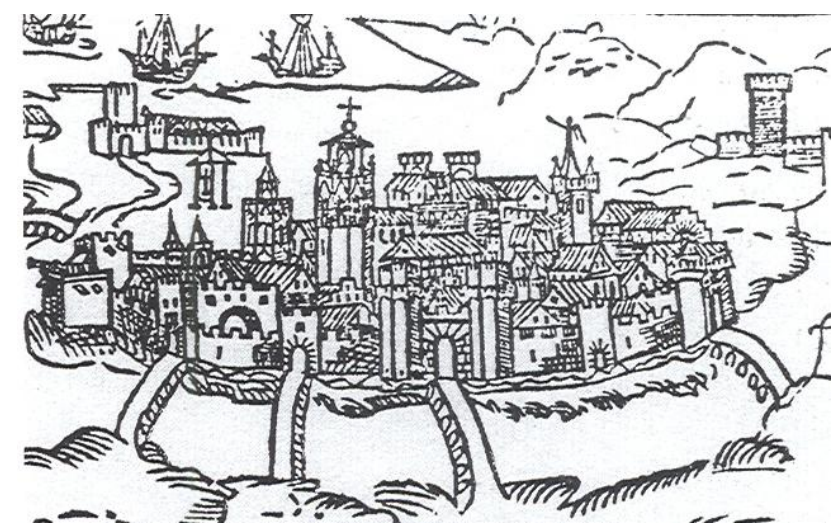

FIG. 6 Grabado de la ciudad de la Valencia intramuros por BREUER, portada de "Primera Parte de la Crónica General de toda España y especialmente del Reino de Valencia", 1546 (ÍCARO )

Finalmente, los tres anejos finales recopilan las fichas relativas a la toma de datos, tanto de fábricas, distribuidas en los barrios de la zona intramuros de la ciudad de Valencia, como de ladrillos, procedentes de excavaciones arqueológicas en ámbito urbano.

Estos tres anejos, cuyos detalles se describen al principio de cada apartado, constituyen el cuerpo empírico de la tesis, así como la serie de reflexiones y pruebas analíticas de laboratorio que se realizan, como complementos al análisis visual. Por lo tanto, esta sección de caracterización de las fábricas contribuye a la definición de las generales pautas cronotipológicas propuesta en el estudio.

\subsubsection{Límites geográficos y temporales}

El ámbito territorial del estudio abarca los cinco barrios de la ciudad intramuros de Valencia, zona actualmente contenida entre el margen derecho del río Turia y el trazado histórico de la muralla cristiana, actual ronda de circunvalación (Calle Colón, Calle Xátiva y Calle Guillén de Castro). El conjunto urbano así delimitado compone la zona de calificación urbanística conocida como Conjunto Histórico 
Protegido "Ciutat Vella" (CHP-1) definida en el Plan General de Ordenación Urbana (PGOU) de la Ciudad de Valencia (aprobado el 28 de diciembre de 1988).

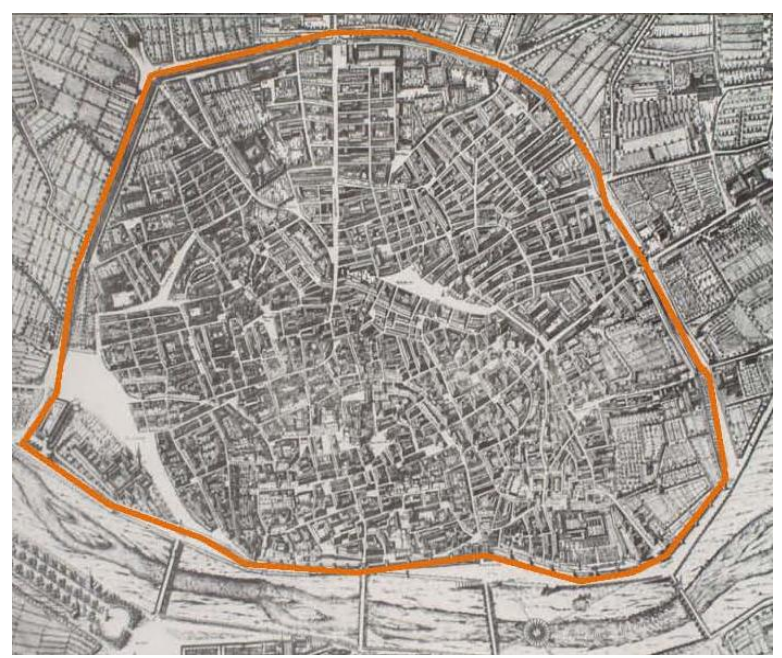

FIG. 7 Perímetro de Valencia intramuros, marcado en el plano más antiguo de la ciudad, grabado por Mançeli A., 1608 (AHMV)

El estudio se focaliza en este ámbito territorial específico debido a varias razones. Por un lado, este entorno es el que cuantitativamente más riqueza, concentración y estratificación de fábricas históricas de ladrillo presenta.

Por otro lado, también hay que indicar que hay una investigación relativa a las fábricas de ladrillo de la zona del ensanche de la ciudad de Valencia ${ }^{2}$, que no menciona ni trata la zona intramuros. Por lo tanto, se trata de completar el estudio, subsanando una laguna de relativa al estudio de las fábricas, justo en la parte más antigua de la ciudad. También, es oportuno, de cara a posibles futuras investigaciones relativas a zonas extraurbanas, tener en cuenta los parámetros propios de la arquitectura monumental en ladrillo (religiosa, palaciega...) del centro político y administrativo de la ciudad de Valencia.

\footnotetext{
${ }^{2}$ BLAT LLORENS, J.V., Presencia del ladrillo cara vista en el primer Ensanche de la ciudad de Valencia, Tesis doctoral dirigida por Lecuona López, Espí Cerdá, Valencia, 1996
} 


\section{MUROSINTRAMUIOS}

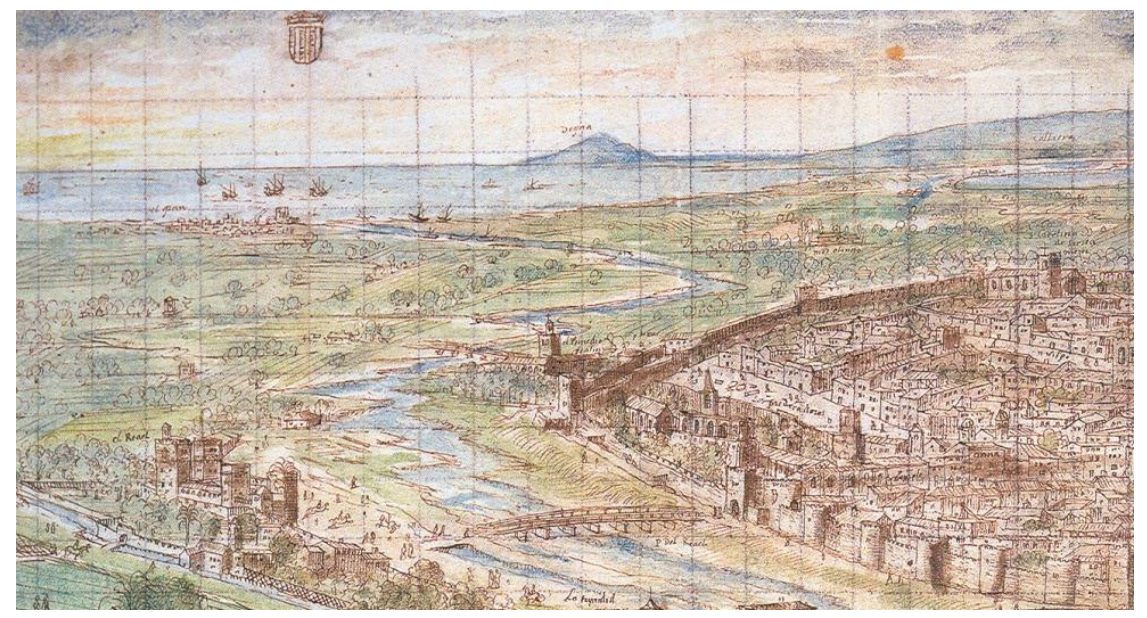

FIG. 8 Vista de la Valencia intramuros según Wijngaerde 1563 (ÍCARO PUB.)

Se trata potencialmente de factores claves, tanto a nivel tipológico, como a nivel constructivo y formal, que pueden servir de referencia para otros ámbitos periféricos y extraurbanos.

Por otro lado, el ámbito temporal del estudio se cierne a la realidad productiva pre-industrial urbana. Por lo tanto, el intervalo temporal analizado abarca desde la producción artesanal romana hasta la llegada de tecnologías industriales decimonónicas ${ }^{3}$.

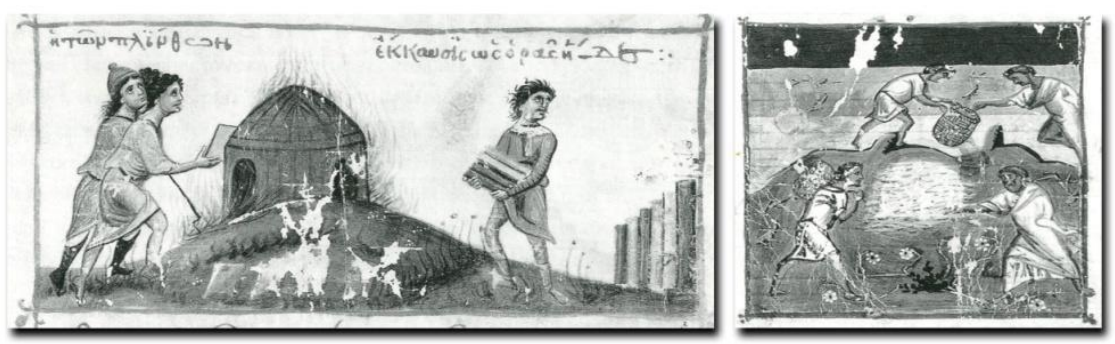

FIG. 9 Ejemplo de algunos de los primeros talleres de ladrillos documentados, en manuscritos de la Librería Vaticana (Ms gr 476-fol.61r y Ms gr 747-fol 78v-OUSTERHOUT)

\footnotetext{
${ }^{3}$ Podemos resumir el ámbito de estudio desde la fundación romana de la ciudad hasta la llegada en la ciudad de la mecanización y el prensado de ladrillos. Se documenta que a partir de 1867 en Meliana, se empieza a utilizar la prensa extrusionadora Whitehead, movida a vapor, ideal para la producción de tubos, cilindros y ladrillos de cerámica. El mismo año coincide también con la llegada del horno Hoffman, con planta circular a doce cámaras, de fuego continuo y regulable. "Cap. 4.1. Una cuestión de roles"
} 
Se trata de un periodo temporal muy amplio, aspecto que hace complejo estructurar y definir el análisis. Pero hay que reconocer, sin duda, que se trata de un ámbito temporal crucial, donde el reciclado y el re-empleo de materiales hacen imposible un recorte cronológico arbitrario.

También hay que considerar que los datos efectivamente documentados sobre las primeras fases productivas/constructivas urbanas son muy escasos, de manera que incluirlos en el estudio permite tener un cuadro más completo relativo a la realidad preindustrial urbana.

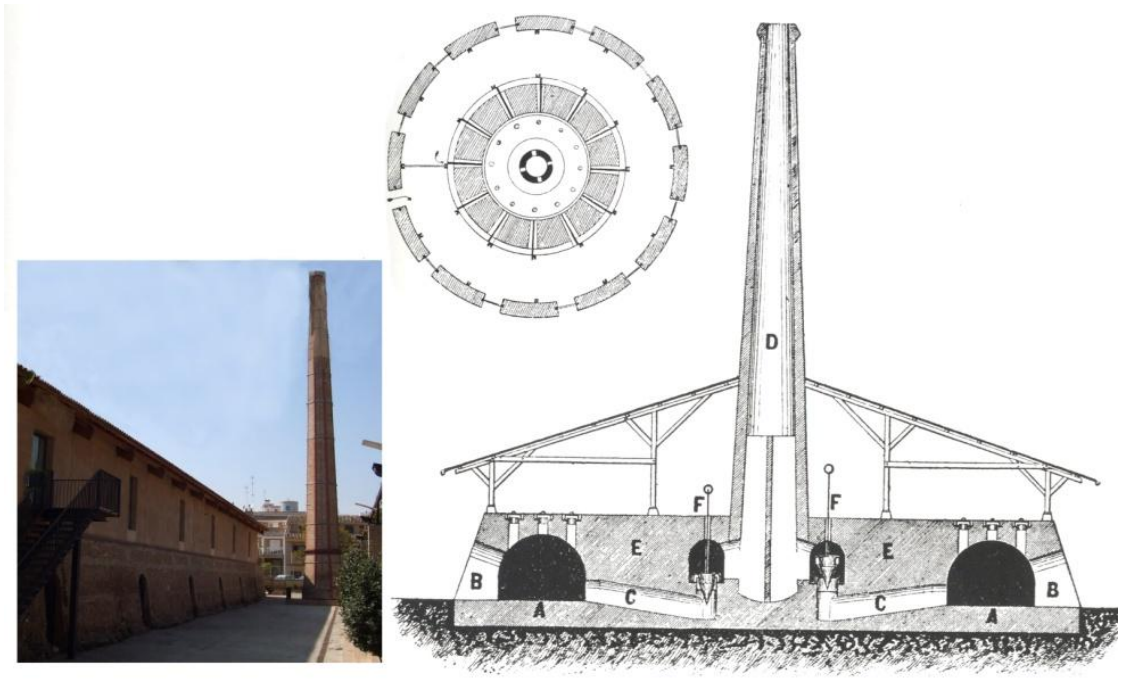

FIG. 10 Estructura tipo de un horno Hoffman musealizado hoy en día, en el Rajolar de Paiporta, Valencia (Principio S. XX) (CRISTINI-CAMPBELL PRICE)

Un factor clave que condiciona el ámbito temporal es también el desequilibrio existente entre arqueología pre-industrial y industrial, que apunta sin duda a esta última. También significar que la documentación relativa a la tecnología industrial del ladrillo, a partir de la segunda mitad del siglo XIX es sin duda más actualizada y profundizada 4 .

\footnotetext{
"Véase la "Asociación Valenciana de Arqueología industrial" (AVAI) y sus publicaciones. http://arqueologiaindustrial.wordpress.com/
} 


\section{murOSINTRAMUIOS}

Por lo tanto, es también por esta razón que la investigación se centra en un ámbito productivo/constructivo pre-industrial, tratándose justamente de un término cronológico bastante desconocido, que deja más pautas para un análisis inédito. Este vacío de información se debe también al hecho que los ladrillos y las fábricas no se consideran restos arqueológicos de especial interés (como por otro lado son restos de pinturas, cerámicas decorativas, etc...) Por esta razón, la información relativa a posibles fábricas, sobre todo arqueológicas es muy escasa y por lo tanto aún más interesante, anónima y desconocida. 


\subsection{Propósitos de la investigación}

\subsubsection{Interés}

El interés de la tesis consiste en aspectos ligados a la protección de la cultura material urbana, vinculada a caracteres tanto tangibles como intangibles de la misma.

La evolución del centro de Valencia en los últimos años, ha sido contundente para el tejido histórico con la desaparición y demolición de un buen porcentaje de edificación residencial histórica. Además, la restauración en algunos casos de edificios de gran valor patrimonial/monumental tampoco ha podido garantizar una vigencia adecuada de estos caracteres.

En este marco, el gran desconocimiento que existe sobre las técnicas tradicionales y la evolución de las mismas en la ciudad de Valencia es sin duda un factor crucial, responsable en buena medida de la insensible demolición a la que están siendo sometidos muchos edificios residenciales.

De allí, por lo tanto el interés de la tesis, presentándose como un documento que puede hacer hincapié en el conocimiento como premisa para la conservación de las técnicas vinculadas al ladrillo y como línea guía para su conservación.

Poder despertar el interés hacia las fábricas de ladrillo o hacia el "Velo de Maya"1 que existe tras de ellas, es también el segundo 


\section{MUROSINTRAMUROS}

punto de interés que motiva esta investigación. Los vendedores de materia prima, los hornos de producción de los tejares, las estrictas normas de compra venta de los ladrillos, son realidades intrínsecas a las propias fábricas.

Se debe indicar también que el estudio constituye una tesela de un proyecto más amplio y ambicioso, que apunta a definir los caracteres constructivos del centro de Valencia, tras una recopilación y análisis exhaustivos de diferentes aspectos constructivos históricos (Mileto 2008).

Por lo tanto el trabajo se enmarca dentro de serie de investigaciones recientes vinculadas la ciudad de Valencia, como son las relativas a forjados y cubiertas (Diodato), balcones (Privitera), carpintería (Maioli), enlucidos (La Spina).

\subsubsection{Objetivos}

El trabajo de investigación propuesto aspira a alcanzar una serie de objetivos diferentes, pero coherentes entre sí, que abarcan unas cuestiones fundamentales que se exponen a continuación.

Antes de nada es importante subrayar que la validez de este enfoque metodológico es precisamente, en sí misma, una premisa básica que se pretende alcanzar con el análisis. La propuesta de un estudio holístico, que abarca distintas pautas teóricas y técnicas, es una perspectiva novedosa a la hora de definir la cultura material urbana.

Se ha apostado por lo tanto en una variedad de disciplinas y métodos para poder definir los caracteres constructivos urbanos en ladrillo.

Por otro lado un objetivo previo de la investigación es ordenar y estructurar un ciclo de reflexiones, estudios y análisis sobre las fábricas urbanas, realizadas en los últimos años. Por esta razón, la tesis presenta una faceta bipolar: por un lado de conclusión y

${ }^{1}$ Schopenhauer A., El mundo como voluntad y representación (2 vol), Trotta, Madrid, 2003 
definición de conceptos, por otro, de abertura y diseño de posibles nuevas investigaciones.

Los aspectos más vinculados a los resultados propios del trabajo se pueden resumir en los siguientes:

-Delineación de un perfil socio/económico/cultural y técnico vinculado a la producción pre industrial del ladrillo y su puesta en obra: se establecen los rasgos principales que vinculan la producción, venta y puesta en obra de ladrillos pre-industriales a un preciso entorno cronológico y geográfico.

-Realización de un registro pormenorizado de fábricas históricas de ladrillo para la zona intramuros de la ciudad de Valencia:

se pretende realizar un catálogo de fábricas de ladrillo, exhaustivo para la zona intramuros de la ciudad de Valencia, reflejando en él una serie de datos métricos y técnicos específicos.

$\star \star$

- Diseño de una curva mensiocronológica para la zona intramuros de la ciudad de Valencia: se proponen estudios previos relativos a la evolución mensiocronológica del ladrillo a escala urbana, para poder definir así variaciones dimensionales y productivas de ladrillos preindustriales.

-Descripción de una posible cronotipología de fábricas históricas de ladrillo para la zona intramuros de la ciudad de Valencia: se propone extraer una serie de datos estadísticos y reflexiones a partir del estudio empírico realizado (a través de los resultados obtenidos por el registro pormenorizado de fábricas, la recopilación de datos arqueológicos y el análisis de laboratorio). 


\section{murOSINTRAMUIOS}

Con estas bases se describen sincronías, diacronías, constantes técnicas detectadas en las fábricas.

-Planteamiento de una posible línea guía a seguir para la intervención en fábricas históricas de ladrillo: se pautan una serie de pasos operativos y metodológicos para poder garantizar la conservación de fábricas históricas de ladrillo. 
2. Método 



\subsection{Proceso de formación de un método}

La definición de un procedimiento, un modus operandi para alcanzar objetivos tan diferentes y heterogéneos como propuestos en el Cap.1.3.1., ha requerido tiempo, dedicación y no pocas dificultades. Pero también se debe reconocer que un lapso de tiempo amplio ha permitido forjar y adaptar diferentes enfoques disciplinares al caso de estudio propuesto. Antes de desarrollar a fondo los criterios metodológicos presentados hay que reconocer que ha resultado decisivo atravesar un proceso de formación y estudio, que se recopila brevemente a continuación.
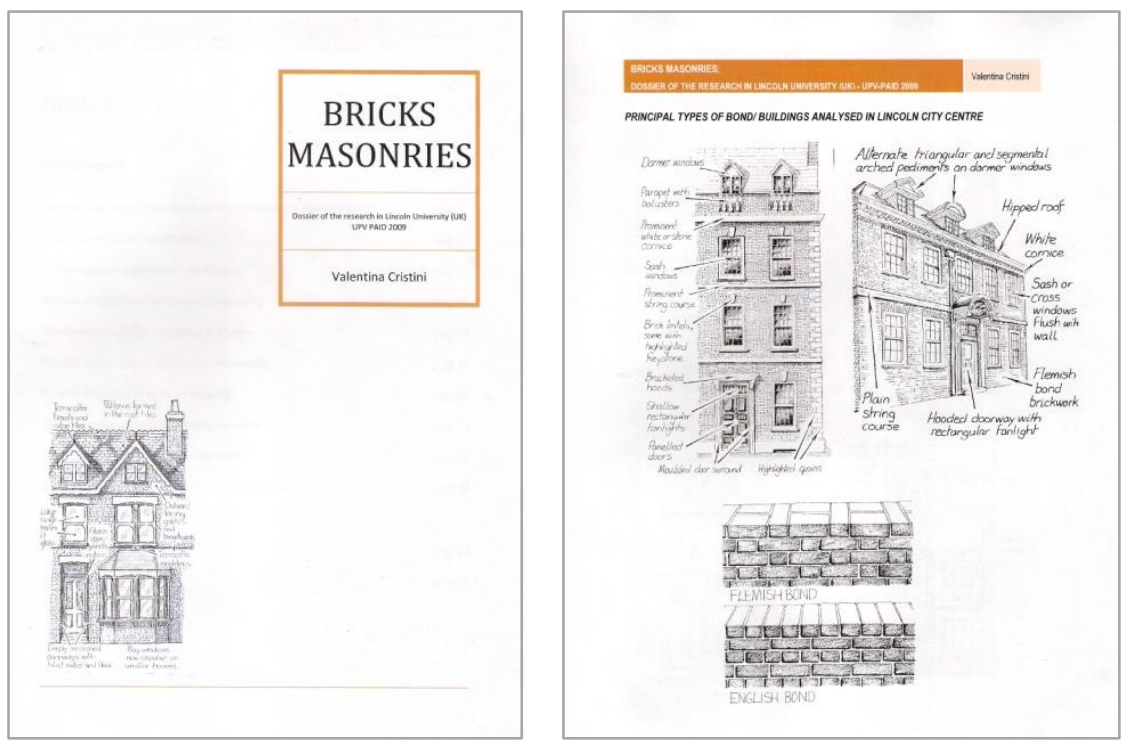

FIG. 11 Detalle del informe presentado tras la estancia en la University of Lincoln, UK (CRISTINI) 


\subsubsection{Estancias de investigación en el marco del estudio}

En los últimos años, concretamente en los años académicos 2009 2010 y 2011 se ha realizado una serie de estancias de investigación vinculadas con el proyecto de doctorado, cuya finalidad ha sido principalmente el contacto con disciplinas cercanas al tema estudiado. Estos diferentes enfoques disciplinares, promovidos por estudiosos extranjeros, han sido muy fructíferos para la redacción de la tesis.

Por un lado se deben considerar los beneficios de poder entrar en contacto con la trayectoria profesional, muy consolidada de investigadores senior, vinculados a la disciplina. Por otro lado, es un gran privilegio poder conocer en primera persona los trabajos desarrollados en otras universidades, afines a la temática de estudio, así cómo poder entrar en contacto con una bibliografía específica y expertos en estas materias.

Las estancias que se han llevado a cabo en este marco han sido las siguientes:

\section{A.A. $2009 / 2010$}

Centro: Department of Forensic and Biomedical Sciences, Heritage Science Research Group, Lincoln University (UK)

Fechas: 05/12/2009-05/03/2010

Título de la investigación: "Conservation of brick buildings: a scientifically approach"

Profesor tutor: Belinda Colston /John Warren

Ayuda recibida: Ayuda UPV PAID 2009, Programa de apoyo a la investigación y desarrollo; Ayuda para estancias en centros de investigación de prestigio

\section{A.A.2010/2011}

Centro: Facoltá di Architettura, DIAP, Politecnico di Milano ( Italia)

Fechas: 18/12/2009-30/01/2011

Título de la investigación: "Albañilería: cambios y transformaciones realizadas en Lombardía y en el Levante Español, durante la Edad Media"

Profesor tutor: Amedeo Bellini

Ayuda recibida: Ayuda UPV PAID 2010, Programa de apoyo a la investigación y desarrollo; Ayuda para estancias en centros de investigación de prestigio 


\section{A.A.2010/2011}

Centro: Fac.de Ingeniería Civil, PUCP, Pontificia Universidad Católica de Perú (Lima/Perú)

Fechas: 15/07/2008-15/09/2011

Título de la investigación: "La arquitectura histórica peruana y el uso de la tierra, técnicas, análisis y conservación"

Profesor tutor: Julio Vargas Neumann

Ayuda recibida: Beca Iberoamérica Santander para jóvenes profesores e investigadores

Analizando las tablas se pueden organizar y agrupar diferentes momentos de investigación. Por un lado, la estancia en la Universidad de Lincoln se ha centrado en el perfeccionamiento de pautas de diagnóstico y análisis relativos a las fábricas de ladrillos, y patologías. La estancia en el Politécnico de Milán, más breve, se ha centrado en el estudio de los actores, concretamente los albañiles y alarifes a lo largo de la Edad Media como momento crucial de cambios constructivos, económicos y sociales tras la caída del Imperio Romano.
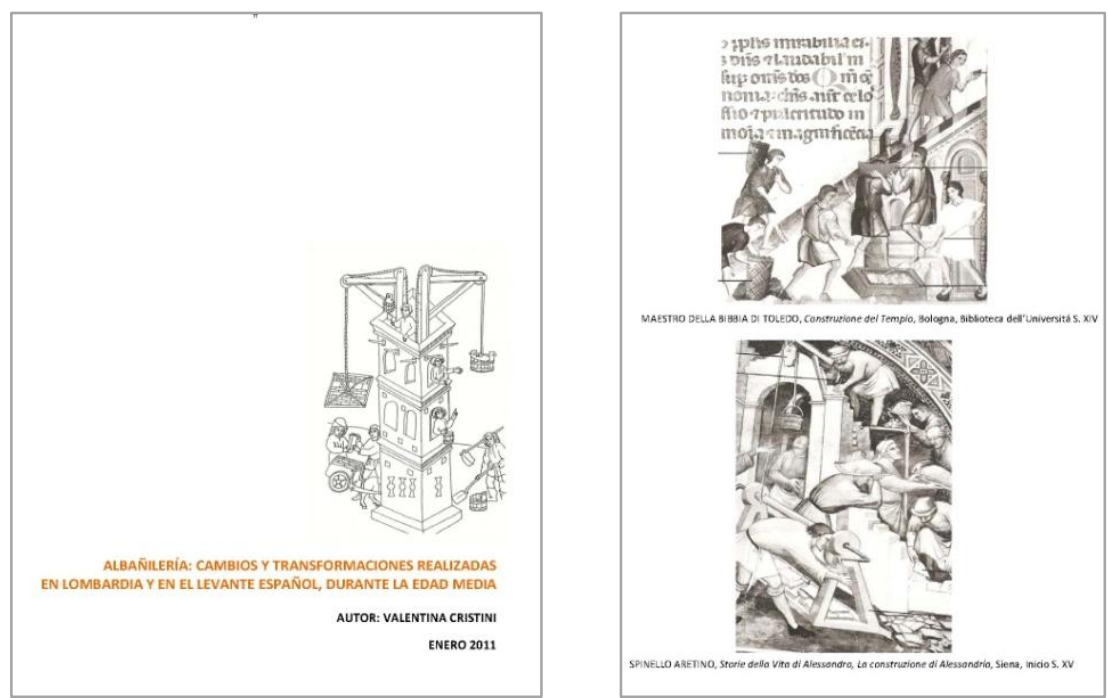

FIG. 12 Detalle del informe presentado tras la estancia en el Politecnico de Milán, It (CRISTINI) 
Finalmente la estancia en la Pontificia Universidad Católica del Perú se ha orientado más bien a la detección de un cuadro constructivo, tipológico y cultural vinculado a la arquitectura de tierra. En este caso se ha ensayado la aplicación de disciplinas como la mensiocronología, la cultura material, la diagnosis, etc. a la arquitectura en tierra, no estrictamente en ladrillo.
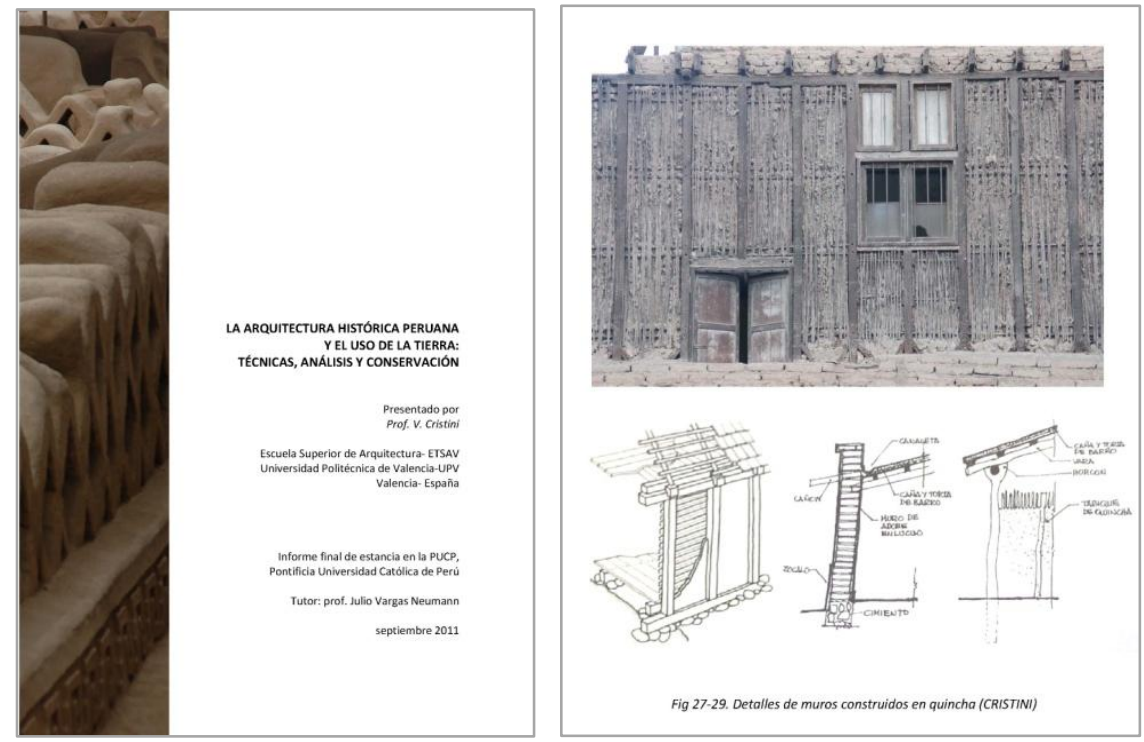

FIG. 13 Detalle del informe presentado tras la estancia en la PUCP, Lima, Perú (CRISTINI)

Se trata por lo tanto de experiencias de estudio bastante diferentes entre sí, que se han traducido en momentos de ensayo y puesta a punto del método, así como de confrontación del mismo para casos de estudio afines, como pueden ser los relativos a la arquitectura en tierra.

\subsubsection{Trayectoria de investigación y primeros resultados}

Los estudios sobre la arcilla, en todas sus variantes en crudo o con cocción, han marcado los últimos años de investigación, también debido a la participación de la autora a una serie de proyectos de investigación europeos, vinculados al grupo de investigación UPV ${ }^{1}$. 
En este marco existen tres proyectos de investigación que pueden ser interesantes a la hora de considerar el estudio presentado. En estos casos se han hecho reflexiones relativas a la técnicas mixtas (tierra y ladrillo, tierra y adobe...etc.), que como se explica en detalle en el Cap. 5. de este tomo, no pueden ser interpretadas de forma aislada y apartada del estudio de las técnicas tradicionales con ladrillos. Por ello los sutiles puntos en común entre la arquitectura de tierra y la arquitectura en ladrillo se han ido afinando también gracias a estas investigaciones:
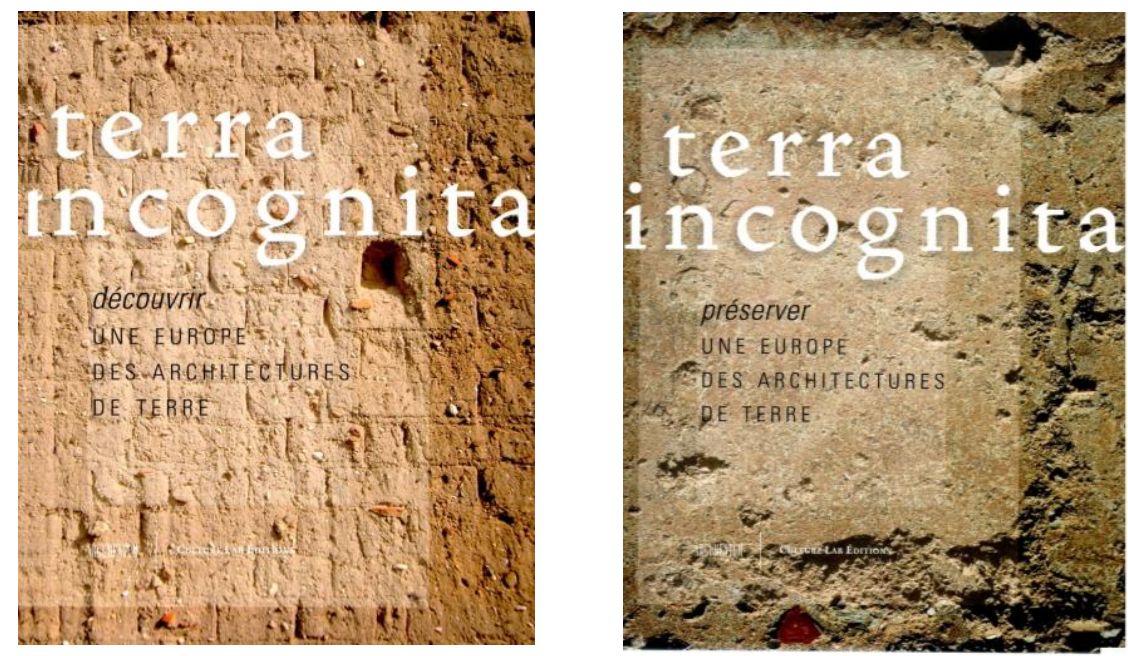

FIG. 14 Portadas de las publicaciones del programa Culture 2000/ Convetion 2006-2344 a las que la doctoranda ha participado como autora con estudios de fábricas mixtas, tapia y adobe

\section{TERRA}

\section{INCOGNITA}

European Commission - Culture 2000 (Convention n² 2006-2344) Investigador principal: Gilles Nourissier, Ecole d'Avignon

Duración: 2006-2007

\footnotetext{
${ }^{1}$ Los investigadores responsables de estos proyectos, para el Grupo de investigación del IRP, Instituto de Restauración del Patrimonio de la Universidad Politécnica de Valencia, han sido Fernando Vegas y Camilla Mileto. Valentina Cristini ha participado en ellos siendo co-autora de las respectivas publicaciones redactadas en el marco de los proyectos
} 


\section{Resultados:}

VEGAS F., MILETO C., CRISTINI C. (entre otros), Terra Incognita. Decouvrir une Europe des architectures de terre / Terra Incognita. Discovering European Earthen Architecture, Argumentum Ed., Lisboa, 2008

VEGAS F., MILETO C., CRISTINI C. (entre otros), Terra Incognita. Preserver une Europe des architectures de terre / Terra Incognita. Preserving European Earten Architecture, Argumentum Ed., Lisboa, 2008

\section{COUPOLES ET HABITATS}

European Commission (CLT2007/1.2.1 third countries/IT-93)

Investigador principal: Saverio Mecca, Università di Firenze Duración: 2007-2009

\section{Resultados:}

VEGAS F., MILETO C., CRISTINI C. (entre otros) Earthen Domes and Habitats, ETS, Pisa ,2009; cap. "Corbelling dome architecture in Spain and Portugal", cap. "Urban and architectural analysis";

TERRA [IN]COGNITA Earthen architecture in Europe European Commission (2009/0758001/001 CU7 COOP7) Investigador principal: Patrice Morot, Universidad de Avignone (F) Duración: 2009-2011

\section{Resultados:}

VEGAS F., MILETO C., CRISTINI V. (entre otros), Terra Europae. Earthen Architecture in European Union, ETS, Pisa, 2011, cap. "Earthen Architecture in West Central Europe: Czech Republic, Slovakia, Austria, Slovenia, Hungary and Romania", cap. "Earthen Architecture in Southwester Europe: Portugal, Spain, Southern France", cap. "Earthen Architecture in Austria", cap. "Earthen techniques in Europe", cap. "Conclusions"

También es importante considerar que este texto, además de cimentarse en el proyecto final de carrera de la autora y en su proyecto de investigación de doctorado, cuenta con una serie de publicaciones en revistas y actas de congresos. 
Todos estos escritos marcan una trayectoria que se ha ido consolidando progresivamente y que sobre todo retroalimenta, funda y coordina esta investigación.
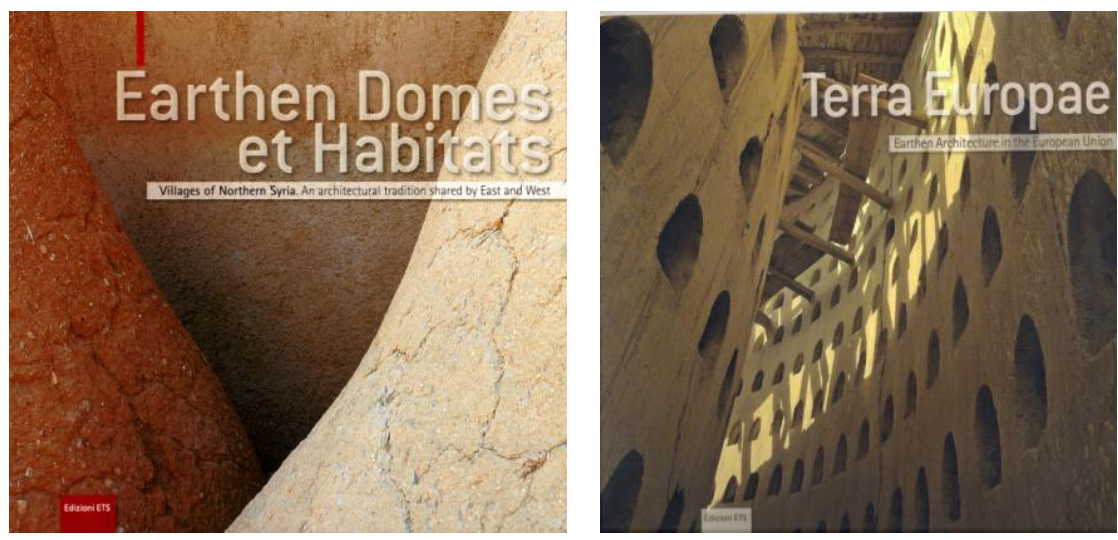

FIG. 15 Portadas de las publicaciones en las que la doctoranda ha participado como autora. Contribuciones al estudio de arquitectura en tierra en Siria y en países de la Comunidad Europea (CRISTINI)

\section{5}

CRISTINI V., Valencia, ciudad vella, ladrillos cara a vista, agramilados, fingidos y enlucidos. Analisi delle murature in laterizio: prassi costruttiva ed evoluzione archeometrica, PFC, Tutores: Bellini A., Mileto C., Pertot G., Politecnico di Milano, diciembre 2005 (inédito)

\section{6}

CRISTINI V., "Valencia, ciutat vella. ladrillos cara a vista, agramilados, fingidos y enlucidos. Analisi delle murature in laterizio: prassi costruttiva ed evoluzione archeometrica", en Loggia, arquitectura y restauración, n¹9, UPV Ed., Valencia, 2006, p.113-114

CRISTINI V., "El centro histórico de Valencia. Análisis de las fábricas de ladrillo. Técnicas constructivas y evolución arqueo métrica", en Asimetrías, Colección de textos de arquitectura, nº9, Valencia, UPV Ed., 2006, p.75-86

VEGAS F., MILETO C., CRISTINI V.,DIODATO M., "Constructive Features of the Historic Architecture at Valencia City", en Arché, Publicación del Instituto de Restauración del Patrimonio, n¹, UPV Ed., Valencia, 2006, p.297-304

2007

CRISTINI V., "Valencia, ciudad vella: Huellas de artesanía constructiva en fábricas tradicionales de ladrillo", en Actas de APT San Juan 2007, Congress of International 


\section{murOSINTRAMUROS}

Association for Preservation Technology, San Juan de Puertorico, APT Ed., 2007, poster

\section{8}

CRISTINI V., "Estudio de fabricas de ladrillos en Valencia: Análisis mensiocronológico y técnicas de acabado", en Arqueología de la Arquitectura, n5, CSIC, Madrid, 2008, p. $243-252$

CRISTINI V., Técnicas constructivas en arcilla: tapia valenciana y ladrillos en el centro histórico de Valencia, hacia el conocimiento y conservación de fábricas tradicionales. Trabajo de investigación, Programa de Doctorado: Patrimonio Arquitectónico: historia, conservación, estudios gráficos, Universidad Politécnica de Valencia, noviembre 2008 (inédito)

CRISTINI V., "Hacia la conservación de fabricas históricas de ladrillos en Valencia: estrategias y conocimiento para preservar ejemplos de edilicia residencial", en Actas de IV Seminario Internacional de Conservación de Patrimonio, Universidad Autónoma de Yucatán, UADY Ed., Mérida, México, 2008, poster

\section{9}

CRISTINI V., RUIZ CHECA JR., "A traditional reinforced rammed lime \& earth technique: the case of study of tapia valenciana", en Actas de Concrete 2009, Technological development of concret: tradition, actualities, prospects; Luciano Ed., Termoli, 2009, p. 661-668

CRISTINI V., RUIZ CHECA JR., "Tapia valenciana, caratteristiche di muri in terra cruda rinforzati con mattoni" en Actas de Mediterra, $1^{\text {th }}$ mediterranean conference on earth architecture, Cagliari, 2009, p. 285-294

CRISTINI V., RUIZ CHECA JR, "A historical Spanish traditional masonry technique: some features about tapia valenciana as a reinforced rammed earth wall", en Actas de $11^{\text {th }}$ Canadian Masonry Symposium, Toronto, Canada, 2009, p. 435-442

CRISTINI V., "Rajoles valencianes. Características de fábricas tradicionales en ladrillo", en Huerta S., Marín R., Soler R., Zaragozá A., en Actas de Sexto Congreso Nacional de Historia de la construcción, Instituto Juan de Herrera, Madrid, 2009, p. 365-374

\section{1}

CRISTINI V., RUIZ CHECA JR, "Carved ceramic: gauged brickwork in Valencia city centre", en Structural studies, repairs and maintenance of heritage architecture, WIT, Wessex Institute of Technology Press, 2011, p. 455-462 


\subsection{Definición de un planteamiento metodológico}

La presencia de la arcilla se puede distinguir a lo largo de la historia urbana como un ingrediente vigente en elementos constructivos y combinaciones técnicas. Se trata de una materia prima que se afirma a lo largo de los siglos en el tejido urbano y, por esta razón, el barro modela Valentia, Balansya, Valencia... con cochura o sin ella, en forma de tapia o de ladrillo, en tipologías constructivas variadas y con acabados diversos. Desde la fundación de la ciudad, la arcilla siempre ha constituido la base de las soluciones técnicas documentadas en sus fábricas.

El ladrillo representa una constante, desde el primigenio módulo romano al más contemporáneo módulo decimonónico. Lo mismo ocurre con la tapia, a veces oculta bajo reformas y revestimientos, o alterada por recortes y mutilaciones. La arcilla se presenta en la gramática constructiva del núcleo urbano e impregna la cultura material de la ciudad a pesar de su humilde condición.

Es complejo y a la vez bastante redundante hacer un recorrido histórico sobre el origen del ladrillo y sus características. Muchos autores se han involucrado profundamente en estas investigaciones y temas ${ }^{1}$, tanto a nivel histórico, constructivo estructural o prestacional.

${ }^{1}$ CAMPBELL J., Brick: a world history, Thames \&Hudson, London, 2003, PEIRS G., La brique: fabrication et traditions constructives, Eyrolles, 2004. WARREN J., Conservation of Brick, Butterworth Heinemann, London, 1999. ASHURST N., Brick, terracotta and earth, Gower Technical Press, London, 1988

SÁNCHEZ-OSTIZ GUTIÉRREZ A., El ladrillo cerámico en la construcción arquitectónica, Dossat Ed, Madrid, 2009. HAYWARD R., The brick book, Batsford Press, London, 1978. PONS SOROLLA 
Por esta razón, se ha preferido centrar el estudio, geográficamente en el ámbito valenciano y temporalmente, en el contexto pre industrial del mundo de la construcción, más autóctono de la ciudad.

Sin embargo, a la vez es necesario resumir con rápidas pinceladas, la trayectoria que este elemento constructivo ha tenido en diferentes aportaciones y escritos. Esto sin la pretensión de realizar un estudio exhaustivo, sino, más bien, para tener en cuenta los hitos propios de la evolución técnico-métrica-constructiva del ladrillo, a lo largo de una disciplina tan poliédrica como la historia de la construcción.

Existen unos puntos clave, unas posibilidades formales, que es necesario considerar para no abstraer el estudio propuesto, sino al contrario para poderlo considerar como parte de un contexto amplio, tanto desde el punto de vista histórico como cultural y geográfico. La presencia del ladrillo en las fábricas intramuros de Valencia es parte de una historia, con mayúsculas, de la que es importante no disociarse y separarse. Considerar estas pautas generales es sin duda necesario para profundizar aspectos más específicos del caso de estudio propuesto y poderlo valorar con una perspectiva más amplia.

A partir de estas consideraciones se puede afirmar que el ladrillo ha vivido diferentes enfoques de estudio. Aspectos constructivos, métricos, tipológicos, físicos químicos, son los que se han analizado en el curso de los siglos.

De cara a la presente investigación ha sido necesario realizar un breve resumen del estado del arte relativo a diferentes aportaciones realizadas en el marco de disciplinas específicas que han constituido avances importantes en la definición de las técnicas constructivas y en los parámetros de ejecución de las mismas. 
Mensiocronología, cultura material aplicada a la arquitectura, cronotipología, y diagnóstico en la restauración son las principales disciplinas consideradas. Todas brindan a la búsqueda de una base metodológica transversal y tangencial para poder abarcar el potencial y las dificultades del estudio propuesto.

\subsubsection{La mensiocronología ${ }^{2}$}

La mensiocronología es un método para la datación de ladrillos, no destructivo y directo, que permite obtener una datación absoluta de estos elementos constructivos merced a su análisis métrico. Las dimensiones de los ladrillos (longitud, anchura, grosor) se miden y, posteriormente, tras su elaboración estadística, se elaboran unas curvas específicas, para relacionar las variaciones métricas con las respectivas fases productivas. Para ello, cada curva debe relacionarse con un contexto específico territorial y económico ${ }^{3}$.

Siendo un método directo, vinculado con la fábrica construida presenta unas ventajas importantes:

- es útil en el análisis de la "edilicia menor", o sea, en contextos constructivos que no pueden referenciarse fácilmente con documentos escritos o representaciones iconográficas (fuentes indirectas)

- no prevé alteración del soporte construido, no implicando expolio y sacrificio de materiales u acabados, etc...

- no está sujeto a errores interpretativos de fuentes externas a la fábrica construida, sean voluntarios o involuntarios.

Siendo un método de datación absoluta, facilita también una identificación precisa de fechas (aunque con intervalos temporales

\footnotetext{
2 Contenidos extraídos de PITTALUGA D., La mensiocronologia dei mattoni, per datare, conocere, comprenderele strutture storiche, Ecig Ed., Genova, 2009

${ }^{3}$ En el proceso por ejemplo hay que tener especial cuidado con zonas de confín entre estados/países/ reinos, etc, que pueden sufrir normativas e influencias variables
} 
más o menos amplios), pudiendo por lo tanto contrastar posibles métodos de datación relativa, como por ejemplo, el análisis estratigráfico.

Para todo ello, la mensiocronología es una técnica de datación que requiere una cierta cautela y cuidado en la fase de toma de datos, como se indica a continuación.

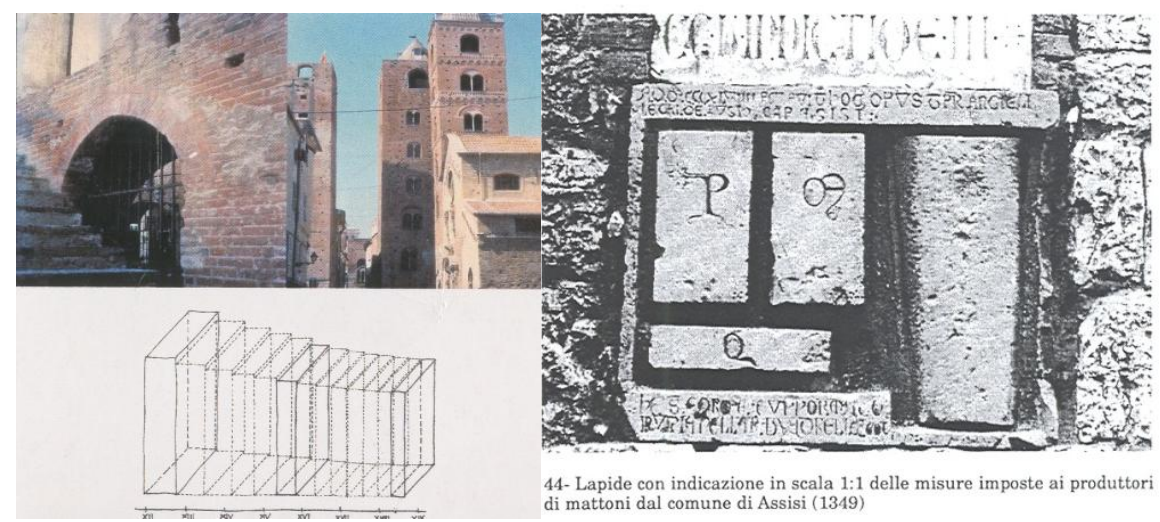

FIG. 16 Estudios mensiocronológicos, ISCUM (PITTALUGA) y plantilla con las indicaciones 1:1 para ladrilleros en Asissi-Italia (CAGNANA)

La mensiocronología es una disciplina que ahonda sus raíces en las herramientas propias de la investigación arqueológico/arquitectónica, sin emplear instrumentos "prestados" de otras disciplinas". Se basa en el estudio de los datos métricos propios de ladrillos, contextualizados en un entorno geográfico específico. La mensiocronología cerámica, como rama específica de la arqueometría ${ }^{5}$, apuesta por establecer relaciones referidas a una cronología especifica de ladrillos vinculados a determinados perfiles urbanos o regionales.

Los métodos se centran en la identificación de las variaciones métricas de los ladrillos analizados, teniendo en cuenta

\footnotetext{
${ }^{4}$ Radiocarbono, termoluminisciencia, petrografía, etc.

${ }^{5}$ La arqueometría es la aplicación de las ciencias experimentales al estudio de los restos arqueológicos. En este marco se consideran diferentes ramas posibles: principalmente dendrocronología, mensiocronología, y estudio de cal y morteros (desde www.iscum.it) archeometría)
} 
principalmente dos factores de variabilidad: modificaciones casuales (retracciones en fase de cocción, alteraciones de las gravillas, bastante comunes en la producción pre-industrial) o voluntarias. En estos casos se consideran leyes de mercado, actas legales y normativas de la producción, llegando incluso a fraudes o estafas en fase de venta y puesta en obra de los elementos constructivos. Los resultados finalmente apuntan a una serie de variaciones métricas codificadas en arcos temporales determinados.

Por lo tanto, para obtener resultados validos, el estudio tiene que contar con un muestreo amplio, con elementos enteros, que luego se discriminan según la distribución estadística de sus parámetros de medidas. Finalmente, la clasificación de los módulos analizados es posible, tras una esmerada identificación y ordenación de todas las variaciones métricas.

Sin duda se puede considerar que una de las ventajas principales del método es su carácter no destructivo, que se basa en una datación absoluta, relacionando las medidas de los ladrillos con una específica variación cronológica.

La trayectoria, bien formalizada, de estos estudios tiene su raíces en el IMS "Demokritos" (Attiki, Grecia) y su vinculación con la organización del ISA, "International Symposium on Archeometry" ${ }^{6}$ que desde los años '60 reúne diferentes expertos en el campo de la arqueometría arqueológica (Tite, Maniatis, Barba, Biró, Faruqar, Memmi Turbanti, Moreau Përez Arantegui, Tikot, Wnag, Wisseman entre otros).

A partir de estos avances se puede apreciar cómo en Europa van surgiendo diferentes ramas de escuelas, asociaciones y revistas que abarcan las diferentes disciplinas arqueométricas (Amsterdam, Siena, Budapest, Zaragoza son las ciudades más vinculadas al ISA).

\footnotetext{
${ }^{6}$ El IMS (Institute of Material Science "Demokritos", Attiki, Grecia) lleva 39 ediciones en activo organizando el principal simposio internacional bienal, que reúne expertos arqueólogos, tanto de Europa como de America; pagina web de referencia: www.ims.demokritos.gr/ISA
} 
Pero es solo en Italia, a partir de los años '70, cuando se va consolidado una línea de estudios específica de la disciplina arqueométrica. El avance de la investigación se plasma en el hecho que los análisis cuentan con un enfoque más arquitectónico, y no meramente arqueológico. Estas actividades fraguan en estudios relativos a materiales de construcción, vinculados principalmente a distintos contextos medievales, tanto urbanos como regionales. En este contexto destacan así las investigaciones aportadas por el ISCUM desde hace más de 30 años (Génova-Italia) ${ }^{7}$.

Haciendo un simple excursus geográfico podemos decir que en la península italiana las contribuciones son bastante variadas, entre ellas los estudios más interesantes se han llevado a cabo en: Liguria (Mannoni, Ghislanzoni, Pittaluga), Lombardía (Brogiolo, Della Torre, Casolo Ginelli), Veneto (Varosio, Doglioni, Trovó, Squassina), Emilia Romagna (Rota, Pastori, Gelichi, Novara, Gabrielli), Toscana (Parenti, Quirós Castillo, Corsi, Redi), Campania (Guerriero, Rondinella). Las principales contribuciones a estos temas han salido a la luz en los últimos veinte años, en la publicación "Archeologia dell'Architettura"

Se trata de una revista italiana ${ }^{8}$, anexo anual de la publicación "Archeologia Medievale", con una larga tradición en el panorama arqueológico italiano (Francovich 1972). Hasta ahora "Archeologia dell'Architettura" cuenta con XII números editados a partir de 1996. Tras su publicación, se editó en España una revista con una filosofía similar, que sirvió de referencia y punto de encuentro para todos los expertos de la disciplina: "Arqueología de la Arquitectura" ${ }^{\prime \prime}$. Se trata de una publicación de rigurosa divulgación científica, de periodicidad anual, dirigida a arqueólogos, historiadores, historiadores de la

\footnotetext{
${ }^{7}$ MANNONI a partir de los años '70 ha recogido con su equipo del centro de investigación ISCUM (Instituto di Storia della cultura materiale, Genova-Italia) 50.000 datos relativos a ladrillos de la zona de Liguria y unos 20.000 datos propios de otras ciudades de norte de Italia

${ }^{8}$ La revista "Archeologia dell'Architettura" es editada por L'insegna del Giglio Ed. (FlorenciaItalia) y cuenta con la dirección editorial de BROGIOLO G.P. y GELICHI S.; tras la dirección histórica de MANNONI; ISSN 1126-6236; página web de referencia: www.edigiglio.it

${ }^{9}$ La revista es editada por CSIC/UPV (Universidad del País Vasco) cuenta con la dirección editorial de CABALLERO ZOREDA L., ISSN 1695-2731; página web de referencia: www.arqarqt.revistas.csic.es
} 
arquitectura y del arte, pero también a restauradores, arquitectos y profesionales relacionados con la documentación, estudio e intervención en el patrimonio edificado.

Su objetivo es doble: por una parte quiere promover marcos de debate e intercambio de ideas entre los estudiosos interesados en la arqueología de la arquitectura y, por otra, desea impulsar la creación de instrumentos básicos que den coherencia a las experiencias realizadas dentro de este ámbito disciplinar. Es una revista anual que hasta ahora cuenta con 7 números editados (2002/2010).

En los diversos números aparecidos en la revista han ido abordando áreas concretas de la geografía peninsular, objeto de estudios punteros de arqueometría. Estos análisis se han llevado a cabo principalmente en Andalucía (Almagro Gorbea, Graciani García, Tábales Rodrigúez) en el País Vasco (Azkárate Garai, Olaun, Lasagabaster Gómez, Quirós Castillo) en Galicia (Blanco Rotea) y Cataluña (López Mullor).

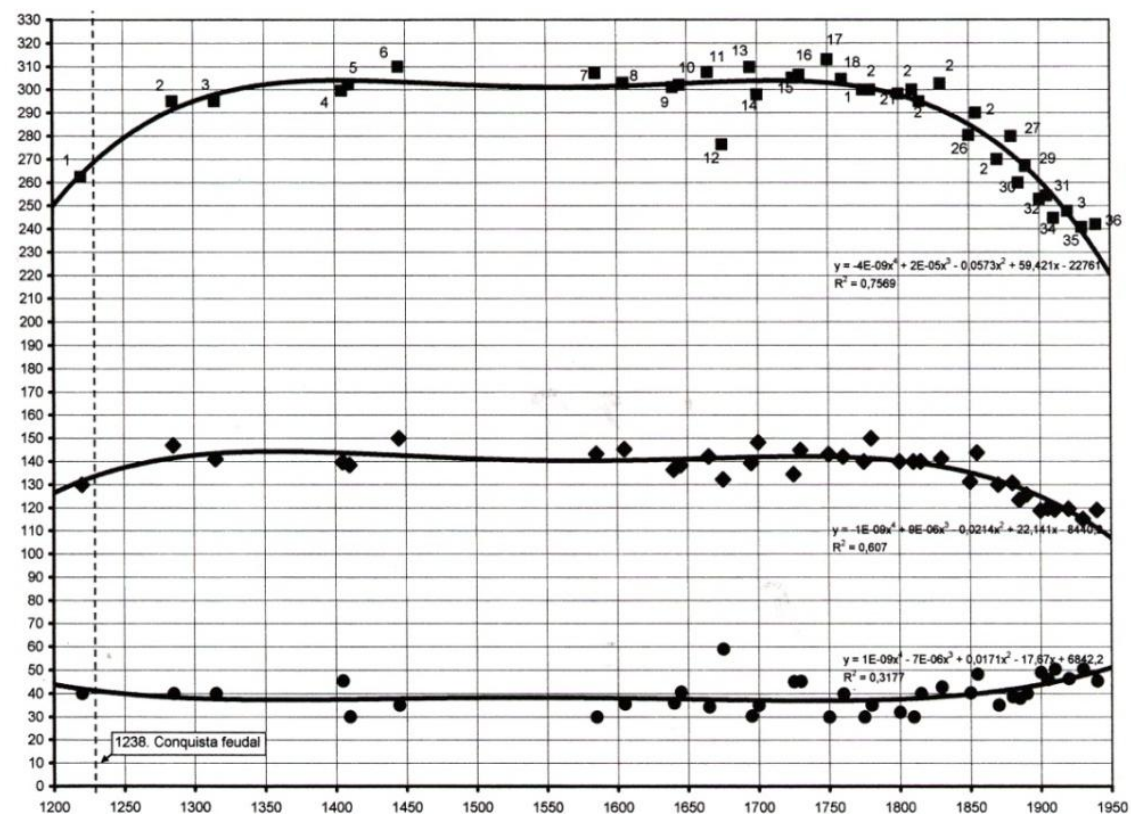

FIG. 17 Primera curva mensiocronológica para la ciudad de Valencia, longitud, anchura y espesor de ladrillos desde 1200 hasta 1960 (ALTARRIBA, GUILLÉN, GUZMÁN, ROJO, MARTÍ) 
En el caso concreto analizado por la autora, contextualizado en ciudad de Valencia, se marcan los estudios urbanos realizados por el SIAM (Altarriba, Guillén, Guzmán, Rojo, Martí).

La mensiocronología, o sea la disciplina capaz de relacionar fechas de producción/puesta en obra de los ladrillos con sus medidas, tiene sus pautas metodológicas en el análisis estadístico.

En este marco los principales parámetros aplicados a la mensiocronología tratan:

La muestra analizada. Es necesario seleccionar una muestra significativa, que sea representativa de la fábrica que se está analizando, para poder así depurar posibles factores de interferencias y error del análisis.

La media de las medidas registradas. Es necesario considerar la media de las diferentes medidas tomadas en situ (para poder controlar posibles errores debidos a alteraciones voluntarias de la fase de producción).

La desviación estándar de las medidas registradas. Es necesario considerar un índice específico (la media de la distancia entre las muestras y sus valores medios) de las diferentes medidas tomadas in situ. Este paso es fundamental para poder controlar posibles errores debidos a alteraciones involuntarias de la fase de producción).

La curva de distribución de las medidas. Es necesaria para considerar posibles errores en caso de re-empleo de material o soluciones de fábricas complejas.

Cruzando estos datos es posible elaborar un diagrama cartesiano que reúne dos variables, las fechas de producción y puesta en obra con las medidas de los ladrillos analizados.

Para un buen éxito del análisis es oportuno considerar un número suficiente de ladrillos a medir (15/20 ladrillos ya permiten considerar una toma de medidas potencialmente valida). También es importante considerar las tres dimensiones de los elementos medidos, 


\section{murOSINTRAMUROS}

considerando tanto la longitud (soga), como la anchura (tizón), así como el grueso (espesor) en todo tipo de análisis efectuado. Tras la selección de las zonas a estudiar no se prevé una selección por parte del medidor de los ladrillos visibles; no es oportuno medir voluntariamente muestras, bien al contrario es importante analizar todos los ladrillos visibles en un área homogénea. Una medición esmerada y rigurosa es la herramienta indispensable para el análisis que combina un sistema normalizado de fichas. Por todo esto, la mensiocronología no es una disciplina autónoma y fundamental. Se trata de cruzar los datos métricos con lecturas históricas, estratigráficas y constructivas, garantizando así la comprensión profunda del "documento/edificio" analizado.
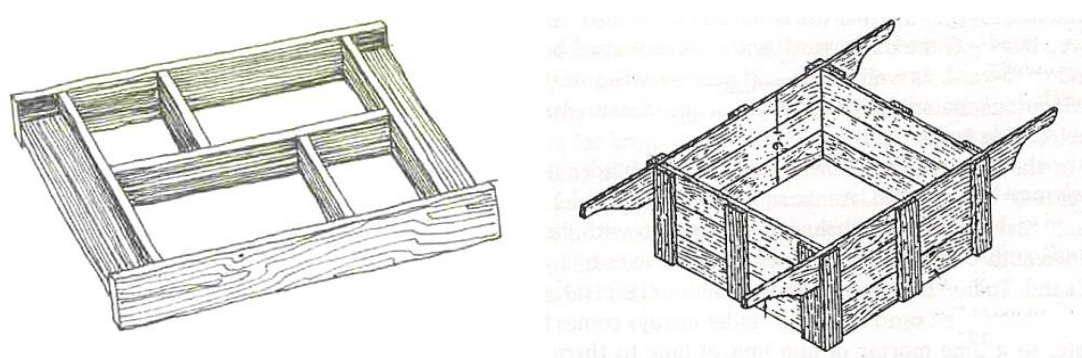

FIG. 18 Diferentes tipos de molde para ladrillos, simple y múltiple (MARTí y LINCH)

\subsubsection{El estudio de la cultura material ${ }^{10}$}

La cultura material es objeto de un vasto repertorio de disciplinas como la historia, la arqueología, la antropología cultural, etc... Con ella se suele indicar el conjunto de huellas culturales que una sociedad refleja en utensilios, herramientas, manufacturas, etc.

\footnotetext{
${ }^{10}$ Esta expresión se empleó por primera vez en ámbito filosófico a finales del siglo XIX (empleada entre otros por MARX y ENGELS), hasta fraguar en una primera definición gracias a Witold Kula, historiador polaco, director del "Instituto para el estudio de la cultura material de Varsovia" (1953). Por primera vez con sus estudios se separaron los conceptos de "historia económica"(que estudia los factores sociales que condicionan la producción y el consumo) de lo de "historia de la ciencia y de la técnica" (que estudia el nivel tecnológico de una sociedad, desvinculándolo de la producción). Para mayor detalle véase: BUCAILLE R., PESEZ J.M. ,Cultura materiale in Enciclopedia Einaudi. Torino, 1978. V. IV, p. 271-305
} 
vinculados a actividades productivas específicas y artesanales. Se trata entonces de una definición que aborda aspectos tangibles, reales y objetivos.

La noción de la cultura material, aplicada a la arquitectura, se ha desarrollado en los '70, sobre todo en arqueología, por una influencia indirecta ejercida por el materialismo histórico ${ }^{11}$. A partir de entonces se ha puesto la atención sobre los aspectos tangibles de la actividad productiva artesanal vinculada a la arquitectura, considerando productos, herramientas, así como los diferentes tipos de técnicas, materiales y objetos concretos relacionados con ella.

El estudio de la cultura material hace hincapié en todos estos aspectos, para relacionar entre sí, espacio, tiempo y sociedad. Incluso el hombre es parte del concepto de "cultura material", y sus acciones, vinculadas a oficios de la construcción, son transductoras de la semiótica, teselas para reconstruir la imagen global de una cultura constructiva de un determinado entorno.

Sin embargo, los objetos materiales, que constituyen la fábrica construida como el ladrillo, la piedra, la madera, el mortero, etc. traen consigo otras matrices culturales importantes, relacionadas con las artes, el derecho, la religión, el mercado económico, que a partir de los años '70 empezaron a no ser ya infravalorados.

La cultura material aborda tanto la construcción material como las relaciones indirectas vinculadas con la misma. Considerar los elementos constructivos históricos significa, por lo tanto, tener en cuenta toda una serie de factores tangenciales importantes vinculados a todo lo construido. La producción, el trasporte y el intercambio de los elementos constructivos, así como la venta, la puesta en obra, el empleo, etc. son parte de un abanico de términos

\footnotetext{
11" La concepción materialista tiene como axioma que la materia existe de forma independiente a la existencia de otras acciones. La evolución de la materia, su trabajo y su forma coinciden con la evolución humana" en MONDOLFO R., Il materialismo storico di Federico Engels, Firenze, 1972
} 
que formarían parte por tanto, de la cultura material de un determinado entorno social.

Todo esto se refiere a un enfoque metodológico que analiza no sólo la manufactura de lo construido, sino también la práctica de los diversos oficios que en cada inmueble pudieran devenir. La ejecución, el empleo, el derribo, la sustitución de la construcción histórica dejan huellas que podrían ser reconstruidas e identificadas.
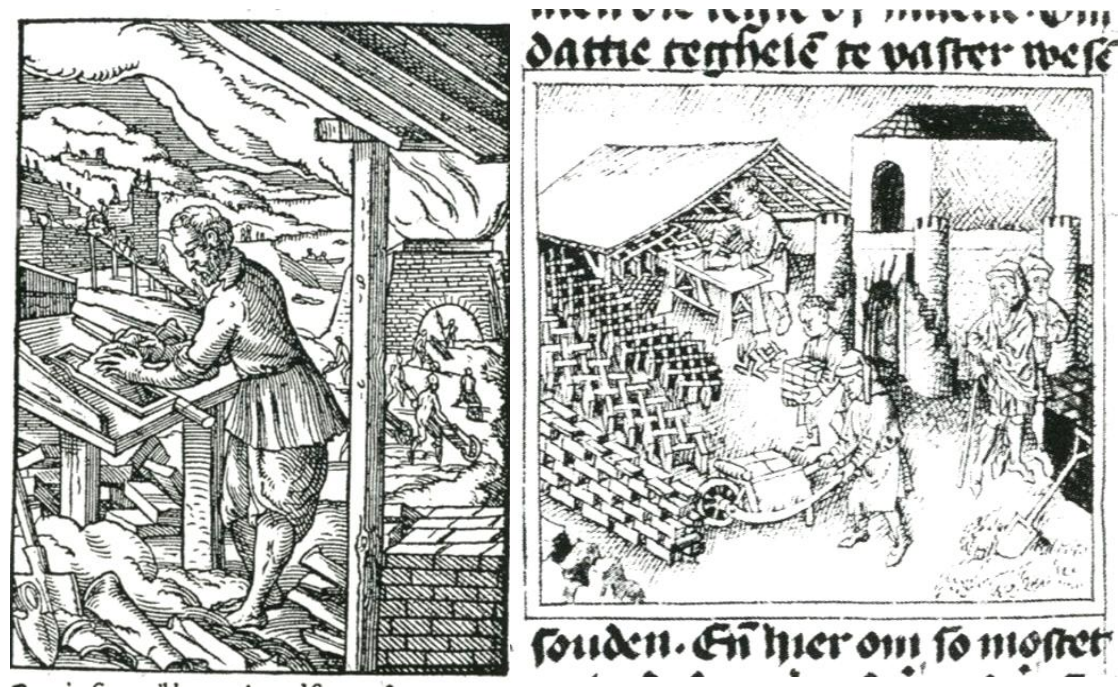

FIG. 19 Talleres medievales de ladrillos. Ilustración de Hartmanuss Shopperus's en Panopilia, Frankfurt- 1568 y Nederlandische Bijebel, Utrecht- 1425 (CAMBELL PRICE)

Por esta razón, con este tipo análisis de las técnicas constructivas y de todos los trabajos auxiliares, se pueden aclarar acciones y circunstancias históricas vinculadas entre sí. No sólo esto, sino también establecer relaciones entre actividades productivas con determinadas posturas sociales y gremiales.

"La cultura materiale di ogni gruppo sociale può essere ritenuta costituta cumulativamente dall'insieme dei manufatti, dai comportamenti o pratiche messe in atto per produrli, scambiarli, usarli, romperli, scartarli, dalle attribuzioni di significato relative sia ai manufatti in quanto tali sia al loro impiego. Ognuno di questi tre 
elementi costitutivi la cultura materiale è in rapporto con i restanti due con modalità dipendenti dal contesto e dalle reciproche storie.

La storia della cultura materiale deve sempre prendere in considerazione anche il sapere tecnico e la capacità operazionale di base indispensabile alla produzione e all'uso efficace di cui, in effetti, sono sempre leggibili i segni nella qualità complessiva data alla materia.

Insomma per portare a compimento le proprie indagini, la storia della cultura materiale, come prerequisito, deve padroneggiare quello che è stato definito il vocabolario o la lingua, deve cioè essere capace di riconoscere le correlazioni possibili tra resti materiali e comportamenti"12.
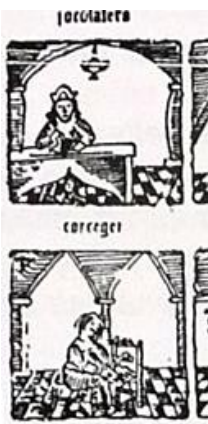

embagad ot

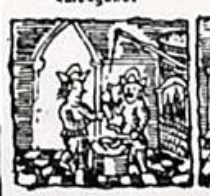

ferisder

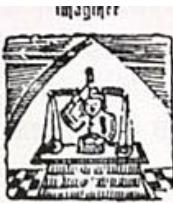

carnitu

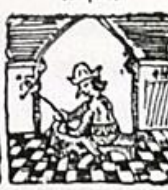

(s;uset

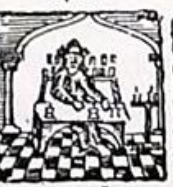

pasamanter

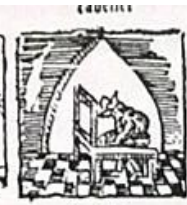

botidylor

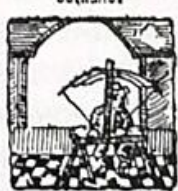

lornct

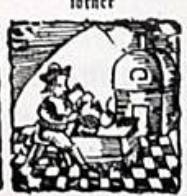

vitrits

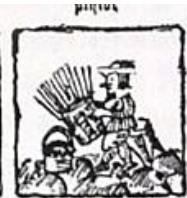

risteller

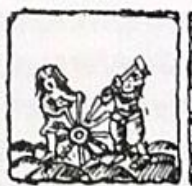

upsity daiso

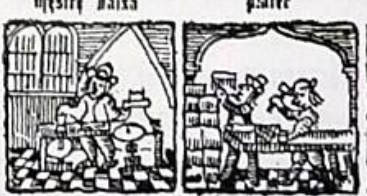

ericaderuador

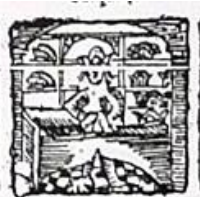

soupbrater
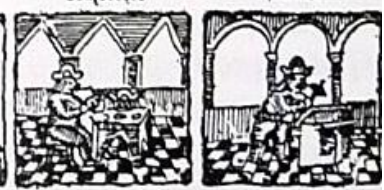

Itd:epigues

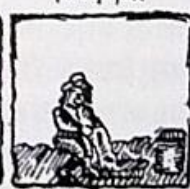

FIG. 20 Extracto de "Aleluya de los Oficios", impresa en valencia, por Miquel Borrás, en 1578, según Gayano Lluch la más antigua de España (SANCHIS GUARNER)

\subsubsection{Cronotipología}

Referirse al concepto de tipo y tipología en arquitectura es una cuestión sumamente delicada, debido a la gran cantidad de matices

\footnotetext{
${ }^{12}$ GIANNICHEDDA E., Cultura materiale, in R. FRANCOVICH R., D. MANACORDA D. (editores) Dizionario di archeologia, Torino, 2000, p. 99-104
} 
que estos términos han asumido en disciplinas como historia del arte o de la arquitectura. Pero a la vez es necesario establecer de una manera clara el proceso de construcción de las fábricas del centro urbano de Valencia, todo ello gracias a la determinación de unos parámetros definidos en el tiempo y en el crecimiento urbano.

Por esto los indicadores empleados en el estudio apuntan a establecer cronotipologías, dejando a un lado otros tipos de baremos "tipológicos funcionales, artísticos o técnicos" (Clarke 1978- Klejn 1982). El indicador cronotipológico, aplicado al ámbito de la arquitectura, busca una declinación menos idealista y mucho más material de la construcción histórica, sobre todo, porque su empleo tiene fines distintos de un mero análisis filológico-formal (Quirós Castillo 1996).

Esta aproximación a las estructuras históricas es bastante reciente, habiéndose aplicado por primera vez en Italia entre los años '70 y '80. En estos casos, la postura de los estudiosos se aleja de una posición idealista; al revés, busca una cercanía con el contexto concreto y bien determinado del edificio vinculado a su cultura material (Ferrando, Mannoni, Pagella, 1989).

En este contexto las partes de los edificios, susceptibles de ser analizadas son aquellas que, limitadas a espacios geográficos determinados, ofrecen una cierta homogeneidad productiva. Por esto, una vez identificados un grupo de edificios, es posible identificar aquellos elementos distintos y significativos para, de este modo, obtener unas cronologías más precisas de sus secuencias constructivas (Quirós Castillo 1996).

Según estas líneas-guía una de las tipologías más útiles y más estudiada en los edificios es la de los vanos (puertas y ventanas) y sus acabados, que se han definido como "los ojos y la boca del edificio" por su carga simbólica y decorativa, y que se han empezado a estudiar de forma sistemática en contextos de arqueología de la arquitectura, en Italia en los '80 (Ferrando, Mannoni, Pagella, 1989- 
Ferrando, Gardini, Annoni, 1978- Ferrando Crusi 1980, Quirós Castillo 1992).

La presencia de instrumentos cronológicos de ámbito local es un indicador muy significativo del desarrollo y de la madurez del estudio de la arquitectura histórica de un determinado entorno. Por esto la falta de estos indicadores en el ámbito del centro histórico de Valencia, hacen necesaria y potencialmente crucial la definición de un atlas que recoja todos estos parámetros indicados.

Según los autores de los estudios realizados en Italia y España, la identificación de una cronotipología requiere la elaboración de un programa de recogida y definición de datos adecuados al tipo de evidencia constructiva que se quiere definir. Por ello, en este marco, se han propuesto los siguientes parámetros de búsqueda:

- Elección de muestras datadas

- Documentación de discriminantes cronológicos

- Elaboración de datos

- Definición del área de aplicación del método

Elección de muestras. Para realizar una cronotipología es necesario contar con unos elementos arquitectónicos que se puedan fijar y fechar con certeza. Cuanto mayor es el conjunto de ejemplares datados, más amplia y segura será la cronotipología.

Documentación de discriminantes cronotipológicos. Estos son muy variados, desde aspectos dimensionales hasta factores microformales pueden ser factores discriminantes de gran importancia (como por ejemplo aparejos/ acabados/ vanos/ remates/ molduras...etc).

Elaboración de datos. Es la fase más crítica de la propuesta de cronotipología por el hecho que no existe un modelo universal que puede sugerir posturas pre determinadas, dependiendo de los datos que se encuentran según el caso estudio realizado. Pero reagrupar tipologías es siempre una acción indispensable en los estudios cronotipológicos. De hecho, sólo a través de este análisis es posible 
identificar soluciones básicas recurrentes y empleadas en periodos muy amplios, así como casos anómalos y puntuales que pueden alterar la cronotipología definida (aspectos interesantes a considerar en cualquier caso).

Definición del área de aplicación del método. Identificar el área de estudio es una de las premisas necesarias antes de emplear identificadores cronotipológicos locales. Es indispensable en este caso definir tanto los diferentes grados de "pureza" y de "hibridación" que tienen los indicadores en ámbito local, para poder así calibrar bien el estudio cronotipológico.

\subsubsection{Diagnóstico y estudios analíticos}

La identificación de las patologías que afecta a las fábricas del centro histórico de Valencia y a la vez, la definición de pautas que marcan unas líneas-guía para su conservación, son aspectos que ahondan sus raíces en la disciplina de la diagnosis vinculada a la restauración arquitectónica.

El diagnóstico (del griego diagnostikós, a su vez del prefijo día, "a través", y gnosis, "conocimiento" o "apto para conocer") alude, en general, al análisis que se realiza para determinar una situación y las posibles tendencias vinculadas a ella. Este proceso, posible gracias a una base de datos y hechos recogidos y ordenados sistemáticamente, permite evaluar un cuadro patológico definido. Esta disciplina, aplicada a la construcción histórica, en este caso histórico, permite determinar situaciones críticas y delicadas, asociadas a específicos ámbitos construidos.

Las alteraciones se identifican, como potenciales modificaciones materiales, pero sin implicar necesariamente un empobrecimiento de la construcción, sino más bien una invariable evolución en el tiempo.

Por lo tanto, una vez identificadas situaciones críticas se procede a remarcar las causas de alteración de las fábricas y proceder a identificar posibles medidas correctivas. 


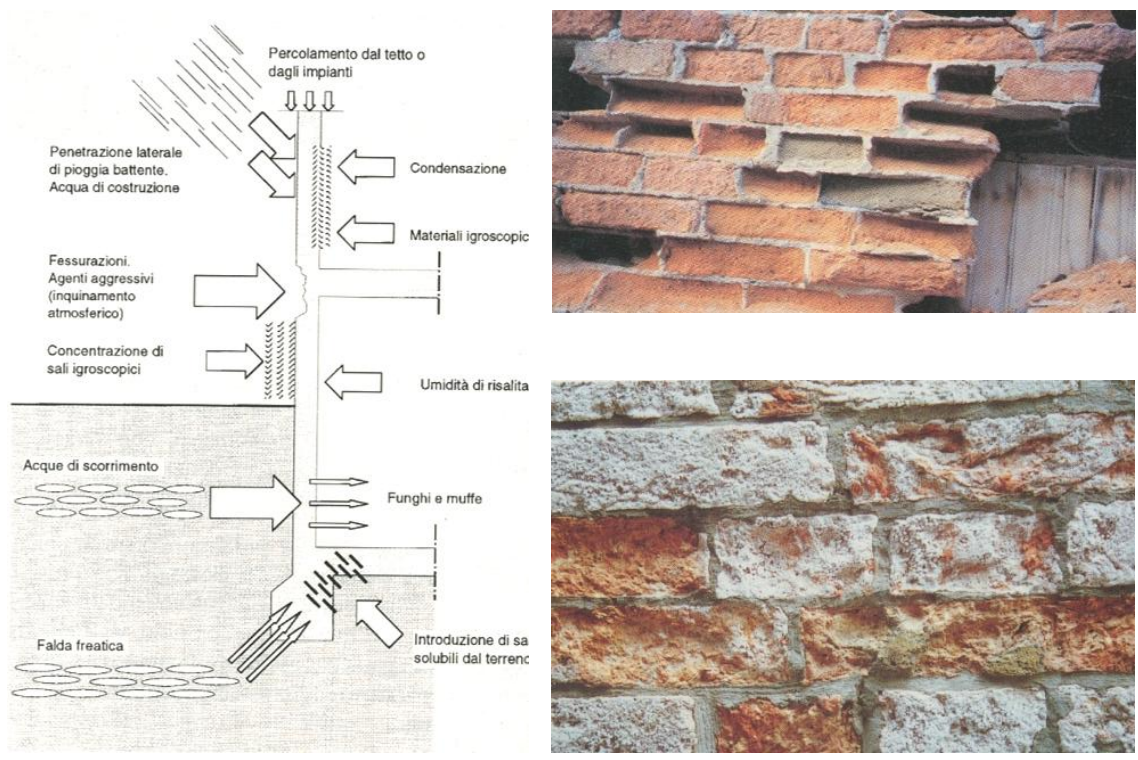

FIG. 21 Esquema de las principales causas que pueden afectar a fábricas de ladrillos diferentes problemas de humedad (LANER, GIACALONE, PALA)

El diagnostico vinculado a las fábricas históricas de ladrillo es una disciplina enraizada en España, pero que tiene poco nivel de profundización y muy pocas investigaciones recientes. Ladrillos históricos solo han sido objeto de un único congreso/encuentro internacional en $1999^{13}$. A partir de entonces, a pesar de los importantes pasos realizados por la ciencia y las tecnologías vinculadas al diagnóstico, no se han realizado otros encuentros $u$ otros momentos de reflexión en territorio nacional. Sin duda hay más información y más guías de intervención para la correcta puesta en obra de ladrillo en las fábricas nuevas. Por lo tanto los problemas de ladrillo cara a vista en edificios contemporáneos, así como indicaciones normativas relativas al cumplimento de códigos técnicos o prestaciones estructurales y ensayos para el ladrillo en las obras contemporánea son objeto de una bibliografía actualizada y sin duda mucho más puesta al día.

\footnotetext{
${ }^{13}$ AA.VV., Actas del Congreso Internacional sobre restauración del ladrillo, IEA Ed., León, 1999
} 


\subsection{Propuesta metodológica descriptiva y analítica}

La metodología empleada en el desarrollo del estudio de las técnicas constructivas de fábricas de ladrillo en la zona intramuros de Valencia profundiza en la línea marcada en el anterior estudio de la autora ${ }^{1}$. Se ha intentado buscar un método de investigación progresivo y multidisciplinar de las fábricas históricas. Las fuentes consultadas en la investigación, de doble tipología, tanto directas in situ como indirectas, han permitido descubrir aspectos no conocidos e interesantes, sobre todo relativos a una posible identificación de las fábricas. Por esta razón, la metodología de investigación se plantea para la elaboración de un registro de información, orientando a la documentación y catalogación de las fábricas de ladrillo de los edificios.

\subsubsection{Fuentes directas}

El análisis y la reflexión sobre el propio tejido urbano es el punto de partida fundamental del estudio. Con la base del plano del catastro de Valencia (COACV) se han fotografiado y catalogados 4.437 edificios del centro histórico de la ciudad ${ }^{2}$, según el barrio de pertenencia. Se ha procedido más adelante a la selección y clasificación de las fotos, filtrando los 84 ejemplos destacados que

\footnotetext{
${ }^{1}$ CRISTINI V., "Valencia, ciudad vella, ladrillos cara a vista, agramilados, fingidos y enlucidos. Analisi delle murature in laterizio: prassi costruttiva ed evoluzione archeometrica"; Tutores: Bellini A., Mileto C., Pertot G., Politecnico di Milano, diciembre 2005

${ }^{2}$ MILETO C. (investigador principal entre otros), Carácteres constructivos del centro histórico de Valencia; Análisis, caracterización y conservación; Generalitat Valenciana (ref: GVPRE/2008/240)
} 


\section{MUROSINTRAMUROS}

tenían fábricas de ladrillos, en todas sus variantes, en buen estado de conservación, y con suficientes elementos cerámicos identificables para el estudio (5 hiladas visibles).
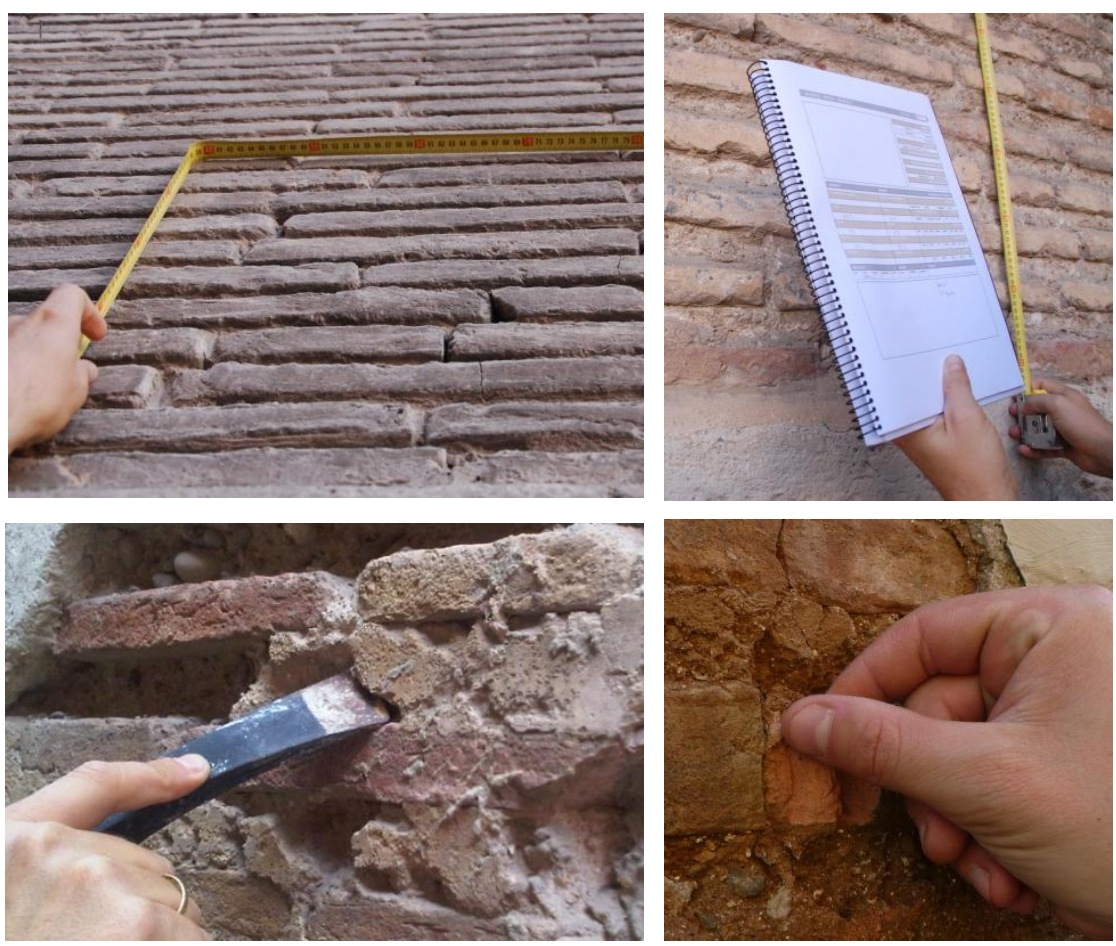

FIG. 22. Mediciones, toma de datos, selección extracción y recogida de muestras de ladrillos y morteros. Análisis empírico in situ (CRISTINI)

Una vez identificados los edificios con presencia de ladrillo en la zona intramuros, se ha realizado una recopilación de los aspectos técnicos/diagnósticos/analíticos de las fábricas analizadas, a través de 95 fichas, que recopilan datos tomados in situ sobre las diferentes características constructivas ${ }^{3}$. Se ha procedido a elaborar criterios de intervención de las fábricas, una vez analizadas sus probables patologías y problemas, con la finalidad de delimitar posibles tratamientos de los paramentos analizados. Estos procedimientos

3 Las fábricas analizadas se reparten en barrio del Carmen (32) ,Mercat (17), S.Francesc (9), Velluters (16), la Seu-Xerea (21) 
han sido propuestos según una identificación y comprensión de las características constructivas, intentando reducir y limitar la posible intromisión de criterios subjetivos, gustos personales o modas (ver. Anejo II).
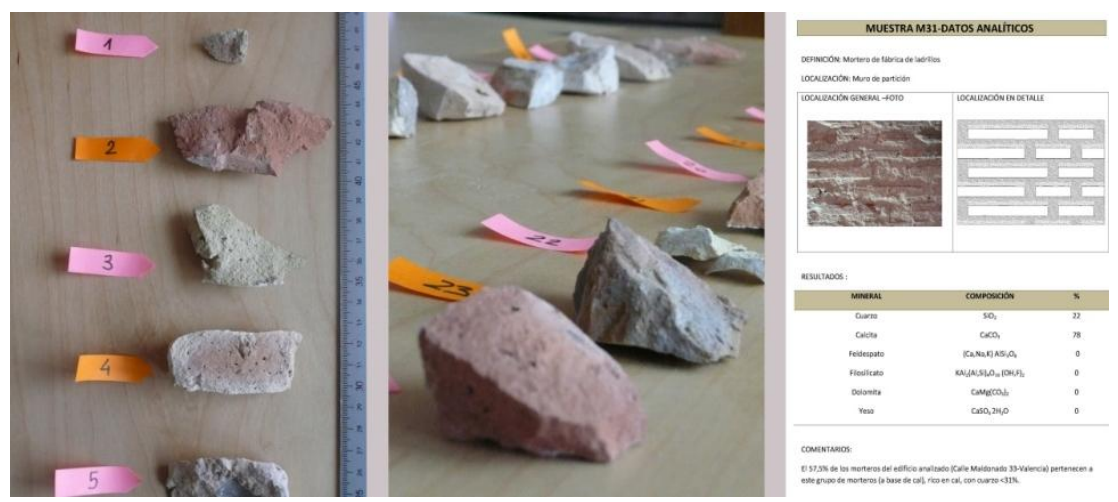

FIG. 23.Proceso de clasificación de muestras de ladrillos y morteros (CRISTINI)

En algún caso significativo se han procedido a efectuar análisis químicos y granulométricos de algunas muestras. En este caso, se han analizado muestras de ladrillos (6análisis efectuados ${ }^{4}$ para establecer la materia prima de morteros y arcilla empleada en las fábricas u otros posibles aditivos y componentes) ${ }^{5}$ (ver Anejo III).

\subsubsection{Fuentes indirectas}

No es posible tener un panorama completo del estudio del centro histórico de Valencia sin realizar un detenido análisis cultural, sociológico, geográfico intentando identificar unos "marcadores" específicos sobre el contexto autóctono. El ámbito mercantil y comercial o los hábitos gremiales son realidades interesantes, que pertenecen a la tesitura más íntima de las fábricas cerámicas.

Se ha procedido a un estudio de la documentación de algunos de los Fondos del Archivo Histórico Municipal, en el que se conservan los

\footnotetext{
${ }^{4}$ La muestras se han efectuado para las fábricas Cg01, Cf30, Va119, Cg48, Va 82 y Fa153
} 


\section{murOSINTRAMUROS}

expedientes de la Policía Urbana, considerados interesantes para definir las posibles modificaciones de fachadas hasta finales del siglo XIX.

Realmente este fondo documental constituye una fuente inagotable de información para el estudio de las características formales y estilíisticas de las construcciones desarrolladas en Valencia en los últimos siglos. Pero aún más interesante para el estudio ha sido la consulta de los libros del Mustaçaf, funcionario urbano que controlaba la venta y el comercio de la arcilla y los ladrillos ${ }^{6}$.
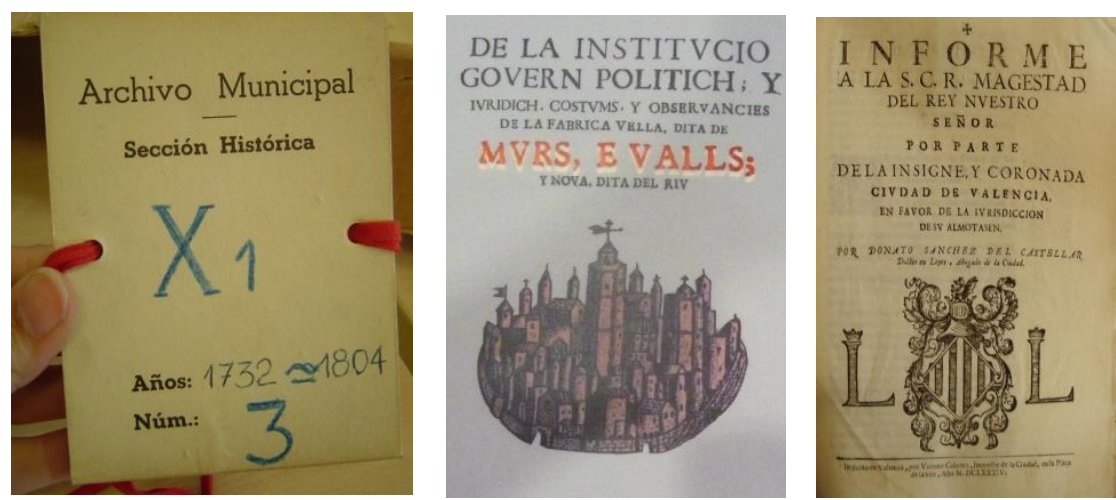

FIG. 24. Consulta de informes del Mustaçaf en el Archivo Histórico Municipal de Valencia (CRISTINI)

Para abarcar también un análisis sobre posibles huellas arqueológicas de la ciudad, se ha realizado el "vaciado" del depósito del SIAM (Servicio de Investigación Arqueológica Municipal de la ciudad de Valencia), donde se han podido redactar 19 fichas relativas a diferentes ladrillos (romanos, bajo medievales, alto medievales).

Estas muestras, localizadas en los $2.300 \mathrm{~m}^{2}$ del depósito del SIAM en el Polígono de Vara de Quart (Valencia), pertenecen a 10 excavaciones arqueológicas que recogen, entre el material clasificado, muestras de piezas enteras de ladrillos ${ }^{7}$.

\footnotetext{
"Véase "Cap. 4.3. Vendedores y controladores: mercato y comercio"

${ }^{7}$ Véase "Anejo II. Recopilación de datos arqueológicos"
} 

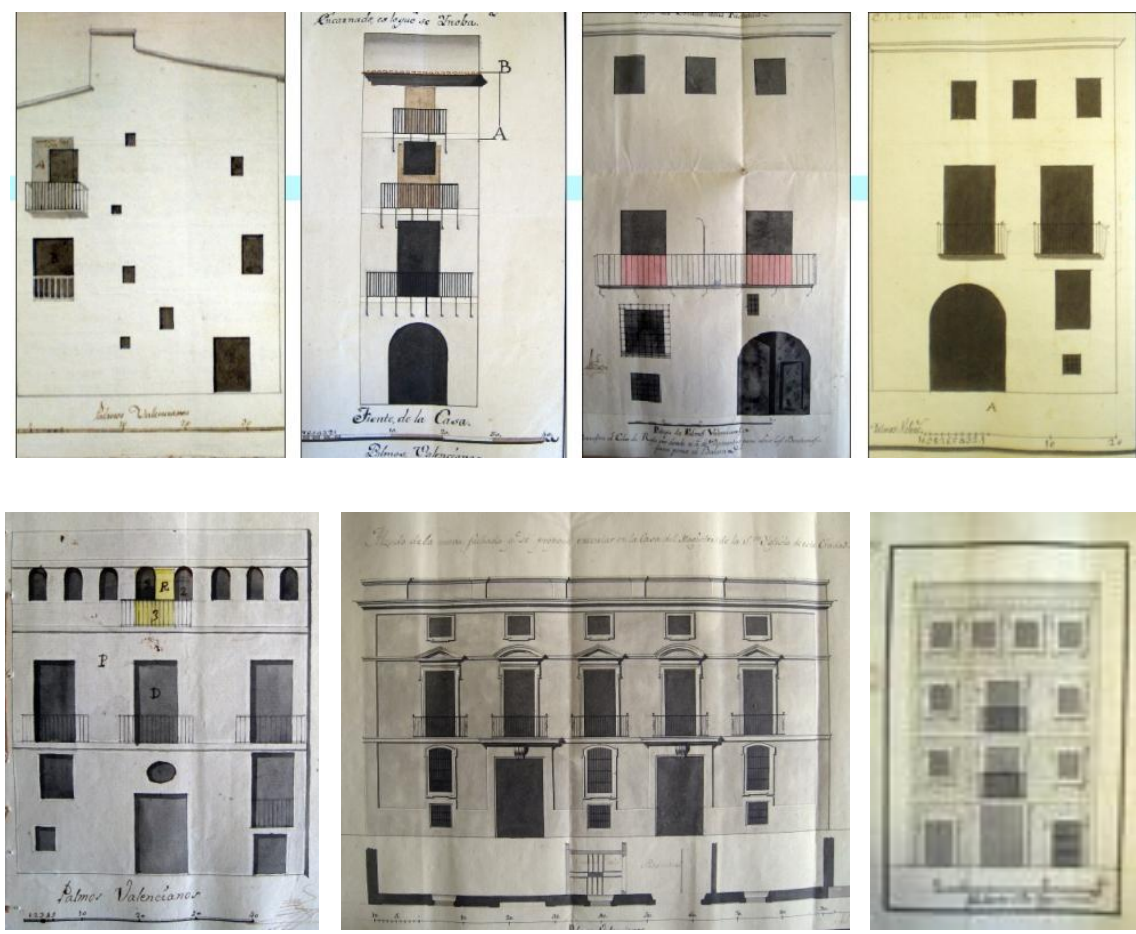

FIG. 25. Selección de Fachadas hasta finales del S. XIX, con posibles referencias a fábricas de ladrillo, Expedientes de Policía Municipal, Archivo Histórico Municipal de Valencia (CRISTINI)

Finalmente tras la información cruzada, entre análisis directo in situ ${ }^{8}$ y análisis indirecto a través de documentos bibliográficos documentales, ha sido posible establecer una propuesta de cronotipología de las fábricas que vamos a presentar a continuación?

\footnotetext{
${ }^{8}$ Se han realizado globalmente 2.070 mediciones de ladrillos (puestos en obra y arquelógicos) así como de 3.120 mediciones de juntas (llagas y tendeles). Esto suma un total de 5.190 mediciones

${ }^{9}$ Véase "Cap.7. Conclusiones"
} 
MUROSINTRAMUROS
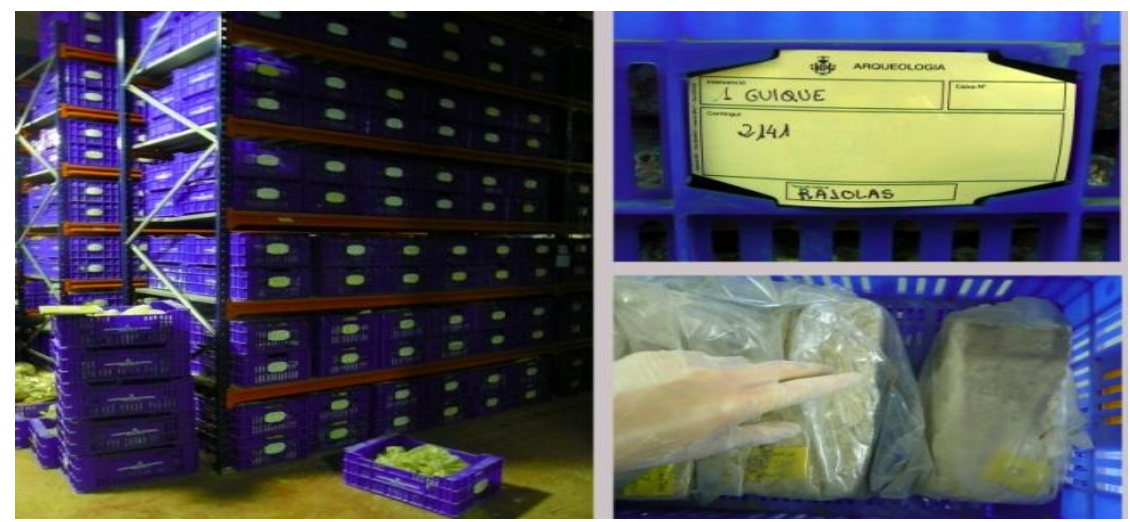

FIG. 26. Vaciado del depósito del Siam; selección de ladrillos, limpieza y estudio (CRISTINI)
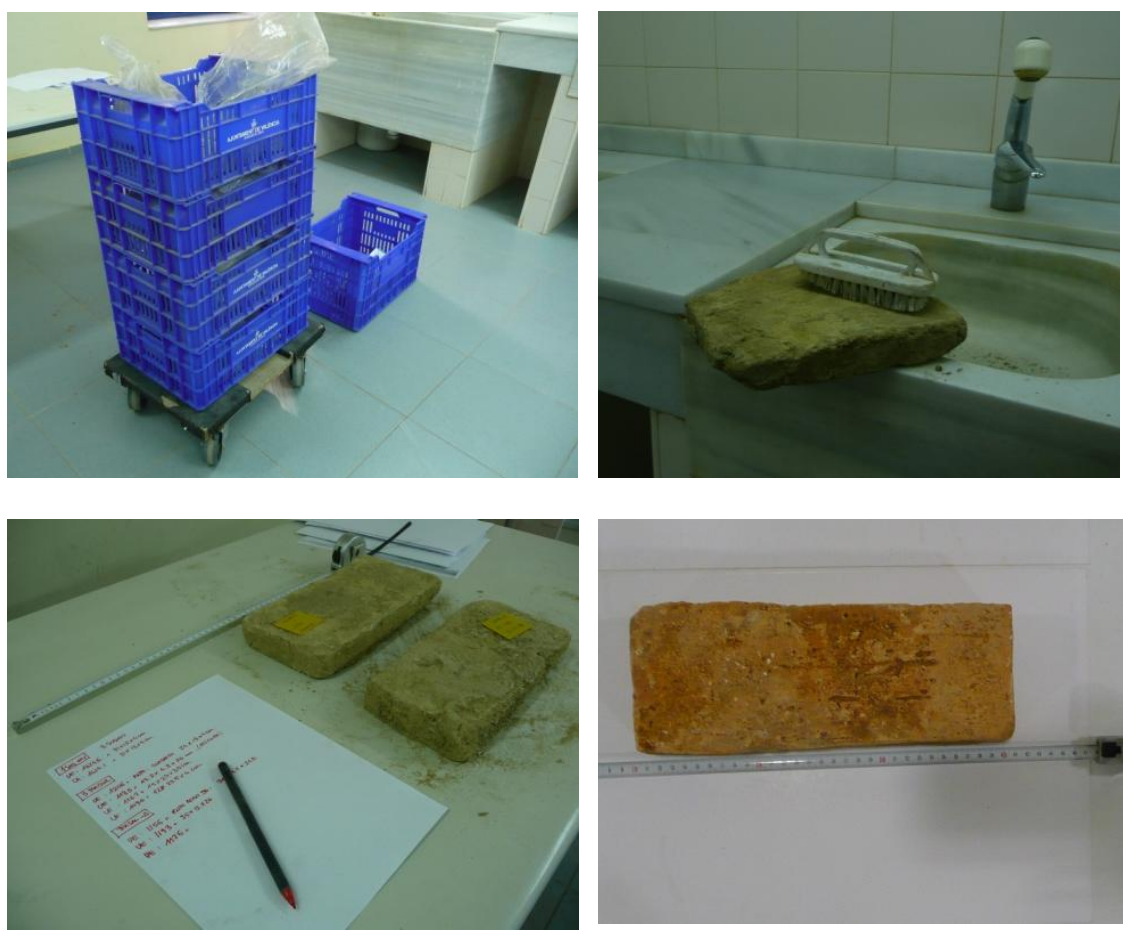
3. La identidad del centro histórico de Valencia 



\subsection{Perfil geomorfológico y geológico}

Desde la disciplina de la edafología ${ }^{1}$, el área urbana de Valencia se puede definir como una amplia depresión de origen tectónico, conformada por diversas unidades fisiográficas que se estratifican en la llanura de inundación costera del Río Turia. Entre estas unidades, muchos autores ${ }^{2}$ destacan la calidad de la arcilla de la plataforma pleistocena del Pla de Quart, rica en hierro y manganeso, y también los yacimientos Los Cabeços d'Alhet.

En general, estas zonas se enfrentan a la amplia y estéril barrera arenosa del litoral de la costa entre Valencia y Cullera, una zona marcada por regulares y periódicas plataformas detríticas (Carmona) . $^{3}$

Por otro lado, si hablamos en términos de geomorfología, la llanura aluvial del Río Turia, se corresponde a una estrecha y continua franja de época cuaternaria rica en arcillas, que se conforma con una secuencia regular de terrazas encajadas en un abanico aluvial. Justo en este entorno se han generado los estratos de arcilla, merced al milenario aporte a lo largo del Pleistoceno de detritos y movimientos del lecho del Río Turia.

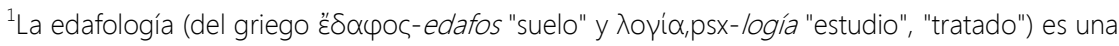
rama de la ciencia del suelo que estudia la composición y naturaleza del terreno (RAE)

${ }^{2}$ AURA, DOMENECH, MOLERA, VENDRELL, COLL CONESA entre otros...

${ }^{3}$ CARMONA P., "El Medio natural", en La Ciudad de Valencia, Geografía y Arte, vol.II, Ayto. Ed., Valencia, 2009.p. 21-43

CARMONA P. "Las terrazas del bajo Río Turia", Tesis doctoral, UV, Facultat de Geografía, Valencia, 1982, p.134-167

CARMONA P. "Geomorfología de la llanura de Valencia; el Río Turia y la Ciudad" en Historia de la ciudad II, Territorio, Sociedad y patrimonio, ICARO, Valencia, 2002
} 
En los alrededores de la ciudad se encuentran estos estratos, reconocibles por sus marcados niveles de materiales arcillosos y limosos. Sus característicos colores de de tonos rojizos, con nódulos de carbonatos, bandas de conglomerados y costras de carbonatos, acompañan la evolución constructiva urbana de la ciudad (Añadon Alcalá 2004) $)^{4}$.

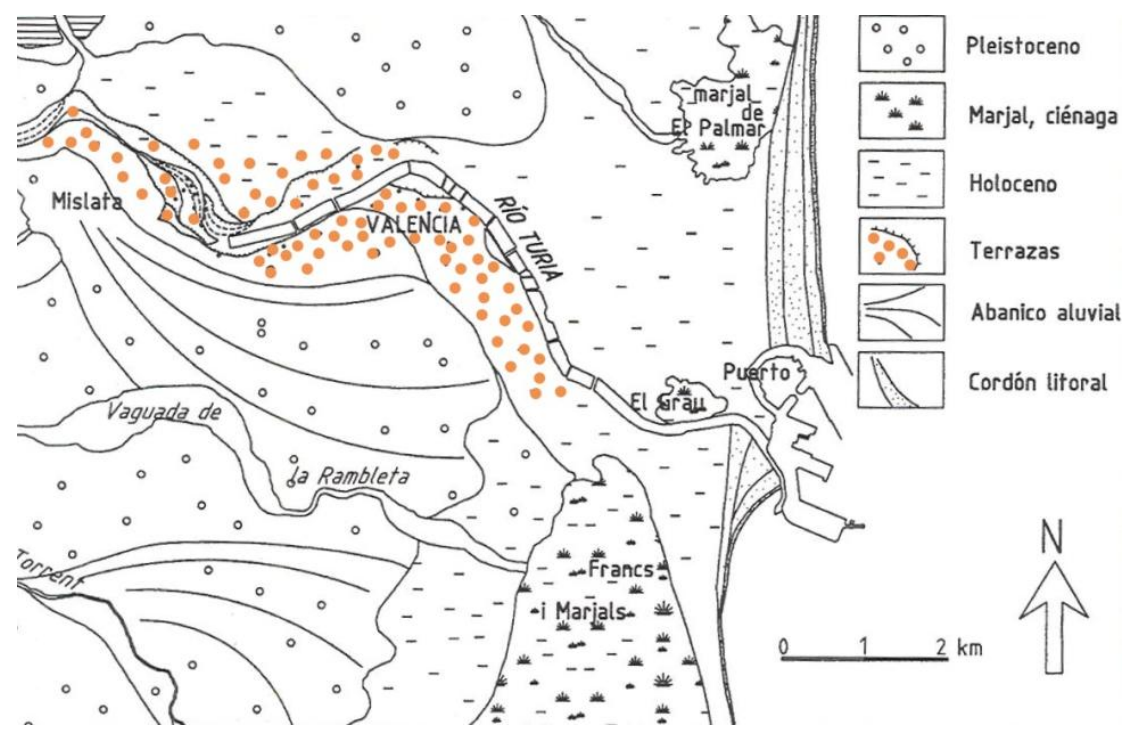

FIG. 22 Geomorfología de la llanura de Valencia; en naranja se evidencian las terrazas con depósitos de arcilla de mayor calidad y concentración (CARMONA-RUIZ)

Pero hay que considerar también que los sedimentos, a pesar de su presencia a escasa profundidad en el subsuelo, no son todos iguales. Las arcillas están camufladas y alternadas por los estratos de limos del delta del Río Turia, que conforman las capas más superficiales y fértiles de la llanura aluvial costera.

Estos mismos estratos que constituyen el material fértil de la conocida huerta valenciana, conforman paquetes de cantos y gravas empastados en una matriz suelta de arenas y fértiles limos.

${ }^{4}$ AÑADÓN, ALCALÁ, "Morphological taphonomic transformations in continental environments, and repercussions on their chemical composition" en Archaeometry, no 44, Fribourg, p. 353-36 
Una vez identificados estos rasgos geológicos de la zona de Valencia es bastante inmediato conectar los caracteres constructivos históricos de la ciudad a la materia prima inmediata que se podía encontrar en los alrededores del recinto urbano.

UNIDADES LITOLÓGICAS DE AMBIENTE FLUVIODELTAICO

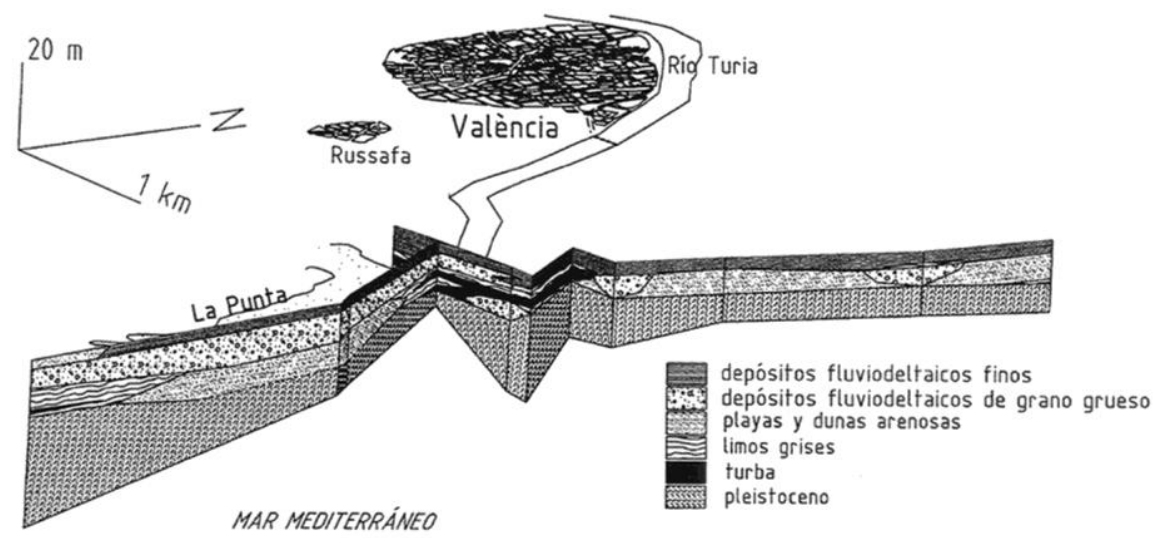

FIG. 23 Unidades litológicas estériles del ambiente fluviodeltaico, con ausencia de depósitos de arcilla en zonas próximas a la costa (CARMONA RUIZ)

En esta zona llana y rica de sedimentos, la arcilla ha adquirido el protagonismo de las construcciones históricas desde la Antigüedad. Las arcillas, en esta zona llana, rica de sedimentos, han sido la base de las construcciones históricas. El río Turia, con una longitud de 280 $\mathrm{km}$ y con una cuenca de drenaje de $6.393 \mathrm{~km}^{2}$, ha sido siempre un inagotable recurso de arcilla para la ciudad, con fáciles afloramientos freáticos ricos de abundantes materias primas, próximas a los marjales costeros. Se conoce incluso que las frecuentes inundaciones que la ciudad ha sufrido a lo largo de los siglos ${ }^{5}$ han garantizado indirectamente depósitos abundantes de materias primas (siempre en términos de arcillas) para el abastecimiento urbano. ${ }^{6}$

\footnotetext{
${ }^{5}$ A lo largo de un periodo de 700 años se han registrados unos 89 sucesos de inundaciones y episodios dramático relativos a las inundaciones del Turia, registrados entre 1300 y 2000, (CARMONA 2009)
} 


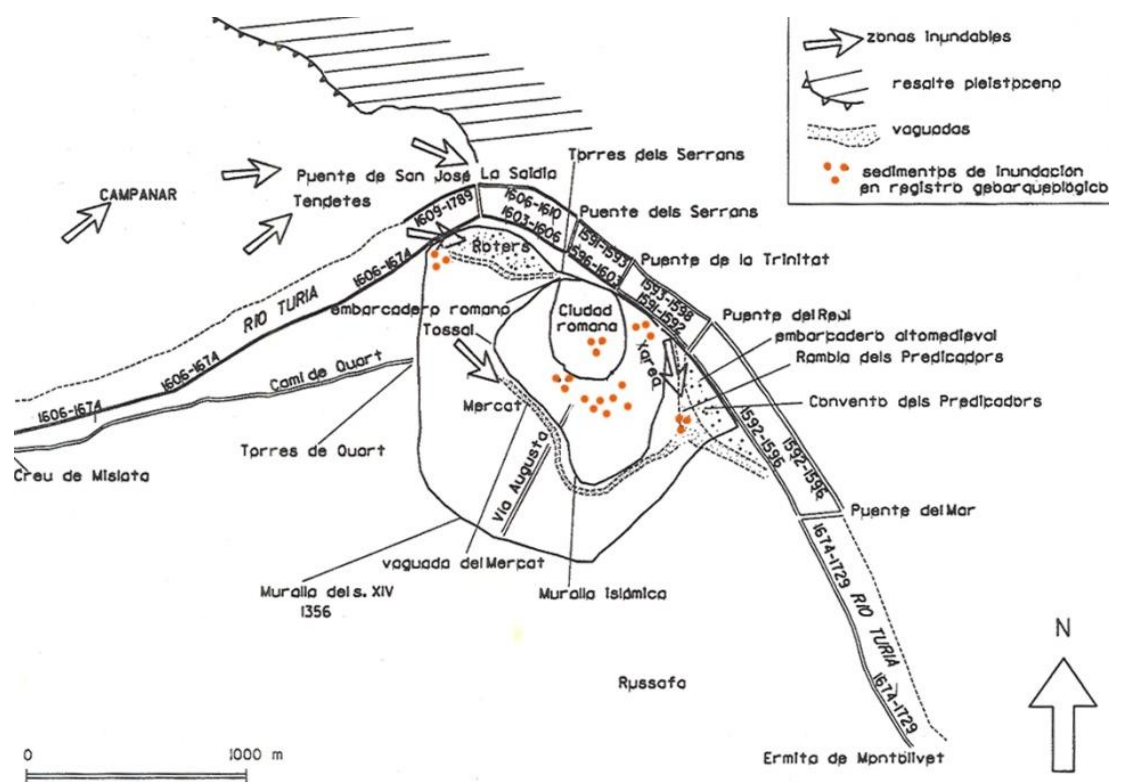

FIG. 24 Áreas con concentración de sedimentos de inundación a base de arcillas (CARMONA)

\subsubsection{La mirada histórica hacia la edafología de Valencia}

Una contribución al estudio que define una importante postura histórica y edafológica relativa al tema de las arcillas, es la investigación de Cavanilles Y Palop A.J (1795), en la que, a lo largo de la descripción de los bienes naturales del Reino de Valencia, se recopilan unos pasos interesantes relativos a las diferentes arcillas y minerales que caracterizan los suelos de la capital del Turia.

"...Por esto se observa cierta semejanza en las tierras del Reino de Valencia, según el origen que tuvieron. En todas se reconoce la marga, dominando por lo común la arcilla, siendo esta tan abundante y fina en muchas partes, que sirve para las fábricas de alfarería y loza. Dos son los colores principales de la tierra, blanco y rojo. Este se ve en la larga extensión que hay desde Oliva hasta

${ }^{6}$ Las crónicas escritas más significativas y detalladas sobre las riadas que han afectado a la ciudad y que, indirectamente, han proporcionado también sus ricos substratos son, entre otras: SALES, 1760, TEIXIDOR 1767, CARBONERES 1873, PORCAR 1934, ALMELA 1957 
Castelló de la Plana, continuando después hacia el norte por el Maestrazgo de Montesa: el blanco es más general, y con varios tintes cubre el resto del Reino. La tierra roja no se halla en el mismo estado en todas partes. Siempre es arcillosa, y se halla mas ó menos tostada, y con varias mezclas de arenas..."

\section{"... Esta especie de tierra pasa de la suma dureza al estado de polvo} sin unión, cuando se deja por un año expuesta á la inclemencia del tiempo, y en tal estado sirve de abono para fertilizar los campos arenosos, recurso que practican con conocimiento muchos labradores. Cuando en las lomas y cerros llegó á tomar la consistencia de piedra floja, dispuesta en hojas muy sutiles, admite gran variedad de colores desde el blanco hasta el de color de hígado. Estos colores se alteran al fuego, pasando del amarillo al rojo, y del pardo al amarillo; pero no es constante esta mutación, porque muchas veces el blanco y el pardo conservan su color al fuego más activo. ¡Qué variedad en la apariencia y caracteres! ¿Serán por ventura de diferente naturaleza estas tierras, como parecen indicarlo las señales exteriores ?: O deberán atribuirse estos fenómenos á varías mezclas y combinaciones de los elementos primordiales ?." "8

"...La huerta entera de Valencia hasta las raíces de los cerros y montes debió ser mar en otros siglos posteriores á la época en que todo el Reino estuvo sumergido. El grueso banco de arena que desde el mar se prolonga hasta los cerros opuestos, siempre á mayor profundidad según la distancia; la arcilla que cubre las arenas, mas ó menos sólida y de diferente espesor; la tierra en fin que desde la arcilla sigue hasta la superficie actual de nuestro suelo, todo prueba que las aguas produjeron esta dicha mutación..."

\footnotetext{
${ }^{7}$ CAVANILLES Y PALOP A.J., Observaciones sobre la Historia Natural, Geografía, Agricultura, población y frutos del reyno de Valencia, Imprenta Real, Madrid, 1795, tomo 1, p.8-9

${ }^{8}$ (CAVANILLES Y PALOP A.J.), op. cit, p.9

${ }^{9}$ (CAVANILLES Y PALOP A.J.) op. cit, p.130
} 
"...Por la izquierda del río siguen hacia todas partes llanuras no menos fértiles que bien aprovechadas. Un cuarto de legua al noreste a Campanar se halla Beniferri, pueblo de 50 vecinos, ocupados en cultivar hermosa huerta. Atravesando después las acequias de Tormos y Moncada, se ve la izquierda de esta última sembrada de lugares, muchos de ellos considerables por su vecindario y riqueza: estos son Benimaámet, Burjasot, Godella, Rocafort, Masarrojos, Moncada y Alfara del Patriarca."
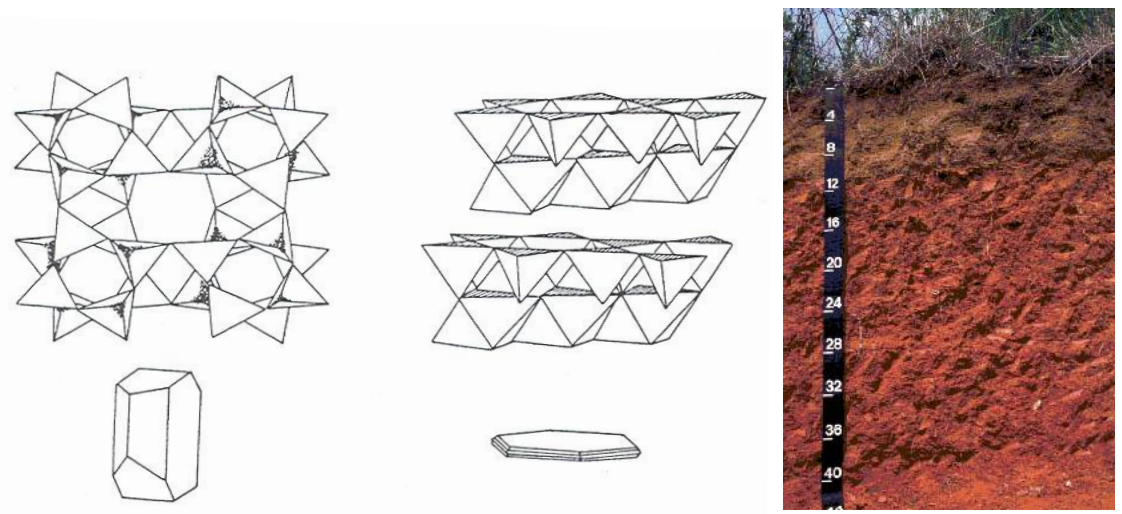

FIG .25 Estructura molecular de dos diferentes tipos arcillas, más calcárea (izquierda) o con más hierro (derecha). Esta última caracteriza una sección litológica efectuada en Alfara del Patriarca (Valencia) (CAGNANA- CRISTINI)

"Se extienden sus términos por la parte occidental formando lomas y cerros incapaces de riego por su mucha altura, pero por lado oriental son todos huertas plantadas de moreras, y sembradas de producciones utilisimas... Todas aquellas lomas son de piedra caliza que se beneficia, y rinde á dichos pueblos sumas muy considerables por el grande y continuo consumo que de ella se hace en la capital. De alli estos sillares y la cal, cuyo tráfico ocupa gran número de carros y vecinos. Alli se fábrica la mayor proporción de ladrillo y teja que se emplea en los edificios de Valencia y pueblos más cercanos, aprovechando de este modo la excelente arcilla y la leña de aquel recinto..." 10

${ }^{10}$ (CAVANILLES Y PALOP A.J.) op. cit, p. 146 
"...la tierra es algo arenisca hasta el cerro contiguo al camino real, y alli muda de aspecto, siendo en lo sucesivo marga arcillosa colorada. Bowles pretende que la tierra roja es la más fértil; pero en el Reino de Valencia vemos que la cenicienta y blanquecina es la mejor. La larga experiencia hace decir á los de Alberíc: "¿Terra roja ? quand te fasa goig venia esto es ¿tierra roja? pues véndela guando mas gozo te haga". También escribe dicho autor en la pág. 11 del discurso preliminar, que las tierras del Reino de Valencia se formaron de la descomposición de las peñas de cal, esto es, de aquellas que aunque calizas contienen un poco de arena y greda.
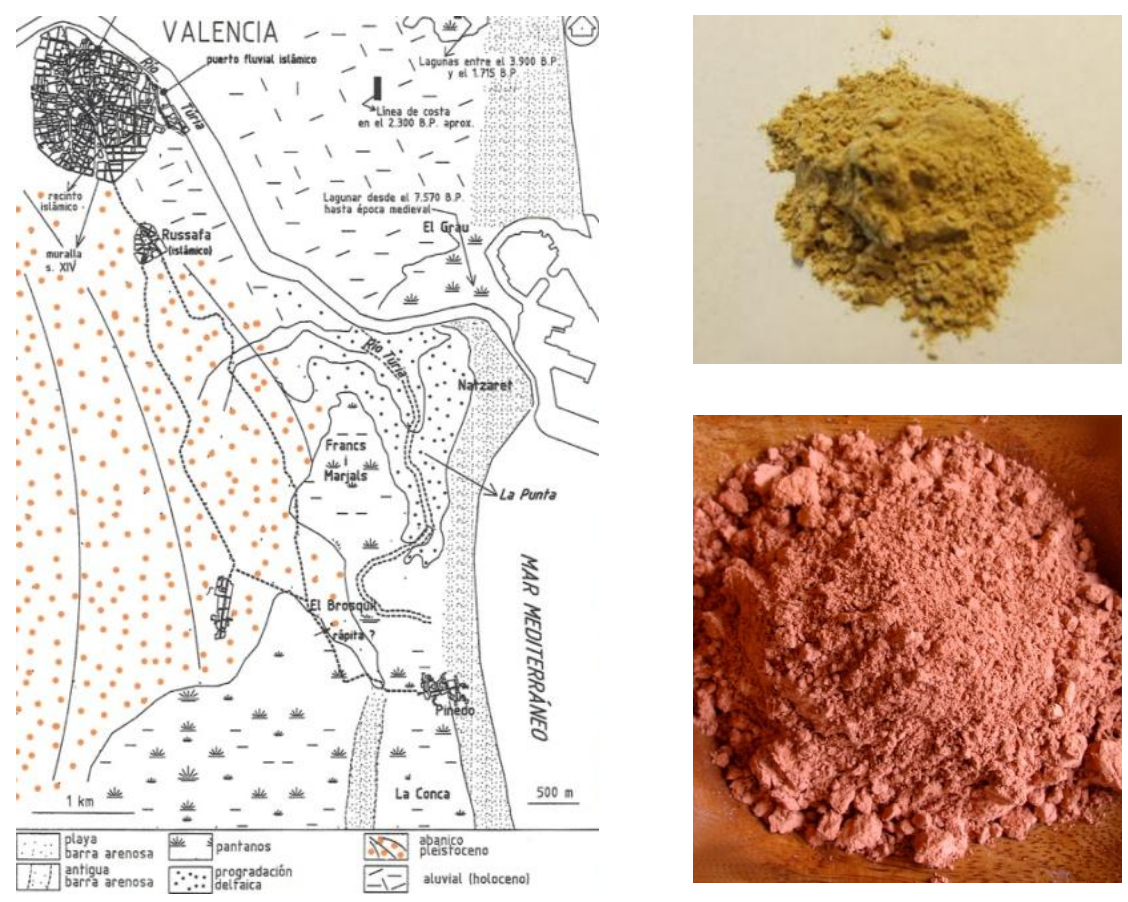

FIG. 26 Zonas de detritos del abanico de Pleistoceno ricas en arcillas, aunque de menor calidad de la zona de Pla de Quart (en este caso con arcillas ricas en óxido de hierro) (CARMONA)

Parece falsa esta opinión en casi todo el reino; porque al lado de laderas donde no hay vestigios de cal se ve mucha tierra roja granugienta compuesta de arcilla y arena. Al lado de los montes de piedra caliza, esto es, según el sentido del mismo autor, de aquella 
que se halla despojada de otros cuerpos, hay enormes masas de greda como en Buixcarró. El valle de Albayda es de marga blanquecina í la Plana, las Ilanuras de Alcalá de Chivért, y otras, de tierra arcillosa roja, viéndose cercados estos sitios de montañas calizas".

"... ¿De dónde puede venir el color rojo, si la descomposición de la piedra lo da blanco i De dónde la marga pura, si las montañas son de cal? Y en fin cómo se pudieron amontonar por capas horizontales las enormes masas de marga pura de 50 y mas pies que vemos en las cercanías de Ontiñent y Planes i Creo que la descomposición de los montes contribuyó en parte á formar los campos i pero estoy persuadido que los grandes depósitos de marga se hicieron antes que el mar mudase de sitio\} y que las aguas dulces que corrieron después por el antiguo cauce de las marinas alteraron la naturaleza de las tierras mezclando la caliza con arenas, greda y otros cuerpos..."11

Todo ello puede responder a la pregunta de como, la arcilla, ha pasado a ser la materia protagonista en las construcciones de los sucesivos pueblos asentados en este meandro del río Turia.

${ }^{11}$ (CAVANILLES Y PALOP A.J.) op. cit, p.188-189 


\subsection{Perfil histórico y cultural}

La arqueología y la historiografía han refrendado ampliamente las etapas principales de la historia de la ciudad de Valencia. Pero, menos se sabe sobre su evolución relacionada con las variaciones y los cambios de las técnicas constructivas. La historia de los caracteres constructivos de la ciudad de Valencia es un conjunto de hechos, cuyas líneas directrices destacan sobre un fondo, tanto más nebuloso y oscuro cuanto más nos alejamos en el tiempo. De aquí, por tanto, la necesidad de desnudar la continua sucesión de soluciones constructivas surgidas a lo largo de la historia de la ciudad. Concretamente se intenta proponer una evolución de las fábricas en la zona intramuros que pueda abarcar aspectos económicos, sociales y culturales, que se entrelazan y designan tanto etapas constructivas como el empleo de diversos materiales.
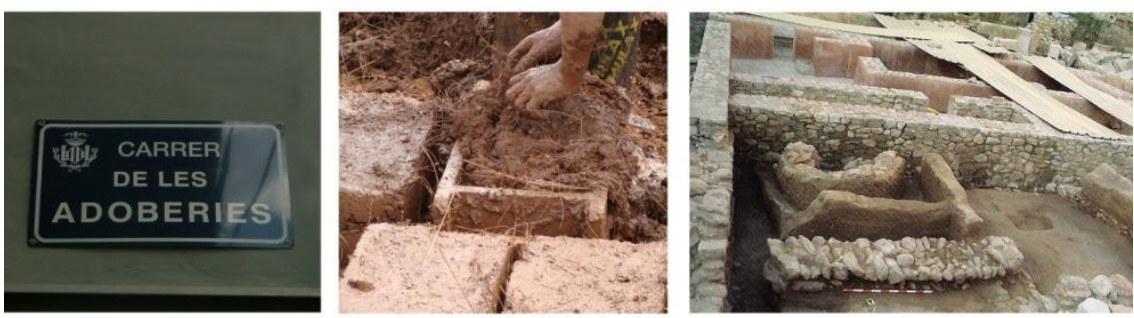

FIG. 27 Detalles de la presencia de adobe en el yacimiento arqueológico de la Almoína y en la toponimia de la ciudad (barrio del Carmen) (CRISTINI-AA.VV. 2010)

Se sabe que en 138 a. C. soldados romanos se asentaron en las orillas del Turia, próximos a su desembocadura en el Mare Nostrum. El general Junio Bruto fundó un núcleo urbano que se rodeaba de un 
territorio propio de una llanura aluvial, con áreas palustres ricas en limos, arcillas y sedimentos con óxidos de hierro.

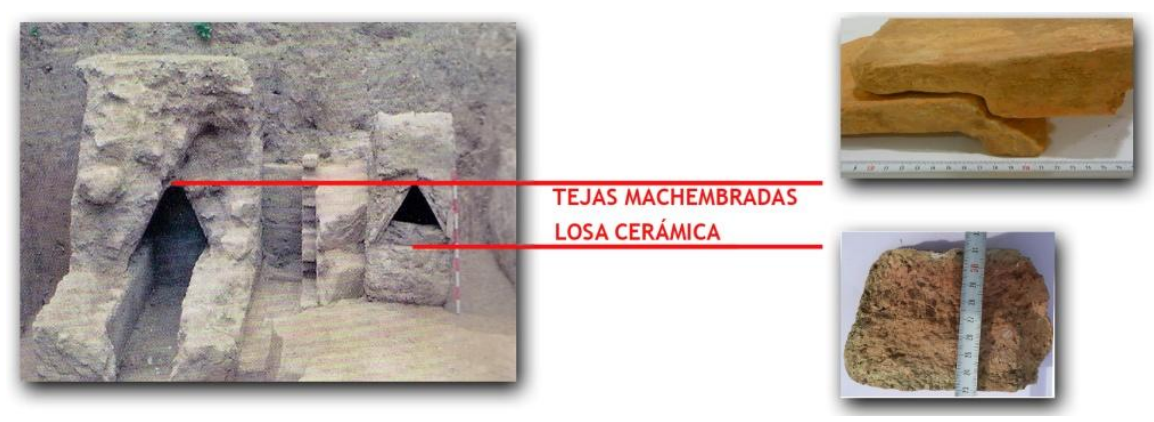

FIG. 28 Empleo de losas y tejas cerámicas en el cementerio romano de C/Virgen de la Misericordia (ROSELLÓ MESQUIDA)

Poco a poco, se dio forma a una Urbe que, como dicen las letras que conforman su nombre, desvelaba un potencial económico, agrícola y civil propio de una de las más destacadas ciudades de Hispania. A su destrucción por mano de Pompeyo siguió un rápido proceso de reconstrucción y repoblación en época augustea. Con esa etapa se consolidó una planta urbana de $600 \mathrm{~m}$ de lado, prevaleciendo la piedra en los edificios públicos (Horreum, Termas, Curia y Basilica entre otros...) y adobe y paja en el resto del tejido urbano. Ya en época romana hubo constancia del empleo de ladrillo, tanto en estructuras hidráulicas, como en edificación, materiales utilizados y trabajados según el carácter plenamente itálico de la ciudad ${ }^{1}$.

La caída del imperio romano, el 476 d. C. ante el empuje de los invasores godos supuso el inicio del ocaso de la Urbe, entrada en una espiral de decadencia ya desde el siglo III. El reino visigodo de la antigua Hispania Romana no tuvo un dominio efectivo del territorio valenciano, por lo que el vacío de poder fue ocupado progresivamente por las diócesis religiosas cristianas.

\footnotetext{
${ }^{1}$ JIMÉNEZ SALVADOR, J. L. y RIBERA i LACOMBA, A. (2000): Urbanismo y arquitectura de la Valencia romana y visigoda. Historia de la ciudad. Recorrido histórico por la arquitectura y el urbanismo de la ciudad de Valencia. Valencia, Colegio Oficial de Arquitectos de la Comunidad Valenciana, p.9-37
} 
Valencia en el siglo VI se preparó por lo tanto, a vivir un momento de transición entre dos culturas. En estos momentos, se empezó a reutilizar de forma sistemática los materiales de construcción, tanto ladrillos como piedra, que provenían de las fábricas y monumentos romanos. ${ }^{2}$ La ciudad siguió cuñando moneda, pero sin la misma pujanza que en época imperial romana, y sin la que tendría en la posterior etapa musulmana.

La derrota visigoda en la batalla de Guadelete (711) cedió el paso a la rápida invasión de las tropas musulmanas al mando de Muza y Tarik. La organización del territorio en la región del este peninsular se estructuró como Sharq al Andalus, convirtiéndose en cora o provincia denominada Balansiya (Valencia), mientras tanto la capital pasó a la historia como Madinat al Turab, la ciudad de tierra.

Y efectivamente la vulgarmente llamada tierra, es la materia prima que marcó el skyline de la densa trama de atzucacs y callejuelas. Tanto en alquerías como en viviendas (adobe y tapia) ${ }^{3}$ como en arquitectura militar (Muralla y Babs $^{4}$ ) la arcilla fue la materia prima

\footnotetext{
2 TORREÑO M., Arquitectura y urbanística en Valencia, Carena Ed., Valencia, 2005, p.8

${ }^{3}$ GUICHARD P., VAN STAEVEL JP., "La casa andalusí: ensayo de lectura antropológica" en Casas y Palacios de Al-Andalusí, Barcelona, 2003, PP.45. Según los autores el modelo de la casa patio central musulmana es la transportación arquitectónica del paradigma familiar de la casa extensa, consustancial a la sociedad musulmana, directamente de la vivienda a la jardinerapatio, esta parte de la casa tiene una función constructiva primordial. Es allí donde, en el seno domestico viven varias células conyugales. Justo la jardinera del patio desempeña un papel fundamental: de ella se saca la tierra para hacer tapias y en ella se labra la tierra como material de construcción para el crecimiento celular de la vivienda. Estas casas están constituidas por fábricas de adobe y tapia, cuya materia prima se extrae, en muchos casos, como se ha explicado, en la propia jardinera de la casa. En este espacio se trabaja la masa, se arrojan los materiales de derribo y se sepulta la basura doméstica. La dinámica del agua es bastante más compleja. Para captar el agua del consumo de las casas se suele contar con un pozo, excavado en el patio, y otras cisternas y aljibes subterráneos, realizados con estructuras de ladrillos. Estos mismos son los que se suelen utilizar en canalillos, andenes y estructuras auxiliaras de desagüe y sistemas de canalización más complejos

${ }^{4}$ COSCOLLA SANZ V., La Valencia musulmana, Carena ed., Valencia 2003. Según el autor la muralla se construyó en el periodo de los reyes de Taifas, reinando Abd al Aziz, entre 1021 y 1061. La anchura de las fábricas, de tapia calicastrada con refuerzo de de mampuestos, es de 2.30m. La estructura está marcada por la presencia puntual de torres (Babs). Como las Bab al Buyatalla (Boatella), Bab al- Xaría (Xerea), Bab al Sakar (Temple)
} 
protagonista de la arquitectura, y el ladrillo pasó en segundo plano en las fábricas de Xarq Al Andalus ${ }^{5}$. En este caso las documentaciones arqueológicas llevadas a cabo, suelen registrar con frecuencia la presencia de muros encofrados, realizados por tierra simple o con bastante frecuencia mejorada con cal, mampuestos de refuerzo y costras (acerado) ${ }^{6}$.
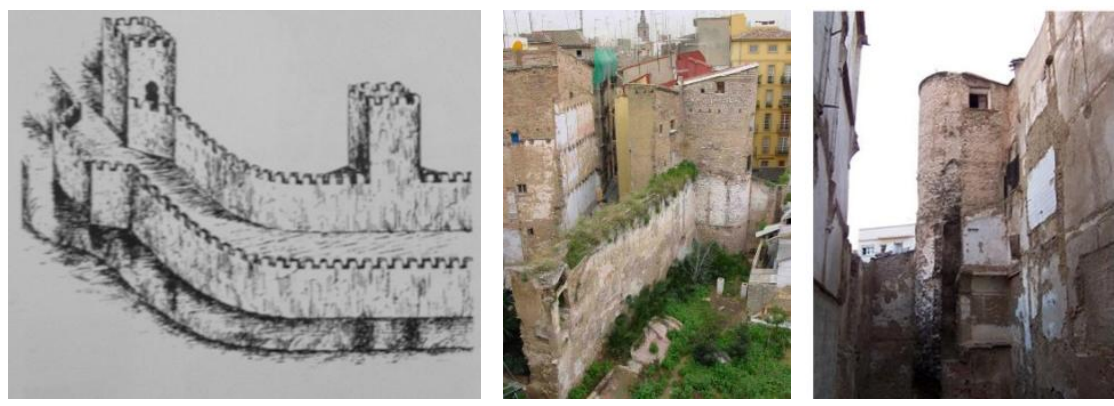

FIG. 29 Croquis de la muralla árabe (SANCHIS GUARNER) visible hoy en día en la Calle Del Ángel y sus alrededores (PALACIOS)

También es muy nítido el papel desempleado por las acequias próximas al núcleo urbano, como la del sistema hidráulico Rovella/Favara, verdaderos motores que alimentan innumerables talleres de alfarería. La ocupación musulmana de la zona de Valencia

MARTí J., ROCA L., "Obra pública y espacio doméstico en la urbanización del sector meridional de Mâdinat Balansiya" en Historia de la ciudad, IV Memoria urbana, ÍCARO 2005. Según el autor, la fábrica de la muralla islámica estaba costituida por una sólida fábrica de hormigón de arena, cal y grava, reforzada con abundante piedra. Las dimensiones de las estructuras y la solidez de su fábrica dejan pocas dudas respecto a que se trate de un tramo de muralla árabe, p.57. También véase: GÓMEZ SERRANO, PRIMITIU SERRANO, "la muralla de valenciana que conquistaron el Cid y Jaime I"en Feriario, no 9, 1945

${ }^{5}$ El historiador ha sido uno de los primeros estudiosos a probar como el empleo de ladrillos en la arquitectura de Al_Andalus es poco sistemático y constante. BAZZANA A., "Maison d'AlAndalus. Hábitat medieval et estructures de peuplement dans l'espagne oriental.", Madrid, Bibliothèque de la Casa de Velázquez n.37, 1998

${ }^{6}$ MARTí J. "A la luna de Valencia, una aproximación arqueológica al espacio periurbano de la ciudad musulmana" en Historia de la ciudad II, Territorio, Sociedad y patrimonio, Ícaro Ed., Valencia, 2002. Según la documentación aportada por las excavaciones arqueológicas en C/Mesón de Morella, C/Sogueros y Ripalda, C/Corona, C/Virgen de la Misericordia, C/Blanquerías del SIAM, Valencia. En estas excavaciones se han encontrado aglomeraciones de viviendas entre los siglos XII-XIII, realizadas con fábricas de tapia de tierra. Toda la zona alrededor de la acequia de Rovella se caracteriza por haber presentado huellas de talleres de tintoreros y alfarería. Entre ellos destacan el de la C/Sagunto y C/Mesón de Morella 
se extendió desde el año 718 hasta la conquista de la ciudad por Jaime I en 1238. Se sabe que la grandiosa obra de "argamasa de tierra y cal durísima", 7 más conocida como la antigua cerca defensiva musulmana, siguió funcionando en plena Reconquista, hasta 1337. A partir de esta fecha, exigencias tanto higiénicas, de contención hídrica, como estratégicas, empujaron Pedro IV a pensar en el trazado de una nueva muralla. Factores amenazantes como los provenientes de Marruecos y de los reinos de Granada o Castilla contribuyeron a esta decisión estratégica. Algunos años fueron necesarios para conformar este fortificación/dique, realizada sólo con tapia calicastrada al principio y luego reforzada por rebles y mejorada con cal y ladrillos.

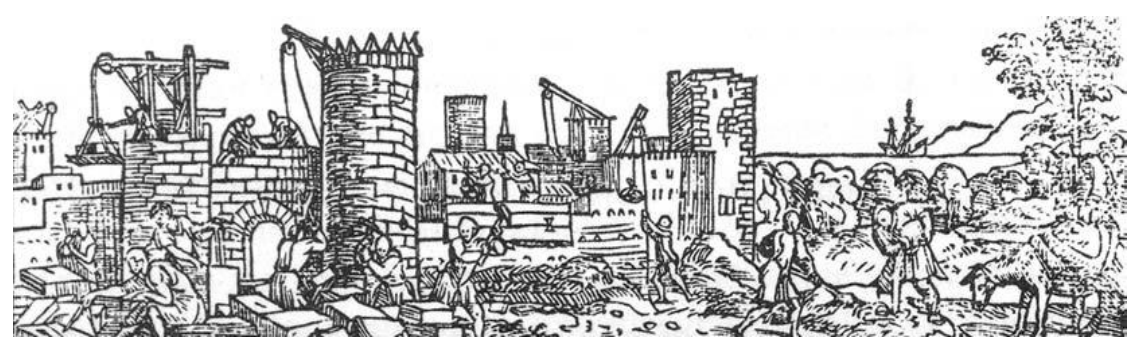

FIG. 30 Valencia, fases de construcción de la muralla cristiana, donde se aprecian los encofrados de tapia; por BREUER, portada de "Primera Parte de la Crónica General de toda España y especialmente del Reino de Valencia" 1546 (SERRA DESFILIS)

Por todo ello la documentación aportada hasta ahora, considera la muralla como uno de los ejemplos más antiguos de utilización de tapia valenciana en la ciudad. ${ }^{8}$ El fuerte auge de esta técnica constructiva queda definitivamente ratificado tras la constitución de "Fabrica Vella de Murs i Valls, y Nova, dita del Riu" institución promovida por el rey Pedro IV en 1358, a raíz de una trágica riada del Río Turia, que obligó a realizar mejoras y nuevas obras en algunas infraestructuras dañadas ${ }^{9}$.

${ }^{7}$ GÓMEZ SERRANO I., PRIMITIU SERRANO (Op. Cit.), p.68

${ }^{8}$ SERRA A., "Ingeniería y construcción en las murallas de Valencia en el siglo XIV" en Actas del Quinto Congreso Nacional de Historia de la Construcción, Burgos, 2007 
Sabemos que a finales del siglo XIV, principio del siglo XV Valencia vivió un momento de prosperidad. Se trató de una ciudad que sin duda se enmarcó entre las potencias del Mediterráneo, equiparable a potencias marítimas como Marsella, Venecia o Génova; y a la vez fue un centro que tenía un significativo nivel de bienestar, debido sobre todo a la política internacional de Alfonso el Magnánimo. En esta época se desarrolló una arquitectura civil de extrema calidad, reflejo de este general clima de bonanza económica.

El monarca, las ciudades y los comerciantes rivalizaron en la construcción de edificios. En estos años se abrió un gran paréntesis en la construcción de edificios públicos urbanos de ladrillo. Se redujo la presencia del ladrillo y se dio más protagonismo a construcciones de sillería. Éstas caracterizaron la arquitectura de la época a través de la esterometría al servicio de nuevas formas y nuevas geometrías, que destacan como marco autóctono significativo de una época. (Zaragozá Catalán) ${ }^{10}$.También se tiene constancia de una prosperidad económica fuera del recinto amurallado, reflejada por algunas poderosas alquerías como del Moro, del Rei, Fonda, entre otras (Del Rey) ${ }^{11}$.

"Valencia la hermosa", según las palabras de Andrea Navagero" ${ }^{12}$, fue una ciudad que se enfrentó rápidamente al siglo XVI sin ser sometida a ninguna ordenación sistemática del conjunto urbano. Fue un centro que siguió con una configuración bajomedieval, enmarcada por una falta de rigor geométrico urbano y por la presencia de estructuras edilicias de ascendencia medieval. Según Bartolomé Joly ${ }^{13}$ "... las casas

\footnotetext{
${ }^{9}$ SERRA A., "Ingeniería y construcción en las murallas de Valencia en el siglo XIV" en Actas del Quinto Congreso Nacional de Historia de la Construcción, Burgos, 2007

${ }^{10}$ ZARAGOZÁ CATALÁN A, Arquitectura gótica valenciana, Siglo XII-XIV, Generalitat Valenciana Ed., Valencia, 2000

11"DEL REY M."Arquitectura Rural Valenciana", en Geográfica Valenciana. La Casa Viva,Valencia, 1990.Valencia, 1990

${ }^{12}$ Embajador veneciano, político y humanista (1523). Viaggio fatto in Spagna ed in Francia (traducido al castellano "Viaje hecho a España y a Francia", Venecia, 1563). Traducido al castellano por Fabié en 1879 y por José María Alonso Gamo (Valencia: Castalia, 1951)

${ }^{13}$ Viajero francés, acompañando al abad cisterciense Baucherat, visitador de los monasterios de la Orden de Franciscanos, describe con la poca claridad de quien era limosnero del Rey de
} 
son altas y algunas están construidas en parte con ladrillos y en parte con piedra y mortero, otras sin embargo solo están hechas de piedra pilada, sin ladrillos...".

La ciudad contaba también con mezcla de habitantes, culturas y razas. Entre ellas destacaba la presencia de los judíos y de los moriscos, que vivían en zonas específicas de la ciudad. Se debe indicar que los moriscos eran una comunidad, principalmente rural, que tenían superioridad numérica, pero a la vez constituían una marcada minoría étnica sumisa y explotada. Está situación abocó inicialmente a una represión enmascarada (1530-1550) a la que siguió un autentica represión.

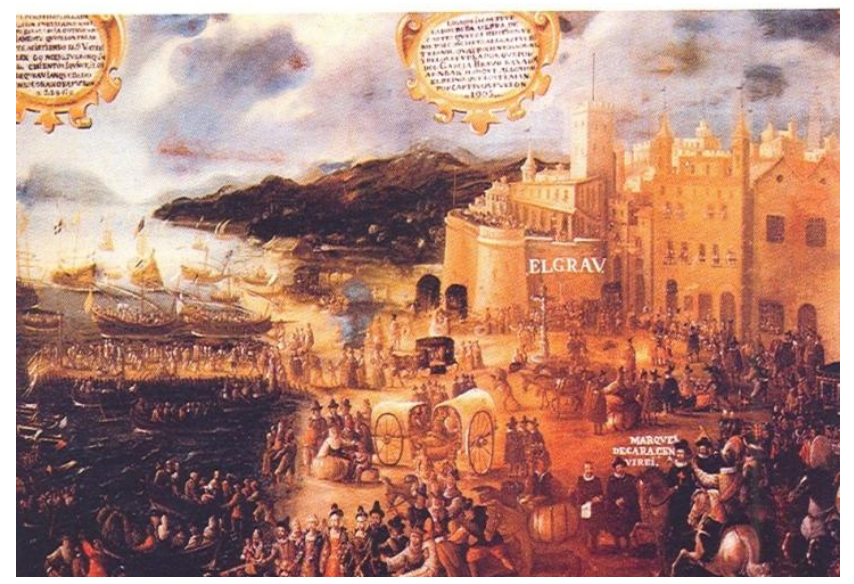

Fig. 31 Embarco de moriscos en el Grao de Valencia, por Oromig Pere 1613 (FUN. BANCAJA)

Acontecimientos como el saqueo de Cullera (1550), de Xilches (1583), la revuelta en la Alpujarras (1568-70) y el general aumento de la presión turca y barbárica en el Mediterráneo fueron factores que marcaron una progresiva política de desconfianza hacia esta población por parte de Felipe III.

No se trata de un fenómeno aislado: a nivel europeo las tensiones contrastes de los Hugonotes protestantes (bajo el reinado de Enrique IV) y de los movimientos católicos irlandeses (bajo el reinado de

Francia. Tras finalizar su viaje escribió un libro titulado: "Voyage en Espagne, 1603-1607" (traducido al español como: "Viajes de Extranjeros por España y Portugal") 
James I) favorecieron un clima de tensiones constantes contra las minorías étnicas. Todo este contexto llevó a que el Virrey Marques de Caracena publicara el 02.09.1609 el bando de expulsión de la población morisca ${ }^{14}$
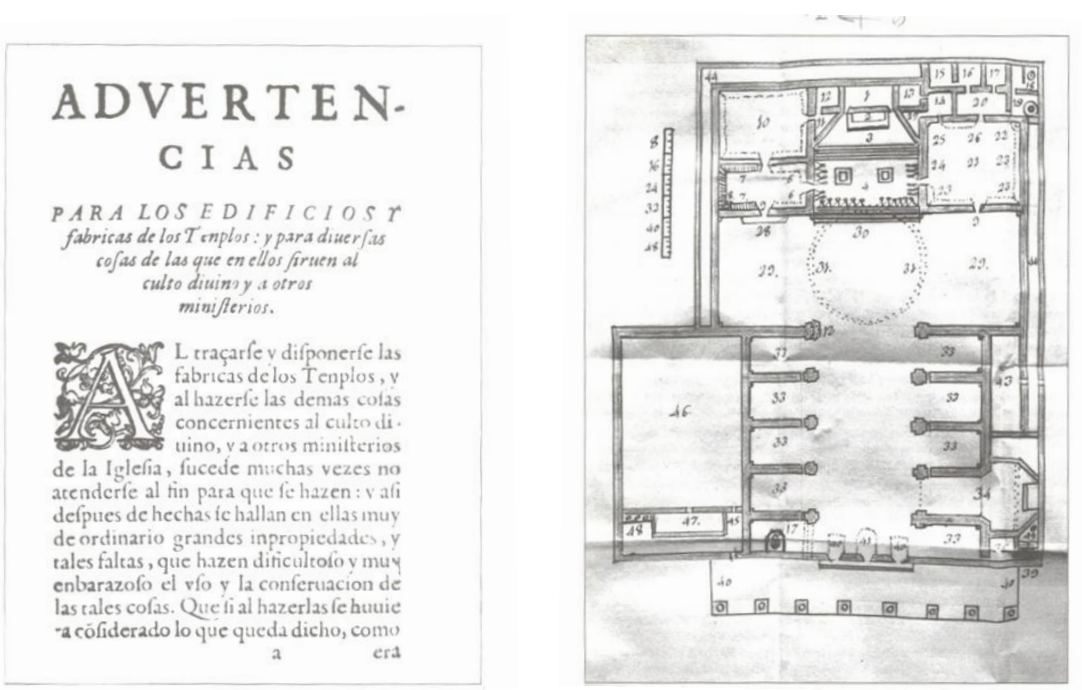

FIG. 32 Manuscrito, "Advertencias para los edificios y fábricas de Templos" por Isidoro Aliaga, 1631. Se considera el texto que impulsó a nivel constructivo los principios de la contrarreforma y el empleo del ladrillo en Valencia para estas soluciones constructivas (PINGARRÓN)

Sin duda el empleo masivo del ladrillo en la ciudad de Valencia creció paralelo al mismo ritmo que la afirmación de la religión católica y contrarreformista en la ciudad (Araguas ${ }^{15}$ ), impulsando la realización de iglesias, modestas en su mayoría, siguiendo escrupulosamente los decretos expuestos en el Concilio de Trento. ${ }^{16}$ (Gómez UrdañezCadarso 2008).

\footnotetext{
${ }^{14}$ BRAUDEL L., La Mediterranée et le monde mediterranéen a la epoque de Philippe II, Paris, 1949

"...Las ciudades y los lugares grandes...las iglesias, monasterios, de frailes y monjas, hospitales, cofradías, ejecuciones de causas, llegados píos, nobles, caballeros y ciudadanos, finalmente todos cuantos son necesarios en la república para el gobierno y ornato espiritual de ella dependen del servicio de los moriscos y se sustentan de los censales que han cargado, ellos o sus antecesores, sobre lugares moriscos

${ }^{15}$ Véase el estudio de ARAGUAS F., Brique et architecture dans I'Espagne médievél, Bibliothèque de la Casa de Velázquez, n.52, Madrid, 2003, p.562
} 


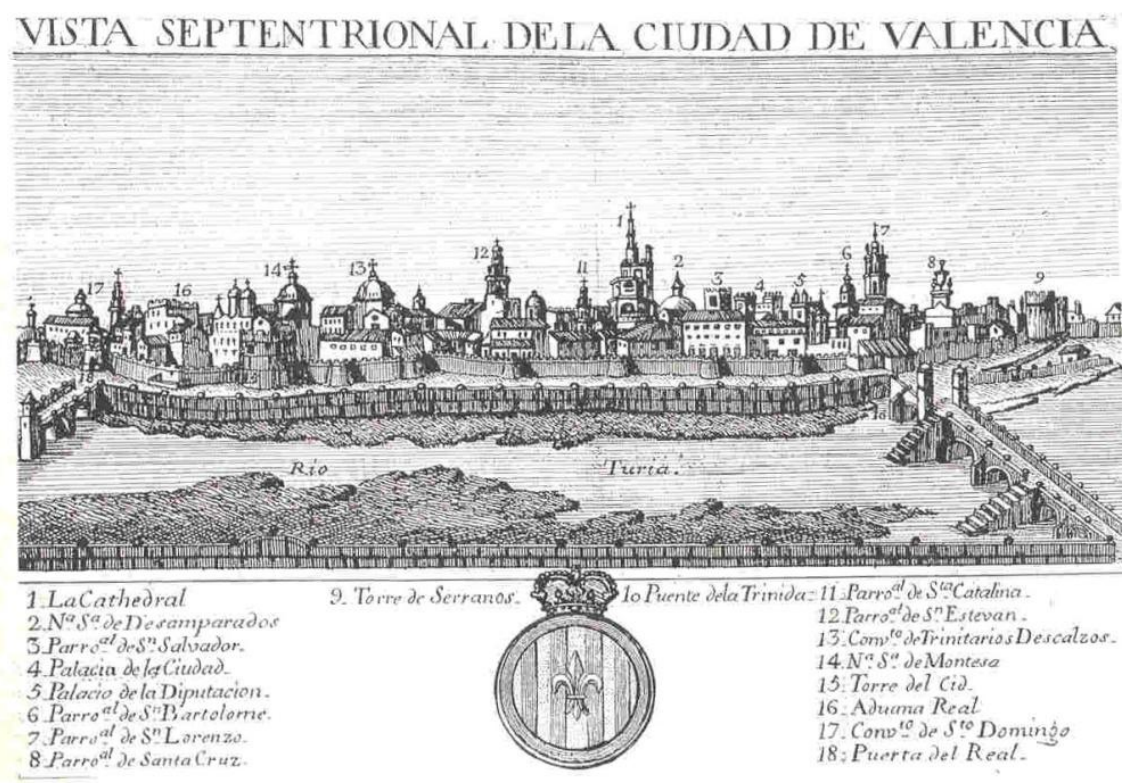

FIG. 33 Imagen de la plenitud constructiva tras la contrarreforma cristiana. Vista septentrional de la ciudad de Valencia, desde el Puente de la Trinidad hasta las Torres de Serrano, por Palomino J.F. 1784. Marcan lo skyline los campanarios de la ciudad conventual (NOGUERA)

Se sabe que la difusión de los ladrillos como materiales de construcción fue también fuertemente relacionada con el proceso migratorio desarrollado a lo largo del siglo XVII, principalmente proveniente de Aragón. Ésta región tenía una constancia productiva y técnica en el empleo de ladrillos, y por lo tanto, de allí llegaría posiblemente una influencia sistemática del uso de esta materia prima (Gómez Urdáñez y Rosas Artolas).

A lo largo del siglo XVII la ciudad sufrió un revés que afectó al orden económico, cultural y principalmente social, provocado por la crisis, la inflación y los impagos generados por la expulsión de los moriscos (Escolano 1610). La bancarrota de la Taula de Canvis (1613) y el declive de las Cortes Valencianas a lo largo del primer cuarto de siglo dejaron el paso, poco a poco a una recuperación intelectual, jurídica y económica, reflejo de las primeras inquietudes intelectuales vinculadas al ambiente pre-ilustrado. Se fomentó el comercio marino,

\footnotetext{
${ }^{16}$ Varias iglesias de Valencia de la contrarreforma valenciana reflejan los preceptos del Arzobispo Isidoro Aliaga, rígido propulsor de la contrarreforma en ámbito urbano
} 
aspecto que llevó la renovación y la reforma de las Atarazanas ${ }^{17}$, pero la estabilidad tardó en llegar a la ciudad hasta la Batalla de Almansa (1707), cuando Valencia reconoció, con la abolición de los Fueros, el imperialismo centralizado e imperialista de los Borbones.
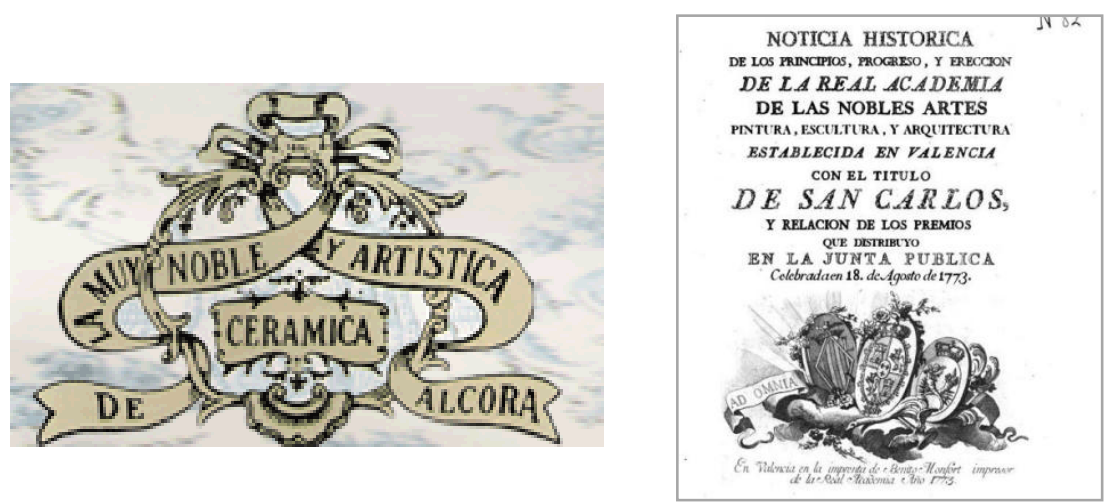

FIG. 34 La fundación de la fábrica Cerámica de l'Alcora 1727(Castellón) y de la Real Academia de Nobles y Bellas Artes de San Carlos, Valencia (1768) son momentos claves para comprender el cambio de gusto que viven las artes y la arquitectura vinculadas a la cerámica a lo largo del Siglo XVIII (COLL CONESA)

El siglo XVIII se presentó por lo tanto con una buena estabilidad económica en la ciudad y en general en Europa. Las enfermedades epidémicas, como la peste, parecían controladas y en general la ciudad registró un importante incremento demográfico. Fue a lo largo de este siglo cuando se reafirmó el uso del ladrillo como material de construcción sobre todo en viviendas. Valencia sufrió un afrancesamiento generalizado, que se reflejó en un gusto neoclásico riguroso y elegante. Los ladrillos se adaptaron perfectamente a la articulación del lenguaje neoclásico. Molduras, voladizos, columnas adosadas, aparecieron por doquier, empleándose la pasta cerámica para su elaboración. La plasticidad del material permitió así acercarse a los preceptos del nuevo lenguaje reinante en el siglo XVIII ${ }^{18}$.

Se debe añadir el hecho de que la cerámica, en general, en estos años adquirió en Valencia un rol nuevo, vigoroso y mucho más

\footnotetext{
${ }^{17}$ CONTRERAS ZAMORANO G.M., Las Atarazanas del Grao de Valencia, arquitectura y recuperación, Ayto. Valencia, 2002

${ }^{18}$ Edificios como Temple (1761-1780), Aduana (1758-1802), Escuelas Pías (1767-73), etc.
} 
refinado. En 1727 nació la fábrica de Cerámica de Alcora del Conde Aranda, se reafirmaron los gremios y por primera vez se manifestó una producción de cerámicos no meramente artesanal, sino más bien preindustrial.

El nacimiento de la fábrica marcó un profundo cambio en la organización de la producción y su normalización. Se podría definir posiblemente como un punto de inflexión en la historia de la producción cerámica local (Coll Conesa). A esto se añade la fundación de la Academia de Bellas Artes (al principio fundada como Academia de Pintura, Escultura y Arquitectura de Santa Barbara 1754) y la Real Academia de Nobles y Bellas Artes de San Carlos (1768). Estas entidades contribuyeron a alimentar un afán arquitectónico cosmopolita que miraba a Francia y a los acontecimientos que pronto cambiarían el paradigma del mundo.

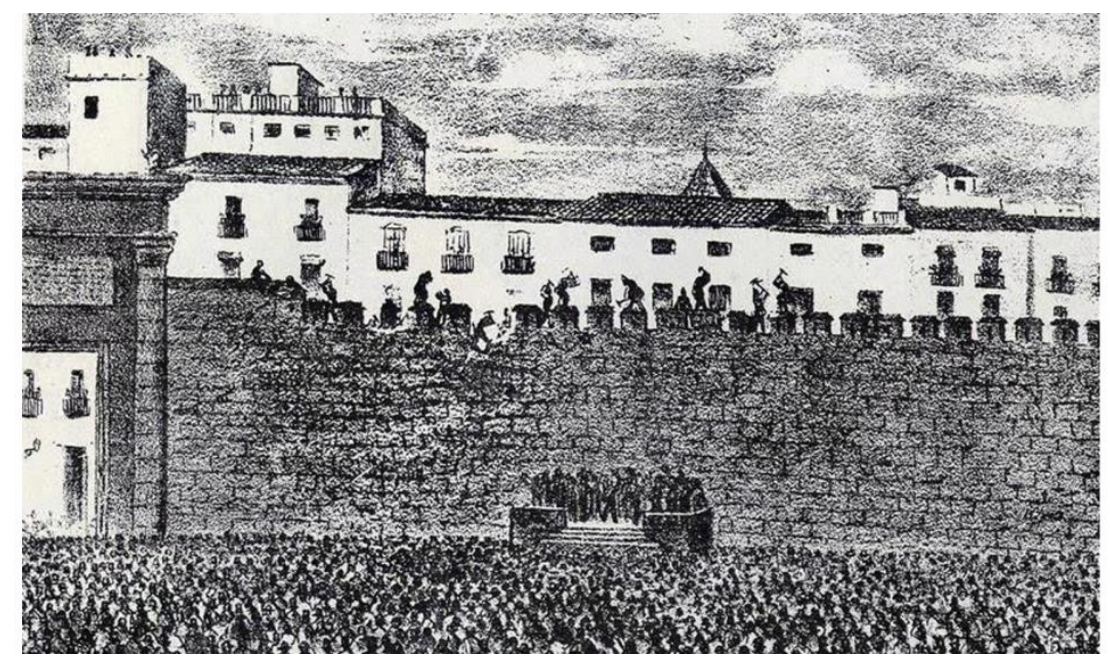

FIG. 35 Derribo de la Muralla Cristiana, junto a la Pta. del Real, 1865 (SANCHIS GUARNER)

Después de la revolución francesa, Valencia entró de pleno en el espíritu dieciochesco, marcado por una etapa fecunda llena de cambios importantes para la sociedad valenciana. Se fueron definiendo las diferencias de clase entre la clase proletaria y nueva burguesía, reflejando estos cambios en un clima febril de 
ampliaciones urbanas, interrumpidas sólo por la Guerra de Independencia contra Napoleón (1808) y los estragos que a ella siguieron (1812).

Fue en la segunda mitad de siglo XIX cuando el ladrillo entró de pleno en el proceso constructivo, esta vez con técnicas productivas industriales, gracias a la introducción del sistema de cocción Hoffman.

El resultado fueron productos de mayor homogeneidad y regularidad, ladrillos más estandarizados y controlados. De este modo, la edificación del nuevo ensanche y el crecimiento extramuros de la ciudad valoraron la producción regular de ladrillos como material de construcción, realizados cada vez más con técnicas y procesos productivos ordinarios, codificados y continuos. ${ }^{19}$

\footnotetext{
${ }^{19}$ Para más detalles sobre el empleo del ladrillo en Valencia en el siglo XIX véase BLAT LLORENS, J.V., Presencia del ladrillo cara vista en el primer Ensanche de la ciudad de Valencia, Tesis doctoral dirigida por Lecuona López, Espí Cerdá, Valencia, 1996
} 
4. Las fábricas en Valencia: hacia una interpretación 



\subsection{Una cuestión de roles}

Un muro constituye el resultado de un complejo ciclo productivo que se inicia con la extracción de la materia prima y se acaba cuando ésta viene colocada en el edificio. Por ello, reconocer y definir tipológicamente una técnica constructiva implica reconstruir este ciclo productivo y reconocer el contexto técnico, social y económico que ha dado lugar a una construcción (Mannoni 1988).

Por tanto, a la hora de hablar de muros en la ciudad debemos tener en cuenta el diverso papel desempeñado por varios grupos de profesionales que participan en este ciclo productivo. No se trata de un proceso lineal.

Por un lado, existe el abastecimiento de materias primas, propio de los artesanos que fabrican los ladrillos. Por otro lado, aparece la venta de los productos cerámicos $y$, posteriormente, se debe tener en cuenta la puesta en obra de los muros de tapia valenciana o los muros de ladrillos.

Por tanto, los gremios de ladrilleros, tapiadores, obrers de vila e instituciones como el Tribunal del Repeso o la Fábrica de Murs y Valls son los diferentes actores que desempeñan un rol importante a la hora de comprender la industria y regulación de las fábricas urbanas. 


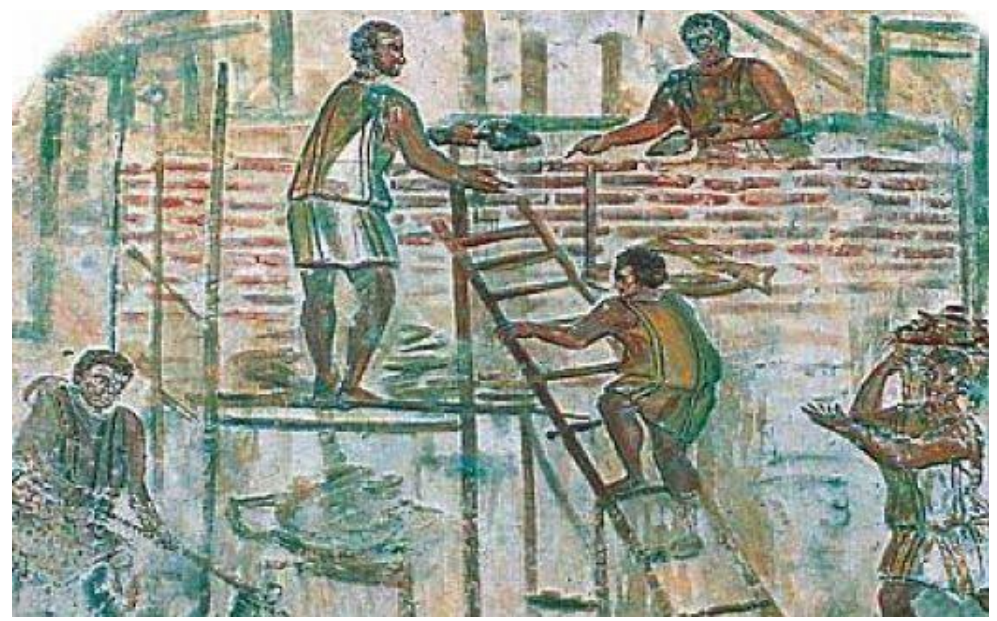

FIG. 36 Hipogeo di Trebio Augusto, Vía Latina, Roma; aparejo con opus latericum (RIVORIA)

Quien produce la materia prima, quien la vende y quien la usa forman parte de un abanico de categorías profesionales diferentes que requieren un estudio específico, no sólo desde el punto de vista normativo o legislativo histórico, sino sobre todo desde una perspectiva arquitectónica.
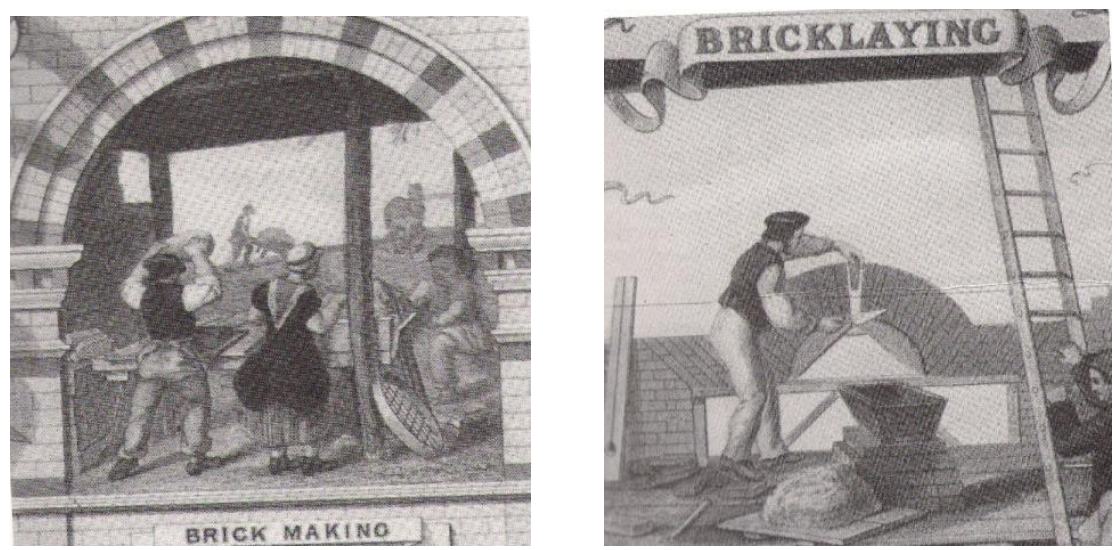

FIG. 37 Manufactura y puesta en obra de ladrillos en la Edad Media en Plymouth, UK (LYNCH)

Se pueden dividir en dos grandes grupos:

- alfareros/ladrilleros: producción y cocción

- vendedores/controladores: mercado y comercio 


\subsection{Alfareros y ladrilleros: producción y cocción \\ "Teules o maons de maig més forts que fusta de faig..." "D'obra de maig ma casa faig..."}

La producción de ladrillos en la ciudad de Valencia siempre ha sido artesanal, hasta llegar a la segunda mitad del siglo XIX, cuando poco a poco un proceso de sistematización de la producción ha dejado espacio a los hornos industriales, conocidos como de tipo Hoffman ${ }^{2}$. Muchos autores se han enfrentado al estudio de la producción de cerámica decorativa, tanto desde un punto de vista etnoarqueológico (González Martí 1952, Bazzana 1990, Amigues 1994, Mesquida 2001, Coll Conesa 2009), así como tecnológico (Soler Ferrer 1992 y Molera 1997). Pero estos estudios no abarcan con suficiente definición la producción cerámica arquitectónica, sugiriendo apenas indicaciones sobre estos temas. Por ello se han considerado estos estudios como importantes puntos de partida, para lograr arrojar luz sobre el vacío de documentación relativo a la producción pre industrial de ladrillos. Se conoce que el conocimiento de las técnicas de la alfarería en la Comunidad Valenciana ${ }^{3}$ se enraíza con la producción de la cultura íbera, conocida por técnicas rudimentarias y básicas ${ }^{4}$, pero

\footnotetext{
${ }^{1}$ Refranes populares del la Plana vinculadas a la producciones pre-industriales de cerámicos (fuentes orales)

2 Véase, por ejemplo el Rajolar de Paiporta, donde se instalaron hornos de producción Hoffman en la segunda mitad del siglo XIX, u otros como en Alfara del Patriarca o Paterna

${ }^{3}$ Los principales núcleos de producción cerámica en la zona del Levante son Ayora, Alicante, Onda, Alzira, Valencia, Elche, Denia y Sagunto (BAZZANA)

${ }^{4}$ Los hornos más antiguos, encontrados en el entorno de la Comunidad Valenciana, son las horneras pertenecen al sistema doméstico de producción, en un ambiente que manifiesta una total ausencia de tecnologías especializadas para la producción masiva, a pesar de que ésta se
} 
documentadas en la zona del Levante ya a partir del siglo IV-V a.C. (Coll Conesa 2009). Pero se debe reconocer que es sólo con la conquista romana de la zona del Levante cuando se formaliza la producción de cerámicos. A partir de entonces se considera Figulus (figlinus o figulinus) a aquel que trabajaba la arcilla, por lo tanto, era conocido como figlinum un alfarero especializado. En época romana, la gran industria de las figlinae hacía referencia a una serie de talleres (officinae, statione, y en la tardo-antigüedad, rationes), donde tenía lugar la manipulación y la hornada de la arcilla. Los figlinae fueron clasificados según la producción cerámica: opus doliare (material de construcción y dólias, más conocidas como ánforas de gran tamaño) y el opus figlinum, aplicado exclusivamente al arte de la cerámica.

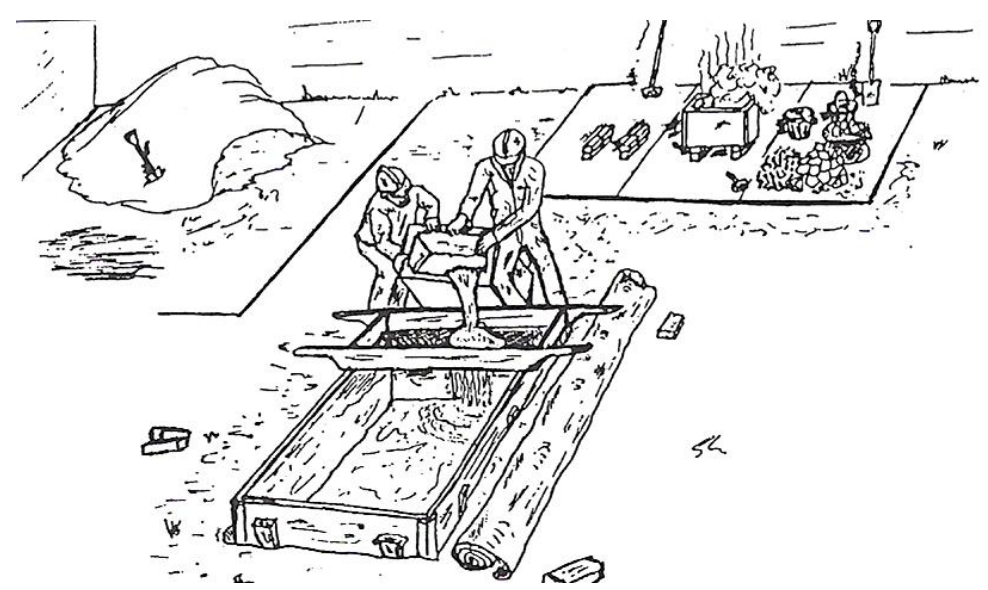

FIG. 38 Selección y criba de arcilla en un taller de ladrillos pre-industrial (LYNCH)

Las marcas ante cocturam (sellos, estampillas, marcas...etc) se han venido identificando tradicionalmente en Roma y alrededores, grosso modo, como indicios para controlar la producción, siendo señales de carácter tanto mercantil como comercial. Los posibles significados de estas marcas no están exentos de polémica. Unos investigadores la asocian a la organización interna de la alfarería, bien para controlar o

encuentra perfectamente adaptada a la calidad del producto requerido y a su producción limitada para cortas demandas

Tipos más arcaicos son los hornos de ladera. Esos constan de dos cámaras dispuestas en una ladera en la que suelen excavarse de forma escalonada. En el escalón inferior se ubica el hogar que se abre hacia el escalón superior o laboratorio con un gran conducto frontal 
contabilizar la producción de los envases en los procesos ante cocturam, y, otros, como marcas de propiedad. No existen hallazgos significativos documentados sobre este tipo de ladrillos sellados en Valencia y alrededores, tal vez debido a una producción de menor escala respecto a la itálica y a un mercado mucho más limitado. De hecho existe poca constancia del empleo de ladrillos en Valentia.
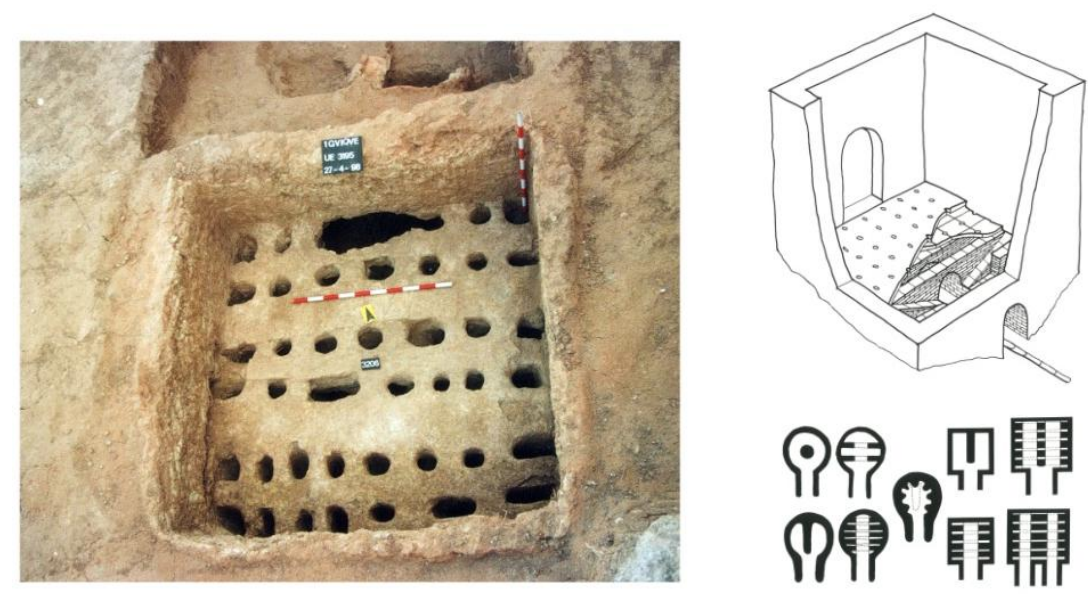

FIG. 39 Hornos cerámicos romanos y restos de talleres en la C/Guillem de Castro, (siglo XIII), ejemplos que marcan la continuidad en know-how técnico (ROSSELÓ MESQUIDA -CAMPBELL)

Quedan abundantes restos de tegulae para sepulturas y escasos ejemplos de construcción en ladrillo, en este caso vinculados a espacios e infraestructuras hidráulicas, (por ejemplo restos de canalizaciones, balsas, zonas acotadas de las Termas del parque arqueológico de la Almoina..., pero no existen restos evidentes del uso de later o ladrillo, sino más bien de later crudus, el adobe, visible en viviendas y espacios de servicio de la urbe) $)^{5}$.

En el caso concreto de Valencia la documentación más antigua se refiere a los hornos hispanomusulmanes ${ }^{6}$, que crearon un continuum

\footnotetext{
${ }^{6}$ Estos hornos suelen ser de tiro directo, con doble cámara, gracias a una parrilla que separa la zona de combustión de la de cocción. Hay diferentes tipos de hornos con sistema de parrilla:

Sustentación alveolar. El apoyo se produce por el sistema de bóveda plana, sostenida directamente sobre los muros o en machones salientes realizados por aproximación de hiladas, en forma de estructura compacta.
} 
con las técnicas desarrolladas previamente por los romanos. Los hallazgos de hornos cerámicos se concentran mayoritariamente en arrabales, manifestando la extensión periférica de las zonas artesanales hasta distancias que pueden llegar a 2-3 km del núcleo urbano de habitación densa. Aún así, existen casos en los que los alfares se instalan intramuros en la periferia urbana, en zonas de huertos o que poseen baja densidad de ocupación, para evitar contaminación y humos ${ }^{7}$.

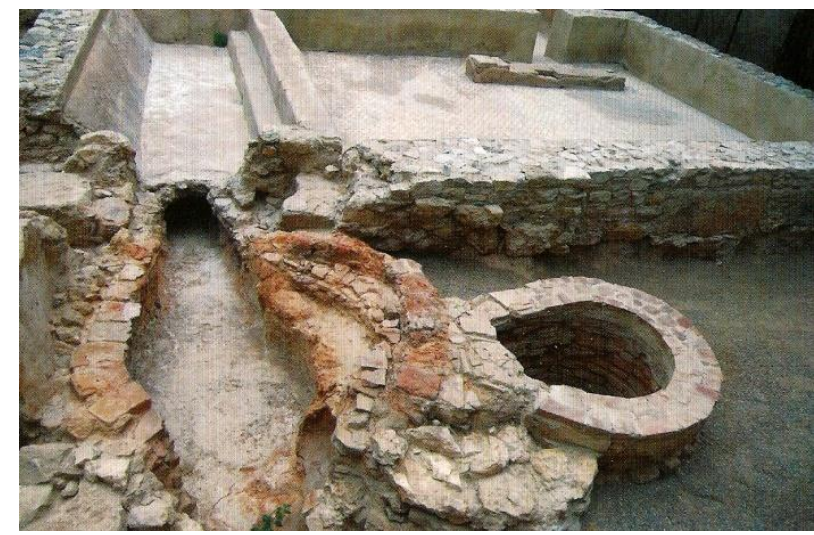

FIG. 40 Empleo de ladrillos romanos en estructuras hidráulicas: el prefurnium y del hypocaustum de las termas de la Almoína, Valencia (MARTíN JORDÁ-RIBERA LACOMBA)

Más generalizado es el hecho de que estén próximos a puertas o caminos importantes, tanto intramuros como extramuros. En este sentido, la mayor concentración de hornos se ha documentado en el

Sustentación por arcos. Es el sistema de tradición romana por excelencia, aunque no fuera la única solución estructural en ellos. El apoyo de la parrilla se produce sobre arcos vivos, de medio punto o de arco apuntado. En general los arcos son de adobe, aunque no cabe descartar el uso de ladrillos.

Sustentación por columna. Pocos ejemplares presentan una columna central de soporte de la parrilla. Ésta suele sostener un piso de tipo alveolar o plano, a pesar de que desde la cara inferior se visualice una bóveda formada por los densos revestimientos y por la propia estructura de bóveda realizada por aproximación de hiladas. Los hornos de convección, sobre todo por sustentación con arcos, son los más extendidos en el entero Mediterráneo hasta el siglo XIX. Estas tipologías, inicialmente desarrolladas por los romanos, fueron recuperadas por los productores islámicos, y estos hornos han pasado a la historia como "árabes".

${ }^{7}$ Muchos expedientes del Tribunal del Repeso, hasta el siglo XVIII apuntan a prohibiciones para los dueños de terrenos y almacenes de abrir talleres alfareros en contextos urbanos. Humos, riesgo de incendios, contaminación son algunos de los factores limitantes (Archivo Municipal de Valencia, Tribunal del Repeso, Policía Urbana (5) 
extrarradio de la ciudad de la ciudad de Valencia. La arqueología ha desvelado en Valencia importantes evidencias de talleres, hornos y presencia de alfareros especializados. En la Calle Sagunto se han encontrado alfarerías fechadas entre los siglos X-XIII (Coll Conesa, Pascual Martí 1989) ${ }^{8}$.

También existen zonas del actual sector de Velluters que, desde época islámica, se transforman en zonas de producción de auténtica alfarería especializada en la producción de ladrillos, tejas y vajillas, confirmando así la vocación artesanal del barrio (solar del actual Museo del Muvim y, más hacia el barrio del Carmen, horno en la C/Mesón de Morella). Según los datos extrapolados de las fuentes arqueológicas $^{9}$ en calles alrededor de la Plaza Almansa también había un bullicio de talleres especializados.
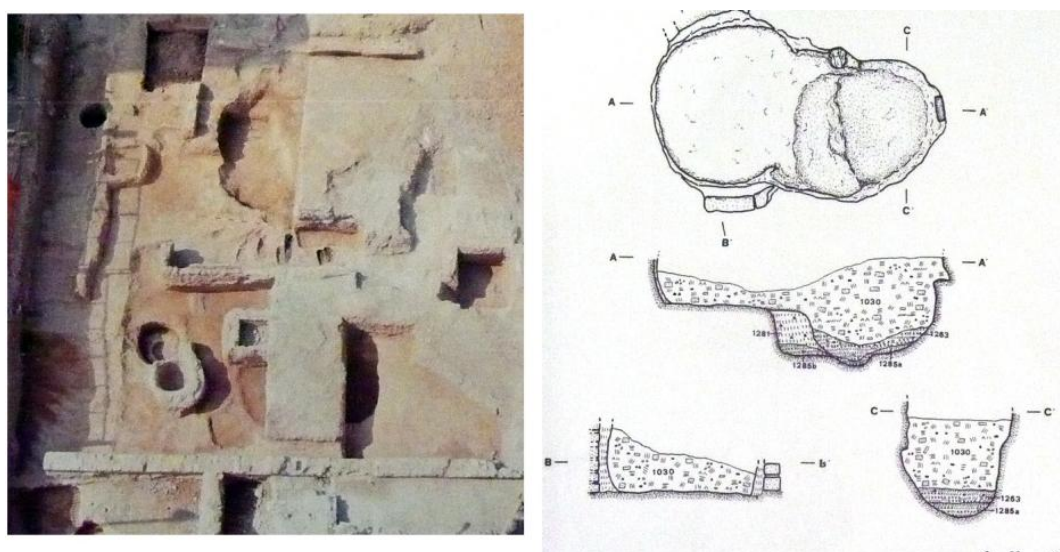

FIG. 41 Hallazgos de talleres cerámicos en excavaciones arqueológicas de la C/ Sagunto, Valencia (finales S.XII- principios S.XIII) (GARCÍA VILLANUEVA-RUIZ VAL)

El siglo XIII coincide con una atomización productiva (Azuar Ruiz) a la cual sigue una proliferación de talleres de distribución local en áreas

\footnotetext{
${ }^{8}$ En este caso se ha hallado un pozo, para extraer agua, conectado a una base cuadrada y a un pozo de decantación. Se ha documentado una primera ocupación del solar con cinco pequeñas estructuras de combustión a las que sigue una segunda ocupación con 7 hornos, más grandes, de planta ovalada, probablemente para producción de cerámicas bizchochadas.

${ }^{9}$ AA.VV., Recuperando el Centro Histórico: urbanizaciones y actuaciones en plazas, calles e edificios, Ayto. de Valencia Ed., Valencia, 2006
} 
tanto urbanas como suburbanas, de buen nivel técnico, que aprovechan acequias como la de "Rovella" y la "Podrida", pero siguen siendo ejemplos de realidades productivas aisladas entre sí, no uniformadas en un mercado.
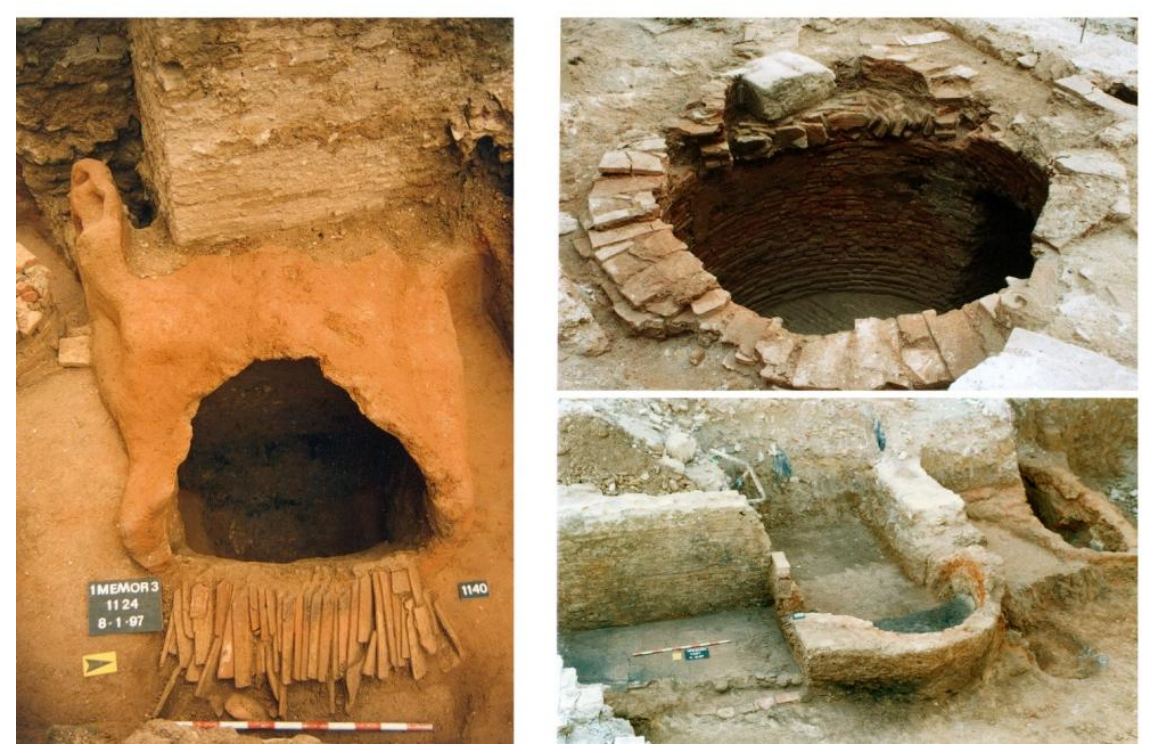

FIG. 42 Hallazgos de talleres cerámicos en excavaciones arqueológicas del centro histórico de Valencia; hornos de la C/Mesón de Morella (S. XIII-XIV) y de la C/Corona, Valencia (S. XVII-XVIII) (GUERÍN-SERRANO)

La inestabilidad social de este siglo, con revueltas de los mudéjares, en 1247 y 1264 marca un clima que dificulta la continuación de muchos oficios (López Elum 2001). Según autores (Coll ConesaPascual Martí, 1989) existe una transferencia técnica entre ambas culturas, la islámica y la cristiana, que se basan en substratos comunes que van evolucionando a la vez. Estos autores refieren a los años tras la conquista como los momentos claves en los que a la atomización de la producción sigue la afirmación de importantes centros alfareros como Manises, Mislata, Quart y Alaquàs. Valencia cristiana es una ciudad donde se siguen produciendo ladrillos. Se mencionan rajoleres importantes como Ferdinandus Pérec, vecino valenciano año 1320 y Bonant Nicolau, ambos del barrio de Russafa 


\section{murOSINTRAMUROS}

(Coll Conesa). También el mismo autor afirma como debido a la guerra entre Castilla y Aragón, muchos habitantes de los alrededores de la ciudad, como Manises se refugiaron en la urbe...generando una producción cerámica más homogénea entre centro y suburbios.

Importantes hallazgos de este periodo se encuentran en los talleres y testares, o vertederos de producción cerámica de la Calle del Agua en Valencia (Serrano 1995) y del sistema complejo de talleres Olleries Menors y Olleries Mayors en Paterna (OSMA 1908y GIMENO 1995). En el "Dietari del Capellá" de Alfons el Magnanim (1459) y en la "Aleluya de los Oficios" de Miquel Borràs (1578) no hay una referencia directa a la categoría del "ladrillero". No hay una documentación cierta sobre la existencia de un gremio específico, vinculado a la producción y/o al uso de ladrillos. Se sabe que la primera referencia documental se refiere al acuerdo de 1307 sobre el precio máximo que podía alcanzar el producto ${ }^{10}$. Por eso, algunos historiadores han propuesto como hipótesis una general falta de organización específica sobre este ramo productivo. ${ }^{11}$
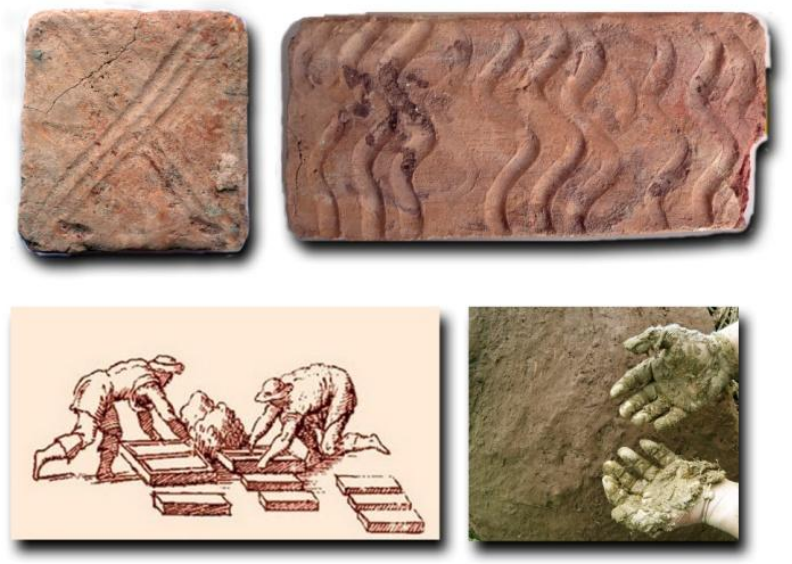

FIG. 43 Producción cerámica artesanal y sus huellas. Ladrillos catalogados en la excavación arqueológica de la C/Gobernador Viejo esquina con C/Conde de Montores (ROSSELÓ MESQUIDA-JUANELO TURRIANO FUND.-CRISTINI)

\footnotetext{
10 "...15 sueldos el millar de rajola blanca y 12 sueldos el de mijtancera". En este se habla de un general "hombre de qualsevol condició que faça rajola". AHV, Manuals de Consells, 48, f.218.

11 GONZÁLEZ MARTí, Cerámicas del Levante Español, siglos medievales, Ed. El Labor, Barcelona, 1944. Tomo II, p.98
} 
La producción cerámica en Valencia a lo largo del siglo XVI se ve vinculada e influenciada por el movimiento de Las Germanias así como por el conflicto morisco. Este colectivo de alfareros estába constituido tanto por alfareros moriscos como por "cristianos viejos" esto se da en la existencia de comunidades mezcladas en los barrios alfareros de Paterna y Manises (Gimeno 1995).

En este siglo nace la Cambra de Rajola de Manises, el primer depósito de materiales de construcciones documentados con rigor, para reparaciones y abastecimientos. Esta institución junto a la provisión de otras materias primas (ej. el plomo para la decoración de las lozas) es un ejemplo palpable de los problemas de suministro que perduran en la zona de Valencia/Manises a lo largo de todo el siglo XVII. Ese aspecto podría atender a la acuciante decadencia provocada por la expulsión de los moriscos, y la crisis que está provoca en todo el entorno.

Se debe esperar hasta el siglo XVIII, concretamente hasta la Fundación de la Real Fábrica de Loza de Alcora (1727), para observar un profundo cambio en el sistema productivo imperante en el "mundo de la cerámica". Finalmente el mecanismo anquilosado y sub desarrolado que marca todo el siglo XVII llega a su fin. Importantes cambios en la organización gremial, normativas, y en la división de competencias, entre ladrilleros y alfareros, marca profundamente el mercado, que se abre a establecimientos normativos novedosos y rigurosos. Los cambios importantes que afectan a la cerámica decorativa influyen directamente en la producción de la cerámica arquitectónica, importando un modelo ilustrado y racional de la producción, que dio origen a auténticas manufacturas preindustriales. Se pasa de talleres a fábricas preindustriales, con un importante cambio de la codificación productiva y organizativa del mercado. El crecimiento urbano, con la demanda en continuo aumento de cerámica arquitectónica, así como el crecimiento urbano constante, la mejora de vías de comunicación y transporte, son algunos de los principales factores que impulsaron el mercado de los ladrillos. 
En la ciudad se apunta a la zona de la Calle Corona, donde discurría la acequia de Rovella, como un área de vocación productiva importante (históricamente con presencia de tintoreros, y pelaires). En esta calle y en la de S. Ramón se asientan numerosos talleres de alfareros. Justo esta última es la que antiguamente se conoce como "Calle dels Fornals" en todas las providencias del Mustaçaf, en el siglo XIV-XVIII. También en las áreas próximas a la plaza Mosén Sorell, se encuentran talleres históricos conocidos y famosos, como el de Vicente Navarro, activo hasta al 1799, un reconocido alfarero de la ciudad (Pérez Guillén 1990). En la Calle Padre Huérfanos/Guillem de Castro se ubican otros núcleos de producción urbana reconocida, una de González Valls, otra de José Monserrat, dueños de fábricas de la primera mitad del siglo XIX (Gonzalez Martí 1952).

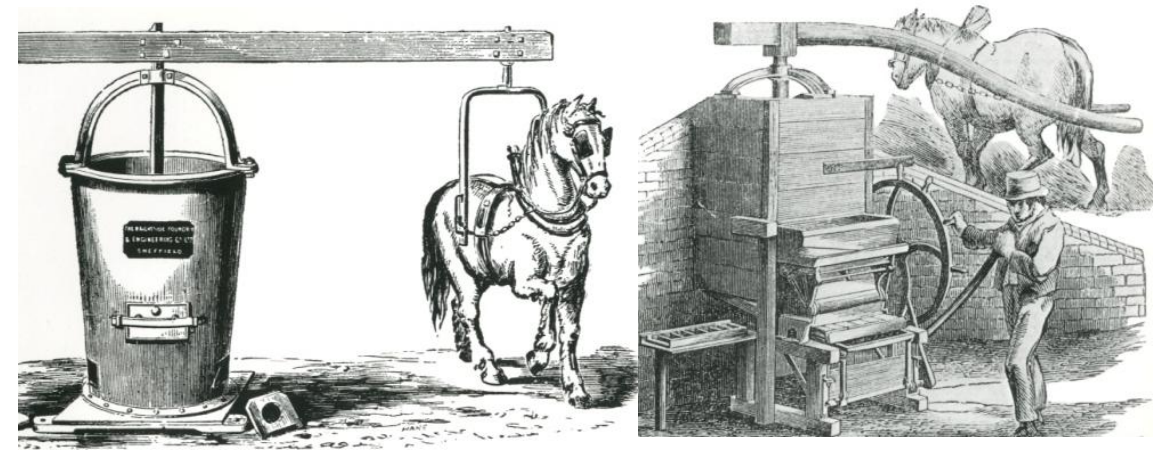

FIG. 44 Primeras patentes que emplean la fuerza animal para mezcla de arcilla y extrusionadoras de ladrillos, 1845, Sheffield, UK (CAMBELL-PRICE)

El mismo autor también nombra establecimientos menores, en la C/Murviedro, C/Jesus, C/Quart, Llano de la Zaidia, C/Llano del Remedio, entre otros. No se sabe con exactitud dónde y si hay un linde entre producción de vajillas/lozas y de ladrillos/tejas. Pero si, se conoce que en el siglo XIX se logra un reto importante para la producción de cerámicos: la mecanización y el prensado de ladrillos.

Se documenta que a partir de 1867 en Meliana, se empieza a utilizar la prensa extrusionadora Whitehead, movida a vapor, ideal para la producción de tubos, cilindros y ladrillos de cerámica. 
El mismo año coincide también con la llegada del horno Hoffman, con planta circular a doce cámaras, de fuego continuo y regulable.

A finales del siglo XIX también en la fábrica "La Alcudiana", por primera vez, se utiliza otro tipo experimental de horno. En este caso se trata del tipo de vagonetas, Boulét-Fréres, que también garantiza un proceso continuo de horneado/descarga, con importantes mejoras en la regulación y normalización de la producción (CollConesa 2009).
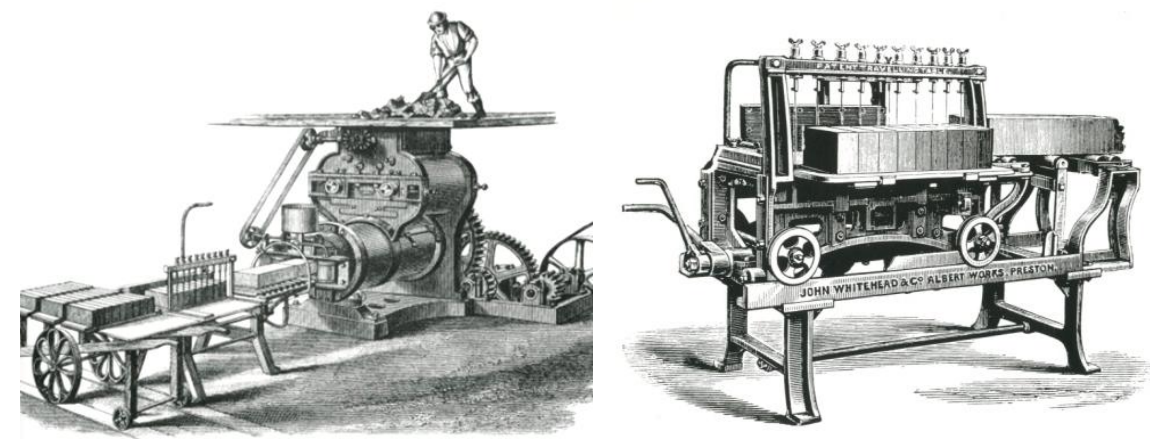

FIG. 45 Dos distintos modelos experimentales de extrusionadoras a vapor, patente inglesa Whitehead, 1860 (CAMBELL-PRICE)

Por tanto, con el análisis propuesto podemos registrar esta hipótesis de secuencia de fenómenos productivos en el entorno valenciano:

1) Producción inicial de ladrillos con carácter doméstico, estacional y no altamente especializado (fundación de la ciudad)

2) Progresión hacia una producción de ladrillos con hornos e instalaciones temporales, progresivamente especializadas, que se realiza a través de alfareros expertos (edad romana imperial)

3) Regreso hacia una producción de ladrillos de carácter domestico, estacional y no especializada (caída del imperio romano / época visigoda)

4) Impulso hacia una producción de ladrillos con hornos e instalaciones en la mayoría de los casos estacionales, pero 


\section{murOSINTRAMUROS}

especializadas, que se realiza a través de alfareros expertos (dominación islámica)

5) Evolución hacia una producción estable, especializada, localizada en áreas extraurbanas, que refleja un auténtico mercado controlado (Reconquista /siglo XVI)

6) Afirmación de un mercado codificado y homogéneo, cada vez más estructurado y de calidad (ej. ladrillos aplantillados), impulsado también por la afirmación de la industria cerámica y la producción preindustrial (Siglo XVI-XIX)

\subsubsection{El ladrillar/rajolar ${ }^{12}$}

El oficio relacionado a la producción de ladrillos era considerado duro y de baja calidad social, desarrollado sobre todo desde febrero a octubre, dejando para los meses fríos, las labores de mantenimiento del ladrillar (o tejar). Por eso el "calendario" del ladrillero o rajoler, duraba desde San José hasta las primeras heladas del invierno, aproximadamente.

Hay una clara estructura jerárquica: los terraires extraían la tierra y la trasportaban hasta la balsa de trabajo; los bassers, mezclaban la tierra con el agua, los rajolers, llamado els oficials, eran los que hacían la mezcla. Los bailos eran ayudantes y aprendices al mismo tiempo. Los enfornadors, colocaban las piezas cerámicas en el horno $y$, finalmente, los couadors se encargaban del mantenimiento del fuego.

A veces, y según el volumen de ladrillos, diferentes oficios eran asumidos por la misma persona. Las figuras del enfornador y del couador eran más propias de los hornos tipo Hoffman, ya más

\footnotetext{
${ }^{12}$ CORNELLAS P., CRUZ P., L'ofici de rajoler, Editorial Alpina, Granollers, 2010 MONESMA E., Los ladrilleros, las tejas, teja, ladrillo y baldosa, el cañicero, el cielo raso, Huesca Pirynee Ed., Huesca, 2004 (DVD)
} 
modernos. La jornada laboral transcurría aproximadamente desde las 6.45 de la mañana a 18.45 de la tarde, horario conocido como "de sol a sol", 12 horas diarias de lunes a sábado. Los domingos podían ser laborales siempre y cuando el fuego de los hornos se hubiese encendido. A las 9 de la mañana se solía realizar un descanso/pausa para almorzar; a las 10.45 había otra parada de 10 minutos Ilamada "cigarret i beguda" o" fer beguda", descanso que se iba a repetir a mitad de tarde.
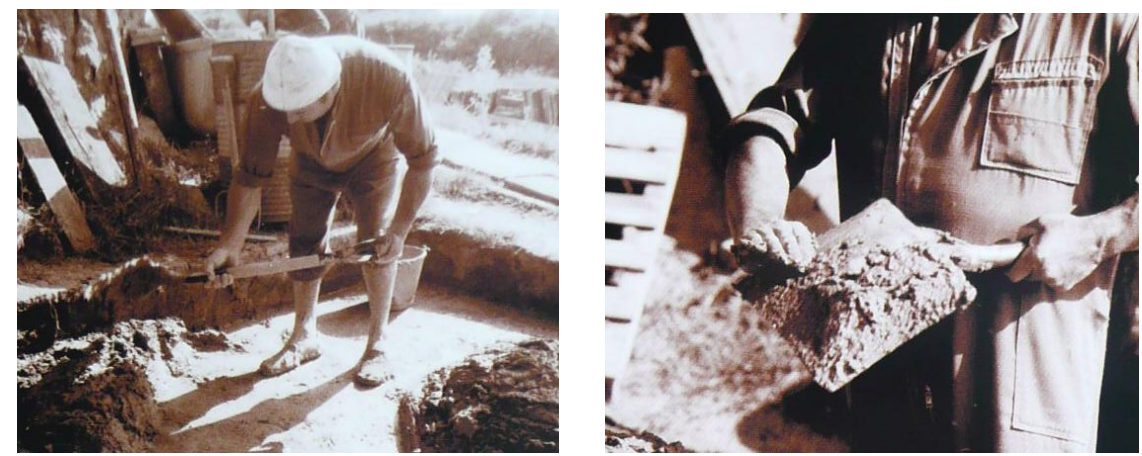

FIG. 46 Terraires y bassers moldeando ladrillos, en un rajolar de Granollers (CORNELLAS)

Independientemente del tipo de horno, el proceso de fabricación de un ladrillo es parte de un ritual bastante codificado, básico, e inalterado en el tiempo. Con la revolución industrial se ha mejorado la mecanización, calidad y control de la producción. Pero las etapas que se pueden identificar en el día a día del oficio del rajoler son fundamentalmente estas seis ${ }^{13}$.

-Preparación de la arcilla (extracción, desmenuzado, pisado, remoción)

-Amasado (mezcla oportuna con agua, pisado y removido)

-Moldeo (moldeado a través de un bastidor)

-Rasero (alisado de las superficies y sus acabados)

${ }^{13}$ VEGAS F., MiLETO C., GUIMARAENS G., Homo faber, Arquitectura preindustrial del Rincón de Ademuz, Prames 2008, p.202-207 
-Secado (colocación en las esplanadas de los rajolars, colocación de los ladrillos en rejales o rimes, o sea de canto, apilados, para favorecer el secado)

- Cocción (en hornos de leñas o tobas, con tiempo variable entre diez, doce o seis días, hasta que la llama es de color blanquecino y sale sin humo) ${ }^{14}$.
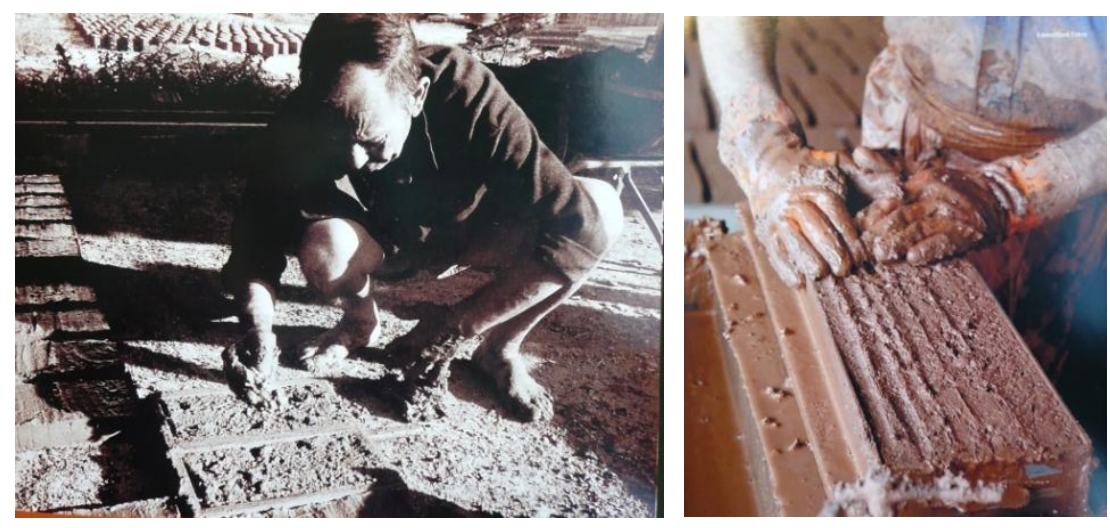

FIG. 47 Rajoleres y bailos moldeando ladrillos, en un rajolar de Granollers (CORNELLAS)

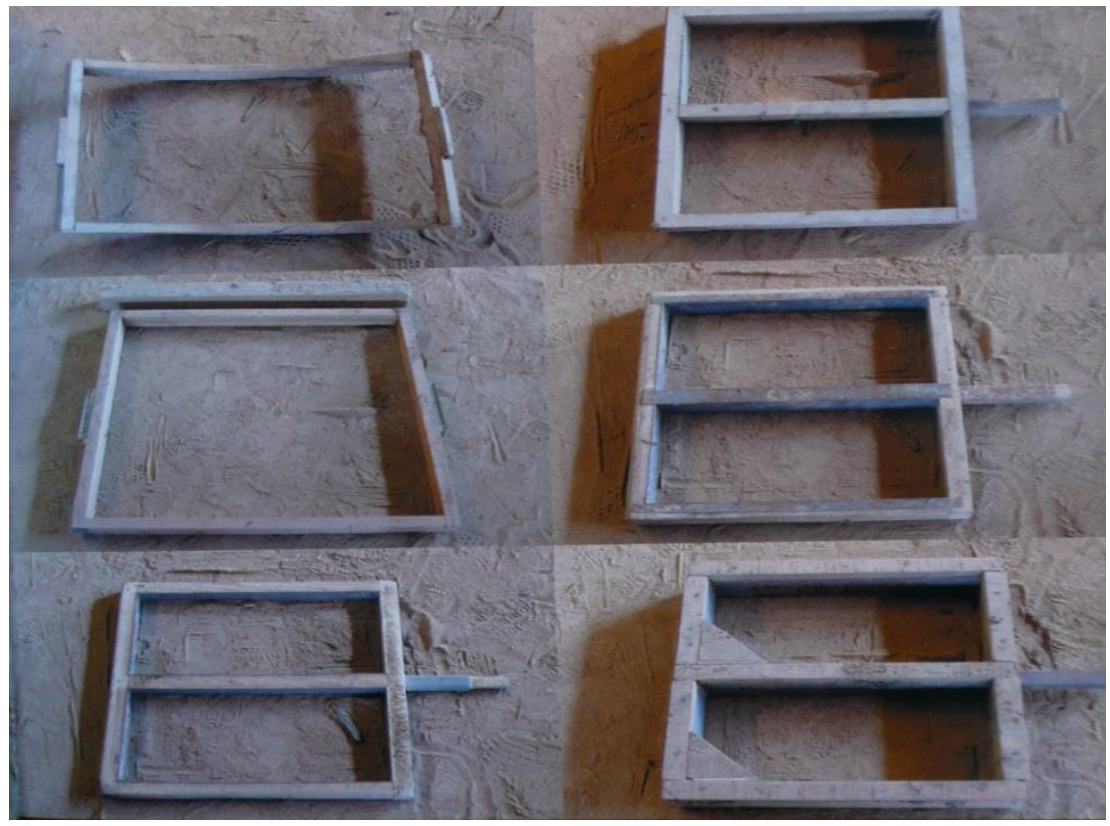

${ }^{14}$ Entre otros, MARCO Y BAUSÁ, El Manual del Albañil, Madrid, 1835, p.61-64 
Los encargados de seleccionar el arcilla, los terraires, iban seleccionando la materia prima, evitando partidas con alto contenido de cal y/u arena para luego mezclara con la dosificación de agua apropiada.

Se trataba de una extracción a mano, de yacimientos siempre bastante próximos al punto de empleo del ladrillo. En muchos casos la extracción era en depósitos bastante superficiales, hecho que implicaba en muchos casos la eliminación de materia orgánica, incluso de vegetación.

El método tradicional preveía la extracción de la arcilla en otoño, para luego proceder al mezclado y amasado al principio de la primavera, momento en el que se procedía también al atemperado del amasado.

Airear bien la mezcla y proceder a su amasado, en muchos casos con manos y pies, era un momento fundamental de la buena producción de la partida de ladrillos. Se podían quitar piedras u otros elementos inoportunos detectados y, a la vez, añadir aditivos, como ceniza, arena, ladrillo molido, etc.

Eran los pasteres, los que se ocupaban de la justa dosificación de materias primas, que se iba apilando en la era en barreres, depósitos regulares.

La mezcla, trabajada tanto por los rajolers como por los aprendices/ayudantes, los bailos, se realizaba en una era, con la ayuda de una munydora, un capazo lleno de agua para calibrar y afinar así la cantidad de agua presente en la mezcla de arcilla. Antes de introducirse el más moderno extrusionado en el siglo XIX, el moldeado se hacía con mezcla de arcilla más líquida o más densa.

El tipo conocido como "de paleta" se realizaba con arcilla más maleable, pastosa, a través de moldes espolvoreados de arena, y con un perfilado final de los bordes de los ladrillos gracias a una paleta. 

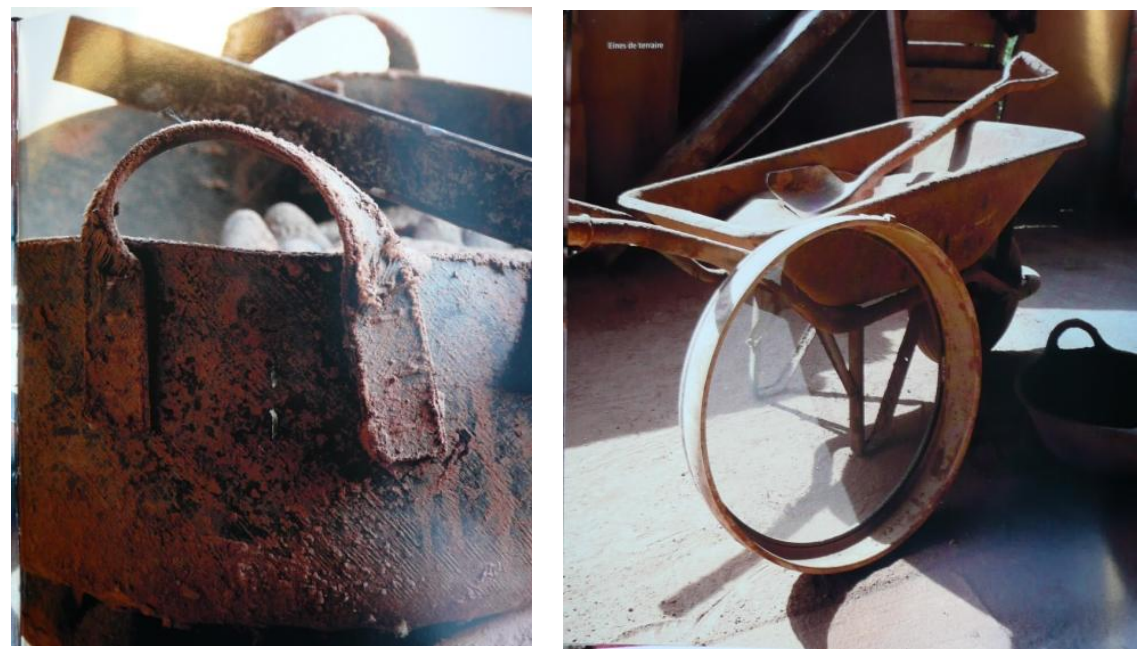

FIG. 48 Munydora y carrega, herramientas básicas del rajolar de Granelles (CORNELLAS)

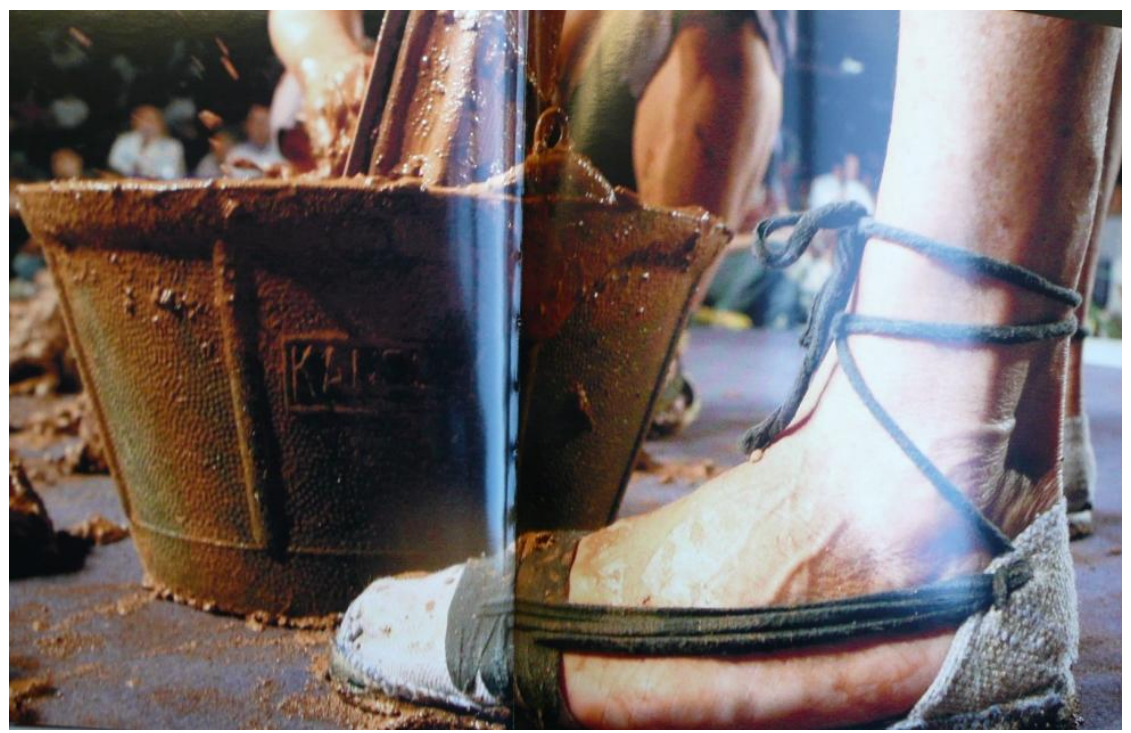

Por otro lado, el moldeado de "barro blando" se realizaba con lodo más líquido y humectado. En este caso, el enarenado se sustituía por un simple mojado, para evitar que la mezcla de arcilla se pegara a la gravilla. La obra crua, así es como se llamaba el producto recién moldeado, se dejaba secar y reposar, para lograr de esta forma la obra verda, o sea, la producción madura de los elementos constructivos "en crudo". Los esbravadors eran los especialistas que 
se ocupaban de perfilar bien los prismas de arcilla y de ordenar los ladrillos en enreixats o rimes, o sea en áreas regulares, con piezas uniformes dispuestas de canto, en las que la separación de los elementos y la justa ventilación, garantizaban un secado apropiado.

A veces estas hiladas también recibían el nombre de ratles, que variaban entre 7-10 en cada enreixant o sector de trabajo. Dependiendo del grado de humedad y de la temporada, los ladrillos se dejaban secar unas semanas, más o menos dependiendo de las características climatológicas. La lluvia era un enemigo endémico del oficio, así como el clima demasiado seco.

La materia prima para encender el fuego y los hornos eran los matorrales, nombrado comúnmente gavella. La personas que alimentaban la búsqueda de materia prima se nombraban los boscaters, cuyo medio de transporte, era conocido como carros de trabuc o d'escala. Cada fajo de matorral, comercializado por cárregues, equivalía aproximadamente a 3 manojos de matorral, de unos $1.5 \mathrm{~m}$ de largo y $50 \mathrm{~cm}$ de diámetro. Forcats o forquetes, horcas de diferentes tamaños alimentaban el fuego de la cámara de combustión del horno. 


\subsection{Vendedores y controladores: mercado y comercio}

\subsubsection{Instituciones}

En la ciudad se realiza un control férreo sobre el comercio de ladrillos, sobre moldes empleados y precios de venta, igual que se hace con diversas manufacturas. ${ }^{1}$ Hay referencias poco definidas sobre magistri romanos y controladores islámicos ${ }^{2}$, hasta la llegada de Jaime I, con el que se marca un paso importante en la normativa de abastecimiento de los materiales de construcción.

A partir de entonces, se documenta el papel del Mustaçaf ${ }^{3}$, responsable municipal de pesos y medidas urbanas, prohombre que desempeña un rol fundamental en el mecanismo de regulación de las actividades y movimientos mercantiles urbanos, controlados por el Tribunal del Repeso. Como se ha indicado, esta profesión, esta

\footnotetext{
${ }^{1}$ El documento más antiguo encontrado a tal propósito referido a la alfarería valenciana se refiere al arrabal de Xàtiva, donde en 1251 se fija a los cantareros una "franquicia para fabricar cánters, olles teules i rajoles" (APARICI-ROSAS)

${ }^{2}$ El nombre es heredero del Muhtasib árabe, un oficial encargado de la institución musulmana llamada Hisba, que tenía como misión la vigilancia y comprobación de las pesas y de las medidas, la equidad del mercado y la regulación de diferentes oficios de la ciudad

${ }^{3}$ Otros nombres conocidos son también como Mostaçaf, Mudaçaf, Almustaçaf, Almostaça, Almotacenf...Según LÉVI-PROVENÇAL, L'Espagne musulmane au Xme siécle, pp.185: "Chaque ville avait aussi un délégué du governement dont la misión étatit sans rapport avec le systéme financier: elle consistait dans la surveillance des artisans et de merchandans dasns la policedes marchés; le titulaire occupait une place assez considerable parmi les fonctionnaires civils: c'éait le muhtasib..."
} 


\section{murOSINTRAMUROS}

documentada en la ciudad desde los fueros otorgados con la Reconquista, y perdura hasta el siglo XVIII cuando, tras la Guerra de Sucesión, se abolía la legislación foral valenciana.

Si queremos definir las pautas históricas que definen esta profesión, tenemos que remontarnos a 1238, momento en el que el nuevo régimen municipal, definido por Jaime $\mathrm{I}^{4}$, consigna y define con meticulosidad las leyes metrológicas básicas de la ciudad. En este momento se define el papel de un funcionario, inspector de pesos y medidas, pasando a ser una auténtica autoridad jurídica y social de la ciudad. Este modelo fue exportado a otras ciudades, como Mallorca Barcelona, Alicante u a centros menores (Albalat, Catí, Alcira...) donde también se documenta esta institución (Pons 1949-Chalmeta 2008).
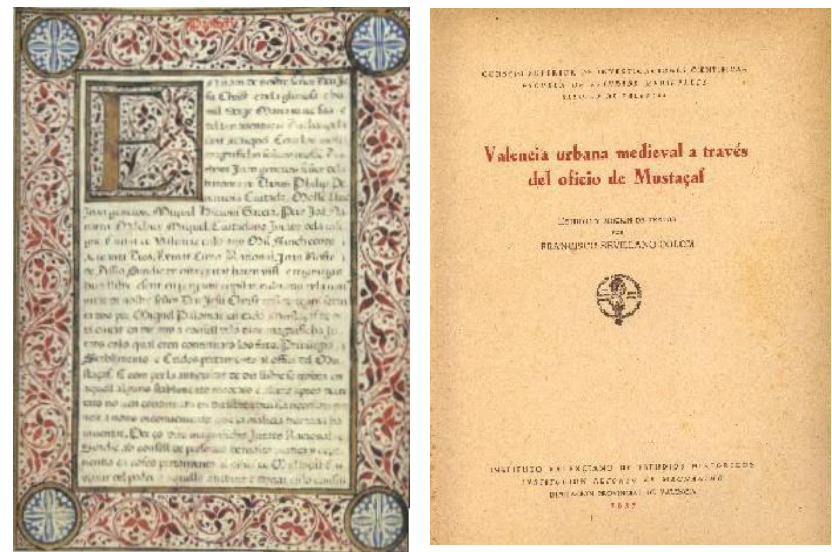

FIG. 49 Detalle (caja contenedora por PALOMAR M.) de la primera edición de los Privilegi de la ciutat de Valencia, donde se recopilan las actuaciones el Mustaçafjunto con los fueros 1372, A la derecha la portada del pionero texto de SEVILLANO COLOM, De la Institución del Mustaçaf de Barcelona, de Mallorca y de Valencia, Madrid, 1952 (AYTO. VALENCIA)

La labor del Mustasaf estaba basada en vigilar la buena calidad de los víveres y artículos de consumo, así como los precios y transacciones y sancionar los fraudes mercantiles con un

${ }^{4}$ En los fueros de Valencia (Fori, rub. CXXXXVII, 6) Don Jaime I "... determina que cada año, por S.Miguel de septiembre sea elegido por los prohombres de la ciudad y por cada Curiaun prohombre habitante de la Ciudad, que tenga, durante el año que sea elegido, el oficio de la almudaçafía..." 
procedimiento judicial público y oral $\left.\right|^{5}$. No es aventurado suponer que, hay una continuidad entre el funcionario islámico y el cristiano. A lo largo del siglo XIII no tuvieron más que adaptar a nuevas necesidades una institución ya existente.

Se trata de un funcionario municipal, de elección anual, que por sus funciones depende del Consell. Su papel es de jurisdicción absoluta sobre todas las clases sociales y todos los oficios. Entre las tareas principales que más nos pueden interesar del Mustaçaf," en el ámbito de arquitectura es, sobre todo, el control de los materiales de construcción que se producen y venden, el control de servidumbres, medianeras, paredes, ventanas, higiene, etc.

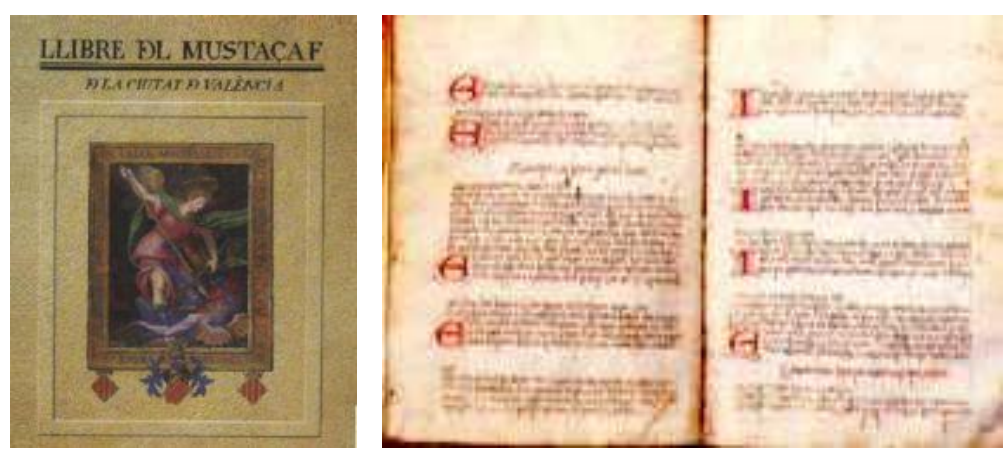

FIG. 50 Detalle (portada por PORTA M..J.) de la actualización de las instituciones forales del Mustaçaf, 1568 (ALMELA Y VIVES). A la derecha ejemplo de las páginas del Llibre del Mustaçaf conservado en el archivo del Ayto. de Catí, Castellón (CHALMETA)

A estos años se remontan los primeros cumplimientos de disposiciones que aseguren higiene en las viviendas urbana, con ordenanzas que reducen la falta de higiene en las estrechísimas calles de origen musulmán de la ciudad, evitando el oscurecimiento y procurando una mejora de la ventilación.

Las ventanas abocinadas ${ }^{6}$ que mejoran la luz y la ventilación de las viviendas, podrían vincularse a estas disposiciones. En las

\footnotetext{
${ }^{5}$ ALMELA Y VIVES F., Llibre del Mustaçaf de la ciutat de València, Ayto Ed., Valencia, 2003

${ }^{6}$ Lib. De Privilegios, XXIX, 1 y Lib. De Ordenaciones del Mustaçaf de Valencia, LXII,I (AHMB). En arquitectura se conoce como abocinado de un hueco o vano en un muro en el que la posición
} 
disposiciones de Jaime II, de 1321, se precisa también cómo las fábricas no tienen que tener aleros con más de $1 / 3$ de anchura de la calle, de este modo se garantizaba un espacio por donde penetrara la luz. También se encomienda al Mustasaf que exigiera el cumplimiento de esta disposición.

Al mismo tiempo, el Conse// se encarga de la adquisición de muchos saledizos o miradores de las casas y de su destrucción en ocasión de una visita real o de procesiones, prohibiendo posteriormente su reconstrucción (Sanchis Sivera 1992).

La importancia del Mustaçafen Valencia es tan grande que incluso el magistrado tiene un edificio proprio para el desempeño de su cargo. En 1371 la Ciudad compra un solar donde en 1372 se construye la Llotgeta del Mustaçaf, cerca de la esquina de la iglesia de Santa Catalina ${ }^{7}$ Sevillano Colom 1952) y también en la Calle Trench, cerca de la Plaza Redonda, sabemos que había una piedra rectangular donde se efectúaban las diferentes operaciones del repeso ${ }^{8}$.

Según las fuentes (Tarazona 1580) el Mustaçaf no actúa de forma aleatoria, siempre se conforma a una serie de normas preestablecidas por las autoridades o corporaciones pertinentes. Las primeras ordenanzas fueron recopiladas en 1372, por Miguel Palomar, ciudadano que entonces ejercía el cargo y luego fueron

de sus paredes laterales, no paralelas, presentan una anchura aumenta progresivamente, garantizando así más entrada de luz y aire por el vano

${ }^{7}$ El Mustaçaf tiene una importante proyección también sobre otras ciudades. Precisamente al conceder Pedro IV el Ceremonioso este mismo oficio a la ciudad de Barcelona, con la expresa indicación de que siguiera el modelo valenciano, provocó la demanda de los libros del Mustaçaf de Valencia, hecha por los consellers de Barcelona. Ya gracias a estas copias-ya que los originales no se conocen y a las cartas que se cruzaron entre las ciudades, hoy en día podemos ver el cargo edilicio del Mustaçaf, perfectamente definido. SEVILLANO COLOM, De la Institución del Mustaçaf de Barcelona, de Mallorca y de Valencia, Madrid, 1952

8 "...la piedra del Mustaçaf era un bloque rectangular de dos palmos en cuadro y casi cuatro de alto desde flor de tierra... fue muchísimos años el tablero o pedestal para repesar oficialmente, cuando el caso lo ruquería, los artículos, sobre cuya exactitud había dudas en las transacciones..." MARQUÉS DE CRÜILLES, Guía urbana de Valencia Antigua y Moderna, Valencia, 1876, p.339 
ordenadas, corregidas y actualizadas en 1549, por el Consejo General de Jurados, Racional Abogados y Síndicos', así como en 1692. El libro simbólicamente tiene en la portada una representación polícroma de S. Miguel, un frontispicio que alude a la equidad en los pesos dada por la balanza que porta el Santo en sus manos.
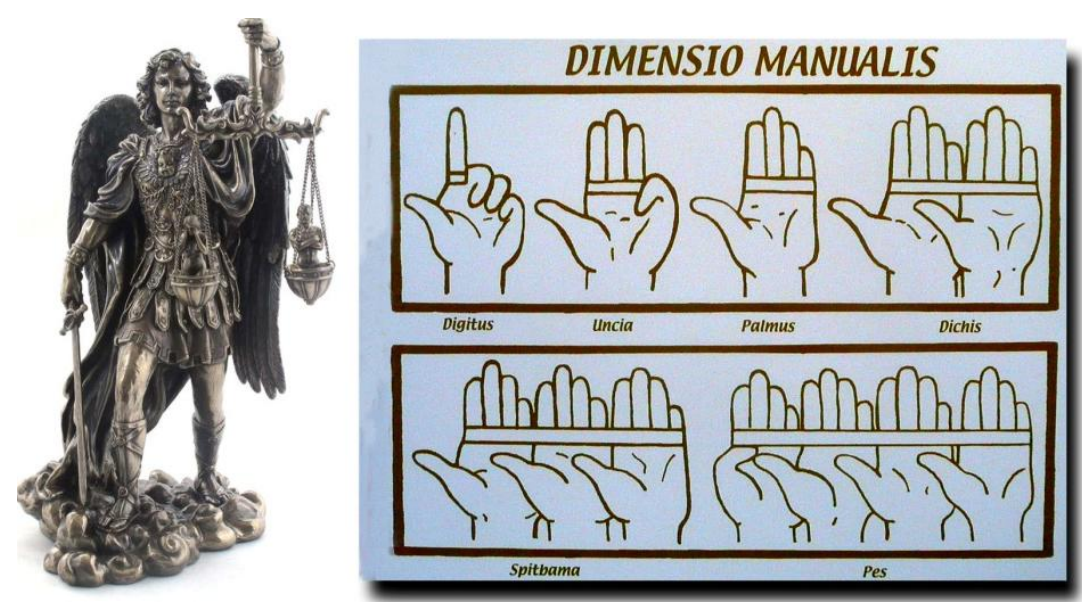

FIG. 51 San Miguel, como símbolo del Mustaçaf, prohombre responsable de pesos y medidas (en el caso de los ladrillos...la unidad de medida eran los palmos $1 \mathrm{p}=23 \mathrm{~cm}$...y los dedos $1 \mathrm{~d}=2 \mathrm{~cm}$ ) (MUSEO DE LA CIUDAD VALENCIA)

El cambio más significativo relativo al rol del Mustaçaf coincidió con las reformas borbónicas. El encargo fue suplantado en 1718 por uno de los regidores, que por turnos semanales ejercía las funciones del antiguo almotacén.

Más tarde fue creado el cargo de Fiel Almotacén Provincial, Institución que fue substituida en 1871 por el Fiel Contraste de Pesas y Medidas, que marca el fin de la antigua institución ciudadana que regula la Valencia pre y post medieval (Sevillano Colom 1952).

${ }^{9}$ CHINER GIMENO J., GALIANA CHACÓN J., Libre del Mustaçaf, edición del manuscrito del archivo municipal de Valencia de 1549, Graficas Ronda, Valencia, 2003 


\section{murOSINTRAMUROS}

\subsubsection{Cuerpo normativo y legal}

De 1340 es el "Establiment dels rajolers"10 uno de los pocos documentos explícitos que se pueden encontrar sobre la regulación de la producción de los ladrillos y de las tejas. En éstos se lee cómo los ladrilleros tienen normas precisas para que sus moldes (gravillas) tengan bordes de hierro y una varilla transversal. De lo contrario el Mustaçaf está autorizado a romperlos e obligar a rehacerlos ${ }^{11}$. Finalmente también sabemos que entre $1335-1340^{12}$ se fija por primera vez el precio de ladrillos en Valencia, debido a la falta de actualización de los mismos desde 1310.

Según las fuentes ${ }^{13}$ se conoce que estos precios eran de:

"1000 ladrillos medianos, por 15 sueldos.1000 ladrillos blancos, por 19 sueldos. 1000 teyas por 20 sueldos." ${ }^{14}$ Por lo que piden un aumento de precio por millar. Además, se indican los precios de las fracciones de miles de cada clase. En el Conse// reconociendo lo justo de la demanda, que se apoya en el salario de los obreros de la construcción, accede a la petición y ordena nuevos precios que son los siguientes:

${ }^{10}$ GARCÍA OLIVER F., Libre de establimenti e ordenacions de la ciutat de Valencia, I, 1296-1345, UV. Ediciones, Valencia, 2007.(Fax-simil del libre de Claveria, 1401_folio 405). p.364-65

${ }^{11}$ Lib. De Ordenaciones del Mustaçaf de Valencia s LXII (AHMB)

"1. Stabileren et ordenaren lo justicia, els jurats et els prohomens conseyllers que tots los rajolers de la orta et del terme de la ciutat de Valencia sien tenguts de tenir los motles ab que fan les rajoles ferrats per les ores ab vergura de ferre, aixi com es la barcella, et aquel qui no fara sia tengut de paguar al mustaph $L X$ sol de reals, et que el motle sia trencat

2. Item ordenaren que tots los motles sien sen/ yalats ab lo señal real, jatsia aço que sien ferrats; et qui no o fara, pach per pena V sol., et si no era de la amplea del padro del Mustaçaf et de la longuea et sisa, pach los damnut dits $L X$ sol.

${ }^{12}$ No hay una fecha clara, debido al disorden con el que se transcribieron las ordenanzas del Mustaçaf

${ }^{13}$ HAMILTON E.J., Money, prices, and wages in Valencia, Aragon, and Navarre, 1351-1500, Harvard University Press, 1936, vol.51

${ }^{14}$ Lib. De Ordenaciones del Mustaçaf de Valencia, V, 1 a 6. (AHMB) 
"1000 ladrillos medianos, por 16 sueldos, 1000ladrillso blancos 19 sueldos, 1000 tejas 20 sueldos." Por lo tanto existe un aumento importante por millar de unidades.

"500 ladrillos medianos, 8 sueldos, 500 ladrillos blancos, 9 sueldos y 1/2. 250 ladrillos medianos, 4 sueldos. 250 ladrillos blancos 4 sueldos y 1/2. 100 ladrillos blancos 23 dineros." ${ }^{15}$ Los precios siguen aumentando:

". .1000 ladrillos medianos 21 sueldos. 1000ladrillos blancos 25 sueldos. Y 1000 tejas 20 sueldos..." ${ }^{16}$ Por lo tanto se puede notar como en poco años hay una aumento de casi 5-9 sueldos para cada clase de las citadas."

De 1484 existe documentación, aunque un poco nebulosa, sobre la categoría profesional de los ladrilleros. En él se establece la forma de acceso a la profesión y el criterio para establecer penas en caso de fraude. Unos años después, en 1500, se definen con más detalles estos mismos aspectos, especificando ordenanzas y nombres de maestros potenciales. ${ }^{17}$ Con el tiempo al libro escrito en pergamino fueron añadiéndose nuevos fueros, privilegios, ordenanzas y pregones. Muchas ordenanzas se iban revocando, otras se iban modificando y se necesitaba "proveer a nuevos inconvenientes que había inventado la malicia humana" (Chiner Gimeno- Galiana Chacón 2003).

Finalmente la producción y la venta parecen codificadas y actualizadas a partir del siglo XVI. Leyendo en la "Rubrica de rajola e teula" del libro "revisado "del Mustaçaf de 1549. Allí consta que la producción de ladrillos entra en la regulación del macro-grupo "otras industrias". En este apartado no están mencionadas todas las industrias que seguramente eran practicadas en Valencia. Pero sí que en este "no bien precisado grupo" aparece el nombre, de los

\footnotetext{
${ }^{15}$ Lib. De Ordenaciones del Mustaçaf de Valencia, LII, 5. (AHMB)

${ }^{16}$ Lib. De Ordenaciones del Mustaçaf de Valencia, LII, 6. (AHMB)

${ }^{17}$ AHMV, Manuals de Consells, 50, f.201
} 


\section{MUROSINTRAMUROS}

ladrilleros, mientras otros gremios se agrupan en otras subasociaciones (Carrera Pujal) ${ }^{18}$. También en 1549, debido a los continuos fraudes, se establece un molde de referencia, conservado por el Mustaçaf, al que tienen que conformarse los demás rajoleres. El nuevo libro, confeccionado por Miguel Juan Porta, pintor, y Cristobál Sebastián Ramírez, escribiente, se conserva aún en el Archivo Municipal de Valencia, y se puede considerar el volumen en pergamino que mejor puede aclarar el cuerpo normativo histórico relativo a la producción y ventas del ladrillo en la ciudad de Valencia.
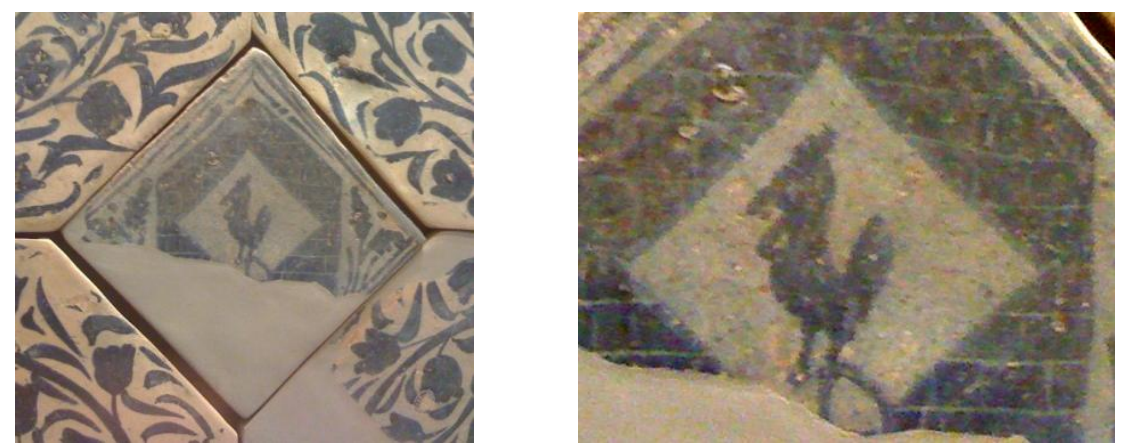

FIG. 52 Azulejos con el emblema del Gremio de los ladrilleros, Manises, Valencia posiblemente 1415. La casa gremial era identificada por un muro de ladrillos sobre el que se superponía un gallo, símbolo del santo protector de la misma, S. Pedro. (MUSEO NACIONAL DE CERÁMICA)

El siglo XVII no se caracteriza por ser un enclave temporal que destaca por su excelencia normativa, sino más bien por "reciclaje" y actualización de la normativa existente ${ }^{19}$. A partir de la renovación del libro del Mustaçaf de 1549, siguen ulteriores actualizaciones y cambios. Por ejemplo en el siglo XVII se consolida la agrupación del

\footnotetext{
${ }^{18 " ~ L a ~ c i u d a d ~ d e ~ V a l e n c i a ~ e s ~ r i c a ~ p o r ~ e l ~ g r a n ~ c o m e r c i o ~ d e ~ m e r c a d e r e s ~ y ~ v i s t o s a ~ p o r ~ l a ~ v a r i e d a d ~}$ de infinitos oficios mecánicos y arte de vivir..."en CARRERA PUJAL, Historia de la Economía Española, Bosh Ed., Barcelona, 1943-47

${ }^{19}$ BAIXAULI JUAN I.A., Els artesans de la València del segle XVII. Capítols dels oficis i collegis, Universitat de València Ed., Valencia, 2001, p.11.

"...durant la segona meitat de la centúria el món de la construcció, tant obrers de vila, picapedrers com rajolers, regula la seua actividad. No es gens casual que els obrers de vila es dediquen a reglamentar el seu ofici a finals del segle, concretament el 1676, 1695, 1697, com també ho fan pedrapiquers el 1686 i rajoleres el 1692..."

BAIXAULI JUAN I. A. (2001) Op. Cit,, p.16
} 
sector de la construcción, como una rama bien estructurada de "Obrers de vila, pedrapiquers i rajoleres".20 Sigue una reforma del texto significativa de 1692 (Baixauli Juan), aunque las nuevas ordenanzas tendrían corto plazo de vida.

De hecho con la abolición de los fueros, en 1707, desaparece el rol del controlador municipal heredando sus atribuciones primero regidores y después concejales y otras autoridades y organismos. Por ejemplo en 1838, todavía en nombre de esta institución municipal, se escribe cuales son los productos que se autorizan y sus dimensiones optimas (Sanahujia).

1) TOVAS= son piezas rectangulares, desecadas al sol, no cocidas, reguladas por medidas de de 1 palmo y 4 líneas de longitud $\left(29.4 \mathrm{~cm}^{21}\right), 8$ dedos de anchura $(16 \mathrm{~cm})$ y 2 dedos y 8 líneas de grosor $(5.28 \mathrm{~cm})$. A veces se denotan con este nombre de modo impropio los ladrillos sometidos a cochura.

2) $\angle A D R I L L O S$ GORDOS= son piezas reguladas por medidas de 1 palmo y 5 dedos de longitud $(33 \mathrm{~cm})$, por 7 dedos y 9 líneas de anchura $(15.44 \mathrm{~cm})$, y 2 dedos y 3 líneas de grosor $(4.48 \mathrm{~cm})$.

3) LADRILLOS DELGADOS= son piezas reguladas por medidas de 1 palmo, 5 dedos y 4 líneas de longitud $(33.6 \mathrm{~cm})$, por 7 dedos y 11 líneas de anchura $(15.76 \mathrm{~cm})$, y 1 dedo y 9 líneas de grueso $(3.44 \mathrm{~cm})$.

\footnotetext{
${ }^{20}$ BAIXAULI JUAN I. A. (2001) Op. Cit, ,p.9

${ }^{21}$ El pasaje de las medidas valencianas a las métricas es el siguiente: 1 palmo $(23 \mathrm{~cm})$ se divide en 12 dedos; 1 dedo $(2 \mathrm{~cm})$ se subdivide en 12 líneas; 1 línea $(1.6 \mathrm{~mm})$ LÓPEZ GONZÁLEZ C. y GARCÍA VALLDECABRES J., "La instauración del sistema metrológico valenciano y Jaime I en la tradición medieval: los sistemas de unidades, las prácticas de control y los usos ", ETSIG, Valencia
} 
4.3.3. Rúbrica de la rajola e teula $a^{139} 22$

\section{LOS MOTLES DE LES RAJOLES SIEN FERRATS PER LES VORES 140 //FOI.CL V.//}

Stabliren e ordenaren lo justitia, els jurats y els prómens consellers que tots los rajolers de la orta y del terme de la ciutat de Valéntia sien tenguts de tenir los motles ab que fan les rajoles ferrats per les [v]ores ab verga de ferre axí com és la barçella. Y aquell qui no o fará, sia tengut de pagar al mustaçaf $L X$ sous de reals y aqu.I motle sia trencat.

LOS MOTLES DE RAJOLES SIEN MARCATS Y TINGUEN LA MIDA DEL PATRO ${ }^{141}$

Item, ordenaren que tots los motles sien senyalats ab lo senyalats ab lo señal reyal jastia acó que sien ferrats y qui no lo fará, pach per pena $V$ sous. Y, si no será de la amplea del patró del mustaçafy de la longuera y sisa, pach los damunt dits $L X$ sous.

\section{RAJOLA E TEULA NO SIA REVENUDA 142}

Encara stabliren e ordenaren que, de hui avant, null hom de qualque condició o manera será no gos comprar manifestamente ne amagada ço és a saber, rajola blanca, o rajola mijançera ne teula per revendré per nenguna manera, exceptat quen pusca comprar per obra sua própria que, encontinent, la haja necessária a metre en obra. En altra manera qui contra açò farà, perdrà tota la rajola o teula y pagarà per pena sexanta sous. // Fol. CII r.//

\section{NO. S MESCLE HUNA SORT DE RAJOLA AB ALTRA}

Item, ordenaren que, a esquivar frau, negun rajoler no gos vendre ne mesclar rajola mijançera ab rajola blanca. E qui contrafará, perdrá la

\footnotetext{
${ }^{22}$ CHINER GIMENO J.J., GALIANA CHACÓN J.P., Llibre del Mustaçaf, edición del manuscrito del archivo Municipal de Valencia, Gráfíca Ronda, Valencia, 2003, p.117- 120
} 


\section{MUROSINTRAMUROS}

rajola mijançera e, ultra açò, encorrerà en pena de XII sous lo mil ler per quantesque vegades contrafarà.

\section{RAJOLA E TEULA SIEN FETES L LEALMENT}

Item, ordenaren, a esquivar frau u profit de les obres, que.Is rajoleres de la ciutat, presents e qui per temps serán, sien tenguts de fer rajola y teula bé y lealment, en manera dels motles antichs, y dretament per tal que la rajola y teula sia egual. E qui contrafarà, encorrerà en pena de XII diners per mil ler.

\section{PARTICIÓ DE LES PENES}

De les quals calònies, será lo terç del señor rey, lo terç de la ciutat e, lo terç de l'accusador.

Die lune XXVIIoctobris anno MCCCLXXI

NO.S VENA RAJOLA O TEULA FIADA NE SIA IMPEDIT ALGÚ DE PORTAR LA OBRA QUE HAURÀ COMPRADA

Axí matex és estat stabilit y ordenat que alcun rajoler o teuler no sia osat de vendre rajola o teula a diners primers ne al legar que aquella //Fol CII v.// que té o tendrá si aja venuda, ne en altra manera escusar que no vena a cascú per sos diners de la rajola o teula dementre que.n tinga, ne contrastar a negú de tirar o fer tirar rajola o teula ab ses bésties pròpries o llogades, ne induir o fer de manera que sia tirada ab bèstia del dit rajoler o teuler. A XI de maig MDLXIII.

NINGUN OBRER DE VILA COMPRE OBRA PER ALTRI

Item, que algún maestre de obra de vila no sia osat comprar per a obs d'altri rajola o teula o algepz en pena de LX sous per quantesque vegades contrafarà. Die veneris XVIII februarii anno 1373.

\section{LA OBRA SIA FETA LLEALMENT}

Item, és estat ordenat y stabilit que tota rajola y teula sia feta lealment y beé, ab tot compliment de miday de gruxa, segons los 
motles antichs, sots pena de $L X$ sous per cascun mil ler, pagadors per cascun contrafahent e per cascuna vegada que contrafarà. E si sobre la leyaltat de la rajola o de la teula, o sobre lo compliment de la mida o gruxa de aquella, haurà debat o contrast que aquell sia declarat y determinat per l'onrrat mustaçaf ab consell dels onrrats jurats o dels //Fol. CIII r.// dos d'ells, e no sens aquells. Die 1 mensis augusti anno a nativitate Domini MDXXXXIIII.

\section{SUSPENSIÓ DE FERRAR LOS MOTLES DE RAJOLES}

Los magnifichs mosseén Manuel Penarroja, generós; En Thomas Roig, ciutadà; mossén Hieronim Gaçull, cavaller; en Miquel Hieronym Garcia, En Garcia d Artés, En Bernart Cimó, ciutadans, jurats en 10 anypresent de la insigne ciutat de Valéntia, ajustatsen la cambra de Consell secret de la sala de aquella, oÿda y entesa la relació que per los magnifichs misser Francesch Ros, doctor en cascun dret, e per En Joan Garcçia, citadà, mustaçaf en lo any present de la dita ciutat de Valèntia, tenint comissió per los magnífich mustaçaf En Miquel Joan Noguera, e.N Christòfol Dexea, rajolers, e altres rajolers, sobre los motles de fer rajoles, los quals per lo dit magnifich mustaçafse pretenia que no staven de la forma que devien juxta los stabliments antichs de la dita ciutat. E, com segons lo parer e determinació dels dits misser Frances Ros e En Joan Garçia, mustaçaf de present, no.s puxa donar ley, assento, ni forma com los dits motles fer rajoles, axí grossa com blanca y vermella, deien estar finstant sia determenada e donada senténçia en certa causa que.s tracta, entre lo magnifich sindich de dita ciutat de una e lo guar-// Fol. CIII v.// dià de la devesa del rey de la part altra, sobre lo poder traurelenya e tallar junch per a coure dites rajoles en lo marjal, lo qual proçés e causa están ja en punt de acort. Per tal, inseguint lo parer dels dits misser Françes Ros, e En Joan García, mustaçaf, provehexen que la instancia que per part del dit magnifich mustaçaf se fa contra los dits rajoleres de voler executar aquells per les penes en què pretenia serésser encorreguts per no tenir los motles marquats e de la forma contenguda en los dits stabliments antichs, pare e cesse fins tant que en lo dit proçés e causa que.s tracta ab lo dit guardià de la devesa sia donada 


\section{murOSINTRAMUROS}

sentencia e que lo dit magnífich mustaçaf faça ferrar hun molde de fusta, que per aquell és stat mostrat,

lo qual stiga reservat en la longeta del mustaçaf, e serveixca per a patró de fer dites rajoles e que nengun rajoler puixa fer dites rajoles sinó ab motle marcat per lo dit magnifich mustaçaf ab lo dit patró e, si lo contrari será fet, encórrega en pena de LXsous e que, per marcar cascun motle, los dits rajolerespaguen e hajen de pagar hun diner e no més al ministre del dit mustaçaf qui tendrá càrrech de marcar dits motles e que, puix los dits rajolers façen dites rajoles ab motle marcat de señal real jatsia aquell no stiga ferrat com stà la barçella juxta forma del dit antich stabliment, no puxen ésser marcats ni penyoratsper ningún mustaçaf puix donanda la dita sentèntia en dit procès que.s tracta entre la dita ciutat e lo dit guardiá de la devesa se donarà la forma per lo magnifich Consell e ju- // Fol. CIII r.//rats com e en quina manera lo dit motle deurà star per a benefici eutilitat, axi del poble com dels dits rajolers. A XXI de noembreany MDLI.

\section{RÚBRICA DE CALÇ $C^{69}$ FOLIXLV}

\section{CAFIÇOS PER A MESURAR CALÇ O CARBÓ SIEN FETS ENÇERCOLATS}

Primerament, que tots sparters o latres qualsevol persones que de açí avant faran cafiç o cafiços de spart per a mesurar calç o carbó, façen e sien tenguts fer aquellls encercolats. E açó en pena xixanta sous partidos lo terç al señor rey, elo terç al comú de la ciuta, e lo terç a l'accusador, per quantesque vegades contrafará.

\section{NINGÚ TINGA NE MESURE AB CAFIÇOS NO CERCOLATS}

Encara, és stat proveit e ordenat que passats los dits deu diez nenguna persona no gos tenir en sa casa alcun dels dits cafiços que no sien encercolats, ne algún mesurador no sia gosat mesurar ab aquells, ne altra qualsevol persona gos o presumesca lliurar o rebe alcuna quantitat de cañç ab alcun //Fol XLV V.// dels dits cafiços no 


\section{MUROSINTRAMUROS}

cercolats sots la dita pena partidora segons que dessús, per quantesque vegades contrafarà. Divendres a III de febrero de l'any MCCCLXXVIIII fo fet. En lo següent dissapte cridat ensemps ab altres, lo stabliment següent.

\section{LA CALÇ SIA VENUDA AB MESURA ENO A ULL}

Item, que la calç no sia venuda a ull mas a mesura a raó de cafiç e mesurada ab cafiç ordenat per fur e que sia mesurada e lliurada en la ciutat o en lo lloch on será la obra. E qui contra les coses del present capitol e qualsevol de aquelles fará, perdrá lo preu de la calç e pagará sinch sous per cascuna cárrega en què haurà fet, la dita pena partidora per terç segons que dessús.

\section{RÚBRICA DE ALJEPÇ ${ }^{71}$ FOLIXLVIT}

Crida feta per los magnifichs justítia e jurats, mustaçaf e phohòmenes de la ciutat de valèntia sobre lo vendre de l'aljepç

Ara ojats, que.s fan a saber los magnifichs justitia, jurats e mustaçaf de la dita ciutat de Valèntia que com per beneffici de la cosa//Fol. XLVI r.// pública de la dita ciutat e dels habitadors en aquella, havent poder del Consell general de la dita ciutat, hajen provehit e ordenat sobre lo vendre lo aljepç. És stat provehit, statuit, stabilit e ordenat lo que.s segueix:

LO ALJEPÇ SIA VENUT A PES, AXÍ QUE LA ARROVA SUCCEEXCA EN LLOCH DE BARÇELLA

E primerament, provehexen que no.s puxa vendre aljepç sens que aquell sia pesat e que sia bo e rebedor. E que lo dit aljepç cascun trafiçtinga a pesar dotse arrobes, sots pena de xixanta sous e de

\footnotetext{
${ }^{23}$ SEVILLANO COLOM (1952) op. Cit. Pp.76; Pesos: el quintal tiene 4 arrobas; la arroba tiene 30 libras.; la libra tiene 2 onzas; 1 onza 355gr. Longitud: alna, 4 palmos, mide $91 \mathrm{~cm}$
} 


\section{murOSINTRAMUROS}

perdre lo dit aljepç partidors en tres parts co és, lo terç a l'accusador e, los terços al mustaçaf.

\section{LO ALJEPÇER SIA OBLIGAT TENIR PES}

E més avant, provehexen que cascun aljepcer tinga y haya a tenir en casa sua son pes affinant per a pesar el aljepç.

\section{CASCUN ALJEPÇER VENA SON ALJEPÇ EN SON MOLÍ}

E més avant provehexen que cascun aljepcer tinga a vendre lo aljepç que fará acascú en son molí sots pena de xixanta sous e perdre lo dit aljepç, partidors ut suppra e que no.I puxa portar en altre lloch a vendre. //Fol XIVI V.//

\section{NO SE POSE ARGILA ENTORN DEL REGLÓ}

E més, provehexen que no sia nengun aljepcer puxa posar arcila entorn del totló o casa del molí on molen dit aljepç, sots pena de xixanta sous partidors ut suppra.

\section{NO SEMESCLEN ALJEP ÇONS AB LO ALJEPS}

E més, provehexen que no sia persona alguna que puxa mesclar, ab lo dit aljepç, aljepçons, que són troços de aljeps que hajen servit, ni menys ningún aljepcer puxa tenir forn en casa sua perqué no puxa coure los dits aljepçons sots la dita pena e perdre lo dit aljepç partidors ut suppra.

\section{CASCÚN PUXA TALLAR ALJEPÇ DE HON VOLDRÁ, SEGONS ESTÁ PER FUR}

E, per quant per los qui.s diuhen senyors de les pedreres de l'aljepç se diu ésser-se cominat que no darán ni vendrán aljepç als aljepçers, dehon se poría seguir gran dan a la républica de la dita ciutat, manen, per ço, los dits magnifichs justítia, jurats e mu //Fol. XLVII r.//staçaf manen fer e preconizar la prèsent pública crida per la present ciutat e llochs acostumats de aquella, intimant e notificant a 
tothom les damunt dites coses perqué de aquelles en sdevidor per algú o alguns ignorancia no puxa ésser al legada e guart-se qui guardar-se ha.

Post modum vero die lune intitulada sexta mesis junii anno MDII, Miquel Artús, trompeta públich de la dita ciutat de Valéntia féu relació que en lo dia de hui, ensemps ab sos companyons ab trompes y tabals, per lochs acostumats de la dita ciutat havia preconisat la damunt dita crida lliurant aquella al scrivá del magnifich mustaçaf. Die XI mensis maii anno MDLXII

\section{LO ALJEPÇ NO TINGA MESCLA DE ALTRA COSA ALGUNA}

Los magnifichs jurats, millorant hun stabilent per los tunc jurats sos predecessors, proveit VI novembris MDLIII, provehexen e ordenen que ningún aljepçer, axí lo qui talla lo aljepç de la pedrera e cou aquell com lo qui.l mol, o otra persona alguna gose vendre dit aljepcs ab mescla de aljepç cuyt, dit aljepçons, ne de terra ne de altra cosa alguna per hon aquell sia pichorat ne guastat. En lo qui contrafarà, encórrega en pena de cent sous e perdició del aljepç, de la //Fol XL VII v.// qual pena sien les dos parts applicades al comú de la ciutat e lo terç, a l'accusador. E la judicadura de dit aljep haya de fer lo magnifich mustaçaf a consell del veedors de obres de vila o altres persones expertes de fer aljepç a electió del dit magnifich mustasaf.

Die martis intitulado sexto mensis novembris anno a navitate Domini MDLIIII, los magnifichs urats, racional e sindich ajustats en la cambra daurada per donnar forma e llevar los abusos que.s fan, axí en lo preu del algepç com en la bondad de aquell, provehexen que los pedrapiquers que tallen e corten la gleba de l'aljepçs hajen a donar la dita gleba cuyta a raó de quatre dinés lo quitar, la qual gleba sia bona e sens mixtura de terra alguna. E, si mesclaran dita terra, sien encorreguts en pena de sexanta sous partidors lo terç a l'acusador e les dos parts al comú de la dita ciutat. La qual pena sia executada per 


\section{murOSINTRAMUROS}

lo magnifich mustaçaf de la dita ciutat irremisiblement e que sia intimada la present provisió als pedrapiquers.

Die decimo tercio mensis novembris, la sudita provisió fonch intimada e notifficada per En Miquel Navarro, verguer dels magnifichs jurats, a Peris Bordàs y a Joan Martial, pedrapiquers de Ribaroja, e a Joan Gascó, Ferrando y Bernat Gascons en la pedrera de Picaçest. //Fol. XLVIII.r.//

\subsubsection{Els Rajolers ${ }^{24}$}

\section{2, maig 28}

Onze capitols de rajolers que regulen com han d'ésser les rajoles, taulells i teules en les seuesvariants i on s'han de vendre.

I. Primerament, que lo magnifich mustasaf hacha de regonèixer tots los mol les del racholers, aixi de racholes, taulleles grans y chics, rachola grosa y prima, y teules grans y chiques, per a qué estiguen afinatssegons los copatronsde la seua cort. Y que dins10 dies de la publicació del pregó tinguen obligació els racholers de portar el mol les a dita cort per a quèels refinen y marquen. Y que pasats 20 de la publicació del pregó, qualsevols molls que es trobaran en poder dels dits racholers sien estos eixecutats en pena de 3lliures, y trosejats los moles. Y que al racholer que li trobaran segona vegada mol les que no estarán afinats ymarcats, encórrega en pena de 6 lliures, y que esta no es puixa remetre. Y que si será attrobat tercer vegada, la pena sia arbitrària al magnifich mustasaf.

II. Ittem, que per quant la experiencia ha mostrat que el estar ferrat los mol les causa imepdiment per a treballar les peces, per so statuheixen que sempre y quant qualsevol mol le será trobat mimbe aixi de amplària com de llargària. Encórrega lo racholer en què será attrobat [f.226r] en pena de 3lliures, y els moles romptus. Y que en

\footnotetext{
${ }^{24}$ Recopilado por BAIXAULI JUAN I. A. (2001) Op. Cit,pp.69-72, copia de ARV, Governació, Litium, 2768, mà 5, fs.225v-227v.
} 
respecte de la segona y tercera vegada se haja de obsevar la disposició foral que parla de les pedres, pesar y pessades, mimbes.

III. Íttem, que sempre y quant se trobaran racholes primes y groses, taulells, taulellets grans y chiquets en qualsevol part y de fäbrica de qualsevol racholer, si estes es trobaran curtes o estretes y que no són conformes als mol les marcats per lo magnífich mustasaf, el tal mestre encórrega en la pena expresada en lo capítol primer.

IIII. Íttem, que ninguna persona de la present ciutat y contribució de ella, de qualsevol estat y condició, que sia osada comprar dels racholers teules, taulells grans ni chichs y revendré en sa casa, o en altra part per qualsevol títol y causa que sia, encara que diguen que els han donat per pago de deute o per altre cami, y encara que sien obrers de vila els tals compradors perque lo ajust y verdader és que els obratjes de racholes, taulells y teules de qualsevol calitat que sien se hacen de comprar inmediatament del racholers, y no de altres particulars revenedors sots pena de 10 lliures y la obra perduda.

$V$. Ittem, que ningún obrer de vila puga comprar racholes, taulells eo teules dels racholers encara que sia per obres de particulars que les fan los tals obrers, perque per a eixos casos los materials los han de comprar los mateixos amos de la matiexa obra, sots pena de 10 lliures y els materials perduts. Y tan solament lo obrer de vila puixa comprar racholes, taulells o teules en casos de tenir, lo tal obrer de vila, alguna obra en casa pròpria de aquell o a estall, y que per eixos casos haja de manar llicència al magnifich mustasaf, la qual hacha de donar per temps limitat y amb expreció de la obra y per escrit, y no tenint la tall llicència, encórrega en pena del present capítol.

VI. Ittem, per quantsi lleven ab los presents capitols totes les cosses de venderies de racholes eo revenderies, y és just que en la present ciutat no falten estos materials per tantes obres que es fan contínuament dins la present ciutat no falten estos materials per a tantes obres que es fan continuament dins la present ciutat no falten estos materials per a tantes obres que es fan contínuament dins la 
present ciutat y sa contribució. Estatuheixen y determinen que en la present ciutat, continuament, hajen de tenir los racholers 4 cases en diferents [f.226v] puestos de la present ciutat, que, continuament, estiguen abastides de racholes groses y primes, taulells y taulellets, teules grans y chiques per a habastir la present ciutat y sa contribució. Y que sempre y quant es trobarà faltar alguns de dits materials en les referides quatre casses de gènere que contínuament an de tenir en elles, y cascunade elles dos mil lers de cascú de dits asortiments y espècies damunt expresades, altrament encórreguen en pena de 10lliures per cascuna casa. Y que se li hajen de manifestar cascun any al magnifich mustasaf les persones per aquí corren los asortiments de dites casses, o quant se mudaran les tals persones per a què estos ajen als que han de conèixer los mustasf en la execució de les penes, addnotant-ho lo Escrivá per via de acte expresant en ell com se sotsmeten al seu for y jurisdicció.

VII. Íttem, que ningún racholer sia osat en les partides de racholes que venen mesclar rachola micha ab rachola blanca, que es la grosa, sots pena de 3 lliures, y la rachola perduda.

VIII. Íttem, que no obstant lo contingut en los presents cápitols, puixa lo magnifich mustasaf sempre que li parega de offici regonèixer qualsevols racholes, teules y taulells per a què a demés de poder eixecutar les contravencions dels capitols damunt expresats puga també averiguar si la rachola está ben treballada, o nomenant a sa voluntat experts per a eixe effecte. $Y$ en casde haver-les tronbades mal-treballades, encórrega racholer en pena de 3lliures, la rachola perduda, y que eixe cas la rachola se haja de trosechar públicament per a escarment dels que en fabriquen.

VIIII. Íttem, que sempre y quant, qualsevol particular arriba a comprar racholes y deés obratjes als racholers, així a sos taulars y racholars com a les quatre cases que se han de tenir en la present ciutat, puguenpendre de les racholes y obratjes que els pareixerà, pagant lo just valor, no obstant que el racholer diga laté venuda a altre, sots pena de 3lliures. 


\section{murOSINTRAMUROS}

X. Ittem, que tots los racholers que voldran fer racholes, teulellsy teules per a consumir en la present ciutat hajen de annar dins 30dies despúes de la pubblicació [f.227r] del pregó a la cort del magnifich mustasaf a manifestar-se sotsmetar-se allí al for y jurisdició del magnific mustasaf mediant acte eo actes per lo Escrivá rebedor, pagant-li per cascú la cantitatde 6 sous. Y que els tals racholers que no hauran fet los dits actes y manifest se'ls negue la entrada per los portals de la present ciutat dels seus obratjes hasta que, efectivament, lo hajen fet. Y que lo magnifich mustasaf puga donar orde als porters per a que no deixen entrar dits obratjes. Y que en cas de entrar-los en nom de altres suposadament, y ab cautela,y engany, encórreguen en pena del present capítol, tinga obligació el magnifich mustasaf donar una bolleta als que es manifestaran per a què ab ella se'ls done entrada per los portals, y no de altra manera.

XI. Ittem, que el acayt de la llonjeta del magnifich mustasaf tinga obligació, sempre que sia request, de marcar los mol-lesdels dits racholers posant una marca en cada mol le y només. Y que per lo refinar y marcar sols tinga obligació de pagar quatre diners per pesa en la conformitat desusdita se ha y dehuen decretar per no ser contra els furs, privilegis ussos y bons costums de la present ciutat, ans bé, ser utilosos y benificiosos ab comú de aquella y als dits racholers. Per ç oses senyories, aconsellats del magnifichs doctors $G$. Jornet y J. Baptiste Lopes de Perona, advocats ordinaries y Miquel Geroni Llop y doctor P. Rodrigo, advocats extraordinaris de la present ciutat, authorisen y decreten los dits capitols. Sia observat y guardat "ad unquem"reservant-sefacultat per a millorar y corregir aquells, eo revocant-los en tot o en part, sempre que voldran y ben vist lo será manant. "Etiam" que sia lliurada cópia de capitols als tinint interés en aquells sempre que-I voldran haver la qual decretació fan usant de la facultat que tenen concedida, aixi, per lo insigne consell general, celebrat en 23 de juny 1548, com per furs y privilegis del present regne, y en particular fur fet en les corts generals, celebrades per sa magestat als regnicoles del present regne en la vila de Mosó en 10 añy 1585. Prevehint "etiam"que dits capitols sien registrats en 10 manual de consell y establiments de la present ciutat per haver-ne 
memoria en lo esdevenidor, y sien preconisats per la present ciutat [f.227v], y llochs acostumats de aquella.

1692, maig 28

Modificacions dels capitols de rajolers.

ARV, Governació, Litium, 2768, má5, f.229r.

Ab la presentdecreta los dits capitols ab les modificacions següents. la primera, que de les penes que si han de encórrer en cas de contravenció se aplique los ters als reals còfrens de sa magestat; lasegona que el capitol 5, en que-s dispon que les racholes, taulells, eo teulkes dels racholers les hajen de comparar los mateixos amos de les obres o altres persones de son orde, com no sien revenedors, ni es compra per a revenedors; que el capitol 6 se declare de que la pena de 10 lliures se haya de encorrer per cascuna casa de les que se han de señalar per cascuna vegada que es trovará faltar les racholes, taulells o teules; que el capitol 7 se declare en esta forma que en cas de mesclar-se rachola michana ab rachola grosa,s ent les racholes que es mesclaran fin en numero de 50, se encórrega en la pena y esta es regule a 3 lliures per cascuna vegada, y rachola perduda. $Y$ que la obligació que se li imposa en dits capitols de sos Mestres els racholers al for y jurisdició del magífich mustasafy no en los casos en qué peculiarment toca el coneixement del present tribunal y en lo demés los authorisa.

Gracias a todas estas fuentes podemos cruzar información y lograr hacer un cuadro más claro sobre el tipo de profesión y problemáticas asociadas a los mecanismos de control de la producción histórica. Con estos documentos sabemos que los productores de ladrillos tenían normas precisas y que los ladrillos eran objeto de transacción en el mercado, regulados por una absoluta obligatoriedad de venta de dichos artículos ${ }^{25}$. El comprador, según las prescripciones, podía

\footnotetext{
${ }^{25}$ Lib. De Ordenaciones del Mustaçaf de Valencia, LXXX, 10. (AHMB)
} 
llevarse el material comprado con el medio de transporte más oportuno, sin que el vendedor pudiera impedírselo ni imponer sus servicios. Además si el cliente querría que el vendedor transportara a su destino el material de construcción, no se podía recargar el precio a más de 4 sueldos el millar por dicho transporte (desde el horno a cualquier sitio de la ciudad ${ }^{26}$ ).

Como siempre se prohibía la re-venta y se insistía que cada uno sólo debería comprar la cantidad de ladrillos y tejas que necesarias para sus propias construcciones. ${ }^{27}$ Por otro lado, se sabe que también el mortero, con el que se tienen que aparejar las fábricas, se vendía en el mercado. Las disposiciones del Mustaçaf preveían que la cal tenía que venderse con regularidad, excepto el jueves, por ser día de mercado, hallándose éste demasiado concurrido estropeando la cal el paso ${ }^{28}$.

\footnotetext{
${ }^{26}$ Lib. De Ordenaciones del Mustaçaf de Valencia, XXI, 1, LVIII, 6 y LXXX, 11. (AHMB)

${ }^{27}$ Lib. De Ordenaciones del Mustaçaf de Valencia, LVIII, 6, y LXXX, 11. (AHMB)

${ }^{28}$ Lib. De Ordenaciones de/ Mustaçaf de Valencia LXVIII, 2. (AHMB)
} 


\title{
4.4. Tratados y manuales: de lateribus
}

\author{
"...De lateribus ex qua terra, quo tempore, \\ et qua forma, duci eos oporteat..."
}

Este apartado ${ }^{2}$ no pretende recopilar un corpus completo relativo a la tratadística del ladrillo en albañilería, siendo el tema potencialmente objeto en si de un estudio mucho más amplio y especifico;

Simplemente la finalidad de esta recopilación apunta a una reflexión histórica, sobre las técnicas constructivas y la comprensión de oficios, herramientas, soluciones constructivas, detalles. Aspectos perdidos, en muchos casos obsoletos, pero generosos de datos, con esmerada restitución gráfica, cultas referencias que alimentan la investigación sobre las fábricas de ladrillo del centro histórico de Valencia.

Los tratados dedican muchas páginas a los ladrillos, especialmente al apartado de selección de materias primas y, por otro lado, relativamente escasas son las referencias a las cuestiones más prácticas de pura puesta en obra. Es importante por lo tanto tener en

\footnotetext{
${ }^{1}$ VITRUVIO POLIÓN, M.. Los Diez Libros de Arquitectura de M. Vitruvio Polión. Ed. Consultada: ORTIZ Y SANZ. Madrid, Imprenta Real, 1787"...De los ladrillos: en primer lugar hablaré de la tierra de las temporadas y de la forma con las que se tienen que fabricar...", Libro II, Cap. III, p.31

2 Este capítulo se ha extraido parcialmente de TROGU ROHRICH L., I mattoni" en Le tecniche di costruzione nei trattati di architettura, Edicom Ed., Monfalcone, 1999
} 
cuenta esta praxis constructiva dilatada en los siglos, que define este material de construcción y su vigencia histórica.

\section{El ladrillo en una breve selección de tratados de arquitectura}

Desde siempre la tratadística está conectada íntimamente con el texto más antiguo, llegado a nuestros días, el "Los Diez Libros de Arquitectura" de Vitruvio Pollione. Sin duda, entre las esmeradas descripciones del autor, destacan la distinción y definición de lateres y testae, respectivamente el ladrillo crudo y el ladrillo post-cocción, aspectos que solo este autor define, siendo luego objeto de estudio el tradicional ladrillo cocido.

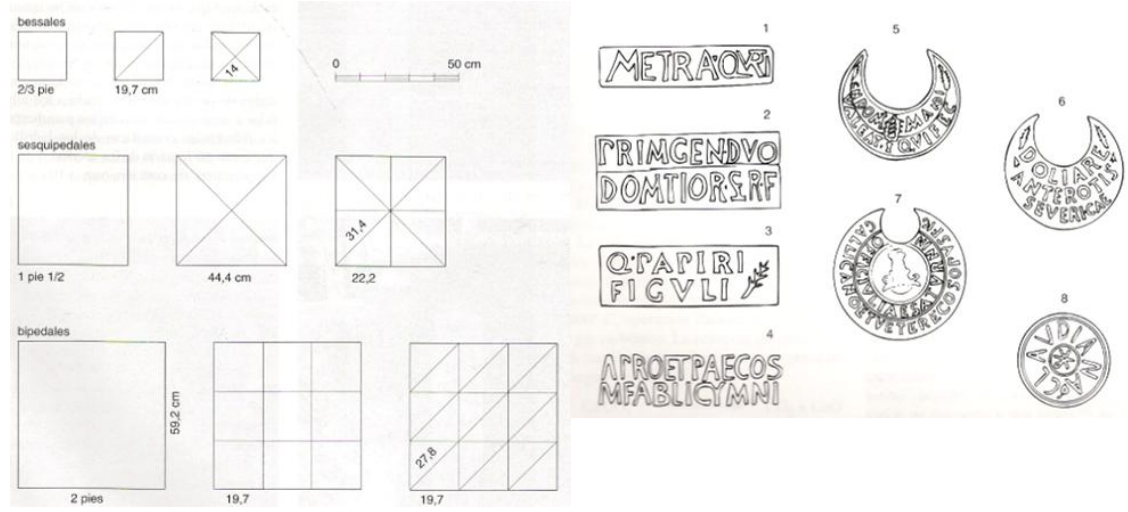

FIG. 53 Partición de ladrillos cuadrados romanos de medidas corrientes. A la derecha estampillas de las principales figlinae romane. Hasta ahora no se han encontrado en Valencia restos de ladrillos con estas marcas de productores, ni en las formas más arcaicas rectangulares, ni en las más recientes a media luna (ADAM)

El material elegido es objeto común de análisis en muchos tratados. Se prescribe una buena selección de materias primas, evitando el empleo de arenas e impurezas, aunque a veces los tratados mezclan términos relativos a nomenclaturas de arcillas o arenas, descartando referencias prácticas.

También la metrología es una disciplina que no une las posturas de los autores, donde los puntos de encuentro 


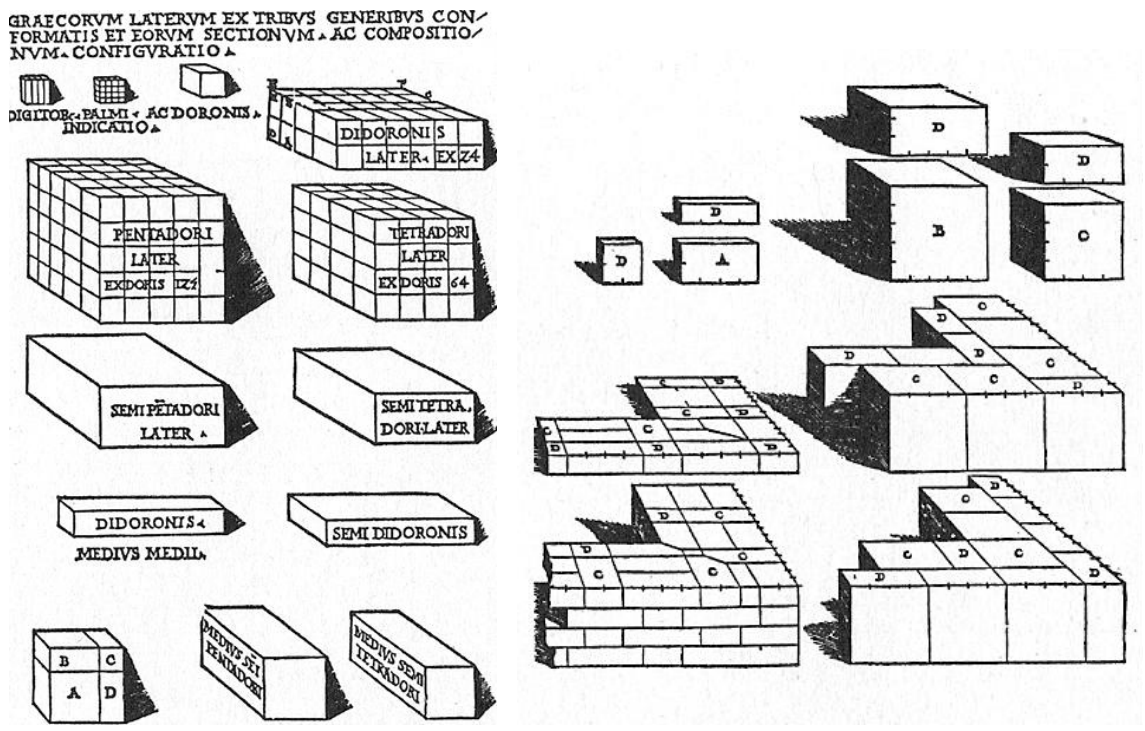

FIG. 54 Distintas formas y tamaño de ladrillos antiguos por CESARIANO 1521 y a la derecha por RUSCONI 1590 (TROGU ROHRICH)

dimensional siguen siendo hasta el Renacimiento el "dídoron" el "pentádoron "y el "tetrádoron", de manufactura griega clásica. ${ }^{3}$

Vitruvio analiza los diferentes ladrillos empleados en su época, aunque su descripción tiene poca correspondencia con las huellas de

\footnotetext{
${ }^{3}$ El "doron" o tipo lidio, corrsponde a 1 pie y $1 \frac{1}{2}$ romanos, el "pentadoron" de 5 palmos y el "tetradoron"de 4 palmos. VITRUVIO, op. cit., pp.32"... Hácense ladrillos de tres especies: al primero llaman los Griegos dídoron, del cual usan los nuestros á saber, un pie de largo y medio de ancho. De las otras dos especies usan solamente los Griegos, y son el que llaman pentádoron y el tetrádoron. La palabra doron en lengua Griega significa el palmo, derivado del hacer regalos y presentes que también se llaman doron; pues el regalo siempre se presenta con las palmas de las manos: asi, el ladrillo que tiene cinco palmos por cada lado se llama pentádoron, y el de cuatro tetrádoron. Hacen las obras públicas con el pentádoron y con el "tetrádoron las particulares. Para con estos ladrillos" se hacen otros llamados medios ladrillos es, los cuales se sientan en la fabrica alternativamente, esto es, una fila de enteros y otra de medios, y prosiguiendo así en ponerlos á nivel por ambas partes, quedan las paredes bien trabadas; y los medios-ladrillos sentados sobre las juntas de los enteros concilian firmeza al muro, y no hacen mala vista..."
} 
la arquitectura romana que conocemos. De hecho, el autor latino hace referencia a los lateres, enfatizando su condición de, ladrillos disecados al sol, por tanto, no trata la verdadera obra latericia, que se desarrollará sólo a final del imperio de Augusto, con Tiberio, tras la muerte de Vitruvio.

Los comentarios posteriores de Cesariano (1521) y Rusconi (1590), al texto de Vitruvio, ponen el acento sobre el hecho de que el ladrillo cocido es sin duda más resistente y práctico que el módulo sin cocer, interpretando así de forma bastante arbitraria el texto latino. ${ }^{4}$

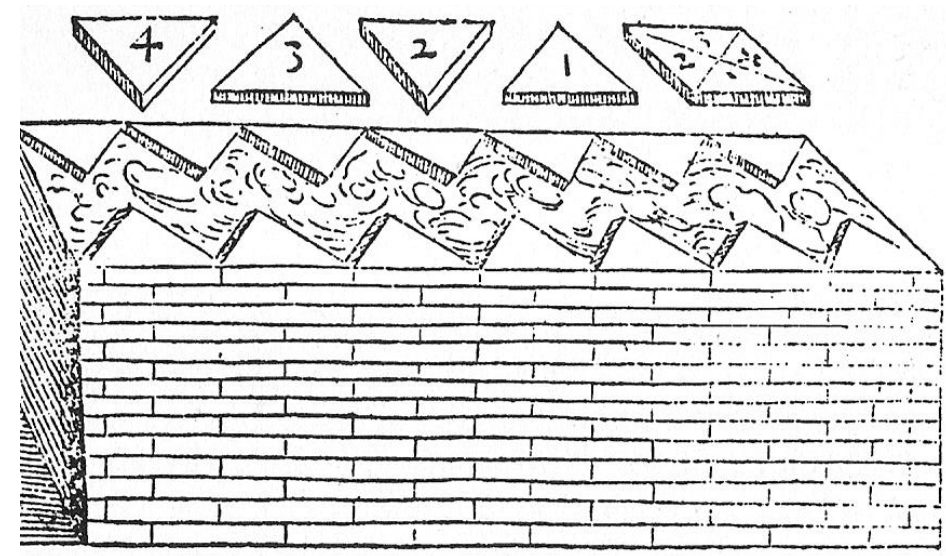

FIG. 55 Muro "a sacco" o a la romana, realizado con ladrillos triangulares (ALBERTI 1485, BARTOLI 1565) (TROGU ROHRICH)

También Bartoli (1565) ${ }^{5}$, integrando el texto de Vitruvio con el de L.B: Alberti (1485) ${ }^{6}$ afirma que el ladrillo cocido es un material de construcción consolidado y común.

En lo que atañe al proceso de cocción del material se deben recoger las definiciones de Filarete $(1464)^{7}$, y L. B. Alberti (1485), que se

\footnotetext{
${ }^{4}$ CESARIANO C., Di L. Vitruvio Pollione, DE Architectura libri decem traducti de latino in Vulgare affiguratti, Como, 1521.Ed. Consultada: ROVETTA C., UV Universitá Ed., Milán, 2022

RUSCONI G.A., Dell'architettura secondo i precetti di Vitruvio, Venezia, 1590

${ }^{5}$ ALBERTI L.B., De Re Aedificatoria, 1485. Ed. Consultada: BARTOLI, Venezia, 1565

${ }^{6}$ ALBERTI L.B., De Re Aedificatoria, 1485. Ed. Consultada: ORLANDI, PORTOGHESI, Ed. Polifilo, Millano, 1966
} 


\section{murOSINTRAMUROS}

cuentan entre las más completas y prácticas. Palladio $(1570)^{8}$, por otro lado, no aporta datos muy significativos relativos al asunto más allá de cuanto nos describían Vitruvio y Alberti. Realmente se debe esperar hasta las contribuciones más maduras de Scamozzi ${ }^{9}$ y Serlio ${ }^{10}$ para tener datos más específicos relativos a indicaciones relativas a las temporadas del año más aptas a la producción, y a las condiciones óptimas para la producción de ladrillos.
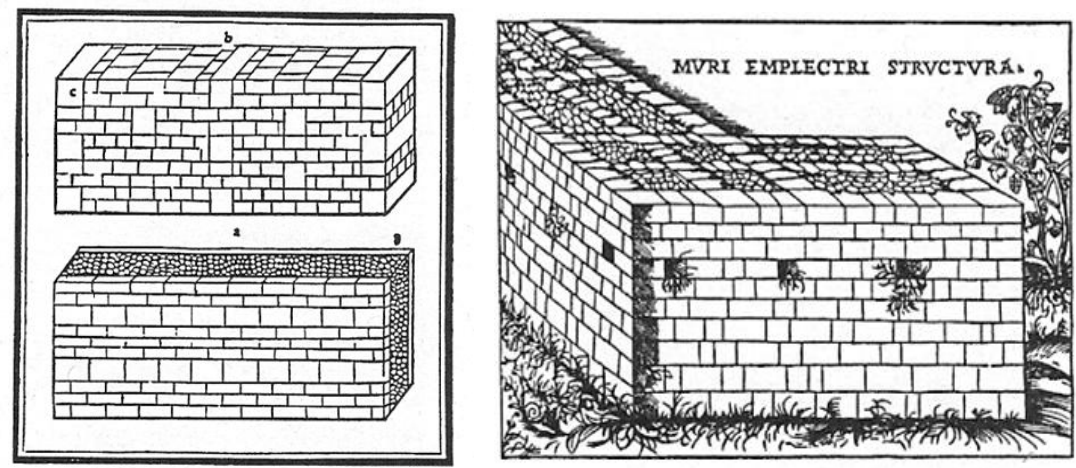

FIG. 66 Antiguas fábricas de ladrillo por FRA GIOCONDO 1511 y CESARIANO 1521

(TROGU ROHRICH)

\subsubsection{El siglo XIX, maduración de manuales técnicos sobre ladrillos}

El siglo XIX destaca por presentar un corpus teórico muy denso y específico sobre el mundo de la construcción, más concretamente, las fábricas de ladrillo.

Hoy, según la RAE, podemos definir "LADRILLO Del dim. del ant. *ladre, del lat. later-ëris).1. m. Masa de barro, en forma de

\footnotetext{
${ }^{7}$ ARVELINO A., (FILARETE) Trattato Di architettura, 1464. ED. Consultada: FINOLI, GRASSI, Il Polifilo Ed., Milano, 1972

8 PALLADIO A., I quattro libri dell'architettura, 1570. Ed. Consultada RIERA J., Akal Ed., Madrid, 1998

${ }^{9}$ SCAMOZZI V., l'ídea di architettura universale divisa in dieci libri, Venezia, 1615. Ed. Consultada TICOZZI S., Borroni e Scotti Ed., Milano, 1935

${ }^{10}$ SERLIO S., I cinque libri dell'architettura. Venecia, 1964. Ed. Consultada Dover Publication, Toronto, 1982
} 


\section{MUROSINTRAMUIOS}

paralelepípedo rectangular, que, después de cocida, sirve para construir muros, solar habitaciones, etc. Pero ¿qué términos castellanos más emblemáticos se pueden encontrar relativos a este material de construcción?

A continuación se plantea, una breve antología de los vocablos más interesantes, encontrados en una selección de textos, en muchos casos, ya en desuso ${ }^{11}$.
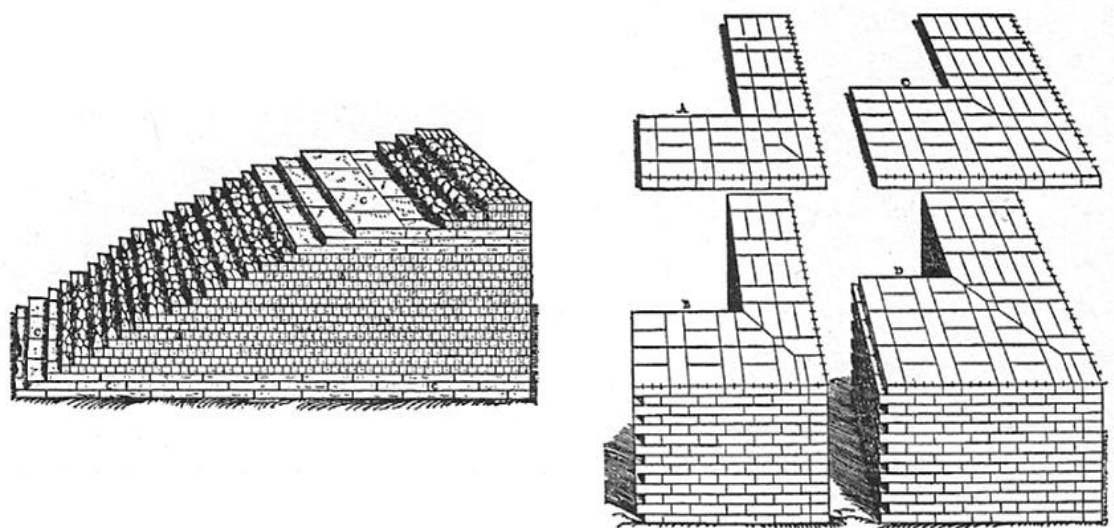

FIG. 67 Distintas distribuciones a Emplecton, RUSCONI 1590 (TROGU ROHRICH)

\section{Ladrillo...}

"Común. El que tiene de largo un pie, de ancho medio y de grueso unos dos dedos y medio.

De pata de jamón. El que tiene un rebajo y sirve para construir mochetas, dejando en ellas la caja para el cerco de las persianas De pinta. El muy cocido y que tiene el color mas encendido, que sale del centro del horno y se usa en construcciones exteriores.

Fabriquero. EI que tiene ocho o nueve dedos de ancho, un pie de largo y dos dedos escasos de grueso.

Fino. El compuesto de arcilla pura y que resulta idóneo para obras al descubierto y para moldear o refinar puesto en obra.

Flotante. El más ligero que el agua.

Gordo. El común con más de dos y medio de grueso.

\footnotetext{
${ }^{11}$ Para mayor detalle relativo a términos, véase el glosario al final del trabajo (Tomo II)
} 
Hueco. El que tiene la forma de un cilindro hueco y se suele usar para la construcción de muros circulares y para las bóvedas por su ligereza. En la paredes tienen la ventaja de que interponiéndose el aire, incomunican la humedad y el sonido.

Portero. El que se coloca en la parte superior del horno que no ha tomado ni la dureza ni el color suficiente y sale tiznado; se emplea para tabiques, entramados, etc.
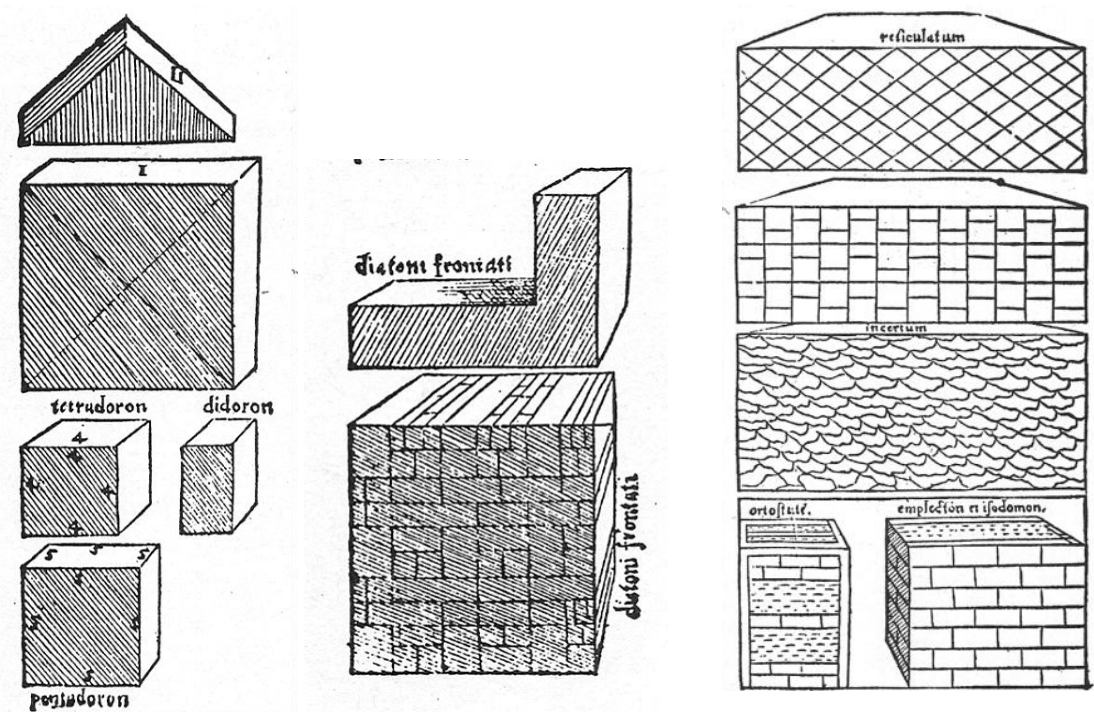

FIG. 68 Ejemplos de fábricas de ladrillos antiguos BARBARO 1556 (TROGU ROHRICH)

Rasilla. El fino y muy delgado.

Recocho. El que ha estado muy próximo al fuego y es muy duro.

Refractario. El que no funde al mayor grado de temperatura que se necesita en la industria. Esta propiedad es debida a la arcilla contenida, que es pura y no contiene óxidos. Estos ladrillos se componen de arcilla y cuarzo de grano muy fino o rotura compacta. Rosado. El que se reputa de ínfima calidad.

Tosco. El inmediato superior en calidad del un ladrillo portero. La mayor parte de estos adjetivos ó las cualidades varían con los países y circunstancias locales". 
"Aplantillado. El que se ha cortado de forma longitudinal o de moldura especial, para que coincida con las dimensiones de la pared, que no se confunda con el ladrillo terciado.

Biselado. El que está especialmente moldeado con una o más esquinas en diagonal.

Castellano (o de rana). El cuyo nombre proviene de la hendidura que se practica al ladrillo durante el proceso de moldeo, parecida a la del casco de un caballo.

De albardilla. El que está especialmente moldeado para que los cantos sobresalen de la pared, con moldura de goterón, para expulsar el agua de lluvia.

De caja. El que es terciado tres cuartos, con medio tizón cortado en diagonal, para que la cara parezca aplantillada, y con el corte diagonal escondido dentro de la pared.

De corrección. El que está moldeado y se coloca en los bordes al final del muro, sin proteger a los ladrillos inferiores.

Pata de perro. El que está hecho con una forma especial, para que encaje en ángulos (véase ladrillo de pata de jamón).

De nariz de vaca. El que tiene un lado acabado en forma semicircular.

De zócalo. El que tiene un corte a bisel para adaptarse a la reducción del grosor de la pared entre el zócalo y el muro.

Esculpido. El que tiene carácter decorativo especial, que se fabrica dándole forma a la arcilla a mano, antes de la cocción.

De paramento. El de color muy uniforme y sin imperfecciones, muy apropiado para su empleo en el lado visible de la pared (opuesto al ladrillo común).

Común. El de baja calidad, con una serie de imperfecciones en la superficie, que no es adecuado para fachadas, pero sí para paredes interiores (opuesto al ladrillo de paramento).

Terciado. El que se ha cortado para que encaje a lo ancho (o se ha dado una forma especial al moldearlo), que no se confunda con el ladrillo aplantillado. 
Vidriado. El que tienen un extremo o cuna cara vidriada, muy utilizado a finales del siglo XIX, por su fácil limpieza y su capacidad de reflejar la luz y crear juegos cromáticos, reflejando la luz ${ }^{12 " .}$

\subsubsection{Prácticas de albañilería en los manuales de arquitectura}

¿Qué libros podrían circular en Valencia y que pudieron influir en el mundo de la construcción?... ¿Qué pautas prácticas se pueden reconocer en los manuales? ¿Qué instrucciones podrían pertenecer a la íntima cultura material de la ciudad de Valencia?

Para responder a estas preguntas se ha buscado una selección de textos, procedentes de algunos de los principales manuales de construcción decimonónicos, relativos a técnicas constructivas y soluciones formales visibles hoy en día en el centro histórico.

Estos textos, influenciados por la cultura enciclopédica, evidencian la madurez de la "regla del arte" de la albañilería. Por esta razón, los manuales dirigidos a los capataces recopilan los "correctos" pasos a seguir; reseñan los productos utilizables o formulan los avances técnicos de la época. Todos estos factores se reflejan en las páginas de los manuales más prácticos, y se han seleccionados porque son ejemplos cercanos a la realidad constructiva urbana, manifestando un sólido contexto profesional, que se abre a la madurez técnica del siglo XX.

El objetivo ha sido la búsqueda de información en libros puramente prácticos, pocos costosos, y con un lenguaje sencillo y cercano al oficio, que dejan a un lado cálculos, componentes teóricas y críticas, textos donde se exponen de forma explícita las reglas del oficio. Se trata en definitiva de una recopilación donde se establecen las bases de la destreza en albañilería, con pautas claras, transformando un aprendizaje rutinario en una serie de pasos fundados y razonados.

\footnotetext{
${ }^{12}$ CAMPBELL J., PRICE W., Brick, A world History, Blume Ed., Thames\&Hudson, London, 2003
} 


\section{CAPÍTULO X_DE LA ALBAÑILERÍA DE LADRILLO Y DE LOS CUERPOS QUE CON ELLA SE FABRICAN}

1827 VILLANUEVA, p.41

"El ladrillo sentado en el plano (lam.VI, fig.2) puede tener dos situaciones respecto a la dirección de la pared, una a lo largo, y otra a lo ancho. Cuando lo largo del ladrillo se sienta de modo que sigue la dirección de la pared, se llama sentado de soga, y cuando su largo se introduce en el grueso, y su ancho sigue la dirección de la pared se dice de asta. , y este es el modo más regular de sentarle cuando las paredes son más gruesas que el ancho del ladrillo.

Entonces si el primer ladrillo se puso entero, el segundo debe de ser medio, el tercer entero, y así lo demás. Y el oficial que está al otro lado debe hacer lo mismo de los suyos, á fin de que los vanos que se van dejando en el centro de la pared quedan regulares..."

\section{VILLANUEVA, p_41/42}

"...tenida que sea una hilada por todo el grueso, con la prevención que las juntas no se encuentren unas sobre otras, se llenan esta de la mezcla y con la paleta se recorta y revaba de la mezcla el frente. Esto se debe de hacer con curiosidad, introduciendo la punta de la paleta debajo del ladrillo acabado de sentar, y corriéndola formando un planillo inclinado del grueso del tendel hasta la encía del ladrillo de la hilada de más abajo.

Y en las juntas se hacen las llagas con la punta de la paleta. Así quedará rematada con curiosidad la obra, mientras que otros suelen enfocarla o fregarla con la mezcla, corriendo la regla de canto a una pared o a la otra con las dos manos; este modo no es tan limpio. Pero oculta todos los defectos de la albañilerías y solo se puede usarse cuando se han de jarrar o revocar las paredes..." 


\section{VILLANUEVA, p_43}

"...Si la obra lo necesita o se si formasen otro género de angulo, será preciso cortar el ladrillo con la piquetilla o la alcotana y darle la figura del angulo que debe cosntituir..."

\section{VILLANUEVA, p_47}

"...Cuando el angulo no es muy agudo ni muy abierto y se ha de guarnecer después, se puede escusar de cortar los ladrillos, procurando de colocarlos de modo que, uno sobre el otro, se abran en su largo, y formen el angulo, pues que, aunque les falte alguna cosa, la guarnición lo suple"
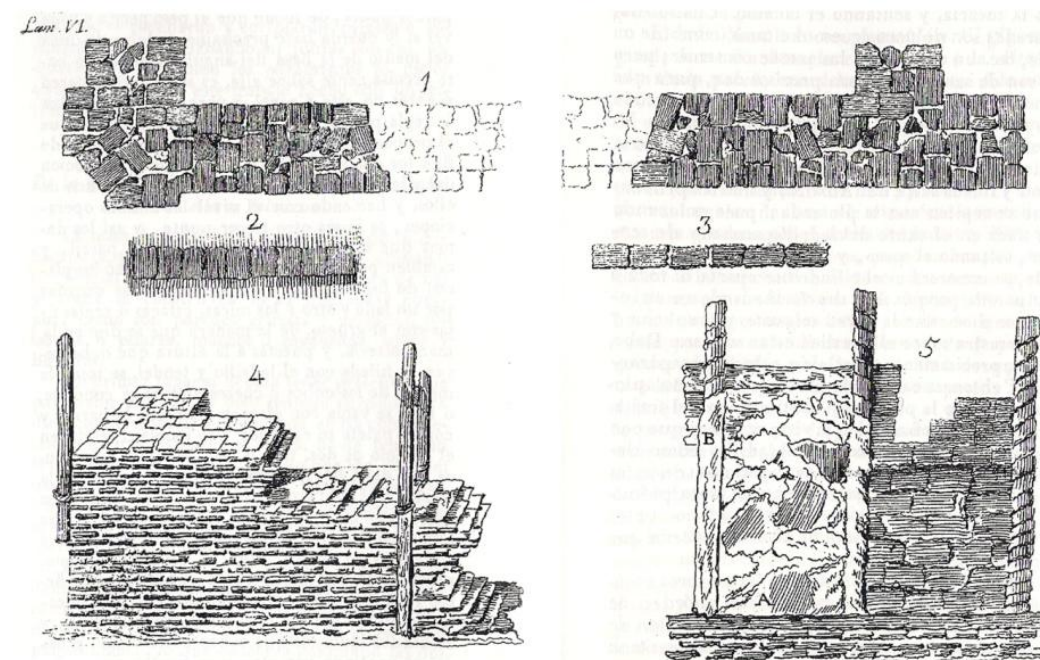

3

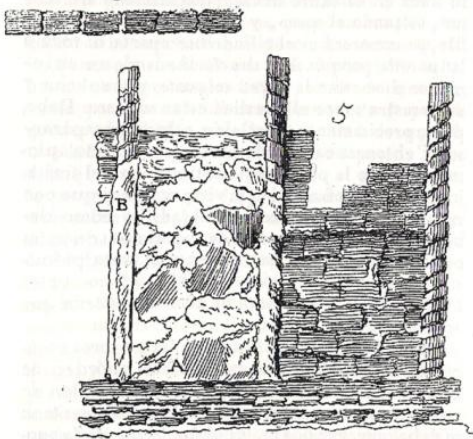

FIG. 69 Aparejo de fábrica de ladrillos (Lam.VI-VILLANUEVA 1827)

CAPÍTULO XI_DE COMO SE SIENTAN LOS NUDILLOS Y UMBARLES, Y SE HACEN LOS SALMERES Y LOS ARCOS QUE HAN DE CERRAR LOS HUECOS

\section{VILLANUEVA, p_46}

"...Llamase salmeres los dos primeros planos horizontales ó inclinados que sirven de apoyo a los arcos. Para formar los salmeres horizontales (A) basta apartarse de la mocheta con hiladas una cierta distancia, que por lo regular es lo alto de la dovela que ha de tener el 
arco, y dejando este espacio a nivel, se continúan las hiladas dejándolas a trabazón o endejas para unirlas con las que han de componer el arco"

\section{VILLANUEVA, p_46}

"...Si el salmer (B) ha de ser oblicuo, dejando un poco de retiro de la mocheta como de unos cuatro o cinco dedos para sentir la cimbra, subiendo las hiladas, retirando en cada uno lo preciso para formar la inclinación del salmer, que deberá arreglarse a la plantilla (C), sacada con arreglo el género de arco que se deberá construir"

\section{VILLANUEVA, p_47}

"...pónese para mayor acierto de este trabajo un cintrel (D) que es una regla fija por su extremo en el centro y, que pueda rodar sobre él, á fin de que sus distintas señalen la oblicuidad de las hiladas.

Este es el medio más cierto y seguro aunque algo impertinente, y para excusar esta detención, suelen en la práctica valerse de otro medio para registrar si la hilada lleva la inclinación debida, colocando sobre este y contra la cimbra de un ladrillo de canto (E)"

\section{VILLANUEVA, p_48}

"...también se suele formar una plantilla, cuando no se puede asegurar en el centro el cintrel el ángulo que el radio prolongado forma exteriormente con la cimbra, y por esto está compuesto por dos líneas, una recta y una curva..."

\section{VILLANUEVA, p_49}

"...suelen hacerse también arcos de mampostería, sola o verdugada, y no menos fuertes (5-A), bien construidos, que los ladrillos, que si fuesen de piedra incierta..."

1827 VILLANUEVA, p_49

"...también se hacen arcos de tabicado con yeso y solo se distinguen de los otros explicados, en el que estos se sientan a hiladas, tenidos 
sobre el haz inferior de la forma del arco, como se hacen las obras de albañilería, horizontal, una hilada, sobre otra, hasta que se componen en alto de su dovela"
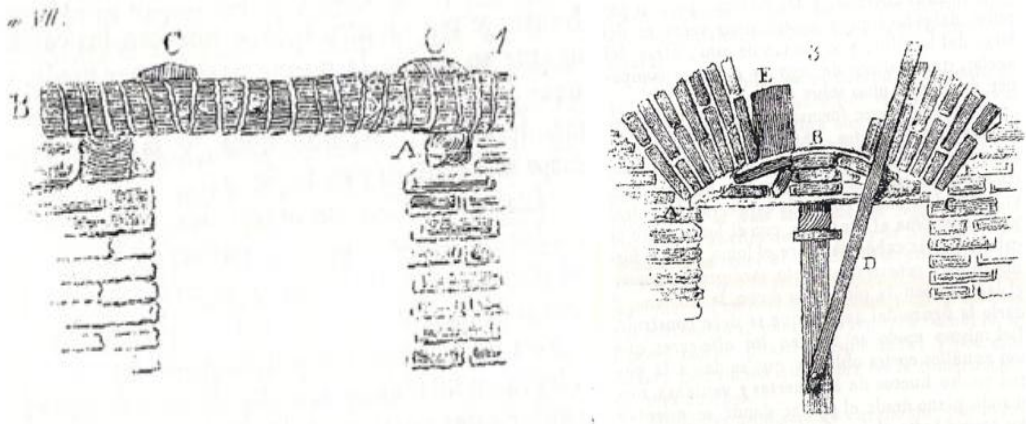

FIG. 70 Soluciones para dinteles de fábricas de ladrillo (Lam.VII-VILLANUEVA 1827)
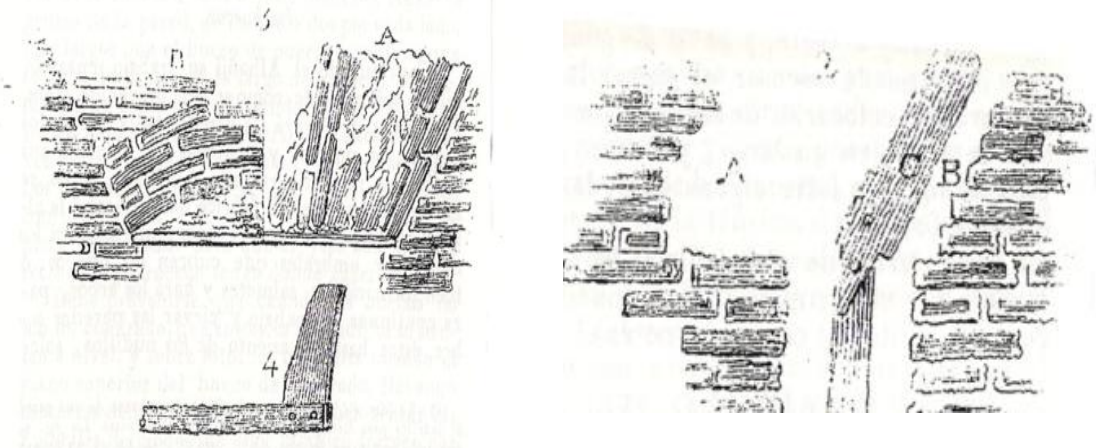

CAPÍTULO XII_DE LA CONSTRUCCIÓN DE FAJAS, RESALTOS, IMPOSTAS CORNISAS DE ALBAÑILERÍA DE LADRILLO

1827 VILLANUEVA, p_50

"... Todo lo difícil de estos trabajos consiste en que la parte que debe formar salga inmediatamente perceptible en su determinada forma sin la ayuda de guarnición de cal, yeso u otro material" 


\section{VILLANUEVA, p_51}

"...Si los cuerpos se forman con el ladrillo común, tendrá la pena de irlos cortando y reduciendo á la forma y figura necesaria, á no ser que esta operación se prevenga y ejecute por distinta mano"

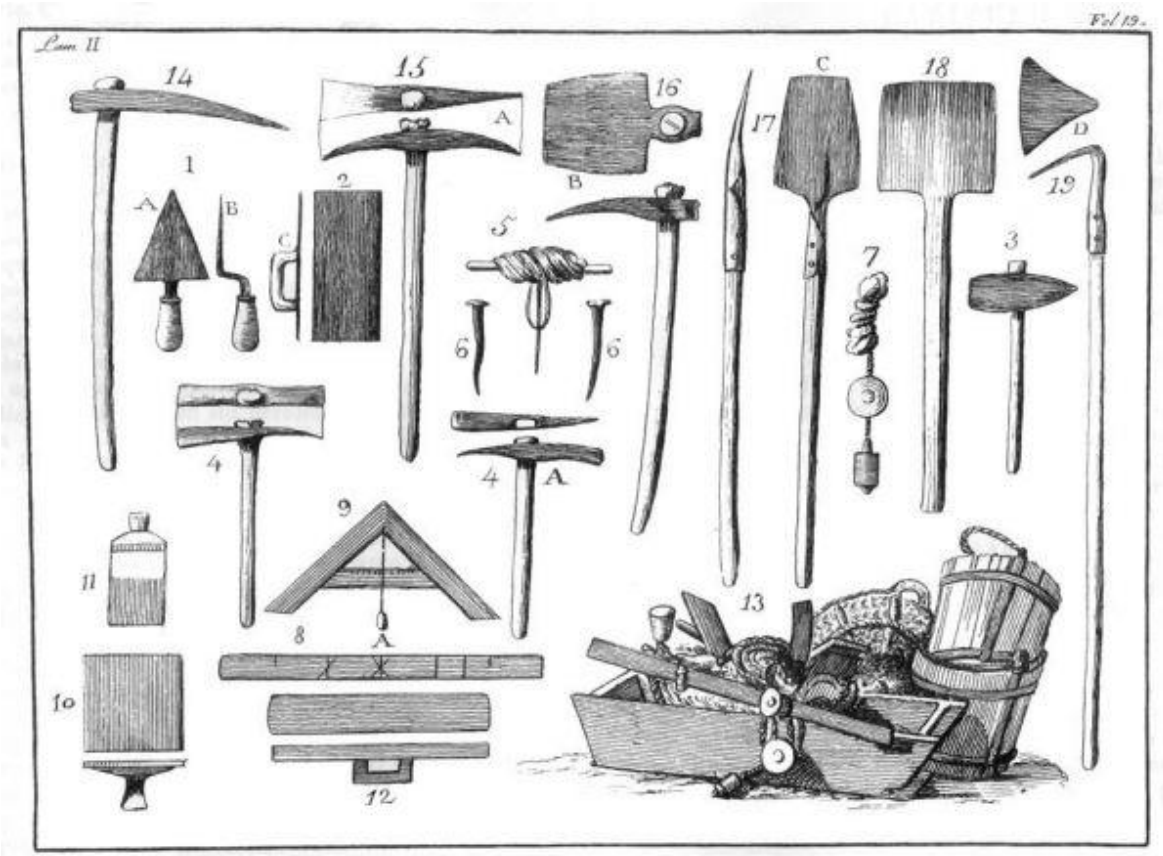

FIG. 71 Herramientas de albañilería (Lam.II-VILLANUEVA 1827)

MARCOS Y BAUSÁ R., Manual Del albañil, Serie de la Biblioteca de EnciclopedIa Popular Inlustrada, Secc. I, Artes y Oficios, Madrid, 1879 (fax simil Maxtor Ed., Valladolid, 2003)

1879_MARCOS Y BAUSÁ, p.145

"...el grueso del tendel no debe ser excesivo, porqué si bien es cierto que se economiza ladrillo, la obra baja mucho en calidad, es decir, hace mucho asiento y puede presentar grietas y desuniones en trabazón de aquellos; generalmente no pasa dicho tendel de unos 5 mm y, si es menor la fábrica se dice a hueso, y degollada, cuando el 
tendel llega en las juntas solo hasta tres o cuatro cm del haz exterior, lo cual hace se hace unas veces para rellenar estos huecos con mortero más fino o hidráulico, si el frente ha de quedar aparente, y otras veces con el fin de que agarre mejor el yeso o mortero que tiene que cubrirle posteriormente..."

1879_MARCOS Y BAUSÁ, p.169

"...las tapias o tapiales que estos dos nombres reciben las construcciones de tierra apisonada, pueden hacerse con este sólo material, dispuesto en cajones ó hiladas...unos encima de otrosmy a nivel en toda la longitud de la tapia, o también en machos de fábricas de ladrillo... con objeto de regularizar los asientos de la fábrica y darle trabazón puede también colocarse encima de cada hilada de cajones, una o dos de ladrillos, sentados con mortero y a nivel, que se llama verdugos y verdugada la construcción..."
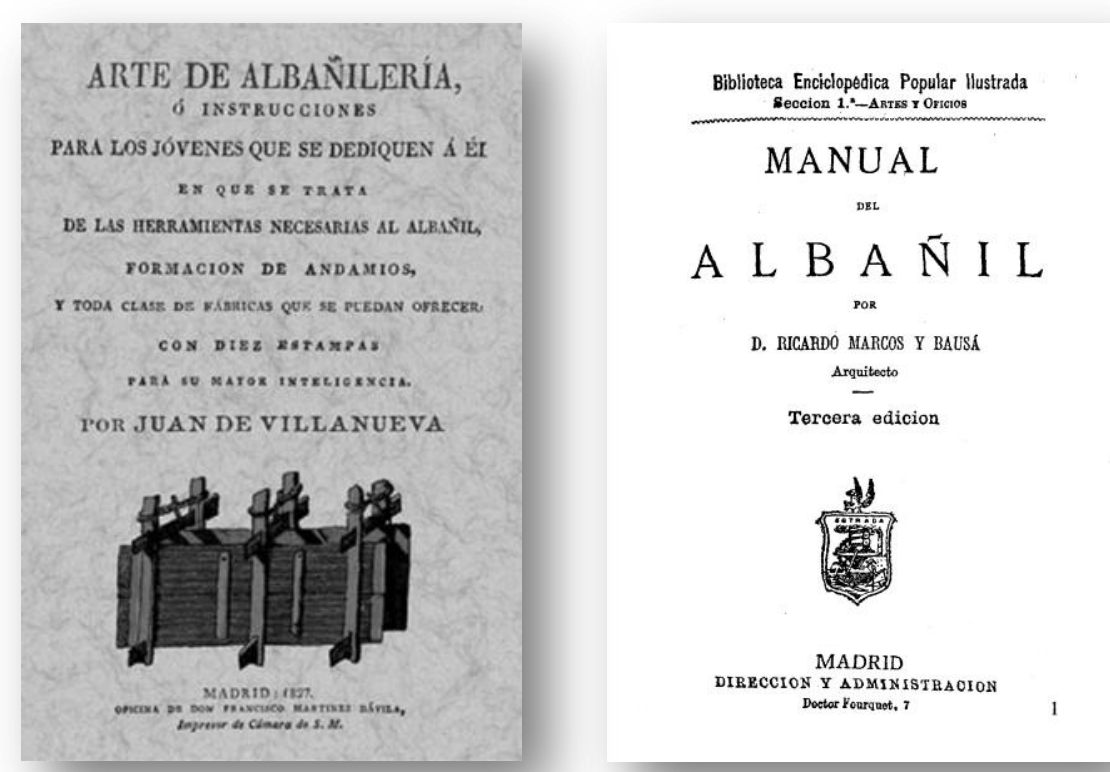

FIG. 70. Portadas de VILLANUEVA, Arte de la Albañilería y MARCOS Y BAUSÁ R., Manual Del albañil. 
1879_MARCOS Y BAUSÁ, p.217

"... Retundido o agramilado. Construida las fábrica de ladrillo, si estos han de quedar aparentes en el paramento exterior, se recorren las juntas de las hiladas, extrayendo, con el palustrillo, el mortero hasta cierta profundidad, para rellenar después este hueco con mortero hidráulico, recortando por igual los tendeles o llagas, á fin de que a la vista presenten el mismo ancho, y hagan más regulares las hiladas, cuya operación constituye el rehundido.

Si el muro estuviera construido con ladrillo fino, estos se agramilan, es decir, se cortan sus cantos, se apomazan con piedra arenisca para que resulten tersos y lisos y se frotan con la misma piedra, para que, hecha la fábrica, se pulimenten y se saque el brillo..."

1879_MARCOS Y BAUSÁ, p.223

"... Ios abultados de las fábricas de ladrillo, tanto en las cornisas ó parte saliente superior, como en las impostas divisorias de los pisos, se reviesten con yeso, empleando la terraja, que consiste en una chapa de sínc o palastro, cortada por uno de sus cantos, según la forma que haya de tener la moldura, pero en sentido inverso; es decir que las partes salientes de ésta son entrantes en aquella, y viceversa..." 
murOSINTRAMUROS

\section{5."muros intramuros": el estudio de las fábricas}

"...La obra de ladrillo es la más bella de la albañilería, y por lo mismo

pide toda la atención del oficial..."

${ }^{1}$ VILLANUEVA, Arte de la Albañilería, Madrid, 1827, Cap.X, p.35 



\subsection{Hacia la evolución de las técnicas constructivas en arcilla}

El estudio de la transformación de los muros del centro histórico de Valencia constituye uno de los principales argumentos para el análisis de la evolución de las técnicas constructivas autóctonas. Con instrumentos cronológicos para poder analizar históricamente las construcciones, es posible estudiar los mecanismos técnicos y sociales que subyacen a una determinada técnica constructiva (organización de la producción, bagaje técnico de los artesanos, materiales empleados), y por tanto, llegar a reconstruir el ciclo productivo arquitectónico vinculado a las fábricas.

En esta perspectiva, el estudio de las técnicas relacionadas con la arcilla permite realizar una historia social de la arquitectura de Valencia, analizando los mecanismos de control de la producción y de las fuerzas productivas.

Según las fuentes arqueológicas², el ejemplo clásico de la primera aplicación de arcilla en la ciudad fue el ladrillo sin cocer, el adobe.

Su molde se confeccionaba en función de las posibilidades y del ingenio: se podía tratar de un encofrado simple formado por un enrejillado de tablas de maderas o se puede aventurar la hipótesis de una formación inicial en nichos excavados en el suelo, técnica que aún se conserva en Egipto, Mesopotamia y pueblos costeros del

\footnotetext{
${ }^{2}$ AA.VV., Recuperando el Centro Historico: urbanizaciones y actuaciones en plazas, calles e edificios, Ayto. de Valencia Ed., Valencia, 2006
} 
Mediterráneo, y que podría corresponderse con el material encontrado en las primeras fases de construcción de Valentia ${ }^{3}$.

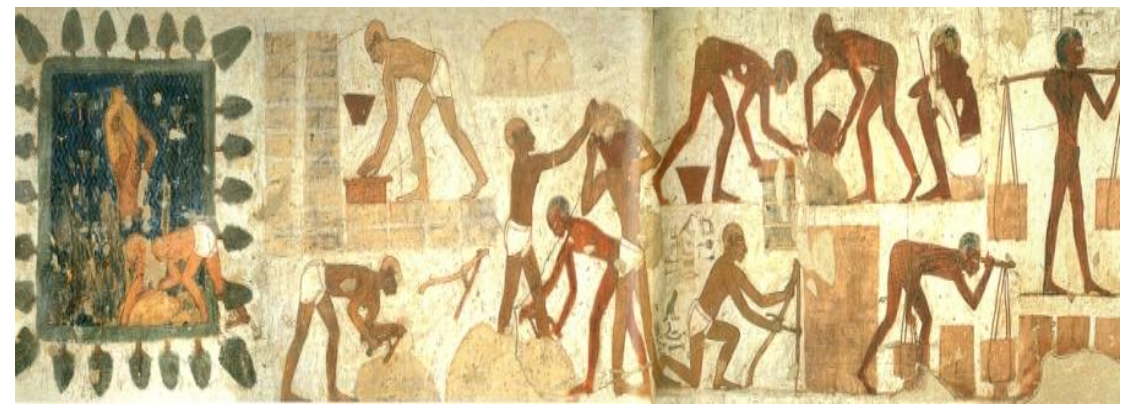

FIG. 71 Producción de adobe, visible en la pintura mural de la Tumba de Reck-Mi-Re, a Tebas, Luxor, Egipto, 1450 a.C. (CAMBELL-PRICE)

En una fase posterior de la evolución, se llega a una mejora constructiva, con una segunda fase más avanzada, que prevé el amasado de arcillas por tongadas sucesivas, en un encofrado llamado tapial ${ }^{4}$. La gran diferencia entre la tapia y la fábrica de adobe radica en la necesidad de encofrado, con un empleo preferente en la construcción de murallas, cercas, vallados ${ }^{5}$.

Ambas técnicas, elementales únicamente en apariencia, basan su eficacia en simbiosis con un clima cálido y poco húmedo. La exposición al sol permite conseguir un secado adecuado, junto al

\footnotetext{
${ }^{3}$ AA.VV., L'arqueologia fa ciutat: les excavacions de la plaça de Cisneros, Ayto. Ed., Valencia, 2000

"Los hallazgos más antiguos documentados en la excavación datan de la fundación de la ciudad al 138 a.C.... Ios muros de estas primeras edificaciones eran de tapia de tierra y adobe, reforzados con piedras en las esquinas..."según SERRANO M.L. (Op. Cit.)

${ }^{4}$ LÓPEZ MARTÍNEZ, Tapiería en fortificaciones medievales, Región de Murcia, Tesis doctoral, dirigida por Noguera Giménez, UPV, Valencia, 2003. Los orígenes del nombre son inciertas. Hay quien remonta la palabra "tapia "a "tabya" (COROMINAS-PASCUAL), término que define al molde que se utiliza en el amasado de tierra y quien marca la origen del nombre onomatopeya de "TAP, TAP..." dado por el sonido del pisón, la herramienta con la que se compactan las diferentes tongadas de tierra(MALDONADO RAMOS)

${ }^{5}$ El origen de cualquier ciudad está en el muro que la protege, define y defiende. La muralla origina la formación de dos mundos, un "intra-radio" y un "extra-radio", que crean normas y vínculos para lo cercado. Dos mundos separados que tienen identidad propia
} 
hecho de una exposición controlada a la lluvia. Las principales aplicaciones de las arcillas en la edificación urbana coinciden con la progresiva capacidad de regularización de la producción y de mejora, a lo largo del tiempo, de las técnicas de relleno, cegado, impermeabilizado.

Sin embargo, el clima valenciano, con sus rasgos cálidos y húmedos, favoreció la mejora de estos sistemas constructivos, llevando a la cocción de la arcilla y a su mejora de características, tanto frente al agua como frente a esfuerzos mecánicos ${ }^{6}$.
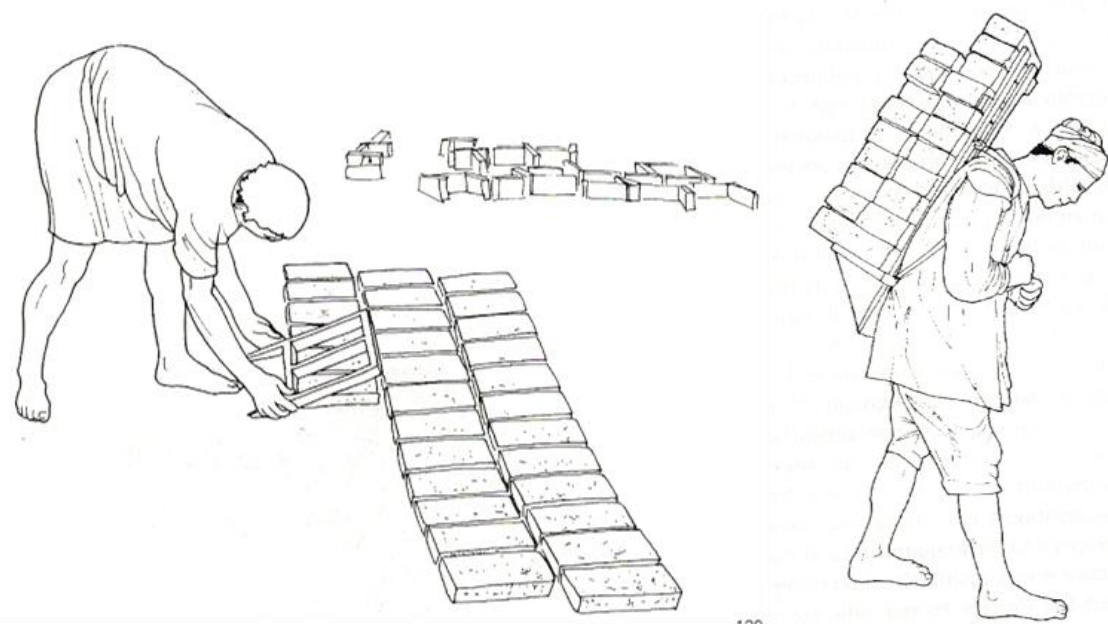

FIG. 72 Preparación, secado y transporte de ladrillo en Túnez, S. XIX (ADAM)

\footnotetext{
${ }^{6}$ El primer ejemplo histórico de que se tiene noticia data de alrededor de 8.000 a.C. y se trata de ladrillos secados al sol procedentes de las excavaciones de Jericó: las piezas se asemejan a una gran hogaza de pan con marcas de pulgares en su cara superior, probablemente con objeto de aumentar su adherencia al material de agarre. Por otro lado, el primer empleo de ladrillo cocido se remonta en Mesopotamia (3.900 a.C.) procede del material arcilloso del Tigris e del Éufrates.

En Valencia tenemos constancia de un acertado empleo de ladrillos tanto en crudo como cocidos, empleado a la vez que los primeros hormigones y morteros hidráulicos
} 
A partir de estas premisas, el estudio propone un análisis visual material y empírico de 95 ejemplos de fábricas, localizadas en 84 edificios de la zona intramuros de la ciudad de Valencia ${ }^{7}$, con la finalidad de realizar un cuadro cronotipológico de soluciones constructivas realizadas en ladrillo, cuyas características se presentan a continuación ${ }^{8}$.

\footnotetext{
${ }^{7}$ Los edificios analizados en Valencia se localizan en la antigua zona intra muros de la ciudad, en el cuadrante definido por la C/Guillem de Castro, C/Blanquería, C/Pintor López, Glorieta, C/Cristóbal Colón y C/ Xàtiva, según una geometría abstracta que reproduce el recinto de la muralla cristiana de la ciudad (1356-1865). En 9 edificios analizados se ha encontrado más de una fábrica a estudiar

${ }^{8} \mathrm{~A}$ la hora de considerar casos de estudio representativos de fábricas de ladrillo, se han establecido requisitos como: la localización del caso de estudio en la zona intramuros de la ciudad de Valencia, la presencia de ladrillos de producción pre-industrial, como máximo de la primera mitad del siglo XIX y la presencia de una superficie a estudiar de al menos 5 hiladas de ladrillos (15/20 elementos), homogénea con ladrillos enteros
} 


\subsection{Fábricas con ladrillos}

\subsubsection{Tapia valenciana}

Se trata de una tapia híbrida, donde la argamasa comparte protagonismo con refuerzos puntuales de ladrillos, en una mezcla de cal, grava y tierra apisonada. Por esto, el resultado ofrece un acabado equívoco de las caras de las fábricas, un status a medio camino entre el muro encofrado y el muro aparejado. La mayoría de las veces el acabado está constituido por la misma costra de cal, que debido al desencofrado, genera una textura peculiar en forma de fino rebosado de argamasa sobre los bordes de los ladrillos.

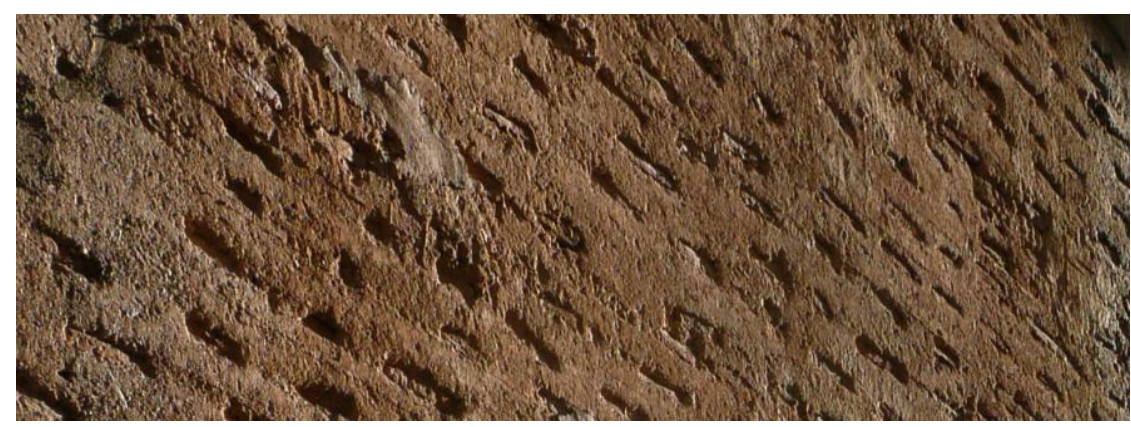

FIG. 73 Tapia valenciana, equilibrio híbrido entre fábricas encofradas y de ladrillos, C/Prócida, Valencia (Fa153) (CRISTINI)

"Alrededor de los siglos XIII y XIV se consiguió un nivel de perfección y dominio de la técnica de la tabiya sobresaliente, hasta el punto que, de la misma manera que hoy en día para hacer una pared de ladrillo utilizamos cuerdas y reglas para alinearla y plomarla, antiguamente también se echaba mano del encofrado, como medio para la 
ejecución de un muro de ladrillo, sobre todo en elementos de poco espesor. Por tanto, dentro del encofrado se colocaban los ladrillos aparejados a soga y tizón con hormigón de cal. Y si el muro era de gran espesor, entre las hojas exteriores de ladrillos se vertía hormigón de cal con mampuestos de diferente tamaño.

Estos muros de tapia ofrecen una apariencia de simple fábrica de ladrillo, pero tras una atenta observación podremos comprobar que las llagas de mortero alcanzan incluso los $10 \mathrm{~cm} . . . " 9$.

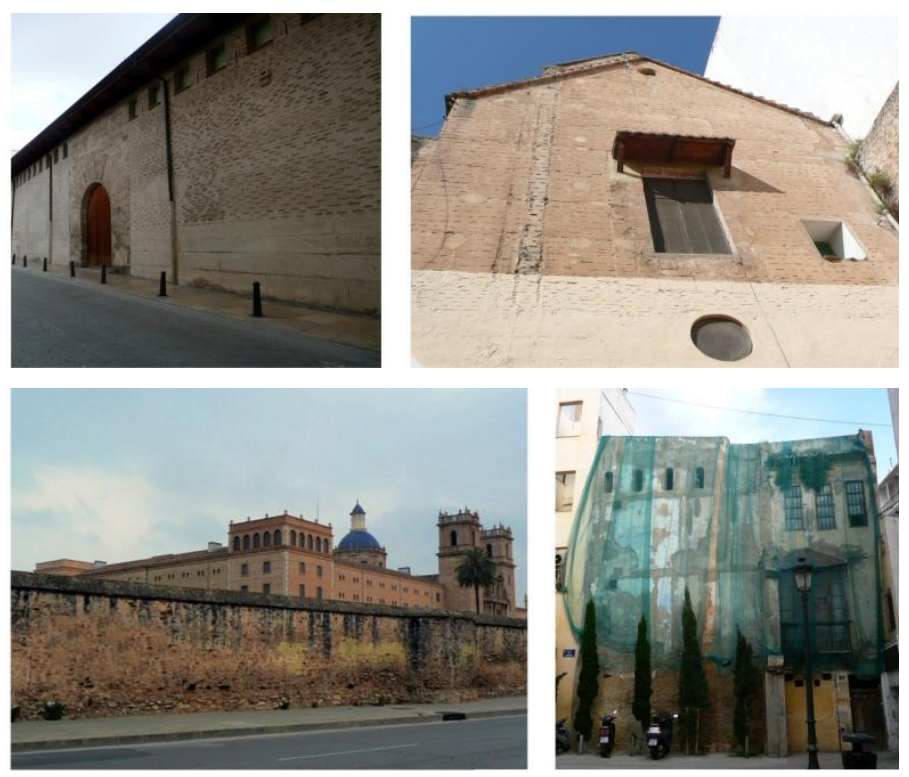

FIG. 74 Ejemplos de fábricas de tapia valenciana visibles en Valencia, tras intervenciones u olvido. El Almudín (Xc96), el Convento de la Trinidad. Abajo el cercado junto a de S. Miguel de los Reyes, las Viviendas en Plaza del Autor (Cg48), en el Barrio del Carmen (CRISTINI)

Realmente esta técnica, una curiosa mezcla entre la aplicación de arcilla en crudo (tapia) y cocida (ladrillo), no se encuentra en las fuentes arqueológicas hasta la segunda mitad del siglo XIII ${ }^{10}$. Pero su

${ }^{9}$ FONT F., HIDALGO P., "Arquitecturas de tapia", COAT, Castellón, 2009, p.73

${ }^{10}$ Archivo del SIAM, sin especificar si se trata de la Primera o de la segunda mitad del siglo XIII. 
nombre no se detecta de forma explícita hasta el siglo XVI ${ }^{11}$. A la vez es muy llamativo el apelativo tan autóctono ("valenciana") que se da a estos muros, a pesar de que realmente otras zonas de la Comunidad presentan fábricas con estas características (Alcira, Xàtiva, Alaquàs, Castellón, Mascarell, Masamagrell, Sagunto, entre otras...) y también en Murcia, Aragón, hasta llegar a la granadina Guadix.

Si por otro lado analizamos las características métricas de estas fábricas tenemos que rendirnos a una total heterogeneidad de los ladrillos empleados. A pesar de la disposición a modo de "clave", a tizón, de los elementos cerámicos, siempre encontramos tamaños y tipos de arcilla empleados, variables a lo largo de la misma fábrica. Por eso, se debe reconocer que estos tipos de fábricas se realizan más bien con materias primas recicladas, tal vez defectuosas y de recuperación.

La presencia de los ladrillos irregulares no es imprudente, debido al hecho que su rol en el muro encofrado es de refuerzo puntual, es un armado, no es completamente un aparejo. Por esto las materias primas empleadas pueden ser heterogéneas entre sí, porqué no responden a lógicas de orden sino más bien de sujeción y engranaje.

¿Cuál es el origen de esta técnica y por qué razón se puede hablar de tapia con ladrillos? Actualmente se están barajando opciones, pero la hipótesis más determinante parece apuntar a la antigua Fábrica de Murs y Valls como motor de la transformación tecnológica, concretamente a lo largo del proceso de construcción de la muralla cristiana de la ciudad. Pero este motor no propulsó el empleo de estas técnicas de forma gratuita, sino más bien en el marco de una solida tradición constructiva urbana preexistente.

\footnotetext{
${ }^{11}$ GALARZA TORTAJADA, "La Tapia Valenciana: una técnica construida poco conocida", en Actas del Primer Congreso Nacional de Historia de la Construcción, Madrid, 16-21 septiembre 1996, Instituto Juan de Herrera Ed., Madrid, 1996, p.211
} 
"..el Mediterráneo es un mar interior lo suficientemente extenso como para permitir la diversidad de sus ribereños y no lo suficientemente extendido para separarlos..."12
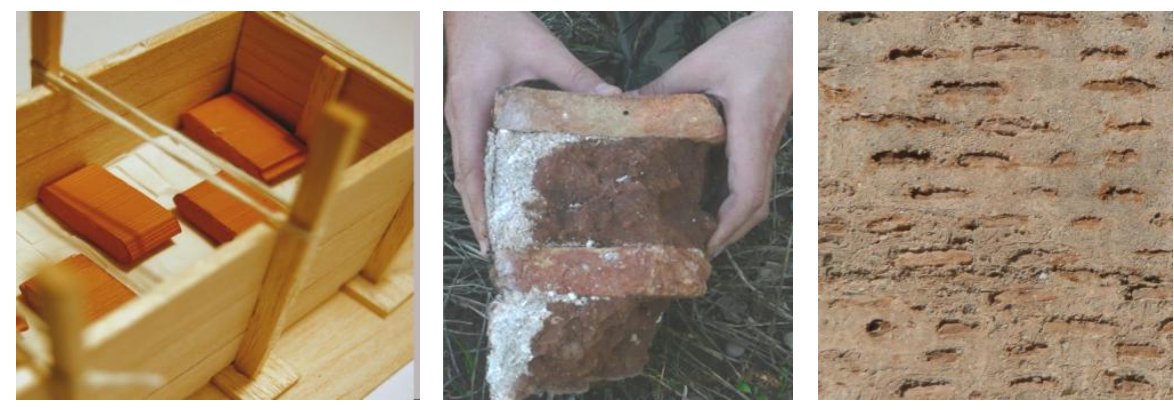

FIG. 75 Tapia valenciana: maquetas, ensayos y toma de datos (CRISTINI-RUIZ CHECA)

\subsubsection{Posibles antecedentes históricos: fábricas de ladrillo en el mundo bizantino}

Como se ha señalado previamente, existe un vacío a tener en cuenta en la historia urbana de la ciudad en los siglos IV, V y VI, vinculado a la transición sociocultural y el cambio desde el control político romano al musulmán. No existe sólo Valentia y Balansiya, existe una entidad híbrida entre las dos, apenas conocida y documentada que abarca muchos siglos de Historia ${ }^{13}$. Godos y bizantinos controlan la

\footnotetext{
${ }^{12}$ RIDHA T. (entre otros), El legado Andalusí, Monografía de la Junta de Andalucía Ed., nº6, Granada, 2009

${ }^{13}$ En la segunda mitad del siglo III, de manera paralela al resto del Imperio, Valentia atraviesa una etapa de crisis que marca el inicio de un largo periodo de decadencia, a lo largo del cual la ciudad reduce su perímetro, vive la despoblación de barrios enteros y el abandono de las redes de infraestructuras.

Un siglo después, coincidiendo con las primeras oleadas de pueblos germánicos y con el vacío de poder dejado por la administración imperial, la Iglesia asume las riendas de la ciudad y los edificios de culto cristianos sustituyen a los templos romanos. En tiempos del Obispo Justiniano,

en el siglo VI, Valencia experimenta una cierta recuperación, frenándose por algún tiempo la degradación urbana y celebrándose en ella un importante Concilio Regional.
} 
Provincia de Hispania desde la caída del imperio hasta el 625 d. C., año en el que tiene lugar la expulsión de los bizantinos, un acontecimiento del que existen escasos documentos publicados ${ }^{14}$.
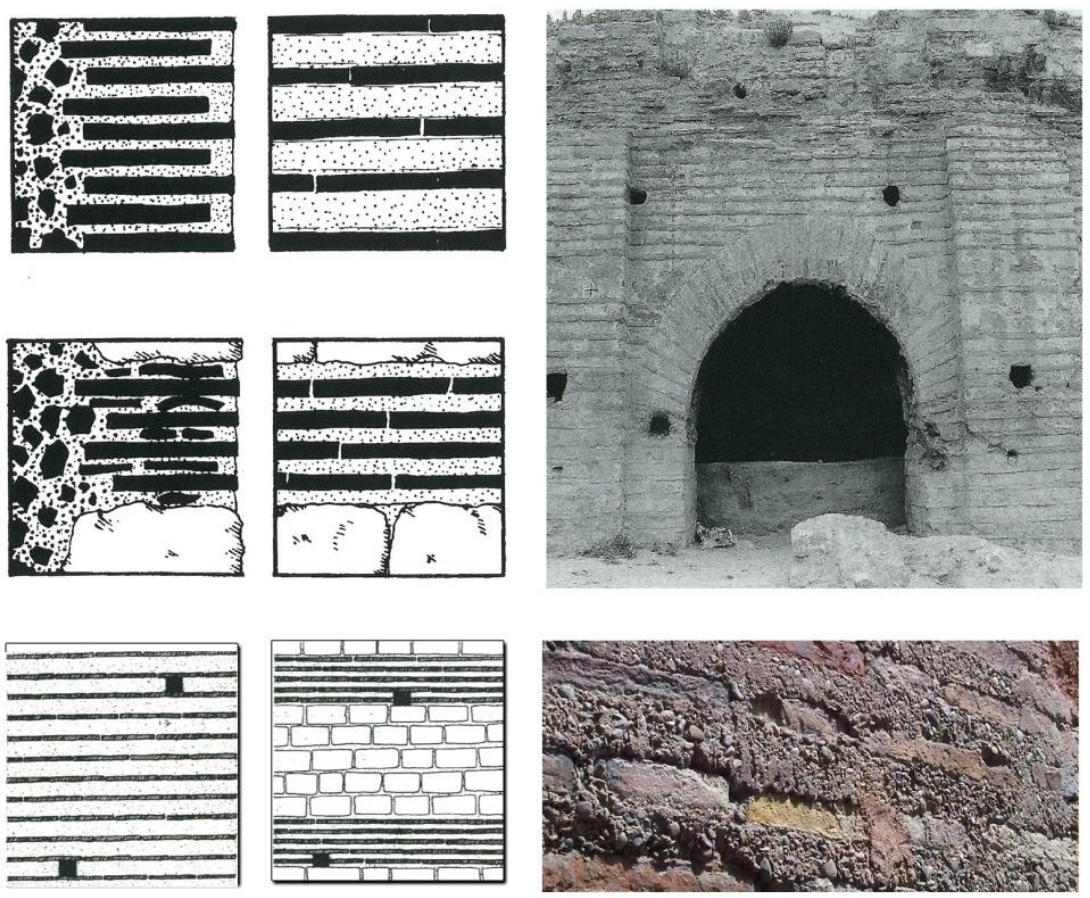

FIG. 76 Arquitectura bizantina y caracteres constructivos: detalles de muros con hiladas retranqueadas y gruesa juntas. ¿Posibles antecedentes de fábricas valencianas? (OUSTERHOUT) La presencia de fábricas con tendeles tan marcados apunta a lo largo de todo el Mediterráneo ${ }^{15}$ a la tradición constructiva bizantina,

Finalmente sabemos que, con la invasión bizantina del sudeste de la península en 554, la ciudad cobra una importancia estratégica, instalándose contingentes militares visigodos que emprenden tareas de fortificación del antiguo circo romano. Tras la expulsión de los bizantinos en el 625 se inicia una etapa oscura de la que apenas existe documentación y que se parece corresponda con un empobrecimiento general de las condiciones sociales y culturales.

Muchos factores históricos por lo tanto apuntan a una posible herencia tecnológica vinculada con el mundo bizantino, un aspecto hasta ahora definido como posible, pero pendiente de la verificación por fuentes arqueológicas

${ }^{14}$ VIZCAÍNO SÁNCHEZ J., La Presencia bizantina en Hispania, siglos VI-VII, la documentación arqueológica, Monografías históricas sobre arte antigua, Universidad de Murcia Ed.2007

${ }^{15}$ MANGO C., Byzantine architecture, Electa, 1978 
caracterizada por fábricas con juntas tan gruesas como los ladrillos o incluso más, con grosores de hasta 70-90 mm. Existen diferentes técnicas que proceden de Oriente realizadas con ladrillos de este tipo. Algunas son mixtas, con piedra o madera, y otras se erigen únicamente con elementos cerámicos.

Merece la pena definir con más detalle una de estas técnicas que se remonta a la segunda mitad de siglo $V$. Se trata de la conocida como "fábrica con ladrillos retranqueados" ${ }^{16}$. En este caso, tal y como indican las palabras, el muro se construye con una hilada de ladrillos retranqueados respecto a la vertical del paramento en hiladas alternas.

Las hiladas retranqueadas quedan ocultas por la junta de mortero, marcando esta última un grueso casi doble respecto a la junta real ${ }^{17}$. Existen diferentes hipótesis que justifican esta solución constructiva ${ }^{18}$. Por un lado, el efecto rayado de la pared tiene un matiz estético, que se difunde desde Bizancio hasta la Capadocia (Çanli Kilise) y Cipre (Nicea). Pero la presencia de hiladas embebidas en el muro tiene una función estructural importante.

En el caso, por ejemplo del Panagia Chalkeon, en Tesalónica (Grecia), la técnica se aplica en zonas estratégicas de las fábricas, como esquinas y ábsides, donde los ladrillos desempeñan el rol de conectores y estabilizantes. La lógica de este método también se puede remontar a las construcciones de la Antigua Roma, donde el paramento realizado con opus latericium, se aparejaba con piezas de ladrillo triangular. Éstas poseían un acabado superficial liso pero presentaban un perfil dentado hacia el núcleo, que favorecía la traba.

\footnotetext{
${ }^{16}$ Se conoce más como "recessed-brique technique", investigada sobre todo por OUSTERHOUT R., Master builders of Bizantyum, Princeton University Press, 1999, cap.VI, p.157-184

${ }^{17}$ WARD PERKINS J.B., "Notes on the structure and buildings methods of early byzantine architecture" and "notes of structure" in The great Palace of the byzantine emperors, II' report, St. Andrew Ed., 1954

${ }^{18}$ OUSTERHOUT R. (1999) Op. cit, p.174
} 
Otra técnica interesante que deriva de esta última, es la que prevé un relleno con ladrillos de recuperación, retranqueados, en los gruesos tendeles de las paredes ${ }^{19}$. Se trata sobre todo en un método que prevé alternar gruesos ladrillos con otros más finos, embutidos en la pared, alternados o yuxtapuestos a tejas y tejoletas, procedentes de expolio o de producciones de menor calidad constructiva.

Una vez acabada la construcción de la pared, bien con retranqueo de hiladas, bien con relleno de las mismas...el refuerzo de ladrillos queda oculto. La pared no desvela, tras su acabado de mortero en los tendeles, su solido núcleo dentado. Eventualmente, las fábricas pueden haberse copiado, a semejanza de las de Bizancio ${ }^{20}$, a lo largo del Imperio y del tiempo, pero no siempre bien construidas, por capas retranqueadas, sino más bien, solo por mímesis, con la mera reproducción de gruesos estratos de mortero ${ }^{21}$.

\subsubsection{Posibles antecedentes históricos:}

las fábricas de tapia en Al-Andalus

La presencia de la tapiería 22 más antigua en España se remonta a Plinio, que en su Historia Natural nombra la tapia como formatium, un modulo constructivo que se realiza con una horma/cajón, herramienta básica para la ejecución del muro. Pero es solo con la llegada andalusí cuando se encuentran descripciones más extensas de estas técnicas y cuando se pueden apreciar soluciones constructivas más completas. Pero es a partir del siglo VIII, cuando esta tecnología de muros encofrados madura plenamente, y sus reflejos constructivos alcanzan la ciudad de Valencia.

\footnotetext{
${ }^{19}$ Se conoce más como "brick-filled mortar joints", OUSTERHOUT R. (1999), Op. cit, p.177

${ }^{20}$ Entre ellas, la Iglesia de Saint George of Mangana, Latmos, Bogdan Saray, Isa KapiMescidii, etc.

${ }^{211 . . .}$ the outer appearance could have been copied in the Empire, as it apparently was at the Koimesis of Nicaea and at Çanly Kilise, but without the structural advantage of the recessed courses..." OUSTERHOUT R. (1999), Op. cit, p.179

${ }^{22}$ Término empleado por LÓPEZ MARTÍNEZ F.J., Tapiería en fortificaciones medievales, Región de Murcia; Tesis Doctoral, UPV, dirigida por NOGUERA F., 2003
} 
Se sabe que las huellas arqueológicas y los lienzos que quedan de arquitectura islámica en Valencia no presentan abundancia de ladrillo, sino más bien de adobe y de muros de tapia. Estos muros no son de tierra pura, sino que se realizan con técnicas mixtas, con refuerzos en muchos casos ocultos, como la tapia de argamasa con mampuestos o la tapia real (muros estabilizados con cal). Estos ejemplos, se pueden ver hoy en día en algunos lienzos de muralla como en la cerca del Portal de la Valldigna, o en la zona de la plaza del Tossal de Valencia, que forman parte de la defensa de más de 1 m de grosor, que empezó a construirse en el siglo XI alrededor de la medina (Molina-Al Udri 1982).

Pero es con la mejora de murallas y estructuras defensivas de almorávides y almohades (siglos XII-XIII) cuando se alcanza el momento cumbre con un auténtico dominio de la técnica constructiva. La ejecución de muros llega a su máximo nivel de maduración, tal como reflejan los sistemas de castillos, torres y fortalezas (Gallego Roca 1996). De esta manera es posible determinar una cierta cercanía entre las fábricas de tapia valenciana y sus antecesores constructivos ligados a la tradición musulmana. Es pues posible poder determinar a la tapia valenciana como la secuencia entre la tapia de argamasa y la fábrica de ladrillo, o mejor como el enlace entre la cultura constructiva musulmana y la cristiana.

El testimonio más antiguo que se puede encontrar referente a este momento de transición técnica y paso de testigo nos llega directamente desde las Crónicas de Jaime I, quien ordenó que la tapia fuera la solución constructiva con la que reconstruir castillos reconquistados. No solo, sino que también muchos medievalistas dudan sobre el punto de contacto tecnológico existente entre las dos culturas, reconociendo un flujo bastante natural, espontaneo, entre las diferentes tradiciones constructivas (Pérez Guillen 1990-López Elum 2001). Existe una profunda huella dejada por la tapiería en las comarcas del Levante español, matiz que permitiría interpretar la 
tapia valenciana como una solución constructiva propia de la Reconquista Cristiana, y un elemento más del lenguaje técnico valenciano que, sumado a las bóvedas tabicadas y los arcos diafragmas, constituiría el abecedario constructivo del avance cristiano en la península.

\subsubsection{Posible propulsor de la difusión de la técnica:}

La Fábrica Vella, dita de Murs y Valls

Una serie de privilegios de 1251, 1269, 1328 y 1358 forman el corpus que constituye la base de la institución valenciana encargada del control de obras públicas como murallas, acequias, puentes y caminos. Concretamente en 1358, con un privilegio de Pedro IV se origina la Junta de Murs y Valls, que luego será llamada Fábrica Vella de Murs i Valls, para distinguirla de la Fábrica Nova del Riu, constituida en 1590 (Teixdor De Otto 1982). El Llibre de Memories de la Catedral de Valencia recoge en sus páginas el momento de fundación de la Junta, precisamente debido a las consecuencias graves de las riadas de la primera mitad del siglo XIV.

Por Murs se entendían murallas, puertas, torres que requerían construcción y, sobre todo, manutención constante. Por otro lado, Valls, se consideraban alcantarillas, canales, así como caminos y puentes, que también requerían reparaciones, adecuaciones y limpieza periódica.

Participaciones personales y donativos a las obras de la Junta, a modo de obras pías se unían a impuestos públicos y sisas recaudados por la alcaldía. De esta forma, así, todos los ciudadanos eran contribuyentes de esas obras públicas urbanas de construcción y reparación de muros, fosos, caminos, puentes e acequias. A esta gran actividad constructiva se corresponde a la vez una interesante actividad de autorización de demoliciones y desmantelamiento de fábricas en desuso. 
Es interesante ver como existe una alternancia de ciclos continuos de construcción y demolición. Por ejemplo, a lo largo del siglo XIV-XV se autorizan constantemente por parte de la Junta derribos de obras de construcción realizada a contrafueros. Existen también ciclos constructivos/destructivos más interesantes.

De 1339 a 1351 se adoptan medidas para la construcción de una nueva muralla urbana. De forma tal que finalmente de 1351 a 1365 se ponen en marcha nuevas obras defensivas e indemnización a los afectados por las construcciones. Es curioso ver como a estas fases constructivas se contraponen ciclos importantes de derribos. De 1365 a 1372 se recopilan licencias de venta de muros antiguos, una vez perdido su uso defensivo. A la vez en 1377, 1392 y 1397 hay acciones en torno al cierre y desmantelamiento del burdel de la ciudad. En 1390 se repite lo mismo, pero con la propuesta del cierre de la judería.

Se debe considerar hasta qué punto la reutilización de ladrillos y de otros materiales de construcción internos a los ciclos constructivos de la Junta, parece autolegitimarse a través de estos datos. Así se delinea un panorama de mercado interno para la Junta, paralelo al abastecimiento de materiales constructivos nuevos, que incide en la praxis edilicia. Y con estos datos es lícito preguntarse si las técnicas constructivas de las fábricas siguen inalteradas o si se pueden observar cambios y variaciones constructivas, propias del mercado de reciclaje de materiales constructivos, como el caso de la tapia valenciana, nombrada antes.

En 1337 el Conse// de la ciudad empieza a plantear un nuevo recinto amurallado. La defensa debía actuar tanto frente a las avenidas del río, "enemigo invisible" como apuntan muchos estudiosos, así como ante un ataque enemigo, como era el posible contragolpe musulmán desde Granada. 
La construcción de la nueva muralla dejó sin utilidad la anterior musulmana, que podía ser derribada o incorporarse a otras construcciones, mientras que el nuevo foso cumplía con sus plenas funciones hidráulicas. La voluntad de Pedro IV de fortificar Valencia se manifiesta ya claramente en 1337, pero la obra oficialmente comienza solo en 1351, y se retoma con ahínco en 1356 (Serra Desfilis 1990).

Guillem Nebot estuvo al frente de la obra de tapia valenciana posiblemente más emblemática, antigua y colosal que se conoce en la ciudad de Valencia. Es el encargado responsable de los tapiadores especializados en los muros de encofrado (tapiadors).

Se sabe que los tapiadores levantan un muro con tapia de tierra, arena y cal, reforzado por "reble"23, al que se aplica un revestimiento de costra de cal. Sin embargo, se conoce también que en 1358 las riadas se llevaron todo posible sistema de contención y, en particular, la nueva muralla recién construida con el aprovechamiento de la tierra de los fosos. Por ello se impuso una necesidad, tanto urgente como técnica, de reparar los muros, de forma rápida, duradera y eficaz. En 1362 Pedro el Ceremonioso ordenó que se trabajase intensivamente las obras de fortificación con diez "parelles de tapiers", es decir, equipos de trabajadores que construyesen rápidamente el muro con la técnica de tapia encofrada ${ }^{24}$.

Es probable que los muros de tapia de tierra de origen musulmán no respondieran bien a la acción violenta de las riadas y, por esta razón, que se decidiera reforzar las fábricas con otros materiales de construcción, para hacer frente a las exageradas lluvias otoñales ${ }^{25}$.

\footnotetext{
${ }^{23}$ Se define como reble un cascajo o fragmento de ladrillos y de otros materiales que sirve como relleno ( del latín replum, de replère, rellenar ) RAE

${ }^{24}$ AHMV- Manual de Consells, A-14, f.8r, 8-VII, 1362

${ }^{25}$ SERRA DESFILIS, Ingeniería y construcción en las murallas de Valencia, siglo XIV, en Actas del Congreso Nacional de Historia de la Construcción, Burgos, 2007, p.883-894
} 
Las obras fueron dirigidas por Arnau Agafull entre 1398 y 1400, con el propósito de remplazar las fábricas de tierra por otras, como se ha apuntado de argamasa con reble ${ }^{26}$ ¿Es ésta la primera aplicación a gran escala de la técnica conocida como tapia valenciana? ¿Nace desde estas exigencias la primera aplicación de ladrillos en la mezcla de tierra y cal?
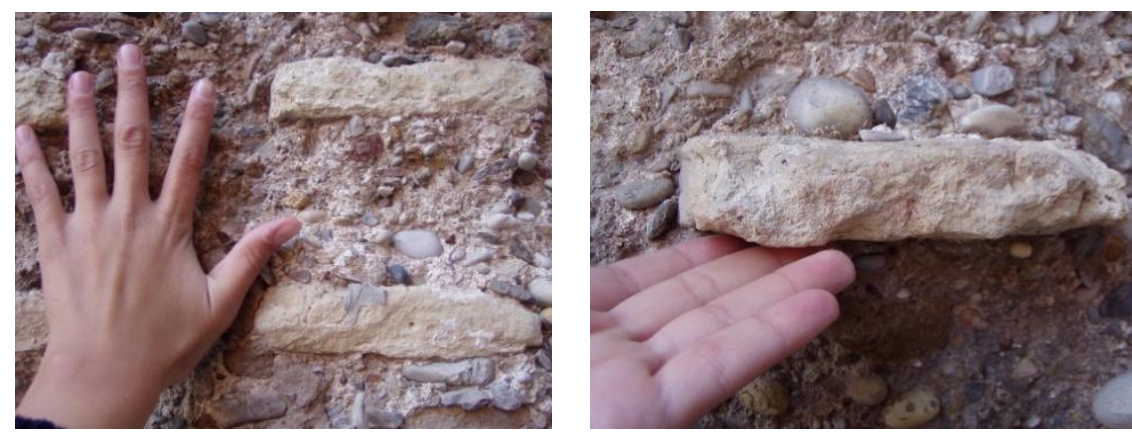

FIG. 77 Tapia valenciana. Detalles de refuerzo con ladrillos en la muralla cristiana de la ciudad de Valencia (Cb65) (CRISTINI)

Los problemas de las inundaciones obligan a prescripciones severas, como" que la obra se realizara tota de d'argamasa e de reble" en vez que sólo de "de crosta de argamassa e de terra tapiant"27.

Los conventos mendicantes contribuyen en el proceso de urbanización del área extramuros, al implantarse como constelación que gravita alrededor de la antigua medina, sus vías de acceso y los arrabales más prósperos. La muralla es antes de todo un dique, para evitar que las aguas del río puedan ocupar así las zonas urbanizadas.

Hoy en día en la ciudad, quedan pocos y escasos ejemplos visibles de esta técnica. En muchos casos las fábricas están enlucidas, alteradas en sus acabados y ocultas por las reformas. Se encuentran huellas que se remontan a edificaciones de la parcelación gótica, como las fábricas visibles en el Palacio de los en Bou (Mb72)...el Palacio del Gremio de Carpinteros (Va34)... ejemplos más

\footnotetext{
${ }^{26}$ AHMV, Sotsobrería de Murs y Valls, d3-10, ff.11-81, 1398. Ver nota

${ }^{27}$ AHMV, Manual del Consells, A-18, f.16. 6-XI-1383
} 
"humildes" como la medianera del Conjunto de la C/Eixarchs (Va82) y el edificio de la Plaza del Autor (Cg48). En áreas puntuales, como contrafuertes y machones, se constata la presencia de tapia con ladrillos aparejados de soga y tizón...sobretodo en medianeras de conjuntos religiosos, como los vallados del Monasterio de la Trinidad, del "Patriarca" (Fa82) del Pilar (Vb67), y de la Iglesia del Carmen $(\mathrm{CgO1b})^{28}$.
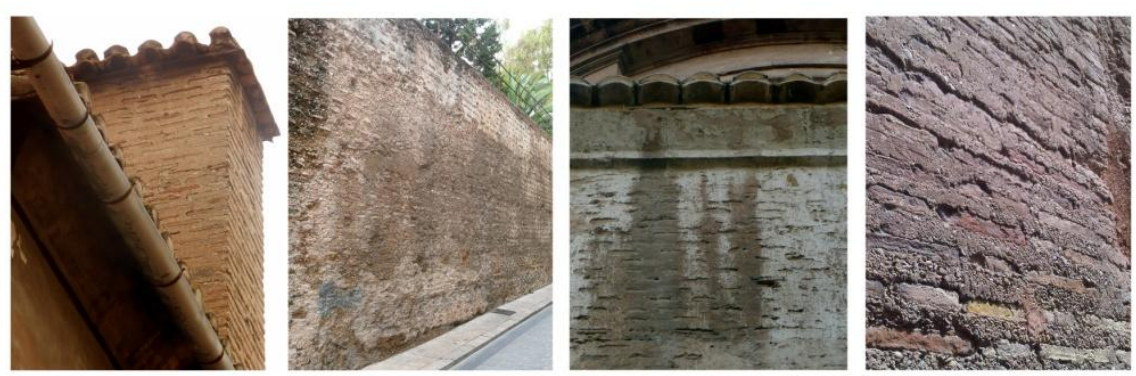

FIG. 78 Tapia valenciana en algunos edificios religiosos/monumentales intramuros; (a la izquierda) alzado de la Iglesia de San José (Cg14), muralla junto a las Torres de Quart (Cb65), cerca del Monasterio del Carmen (Cgolb), alzado del Convento del Pilar (Vb67) (CRISTINI)

En esta dirección nos queda además un reducido y en parte alterado lienzo de la muralla cristiana (Cb65), junto al portal de las Torres de Quart, en la Plaza Santa Úrsula. No obstante a pesar de ser un alzado de reducida altura, también existe un ejemplo mejor conservado de lienzo de la muralla cristiana en la Sala subterránea Museo IVAM, en la C/ Guillem de Castro.

La técnica se emplea en muros de carga, donde se abren vanos muy regulares, grandes ventanales ordenados con logias, como en el caso concreto de las estructuras religiosas de los siglos XV y XVI (la Trinidad, el Patriarca, el Carmen, el Pilar, de los Agustinos). En lo que atañe a la edificación civil, los ejemplos más destacados son el Almudín (Xc96) y la sede del Gremio de Carpinteros (Va34). A pesar de la intervención de los años 90, se puede reconocer en las fotos de

\footnotetext{
${ }^{28}$ FONT F., HIDALGO P., "Arquitecturas de tapia", COAT, Castellón, 2009, p.73
} 
análisis previo y en las obras, importantes lienzos realizados con fábricas de tapia valenciana, según fuentes arqueológicas fechables a los siglos XIV y XV. La investigación, llevada a cabo hasta hora, indica la importancia de la cronología de tres edificios: por un lado el Convento de San José de las Carmelitas Descalzas, en la calle $\mathrm{Na}$ Jordana (Cg14) y, por el otro, el Palacio de los Valeriolas en la calle del Mar y el lateral de la Iglesia de San Juan de la Cruz (Fa153).

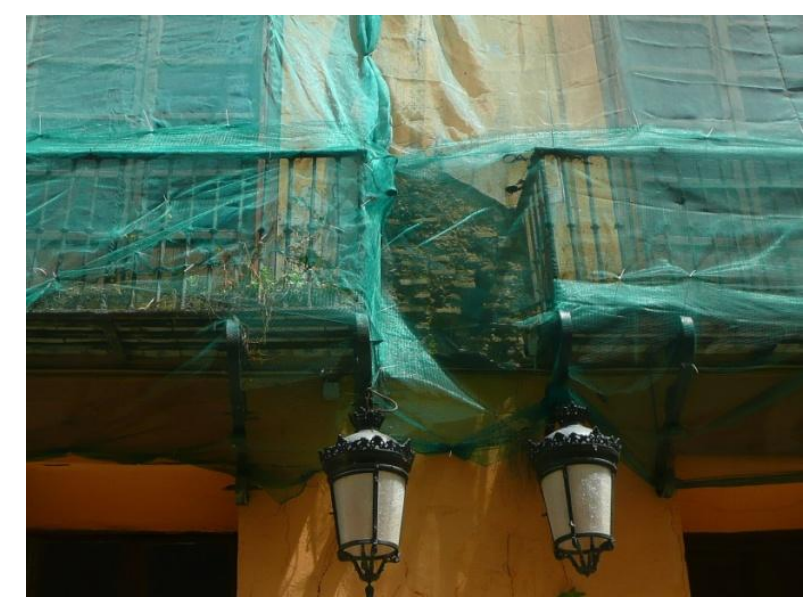

FIG. 79 Huellas de fábricas de tapia valenciana, oculta y transformada en los siglos. Palacio de los Valeriolas, C/ del Mar (CRISTINI)

Estos inmuebles se remontan a la primera mitad del siglo XVII, y son posiblemente los últimos que podemos encontrar en la ciudad realizados con esta técnica. Además, en estos casos, las fábricas responden a exigencias estructurales de zonas especialmente solicitadas, como contrafuertes, esquinas y machones. A la luz de lo aportado, se puede encuadrar el desarrollo maduro de la técnica en la segunda mitad del siglo XIV y la desaparición progresiva y lenta de la tecnología a partir de la segunda mitad del siglo XVII. Pero, ¿a qué responde esta progresiva pérdida de las técnicas para encofrar fábricas? Los indicios remitirían a la pérdida gradual de conocimientos técnicos previamente heredados por el mundo andalusí, sucesivamente contaminados con técnicas de la 
Reconquista, y paulatinamente desvanecidos tras la expulsión radical de los moriscos en 1609.
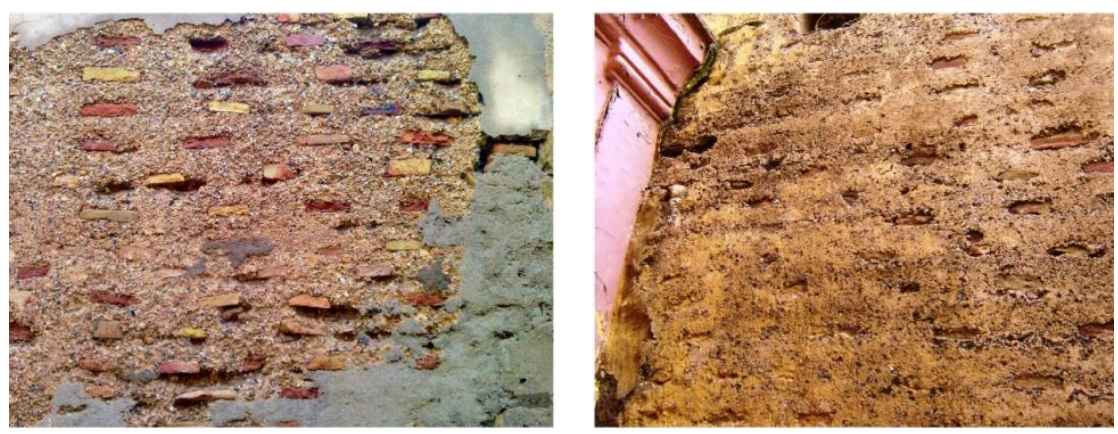

FIG. 80 Imágenes de fábricas en tejido residencial de la ciudad de Cherchell (Argelia), S. XVII (por cortesía de Prof. Chenouy-Universidad de Argel-Argelia)

Este proceso implicó la expulsión de un 4\% de la población activa, aspecto significativo, sobre todo, si se considera que este colectivo constituía mano de obra en el mundo de la construcción, así como oficios en las actividades manufactureras. La expulsión puede haber supuesto una merma en la pérdida de sabiduría constructiva, con la consiguiente hibridación de las técnicas, que poco a poco desaparecen. La población morisca estaba concentrada sobre todo en las afueras de los centros urbanos, pero está documentado que la repercusión del fenómeno llegó hasta las ciudades, donde se desequilibró totalmente la economía, tal como relatan las cartas alarmadas del Patriarca de Valencia al Rey Felipe $\mathrm{II}^{29}$.

Otra prueba de la posible conexión entre la cultura morisca y la tecnología del encofrado, reside en las fábricas encofradas en las áreas costeras de Argelia, en centros como Cherchell y Korea, donde

\footnotetext{
29 "Las ciudades y lugares grandes....las iglesias, monasterios de frailes y monjas, hospitales, cofradías, ejecuciones de causas y llegados píos, nobles, caballeros, ciudadanos y finalmente todos cuantos son necesarios en la republica para el gobierno y ornato espiritual de ella dependen del servicio de los moriscos y se sustentan de los censales que han cargado, ellos o sus antecesores, sobre lugares moriscos" en BRAUDEL F., "La méditerranèe et le monde mediterranéen a la epoque de Philippe II", Paris, 1949, p.32
} 
desembarcaron las poblaciones excluidas de la comunidad valenciana por el bando del Virrey.
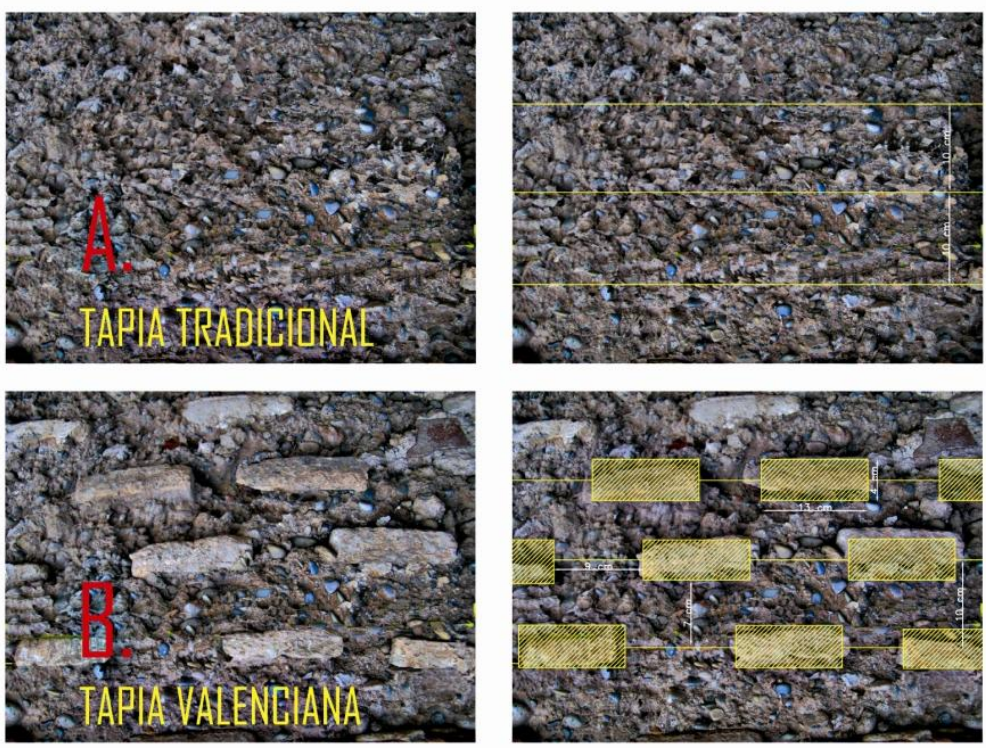

FIG. 81 Diferencias entre tongadas de tapia de argamasa y tapia valenciana (CRISTINI)

En ese otro lado del Mediterráneo, se puede observar el empleo de fábricas con tapia valenciana, como en la muralla de Argel, que se remonta a los siglos XVII y XVIII. 


\subsection{Fábricas DE ladrillo}

Ladrillo visible, visto, oculto

Según los resultados analíticos efectuados hasta ahora sobre muestras de ladrillos seleccionados en diferentes edificios del centro histórico de la ciudad ${ }^{1}$, dos son las clases de arcilla más empleadas. Según las mezclas podemos distinguir entre una arcilla plástica y una arcilla con margas. La primera es compacta y algo untuosa, desmoronadiza y suelta en estado seco, y muy dúctil en estado húmedo, que adquiere al fuego una gran dureza. La arcilla con margas está marcada por la presencia combinada de cal, que suele deshacerse a contacto con el agua, tiene color pálido debido a la concentración de carbonato cálcico, que sirve como desengrasante en modesta proporción, y que confieren el tono blanquecino de algunas producciones de ladrillos. Debido a la presencia de ambas arcillas en los alrededores de la ciudad, se puede encontrar tanto un tipo de ladrillo como el otro, empleados en las fábricas de la arquitectura residencial y monumental urbana.

\subsubsection{Ladrillo visible}

En el centro histórico de la ciudad se detectan unas fábricas que muestran características muy peculiares. Se han descrito como fábricas de "ladrillo visible", porque no presentan las características de las fábricas enlucidas, pero tampoco se pueden considerar como aparejos cara a vista. Se trata de todas aquellas fábricas que

\footnotetext{
${ }^{1}$ Véase "Anejo III. Caracterización y análisis de las fábricas"
} 
presentan un sellado y acabado, que cubre las juntas de la fábrica y, en parte, los ladrillos, con morteros de diferente composición. ${ }^{2}$.
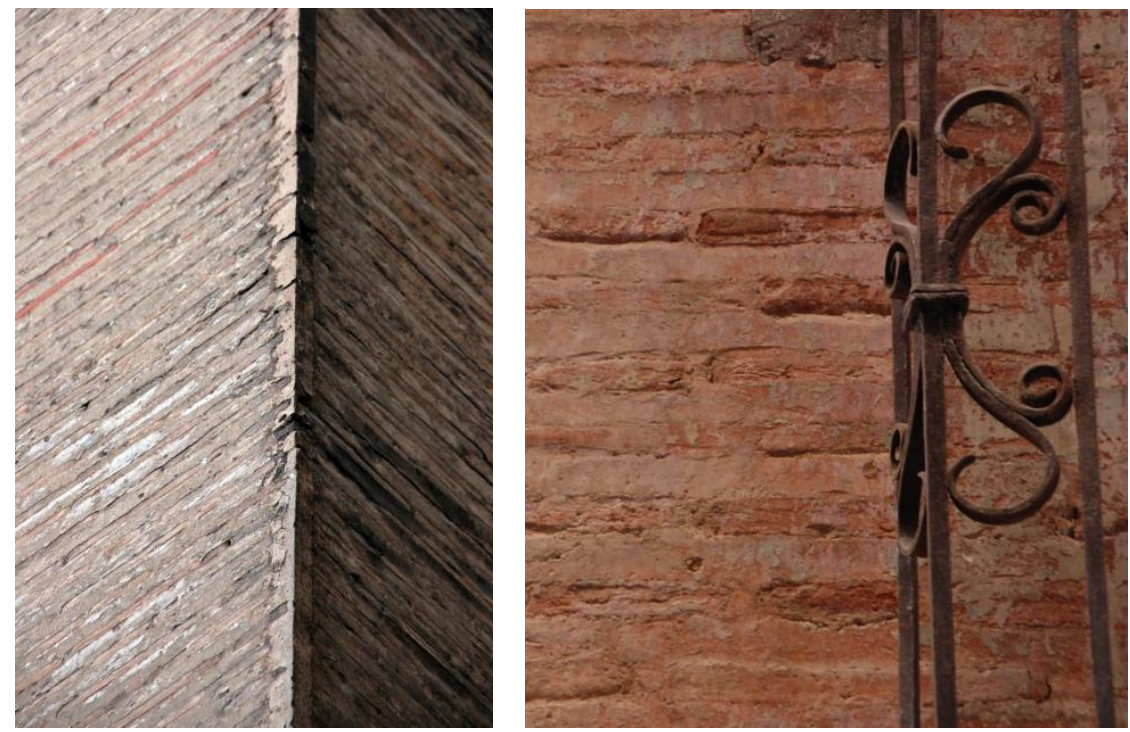

FIG. 82 Fábrica de ladrillo agramilado, en hilo entre un muro cara vista y uno enlucido; vivienda en la C/Bonaire (Fb57), Valencia (CRISTINI)

Ladrillo agramilado/sellado. En la ciudad, se encuentran muros caracterizados por ladrillos de grosores marcados, de hasta $4.5 \mathrm{~cm}$ con llagas milimétricas y con gruesos tendeles, de hasta $5 \mathrm{~cm}$. Se trata de una fábrica con una evidente disparidad en las juntas, aspecto subrayado además por un sellado superficial de los tendeles

En estos muros, lo más sorprendente es la firme jerarquía entre llaga y tendel. La junta vertical o llaga apenas se define por aparejarse los ladrillos de manera adyacente, mientras la junta horizontal o tendel se remarca hasta con un doble estrato de mortero. En este último caso, se apareja el muro creando juntas horizontales con una

\footnotetext{
${ }^{2}$ Este acabado, a pesar de modificaciones y rejuntados en el tiempo, caracteriza casos de edificios monumentales así como residenciales valencianos. A pesar de que hayan sufrido modificaciones es posible observar que las medidas de las juntas se corresponden todavía con el antiguo sellado y que la lógica del sistema "junta de asiento+rejuntado de acabado" sigue siendo visible
} 
pendiente muy inclinada, de $30^{\circ}$ aproximadamente, para permitir el agarre y la adherencia de la sucesiva capa de mortero de acabado, compuesto con una mezcla rica en inertes finos bien tamizados, para optimizar el nivel de alisado y bruñido del muro.

Al final de la ejecución, la fábrica aparece uniforme y casi cosida, merced al efecto visual creado por la preponderancia de las juntas horizontales, más gruesas y más marcadas que las verticales. Al mismo tiempo, este sistema, basado en una doble junta, una de asiento y una de sellado o acabado, proporciona y garantiza una adherencia al ladrillo. De hecho, este sellado recubre parcialmente los perfiles de los ladrillos, que son puntos débiles de discontinuidad, favoreciendo al mismo tiempo una esmerada protección de los mismos. La perfecta cohesión entre la junta de preparación, su sellado y los ladrillos desempeña un papel crucial para la protección y el comportamiento estructural del muro.
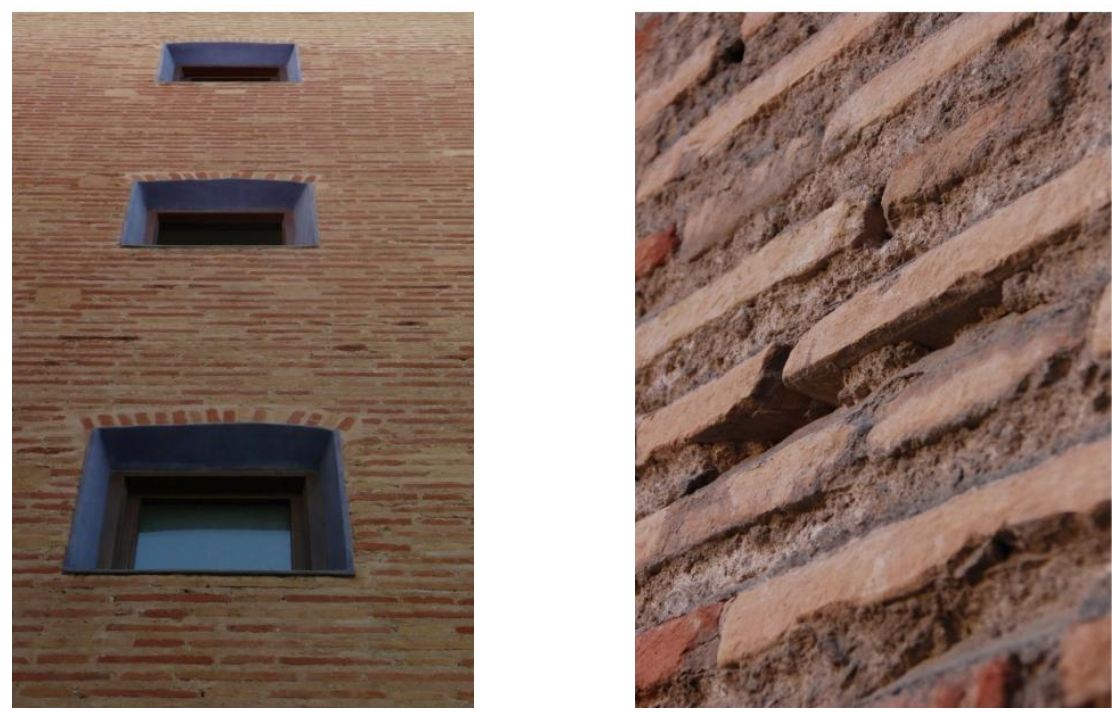

FIG. 83 Muro con doble sellado de tendeles, de asiento y de acabado; vivienda en la C/ San Ramón (Cd15), Valencia (CRISTINI)

Además, el empleo de este método permite resolver la lentitud de fraguado de la cal empleada en los morteros. Para ello, el sellado 
posterior de los tendeles se verifica sólo una vez fraguado el mortero de asiento del aparejo. Incluso, la junta inclinada facilita una ligera excursión térmica dentro del mismo tendel a través de sombras marcadas por la pendiente que agiliza el fraguado del grueso espesor de mortero.

Es evidente que la presencia de estos gruesos tendeles supone una suerte de "trastorno" de la técnica constructiva tradicional, según la cual los estratos de mortero deben servir para regularizar el nivel de puesta en obra de los ladrillos, que desempeñan la principal función estructural, gracias a su aparejo. En este caso la resistencia es más propia del mortero, donde el aparejado correcto de las piezas cerámicas contribuye al rol estructural, pero no prevalece. Es realmente el núcleo de argamasa el que juega un papel fundamental, como si de un opus cementitium se tratara. Los ladrillos en este caso desempeñan un rol parecido al de los áridos, confiriendo al mortero más rigidez que resistencia propiamente dicha.

El mortero ejerce un papel estático fundamental ${ }^{3}$ tanto frente a las acciones dinámicas que sufre el muro, como frente al asentamiento ${ }^{4}$. El grosor de la junta de mortero aumenta el comportamiento dúctil de la pared, mejorando la capacidad de disipación de los esfuerzos horizontales del muro, que se aleja del comportamiento elásticofrágil, exactamente como ocurre en las fábricas bizantinas ${ }^{5}$.

El análisis empírico de las fábricas visibles en el centro histórico de Valencia permite constatar la existencia de un verdadero método de rejuntado de los tendeles pensado para enrasarse con las fábricas, gracias a una solución que se repite en muchos edificios del centro

${ }^{3}$ BINDA L., TEDESCHI C., BARONIO G., Mechanical behavior at different ages of masonry prisms with thick mortar joints reproducing a byzantine masonry, Politecnico di Milano, 1999

${ }^{4}$ ANTHOINE A., MAGENES G., MAGONETTE G., "Shear compression testing and analysis of bricks masonry walls", en Actas de 10th Europ. Conf. on Earthquake Engni, Vienna, 1999

5 "MEZZINA M., UVA G., Modellazione costitutiva per dannaggiamento per l'analisi della risposta della muratura storica di Hagia Sofia, Politecnico di Bari, 1999 
histórico. Auténticos ejemplos de este tipo son visibles en viviendas como las de la C/Carniceros (Va104/108), C/ Bonaire (Cd15), C/Roger de Flor (Vb39), C/ Garsilaso (Cg57), C/ de Sant Antoni (Vb62), C/Engordo (Xg74) C/Corona (Cd10), C/S. Ramón (Cd15), P.za del Olmo (Me52) y C/Balmes (Va34), concentradas sobre todo en los barrios de Velluters y del Carmen ${ }^{6}$. En este caso, se trata de edificios de viviendas de 3 o 4 plantas, que aún conservan las fábricas selladas, a pesar de presentar diferencias entre sí, debidas sobre todo a diferentes niveles de conservación.
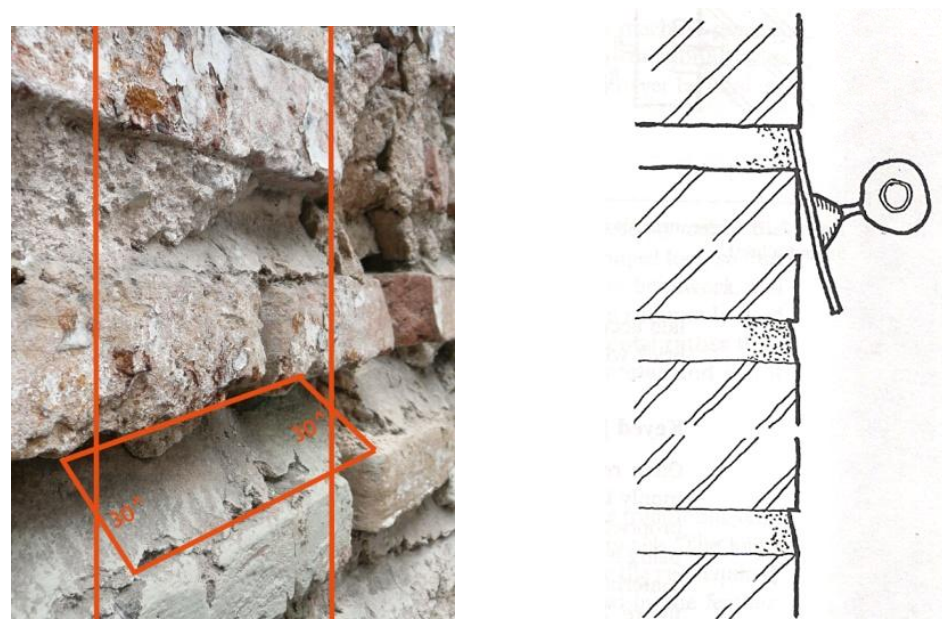

FIG. 84 Tendel con gruesa capa de mortero de asiento, inclinado de aprox.30, luego rejuntado y alisado; vivienda en la C/Quart (Cb55) (CRISTINI)

Por tanto, la presencia de esta lógica constructiva, articulada en sistema "junta de asiento+rejuntado de acabado" sigue siendo visible en el centro histórico de Valencia, sin que esté vinculada a edificios tipológicamente destacados: edificios tanto civiles como religiosos, tanto monumentales cómo humildes, presentan estas características.

\footnotetext{
${ }^{6}$ En la arquitectura monumental se puede reconocer especialmente en algunos cuerpos principales o accesorios de edificios religiosos con estas características. La capilla de la Comunión de los Santos Juanes (Me212a), el convento de San Carlo Borromeo (Vb68/69), la Iglesia de Santa Úrsula (Cb64), las sacristías de las iglesias de San Esteban (Xd13), San Nicolás (Ma92), el Carmen (Cg02), San Juan de la Cruz (Fa153)... son algunos de ellos
} 
Además, aunque muchos edificios hayan sufrido modificaciones, es posible observar que las medidas de las juntas se corresponden todavía con el antiguo sellado, a pesar de haber sustituido en el tiempo llagas o tendeles. Tras diferentes intervenciones se han cambiado las materias primas empleadas para los morteros, pero no la jerarquía de las juntas, ni la traba de las fábricas.

"....tenida que sea una hilada por todo el grueso, con la prevención que las juntas no se encuentren unas sobre otras, se llenan esta de la mezcla y con la paleta se recorta y rebaba de la mezcla el frente. Esto se debe de hacer con curiosidad, introduciendo la punta de la paleta debajo del ladrillo acabado de sentar, y corriéndola formando un planillo inclinado del grueso del tendel hasta la encía del ladrillo de la hilada de más abajo. Y en las juntas se hacen las llagas con la punta de la paleta. Así quedará rematada con curiosidad la obra, mientras que otros suelen enfocarla o fregarla con la mezcla, corriendo la regla de canto a una pared o a la otra con las dos manos; este modo no es tan limpio. Pero oculta todos los defectos de la albañilerías y solo se puede usarse cuando se han de jarrar o revocar las paredes..."7

"... Retundido o agramilado. Construida las fábrica de ladrillo, si estos han de quedar aparentes en el paramento exterior, se recorren las juntas de las hiladas, extrayendo, con el palustrillo, el mortero hasta cierta profundidad, para rellenar después este hueco con mortero hidráulico, recortando por igual los tendeles o llagas, á fin de que a la vista presenten el mismo ancho, y hagan más regulares las hiladas, cuya operación constituye el rehundido. Si el muro estuviera construido con ladrillo fino, estos se agramilan, es decir, se cortan sus cantos, se apomazan con piedra arenisca para que resulten tersos y lisos y se frotan con la misma piedra, para que, hecha la fábrica, se pulimenten y se saque el brillo..."

\footnotetext{
${ }^{7}$ VILLANUEVA, Arte de la Albañilería, Madrid, 1827, Cap.X, p.41-42
} 
Desde un punto de vista semántico, el mismo concepto de rejuntado remite a un ciclo de mantenimiento, reposición, cambio y alteración en el tiempo. Es complejo buscar un origen claro y rotundo propio de esta solución constructiva, dado que la información proporcionada se encuentra sólo en manuales difundidos a partir del siglo XIX. Pero, como se ha sugerido, estas fábricas recuerdan a las fábricas bizantinas precisamente por su marcado grosor de tendeles, y resulta oportuno considerar esta referencia, aunque sea de un modo tangencial. Tal vez, se trate de una relación sólo hipotética, pero tampoco se trata de una relación azarosa si se consideran los acontecimientos históricos, que marcan una etapa larga de relación de la ciudad con Oriente.

\subsubsection{Ladrillo visto}

Durante el análisis de los diferentes casos de estudio del centro histórico de Valencia, no ha sido posible identificar muchas fábricas con ladrillo cara a vista, sino más bien muros que presentan hoy en día acabados superficiales que no se corresponden a las soluciones constructivas primigenias. ¿Cuántos muros históricos de ladrillo cara a vista de hoy en día pertenecen a fábricas vistas, y cuántos son el resultado del raspado y eliminación de enlucidos históricos o de sus alteraciones en el tiempo?

Los ladrillos empleados en Valencia se correspondían con producciones artesanales que no estaban pensadas para dejarse a la vista. Tienen imperfecciones, irregularidades... y por esto las superficies se han revocado o, por otro lado, se han sellado las juntas.

Se debe esperar a las primeras producciones regulares ${ }^{9}$, fruto de los procesos de mecanización del siglo XIX, para considerar ladrillos bien

\footnotetext{
${ }^{8}$ MARCOS Y BAUSÁ, Manual del Albañil, Madrid, 1887, p.217
} 
cocidos, característicos ya de talleres más grandes y controlados, que pueden ser dejados como ladrillos cara a vista en los muros. Ya a finales del siglo XVIII, la economía de la ciudad se encuentra en un progresivo auge ${ }^{10}$ : mejora la calidad de las construcciones $y$, a la vez de las instituciones que se ocupan de la "hermosura" y el decoro urbano. Destaca la presencia de entidades urbanas como la Academia de la Matemática (1738) y la conocida Real Academia de Bellas Artes (1770).
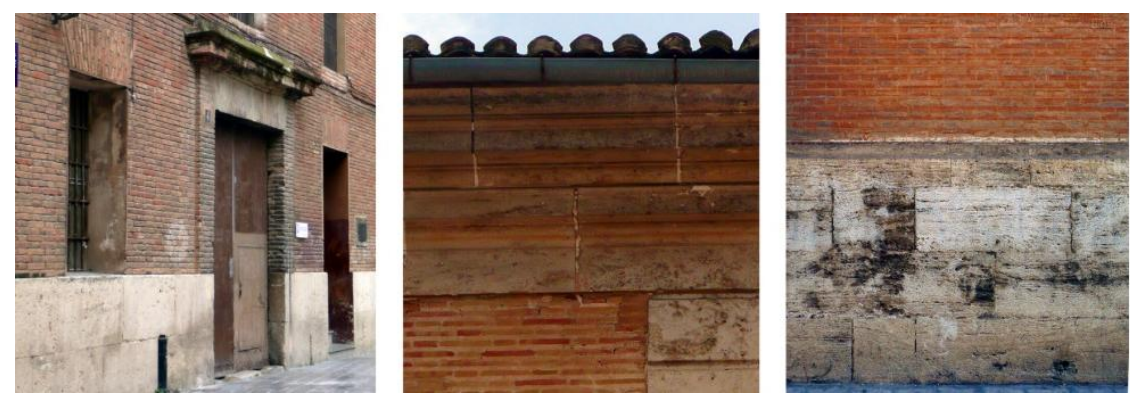

FIG. 85 Muros con ladrillos visto yuxtapuesto con piedra (en zócalos o columnas adosadas...); conjunto del Seminario (Xc16), complejo de la Nau (Fa39), sacristía de la Iglesia de la Congregación (Xf26) (CRISTINI)

La producción, mucho más controlada sobre todo a partir del siglo XIX, permite que los ladrillos asuman características técnicas cada vez más tangibles. Los ladrillos adquieren nuevos roles en los muros, gracias a la progresiva difusión de maquinas amasadoras de arcilla y de moldeo de piezas cerámicas (tanto de prensado como de extrusionado), que hacen realidad la fabricación del ladrillo "de

${ }^{9}$ Para mayor detalle se pueden ver los informes de las actuaciones arqueológicas del SIAM, como:

MARTí J., PASCUAL J., "Arqueología y proyecto urbano. Nuevas aportaciones para el conocimiento de la ciudad de Valencia", en Boletín de Arqueología Medieval, n.9, SIAM Ed., Valencia, 1995. GUERIN P., Informe de la intervención arqueológica en Calle Mesón de Morella de Valencia, SIAM Ed., 1997. SERRANO M.L., Informe de la actuación arqueológica realizada en los n.9 y 11 de la Calle Corona de Valencia, SIAM Ed., Valencia, 1995

${ }^{10}$ Gracias, sobre todo, a la general recuperación económica que se verifica con Fernando VI y Carlos III, reyes que comulgan con el despotismo ilustrado de la política de matriz centroeuropea 
manual", que cada vez alcanza más perfección técnica. Los ladrillos pasan de ser elementos constructivos ocultos a ser manifiestos en los paramentos. Los módulos utilizados, sobre todo a partir de la segunda mitad del siglo XVIII, son piezas gruesas, con grosores de 40-45 mm, que son muy resistentes y se ponen en obra, con hiladas regulares, con tendeles y llagas de 15-22 mm. Esto implica una importante reducción dimensional de las juntas y una predominancia de juntas enrasadas, o también en muchos casos, a hueso.

En este sentido, se puede observar que la calidad misma de los elementos constructivos permite una solución de acabado que no precisa de enlucido o protección particular. En algún caso puntual los muros se protegían ligeramente con lechadas de cal muy transparentes aplicadas repetidamente en capas sucesivas, que garantizaban un progresivo proceso de consolidación ${ }^{11}$.
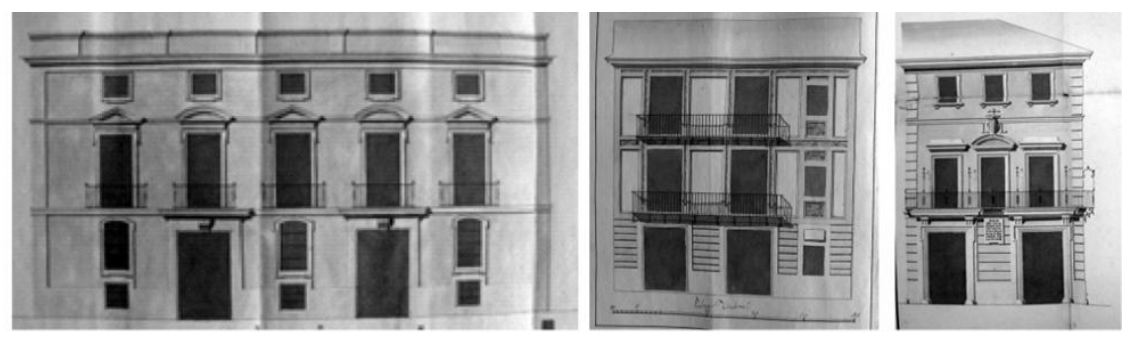

FIG. 86 Expedientes del Archivo Histórico de Valencia que registran los "cambios de gusto" de finales del siglo XVIII; columnas adosadas, zócalos, cornisas... reflejo de criterios académicos en la maquetación de fachadas (AHMV)

Ladrillo cara a vista. Con la llegada de la Ilustración llegan importantes avances técnicos en la fabricación de ladrillos, que y se consolidan sobre todo a lo largo del siglo XIX. Justo en este marco de "revival clásico" de finales de '700, es cuando podemos apreciar en Valencia una autentica "moda" por edificios bícromos,

\footnotetext{
${ }^{11}$ Estas mezclas se realizaban normalmente con 15 partes de arena tamizada fina, 5 partes de cal apagada, 2.5 partes de alumbre y 7.5 partes de agua, aproximadamente. Por detalles sobre las lechadas de cal: ALBAREDA D., Revestimientos continuos en la arquitectura tradicional española, Ministerio de Obras Públicas y Transportes Ed., Madrid, 1998
} 
caracterizados por "dos tonos", el blanco y el rojo, y la composición de pétreos con ladrillo.

La piedra, sobre todo en edificios señoriales destacados en el contexto urbano, es el material apreciado por definición. Pero la combinación con el ladrillo, con piedra de Godella, Ulldecona o Bateix... es una opción más sugerente, más refinada... y también, ¿por qué no? más económica.

Los juegos cromáticos garantizan un fuerte efecto de enmarcado, que empieza en los volúmenes y en el perfil de los edificios (zócalos, esquinas y frontones), y se extiende a los pisos (cornisas) o a los vanos (marcos y molduras). En muchos casos, para lograr esquinas más marcadas, se suelen utilizar piedras angulares, que se exageran, con un fuerte efecto de recercado y bordeado del paramento.

Es el caso de la Antigua Aduana (Fb117), la Casa Vestuario (Mb155), la Iglesia de la Congregación (Xf26), el conjunto de las Escuelas Pías (Va103), la Nau (Fa39), o el Monasterio del Temple( Xf25), entre otros edificios destacados en esta línea.

Ladrillo "almohadillado". Una solución cronológicamente bastante madura que se encuentra en las viviendas y en las muestras más propias de arquitectura palaciega o residencial, son las fábricas aparejadas con falso almohadillado. Se trata de un tipo de acabado exterior de los paramentos aparejados en ladrillos, que consiste en una forma de crear un relieve de la cara vista de la pared rehundiendo una o más hiladas aparejadas.

Los ladrillos empleados en estas fábricas presentan características técnicas de buena calidad. De hecho se trata de elementos regulares, bien cocidos y de grosor considerable. El retranqueo del aparejo es posible precisamente gracias a estas piezas normalizadas, volumétricamente definidas, que permiten un despiece muy ajustado de los ladrillos, imposible con elementos irregulares. El origen de esta 
solución se remonta a la arquitectura renacentista italiana, cuya influencia llega más bien como revivalen Valencia.
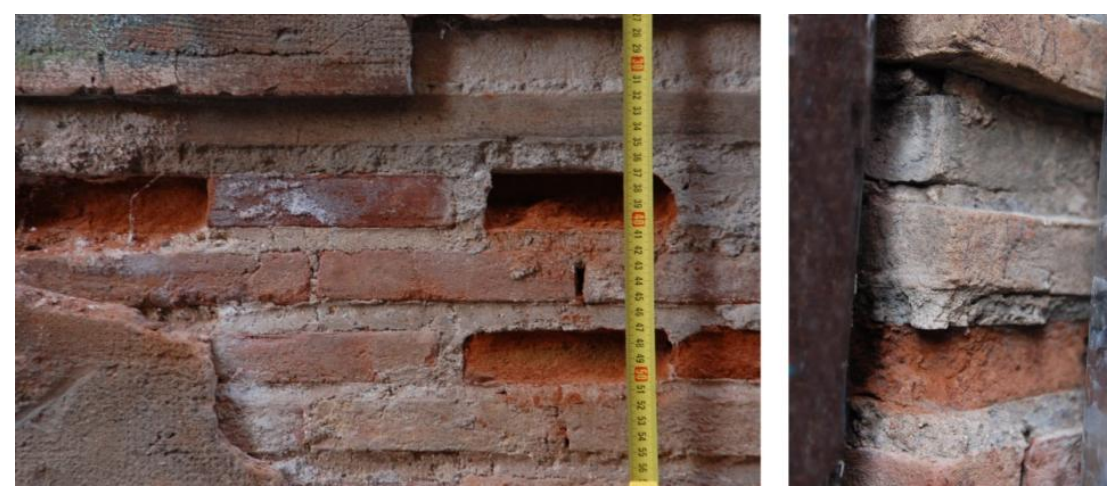

FIG. 87 Almohadillado en un alzado; viviendas en la C/Cadirers (Ma82) en Valencia (CRISTINI)

En este marco hay diversos tipos de acabados con efecto "almohadillado", sobre todo en fachadas eclécticas del siglo XIX. Existen los almohadillados abstractos, realizados con un retranqueo horizontal de las hiladas, o los despieces de cuadrantes, realizados con diferentes formas de aparejo de ladrillos (deslices de hiladas tanto horizontales, como verticales $u$ inclinados). Los recuadros uniformes o diferenciados en los paramentos pueden ser tanto vistos como enlucidos, con colores claros, para simular sillares y volúmenes.
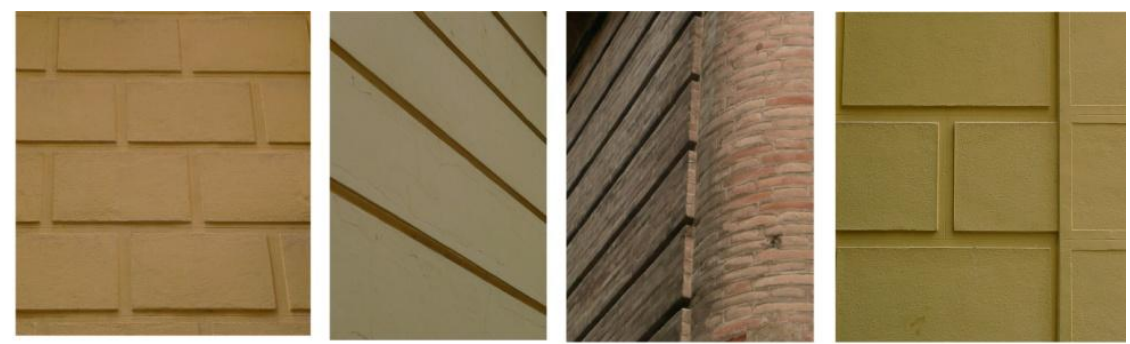

FIG. 88 Posibles soluciones de "ladrillos para almohadillados" en viviendas del Barrio de San Francesc y de la Seu-Xerea, Valencia (CRISTINI)

Ladrillo vidriado. En zonas del centro histórico de la ciudad que se han consolidado a finales del siglo XIX, sobre todo como en el Barrio de San Francesc, en el cuadrilátero C/de la Pau, C/S. Vicente, 
C/Xativa, C/Colon, es bastante común encontrar ladrillo vidriado o esmaltado utilizado para el acabado de las fachadas.

Los elementos utilizados presentan una cara vidriada, que garantiza una fácil limpieza y una especial capacidad de reflejar la luz y crear juegos cromáticos. El esmalte, sobre todo en el contexto del clima suave valenciano, es una solución de revestimiento especialmente apta, estando la zona del Levante exenta de heladas y bajadas de temperatura que puedan afectar al acabado.

El empleo del vidriado remite también el desarrollo de un gusto policromado, que permite introducir color en las fachadas. Por esto en muchos casos estudiados el vidriado abarca un colorismo fuerte, marcado por con tonos ocres, azules, verdes, que apuntan a un cromatismo que se reforzará aún más en el lenguaje ecléctico y modernista.
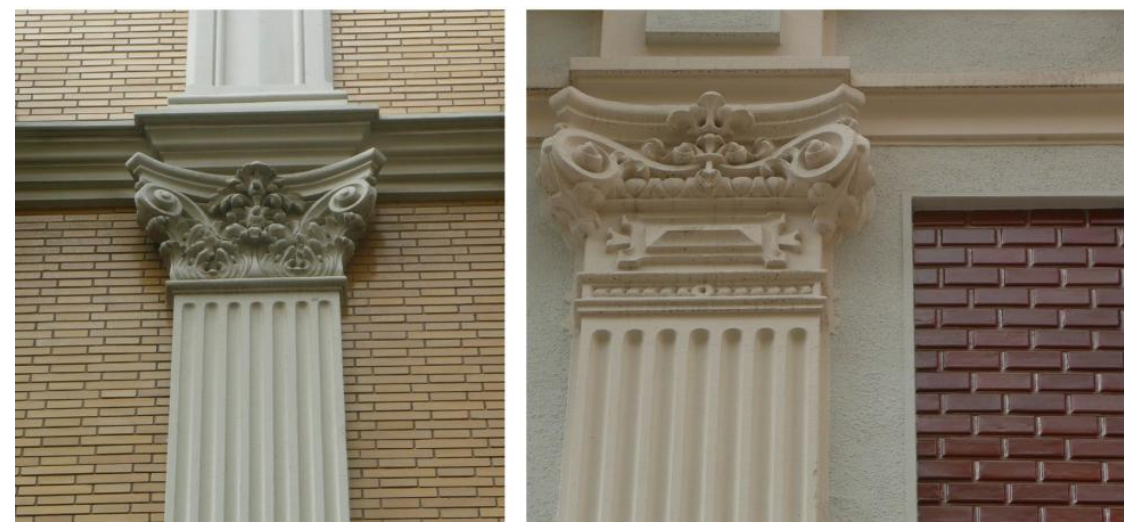

FIG. 89 Fachadas con ladrillos vidriado; viviendas en C/ de la Pau, Valencia (CRISTINI)

Ladrillo aplantillado y recortado. El final del siglo XVI en Valencia fue testigo de la progresiva presencia de ladrillo aplantillado en la arquitectura civil y monumental urbana. En este momento la ciudad vive una transición entre el protagonismo constructivo de la piedra y el nuevo rol ornamental adquirido por la cerámica. Las calizas, como la piedra de Godella o las sedimentarias orgánicas, como Borriol, Ulldecona y otras calizas marmóreas de la zona del Levante Español, 
ceden el paso a la arcilla, que hace acto de presencia también en aplicaciones decorativas, como en el caso de la terracotta.

Durante los siglos XIII y XIV, la ciudad ha vivido su apogeo constructivo con obras monumentales realizadas en piedra perfectamente labrada, con virtuosismos técnicos extraordinarios (Zaragozá-Iborra 2005). Pero el coste de la construcción y la progresiva decadencia económica provocan que en siglo XV el protagonismo de la piedra se limita a aderezos u adornos que enmarcan zócalos, puertas y ventanas, que dejan al ladrillo un papel que no es sólo estructural si no también decorativo. La emulación de la arquitectura clásica, que empieza en la ciudad bajo la influencia del Renacimiento italiano, adquiere un lenguaje decorativo que emula los modelos del mundo romano y helénico.
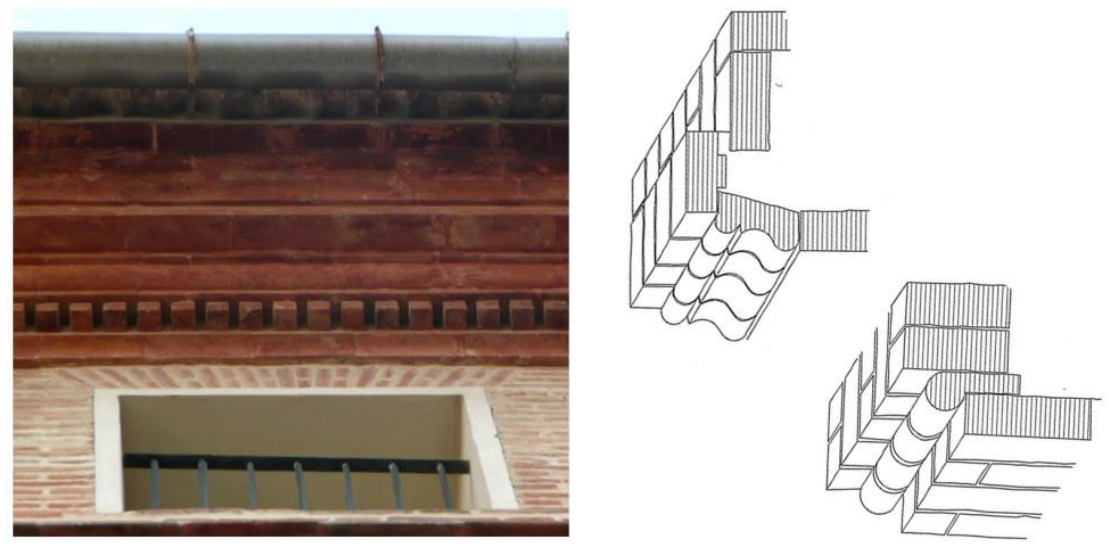

FIG. 90 Soluciones con ladrillos aplantillados para aleros y esquinas, Palacio Pineda (Ce71) en Valencia (CRISTINI)

Los arquitectos valencianos ya no pueden recurrir a los recursos económicos del siglo de oro valenciano, por lo que se ven obligados a utilizar el ladrillo, más económico, fácil de producir, autóctono y presente en la ciudad desde su fundación romana.

Los arquitectos se enfrentan a un problema a resolver: solucionar un lenguaje compositivo y constructivo clásico con un material diferente. Las soluciones que adoptaron son diversas. La más simple y común consistía en ocultar el ladrillo con estuco o pintura para simular una 
superficie, uniforme, monolítica en piedra. Pero poco a poco, el gusto por el redescubrimiento de la arquitectura clásica abrió el camino para una nueva sensibilidad, que rebuscaba formas complejas y originales, cuyo punto cumbre llegará en el siglo XVII. La capacidad de los artesanos locales y capataces hizo posible que el ladrillo fuera conciliable con formas extrañas e inusuales. Por esto, otra solución que se puede encontrar es la exuberancia del ladrillo aplantillado, acompañado siempre de escayola y estuco que facilitan la compleja riqueza de ornamentación.
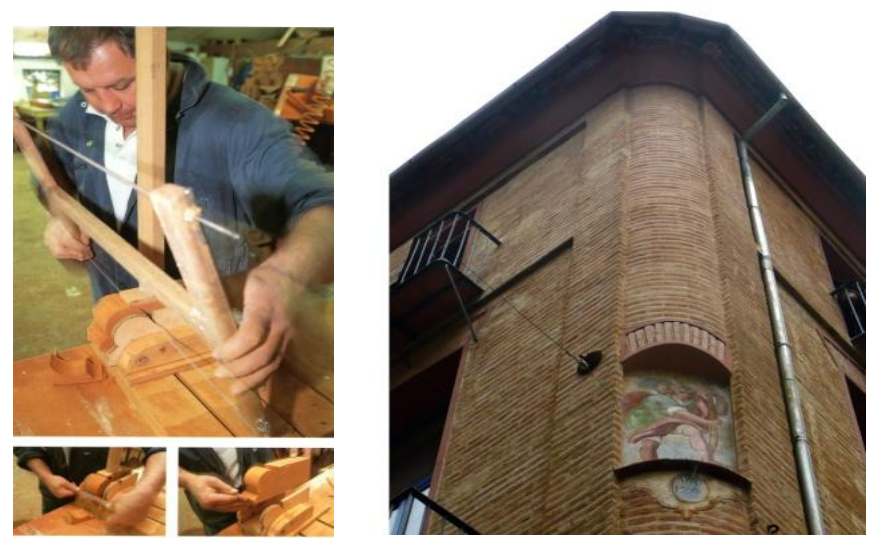

FIG. 91 Corte de ladrillos en un taller artesanal gracias a la guía de una caja de madera con plantillas (CAMBELL-PRICE). Soluciones con ladrillos aplantillado y escafilado para aleros y esquinas, vivienda de la C/ Carniceros (Va104) en Valencia (CRISTINI)

Hasta finales del siglo XVIII en la ciudad sigue prosperando la arquitectura monumental en dos tonos, prolongándose esta tendencia en las primeras décadas del siglo XIX. La combinación ladrillo / piedra sigue creando un fuerte efecto de enmarcado, y el rol de ladrillo adquiere verdadera excelencia. A lo largo de estos siglos, desde los tímidos escarceos de la arquitectura renacentista de finales del XVI hasta el gusto ecléctico del siglo XIX, se construyen increíbles pliegues estereométricos de extraordinaria calidad, aparejados con piezas cerámicas. Las soluciones técnicas de ladrillo aplantillado que se pueden encontrar en Valencia son tanto estructurales como decorativas. El empleo más constructivo se detecta en el caso especial de piezas para aleros, esquinas, dinteles e 
arcos. El empleo más decorativo se aprecia en soluciones para marcos, columnas adosadas, capiteles y remates.
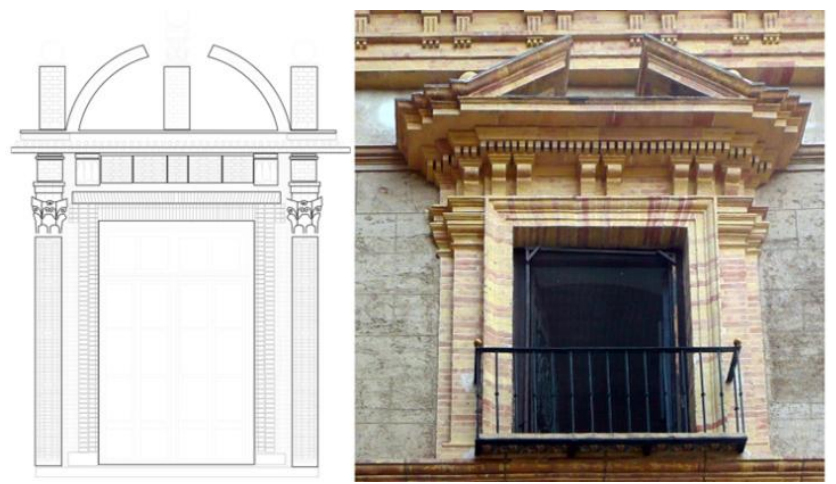

FIG. 92 Ladrillos aplantillados en el Palacio del Marqués de Campo, y en la fachada trasera de la Iglesia de la virgen de los Desamparados (Xd65), Valencia (CRISTINI)

La calidad del ladrillo empleado es variable. Se trata de piezas cortadas in situ, y elementos moldeados con formas especiales. También la calidad constructiva de la materia prima empleada varía bastante.
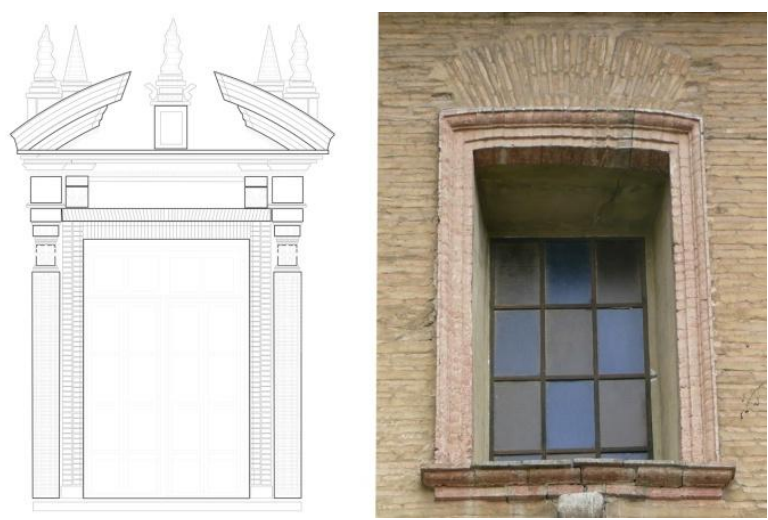

FIG. 93 Ladrillos aplantillados en el Palacio de los Condes de Alpuente (Ca 113) y en la fachada Iglesia de S. Úrsula (Cb64), Valencia (CRISTINI)

Se registra sobre todo la búsqueda de arcillas uniformes y más bien con margas o calizas que, gracias a la presencia desengrasante de los carbonatos, permiten controlar la retracción de las piezas moldeadas durante la cocción. Estas arcillas, más bien amarillentas debido a los componentes calizos, se ubican sobre todo en las 
afueras de la ciudad, en la zona norte, alrededor de los pueblos de Alfara del Patriarca, Manises y Paterna.

Ladrillo aplantillado estructural. El ladrillo aplantillado ha sido una solución técnica fundamental para resolver elementos arquitectónicos como arquerías, dinteles y esquinas de edificios. El coste elevado de la mano de obra especializada hace del aplantillado un recurso especial, para edificios de carácter público, como iglesias o edificios nobles. Es el caso del arzobispo valenciano San Juan de Ribera, que a través de su influyente figura promueve un cambio importante en la arquitectura religiosa valenciana.

Por esto el conjunto de la gran manzana trapezoidal del "Patriarca" (Fa82), el Real Colegio Seminario del Corpus Cristhi (1585-1615), construido por él, presenta un importante punto de inflexión en la arquitectura de transición, que se aleja del la estereometría gótica y empieza a dar los primeros pasos hacia un maduro lenguaje renacentista, haciendo propia la voz de Serlio, Vignola u otros tratadistas.

La arquería de la fachada principal puede ser considerada uno de los iniciales ejemplos de empleo de ladrillo aplantillado en la ciudad de Valencia, que cede el paso a ulteriores aplicaciones del mismo en la ciudad.

Un ejemplo especialmente destacado en este caso es el antiguo Palacio de los Condes de Alpuente (Ca113) (principio del siglo XVIII) donde el ladrillo aplantillado tiene una fuerza plástica notable, tanto en los aleros así como en los grandes frontones y cornisas que marcan la fachada principal. Lo mismo se puede apreciar en la fachada, en este caso más tardía, del Palacio del Marqués de Campo (1857) donde tanto en la fachada principal, así como en el patio, podemos apreciar el empleo del ladrillo aplantillado para la arquería, molduras y los recercados de las ventanas. 
Algún palacio particular, de mejor calidad constructiva, presenta pequeños detalles, realizados con piezas especiales, definida con moldes; es el caso de esquinas realizadas con ladrillos de perfil curvo... o de aleros con elementos estampados. Por ejemplo, en el caso de Palacio Pineda (Ce71) del 1728 o de edificios más tardíos como la Nau (Fa39) de 1839 o el Antiguo Seminario Conciliar (Xc16) de 1853...encontramos esquinas, detalles y aleros que presentan perfiles aplantillados y recortados. Generalmente las piezas suelen tener perfiles curvilíneos, tanto cóncavos, como convexos, para resolver la transición de planos y superficies. Son piezas que suelen repetirse, a lo largo de las superficies analizadas, de forma regular y rítmica, en muchos casos marcadas por perfiles bombeados. También es común encontrar elementos en forma de trapecio para dinteles, nichos y arcos, en la mayoría de los ejemplos cortados a mano.

Ladrillo aplantillado decorativo. El empleo de estas soluciones, es orientada sobre todo a la búsqueda de uniformidad exacta de las piezas cerámicas, colocando juntas de solo unos escaso mm entre los ladrillos. Además en muchos casos, se puede ver como la colocación de estas piezas especiales, con juntas en hueso, prevé el uso de masilla de cal en lugar de mortero, a menudo coloreada para dar a la pared una apariencia totalmente uniforme (Lynch 2006).

Se pasa por lo tanto desde el tratamiento del ladrillo, como unidad, al concepto de muro, continuum y compacto, gracias al pulido y escafilado (esmolado) de las piezas cerámicas, sobre todo en las caras exteriores. Si en el caso del aplantillado estructural el cuidado en la disposición de las piezas es más ágil...en el caso de detalles decorativos, las piezas requieren ser cortada a medida, con esmero y atención totalmente artesanal (Campbell 2003).

Es probable que en época borbónica, en el siglo XVIII, haya estado clave la influencia de la arquitectura italiana manierista y barroca, y por otro lado, otra referencia posible, haya estado la esfera artística 
francesa, fraguada definitivamente en la ciudad con la Real Academia de Bellas Artes de San Carlos (1768).

El virtuosismo decorativo del ladrillo, que se origina en el mundo romano, vive en Italia, sobre todo con Peruzzi (la Farnesina), Borromini (Oratorio dei Filippini e Collegio della Propaganda Fide), Guarini (Palazzo Carignano) e Vanvitelli (Palazzo Reale di Napoli) un momento decisivo en la historia de la arquitectura (SERAFINI), cuyas influencias, llegan a Valencia. La "robba minuta" de Borromini, o sea, las piezas unitarias, que constituyen el cuerpo de un edificio, son a la base del virtuosismo cerámico que se propaga hacia la península ibérica.
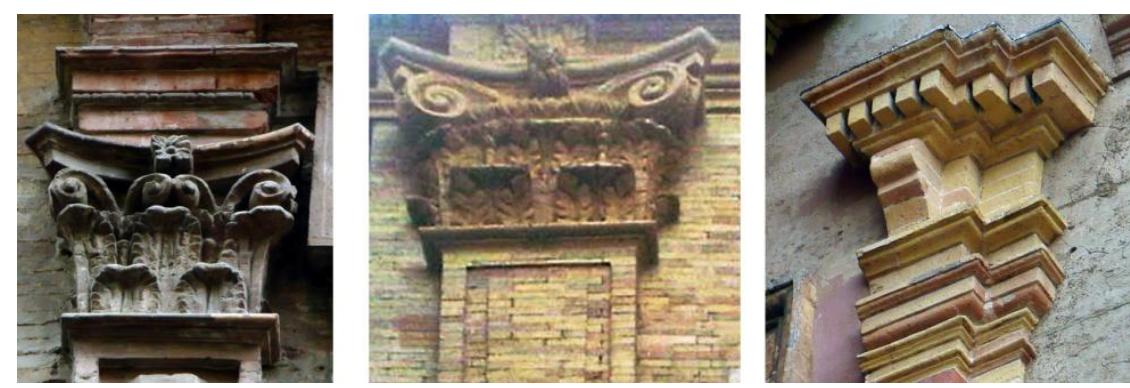

FIG. 94 Detalles de ladrillos escafilados en la Capilla de la Iglesia de S. Martín (Fa105) y en la fachada trasera de la Iglesia de la Virgen de los Desamparados (Xd65) (CRISTINI)

En esta línea destaca la Real Basílica de Nuestra Señora de los Desamparados (Xd65) de 1653, donde el ladrillo, tanto pardo, como amarillento, se utiliza en cornisas, tímpanos, capiteles. Casi contemporánea es también la Capilla de la Comunión de la Iglesia de San Martín (Fa105) de 1669-1674, donde las columnas adosadas de la fachada, realizadas con ladrillo grueso, aparejado en hueso, se decoran con ladrillos aplantillados, para dar forma a los capiteles corintios, en un juego plástico que nada tiene que envidiar a la fachada en piedra.

Las piezas usadas en las decoraciones, a diferencia de las que tienen un empleo más estructural, suelen ser especiales, realizadas con plantillas pero siempre bien perfiladas a mano. No se suelen repetir, 
a lo largo de las superficies analizadas, son "teselas" esmeradas, que solo se localizan en un punto específico de la pared, y son diferentes de las que las rodean. Se pulen y refinan a pié de obra, así como se haría para una escultura.
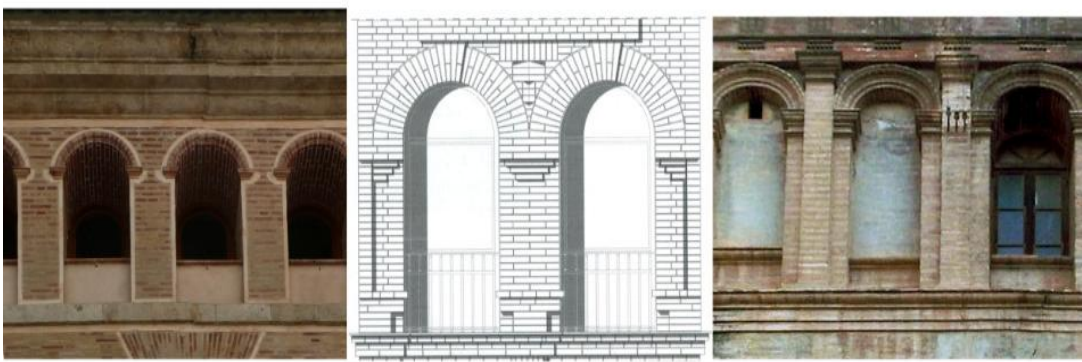

FIG. 95 Arquería con ladrillo aplantillado en el conjunto del "El Patriarca" (Fa82) y en el

Convento de S. Carlos Borromeo (Vb69) (CRISTINI)

El ladrillo aplantillado, caro, pero más barato de complejas decoraciones de piedra es también un recurso importante para la decoración de tambores, cúpulas y campanarios. La altura de estas estructuras hace posible que recurrir al ladrillo, garantice un acabado ortodoxo, pero a la vez más económicamente accesible que un acabado pétreo.
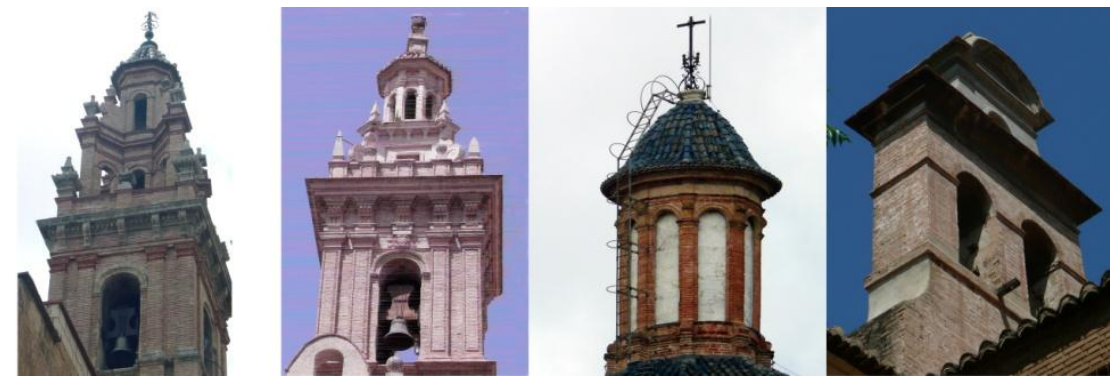

FIG. 96 Empleo de ladrillos aplantillados en los campanarios de la Iglesia de S. Esteban, Conjunto de "El Patriarca" (Fa82), Basílica de la Virgen de los Desamparados (Xd65) y Convento de San José (Cg14) (CRISTINI)

La torre de San Bartolomé (1703), el campanario de la Iglesia de San Lorenzo (1746), de San Valero (1676), de San Nicolás (1658) el tambor de la Iglesia de la Virgen de los Desamparados (1653) son algunos ejemplos, también rematados por pinturas con almagra que mejoran la solución de acabado de los ladrillos. 
Ya en edificios monumentales más tardíos, es posible ver como la combinación bicróma piedra/ladrillo prevale en molduras y remates. Es el caso de los muros de la Iglesia de la Congregación (1725-1736), Iglesia de San Miguel y San Sebastián (1726-1739) o así como el conjunto de las Escuelas Pías (1739-1773), el Palacio de Justicia (1756-1762) o la Casa Vestuario (1800). Gracias al estudio de estas fachadas, maquetadas según rígida estructura clásica, es posible apreciar como a lo largo del siglo XVIII la cantería vuelve a presenciar un pequeño revival, bajo el empuje del gusto neoclásico y de la composición jerárquica de las fachadas.

Pero se trata de una pausa breve; el modernismo y el lenguaje ecléctico volverán a aplicar de nuevo la versatilidad de la cerámica en la construcción, sobre todo en la zona del Ensanche, la ampliación decimonónica de la ciudad.

\subsubsection{Ladrillo oculto}

Las fábricas de ladrillo intramuros de la ciudad de Valencia han sido expuestas a diferentes soluciones de acabado a lo largo de la historia. Tras estas pieles han existido tanto razones técnicas (protección frente a los agentes meteóricos y antrópicos) como estéticas.

Estos estratos de acabado con diferentes atributos y propiedades han desempeñado distintas acciones: proteger, enmascarar, camuflar, impermeabilizar, reparar los muros de ladrillo. Este "ropaje" de los muros vuelve ininteligible la lectura hoy en día de muchas fábricas históricas de la zona intramuros. Pero a pesar de los revestimientos, gracias a cuadros patológicos o intervenciones, es todavía posible hallar características propias de fábricas ocultas.

Ladrillo enlucido. En este caso, la técnica empleada se basa en la protección de la pared con un revoco, efectuado en varias capas 
cada vez más finas de cal y/o yeso ${ }^{12}$. Las mezclas mejores presentan una mezcla bien tamizada y apagada, a la que se añaden pigmentos (principalmente ocres/blancos/almagra ${ }^{13}$.

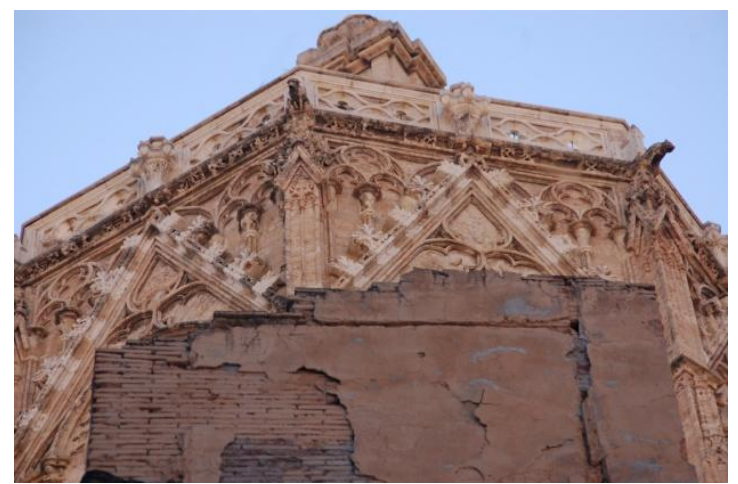

FIG. 97 Fábrica de ladrillo enlucido, C/Subida del Toledano, Valencia (CRISTINI)

Los muros que presentan esta solución de revoco muestran elementos constructivos bastante irregulares, con gruesos variables y tendeles o llagas con medidas desviadas, entre los datos recopilados en las diferentes muestras.

Además, se presentan casos de ladrillos de color claro, evidencia de materias primas de escasa calidad y cocción heterogénea.

En casos concretos también se aprecia cómo las fábricas no muestran un aparejo regular y, en muchos casos, la horizontalidad de las hiladas no está marcada, debido al hecho que los ladrillos no son homogéneos entre sí.

\footnotetext{
${ }^{12}$ VEGAS F., MILETO C., LA SPINA V., Is gypsum external rendering possible? The use of gypsum mortar forrendering historic façades of Valencia's city centre, in "Advanced Materials Research", Vols. 250-253, Trans Tech Publications, Switzerland, 2011

${ }^{13}$ La cantidad óptima que se añade a la mezcla de cal es de $1 \mathrm{~kg}$ de alumbre cada 25 litros de agua. GÁRATE RIOJAS I. (2000). El alumbre es un sulfato particular, soluble en el agua ligeramente calentada, que se solía disolver en la mezcla de cal y pigmentos. Posteriormente, el compuesto simplemente se aplicaba en el muro con una brocha ordinaria. La principal propiedad del alumbre, rico en potasio, es su carácter coagulante/fraguante, útil sobre todo en consideración a las circunstancias difíciles del lento proceso de fraguado de la cal.
} 

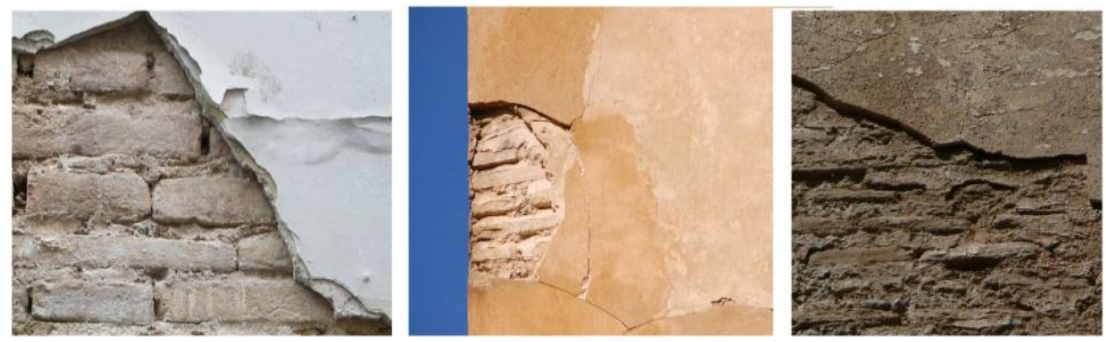

FIG. 98 Muros con ladrillo enlucido en el barrio del Carmen, Valencia (CRISTINI)

Ladrillo fingido. Resulta bastante difícil encontrar casos de fingidos que no muestren hoy en día intervenciones o recientes alteraciones ${ }^{14}$. No obstante, el análisis directo de los muros, combinado con la documentación histórica relativa a las técnicas tradicionales de revocos, ha permitido arrojar luz sobre cuándo y por qué se emplea esta solución de decoración. En este marco no se ha concluido todavía el debate entre los especialistas, sobre si las trazas de fingidos que se encuentran se deben a procedimientos de manutención sucesivos o nacen con los edificios ${ }^{15}$.

\footnotetext{
${ }^{14}$ Son los casos por ejemplo de la Iglesia de San Tomás y Felipe Neri (fachada con solución fingida reintegrada en 1903); Iglesia de las Escuelas Pías (restauración de la fachada y reintegración del fingido en los años 1994-95); Palacio de la Aduana (intervención general de rehabilitación en los años 1996-97)

${ }^{15}$ MARCONI P., "El color en la arquitectura italiana", en Francisco Javier Gallego Roca, Revestimiento en la arquitectura, Conservación y Restauración, Servicio Publicaciones Universidad de Granada, Granada 1996, p.22-23

"Numerosas trazas, sobre lienzos excelentes e importantes como lo de los del Palacio de los Conservadores en el Campidoglio, del Palacio Farnese de la Villa de Giulio III, de estratificaciones de estuco de pequeños espesores, a su vez señaladas por delgados rayados horizontales, a imitación, sobre lienzo de ladrillo, de un lienzo de ladrillo, sucesivamente teñido en el color del ladrillo.

Es probable que tales trazas se deban a procedimientos de manutención sucesivos; permanecen inexplicables, por otro lado, lienzos realizados por los mismos gremios, como lo de Palacio Farnese o Villa Giulia, donde hay unos arrepentimientos evidentes, y por añadir diseños autónomos de la retícula de ladrillos a guisa de rombos, y por tanto, ciertamente intencionales, realizado alternando ladrillos rojos o ladrillos amarillos..."

"... Tales diseños se explican solamente en la perspectiva de teñir posteriormente el lienzo, o sin más, estucarlo y sucesivamente señalarlo para simular un lienzo más armónico (quizás), o más
} 
El fingido es un revoco que reproduce una fábrica aparejada de ladrillo, merced a una nueva trama, pintada en blanco encima de un estrato de pintura rojiza, que simula una pared más regular. Se trata de un tratamiento mate, cuya técnica es intermedia entre el empleo del enlucido y una simple lechada de cal. Esta solución se detecta en fábricas que muestran ladrillos de buena calidad, muchas veces con partes o zócalos de sillerías, con un resultado de intenso juego cromático, debido al contraste entre el rojizo y el blanco, entre el pigmento almagra ${ }^{16}$ y la cal.

El primero es un pigmento "rojo sangre" muy resistente, mucho más compatible con la cal que los minios o los cinabrios y, al mismo tiempo, más conocido antiguamente como simple derivado de los óxidos de hierro ${ }^{17}$. Se llama también albín $y$, en Valencia, este pigmento proporciona el color carmesí obscuro, extraído sobre todo

concordado a trazados"platónicos" (quizás), o sólo coloreado y patinado de manera que parezca ambientado desde antes.

Entiéndase bien, también los lienzos de ladrillos son citaciones de sistemas constructivos romanos antiguos: éstos no obstante se distinguen al menos en dos categorías: aquellos que a pesar de la perfecta técnica de colocación y elaboración de los ladrillos estaban destinados a permanecer a cara vista, sobre todo como en algunos monumentos sepulcrales extramuros de la ciudad. Los primeros eran revestidos por espesas capas de revoque, en seis o siete estratos sucesivos, en seis o siete estratos sucesivos, como recomienda Vitrubio; tales revoques estaban destinados en suma a ser teñidos a imitación de los paramentos marmóreos o de piedra de corte, con técnicas bastante similares a la de fresco..."

"... En el Renacimiento la competición hace referencia a los paramentos cara a vista, y estudios recientes demuestran que los prototipos romanos eran estudiados cuidadosamente para llegar incluso a producir ladrillos similares a los antiguos en cuanto a material de cocción, Los paramentos romanos enlucidos, por otro lado llevaban aún bien grabados los signos de la imitación de los lienzos de ladrillos y del opus reticolatum, completados por tintes muy cuidados: he aquí un óptimo y antiguo punto de arranque para proceder a las imitaciones ... en cualquier caso hemos visto que, tanto la imitación con el revoque teñido de los revestimientos lapídeos, como la de los revestimientos de ladrillo, o ambas al mismo tiempo, están endeudadas con el ejemplo, en su tiempo no dictado por la pobreza como por la diferenciación jerárquica de los revestimientos ( en el interior aquellos más preciosos, como el mármol, en el exterior los imitados, destinados a practicarse repetidas de manutención) viene recogido en diferentes situaciones socioeconómicas, y desplazados de la escala de las Grandes Termas o de los Templos, a la escala de la edilicia ciudadana. Las fábricas antiguas tenían de todas formas en común con las modernas el problema: el de reproducir sobre las fachadas una arquitectura realizada en piedra o en ladrillos con una sintaxis y una gramática en correspondencia al lenguaje clasicista..."

${ }^{16}$ GÁRATE RIOJAS I., Artes de la Cal, MRRP; Universidad de Alcalá Ed., Madrid, 2000

${ }^{17}$ GALLEGO I., El color en la arquitectura nazarí, Universidad de Granada Ed., Granada, 1996 
de las piedras de las minas de cobre. La almagra, mezclada con la pintura a la cal, se empleaba para enlucir, con una ligera "sábana", la pared aparejada. El color de los ladrillos, gracias a este acabado, podía ser vigorizado e intensificado, gracias al tono más brillante, proporcionado por los óxidos.

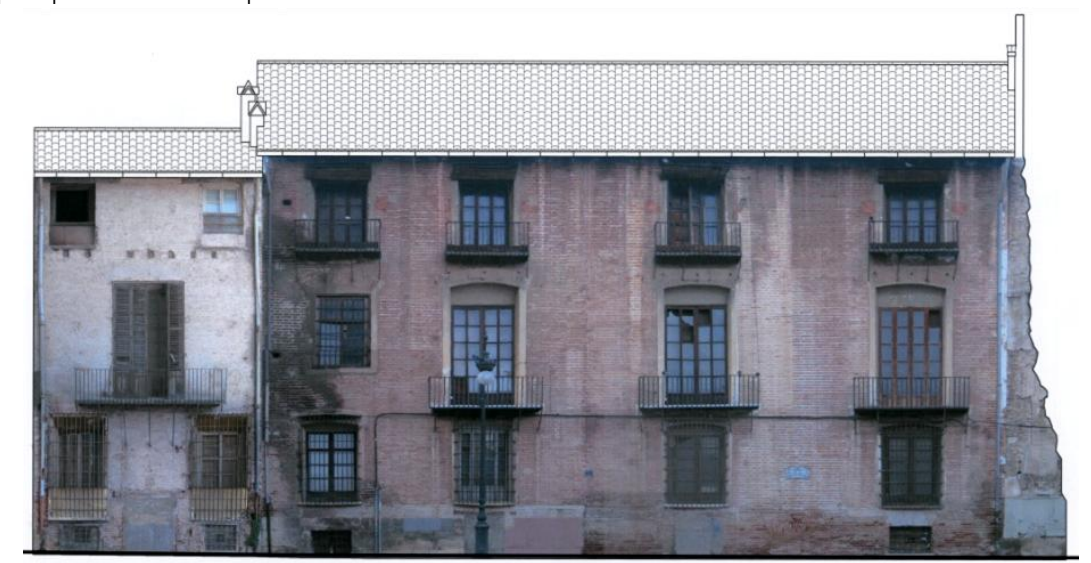

FIG. 99 Palacio de la Calle Eixarcs (Va81/82), alzado con acabado de ladrillos fingidos (CRISTINI)

Al mismo tiempo, la trama regular, realizada con trazado a base de cal, garantizaba un aparejo muy homogéneo y estéticamente agradable. Es significativo observar también, cómo los dos aparejos el real y el fingido solapado no se superponen. Esta circunstancia se puede explicar considerando que los ladrillos pintados son más grandes de los ladrillos reales $y$, al mismo tiempo, que las juntas fingidas son más esbeltas y regulares de las juntas constructivas de mortero. Además, tendeles y llagas pintadas se pueden realizar ligeramente en relieve, resaltando algunos milímetros de la superficie del muro, garantizando así un mayor resalte de las hiladas uniformes de ladrillo.

Ejemplos de este tipo de acabado más refinado no se encuentran fácilmente en las viviendas urbana... aunque hay trazas bien visibles de "fingido" en el Palacio en la plaza de la Cruz/ esquina Pintor Fillol (Ce101), en la C/ Gutemberg (Cf42), en la calle Carniceros (Va103), 
en la C/Eixarcs( Va81a) y en el Palacio de los Catalá de Valeriola (aunque en este caso se puede más bien hablar de un trompe l'oeii).

Históricamente este gusto por el equilibrio en la construcción, así como por la precisión y la regularidad en la maquetación de las fachadas, se justifica sobre todo por las ideas y las reglas academicistas, surgidas en la ciudad a lo largo del siglo XVIII. La atención en cuidar soluciones específicas para juntas, así como el esmero en regularizar fábricas, permite comprender el interés por la precisión constructiva proprio de las academias y del mundo clásico. Estas fábricas suelen tener un aspecto "pulcro", subrayado por una solución de fingido (tanto despieces pintados de sillares como de ladrillos), que simula un acabado regular y riguroso, cuyas raíces y antecedentes históricos se pueden encontrar en la arquitectura árabe/nazarí ${ }^{18}$.

Esto no quiere decir que estas construcciones manifiestan de manera directa el material del que estaban construidas, pues en sus paramentos se simularon fábricas grandes de sillares. Estos materiales otorgaban a estas juntas fingidas un cromatismo claro,

\footnotetext{
${ }^{18}$ ALMAGRO GORBEA A., "El color en la Arquitectura Nazari", y GALLEGO ROCA F. J., Revestimiento en la arquitectura, Conservación y Restauración, Servicio Publicaciones Universidad de Granada, Granada 1996, p.100-104

"...Las murallas y las construcciones militares constituyen un elemento visible fundamental en una ciudad durante la fase de denominación árabe, y no cabe duda de que tuvieron que influir notablemente en esa imagen, tanto por su posición que como por su tamaño y características..."

"...Las construcciones de tapial que constituyen las murallas no tuvieron en principio un tratamiento cromático especial, sino que solo el color proprio de los materiales utilizados fue el determínate de su coloración general. Esto no quiere decir que estas construcciones manifiestan de manera directa el material de la que estaban construidas, pues en sus paramentos se simularon fábricas grandes de sillares mediante la disposición de falsas juntas realizadas por medio de la superposición de unas tiras de mortero de cal y yeso. Estos materiales otorgaban a tales juntas fingidas un cromatismo claro, casi blanco, que debería destacar sobre el color del hormigón de cal y gravas, de tonalidad rojiza de la masa del tapial. Este extremo ha podido ser perfectamente identificado en la Puerta de Elvira, y responde sin duda a una tradición constructiva que arranca al menos desde la época califal..."
} 
que debería destacar sobre el color de las tongadas, respecto a la tonalidad más rojiza de la masa de la tapia.
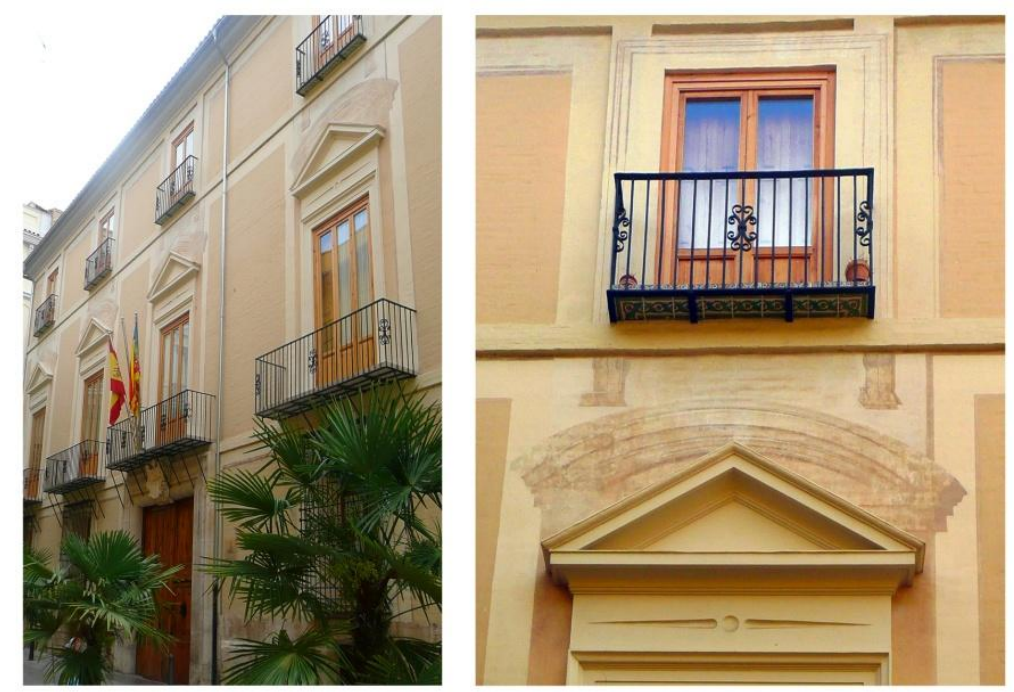

FIG. 100 Detalle del fingido trompe l'oeil, Palacio Catalá de Valeriola (Xa46), Valencia (CRISTINI)

Se sabe que "...los procedimientos técnicos, los materiales constructivos y los respectivos tratamiento cromáticos jugaron un papel importante en la realización de imitación de materiales, ante la falta de éstos en ciertas construcciones dispuestas en la obra. El color se unía al material de la obra, y tenía un gran valor visual en los elementos que articulan el espacio. Se han encontrado coloraciones al exterior de los templos en las que los maestros de obra recurrieron al color como elemento especial para la limitación y ornato de los diferentes elementos que constituyen la composición arquitectónica como en: molduras, cornisas, capiteles, pilastras, o en los mismos fondos de los paramentos..."19

\footnotetext{
${ }^{19}$ TORRES BARCHINO A., "Color y técnicas tradicionales en la arquitectura religiosa del siglo XVIII en Valencia", en Investigando los bienes arquitectónicos, Dep. de Expresión Grafica Arquitectónica, UPV, 2005, p.146-153
} 
Realmente gracias a estas contribuciones es posible marcar una cierta continuidad y homogeneidad propia de la solución del fingido, que se puede encontrar en edificios bien monumentales, bien civiles.
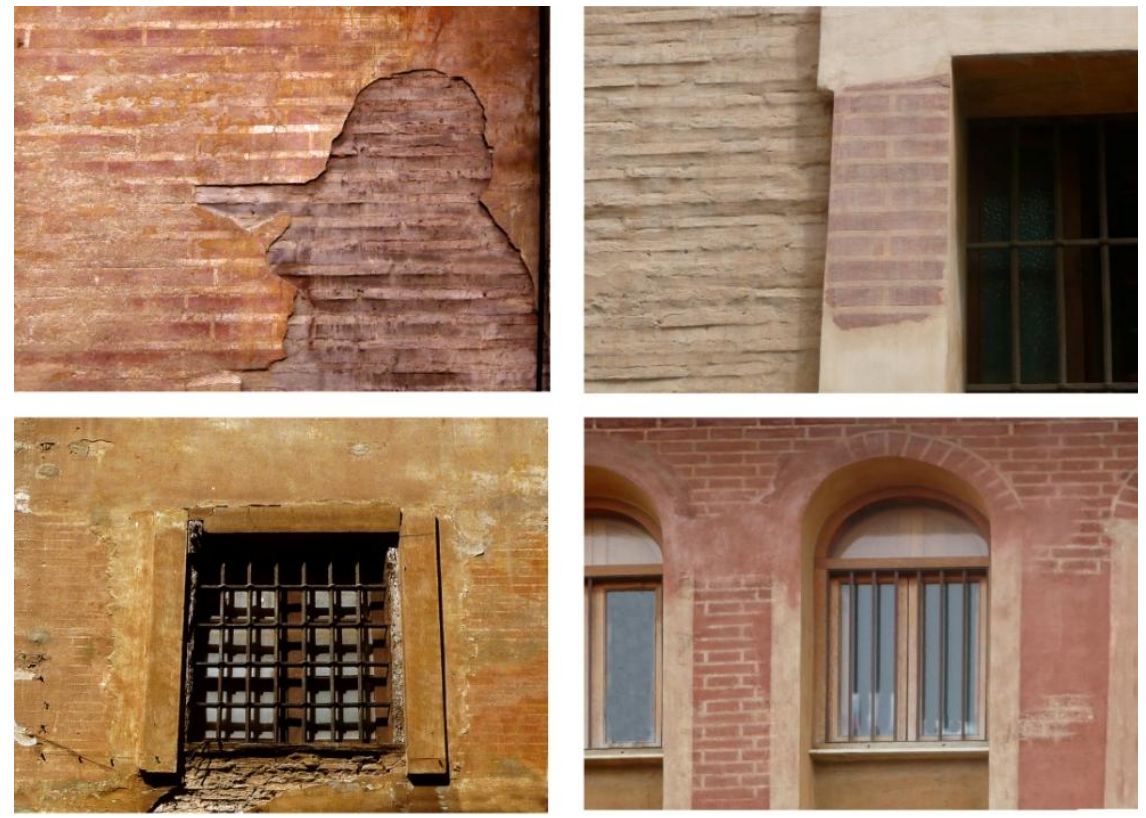

FIG. 101 Acabados con ladrillos fingidos en edificios de la I P.za de la Cruz (Ce101),

C/Gutemberg (Cf42) en Valencia (CRISTINI)

En este marco hay ejemplos destacados como el Convento de la Trinidad, la Real Basílica de Nuestra Señora de los Desamparados, la Iglesia de Santo Tomás y Felipe Neri, la Iglesia de la Compañía de Jesús; la Iglesia de San Juan de la Cruz,la Iglesia de los Santos Juanes, la Iglesia de los Santos Juanes, el Palacio de Justicia-Antigua Aduana, el Complejo de Las Escuelas Pías, los edificios de viviendas de la Calle Eixarchs y el Palacio en Plaza de la Cruz n.23. 


\section{PIGMENTOS NATURALES DE VALENCIA}

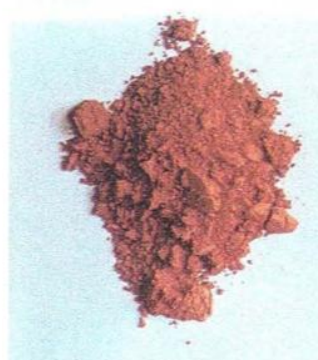

ALMAGRA

Fig.125 Campione di pigmento. (TORRES BARCHINO).

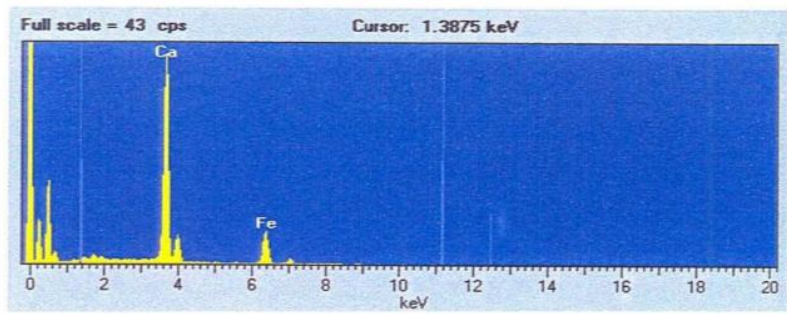

Fig.126 Analisi effettuata con diffrattometro (TORRES BARCHINO).

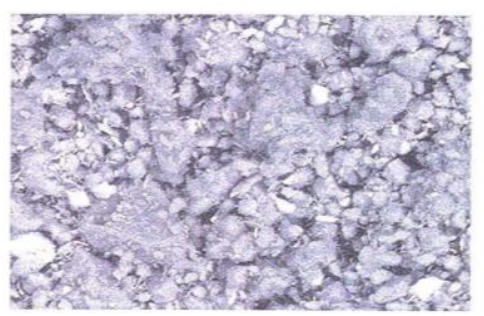

Fig.127 Fotografia effettuata con microscopio elettronico (TORRES BARCHINO).

FIG. 102 Detalles del Almagra, pigmento natural, empleado para "fingir" aparejos de ladrillo (TORRES BARCHINO) 
murOSINTRAMUIOS

6. Fábricas: hacia una propuesta de conservación 



\subsection{Análisis diagnóstico de las fábricas analizadas}

Existen muchas técnicas de intervención para corregir la presencia de patologías materiales en las fábricas de ladrillo. Además, todas ellas suelen constituir un sistema de intervención por sí mismo, o ser parte de un proceso más complejo en el marco de una intervención global relativa a una fachada histórica. En ambos casos, de todas formas, se trata de un proceso delicado, que requiere un análisis detallado, que no se puede realizar a priori.

A continuación, se proporciona un extracto de posibles métodos y pautas a seguir, que constituyen un abanico de métodos, adaptados a las características de las fábricas analizadas en el centro histórico de Valencia. Por lo tanto, se delinea una propuesta metodológica, que sirve como guía de orientación a la hora de realizar operaciones de intervención. A su vez, la redacción de un posible guión ayuda a la comprensión de los métodos disponibles frente a las principales patologías materiales. No se trata de la solución para intervenir en las fábricas, sino más bien un esquema metodológico de pautas a seguir frente posibles patologías materiales reincidentes en el centro histórico.

Para todo ello los textos específicos, y referencias consultadas han sido las siguientes:

-AA. VV. Patologías, Técnicas de intervención y limpieza de fábricas de ladrillo, Intemac Ed., Madrid, 2003 
-ACCARDO G., VIGILIANO G., Strumenti e materiali del restauro, metodi di analisi misura e controllo, Kappa Ed., Roma, 1998

-AMOROSO G.G., Trattato di scienza della costruzione dei monumenti, Alinea Ed., Firenze ,2002, pp.148

-BISCONTIN G., L'intonaco, storia cultura e tecnologia, (Atti del Congresso di Bressanone 1985) Libreria Progetto Ed., Padova, 1985, pp.63

-ASHURST N., Brick, terracotta and earth, Gower Technical Press, London, 1988

-ASHURST N., Cleaning Historic Buildings, Donhead Ed., London, 1994

-BURN, R.S., Masonry, Bricklaying and Plastering (1871 Ed.), Donhead Ed., Shaftesbury, 2001

-CANEVA G., NUGARI M.P., SALVATORI O., La biología del restauro, Nardini Ed., Firenze, 1994, Cap.3.

-DEL BUFALO A., Conservazione edilizia e tecnología del restauro, Kappa Ed., Roma, 1992

-GARCÍA DE MIGUEL J.M., Tratamiento y conservación de la piedra, el ladrillo y los morteros: en monumentos y construcciones, Consejo General de la Arquitectura Técnica de España, Madrid, 2009

-GASPAROLI P., Le superfici esterne degli edifici. Degradi, criteri di progetto e tecniche di manutenzione, Alinea Ed., Firenze, 2002

-LORUSSO S., MARABELLI M., VIVIANO G., La contaminazione ambientale ed il degrado dei materiali di interesse storico-artistico, Pitagora Ed., Bologna, 2006 (II Ed.) pp.247-68

-MONTAGNI C., Materiali per il restauro e la manutenzione, Utet Ed., Torino, 2000

-MUSSO F.S., Recupero e restauro di edifici storici. Guida pratica al rilievo e alla diagnostica, EPC Ed., Roma, 2004

-PEDEMONTE E, FORNARI G., Chimica e restauro, la scienza dei materiali per /'architettura, Marsilio Ed., Venezia, 2003

-SCARZELLA P., ZERBINATTI M., Recupero e conservazione dell'edilizia storica, Alinea, Firenze, 2009

-TORSELLO P.B., MUSSO S.F, Tecniche di Restauro Architettonico, Utet, Torino, 2002 
-VEGAS F., MILETO C., Aprendiendo a restaurar, Valencia, COACV, Valencia, 2011

-WARREN J., Conservation of brick, Butterworth-Heinemann Ed., Oxford, 1999
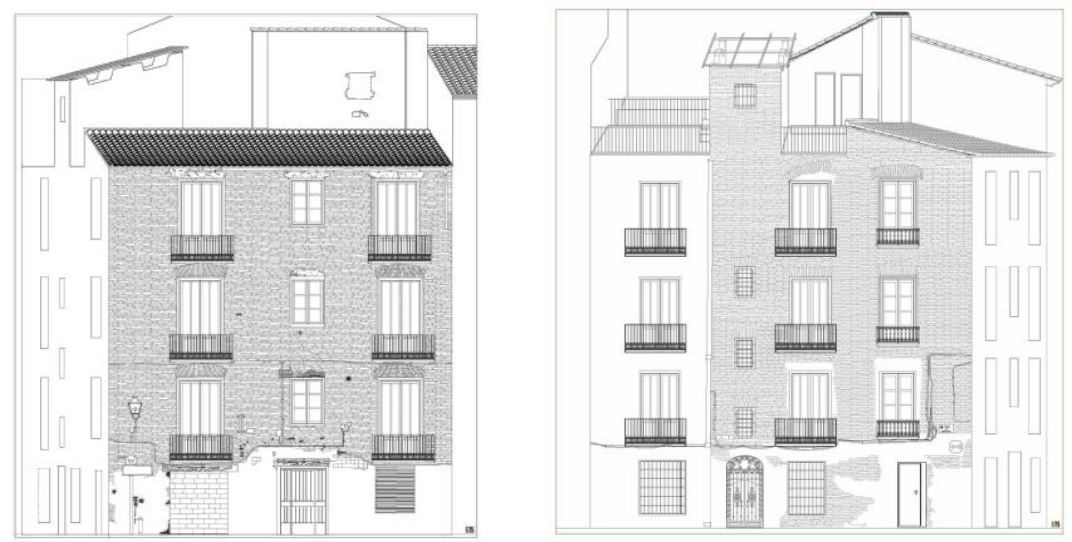

FIG. 102 Alzados estudiados por la autora, C/Roger de Flor 39, Valencia, ficha Vb22 (CRISTINI)

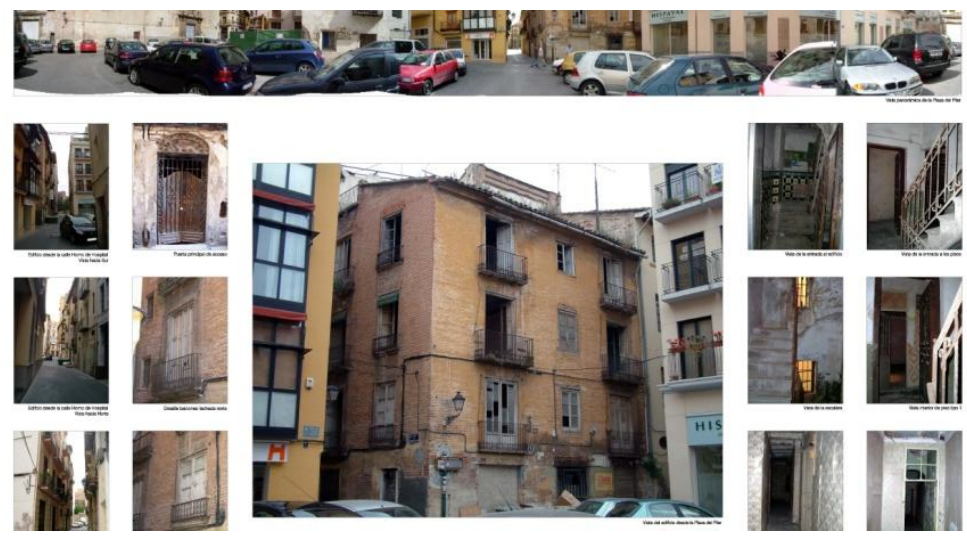

FIG. 103 Edificio C/Roger de Flor 39, Valencia, (VEGAS, MILETO, CALABUIG)

Además se ha procedido a la toma de datos y al registro de pautas operativas realizadas por la autora, como colaboradora asistente a la dirección de obra, en el marco del proyecto: 
VEGAS F., MILETO C., CALABUIG J.L., Proyecto de ejecución de rehabilitación de un edificio de seis viviendas en la calle Roger de Flor 39 esquina con la plaza del Pilar, Valencia., Valencia, noviembre 2006

\subsection{2. ¿Qué patologías?}

El conjunto de problemas que afecta a las fábricas de ladrillo del centro histórico de Valencia es bastante heterogéneo, aunque es posible en la mayoría de los casos encontrar patologías repetidas y frecuentes.

Las principales, que se han registrado en el Tomo II/Anejo I, han sido diferenciadas, en problemas que afectan a las piezas de ladrillo o a juntas. Concretamente se han considerado:

\section{Ladrillos}

\section{eflorescencias}

erosión

Código alfanumérico

Patologías

\begin{abstract}
erosión
\end{abstract}

$\begin{array}{ll}\text { micro fisuración } & \text { grietas } \\ \text { disgregación } & \text { descamación }\end{array}$

\section{Juntas}

\section{Patologías} eflorescencias

erosión
micro fisuración
disgregación

grietas

pulverización

LADRILLO:

PRESENCIA DE PATOLOGÍAS

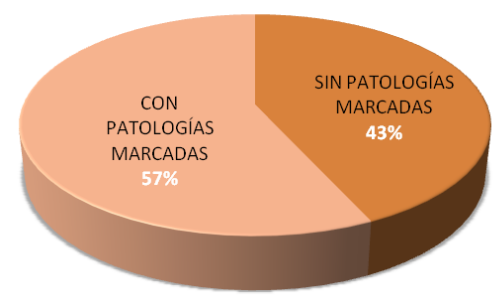

FIG. 104 Gráficos: presencia de patologías en ladrillos y clasificación (CRISTINI)

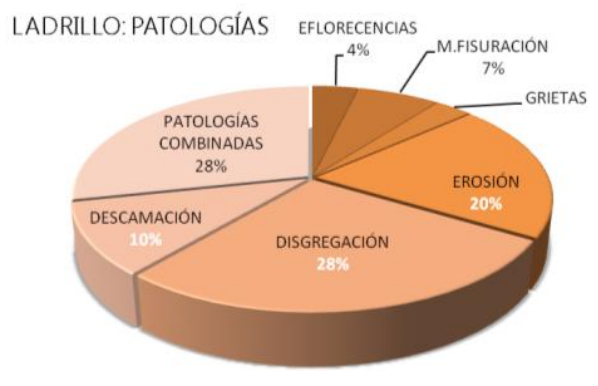




\section{Eflorescencias en ladrillos aparejados}

Se trata de una patología química, que se detecta por la presencia marcada de cristales de sales, tanto en la superficie del ladrillo, como en zonas más ocultas del mismo (criptoeflorecencias). Estas incrustaciones suelen ser blanquecinas, con consistencia más blanda (copos) o más sólida (cristales). Además, la facilidad de algunas sales a ser solubles en $\mathrm{H}_{2} \mathrm{O}$, facilita procesos de capilaridad, a través de los materiales porosos. Como consecuencia de este hecho se reconocen frecuentemente estratos de sales depositadas en su superficie frente a fenómenos de evaporación de agua.
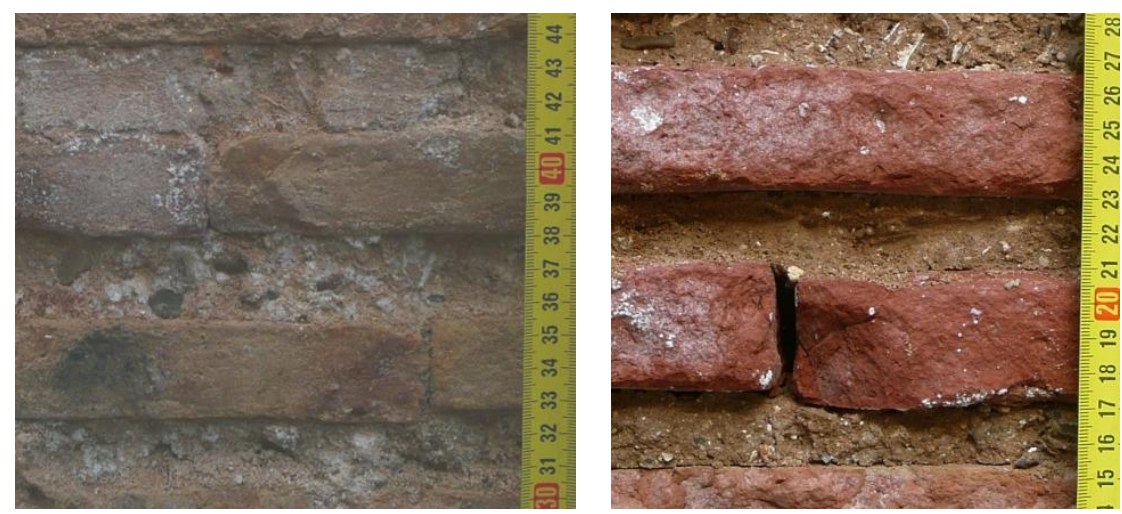

FIG. 105 Detalles de eflorescencias en ladrillos, fichas Cg48 y Ca82 (CRISTINI)

Por tanto, suelen ser objeto de sales sobre todo los ladrillos de los edificios o casos de estudio puestos en obra en zonas húmedas, con transmisiones térmicas o variaciones de temperatura muy marcadas (alzados orientados a sur y oeste). También el empleo de técnicas incompatibles con las fábricas históricas analizadas (acabados no traspirantes o resinas o empleo indiscriminado de mortero de cemento, etc.) favorece este fenómeno.

\section{Erosión en ladrillos aparejados}

Se trata de una patología física, que se detecta por la pérdida (ligera o profunda) de la superficie de la cara del ladrillo puesto en obra. Varios factores inciden en esta diminución de sección útil del ladrillo. 
Desgastes antrópicos, por impacto, uso o rozamiento suelen ser los factores principales detectados en las fábricas analizadas (también teniendo en cuenta la altura de los lienzos analizados, frecuentemente en planta baja o zócalo).
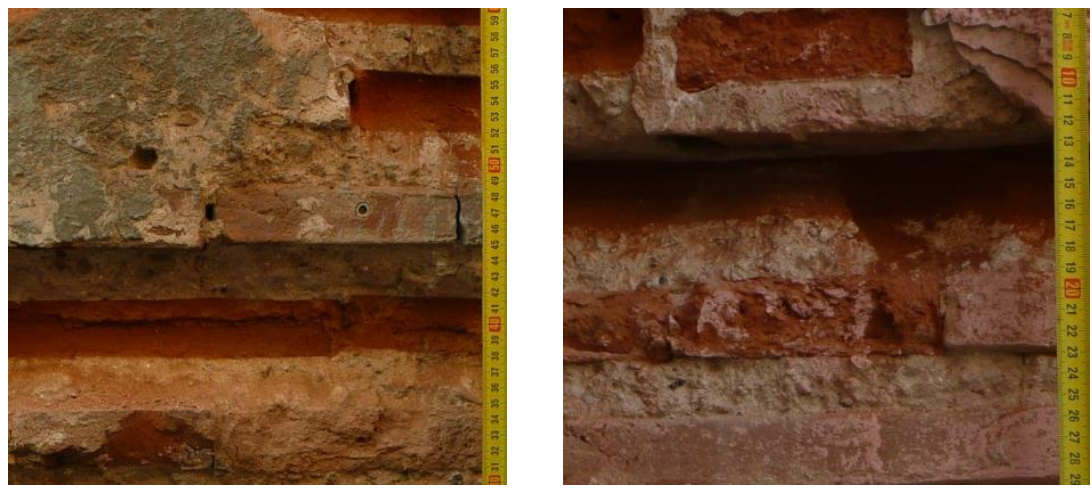

FIG. 106 Detalles de erosiones en ladrillos, fichas Cf39 y Cf42 (CRISTINI)

Micro fisuración en ladrillos aparejados

Se trata de una patología principalmente física que afecta a los ladrillos sin comprometer sus prestaciones estructurales, pero sí, alterando el rol de los elementos puestos en obra. Se reconoce más como una micro discontinuidad del material más que como un defecto estructural.

Está causado por el empleo de materiales inoportunos que constituyen la mezcla de la materia prima, o por un posible proceso de cocción inadecuado o alterado.
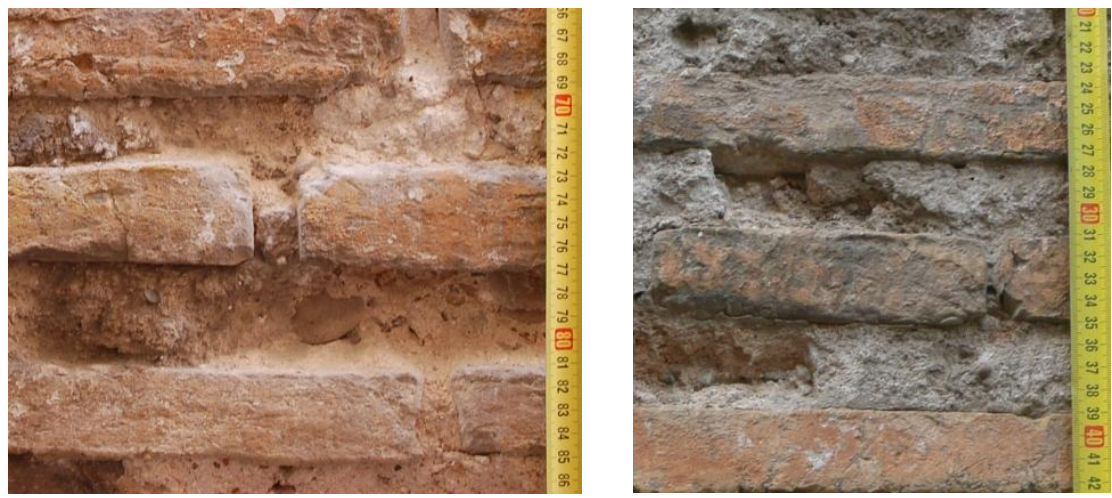

FIG. 107 Detalles de micro fisuración en ladrillos, fichas Ma91 y Cg01/b (CRISTINI) 


\section{Disgregación en ladrillos en ladrillos aparejados}

Se trata de una patología físico-química que se detecta como episodio de vulnerabilidad en la superficie y, en casos más graves, en el núcleo del ladrillo. En los casos analizados, esta discontinuidad se marca como un proceso de pulverización de los elementos constructivos, acompañado por una pérdida de cristales de arcilla y alteración de los mismos. La exposición a las aguas meteóricas o los excrementos de aves aparecen entre los principales factores a considerar. También el empleo de técnicas incompatibles con las fábricas históricas analizadas (acabado no traspirantes, o resinas o empleo indiscriminado de mortero de cemento, etc.) favorece este fenómeno.
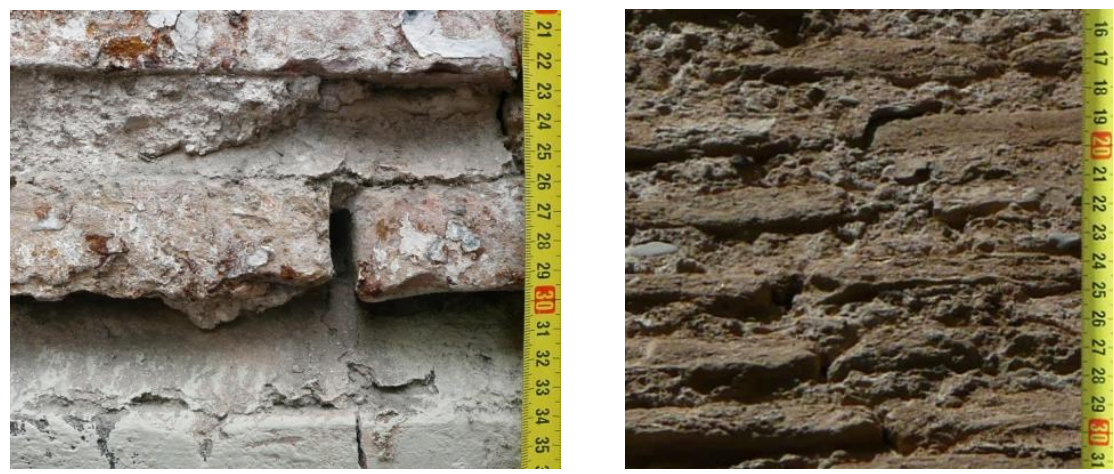

FIG. 108 Detalles de disgregación en ladrillos, fichas Ca55 y Cf23 (CRISTINI)

\section{Grietas en ladrillos en ladrillos aparejados}

Se trata de una patología principalmente físico-mecánica que afecta a los ladrillos puestos en obra, comprometiendo sus prestaciones estructurales, según diferentes niveles de gravedad. En este caso, a diferencia de la micro fisuración, más bien relacionada con retracciones en fase de moldeo y cocción, se detectan discontinuidades pasantes, que cruzan de cara a cara el ladrillo. Varios factores pueden incidir en estos casos, que se tienen que analizar de forma específica y puntual. Los principales pueden ser esfuerzos estructurales o higrotérmicos, así como errores de intervención y/o puesta en obra. 


\section{MUROSINTRAMUROS}

\section{Descamación en ladrillos aparejados}

Se trata de una patología principalmente física que consiste en el desprendimiento de la epidermis de los ladrillos analizados, en forma de escamillas más o menos regulares, dispuestas por planos paralelos. Las causas encontradas son parecidas a las de la erosión mecánica o antrópica.
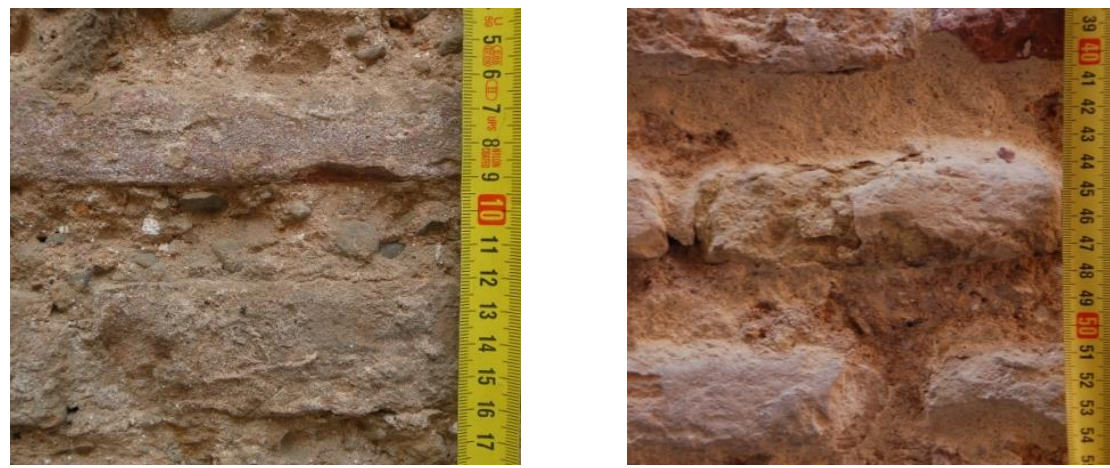

FIG. 109 Detalles de descamación en ladrillos, fichas Xc78 y Ma82 (CRISTINI)

\section{Eflorescencias en las juntas}

Se trata de una patología química, que se detecta por la conversión en polvo de diversas sales, tras perder el agua de cristalización, marcando así un fenómeno visible en las llagas, tendeles o en su profundidad (criptoeflorecencias). Como en el caso de los ladrillos, estas incrustaciones suelen ser blanquecinas, con consistencia más blanda (copos) o más solida (cristales). Además la facilidad de algunas sales a ser solubles en $\mathrm{H}_{2} \mathrm{O}$, favorece que el agua contenida en el mortero las vehicule con facilidad.

Como en el caso de los ladrillos, los edificios o casos de estudio puestos en obra en zonas húmedas, con transmisiones térmicas o variaciones de temperatura muy marcadas (alzados orientados a sur y oeste) suelen presentar este problema. Este fenómeno además, es agudizado por el empleo de técnicas incompatibles con las fábricas históricas analizadas (acabado no traspirantes, o resinas o empleo indiscriminado de mortero de cemento, etc.). 


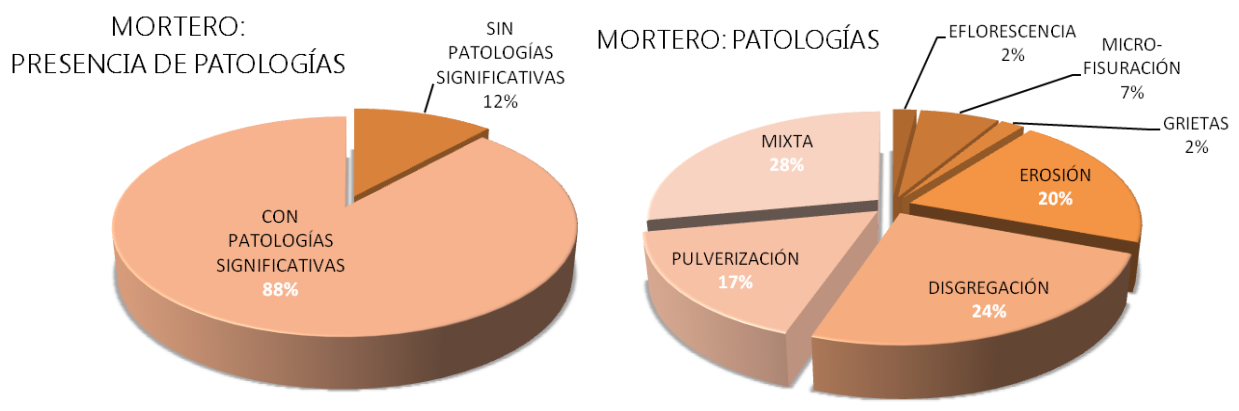

FIG. 110 Gráficos: presencia de patologías en morteros y clasificación (CRISTINI)

\section{Erosión en las juntas}

Se trata de una patología física, que se detecta por la pérdida (ligera o profunda) de la superficie de llagas o tendeles puestos en obra. Varios factores inciden en esta diminución de sección útil y desgaste del mortero.

Causas antrópicas, por impacto, uso o rozamiento suelen ser los factores principales detectados en las fábricas analizadas (también teniendo en cuenta las alturas de los lienzos analizados, frecuentemente en planta baja o zócalo). Además en las fábricas de tapia valenciana o en fábricas con gruesos tendeles, este fenómeno se agrava, debido a la mayor exposición que tienen las juntas a las acciones atmosféricas.
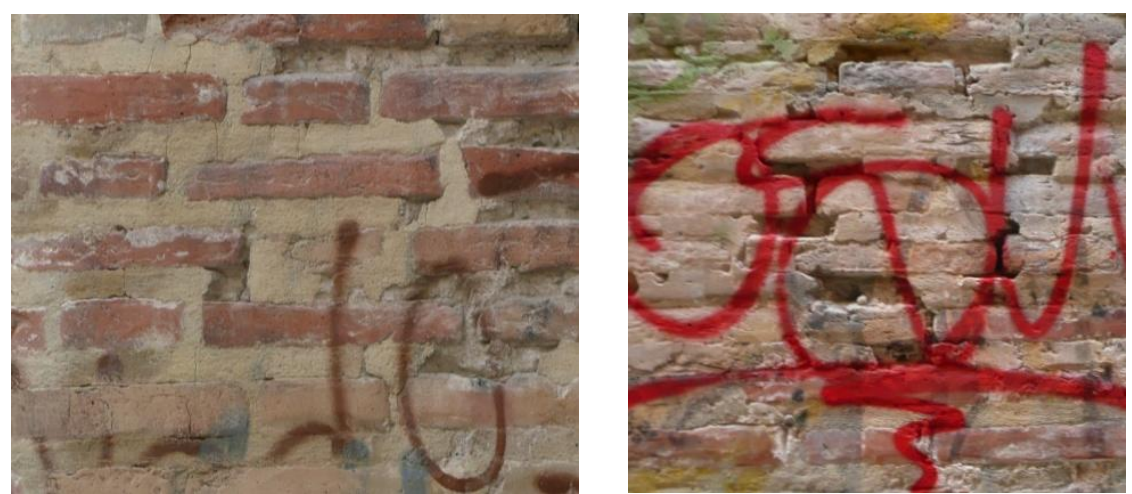

FIG. 111 Detalles de daños antrpoicos/graffiti (CRISTINI) 


\section{Microfisuración en las juntas}

Se trata de una patología principalmente física que afecta al mortero sin comprometer sus prestaciones estructurales pero sí alterando su correcta puesta en obra. Se reconoce más como una micro discontinuidad del material que por un defecto estructural, y es que este problema está causado por retracciones en fase de puesta en obra así como por incompatibilidades, detectadas en los casos de estudio, entre morteros de reparación, rejuntados y morteros históricos (diferente elasticidad y rigidez de los materiales empelados).
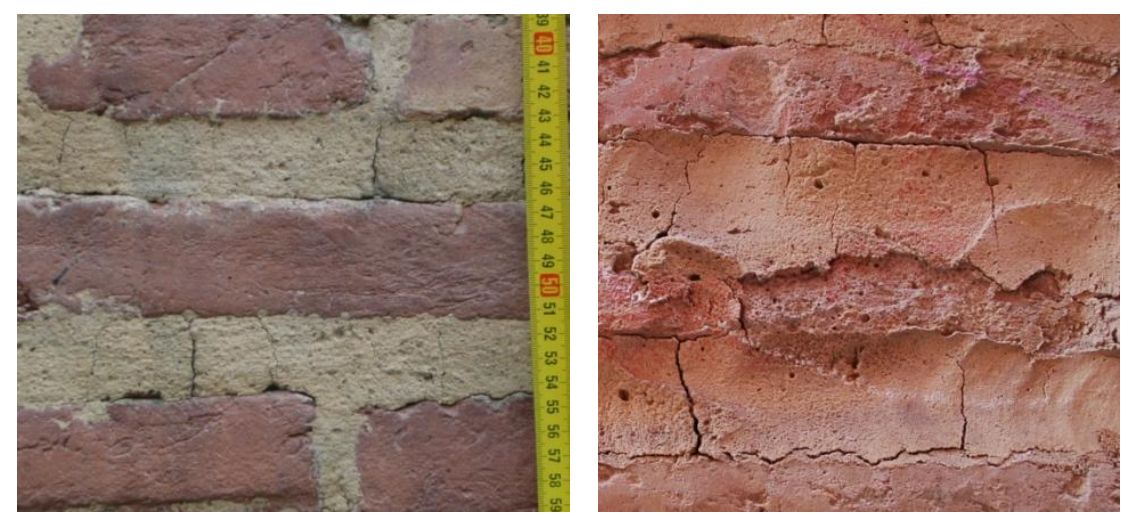

FIG. 111 Detalles de micro fisuración de las juntas, fichas Ce71 y Me52 (CRISTINI)

\section{Disgregación en las juntas}

Se trata de una patología físico-química que se detecta como episodio de vulnerabilidad en la superficie y, en casos más graves, en el núcleo de las juntas. En los casos analizados esta discontinuidad se marca como un proceso de pulverización del mortero acompañado por una pérdida de cristales de cal y/o alteración de los mismos. La exposición a las aguas meteóricas o los excrementos de aves aparecen entre los principales factores a considerar. También el empleo de técnicas incompatibles con las fábricas históricas analizadas (acabados no traspirantes o resinas o empleo indiscriminado de mortero de cemento, etc.) favorece este fenómeno. 


\section{Grietas en las juntas}

Se trata de una patología principalmente físico/mecánica que afecta a las juntas de las fábricas de ladrillo, comprometiendo sus prestaciones estructurales, según diferentes niveles de gravedad,. En este caso, a diferencia de la micro fisuración, más bien relacionada con retracciones en fase de puesta en obra, se detectan discontinuidades marcadas que atraviesan distintas hiladas aparejadas. Varios factores pueden incidir en estos casos para analizar de forma específica y puntual.

Los principales pueden ser:

la falta de adherencia entre ladrillo y junta, motivada por la deficiente humectación de los ladrillos antes de su colocación, o también presencia de esfuerzos de tracción y/o rasantes superiores al que la junta es capaz de absorber.
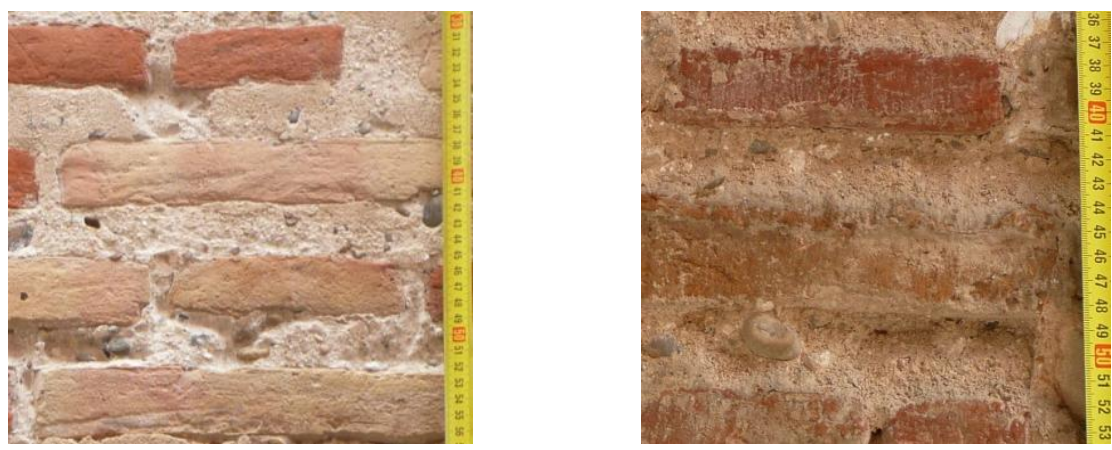

FIG. 112 Detalles de disgregación de las juntas, fichas Cg02 y Xc94 (CRISTINI)

\section{Pulverización en las juntas}

Se trata de una patología físico-química que se detecta como episodio de vulnerabilidad en la superficie y, en casos más graves, en profundidad de llagas o tendeles. En los casos analizados esta discontinuidad se marca como un proceso de pulverización de los elementos constructivos, acompañado por una pérdida de cristales de cal y alteración de los mismos. La exposición a las aguas meteóricas, presencia de sales, o los excrementos de aves aparecen entre los principales factores a considerar. También el empleo de 
técnicas incompatibles con las fábricas históricas (acabado no traspirantes o empleo indiscriminado de mortero de cemento, etc.) favorece este fenómeno.
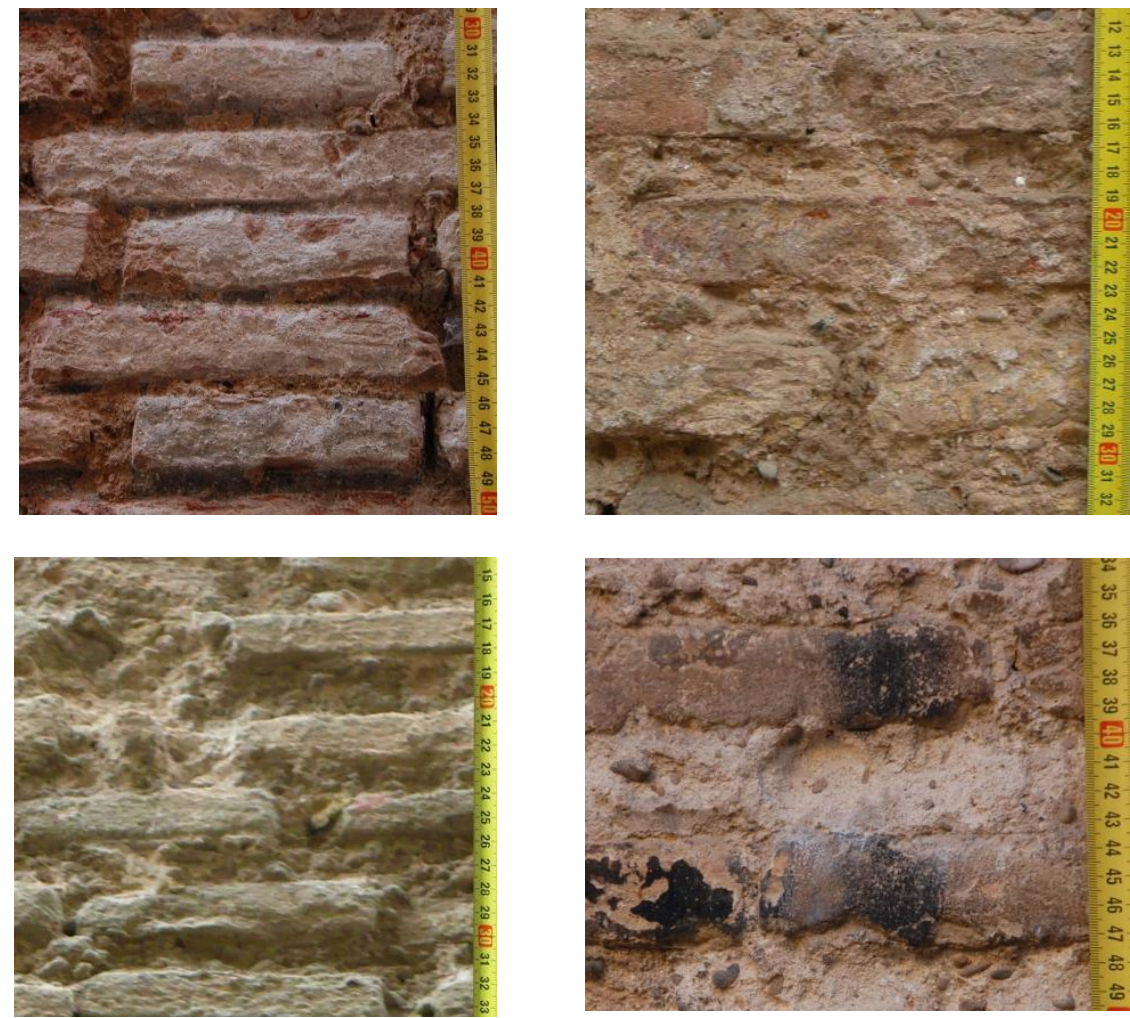

FIG. 113 Detalles de pulverización de las juntas, fichas Ma84, Xc78,; abajo Ca15, Ma92(CRISTINI) 


\subsection{Líneas guía para una posible intervención ${ }^{1}$}

A la hora de elegir entre los posibles métodos de intervención en fábricas históricas que a continuación se describen es oportuno seguir unas pautas previas generales que pueden ayudar a definir con más detalle el estado previo de las fábricas². Por esto es importante definir y analizar:

A) El entorno del edificio, con el objeto de determinar la accesibilidad, el tipo de andamio a instalar, etc.

B) Las características de las fachadas, de cara a comprobar si existen desórdenes o aspectos especiales en la fachada que condicionen el método a seguir. Entre otras cosas, para garantizar la protección contra la humedad, se verificará la estanqueidad de las carpinterías y el correcto funcionamiento del sistema de evacuación del agua residual procedente del lavado.

C) La naturaleza de los materiales constituyentes de la fachada (ladrillo y mortero) que condicionará el sistema que debemos emplear para no deteriorar dichos materiales: ciertos métodos pueden ser inadecuados por ser excesivamente abrasivos $\mathrm{O}$, por el contrario, pueden resultar insuficientes por ser demasiados blandos para las características de los materiales.

\footnotetext{
${ }^{1}$ Extracto del trabajo de investigación del DEA, diploma de estudios avanzados de la Autora, Op. Cit. CRISTINI (2008)

${ }^{2}$ MONTAGNI C., Materiali per il restauro e la manutenzione, Utet Ed., Torino, 2000, p.425-433
} 
D) Las características, las causas, y el grado de ensuciamiento.

Una vez llevado a cabo el análisis deberemos elegir entre los diversos sistemas de limpieza, recomendando como posibles criterios generales, el empleo del método menos agresivo de entre los que podamos considerar.

Centrándonos en la concreta problemática del material cerámico, sin consideraciones de tipo estructural, las intervenciones para su restauración y conservación se pueden agrupar en las siguientes:

\section{LIMPIEZA}

\section{CONSOLIDACIÓN}

HIDROFUGACIÓN

COMPLEMENTACIÓN DE PIEZAS

SUSTITUCIÓN DE PIEZAS

REPARACIÓN DE JUNTAS

REPARACIÓN DE FISURAS

PROTECCIÓN FINAL

\subsubsection{Procesos de limpieza general}

Básicamente los sistemas para la limpieza de fábricas de ladrillo se pueden englobar en:

LIMPIEZA CON AGUA

LIMPIEZA MECÁNICA

LIMPIEZA QUÍMICA

LIMPIEZA CON PASTAS ABSORBENTES 


\section{Procedimientos de limpieza con agua}

LIMPIEZA MANUAL

LIMPIEZA CON AGUA PULVERIZADA

LIMPIEZA CON AGUA NEBULIZADA

LIMPIEZA CON AGUA A PRESIÓN

LIMPIEZA CON VAPOR DE AGUA A PRESIÓN

\section{LIMPIEZA CON PROYECCIÓN HIDRONEUMÁTICA}

Antes de proceder a la limpieza mediante el empleo de agua, es muy importante verificar y evaluar el estado de las juntas de mortero de la fábrica y la existencia de posibles fisuras. Debe tenerse en cuenta que el agua puede penetrar en el interior, a través de los restos de mortero (en juntas que presentan falta de material) o a través de las fisuras, pudiendo provocar humedades y deterioro de la fábrica debido a la retención de humedades.

En estas situaciones la mínima actuación consiste en sellar las fisuras y renovar el material afectado, en su caso como mínimo en los tres centímetros exteriores, mediante un mortero sin retracciones durante su endurecimiento.

En fábricas antiguas de ladrillos, realizadas con morteros mixtos, los problemas de entrada de agua son debidos generalmente a fisuraciones en el propio mortero o a filtraciones a través de la superficie de contacto con los ladrillos.

Otros posibles problemas que se pueden crear con el uso de técnicas de limpieza húmedas es el desarrollo de microorganismos, fenómeno que puede evitarse mediante la utilización de biocidas aplicados tras la limpieza con agua. Otra advertencia general consiste en evitar la saturación de los ladrillos que se procede a limpiar. En estos casos se suele recomendar lavados discontinuos, con el uso 
controlado de nebulizadores, atomizadores y pulverizadores, y siempre con una temperatura superior a 5 grados $^{3}$.

Existen varios procedimientos o métodos de limpieza con agua y, entre estos, los más recomendados en fábricas de ladrillo macizo son:

\section{Limpieza manual ${ }^{4}$}

Es el método más sencillo y bastante eficaz que necesita básicamente un recipiente en el que poder introducir el agua o solución limpiadora, en el caso de que se utilicen detergentes o productos químicos, y un cepillo adecuado para su aplicación. Habitualmente suele aplicarse una solución de impregnación con agua a efectos de reblandecer la superficie del material y desprender la suciedad, las sales nocivas y las posibles eflorescencias de la fábrica.

Posteriormente se procede a un cepillado manual mediante un cepillo blando (de nylon por ejemplo) o púas de cerdas naturales etc. Al objeto de no deteriorar el material, y, por último, a un aclarado con abundante agua que elimine la suciedad.

Pueden emplearse también detergentes, en función del tipo de suciedad y de las características del soporte, aunque, como criterio general, sería mejor emplear pocos productos, cómo los que tienen Ph neutro y que son no iónicos, con el objeto de evitar depósitos de sales solubles ${ }^{5}$. Estos jabones se emplean diluidos en agua, caliente o fría, principalmente para la limpieza de superficie cerámicas que presenten una suciedad superficial, grasa y no muy adherida. La acción de los jabones se mejora combinándola con vapor de agua.

\footnotetext{
${ }^{3}$ ASHURST N., Cleaning Historic Buildings, Donhead Ed., London, 1994, p.165

${ }^{4}$ El texto de referencia por esta sección es: LORUSSO S., MARABELLI M., VIVIANO G., La contaminazione ambientale ed il degrado dei materiali di interesse storico-artistico, Pitagora Ed., Bologna, 2006 (II Ed.) p.247-68

${ }^{5}$ PEDEMONTE E, FORNARI G., Chimica e restauro, la scienza dei materiali per /'architettura, Marsilio Ed., Venezia, 2003. p.138
} 
En el caso que la limpieza manual se combine con limpieza química, deben protegerse previamente todos los materiales y elementos de la edificación que sean susceptibles de ser atacados por el agente químico del producto, tales como maderas, vidrios, metales, piedras calizas, etc., y empapar y saturar bien con agua limpia todo el área a tratar, de arriba abajo, saturando las zonas inferiores para evitar que absorban lo que escurre del producto y la suciedad arrastrada.

Una vez que la solución limpiadora ha permanecido sobre la pared el tiempo útil, es necesario eliminarla por lavado con abundante cantidad de agua limpia, para arrastrar así todos los residuos.
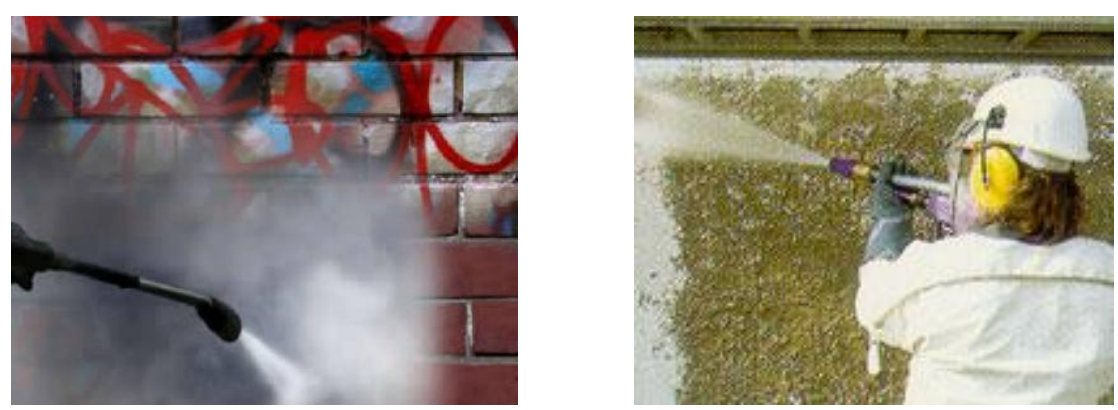

FIG. 113 Ejemplos de diferentes tipos de limpieza a base de agua, con distintos métodos de proyección (CRISTINI)

\section{Agua pulverizada}

Se puede realizar un rociado de la fábrica de ladrillo por aspersión con gota gruesa, y a temperatura siempre superior a 5 grados $^{6}$. Se utiliza sobre todo para casos de suciedad leve y cuando el ladrillo se encuentra en mal estado. Hay determinados casos en los que por la existencia de determinadas sales en la fábrica debe ser estudiada la salinidad del agua a utilizar y en casos excepcionales recurrir el empleo de aguas de muy reducida salinidad, o mejor aún, de agua desionizada.

\footnotetext{
${ }^{6}$ Ibídem (2003) p.143
} 
Para evitar la saturación de agua, ésta se aplica en pulverizaciones de corta duración, que pueden ser reiteradas si es necesario, con periodos máximos de actuación de aproximadamente media hora, en función de la temperatura ambiental y de la exposición a la radiación solar.

La duración del tratamiento puede reducirse combinándolo con las zonas más afectadas con el empleo de métodos manuales, mediante brochas o cepillos vegetales e incluso, usando agentes químicos suaves y un posterior enjuagado a presión moderada para evitar la infiltración de sales, daños de elementos metálicos, que pueden derivarse de empapado de la fachada de la fábrica de ladrillos.

Este método no altera prácticamente la superficie del material pero puede hacer correr determinados riesgos como son la saturación de los ladrillos de agua, sobre todo en climas fríos, la formación de eflorescencias, la penetración de agua en el edificio a través de ventanas, fisuras, juntas sin proteger, la aceleración de la corrosión de grapas y fijaciones en el muro, o incluso puede provocar pudriciones orgánicas, exteriores e interiores.

\section{Agua nebulizada}

El método consiste en rociar intensamente la fábrica con una nube de gotas finas proyectadas mediante unas lanzas ajustables con varias boquillas muy pequeñas y un equipo de control de tiempo y flujo, eliminando posteriormente la suciedad ablandada mediante cepillos de cerdas blandas. Este sistema reduce la cantidad de agua necesaria y suele ser utilizado de forma combinada con otros métodos de limpieza, como pastas absorbentes y abrasión selectiva, etc...

\section{Agua a presión}

Consiste en aplicar agua por proyección, a baja, media o alta presión, controlada por el manorreductor de la boquilla del dispositivo de proyección. El sistema de agua a presión permite eliminar con 
rapidez la suciedad muy superficial y los residuos sueltos pocos adheridos. Además, cuando junto al agua presión se incluyen agentes químicos de limpieza o materiales abrasivos, se logran buenos resultados $y$, al mismo tiempo, se reducen los efectos agresivos que pueden producir ciertas técnicas de limpieza química y abrasiva, en el caso de ser aplicadas independientemente. A la hora de seleccionar el sistema de proyección más adecuado para la fábrica de ladrillo deberán tenerse en cuenta los siguientes factores ${ }^{7}$ :
A) Presión de chorreado
B) Flujo o caudal de agua
C) Ángulo de incidencia
D) Tipo y Tamaño de la boquilla
E) Temperatura
F) Uso de productos químicos

\section{Vapor de agua a presión}

Esta técnica consiste en la proyección, bajo presión, de agua sobrecalentada, realizándose como el método normal y proyección de agua caliente, pero elevando la temperatura a $140^{\circ} \mathrm{C}^{8}$, de forma que la salida de la pistola se convierte en vapor de agua. Este vapor saturado húmedo se condensa por enfriamiento al contacto con la superficie del material. El agua condensada produce el reblandecimiento de las costras de alteración, incrustación, mugre, que se desprenden, siendo eliminadas por el agua que se desliza en el paramento. La aplicación debe realizarse con rapidez al objeto de evitar el riesgo de producir un grave choque térmico.

El uso del vapor de agua a alta o baja presión permite limpiar obras delicadas o deterioradas que no soportarían la acción de presiones

\footnotetext{
${ }^{7}$ GASPAROLI P., Le superfici esterne degli edifici. Degradi, criteri di progetto e tecniche di manutenzione, Alinea Ed., Firenze, 2002, p.87-110

${ }^{8}$ BISCONTIN G., L'intonaco, storia cultura e tecnologia, (Atti del Congresso di Bressanone 1985) Libreria Progetto Ed., Padova, 1985, p.63
} 
más altas o de abrasivos y es eficaz para la eliminación de residuos orgánicos.

Este método funciona tanto mejor cuanto más impermeable es la superficie de los ladrillos y, por esta razón, resulta especialmente indicado para obras con ladrillos bien cocidos de superficie muy lisa o con ladrillos con superficie vidriada. En general, cuanto menos poroso sea el ladrillo mejor resulta la aplicación de esta técnica.
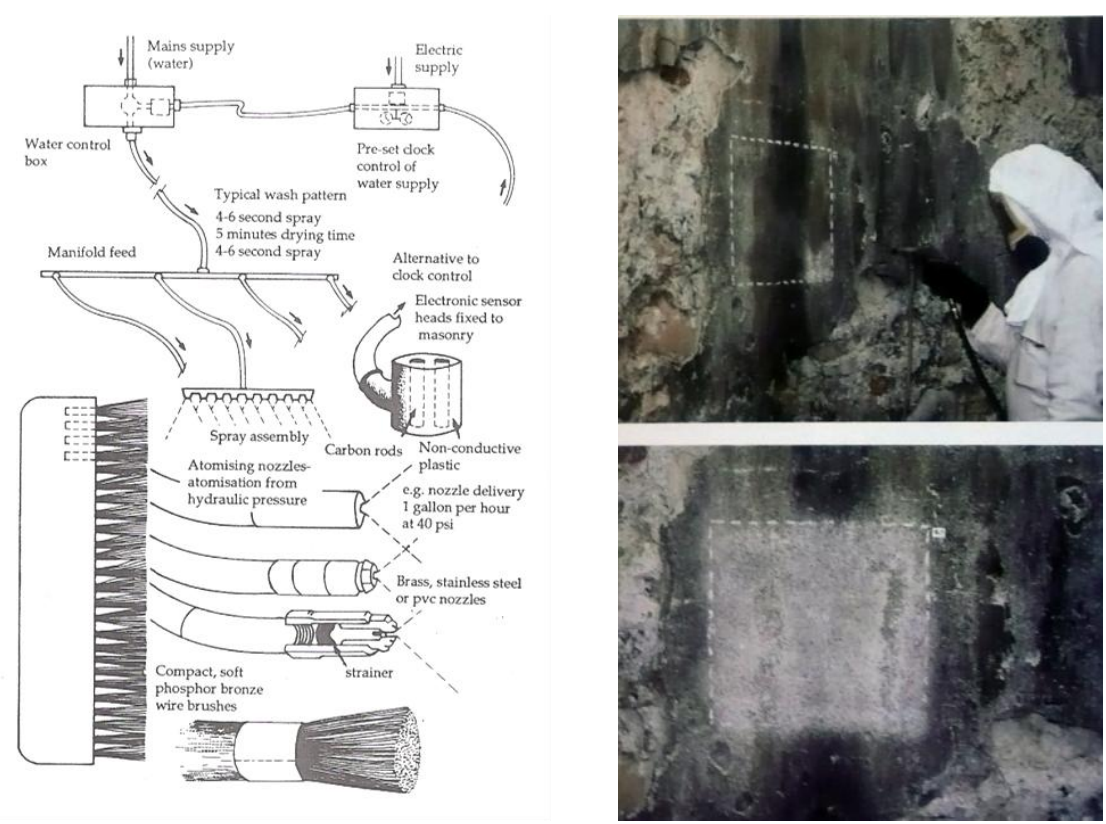

FIG: 114 Detalles de dispositivos de presión de chorreados y aplicación en fábricas históricas (LYNCH- FEIFFER)

Una variante al sistema tendente a reducir el riesgo de producir daños en la fábrica debidos al mencionado choque térmico en los ladrillos consiste en proyectar sobre la fachada una mezcla de vapor de agua en las proporciones de 40/60\% ; es decir, combinando el vapor saturado húmedo con la pulverización de agua, de forma que

\footnotetext{
${ }_{9}^{9}$ AMOROSO G.G., Trattato di scienza della costruzione dei monumenti, Alinea Ed., Firenze, 2002, p.148
} 
la aportación de agua disminuya el choque térmico producido por la proyección de vapor, y permita aplicar el chorro durante un tiempo superior.

En la aplicación de estos métodos se deben tomar las precauciones adecuadas para evitar los riegos de manejo de vapor a las temperaturas. La nube de vapor que incide sobre las superficies a limpiar hace difícil la necesaria observación del resultado del trabajo del operario. Esta incomodidad es causa de que, en algunos casos, la limpieza sea defectuosa y aparezcan áreas diferenciadas por haber sufrido distinto tratamiento.

El tratamiento con vapor produce un reblandecimiento de la suciedad y, por ello, cuando existen depósitos gruesos, puede utilizarse la acción del vapor como un tratamiento previo para lograr su reblandecimiento. La limpieza de una suciedad reblandecida se logra con menores volúmenes de agua, con menores presiones, y con menor concentración de agentes químicos de limpieza.

\section{Proyección hidroneumática}

Este método, frecuentemente aplicado, consiste en proyectar simultáneamente dos agentes distintos: agua y un mineral de granulometría determinada.

Los minerales a utilizar suelen ser los mismos que los empleados en proyección en seco, dosificándose de forma que la acción abrasiva del mineral sea la adecuada. Para ello deberá regularse la presión del aire, la granulometría, la naturaleza, y cantidad del material empleado.

Como norma general nunca debe aplicarse el agua a tal presión que pueda dañar la superficie del ladrillo y las juntas de mortero. Tampoco es recomendable el uso de chorros de vapor de agua sobre los ladrillos de alta succión, por el peligro de que el agua se pueda introducir en el interior de la fábrica. 
Los sistemas de limpieza con agua se pueden utilizar para todos los tipos de suciedades solubles en agua pero, aún más interesante, también para otros tipos de depósitos que no lo son, y que por esta razón requieren del vapor a presión o de otros métodos que contribuyan a su reblandecimiento y faciliten su posterior eliminación. En general, existen sistemas aconsejables según la calidad y el estado superficial del ladrillo ( $y$, en consecuencia, la resistencia del material cerámico) y según las características físicas del tipo de ladrillo.

- Procedimientos de limpieza mecánica ${ }^{10}$

$$
\text { MÉTODOS MÉCANICOS MEDIANTE PROYECCIÓN }
$$

PROYECCIÓN DE MICRO ABRASIVOS EN SECO

Estos procedimientos se basan en el empleo de medios mecánicos para eliminar la suciedad sin alterar sustancialmente la superficie de los ladrillos y morteros.
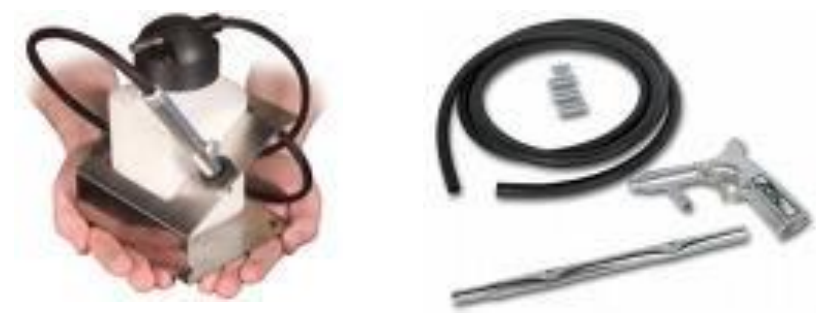

FIG. 115 Ejemplos de herramientas que se pueden emplear para la proyección de fachadas (ASHRUST)

Estos sistemas de limpieza se utilizan generalmente para eliminar manchas de pintura, formaciones calcáreas originadas por lixiviado, sales de vanadio o depósitos de suciedad fuertemente adheridos al substrato.

\footnotetext{
${ }^{10}$ El texto de referencia por este capítulo es DEL BUFALO A., Conservazione edilizia e tecnología del restauro, Kappa Ed., Roma, 1992, p.76-118
} 
La dificultad del método radica en que su empleo requiere un cuidado extremo, pudiendo en caso contrario producirse fisuras superficiales y originarse erosiones, sobre todo en esquinas y ángulos.

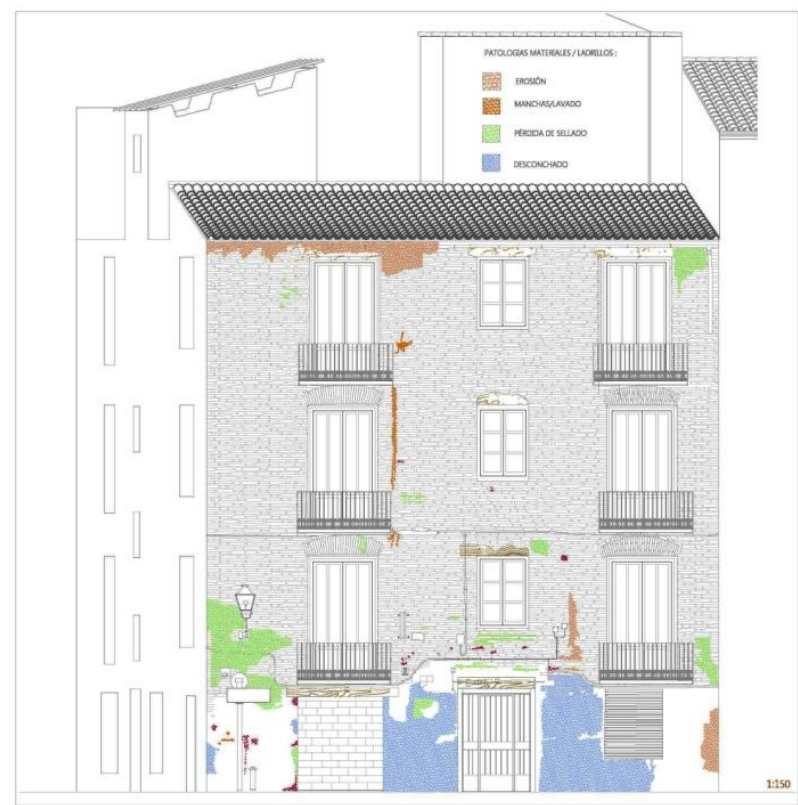

FIG. 116 Estudio de patologías, alzado principal C/R. de Flor n³9, Valencia, (Vb22) (CRISTINI)

\section{Métodos mecánicos manuales}

Estos métodos actúan eliminando una porción de la capa superficial mediante herramientas manuales o abrasivos, por lo que, en mayor o menor medida, suelen provocar el deterioro de los planos y alteración de esquinas, molduras y relieves, incluso llevados a cabo de una forma segura y controlada; requieren mucha experiencia, además de ser procesos lentos y por tanto costosos. Una de las formas de realizar la limpieza por este método es mediante un cepillado normal, en seco, por medio de cerdas vegetales, si bien suele ser insuficiente en la mayoría de los casos para obtener una adecuada limpieza. También se puede realizar un cepillado en seco para la eliminación de algunas eflorescencias. Para ello, el cepillado 
no deberá ser enérgico, empleándose cepillos cuyas púas no arañen la superficie de ladrillo, como la cerda natural.

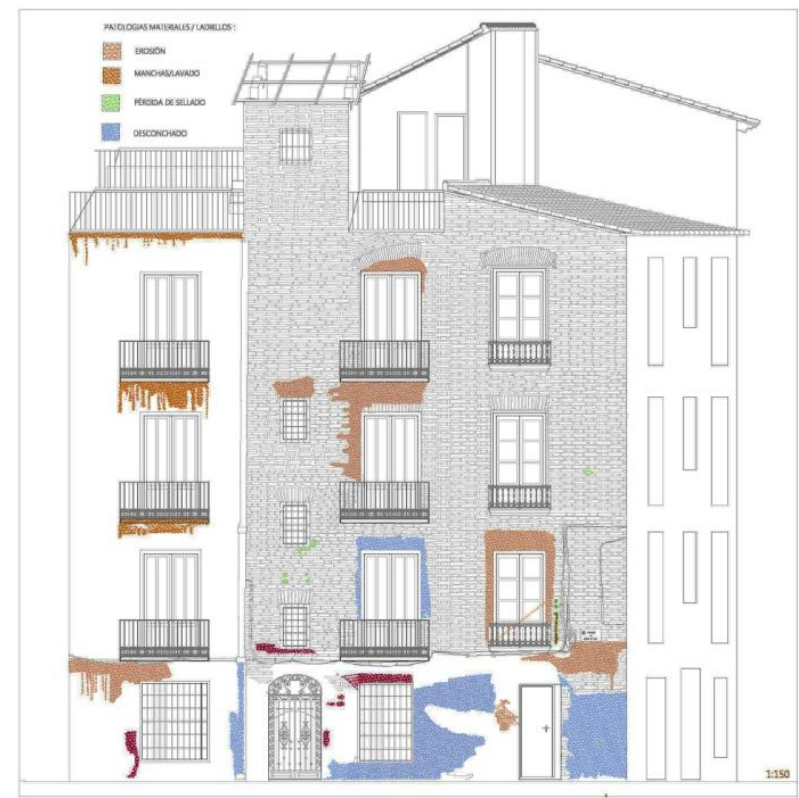

FIG. 117 Estudio de patologías, alzado lateral C/R. de Flor n³9, Valencia, (Vb22) (CRISTINI)

\section{Métodos mecánicos mediante proyección}

Estos procedimientos se basan en la proyección de diversos chorros de arena, mediante máquinas neumáticas y eléctricas, con características de regulación de presión (baja, media y alta) que así mismo pueden incorporar equipos de aspiración de polvo y de reciclaje de partículas, y sistemas para proyectar tanto partículas en seco como con un cierto grado de humedad. Para ello se emplean diferentes materiales de proyección caracterizados básicamente por su tamaño, dureza, pH, que deberán ser compatibles con el tipo de fábrica, lo cual se debe determinar mediante pruebas previas en obra.

El procedimiento admite diferentes variables en función de que sea en seco o en húmedo, de la composición de las partículas, dureza, tamaño, forma y presión, por lo que sería necesario acotar y probar 
in situ los distintos parámetros para garantizar un correcto resultado (en fábricas antiguas resulta imprescindible comprobar de forma especial el estado del rejuntado y la posible alteración de los ladrillos que pueda ocasionar el tratamiento).
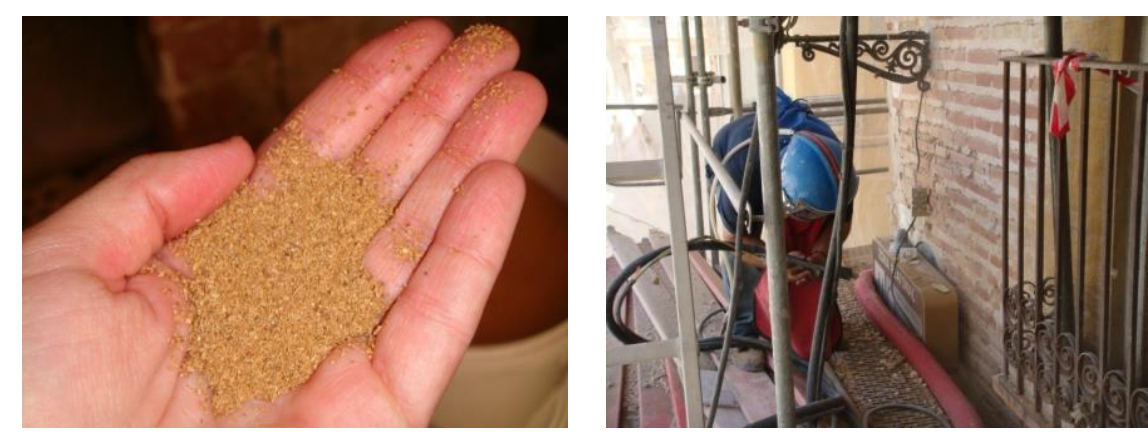

FIG. 118 Detalle de limpieza con método mecánico, proyección abrasiva en seco con cascaras de almendras en las viviendas de C/Roger de Flor n³9, Valencia (VEGAS-MILETO)

En fachadas históricas existen muchos especialistas que, en cualquier caso, desaconsejan, en general, este procedimiento, por la posibilidad de formar una rugosidad sobre la superficie limpia que predispone al material un deterioro acelerado. Existen unos cuantos problemas que se pueden generar por un uso inadecuado de los sistemas mecánicos, entre estos ${ }^{11}$.

A) Riesgo de abrasión de partes más delicadas y/o ornamentales

B) Riesgo de exponer la parte interior de los ladrillos a los agentes atmosféricos y a un probable acelerado deterioro

C) Riesgo de formar picaduras, bien de los ladrillos bien de las juntas

D) Riesgo de abrir vías de agua, en las fábricas

E) Por estas razones en los procedimientos hay unas cuantas variantes, para limitar los problemas, sobre expuestos

${ }^{11}$ Op. Cit. AMOROSO G.G. (2002), p.213 


\section{MUROSINTRAMUROS}

\section{Proyección de micro abrasivos en seco}

Consiste en proyectar un polvo muy fino y triturado, hecho con partículas de vidrio. Con este sistema se consigue una abrasión superficial de fábricas mucho menos fuerte y proporcionada a un acabado mucho más liso, gracias al control del chorro de arena.

\section{-Proyección abrasiva en seco}

Consiste en el proyectar partículas en seco y bajo presión de aire por medio de una maquina dotada de un depósito de almacenamiento de la arena (típicamente se suele usar arena de sílice, reducida al 5\% de sustancia libre, para evitar problemas de silicosis ${ }^{12}$. Gracias a la proyección con boquilla controlada este sistema también permite proporcionar mejor el acabado de las superficies que se tratan.
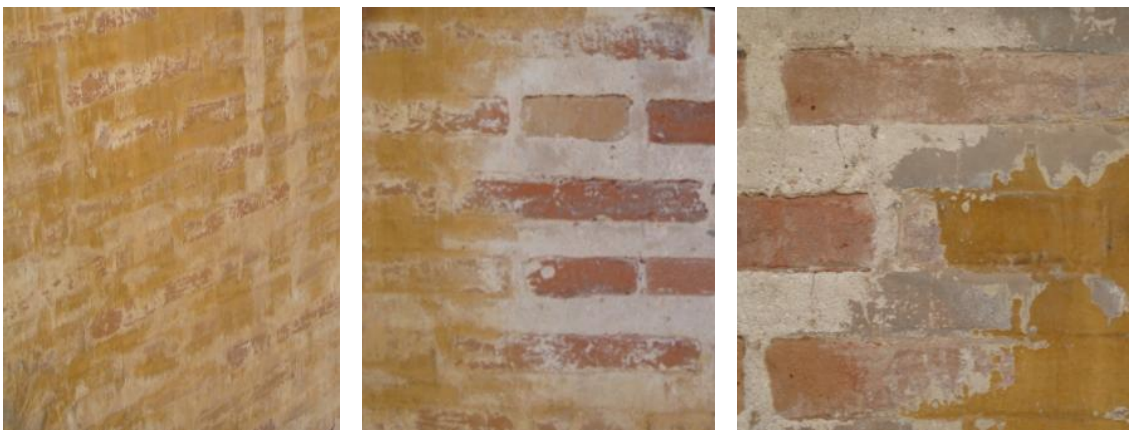

FIG. 119 Detalle de limpieza, varias intensidad de proyección con cáscaras de almendras, viviendas de C/Roger de Flor n³9, Valencia (CRISTINI)

-Proyección de hidroarenado

Consiste en proyectar una mezcla de arena y agua sobre la fachada. Ésta es una solución bastante compleja, bien por la dificultad del operario de ver las superficies que se tratan (debido a los lodos de la proyección), bien por la elevada presión de trabajo. Una versión de este método es la limpieza hidroneumática. La diferencia, en comparación con el simple hidroarenado, radica en la presencia de dos conductos distintos, para el agua y para la arena. Esta separación

\footnotetext{
${ }^{12}$ Op. Cit. GASPAROLI P. (2002), p.121
} 
de los conductos permite un procedimiento de proyección más limpio, con menos polvos y más seguridad para los aplicadores.
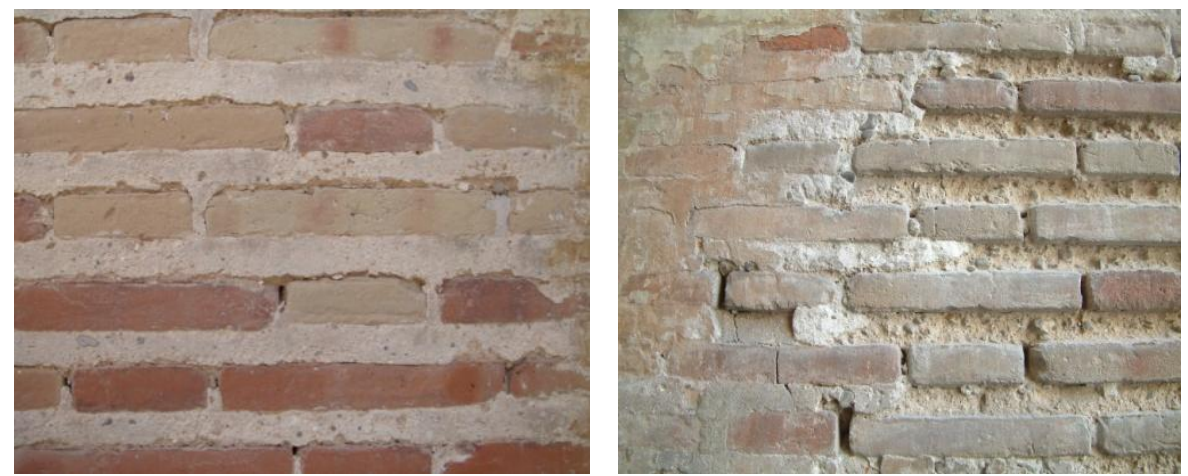

FIG. 120 Detalle de limpieza, zonas con excesiva proyección mecánica, viviendas de C/Roger de Flor n039, Valencia (CRISTINI)

En general existen unas series de recomendaciones que se deberían llevar a cabo para evitar problemas de deterioro y aceleración de la degradación de las fábricas de ladrillos macizos que se $\operatorname{tratan}^{13}$.

A) Ensayar unas zonas acotadas antes de intervenir sobre grandes superficies

B) Proteger las superficies adyacentes a las que se tratan con cintas

C) Evitar incidir sobre las llagas de mortero, y procurar limpiar sólo la superficie de los ladrillos
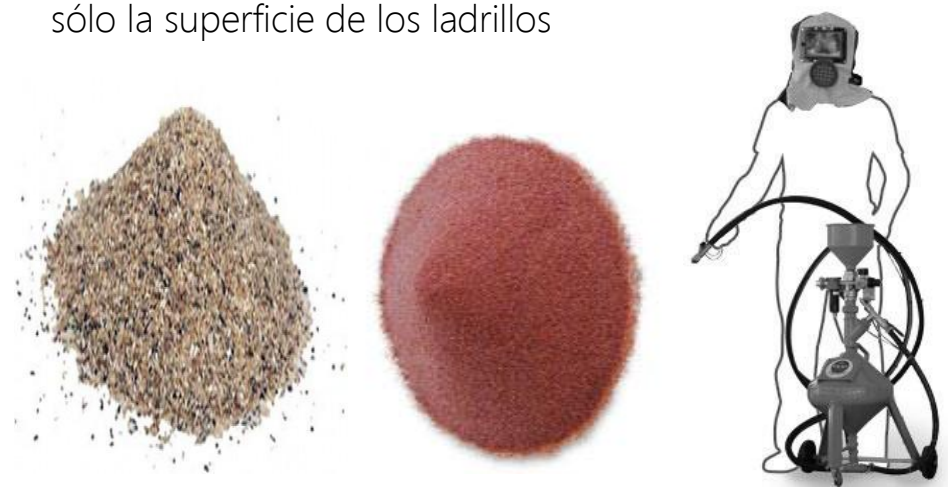

FIG. 121 Diferentes tipos de arenas para micro-arenado y aparato para la proyección (SABIX)

${ }^{13}$ Op. Cit. ASHURST N. (1992), p.35 


\section{LIMPIEZA MECÁNICA EN RELACIÓN CON LAS CARACTERÍSTICAS DEL LADRILLO HISTÓRICO ${ }^{14}$}

\begin{tabular}{|c|c|c|c|}
\hline TIPO DE LADRILLO & SUCIEDAD BAJA & SUCIEDAD MEDIA & SUCIEDAD ALTA \\
\hline $\begin{array}{l}\text { LADRILLO } \\
\text { CERÁMICO } \\
\text { VISTO O } \\
\text { AGRAMILADO }\end{array}$ & $\begin{array}{l}\text {-Agua } \\
\text { pulverizada } \\
\text {-Proyección de } \\
\text { agua fría } \\
\text { - Vapor a presión } \\
\text {-Proyección de } \\
\text { polvo de vidrio } \\
\text { fino y } \\
\text { micronizado }\end{array}$ & $\begin{array}{l}\text {-Proyección con } \\
\text { agua caliente } \\
\text {-Vapor a presión } \\
\text {-Proyección ligera } \\
\text { con áridos } \\
\text {-Proyección de } \\
\text { polvo de vidrio } \\
\text { fino y } \\
\text { micronizado }\end{array}$ & $\begin{array}{l}\text {-Proyección con } \\
\text { agua caliente y } \\
\text { adición de } \\
\text { productos } \\
\text { químicos } \\
\text {-Proyección de } \\
\text { polvo de vidrio } \\
\text { micronizado } \\
\text {-Proyección } \\
\text { hidroneumática } \\
\text { con áridos }\end{array}$ \\
\hline $\begin{array}{l}\text { LADRILLO SILICO/ } \\
\text { CALCÁREO } \\
\text { (AMARILLENTO) }\end{array}$ & $\begin{array}{l}\text {-Agua } \\
\text { pulverizada } \\
\text {-Proyección de } \\
\text { agua fría a } \\
\text { presión } \\
\text {-Vapor a presión } \\
\text {-Proyección de } \\
\text { agua caliente a } \\
\text { baja presión } \\
\text {-Proyección de } \\
\text { polvo de vidrio } \\
\text { micronizado con } \\
\text { superfino o } \\
\text { microfino }\end{array}$ & $\begin{array}{l}\text {-Proyección de } \\
\text { agua fría a } \\
\text { presión } \\
\text {-Proyección de } \\
\text { agua caliente a } \\
\text { baja presión } \\
\text { - Vapor a presión } \\
\text { Proyección de } \\
\text { polvo de vidrio } \\
\text { micronizado con } \\
\text { superfino }\end{array}$ & $\begin{array}{l}\text {-Proyección de } \\
\text { agua caliente a } \\
\text { baja presión } \\
\text { - Vapor a presión } \\
\text {-Proyección de } \\
\text { polvo de vidrio } \\
\text { micronizado con } \\
\text { superfino o } \\
\text { microfino }\end{array}$ \\
\hline $\begin{array}{l}\text { LADRILLO CON } \\
\text { FINGIDOS/PINTURAS }\end{array}$ & \multicolumn{3}{|c|}{$\begin{array}{l}\text { Proyección de agua a media presión y detergente neutro } \\
\text { Agua y jabón neutro, mediante cepillo de cerda y posterior } \\
\text { aclarado }\end{array}$} \\
\hline
\end{tabular}

\footnotetext{
${ }^{14}$ V.AA. Patologías, Técnicas de intervención y limpieza de fábricas de ladrillo, Intemac Ed., Madrid, 2003, p.32
} 
Procedimientos de limpieza química ${ }^{15}$.

LIMPIEZA CON ÁCIDO FLUORHÍDICO

LIMIPEZA CON ÁCIDO CLORHÍDRICO

LIMPIEZA CON AGENTES ALCALINOS

La aplicación de productos químicos constituye con frecuencia un complemento de los sistemas de limpieza con agua, actuando sobre el soporte de la suciedad, favoreciendo su ablandamiento. Realmente no se puede considerar un método de limpieza unicum, sino como una fase asociada a la fase de limpieza con agua. Existen muchos productos que se pueden emplear, según el tipo de fábrica y la clase de suciedad. La aplicación de estos productos, bien con brochas, cepillos o rodillos, es posible dejando actuar sobre las superficies por un periodo recomendable limitado bien por tiempo de aplicación bien por superficie a tratar. A continuación se humedece con agua, se frota y se enjuaga con agua para eliminar todos los residuos de la sustancia soluble.

En general sería recomendable $e^{16 .}$

A) Evitar contacto con elementos de la fábrica que no necesiten tratamiento (realizar sellado, obturación, cintas de protección...)

B) Controlar con utensilios adecuados la posible agresividad de los productos

C) Diluir bien los productos, tanto para no alterar el soporte (su textura, cromatismo, tonalidad...) como para no perjudicar otros materiales.

D) Realizar catas de prueba en zonas no especialmente delicadas y significativas del soporte a tratar

\footnotetext{
${ }^{15}$ El texto de referencia por este capítulo es: PEDEMONTE E., FORNARI G., Chimica e restauro, la scienza dei materiali per l'architettura, Marsilio Ed., Venezia, 2003. p.118-121

${ }^{16}$ LORUSSO S., MARABELLI M., VIVIANO G., La contaminazione ambientale ed il degrado dei materiali di interesse storico-artistico, Pitagora Ed., Bologna, 2006 (II Ed.) p.252
} 
Existen diferentes tipos de productos para la limpieza química

\section{Limpieza con acido fluorhídrico}

Este producto $(\mathrm{FH})$ actúa por medio de una reacción de efervescencia, que se realiza en el soporte, empleando a veces, también tras la aplicación de un desengrasador alcalino.

Este ácido es muy utilizado por su eficaz acción contra la suciedad acumulada en la superficie de los ladrillos; funciona diluyendo la interfase entre la pared y la suciedad. Su empleo es a muy baja concentración (no más de un 2-8\% de ácido puesto en solución) ${ }^{17}$, debido al hecho que el ácido fluorhídrico puede atacar los morteros de cal y, también, disolver los silicatos y el sílice que constituye el "vidrio" de superficie de un ladrillo macizo. Al mismo tiempo, a diferencia de otros ácidos, el ácido fluorhídrico tiene menor tendencia a dejar residuos salinos solubles sobre la fachada. En consecuencia, se producen menores alteraciones cromáticas localizadas.

El ácido fluorhídrico se debe utilizar únicamente en bajas concentraciones (2-8\%), ya que si se utiliza en elevadas concentraciones puede disolver el sílice y los silicatos que constituyen el vidrio o barnices cubiertas, lo que puede conducir posteriormente a la re-precipitación del sílice coloidal, prácticamente imposible de eliminar sin dañar el substrato, además de disolver los morteros de $\mathrm{cal}^{18}$.

Se debe tener en cuenta en el caso valenciano la presencia de materiales pétreos próximos a la fabricas de ladrillos con alto contenido en carbonatos (Piedra de Ulldecona, de Godella...). En estos casos podría haber una reacción química entre ambos

\footnotetext{
${ }^{17}$ V.AA. Patologías, Técnicas de intervención y limpieza de fábricas de ladrillo, Intemac Ed., Madrid, 2003, p.34-35

${ }^{18}$ PITTALUGA D., Consolidare le cortine murarie e gli apparati decorativi in laterizio, Arcadia ed., Venezia 2007, Cap.4
} 
compuestos que puede derivar en cristalización en los poros de fluoruro cálcico.

La utilización de este compuesto, además, requiere una humectación previa abundante del soporte a tratar, un tiempo limitado de permanencia sin dejarlo evaporar y un buen aclarado. También conviene tener en cuenta que este ácido es extremamente peligroso, sobre todo, cuando está concentrado, y por lo tanto, debe manejarse obedeciendo estrictamente a todas las normas de seguridad, aplicando un alto grado de protección a todas las superficies cercanas que no vayan a ser tratadas, sin olvidar realizar un profundo aclarado de todas las superficies una vez terminada su utilización.

\section{Limpieza con ácido clorhídrico}

Este ácido, muy fuerte en el caso de ataque a las formaciones calcáreas y en la solubilización de yeso y otras sales cristalinas, no es un producto que se emplea para limpieza general, sino sólo en ciertos tratamientos contra las eflorescencias.

Se usa para eliminación específica de manchas de cal, cemento, otros productos alcalinos, aunque su empleo en mayores concentraciones a las necesarias para este tipo de suciedad es muy peligroso, pues posee alta capacidad de generación y deposición de sales solubles, pudiendo aportar cloruros que provoquen posteriores fenómenos de cristalización de sales y de corrosión de materiales metálicos.

Por ello se debe realizar un profundo aclarado de todas las superficies tratadas una vez finalizado el tratamiento, controlando el $\mathrm{PH}$ de las aguas de lavado hasta conseguir que sean neutras.

\section{Limpieza con agentes alcalinos}

Estos tipos de productos se emplean como agentes desgrasantes para desprender costras de suciedad y, en general, cuando existen suciedades en forma de grasas. Entre los agentes alcalinos más utilizados destacan por su eficacia comprobada el hidróxido sódico, hidróxido potásico, el hidróxido amónico y la acetona. El amonio 
forma parte de las formulaciones más eficaces y utilizadas. Sobre todo, estos productos, se pueden utilizar con agua y/o vapor para reducir la cantidad de agua necesaria que se va a aplicar en la superficie; y en el caso de las pulverizaciones puede asimismo reducir la presión a utilizar. Como en el caso de los compuestos ácidos, se deben humectar bien las superficies, con aplicaciones repetidas, un enjuagado cuidadoso y una posterior neutralización.
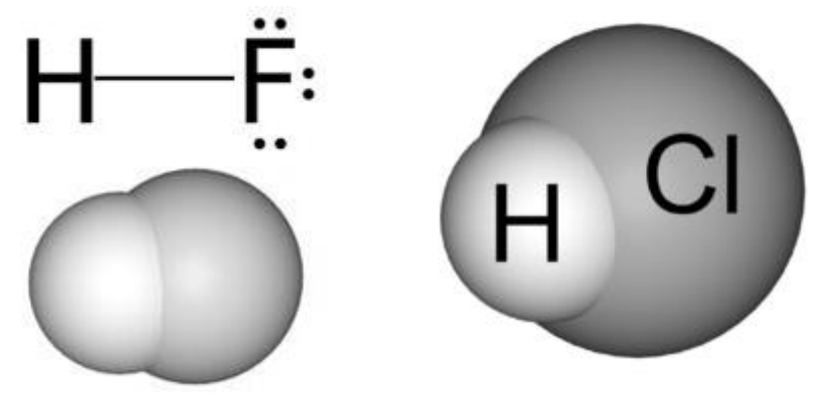

FIG. 122 Moléculas de acido clorhídrico y fluorhídrico (CRISTINI)

Entre los efectos no recomendables de estas sustancias aparece el problema de las huellas de residuos; si las operaciones no se completan adecuadamente queda sobre la superficie un residuo de suciedad y de sustancias químicas que después se manifiesta en forma de manchas o de eflorescencias. Existe también el riesgo de rayados y limpieza desigual si no se aplica el producto homogéneamente, y un especial riesgo de daños y destrucción de pinturas si las partes próximas a las que se van a tratar no se protegen adecuadamente. Es también posible combinar limpiadores alcalinos con ácido fluorhídrico para una disminución de concentración del ácido y de su tiempo de actividad. Existen unas posibles indicaciones que se pueden dar de forma somera, aunque los textos siempre antes recomiendan aplicaciones previas, pruebas cuidadosas y catas empíricas. 


\begin{tabular}{|c|c|}
\hline \multicolumn{2}{|c|}{$\begin{array}{c}\text { LIMPIEZA QUÍMICA EN RELACIÓN CON } \\
\text { LAS POSIBLES CARACTERÍSTICAS DEL LADRILLO HISTÓRICO }{ }^{19}\end{array}$} \\
\hline ALTERACIÓN & TRATAMIENTO QUÍMICO ACONSEJABLE \\
\hline Eflorecencias & $\begin{array}{l}\text { Lavado mediante cepillo con gel ácido ( } \mathrm{PH} \text { 5), } \\
\text { aclarado con agua desionizada y posterior } \\
\text { tratamiento hidrófugo micro poroso }\end{array}$ \\
\hline Líquenes & $\begin{array}{l}\text { Biocída de amplio espectro para musgos y algas. } \\
\text { Limpieza con diclorometano }\end{array}$ \\
\hline Manchas orgánicas & $\begin{array}{l}\text { Soluciones puntuales con perióxido de oxígeno } \\
\text { (agua oxigenada) }\end{array}$ \\
\hline Plantas adheridas & $\begin{array}{l}\text { Soluciones puntuales con perióxido de oxígeno } \\
\text { (agua oxigenada) }\end{array}$ \\
\hline Manchas de hongos & $\begin{array}{l}\text { Biocida de amplio espectro, parafina o aceite de } \\
\text { linaza }\end{array}$ \\
\hline Manchas & $\begin{array}{l}\text { Tratamiento con fungicida para las manchas } \\
\text { negras y con amonio cuaternario para manchas } \\
\text { amarillas; posteriormente tratamiento hidrófugo } \\
\text { micro poroso }\end{array}$ \\
\hline Salitre & $\begin{array}{l}\text { Neutralización mediantes ácidos en bajas } \\
\text { concentraciones }\end{array}$ \\
\hline Costras blancas & $\begin{array}{l}\text { Lavado con gel ácido y tratamiento posterior de } \\
\text { hidrofugación, o aplicación de papetas de celulosa } \\
\text { y posterior lavado para neutralizar }\end{array}$ \\
\hline Costras negras & $\begin{array}{l}\text { Lavado mediante cepillo con gel básico (PH 8) más } \\
\text { aclarado y posterior tratamiento hidrófugo. } \\
\text { Papetas de pulpa de papel o emplastos de arcilla. }\end{array}$ \\
\hline $\begin{array}{l}\text { Desagregación } \\
\text { arenosa }\end{array}$ & $\begin{array}{l}\text { Silicato de etilo modificado (para consolidar la } \\
\text { superficie) y posterior tratamiento hidrófugo } \\
\text { microporoso }\end{array}$ \\
\hline Disolución & y posterior tratamiento hidrófugo \\
\hline
\end{tabular}

\footnotetext{
${ }^{19}$ VV.AA. Patologías, Técnica de intervención y limpieza de Fábricas de ladrillo, Intemac Ed., Madrid, 2003, p.35
} 


\section{Limpieza con pastas absorbentes ${ }^{20}$}

Este método se basa en el empleo de pastas que aplicadas sobre la suciedad, actúan al modo de apósitos, durante varias horas, absorbiendo las sales solubilizadas, reblandeciendo o disolviendo manchas aisladas de productos orgánicos, microorganismos, manchas de cobre, hierro, residuos de una limpieza líquida. Se utilizan compuestos orgánicos como papetas de celulosa, e inorgánicos, a base de arcillas de elevada absorción de agua, como la sepiolita y atapulgita.
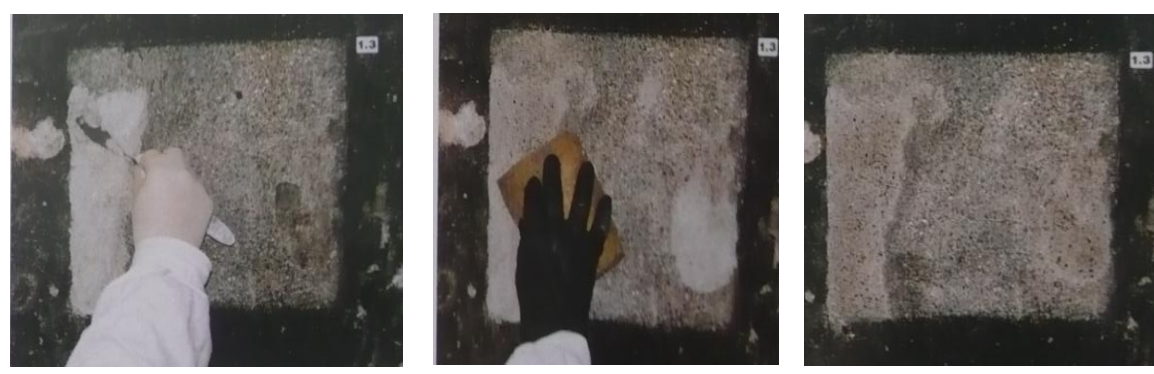

FIG. 123 Limpieza con compuestos de celulosa en fábricas previamente limpiadas (FEIFFER)

Para la eliminación de sales solubles se suelen utilizar los emplastos de arcilla (sepiolita o atapulgita). El método consiste en diluir las arcillas en una cantidad de agua desionizada o destilada, aplicando posteriormente la pasta, en forma de emplasto, formando una capa de más de 6 milímetros sobre la mancha. A continuación, se deja secar la arcilla, que actúa como absorbente, y finalmente se elimina limpiándola con agua.

Unas veces se aplica el emplasto y se deja secar y endurecer (verdaderos emplastos) y otras se mantiene cubierto y húmedo, durante el tiempo de permanencia (pasta absorbente). Estas pastas y emplastos no deben aplicarse directamente sobre materiales que se encuentran en mal estado ya que la pasta puede arrastrar

\footnotetext{
${ }^{20}$ OFFESTEIN F., Compatibilitá dei materiali. Come associare i materiali da costruzione, Utet Ed., Torino, 2000, p.213
} 
fragmentos sueltos. Si esta aplicación no fuera suficiente, se pueden añadir pequeñas cantidades de productos químicos mezclados con agua destilada para lograr una mayor eficacia. Con esta combinación, el parámetro requiere ser tapado con un plástico impermeable durante más de 24 horas.

Cuando se desea realizar un desengrasado inicial de los ladrillos, se utilizan pastas absorbentes alcalinas a base de arcilla, con hidróxido sódico. Este método es muy efectivo sobre soportes muy sucios donde es insuficiente un corto tiempo de permanencia de líquidos ${ }^{21}$. Su técnica requiere la neutralización con una baja concentración de acido acético o fluorhídrico y un aclarado posterior con agua.

Los geles alcalinos no son verdaderos emplastos y requieren un alto grado de protección. Su principal característica es su consistencia que ayuda a reducir la profundidad de penetración del agente limpiador. Los decapantes alcalinos formados por hidróxidos alcalinos disolventes se utilizan para la eliminación de pinturas tradicionales al aceite o pinturas a base de resinas. Los disolventes orgánicos se utilizan para eliminar depósitos superficiales no solubles en agua, como pinturas, aceites, grasas, bien con aplicaciones directas bien con emplastes.

\subsubsection{Consolidación $n^{22}$ :}

CONSOLIDANTES INORGÁNICOS

CONSOLIDANTES ORGÁNICOS

CONSOLIDANTES ORGANOSILÍCICOS

\footnotetext{
${ }^{21}$ Op. Cit. PEDEMONTE E, FORNARI G (2003), p.223-225

${ }^{22}$ El texto de referencia para este capítulo es: TORSELLO P.B., MUSSO S.F, Tecniche di Restauro Architettonico, Utet, Torino, 2002
} 
La consolidación consiste en la aplicación de un material de endurecimiento superficial con el fin de restituir las zonas disgregadas, haciendo que, en gran medida, la fabrica conserve su aspecto original y sus propiedades fisicoquímicas iniciales 0 mejoradas.

Aun cuando los procesos de consolidación son más frecuentes, en algunas fábricas históricas de ladrillo el método no se aconseja. Los principales factores que se deberían tener en cuenta a la hora de aplicar el producto consolidante deberán ser:

A) Alta capacidad de impregnación o penetración en el ladrillo, hasta la zona no alterada, para lo que deberá conocerse la estructura porosa del material (porosidad, absorción, succión capilar, coeficiente de saturación...)

B) Compatibilidad física con el ladrillo, de forma que las expansiones o retracciones que manifiesten las piezas sin tratar debidas a choques térmicos o variaciones de humedad sean análogas a las del material una vez consolidado

C) Compatibilidad química. No debe reaccionar con el soporte dando lugar a subproductos que puedan dañar posteriormente a la fábrica

D) Inalterabilidad de las características de aspecto (tonalidad de color, brillo, etc.) y estabilidad en el tiempo, particularmente frente a la radiación ultravioleta

E) Permeabilidad al vapor análoga a la del ladrillo sin tratamiento. En este caso la actuación se realizará sobre la parte dañada del material hasta llegar a la zona sólida sana, eliminándose en primer lugar el material disgregado o mal adherido, e impregnándose a continuación en profundidad con el producto consolidante. El material deberá saturarse completamente, llegado al rechazo del producto cuando éste alcance, la parte sana, evitando la creación de 
costras endurecidas superficiales que terminarían desprendiéndose. La aplicación se realizará superficialmente mediante brocha, rodillo o utilizando procedimientos de proyección.

Existen muchos tipos de consolidantes que se pueden emplear: inorgánicos, orgánicos y organosilícicos. Estos últimos son los que se pueden considerar más adecuados para su empleo de fábricas de ladrillo histórico, como vamos a explicar a continuación:
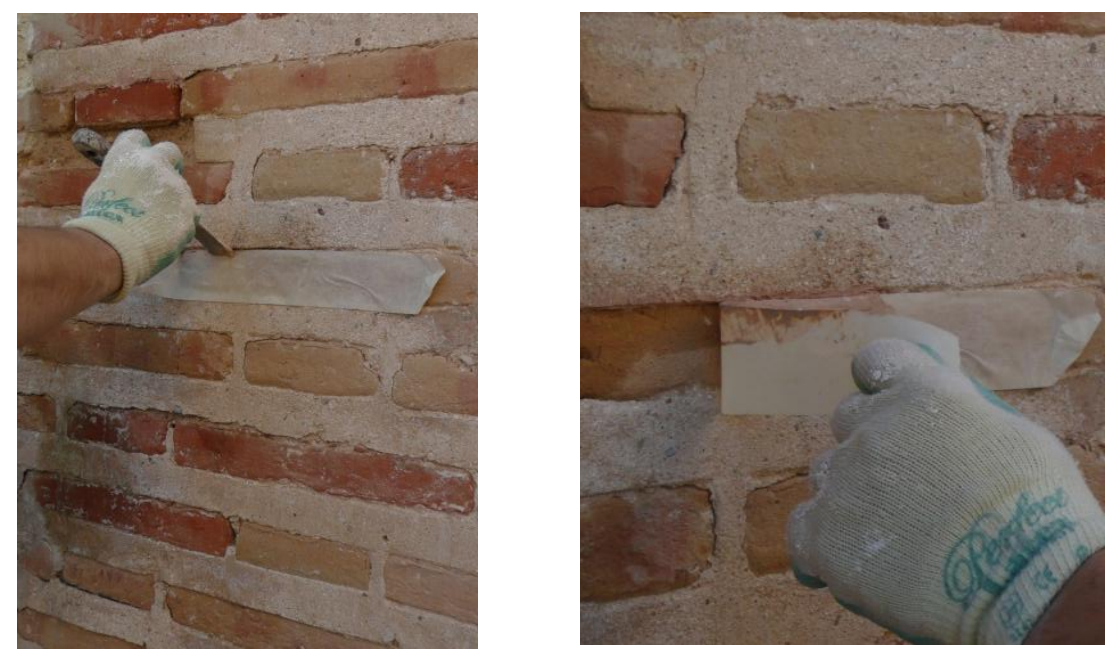

FIG. 124 Protección y consolidación, viviendas de C/Roger de Flor n³9, Valencia (CRISTINI)

\section{Consolidantes inorgánicos}

Estos productos tienen una actuación que está basada en la restitución del material degradado con una nueva sustancia compactante de origen inorgánico, como el aluminato de potasio, los fluorsilicatos. Su uso es apropiado como consolidante de materiales porosos, al tener cierta similitud con los componentes de ladrillo. Resisten mejor que los productos orgánicos a la acción de la intemperie y suelen tener una mayor estabilidad biológica y térmica. Los consolidantes inorgánicos poseen la ventaja frente a los consolidantes orgánicos de su similitud con los componentes de los ladrillo. Sin embargo en sus características mecánicas son inferiores a los orgánicos, tienen menor flexibilidad, mayor dificultad en la 
penetración del tratamiento y, por tanto, el proceso de consolidación es más lento y realmente tiene dificultad de penetración. El tratamiento una vez aplicado es irreversible.

\section{Consolidantes orgánicos}

Como consolidantes orgánicos se han utilizado ceras y resinas. Las ceras más utilizadas son las sintéticas, del tipo parecido a la parafina y ceras microcristalinas. Entre las resinas utilizadas en la consolidación de material cerámicos destacan las acrílicas, epoxídicas, de poliéster, poliuretánicas ${ }^{23}$. Su actuación está basada en la incorporación al material degradado de una nueva sustancia cimentadora de naturaleza distinta a la original, empleándose para ello las sustancias nombradas. La actuación de estos consolidantes se realiza por la formación de una fina capa que recubre la superficie del sistema poroso del ladrillo, uniendo sus componentes por su capacidad adhesiva.

\section{Consolidantes organosilícicos}

Estos tipos de consolidantes actúan de forma semejante a los silicatos inorgánicos, pero con la ventaja de que no producen subproductos dañinos sales) en su reacción. Son derivados del acido silícico, que por sus procesos de sustitución de radicales y polimerización dan lugar a diversas familias de productos. Para su uso como consolidante el producto más utilizado es el silicato de etilo, cuya reacción de hidrólisis en el interior del ladrillo histórico da lugar a un precipitado de gel de sílice, que rellena y aglutina el material. La forma de actuar de este consolidante no es como la de las resinas, cuya capacidad adhesiva permitía ligar a los componentes, recubriéndolos de una película fina. Los silicatos de etilo o esteres orgánicos de silicio producen la consolidación por cementación de los poros de ladrillo, mediante reacción del gel de sílice con el material cerámico. Esta reacción es muy lenta, por ello, la efectividad de estos tratamientos está muy ligada con la forma de aplicación y

${ }^{23}$ Op. Cit. MONTAGNi C. (2000) Cap. III 
condiciones de curado (la polimerización se ve favorecida con ambientes secos y humedad relativa reducida en la masa interna de los ladrillos).

\subsubsection{Hidrofugación ${ }^{24}$}

Debido a la gran problemática de las fábricas de ladrillo frente a la humedad, es imprescindible la eliminación previa de la causa, realizando la hidrofugación cuando el soporte se encuentre seco. Entre los productos utilizados como hidrofugantes se deben señalar las siliconas (del grupo de los compuestos organosilícicos) que, además de la acción hidrofugante, actúan como consolidantes, como se ha señalado anteriormente. En los casos en los que se haya perdido el acabado original de los ladrillos y la superficie permanezca expuesta, se pueden utilizar capas a base de silicatos que dejen transpirar a la fábrica, ya que una de las posibles causas de su pérdida es que no fueran lo suficiente permeables al vapor de agua.

El proceso de hidrofugación consiste en la aplicación de un producto incoloro hidrorrepellente, tras la limpieza completa de la fábrica de ladrillos históricos, para preservar ésta de la acumulación de nuevas suciedades 0 agentes agresivos que puedan depositarse superficialmente o difundirse en el interior de los paramentos verticales, así como para crear una barrera frente la penetración de las humedades.

El proceso no es sencillo, se deben tener en cuenta los graves problemas que puede ocasionar un inadecuado tratamiento de hidrofugación, en forma de eflorescencias, modificación de tonalidad de la fábrica, sobre todo, si tiene un acabado en fingido, estallidos o pérdidas de la piel o capa superficial de los ladrillos, debiendo analizarse al respecto detenidamente, previamente a su aplicación, el efecto de la aplicación mediante ensayos de laboratorio.

${ }^{24}$ Op. Cit. SCARZELLA P., ZeRBinATTI M. (2009), Cap. I-II 
Un producto hidrofugante suele actuar mediante tres modalidades diferentes en la fábrica de ladrillos: bien rellenando sus poros, bien formando una película en la interfase entre el poro y el sustrato cerámico, o por la formación de película exterior creando ángulos de contacto que inhiben la difusión del agua hacia el interior, pero configurando una barrera permeable al vapor de agua.

Los requisitos de estos productos para poder ser utilizados en fábricas de ladrillo son principalmente ${ }^{25}$.

A) Permeabilidad al vapor del agua. Es muy importante analizar que no vayan a producirse condensaciones en el muro como consecuencia de una insuficiente permeabilidad al vapor del agua del ladrillo tras la aplicación del producto, de modo que su comportamiento a este respecto debe ser análogo al del material sin tratar, sin alterar las propiedades de respiración de la fábrica.

B) Eficacia del producto. Habrá que comprobar la eficacia del producto hidrófugo realizando ensayos de absorción y succión de agua y de evaporación en la fábrica antes y después de la aplicación del tratamiento. La absorción de agua del material cerámico deberá manifestar un descenso considerable, y a su vez, la aplicación del tratamiento no deberá llevar consigo una modificación o aumento de la velocidad de evaporación del agua que penetre en la fábrica.

C) Compatibilidad con el soporte, comprobando que no se produzcan cambios de color, mediante medida de las coordenadas cromáticas antes y después de la aplicación del producto, y que el hidrofugante no es capaz de general subproductos que resulten dañinos.

D) Durabilidad. Mediante unos ensayos en laboratorio de envejecimiento acelerado frente a la radiación ultravioleta, para

${ }^{25}$ Op. Cit. OFFESTEIN F. (2000) p.112 
evaluar la eficacia del tratamiento con el paso del tiempo, efectuando ensayos de resistencia a la cristalización de sales, absorción, succión de agua (bien antes del tratamiento, bien durante, bien una vez aplicado, bien concluido el envejecimiento artificial acelerado).

También a la hora de aplicar un producto hidrofugante es importante proceder a la aplicación del producto realmente sólo después que se haya erradicado la causa de la patología o, al menos, una vez alcanzada su estabilización. En este caso, deberá haberse corregido el origen de humedad y se actuará sólo cuando el soporte esté realmente seco, limpio, sin porcentaje elevado de eflorescencias en la fábrica. Como precaución y fase previa a cualquier intervención, se garantizará el análisis exhaustivo de la naturaleza de la fábrica, el conocimiento del tipo de ladrillo, su acabado (fingido, cara a vista, agramilado, enlucido), para evitar los efectos irreversibles en consecuencia de la aplicación de un método inapropiado. Se deberá también exigir que los productos elegidos sean resistentes a los álcalis (como los componentes con morteros alcalinos) para garantizar una mayor durabilidad del tratamiento.

La mayoría de estos productos se suministran preparados para su inmediata aplicación mediante brocha, rodillo o boquilla de proyección de baja presión, que garantiza una penetración e impregnación uniforme en la fábrica histórica de ladrillos. Entre los principales productos hidrofugantes, aptos para fábricas históricas de ladrillo, destacan los siguientes ${ }^{26 .}$

A) Productos fabricados a partir de compuestos organosilíceos, como son las siliconas, que polimerizan en el interior del ladrillo después de la evaporación del disolvente. Estos productos tienen un grado de hidrofugación alto y generalmente son permeables al vapor de agua. No suelen producir cambios cromáticos significativos

\footnotetext{
${ }^{26}$ CANEVA G., NUGARI M.P., SALVATORI O., La biología del restauro, Nardini Ed., Firenze, 1994, Cap.3
} 
en la superficie del ladrillo, pero tienen como inconveniente que su efectividad disminuye con el paso del tiempo.

B) Productos fabricados a partir de resinas de tipo acrílico, mezclados con siliconas. Por lo general, usadas de forma aislada, son menos eficaces que la siliconas, ya que aunque presentan mayor capacidad de impregnación que éstas, su durabilidad con el paso del tiempo es menor, sobre todo en ambientes lluviosos y húmedos. Actúan por tensión superficial dentro de los poros del material cerámico, lo que las hace más transpirables, aunque menos estables o duraderas. No suelen variar las condiciones estéticas de acabado, tonalidad de color y brillo del ladrillo.

C) Productos fabricados a partir de ceras minerales, procedentes de hidrocarburos, parafinas y sobre todo, a partir de ceras microcristalinas, formadas por hidrocárburos de elevado peso molecular. Debido a que tienen poca adherencia al soporte y escasa penetrabilidad, suelen ir mezcladas con resinas acrílicas o siliconas, que facilitan su aplicación y mejoran sus resultados.

\subsubsection{Complementación de piezas}

En el caso en el que la alteración se haya producido en una sola pieza o en una pequeña zona, pueden utilizarse plaquetas de unos pocos milímetros de espesor, debiendo presentar las características similares a las citadas para la sustitución de ladrillos enteros. Este método se utiliza si existe peligro de dañar el resto de fábrica adyacente, siendo preferible insertar sólo una porción de ladrillo.

Las plaquetas deben colocarse sólidamente en el hueco preparado sobre una base de mortero con o sin la necesidad de sujeciones metálicas o compuestos adhesivos. 

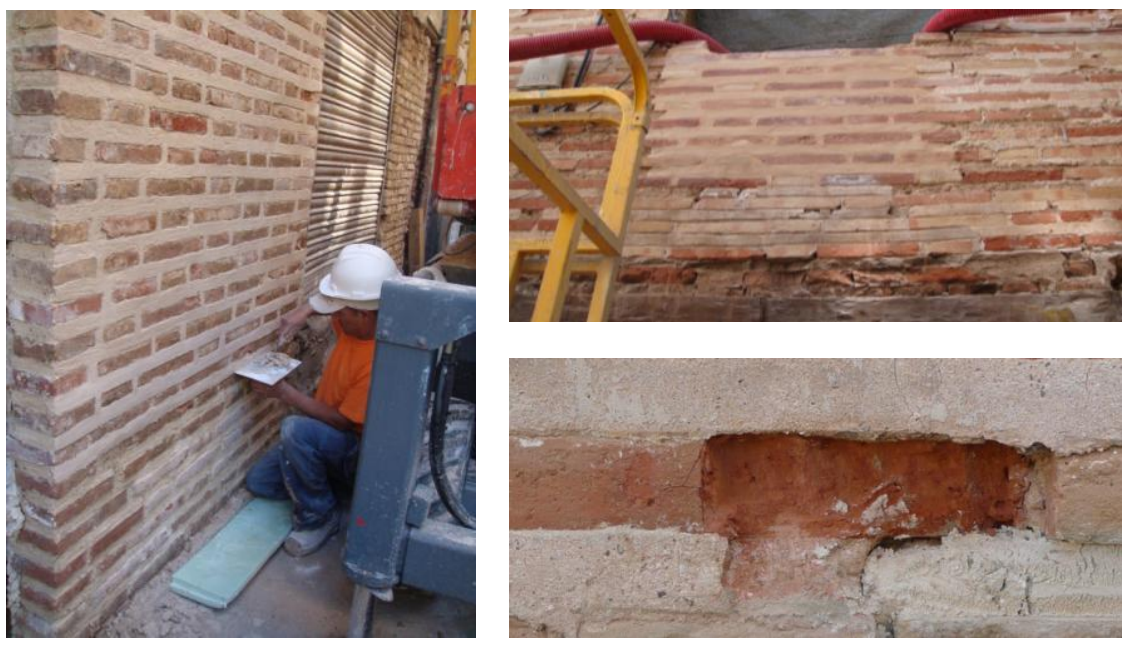

FIG. 126 Complementación de piezas, viviendas C/Roger de Flor n³9, Valencia (CRISTINI)

Las cavidades formadas se deben limpiar y regularizar y el mortero ha de ser compatible con el original de la fábrica. Si se utiliza epoxi u otro tipo de mortero de resinas para la colocación de plaquetas en grandes zonas, se pueden originar problemas de reducción de la permeabilidad del agua $y$, por tanto, desconchados en las zonas reparadas o en zonas adyacentes.

Si el área a reparar es de grandes dimensiones, será necesario atar la nueva hoja a la fábrica existente, utilizando ladrillos a tizón, llaves metálicas o los anclajes apropiados.

Las mayores dificultades que presenta este tipo de restauración atañen a las fábricas ornamentales. Cuando no es posible encontrar ladrillos que armonicen con los originales, es necesario llevar a cabo métodos alternativos. También se pueden utilizar morteros modificados con polímeros.

El último recurso para evitar los cambios de color es el pintado de los paramentos de fábrica de ladrillo, el cual confiere una fría uniformidad distante de las totalidades y texturas que poseen los muros de estas características. 


\subsubsection{Sustitución de piezas}

La sustitución de ladrillos en una fachada es un proceso complejo que se tiene que considerar como el último entre el abanico de soluciones mencionadas hasta ahora. En primer lugar deberá conocerse si el muro objeto de intervención se trata de un elemento o paramento resistente o simplemente un cerramiento de fachada. Tanto en uno como en otro caso se deberá delimitar la zona de intervención y el número de piezas sobre las que se hace necesario actuar (con un control inicial bien documentado fotoplanos y fotografías de control...). Pasos importantes que se deben tener en cuenta son ${ }^{27}$ :

A) Estudio del mortero. El estudio del mortero original es aconsejable desde varios puntos de vista, tanto el aspecto y color, como en su granulometría y composición. Es siempre conveniente utilizar para la toma de nuevas piezas, el mismo tipo de mortero con que se trabajó durante la primera ejecución, no utilizando cementos en edificaciones donde se construyó con morteros de cal, evitando así cambios de tono, manchas, ciertas eflorescencias e incluso retracciones y rigidación excesiva de las fábricas. Por somero que sea el análisis, del mortero utilizando originariamente se hará en llagas y tendeles (una vez eliminada la zona que pudiera estar degradada por el efecto continuo de la exposición a la intemperie, o en pelladas más al interior si es posible). Hay que tener en cuenta la conveniencia de disponer, también en lo posible, de una pasta de recibido que sea dócil y plástica para conseguir una buena puesta en obra.

B) Estudio del ladrillo. El análisis mensiocronológico de las fábricas de ladrillo es un estudio fundamental para conocer realmente la fábrica que se debe sanar. En este caso es fundamental estudiar las partes en buen estado de la fábrica, para conocer las características de los ladrillos, su nivel de absorción, succión,

\footnotetext{
${ }^{27}$ AMOROSO G. G. (2002) Cap.2
} 
eflorescibilidad, resistencia a la comprensión, para que sean lo más parecidas posibles y compatibles con los de la obra a restaurar, intentando con ello que el comportamiento de estas nuevas piezas no difiera mucho respecto de las existentes.
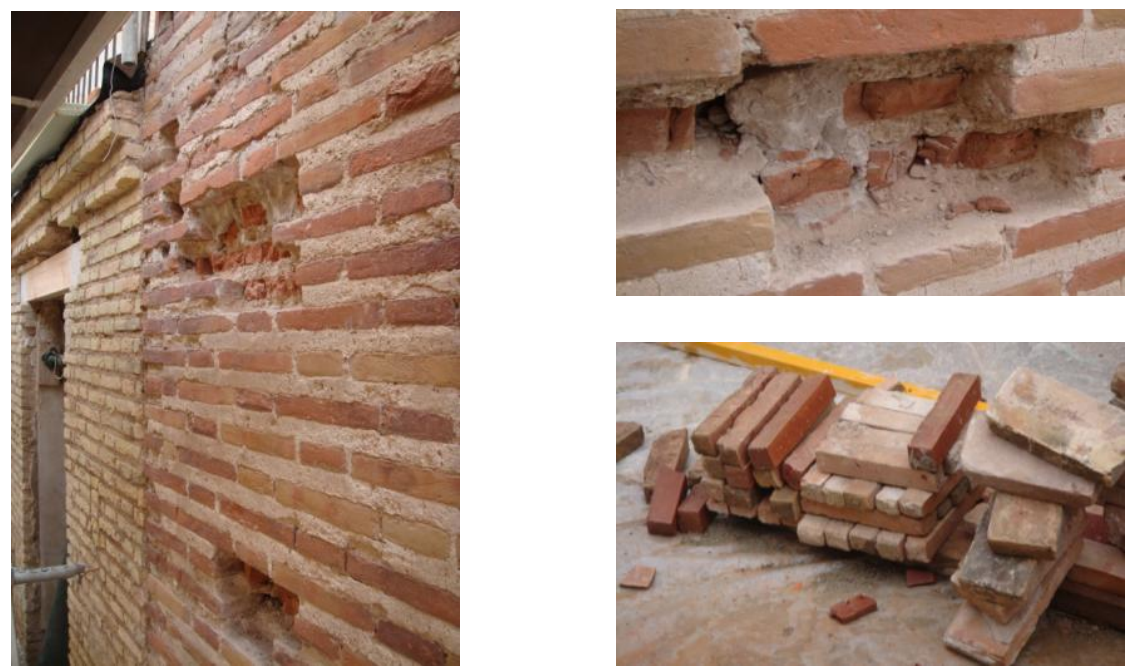

FIG. 127 Sustitución de piezas en viviendas de C/Roger de Flor n³9, Valencia (VEGAS-MILETO)

C) Dependiendo del tipo de fábrica que sea resistente o no, y del aparejo y ejecución prevista, se dispondrán los necesarios elementos estabilizadores externos como andamios y apeos. En cualquier caso, siempre que se pueda, se utilizaran medios manuales y ligeros para la preparación de la zona a intervenir, eliminando mediante picado todos los ladrillos que vayan a sustituirse y que habrán sido seleccionados y marcados previamente como ya se ha dicho.

La profundidad de la actuación será tal que se garantice la inalterabilidad de la restante obra de fábrica. Igualmente se sanearán o retirarán, en su caso, aquellos agentes del deterioro de la fábrica, si todavía existen. Lo ideal sería, una vez abierto el hueco necesario se procederá a su limpieza mediante la acción de aire comprimido que elimine el polvo formado, además de las partículas sueltas de la 
fábrica generadas en la operación anterior de saneo del material deteriorado.

Posteriormente se humectaría con agua la nueva superficie resultante de contacto, en proporción adecuada a las condiciones del resto de la fábrica de tal modo que ésta no cause una desecación indeseada de los nuevos morteros a aplicar, lo cual conduciría a problemas de fraguado y al no establecimiento de la interfase que nos garantice la necesaria adherencia y, por tanto, la estabilidad y continuidad en los elementos restituidos.

Se debe hacer un replanteo cuidadoso en cuanto a la necesaria planeidad o ligero retranqueado de la nueva fábrica, para controlar la formación de cejas y revirados de sogas y tizones, defectos que indicarían la falta de calidad de la reposición. El ladrillo no debe colocarse totalmente seco para evitar señales de humedad en los bordes a causa del agua del mortero. Igualmente este mortero deberá ser de manejo dócil para garantizar el relleno de todas las juntas entre piezas y el consiguiente "cierre "de toda la zona restaurada.

Existen varias maneras para obtener los ladrillos de sustitución: el ladrillo se puede obtener de las demoliciones de edificios, de la misma época y características similares. Si esto no fuera posible, se puede recurrir a su fabricación por los mismos procedimientos antiguos, de tejares tradicionales, realizando un análisis previo de sus componentes y sus propiedades para que difiera lo menos posible de los ladrillos originales.

Si bien compleja, otra solución sería utilizar el reverso de los ladrillos, pero realmente es un proceso difícil por lo que raramente se lleva a cabo. Cuando los ladrillos antiguos se reutilizan para reparaciones, deberían ensayarse previamente algunas muestras para determinar su contenido en sal y calidad. 
No deberían emplearse estos ladrillos en zonas expuestas a la humedad excesiva o a ciclos de agentes atmosféricos.

\subsubsection{Reparación de juntas ${ }^{28}$}

Cuando las juntas están fisuradas o constituyen una vía permanente de penetración de agua y de debilidad potencial de la estructura, así como cuando existía pérdida de mortero, es necesario realizar su reparación pormenorizada y selectiva.
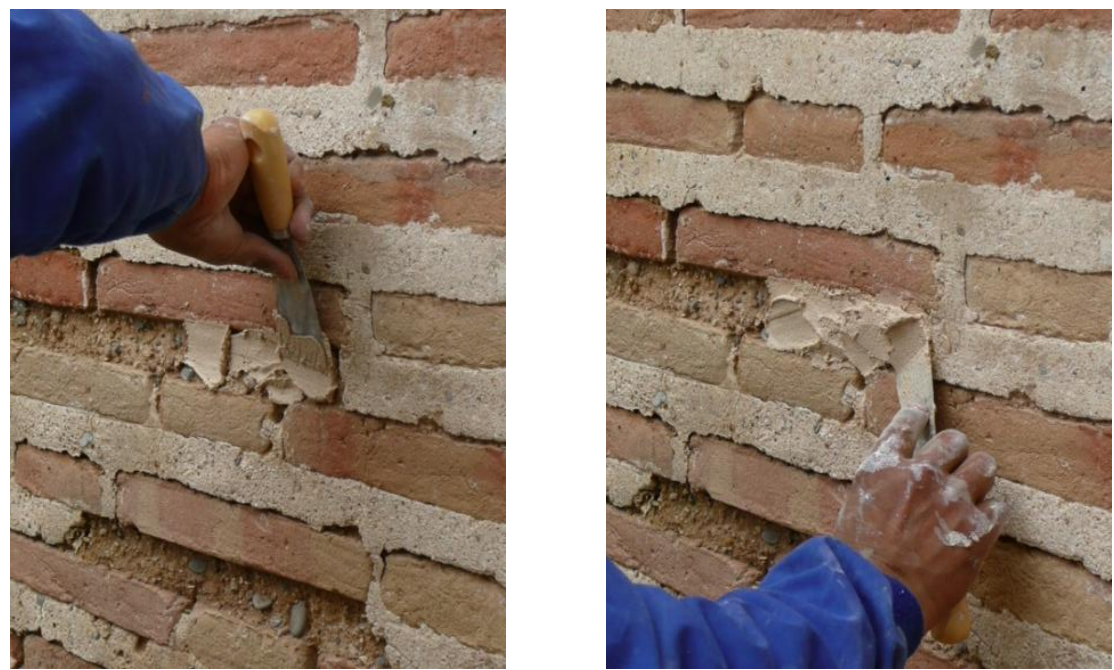

FIG. 128 Reparación de juntas, viviendas de C/Roger de Flor n³9, Valencia (CRISTINI)

En este caso la reparación de juntas y fisuras se puede llevar a cabo considerando los siguientes puntos:

A) Examen de la fábrica, análisis del mortero original y su disposición en el muro; si las cuestiones relativas al color, textura o disposición son variables y opinables, la resistencia a compresión del nuevo mortero y su composición química deben ser similares al

\footnotetext{
${ }^{28}$ FRANCESCHI S., GERMANI L (2007), p.121-132
} 
mortero existente, tanto para evitar tensiones localizadas, como para prevenir la presencia posible de sales y eflorescencias

B) Identificación de las juntas a reparar y selección de las juntas con niveles de degradación patológicos

C) Preparación de la junta dañada a reparar, eliminando unos milímetros de la misma, más o menos desde $15 \mathrm{~mm}$ hasta $40 \mathrm{~mm}$ para llegar al material sano. Se puede proceder de forma manual a sanear la llaga, mediante por ejemplo un punzón, o con cincel y martillo, eliminando los restos de mortero antiguo, sólo donde es estrictamente necesario
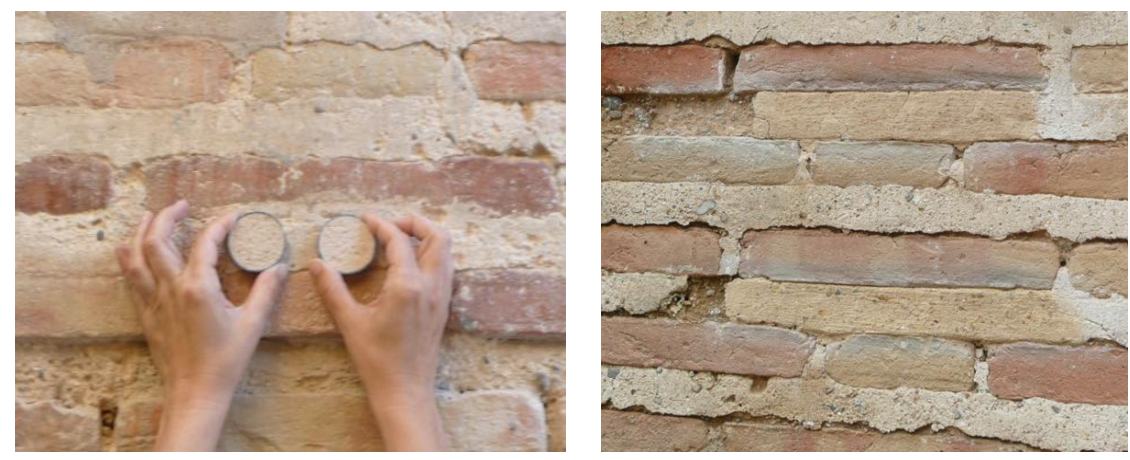

FIG. 129 Pruebas de entonado de morteros, viviendas C/Roger de Flor n³9, Valencia (CRISTINI)

D) Eliminación con cuidado de los restos de polvo y de material disgregado mediante métodos mecánicos, bien lavado con chorro de agua a baja presión, bien con aire comprimido e incluso humedeciendo someramente con agua

E) Humectación del soporte y colocación de nuevo mortero ejerciendo presión para lograr la adecuada compactación, bien con una herramienta adecuada, bien con una pistola de sellado para las partes menos delicadas. En general, se aconseja siempre el rejuntado a mano o herramienta de precisión 
F) Importante en el caso del ladrillo agramilado, respectar el sellado de las llagas, teniendo cuidado en la fase de limpieza final, de quitar los restos de mortero que rebosen.

\subsubsection{Reparación de fisuras}

Como una particularidad dentro de la técnica de reparación de juntas, se puede incluir la reparación de las fisuras, aunque previamente sería necesario el corregir la causa de fisuración. Una vez que se haya eliminado el motivo del problema y verificado que la fisura se encuentra estabilizada, se puede proceder a la fase de sellado de las fisuras.
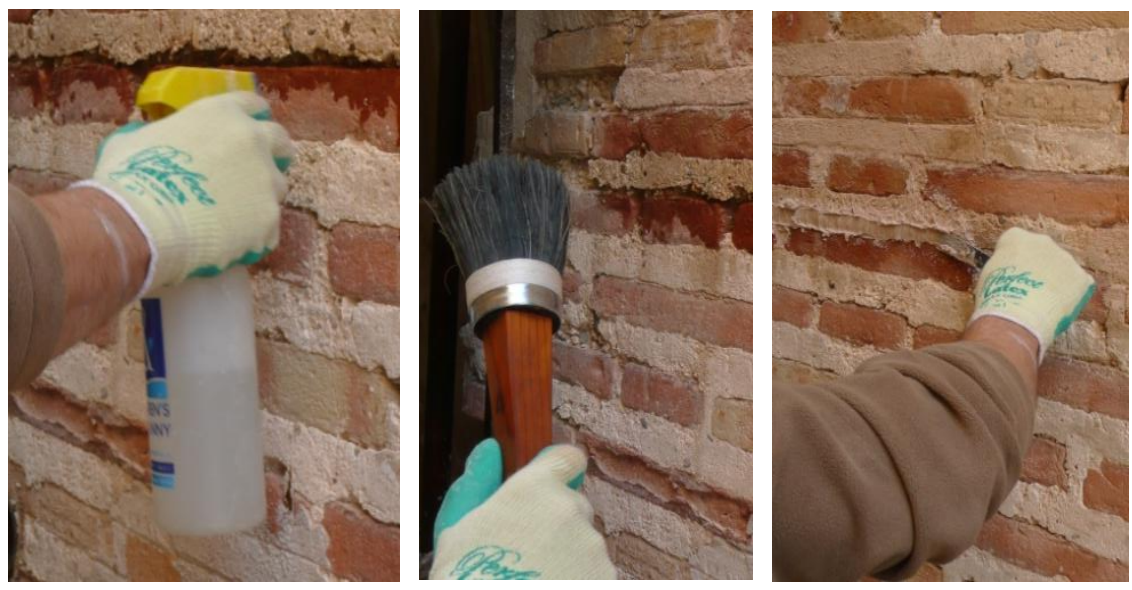

FIG. 130 Reparación de fisuras y perfiles de juntas históricas, viviendas de C/Roger de Flor n³9, Valencia (CRISTINI)

En aquellas piezas que estén fisuradas y donde exista peligro de desprendimiento de parte de las mismas o que generen inestabilidad, se puede recurrir, tanto a la sustitución parcial o total de las mismas como a su consolidación, atado o sellado, garantizando en ambos casos, el adecuado anclaje con el conjunto. En los casos en los que existan fisuras que recorran la fábrica de ladrillo bordeando las piezas, se repararan con el mortero adecuado que amortigüe los posibles movimientos de la misma y que impida la entrada de agua. 
En términos existen unos factores que se pueden considerar básicos en la fase de reparación de fisuras ${ }^{29}$.
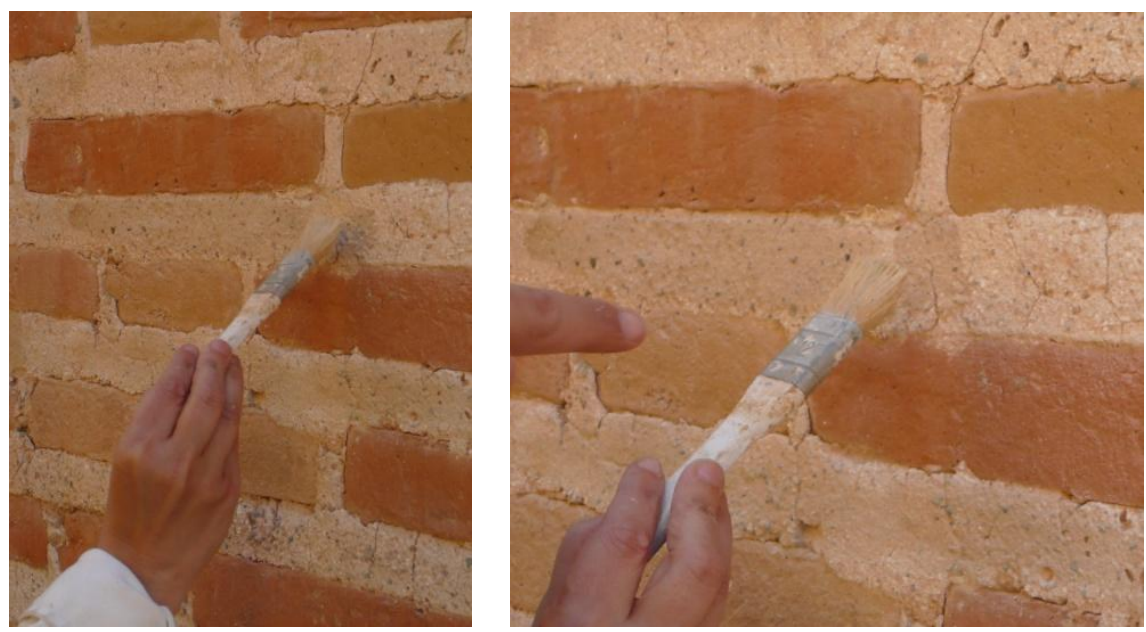

FIG. 131 Consolidación con agua de cal de micro fisuras, viviendas de C/Roger de Flor n³9, Valencia (CRISTINI)

A) Limpieza del interior y de los labios de la grieta

B) Aplicación de un mortero compatible con la dimensión de la fisura. En algún caso se puede aumentar dicho ancho o bien practicar unos orificios tendentes a facilitar la entrada y la inyección del mortero, si resulta estrictamente necesario por razones estructurales.

C) Inyección de mortero, más o menos fluido dependiendo del caso, compatible con el mortero pre existente (con cal, yeso o mezcla de los dos...). En casos de escasa adherencia con la superficie, se puede ponderar la posibilidad de añadir resina epoxi en muy bajo porcentaje.

D) Retacado superficial de la fisura, evitando emplear un producto elastómero para formalizar una junta de dilatación.

\footnotetext{
${ }^{29}$ ACCARDO G., VIGILIANO G., Strumenti e materiali del restauro, metodi di analisi misura e control/o, Kappa Ed., Roma, 1998, p.72-77
} 


\subsubsection{Protección final ${ }^{30}$.}

PROTECCIÓN CON BIOCIDA

PROTECCIÓN ANTIGRAFFITI

PROTECCIÓN CONTRA AVES

\section{Protección biocida}

Este acabado final permite tener un efecto preventivo de los defectos estéticos y destructivos que pueden originar a lo largo de los años musgos, líquenes, sobre todo en los alzados expuestos a norte o en los casos de trama urbana demasiado umbría y con poca ventilación. En este caso, la aplicación prevé una impregnación superficial del material soporte mediante una solución líquida que se introduce en el interior del material para proceder posteriormente a una aplicación de acabado o protección. Existe otra posibilidad que contempla la opción de aplicar el producto biocida junto con los consolidantes, hidrofugantes o pinturas. Sin embargo, a la vista del nivel de toxicidad de estos productos merece tener en cuenta la necesidad real de su aplicación en los casos de fábricas históricas a restaurar.

\section{Protección antigraffiti}

El carácter urbano de la labor propuesta tiene en cuenta la problemática bastante frecuente de deber proteger un edificio recién restaurado frente a los efectos de las pinturas de graffiti en las fachadas. La efectividad de productos protectores de fabricación industrial depende en gran medida del tipo de porosidad y textura del soporte. En general, los factores que se deberían tener en cuenta son la permeabilidad al vapor, la durabilidad, la inalterabilidad del color de la fábrica y la resistencia al envejecimiento. Existen unos productos incoloros, que dejan la superficie satinada $y$, tras su

\footnotetext{
${ }^{30}$ CANEVA G., NUGARI M.P., PINNA D., SALVATORI O., Il controllo del degrado biológico. I biocidi nel restauro dei materiali lapidei e intonaci, Nardini Ed., Firenze 1996, p.134
} 
aplicación, permiten eliminar las huellas pintadas mediante un sistema de limpieza en seco con cepillos. Por otro lado, hay también pinturas de poliuretano. Éstas se aplican como una impregnación sobre el material base, limpio de pintadas. Dejan la superficie un poco brillante $y$, sobre ella, se pueden aplicar productos disolventes y limpiadores.
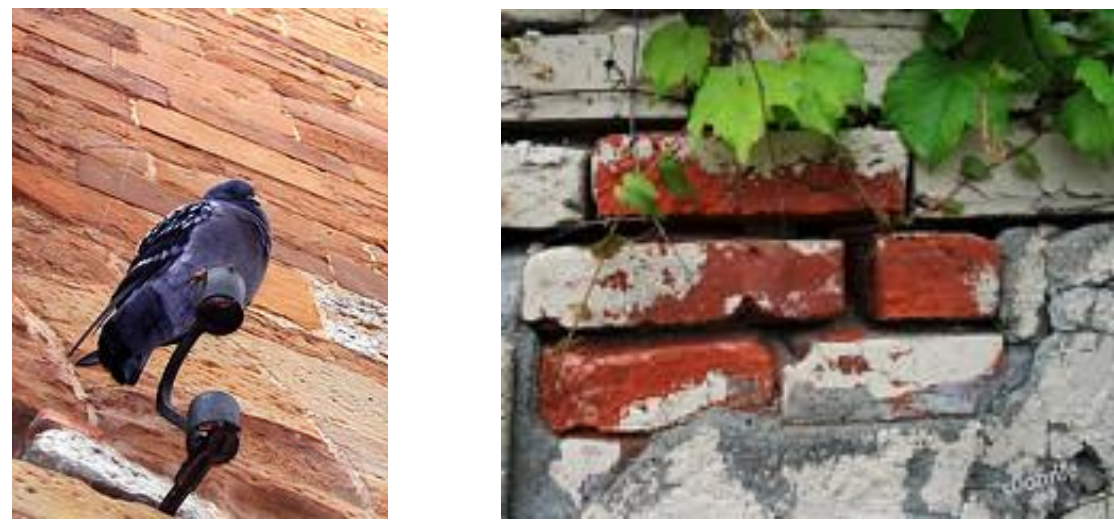

FIG. 132 Ejemplo de dos enemigos "históricos" de fábricas: aves y plantas trepadoras (CRISTINI)

\section{Protección contra aves}

Los excrementos de las aves son especialmente dañinos, no sólo estéticamente, sino también químicamente en combinación con la lluvia formando sustancias ácidas.

Los sistemas de protección para proteger los paramentos, sobre todo, en los casos especiales de fábricas monumentales, son en su mayoría físicos, y se emplean para impedir la nidificación y la aproximación de las aves a aquellas zonas de fachada que, por su geometría y exposición, se prevén propias para ello. En estos casos entran también los aparados más complejos de ultrasonidos y de producción de campos magnéticos que molestan y desorientan las aves. 


\subsection{Núcleo, conectores y costra: intervenir en fábricas de tapia valenciana}

\section{Construir un muro en tapia valenciana y/o restaurarlo i?}

La siguiente reflexión ha surgido a partir de una exigencia empírica de la autora, que proponía el análisis de las fábricas de tapia valenciana, focalizando la atención sobre todo en los conectores (ladrillos) y su rol en la traba del muro. Ahora bien, a la hora de analizar las fábricas, medirlas, dibujarlas... ha sido inevitable encontrase con diferentes casos restaurados, modificados, alterados con lógicas y criterios muy variables y heterogéneos.
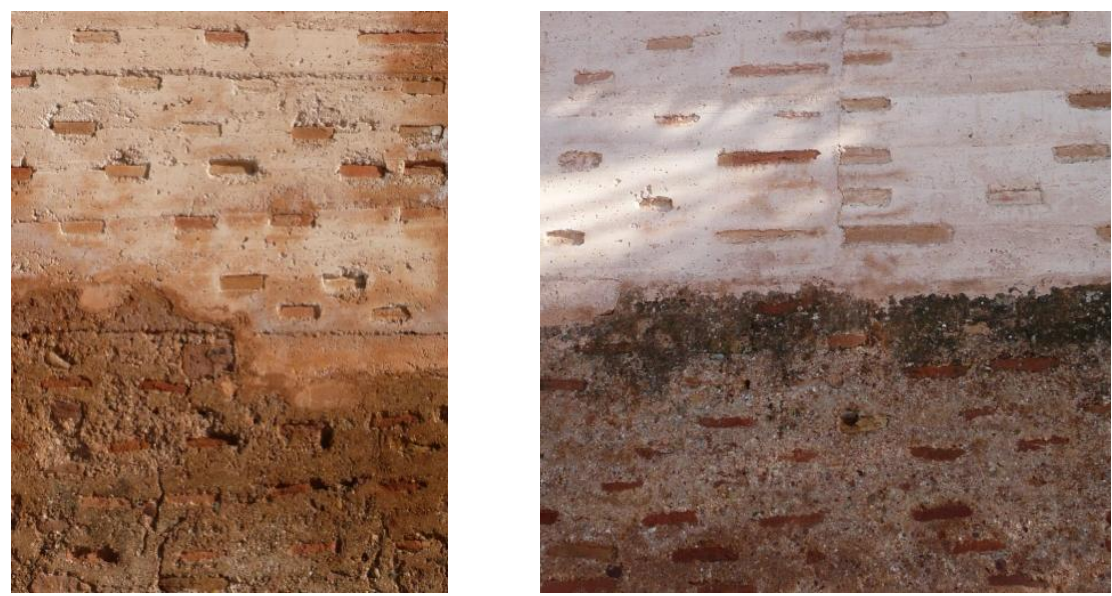

FIG. 133 Detalle de reconstrucción de fábricas de tapia valenciana, Mascarell, Castellón (CRISTINI)

De allí la idea de documentar estos casos, agrupando las diferentes opciones de intervención, con la finalidad de ordenar las posibles actuaciones e identificar líneas comunes y diferencias entre ellas. 


\section{El núcleo}

Las fábricas de tapia valenciana suelen tener grosores diferentes, debido al destino de uso de los edificios construidos, variando desde simples vallados y muros medianeros, hasta llegar al caso de murallas o muros de carga. Por esto podemos decir que de las tres variables que constituyen un muro de este tipo (núcleo, conectores y costra) el núcleo de argamasa es realmente la componente que puede variar más según los casos de estudio, tanto por su profundidad, como por su composición (ligantes y/o áridos).
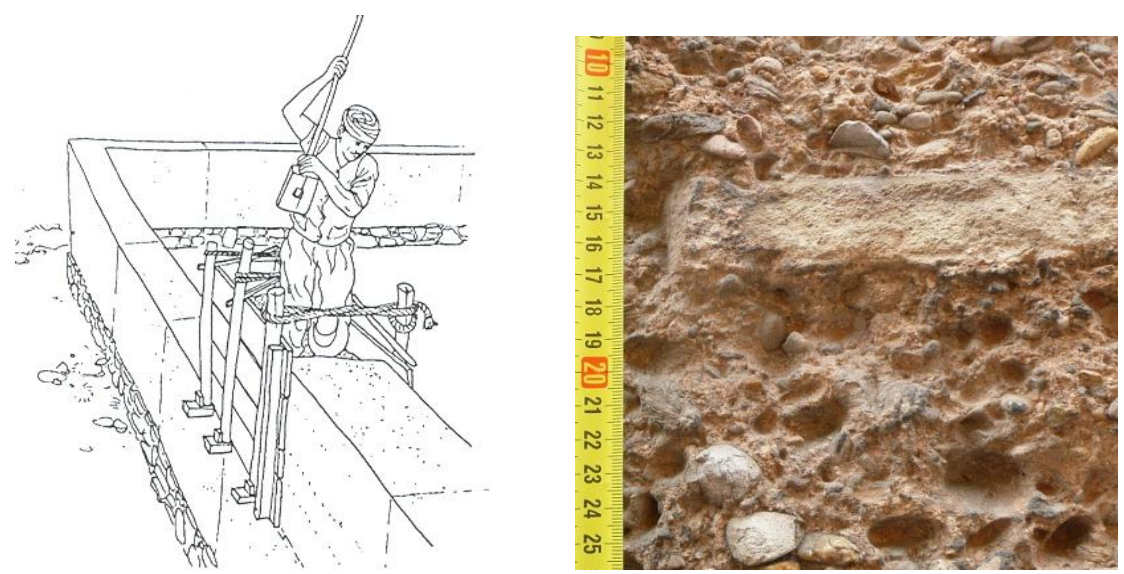

FIG. 134 Tapial, encofrado en el que se apisonan argamasa de tierra, cal y grava en estratos regulares (ADAM-CRISTINI)

\section{Los conectores}

Los ladrillos, en el caso de fábricas de este tipo, no son realmente aparejados, sino más bien piezas dispuestas en el encofrado, en cada tongada, de forma no aleatoria, siempre próximos a los tableros laterales.

Los conectores son siempre heterogéneos, tanto por color, como por dimensiones, materias primas y textura. En algunas ocasiones se pueden encontrar piezas de ladrillo parcialmente fragmentadas, aspecto que también contribuye a establecer posibles hipótesis sobre el re-empleo de materiales de construcción. Otro aspecto que siempre se repite en los casos estudiados es la aureola de costra 
perimetral alrededor de los ladrillos. Los conectores quedan retranqueados, invariablemente embebido en la costra. Ahora bien, la presencia de los ladrillos, casi siempre a tizón, puede presentarse, especialmente en machones, esquinas o contrafuertes, con disposición a soga o soga tizón.
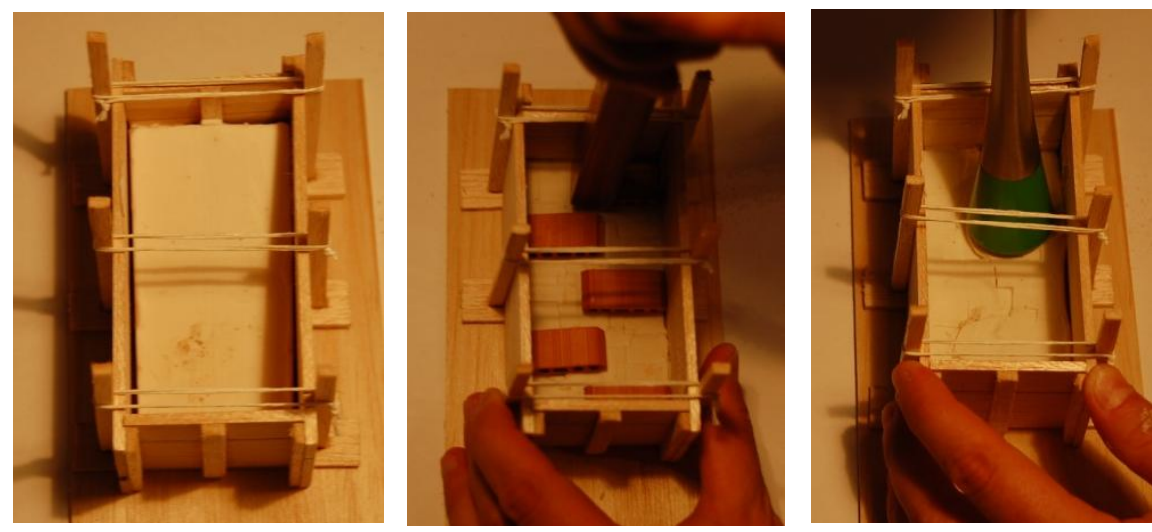

FIG. 135 Esquema de apisonado en con estratos de argamasa y refuerzo de ladrillos (CRISTINI)

\section{La costra}

Como anticipado en el punto anterior la costra de cal que sella la superficie del muro se realiza por una combinación de rebosado de las tongadas apisonadas. La distribución de los ladrillos y el grosor así como los constituyentes de la costra no varían según el grosor del muro y su destinación de uso; más bien la costra puede presentar áridos más finos y tamizados, y cal más grasa...pero siempre el acabado de las fábricas es el mismo.

Sin duda el hecho que las fábricas constituyan un "todo en uno", o sea, un proceso constructivo determinado por una única operación secuenciada (apisonado rítmico de tongadas entre tableros, con distribución de conectores y desmoldado del tapial) hace inevitable una reflexión sobre la posible intervención a posteriori en las fábricas, y sobre las posibles posturas de actuación. 
Es difícil encontrar fábricas de tapia valenciana que no hayan sido intervenidas, que mantengan viva su vigencia sin cuadros patológicos marcados y que puedan servir como base de estudio de la técnica. Ahora bien, justo por esto, los autores han ido apoyándose en las diferentes intervenciones, que en parte han ayudado a comprender la técnica constructiva y su lógica.
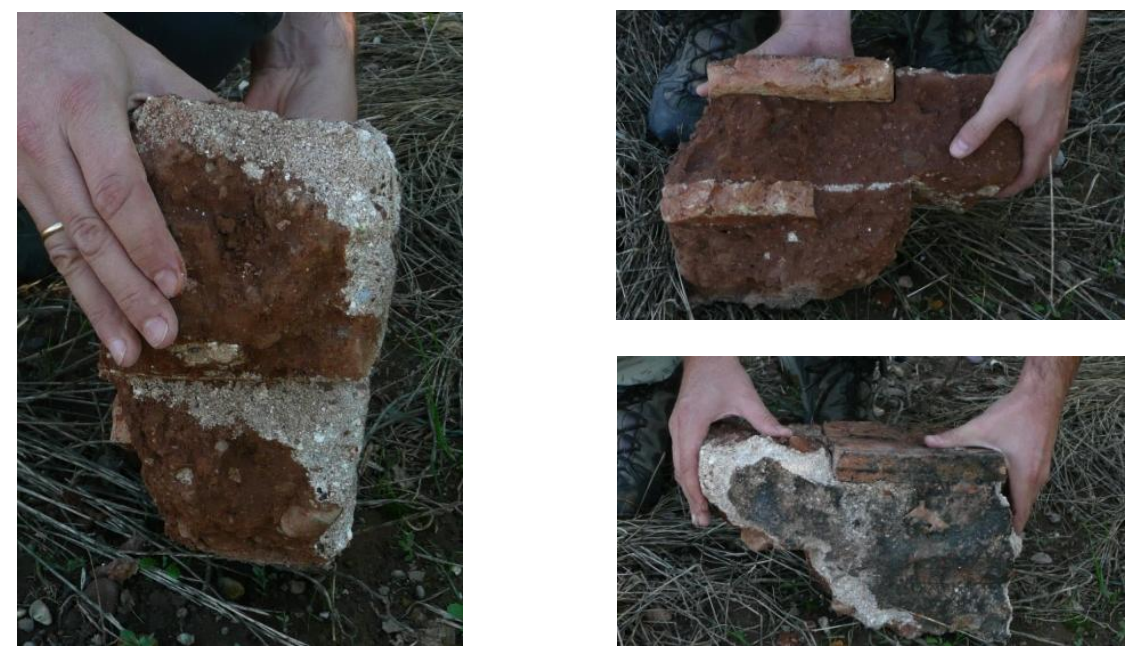

FIG. 136 Detalles de distintos tipos de costras en fábricas de tapia valenciana (CRISTINI)

\section{Análisis de las intervenciones}

Los principales muros analizados, tras las intervenciones, muestran operaciones realizadas principalmente en las costras. Se trata en muchos casos de enfoscados, tratamientos anti grafitis, embadurnados...que actúan en muchos casos en la "superficie de sacrificio" de los muros, sustituyendo o cubriendo la superficie primigenia. Pocos casos muestran simple consolidación de la epidermis, con procesos de sellado de micro-fisuras y discontinuidades. Realmente la intervención en la costra, que se realiza en muchos casos picando el acabado inicial y ocultado la fábrica, es también debida al hecho que estos tipos de muro, históricamente no gozan de extenso consenso estético. 
Se trata de superficies bastante irregulares, típicamente asociadas a estructuras humildes, y por lo tanto menos "dignas" que las más regulares fábricas de ladrillo cara vista.

Este proceso, finalizado tras la ocultación de las fábricas, con acabados mates, se ha llevado a cabo para mejorar el decoro de las superficies (en muchos casos de edificios hoy en día monumentales), y ha sido una práctica ampliamente aceptada en los últimos años. Estas praxis, según el material empleado (más o menos compatible con el soporte) ha dado origen a acabados mejor adheridos o tal vez, en algunos casos sujetos a pulverización, desconchados y erosiones.
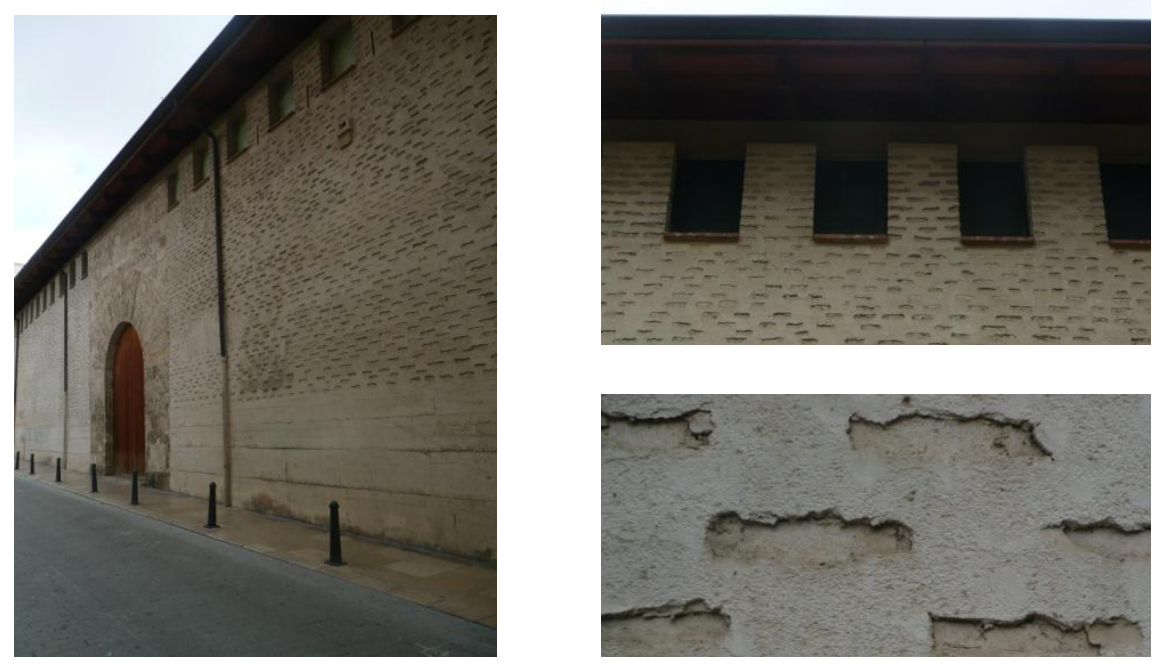

FIG. 137 Detalles de tapia valenciana restaurada, Almudín, Valencia, ficha Xc 96 (CRISTINI)

En algunos casos, además, la textura original de la fábrica ha sugerido acabados ritmados, que simulan la trama de la tapia, que se inspiran a ella, con resultados más o menos logrados. Plantillas de decoración y búsqueda de grafismos han caracterizado algunas intervenciones contemporáneas, en búsqueda de trazados abstractos que recuerdan y simulan el despiece de los ladrillos. 
Otras intervenciones, más estructurales proceden a sustituir parte de los conectores, típicamente los más degradados y descamados, extrayendo los elementos alterados y re-emplazando por piezas de ladrillo. En este caso también las operaciones pueden ser más o menos compatibles con el soporte (emplear ladrillos de recuperación, o macizos artesanales, entonados por tamaño, color y textura...) actuando en la capa exterior, la costra. En este caso las intervenciones proporcionan zurcidos de morteros en las zonas próximas a los ladrillos, con una operación llevada a cabo tras la colocación de los conectores.
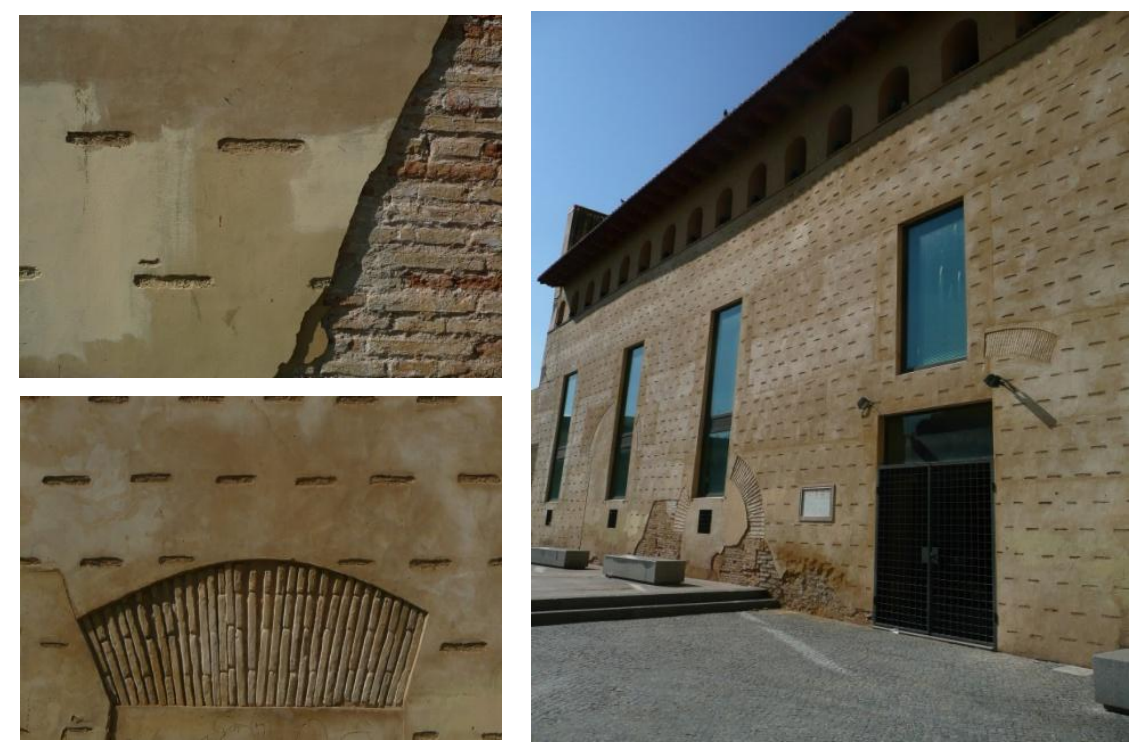

FIG. 138 Simulación de tapia valenciana, Gremio de Carpinteros, Valencia, ficha Va34 (CRISTINI)

Menos comunes son los casos de intervención en el núcleo. La profundidad de estos tipos de intervenciones ya requiere un cambio de registro, tratándose más bien de reconstrucciones volumétricas. Sin duda estos casos contemplan un porcentaje de pérdida de fábrica histórica mucho más marcada, en muchos casos recuperada en masa, sin la presencia de ladrillos/conectores. Estos casos son los que suelen presentar encofrados exnovo para los muros (tanto a una 
cara como a doble cara) con morteros de diferente composición, textura o retranqueos, solapes y recortes con la pre-existencia.

Tras estas observaciones se pueden establecer nuevos límites, retos... que marquen propuestas para restaurar de manera unitaria las partes constituyentes de las fábricas de tapia valenciana.
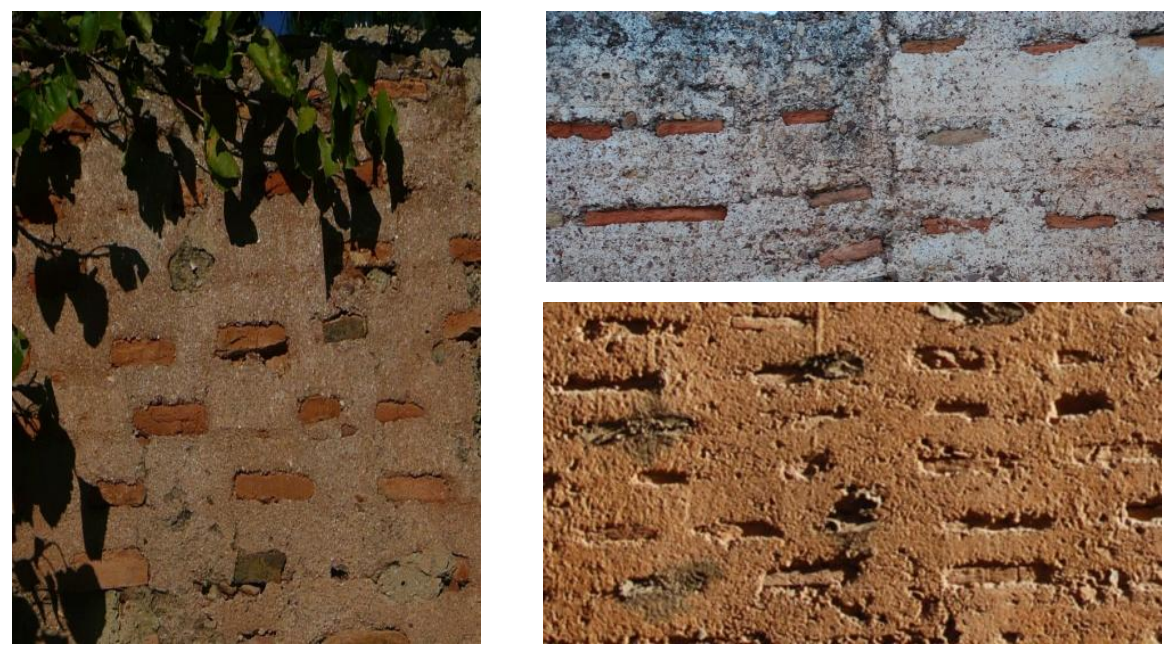

FIG. 139 Costras de tapia valenciana con acabados históricos, Iglesia de S. Jaume Fadrell, Castillo de Vilavella y Alqueria Carmona, Castellón (CRISTINI)

Pero, ¿por qué resulta tan complicado intervenir en este sistema tripartito, de núcleo/conectores y costra? Tal vez, para responder a la pregunta, tenemos que volver otra vez a la comprensión de la propia técnica. La tapia valenciana, realizada por tres materiales diferentes, argamasa, arcilla cocida y mortero, debe sus características a la presencia de los ladrillos. Justo estos elementos, que en parte contribuyen en la absorción de posibles esfuerzos rasantes, son los que desempeñan un papel fundamental en el muro. Son, como se ha explicado previamente los auténticos conectores, que unen la costra con el núcleo; fijando la partes y contribuyendo a solidarizar la piel exterior con el interior. Intervenir en un muro de tapia valenciana significa intervenir en una fábrica de argamasa que presenta un encofrado perdido adherido a ella. Justo este molde, realizado a partir de un claro binomio ladrillos/costra, es el que permite una 
digna protección del núcleo, siendo esta la parte más vulnerable de los muros.

\section{Conclusiones}

Las intervenciones analizadas en fábricas de tapia valenciana suelen responder a criterios, muchas veces guiados por el nivel de degradación de la fábrica y otras, por el cambio de uso, del que es objeto el conjunto. El grado de actuación va desde operaciones de mínima intervención (como consolidación/retacado de costras) acciones de sustitución/reparación de partes (relevo, renueve o suplemento tanto de ladrillos como de pieles) hasta otras más contundentes de reconstrucción volumétrica.
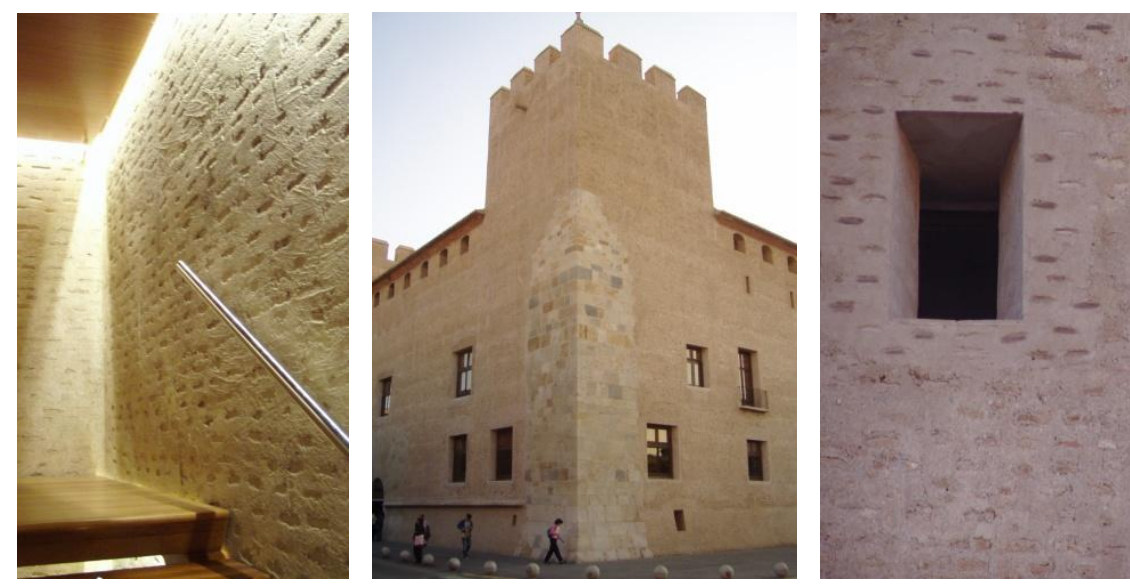

FIG. 140 Tapia valenciana restaurada, Castillo de Alaquàs, Valencia (CRISTINI)

Por lo tanto, podemos afirmar que la intensidad de la intervención es mayor cuanto mayor es su profundidad hacia el núcleo. Ahora bien, si consideramos la fábrica de tapia valenciana como una pared con encofrado perdido, aglutinado y solidario, la lectura de la técnica y de las posibles intervenciones cambia. Actuar en un encofrado incorporado a la pared (dado por el sistema ladrillos/costra) es una operación extremadamente delicada, que parte del presupuesto que el sistema funciona como un "todo". Podemos, entonces, considerar dos extremos: por un lado la mínima intervención, que apenas fija la 
milimétrica costra de la piel de las fábricas y se preocupa en garantizar su adhesión...y por otro lado podemos definir la reconstrucción volumétrica, de partes ex novo.
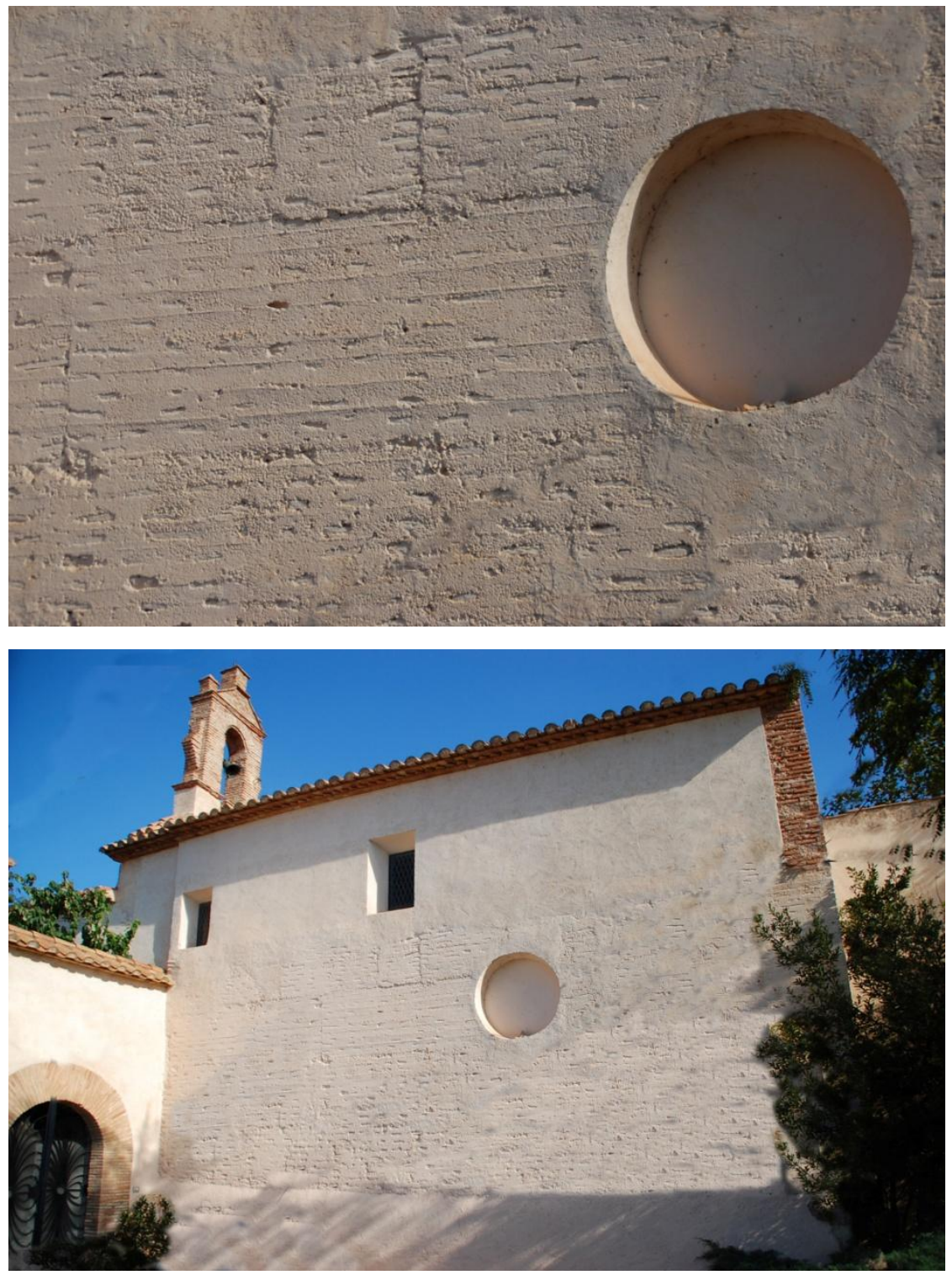

FIG. 141 Ejemplo de tratamiento de superficie; encalado en una fábrica de tapia valenciana, S. Jaume de Fadrell, Castellón. (CRISTINI) 
Así una intervención "intermedia", que proponga cambios en las claves cerámicas (remoción, sustitución, reparación o adición...) sea posiblemente la más delicada. Ya que el riesgo de desligar las partes es más alto, los elementos cerámicos tienden a arrastrar con ellos parte de la argamasa, el mortero de reparación acaba siendo heterogéneo tanto respecto al núcleo como al acabado. El riesgo de pérdida de adhesión es más marcado, así como la sujeción de las partes es más débil.
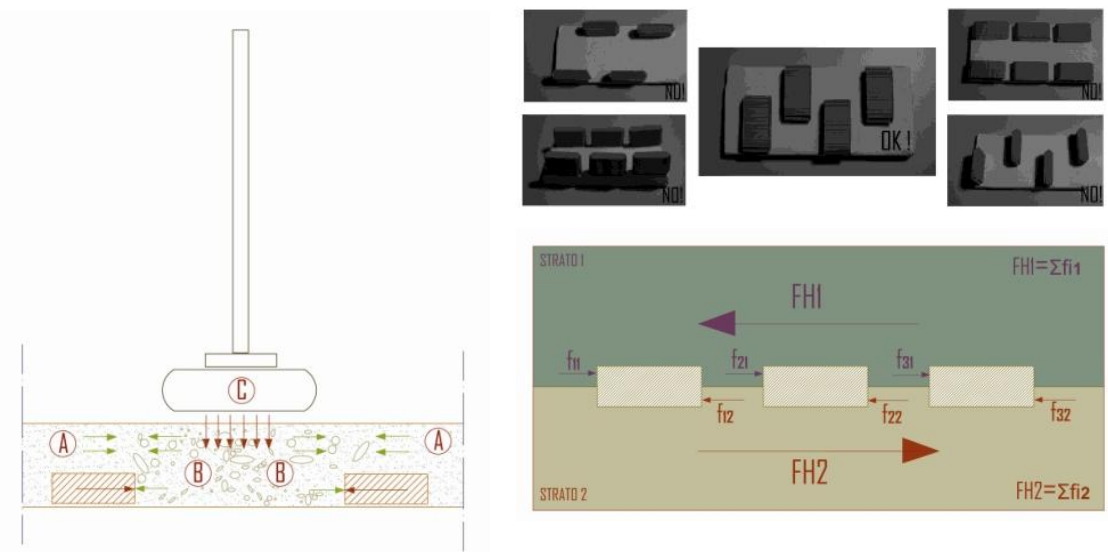

FIG. 142 Rol de los conectores dentro del sistema "tapia valenciana". Su correcta posición absorbe esfuerzos rasantes, aspecto importante a considerar en las intervenciones (CRISTINI)

Las intervenciones en las costras, en muchos casos de sustitución y picado, no siempre se calibran en relación con el grosor de las paredes. En algunos casos muros de carga de más de $60 \mathrm{~cm}$ de grosor viven espolios de pieles y rejuntados, más bien debido a operaciones de decoro urbano o de ámbito proyectual. Esta reflexión sobre los criterios de intervención en estas fábricas, propone un cuadro relativo a operaciones realizadas en los edificios, sin ánimo de crítica, sino más bien de puesta en común de actuaciones y de comprensión de las mismas en relación a la lógica constructiva de la técnica. 
murOSINTRAmurOS

7. Conclusiones 



\subsection{Sincronías y diacronías técnico/tipológicas}

El balance definitivo del análisis relativo de 95 fábricas históricas distribuidas en los cinco barrios del centro de la ciudad (Carmen, Velluteres, La Seu-Xerea, San Francesc y Mercat), podría definirse como un gran mosaico constituido por testigos en la historia de la construcción.
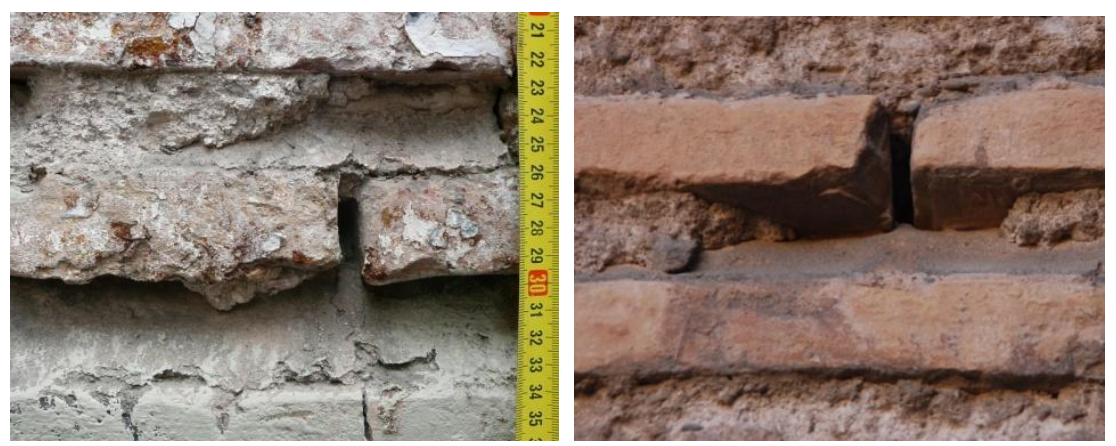

FIG. 142 Secuencia de juntas estructurales y de acabado, Capilla de la Iglesia de S. Juanes, ficha Me212a y Vivienda C/Quart n²16, ficha Cb55 (CRISTINI)

Estas fábricas, a pesar de ser restauraciones más o menos afortunadas, son huellas vigentes de una profunda estratificación constructiva, que permite definir un cuadro evolutivo, marcado más por pasos fluidos que por drásticas interrupciones.

La evolución de estas fábricas en Valencia se acompaña por un amplio conjunto de factores. Por ello, a medida que el estudio avanza, van mezclándose y solapándose técnicas, modas, exigencias económicas, realidades sociales e históricas. 


\section{murOSINTRAMUROS}

En biología, el cambio de piel es un hecho conocido y periódico, y esto se hace proporcionalmente al crecimiento del animal. Este proceso tiene múltiples componentes, ya que su función es doble, reparar heridas y librarse de parásitos externos. La renovación periódica ha convertido a algunos de estos animales, como los reptiles, hasta en un símbolo de salud (en medicina, en la vara de Asclepio, por ejemplo, una serpiente entrelazada alrededor del bastón simboliza, el rejuvenecimiento, debido a la periódica muda de tejidos).

De la misma forma, los muros viven cambios, a lo largo de la historia, que no necesariamente coinciden con evoluciones o retrocesos técnicos, sino más bien con "simples" transformaciones. Las fábricas cambian sus pieles, crecen, se trasforman, o dejan restos.

Son pasos que recuerdan un proceso biológico...que básicamente se resume en acciones constructivas que visten o desnudan las fábricas a lo largo de ciclos de intervenciones coherentes con cuadros socio/económicos específicos.

La arcilla constituye la materia prima básica de los muros de adobe, presentes en el tejido urbano, desde la fundación romana de la ciudad. Como en otras zonas de España, la arquitectura popular y doméstica, es decir la más humilde confía su solidez en estos elementos constructivos. Por ello el adobe sigue marcando una trayectoria en la arquitectura urbana ordinaria, sobre todo, hasta el final de la Edad Media. Se debe reconocer a la vez, que el empleo del ladrillo en la Valencia romana, es bastante tímido, y limitado a lugares específicos. Los datos arqueológicos proporcionados por el Servicio Arqueológico Municipal apuntan a la piedra, para estructuras públicas y al ladrillo sólo para infraestructuras hidráulicas (alcantarillado, pozos, suspensurae, acabados en opus signinum, etc...) y arquitectura funeraria (tejas y ladrillos para sepulturas). 
Se debe esperar a los siglos $\vee$ y VI para observar como en la ciudad poco a poco se empiezan a erigir las primeras fábricas de ladrillo, bajo la influencia de la cultura bizantina. Una tecnología por otro lado, marginal a todos los efectos. Este proceso es claramente significativo tras la ocupación islámica de la ciudad (S. VIII-XIII) cuando el adobe y tapia prevalecen sobre el empleo de ladrillo.

Argamasa apisonada, con piedra, cal y tierra se muestra como el elemento constructivo estrella en la arquitectura monumental y militar, dejando más bien al adobe un rol clave en la arquitectura doméstica. Realmente, es sólo con la reconquista cristiana de la ciudad, cuando el ladrillo empieza a ser protagonista de la arquitectura doméstica y de las obras públicas, de la mano de la Fábrica de Murs y Vals (institución pública de la Valencia medieval encargada de la construcción y del mantenimiento de murallas, caminos, puentes e infraestructuras hidráulicas). Se puede apuntar, como a nivel constructivo, las bóvedas tabicadas, los arcos diafragmas y la tapia valenciana marcan el avance de las tropas cristianas. Precisamente, los siglos XV y XVI destacan especialmente por las construcciones con tapia valenciana. Posteriormente, se registra un lento declive de la técnica, que comienza con la expulsión de los moriscos y culmina a finales del siglo XVII. La tapia cede el testigo a las fábricas de ladrillo agramilado, con doble junta, de asiento y de acabado con veladuras, que caracterizará importantes edificios religiosos de la conocida Valencia conventual (S. XVII).

El agramilado o el ladrillo visible como se ha indicado en los capítulos previos, ahonda sus raíces en el pasado constructivo de la ciudad, posiblemente en las fábricas bizantinas con gruesas juntas, y se afirma como una técnica totalmente autóctona. De hecho el grosor de las juntas responde de forma eficaz a los posibles asientos diferenciales producidos bien por la deficiente distribución de cargas del subsuelo (hay que recordar que en la ciudad de Valencia está compuesto por sedimentos en los estratos superficiales y que estos podrían ser responsable de posibles asientos diferenciales), o por una 


\section{murOSINTRAMUROS}

deficiente distribución de cargas en la propia fábrica. Si la tapia valenciana coincide con los años de la reconquista cristiana y el definitivo enraizamiento de la cultura cristiana en la ciudad, las fábricas con ladrillo agramilado reflejan la arquitectura contrarreformista y por tanto, ligada a una rígida lógica litúrgica.

Sólo tras la influencia borbónica, a partir del siglo XVIII, los gustos constructivos cambian y se refinan. Las fábricas buscan un lenguaje más señorial, con ladrillo fingido, ladrillo aplantillado y arquitectura bícroma. A partir del siglo XVIII, el ladrillo adquiere un nuevo status, tras unos intentos pioneros en la ciudad, dado por algunos edificios renacentistas (entre ellos los destacados conjuntos del Patriarca y de S. Miguel de los Reyes). La nueva regularidad geométrica derivada de una producción estandarizada permite al ladrillo aspirar a convertirse en un lenguaje constructivo autónomo.
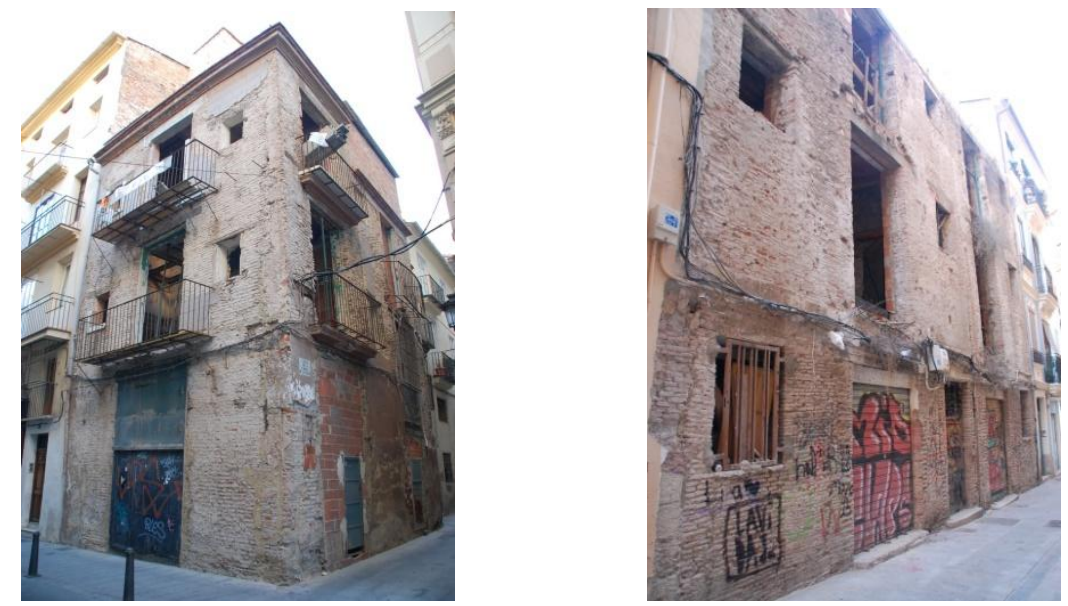

FIG. 143 Efecto "scraping", muy común en edificios de viviendas sin alto grado de protección.

Edificio en la C/Avellanas n5, ficha Xe 14 y viviendas C/Belén n7, ficha Ma48 (CRISTINI)

La mejora en las técnicas permite al ladrillo convertirse en un material noble, susceptible de ser empleado en edificios públicos, útil también para decorar y plasmar superficies. A finales del siglo XIX, el ladrillo vidriado y a cara vista forma parte de las construcciones eclécticas de 
los ensanches urbanos y las nuevas avenidas que se abren intramuros.

A pesar de los cambios, se debe reconocer una sabia lógica constructiva detrás de la historia de las fábricas en el centro histórico de la ciudad. Nada se elimina, todo se trasforma. Existen fábricas que pasan de la etapa agramilada a la fingida o enlucida; tapia valenciana o fingidos que se revocan; o edificios hoy en día a cara vista que estaban ocultos hasta tiempos recientes por sucesión de acabados. En muchos casos, las soluciones constructivas florecen la una sobre la otra, en una secuencia de muda codificada.

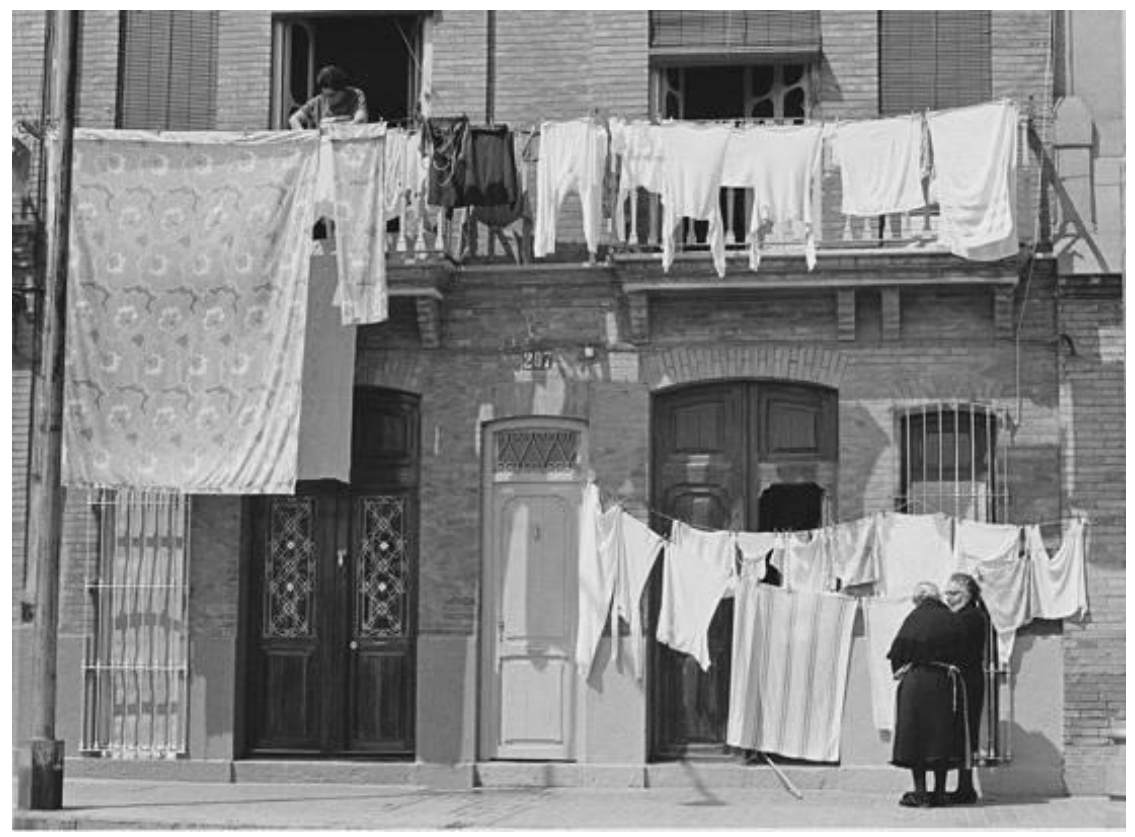

FIG. 144 Fábricas de ladrillos en el barrio del Carmen, principio S. XIX (VIDAL)

Sólo algunas intervenciones recientes alteran esta lógica constructiva. De hecho, se aprecia como algunas fábricas agramiladas o fingidas se "desnudan" y se transforman en vistas. O al contrario, un perverso pudor lleva también a enlucir y ocultar fábricas, sean estas de tapia valenciana o de ladrillo. 
Estos continuos cambios producidos en el "exoesqueleto" de las fábricas valencianas forman una secuencia de pasajes derramados en el tiempo. No se trata de cambios drásticos de lenguaje, sino que las técnicas conviven entre ellas, con puntos de inflexión históricos y económicos (como por ejemplo la reconquista cristina, la expulsión de los moriscos, la Contrarreforma, la llegada de los Borbones...). Se marcan importantes cambios de dirección, alteraciones en la evolución de las fábricas. Por todo ello, no se puede definir de forma encorsetada una secuencia propia de fábricas urbanas. Se trata más bien de un puzle de pautas y directrices, hibridas y macladas, lleno de matices técnicos y revivals estéticos.

Se obtiene así un cuadro tejido por una madeja de hilos diversos, que no coincide con evoluciones o involuciones, sino más bien con metamorfosis, saludables mudas diluidas en el tiempo, que hacen de las fábricas un inagotable tema de estudio.

La especulación y la falta de medidas de protección sobre la arquitectura histórica urbana, han coayudvado a distorsionar estas lógicas constructivas. En muchos casos, las intervenciones recientes han dejado escasas huellas que ofrezcan una clara comprensión de las fábricas de ladrillo. Una de estas huellas podrían ser las sutiles relaciones entre ladrillos y juntas. Pero las fábricas tradicionales siguen corriendo un alto riesgo, derivado del escaso conocimiento que de los caracteres constructivos más autóctonos se tiene. El objetivo del estudio, por ello, es también contribuir a una lectura completa de fábricas, estableciendo sinergias hacia la plena comprensión de posibles sincronías y diacronías constructivas, no solo centrada en la mera percepción de la epidermis. 


\subsection{Elaboración de una curva mensiocronológica}

Como se ha indicado en el planteamiento metodológico, la aplicación de la mensiocronología a las fábricas del centro histórico de la ciudad de Valencia permite relacionar las dimensiones de los ladrillos (longitud, anchura, grosor) a específicas curvas evolutivas que unen las variaciones métricas con indicadores cronológicos.

Realmente los datos métricos no presentan variaciones tan marcadas, como en otros contextos donde el método mensiocronológico se ha aplicado ${ }^{1}$. Las variaciones en los siglos, en muchos casos, son más bien milimétricas, haciendo complejo emplear cómo únicos discriminadores del estudio los datos métricos y temporales. Según los datos aportados en el texto, las modificaciones mínimas en la producción de los ladrillos son posiblemente debidas al control continuo ejercitado en la ciudad sobre su producción, su comercio y su puesta en obra. ${ }^{2}$ En los siglos las producciones cerámicas se regulan y fiscalizan a través figuras como las del Magister romano, el Muhtasib musulman, el Mustaçaf cristiano, el iluminado Fiel Almotacén Provincialy finalmente el decimonónico Fiel Contraste de Pesas y Medidas. Además hay también constancia de un continuo reciclaje y mestizaje tecnológico a nivel productivo, marcado por hallazgos arqueológicos ${ }^{3}$ que señalan un continum evolutivo entre la alfarería íbera, romana, musulmana y cristiana. Los cambios tecnológicos que no son drásticos, sino más bien fluidos en el

\footnotetext{
${ }^{1}$ Véase" Cap. 2.2.1 La mensiocronología"

2 Véase "Cap. 4.3 Vendedores y controladores: mercado y comercio"

3 Véase" AnejoII.1.1 Extractos de informes arqueológicos"
} 
tiempo, contribuyendo estos a definir una sustancial homogeneidad productiva, que se refleja en la curva mensiocronológica. Asimismo, la pertinaz constancia del sistema métrico en el tiempo ${ }^{4}$ contribuye a la homogeneidad indicada en las variaciones dimensionales.

\section{Análisis mensiocronológico}

Se ha procedido a la selección y clasificación de los datos, filtrando entre los 95 ejemplos destacados que tenían fábricas de ladrillos, los 45 casos de estudio con fechas documentables ${ }^{5}$.

\section{Barrio del Carmen: fábricas con fechas documentadas}

\section{Ca113; Ca118; Ce71; Cg01a; Cg01b; Cg02; Cg14}

\section{Barrio de S. Francesc: fábricas con fechas documentadas}

Fa39; Fa82; Fa105; Fa153a ;Fa153b ;Fa153c ;Fb117

\section{Barrio del Mercat: fábricas con fechas documentadas}

Ma28; Ma31; Ma54; Ma92; Ma93; Mb72; Mb155; Me212a

\section{Barrio de Velluters: fábricas con fechas documentadas}

Va34;Va81a; Va81b;Va82;Va103a;Va103b;Va104;Vb67;Vb68;Vb69

\section{Barrio de la Seu-Xera: fábricas con fechas documentadas}

Xa46; Xc16a; Xc16b; Xc16c; Xc96a; Xc96b; Xd13; Xd54a; Xd54b; $\mathrm{Xd65;}$ Xe66; Xf25; Xf26

Tras esta primera selección se ha podido comprobar que hoy en día, en la trama urbana intramuros de Valencia, quedan 45 ejemplos tangibles de fábricas de ladrillo pre industrial, espaciados desde el siglo XV hasta la segunda mitad del siglo XIX.

\footnotetext{
${ }^{4} 1$ palmo $(23 \mathrm{~cm})$ se divide en 12 dedos; 1 dedo $(2 \mathrm{~cm})$ se subdivide en 12 líneas; 1 línea (1.6 mm). Op. Cit. LÓPEZ GONZÁLEZ, GARCÍA VALLDECABRES (1999)

${ }^{5}$ AA. VV., Guía de Arquitectura de Valencia, Ícaro Ed., Valencia, 2007
} 
Con más detalle podemos resumir:

\section{S. XV (con posibles intervenciones en S. XVI)}

Mb72 Xc96a Va34 Xc96b Xa46 Va81b Ca113 Cg01a Fa82

\section{S. XVII (primera mitad)}

Fa153b Fa153c Xd13 Cg01b Ma54 Me212a Xd65

\section{S. XVII (segunda mitad)}

Xe66 Ma92 Fa105 Vb67

S. XVIII (primera mitad)

Xf26 Ce71 Fa153a Va103a Va82 Va103b Fb117 Va81a

\section{S. XVIII (segunda mitad)}

Ma93 Vb68 Vb69 Xf25 Xd54a Xd54b Cg02

\section{S. XIX (primera mitad)}

Mb155 Xc16a Xc16b Xc16c

\section{S. XIX (segunda mitad)}

\section{Ca118 Ma28 Ma31 Fa39}

A estos datos se añaden las informaciones métricas procedentes de las 19 fichas arqueológicas que, aunque de forma más general, pueden contribuir a mejorar pautas dimensionales. No es oportuno emplear datos tan inciertos en la curva métrica principal; hay que considerar que los ladrillos documentados en excavaciones arqueológicas, hoy en día almacenados en el archivo del SIAM, no proceden de un análisis directo realizado por la autora. El empleo de estos ladrillos está apenas documentado en los extractos arqueológicos, por lo tanto se ha considerado oportuno incluir estas 
informaciones de manera independiente, no siendo suficientes estos datos para confeccionar un cuadro mensiocronológico. De hecho para un buen éxito del análisis es oportuno considerar un número suficiente de ladrillos puesto en obra (15/20 elementos) aspecto que no se ha podido tener en cuenta en el estudio arqueológico de los ladrillos. Los elementos almacenados en las excavaciones arqueológicas son escasos, no están aparejados y no presentan trazas significativas de juntas o mortero. Solo con un ejemplo se ha procedido a medir 13 ladrillos (ficha S4), limitándose, en los restantes casos al análisis de 1/3/6 elementos constructivos.

Otro aspecto que limita los datos de proveniencia arqueológica es sin duda la selección de ladrillos efectuada por parte del responsable de la excavación. En este marco hay que considerar que uno de los principios básicos de la mensiocronología prescribe evitar la selección, o medida voluntaria de los ladrillos. Más bien el contrario, recomienda medir, todos los ladrillos visibles en un área constructiva homogénea.

A pesar de todas estas limitaciones, debidas a un análisis de ladrillos que proceden en parte de una selección arqueológica indirecta, es importante extrapolar datos extraidos de las fichas, ya que contribuyen a orientar el estudio, afirmar el empleo de ladrillos en distintas épocas constructivas y según diferentes formatos.

Si se consideran las curvas generadas tras el estudio mensiocronológico se pueden identificar tres gráficos ${ }^{6}$.

${ }^{6}$ Los tres diagramas de dispersión, representan las variaciones métricas de los ladrillos determinadas en el tiempo.

Los interesantes datos de variación de las medidas en el intervalo cronológico se han procesado mediante las operaciones siguientes:

- cálculo del coeficiente de correlación linear, como valor índice que expresa la validez de la relación linear existente entre las dimensiones encontradas y el intervalo cronológico atribuido. - índice de la variabilidad de las dimensiones encontradas es atribuible a un parámetro R, de relación con el intervalo cronológico. Este índice puede variar entre 0 y 1 . Para los valores de $R$ 
A) Variación de la longitud de los ladrillos (eje de ordenadas) respecto a las fábricas fechadas (eje de abscisas )

B) Variación de la anchura de los ladrillos (eje de ordenadas) respecto a las fábricas fechadas (eje de abscisas )

C) Variación del grosor de los ladrillos (eje de ordenadas) respecto a las fábricas fechadas (eje de abscisas)

En este marco se analizan las líneas de tendencia de los gráficos, en relación a los 7 periodos indicados:

S. XV-XVI

S. XVII (primera y segunda mitad)

S. XVIII (primera y segunda mitad)

S. XIX (primera y segunda mitad)

De todo ellos se extraen una serie de reflexiones interesantes.

\section{En los siglos longitud y anchura son parámetros inversamente proporcionales al grosor de los ladrillos.}

A pesar de que la anchura permanece de un modo más constante en los siglos, respecto a la longitud, ambos parámetros muestran una tendencia bastante clara, marcada por una sustancial diminución métrica en el tiempo. Esta directriz es más manifiesta en la longitud de los ladrillos y más sutil en la distribución de las anchuras ${ }^{7}$.

próximos a la unidad, toda la variabilidad de las medidas realizadas en los ladrillos sería atribuible idealmente a la relación con el intervalo cronológico.

- análisis de la variación. Este análisis permite comprobar si la variabilidad de las medidas encontradas en cada edificio es más pequeña que la variabilidad encontrada entre los diferentes edificios, con una confiabilidad igual o superior al $95 \%$.

- cálculo de los valores de síntesis de los "n" ejemplos estudiados. Entre éstos, el cálculo del valor medio y de otros valores denominados de "posición".

${ }^{7}$ Estas tendencias se habían constatado en los estudios previos realizados por la autora PFC (2005) y Trabajo de investigación DEA (2008). También la primera curva mensiocronológica para la ciudad de Valencia (ALTARRIBA, M., GUILLÉN, R., GUZMÁN, R., ROJO, N., MARTí, J 2001). Respecto a estas aportaciones en el marco del estudio actual se han considerado más 
Longitud y anchura son parámetros que varían de forma más gradual, siendo mucho más irregular la tendencia marcada por el grosor.

Estos valores se pueden resumir de forma esquemática en estas tablas:

\section{S. XV -XVI}

Soga 28.5/29.5cm; tizón 13/14.5cm, grueso 3.9/4.1 cm Proporción tendel//laga 0.5/0.9

\section{S. XVII (primera mitad)}

Soga 29.7/30.5 cm; tizón 13.9/14.2cm, grueso $3.5 / 4.2 \mathrm{~cm}$ Proporción tendel/llaga 3.2/3.8

\section{S. XVII (segunda mitad)}

Soga 29.9/30.5cm; tizón 14/14.6 cm, grueso 3.8/3.9cm Proporción tendel/llaga 3.5/4.4

\section{S. XVIII (primera mitad)}

Soga 30.5/31.2cm; tizón 14.2/15cm, grueso 4.1/4.2cm Proporción tendel/llaga 3.1/3.2

\section{S. XVIII (segunda mitad)}

Soga 29.2/30 cm; tizón 14.1/14.6cm, grueso $4.0 / 4.1 \mathrm{~cm}$ Proporción tendel//laga 2.2/2.6 


\section{S. XIX (primera mitad)}

Soga 27.8/29.4 cm; tizón 13.5/ 14 cm, grueso 4.6/5 cm Proporción tendel/llaga 1.2/1.6

\section{S. XIX (segunda mitad)}

Soga 26.2/24.5 cm; tizón 11.5712 cm, grueso $4.3 / 4.4 \mathrm{~cm}$ Proporción tendel//laga 1.1/1.7

Las curvas mensiocronológicas se caracterizan por un curso estable, aspecto que lleva a considerar otros factores significativos para el estudio, no solo los métricos. Por ello las juntas, las texturas y los acabados de las fábricas se revelan fundamentales para realizar una cronotipología de fábricas.

Esta ausencia de una correlación estricta entre la variación de medidas y la variación temporal ha permitido centrar la atención en la búsqueda de otros factores de discriminación y en la justificación de una marcada uniformidad. 

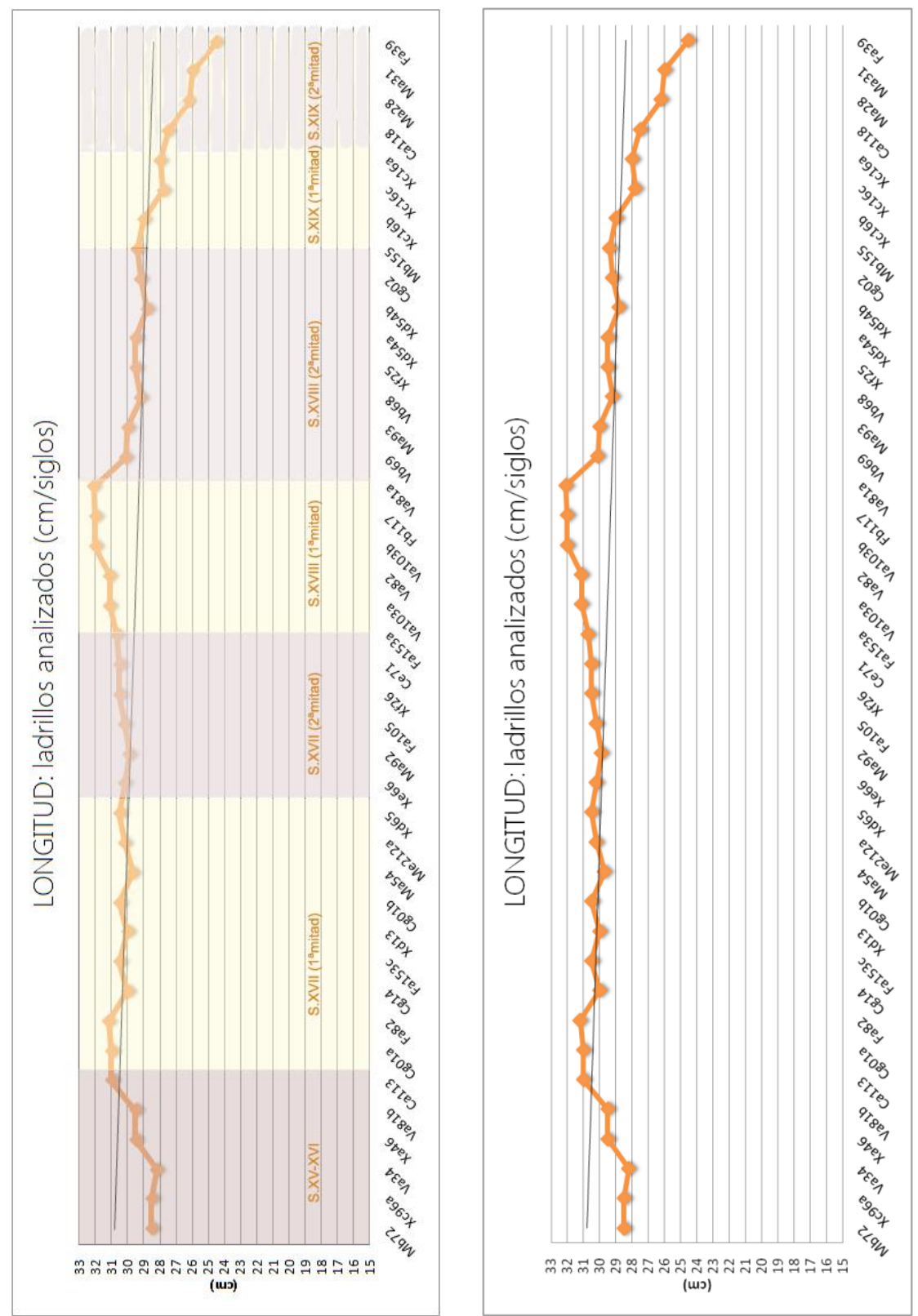

FIG. 146 Curva mensiocronológica relativa a la longitud de ladrillos analizados (CRISTINI) 


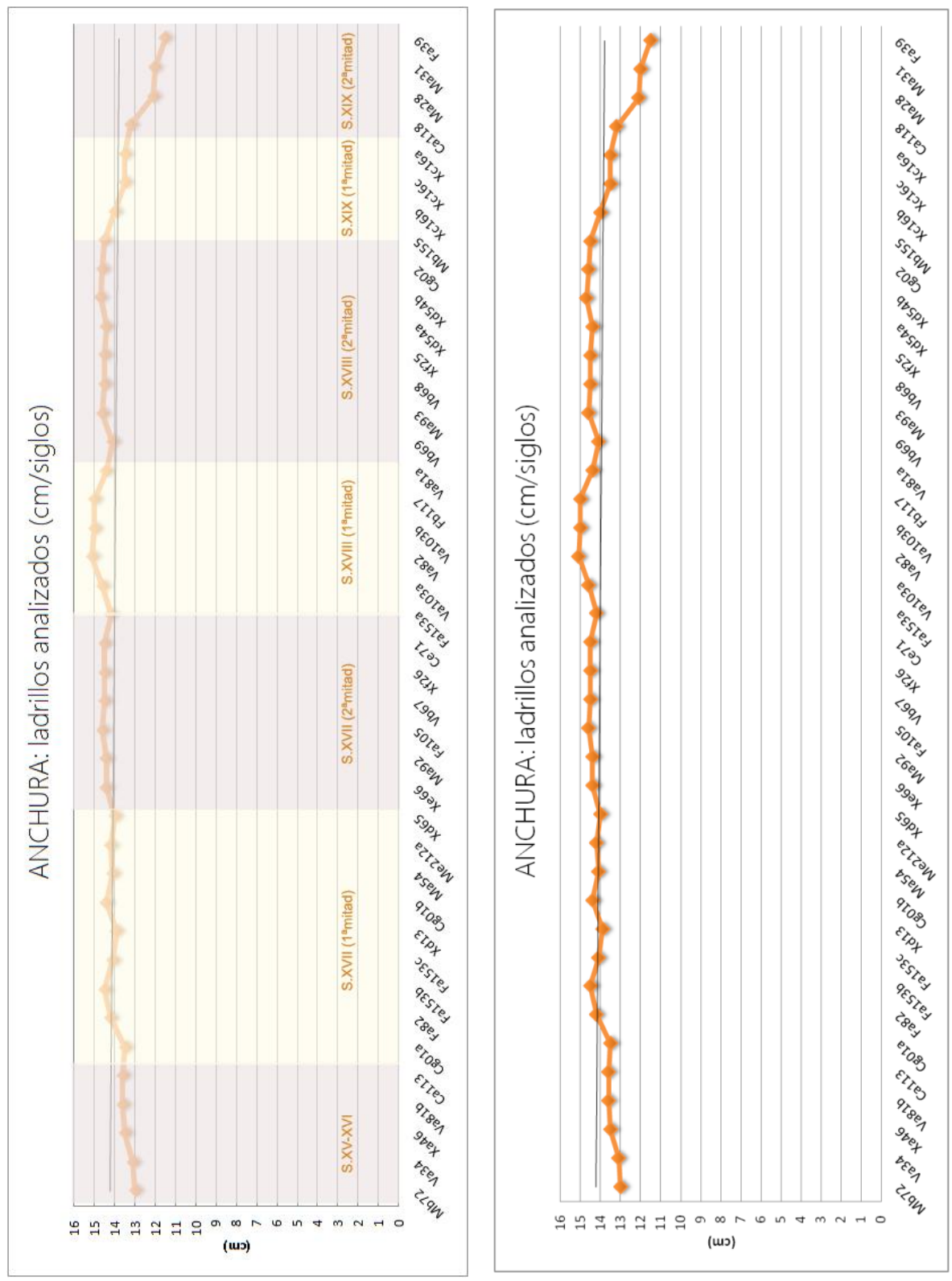

FIG. 147 Curva mensiocronológica relativa a la anchura de ladrillos analizados (CRISTINI) 


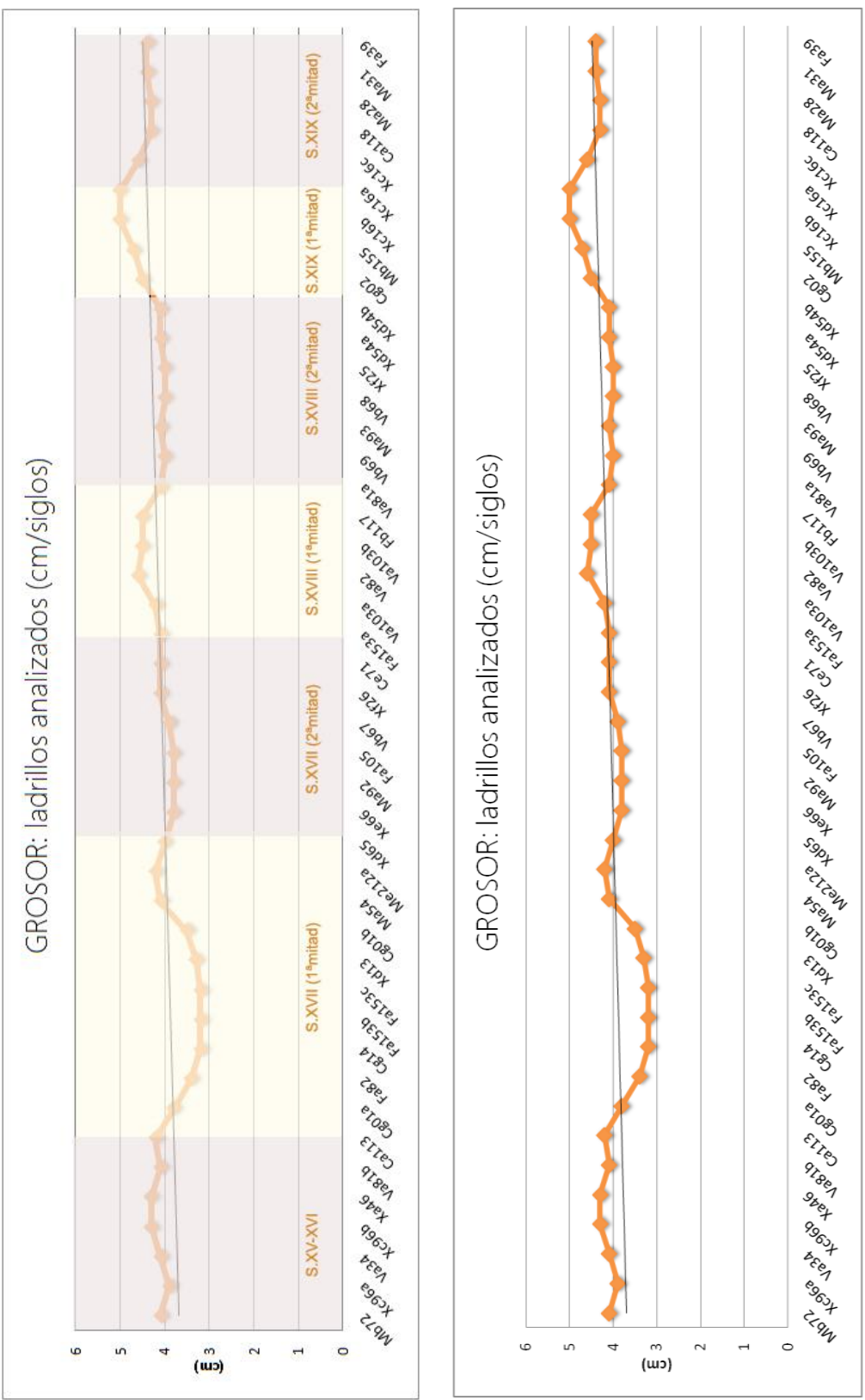

FIG. 148 Curva mensiocronológica relativa al grosor de ladrillos analizados (CRISTINI) 


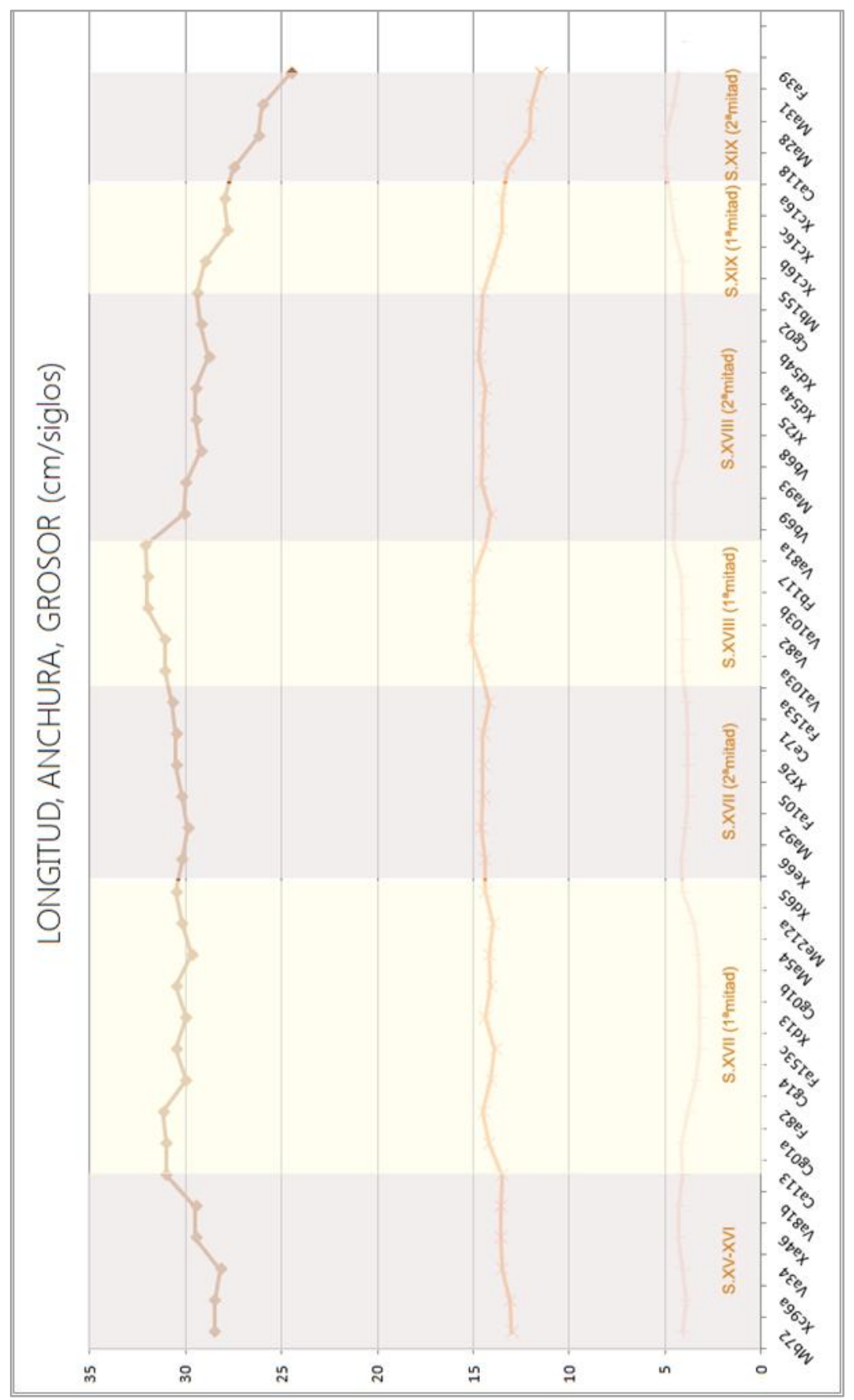

FIG. 149 Curva mensiocronológica (resumen con periodización) de ladrillos analizados 


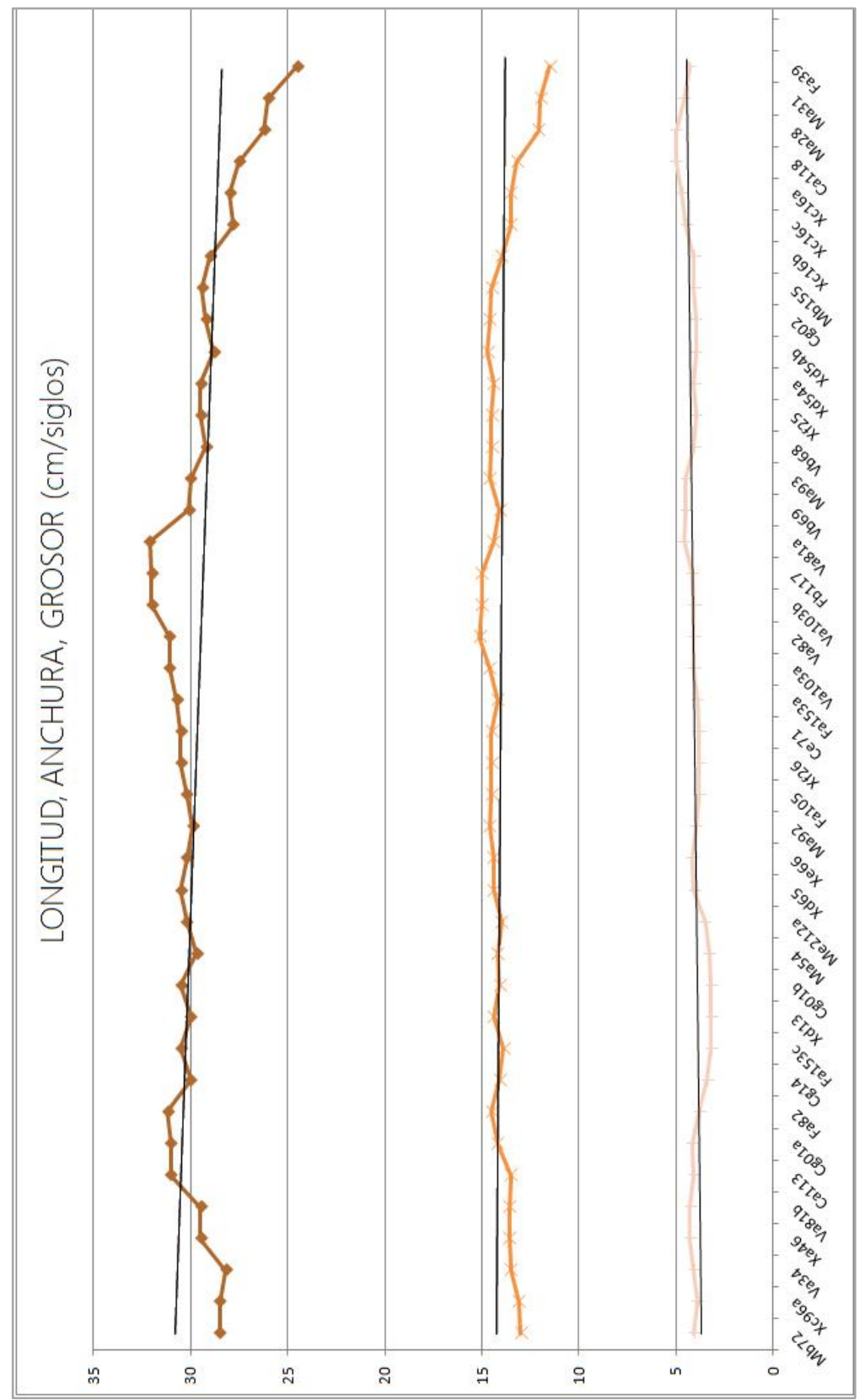

FIG. 150 Curva mensiocronológica (resumen) de los ladrillos analizados (CRISTINI) 
El análisis ha sido posible gracias a la creación de fichas específicas de los detalles constructivos de los muros, merced a las cuales se han podido reconocer los aparejos y sus técnicas, así como distinguir afinidades y divergencias. De manera resumida, estos factores de identidad se pueden sintetizar de la siguiente forma:

a) tipo de ladrillo:

- relación entre color y grueso del ladrillo;

- relación entre color y solución de acabado;

b) tipo de junta:

- relación entre las características de las juntas (llagas y tendeles) y el grueso de los ladrillos;

- relación entre características de las juntas (llaga y tendeles) y la solución de acabado.

\section{Relación entre color y grosor del ladrillo}

Los ladrillos con gruesos reducidos suelen mostrarse más claros y amarillentos. Este tipo de material puede remitirnos a talleres urbanos que dan testimonio de la recesión productiva que caracteriza la situación valenciana, en particular, a lo largo del S. XVI y principio del S. XVII.

Debido a estos factores, estos ladrillos son elementos ligeros, muy porosos, constructivamente poco idóneos para ser dejados vistos. Además, algunas de sus características (medidas, color, simplicidad de la argamasa) se corresponden con los ladrillos empleados como refuerzo en las fábricas de tapia valenciana (en este caso con una proporción tendel/llaga de 2.1/2.7), confirmando claramente una continuidad de las dos técnicas constructivas. Estos muros demuestran una total compatibilidad y ofrecen la posibilidad de combinar estas dos técnicas, mezclándose e influenciándose en sus respectivas soluciones de acabado. 
Por otro lado, se puede observar cómo en edificios posteriores, que ya pertenecen sobre todo a construcciones del siglo XVIII (tanto primera como segunda mitad), se encuentran ladrillos más pardos, compactos, con mayor cantidad de arcilla y óxidos de hierro, que además son gruesos y uniformes.

\section{Relación entre color y solución de acabado}

En el siglo XV, XVI y principio del XVII las fábricas de ladrillos suelen ser bastante simples, caracterizadas por gruesos tendeles, protegidos contra la penetración de agua a base de sucesivas capas de enlucido. Estos tipos de muros, aparejados con ladrillos finos de 3.4-3.6 cm de grueso y con tendeles de $4.0-4.5 \mathrm{~cm}$, no se pueden dejar expuestos a la intemperie, a causa del bajo grado de impermeabilidad del mortero empleado.

A menudo en estos casos, las fábricas presentan una técnica de simulación, con revocos pintados, de diferentes características.

Por otro lado, el análisis in situ de estos muros ha permitido identificar ladrillos con un grueso mayor, que oscila entre los 4.0-4.5 $\mathrm{cm}$. Al mismo tiempo, el aparejo realizado con estos materiales es más uniforme, compacto y visiblemente más regular y acabado que en el caso de los ladrillos más claros, delgados y finos.

Relación entre las características de las juntas (llaga y tendeles) y el grueso de los ladrillos

Existe una clara proporción entre las medidas de los elementos empleados y el tipo de llagas o tendeles visibles en los muros estudiados. Allí donde se encuentran ladrillos esbeltos (entre 3.4-3.6 $\mathrm{cm}$ de grueso) se pueden esperar tendeles muy marcados (entre 4.0$4.5 \mathrm{~cm}$ ). Por el contrario, allí donde los ladrillos aparejados muestran medidas más grandes y gruesas, se puede detectar la presencia de tendeles mucho más reducidos, que oscilan entre $2.0-3.5 \mathrm{~cm}$ de grosor. Por esta razón, se puede afirmar que existe una proporción inversa entre el espesor de los ladrillos y el grosor del mortero empleado. 
Igualmente, esta relación se detecta también entre las llagas y los tendeles de los muros analizados. Se observa cómo, por ejemplo, las llagas son siempre mucho más esbeltas que los tendeles, sobre todo en el S. XV, XVI y la primera parte del siglo XVII. También, se muestra como estas diferencias van reduciéndose a medida que avanza este siglo, durante el cual las juntas se van tendiendo hacia un equilibrio entre las dos dimensiones, la vertical y la horizontal.

Relación entre las características de las juntas (llagas y tendeles) y la solución de acabado

Existe una clara relación entre las juntas existentes y la tipología de acabado de las fábricas. En estos casos, surgen dos tipos de situaciones. Allí donde existen tendeles gruesos y ladrillos esbeltos se encuentran técnicas de sellado final para protegerlos. Por otra parte, se puede constatar que los tendeles delgados y finos presentan soluciones de acabados más transparentes, con técnicas como el revoco pintado con ladrillos fingidos o la más simple que deja sólo los ladrillos a cara vista.

Las soluciones con sellado caracterizan los muros de inicios del S. XVII. Este modo de proteger el aparejo, con un verdadero "sello" de la junta, permite marcar las nuevas juntas horizontales sobre las debajo, aproximadamente con la misma irregularidad que caracterizaba al muro originalmente. Otra posibilidad era la que empleaba un revoco de pintura a la cal, efectuada a base de capas, progresivamente más finas. Las mezclas empleadas presentan una pasta de cal bien tamizada y apagada, a la que se añaden pigmentos y aditivos.

Es a partir del siglo XVIII cuando se utiliza una técnica intermedia entre el empleo del enlucido o una simple lechada de cal: el fingido. Se trata de un revoco que reproduce una fábrica aparejada de ladrillo, merced a una nueva trama, pintada, que simula una pared más regular. Se trata de un tratamiento mate, muy difícil de encontrar en un buen estado de conservación en la ciudad. Este 
revoco es posible gracias al empleo de la almagra, mezclada con la pintura a la cal. Este óxido se empleaba para enlucir, con una ligera capa las fábricas, revitalizando e intensificando el tono de los ladrillos.

Sólo a partir de la segunda mitad del siglo XVIII, los ladrillos empezaron a ser dejados a la vista merced a su producción regular y su buena cocción en talleres más especializados. La producción estaba mucho más controlada y permitía el empleo de ladrillos con un grueso más significativo que no necesitaban tendeles y llagas marcadas. Las cualidades propias de los ladrillos permiten dejar vistas las fábricas que se acompañan por molduras, remates y cornisas de piedra. 


\subsection{Fábricas monumentales y residenciales: interpretación del registro de fichas}

Como ya se ha especificado en el "Anejo I.1 Criterios para la redacción de un registro de fichas" el diseño de la FICHA DE ESTUDIO DE LAS FÁBRICAS se ha dividido en seis grandes bloques. Con ellos se ha realizado una catalogación descriptiva, con un enfoque que aborda desde la localización general del edificio hasta la definición en detalle de sus fábricas de ladrillo.

Los 6 apartados indicados en las fichas son:

\section{Datos generales}

\section{Fachada}

\section{Fábrica}

\section{Ladrillos}

\section{untas}

\section{Imágenes}

A través de estos puntos se han podido elaborar 32 gráficos, que facilitan la comprensión del conjunto de fábricas analizadas, así como algunos aspectos específicos de cuadros patológicos o características 
constructivas $^{1}$. Sin duda sorprende reconocer como existe un equilibrio sustancial entre lenguajes compositivos y constructivos, entre las fábricas residenciales y las monumentales del centro histórico de Valencia. Aspecto especialmente evidente entre viviendas y edificios anexos a iglesias (cómo capillas, sacristías, espacios de servicios...etc.)

Es oportuno evidenciar como, entre estos tipos de edificios, cambian las calidades de las materias primas y la diferente competencia de los alarifes en la puesta en obra...a pesar de ello no se modifican sustancialmente las técnicas constructivas.

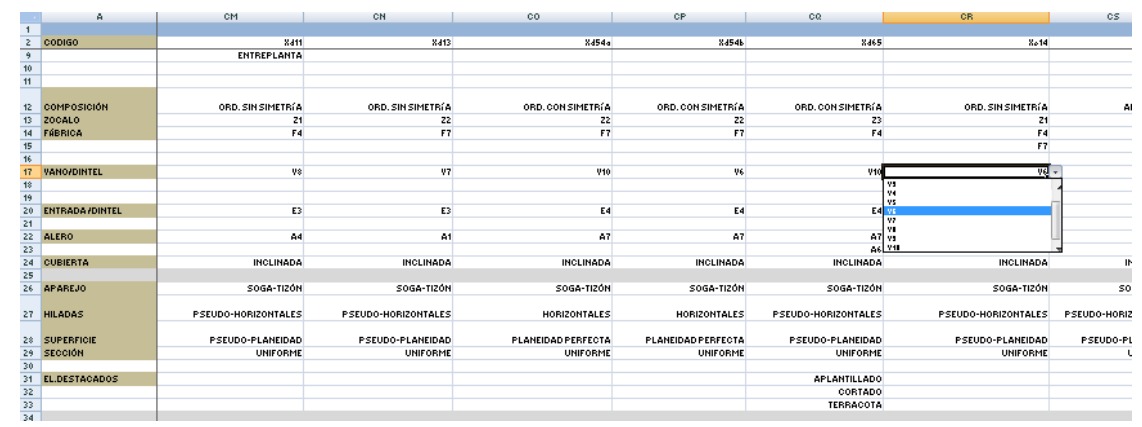

FIG. 151 Ejemplo de hoja generada en la base de datos (CRISTINI)

Tipos de aparejos, soluciones formales y compositivas (para zócalos, vanos, aleros...) se reflejan de forma muy uniforme, entre arquitectura residencial y monumental, sobre todo a lo largo del XVII siglo.

Esta tendencia progresivamente se diluye a lo largo de la segunda mitad del siglo XVIII, cuando la llegada de la arquitectura bícroma, en ladrillos y material pétreo, progresivamente aleja la arquitectura residencial, de la civil y religiosa.

A continuación, se resumen los datos relativos a los "muros intramuros" de la ciudad de Valencia, ya sean residenciales o

${ }^{1}$ Los gráficos relativos a las patologías analizadas en las fábricas son consultables en el "Cap.6.1.2 ¿Qué patologías?" 


\section{murOSINTRAMUROS}

monumentales, extrapolados a través de la base de datos, generada por la autora.

\section{Datos generales}

TIPPO DE EDIFICIOS ESTUDIADOS

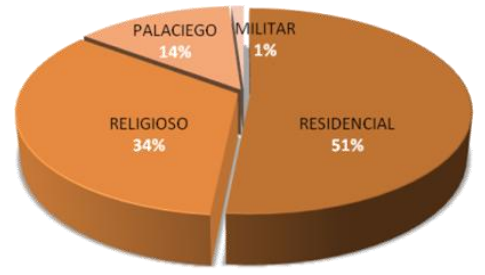

GRADO DE PROTECCIÓN DE LOS EDIFICIOS ESTUDIADOS

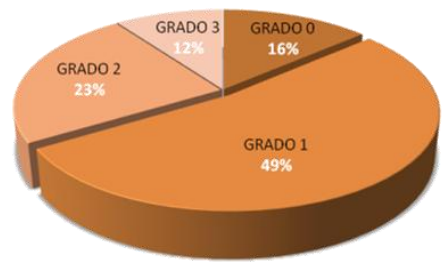

FIG. 152 Gráficos de estudio. Tipo de edificios y grado de protección (CRISTINI)

La mayoría de los edificios documentados son residenciales (51\%), siendo el restante (49\%) monumental (Go1: religioso, palaciego y militar). Por otro lado, llama la atención constatar como los edificios residenciales tienen grado de protección bastante heterogéneo. Entre ellos se registran diversos equilibrios: un nivel de protección estructural ( $\mathrm{G}^{\circ} 2$ ) bastante amplio (23\%), un nivel arquitectónico (G3) discreto (12\%), y el último (G०0) compuesto por una llamativa falta de protección (16\%).
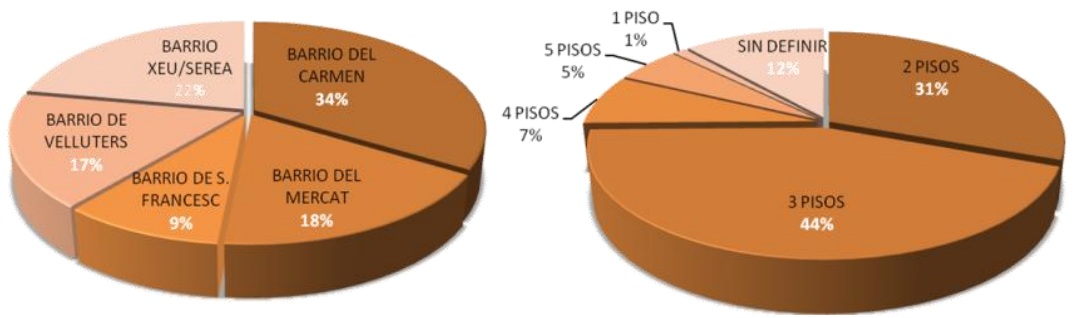

FIG. 153 Gráficos de estudio. Distribución de las fábricas y Nº de pisos de los edificios (CRISTINI)

La distribución de las fábricas se concentra en el barrio del Carmen (34\%), se mantiene equilibrada entre el área de la Seu-Xerea (22\%), 
Mercat (18\%), Velluters (17\%) queda su empleo más limitado en el barrio de San Francesc (9\%).

En los ejemplos estudiados prevalecen edificios residenciales de 3 alturas (44\%), seguidos de inmuebles de 2 niveles (31\%). Los edificios con sólo planta baja son escasos (1\%). Además un bajo porcentaje de los casos estudiado tiene 4 (7\%), o 5 niveles (5\%). Al margen de ello, caben destacar algunas fachadas de conjuntos monumentales y religiosos, en los cuales no es posible definir con exactitud el número de niveles (12\%).

\section{Fachada}

Si por otro lado se consideran los datos del estudio de las fachadas, la tendencia principal prevé alzados ordenados pero sin respetar reglas absolutas de simetría (47\%), reflejando así probables modificaciones y estratificaciones producidas en la vida útil del edificio.

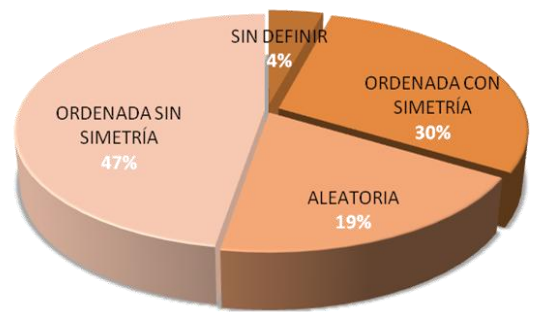

FIG. 154 Gráficos de estudio. Composición de las fachadas (CRISTINI)

Son menos frecuentes las fachadas totalmente simétricas (30\%), resultado de proyectos unitarios, en muchos casos monumentales, reflejo de proyectos más maduros y recientes (a partir del S. XVIII). Más difícil, es encontrar edificios con rasgos compositivos aleatorios, que apuntan a inmuebles residenciales humildes (19\%), fruto de unión de fachadas (posiblemente de los siglos XV-XVI-XVII). 


\section{murOSINTRAMUROS}

Finalmente hay que considerar la existencia de ejemplos estudiados que no contemplan parámetros de una lógica compositiva definida (muros medianeros/ vallados...) considerados como parte de una categoría que no tiene datos significativos a incluir (4\%).
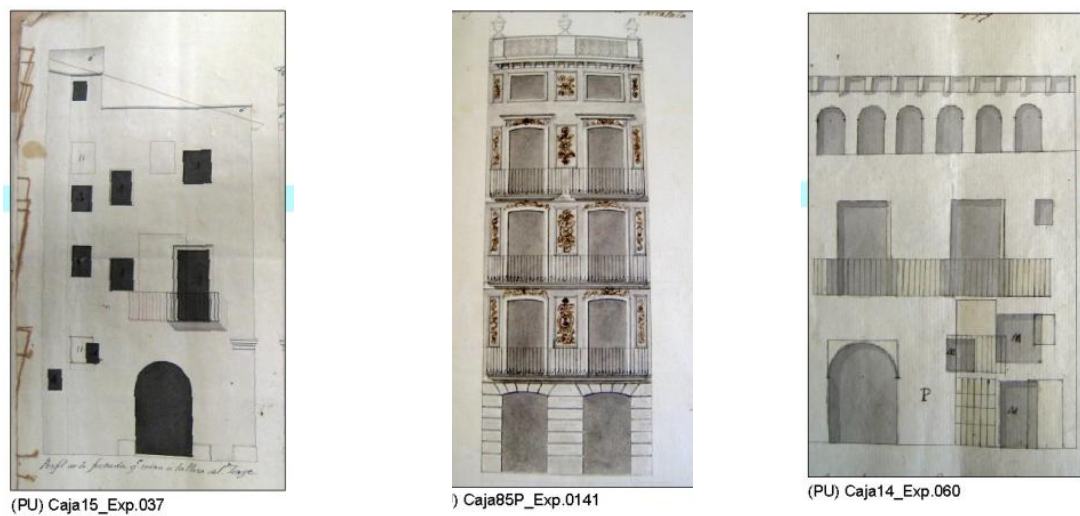

HIG. IbS tjemplo de tachada: aleatoria, ordenada con simetría, ordenada sin simetría, Expedientes Policía Urbana (AHMV)

Hablando de los caracteres constructivos de las fachadas se pueden indicar algunos perfiles generales ${ }^{2}$, indicados a continuación.

Los zócalos analizados son mayoritariamente de piedra calcárea, con sillares regulares y labrados con una altura aproximada de 50/70 cm (tipo Z2; 40\%); esta es una solución común, eficaz en términos de prestaciones técnicas, destacada tanto en edilicia monumental como residencial. A esta solución siguen zócalos más simples, a base de ladrillo, como continuidad a los paños de las fábricas (tipo Z1; 33\%) y estos se identifican más bien con casos de edilicia residencial. Sin duda menos abundantes son las soluciones con altos zócalos de piedra calcárea, con una altura de 1.80/2.00m (tipo Z3; 9\%), propias de conjuntos monumentales. En soluciones más contemporáneas se prevé el empleo de zócalos aplacados (tipo Z4; 16\%) o enlucidos (tipo Z5; 2\%).

\footnotetext{
${ }^{2}$ Véase "Anejo I .Cap. I.3. Ábaco de detalles de fábricas históricas de ladrillo"
} 
FACHADA: ESTUDIO DE ZÓCALOS

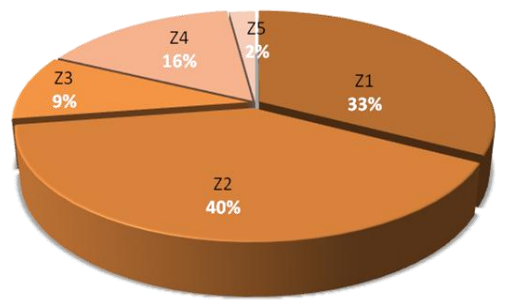

FACHADA: ESTUDIO DE FÁBRICAS

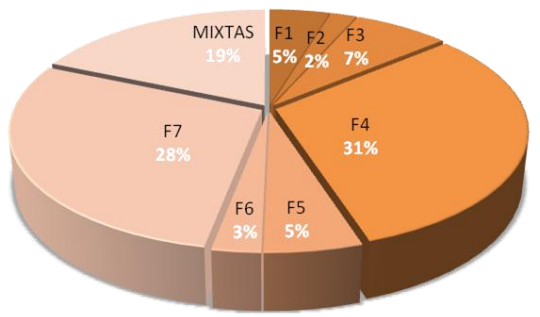

FIG. 156 Gráficos de estudio. Estudio de zócalos y de fábricas (CRISTINI)

Los datos relativos a fábricas, residenciales o monumentales, registran bastante equilibrio entre fábricas enlucidas: un tercio con la solución con aparejo de soga y tizón marcado por gruesos tendeles y finas llagas (tipo F4; 31\%), otro tercio con fábricas de ladrillo cara a vista, regular y con juntas enrasadas (tipo F7; 28\%). Es significativa la vigencia, aunque en "peligro de extinción", que tienen las fábricas más autóctonas...de tapia valenciana aparejada de soga (tipo F1; 5\%) o de soga/tizón (tipo F2; 2\%); así como agramilada (tipo F3; 7\%). Estos últimos casos son propios de los siglos XV-XVI- XVII, visibles hoy en día en conjuntos religiosos $y$, apenas presente, en casos residenciales. Un conjunto de soluciones más minoritario, lo constituyen las fábricas monumentales académicas con fingido (tipo F5; 5\%) o las decimonónicas palaciegas con ladrillos almohadillados, marcadas por hiladas retranqueadas (tipo F6; 3\%).

Es interesante considerar como las hibridaciones son muy frecuentes; los muros analizados son bastante homogéneos, pero se encuentran hasta un 19\% de ejemplos de fábricas mixtas, con combinaciones como "cara a vista con almohadillado", "agramilado con cara a vista" o "enlucido con tapia valenciana". 


\section{murOSINTRAMUROS}

FACHADA: ESTUDIO VANO/DINTEL

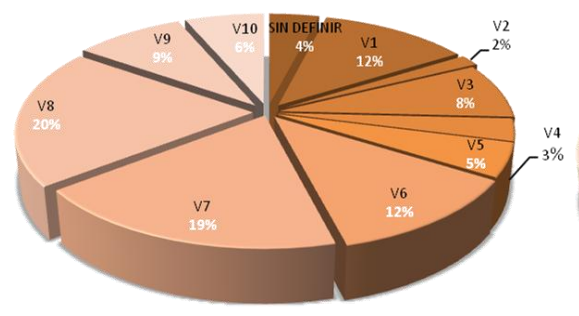

FIG. 157 Gráficos de estudio. Definición de vanos/dintel y entrada/dintel (CRISTINI)

Las relaciones entre vanos y dinteles permiten definir cuadros de análisis bastante heterogéneos. La tendencia principal queda marcada por vanos enlucidos (tipo V8; 20\%) que no desvelan detalles constructivos. También son frecuentes los vanos con arcos realizados con ladrillos aparejados con escopeta. El intradós en este caso es plano y el extradós es curvo (tipo V7; 19\%), siendo esta una opción constructiva temprana, visible a partir de finales del siglo XVI, tanto en conjuntos religiosos como residenciales, hasta la segunda mitad del siglo XVIII. Esta solución parece la más común, a menudo asociada también a vanos académicos, caracterizados por intradós y extradós curvos (tipo V6; 12\%).
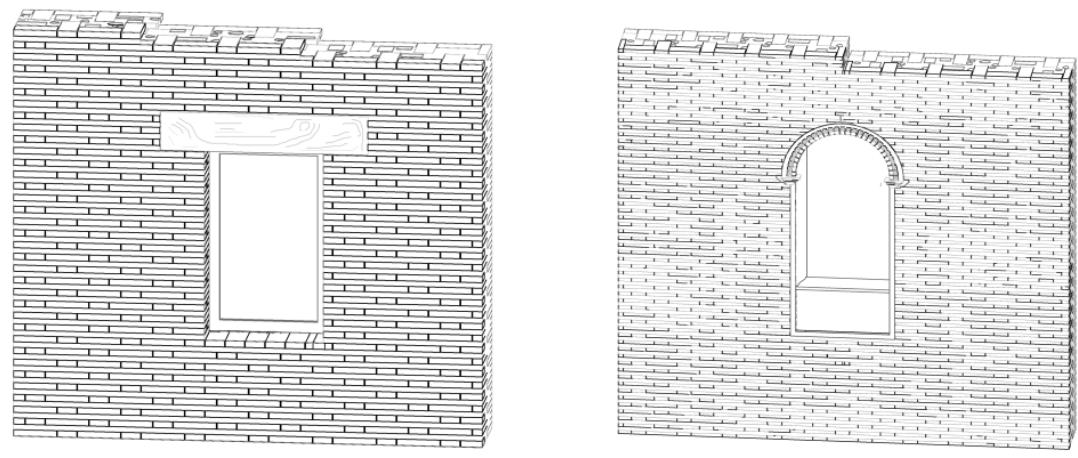

FIG. 158 Solución de vano más simple, con dintel de madera, frecuente hasta pleno S. XIX (tipo V1) y más compleja (tipo V3) con ladrillos aplantillados, del S. XVIII (CRISTINI)

Este mismo porcentaje se puede encontrar para dinteles simples de madera (tipo V1; 12\%), presentes en arquitectura residencial hasta el 


\section{murOSINTRAMUIOS}

S. XIX. Su variante más destacada, posiblemente de especiales bajos comerciales, es con una moldura unitaria marcada por jambas pétreas y dintel de madera con bocel (tipo V2; 2\%).
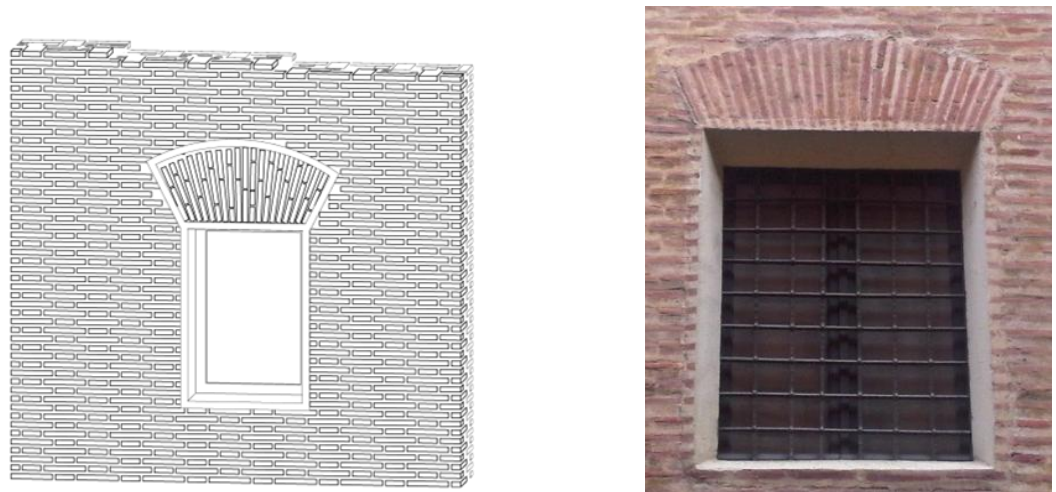

FIG. 159 Solución frecuente desde finales de S: XVI hasta mitad del S. XVIII con arco de extradós curvo, intradós plano (tipo V7). Las soluciones primigenias son más peraltadas, las tardías más abombadas; en la imagen un detalle de la ficha Xe66. (CRISTINI)

Soluciones más especiales y puntuales, aunque reiteradas especialmente en la arquitectura monumental presentan logias realizadas con una arquería en ladrillo (tipo V3; 8\%), vanos ovalados y circulares (tipo V4; 3\%), arcos adintelados (tipo V5; 5\%) o en el caso de soluciones académicas, vanos con recercado en ladrillos (tipo V9; 9\%) o pétreos (tipo V10; 6\%).
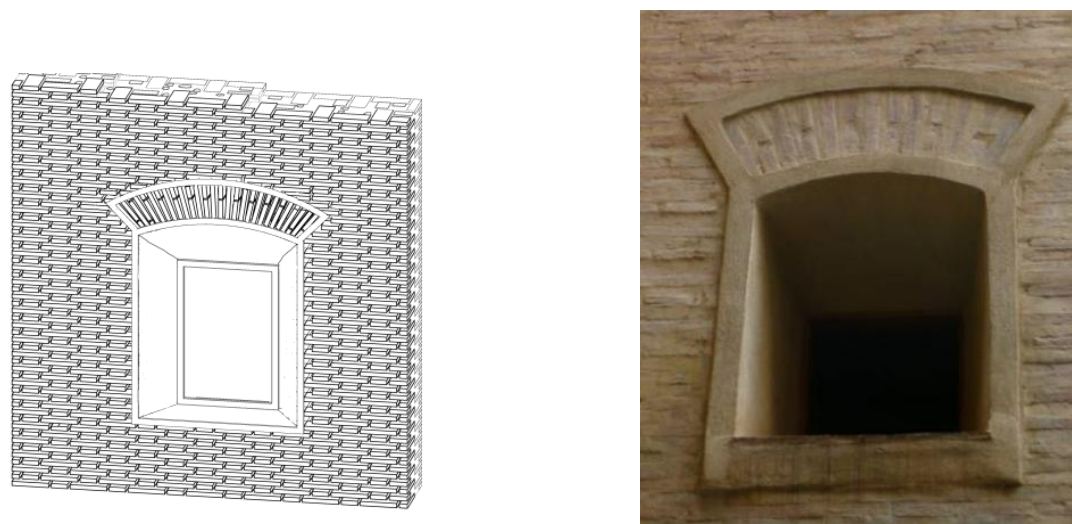

FIG. 160 Solución frecuente a lo largo de S. XVIII con arco de extradós e intradós curvo (tipo V6) en un detalle de la ficha Cg57 (CRISTINI) 


\section{MUROSINTRAMUROS}

Finalmente considerar que existen ejemplos estudiados que no contemplan la presencia de vanos (como por ejemplo en el caso de muros medianeros/ vallados...) que se consideran como parte de una categoría que no tiene datos significativos a incluir (4\%).
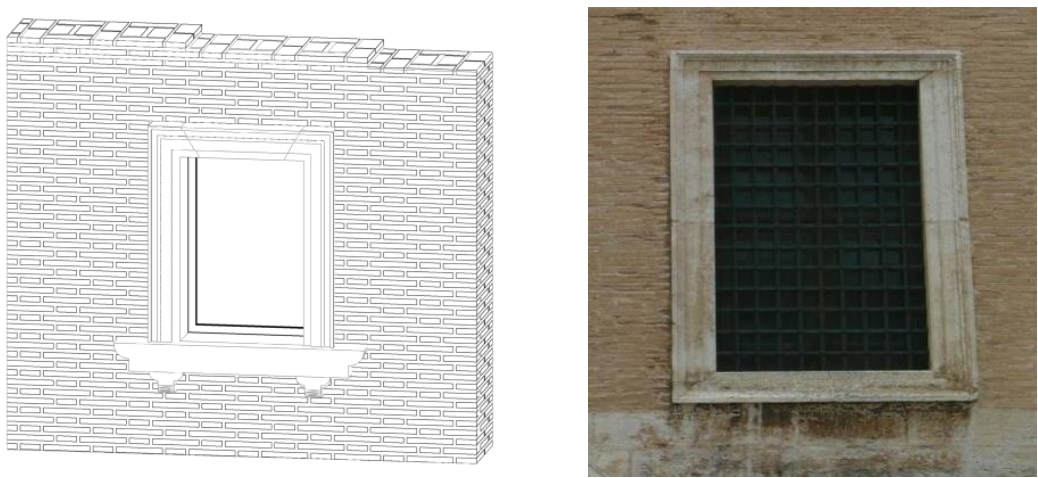

FIG. 161 Solución de vano académico, con recercado pétreo (tipo V10), común en arquitectura monumental en un detalle de la ficha Xd 54 (CRISTINI)

Por otro lado, si se consideran los accesos a los edificios estudiados, predominan los vanos de entrada con sillares labrados (tipo E4; 53\%), opción seguida por accesos con enlucidos (tipo E3; 27\%). Menos comunes son los de vanos de entrada con dintel de madera (tipo E1; 12\%) o los caracterizados por una moldura unitaria con jambas pétreas y dintel de madera (tipo E2; 1\%).
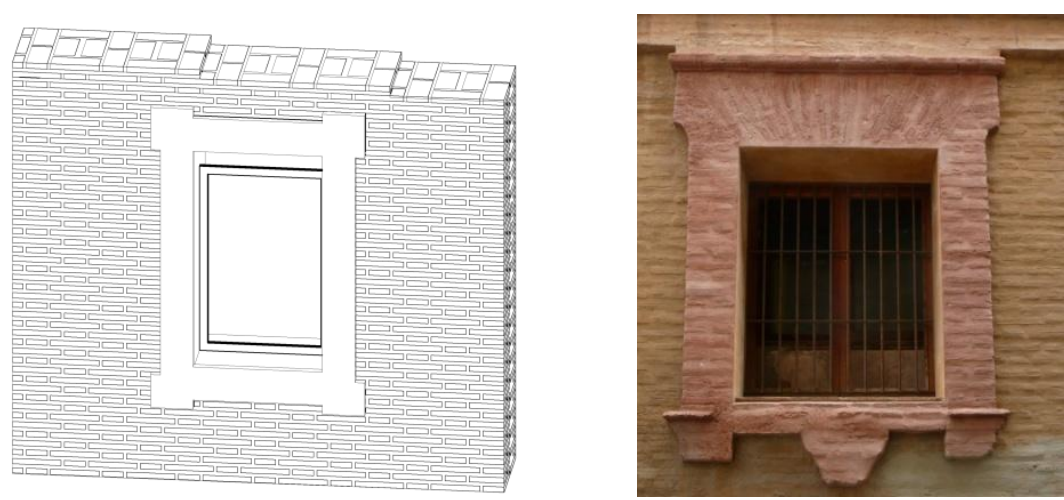

FIG. 162 Solución de vano académico, con recercado con ladrillos (tipo V9), frecuente en arquitectura residencial y religiosa en un detalle de la ficha Vb103 (CRISTINI) 
También en este apartado deben considerarse ejemplos que no contemplan la presencia de entradas (como por ejemplo en el caso de muros medianeros/ vallados...) o que se consideran como parte de una categoría que no tiene datos significativos a incluir (7\%).

FACHADA: ESTUDIO DE ALEROS

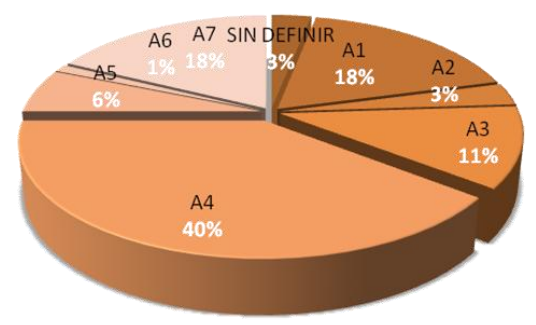

\section{FACHADA:ESTUDIO DE CUBIERTAS}

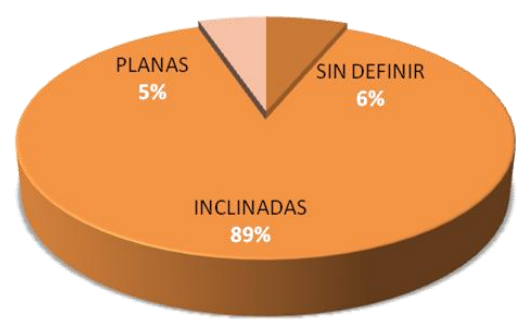

FIG. 163 Gráficos de estudio. Análisis de aleros y cubiertas (CRISTINI)

Los aleros de los edificios estudiados muestran una combinación con acabados enlucidos, con presencia variable de molduras decorativas cuyas características constructivas quedan ocultas (tipo A4; 40\%). Siguen a distancia aleros de edificios monumentales, marcados por molduras aplacadas en piedra labrada (tipo A7; 18\%) o aleros de madera, con canecillos o con acabado más tosco (tipo A1; 18\%), posiblemente anteriores a la segunda mitad del S. XVIII.

Soluciones más puntuales son las de aleros con múltiples hiladas de ladrillos, que marcan una progresión horizontal del voladizo (tipo A3; 11\%) o aleros con múltiples hiladas de ladrillos, que marcan una progresión inclinada del voladizo (tipo A5; 6\%). Finalmente casos aislados como aleros con una o dos hiladas de ladrillos (tipo A2; 3\%) - con múltiple progresión horizontal de piezas articuladas en dentículos o bandas (tipo A6; 1\%). En este apartado se tienen que considerarse ejemplos que no contemplan la presencia de aleros o 


\section{MUROSINTRAMUIOS}

remates (como por ejemplo en el caso de muros medianeros/ vallados...) y que se pueden considerar como parte de una categoría que no tiene datos significativos a incluir (3\%).

Para concluir el análisis relativo a las fachadas estudiadas, es interesante, aunque simplemente orientativo, considerar el tipo de cubiertas. Los datos apuntan a una tendencia marcada por cubiertas inclinadas (89\%), con un exiguo número de cubiertas planas (5\%). Desafortunadamente en un $6 \%$ de los casos analizados no ha sido posible establecer criterios para su caracterización, tratándose de muros medianeros o vallados.

\section{Fábrica}

Los detalles relativos a las fábricas presentan características interesantes, propias del tipo de aparejo empleado en el centro histórico de Valencia. Llama la atención la alta concentración de fábricas a soga y tizón (89\%), limitándose a casos aislados el empleo de aparejo a tizón (5\%) o solo a soga (6\%), propios de ejemplos de tapia valenciana.

\section{FÁBRICA: ESTUDIO DE APAREJOS}

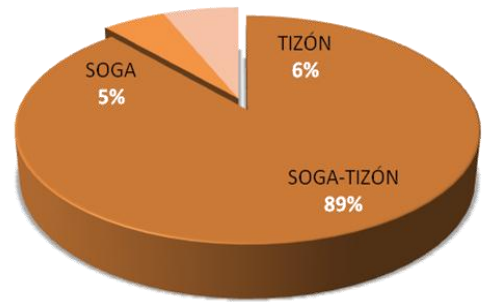

FÁBRICAS: ESTUDIO DE HILADAS

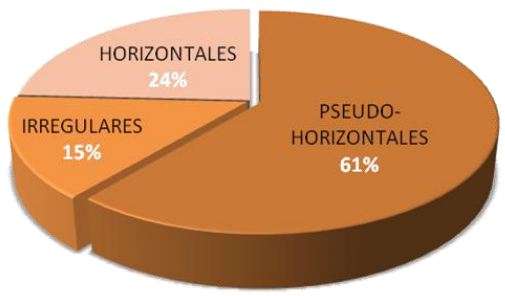

FIG. 164 Gráficos de estudio. Análisis de aparejos e hiladas (CRISTINI)

La abundancia de fábricas enlucidas también es un dato a tener en cuenta en el estudio de las hiladas. Así se confirma la presencia de hiladas pseudo-horizontales (61\%), que coinciden con aparejos un 


\section{murOSINTRAMUIOS}

poco irregulares, típicos de fábricas de ladrillo enlucidas o con agramilado. El ladrillo cara a vista y el almohadillado, por otro lado, se caracterizan por hiladas horizontales y regulares (24\%) siendo más confusas (15\%) las hiladas vinculada a casos de tapia valenciana o toscas fábricas enlucidas.

FÁBRICAS: ESTUDIO DE SUPERFICIES

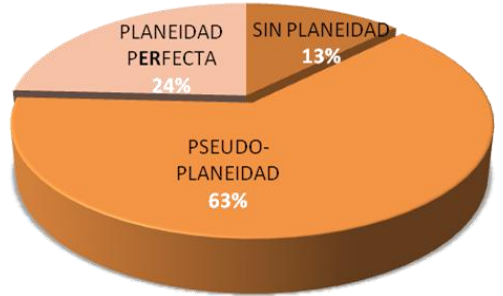

FÁBRICAS: HIPÓTESIS DE SECCIÓN

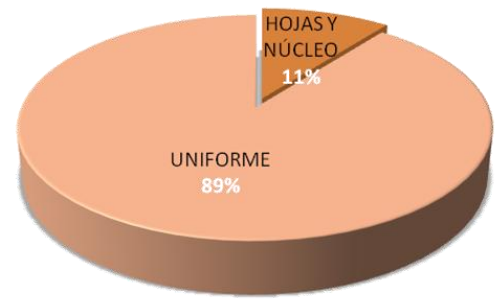

FIG. 165 Gráficos de estudio. Análisis de superficies e hipótesis de sección (CRISTINI)

Como continuidad al punto previo, también podemos observar como existe una interesante proporcionalidad entre pseudo-horizontalidad de las superficies y de las hiladas.

En este caso la tendencia sigue marcándola la presencia de fábricas con superficies casi planas, que presentan ligeras irregularidades (63\%), pudiendo ser absolutamente regulares solo una parte reducida de los casos estudiados (24\%). Se llega también a ejemplos totalmente irregulares, con ausencia absoluta de planeidad (13\%), como es el caso de fábricas de tapia valenciana.

Es sin duda más complicado poder extraer datos relativos a las secciones de los muros analizados. En la mayor parte de los casos el estudio solo pudo limitarse a la inspección de fachadas. A pesar de ello, es posible establecer una hipótesis.

Esta indica una sección potencialmente uniforme para la mayoría de los casos estudiados (89\%), limitándose el concepto de muro realizado por hojas y núcleos a los casos de tapia valenciana en sus variantes soga o soga/tizón (11\%). 


\section{murOSINTRAMUROS}

Los vanos de las fábricas analizadas muestran en algunos casos ejemplos de abocinados (20\%), situación posible tanto en edificios monumentales como residenciales, más bien anteriores a la segunda mitad del siglo XVIII.

Los restantes casos no presentan esta característica, probablemente asociada a una posible mejora de la ventilación e iluminación de los espacios (80\%).

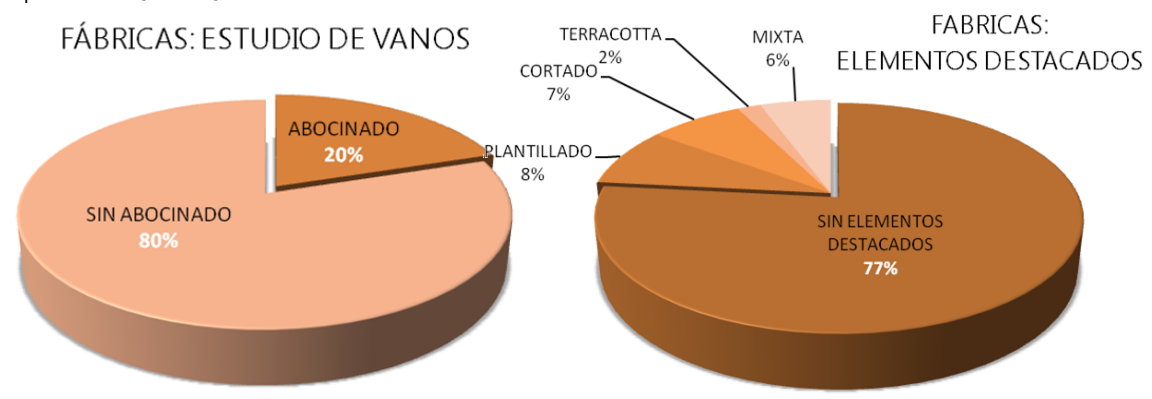

FIG. 166 Gráficos de estudio. Análisis de vanos y elementos destacados (CRISTINI)

Se sabe que, en el siglo XVIII empiezan las reformas urbanas dirigidas hacia la ampliación y regularización de los trazados urbanos, aspecto que podría enlazarse con la progresiva disminución del abocinado.

Destaca la presencia de casos puntuales, más bien de edificios monumentales y palaciegos, que a partir del S. XVII, presentan ladrillos aplantillados (8\%) escafilados (7\%) O con apliques en terracota (2\%); estos elementos, se presentan asociados (6\%). En todo caso, se trata de un porcentaje bastante limitado, teniendo en cuenta que, la mayoría de los casos analizados, presentan elementos simples (77\%).

\section{Ladrillos}

El estudio específico de los ladrillos, más allá de información métrica, ha permitido identificar características visuales relativas a la materia prima empleada en las fábricas de Valencia. 


\section{LADRILLO: CARACTERISTICAS}

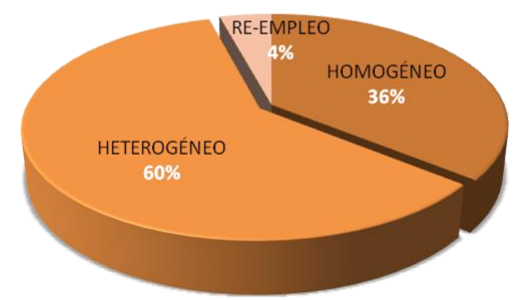

LADRILLO: ESTUDIO DEL COLOR

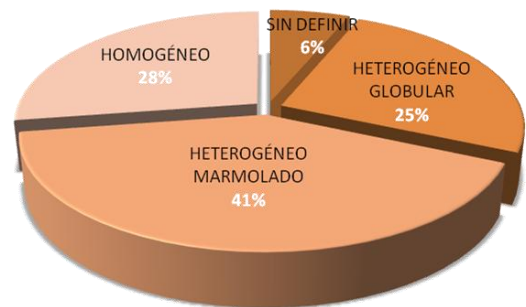

FIG. 167 Gráficos de estudio. Características de los ladrillos y estudio del color (CRISTINI)

Los ladrillos analizados son bastante heterogéneos entre sí (60\%), tratándose de producciones preindustriales, carentes de regularidad y control técnico de la producción.

A estos, se suman casos analizados con especial grado de disparidad y mezcla en la fábrica, aspecto que apunta a un posible re-empleo de ladrillos (4\%). Finalmente sólo un reducido porcentaje de piezas analizadas (36\%) muestra un discreto grado de homogeneidad, factor que indica posibles producciones más maduras, de finales del S. XVIII, principios de S. XIX.

Este elevado nivel de heterogeneidad se refleja también en términos cromáticos; solo pocos ejemplares de ladrillos muestran caracteres uniformes (28\%), marcándose en la mayoría de los casos variaciones cromáticas en estrías, bandas marmoladas (41\%) o cambios de tonos en granos o glóbulos (25\%); en algunos casos, tratamientos semi opacos o veladuras hacen difícil identificar los caracteres de los ladrillos (6\%).

\section{untas}

El estudio de las juntas de mortero va asociado al estudio de la definición de las características de los ladrillos, fundamental a la hora de comprender las fábricas. 


\section{murOSINTRAMUROS}

Es complicado encontrar casos de estudio que no hayan sufrido cambios, rejuntados y parches, destacando todos ellos por su acabado simple (16\%) o doble (4\%) que coinciden con el propio origen de las fábricas.

JUNTA: TIPO DE ACABADO

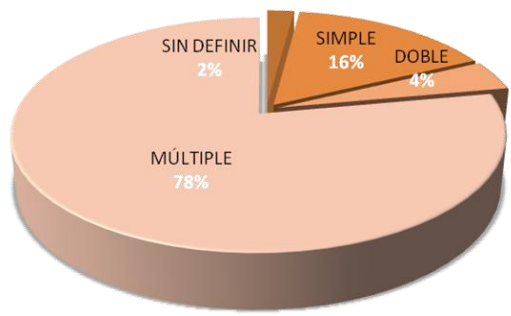

JUNTA DE ASIENTO

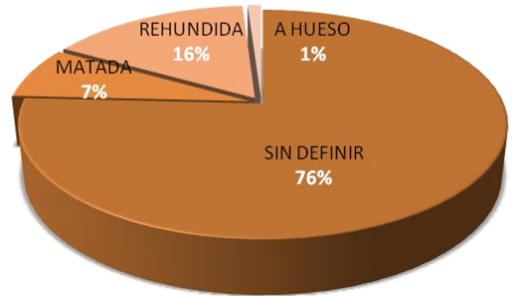

FIG. 168 Gráficos de estudio. Tipo de acabado y análisis de juntas de asiento (CRISTINI)

El resto de los casos, a pesar de respetar las proporciones y la "jerarquía" de las juntas, tanto de tendeles como de llaga, presentan fábricas transformadas en el tiempo, con acabados múltiples (78\%) o pastiches tan variados que impiden la lectura (2\%).

La dificultad a la hora de comprender los estratos es especialmente evidente a la hora de identificar juntas de asiento.

JUNTA DE ACABADO

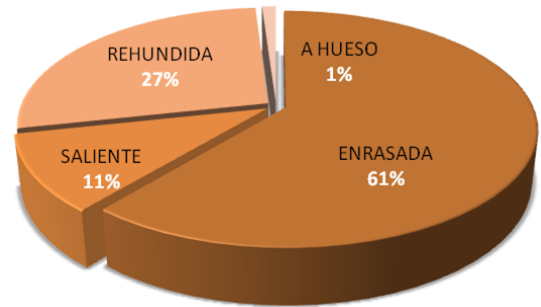

MORTERO: TIPO

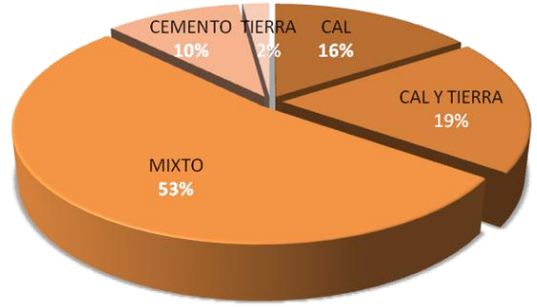

FIG. 169 Gráficos de estudio. Análisis de junta de acabado y tipo de mortero (CRISTINI)

En casi $3 / 4$ de las fábricas no es posible identificar estos tendeles (76\%). Este aspecto, por otra parte, es equilibrado por la posibilidad de detectar ejemplos con juntas rehundidas, para facilitar el revoco 
(16\%) casos más puntuales de fábricas agramiladas con junta matada (7\%) y casos muy aislados a hueso (1\%).

Las juntas de acabado permiten una lectura más inmediata, siendo en la mayoría de los casos enrasadas con las fábricas (61\%). También hay que considerar el contrapunto dado por las juntas salientes, a fajas, típicas de fábricas agramiladas o de tapia valenciana (11\%) o ligeramente rehundidas, más bien por posibles erosiones (27\%) y a hueso (1\%).

Si se extrapolan los datos relativos a la caracterización visual del mortero se puede ratificar como las intervenciones en el tiempo han dado origen a morteros híbridos, mixtos (53\%), cuya definición es compleja. A pesar de ello es posible identificar unos datos interesantes, respaldados además por los análisis efectuadas en laboratorio ${ }^{3}$.

MORTERO: MORFOLOGİAI

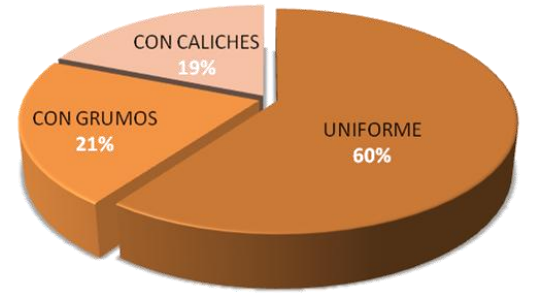

MORTERO: MORFOLOGÍA II

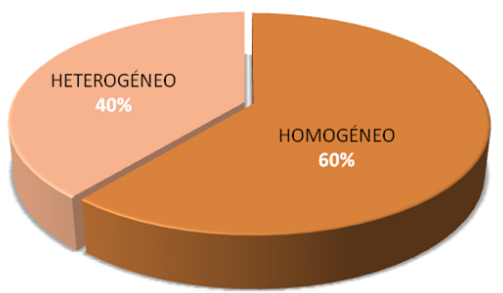

FIG. 170 Gráficos de estudio. Análisis de la morfología de mortero (CRISTINI)

La presencia de la arcilla es visible en un buen porcentaje de muestras, sobre todo de arquitectura residencial, con distribución bastante uniforme a lo largo de los siglos; mezclada con cal (19\%) o en casos más humildes, sin mezclar (2\%). Por otro lado, hoy en día pocos casos presentan juntas con mortero de asiento o de acabado exclusivamente a base de cal (19\%); afortunadamente, pocas son las

\footnotetext{
${ }^{3}$ Véase "Anejo. III.3 Informe analítico: selección de ladrillos y morteros (FT-IR)" y "Anejo III.4 Informe analítico: selección de ladrillos y morteros (SEM/EDX/MO)"
} 


\section{murOSINTRAMUROS}

fábricas que han sido totalmente alteradas con morteros de cementos (10\%).

Los datos morfológicos relativos a las fábricas constatan el empleo de morteros de bastante calidad, uniformes y homogéneos (61\%). Este aspecto es relevante en las fábricas monumentales, sobre todo a partir del siglo XVIII.

\section{MORTERO: COLOR}

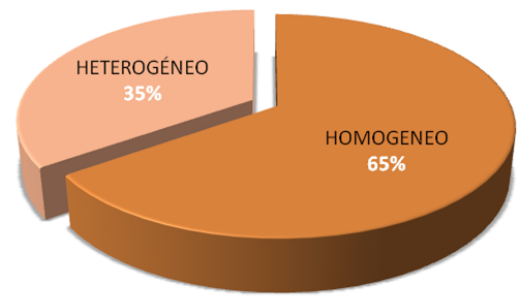

FIG. 171 Gráficos de estudio. Análisis del color de mortero (CRISTINI)

El panorama es diferente para las fábricas residenciales, con morteros, con un contenido en cal más reducido, a menudo mezclada con arcilla y arena, sobre todo en casos del S. XVII. Por este motivo son frecuentes las muestras de morteros con heterogeneidad (40\%) presencia evidente de impurezas con grumos (21\%) o caliches (19\%). Aspectos que sustancialmente se reflejan hasta a nivel cromático. El color del mortero es generalmente uniforme e igualado en la mayoría de los casos (65\%), siendo más desigual y aleatorio en aproximadamente un $1 / 3$ de los casos.

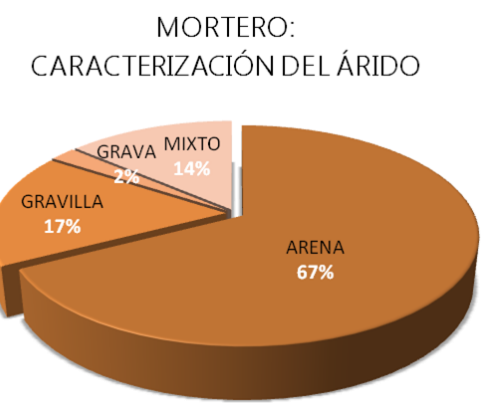

MORTERO: COLOR DEL ÁRIDO

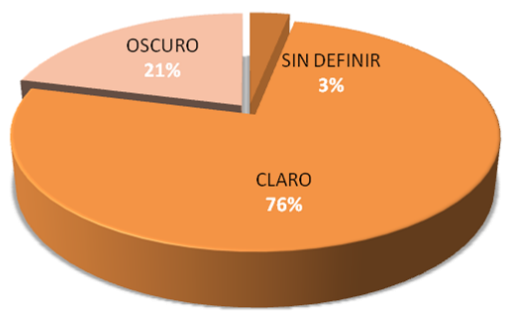

FIG. 172 Gráficos de estudio. Caracterización de áridos y su color (CRISTINI) 


\section{murOSINTRAMUIOS}

Para concluir, el análisis del árido que constituye las muestras de morteros permite una serie de reflexiones relativas al empleo de materias primas específicas. Tal y cómo confirman los datos de laboratorio los principales áridos empleados en la confección de morteros son arena de rio de grano fino y redondeado (67\%) y, en casos más limitados, gravilla (17\%). Las fábricas de tapia valenciana presentan áridos menos finos por otro lado en algunos casos como las fábricas enlucidas, es frecuente encontrar grava (2\%) o presencia mixta de grava y gravilla (14\%).

Estos datos, además se reflejan en la caracterización cromática de los áridos. La mayoría de ellos, a base de cuarzos y feldespatos, son bastantes claros (76\%), mientras que el empleo de grava o gravilla de río con filosilicatos contribuye a oscurecer la gama de colores de los áridos (21\%). 


\subsection{Futuras investigaciones}

Como se adelantó en la introducción "Muros intramuros" no se concluye con este texto, realmente la investigación deja espacio a futuros estudios, aspecto positivo y coherente con el tema analizado, que queda abierto y por definición no limitado.

Sin duda averiguar la evolución, el cambio y la transformación de las fábricas de la zona intramuros de la ciudad de Valencia es en sí un capítulo siempre abierto, que puede contar con la mejora y la implementación en el tiempo de datos arqueológicos, así como de aportaciones históricas, documentales o constructivas.
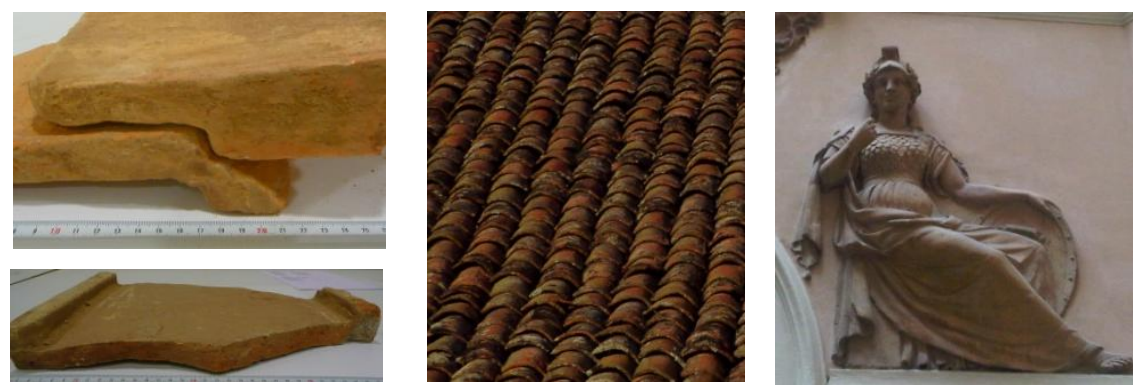

FIG. 172 Tejas romanas, depósito SIAM, tejas puestas en obra, cerámica arquitectónica en el Patio del Museo Nacional de Cerámica, Valencia (CRISTINI)

Para una posible ampliación de contenidos materiales

Sin duda, existen algunos puntos especialmente interesantes entre los temas que se pueden ampliar de cara a futuras investigaciones. Particularmente significativa puede ser la definición de líneas guías especificas para el ábaco de detalles constructivos, relacionando pautas operativas a diferentes sistemas de fábricas, zócalos, dinteles y vanos. 
También se puede proceder a definir con mayor detalle la restitución gráfica de distintos elementos constructivos y estratigrafía, aspectos que se han podido solo concretar en parte, debido al ámbito limitado de estudio parcial de las fachadas de los edificios. En el ámbito documental otro aspecto interesante sería la posible mejora del análisis histórico y constructivo, procediendo a ampliar información sobre el ámbito gremial, tanto del mundo de la producción, como de puesta en obra de ladrillos.

Además, este tema se abre hacia aspectos vinculados con la manufactura y la fabricación de tejas y terracota arquitectónica, elementos cerámicos cuyo proceso productivo es análogo a la elaboración de ladrillos. Estos dos temas estarían potencialmente relacionados con la evolución de las fábricas, con probables puntos en común y con un amplio campo de investigación inexplorado en el ámbito de estudios urbanos valencianos.
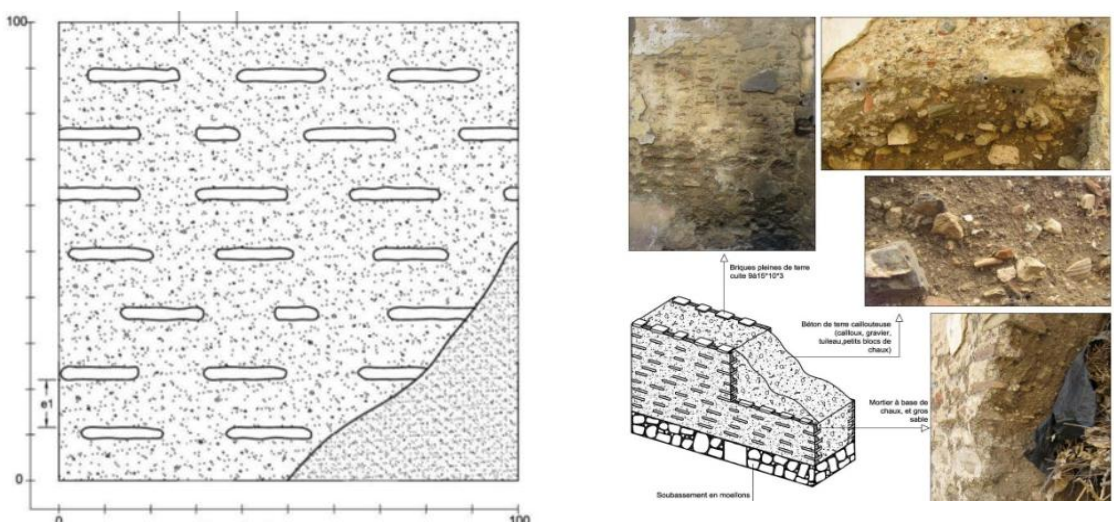

FIG. 173 Detalle de fábricas de tapia valenciana en la costa norte de Argelia, en la ciudad de Cherchell (imágenes cortesía de Alliche Samira)

\section{Para una posible ampliación geográfica}

El estudio ceñido al centro histórico de la ciudad de Valencia, ha sido un primer paso fundamental para la toma de contacto con la realidad urbana pre-industrial relativa a la producción de ladrillo y su puesta en obra, con los actores vinculados al proceso, con las tendencias constructivas. 


\section{murOSINTRAMUROS}

Aprovechando esta base en un futuro, se podrían contrastar los resultados del estudio con otros contextos urbanos de la Comunidad (Castellón, Alicante, Alcoy, Xàtiva...) con el objetivo de poder contar con espectros mucho más amplios. De este modo, además, averiguar sincronías o diacronías técnicas, así como diferencias productivas y constructivas respecto a la ciudad de Valencia.

Los beneficios de la "apertura" del estudio a otros contextos geográficos hacen posible una mejor calibración de la propuesta cronotipológica, así como de un provechoso proceso de refinado de las teorías propuestas. También sería interesante considerar el estudio dentro de un marco nacional, intentando comprobar la validez del método así como los resultados, respecto a otras aportaciones en la línea de investigación presentada.

Además tanto en los capítulos relativos al perfil histórico y cultural de la Ciudad de Valencia, en los concernientes con las técnicas constructivas, se ha hecho referencia a dos realidades específicas: el contexto constructivo bizantino y el musulmán.
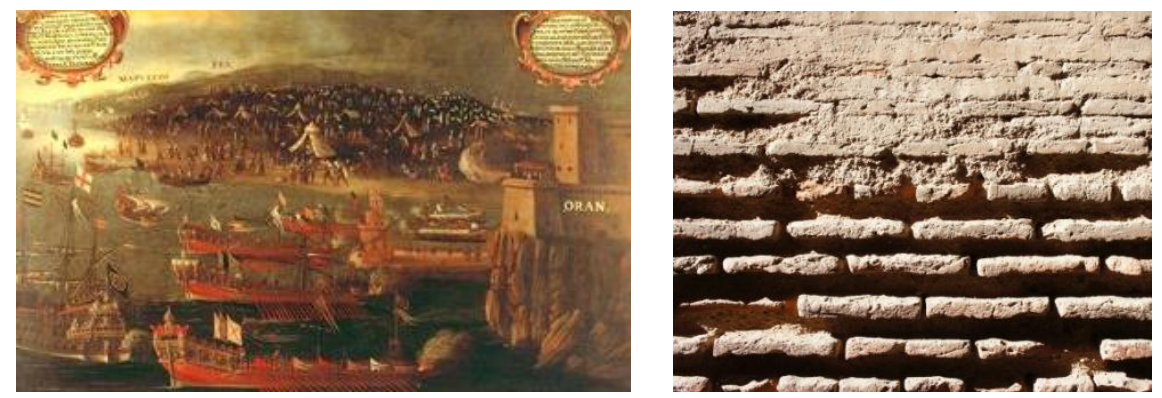

FIG. 174 Escena de la llegada de los moriscos a Oran (Argelia), por Mestre V., 1613 (BANCAJA); fábricas de ladrillo agramilado en el barrio de Der Timija, Marrakech, Marruecos (CRISTINI)

El estudio propuesto se ha limitado a presentar posibles influencias, contaminaciones y solapes existentes entre estas culturas constructivas y la realidad valenciana más autóctona...sin poder profundizar, por evidente falta de medios, en estas dos potenciales civilizaciones mediterráneas. 
Los datos aportados ${ }^{1}$ apuntan hacia algunos antecedentes constructivos especialmente interesante documentados y visibles hoy en día en la actual costa mediterránea de Marruecos/Argelia...así como en la costa meridional de Turquía.
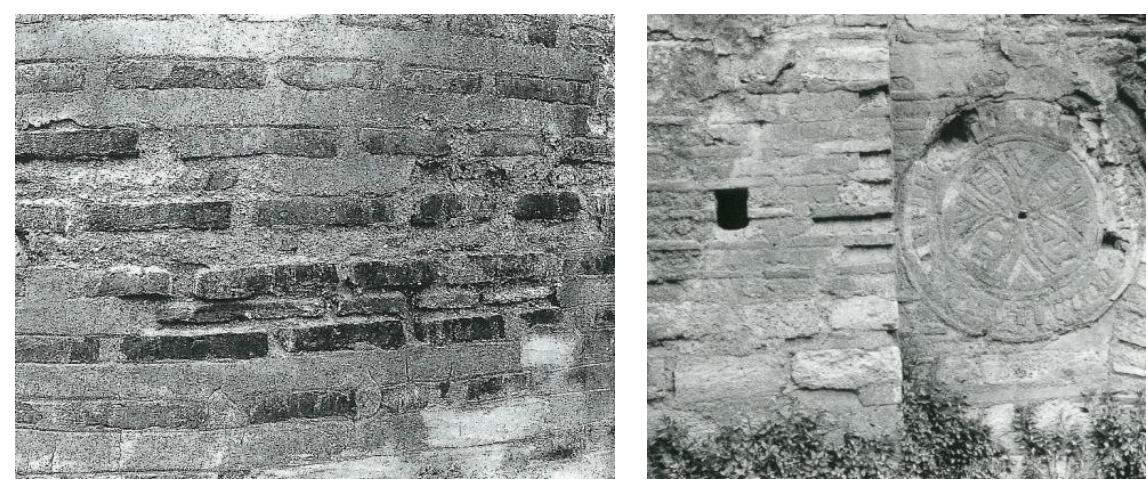

FIG. 175 Fábricas de ladrillos de Turquía. Detalle de la fachada de Panagia Chalkeon, con "recessed bricks", nártex de la Iglesia de Christ Pantepoptes en Estambul (HOSTEROUT)

Por lo tanto abrir el estudio a nivel regional, así como en ámbito nacional o internacional puede ser parte de un potencial trabajo no solo de mejora y ampliación, sino de auténtica verificación de la tesis propuesta.

"Véase "Cap.5.2.2 Posibles antecedentes históricos: fábricas de ladrillo en el mundo bizantino" y "Cap. 5.2.3 Posibles antecedentes históricos: fábricas de tapia en Al-Ándalus" 
murOSINTRAMUIOS

8. Versión italiana reducida 



\subsection{Motivazioni alla base della ricerca}

\subsubsection{Introduzione}

Quando verso la fine dell'anno 2004 presi in considerazione la realizzazione del lavoro che avrei dovuto presentare come tesi di laurea $^{1}$, mi interessò l'idea di documentare alcune forme delle tecniche costruttive utilizzate nel centro storico di Valencia.

La città (che avevo iniziato a conoscere nell'anno di interscambio accademico al quale avevo aderito) mostrava notevoli differenze architettoniche rispetto ai centri storici delle città del Nord Italia, dove avevo percorso la mia carriera di studi.

La mia attenzione venne colpita dalla fitta trama urbana realizzata nel passare degli anni, oggetto di sventramenti, speculazioni, miglioramenti e interventi più o meno drastici.

Il centro storico metteva in mostra il suo tessuto intimo in un susseguirsi di impalcature, di sostituzione di intonaci, demolizioni parziali e contemporaneamente presentava l'opportunità insperata di capire come era stata costruita la città nel passare dei secoli, in quale modo erano stati innalzati muri, con quali tecniche, con quali materiali e con quali caratteristiche.

Ogni demolizione costituiva l'occasione di indagare, per portare alla luce una particolare tecnica costruttiva.

Ogni facciata, in alcuni casi solo uno schermo di un immobile sventrato, giustificava la sua ragion d'essere e i suoi criteri costruttivi.

${ }^{1}$ CRISTINI V. Valencia, ciudad vella, ladrillos cara a vista, agramilados, fingidos y enlucidos. Analisi delle murature in laterizio: prassi costruttiva ed evoluzione archeometrica. Relatori: Bellini A., Mileto C., Pertot G., Politecnico di Milano, dicembre 2005 (inedito) 
La sostituzione di edifici che in maniera arbitraria o giustificata caratterizzava il centro storico cittadino, era una circostanza unica per conoscere e analizzare in forma globale alcune delle caratteristiche storico-costruttive del centro città.

Lo studio delle murature si presentava come interessante e suggestivo, anche se apparentemente di scarso valore, che (paradossalmente) non era stato oggetto di studi sistematici.

Senza dubbio ad un primo punto di vista i paramenti in laterizio possedevano aspetti estremamente banali e basici, caratteristiche poi smentite dal progresso della ricerca.

Alle evidenti caratteristiche costruttive iniziali, si sostituirono aspetti di particolare rilievo: gli edifici andavano svelando tecniche vincolate a specifici contesti culturali ed economici che variavano nei secoli.

In tal senso prendevano forma precise sequenze di soluzioni tecniche adottate, in alcuni casi sottili e sofisticate, sino ad allora fortunatamente sfuggite agli occhi committenti e costruttori.

Lo studio delle murature in mattone svelava così uno dei sistemi costruttivi che mantenevano integro il loro valore durante la secolare evoluzione urbana,senza dubbio ponendo in luce come il mattone fosse uno dei materiali edili più antichi presenti nella città. Così, poco a poco, con il susseguirsi di indagini e raccolte di dati, vennero alla luce dettagli e informazioni tecniche, che venivano raccolte e ordinate nella tesi di laurea?

Partendo da tale presupposto si è concretizzato un progetto che includeva una vasta gamma di edifici valenciani, sia palazzi nobiliari che edifici religiosi, nei quali erano presenti, documentate e datate differenti murature in mattone ${ }^{3}$.

Il progetto celava pertanto una serie di obiettivi specifici: studiare le

\footnotetext{
${ }^{2}$ Ibidem

${ }^{3}$ CRISTINI V. "Estudio de fábricas de ladrillos en Valencia: análisis mensiocronológicos y técnicas de acabados" en Arqueología de la Arquitectura, n. 5, Universidad del País Vasco CSIC Ed. 2008
} 
tecniche costruttive, la loro evoluzione, e le caratteristiche dei laterizi utilizzati, così come la loro evoluzione mensiocronologica ${ }^{4}$.

Una volta definite le caratteristiche delle principali murature monumentali, restava una grossa lacuna, la mancanza di informazioni sulle murature di mattoni di edifici residenziali, dei quali a malapena erano stati realizzati studi tecnici appropriati.

Questo passo, che iniziò nel 2008 col lavoro di ricerca finalizzato al conseguimento del DEA ${ }^{5}$ (Diploma de Estudios Avanzados) costituì il preambolo verso uno studio più approfondito che si accentrò specialmente nel quartiere storico di Velluters.

In questa circostanza si preferì approfondire maggiormente gli aspetti tecnico-analitici delle murature, accentrando l'attenzione sulla diagnostica di possibili patologie e sulle successive, idonee proposte volte ad interventi mirati a contrastarle.

In questo ambito, la tesi dottorale tenta di completare lo studio analizzando la totalità del centro storico cittadino mediante la lettura

\footnotetext{
${ }^{4}$ Seguendo I'ordine cronologico di stesura della tesi di laurea dell'Autrice, furono studiati i seguenti edifici:

Iglesia del Patriarca (prospetto laterale); Iglesia de lo Santos Juanes (facciata della Capilla de la Comunión e muro con nicchia nella navata laterale); Iglesia de Santa Úrsula (facciata principale); Iglesia de la Virgen de los Desamparados (tamburo); Catedral (pareti della sagrestia); Iglesia de San Nicolás (parete della Cappella laterale); Iglesia del Carmen (facciata della Capilla di Nostra Signora del Carmen e muro tra facciata della Chiesa e campanile); Iglesia de San Martín (parete laterale della Capilla de la Comunión); Convento del Pilar (facciata principale);Iglesia de San Esteban (parete della Capilla de la Comunión); Iglesia de San Tomás y Felipe Neri (parete laterale); Palacio Pineda (facciata principale); Iglesia de San Andrés (parete laterale); Palacio de los Català (facciata laterale); Palacio Cerveró (facciata principale); Palacio de la Aduana (facciata principale); Iglesia de los Genoveses (facciata principale); Iglesia de las Escuelas Pías (facciata principale); Casa Vestuario (facciata principale). La scelta effettuata si è basata sull'esistenza di dati probanti le diverse fasi costruttive; in contemporanea l'osservazione diretta ha permesso di identificare aree omogenee ben definite, valutando l'uso di materiali differenti ed eventuali interventi apportati in epoche successive

${ }^{5}$ CRISTINI V., Técnicas constructivas en arcilla: tapia valenciana y ladrillos en el centro histórico de Valencia, hacia el conocimiento y conservación de fábricas tradicionales. Lavoro di ricerca svolto per il Programma di dottorato "Patrimonio Arquitectónico: história, conservación, estudios gráficos". Universidad Politécnica de Valencia, novembre 2008 (inedito)
} 
muraria dettagliata di 95 paramenti nel Barrio de San Francesc, nel Barrio del Carmen, nel Barrio de la Xeu-Serea, prossimi al Barrio de Velluters, precedentemente studiato.

Questa nuova ricerca si è prefissa anche di migliorare la conoscenza della produzione pre-industriale di mattoni in Valencia, non solo il loro utilizzo.

Le figure coinvolte nel processo (fabbricanti fornaciai, venditori, controllori di vendita, muratori, ecc.) giocano un ruolo importante al fine di analizzare e capire questi paramenti.

Non a caso i problemi legati alla produzione, vendita e messa in opera di questi materiali in Valencia completano l'analisi dei casi di studio visibili nella zona interna (intramuros) dell'antica cinta muraria cittadina.

La speculazione edilizia ${ }^{6}$ nel centro storico della città ha costituito paradossalmente un'occasione unica (e agrodolce, nel contempo) per riflettere sopra alcuni aspetti costruttivi delle "murature intamura".

Da tutto ciò scaturisce anche un aspetto di riflessione (che viene descritto nelle pagine seguenti) che si presenta come potenziale opportunità di studio sulla varietà e complessità di trame socio/economiche e produttive vincolate ai caratteri costruttivi del centro storico di Valencia.

\subsubsection{Perché nasce "muros intramuros"}

Quella che si presenta di seguito è una ricerca lenta e continua che mi ha accompagnato nel controllo progressivo di una lingua nuova,

\footnotetext{
${ }^{6}$ RAE (Dizionario della Reale Accademia Spagnola): "int. commerciare, trafficare, procurare profitto o guadagno al di fuori del commercio mercantile". Il verbo "especular" in spagnolo ha questi significati nella sua forma intransitiva. Da qui nasce il gioco di parole "Especular SOBRE el ladrillo o especular CON el ladrillo"

${ }^{7}$ RAE (Dizionario della Reale Accademia Spagnola): "trans. meditare, riflettere, teorizzare, registrare, osservare con attenzione qualcosa per riconoscerlo o esaminarlo". Il verbo "especular" in spagnolo ha questi significati nella sua forma transitiva. Da qui nasce il gioco di parole "Especular SOBRE el ladrillo o especular CON el ladrillo"
} 
che è cresciuta con me, condivisa da principio con l'interesse dei miei genitori, colleghi e infine con la complicità di un compagno che pure espleta la mia professione.

Le ricerche sono state svolte in differenti città e contesti valenciani, vivendo inevitabili fasi di alti e bassi, di momenti bui e poi di vigore in istanti più felici della mia vita.

Però l'impegno si è rinforzato di pari passo col mio maturare, accompagnato da progressi lenti e da immagini fotografiche, inizialmente ingenue e via via sempre più mirate e critiche. Per questo posso considerare questa ricerca lo specchio della mia irrequietezza e della mia curiosità, essendo uno studio entrato a far parte del bagaglio di vita che ha accompagnato una giovane, poco più che ventenne, in un appassionante percorso lavorativo.

Per tanto, quella che segue può considerarsi una ricerca personale, non semplicemente professionale, impregnata di interesse per la cultura materiale più autoctona legata alla città che mi ha adottato.

Considero questa ricerca una tappa della mia vita che ho potuto percorrere anche grazie ad un ampio lavoro a margine della stessa: nel tempo i vari capitoli sono stati oggetto di ampi ricontrolli, cercando di usare le terminologie più corrette ed appropriate, chiarendo dati empirici.

Per questo lo scritto non vuol essere un mero riassunto delle ricerche eseguite, al contrario intende presentare in forma ottimale il risultato di idee ponderate, selezionate e revisionate nel tempo, filtrate attraverso varie fonti, prima della loro definitiva esposizione.

D'altro canto queste pagine rappresentano anche un punto di partenza per intraprendere future ricerche correlate a queste tematiche e, sempre su questa base, spero che lo studio possa irrobustirsi in futuro con ulteriori esperienze, migliorie metodologiche e punti di vista di altre discipline.

Mi auguro che alla prossima revisione di questo lavoro possano contribuire differenti ricerche analitiche, modelli storici, dati tecnici, 
contatti con altre realtà geografiche limitrofe, sia regionali che nazionali o internazionali, mantenendo sempre appassionante la ricerca nel settore dell'architettura.

Fa sorridere e riflettere vedere come uno studio che è cominciato in modo assolutamente fortuito e personale, sia cresciuto, abbia preso forma, cambiato registro e si sia condensato in un testo che aspira ad essere rigoroso, serio e perché no, precursore di altre attitudini curiose e flâneur, proprie di un attento osservatore urbano, come diceva Baudelaire, nei confronti dei più autentici caratteri costruttivi valenciani. 


\subsection{Tematiche presenti nella ricerca}

La ricerca propone la stesura di un registro di informazioni, destinato a documentare, catalogare e analizzare le caratteristiche di murature storiche in mattoni, vincolate a edifici residenziali e monumentali della zona "intramuros" di Valencia.

In questo contesto pertanto l'obiettivo è quello di approfondire una traccia di ricerca che è andata maturando negli anni, sfociando in una serie di studi realizzati dall'Autrice ${ }^{1}$, come precedentemente descritto.

Tutti questi risultati intendono proporre una serie di riflessioni in merito alle murature in laterizio del centro storico: cosa svelano i muri in mattone-(non è una semplice domanda metaforica ma il perno su cui ruota tutta la tesi)? Quali realtà tecnologiche, produttive, sociali, materiali ed economiche, intimamente vincolate alle murature, si possono identificare aldilà della evoluzione urbana? Che nessi sussistono fra loro?

E' complicato cercare di entrare in queste trame storiche e sociali poiché si corre il rischio di destreggiarsi ingenuamente fra discipline vicine all'architettura ma da questa differenti, quali sono per esempio la sociologia, l'economia e l'antropologia.

Tutto ciò però fa parte della sfida di cui si è accennato all'inizio del lavoro, basata proprio sull'intento di incrociare differenti fonti documentali. Questo con la finalità di poter filtrare informazioni

${ }^{1}$ CRISTINI V., Op. Cit., (2005/2008) 
eterogenee, tangenti a svariate discipline per poter così successivamente formare l'ossatura di uno schema chiaro e referenziato, sull'evoluzione delle murature in laterizio del centro storico di Valencia.

\subsubsection{Contenuto materiale}

Lo studio si realizza grazie ad una serie di capitoli specifici, articolati in base a diverse messe a fuoco di analisi e riflessioni (Tomo I):

\section{L'IDENTITA' DEL CENTRO STORICO DI VALENCIA}

- Profilo geomorfologico e geologico Lo sguardo storico verso l'edafologia di Valencia

- Profilo storico e culturale

\section{LE MURATURE IN VALENCIA: VERSO UN'INTERPRETAZIONE}

- Una questione di ruoli

- Ceramisti e addetti alle fornaci: produzione e cottura

Il laboratorio e la fornace

- Venditori e controllori: mercato e commercio

Istituzioni

Corpus normativo e legale

Rubrica de la Rajola y la Teula

Els rajolers

- Trattati e manuali: de lateribus

Il Secolo XIX e la maturazione dei manuali

pratici relativi ai laterizi

Esempi pratici di muratura nei manuali di architettura

\section{"MUROS INTRAMUROS": STUDIO DELLE MURATURE}

- Verso l'evoluzione delle tecniche costruttive in argilla

- Murature con laterizi

Tapia valenciana

Possibili antecedenti storici: murature in mattoni nel 
mondo bizantino

Possibili antecedenti storici: murature in tapia in Al-Andalus

Possibile promotore della tecnica:

La Fábrica Vella dita de Murs y Vals

- Murature di laterizi

Il mattone visibile/intuibile

Il mattone visto

Il mattone nascosto

\section{MURATURE: VERSO UNA PROPOSTA CONSERVATIVA}

- Analisi diagnostica dei muri oggetto di studio

Quali patologie?

- Linea guida per possibili interventi

Procedimenti di pulizia

Consolidamento

Idrorepellenza

Completamento di volumi

Sostituzione di elementi

Riparazione di giunti

Riparazione di fessure

Protezione finale

- Nucleo, connettori e crosta: intervenire in murature di tapia valenciana

Inoltre la ricerca proposta si basa su di una fase di analisi empirica, raccolta in tre allegati al testo base che costituiscono un registro dettagliato di schede e dati di studio (Tomo II).

\section{ALLEGATO I: REGISTRO DETTAGLIATO DELLE MURATURE STUDIATE}

- Criteri per la redazione di un registro di dati Database

Murature storiche: Barrio del Carmen

Murature storiche: Barrio de Mercat

Murature storiche: Barrio de S: Francesc 
Murature storiche: Barrio de Velluters

Murature storiche: Barrio de la Xeu/Serea

- Alcuni dei principali dettagli relativi a murature storiche in laterizi

\section{ALLEGATO II: RACCOLTA DI DATI ARCHEOLOGICI}

- Estratto dei dossier archeologici consultati

- Base di dati.

Mattoni provenienti dal deposito SIAM

\section{ALLEGATO III: CARATTERIZZAZIONE E ANALISI DELLE MURATURE}

- Proprietà chimiche, fisiche e meccaniche di mattoni storici

Caratteristiche mineralogiche

Proprietà fisiche

Proprietà idrauliche

Proprietà meccaniche

Proprietà di durata

- Criteri per lo studio di mattoni e di malte

- Studio analitico: selezione di mattoni e malte (FT-IR)

- Studio analitico: selezione di mattoni e malte (SEM/EDX/MO)

Il capitolo relativo alla "Identità del centro storico di Valencia" propone una messa a fuoco iniziale e propedeutica allo studio, per potere correlare chiaramente i caratteri costruttivi a uno specifico contesto urbano.

Pertanto, conoscere il profilo geomorfologico, geologico, storico o, in senso più ampio, culturale della città di Valencia, è un passo indispensabile per capire la traiettoria dell'ampia diffusione dei laterizi in ambito urbano.

Tale sintetico capitolo, costituisce la base teorica che spinge ad una riflessione più dettagliata, sviluppata nei capitoli successivi relativa ai differenti attori coinvolti nei settori della produzione, del controllo e della messa in opera dei laterizi. 
Professioni differenti prendono forma nella descrizione di questo profilo urbano, presentando la loro storia, la loro evoluzione o il loro tramonto.

Ceramisti, fornaciai, venditori, controllori, così come contributi teorici desunti da manuali e trattati, permettono approfondire la conoscenza delle murature in laterizi.

Questa conoscenza a priori permette di affinare l'analisi fino alla scala architettonica, e proprio nel successivo capitolo "Muros intramuros, studio delle murature" consentirà di indagare sulla sottile differenza esistente tra murature con mattoni e murature di mattoni.

Inoltre viene proposta la definizione di una serie di varianti specifiche: tra esse si incontrano murature con mattoni visibili/intuibili, visti o nascosti, attraverso sequenze e stratificazioni temporali che delineano l'evoluzione cronotipologica muraria nel centro storico.

Dopo aver definito queste possibili combinazioni tecniche, lo studio continua nel capitolo "Murature: verso una proposta conservativa" trattando l'identificazione di potenziali aspetti patologici riscontrati nei casi oggetto di studio, come pure la proposta di un possibile excursus operativo finalizzato agli interventi.

Infine i tre allegati finali riassumono e ordinano la raccolta di dati relativi alle letture murarie, sia dei paramenti distribuiti nei quartieri della zona intramuros, sia dei mattoni affiorati da scavi archeologici nell'area urbana e successivamente catalogati dalla Municipalità.

Questi tre annessi, i cui dettagli vengono descritti all'inizio di ogni paragrafo, costituiscono il corpo pratico ed empirico della tesi, così come una serie di dati procedenti da prove analitiche di laboratorio realizzate come completamento dell'analisi visiva.

In tal senso, queste tre sezioni, specifiche sulla caratterizzazione delle murature, contribuiscono alla definizione dei modelli cronotipologici generali proposti nello studio. 


\subsubsection{Limiti geografico-temporali}

Lo studio abbraccia cinque quartieri (barrios) della zona intramuros della città, attualmente delimitata dalla riva destra del primordiale alveo del fiume Turia e dal tracciato storico delle mura cristiane che formano il contemporaneo anello di circonvallazione interna (Calle Colon, Calle Xativa e Calle Guillen de Castro).

L'insieme topografico così delimitato compone la zona urbana nota come Quartiere Storico Protetto "Città Vecchia" (CHP-1) definita nel Piano Generale di Ordinamento Urbano (PGOU) della città di Valencia, approvato il 28 dicembre 1988.

Lo studio si accentra in questo spazio territoriale per motivi specifici: da un canto, questa zona è quella che presenta la maggior concentrazione, ricchezza e stratificazione di murature storiche in mattone; da un altro va ricordato che esiste anche un'altra ricerca precedente sulle murature in laterizio della zona di ampliamento ottocentesco della città ${ }^{2}$ che però non menziona ne' tratta la zona intramuros.

La proposta di studio, nasce quindi anche dall'esigenza di completare detto lavoro, colmando una lacuna relativa allo studio delle murature, in questo caso proprio nella zona più antica della città.

E' anche opportuno prendere in considerazione il fattore chiave proprio dei paramenti in laterizio (di edifici religiosi, residenziali, ecc.) del centro politico e amministrativo di Valencia, che potranno servire da riferimento, sia a livello costruttivo sia a livello formale e tipologico, a fronte di possibili future ricerche relative a zone periferiche o extra urbane, tanto provinciali come regionali.

Lo spazio temporale della ricerca si vincola alla realtà produttiva pre-

\footnotetext{
${ }^{2}$ BLAT LLORENS J. V., Presencia del ladrillo cara vista en el primer Ensanche de la ciudad de Valencia, Tesi dottorale diretta da Lecona Lopez, Espí Cerdá; Valencia, 1996
} 
industriale urbana e in tal senso assorbe un intervallo di tempo che parte dall'epoca romana, contraddistinta da una primordiale produzione artigianale di laterizi, sino a giungere all'affermarsi delle tecnologie industriali del XIX secolo ${ }^{3 .}$

Un periodo così ampio rende complicato impostare e definire I'analisi, essendo uno spazio di tempo cruciale, che richiede uno studio globale, dato che il continuo riciclo e il riutilizzo dei materiali rende impossibile tagli e salti cronologici a priori.

Non va dimenticato che i dati effettivamente disponibili sulle prime fasi produttive/costruttive urbane sono molto scarsi, per cui includerli nella ricerca permette di delineare un quadro più completo della realtà pre-industriale urbana.

Un fattore chiave che condiziona lo spazio temporale è anche lo squilibrio esistente fra archeologia pre-industriale e industriale, che sicuramente volge a favore di quest'ultima.

È necessario infatti tenere conto che la documentazione relativa alle tecniche produttive e costruttive dei mattoni industriali, a partire dalla seconda metà del XIX secolo, è di certo più aggiornata e approfondita ${ }^{4}$.

E' per questo che la ricerca si concentra nel periodo produttivo/costruttivo pre-industriale, trattandosi di un arco temporale piuttosto sconosciuto, che concede più spazio ad un'analisi inedita. Questa lacuna di informazioni e ricerche è anche dovuta al fatto che semplici laterizi provenienti da murature sono

\footnotetext{
${ }^{3}$ L'arco temporale della ricerca parte dall'epoca della fondazione romana di Valencia fino all'arrivo in città della meccanizzazione e dello stampaggio dei mattoni. E' noto che a Meliana, dal 1867, si inizia a usare la pressa-formatrice a vapore Whitehead, eccellente per produrre tubi, canalette e mattoni in ceramica. Nello stesso anno si comincia ad usare il forno Hoffman a fuoco continuo e regolabile, a pianta circolare e a dodici camere di cottura (Cap. 4.1" una questione di ruoli")

${ }^{4} \mathrm{Si}$ veda" Associazione Valenciana di Archeologia Industriale" (AVAI) e le pubblicazioni disponibili su: http://arqueologiaindustrial.wordpress.com/
} 
considerati resti archeologici di scarso interesse (come pure tracce di intonaci, piastrelle, ceramiche o resti di solai, ecc.). Per questo i pochi reperti di mattoni raccolti nei fondi dei depositi archeologici municipali rappresentano esemplari peculiari, particolarmente interessanti per contribuire allo studio. 


\subsection{Finalitá della ricerca}

\subsubsection{Interesse}

L'interesse della tesi si radica nell'analisi degli aspetti vincolati alla protezione della cultura materiale urbana, tanto di caratteri tangibili quanto intangibili della stessa.

L'evoluzione urbana del centro di Valencia negli ultimi anni ha avuto un notevole impatto sul tessuto storico della città, con la demolizione e la scomparsa di una buona percentuale di edifici residenziali storici. Il restauro di edifici di elevato valore patrimoniale/monumentale, in certi casi non ha neppure potuto garantire la piena e completa corrispondenza alle strutture autoctone preesistenti.

In questa circostanza, la grande ignoranza esistente sulle tecniche tradizionali valenciane e sulla loro evoluzione nel tempo, è certamente responsabile della demolizione brutale e irriguardosa alla quale sono soggetti molti edifici residenziali.

Da qui nasce lo sviluppo della tesi, che si presenta come un documento capace di mettere l'accento sulla conoscenza come premessa per conservare le murature in laterizio, stabilendo una possibile linea guida per il loro mantenimento.

Potere destare interesse verso le murature o verso il "Velo di Maya"12 che metaforicamente schiudono, rappresenta il secondo punto di interesse motivante questa ricerca.

I venditori di materia prima, i forni produttori di laterizi, le restrittive norme di compra e vendita dei mattoni, sono realtà intrinseche ad 
ogni singola muratura.

Va pure segnalato che lo studio condotto costituisce solo una parte di un progetto più vasto ed ambizioso, che mira a definire i caratteri costruttivi del centro di Valencia tramite una raccolta e un'analisi esaustiva di differenti aspetti costruttivi storici (Mileto, 2008).

Quindi il lavoro si inserisce in una serie di recenti ricerche legate alla città di Valencia, come quelle relative a solai e coperture (Diodato), balconi (Privitera), carpenterie (Maioli), intonaci (La Spina).

\subsubsection{Obiettivi}

Il lavoro di ricerca proposto intende raggiungere una serie di obiettivi differenti e allo stesso tempo tra loro coerenti, che abbracciano una serie di quesiti fondamentali.

E' importante evidenziare che la validità di questa proposta metodologica costituisce di per se' una premessa di base che si intende raggiungere con l'analisi.

La proposta di uno studio olistico, che racchiude diversi aspetti teorici e tecnici, è una prospettiva nuova, finora non approfondita per definire la cultura materiale urbana vincolata alla costruzione in laterizio.

Si è voluto scommettere in tal modo su un'ampia varietà di discipline e metodi per potere definire i caratteri costruttivi urbani con mattoni.

D'altro canto un obiettivo importante della ricerca è anche ordinare riflessioni, studi e analisi relative alle murature, realizzati dall'autrice negli ultimi anni. Per tale motivo la tesi presenta due aspetti basici: da un lato di conclusione e definizione dei concetti, dall'altro di apertura e disegno di possibili nuove ricerche. 
Gli aspetti maggiormente vincolati ai risultati scaturiti dal lavoro sono i seguenti:

Delinearsi di un profilo socio/economico/culturale/tecnico vincolato alla produzione pre-industriale del mattone e alla sua messa in opera: si stabiliscono i tratti fondamentali che legano la produzione, vendita e messa in opera dei mattoni pre-industriali ad un preciso intorno cronologico e geografico.

Creazione di un registro dettagliato di murature storiche in mattoni della zona "intramuros" della città di Valencia: si intende catalogare in maniera esaustiva la presenza di murature in mattoni nella zona "intramuros" di Valencia, riportandovi una serie di dati tecnici e metrici specifici.

$\star \star$

Disegno di una curva mensiocronologica per la zona "intramuros" della città di Valencia: si propongono conclusioni relative allo studio e alle indagine previe sull'evoluzione mensiocronologica del mattone nel suo utilizzo urbano, per potere così definire variazioni dimensionali e costruttive dei laterizi preindustriali.

Descrizione di una possibile cronotipologia di murature in laterizio della zona "intramuros" della città di Valencia: si propone desumere una serie di dati statistici e riflessioni partendo da basi empiriche (grazie ai risultati estrapolati dal registro dettagliato delle murature, dai dati archeologici e dalle analisi di laboratorio). 
Riferendosi a questi dati si descrivono sincronie costruttive o salti temporali esistenti fra le differenti soluzioni di murature.

Messa a punto di una potenziale linea guida che orienti gli interventi sulle murature storiche in mattoni: si descrive una serie di passaggi operativi e metodologici per potere garantire la conservazione dei muri storici in mattoni. 


\subsection{Conclusioni: sincronie e diacronie tecniche tipologiche}

Nel momento di realizzare un bilancio conclusivo relativo allo studio di 95 murature storiche, distribuite nei cinque quartieri della centro storico di Valencia (Carmen, Velluters, la Xeu Serea, San Francesc e Mercat), si propone di considerare ciascun esempio come la tessera di un complesso mosaico che da vita all'evoluzione dei laterizi e del loro utilizzo a Valencia.

Questi esempi, nonostante siano stati oggetto di restauri più o meno accertati o interventi più o meno drastici, sono comunque tracce vivide della complessa stratificazione costruttiva, che permette di tracciare un quadro evolutivo, contraddistinto da fasi fluide piuttosto che da brusche interruzioni e salti tecnologici.

Le modificazioni storiche che vivono le murature in mattoni sono dovute a una serie di concause, non solo a fattori avulsi. Per questa ragione, nel momento di definire le linee guida dello studio si mescolano e sovrappongono tecnologie differenti, mode, esigenze economiche o sociali e perfino aspetti puramente storici.

In biologia il cambio dell'epidermide è un processo conosciuto e stagionale, intrinseco alla crescita dell'animale, e senza dubbio con una serie di effetti benefici, tanto che la muta è riconosciuta per le sue proprietà che permettono di liberarsi da insetti e per favorire la rimarginazione di ferite; è perfino un processo che simbolizza la salute. In medicina, il bastone di Esculapio è rappresentato con 
attorno un serpente arrotolato, metafora del ringiovanimento e del vigore, dati proprio dalla periodica modificazione dell'epidermide del rettile.

Nello stesso modo le murature vivono cambi, attraverso i secoli, che non necessariamente coincidono con evoluzioni o retrocessioni tecniche, quanto piuttosto con semplici e continue trasformazioni. Le murature modificano le loro superfici, cambiano, crescono, si trasformano e tuttora, a volte, permangono resti, tracce, di queste sostituzioni.

Sono passi che ricordano un processo biologico, che fondamentalmente si riassume in azioni costruttive che vestono o spogliano le murature durante cicli di interventi coerenti con periodi socio/economici specifici.

L'argilla costituisce la base di murature in adobe, la cui presenza oggi scomparsa nel tessuto storico è documentata nelle fonti archeologiche come propria della città romana. Come in altre regioni spagnole, l'architettura più povera e umile (soprattutto in zone extraurbane) continuerà utilizzando questo materiale fino al termine del Medioevo. Si deve comunque riconoscere come, allo stesso tempo, il mattone cotto (il later, nella Valencia romana) presenta una diffusione limitata solamente a infrastrutture idrauliche (condotte idriche, pozzi, suspensurae, opus signinum) o funerarie (tegole e mattoni per sepolture), così come mostrano gli scavi archeologici effettuati dal SIAM, il Centro di Ricerca di Archeologia Municipale di Valencia dove prevalgono resti di costruzioni in pietra, soprattutto per edifici civili di rilevanza emblematica.

In base alle fonti documentali si dovrà aspettare sino ai secoli V-VI per poter osservare come la città poco a poco cominci a presentare esempi più significativi di murature in mattoni, con influenza potenziale della cultura bizantina; tecnologia costruttiva che comunque rimane marginale, dato che con la dominazione islamica 
(secoli VIII-XIII) le murature con formatura in terra cruda, calce e pietra diverranno le autentiche protagoniste dell'architettura sia civile che militare, convivendo parallelamente con l'uso dell'adobe soprattutto nell'architettura domestica.

Sarà solo con la riconquista cristiana della città (1238) quando il mattone inizierà a essere ampiamente utilizzato tanto nell'architettura domestica quanto nelle opere pubbliche, grazie alla presenza della Fabrica de Murs y Vals (istituzione pubblica medievale che si occupava della costruzione e mantenimento delle mura urbane, così come di ponti, strade e sistemi idraulici). In termini costruttivi si può anche affermare che le volte laminari in laterizio, gli archi diaframma e la tapia valenciana, costituita da muri formati in terra cruda e rinforzati con mattoni, coincidano con l'avanzata delle truppe della riconquista cristiana.

Soprattutto questi ultimi paramenti si concentrano nei sec. XVI-XVII, mostrando successivamente un lento declino. Questo tramonto della tecnica sembra coincidere con la cacciata dell'etnia islamica (Expulsión de los moriscos, 1609) e culminare alla fine del XVII secolo. La tapia cede progressivamente il passo a murature con mattoni "visibili", conosciuti come agramilados, con doppio giunto, di preparazione e finitura con velature, che caratterizzano importanti edifici religiosi della conosciuta Valencia Conventual (sec. XVII).

La tecnica con agramilado o con laterizi visibili/intuibili nel paramento, si radica nel passato costruttivo della città, nelle possibili murature bizantine con giunti spessi, e si afferma come una tecnica autoctona che risponde bene all'assorbimento di deformazioni tipicamente dovute alla natura fangosa del sottosuolo, così come alle cicliche esondazioni del Turia, il "nemico liquido" della città, o a differenti spinte creantesi nelle murature.

Pertanto si può considerare la tapia valenciana come l'indicatore costruttivo degli anni propri della Reconquista e della definitiva 
affermazione della cultura cattolica, mentre le murature con agramilado sono il riflesso tecnologico degli anni della Controriforma e delle nuove rigide prescrizioni liturgiche.

Solo dopo l'affermazione dell'influenza borbonica, a partire dal sec.XVIII, i gusti costruttivi cambiano e si raffinano. Le murature sono oggetto di sperimentazioni più signorili, dando spazio a giochi cromatici in accostamento con pietra, mattoni sagomati o dipinti.

Proprio a partire dal XVIII secolo il laterizio acquista un nuovo status, che era timidamente sbocciato in edifici pionieri, costruiti nel Rinascimento (come per esempio il Seminario Conciliare del Corpus Christi o il complesso di S. Miguel de los Reyes). La regolarità geometrica delle orditure delle murature, rafforzata dai miglioramenti tecnologici, diventa un linguaggio costruttivo codificato, apprezzato in edifici pubblici non solo residenziali.

Queste innovazioni tecniche vincolate al mondo della produzione contribuiscono a trasformare il mattone in un materiale nobile, utilizzabile in un ventaglio di soluzioni costruttive sempre più complesse, come mostrano edifici eclettici del XIX secolo, con sperimentazioni realizzate in laterizi smaltati e faccia a vista.

Nonostante questi cambi si può riconoscere una logica costruttiva senza dubbio saggia e regolata, nascosta negli interstizi di queste murature. Le murature non si cancellano nel tempo, bensì si trasformano. Esistono edifici che mostrano paramenti con agramilado, che si camuffano con soluzioni di trompe loeil o si intonacano.

Altri casi invece, oggi con murature faccia a vista mostrano cicatrici costruttive formate da possibili tracce di intonaco che rivestivano i paramenti originari. In molti casi quindi le soluzioni costruttive sorgono le une dalle altre, si mescolano, proprio in una sequenza di mutazione di strati e superfici, che come si è accennato, segue delle 
cronologie specifiche.

E'evidente che alcuni interventi recenti alterano queste logiche costruttive. Ciò è latente in murature realizzate in origine come paramenti con laterizi velati o intonacati, che attualmente vivono operazioni di spoglio delle finiture e si trasformano in semplici murature faccia a vista.

O in casi opposti, donde un perverso pudore per l'irregolarità di strati e aggiunte storiche, conduce a nascondere le murature, con intonachi o finiture opache, che mascherano tapia valenciana o murature irregolari.

Questi cambi di "esoscheletro" delle murature valenciane chiamano l'attenzione per essere passaggi totalmente fluidi nel tempo. Non si assiste a cambi drastici di linguaggio, le tecniche convivono mutuamente, con punti di inflessione storici o economici (come per esempio la Reconquista, la Expulsión de los Moriscos, la controriforma, l'arrivo dei Borboni) che segnano importanti cambi di direzione e alterazioni nella storia delle murature.

Per questo motivo non è possibile definire in modo rigido e prestabilito la sequenza delle murature, quanto piuttosto, è prudente orientare I'analisi a questi incroci continui di sfumature tecniche, revivals estetici e componenti ibride, mescolate.

Ne emerge un quadro complesso, intessuto da matrici differenti, non alimentato da evoluzioni o involuzioni, quanto piuttosto da metamorfosi, sani processi di muta, che rendono lo studio delle murature un tema di studio sempre aperto.

Attualmente propositi speculativi e mancanza di sufficienti misure protettive per la architettura storica urbana, minano questa secolare logica costruttiva. In molti casi gli interventi contemporanei rendono solo intuibili soluzioni costruttive, leggibili grazie alle gerarchie 
esistenti fra laterizi e giunti, ma le murature storiche, proprio per la mancanza di conoscimento dei caratteri costruttivi, sono sempre più a rischio. Per questo l'obiettivo di questo studio è anche quello di contribuire alla piena lettura delle superfici murarie, con logiche che aspirano alla completa conoscenza delle sincronie e diacronie costruttive, non solo alla loro superficiale intuizione. 


\subsection{Definizione di una curva mensiocronologica}

Come indicato nel capitolo relativo alla metodologia della ricerca proposta, lo studio mensiocronologico propone di relazionare le distinte misure dei mattoni (lunghezza, larghezza e spessore) a specifiche curve evolutive, che collegano le variazioni metriche con indicatori cronologici.

Di norma i dati metrici non presentano variazioni così evidenti come in altri contesti dove è stata applicata la disciplina mensiocronologica ${ }^{1}$.

Nei secoli le variazioni dimensionali sono a volte millimetriche, rendendo complesso utilizzare come soli fattori di discriminazione dati unicamente metrici e temporali. In base a quanto descritto, le variazioni dimensionali dei laterizi sono minime, probabilmente proprio per il controllo urbano effettuato sulla produzione, commercio e messa in opera dei mattoni².

Nei secoli le produzioni di laterizi nella città si sono regolate e normalizzate attraverso professioni specifiche, come quelle del Magister romano, il Muhtasib musulmano, il Mustaçaf cristiano, l'illuminista Fiel Almotacen Provincial e I'ottocentesco Fiel Contraste de Pesas y Medidas.

\footnotetext{
${ }^{1}$ Si veda "Cap. 2.2.1. La mensiocronologia"

${ }^{2}$ Si veda "Cap. 4.3. Venditori e controllori: mercato e commercio"
} 
Inoltre sono provati il reimpiego e il riciclaggio di materie prime, così come la secolare ibridazione tecnologica delle fornaci, ${ }^{3}$ fattori che evidenziano un continuum di sapere, evidente nei laboratori ceramici iberici, romani, musulmani e cristiani.

I cambi tecnici pertanto non sono drastici, quanto piuttosto diluiti nel tempo, mostrando aspetti che contribuiscono a definire questa sostanziale omogeneità produttiva, che si riflette nell'equilibrio della curva mensiocronologica.

Un ulteriore aspetto importante da considerare è la sostanziale costanza cronologica del sistema metrico, aspetto che rafforza l'uniformità delle produzioni ceramiche nei secoli ${ }^{4}$.

\section{Analisi mensiocronologica}

Si propone la interpretazione di dati metrici grazie alla selezione di 45 murature con datazione documentata e certa, scelte fra i 95 casi di studio analizzati ${ }^{5}$.

\section{Quartiere del Carmen: murature con datazione accertata}

Ca113; Ca118; Ce71; Cg01a; Cg01b; Cg02; Cg14

\section{Quartiere di S. Francesc: murature con datazione accertata}

Fa39; Fa82; Fa105; Fa153a; Fa153b; Fa153c; Fb117

\section{Quartiere del Mercat: murature con datazione accertata}

Ma28; Ma31; Ma54; Ma92; Ma93; Mb72; Mb155; Me212a

\footnotetext{
${ }^{3}$ Si veda "Annesso II.1.1 Estratto dei dossier archeologici consultati"

${ }^{4} 1$ palmo $(23 \mathrm{~cm})$ si divide in 12 dita; 1 dito $(2 \mathrm{~cm})$ si suddivide in 12 linee; 1 linea $(1.6 \mathrm{~mm})$. Op. Cit. LÓPEZ GONZÁLEZ, GARCÍA VALLDECABRES (1999)

${ }^{5}$ AA. VV., Guía de Arquitectura de Valencia, Ícaro Ed., Valencia, 2007
} 
Quartiere di Velluters: murature con datazione accertata

Va34; Va81a; Va81b; Va82; Va103a; Va103b; Va104; Vb67; Vb68; Vb69

\section{Quartiere diXeu-Serea. murature con datazione accertata}

Xa46; Xc16a; Xc16b; Xc16c; Xc96a; Xc96b; Xd13; Xd54a; Xd54b; Xd65; Xe66; Xf25; Xf26

Con questa prima selezione di schede si è potuto comprovare che al giorno d'oggi nel centro storico di Valencia, esistono solo 45 esempi documentati di murature in mattone che presentano sufficienti orditure storiche per stabilire le caratteristiche di pareti urbane che spaziano dal XV sino al XIX secolo.

Più dettagliatamente possiamo stabilire che:

\section{Secolo (con probabili interventi nel Secolo XVI)}

Mb72; Xc96a ;Va34 ;Xc96b; Xa46; Va81b; Ca113; Cg01a; Fa82

\section{Secolo (prima metà)}

Fa153b; Fa153c; Xd13; Cg01b; Ma54; Me212a; Xd65

\section{Secolo (seconda metà)}

Хe66; Ma92; Fa105 ; Vb67

\section{Secolo (prima metà)}

Xf26; Ce71; Fa153a; Va103a; Va82; Va103b; Fb117; Va81a

\section{Secolo (seconda metà)}

Ma93; Vb68; Vb69; Xf25; Xd54a; Xd54b; Cg02 


\section{Secolo (prima metà)}

Mb155; Xc16a; Xc16b; Xc16c

\section{Secolo (seconda metà)}

\section{Ca118; Ma28; Ma31; Fa39}

A questi dati si aggiungono le informazioni metriche dedotte da 19 schede di analisi, ottenute dall'estrapolazione di dati archeologici. É abbastanza imprudente utilizzare questi dati, provenienti da fonti indirette, non opportunamente verificate dall'autrice, che si riferiscono a dossier redatti da responsabili di scavi e campagne archeologiche urbane. I laterizi vengono appena citati nei testi, pertanto si è proceduto a filtrare queste informazioni, soppesandone la provenienza.

Di fatto per realizzare una corretta analisi mensiocronologica è importante considerare un numero abbondante di mattoni, orditi nelle murature (15/20 elementi), non di spoglio: aspetto che non è stato possibile utilizzare nel caso dei laterizi provenienti dal deposito del Centro di Ricerca Archeologico Municipale (SIAM).

In questo caso i mattoni esaminati sono piuttosto esigui, non sono orditi nelle murature e neppure presentano tracce significative di giunti o malte. Solo in un caso è stato possibile misurare 13 elementi (scheda S4), dovendoci limitare nei restanti casi a 1/3/6 elementi costruttivi.

Ulteriori aspetti che limitano l'utilizzo di dati di provenienza archeologica sono i fattori "selezione", "raccolta" e "catalogazione" effettuati dal responsabile dello scavo archeologico. Si deve considerare in questo contesto che una delle prescrizioni fondamentali della mensiocronologia è basata sull'evitare l'arbitrarietà volontaria della selezione dei laterizi analizzati. E' invece importante il contrario, ovvero procedere a misurazioni imparziali, 
considerando tutti i mattoni interi, visibili in un'area costruttivamente omogenea.

Senza dubbio lo studio mette in luce possibili aspetti conflittuali sorti dall'utilizzo di fonti archeologiche indirette, problema scavalcabile grazie alla misurazione diretta dei mattoni catalogati nel deposito municipale, che contribuiscono, anche se solo in parte, a orientare lo studio, conoscere formati di laterizi arcaici e tracciare la storia dell'impiego urbano dei materiali ceramici.

Se si considerano le curve generate dall'analisi mensiocronologica si possono tracciare tre grafici che indicano rispettivamente ${ }^{6}$.

A) Variazioni della lunghezza dei mattoni (asse delle ordinate) rispetto alle murature datate in progressione cronologica ( asse delle ascisse)

B) Variazioni della larghezza dei mattoni (asse delle ordinate) rispetto alle murature datate in progressione cronologica (asse delle ascisse)

C) Variazioni dello spessore dei mattoni (asse delle ordinate) rispetto alle murature datate in progressione cronologica (asse delle ascisse)

\footnotetext{
${ }^{6}$ I tre diagrammi di dispersione rappresentano le variazioni metriche dei laterizi nel tempo considerando le seguenti operazioni:

- calcolo del coefficiente di correlazione lineare, come valore índice che esprime la validità della relazione lineare esistente fra le dimensioni misurate e l'intervallo cronologico attribuito.

- indice della determinazione di "R", esprime che parte della variabilità delle dimensioni incontrata è attribuibile alla relazione con l'intervallo cronologico. Questo indice può variare tra 0 e 1. Per valori di "R" prossimi all'unità tutte le variazioni delle misure dei laterizi sono attribuibili idealmente alla relazione con l'intervallo cronologico.

- analisi della variazione. Questo studio permette di valutare con un'affidabilità uguale o superiore al $95 \%$, se la validità delle misure riscontrate su ciascuna muratura sia più o meno ridotta rispetto alle differenze incontrate fra distinti murature,

- calcolo dei valori di sintesi degli "n" esempi studiati.
} 


\section{murOSINTRAMUROS}

In questo caso se si analizzano le linee di tendenza dei grafici, in relazione agli 7 intervalli temporali marcati:

- XV-XVI Secolo

- XVII Secolo (prima e seconda metà)

- XVIII Secolo (prima e seconda metà)

- XIX Secolo (prima e seconda metà)

si possono desumere una serie di riflessioni interessanti.

Fondamentalmente nei secoli, parametri come la lunghezza e la larghezza dei laterizi sono inversamente proporzionali allo spessore.

Nonostante nel tempo la larghezza dei mattoni analizzati sia un valore molto più costante della lunghezza, entrambi i valori mostrano una tendenza abbastanza chiara sottolineata da una sostanziale diminuzione metrica nel tempo.

Questa tendenza, senza dubbio più evidente nel caso delle lunghezze, è un dato appena percettibile nella definizione delle larghezze?

Parametri come la lunghezza e la larghezza dei mattoni sono fattori che nel tempo si modificano in modo molto più graduale rispetto al loro spessore.

La combinazione di tutti questi valori si può riassumere a livello schematico in queste tavole:

${ }^{7}$ Queste tendenze erano state in parte definite nel testo della tesi di laurea dell'autrice (Cristini 2005) e nella tesina di dottorato DEA (Cristini 2008), così come dati importanti erano stati messi in luce da una ricerca archeologica municipale (ALTARRIBA, M., GUILLÉN, R., GUZMÁN, R., ROJO, N., MARTÍ, J 2001). Rispetto a detti studi, in questo caso sono stati inclusi più campioni di murature e un più vasto campo di indagine 


\section{Secolo}

Lunghezza 28.5/29.5 cm; larghezza13/14.5 cm, spessore 3.9/4.1 cm, proporzione giunto orizzontale/verticale 0.5/0.9

\section{Secolo}

Lunghezza 31/31.5 cm; larghezza $13.5 / 14.5 \mathrm{~cm}$, spessore $3.4 / 3.8 \mathrm{~cm}$; proporzione giunto orizzontale/verticale $0.7 / 0.9$

\section{Secolo (prima metà)}

Lunghezza 29.7/30.5 cm; larghezza 13.9/14.2 cm, spessore 3.5/4.2 $\mathrm{cm}$; proporzione giunto orizzontale/verticale 3.2/3.8

\section{Secolo (seconda metà)}

Lunghezza 29.9/30.5 cm; larghezza 14/14.6 cm, spessore 3.8/3.9 cm; proporzione giunto orizzontale/ verticale 3.5/4.4

\section{Secolo (prima metà)}

Lunghezza 30.5/31.2 cm; larghezza 14.2/15 cm, spessore 4.1/4.2cm; proporzione giunto orizzontale/verticale 3.1/3.2

\section{Secolo (seconda metà)}

Lunghezza 29.2/30 cm; larghezza 14.1/14.6 cm, spessore 4.0/4.1 cm; proporzione giunto orizzontale/verticale 2.2/2.6

\section{Secolo (prima metà)}

Lunghezza 27.8/29.4 cm; larghezza $13.5 / 14 \mathrm{~cm}$, spessore $4.6 / 5 \mathrm{~cm}$; proporzione giunto orizzontale/verticale 1.2/1.6

\section{Secolo (seconda metà)}

Lunghezza 26.2/24.5 cm; larghezza $11.5 / 12 \mathrm{~cm}$, spessore $4.3 / 4.4 \mathrm{~cm}$; proporzione giunto orizzontale/verticale 1.1/1.7 
Le "curve" mensiocronologiche si rivelano piuttosto come "linee", caratterizzate da un aspetto stabile e regolare, aspetto che ha portato a considerare altri fattori, non solamente metrici, quanto piuttosto globali, relativi a giunti, texture, colori e finiture delle murature, per poter mettere in luce possibili differenze e peculiarità costruttive.

Di seguito vengono pertanto espresse delle considerazioni conclusive riguardanti la comparazione dei differenti campioni analizzati. Lo sforzo, in tale caso, e' stato fondamentalmente quello di cercare dei fattori di discriminazione, differenti, per tentare di affinare il risultato apparentemente "troppo semplificato", emerso dalla sola analisi mensiocronologica.

E' così stato possibile risalire a delle differenze notevoli, presenti tra gli elementi costruttivi campionati.

Con sorpresa, proprio all'interno della loro così forte e massiccia uniformità dimensionale, sono state trovate alcune importanti differenze e non solo: allo stesso tempo si sono potute trarre anche altre considerazioni, riguardanti affinità e divergenze proprie della posa in opera dei laterizi e della generale lavorazione delle pareti.

Questa analisi riguarda principalmente:

- Tipo di elemento costruttivo

Relazioni tra colore e spessore del laterizio

Relazioni tra colore e soluzione di finitura

-Tipo di giunto

Relazioni tra tipo di giunto e spessore del laterizio

Relazioni tra tipo di giunto e finitura del giunto

Di seguito vengono proposte in dettaglio le conclusioni relative alle differenze e alle caratteristiche riscontrate nell'applicazione della tecnica costruttiva analizzata sui campioni oggetto di studio. 


\section{Relazioni tra colore e spessore}

E' significativo a questo proposito verificare come vi sia una corrispondenza tra lo spessore del singolo elemento costruttivo e il colore.

Risulta abbastanza evidente che mattoni tendenzialmente sottili sono caratterizzati allo stesso tempo da una colorazione piuttosto pallida.

Questo elemento è importante poiché indica la presenza di una cottura con temperature piuttosto basse e, allo stesso tempo, caratterizza un impasto con una materia prima con basse percentuali di argilla e maggior contenuto in marne, indici di una possibile recessione economica (XVI secolo-inizio XVII secolo).

Tali elementi costruttivi sono più leggeri, porosi, costruttivamente poco indicati per essere lasciati a vista, necessitando di particolari rivestimenti e finiture.

La loro forma, le dimensioni e la colorazione ricordano molto il mattone usato per armare le murature di tapia (in questo caso con una proporzione giunto orizzontale/verticale di 2.1/2.7).

D'altro canto si può apprezzare come a partire dal sec. XVIII le produzioni di laterizi siano più regolari, dando origine a mattoni più compatti, spessi, con maggior quantità di argilla ricca di ossido ferrico, aspetto che ne aumenta la colorazione e anche le caratteristiche meccaniche.

\section{Relazione tra colore e soluzione di finitura delle murature}

Dai risultati ottenuti dalle indagini effettuate è possibile identificare una serie di relazioni interessanti tra elementi costruttivi dei casistudio e metodologie adottate, relativamente alle tecniche di finitura. 
Come sopra affermato, mattoni caratterizzati da colorazioni chiare sono dotati di proprietà meccaniche e di resistenza più modeste rispetto a quelle di mattoni meno porosi, più scuri, con cotture migliori e con materie prime di qualità superiore.

Nei secoli XV, XVI e all'inizio del XVII secolo le murature sono abbastanza semplici, caratterizzate da spessi giunti e protette dagli agenti atmosferici da notevoli strati di intonaco. Questi tipi di paramenti, orditi con mattoni piuttosto sottili di $3.4 / 3.6 \mathrm{~cm}$ di spessore e giunti perfino di $4.0-4.5 \mathrm{~cm}$, non possono essere lasciati "visti."

In molti casi quindi queste murature presentano strati di protezione più o meno semplici. D'altra parte l'analisi in situ delle murature ha permesso indicare come mattoni più spessi, con spessori oscillanti tra 4.0-4.5 cm, presentino una orditura più regolare, in molti casi a vista, più uniforme e compatta rispetto alle murature con laterizi sottili.

\section{Relazione tra le caratteristiche dei giunti e lo spessore dei laterizi}

Esiste una chiara proporzione fra le misure degli elementi ceramici e il tipo di giunti visibili nelle murature analizzate. Dove si incontrano mattoni notevolmente sottili, di $3.4 / 3.6 \mathrm{~cm}$ di spessore, si identificano giunti orizzontali piuttosto marcati $(4.0-4.5 \mathrm{~cm})$.

Contrariamente, dove si identificano mattoni molto spessi e regolari i giunti presentano soluzioni molto più discrete, oscillanti fra 2.0-3.5 $\mathrm{cm}$ di spessore (esiste infatti una certa proporzione inversa fra lo spessore dei mattoni e quello del giunto orizzontale).

Allo stesso tempo questa tendenza si nota anche tra i giunti verticali delle murature analizzate.

Si può apprezzare come i giunti verticali siano tendenzialmente sempre più sottili rispetto ai giunti orizzontali, soprattutto nei secoli 
XV, XVI e nella prima metà del sec. XVII. Poi, poco a poco le differenze andranno annullandosi, arrivando a un sostanziale equilibrio fra le due dimensioni, orizzontali e verticali nel corso del XIX secolo.

Relazione tra le caratteristiche dei giunti e le soluzioni di finitura delle murature

Esiste un legame tra lo spessore dei giunti orizzontali (realizzati nelle murature) e la tecnica di finitura. Si presentano in questi casi due tipi sostanziali di situazioni ricorrenti: laddove sono visibili giunti orizzontali marcati e mattoni piuttosto sottili, si riscontrano soluzioni di rifacimento dei giunti e intonacature.

Invece giunti orizzontali ridotti, con murature caratterizzate da mattoni spessi e ben cotti, sono lasciati faccia a vista, abbinati a soluzioni bicromatiche, con pietra chaira o rinforzate da trame/velature dipinte.

Tra le soluzioni più autoctone valenciane, esiste l'agramilado, processo che prevede la sigillatura dei giunti orizzontali, caratteristico del XVII secolo, riconoscibile proprio per il rilievo e il rinforzo del giunto di finitura, sovrapposto al giunto di allettamento iniziale.

Una altra possibile soluzione era quella di utilizzare finiture a base di calce o gesso, con strati e velature progressivamente sempre più sottili.

Solo a partire dal XVIII secolo si comincia a utilizzare una tecnica intermedia tra l'utilizzo di intonaco e la semplice velatura di calce. Si cominciano a tracciare sulle superfici delle murature trame dipinte, che riproducono le orditure regolari.

Si tratta di una finitura coprente, oggi difficile da incontrare in buono stato nel centro storico, realizzata a base di almagra, pigmento 
estratto dall'ossido ferrico, che rinforzava il colore intenso dei mattoni.

Tra le più recenti finiture si riscontrano murature "faccia a vista", che cominciano a diffondersi nel tessuto cittadino (principalmente monumentale) nella seconda metà del XVIII secolo.

I laterizi, proprio grazie alle buone qualità produttive vengono lasciati "a vista", in paramenti con giunti sempre più sottili e regolari. Spesso per rinforzare la qualità di questi nuovi materiali si utilizzano anche finiture in pietra, come cornici, mensole o appliques. 


\subsection{Murature monumentali e residenziali: interpretazione del registro di schede}

Come indicato Come è stato specificato nel "Cap. I.1 Criteri per la redazione di un registro di dati", la definizione della scheda di studio delle murature è composta da sei parti principali, necessarie per garantire un'analisi rigorosa e progressiva delle pareti, dalla loro localizzazione generale nell'edificio sino alla definizione in dettaglio delle murature.

Le sei parti principali che compongono le schede di studio sono:

\section{Dati generali}

\section{Facciata}

Muratura

Mattoni

\section{Giunti}

Immagini 
Grazie a questi elementi si sono potuti elaborare 32 grafici che facilitano la comprensione dell'insieme di murature analizzate, così come i dati significativi relativi alle loro caratteristiche costruttive o patologiche ${ }^{1}$.

Senza dubbio è abbastanza sorprendente scoprire come esista una continuità di linguaggi e soluzioni costruttive fra architettura residenziale e monumentale, specialmente fra edifici residenziali e spazi annessi ad edifici religiosi (soprattutto cappelle e sacrestie).

Cambiano senza dubbio le qualità delle materie prime e la capacità di esecuzione delle murature, però sostanzialmente non si modificano le tecniche.

Orditure, ma anche caratteri compositivi (in basamenti, architravi, vani, aggetti di gronda, ecc.) si riflettono in modo molto uniforme fra architetture residenziali e monumentali urbane, soprattutto nel XVII secolo. Questa tendenza si smorza con l'arrivo dell'architettura bicroma, in pietra e laterizi, proprio nella seconda metà del XVIII secolo, apportando un progressivo distanziamento fra linguaggi dell'architettura civile, religiosa e residenziale urbana.

Di seguito si presentano dati relativi ai "muros intramuros" del centro storico di Valencia, estrapolati dalla base di dati raccolti dall'autrice.

\section{Dati generali}

Esiste un sostanziale equilibrio nella scelta effettuata sulle murature studiate, trattandosi di edifici residenziali nel 51\% dei casi, e monumentali (religiosi, nobiliari e militari) nel restante 49\% di casi. D'altro canto è interessante sottolineare come il livello di protezione dei differenti edifici residenziali sia apparso piuttosto variabile.

\footnotetext{
${ }^{1}$ Grafici relativi allo studio/definizione delle patologie materiali rilevate nelle murature nel si possono consultare nel "Cap.6.1.2 Quali patologie?"
} 
Si registrano vari gradi di protezione: un primo livello strutturale (grado 2) piuttosto diffuso (23\%), un livello architettonico (grado 3) discretamente presente (12\%), però anche una notevole mancanza di protezione (16\%). La distribuzione delle murature è piuttosto equilibrata, concentrandosi nella maggior parte dei casi nel quartiere del Carmen (34\%), la Xeu-Serea (22\%), Mercat (18\%); Velluters (17\%) e in casi più ridotti nel quartiere di San Francesc (9\%).

Tra i casi studiati prevalgono edifici residenziali di 3 piani (44\%), o 2 (31\%). Sono piuttosto scarsi edifici di un solo piano (1\%), così come più limitati sono casi di palazzi con 4 (7\%) o 5 piani (5\%). Discorso a parte meritano le facciate di complessi monumentali o religiosi (12\%) dei quali non è possibile stabilire con esattezza il numero preciso di piani.

\section{Facciata}

Se d'altra parte consideriamo lo studio della composizione delle facciate, notiamo come la tendenza più evidente preveda il disegno di prospetti ordinati ma non rigidamente impostati secondo regole di simmetria (47\%), riflettendo così possibili cambiamenti e modifiche vissute dall'edificio. Molto più isolati sono i casi di prospetti totalmente simmetrici (30\%), probabilmente dovuti a progetti monumentali più maturi e recenti (sec. XVIII).

Più difficile ma ancora possibile, è trovare facciate con composizioni casuali, che indicano immobili più proletari e umili (19\%), frutto di accorpamenti fra prospetti e probabilmente più antichi (sec. XVII$\mathrm{XVIII)}$. Si deve comunque considerare che esistono casi studiati che non contemplano parametri compositivi definiti (4\%), come nel caso di tramezzi, muri di separazione, ecc. 
Considerando i caratteri costruttivi delle facciate studiate si possono definire questi profili'. I basamenti analizzati sono prevalentemente in pietra calcarea, a blocchi regolari alti ca. 50/70 cm (tipo Z2; 40\%): si tratta di una soluzione piuttosto comune, efficace in termini di prestazioni tecniche, riscontrabile sia in edifici monumentali che residenziali.

Oltre a questa soluzione si trovano basamenti più semplici, in mattoni, che seguono le orditure delle murature (tipo Z1; 33\%) frequenti soprattutto in edifici residenziali. Senza dubbio meno comuni sono soluzioni con alti basamenti in pietra calcarea (circa 1.80/2.00m) (tipo Z3; 9\%), visibili principalmente in edifici monumentali. Altre soluzioni possibili, probabilmente dovute a interventi più recenti, sono coperture con placche (tipo Z4; 16\%) o intonaco (tipo Z5; 2\%).

I dati relativi alle murature residenziali o monumentali, presentano un equilibrio sostanziale fra murature intonacate, con orditure di lista e di testa, marcate da spessi giunti orizzontali (tipo F4; 31\%), e da murature faccia vista, con giunti regolari, piuttosto uniformi (tipoF7; 28\%). Scarsa e a rischio di estinzione, però comunque viva, è la presenza di murature autoctone come quelle di tapia valenciana, con orditure di lista (tipo F1; 5\%) o miste (tipo F2; $2 \%$ ); così come le murature con agramilado, ovvero a giunti orizzontali sigillati (tipo F3; $7 \%)$.

Questi ultimi tre casi (tipici dei secoli XV-XVI-XVII) sono riconoscibili in complessi religiosi e solo in casi isolati su edifici residenziali. Le murature monumentali accademiste con trame di laterizi dipinte (tipo F5; 5\%) o le ottocentesche murature di palazzi sottolineate da orditure a bugnato (tipo F6; 3\%) fanno sempre parte di una minoranza di casi.

\footnotetext{
${ }^{2}$ Si veda "Anejo I .Cap. I.3 Ábaco de detalles de fábricas históricas de ladrillo"
} 


\section{murOSINTRAMUIOS}

È interessante considerare come siano frequenti (19\%) casi di murature eterogenee/miste, con soluzioni come "faccia a vista e bugnato", "agramilado e faccia a vista" o"tapia valenciana e intonaco".

Anche le relazioni fra vani e architravi sono piuttosto variabili. La tendenza principale è quella di aperture intonacate (tipo V8; 20\%) che non svelano particolari costruttivi e, allo stesso tempo, di aperture con archi (tipo V7; 19\%) con intradosso piatto e estradosso curvo. Si tratta di casi piuttosto comuni, tanto in architettura religiosa come residenziale, già visibili in edifici (precorrenti i tempi) dalla fine del XVI secolo sino alla seconda metà del XVIII secolo. Però la soluzione più comune, proprio del XVIII secolo, in molti casi associata ad opzioni accademiche, è quella con intradosso ed estradosso curvo (tipo V6; 12\%). La stessa percentuale si ritrova per architravi in legno (tipo V1; 12\%) diffuse soprattutto in edilizia residenziale fino al XIX secolo, la cui variante più antica e raffinata (probabilmente di botteghe commerciali con maggiore status), con profilo ligneo integrato nelle murature, è senza dubbio limitata (tipo V2; 2\%).

Altre casistiche più particolari, localizzate soprattutto in architettura monumentale, presentano logge con archi in laterizi (tipo V3; 8\%), vani ovali o circolari (tipo V4; 3\%), piattabande (tipo V5; 5\%) o soluzioni accademiche con cornici in mattoni (tipo V9; 9\%) o pietra (tipo V10; 6\%). Come in altri grafici, è anche importante considerare casi che non presentano vani (4\%), come ad esempio studi di muri perimetrali o tramezzi.

Sempre relativi ai vani, sono interessanti i punti di accesso agli edifici, dove prevalgono vani in pietra (tipo E4; 53\%), o semplicemente intonacati (tipo E3; 27\%). Molto meno frequenti sono accessi con architravi in legno semplice (tipo E1; 12\%) o lavorato (tipo E2; 1\%). Anche qui è importante tenere conto di casi che non presentano vani di accesso (4\%), come ad esempio studi di muri perimetrali o tramezzi (7\%). 
Gli aggetti di gronda degli edifici studiati, monumentali o residenziali, mostrano al giorno d'oggi una prevalenza di soluzioni intonacate o con modulazioni coprenti (tipo A4; 40\%), seguite a distanza da soluzioni signorili con bordature e finiture in pietra (tipo A7; 18\%) O semplici travi di legno (tipo $\mathrm{A} 1 ; 18 \%$ ), che probabilmente caratterizzano edifici anteriori al XVIII secolo.

Soluzioni più particolari sono quelle con mattoni orditi con un semplice aggetto di gronda (tipo A3; 11\%) o con orditure inclinate (tipo A5; 6\%). Si incontrano anche casi speciali con disposizioni di laterizi più complesse, con stratificazioni doppie (tipo A2; $3 \%$ ) 0 multiple, con dentature e decorazioni ceramiche sagomate (tipo A6; 1\%). Il 3\% circa delle murature studiate non presenta dati significativi o identificabili riguardo a questo appartato.

\section{Muratura}

Per concludere lo studio relativo ai prospetti vincolati alle murature studiate è interessante, anche se solo orientativo, fare un breve bilancio relativo ai sistemi di copertura. Prevalgono edifici con falde inclinate (89\%), dato alterato solo da una esigua percentuale di palazzi nobili e signorili con coperture piane (5\%). Circa il $6 \%$ delle murature studiate non presenta dati significativi o identificabili riguardo a questo appartato.

I dettagli relativi alle murature presentano caratteristiche interessanti, specifiche proprio dei casi di studio del centro storico valenciano. $\grave{E}$ importante riconoscere la uniformità delle murature con orditure alterne a lista e testa (89\%), limitandosi a casi minoritari l'orditura solo a testa (5\%) o solo a lista (6\%), come avviene nei casi della tapia valenciana. L'abbondanza di murature intonacate è un dato da considerare nel momento di analizzare pareti presentanti orditure pseudo-orizzontali (61\%) tipiche di murature trattate con opacizzanti o con risigillature dei giunti. Murature faccia a vista o con soluzioni a bugnato si distinguono per la presenza di orditure regolari (24\%), 
essendo invece totalmente irregolari (15\%) le trame delle murature in tapia valenciana.

Continuando con le caratteristiche delle murature si può osservare come le superfici delle stesse presentino leggere irregolarità (63\%), potendo aspirare a soluzioni costruttive regolari solo particolari casi di murature monumentali (24\%), sempre in totale contrasto con l'irregolarità delle superfici più antiche, realizzate in tapia valenciana (13\%).

Il poter ricavare dati relativi alle sezioni dei muri analizzati risulta di certo più complesso. In molti casi si sono fatte ipotesi, non avendo potuto accedere agli edifici e ispezionare sezioni costruttive. Nonostante ciò è possibile proporre, in base alle orditure visibili, alcuni probabili modelli di sezioni. Con queste basi si possono ipotizzare murature uniformi (89\%), limitandosi a murature a sacco solo in una bassa percentuale di casi (11\%).

Sempre considerando le sezioni delle murature, si possono riconoscere casi con peculiarità, come vani strombati (20\%), casistica comune tanto ad edifici residenziali come monumentali, probabilmente anteriori alla seconda metà del XVIII secolo. I restanti casi (80\%), non presentano questa particolarità, dovuta probabilmente al miglioramento di rapporti aeroilluminati, anteriori alle riforme urbanistiche del secolo dei lumi, che portano all'ampliamento e regolarizzazione dei tracciati urbani.

Se si considerano altri elementi speciali che compongono le murature, si possono considerare casi di mattoni modulati in crudo (8\%), sagomati post cottura (7\%) o appliques in terracotta (2\%); in molti casi i tre tipi di elementi compaiono associati tra loro (6\%). Si tratta in ogni caso di minime percentuali, limitate a palazzi signorili, con lesene e decorazioni, riconoscibili soprattutto a partire dal XVII secolo. La casistica è piuttosto limitata, dato che la maggior parte 
(77\%) delle murature considerate non presenta questi elementi particolari.

\section{mattoni}

Lo studio in dettaglio dei laterizi, non ha solo permesso di ottenere interessanti informazioni metriche. Infatti attraverso le schedature è stato anche possibile visualizzare una serie di caratteristiche particolarmente interessanti. I mattoni sono risultati piuttosto eterogenei, trattandosi di produzioni pre-industriali (60\%). A ciò si somma l'utilizzo di materiali di recupero (4\%) e laterizi provenienti da produzioni più regolari e uniformi (36\%), di fine XVIII, inizio del XIX secolo.

Questo significativo livello di eterogeneità dei laterizi si riflette anche in termini cromatici. Sono abbastanza scarsi esemplari con caratteristiche uniformi (28\%) trattandosi nella maggior parte dei casi di variazioni di pigmenti marmorizzati (41\%) o cambi di tonalità in globuli (25\%); senza dubbio la presenza di velature o trattamenti applicati alle murature rendono impossibile definire caratteristiche cromatiche di alcuni esemplari di laterizi (6\%).

\section{Giunti}

Di pari passo allo studio dei mattoni, è stata effettuata la valutazione dei giunti, le cui caratteristiche sono intrinseche alla corretta lettura della muratura. È difficile trovare murature totalmente originarie, non sottoposte a interventi o modifiche nel tempo, ma non è impossibile, imbattersi in casi con finitura semplice (16\%) o doppia (4\%) coeva alla nascita delle murature.

Il resto dei casi, nonostante rispetti la gerarchia d'origine fra giunti e laterizi, presenta multiple modificazioni realizzate nel tempo (78\%) o persino rattoppi che rendono impossibile la lettura della parete (2\%). 
Senza dubbio lo studio delle murature diventa più complesso se si cerca di identificare possibili giunti di allettamento originali. Purtroppo nel $76 \%$ dei casi non è possibile identificare questa caratteristica, condizione in parte equilibrata dalla possibilità di riconoscere giunti concavi, che facilitano la successiva adesione di strati di rinzaffo (16\%), giunti inclinati, tipici della soluzione con agramilado (7\%) o casi più rari con giunti a filo (1\%).

La lettura dei giunti di finitura è sicuramente più agevole, trattandosi nella maggior parte dei casi di giunti livellati con la muratura (61\%). Esistono situazioni in cui le finiture sono leggermente in rilievo rispetto alla parete, come nel caso di murature con agramilado o in tapia valenciana (11\%). Si riscontrano anche casi con giunti parzialmente arrotondati, a causa di fenomeni erosivi (27\%) o a filo (1\%).

Se si estrapolano dati relativi alla caratterizzazione visiva delle malte, si possono effettuare interessanti riflessioni relative al cambio di materiali e loro variazioni ibride (53\%). Queste analisi sono sovrapponibili ai contributi dati dalle analisi di laboratorio, con le quali é possibile fare delle considerazioni generali relative alle materie prime ${ }^{3}$.

Per esempio: la costante presenza di argilla nei secoli, è riscontrabile in una buona percentuale di campioni prelevati soprattutto da edifici residenziali. Nella maggior parte dei casi compare abbinata a calce (19\%) ma pure senza mescolanze, specie nei casi di murature più semplici e povere (2\%). D'altro canto oggi pochi casi presentano giunti di malta, sia di allettamento che di finitura, chiaramente a base di calce (19\%). Allo stesso tempo, fortunatamente "poche" murature

\footnotetext{
${ }^{3}$ Si veda "Cap. III.3 Studio analitico: selezione di mattoni e malte (FT-IR)"e "Cap. III.4 Studio analitico: selezione di mattoni e malte (SEM/EDX/MO)"
} 
sono state totalmente alterate da pesanti interventi con malte cementizie (10\%).

Dati morfologici relativi alle malte mettono in luce pregi come l'omogeneità, l'uniformità e la sostanziale qualità delle materie prime (61\%). Questo è un aspetto che contraddistingue soprattutto edifici monumentali, a partire dal XVIII secolo. Gli esempi di architettura residenziale riportabili soprattutto ad umili edifici del XVII secolo, presentano generalmente materie prime di minor qualità, contenenti partite di calce meno pura, tagliata con parecchia sabbia o argilla.

Questi aspetti si ritrovano in casi analizzati che presentano malte eterogenee (40\%) con evidenti impurezze e grumi (21\%) o con calcinaroli(19\%), riflettendosi anche sulle caratteristiche cromatiche. Le malte solitamente presentano toni di colore piuttosto uniformi nella maggior parte dei casi (65\%), avendo a che fare con materie prime piuttosto irregolari solo nel 33\% delle murature studiate.

L'analisi degli inerti completa la caratterizzazione delle malte sopra accennata. Come emerso dalle analisi di laboratorio, i materiali utilizzati nelle malte sono principalmente sabbie e sabbioni di fiume, con spigoli arrotondati (67\%) mentre la ghiaia è presente solo in pochi casi (17\%). Le murature di tapia valenciana, per esempio, contengono soprattutto ghiaia di grosso calibro (2\%) o presentano miscele di ghiaioni (14\%). Questi aspetti si riflettono inevitabilmente anche sulle caratteristiche cromatiche degli inerti. La maggior parte dei casi (76\%) presenta sabbie a base di quarzo e feldspato, con colori piuttosto chiari, mentre le ghiaie contengono soprattutto fillosilicati che contribuiscono a inscurire le tonalità cromatiche (21\%). 


\subsection{Future ricerche}

Come anticipato nell'introduzione, "muros intramuros" non è uno scritto che si conclude con questo testo, dato che realmente si lasciano aperte opzioni di ricerca per futuri studi, aspetto coerente e positivo di un tema non limitabile per definizione, potenzialmente orientato ad ampliamenti dei contenuti.

Senza dubbio definire l'evoluzione, i cambi o le trasformazioni delle murature in mattoni del centro storico di Valencia è in sé un capitolo sempre aperto, che può contare su approfondimenti dati da futuri scavi archeologici, così come da progressi di ricerche storiche, documentali o costruttive.

Per questo si suggeriscono possibili linee di ricerca futura, tenendo in conto che ciascun argomento sviluppato nei capitoli di questo scritto può essere motivo intrinseco di studio e approfondimento. Tra i vari temi si può sottolineare come soprattutto possa essere ampliato lo spettro geografico e cronologico della ricerca, così come il suo contenuto materiale.

Futuri approfondimenti di contenuti

Senza dubbio esistono aspetti particolarmente interessanti che possono essere approfonditi in ricerche future. Significativa può essere la definizione di linee guida più dettagliate, vincolate all'abaco di dettagli costruttivi identificati nel centro storico.

Questo si potrebbe concretizzare migliorando la risoluzione e la grafica di dettagli costruttivi, aspetto sinora limitato allo studio di 
paramenti solo in facciata. D'altro canto, considerando possibili approfondimenti storici, si potrebbero tracciare in modo più nitido le nebulosità socio-economiche delle corporazioni, tanto del mondo della produzione dei laterizi, quanto dell'utilizzo degli stessi.

Esistono interessanti connessioni con altre manifatture ceramiche, che aprono orizzonti di studio relativi alla produzione di tegole, così come della terracotta architettonica. Si tratta di mondi pre-industriali affini alla produzione di laterizi, con punti di contatto interessanti ed evidenti vincoli. Finora non si conoscono studi urbani relativi a questi temi, trattandosi di un terreno vergine con campi di indagine totalmente aperti.

\section{Futuri approfondimento geografici}

Lo studio, finora orientato al centro storico della città di Valencia, è stato un primo passo decisivo per una solida conoscenza del contesto urbano pre-industriale, vincolato alla produzione di laterizi e ai differenti ruoli professionali integrati in questo processo produttivo e costruttivo. Con queste premesse, si possono comparare i risultati dello studio con dati procedenti da altri contesti, distinti nuclei urbani della Comunidad Valenciana (come per esempio Castellón, Alicante, Alcoy, Xátiva, ecc.). Questo può facilitare la lettura muraria, grazie proprio ad uno spettro di analisi più ampio, più idoneo nella comprensione di sincronie e diacronie tecniche, così come nell'identificazione di varianti tipologiche o costruttive.

I benefici di questa potenziale apertura dello studio a contesti geografici più ampi possono manifestarsi chiaramente nella miglior messa a punto della proposta cronotipologica, cosí come in un potenziale raffinamento delle teorie proposte. Oltre a ciò sarebbe comunque interessante considerare lo studio nel seno di un possibile progetto nazionale. Comprovare la validità del metodo, così come i risultati, rispetto ad altri studi relativi a queste tematiche, realizzati in Spagna, è un foglio bianco finora non ancora scritto. In ambito 


\section{murOSINTRAMUIOS}

nazionale in effetti non è stata ancora identificata una visione d'insieme relativa a studi costruttivo/tipologici e mensiocronologici dei distinti capoluoghi di provincia.

Inoltre si può considerare come, sia nei capitoli relativi al profilo storico e culturale della città di Valencia, sia nei paragrafi in cui si descrivono le distinte tecniche costruttive, sia stato fatto riferimento anche a realtà più lontane, come le culture costruttive bizantine o islamiche.

Finora lo studio si è limitato a proporre possibili influenze, cosicome sottili contaminazioni o sovrapposizioni esistenti fra questi contesti costruttivi e la realtà valenciana più autoctona, senza poter approfondire, per evidente mancanza di mezzi, ulteriori assonanze o discrepanze tecnologiche. Le informazioni raccoltel mettono in luce alcuni precedenti costruttivi particolarmente interessanti, documentati e ancora visibili lungo le coste mediterranee di Marocco, e Algeria, così come sulla costa meridionale della Turchia.

Pertanto aprire lo studio a prospettive regionali, nazionali o internazionali può essere parte di un interessante lavoro di miglioramento, affermazione e autentico processo di verifica e affinamento della tesi proposta.

\footnotetext{
${ }^{1}$ Si vedano: Cap. 5.2.2 "Possibili antecedenti storici: murature in mattoni nel mondo bizantino" e Cap. 5.2.3: Possibili antecedenti storici: murature in tapia in Al-Andalus"
} 

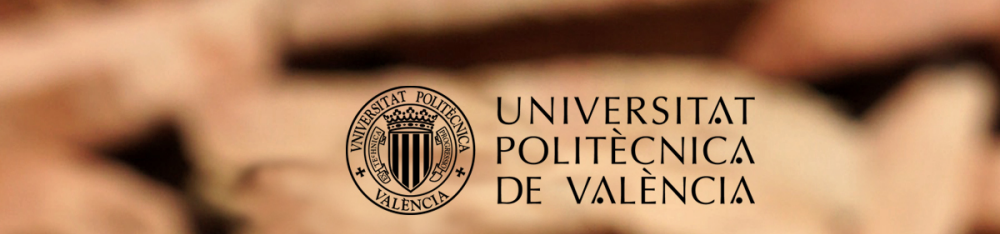

$\frac{\text { n }}{\frac{0}{2}}$

Tesis Doctoral

El ladrillo en las fábricas del centro histórico de Valencia. Análisis cronotipológico y propuesta de conservación

Autora: Valentina Cristini

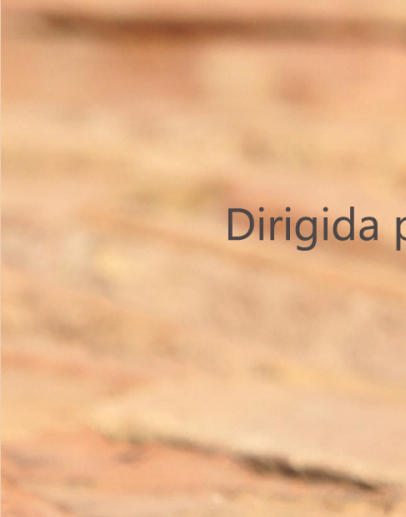

Dirigida por: Dr. F. Vegas López-Manzanares, Dra. C. Mileto
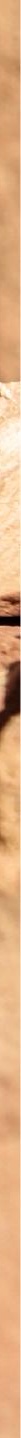


\section{TOMO II/I}

\section{MUROSINTRAMUROS}

El ladrillo en las fábricas del centro histórico de Valencia. Análisis cronotipológico y propuesta de conservación 
TESIS DOCTORAL

Autora: Valentina Cristini

Directores: Fernando Vegas López-Manzanares, Camilla Mileto

Programa de doctorado

"Patrimonio Arquitectónico: historia, composición, estudios gráficos"

Depto. Composición Arquitectónica

Escuela Superior de Arquitectura, Universitat Politècnica de Vàlencia

Valencia, Febrero 2012 


\section{ÍNDICE GENERAL}

\section{TOMO I}

Resumen/Resum/Abstract/Riassunto p.1

Índice general $\quad$ p.5

1. INTRODUCCIÓN p.11

1.1. Razón de ser de la investigación p.13

1.1.1. "Especular CON el ladrillo" vs.

"Especular SOBRE el ladrillo"

1.1.2. Por qué nace "muros intramuros" p.18

1.2. Temas de la investigación p.21

1.2.1. Contenido material p.22

1.2.2. Límites geográficos y temporales p.26

1.3. Propósitos de la investigación p.31

1.3.1. Interés p.31

1.3.2. Objetivos p.32

2. MÉTODO p.35

2.1. Proceso de formación de un método p.37

2.1.1. Estancias de investigación en el marco del p.38 estudio

2.1.2. Trayectoria de investigación y primeros $\quad$ p.40 resultados

2.2. Definición de un planeamiento metodológico p.45

2.2.1. La mensiocronología $\quad$ p.47

2.2.2. El estudio de la cultura material p.53

2.2.3. La cronotipología p.56

2.2.4. Diagnóstico y estudios analíticos p.59

2.3. Propuesta metodológica descriptiva y analítica p.61

2.3.1. Fuentes directas p.61 
3. LA IDENTIDAD DEL CENTRO HISTÓRICO DE VALENCIA p.67

3.1. Perfil geomorfológico y geológico p.69

3.1.2 La mirada histórica hacia la p.72

edafología de Valencia

$\begin{array}{ll}\text { 3.2 Perfil histórico y cultural } & \text { p.77 }\end{array}$

4. LAS FÁBRICAS EN VALENCIA: HACIA UNA INTERPRETACIÓN p.89

4.1. Una cuestión de roles $\quad$ p.91

4.2. Alfareros y ladrilleros: producción y cocción p.93

4.2.1. El ladrillar/rajolar p.103

4.3. Vendedores y controladores: mercado y comercio p.109

4.3.1. Instituciones p.109

4.3.2. Cuerpo normativo y legal p.114

4.3.3. Rúbrica de la rajola e teula p.118

4.3.4. Els Rajolers $\quad$ p.125

4.4. Tratados y manuales: de lateribus p.131

4.4.1. El siglo XIX, maduración de manuales técnicos p.135 sobre el ladrillo

4.4.2. Prácticas de albañilería en los manuales p.139 de arquitectura

5. "MUROS INTRAMUROS": ESTUDIO DE LAS FÁBRICAS p.147

5.1. Hacia la evolución de las técnicas constructivas en arcilla $\quad$ p.149

5.2. Fábricas con ladrillo p.153

5.2.1. Tapia valenciana p.153

5.2.2. Posibles antecedentes históricos: fábricas p.156 de ladrillo en el mundo bizantino

5.2.3. Posibles antecedentes históricos: fábricas p.159 
de tapia en Al-Andalus

5.2.4. Posible propulsor de la difusión de la técnica: La p.161 Fábrica Vella, dita de Murs y Valls

5.3 Fábricas de ladrillo

p.169

5.3.1. Ladrillo visible

p.169

5.3.2. Ladrillo visto

p.175

5.3.3. Ladrillo oculto

p.188

6. FÁBRICAS: HACIA UNA PROPUESTA DE CONSERVACIÓN

6.1 Análisis diagnóstico de las fábricas analizadas

p.199

6.1.2. ¿Qué patologías?

p.202

6.2 Líneas guía para una posible intervención

p. 211

6.2.1. Procesos de limpieza general

p. 212

6.2.2. Consolidación

p. 237

6.2.3. Hidrofugación

p. 240

6.2.4. Complementación de piezas

p. 242

6.2.5. Sustitución de piezas

p.243

6.2.6. Reparación de juntas

p. 245

6.2.7. Reparación de fisuras

p.247

6.2.8. Protección final

p.249

6.3 Núcleo, conectores y costra: intervenir en p.251 fábricas de tapia valenciana

7. CONCLUSIONES

7.1. Sincronías y diacronías técnico/tipológicas

p.263

7.2. Elaboración de una curva mensiocronológica

p.269

7.3. Fábricas monumentales y residenciales: interpretación del

p.285 registro de fichas

7.4. Futuras investigaciones

p.303

$\begin{array}{ll}\text { 8. VERSIÓN ITALIANA REDUCIDA p.307 } & \text { p }\end{array}$

8.1. Motivazioni alla base della ricerca p.309

8.1.1. Introduzione p.309 
8.2. Tematiche presenti nella ricerca p.315

8.2.1. Contenuto materiale p.316

8.2.2. Limiti geografici e temporali p.320

8.3. Finalità della ricerca p.323

8.3.1. Interesse p.323

$\begin{array}{ll}\text { 8.3.2. Obiettivi p.324 } & \end{array}$

8.4. Conclusioni: sincronie e diacronie tecnico/tipologiche p.327

8.5. Definizione di una curva mensiocronologica p.333

8.6. Murature monumentali e residenziali: interpretazione p.345 del registro di schede

8.7. Future ricerche p.355

TOMO II

Índice general $\quad$ p.1

ANEJO I: REGISTRO PORMENORIZADO DE FÁBRICAS ESTUDIADAS p.7

I.1. Criterios para la redacción de un registro de fichas p.9

I.2. Base de datos p.19

I.2.1. Fábricas históricas: Barrio del Carmen p.21

I.2.2. Fábricas históricas: Barrio de Mercat p.153

I.2.3. Fábricas históricas: Barrio de S. Francesc p.225

I.2.4. Fábricas históricas: Barrio de Velluters p.265

I.2.5. Fábricas históricas: Barrio de la Xeu/Serea p.333

I.3. Ábaco de detalles de fábricas históricas de ladrillo p.421

ANEJO II: RECOPILACIÓN DE DATOS ARQUEOLÓGICOS p. 433

II.1. Criterios para la consulta de informes arqueológicos p.435

II.1.1. Extractos de informes arqueológicos p.436

$\begin{array}{ll}\text { II.2. } & \text { Base de datos } \\ & \text { p.445 }\end{array}$ 
III.1. Propiedades químicas, físicas, mecánicas de ladrillos

III.1.1. Características mineralógicas

III.1.2. Propiedades físicas

p. 474

III.1.3. Propiedades hídricas

p. 478

III.1.4. Propiedades mecánicas

p.482

III.1.5. Propiedades de durabilidad

p.484

III.2. Criterios para el estudio de ladrillos y morteros

p.485

III.3. Informe analítico: selección de ladrillos y morteros (FT-IR)

p.523

III.4. Informe analítico: selección de ladrillos y morteros

Glosario

p.589

Bibliografía

p.603

Abreviaciones

p. 625

Índice de imágenes Tomo I/II

p. 626

Índice de imágenes Tomo II/II

p. 629

Agradecimiento

p. 643 



\section{Anejo I.}

Registro pormenorizado de fábricas estudiadas 



\section{I.1. Criterios para la redacción de un registro de fichas}

El casco antiguo de la Ciudad de Valencia está formado históricamente por cinco barrios principales, conocidos con los nombres de Velluters, Carmen, Mercat, Seu-Xerea y Universitat-San Francesc. El ámbito territorial de estos cinco barrios abarca la totalidad de la ciudad histórica intramuros y está actualmente contenida entre el río en su margen septentrional y la ronda de circulación, antiguo trazado de la muralla (Calle Colón, Calle Xàtiva y Calle Guillén de Castro) en sus márgenes meridional, oriental y occidental, fruto de la demolición de las murallas a mediados del siglo XIX. El conjunto urbano así delimitado compone la zona de calificación urbanística conocida como Conjunto Histórico Protegido "Ciutat Vella" (CHP-1) definida por el Plan General de Ordenación Urbana (PGOU) de la Ciudad de Valencia (aprobado el 28 de diciembre de 1988).

La fase de investigación se fundamenta en la redacción de una ficha descriptiva de las edificaciones monumentales y residenciales, que presentan las fábricas de ladrillos en este específico entorno urbano. Como se ha descripto en el cap.1.3, los puntos de partida del estudio han sido el plano catastral vigente y la base de datos de fotografías catalogadas (4.437 edificios del centro histórico de la ciudad) según el barrio de pertenencia ${ }^{1}$. Para ello se han discriminado edificios

\footnotetext{
${ }^{1}$ MILETO C. (investigador principal entre otros), Carácteres constructivos del centro histórico de Valencia; Análisis, caracterización y conservación; Generalitat Valenciana (ref: GVPRE/ 2008/240)
} 
anteriores al último cuarto del siglo XIX, filtrando 95 ejemplos destacados con fábricas de ladrillos pre-industriales, cuya caracterización fuera completa y significativa (con al menos 5 hiladas visibles de ladrillos, en fachada y accesibles).

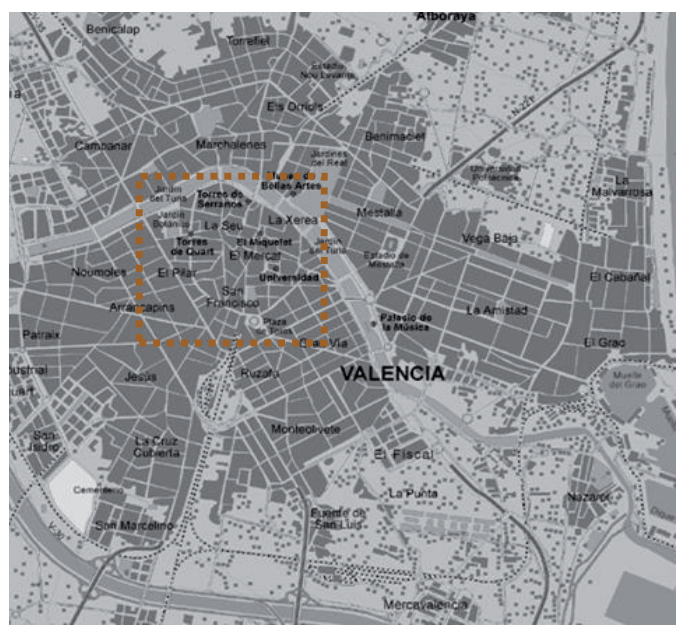

FIG. 1 Cuadrante de estudio del centro histórico de la ciudad intramuros (MILETO)

El objetivo final de esta selección ha sido el estudio, agrupación cronotipológica y catalogación de las fábricas, gracias a la confección de una ficha detallada de estudio de los casos analizados.

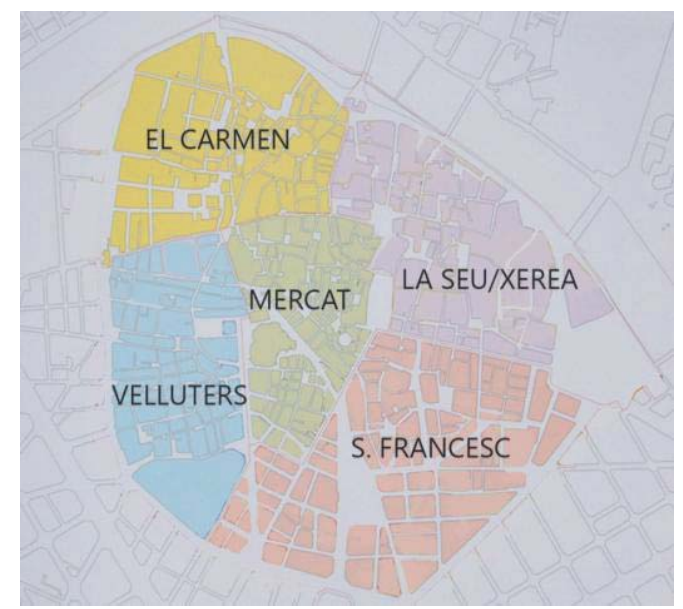

FIG. 2 Localización de los barrios históricos de Valencia intramuros (MILETO) 


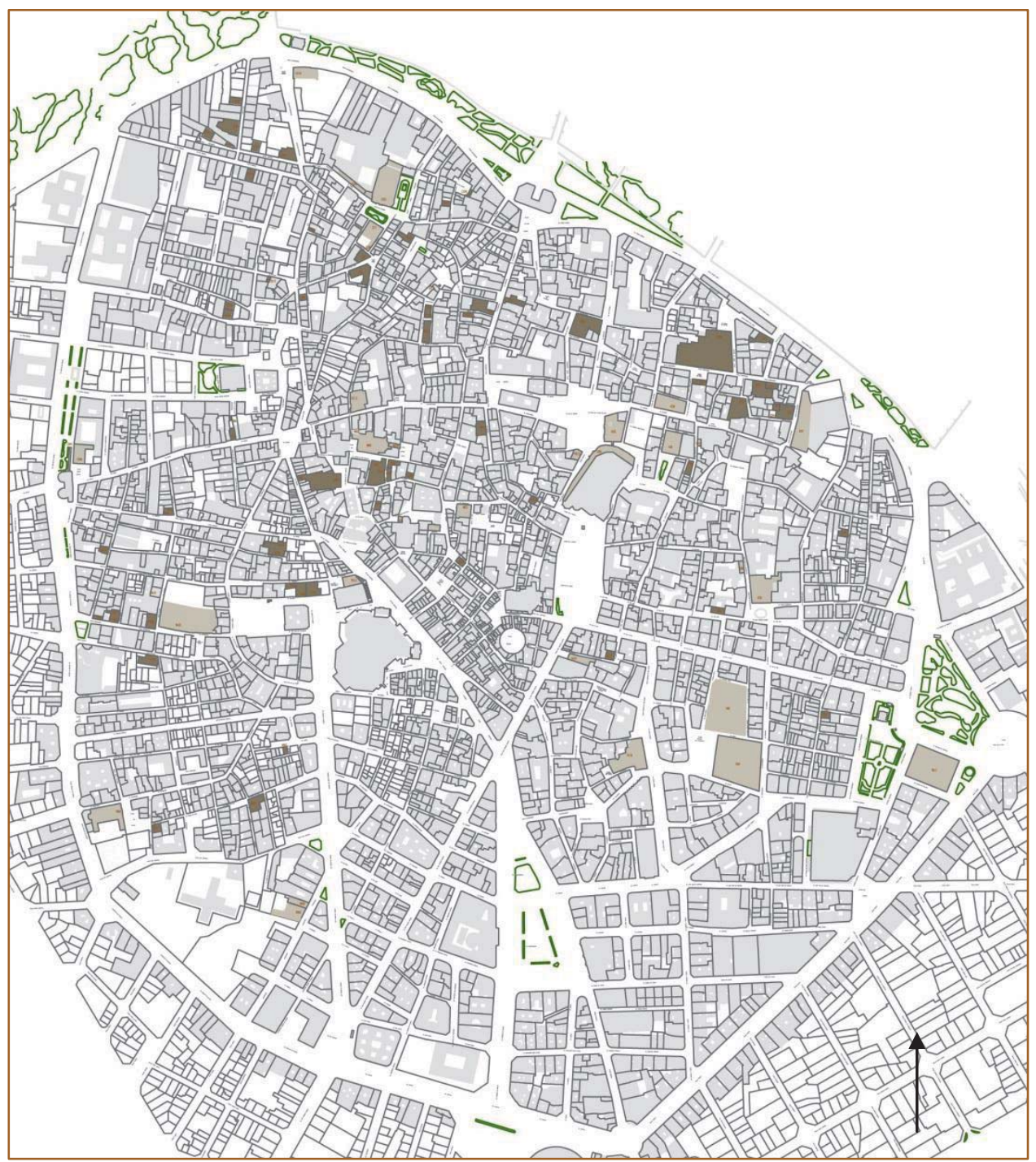

FIG. 3 Localización de los edificios estudiados. Edilicia monumental (beige) y edilicia residencial (marrón) (CRISTINI) 
Redacción de fichas: ladrillos de procedencia arquitectónica

Para realizar este trabajo se ha confeccionado una FICHA DE ESTUDIO DE LAS FÁBRICAS compuesta por seis apartados principales, tanto de catalogación expeditiva como descriptiva. La estructura de la ficha sigue estas pautas de enfoque progresivo, desde la localización general del edificio hasta la definición en detalle de sus fábricas:

\section{Datos generales}

\section{Fachada}

\section{Fábrica}

\section{Ladrillos}

\section{untas}

\section{Imágenes}

Los códigos alfanuméricos identificativos de cada ficha se han establecido en base a la localización del edificio en los distintos barrios del centro histórico de la ciudad. Además, cada distrito se ha dividido en sectores, para facilitar la catalogación y el registro fotográfico.

\begin{tabular}{|l|l|l|}
\hline Barrio & Código clasificación & Código sector \\
\hline Carmen & Código: C & a, b. c, d, e, f \\
\hline Mercat & Código: $M$ & a, b. c, d, e, f \\
\hline San Francesc & Código: $F$ & a, b. c, d, e, f \\
\hline Velluters & Código: $V$ & a, b. c, d, e, f \\
\hline La Xeu-Serea & Código: $X$ & a, b. c, d, e, f \\
\hline
\end{tabular}


Por tanto, cada edificio estudiado se identifica por un código de clasificación de barrio y un código de sectorización, además de un número². Por ejemplo, el edificio Ca82, identifica un inmueble localizado en el barrio del Carmen, sector "a". Por otro lado, también, se han considerado casos complejos y estratificados, donde en un único edificio ha sido posible identificar más de una fábrica. En estos casos puntuales se ha añadido al código un subíndice. Por ejemplo, el edificio Fa153/b identifica un inmueble en el barrio de "S. Francesc", sector "a", fábrica analizada "b". Esta numeración, aparentemente compleja, se desvela útil para tener localizadas de forma expeditiva y sistemática las fábricas, pudiendo ubicarlas entre sí y también garantizando una posible continuidad del estudio en el marco del proyectos de investigación llevado a cabo por el equipo $U P V^{3}$.

\footnotetext{
${ }^{3}$ La numeración se corresponde al código de registro fotográfico progresivo de los 4.437
} edificios, anteriores al siglo XIX, identificados en Op. Cit. MILETO, (2008) 
Los 6 apartados diferentes de las fichas, indican una serie de datos que se pueden resumir a continuación:

\section{Datos generales}

Código alfanumérico

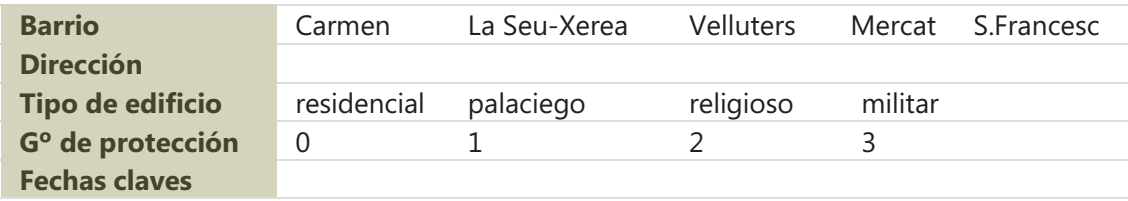

Este apartado, crucial para cada ficha, sirve para identificar el inmueble y definir pautas generales relativas a su situación actual e histórica. Esta sección, por lo tanto, resume datos generales del edificio a estudiar.

La clasificación sigue parámetros como: "Barrio", "Dirección", "Tipo de edificio", "Grado de protección"4, y "Fechas claves"5.

Además, se presenta un plano de situación del edificio, con el código identificativo y con la localización exacta de la fábrica estudiada conjuntamente con una foto significativa de la fachada a analizar.

${ }^{4}$ Los artículos (3.63/3.64/3.65) del Plan General de Ordenación Urbanística (1988) contemplan un régimen de protección específico. NIVEL 1: Se incluyen en este nivel de protección las construcciones que deberán ser conservadas íntegramente por su carácter singular o monumental y por razones históricas o artísticas, preservando sus características arquitectónicas originarias. NIVEL 2: Se incluyen en este nivel de protección los edificios que por su valor histórico o artístico deben ser conservados, al menos parcialmente, preservando los elementos definitorios de su estructura arquitectónica y/o aquellos elementos constructivos singulares de intrínseco valor que existan en el inmueble. NIVEL 3: Se incluyen este el nivel de protección los edificios cuya fachada o elementos visibles desde la vía pública, por su singularidad o su carácter tradicional, o por su notable articulación morfológica con el entorno, contribuyen sensiblemente a conformar determinado ambiente, urbano o rústico, de especial belleza o valor ambiental siendo de interés público su presencia en el escenario urbano o en el paisaje a fin de preservar esas características ambientales

${ }^{5}$ En este caso la información relativa a fechas de edificación así como de intervención en edificios destacados del centro histórico de la ciudad se ha extraído de AA.VV., Guía de Arquitectura de Valenciá, Ícaro CTAV Ed., Valencia, 2007 


\begin{tabular}{|c|c|c|c|c|c|c|c|c|c|}
\hline \multirow{3}{*}{$\begin{array}{l}\text { Pisos } \\
\text { Composición } \\
\text { Zócalo }\end{array}$} & \multirow{2}{*}{\multicolumn{2}{|c|}{$\begin{array}{l}\mathrm{N}^{\circ} \\
\text { aleatoria }\end{array}$}} & \multirow{2}{*}{\multicolumn{3}{|c|}{$\begin{array}{l}\text { sótano entreplanta } \\
\text { ordenada sin simetría }\end{array}$}} & \multicolumn{4}{|c|}{ piso noble caja escalera } \\
\hline & & & & & & \multicolumn{4}{|c|}{ ordenada con simetría } \\
\hline & $\mathrm{Z1}$ & $\mathrm{Z} 2$ & $\mathrm{Z3}$ & Z4 & $\mathrm{Z5}$ & & & & \\
\hline Fábrica & F1 & F2 & F3 & F4 & F5 & F6 & F7 & & \\
\hline Vano/dintel & V1 & V2 & V3 & V4 & V5 & V6 & V7 & V9 & V10 \\
\hline Entrada/dintel & E1 & E2 & E3 & E4 & & & & & \\
\hline Alero & A1 & $A 2$ & $\mathrm{~A} 3$ & A4 & A5 & A6 & A7 & & \\
\hline Cubierta & pla & & incli & & & & & & \\
\hline
\end{tabular}

Este apartado, identificativo de los detalles claves relativos al alzado del inmueble analizado, se estructura en base a los diferentes elementos característicos de la fachada. Datos arquitectónicos y constructivos constituyen este ábaco de posibles combinaciones técnicas. Así se consideran parámetros generales como "No de pisos y organización del alzado","composición de la fachada". Pero también se analizan con detalle soluciones específicas para "zócalo", "fábrica", "relación vano/dintel", "relación entrada/dintel", "alero". ${ }^{6}$

\section{Fábrica}

Código alfanumérico

\begin{tabular}{l|lll} 
Aparejo & soga-tizón & soga tizón & \\
Hiladas & irregulares & pseudo horizontales & horizontales \\
Superficie & sin planeidad & pseudo planeidad & planeidad perfecta \\
$\begin{array}{l}\text { Sección (hip.) } \\
\text { Elementos } \\
\text { destacados }\end{array}$ & uniforme & hojas y núcleo & abocinada (vano) \\
\hline
\end{tabular}

Este apartado es específico para el análisis visual de la fábrica antes de estudiar con detalle ladrillos y juntas. Esta parte de la ficha discrimina sobre todo las fábricas de ladrillos respecto a las de tapia. Además permite identificar fábricas construidas para ser "vistas"

\footnotetext{
6 Para mayor detalle véase el "Anejo I.3 'Abaco de detalles de fábricas históricas de ladrillo" donde se explican las 33 combinaciones sintetizadas en las fichas.
} 
respecto a fábricas reconvertidas o intervenidas en el tiempo. Parámetros básicos para este análisis son "Aparejo", "Hiladas", características de la "Superficie", posible hipótesis relativa a la "Sección" y mapeo de "Elementos destacados". Factores claves considerados en este apartado son la homogeneidad, la planeidad, la regularidad, la uniformidad de la fábrica a analizar.

\section{Ladrillos}

Código

alfanumérico

\begin{tabular}{l|lll}
$\begin{array}{l}\text { No elementos medidos } \\
\text { Longitud }\end{array}$ & \multicolumn{2}{l}{} & \\
\hline $\begin{array}{l}\text { Anchura } \\
\text { Espesor } \\
\text { Volumen }\end{array}$ & $\mathrm{cm}$ & & \\
Tipo & $\mathrm{cm}$ & & \\
Color & $\mathrm{cm}^{3}$ & & \\
\hline Recogida de muestra & homogéneo & heterogéneo & re-empleo \\
\hline Patologías & homogéneo & $\begin{array}{l}\text { heterogéneo } \\
\text { globular }\end{array}$ & $\begin{array}{l}\text { heterogéneo } \\
\text { marmolado }\end{array}$ \\
\hline & $\begin{array}{l}\text { eflorescencias } \\
\text { erosión }\end{array}$ & $\begin{array}{l}\text { Micro fisuración } \\
\text { disgregación }\end{array}$ & $\begin{array}{l}\text { grietas } \\
\text { descamación }\end{array}$ \\
\hline
\end{tabular}

Este apartado es específico para el análisis detallado de los ladrillos que constituyen la fábrica histórica a analizar. Se trata de una parte de la ficha que se estructura por un lado en base a parámetros métricos, propios de la mensiocronología (" $N^{\circ}$ de elementos medidos", "Longitud", "Anchura", "Espesor", "Volumen") 7.

Por otro lado, se codifican indicadores del análisis visual como "Tipo" o "Color". En esta sección, además, se incorporan al registro dos parámetros "extra" para posibles estudios complementarios. Concretamente se identifica la "Recogida de muestra" para estudios analíticos/ petrográficos, así como el parámetro de "patologías" para posibles estudios diagnósticos.

\footnotetext{
${ }^{7}$ Así como se indica en el Cap.2.2.1. la mensiocronología emplea datos obtenidos en base al cálculo del desvío estándar (respecto al valor medio de la muestras analizadas) y del gráfico de frecuencia de las muestras analizadas, identificado con una curva gaussiana
} 


\section{Juntas}

\begin{tabular}{|c|c|c|c|}
\hline $\begin{array}{l}\mathrm{N}^{\circ} \text { elementos } \\
\text { medidos }\end{array}$ & & & \\
\hline Llaga & $\mathrm{cm}$ & & \\
\hline Tendel & $\mathrm{cm}$ & & \\
\hline Altura de 5 hiladas & $\mathrm{cm}$ & & \\
\hline Ladrillo/junta & & & \\
\hline Tipo de acabado & simple & doble & múltiple \\
\hline Junta de asiento & $\begin{array}{l}\text { rehundida } \\
\text { enrasada }\end{array}$ & $\begin{array}{l}\text { a hueso } \\
\text { matada }\end{array}$ & saliente \\
\hline Junta de acabado & $\begin{array}{l}\text { rehundida } \\
\text { enrasada }\end{array}$ & $\begin{array}{l}\text { a hueso } \\
\text { matada }\end{array}$ & saliente \\
\hline Tipo de mortero & cal & cal y tierra & cemento mixto \\
\hline $\begin{array}{l}\text { Morfología de } \\
\text { mortero }\end{array}$ & $\begin{array}{l}\text { con } \\
\text { grumos }\end{array}$ & con caliches & homogéneo heterogéneo \\
\hline Tipo de árido & arena & gravilla & grava \\
\hline Color del árido & claro & oscuro & homogéneo heterogéneo \\
\hline Recogida de muestra & no & sí & código \\
\hline Patologías & $\begin{array}{l}\text { eflorescen } \\
\text { cia } \\
\text { erosión" }\end{array}$ & $\begin{array}{l}\text { m. fisuración } \\
\text { disgregación }\end{array}$ & $\begin{array}{l}\text { grietas } \\
\text { pulverización }\end{array}$ \\
\hline
\end{tabular}

Este apartado es específico para el análisis detallado de las juntas que constituyen la fábrica histórica a analizar. Se trata de una parte de la ficha que se estructura por un lado en base a parámetros métricos propios de la mensiocronología ("No de elementos medidos", "Llaga", "Tendel", "Altura de 5 hiladas", "Proporción ladrillo/junta") ${ }^{8}$. Por otro lado, se codifican indicadores del análisis visual como "Tipo de acabado", "Junta de asiento/acabado", "Tipo de mortero/árido", "morfología del mortero".

Factores claves considerados interesantes para el análisis visual son la homogeneidad, la jerarquía de las juntas y su estratificación, más o menos compleja. Además, como para el apartado relativo a los ladrillos, se incorporan al registro dos parámetros "extra" para

\footnotetext{
${ }^{8}$ Los datos relativos al análisis métrico de las juntas estudiadas se han obtenido con los mismos criterios indicados en la nota previa, relativos al estudio dimensional de los ladrillos
} 
posibles estudios complementarios. Concretamente se identifica la "Recogida de muestra" para estudios analíticos/ petrográficos así como el parámetro de "patologías" para posibles estudios diagnósticos.

\section{Imagenes}

Este apartado se estructura con la recopilación de una serie de fotografías de elementos de interés que destacan claramente dos aspectos interesantes de las fábricas. Por un lado se identifican sectores de fábricas con un reportaje fotográfico/métrico. Por otro, se subrayan los valores arquitectónicos, artísticos, históricos, y constructivos reconocidos en los edificios. Las fotografías, tanto con función métrica, como descriptiva, retroalimentan y verifican la compilación de las fichas. 
murOSINTRAMUIOS

\section{I.2 Base de datos}





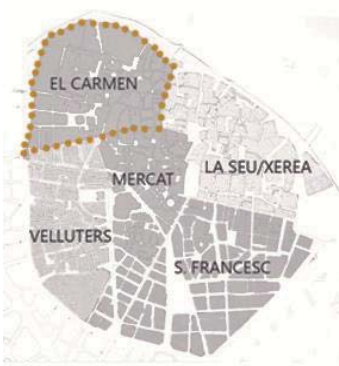

\section{I.2.1 Fábricas históricas: barrio del Carmen}




\begin{tabular}{|c|c|c|}
\hline \multicolumn{3}{|c|}{ Barrio del Carmen: todas las fábricas seleccionadas } \\
\hline Código & Dirección & Edificio \\
\hline Ca15 & Pza. Navarro nº 4 -Pza. Ángel nº 2 & RESIDENCIAL \\
\hline Ca30 & Pza. Navarro n²/7 & RESIDENCIAL \\
\hline Ca32 & C/ Mare Vella $n^{\circ} 12$ & RESIDENCIAL \\
\hline Ca82 & C/ Adoberies n०55 & RESIDENCIAL \\
\hline Ca85 & Pza. Navarro nº 1 & RESIDENCIAL \\
\hline Ca113 & C/ Caballeros n²8 & PALACIEGO \\
\hline Ca118 & C/ Caballeros n 40 & PALACIEGO \\
\hline Cb55 & C/ Quart no 16 & RESIDENCIAL \\
\hline Cb63 & C/ Quart no $16-$ C/ Rei en Jaume s/n & RESIDENCIAL \\
\hline Cb64 & Pza. Sta. Úrsula s/n & RELIGIOSO \\
\hline $\mathrm{Cb} 65$ & C/ Guillén de Castillo s/n & MILITAR \\
\hline Cd10 & C/ Corona no 6 & RESIDENCIAL \\
\hline $\mathrm{Cd15}$ & C/ San Ramón n 5 & RESIDENCIAL \\
\hline $\mathrm{Cd} 75$ & C/ Ripalda no 3 & RESIDENCIAL \\
\hline Cd118 & C/ Na Jordana n 15 & RESIDENCIAL \\
\hline $\mathrm{Ce} 24$ & C/ d'Alt no 24 & RESIDENCIAL \\
\hline Ce62 & C/ Sto. Tomás no 10 & RESIDENCIAL \\
\hline Ce71 & Pza. Carmen no 4 & PALACIEGO \\
\hline Ce93 & C/ D'En Borras no 8 & RESIDENCIAL \\
\hline Ce101 & Pza. de la Cruz s/n esq. C/ Pintor Filloll & PALACIEGO \\
\hline$C f 23$ & C/ dels Horts C/ S. Giner $n^{0} 1$ & RESIDENCIAL \\
\hline $\mathrm{Cf} 26$ & C/ dels Horts no 1-2 & RESIDENCIAL \\
\hline $\mathrm{Cf} 30$ & C/ Gutemberg s/n & RESIDENCIAL \\
\hline $\mathrm{Cf} 42$ & C/ Gutemberg s/n esq. C/ Lliria s/n & RESIDENCIAL \\
\hline Cf44 & C/ Gutemberg n 10 & RESIDENCIAL \\
\hline Cg01a & Pza. Carmen s/n & RELIGIOSO \\
\hline Cg01b & C/ del Museo s/n & RELIGIOSO \\
\hline $\mathrm{CgO2}$ & C/ del Museo no 2 & RELIGIOSO \\
\hline Cg14 & Pza. Portal Nuevo no 6 & RELIGIOSO \\
\hline Cg48a & Pza. Autor no 12 & RESIDENCIAL \\
\hline $\mathrm{Cg} 48 \mathrm{~b}$ & Pza. Autor no 12 & RESIDENCIAL \\
\hline Cg57 & C/ Garcilaso no 3 & RESIDENCIAL \\
\hline
\end{tabular}




\begin{tabular}{|c|c|c|c|}
\hline \multicolumn{4}{|c|}{ Barrio del Carmen: monumentos } \\
\hline Código & Dirección & Edificio & Nombre \\
\hline Ca113 & C/ Caballeros nº 28 & PALACIEGO & $\begin{array}{l}\text { Palacio de los } \\
\text { Condes de Alpuente }\end{array}$ \\
\hline Ca118 & C/ Caballeros n 40 & PALACIEGO & $\begin{array}{l}\text { Palacio de los } \\
\text { Fernandéz de } \\
\text { Córdoba }\end{array}$ \\
\hline Cb64 & Pza. Sta. Úrsula s/n & RELIGIOSO & Iglesia Sta. Úrsula \\
\hline Cb65 & C/ Guillén de Castillo s/n & MILITAR & Muralla Cristiana \\
\hline Ce71 & Pza. Carmen no 4 & PALACIEGO & Palacio Pineda \\
\hline Ce101 & $\begin{array}{l}\text { Pza. de la Cruz s/n esq. } \\
\text { C/ Pintor Filloll }\end{array}$ & PALACIEGO & 1 \\
\hline Cg01a & Pza. Carmen s/n & RELIGIOSO & Convento del Carme \\
\hline Cg01b & C/ del Museo s/n & RELIGIOSO & Iglesia del Carme \\
\hline $\mathrm{CgO} 2$ & C/ del Museo n² & RELIGIOSO & Convento del Carme \\
\hline Cg14 & Pza. Portal Nuevo n 6 & RELIGIOSO & Convento San José \\
\hline
\end{tabular}




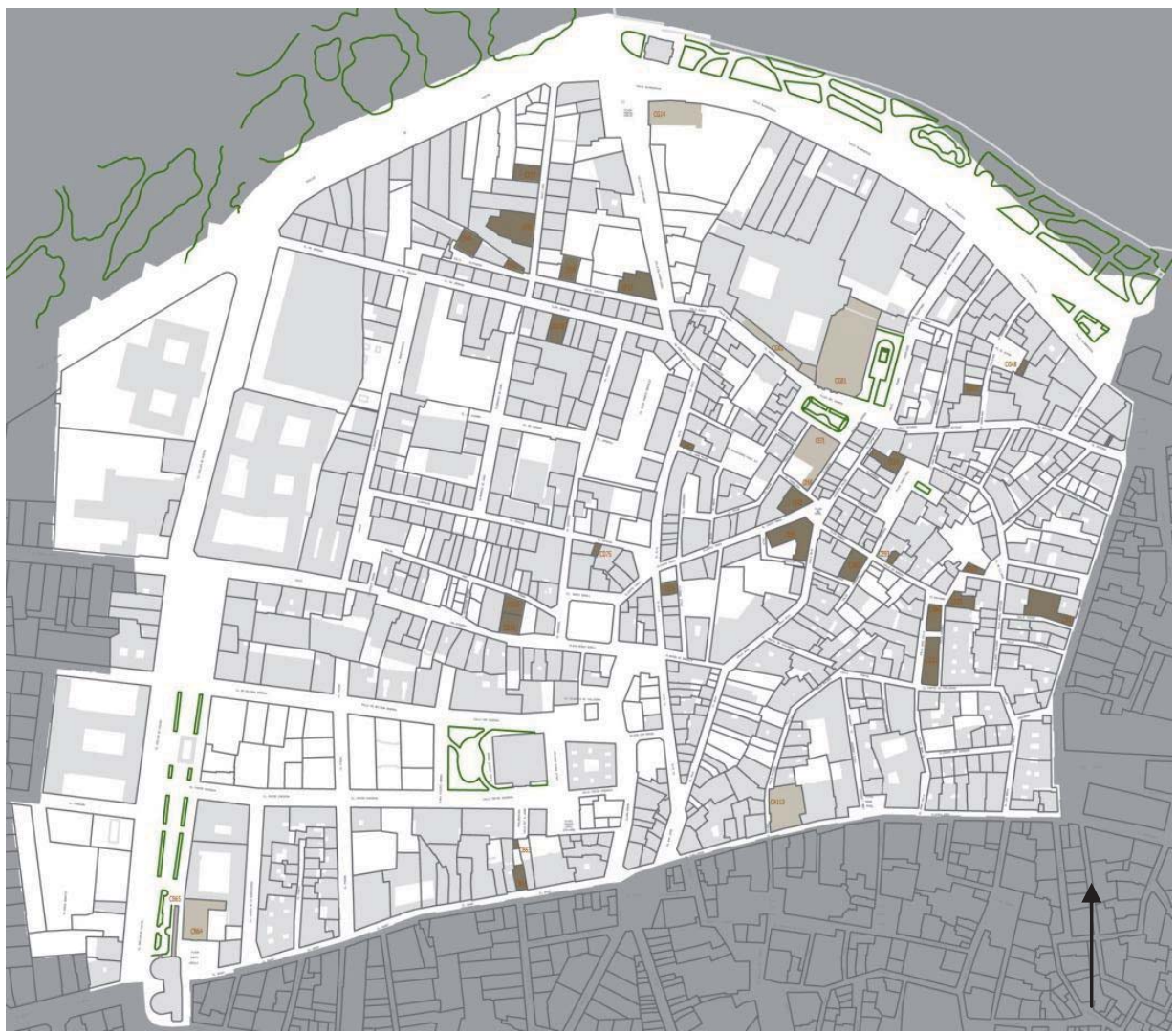

FIG. 4 Mapa de localización de las fichas recopiladas en el barrio del Carmen (CRISTINI) 


\begin{tabular}{|c|c|c|c|c|c|}
\hline Barrio & Carmen & La Seu-Xerea & Velluters & Mercat & S.Francesc \\
\hline Dirección & Pza. Navarr & $n^{\circ} 4 /$ Pza. del A & $n^{\circ} 2$ & & \\
\hline Tipo de edificio & residencial & palaciego & religioso & militar & \\
\hline $\mathbf{G}^{\circ}$ de protección & 0 & 1 & 2 & 3 & \\
\hline Fechas claves & / & & & & \\
\hline
\end{tabular}

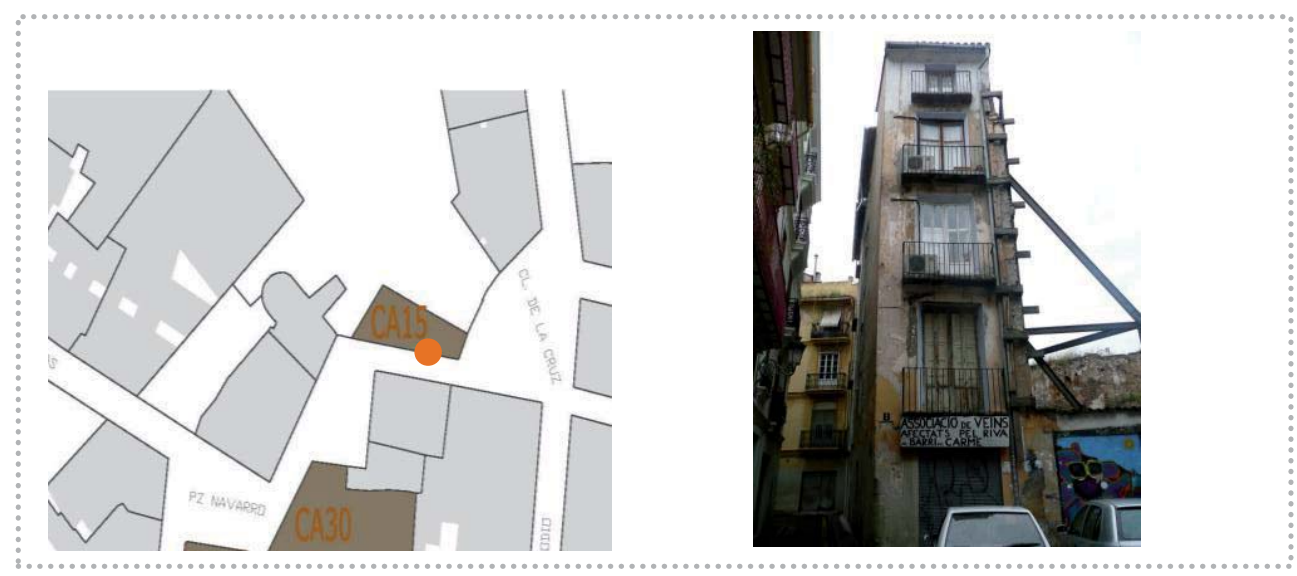

Fachada

Ca15

\begin{tabular}{|c|c|c|c|c|c|c|c|c|c|}
\hline \multirow{3}{*}{$\begin{array}{l}\text { Pisos } \\
\text { Composición fachada } \\
\text { Zócalo }\end{array}$} & \multicolumn{2}{|c|}{$N^{0} 4$} & \multicolumn{3}{|c|}{ sótano entreplanta } & \multicolumn{4}{|c|}{ piso noble caja escalera } \\
\hline & \multicolumn{2}{|c|}{ aleatoria } & \multicolumn{3}{|c|}{ ordenada sin simetría } & \multicolumn{4}{|c|}{ ordenada con simetría } \\
\hline & Z1 & $\mathrm{Z} 2$ & $\mathrm{Z3}$ & Z4 & Z5 & & & & \\
\hline Fábrica & $\mathrm{F} 1$ & $\mathrm{~F} 2$ & F3 & $\mathrm{F} 4$ & F5 & F6 & & & \\
\hline Vano/dintel & V1 & V2 & V3 & V4 & V5 & V7 & V8 & V9 & V10 \\
\hline Entrada/dintel & E1 & E2 & E3 & E4 & & & & & \\
\hline Alero & A1 & $\mathrm{A} 2$ & A3 & A4 & A5 & A7 & & & \\
\hline Cubierta & pla & & inclina & & & & & & \\
\hline
\end{tabular}

Fábrica

Ca15

\begin{tabular}{|c|c|c|c|}
\hline Aparejo & soga-tizón & tizón & \\
\hline Hiladas & irregulares & pseudo horizontales & horizontales \\
\hline Superficie & sin planeidad & pseudo planeidad & planeidad perfecta \\
\hline Sección (hipótesis) & uniforme & hojas y núcleo & abocinada (vano) \\
\hline Elementos destacados & aplantillado & terracota & \\
\hline
\end{tabular}




$N^{\circ}$ elementos medidos
Longitud $(\mathrm{cm})$
Anchura $(\mathrm{cm})$
Espesor $(\mathrm{cm})$
Volumen $\left(\mathrm{cm}^{3}\right)$
Tipo
Color

Recogida de muestra

Patologías

\section{5}

31.1

14.1

4.1

1797.8

\begin{tabular}{lll} 
homogéneo & heterogéneo & re-empleo \\
\hline homogéneo & heterogéneo globular & heterogéneo marmolado \\
\hline no & sí & código \\
\hline eflorescencias & micro fisuración & grietas \\
erosión & disgregación & descamación
\end{tabular}

${ }^{1}$ Datos obtenidos en base al cálculo del desvío estándar (respecto al valor medio de la muestras analizadas) y del gráfico de frecuencia de las muestras analizadas, identificado por una curva gaussiana

\section{Juntas}

\begin{tabular}{|c|c|c|c|c|}
\hline \multirow{2}{*}{$\begin{array}{l}N^{\circ} \text { elementos medidos } \\
\text { Llaga }(\mathrm{cm})\end{array}$} & \multicolumn{4}{|l|}{15} \\
\hline & \multicolumn{4}{|l|}{1} \\
\hline Tendel (cm) & \multicolumn{4}{|l|}{3.5} \\
\hline Altura de 5 hiladas (cm) & \multicolumn{4}{|l|}{38} \\
\hline Proporción ladrillo/junta & \multicolumn{4}{|l|}{1.1} \\
\hline Tipo de acabado & simple & doble & múltiple & \\
\hline \multirow[t]{2}{*}{ Junta de asiento } & rehundida & a hueso & saliente & \\
\hline & enrasada & matada & & \\
\hline \multirow[t]{2}{*}{ Junta de acabado } & rehundida & a hueso & saliente & \\
\hline & enrasada & matada & & \\
\hline \multirow{2}{*}{$\begin{array}{l}\text { Tipo de mortero } \\
\text { Morfología de mortero }\end{array}$} & cal & cal y tierra & tierra & cemento mixto \\
\hline & con grumos & con caliches & homogéneo & heterogéneo \\
\hline Tipo de árido & arena & gravilla & grava & mixto \\
\hline \multirow{2}{*}{$\begin{array}{l}\text { Color del árido } \\
\text { Recogida de muestra }\end{array}$} & claro & oscuro & homogéneo & heterogéneo \\
\hline & no & si & código & \\
\hline \multirow[t]{2}{*}{ Patologías } & eflorescencias & micro fisuración & grietas & \\
\hline & erosión & disgregación & pulverización & \\
\hline
\end{tabular}


Imágenes
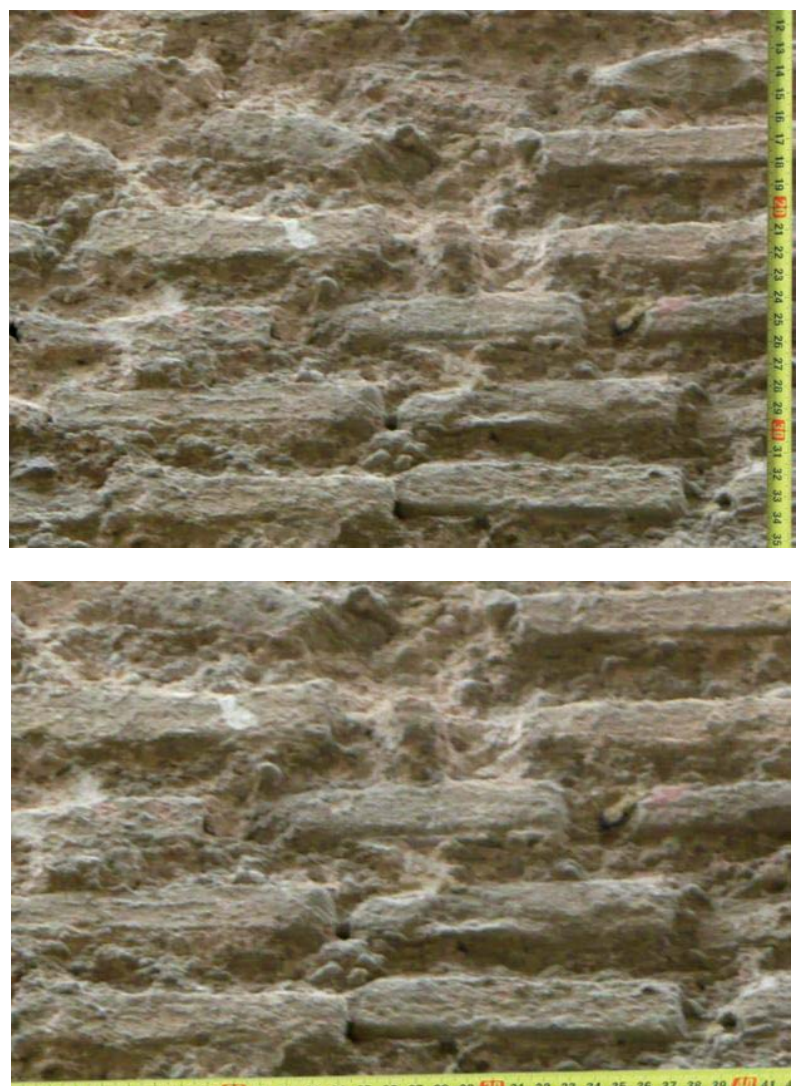

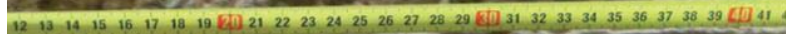

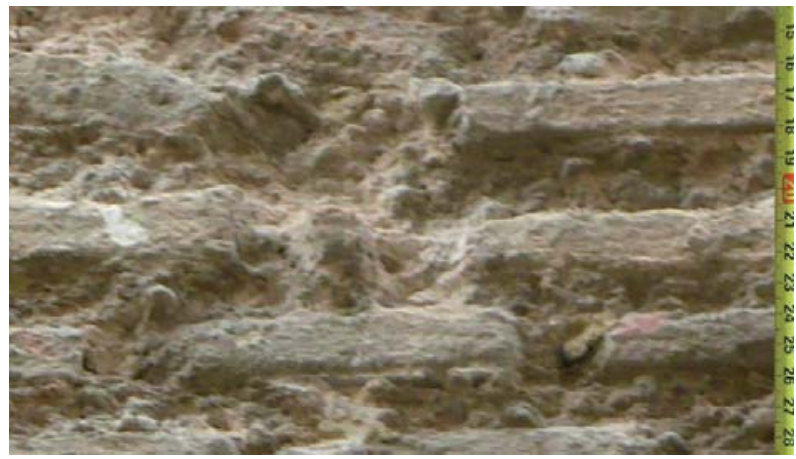


Imágenes

Ca15
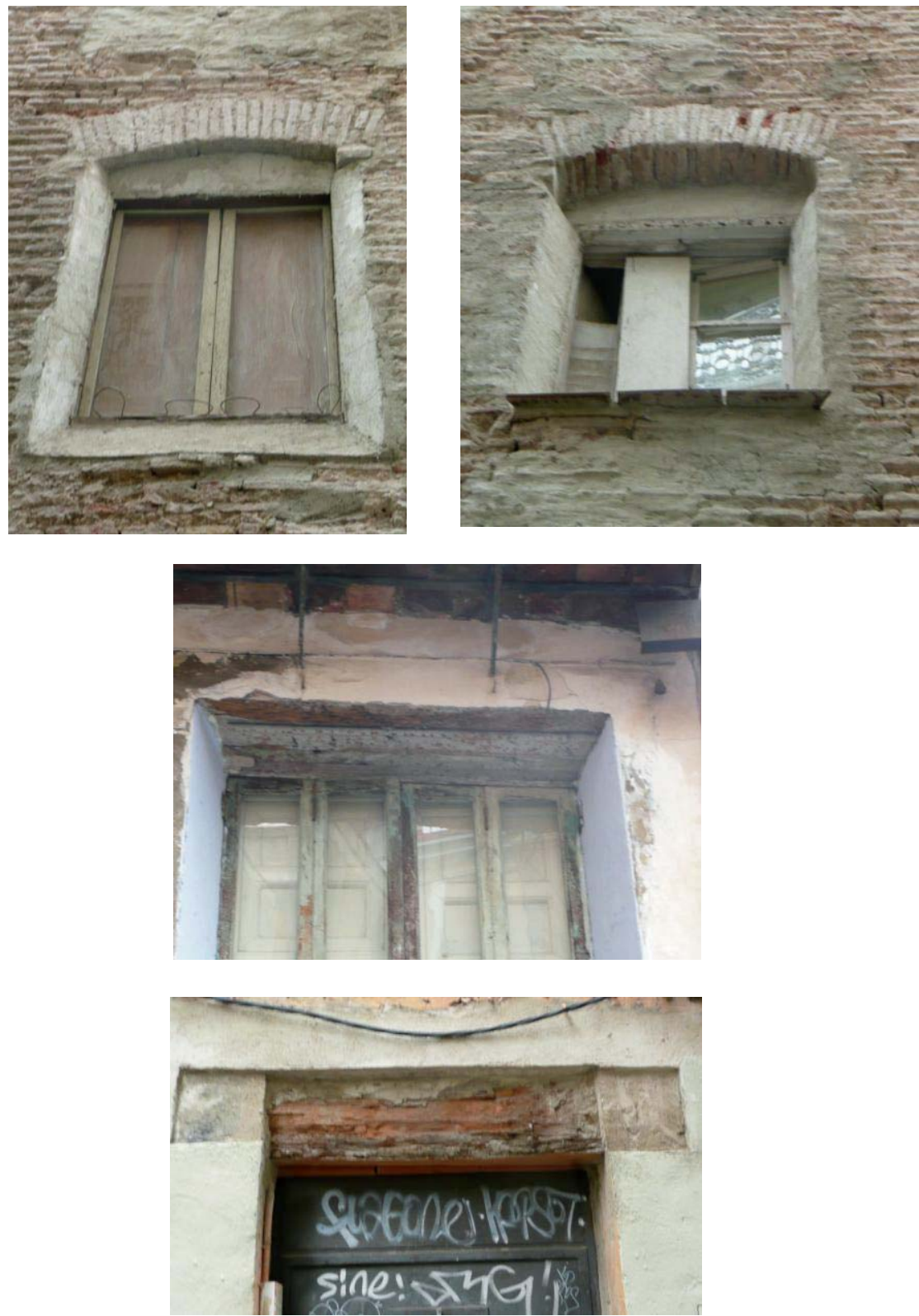
Datos generales

\begin{tabular}{|c|c|c|c|c|c|}
\hline Barrio & Carmen & La Seu-Xerea & Velluters & Mercat & S.Francesc \\
\hline Dirección & Pza. Navarr & $\mathrm{n}^{\circ} 2 / 7$ & & & \\
\hline Tipo de edificio & residencial & palaciego & religioso & militar & \\
\hline $\mathbf{G}^{\circ}$ de protección & 0 & 1 & 2 & 3 & \\
\hline Fechas claves & / & & & & \\
\hline
\end{tabular}

El apartado "fechas claves" se ha extraído de AA.V. ., Guía de Arquitectura de Valencia, Icaro CTAV Ed., Valencia, 2007

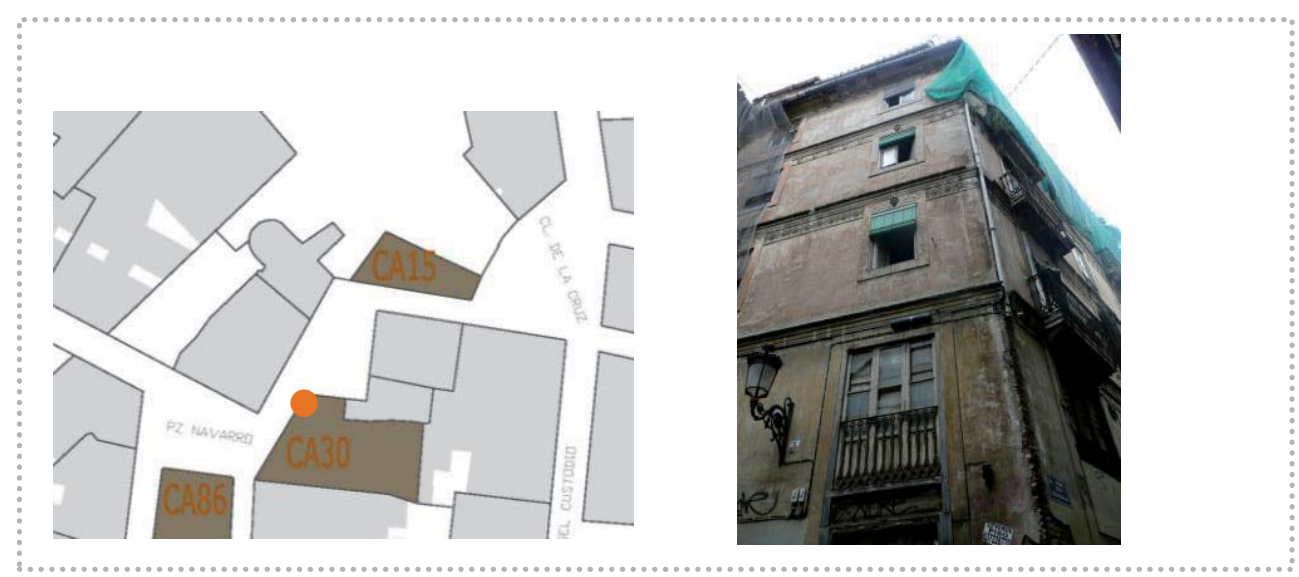

Fachada

Ca30

Pisos
Composición fachada
Zócalo
Fábrica
Vano/dintel
Entrada/dintel
Alero
Cubierta

\begin{tabular}{|c|c|c|c|c|c|c|c|c|}
\hline \multirow{3}{*}{\multicolumn{2}{|c|}{$\begin{array}{l}\mathrm{N}^{0} 3 \\
\text { aleatoria }\end{array}$}} & sótanc & & planta & \multicolumn{4}{|c|}{ piso noble caja escalera } \\
\hline & & \multicolumn{3}{|c|}{ ordenada sin simetría } & \multicolumn{4}{|c|}{ ordenada con simetría } \\
\hline & & Z3 & Z4 & $\mathrm{Z5}$ & & & & \\
\hline F1 & F2 & F3 & $\mathrm{F} 4$ & F5 & F6 & & & \\
\hline V1 & V2 & V3 & V4 & V5 & V7 & V8 & V9 & V10 \\
\hline E1 & E2 & E3 & E4 & & & & & \\
\hline A1 & $\mathrm{A} 2$ & A3 & A4 & A5 & A7 & & & \\
\hline
\end{tabular}

Fábrica

Ca30

\begin{tabular}{l|lll} 
Aparejo & soga-tizón & soga & \multicolumn{2}{c}{ tizón } & \\
Hiladas & irregulares & pseudo horizontales & horizontales \\
\hline Superficie & sin planeidad & pseudo planeidad & planeidad perfecta \\
\hline $\begin{array}{l}\text { Sección (hipótesis) } \\
\text { Elementos destacados }\end{array}$ & uniforme & hojas y núcleo & abocinada (vano) \\
\hline
\end{tabular}




\begin{tabular}{|c|c|c|c|}
\hline$N^{\circ}$ elementos medidos & 15 & & \\
\hline Longitud (cm) & 26 & & \\
\hline Anchura (cm) & 12.7 & & \\
\hline Espesor (cm) & 3.1 & & \\
\hline Volumen $\left(\mathrm{cm}^{3}\right)$ & 1023.6 & & \\
\hline Tipo & homogéneo & heterogéneo & re-empleo \\
\hline Color & homogéneo & heterogéneo globular & heterogéneo marmolado \\
\hline Recogida de muestra & no & sí & Código Ca30/1 \\
\hline Patologías & $\begin{array}{l}\text { eflorescencias } \\
\text { erosión }\end{array}$ & $\begin{array}{l}\text { micro fisuración } \\
\text { disgregación }\end{array}$ & $\begin{array}{l}\text { grietas } \\
\text { descamación }\end{array}$ \\
\hline
\end{tabular}

1 Datos obtenidos en base al cálculo del desvío estándar (respecto al valor medio de la muestras analizadas) y del gráfico de frecuencia de las muestras analizadas, identificado por una curva gaussiana

\section{untas 2}

\begin{tabular}{|c|c|c|c|c|}
\hline \multirow{2}{*}{$\begin{array}{l}N^{\circ} \text { elementos medidos } \\
\text { Llaga }(\mathrm{cm})\end{array}$} & \multicolumn{4}{|l|}{15} \\
\hline & \multicolumn{4}{|l|}{0.4} \\
\hline Tendel (cm) & \multicolumn{4}{|l|}{3.6} \\
\hline Altura de 5 hiladas $(\mathrm{cm})$ & \multicolumn{4}{|l|}{30.6} \\
\hline Proporción ladrillo/junta & \multicolumn{4}{|l|}{0.8} \\
\hline Tipo de acabado & simple & doble & múltiple & \\
\hline Junta de asiento & $\begin{array}{l}\text { rehundida } \\
\text { enrasada }\end{array}$ & $\begin{array}{l}\text { a hueso } \\
\text { matada }\end{array}$ & saliente & \\
\hline Junta de acabado & $\begin{array}{l}\text { rehundida } \\
\text { enrasada }\end{array}$ & $\begin{array}{l}\text { a hueso } \\
\text { matada }\end{array}$ & saliente & \\
\hline Tipo de mortero & cal & cal y tierra & tierra & cemento mixto \\
\hline Morfología de mortero & con grumos & con caliches & homogéneo & heterogéneo \\
\hline Tipo de árido & arena & gravilla & grava & mixto \\
\hline Color del árido & claro & oscuro & homogéneo & heterogéneo \\
\hline Recogida de muestra & no & sí & Código Ca30/2 & \\
\hline Patologías & $\begin{array}{l}\text { eflorescencias } \\
\text { erosión }\end{array}$ & $\begin{array}{l}\text { micro fisuración } \\
\text { disgregación }\end{array}$ & $\begin{array}{l}\text { grietas } \\
\text { pulverización }\end{array}$ & \\
\hline
\end{tabular}


Imágenes
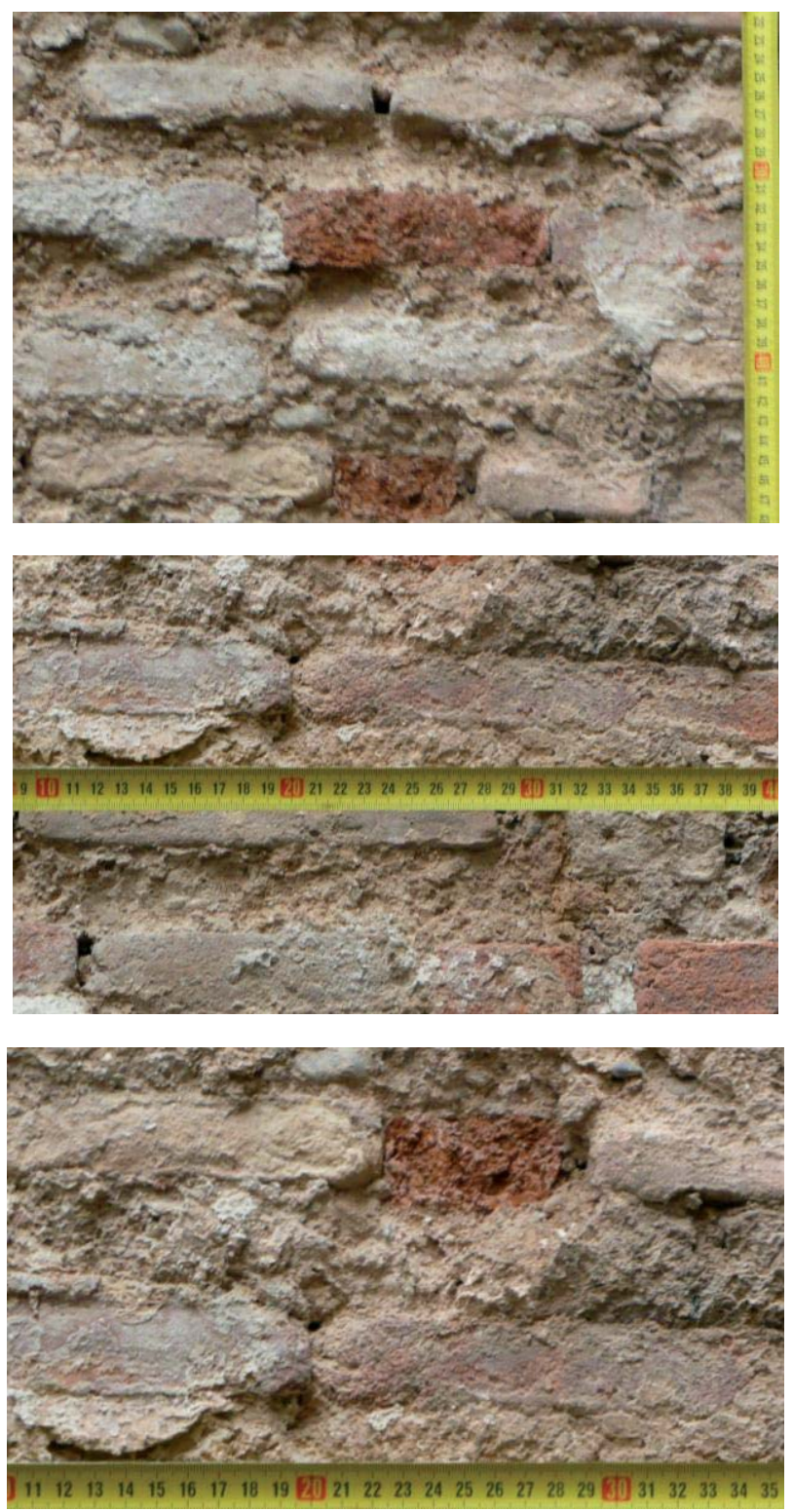

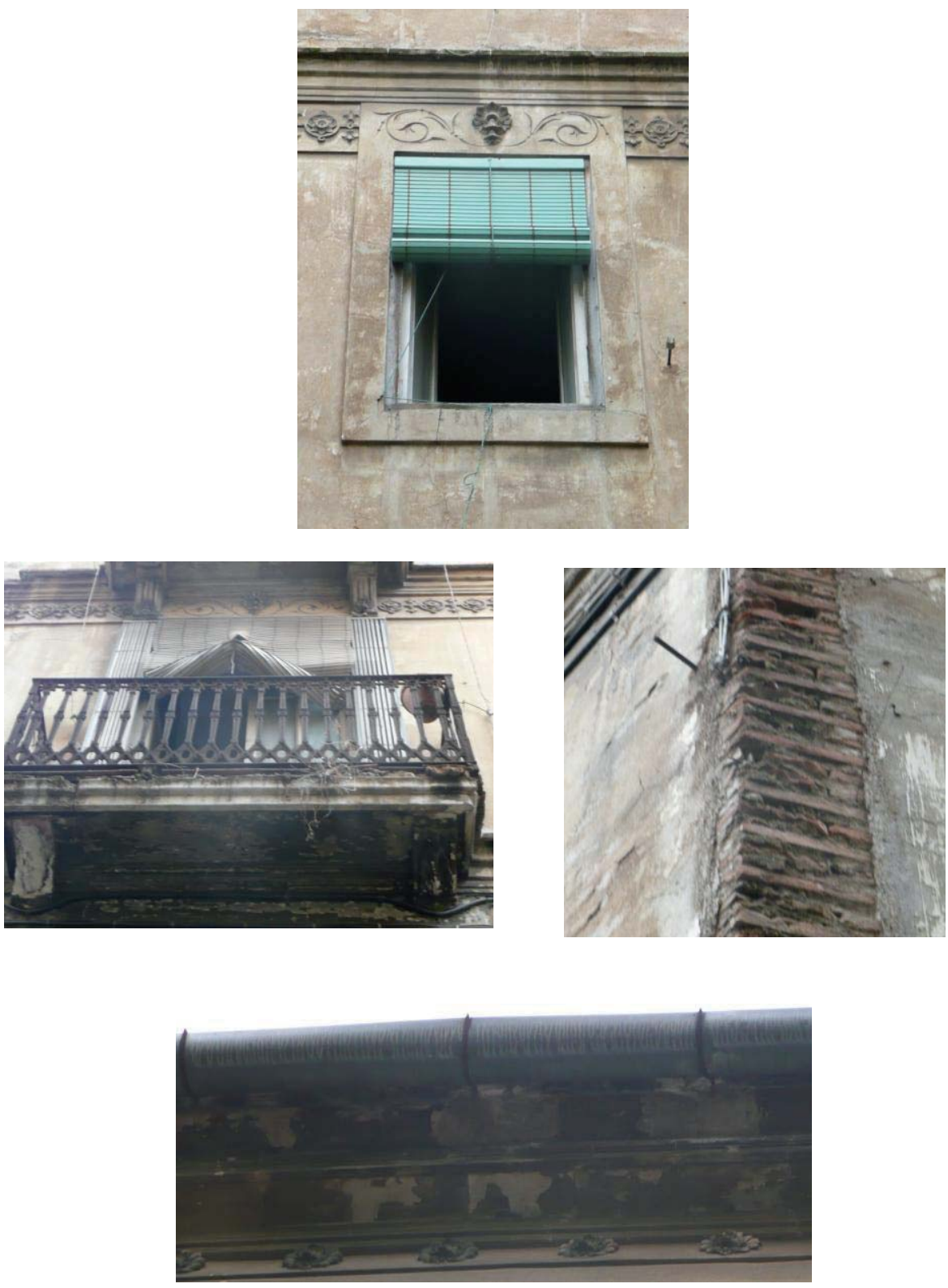
Datos generales

\begin{tabular}{|c|c|c|c|c|c|}
\hline Barrio & Carmen & La Seu-Xerea & Velluters & Mercat & S.Francesc \\
\hline Dirección & Carrer Mar & /ella n¹2 & & & \\
\hline Tipo de edificio & residencial & palaciego & religioso & militar & \\
\hline $\mathbf{G}^{\circ}$ de protección & 0 & 1 & 2 & 3 & \\
\hline Fechas claves & / & & & & \\
\hline
\end{tabular}

El apartado "fechas claves" se ha extraído de AA.V. ., Guía de Arquitectura de Valencia, Icaro CTAV Ed., Valencia, 2007
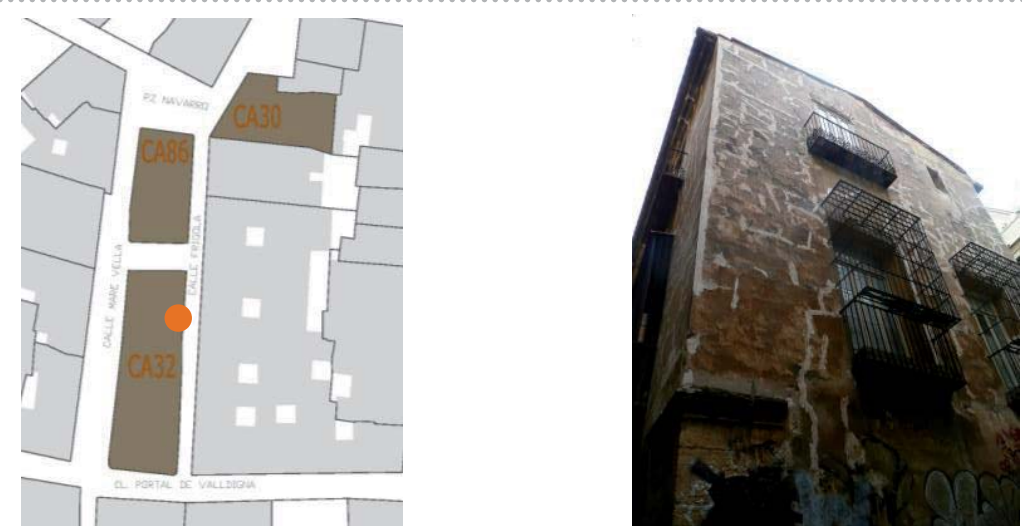

Fachada

Ca32

Pisos

Composición fachada

Zócalo

Fábrica

Vano/dintel

Entrada/dintel

Alero

Cubierta

\begin{tabular}{|c|c|c|c|c|c|c|c|c|}
\hline \multirow{2}{*}{\multicolumn{2}{|c|}{$\begin{array}{l}\mathrm{N}^{0} 4 \\
\text { aleatoria }\end{array}$}} & sótano & \multicolumn{2}{|c|}{ entreplanta } & \multicolumn{4}{|c|}{ piso noble caja escalera } \\
\hline & & \multicolumn{3}{|c|}{ ordenada sin simetría } & \multicolumn{4}{|c|}{ ordenada con simetría } \\
\hline Z1 & $\mathrm{Z} 2$ & Z3 & Z4 & Z5 & & & & \\
\hline F1 & $\mathrm{F} 2$ & F3 & F4 & $\mathrm{F} 5$ & F6 & & & \\
\hline V1 & V2 & V3 & V4 & V5 & V6 & V8 & V9 & V10 \\
\hline E1 & E2 & E3 & E4 & & & & & \\
\hline A1 & $\mathrm{A} 2$ & A3 & A4 & A5 & A6 & & & \\
\hline
\end{tabular}

Fábrica

Ca32

\section{Aparejo \\ Hiladas \\ Superficie \\ Sección (hipótesis) \\ Elementos destacados}

\begin{tabular}{lll} 
soga-tizón & soga tizón & \\
irregulares & pseudo horizontales & horizontales \\
\hline sin planeidad & pseudo planeidad & planeidad perfecta \\
\hline uniforme & hojas y núcleo & abocinada (vano) \\
aplantillado & cortado terracota & \\
\hline
\end{tabular}




\begin{tabular}{|c|c|c|c|}
\hline \multirow{3}{*}{$\begin{array}{l}\mathrm{N}^{\circ} \text { elementos medidos } \\
\text { Longitud }(\mathrm{cm}) \\
\text { Anchura }(\mathrm{cm})\end{array}$} & \multicolumn{3}{|l|}{15} \\
\hline & \multicolumn{3}{|l|}{31} \\
\hline & \multicolumn{3}{|l|}{14.1} \\
\hline Espesor (cm) & \multicolumn{3}{|l|}{4.1} \\
\hline Volumen $\left(\mathrm{cm}^{3}\right)$ & \multicolumn{3}{|l|}{1792.2} \\
\hline Tipo & homogéneo & heterogéneo & re-empleo \\
\hline \multirow{4}{*}{$\begin{array}{l}\text { Color } \\
\text { Recogida de muestra } \\
\text { Patologías }\end{array}$} & homogéneo & heterogéneo globular & heterogéneo marmolado \\
\hline & no & sí & código Ca32/1 \\
\hline & eflorescencias & micro fisuración & grietas \\
\hline & erosión & disgregación & descamación \\
\hline
\end{tabular}

${ }^{1}$ Datos obtenidos en base al cálculo del desvío estándar (respecto al valor medio de la muestras analizadas) y del gráfico de frecuencia de las muestras analizadas, identificado por una curva gaussiana

\section{Juntas}

\begin{tabular}{|c|c|c|c|c|}
\hline \multirow{2}{*}{$\begin{array}{l}N^{\circ} \text { elementos medidos } \\
\text { Llaga }(\mathrm{cm})\end{array}$} & \multicolumn{4}{|l|}{15} \\
\hline & \multicolumn{4}{|l|}{1} \\
\hline Tendel (cm) & \multicolumn{4}{|l|}{3.1} \\
\hline Altura de 5 hiladas $(\mathrm{cm})$ & \multicolumn{4}{|l|}{39.6} \\
\hline Proporción ladrillo/junta & \multicolumn{4}{|l|}{1.3} \\
\hline Tipo de acabado & simple & doble & múltiple & \\
\hline Junta de asiento & $\begin{array}{l}\text { rehundida } \\
\text { enrasada }\end{array}$ & $\begin{array}{l}\text { a hueso } \\
\text { matada }\end{array}$ & saliente & \\
\hline Junta de acabado & $\begin{array}{l}\text { rehundida } \\
\text { enrasada }\end{array}$ & $\begin{array}{l}\text { a hueso } \\
\text { matada }\end{array}$ & saliente & \\
\hline Tipo de mortero & cal & cal y tierra & tierra & cemento mixto \\
\hline Morfología de mortero & con grumos & con caliches & homogéneo & heterogéneo \\
\hline Tipo de árido & arena & gravilla & grava & mixto \\
\hline Color del árido & claro & oscuro & homogéneo & heterogéneo \\
\hline Recogida de muestra & no & sí & código Ca32/2 & \\
\hline Patologías & $\begin{array}{l}\text { eflorescencias } \\
\text { erosión }\end{array}$ & $\begin{array}{l}\text { micro fisuración } \\
\text { disgregación }\end{array}$ & $\begin{array}{l}\text { grietas } \\
\text { pulverización }\end{array}$ & \\
\hline
\end{tabular}


Imágenes
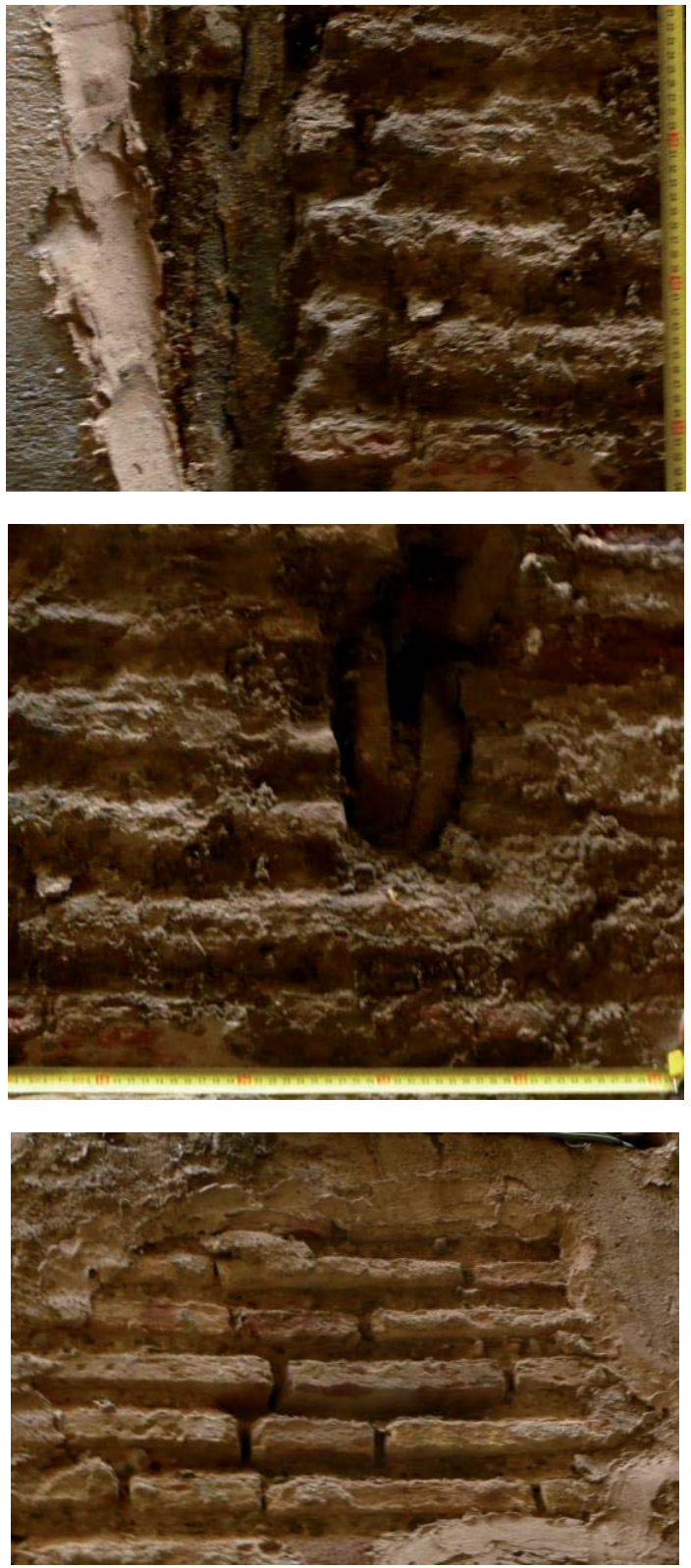
Imágenes

Ca32
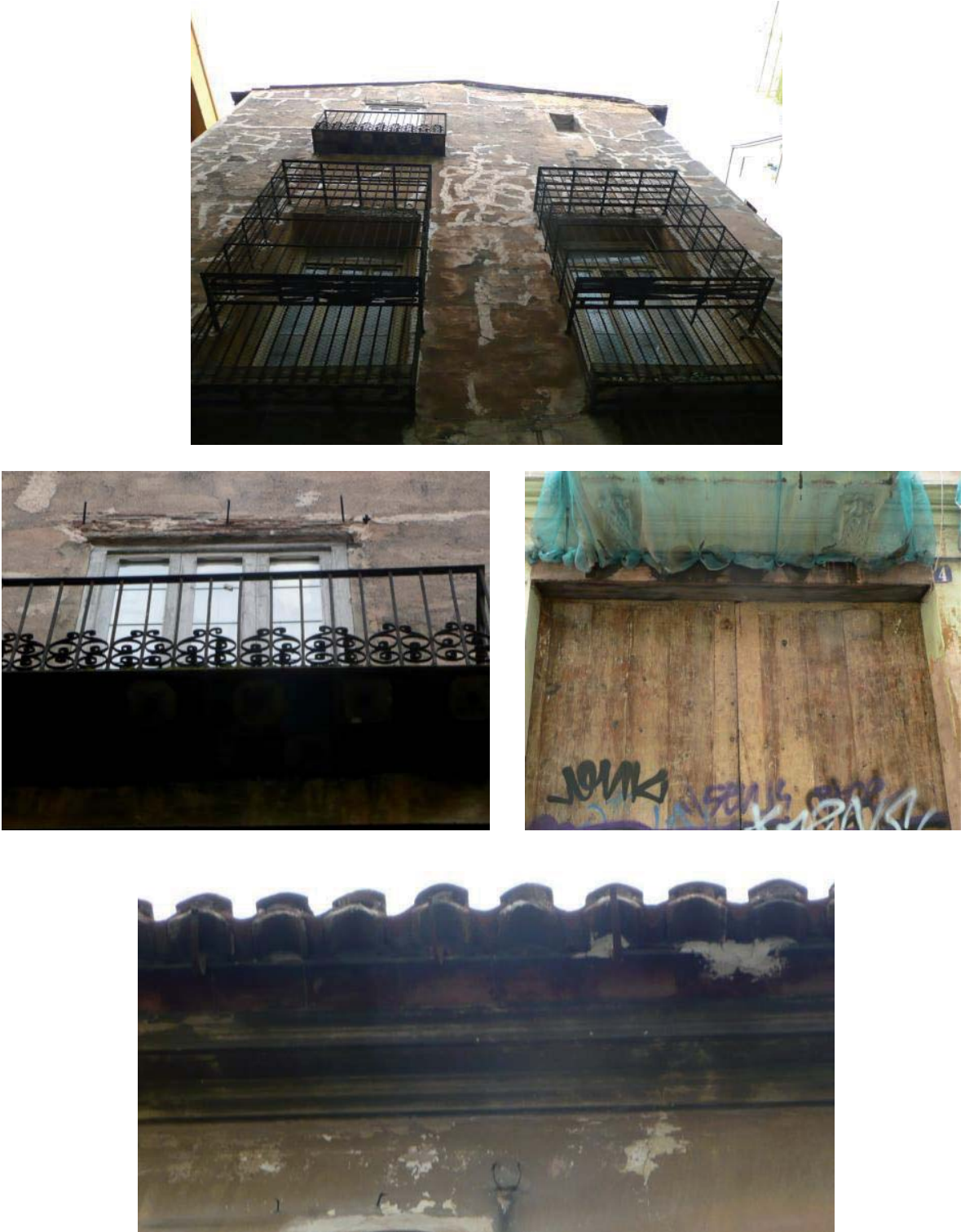
Datos generales

Ca82

\begin{tabular}{|c|c|c|c|c|c|}
\hline Barrio & Carmen & La Seu-Xerea & Velluters & Mercat & S.Francesc \\
\hline Dirección & C/Adoberie & n55 & & & \\
\hline Tipo de edificio & residencial & palaciego & religioso & militar & \\
\hline $\mathbf{G}^{\circ}$ de protección & 0 & 1 & 2 & 3 & \\
\hline Fechas claves & / & & & & \\
\hline
\end{tabular}

El apartado "fechas claves" se ha extraído de AA.V. ., Guía de Arquitectura de Valencia, Icaro CTAV Ed., Valencia, 2007
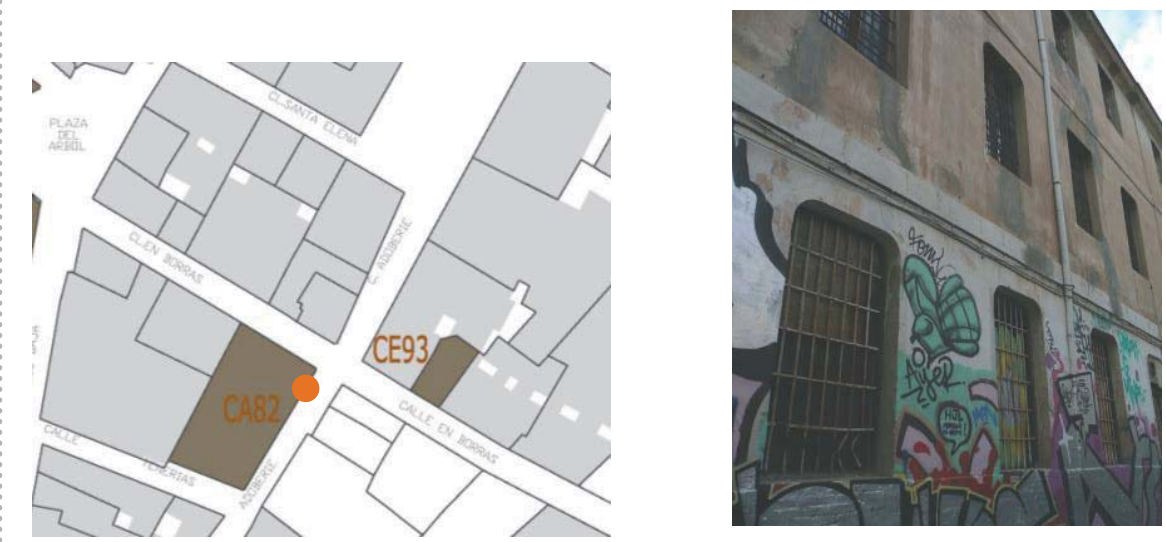

Fachada

Ca82

\begin{tabular}{|c|c|c|c|c|c|c|c|c|c|}
\hline \multirow{3}{*}{$\begin{array}{l}\text { Pisos } \\
\text { Composición fachada } \\
\text { Zócalo }\end{array}$} & \multicolumn{2}{|c|}{$N^{\circ} 2$} & sótano & \multicolumn{2}{|c|}{ entreplanta } & \multicolumn{4}{|c|}{ piso noble caja escalera } \\
\hline & \multicolumn{2}{|c|}{ aleatoria } & \multicolumn{3}{|c|}{ ordenada sin simetría } & \multicolumn{4}{|c|}{ ordenada con simetría } \\
\hline & $\mathrm{Z1}$ & $\mathrm{Z2}$ & Z3 & Z4 & Z5 & & & & \\
\hline Fábrica & F1 & F2 & F3 & $\mathrm{F} 4$ & F5 & F6 & & & \\
\hline Vano/dintel & V1 & V2 & V3 & V4 & V5 & V6 & V8 & V9 & V10 \\
\hline Entrada/dintel & E1 & E2 & E3 & E4 & & & & & \\
\hline Alero & A1 & A2 & A3 & A4 & A5 & A6 & & & \\
\hline Cubierta & pla & & inclinac & & & & & & \\
\hline
\end{tabular}

Fábrica

Ca82

\begin{tabular}{l|lll} 
Aparejo & soga-tizón & soga & \multicolumn{1}{c}{ tizón } \\
Hiladas & irregulares & pseudo horizontales & horizontales \\
\hline Superficie & sin planeidad & pseudo planeidad & planeidad perfecta \\
\hline Sección (hipótesis) & uniforme & hojas y núcleo & abocinada (vano) \\
Elementos destacados & aplantillado & cortado terracota & \\
\hline
\end{tabular}




\begin{tabular}{|c|c|c|c|}
\hline \multirow{2}{*}{$\begin{array}{l}\mathrm{N}^{\circ} \text { elementos medidos } \\
\text { Longitud }(\mathrm{cm})\end{array}$} & \multicolumn{3}{|l|}{15} \\
\hline & \multicolumn{3}{|l|}{27.2} \\
\hline Anchura (cm) & \multicolumn{3}{|l|}{13.2} \\
\hline Espesor $(\mathrm{cm})$ & \multicolumn{3}{|l|}{3.1} \\
\hline Volumen $\left(\mathrm{cm}^{3}\right)$ & \multicolumn{3}{|l|}{1113.0} \\
\hline Tipo & homogéneo & heterogéneo & re-empleo \\
\hline Color & homogéneo & heterogéneo globular & heterogéneo marmolado \\
\hline Recogida de muestra & no & sí & código Ca82/1 \\
\hline Patologías & $\begin{array}{l}\text { eflorescencias } \\
\text { erosión }\end{array}$ & $\begin{array}{l}\text { micro fisuración } \\
\text { disgregación }\end{array}$ & $\begin{array}{l}\text { grietas } \\
\text { descamación }\end{array}$ \\
\hline
\end{tabular}

1 Datos obtenidos en base al cálculo del desvío estándar (respecto al valor medio de la muestras analizadas) y del gráfico de frecuencia de las muestras analizadas, identificado por una curva gaussiana

\section{untas}

\begin{tabular}{|c|c|c|c|c|}
\hline$N^{\circ}$ elementos medidos & 15 & & & \\
\hline Llaga $(\mathrm{cm})$ & 0.5 & & & \\
\hline Tendel (cm) & 2.5 & & & \\
\hline Altura de 5 hiladas $(\mathrm{cm})$ & 29 & & & \\
\hline Proporción ladrillo/junta & 1.2 & & & \\
\hline Tipo de acabado & simple & doble & múltiple & \\
\hline Junta de asiento & $\begin{array}{l}\text { rehundida } \\
\text { enrasada }\end{array}$ & $\begin{array}{l}\text { a hueso } \\
\text { matada }\end{array}$ & saliente & \\
\hline Junta de acabado & $\begin{array}{l}\text { rehundida } \\
\text { enrasada }\end{array}$ & $\begin{array}{l}\text { a hueso } \\
\text { matada }\end{array}$ & saliente & \\
\hline Tipo de mortero & cal & cal y tierra & tierra & cemento mixto \\
\hline Morfología de mortero & con grumos & con caliches & homogéneo & heterogéneo \\
\hline Tipo de árido & arena & gravilla & grava & mixto \\
\hline Color del árido & claro & oscuro & homogéneo & heterogéneo \\
\hline Recogida de muestra & no & sí & código Ca82/2 & \\
\hline Patologías & $\begin{array}{l}\text { eflorescencias } \\
\text { erosión }\end{array}$ & $\begin{array}{l}\text { micro fisuración } \\
\text { disgregación }\end{array}$ & $\begin{array}{l}\text { grietas } \\
\text { pulverización }\end{array}$ & \\
\hline
\end{tabular}


Imágenes

Ca82
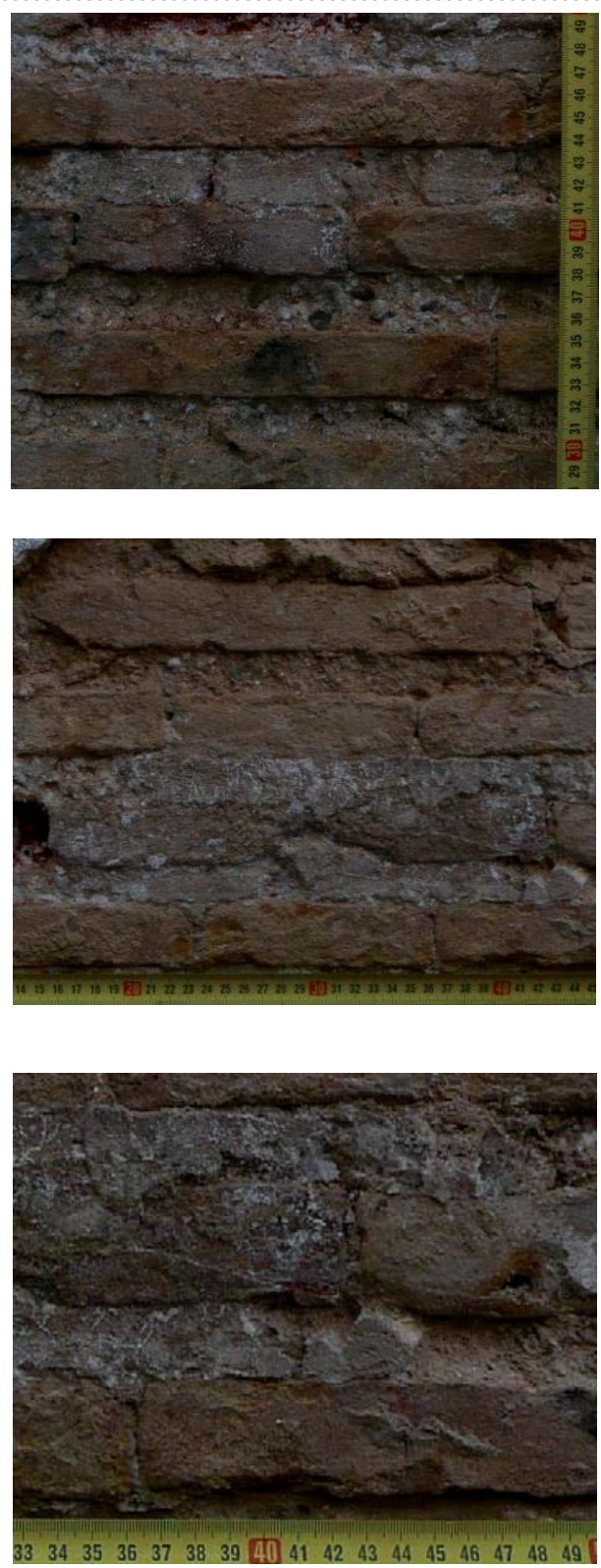
Imágenes

Ca82
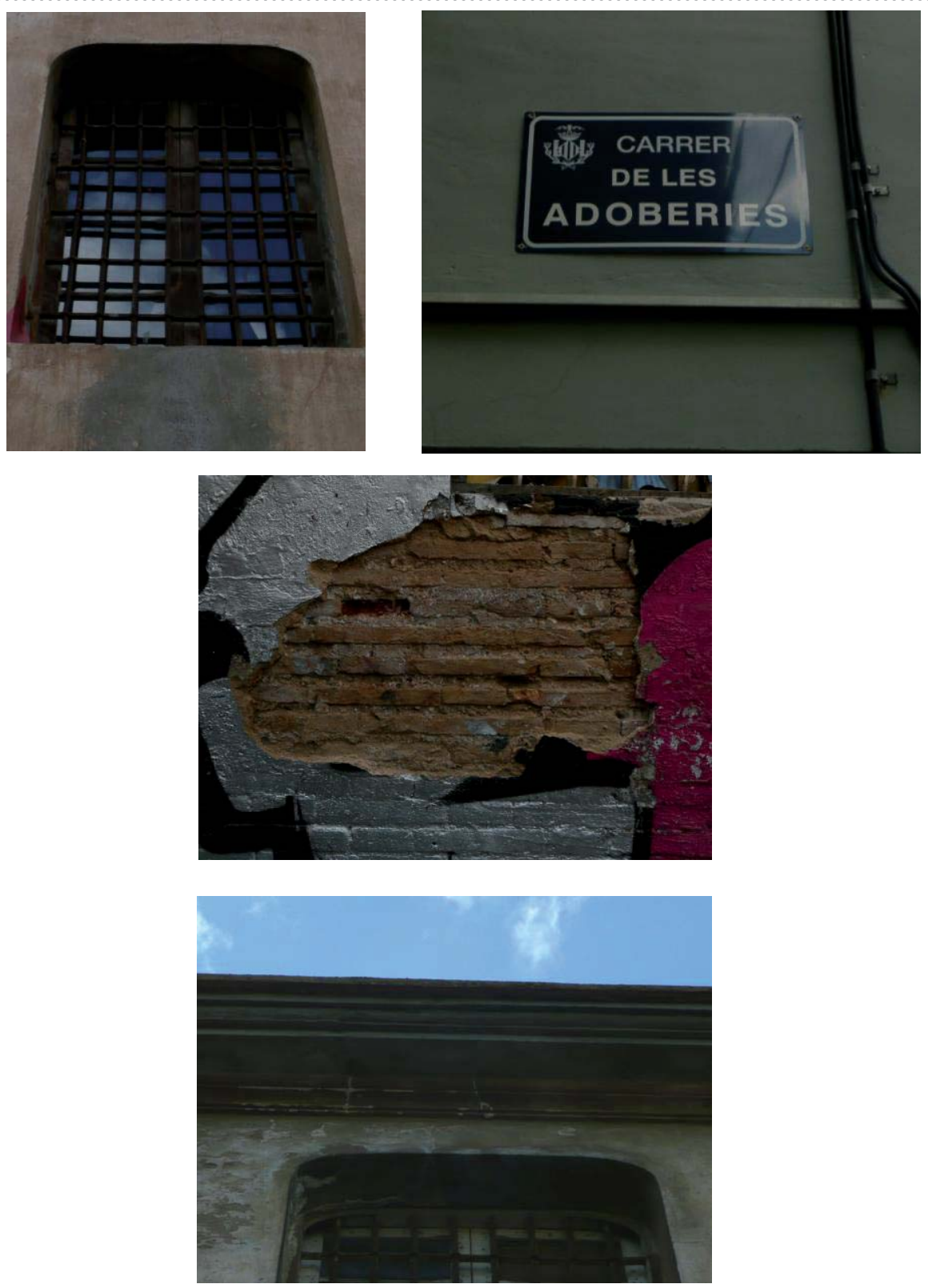
Datos generales

\section{Ca85}

\begin{tabular}{|c|c|c|c|c|c|}
\hline Barrio & Carmen & La Seu-Xerea & Velluters & Mercat & S.Francesc \\
\hline Dirección & Pza. Navarr & $n^{0} 1$ & & & \\
\hline Tipo de edificio & residencial & palaciego & religioso & militar & \\
\hline $\mathbf{G}^{\circ}$ de protección & 0 & 1 & 2 & 3 & \\
\hline Fechas claves & / & & & & \\
\hline
\end{tabular}
El apartado "fechas claves" se ha extraído de AA.W., Guía de Arquitectura de Valencia, Icaro CTAV Ed., Valencia, 2007
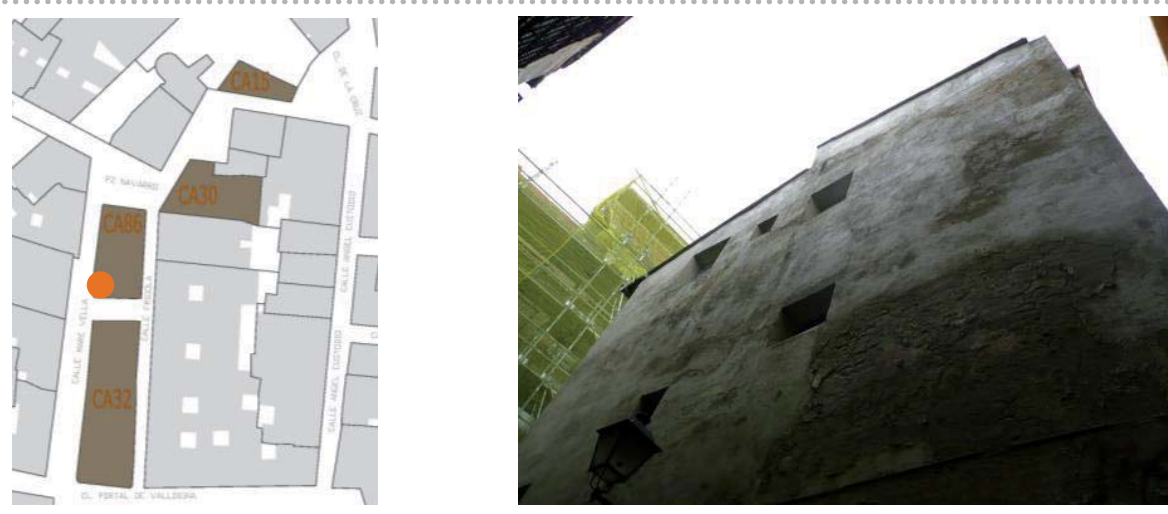

Fachada

Ca85

\begin{tabular}{|c|c|c|c|c|c|c|c|c|c|}
\hline \multirow{2}{*}{$\begin{array}{l}\text { Pisos } \\
\text { Composición fachada }\end{array}$} & \multicolumn{2}{|c|}{$N^{0} 3$} & sótano & \multicolumn{2}{|c|}{ entreplanta } & \multicolumn{4}{|c|}{ piso noble caja escalera } \\
\hline & \multicolumn{2}{|c|}{ aleatoria } & \multicolumn{3}{|c|}{ ordenada sin simetría } & \multicolumn{4}{|c|}{ ordenada con simetría } \\
\hline Zócalo & $\mathrm{Z1}$ & $\mathrm{Z2}$ & Z3 & Z4 & Z5 & & & & \\
\hline Fábrica & F1 & F2 & F3 & F4 & F5 & F6 & & & \\
\hline Vano/dintel & V1 & V2 & V3 & V4 & V5 & V6 & V8 & V9 & V10 \\
\hline Entrada/dintel & E1 & E2 & E3 & E4 & & & & & \\
\hline Alero & A1 & A2 & A3 & A4 & A5 & A6 & & & \\
\hline Cubierta & pla & & inclin & & & & & & \\
\hline
\end{tabular}

Fábrica

Ca85

\begin{tabular}{|c|c|c|c|}
\hline Aparejo & soga-tizón & tizón & \\
\hline Hiladas & irregulares & pseudo horizontales & horizontales \\
\hline Superficie & sin planeidad & pseudo planeidad & planeidad perfecta \\
\hline Sección (hipótesis) & uniforme & hojas y núcleo & abocinada (vano) \\
\hline Elementos destacados & aplantillado & terracota & \\
\hline
\end{tabular}




\begin{tabular}{|c|c|c|c|}
\hline \multirow{2}{*}{$\begin{array}{l}\mathrm{N}^{\circ} \text { elementos medidos } \\
\text { Longitud }(\mathrm{cm})\end{array}$} & \multicolumn{3}{|l|}{15} \\
\hline & \multicolumn{3}{|l|}{31.1} \\
\hline Anchura (cm) & \multicolumn{3}{|l|}{14.1} \\
\hline Espesor (cm) & \multicolumn{3}{|l|}{$4 / 3.5$} \\
\hline Volumen $\left(\mathrm{cm}^{3}\right)$ & \multicolumn{3}{|l|}{ / } \\
\hline Tipo & homogéneo & heterogéneo & re-empleo \\
\hline Color & homogéneo & heterogéneo globular & heterogéneo marmolado \\
\hline Recogida de muestra & no & sí & código Ca 85/1 \\
\hline Patologías & $\begin{array}{l}\text { eflorescencias } \\
\text { erosión }\end{array}$ & $\begin{array}{l}\text { micro fisuración } \\
\text { disgregación }\end{array}$ & $\begin{array}{l}\text { grietas } \\
\text { descamación }\end{array}$ \\
\hline
\end{tabular}

${ }^{1}$ Datos obtenidos en base al cálculo del desvío estándar (respecto al valor medio de la muestras analizadas) y del gráfico de frecuencia de las muestras analizadas, identificado por una curva gaussiana

\section{Juntas}

\begin{tabular}{|c|c|c|c|c|}
\hline \multirow{2}{*}{$\begin{array}{l}N^{\circ} \text { elementos medidos } \\
\text { Llaga }(\mathrm{cm})\end{array}$} & \multicolumn{4}{|l|}{15} \\
\hline & \multicolumn{4}{|l|}{0.9} \\
\hline \multirow{3}{*}{$\begin{array}{l}\text { Tendel }(\mathrm{cm}) \\
\text { Altura de } 5 \text { hiladas (cm) } \\
\text { Proporción ladrillo/junta }\end{array}$} & \multicolumn{4}{|l|}{3.4} \\
\hline & \multicolumn{4}{|l|}{36} \\
\hline & \multicolumn{4}{|l|}{$1.1 / 1.0$} \\
\hline Tipo de acabado & simple & doble & \multicolumn{2}{|l|}{ múltiple } \\
\hline \multirow[t]{2}{*}{ Junta de asiento } & rehundida & a hueso & \multirow{2}{*}{\multicolumn{2}{|c|}{ saliente }} \\
\hline & enrasada & matada & & \\
\hline \multirow[t]{2}{*}{ Junta de acabado } & rehundida & a hueso & \multirow{2}{*}{\multicolumn{2}{|c|}{ saliente }} \\
\hline & enrasada & matada & & \\
\hline \multirow{3}{*}{$\begin{array}{l}\text { Tipo de mortero } \\
\text { Morfología de mortero } \\
\text { Tipo de árido }\end{array}$} & cal & cal y tierra & tierra & cemento mixto \\
\hline & con grumos & con caliches & homogéneo & heterogéneo \\
\hline & arena & gravilla & grava & mixto \\
\hline \multirow{4}{*}{$\begin{array}{l}\text { Color del árido } \\
\text { Recogida de muestra } \\
\text { Patologías }\end{array}$} & claro & oscuro & homogéneo & heterogéneo \\
\hline & no & sí & \multicolumn{2}{|l|}{ código Ca 85/2 } \\
\hline & eflorescencias & micro fisuración & \multicolumn{2}{|l|}{ grietas } \\
\hline & erosión & disgregación & \multicolumn{2}{|l|}{ pulverización } \\
\hline
\end{tabular}

${ }^{2}$ Datos obtenidos en base al cálculo del desvío estándar (respecto al valor medio de la muestras analizadas) y del gráfico de frecuencia de las muestras analizadas, identificado por una curva gaussiana 
Imágenes
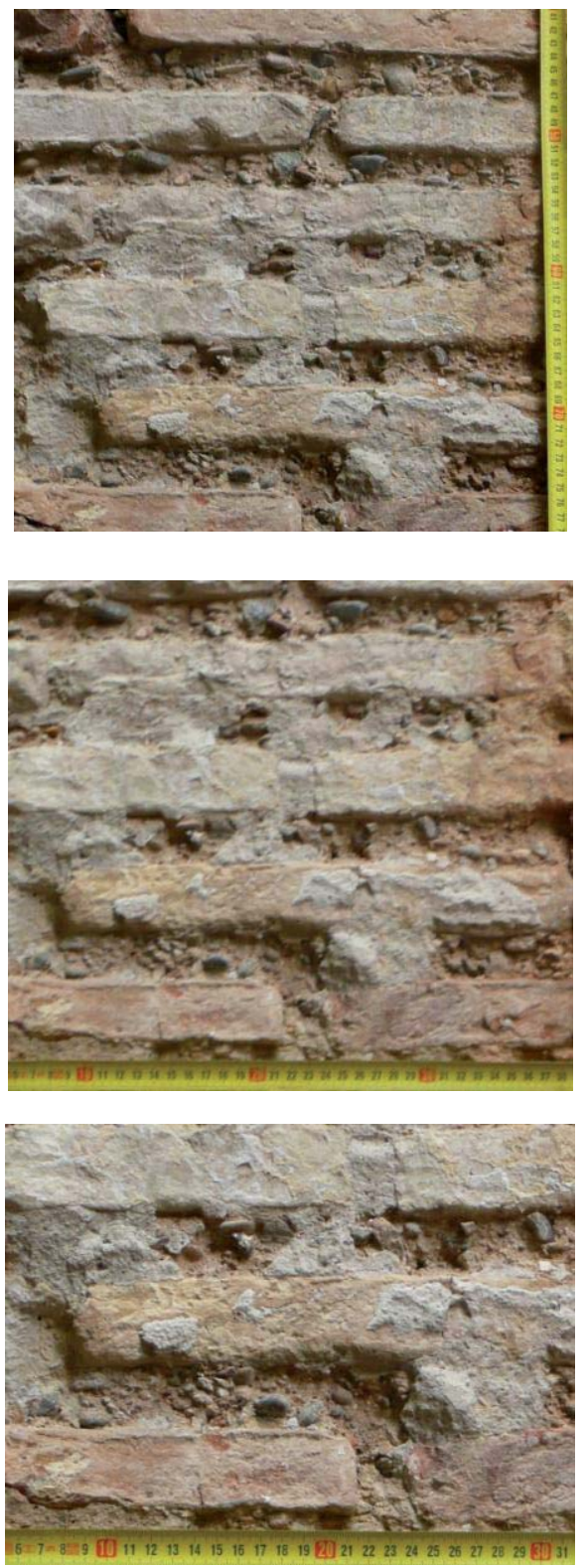
Imágenes

Ca85
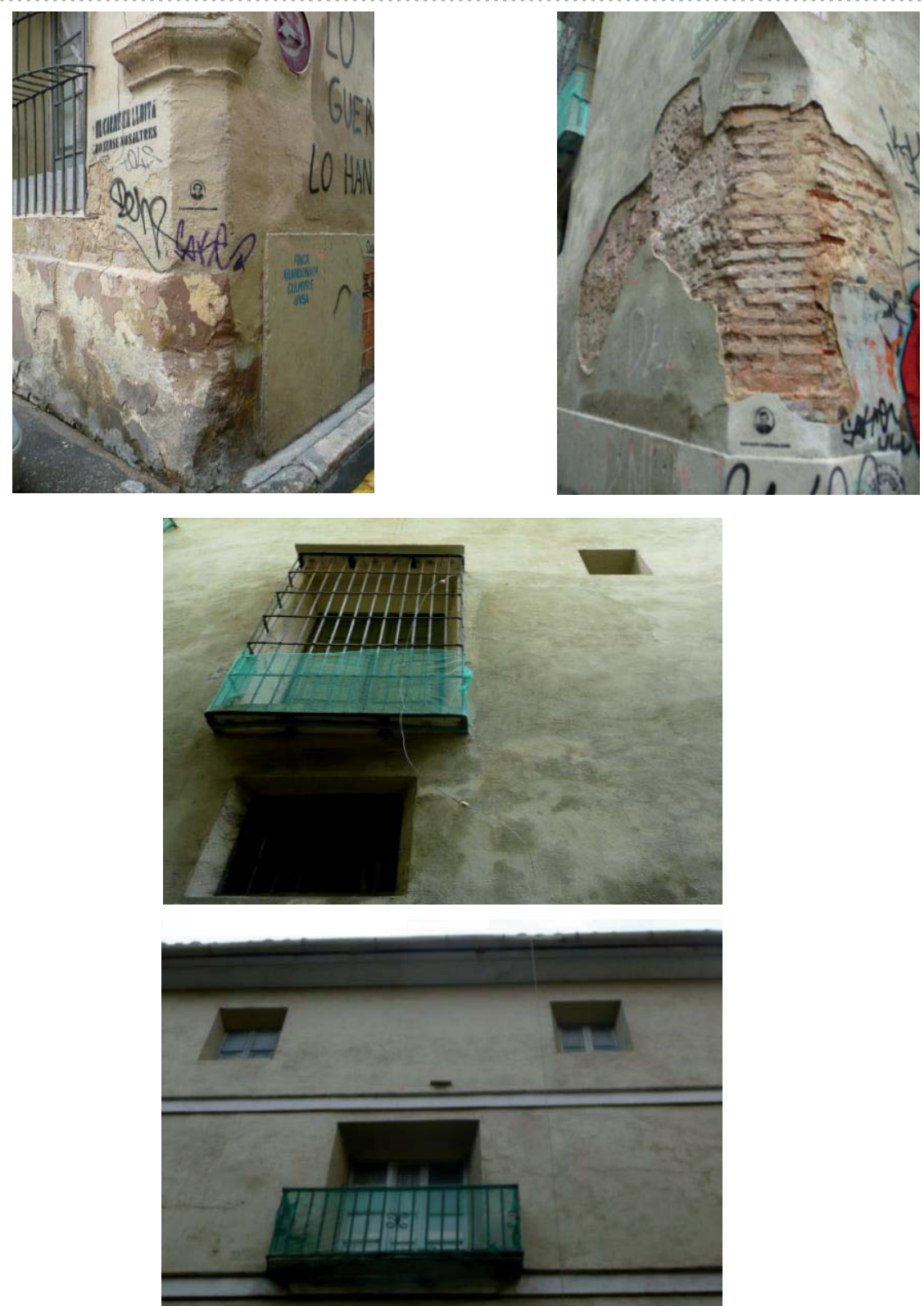
Barrio

Dirección

Tipo de edificio

$\mathbf{G}^{\circ}$ de protección

Fechas claves

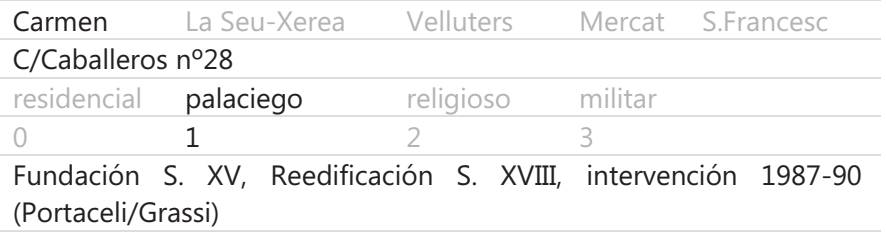

El apartado "fechas claves" se ha extraído de AA.W., Guía de Arquitectura de Valencia, Icaro CTAV Ed., Valencia, 2007
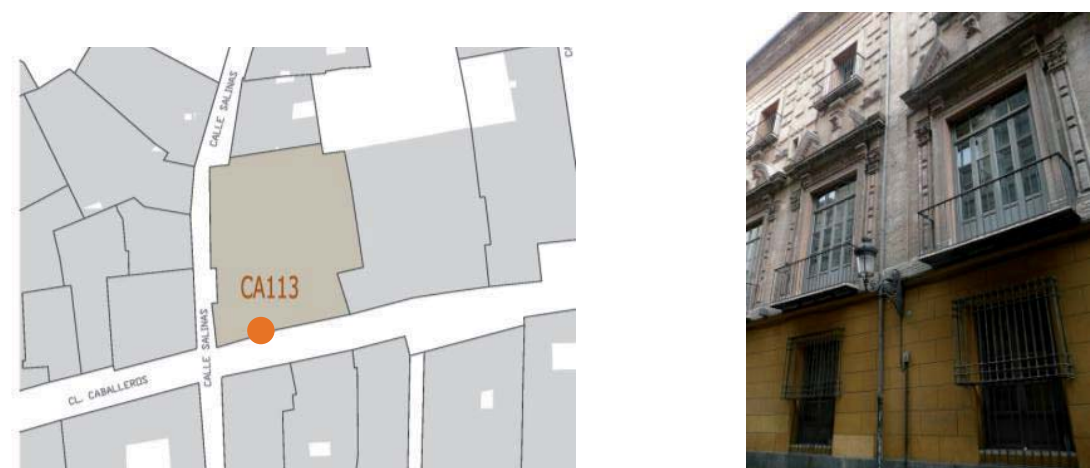

Fachada

Ca113

Pisos
Composición fachada
Zócalo
Fábrica
Vano/dintel
Entrada/dintel
Alero
Cubierta

\begin{tabular}{|c|c|c|c|c|c|c|c|c|c|}
\hline \multirow{2}{*}{\multicolumn{2}{|c|}{$\begin{array}{l}\mathrm{N}^{0} 2 \\
\text { aleatoria }\end{array}$}} & sótano & & planta & \multicolumn{5}{|c|}{ piso noble caja escalera } \\
\hline & & \multicolumn{3}{|c|}{ ordenada sin simetría } & \multicolumn{5}{|c|}{ ordenada con simetría } \\
\hline $\mathrm{Z1}$ & $\mathrm{Z} 2$ & Z3 & Z4 & $\mathrm{Z} 5$ & & & & & \\
\hline F1 & F2 & F3 & F4 & F5 & F6 & F7 & & & \\
\hline V1 & V2 & V3 & V4 & V5 & V6 & V7 & V8 & V9 & V10 \\
\hline E1 & E2 & E3 & E4 & & & & & & \\
\hline A1 & A2 & A3 & A4 & A5 & A6 & A7 & & & \\
\hline pla & & inclinac & & & & & & & \\
\hline
\end{tabular}

\section{Fábrica}

\section{Ca113}

Aparejo
Hiladas
Superficie
Sección (hipótesis)
Elementos destacados

soga-tizón

irregulares

sin planeidad

uniforme

aplantillado soga

pseudo horizontales

horizontales pseudo planeidad

planeidad perfecta hojas y núcleo

cortado abocinada (vano) 


\begin{tabular}{|c|c|c|c|}
\hline \multirow{2}{*}{$\begin{array}{l}\mathrm{N}^{\circ} \text { elementos medidos } \\
\text { Longitud }(\mathrm{cm})\end{array}$} & \multicolumn{3}{|l|}{15} \\
\hline & \multicolumn{3}{|l|}{31} \\
\hline Anchura (cm) & \multicolumn{3}{|l|}{13.6} \\
\hline Espesor (cm) & \multicolumn{3}{|l|}{4.2} \\
\hline Volumen $\left(\mathrm{cm}^{3}\right)$ & \multicolumn{3}{|l|}{1170.72} \\
\hline Tipo & homogéneo & heterogéneo & re-empleo \\
\hline \multirow{4}{*}{$\begin{array}{l}\text { Color } \\
\text { Recogida de muestra } \\
\text { Patologías }\end{array}$} & homogéneo & heterogéneo globular & heterogéneo marmolado \\
\hline & no & si & código \\
\hline & eflorescencias & micro fisuración & grietas \\
\hline & erosión & disgregación & descamación \\
\hline
\end{tabular}

1 Datos obtenidos en base al cálculo del desvío estándar (respecto al valor medio de la muestras analizadas) y del gráfico de frecuencia de las muestras analizadas, identificado por una curva gaussiana

\section{untas}

Ca113

\begin{tabular}{|c|c|c|c|c|}
\hline$N^{\circ}$ elementos medidos & 15 & & & \\
\hline Llaga $(\mathrm{cm})$ & 2 & & & \\
\hline Tendel (cm) & 4.1 & & & \\
\hline Altura de 5 hiladas (cm) & 95 & & & \\
\hline Proporción ladrillo/junta & 1.02 & & & \\
\hline Tipo de acabado & simple & doble & múltiple & \\
\hline Junta de asiento & rehundida & a hueso & saliente & \\
\hline & enrasada & matada & & \\
\hline Junta de acabado & rehundida & a hueso & saliente & \\
\hline & enrasada & matada & & \\
\hline Tipo de mortero & cal & cal y tierra & tierra & cemento mixto \\
\hline Morfología de mortero & con grumos & con caliches & homogéneo & heterogéneo \\
\hline Tipo de árido & arena & gravilla & grava & mixto \\
\hline Color del árido & claro & oscuro & homogéneo & heterogéneo \\
\hline Recogida de muestra & no & si & código & \\
\hline Patologías & eflorescencias & micro fisuración & grietas & \\
\hline & erosión & disgregación & pulverización & \\
\hline
\end{tabular}


Imágenes

Ca113
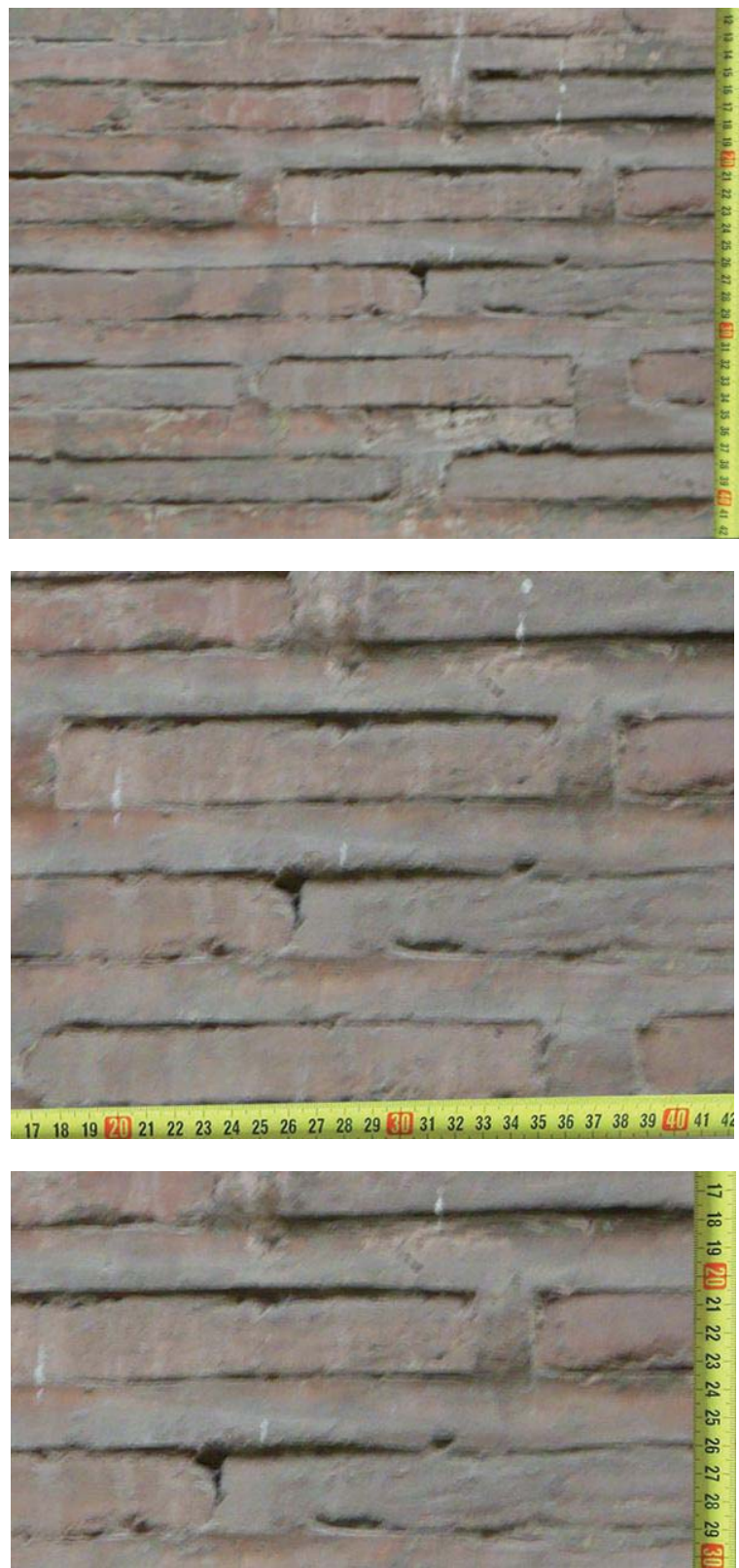
Imágenes

Ca113
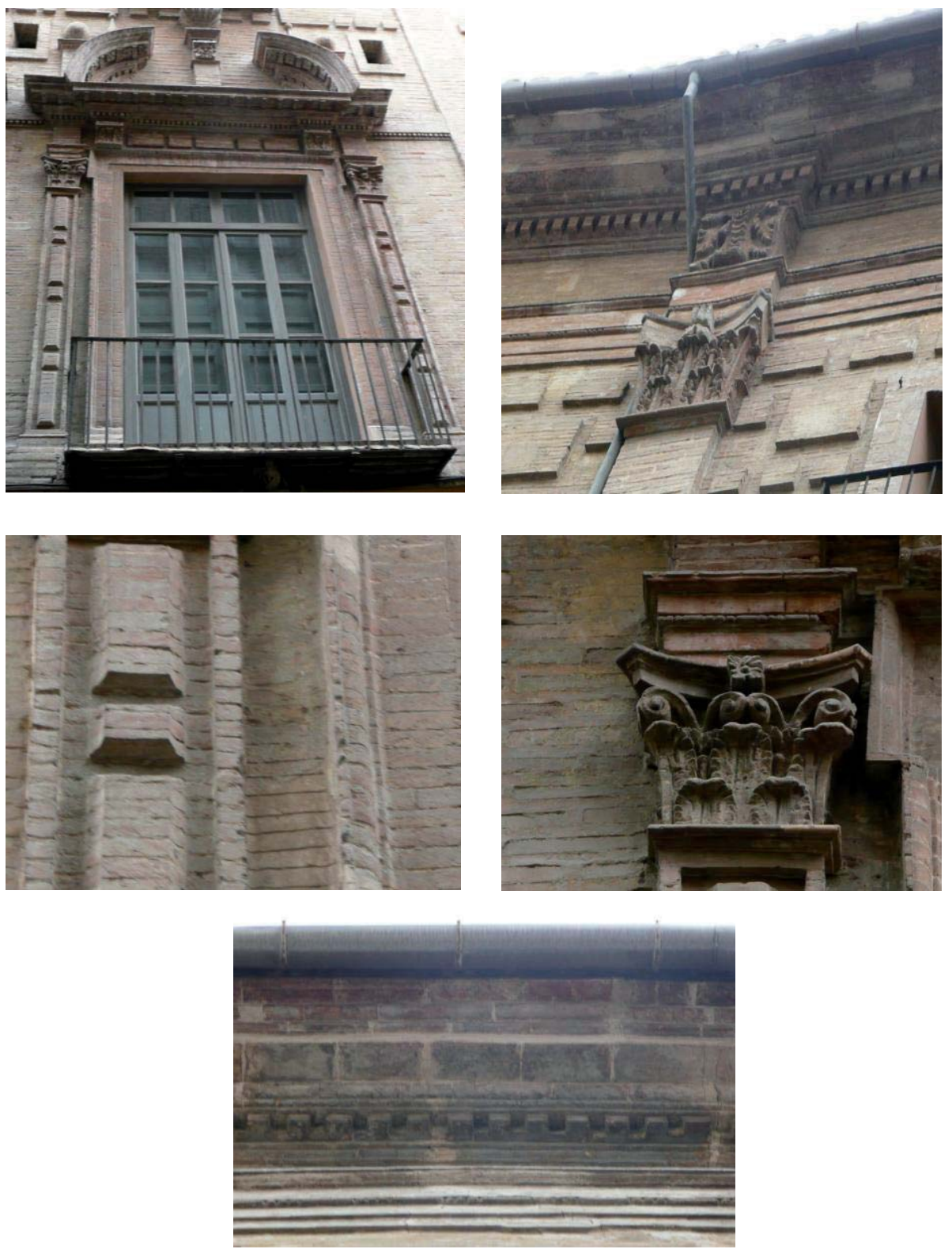
Datos generales

\begin{tabular}{|c|c|c|c|c|}
\hline Barrio & Carmen & La Seu-Xerea & Velluters & Mercat S.Francesc \\
\hline Dirección & \multicolumn{4}{|c|}{ C/Caballeros nº40 } \\
\hline Tipo de edificio & residencial & palaciego & religioso & militar \\
\hline G$^{\circ}$ de protección & 0 & 1 & 2 & 3 \\
\hline Fechas claves & \multicolumn{4}{|c|}{ Fundación 1865 ( Monmeneu Escrig), reforma 1993-95 ( Martí-Vidad) } \\
\hline
\end{tabular}
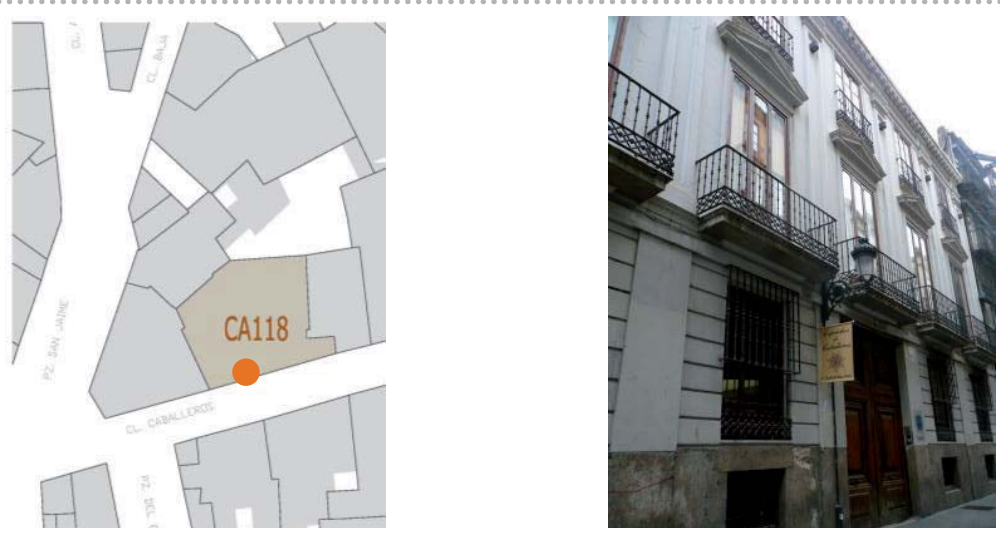

Fachada

Pisos

Composición fachada

Zócalo

Fábrica

Vano/dintel

Entrada/dintel

Alero

Cubierta

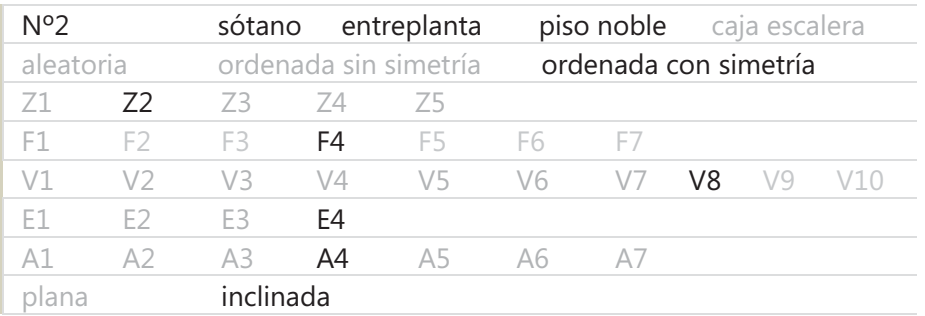

\section{Fábrica}

Ca118

\section{Aparejo \\ Hiladas \\ Superficie \\ Sección (hipótesis) \\ Elementos destacados}

\begin{tabular}{lll} 
soga-tizón & soga & \\
irregulares & pseudo horizontales & horizontales \\
\hline sin planeidad & pseudo planeidad & planeidad perfecta \\
\hline uniforme & hojas y núcleo & abocinada (vano) \\
aplantillado & cortado terracota & \\
\hline
\end{tabular}




\begin{tabular}{|c|c|c|c|}
\hline \multirow{2}{*}{$\begin{array}{l}\mathrm{N}^{\circ} \text { elementos medidos } \\
\text { Longitud }(\mathrm{cm})\end{array}$} & \multicolumn{3}{|l|}{15} \\
\hline & \multicolumn{3}{|l|}{27.5} \\
\hline Anchura (cm) & \multicolumn{3}{|l|}{13.2} \\
\hline Espesor $(\mathrm{cm})$ & \multicolumn{3}{|l|}{4.3} \\
\hline Volumen $\left(\mathrm{cm}^{3}\right)$ & \multicolumn{3}{|l|}{1270.5} \\
\hline Tipo & homogéneo & heterogéneo & re-empleo \\
\hline \multirow{4}{*}{$\begin{array}{l}\text { Color } \\
\text { Recogida de muestra } \\
\text { Patologías }\end{array}$} & homogéneo & heterogéneo globular & heterogéneo marmolado \\
\hline & no & sí & código \\
\hline & eflorescencias & micro fisuración & grietas \\
\hline & erosión & disgregación & descamación \\
\hline
\end{tabular}

${ }^{1}$ Datos obtenidos en base al cálculo del desvío estándar (respecto al valor medio de la muestras analizadas) y del gráfico de frecuencia de las muestras analizadas, identificado por una curva gaussiana

\section{untas}

\begin{tabular}{|c|c|c|c|c|}
\hline \multirow{2}{*}{$\begin{array}{l}N^{\circ} \text { elementos medidos } \\
\text { Llaga }(\mathrm{cm})\end{array}$} & \multicolumn{4}{|l|}{15} \\
\hline & \multicolumn{4}{|l|}{0.9} \\
\hline Tendel (cm) & \multicolumn{4}{|l|}{1.3} \\
\hline Altura de 5 hiladas $(\mathrm{cm})$ & \multicolumn{4}{|l|}{29} \\
\hline Proporción ladrillo/junta & \multicolumn{4}{|l|}{2.3} \\
\hline Tipo de acabado & simple & doble & \multicolumn{2}{|l|}{ múltiple } \\
\hline \multirow[t]{2}{*}{ Junta de asiento } & rehundida & a hueso & \multirow[t]{2}{*}{ saliente } & \\
\hline & enrasada & matada & & \\
\hline \multirow[t]{2}{*}{ Junta de acabado } & rehundida & a hueso & \multirow[t]{2}{*}{ saliente } & \\
\hline & enrasada & matada & & \\
\hline \multirow{2}{*}{$\begin{array}{l}\text { Tipo de mortero } \\
\text { Morfología de mortero }\end{array}$} & cal & cal y tierra & tierra & cemento mixto \\
\hline & con grumos & con caliches & homogéneo & heterogéneo \\
\hline \multirow{5}{*}{$\begin{array}{l}\text { Tipo de árido } \\
\text { Color del árido } \\
\text { Recogida de muestra } \\
\text { Patologías }\end{array}$} & arena & gravilla & grava & mixto \\
\hline & claro & oscuro & homogéneo & heterogéneo \\
\hline & no & sí & \multicolumn{2}{|l|}{ código } \\
\hline & eflorescencias & micro fisuración & \multicolumn{2}{|l|}{ grietas } \\
\hline & erosión & disgregación & \multicolumn{2}{|l|}{ pulverización } \\
\hline
\end{tabular}


Imágenes
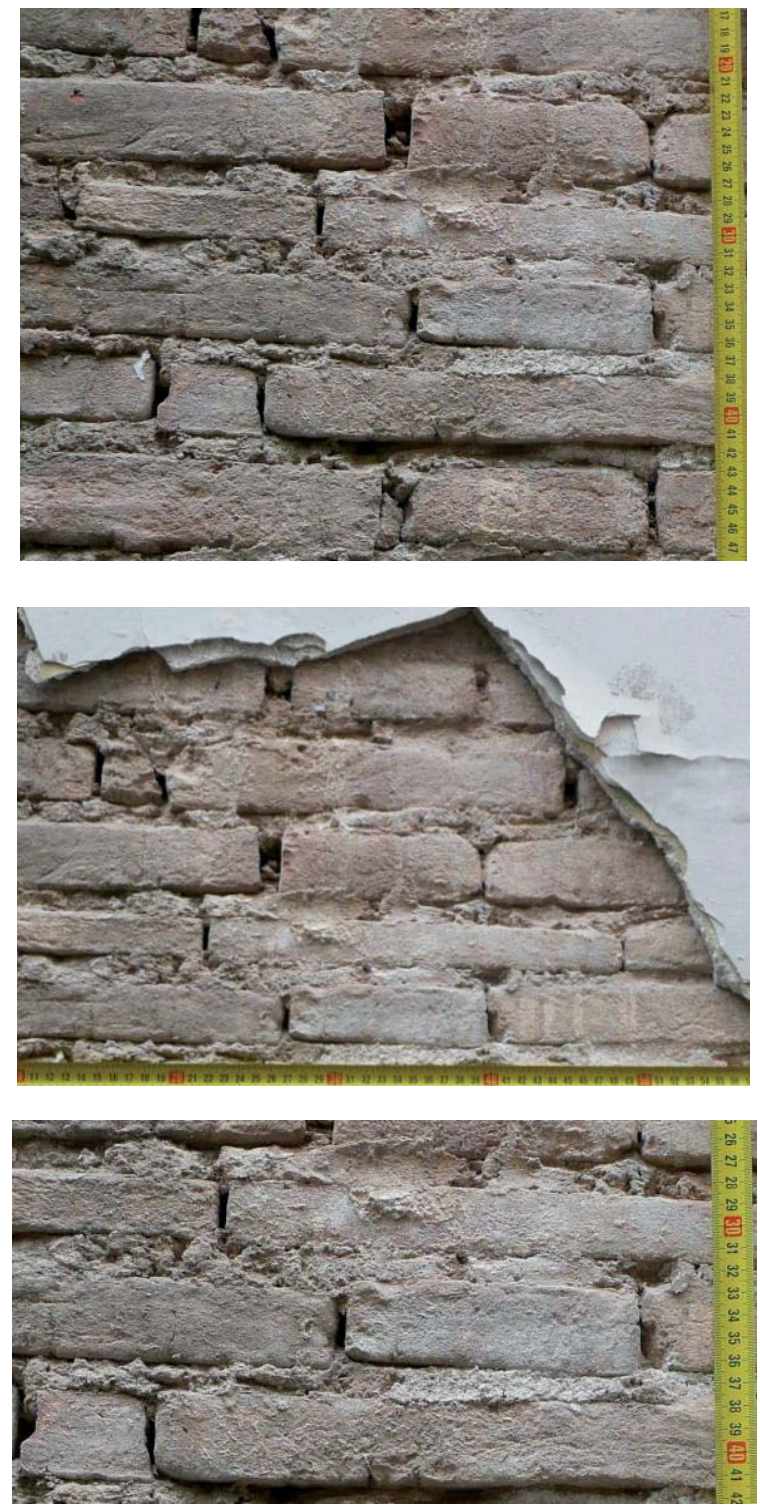
Imágenes

Ca118
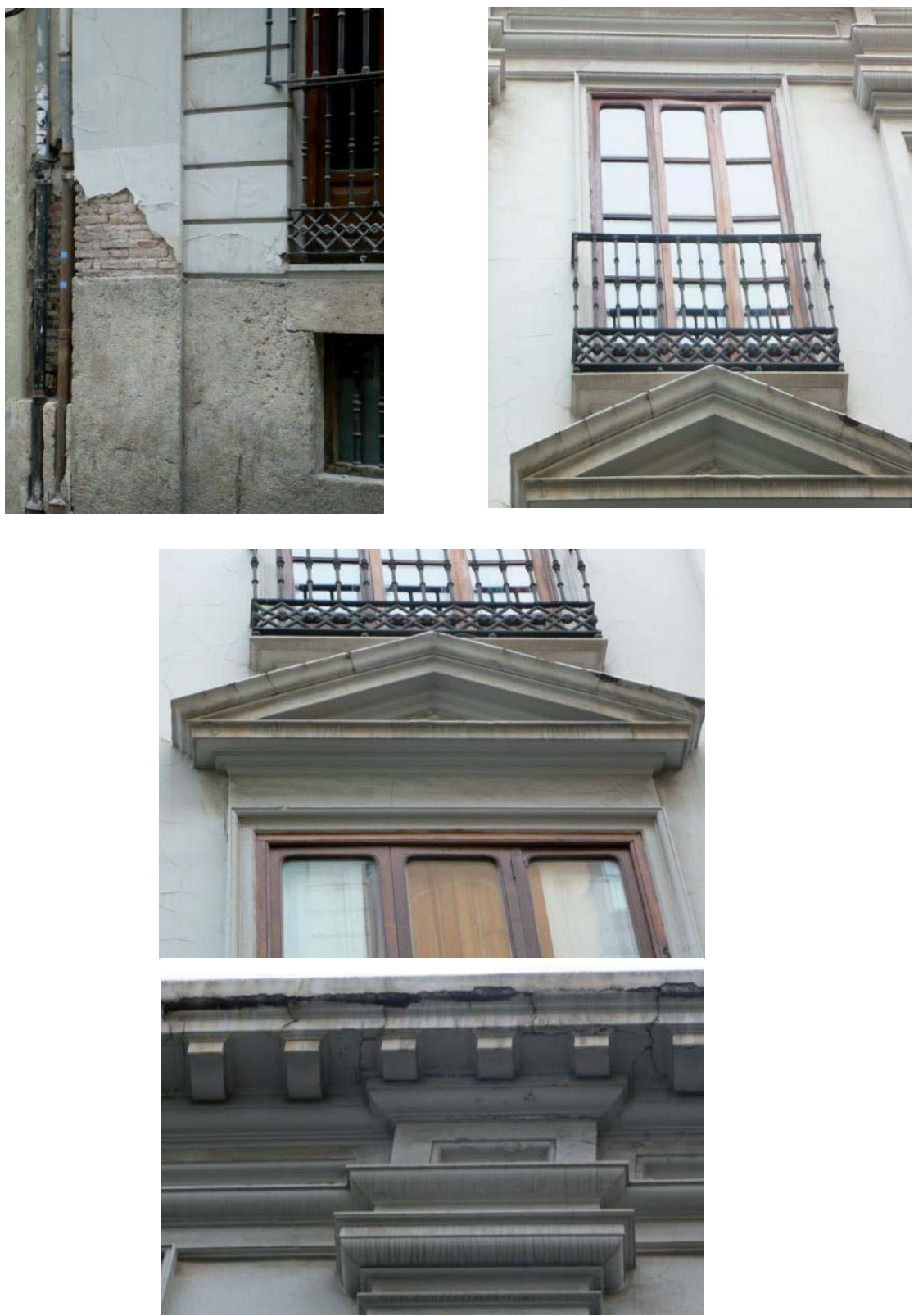
Datos generales

Cb55

\begin{tabular}{|c|c|c|c|c|c|}
\hline Barrio & Carmen & La Seu-Xerea & Velluters & Mercat & S.Francesc \\
\hline Dirección & C/Quart $n^{\circ} 1$ & & & & \\
\hline Tipo de edificio & residencial & palaciego & religioso & militar & \\
\hline $\mathbf{G}^{\circ}$ de protección & 0 & 1 & 2 & 3 & \\
\hline Fechas claves & / & & & & \\
\hline
\end{tabular}

El apartado "fechas claves" se ha extraído de AA.V.., Guía de Arquitectura de Valencia, Icaro CTAV Ed., Valencia, 2007
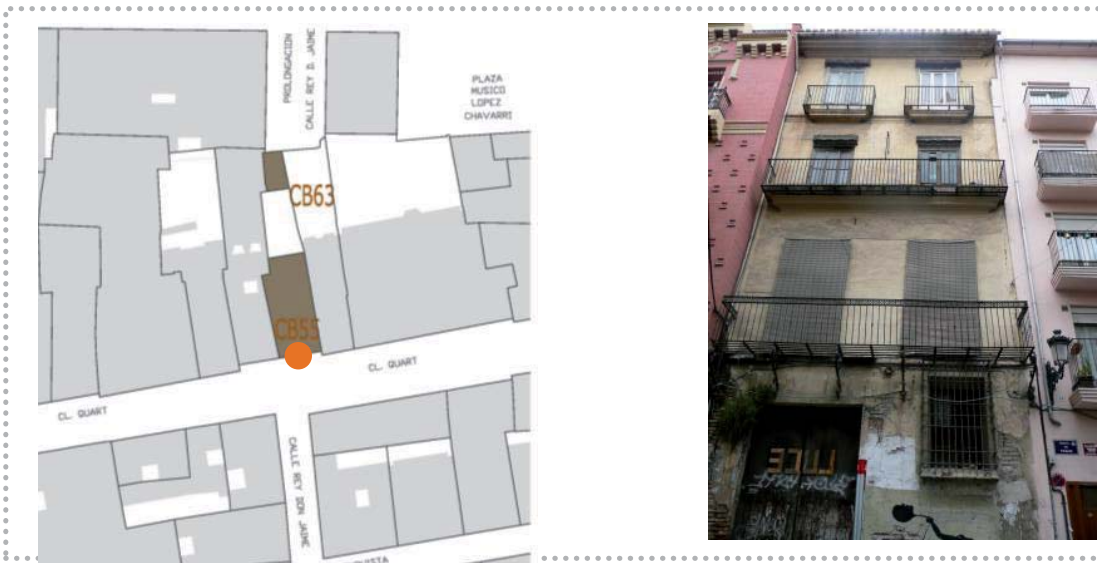

Fachada

Cb55

Pisos

Composición fachada

Zócalo

Fábrica

Vano/dintel

Entrada/dintel

Alero

Cubierta

\begin{tabular}{|c|c|c|c|c|c|c|c|c|}
\hline \multirow{2}{*}{\multicolumn{2}{|c|}{$\frac{\mathrm{N} 03}{\text { aleatoria }}$}} & \multirow{2}{*}{\multicolumn{3}{|c|}{$\begin{array}{l}\text { sótano entreplanta } \\
\text { ordenada sin simetría }\end{array}$}} & \multicolumn{4}{|c|}{ piso noble caja escalera } \\
\hline & & & & & \multicolumn{4}{|c|}{ ordenada con simetría } \\
\hline Z1 & $\mathrm{Z2}$ & $\mathrm{Z3}$ & Z4 & $\mathrm{Z5}$ & & & & \\
\hline $\mathrm{F} 1$ & $\mathrm{~F} 2$ & F3 & F4 & F5 & F6 & & & \\
\hline V1 & V2 & V3 & V4 & V5 & V6 & V8 & V9 & V10 \\
\hline E1 & E2 & E3 & E4 & & & & & \\
\hline A1 & $A 2$ & $\mathrm{~A} 3$ & A4 & A5 & A6 & & & \\
\hline \multicolumn{2}{|c|}{ plana } & \multicolumn{3}{|c|}{ inclinada } & & & & \\
\hline
\end{tabular}

\section{Fábrica}

Cb55

\section{Aparejo \\ Hiladas \\ Superficie \\ Sección (hipótesis) \\ Elementos destacados}

\begin{tabular}{lll} 
soga-tizón & soga & \\
irregulares & pseudo horizontales & horizontales \\
\hline sin planeidad & pseudo planeidad & planeidad perfecta \\
\hline uniforme & hojas y núcleo & abocinada (vano) \\
aplantillado & cortado terracota & \\
\hline
\end{tabular}




\begin{tabular}{|c|c|c|c|}
\hline$N^{\circ}$ elementos medidos & 15 & & \\
\hline Longitud (cm) & 30.1 & & \\
\hline Anchura (cm) & 14.1 & & \\
\hline Espesor (cm) & 3.5 & & \\
\hline Volumen $\left(\mathrm{cm}^{3}\right)$ & 1485.4 & & \\
\hline Tipo & homogéneo & heterogéneo & re-empleo \\
\hline Color & homogéneo & heterogéneo globular & heterogéneo marmolado \\
\hline Recogida de muestra & no & sí & código Cb55/1 \\
\hline Patologías & $\begin{array}{l}\text { eflorescencias } \\
\text { erosión }\end{array}$ & $\begin{array}{l}\text { micro fisuración } \\
\text { disgregación }\end{array}$ & $\begin{array}{l}\text { grietas } \\
\text { descamación }\end{array}$ \\
\hline
\end{tabular}

${ }^{1}$ Datos obtenidos en base al cálculo del desvío estándar (respecto al valor medio de la muestras analizadas) y del gráfico de frecuencia de las muestras analizadas, identificado por una curva gaussiana

\section{Juntas}

\begin{tabular}{|c|c|c|c|c|}
\hline \multirow{2}{*}{$\begin{array}{l}N^{\circ} \text { elementos medidos } \\
\text { Llaga }(\mathrm{cm})\end{array}$} & \multicolumn{4}{|l|}{15} \\
\hline & \multicolumn{4}{|l|}{1} \\
\hline Tendel (cm) & \multicolumn{4}{|l|}{3.5} \\
\hline Altura de 5 hiladas $(\mathrm{cm})$ & \multicolumn{4}{|l|}{40} \\
\hline Proporción ladrillo/junta & \multicolumn{4}{|l|}{1} \\
\hline Tipo de acabado & simple & doble & múltiple & \\
\hline \multirow[t]{2}{*}{ Junta de asiento } & rehundida & a hueso & \multirow{2}{*}{\multicolumn{2}{|c|}{ saliente }} \\
\hline & enrasada & matada & & \\
\hline \multirow[t]{2}{*}{ Junta de acabado } & rehundida & a hueso & \multirow{2}{*}{\multicolumn{2}{|c|}{ saliente }} \\
\hline & enrasada & matada & & \\
\hline \multirow{2}{*}{$\begin{array}{l}\text { Tipo de mortero } \\
\text { Morfología de mortero }\end{array}$} & cal & cal y tierra & tierra & cemento mixto \\
\hline & con grumos & con caliches & homogéneo & heterogéneo \\
\hline Tipo de árido & arena & gravilla & grava & mixto \\
\hline Color del árido & claro & oscuro & homogéneo & heterogéneo \\
\hline Recogida de muestra & no & sí & \multicolumn{2}{|l|}{ código Cb55/2 } \\
\hline \multirow[t]{2}{*}{ Patologías } & eflorescencias & micro fisuración & \multicolumn{2}{|l|}{ grietas } \\
\hline & erosión & disgregación & \multicolumn{2}{|l|}{ pulverización } \\
\hline
\end{tabular}


Imágenes

Cb55
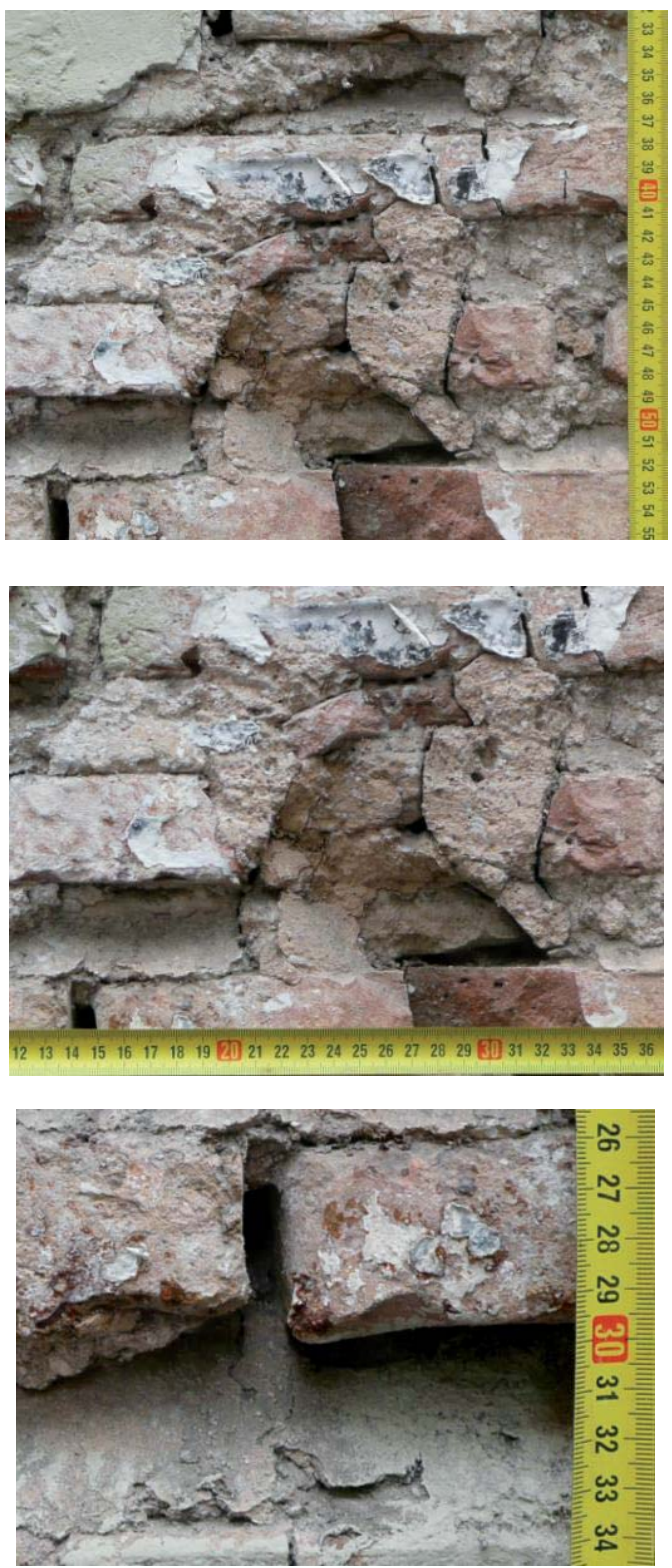
Imágenes

Cb55
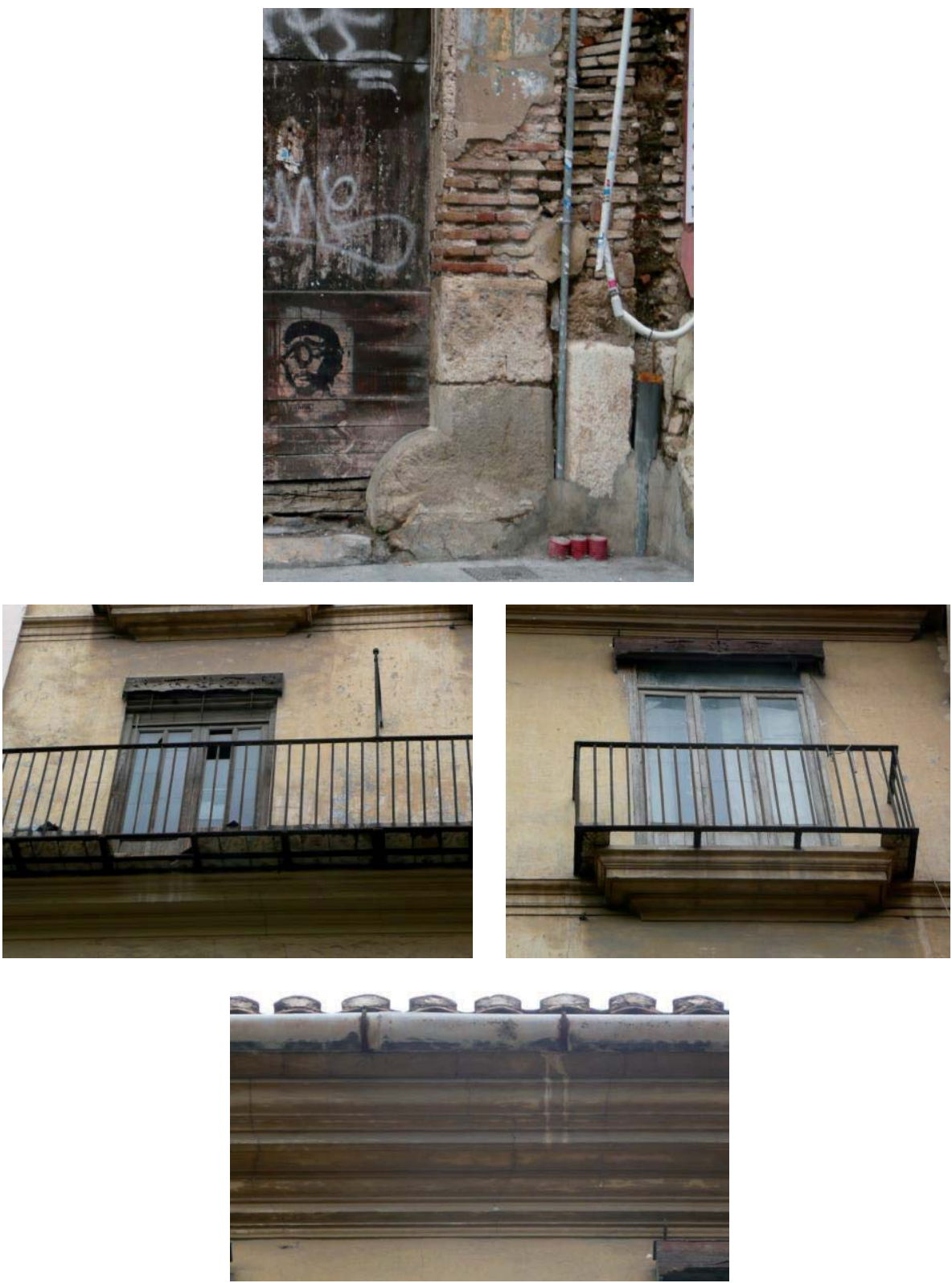
Datos generales

Cb63

\begin{tabular}{|c|c|c|c|c|c|}
\hline Barrio & Carmen & La Seu-Xerea & Velluters & Mercat & S.Francesc \\
\hline Dirección & \multicolumn{5}{|c|}{ C/Quart n¹6 (trasero) Carrer Rey en Jaume s/n } \\
\hline Tipo de edificio & residencial & palaciego & religioso & militar & \\
\hline $\mathbf{G}^{\circ}$ de protección & 0 & 1 & 2 & 3 & \\
\hline Fechas claves & / & & & & \\
\hline
\end{tabular}

El apartado "fechas claves" se ha extraído de AA.V.., Guía de Arquitectura de Valencia, Icaro CTAV Ed., Valencia, 2007
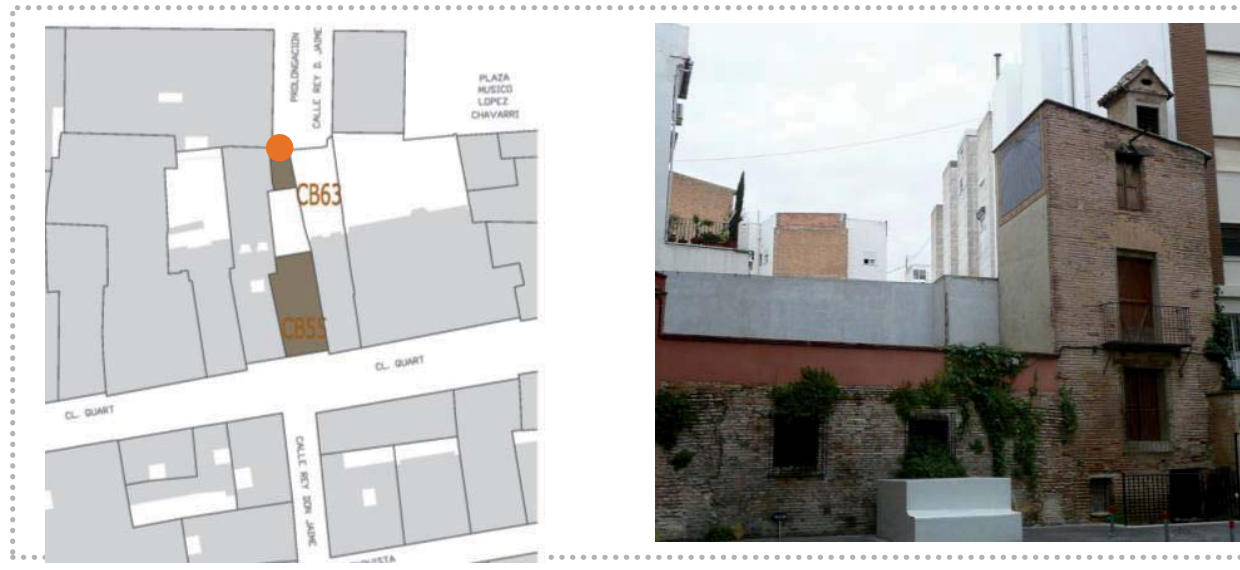

Fachada

Cb63

Pisos
Composición fachada
Zócalo
Fábrica
Vano/dintel
Entrada/dintel
Alero
Cubierta

\begin{tabular}{|c|c|c|c|c|c|c|c|}
\hline \multirow{2}{*}{\multicolumn{2}{|c|}{$\begin{array}{l}\mathrm{N}^{03} \\
\text { aleatoria }\end{array}$}} & sótano & entreplanta & piso noble & $\mathrm{Ca}$ & a esca & \\
\hline & & \multicolumn{2}{|c|}{ ordenada sin simetría } & \multicolumn{4}{|c|}{ ordenada con simetría } \\
\hline Z1 & Z2 & Z3 & Z5 & & & & \\
\hline F1 & F2 & F3 & F5 & F6 & & & \\
\hline V1 & V2 & V3 & V5 & V6 & V8 & V9 & V10 \\
\hline E1 & E2 & E3 & E4 & & & & \\
\hline A1 & A2 & A3 & A5 & A6 & & & \\
\hline \multicolumn{2}{|c|}{ plana } & \multicolumn{2}{|c|}{ inclinada } & & & & \\
\hline
\end{tabular}

\section{Fábrica}

Cb63

\section{Aparejo \\ Hiladas \\ Superficie \\ Sección (hipótesis) \\ Elementos destacados}

\begin{tabular}{lll} 
soga-tizón & soga & \multicolumn{1}{c}{ tizón } \\
irregulares & pseudo horizontales & horizontales \\
\hline sin planeidad & pseudo planeidad & planeidad perfecta \\
\hline uniforme & hojas y núcleo & abocinada (vano) \\
aplantillado & cortado terracota & \\
\hline
\end{tabular}




\begin{tabular}{|c|c|c|c|}
\hline $\mathrm{N}^{\circ}$ elementos medidos & 15 & & \\
\hline Longitud (cm) & 30.5 & & \\
\hline Anchura $(\mathrm{cm})$ & 14.1 & & \\
\hline Espesor (cm) & 3.3 & & \\
\hline Volumen $\left(\mathrm{cm}^{3}\right)$ & 1419.1 & & \\
\hline Tipo & homogéneo & heterogéneo & re-empleo \\
\hline Color & homogéneo & heterogéneo globular & heterogéneo marmolado \\
\hline Recogida de muestra & no & sí & código $\mathrm{Cb} 63 / 1$ \\
\hline Patologías & $\begin{array}{l}\text { eflorescencias } \\
\text { erosión }\end{array}$ & $\begin{array}{l}\text { micro fisuración } \\
\text { disgregación }\end{array}$ & $\begin{array}{l}\text { grietas } \\
\text { descamación }\end{array}$ \\
\hline
\end{tabular}

${ }^{1}$ Datos obtenidos en base al cálculo del desvío estándar (respecto al valor medio de la muestras analizadas) y del gráfico de frecuencia de las muestras analizadas, identificado por una curva gaussiana

\section{Juntas}

\begin{tabular}{|c|c|c|c|c|}
\hline \multirow{2}{*}{$\begin{array}{l}N^{\circ} \text { elementos medidos } \\
\text { Llaga }(\mathrm{cm})\end{array}$} & \multicolumn{4}{|l|}{15} \\
\hline & \multicolumn{4}{|l|}{0.4} \\
\hline Tendel (cm) & \multicolumn{4}{|l|}{4.2} \\
\hline Altura de 5 hiladas $(\mathrm{cm})$ & \multicolumn{4}{|l|}{36.6} \\
\hline Proporción ladrillo/junta & \multicolumn{4}{|l|}{0.7} \\
\hline Tipo de acabado & simple & doble & \multicolumn{2}{|l|}{ múltiple } \\
\hline \multirow[t]{2}{*}{ Junta de asiento } & rehundida & a hueso & \multirow{2}{*}{\multicolumn{2}{|c|}{ saliente }} \\
\hline & enrasada & matada & & \\
\hline \multirow[t]{2}{*}{ Junta de acabado } & rehundida & a hueso & \multirow{2}{*}{\multicolumn{2}{|c|}{ saliente }} \\
\hline & enrasada & matada & & \\
\hline \multirow{3}{*}{$\begin{array}{l}\text { Tipo de mortero } \\
\text { Morfología de mortero } \\
\text { Tipo de árido }\end{array}$} & $\mathrm{cal}$ & cal y tierra & tierra & cemento mixto \\
\hline & con grumos & con caliches & homogéneo & heterogéneo \\
\hline & arena & gravilla & grava & mixto \\
\hline \multirow{4}{*}{$\begin{array}{l}\text { Color del árido } \\
\text { Recogida de muestra } \\
\text { Patologías }\end{array}$} & claro & oscuro & homogéneo & heterogéneo \\
\hline & no & sí & \multicolumn{2}{|l|}{ código Cb63/2 } \\
\hline & eflorescencias & micro fisuración & \multicolumn{2}{|l|}{ grietas } \\
\hline & erosión & disgregación & \multicolumn{2}{|l|}{ pulverización } \\
\hline
\end{tabular}


Imágenes

Cb63
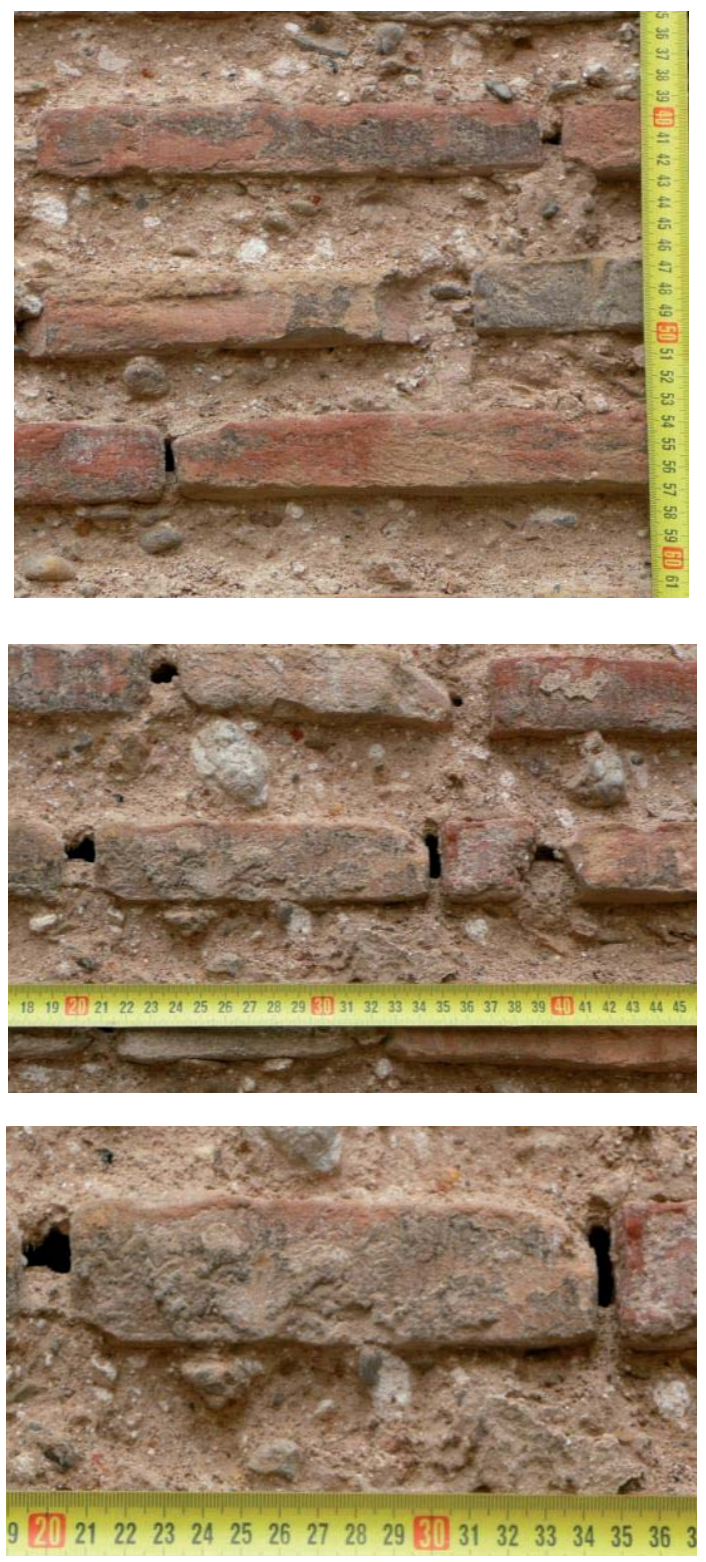
Imágenes

Cb63
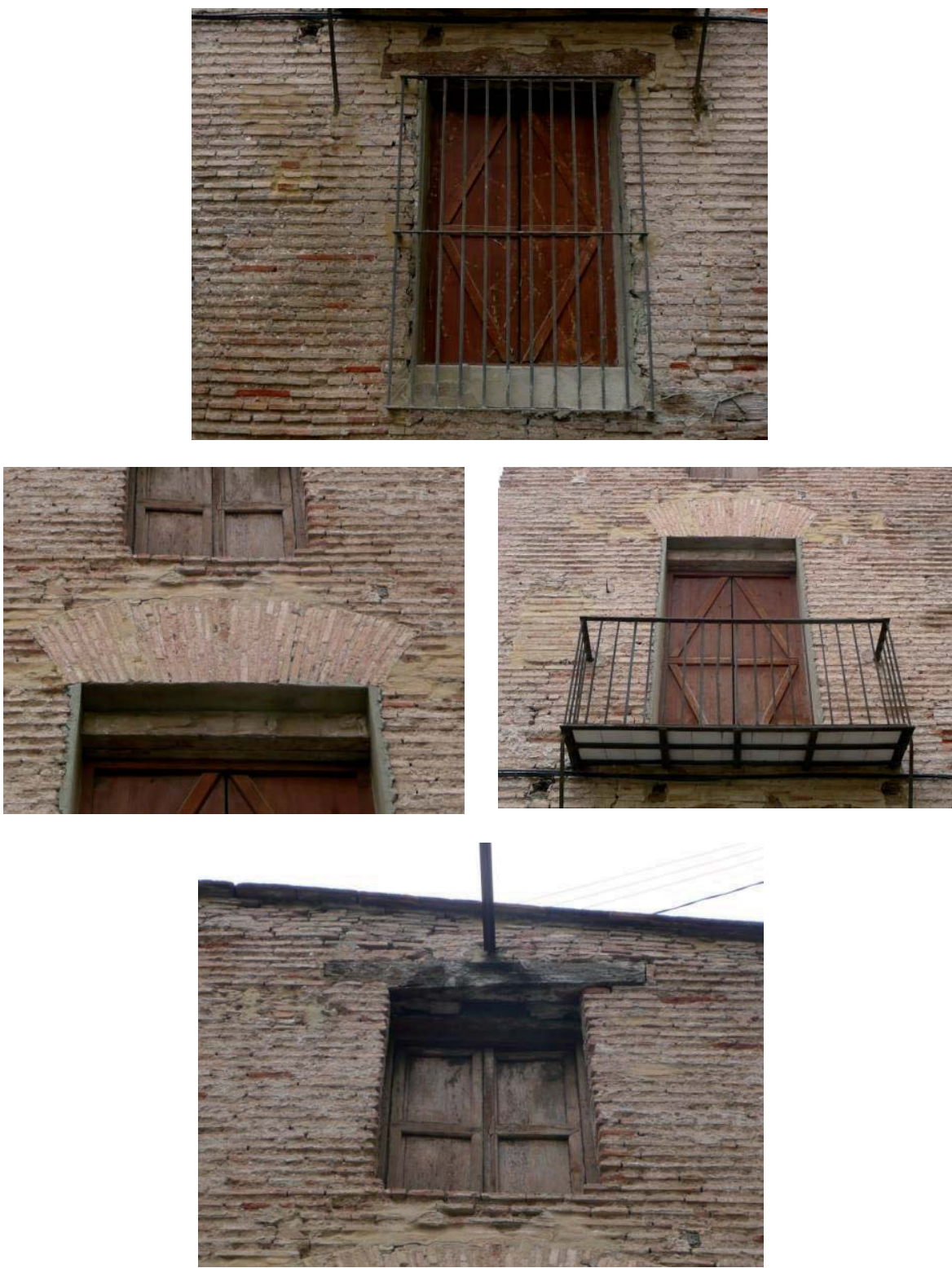
Datos generales

\begin{tabular}{|c|c|c|c|c|c|}
\hline Barrio & Carmen & La Seu-Xerea & Velluters & Mercat & S.Francesc \\
\hline Dirección & Pza. Sta. Uı & la $s / n$ & & & \\
\hline Tipo de edificio & residencial & palaciego & religioso & militar & \\
\hline $\mathbf{G}^{\circ}$ de protección & 0 & 1 & 2 & 3 & \\
\hline Fechas claves & $1605-1645$ & tervención1960 & Say Ramos) & & \\
\hline
\end{tabular}

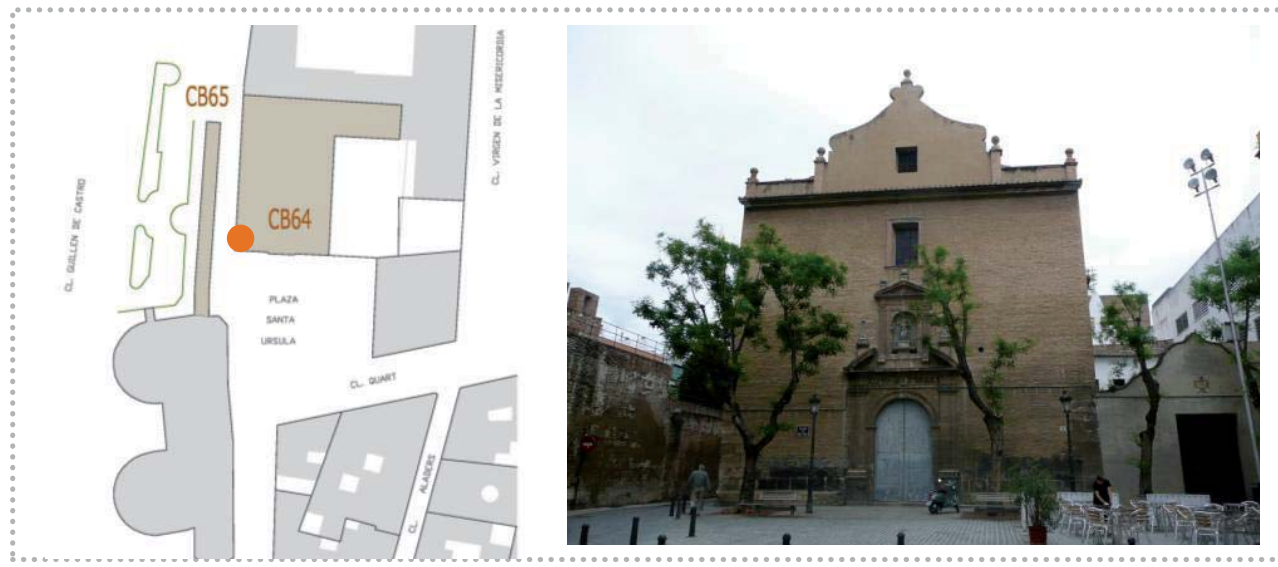

Fachada

Cb64

\begin{tabular}{|c|c|c|c|c|c|c|c|c|c|}
\hline \multirow{3}{*}{$\begin{array}{l}\text { Pisos } \\
\text { Composición fachada } \\
\text { Zócalo }\end{array}$} & \multicolumn{2}{|c|}{ No/ } & sótano & \multicolumn{2}{|c|}{ entreplanta } & \multicolumn{4}{|c|}{ piso noble caja escalera } \\
\hline & \multicolumn{2}{|c|}{ aleatoria } & \multicolumn{3}{|c|}{ ordenada sin simetría } & \multicolumn{4}{|c|}{ ordenada con simetría } \\
\hline & Z1 & $\mathrm{Z2}$ & Z3 & Z4 & Z5 & & & & \\
\hline Fábrica & $\mathrm{F} 1$ & $\mathrm{~F} 2$ & F3 & $\mathrm{F} 4$ & F5 & F6 & & & \\
\hline Vano/dintel & V1 & V2 & V3 & V4 & V5 & V7 & V8 & V9 & V10 \\
\hline Entrada/dintel & E1 & E2 & E3 & E4 & & & & & \\
\hline Alero & A1 & $\mathrm{A} 2$ & A3 & A4 & A5 & A7 & & & \\
\hline Cubierta & pla & & inclinac & & & & & & \\
\hline
\end{tabular}

\section{Fábrica}

Cb64

\begin{tabular}{|c|c|c|c|}
\hline Aparejo & soga-tizón & tizón & \\
\hline Hiladas & irregulares & pseudo horizontales & horizontales \\
\hline Superficie & sin planeidad & pseudo planeidad & planeidad perfecta \\
\hline Sección (hipótesis) & uniforme & hojas y núcleo & abocinada (vano) \\
\hline Elementos destacados & aplantillado & terracota & \\
\hline
\end{tabular}




\begin{tabular}{|c|c|c|c|}
\hline \multirow{2}{*}{$\begin{array}{l}\mathrm{N}^{\circ} \text { elementos medidos } \\
\text { Longitud }(\mathrm{cm})\end{array}$} & \multicolumn{3}{|l|}{15} \\
\hline & \multicolumn{3}{|l|}{30.2} \\
\hline Anchura (cm) & \multicolumn{3}{|l|}{13.5} \\
\hline Espesor (cm) & \multicolumn{3}{|l|}{3.2} \\
\hline Volumen $\left(\mathrm{cm}^{3}\right)$ & \multicolumn{3}{|l|}{1296} \\
\hline Tipo & homogéneo & heterogéneo & re-empleo \\
\hline \multirow{4}{*}{$\begin{array}{l}\text { Color } \\
\text { Recogida de muestra } \\
\text { Patologías }\end{array}$} & homogéneo & heterogéneo globular & heterogéneo marmolado \\
\hline & no & sí & código \\
\hline & eflorescencias & micro fisuración & grietas \\
\hline & erosión & disgregación & descamación \\
\hline
\end{tabular}

${ }^{1}$ Datos obtenidos en base al cálculo del desvío estándar (respecto al valor medio de la muestras analizadas) y del gráfico de frecuencia de las muestras analizadas, identificado por una curva gaussiana

\section{untas 2}

\begin{tabular}{|c|c|c|c|c|}
\hline \multirow{2}{*}{$\begin{array}{l}N^{\circ} \text { elementos medidos } \\
\text { Llaga }(\mathrm{cm})\end{array}$} & \multicolumn{4}{|l|}{15} \\
\hline & \multicolumn{4}{|l|}{0.7} \\
\hline Tendel (cm) & \multicolumn{4}{|l|}{5} \\
\hline Altura de 5 hiladas $(\mathrm{cm})$ & \multicolumn{4}{|l|}{41} \\
\hline Proporción ladrillo/junta & \multicolumn{4}{|l|}{1.5} \\
\hline Tipo de acabado & simple & doble & múltiple & \\
\hline \multirow[t]{2}{*}{ Junta de asiento } & rehundida & a hueso & saliente & \\
\hline & enrasada & matada & & \\
\hline \multirow[t]{2}{*}{ Junta de acabado } & rehundida & a hueso & saliente & \\
\hline & enrasada & matada & & \\
\hline \multirow{2}{*}{$\begin{array}{l}\text { Tipo de mortero } \\
\text { Morfología de mortero }\end{array}$} & cal & cal y tierra & tierra & cemento mixto \\
\hline & con grumos & con caliches & homogéneo & heterogéneo \\
\hline Tipo de árido & arena & gravilla & grava & mixto \\
\hline \multirow{4}{*}{$\begin{array}{l}\text { Color del árido } \\
\text { Recogida de muestra } \\
\text { Patologías }\end{array}$} & claro & oscuro & homogéneo & heterogéneo \\
\hline & no & sí & código & \\
\hline & eflorescencias & micro fisuración & grietas & \\
\hline & erosión & disgregación & pulverización & \\
\hline
\end{tabular}


Imágenes

Cb64
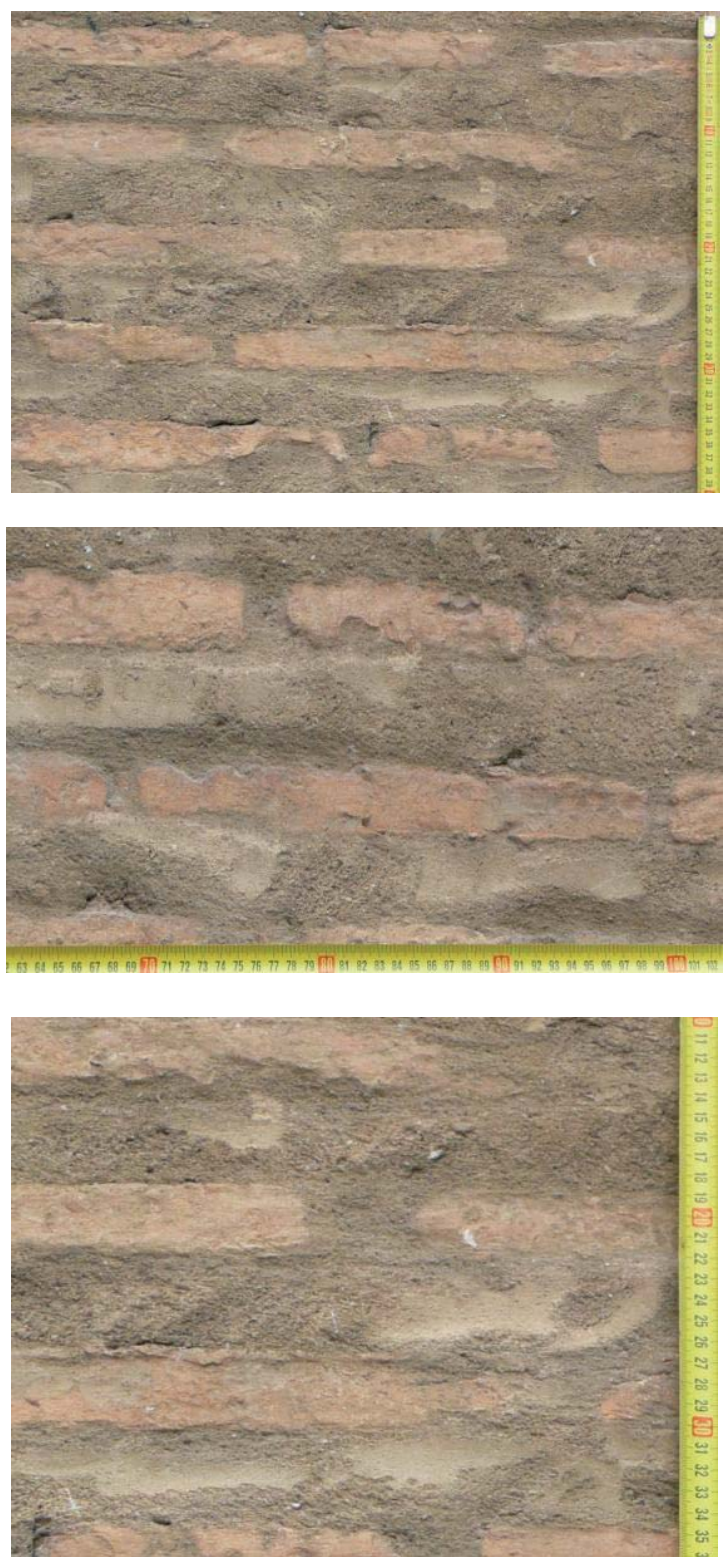

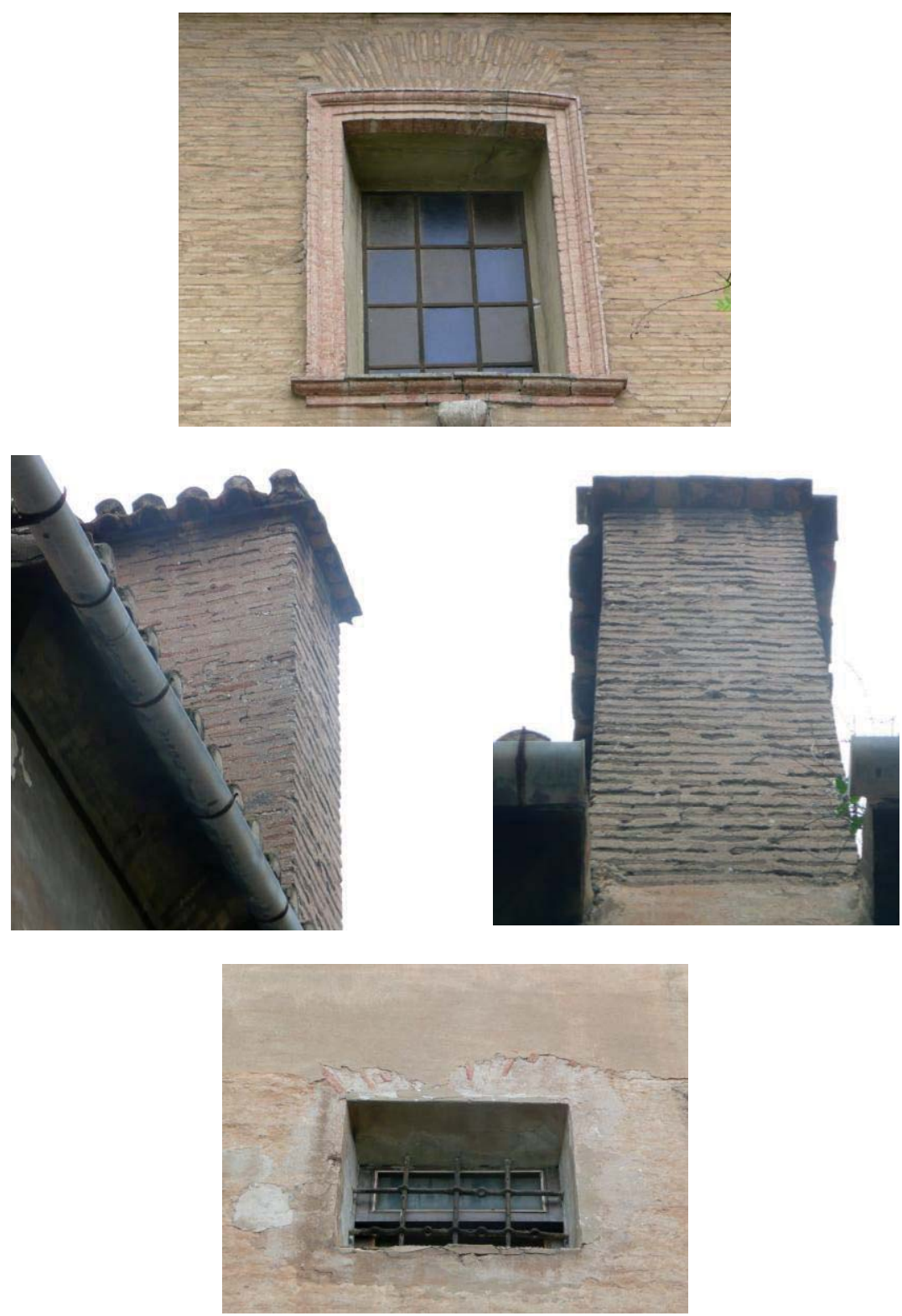
Datos generales

Cb65

\begin{tabular}{|c|c|c|c|c|}
\hline Barrio & Carmen & La Seu-Xerea & Velluters & Mercat S.Francesc \\
\hline Dirección & \multicolumn{4}{|c|}{ C/Guillén del Castillo s/n } \\
\hline Tipo de edificio & residencial & palaciego & religioso & militar \\
\hline $\mathbf{G}^{\circ}$ de protección & 0 & 1 & 2 & 3 \\
\hline Fechas claves & \multicolumn{4}{|c|}{ S. XIV, intervención 1980} \\
\hline
\end{tabular}

El apartado "fechas claves" se ha extraído de AA.V.., Guía de Arquitectura de Valencia, Icaro CTAV Ed, Valencia, 2007

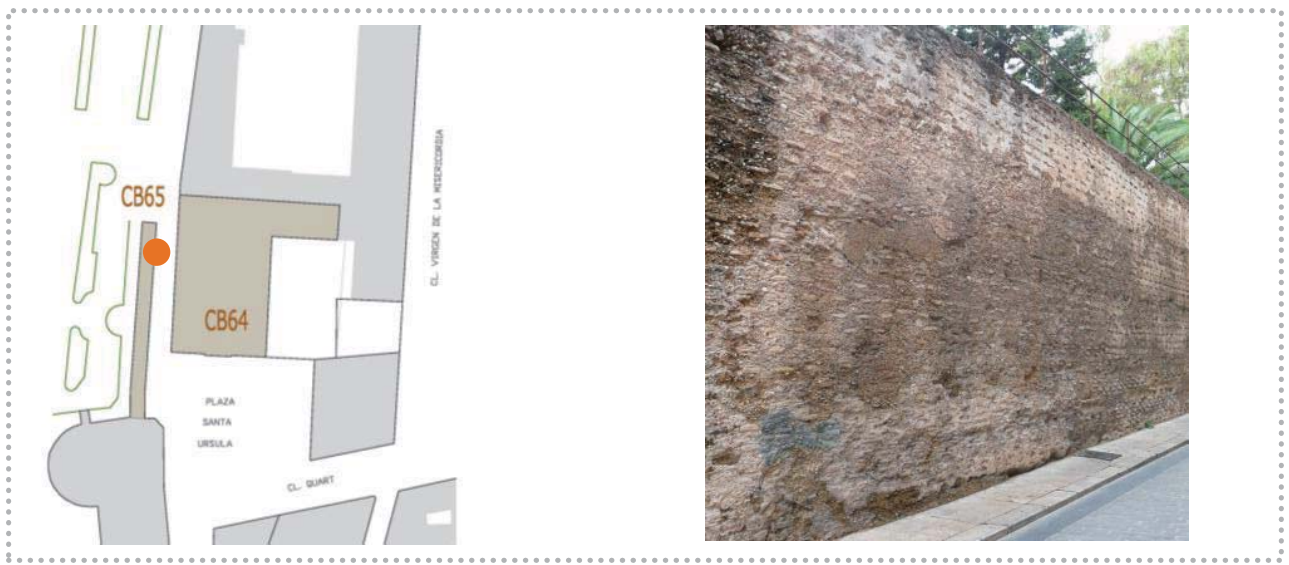

Fachada

Cb65

\begin{tabular}{|c|c|c|c|c|c|c|c|c|c|c|}
\hline \multirow{3}{*}{$\begin{array}{l}\text { Pisos } \\
\text { Composición fachada } \\
\text { Zócalo }\end{array}$} & \multicolumn{2}{|c|}{ No/ } & sótano & \multicolumn{2}{|c|}{ entreplanta } & \multicolumn{5}{|c|}{ piso noble caja escalera } \\
\hline & \multicolumn{2}{|c|}{ aleatoria } & \multicolumn{3}{|c|}{ ordenada sin simetría } & \multicolumn{5}{|c|}{ ordenada con simetría } \\
\hline & Z1 & $\mathrm{Z} 2$ & Z3 & Z4 & Z5 & & & & & \\
\hline Fábrica & $\mathrm{F} 1$ & $\mathrm{~F} 2$ & F3 & F4 & F5 & F6 & F7 & & & \\
\hline Vano/dintel & V1 & V2 & V3 & V4 & V5 & V6 & V7 & V8 & V9 & V10 \\
\hline Entrada/dintel & E1 & E2 & E3 & E4 & & & & & & \\
\hline Alero & A1 & $\mathrm{A} 2$ & A3 & A4 & A5 & A6 & A7 & & & \\
\hline Cubierta & plar & & inclinac & & & & & & & \\
\hline
\end{tabular}

Ver tablas relativas a los códigos indicados, al final de la recopilación de las fichas

Fábrica

Cb65

\begin{tabular}{l|lll} 
Aparejo & soga-tizón & soga & \multicolumn{2}{c}{ tizón } & \\
\hline Hiladas & irregulares & pseudo horizontales & horizontales \\
\hline Superficie & sin planeidad & pseudo planeidad & planeidad perfecta \\
\hline Sección (hipótesis) & uniforme & hojas y núcleo & abocinada (vano) \\
Elementos destacados & aplantillado & cortado terracota & \\
\hline
\end{tabular}




\begin{tabular}{|c|c|c|c|}
\hline \multirow{2}{*}{$\begin{array}{l}\mathrm{N}^{\circ} \text { elementos medidos } \\
\text { Longitud }(\mathrm{cm})\end{array}$} & \multicolumn{3}{|l|}{15} \\
\hline & \multicolumn{3}{|l|}{ / } \\
\hline Anchura $(\mathrm{cm})$ & \multicolumn{3}{|l|}{14.5} \\
\hline Espesor $(\mathrm{cm})$ & \multicolumn{3}{|l|}{3.5} \\
\hline Volumen $\left(\mathrm{cm}^{3}\right)$ & \multicolumn{3}{|l|}{ / } \\
\hline Tipo & homogéneo & heterogéneo & re-empleo \\
\hline Color & homogéneo & heterogéneo globular & heterogéneo marmolado \\
\hline Recogida de muestra & no & sí & código \\
\hline \multirow[t]{2}{*}{ Patologías } & eflorescencias & micro fisuración & grietas \\
\hline & erosión & disgregación & descamación \\
\hline
\end{tabular}

${ }^{1}$ Datos obtenidos en base al cálculo del desvío estándar (respecto al valor medio de la muestras analizadas) y del gráfico de frecuencia de las muestras analizadas, identificado por una curva gaussiana

\section{untas 2}

\begin{tabular}{|c|c|c|c|c|}
\hline \multirow{2}{*}{$\begin{array}{l}N^{\circ} \text { elementos medidos } \\
\text { Llaga }(\mathrm{cm})\end{array}$} & \multicolumn{4}{|l|}{15} \\
\hline & \multicolumn{4}{|l|}{13.1} \\
\hline Tendel (cm) & \multicolumn{4}{|l|}{10.2} \\
\hline Altura de 5 hiladas (cm) & \multicolumn{4}{|l|}{64} \\
\hline Proporción ladrillo/junta & \multicolumn{4}{|l|}{0.3} \\
\hline Tipo de acabado & simple & doble & \multicolumn{2}{|l|}{ múltiple } \\
\hline \multirow[t]{2}{*}{ Junta de asiento } & rehundida & a hueso & \multirow{2}{*}{\multicolumn{2}{|c|}{ saliente }} \\
\hline & enrasada & matada & & \\
\hline \multirow[t]{2}{*}{ Junta de acabado } & rehundida & a hueso & \multirow{2}{*}{\multicolumn{2}{|c|}{ saliente }} \\
\hline & enrasada & matada & & \\
\hline \multirow{3}{*}{$\begin{array}{l}\text { Tipo de mortero } \\
\text { Morfología de mortero } \\
\text { Tipo de árido }\end{array}$} & cal & cal y tierra & tierra & cemento mixto \\
\hline & con grumos & con caliches & homogéneo & heterogéneo \\
\hline & arena & gravilla & grava & mixto \\
\hline \multirow{4}{*}{$\begin{array}{l}\text { Color del árido } \\
\text { Recogida de muestra } \\
\text { Patologías }\end{array}$} & claro & oscuro & homogéneo & heterogéneo \\
\hline & no & sí & \multicolumn{2}{|l|}{ código } \\
\hline & eflorescencias & micro fisuración & \multicolumn{2}{|l|}{ grietas } \\
\hline & erosión & disgregación & \multicolumn{2}{|l|}{ pulverización } \\
\hline
\end{tabular}


Imágenes

Cb65
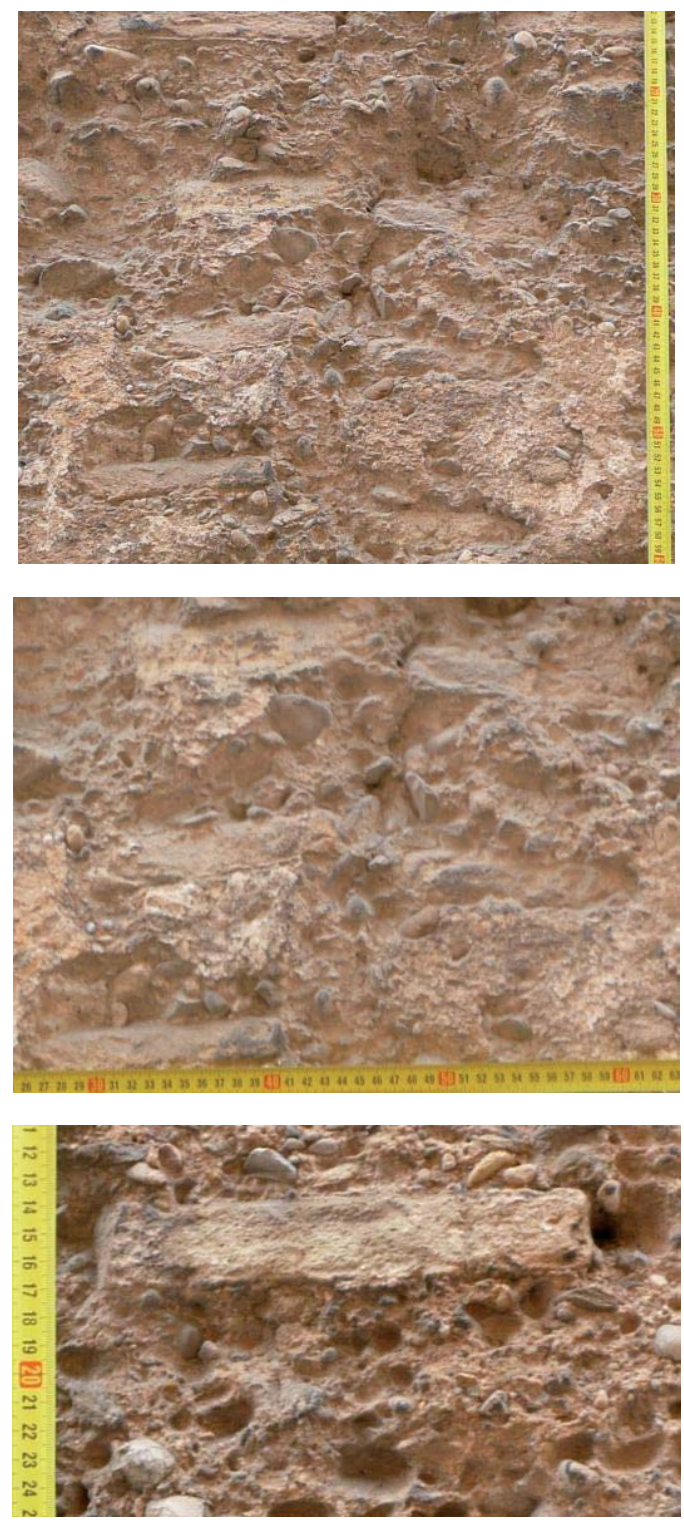
Imágenes

Cb65
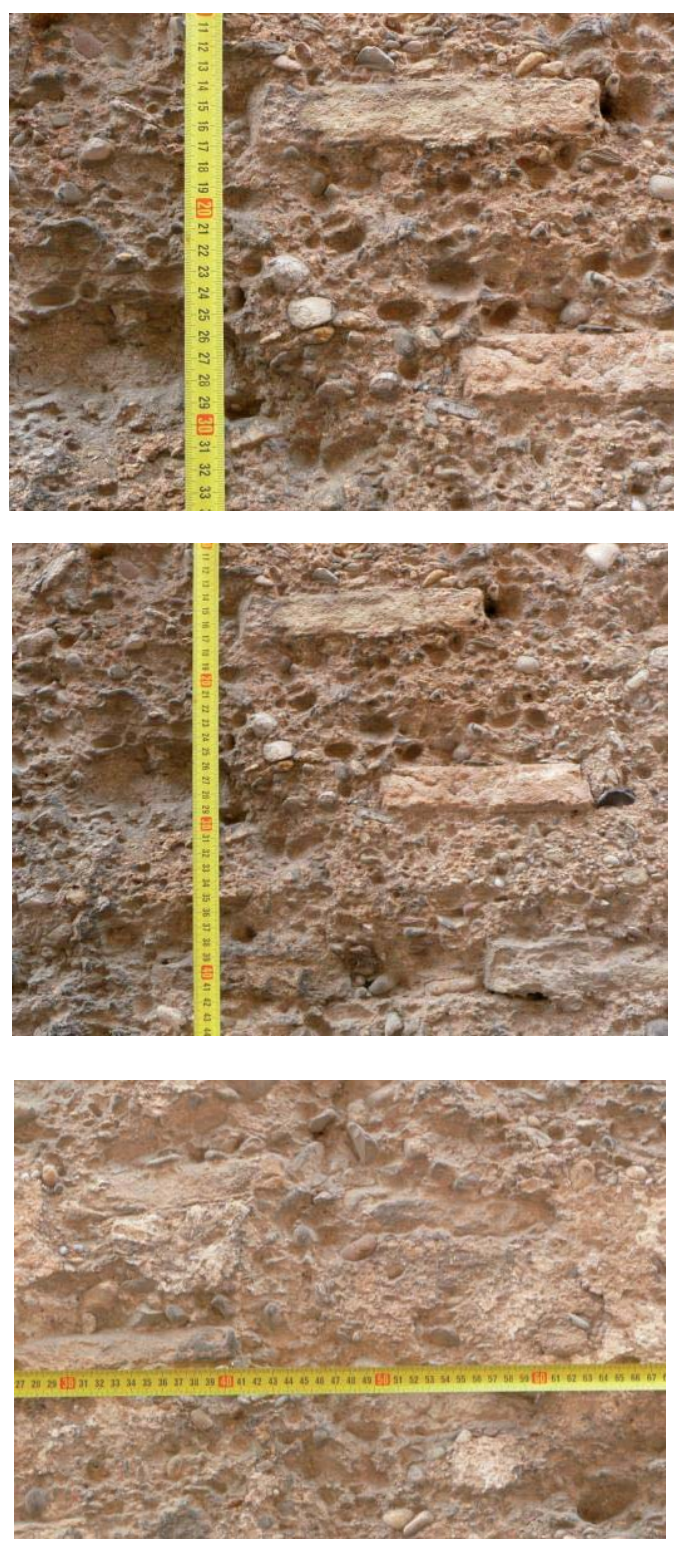
Datos generales

\begin{tabular}{|c|c|c|c|c|c|}
\hline Barrio & Carmen & La Seu-Xerea & Velluters & Mercat & S.Francesc \\
\hline Dirección & C/Corona $\mathrm{n}$ & & & & \\
\hline Tipo de edificio & residencial & palaciego & religioso & militar & \\
\hline $\mathbf{G}^{\circ}$ de protección & 0 & 1 & 2 & 3 & \\
\hline Fechas claves & / & & & & \\
\hline
\end{tabular}
El apartado "fechas claves" se ha extraído de AA.V.., Guía de Arquitectura de Valencia, Icaro CTAV Ed., Valencia, 2007
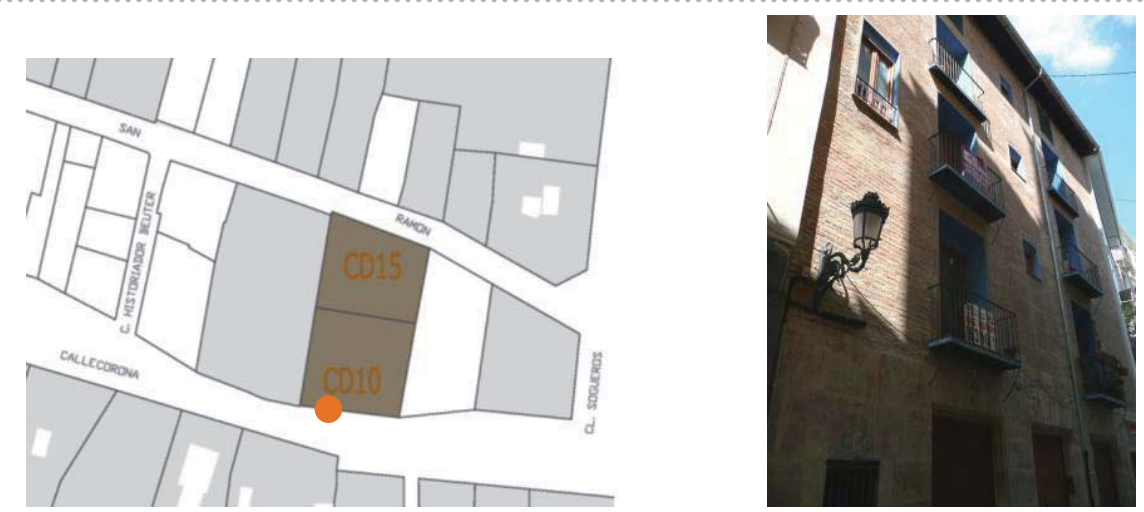

Fachada

Cd10

Pisos
Composición fachada
Zócalo
Fábrica
Vano/dintel
Entrada/dintel
Alero
Cubierta

\begin{tabular}{|c|c|c|c|c|c|c|c|c|}
\hline \multirow{3}{*}{\multicolumn{2}{|c|}{$\begin{array}{l}\mathrm{N}^{03} \\
\text { aleatoria }\end{array}$}} & \multirow{2}{*}{\multicolumn{3}{|c|}{$\begin{array}{l}\text { sótano entreplanta } \\
\text { ordenada sin simetría }\end{array}$}} & \multicolumn{4}{|c|}{ piso noble caja escalera } \\
\hline & & & & & \multicolumn{4}{|c|}{ ordenada con simetría } \\
\hline & & Z3 & Z4 & Z5 & & & & \\
\hline F1 & F2 & F3 & F4 & F5 & F6 & & & \\
\hline V1 & V2 & V3 & V4 & V5 & V7 & V8 & V9 & V10 \\
\hline E1 & E2 & E3 & E4 & & & & & \\
\hline $\mathrm{A} 1$ & $\mathrm{~A} 2$ & A3 & A4 & A5 & A7 & & & \\
\hline
\end{tabular}

Fábrica

Cd10

\section{Aparejo \\ Hiladas \\ Superficie \\ Sección (hipótesis) \\ Elementos destacados}

\begin{tabular}{lll} 
soga-tizón & soga & \multicolumn{1}{c}{ tizón } \\
irregulares & pseudo horizontales & horizontales \\
\hline sin planeidad & pseudo planeidad & planeidad perfecta \\
\hline uniforme & hojas y núcleo & abocinada (vano) \\
aplantillado & cortado terracota & \\
\hline
\end{tabular}




\begin{tabular}{|c|c|c|c|}
\hline \multirow{2}{*}{$\begin{array}{l}\mathrm{N}^{\circ} \text { elementos medidos } \\
\text { Longitud }(\mathrm{cm})\end{array}$} & \multicolumn{3}{|l|}{15} \\
\hline & \multicolumn{3}{|l|}{27.2} \\
\hline Anchura (cm) & \multicolumn{3}{|l|}{12.3} \\
\hline Espesor (cm) & \multicolumn{3}{|l|}{3.5} \\
\hline Volumen $\left(\mathrm{cm}^{3}\right)$ & \multicolumn{3}{|l|}{1170.9} \\
\hline Tipo & homogéneo & heterogéneo & re-empleo \\
\hline Color & homogéneo & heterogéneo globular & heterogéneo marmolado \\
\hline Recogida de muestra & no & sí & código \\
\hline Patologías & $\begin{array}{l}\text { eflorescencias } \\
\text { erosión }\end{array}$ & $\begin{array}{l}\text { micro fisuración } \\
\text { disgregación }\end{array}$ & $\begin{array}{l}\text { grietas } \\
\text { descamación }\end{array}$ \\
\hline
\end{tabular}

${ }^{1}$ Datos obtenidos en base al cálculo del desvío estándar (respecto al valor medio de la muestras analizadas) y del gráfico de frecuencia de las muestras analizadas, identificado por una curva gaussiana

\section{untas}

\begin{tabular}{|c|c|c|c|c|}
\hline \multirow{2}{*}{$\begin{array}{l}N^{\circ} \text { elementos medidos } \\
\text { Llaga }(\mathrm{cm})\end{array}$} & \multicolumn{4}{|l|}{15} \\
\hline & \multicolumn{4}{|l|}{2} \\
\hline Tendel (cm) & \multicolumn{4}{|l|}{4} \\
\hline Altura de 5 hiladas $(\mathrm{cm})$ & \multicolumn{4}{|l|}{38} \\
\hline Proporción ladrillo/junta & \multicolumn{4}{|l|}{0.8} \\
\hline Tipo de acabado & simple & doble & múltiple & \\
\hline \multirow[t]{2}{*}{ Junta de asiento } & rehundida & a hueso & saliente & \\
\hline & enrasada & matada & & \\
\hline \multirow{2}{*}{ Junta de acabado } & rehundida & a hueso & saliente & \\
\hline & enrasada & matada & & \\
\hline \multirow{2}{*}{$\begin{array}{l}\text { Tipo de mortero } \\
\text { Morfología de mortero }\end{array}$} & cal & cal y tierra & tierra & cemento mixto \\
\hline & con grumos & con caliches & homogéneo & heterogéneo \\
\hline Tipo de árido & arena & gravilla & grava & mixto \\
\hline \multirow{4}{*}{$\begin{array}{l}\text { Color del árido } \\
\text { Recogida de muestra } \\
\text { Patologías }\end{array}$} & claro & oscuro & homogéneo & heterogéneo \\
\hline & no & sí & código & \\
\hline & eflorescencias & micro fisuración & grietas & \\
\hline & erosión & disgregación & pulverización & \\
\hline
\end{tabular}



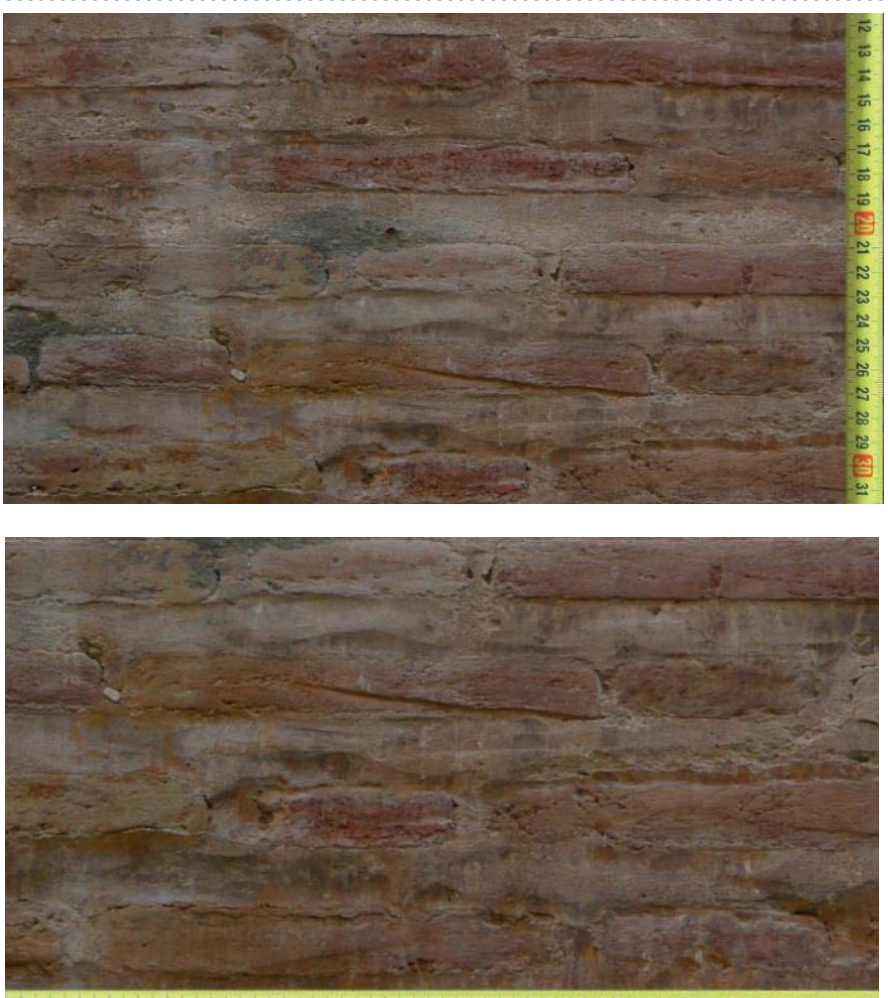

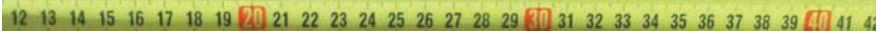

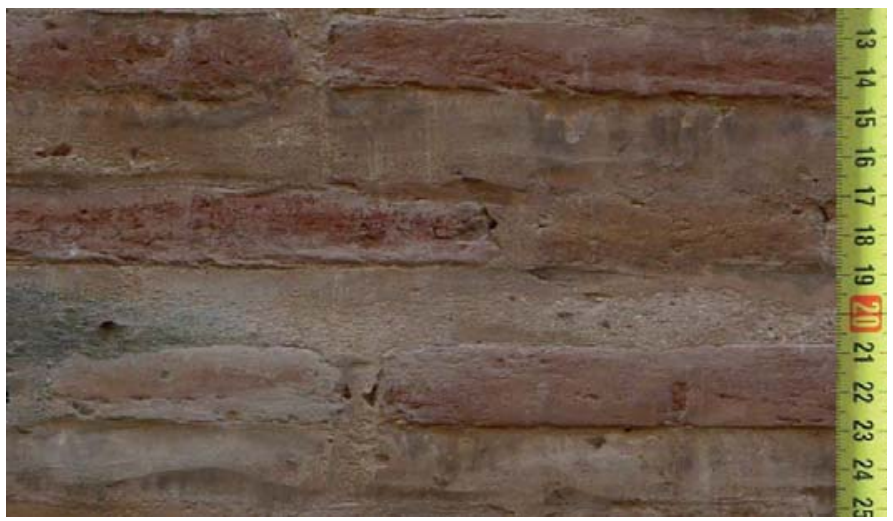



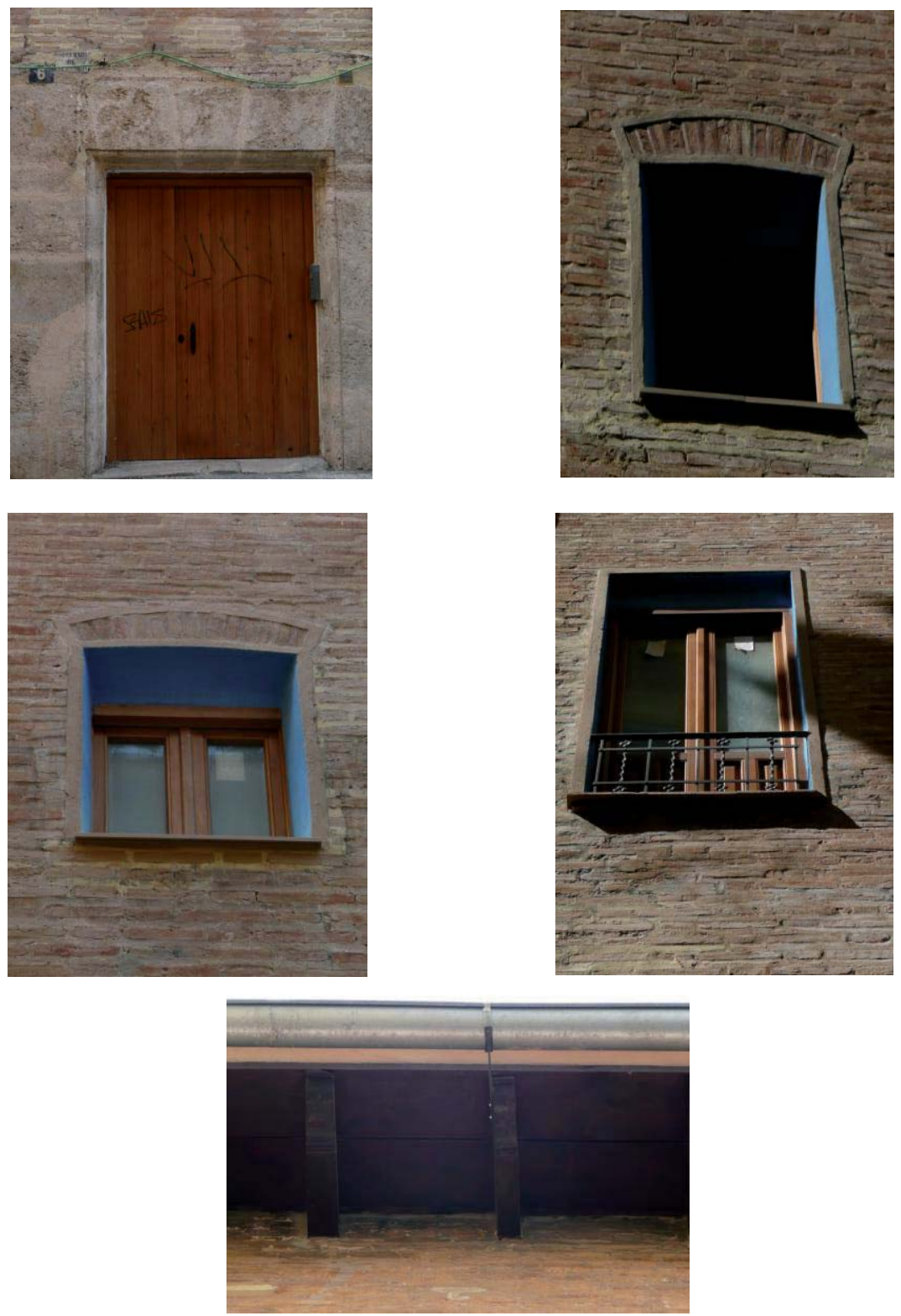
Datos generales

\begin{tabular}{|c|c|c|c|c|c|}
\hline Barrio & Carmen & La Seu-Xerea & Velluters & Mercat & S.Francesc \\
\hline Dirección & $\mathrm{C} / \mathrm{Na}$ Jordar & $n^{0} 15$ & & & \\
\hline Tipo de edificio & residencial & palaciego & religioso & militar & \\
\hline $\mathbf{G}^{\circ}$ de protección & 0 & 1 & 2 & 3 & \\
\hline Fechas claves & / & & & & \\
\hline
\end{tabular}

El apartado "fechas claves" se ha extraído de AA.V. ., Guía de Arquitectura de Valencia, Icaro CTAV Ed., Valencia, 2007
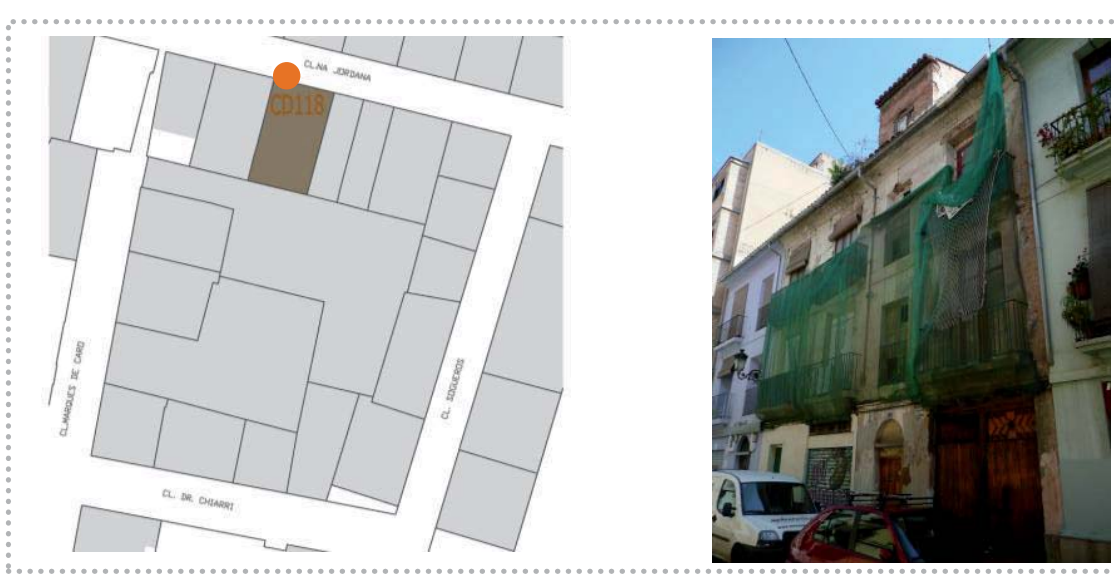

Fachada

Cd118

Pisos
Composición fachada
Zócalo
Fábrica
Vano/dintel
Entrada/dintel
Alero
Cubierta

\begin{tabular}{|c|c|c|c|c|c|c|c|c|c|}
\hline \multicolumn{2}{|c|}{$N^{0} 2$} & sótano & & planta & \multicolumn{2}{|c|}{ piso noble } & $\mathrm{ca}$ & escá & era \\
\hline \multicolumn{2}{|c|}{ aleatoria } & \multicolumn{3}{|c|}{ ordenada sin simetría } & \multicolumn{5}{|c|}{ ordenada con simetría } \\
\hline Z1 & $\mathrm{Z} 2$ & Z3 & Z4 & Z5 & & & & & \\
\hline F1 & $\mathrm{F} 2$ & F3 & F4 & F5 & F6 & F7 & & & \\
\hline V1 & V2 & V3 & V4 & V5 & V6 & V7 & V8 & V9 & V10 \\
\hline E1 & E2 & E3 & E4 & & & & & & \\
\hline A1 & $\mathrm{A} 2$ & A3 & A4 & A5 & A6 & A7 & & & \\
\hline
\end{tabular}

\section{Fábrica}

Cd118

\begin{tabular}{l|lll}
\hline Aparejo & soga-tizón & soga & \multicolumn{2}{c}{ tizón } & \\
\hline Hiladas & irregulares & pseudo horizontales & horizontales \\
\hline Superficie & sin planeidad & pseudo planeidad & planeidad perfecta \\
\hline $\begin{array}{l}\text { Sección (hipótesis) } \\
\text { Elementos destacados }\end{array}$ & uniforme & hojas y núcleo & abocinada (vano) \\
\hline
\end{tabular}




\begin{tabular}{l|lll}
$\begin{array}{l}\text { No elementos medidos } \\
\text { Longitud }(\mathbf{c m})\end{array}$ & 15 & & \\
Anchura $(\mathbf{c m})$ & 28 & & \\
Espesor $(\mathbf{c m})$ & 12.5 & & \\
Volumen $\left(\mathbf{c m}^{3}\right)$ & 4 & heterogéneo & re-empleo \\
Tipo & 1400 & heterogéneo globular & heterogéneo marmolado \\
Color & homogéneo & sínogéneo & Código Cd $188 / 1$ \\
Recogida de muestra & no & micro fisuración & grietas \\
Patologías & eflorescencias & disgregación & descamación
\end{tabular}

${ }^{1}$ Datos obtenidos en base al cálculo del desvío estándar (respecto al valor medio de la muestras analizadas) y del gráfico de frecuencia de las muestras analizadas, identificado por una curva gaussiana

\section{Juntas}

\begin{tabular}{|c|c|c|c|c|}
\hline \multirow{2}{*}{$\begin{array}{l}N^{\circ} \text { elementos medidos } \\
\text { Llaga }(\mathrm{cm})\end{array}$} & \multicolumn{4}{|l|}{15} \\
\hline & \multicolumn{4}{|l|}{0.3} \\
\hline Tendel (cm) & \multicolumn{4}{|l|}{4} \\
\hline Altura de 5 hiladas $(\mathrm{cm})$ & \multicolumn{4}{|l|}{40} \\
\hline Proporción ladrillo/junta & \multicolumn{4}{|l|}{1} \\
\hline Tipo de acabado & simple & doble & \multicolumn{2}{|l|}{ múltiple } \\
\hline \multirow[t]{2}{*}{ Junta de asiento } & rehundida & a hueso & \multirow{2}{*}{\multicolumn{2}{|c|}{ saliente }} \\
\hline & enrasada & matada & & \\
\hline \multirow[t]{2}{*}{ Junta de acabado } & rehundida & a hueso & \multirow{2}{*}{\multicolumn{2}{|c|}{ saliente }} \\
\hline & enrasada & matada & & \\
\hline \multirow{2}{*}{$\begin{array}{l}\text { Tipo de mortero } \\
\text { Morfología de mortero }\end{array}$} & cal & cal y tierra & tierra & cemento mixto \\
\hline & con grumos & con caliches & homogéneo & heterogéneo \\
\hline Tipo de árido & arena & gravilla & grava & mixto \\
\hline Color del árido & claro & oscuro & homogéneo & heterogéneo \\
\hline Recogida de muestra & no & sí & \multicolumn{2}{|c|}{ Código Cd 118/2 } \\
\hline \multirow[t]{2}{*}{ Patologías } & eflorescencias & micro fisuración & \multicolumn{2}{|l|}{ grietas } \\
\hline & erosión & disgregación & \multicolumn{2}{|l|}{ pulverización } \\
\hline
\end{tabular}


Imágenes
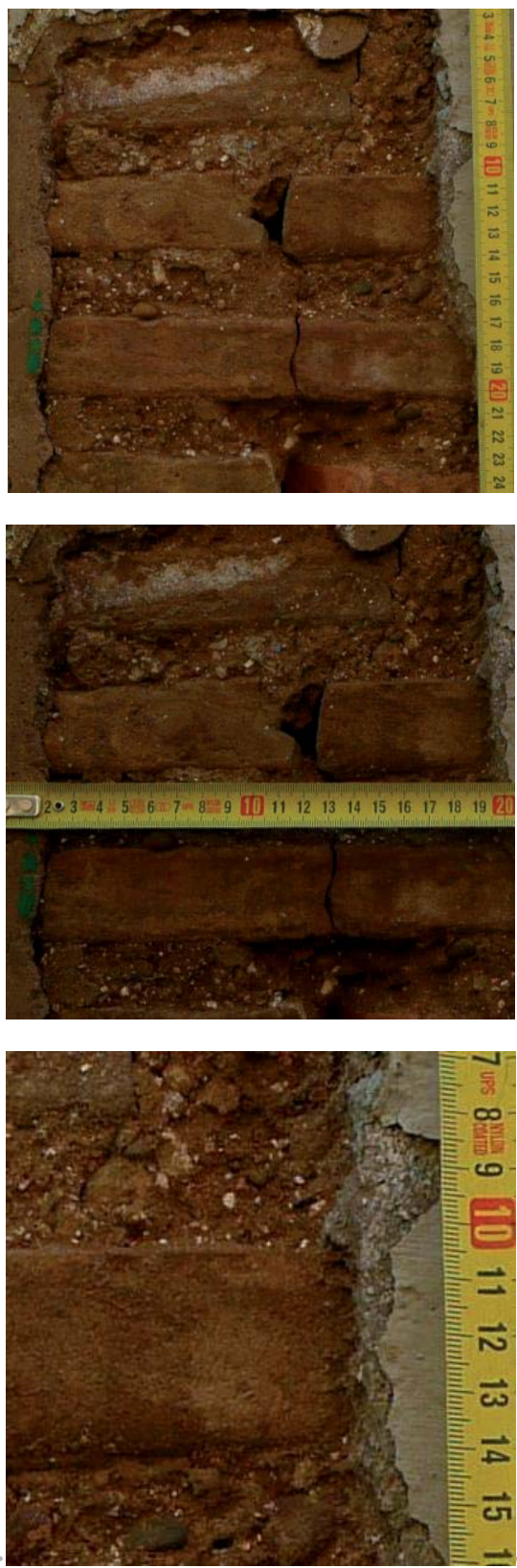

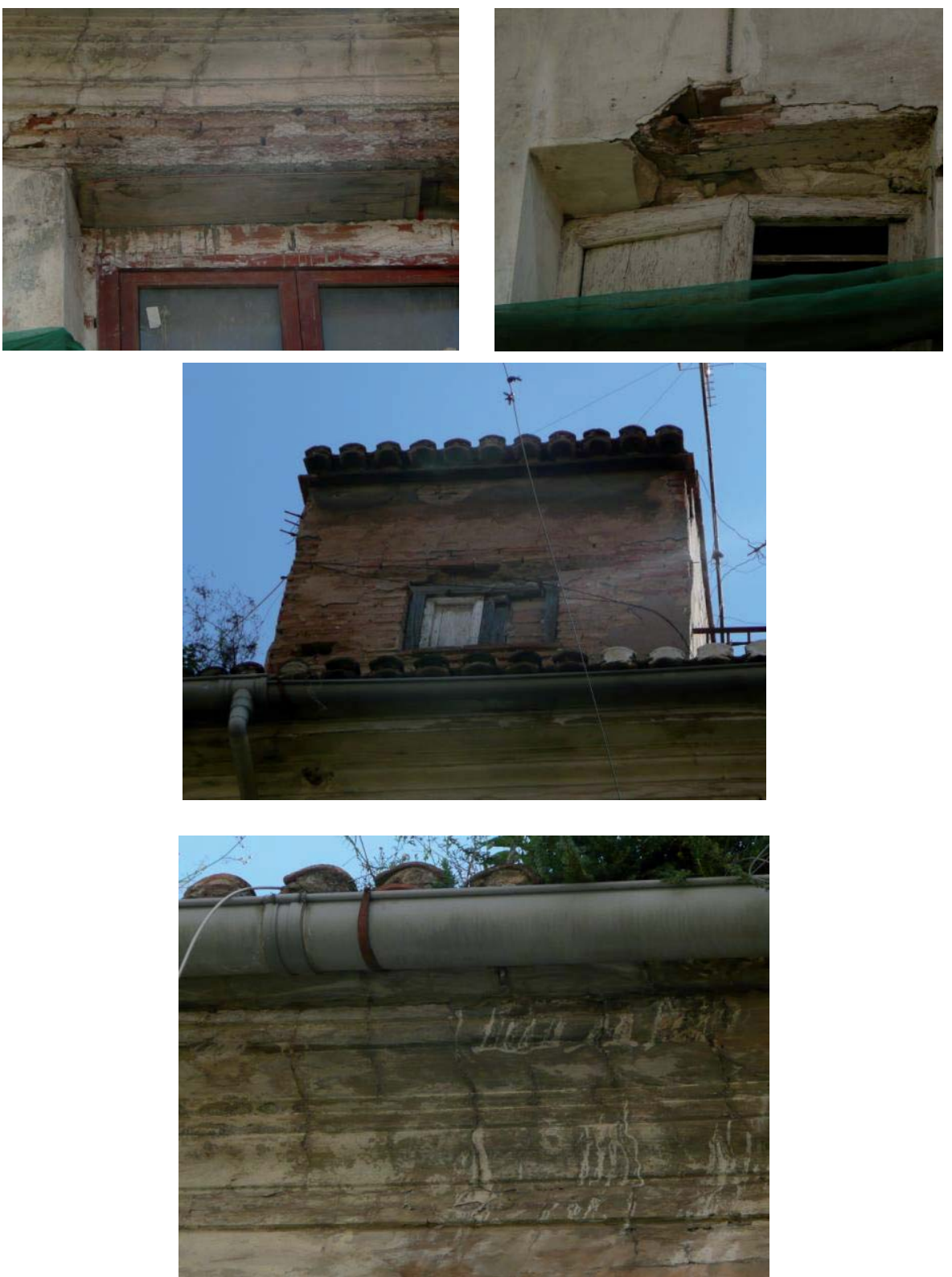
Datos generales

\begin{tabular}{|c|c|c|c|c|c|}
\hline Barrio & Carmen & La Seu-Xerea & Velluters & Mercat & S.Francesc \\
\hline Dirección & C/S. Ramón & 105 & & & \\
\hline Tipo de edificio & residencial & palaciego & religioso & militar & \\
\hline $\mathbf{G}^{\circ}$ de protección & 0 & 1 & 2 & 3 & \\
\hline Fechas claves & / & & & & \\
\hline
\end{tabular}
El apartado "fechas claves" se ha extraído de AA.V.., Guía de Arquitectura de Valencia, Icaro CTAV Ed., Valencia, 2007
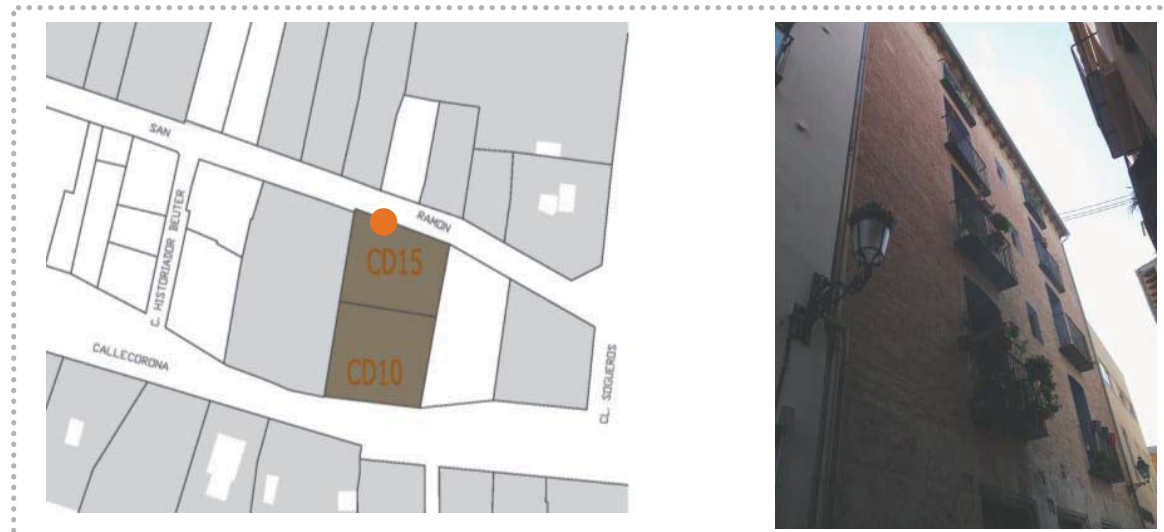

Fachada

$\mathrm{Cd} 15$

\begin{tabular}{|c|c|c|c|c|c|c|c|c|c|}
\hline \multirow{3}{*}{$\begin{array}{l}\text { Pisos } \\
\text { Composición fachada } \\
\text { Zócalo }\end{array}$} & \multicolumn{2}{|c|}{ No5 } & sótanc & \multicolumn{2}{|c|}{ entreplanta } & \multicolumn{4}{|c|}{ piso noble caja escalera } \\
\hline & \multicolumn{2}{|c|}{ aleatoria } & \multicolumn{3}{|c|}{ ordenada sin simetría } & \multicolumn{4}{|c|}{ ordenada con simetría } \\
\hline & Z1 & $\mathrm{Z} 2$ & Z3 & Z4 & Z5 & & & & \\
\hline Fábrica & $\mathrm{F} 1$ & $\mathrm{~F} 2$ & F3 & $\mathrm{F} 4$ & F5 & F6 & & & \\
\hline Vano/dintel & V1 & V2 & V3 & V4 & V5 & V6 & V8 & V9 & V10 \\
\hline Entrada/dintel & E1 & E2 & E3 & E4 & & & & & \\
\hline Alero & A1 & $\mathrm{A} 2$ & A3 & A4 & A5 & A6 & & & \\
\hline Cubierta & plar & & inclina & & & & & & \\
\hline
\end{tabular}

\section{Fábrica}

$\mathrm{Cd} 15$

\section{Aparejo \\ Hiladas \\ Superficie \\ Sección (hipótesis) \\ Elementos destacados}

\begin{tabular}{lll} 
soga-tizón & soga & \multicolumn{1}{c}{ tizón } \\
irregulares & pseudo horizontales & horizontales \\
\hline sin planeidad & pseudo planeidad & planeidad perfecta \\
\hline uniforme & hojas y núcleo & abocinada (vano) \\
aplantillado & cortado terracota & \\
\hline
\end{tabular}




\section{$\mathrm{N}^{\circ}$ elementos medidos}

Longitud (cm)

Anchura (cm)

Espesor $(\mathrm{cm})$

Volumen $\left(\mathrm{cm}^{3}\right)$

Tipo

Color

Recogida de muestra

Patologías

\section{5}

27.2

12.2

3.5

1161.4

homogéneo heterogéneo re-empleo

homogéneo heterogéneo globular heterogéneo marmolado

no sí código

eflorescencias micro fisuración grietas

erosión disgregación descamación

${ }^{1}$ Datos obtenidos en base al cálculo del desvío estándar (respecto al valor medio de la muestras analizadas) y del gráfico de frecuencia de las muestras analizadas, identificado por una curva gaussiana

\section{Juntas}

\begin{tabular}{|c|c|c|c|c|}
\hline $\mathrm{N}^{\circ}$ elementos medidos & 15 & & & \\
\hline Llaga $(\mathrm{cm})$ & 2 & & & \\
\hline Tendel (cm) & 4 & & & \\
\hline Altura de 5 hiladas $(\mathrm{cm})$ & 38 & & & \\
\hline Proporción ladrillo/junta & 0.8 & & & \\
\hline Tipo de acabado & simple & doble & múltiple & \\
\hline Junta de asiento & rehundida & a hueso & saliente & \\
\hline & enrasada & matada & & \\
\hline Junta de acabado & rehundida & a hueso & saliente & \\
\hline & enrasada & matada & & \\
\hline Tipo de mortero & cal & cal y tierra & tierra & cemento mixto \\
\hline Morfología de mortero & con grumos & con caliches & homogéneo & heterogéneo \\
\hline Tipo de árido & arena & gravilla & grava & mixto \\
\hline Color del árido & claro & oscuro & homogéneo & heterogéneo \\
\hline Recogida de muestra & no & sí & código & \\
\hline Patologías & eflorescencias & micro fisuración & grietas & \\
\hline & erosión & disgregación & pulverización & \\
\hline
\end{tabular}


Imágenes

Cd15
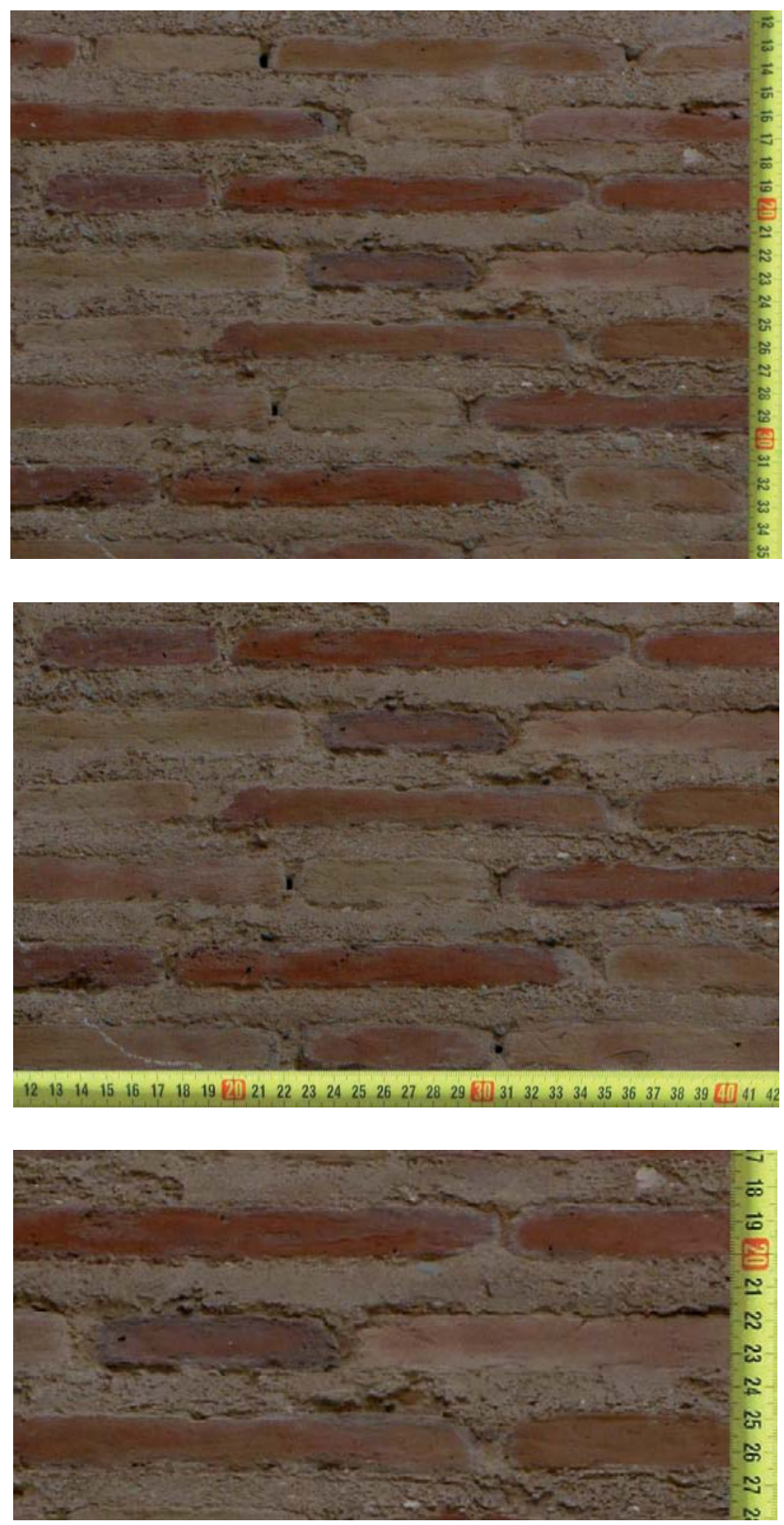
Imágenes

Cd15
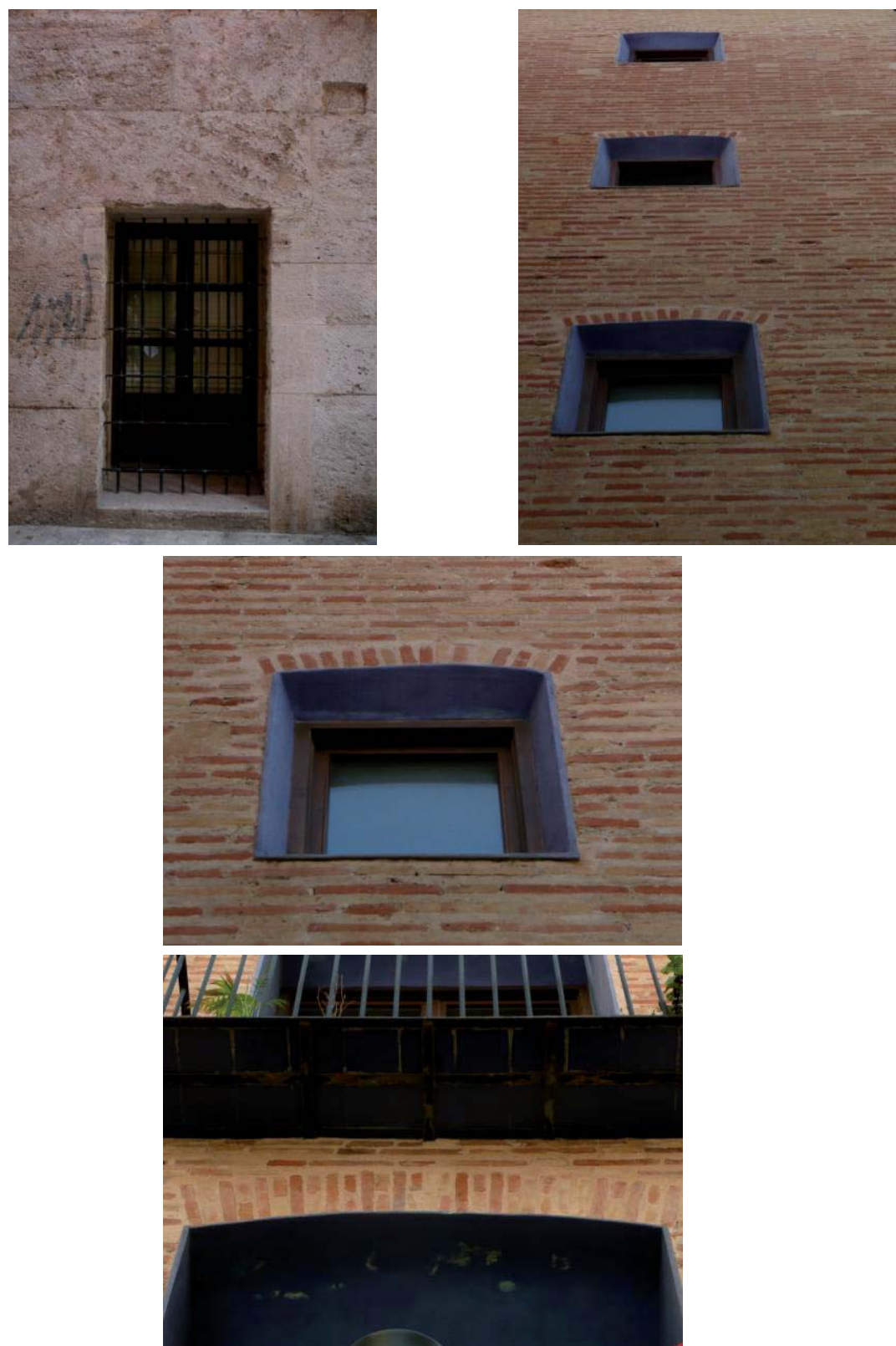
Datos generales

\begin{tabular}{|c|c|c|c|c|c|}
\hline Barrio & Carmen & La Seu-Xerea & Velluters & Mercat & S.Francesc \\
\hline Dirección & C/Ripalda & & & & \\
\hline Tipo de edificio & residencial & palaciego & religioso & militar & \\
\hline $\mathbf{G}^{\circ}$ de protección & 0 & 1 & 2 & 3 & \\
\hline Fechas claves & / & & & & \\
\hline
\end{tabular}
El apartado "fechas claves" se ha extraído de AA.V., Guía de Arquitectura de Valencia, Icaro CTAV Ed., Valencia, 2007
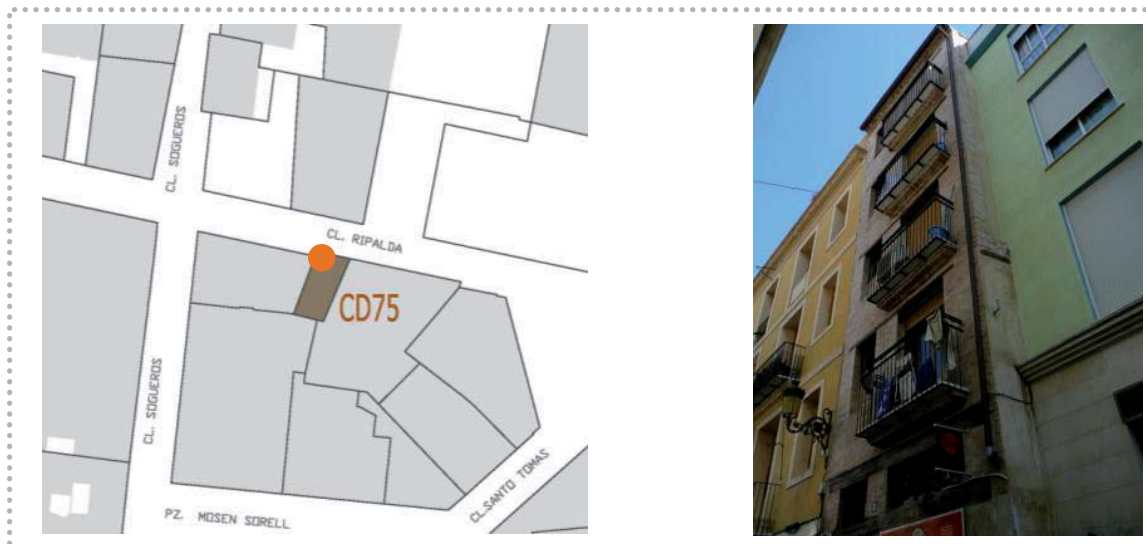

Fachada

Cd75

Pisos
Composición fachada
Zócalo
Fábrica
Vano/dintel
Entrada/dintel
Alero
Cubierta

\begin{tabular}{|c|c|c|c|c|c|c|c|c|c|}
\hline \multirow{2}{*}{\multicolumn{2}{|c|}{$\begin{array}{l}\text { N05 } \\
\text { aleatoria }\end{array}$}} & sótano & & planta & \multicolumn{5}{|c|}{ piso noble caja escalera } \\
\hline & & \multicolumn{3}{|c|}{ ordenada sin simetría } & \multicolumn{5}{|c|}{ ordenada con simetría } \\
\hline $\mathrm{Z1}$ & $\mathrm{Z2}$ & Z3 & Z4 & Z5 & & & & & \\
\hline F1 & F2 & F3 & F4 & F5 & F6 & F7 & & & \\
\hline V1 & V2 & V3 & V4 & V5 & V6 & V7 & V8 & V9 & V10 \\
\hline E1 & E2 & E3 & E4 & & & & & & \\
\hline A1 & A2 & A3 & A4 & A5 & A6 & A7 & & & \\
\hline \multicolumn{2}{|c|}{ plana } & \multicolumn{3}{|c|}{ inclina } & & & & & \\
\hline
\end{tabular}

Fábrica

Cd75

Aparejo
Hiladas
Superficie
Sección (hipótesis)
Elementos destacados

\begin{tabular}{|lll}
\hline soga-tizón & soga & tizón \\
irregulares & pseudo horizontales & horizontales \\
\hline sin planeidad & pseudo planeidad & planeidad perfecta \\
\hline uniforme & hojas y núcleo & abocinada (vano) \\
\hline aplantillado & cortado terracota & \\
\hline
\end{tabular}




$\begin{array}{llll}\begin{array}{l}\text { No elementos medidos } \\ \text { Longitud }(\mathbf{c m})\end{array} & 15 & & \\ \text { Anchura }(\mathbf{c m}) & 30 & & \\ \text { Espesor }(\mathbf{c m}) & 12.5 & & \\ \text { Volumen }\left(\mathbf{c m}^{\mathbf{3}}\right) & 3.5 & \text { heterogéneo } & \text { re-empleo } \\ \text { Tipo } & 1312.5 & \text { heterogéneo globular } & \text { heterogéneo marmolado } \\ \text { Color } & \text { homogéneo } & \text { síno } & \text { código } \\ \text { Recogida de muestra } & \text { nomogéneo } & \text { micro fisuración } & \text { grietas } \\ \text { Patologías } & \text { eflorescencias } & \text { disgregación } & \text { descamación } \\ & \text { erosión } & & \end{array}$

${ }^{1}$ Datos obtenidos en base al cálculo del desvío estándar (respecto al valor medio de la muestras analizadas) y del gráfico de frecuencia de las muestras analizadas, identificado por una curva gaussiana

\section{Juntas}

\begin{tabular}{|c|c|c|c|c|}
\hline \multirow{2}{*}{$\begin{array}{l}N^{\circ} \text { elementos medidos } \\
\text { Llaga }(\mathrm{cm})\end{array}$} & \multicolumn{4}{|l|}{15} \\
\hline & \multicolumn{4}{|l|}{1.5} \\
\hline Tendel (cm) & \multicolumn{4}{|l|}{2} \\
\hline Altura de 5 hiladas $(\mathrm{cm})$ & \multicolumn{4}{|l|}{27.5} \\
\hline Proporción ladrillo/junta & \multicolumn{4}{|l|}{1.7} \\
\hline Tipo de acabado & simple & doble & múltiple & \\
\hline \multirow[t]{2}{*}{ Junta de asiento } & rehundida & a hueso & saliente & \\
\hline & enrasada & matada & & \\
\hline \multirow[t]{2}{*}{ Junta de acabado } & rehundida & a hueso & saliente & \\
\hline & enrasada & matada & & \\
\hline \multirow{2}{*}{$\begin{array}{l}\text { Tipo de mortero } \\
\text { Morfología de mortero }\end{array}$} & cal & cal y tierra & tierra & cemento mixto \\
\hline & con grumos & con caliches & homogéneo & heterogéneo \\
\hline Tipo de árido & arena & gravilla & grava & mixto \\
\hline \multirow{4}{*}{$\begin{array}{l}\text { Color del árido } \\
\text { Recogida de muestra } \\
\text { Patologías }\end{array}$} & claro & oscuro & homogéneo & heterogéneo \\
\hline & no & sí & código & \\
\hline & eflorescencias & micro fisuración & grietas & \\
\hline & erosión & disgregación & pulverización & \\
\hline
\end{tabular}



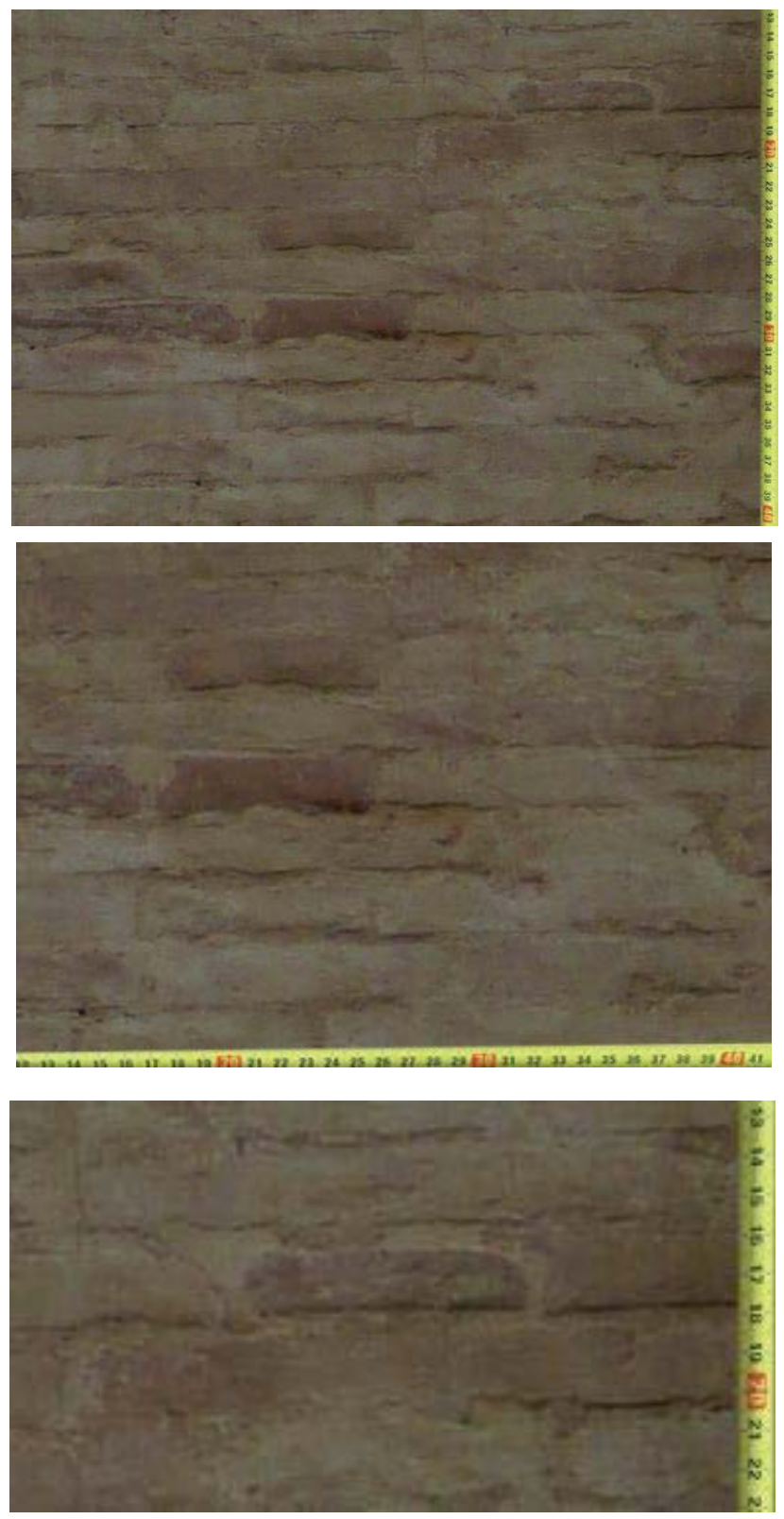

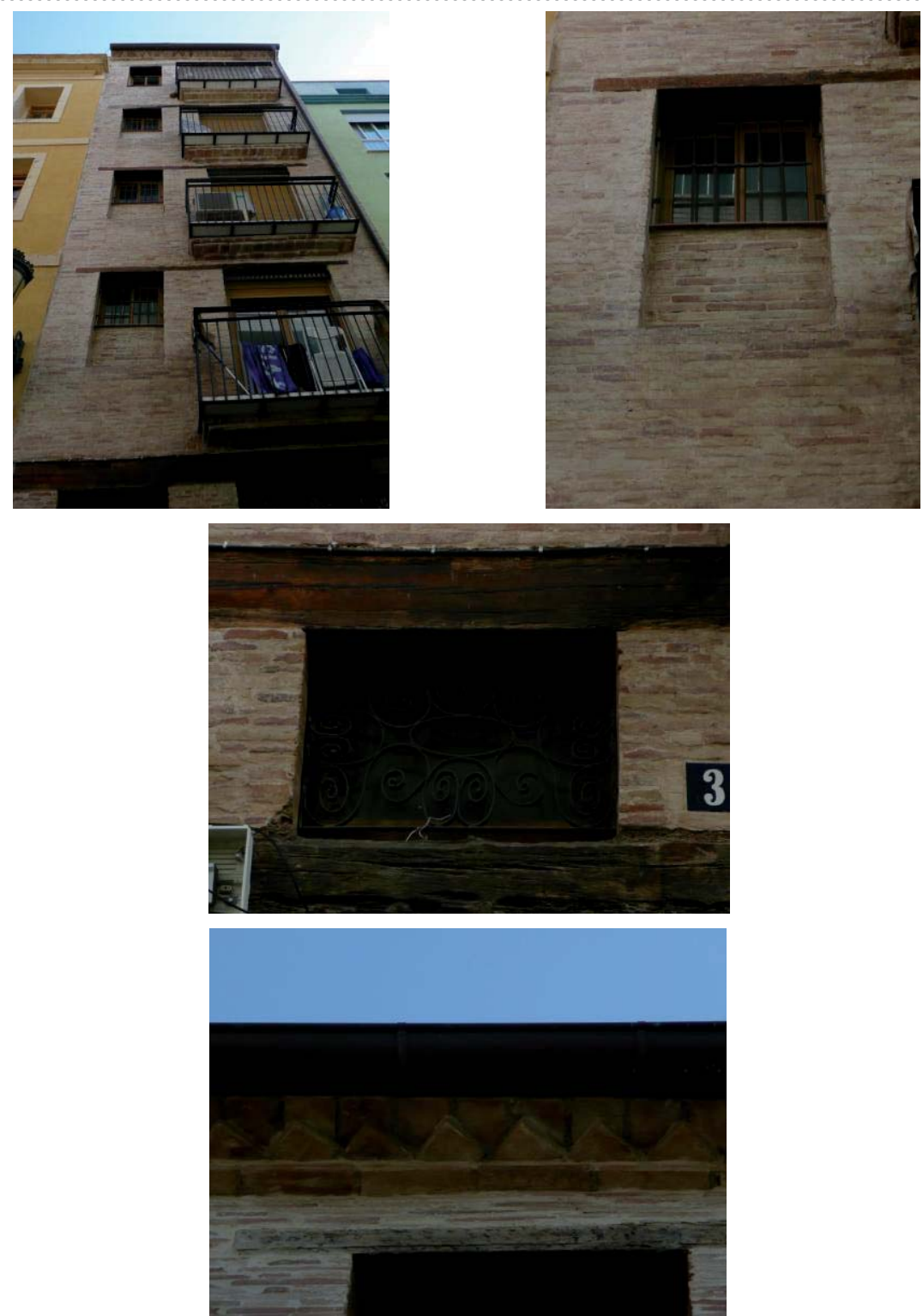
Datos generales

\begin{tabular}{|c|c|c|c|c|c|}
\hline Barrio & Carmen & La Seu-Xerea & Velluters & Mercat & S.Francesc \\
\hline Dirección & \multicolumn{5}{|c|}{ Carrer D’Alt/ n²4 (fachada trasera en la C/Morella) } \\
\hline Tipo de edificio & residencial & palaciego & religioso & militar & \\
\hline $\mathbf{G}^{\circ}$ de protección & 0 & 1 & 2 & 3 & \\
\hline Fechas claves & / & & & & \\
\hline
\end{tabular}

El apartado "fechas claves" se ha extraído de AA.V.., Guía de Arquitectura de Valencia, Icaro CTAV Ed., Valencia, 2007

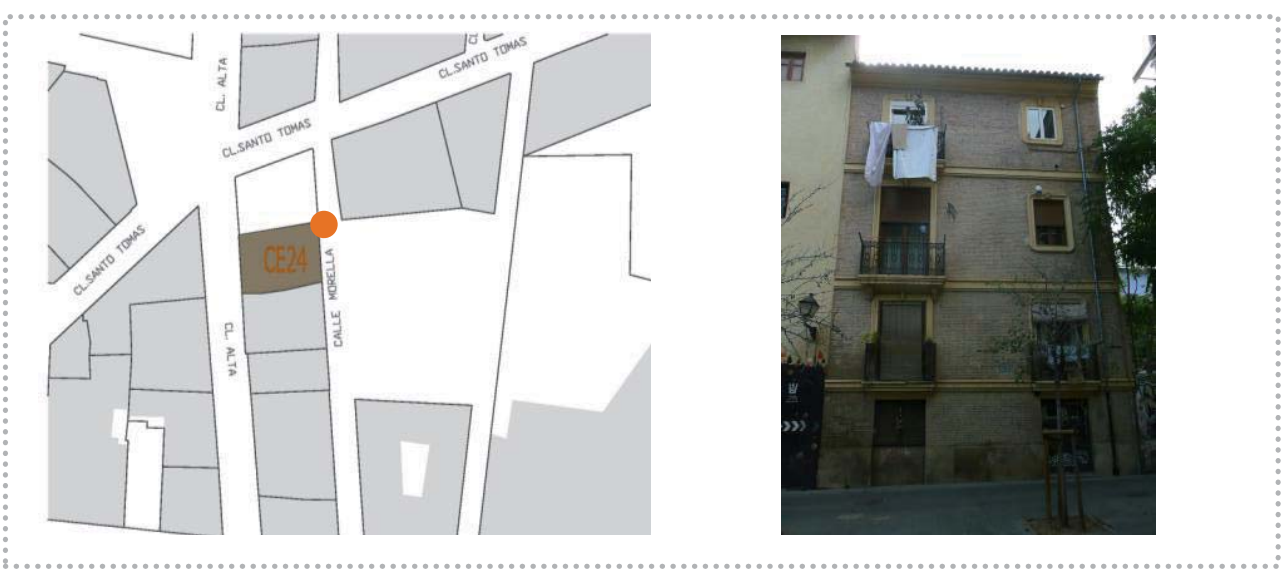

Fachada

Ce24

\begin{tabular}{|c|c|c|c|c|c|c|c|c|c|}
\hline \multirow{3}{*}{$\begin{array}{l}\text { Pisos } \\
\text { Composición fachada } \\
\text { Zócalo }\end{array}$} & \multicolumn{2}{|c|}{$N^{0} 3$} & sótano & \multicolumn{2}{|c|}{ entreplanta } & \multicolumn{4}{|c|}{ piso noble caja escalera } \\
\hline & \multicolumn{2}{|c|}{ aleatoria } & \multicolumn{3}{|c|}{ ordenada sin simetría } & \multicolumn{4}{|c|}{ ordenada con simetría } \\
\hline & $\mathrm{Z1}$ & $\mathrm{Z} 2$ & Z3 & Z4 & $\mathrm{Z} 5$ & & & & \\
\hline Fábrica & $\mathrm{F} 1$ & $\mathrm{~F} 2$ & F3 & $\mathrm{F} 4$ & F5 & F6 & & & \\
\hline Vano/dintel & V1 & V2 & V3 & V4 & V5 & V6 & V8 & V9 & V10 \\
\hline Entrada/dintel & E1 & E2 & E3 & E4 & & & & & \\
\hline Alero & A1 & $\mathrm{A} 2$ & $\mathrm{~A} 3$ & A4 & A5 & A6 & & & \\
\hline Cubierta & pla & & inclin & & & & & & \\
\hline
\end{tabular}

\section{Fábrica}

Ce24

\begin{tabular}{|c|c|c|c|}
\hline Aparejo & soga-tizón & tizón & \\
\hline Hiladas & irregulares & pseudo horizontales & horizontales \\
\hline Superficie & sin planeidad & pseudo planeidad & planeidad perfecta \\
\hline Sección(hipótesis) & uniforme & hojas y núcleo & abocinada (vano) \\
\hline Elementos destacados & aplantillado & cortado terracota & \\
\hline
\end{tabular}




\begin{tabular}{l|lll}
\hline $\begin{array}{l}\text { No elementos medidos } \\
\text { Longitud }(\mathbf{c m})\end{array}$ & 15 & & \\
\hline $\begin{array}{l}\text { Anchura } \mathbf{( c m}) \\
\text { Espesor }(\mathbf{c m})\end{array}$ & 126 & & \\
Volumen $\left(\mathbf{c m}^{3}\right)$ & 3.2 & & \\
Tipo & 1040 & heterogéneo & re-empleo \\
\hline $\begin{array}{l}\text { Color } \\
\text { Recogida de muestra }\end{array}$ & homogéneo & heterogéneo globular & heterogéneo marmolado \\
\hline Patologías & no & sí & Código Ce 24/1 \\
\hline & eflorescencias & micro fisuración & grietas \\
& erosión & disgregación & descamación
\end{tabular}

1 Datos obtenidos en base al cálculo del desvío estándar (respecto al valor medio de la muestras analizadas) y del gráfico de frecuencia de las muestras analizadas, identificado por una curva gaussiana

\section{untas 2}

\begin{tabular}{|c|c|c|c|c|}
\hline \multirow{2}{*}{$\begin{array}{l}N^{\circ} \text { elementos medidos } \\
\text { Llaga }(\mathrm{cm})\end{array}$} & \multicolumn{4}{|l|}{15} \\
\hline & \multicolumn{4}{|l|}{0.3} \\
\hline Tendel (cm) & \multicolumn{4}{|l|}{2.5} \\
\hline Altura de 5 hiladas $(\mathrm{cm})$ & \multicolumn{4}{|l|}{29} \\
\hline Proporción ladrillo/junta & \multicolumn{4}{|l|}{1.28} \\
\hline Tipo de acabado & simple & doble & múltiple & \\
\hline \multirow[t]{2}{*}{ Junta de asiento } & rehundida & a hueso & saliente & \\
\hline & enrasada & matada & & \\
\hline \multirow[t]{2}{*}{ Junta de acabado } & rehundida & a hueso & saliente & \\
\hline & enrasada & matada & & \\
\hline \multirow{3}{*}{$\begin{array}{l}\text { Tipo de mortero } \\
\text { Morfología de mortero } \\
\text { Tipo de árido }\end{array}$} & cal & cal y tierra & tierra & cemento mixto \\
\hline & con grumos & con caliches & homogéneo & heterogéneo \\
\hline & arena & gravilla & grava & mixto \\
\hline \multirow{4}{*}{$\begin{array}{l}\text { Color del árido } \\
\text { Recogida de muestra } \\
\text { Patologías }\end{array}$} & claro & oscuro & homogéneo & heterogéneo \\
\hline & no & sí & código & \\
\hline & eflorescencias & micro fisuración & grietas & \\
\hline & erosión" & disgregación & pulverización & \\
\hline
\end{tabular}


Imágenes
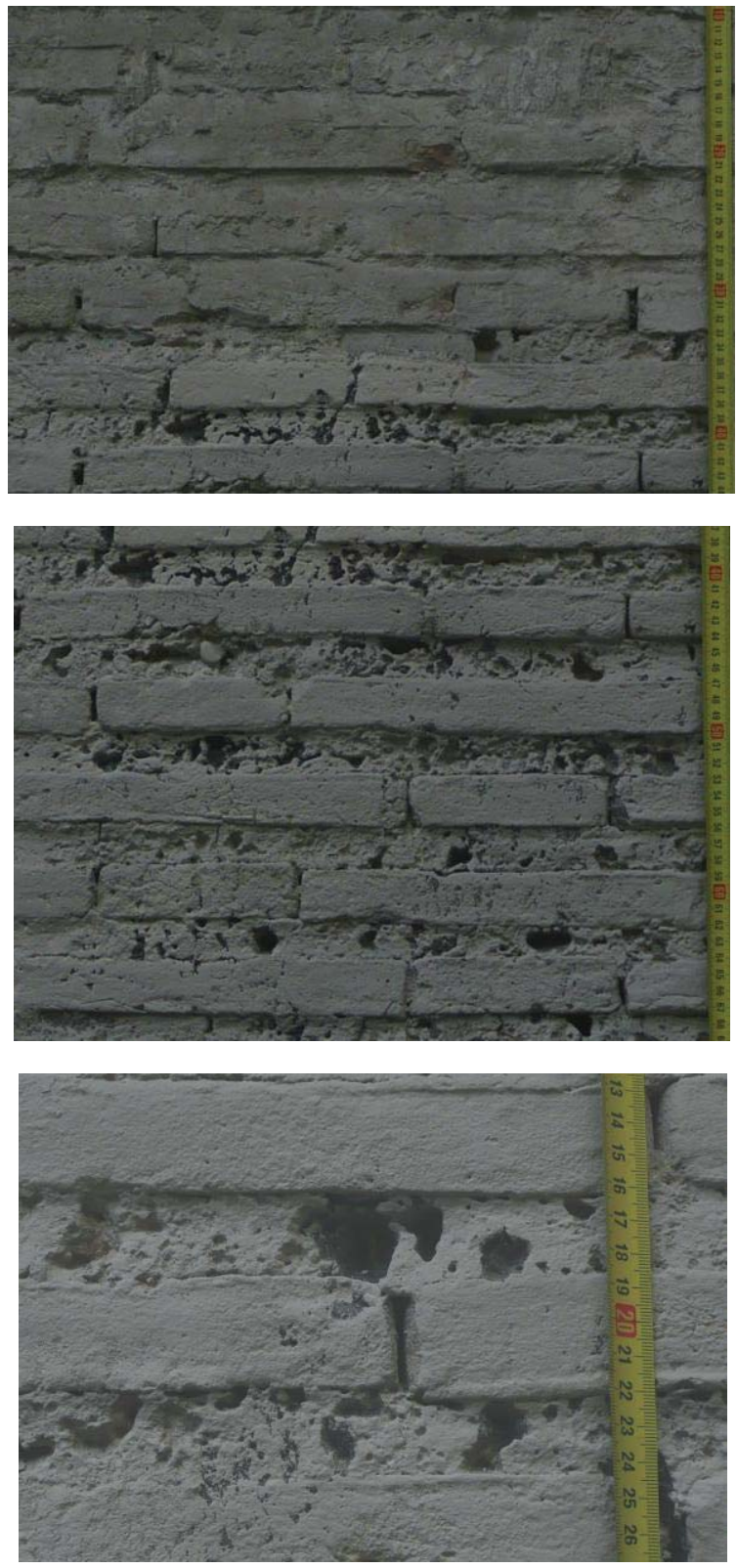
Imágenes

Ce24
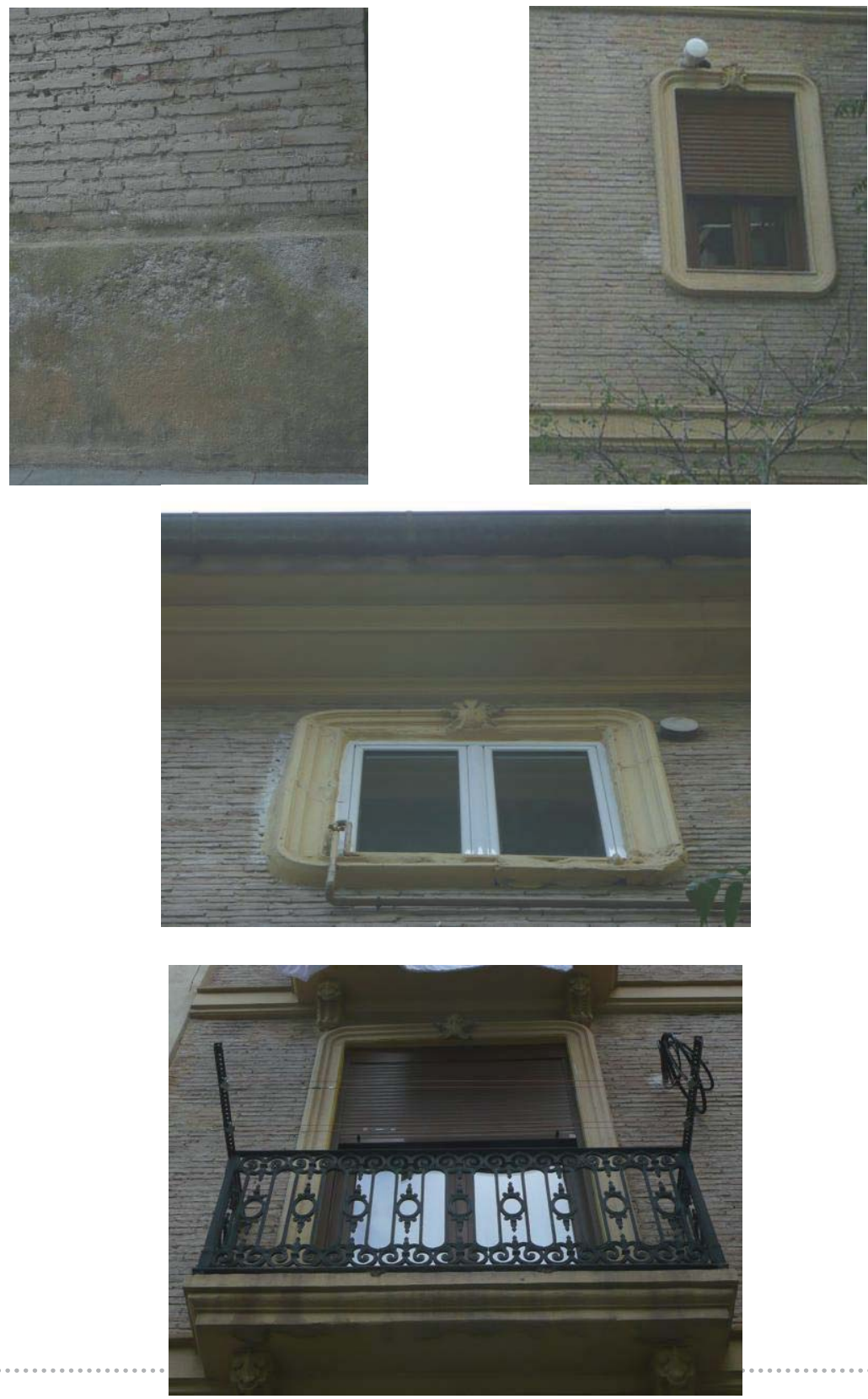
Datos generales

\begin{tabular}{|c|c|c|c|c|c|}
\hline Barrio & Carmen & La Seu-Xerea & Velluters & Mercat & S.Francesc \\
\hline Dirección & \multicolumn{5}{|c|}{ C/Sto. Tomás n¹0 } \\
\hline Tipo de edificio & residencial & palaciego & religioso & militar & \\
\hline $\mathrm{G}^{\circ}$ de protección & 0 & 1 & 2 & 3 & \\
\hline Fechas claves & / & & & & \\
\hline
\end{tabular}
El apartado "fechas claves" se ha extraído de AA.V. ., Guía de Arquitectura de Valencia, Icaro CTAV Ed., Valencia, 2007

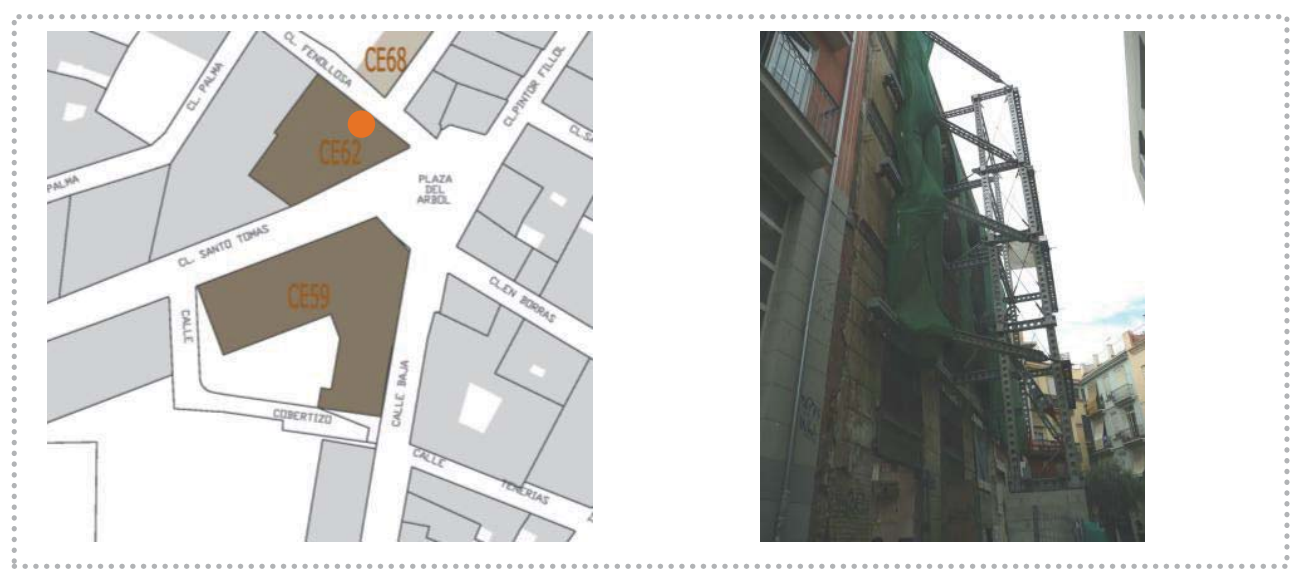

\section{Fachada}

Ce62

\begin{tabular}{|c|c|c|c|c|c|c|c|c|c|}
\hline \multirow{3}{*}{$\begin{array}{l}\text { Pisos } \\
\text { Composición fachada } \\
\text { Zócalo }\end{array}$} & \multicolumn{2}{|c|}{$\mathrm{N}^{0} 3$} & sótano & \multicolumn{2}{|c|}{ entreplanta } & \multicolumn{4}{|c|}{ piso noble caja escalera } \\
\hline & \multicolumn{2}{|c|}{ aleatoria } & \multicolumn{3}{|c|}{ ordenada sin simetría } & \multicolumn{4}{|c|}{ ordenada con simetría } \\
\hline & $\mathrm{Z1}$ & $\mathrm{Z} 2$ & Z3 & Z4 & Z5 & & & & \\
\hline Fábrica & $\mathrm{F} 1$ & $\mathrm{~F} 2$ & F3 & F4 & F5 & F6 & & & \\
\hline Vano/dintel & V1 & V2 & V3 & V4 & V5 & V7 & V8 & V9 & V10 \\
\hline Entrada/dintel & E1 & E2 & E3 & E4 & & & & & \\
\hline Alero & A1 & $\mathrm{A} 2$ & A3 & A4 & A5 & A7 & & & \\
\hline Cubierta & plar & & inclinac & & & & & & \\
\hline
\end{tabular}

\section{Fábrica}

Ce62

\begin{tabular}{l|lll} 
Aparejo & soga-tizón & soga & \multicolumn{1}{c}{ tizón } \\
\hline Hiladas & irregulares & pseudo horizontales & horizontales \\
\hline Superficie & sin planeidad & pseudo planeidad & planeidad perfecta \\
\hline Sección( hipótesis) & uniforme & hojas y núcleo & abocinada (vano) \\
Elementos destacados & aplantillado & cortado terracota & \\
\hline
\end{tabular}




\begin{tabular}{|c|c|c|c|}
\hline \multirow{3}{*}{$\begin{array}{l}\mathrm{N}^{\circ} \text { elementos medidos } \\
\text { Longitud }(\mathrm{cm}) \\
\text { Anchura }(\mathrm{cm})\end{array}$} & \multicolumn{3}{|l|}{15} \\
\hline & \multicolumn{3}{|l|}{26.5} \\
\hline & \multicolumn{3}{|l|}{13} \\
\hline Espesor (cm) & \multicolumn{3}{|l|}{4} \\
\hline Volumen $\left(\mathrm{cm}^{3}\right)$ & \multicolumn{3}{|l|}{1378} \\
\hline Tipo & homogéneo & heterogéneo & re-empleo \\
\hline Color & homogéneo & heterogéneo globular & heterogéneo marmolado \\
\hline Recogida de muestra & no & sí & código Ce62/1 \\
\hline Patologías & $\begin{array}{l}\text { eflorescencias } \\
\text { erosión }\end{array}$ & $\begin{array}{l}\text { micro fisuración } \\
\text { disgregación }\end{array}$ & $\begin{array}{l}\text { grietas } \\
\text { descamación }\end{array}$ \\
\hline
\end{tabular}

1 Datos obtenidos en base al cálculo del desvío estándar (respecto al valor medio de la muestras analizadas) y del gráfico de frecuencia de las muestras analizadas, identificado por una curva gaussiana

\section{Juntas}

\begin{tabular}{|c|c|c|c|c|}
\hline \multirow{2}{*}{$\begin{array}{l}N^{0} \text { elementos medidos } \\
\text { Llaga }(\mathrm{cm})\end{array}$} & \multicolumn{4}{|l|}{15} \\
\hline & \multicolumn{4}{|l|}{0.5} \\
\hline Tendel (cm) & \multicolumn{4}{|l|}{2.5} \\
\hline Altura de 5 hiladas $(\mathrm{cm})$ & \multicolumn{4}{|l|}{32} \\
\hline Proporción ladrillo/junta & \multicolumn{4}{|l|}{1.2} \\
\hline Tipo de acabado & simple & doble & múltiple & \\
\hline Junta de asiento & $\begin{array}{l}\text { rehundida } \\
\text { enrasada }\end{array}$ & $\begin{array}{l}\text { a hueso } \\
\text { matada }\end{array}$ & saliente & \\
\hline Junta de acabado & $\begin{array}{l}\text { rehundida } \\
\text { enrasada }\end{array}$ & $\begin{array}{l}\text { a hueso } \\
\text { matada }\end{array}$ & saliente & \\
\hline Tipo de mortero & cal & cal y tierra & tierra & cemento mixto \\
\hline Morfología de mortero & con grumos & con caliches & homogéneo & heterogéneo \\
\hline Tipo de árido & arena & gravilla & grava & mixto \\
\hline Color del árido & claro & oscuro & homogéneo & heterogéneo \\
\hline Recogida de muestra & no & sí & código Ce62/2 & \\
\hline Patologías & $\begin{array}{l}\text { eflorescencias } \\
\text { erosión }\end{array}$ & $\begin{array}{l}\text { micro fisuración } \\
\text { disgregación }\end{array}$ & $\begin{array}{l}\text { grietas } \\
\text { pulverización }\end{array}$ & \\
\hline
\end{tabular}


Imágenes

Ce62
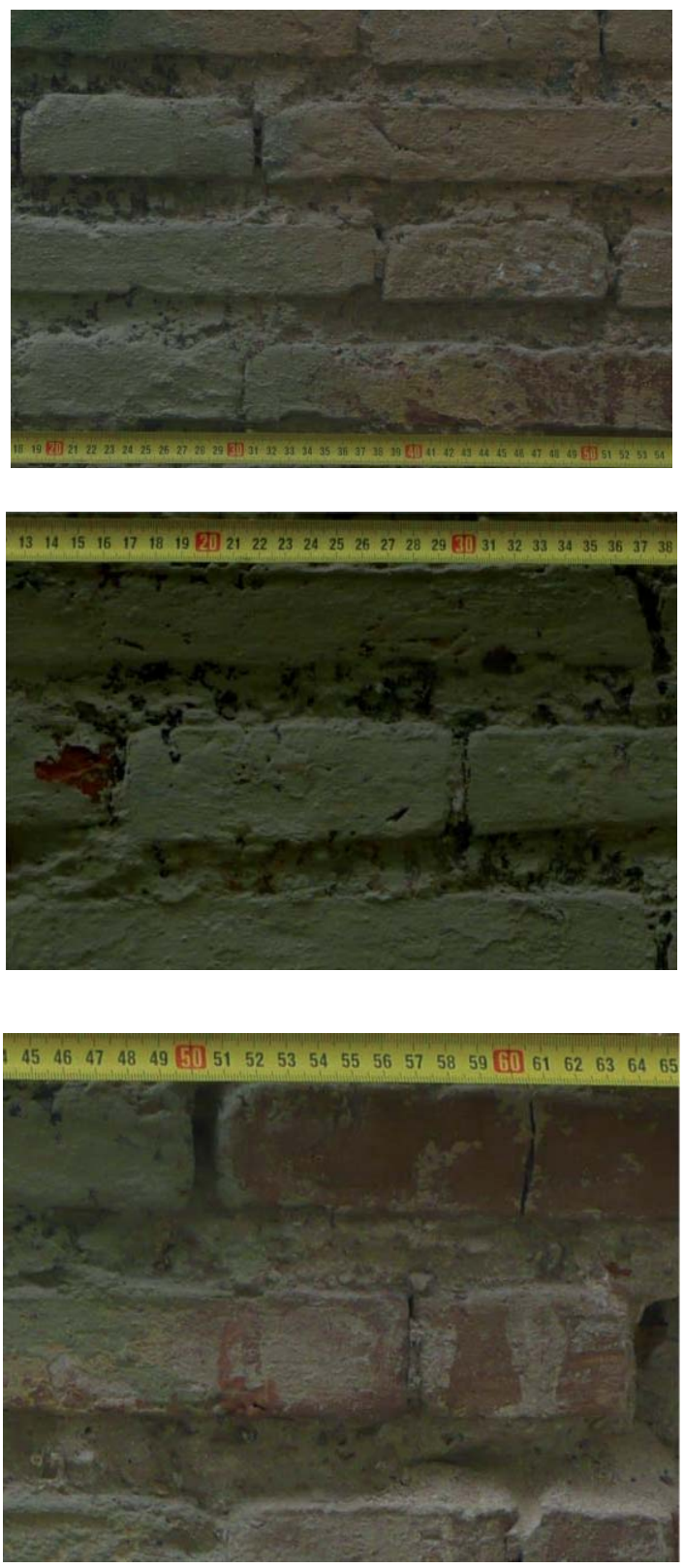

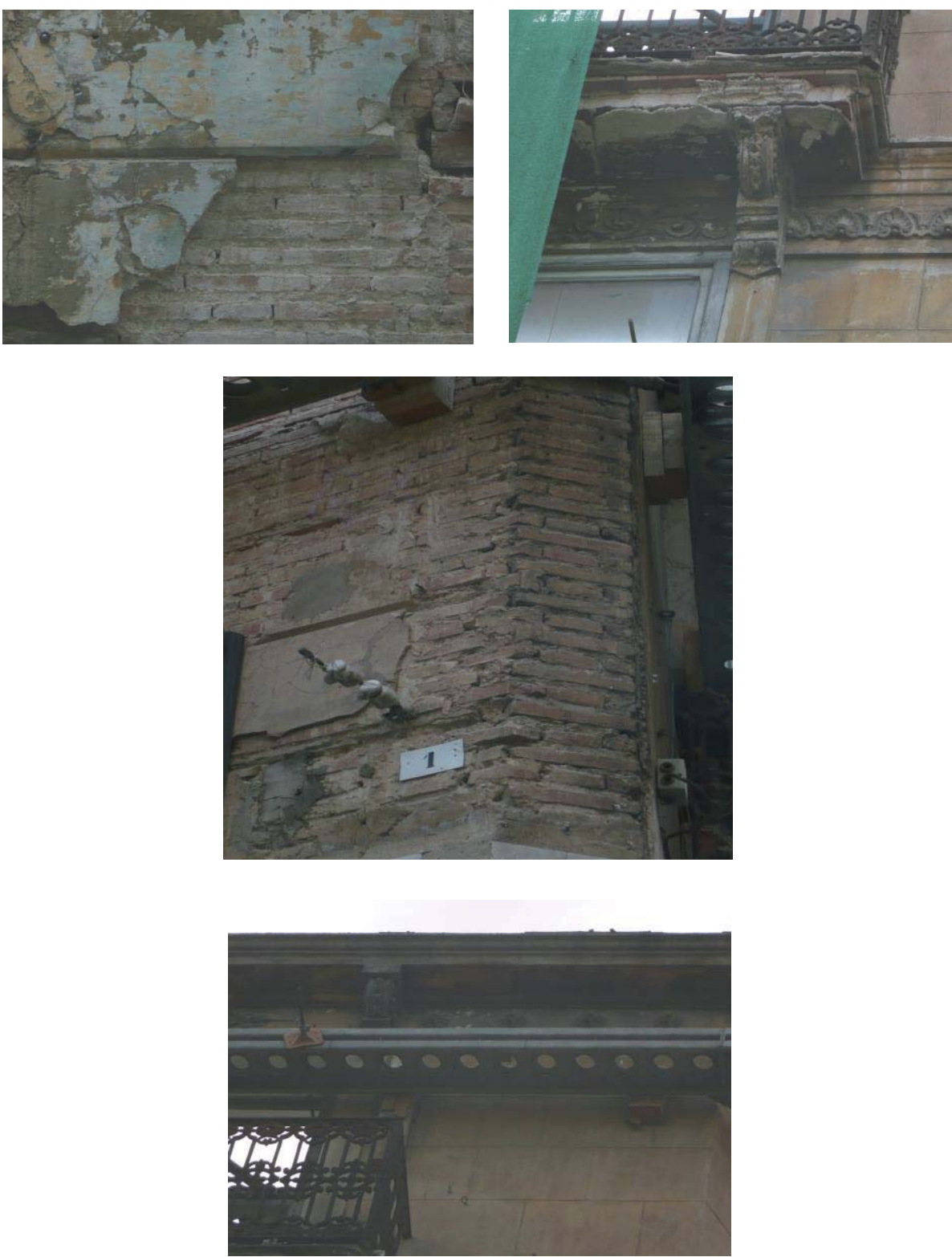
Datos generales

\begin{tabular}{|c|c|c|c|c|c|}
\hline Barrio & Carmen & La Seu-Xerea & Velluters & Mercat & S.Francesc \\
\hline Dirección & \multicolumn{5}{|c|}{ Pza. Carmen n4 } \\
\hline Tipo de edificio & residencial & palaciego & religioso & militar & \\
\hline$G^{\circ}$ de protección & 0 & 1 & 2 & 3 & \\
\hline Fechas claves & \multicolumn{5}{|c|}{ 1728-32, intervención (1990-92) } \\
\hline
\end{tabular}
El apartado "fechas claves" se ha extraído de AA.V.., Guía de Arquitectura de Valencia, Icaro CTAV Ed., Valencia, 2007

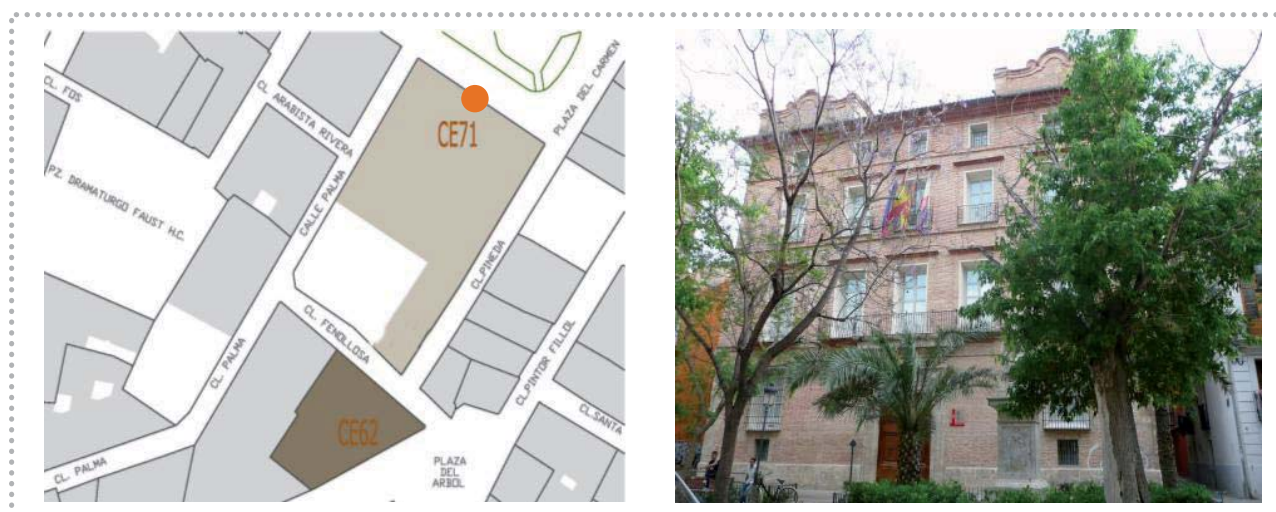

Fachada

Ce71

\begin{tabular}{|c|c|c|c|c|c|c|c|c|c|c|}
\hline \multirow{3}{*}{$\begin{array}{l}\text { Pisos } \\
\text { Composición fachada } \\
\text { Zócalo }\end{array}$} & \multicolumn{2}{|c|}{$N^{0} 3$} & sótano & \multicolumn{2}{|c|}{ entreplanta } & \multicolumn{5}{|c|}{ piso noble caja escalera } \\
\hline & \multicolumn{2}{|c|}{ aleatoria } & \multicolumn{3}{|c|}{ ordenada sin simetría } & \multicolumn{5}{|c|}{ ordenada con simetría } \\
\hline & Z1 & $\mathrm{Z} 2$ & Z3 & Z4 & Z5 & & & & & \\
\hline Fábrica & $\mathrm{F} 1$ & $\mathrm{~F} 2$ & F3 & F4 & F5 & F6 & F7 & & & \\
\hline Vano/dintel & V1 & V2 & V3 & V4 & V5 & V6 & V7 & V8 & V9 & V10 \\
\hline Entrada/dintel & E1 & E2 & E3 & E4 & & & & & & \\
\hline Alero & A1 & $\mathrm{A} 2$ & A3 & A4 & A5 & A6 & A7 & & & \\
\hline Cubierta & pla & & inclinac & & & & & & & \\
\hline
\end{tabular}

\section{Fábrica}

Aparejo
Hiladas
Superficie
Sección (hipótesis)
Elementos destacados

\begin{tabular}{|lll}
\hline soga-tizón & soga & \\
\hline irregulares & tizón & \\
\hline sin planeidad & pseudo planeidad & planeidad perfecta \\
\hline uniforme & hojas y núcleo & abocinada (vano) \\
\hline aplantillado & cortado terracota & \\
\hline
\end{tabular}




\begin{tabular}{|c|c|c|c|}
\hline \multirow{2}{*}{$\begin{array}{l}\mathrm{N}^{\circ} \text { elementos medidos } \\
\text { Longitud }(\mathrm{cm})\end{array}$} & \multicolumn{3}{|l|}{15} \\
\hline & \multicolumn{3}{|l|}{30.5} \\
\hline Anchura (cm) & \multicolumn{3}{|l|}{14.5} \\
\hline Espesor (cm) & \multicolumn{3}{|l|}{4.1} \\
\hline Volumen $\left(\mathrm{cm}^{3}\right)$ & \multicolumn{3}{|l|}{1813.22} \\
\hline Tipo & homogéneo & heterogéneo & re-empleo \\
\hline Color & homogéneo & heterogéneo globular & heterogéneo marmolado \\
\hline Recogida de muestra & no & sí & código \\
\hline \multirow[t]{2}{*}{ Patologías } & eflorescencias & micro fisuración & grietas \\
\hline & erosión & disgregación & descamación \\
\hline
\end{tabular}

${ }^{1}$ Datos obtenidos en base al cálculo del desvío estándar (respecto al valor medio de la muestras analizadas) y del gráfico de frecuencia de las muestras analizadas, identificado por una curva gaussiana

\section{Juntas}

\begin{tabular}{|c|c|c|c|c|}
\hline \multirow{2}{*}{$\begin{array}{l}N^{\circ} \text { elementos medidos } \\
\text { Llaga }(\mathrm{cm})\end{array}$} & \multicolumn{4}{|l|}{15} \\
\hline & \multicolumn{4}{|l|}{1.1} \\
\hline Tendel (cm) & \multicolumn{4}{|l|}{3.5} \\
\hline Altura de 5 hiladas $(\mathrm{cm})$ & \multicolumn{4}{|l|}{38} \\
\hline Proporción ladrillo/junta & \multicolumn{4}{|l|}{1.17} \\
\hline Tipo de acabado & simple & doble & \multicolumn{2}{|l|}{ múltiple } \\
\hline \multirow[t]{2}{*}{ Junta de asiento } & rehundida & a hueso & \multirow[t]{2}{*}{ saliente } & \\
\hline & enrasada & matada & & \\
\hline \multirow[t]{2}{*}{ Junta de acabado } & rehundida & a hueso & \multirow[t]{2}{*}{ saliente } & \\
\hline & enrasada & matada & & \\
\hline \multirow{2}{*}{$\begin{array}{l}\text { Tipo de mortero } \\
\text { Morfología de mortero }\end{array}$} & cal & cal y tierra & tierra & cemento mixto \\
\hline & con grumos & con caliches & homogéneo & heterogéneo \\
\hline \multirow{5}{*}{$\begin{array}{l}\text { Tipo de árido } \\
\text { Color del árido } \\
\text { Recogida de muestra } \\
\text { Patologías }\end{array}$} & arena & gravilla & grava & mixto \\
\hline & claro & oscuro & homogéneo & heterogéneo \\
\hline & no & sí & \multicolumn{2}{|l|}{ código } \\
\hline & eflorescencias & micro fisuración & \multicolumn{2}{|l|}{ grietas } \\
\hline & erosión" & disgregación & \multicolumn{2}{|l|}{ pulverización } \\
\hline
\end{tabular}



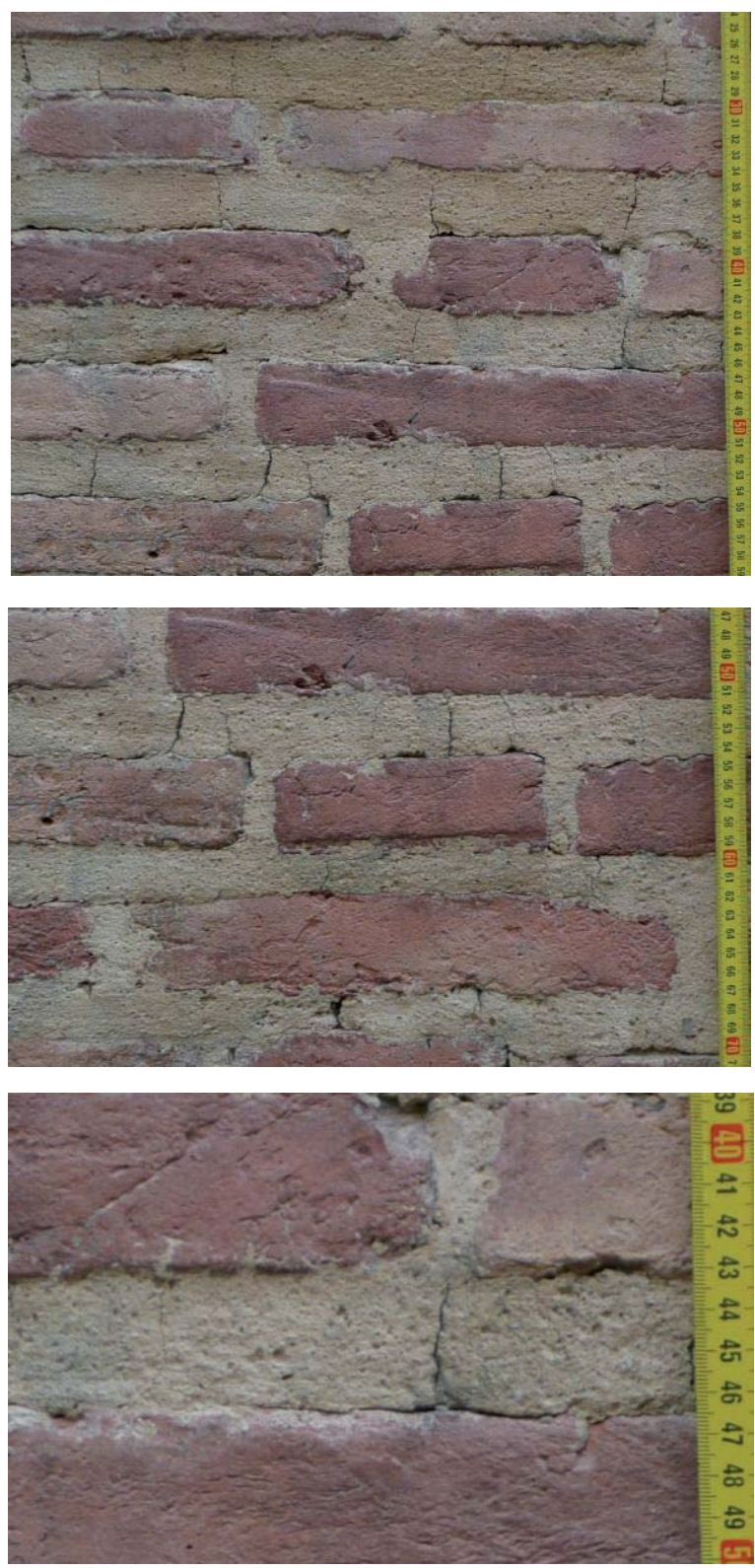

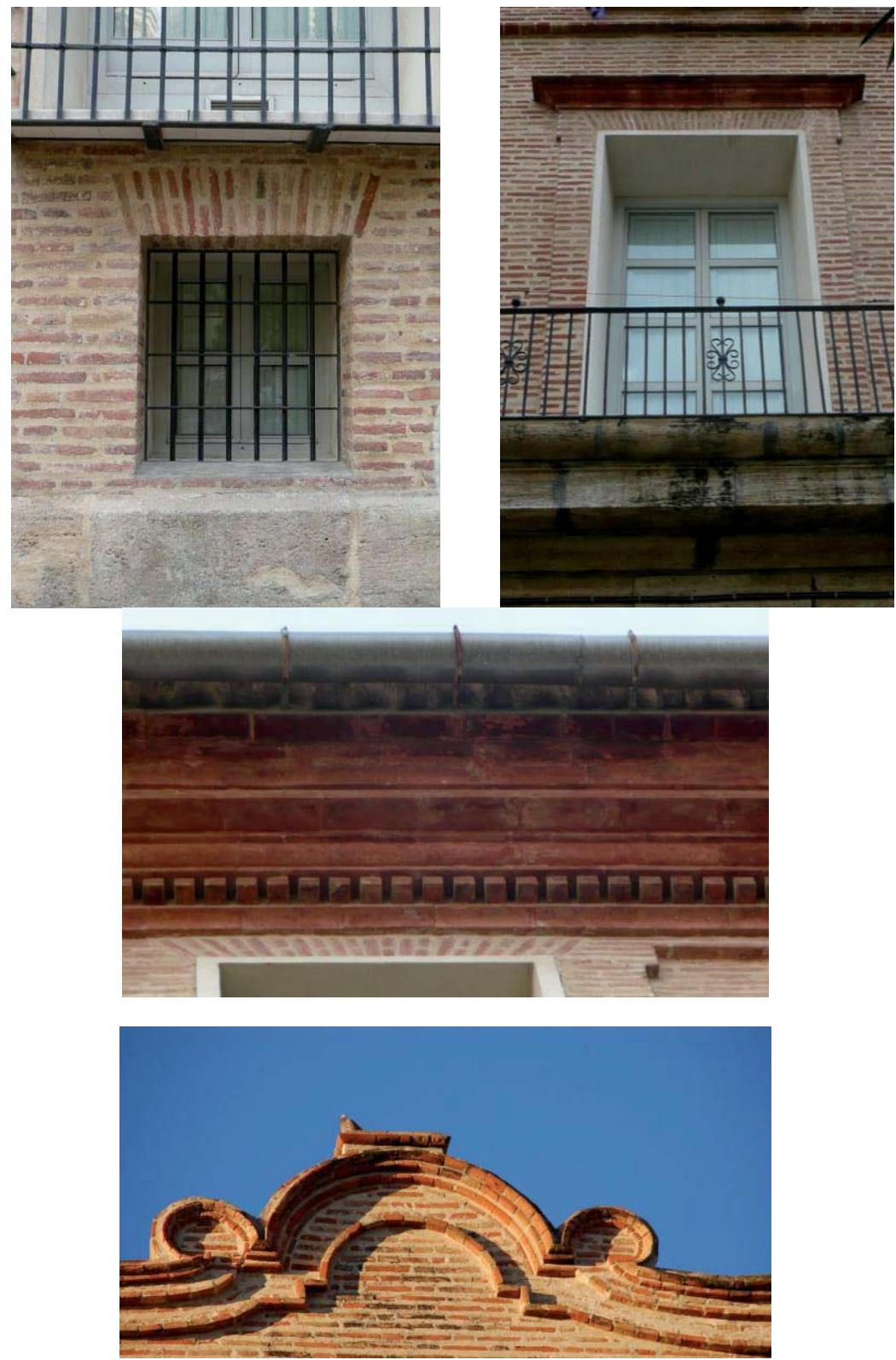
Datos generales

\begin{tabular}{|c|c|c|c|c|c|}
\hline Barrio & Carmen & La Seu-Xerea & Velluters & Mercat & S.Francesc \\
\hline Dirección & C/ D'En Bor & $n^{\circ} 8$ & & & \\
\hline Tipo de edificio & residencial & palaciego & religioso & militar & \\
\hline $\mathbf{G}^{\circ}$ de protección & 0 & 1 & 2 & 3 & \\
\hline Fechas claves & / & & & & \\
\hline
\end{tabular}

El apartado "fechas claves" se ha extraído de AA.V. ., Guía de Arquitectura de Valencia, Icaro CTAV Ed., Valencia, 2007
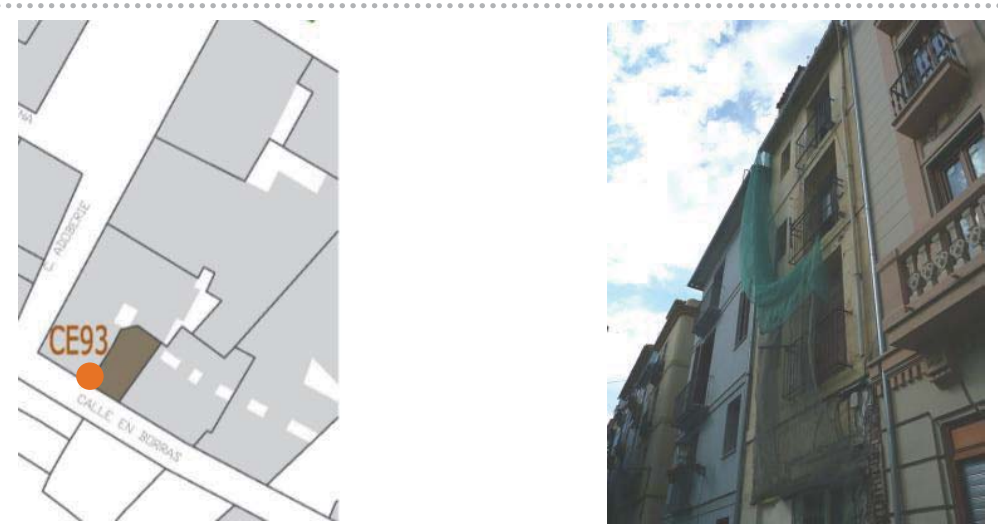

Fachada

Ce93

\begin{tabular}{|c|c|c|c|c|c|c|c|c|c|}
\hline \multirow{3}{*}{$\begin{array}{l}\text { Pisos } \\
\text { Composición fachada } \\
\text { Zócalo }\end{array}$} & \multicolumn{2}{|c|}{$\mathrm{N}^{0} 3$} & sótanc & \multicolumn{2}{|c|}{ entreplanta } & \multicolumn{4}{|c|}{ piso noble caja escalera } \\
\hline & \multicolumn{2}{|c|}{ aleatoria } & \multicolumn{3}{|c|}{ ordenada sin simetría } & \multicolumn{4}{|c|}{ ordenada con simetría } \\
\hline & $\mathrm{Z1}$ & $\mathrm{Z} 2$ & $\mathrm{Z3}$ & Z4 & Z5 & & & & \\
\hline Fábrica & $\mathrm{F} 1$ & $\mathrm{~F} 2$ & F3 & $\mathrm{F} 4$ & F5 & F6 & & & \\
\hline Vano/dintel & V1 & V2 & V3 & V4 & V5 & V7 & V8 & V9 & V10 \\
\hline Entrada/dintel & E1 & E2 & E3 & E4 & & & & & \\
\hline Alero & A1 & $\mathrm{A} 2$ & A3 & A4 & A5 & A7 & & & \\
\hline Cubierta & plar & & inclina & & & & & & \\
\hline
\end{tabular}

\section{Fábrica}

Ce93

\begin{tabular}{l|lll}
\hline Aparejo & soga-tizón & soga & \multicolumn{1}{c}{ tizón } \\
Hiladas & irregulares & pseudo horizontales & horizontales \\
\hline Superficie & sin planeidad & pseudo planeidad & planeidad perfecta \\
\hline Sección (hipótesis) & uniforme & hojas y núcleo & abocinada (vano) \\
Elementos destacados & aplantillado & cortado terracota & \\
\hline
\end{tabular}




\begin{tabular}{|c|c|c|c|}
\hline$N^{\circ}$ elementos medidos & 15 & & \\
\hline Longitud (cm) & 30.1 & & \\
\hline Anchura (cm) & 14.2 & & \\
\hline Espesor (cm) & 4.1 & & \\
\hline Volumen $\left(\mathrm{cm}^{3}\right)$ & 1752.4 & & \\
\hline Tipo & homogéneo & heterogéneo & re-empleo \\
\hline Color & homogéneo & heterogéneo globular & heterogéneo marmolado \\
\hline Recogida de muestra & no & sí & código Ce 93/1 \\
\hline Patologías & $\begin{array}{l}\text { eflorescencias } \\
\text { erosión }\end{array}$ & $\begin{array}{l}\text { micro fisuración } \\
\text { disgregación }\end{array}$ & $\begin{array}{l}\text { grietas } \\
\text { descamación }\end{array}$ \\
\hline
\end{tabular}

${ }^{1}$ Datos obtenidos en base al cálculo del desvío estándar (respecto al valor medio de la muestras analizadas) y del gráfico de frecuencia de las muestras analizadas, identificado por una curva gaussiana

\section{Juntas}

\begin{tabular}{|c|c|c|c|c|}
\hline \multirow{2}{*}{$\begin{array}{l}N^{0} \text { elementos medidos } \\
\text { Llaga }(\mathrm{cm})\end{array}$} & \multicolumn{4}{|l|}{15} \\
\hline & \multicolumn{4}{|l|}{1.5} \\
\hline Tendel (cm) & \multicolumn{4}{|l|}{3} \\
\hline Altura de 5 hiladas $(\mathrm{cm})$ & \multicolumn{4}{|l|}{35} \\
\hline Proporción ladrillo/junta & \multicolumn{4}{|l|}{1.36} \\
\hline Tipo de acabado & simple & doble & múltiple & \\
\hline Junta de asiento & $\begin{array}{l}\text { rehundida } \\
\text { enrasada }\end{array}$ & $\begin{array}{l}\text { a hueso } \\
\text { matada }\end{array}$ & saliente & \\
\hline Junta de acabado & $\begin{array}{l}\text { rehundida } \\
\text { enrasada }\end{array}$ & $\begin{array}{l}\text { a hueso } \\
\text { matada }\end{array}$ & saliente & \\
\hline Tipo de mortero & cal & cal y tierra & tierra & cemento mixto \\
\hline Morfología de mortero & con grumos & con caliches & homogéneo & heterogéneo \\
\hline Tipo de árido & arena & gravilla & grava & mixto \\
\hline Color del árido & claro & oscuro & homogéneo & heterogéneo \\
\hline Recogida de muestra & no & sí & código Ce 93/2 & \\
\hline Patologías & $\begin{array}{l}\text { eflorescencias } \\
\text { erosión }\end{array}$ & $\begin{array}{l}\text { micro fisuración } \\
\text { disgregación }\end{array}$ & $\begin{array}{l}\text { grietas } \\
\text { pulverización }\end{array}$ & \\
\hline
\end{tabular}


Imágenes

Ce93
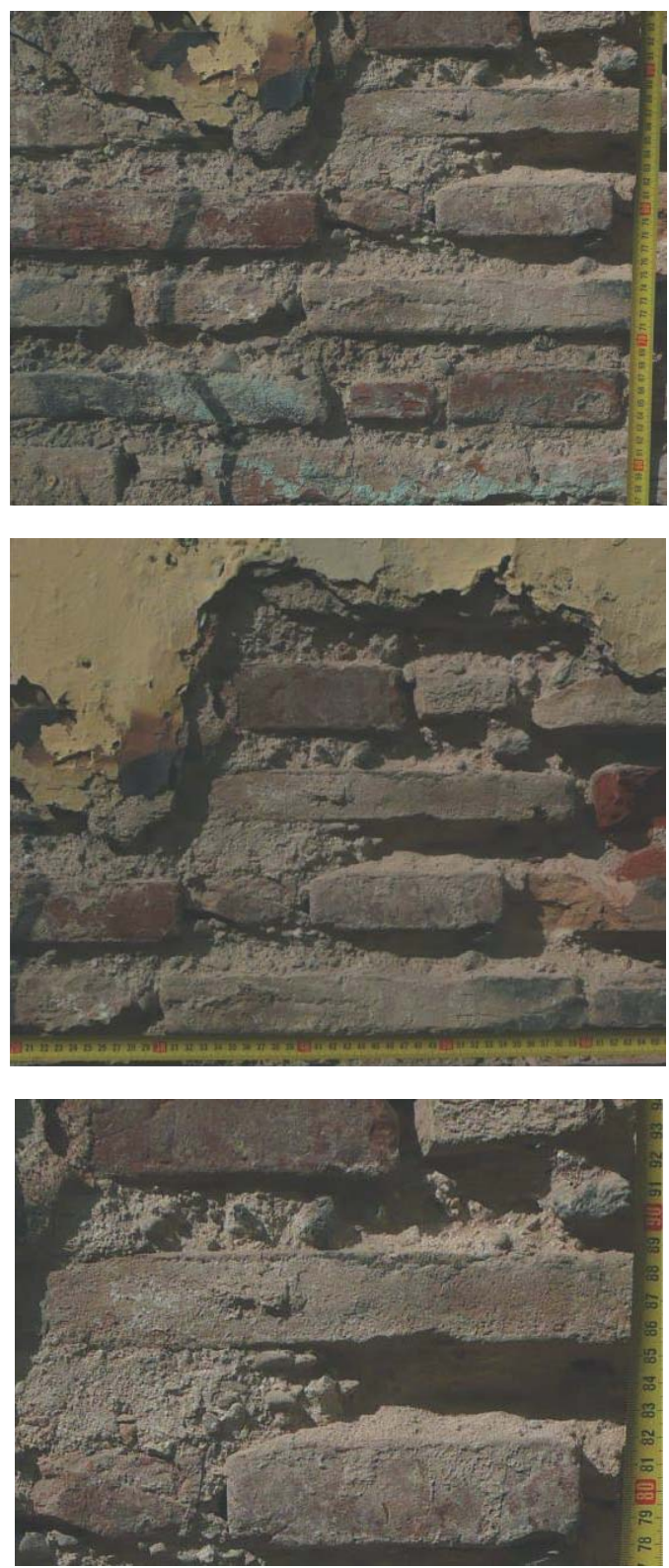

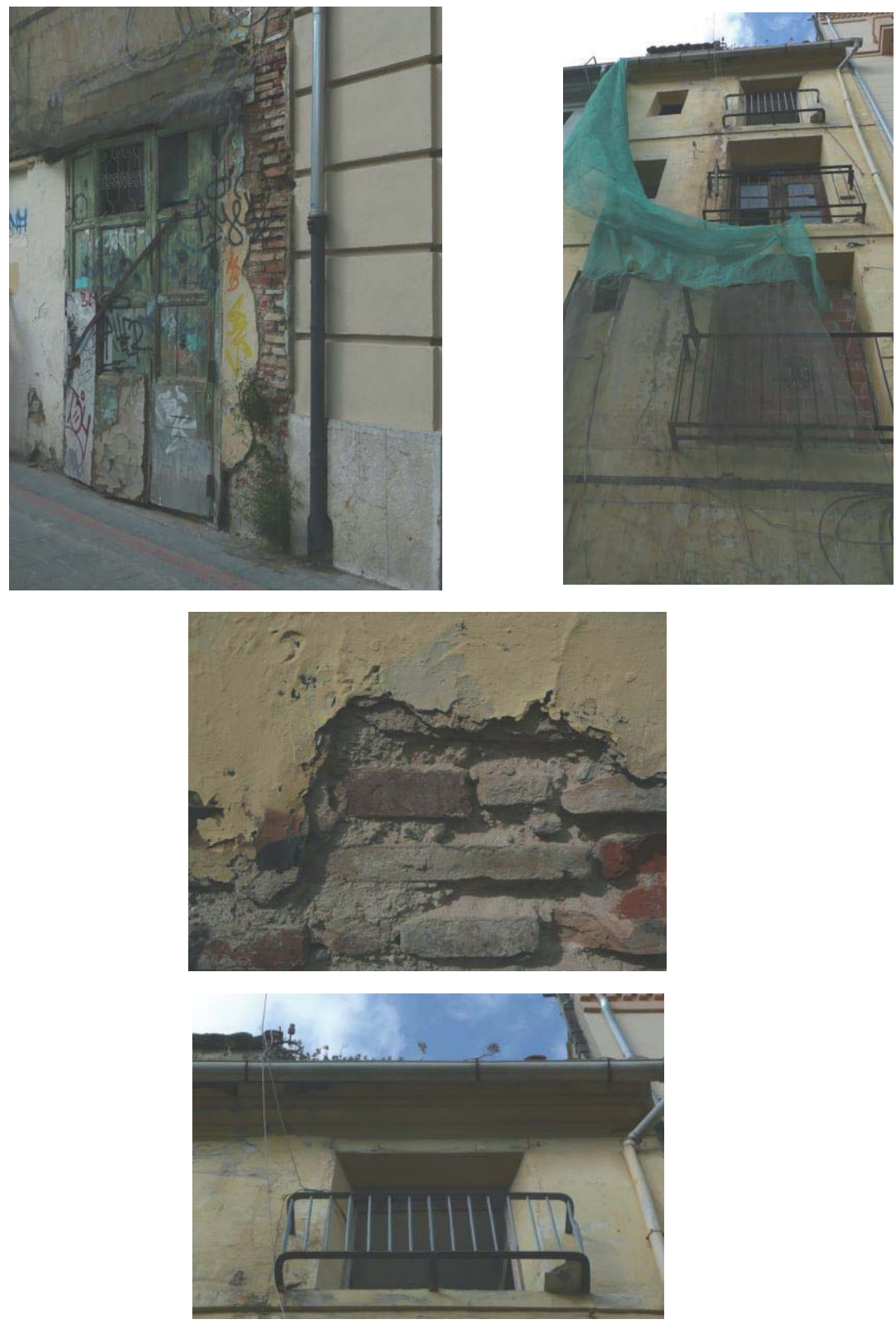
Datos generales

\begin{tabular}{|c|c|c|c|c|c|}
\hline Barrio & Carmen & La Seu-Xerea & Velluters & Mercat & S.Francesc \\
\hline Dirección & \multicolumn{5}{|c|}{ P.za Cruz s/n esquina C/Pintor Fillol } \\
\hline Tipo de edificio & residencial & palaciego & religioso & militar & \\
\hline $\mathbf{G}^{\circ}$ de protección & 0 & 1 & 2 & 3 & \\
\hline Fechas claves & / & & & & \\
\hline
\end{tabular}

El apartado "fechas claves" se ha extraído de AA.V.., Guía de Arquitectura de Valencia, Icaro CTAV Ed., Valencia, 2007

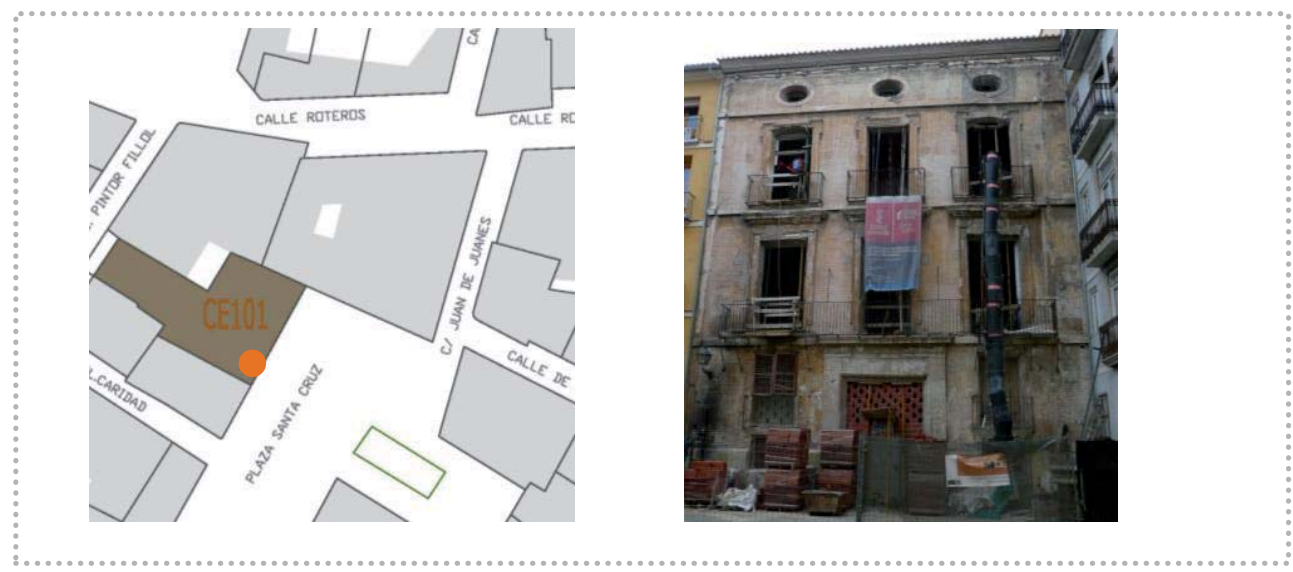

Fachada

Ce101

\begin{tabular}{|c|c|c|c|c|c|c|c|c|c|}
\hline \multirow{3}{*}{$\begin{array}{l}\text { Pisos } \\
\text { Composición fachada } \\
\text { Zócalo }\end{array}$} & \multicolumn{2}{|c|}{$N^{\circ} 3$} & sótano & \multicolumn{2}{|c|}{ entreplanta } & \multicolumn{4}{|c|}{ piso noble caja escalera } \\
\hline & \multicolumn{2}{|c|}{ aleatoria } & \multicolumn{3}{|c|}{ ordenada sin simetría } & \multicolumn{4}{|c|}{ ordenada con simetría } \\
\hline & $\mathrm{Z1}$ & $\mathrm{Z2}$ & Z3 & Z4 & Z5 & & & & \\
\hline Fábrica & $\mathrm{F} 1$ & $\mathrm{~F} 2$ & F3 & $\mathrm{F} 4$ & F5 & F6 & & & \\
\hline Vano/dintel & V1 & V2 & V3 & V4 & V5 & V7 & V8 & V9 & V10 \\
\hline Entrada/dintel & E1 & E2 & E3 & E4 & & & & & \\
\hline Alero & A1 & $\mathrm{A} 2$ & A3 & A4 & A5 & A7 & & & \\
\hline Cubierta & plar & & inclinac & & & & & & \\
\hline
\end{tabular}

\section{Fábrica}

Ce101

\begin{tabular}{l|lll}
\hline Aparejo & soga-tizón & soga & \multicolumn{1}{c}{ tizón } \\
Hiladas & irregulares & pseudo horizontales & horizontales \\
\hline Superficie & sin planeidad & pseudo planeidad & planeidad perfecta \\
\hline Sección (hipótesis) & uniforme & hojas y núcleo & abocinada (vano) \\
Elementos destacados & aplantillado & cortado terracota & \\
\hline
\end{tabular}




\begin{tabular}{|c|c|c|c|}
\hline$N^{\circ}$ elementos medidos & 15 & & \\
\hline Longitud (cm) & 30.1 & & \\
\hline Anchura (cm) & 14.2 & & \\
\hline Espesor (cm) & 4.1 & & \\
\hline Volumen $\left(\mathrm{cm}^{3}\right)$ & 1697.6 & & \\
\hline Tipo & homogéneo & heterogéneo & re-empleo \\
\hline Color & homogéneo & heterogéneo globular & heterogéneo marmolado \\
\hline Recogida de muestra & no & sí & Código Ce101/1 \\
\hline Patologías & $\begin{array}{l}\text { eflorescencias } \\
\text { erosión }\end{array}$ & $\begin{array}{l}\text { micro fisuración } \\
\text { disgregación }\end{array}$ & $\begin{array}{l}\text { grietas } \\
\text { descamación }\end{array}$ \\
\hline
\end{tabular}

1 Datos obtenidos en base al cálculo del desvío estándar (respecto al valor medio de la muestras analizadas) y del gráfico de frecuencia de las muestras analizadas, identificado por una curva gaussiana

\section{Juntas}

\begin{tabular}{|c|c|c|c|c|}
\hline \multirow{2}{*}{$\begin{array}{l}N^{\circ} \text { elementos medidos } \\
\text { Llaga }(\mathrm{cm})\end{array}$} & \multicolumn{4}{|l|}{15} \\
\hline & \multicolumn{4}{|l|}{1} \\
\hline Tendel (cm) & \multicolumn{4}{|l|}{4} \\
\hline Altura de 5 hiladas $(\mathrm{cm})$ & \multicolumn{4}{|l|}{36.3} \\
\hline Proporción ladrillo/junta & \multicolumn{4}{|l|}{1.02} \\
\hline Tipo de acabado & simple & doble & \multicolumn{2}{|l|}{ múltiple } \\
\hline \multirow[t]{2}{*}{ Junta de asiento } & rehundida & a hueso & \multirow{2}{*}{\multicolumn{2}{|c|}{ saliente }} \\
\hline & enrasada & matada & & \\
\hline \multirow[t]{2}{*}{ Junta de acabado } & rehundida & a hueso & \multirow{2}{*}{\multicolumn{2}{|c|}{ saliente }} \\
\hline & enrasada & matada & & \\
\hline \multirow{3}{*}{$\begin{array}{l}\text { Tipo de mortero } \\
\text { Morfología de mortero } \\
\text { Tipo de árido }\end{array}$} & cal & cal y tierra & tierra & cemento mixto \\
\hline & con grumos & con caliches & homogéneo & heterogéneo \\
\hline & arena & gravilla & grava & mixto \\
\hline \multirow{4}{*}{$\begin{array}{l}\text { Color del árido } \\
\text { Recogida de muestra } \\
\text { Patologías }\end{array}$} & claro & oscuro & homogéneo & heterogéneo \\
\hline & no & sí & \multicolumn{2}{|l|}{ código } \\
\hline & eflorescencias & micro fisuración & \multicolumn{2}{|l|}{ grietas } \\
\hline & erosión & disgregación & \multicolumn{2}{|l|}{ pulverización } \\
\hline
\end{tabular}


Imágenes
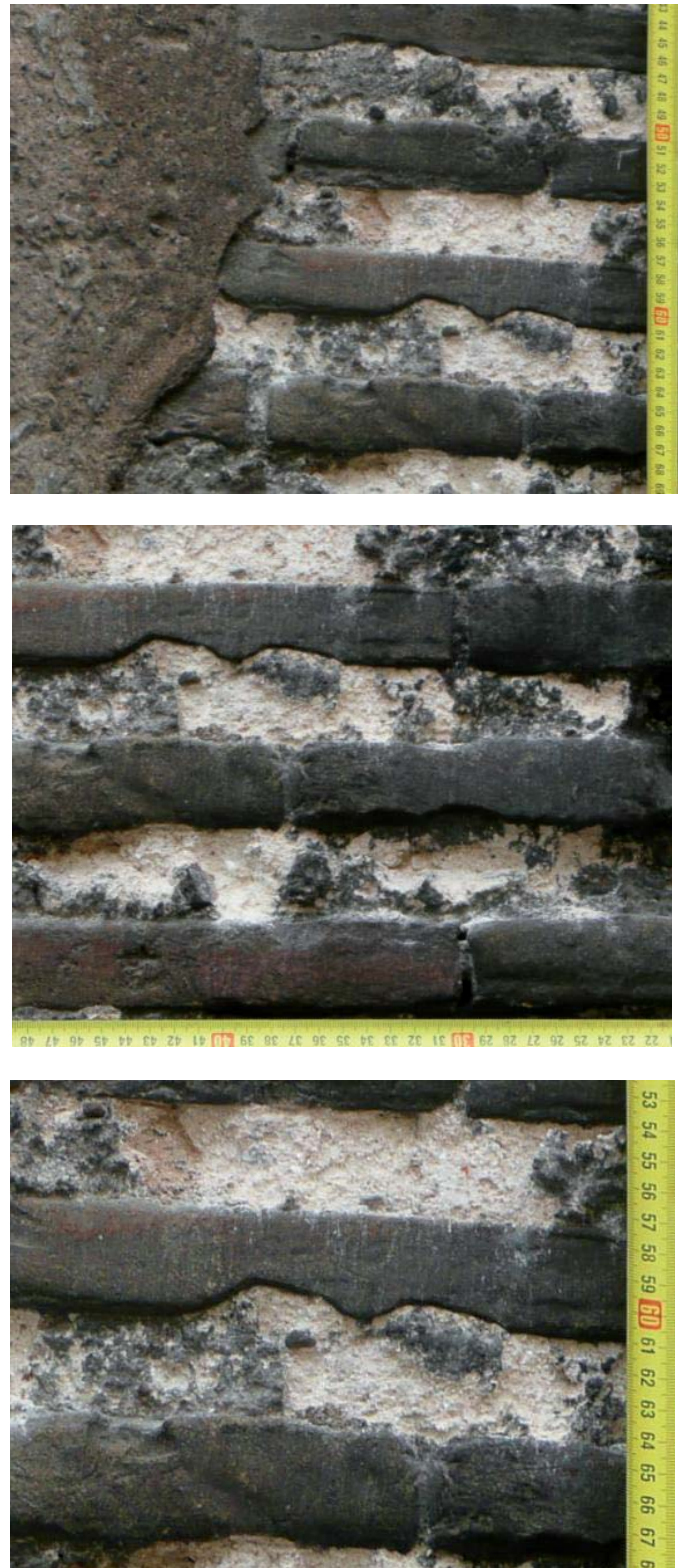


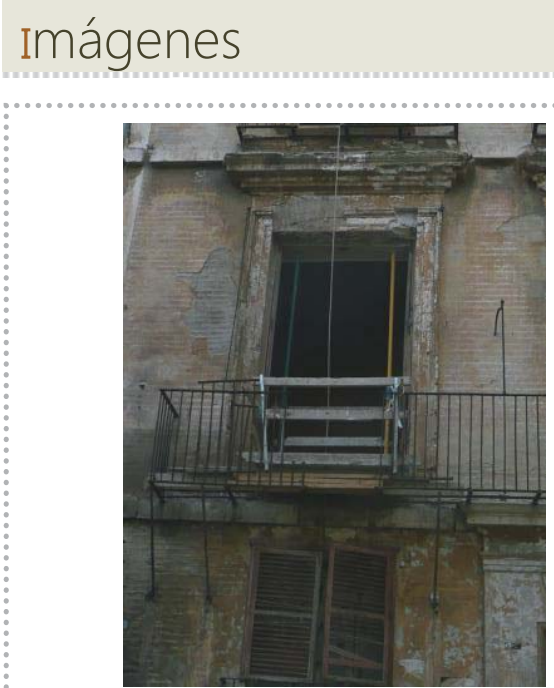

Ce101
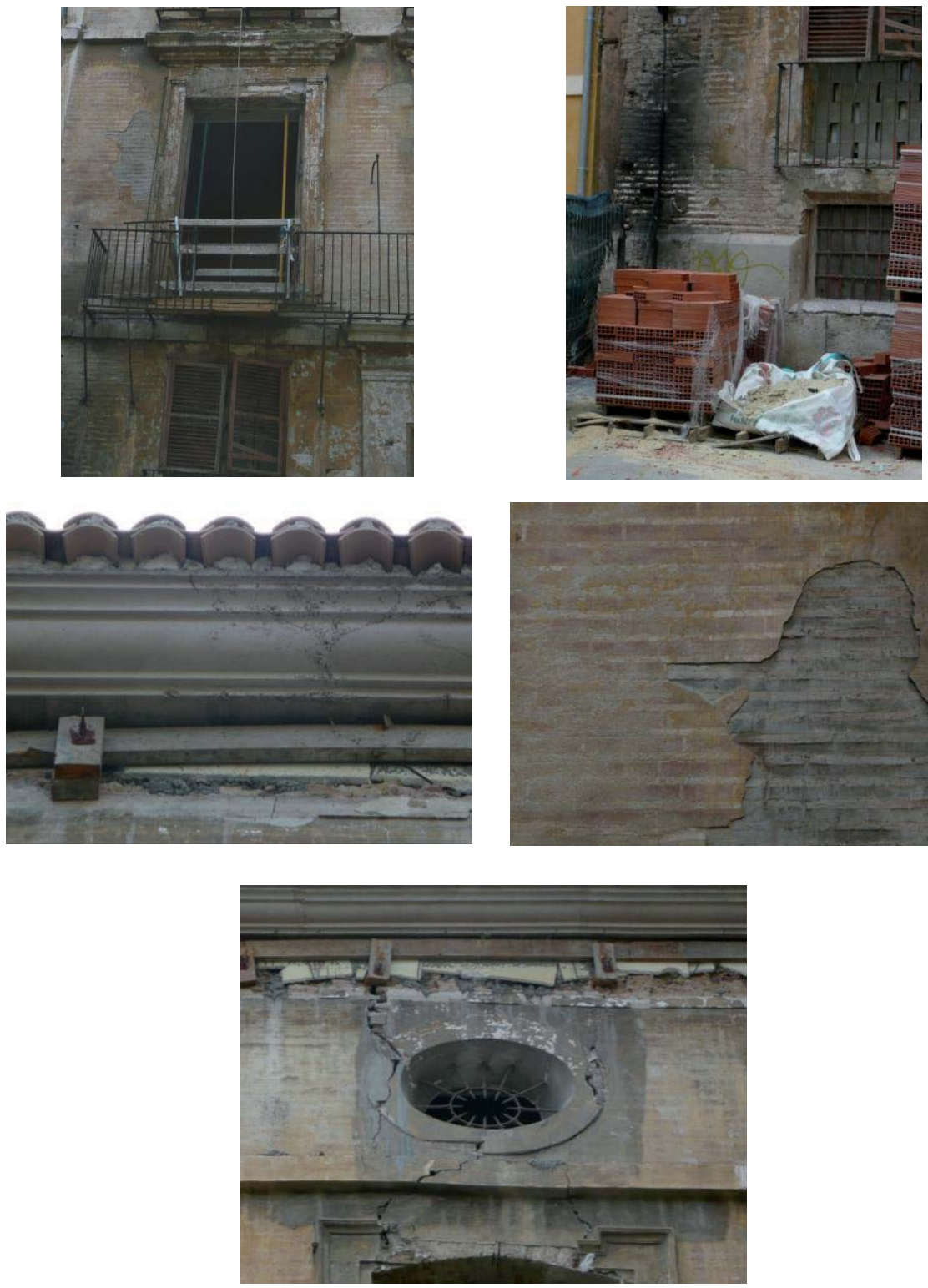
Datos generales

\begin{tabular}{l|lcccc} 
Barrio & Carmen & La Seu-Xerea & Velluters & Mercat & S.Francesc \\
\hline Dirección & Carrer dels Horts/Carrer Salvador Giner $\mathrm{n}^{\circ} \mathbf{1}$ & \\
Tipo de edificio & residencial & palaciego & religioso & militar \\
$\mathbf{G}^{\circ}$ de protección & 0 & 1 & 2 & 3 \\
Fechas claves & $/$ & & &
\end{tabular}

El apartado "fechas claves" se ha extraído de AA.V. ., Guía de Arquitectura de Valencia, Icaro CTAV Ed., Valencia, 2007
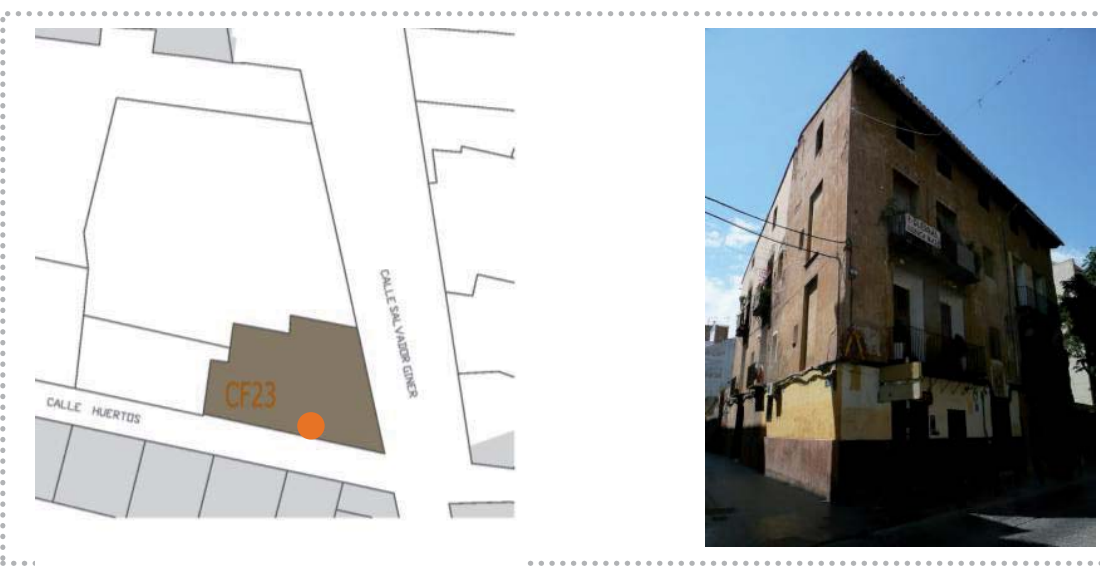

\section{Fachada}

Cf23

Pisos

Composición fachada

Zócalo

Fábrica

Vano/dintel

Entrada/dintel

Alero

Cubierta

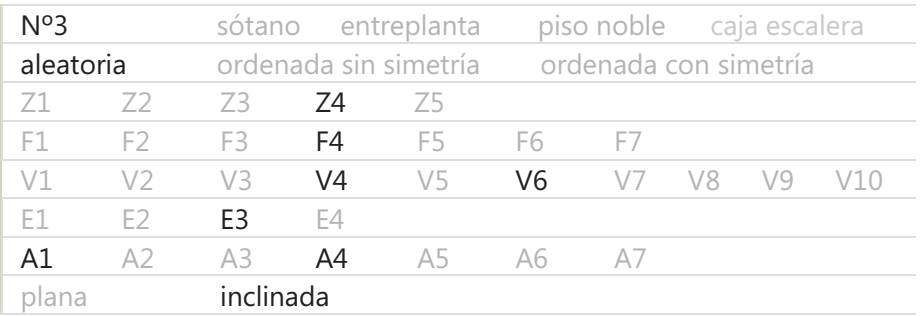

\section{Fábrica}

$\mathrm{Cf} 23$

\section{Aparejo \\ Hiladas \\ Superficie \\ Sección (hipótesis) \\ Elementos destacados}

\begin{tabular}{lll} 
soga-tizón & soga & \\
irregulares & tizón & \\
sin planeidad & pseudo planeidad & planeidad perfecta \\
\hline uniforme & hojas y núcleo & abocinada (vano) \\
aplantillado & cortado terracota & \\
\hline
\end{tabular}




\begin{tabular}{|c|c|c|c|}
\hline \multirow{2}{*}{$\begin{array}{l}N^{0} \text { elementos medidos } \\
\text { Longitud }(\mathrm{cm})\end{array}$} & \multicolumn{3}{|l|}{14} \\
\hline & \multicolumn{3}{|l|}{30} \\
\hline Anchura (cm) & \multicolumn{3}{|l|}{14} \\
\hline Espesor (cm) & \multicolumn{3}{|l|}{3.3} \\
\hline Volumen $\left(\mathrm{cm}^{3}\right)$ & \multicolumn{3}{|l|}{1386} \\
\hline Tipo & homogéneo & heterogéneo & re-empleo \\
\hline Color & homogéneo & heterogéneo globular & heterogéneo marmolado \\
\hline Recogida de muestra & no & sí & código \\
\hline \multirow[t]{2}{*}{ Patologías } & eflorescencias & micro fisuración & grietas \\
\hline & erosión & disgregación & descamación \\
\hline
\end{tabular}

${ }^{1}$ Datos obtenidos en base al cálculo del desvío estándar (respecto al valor medio de la muestras analizadas) y del gráfico de frecuencia de las muestras analizadas, identificado por una curva gaussiana

\section{Juntas}

\begin{tabular}{|c|c|c|c|c|}
\hline \multirow{2}{*}{$\begin{array}{l}N^{\circ} \text { elementos medidos } \\
\text { Llaga }(\mathrm{cm})\end{array}$} & \multicolumn{4}{|l|}{20} \\
\hline & \multicolumn{4}{|l|}{0.5} \\
\hline Tendel (cm) & \multicolumn{4}{|l|}{2.5} \\
\hline Altura de 5 hiladas $(\mathrm{cm})$ & \multicolumn{4}{|l|}{29} \\
\hline Proporción ladrillo/junta & \multicolumn{4}{|l|}{1.32} \\
\hline Tipo de acabado & simple & doble & \multicolumn{2}{|l|}{ múltiple } \\
\hline \multirow[t]{2}{*}{ Junta de asiento } & rehundida & a hueso & \multirow[t]{2}{*}{ saliente } & \\
\hline & enrasada & matada & & \\
\hline \multirow[t]{2}{*}{ Junta de acabado } & rehundida & a hueso & \multirow[t]{2}{*}{ saliente } & \\
\hline & enrasada & matada & & \\
\hline \multirow{2}{*}{$\begin{array}{l}\text { Tipo de mortero } \\
\text { Morfología de mortero }\end{array}$} & cal & cal y tierra & tierra & cemento mixto \\
\hline & con grumos & con caliches & homogéneo & heterogéneo \\
\hline \multirow{5}{*}{$\begin{array}{l}\text { Tipo de árido } \\
\text { Color del árido } \\
\text { Recogida de muestra } \\
\text { Patologías }\end{array}$} & arena & gravilla & grava & mixto \\
\hline & claro & oscuro & homogéneo & heterogéneo \\
\hline & no & sí & \multicolumn{2}{|l|}{ código } \\
\hline & eflorescencias & micro fisuración & \multicolumn{2}{|l|}{ grietas } \\
\hline & erosión & disgregación & \multicolumn{2}{|l|}{ pulverización } \\
\hline
\end{tabular}


Imágenes

Cf23
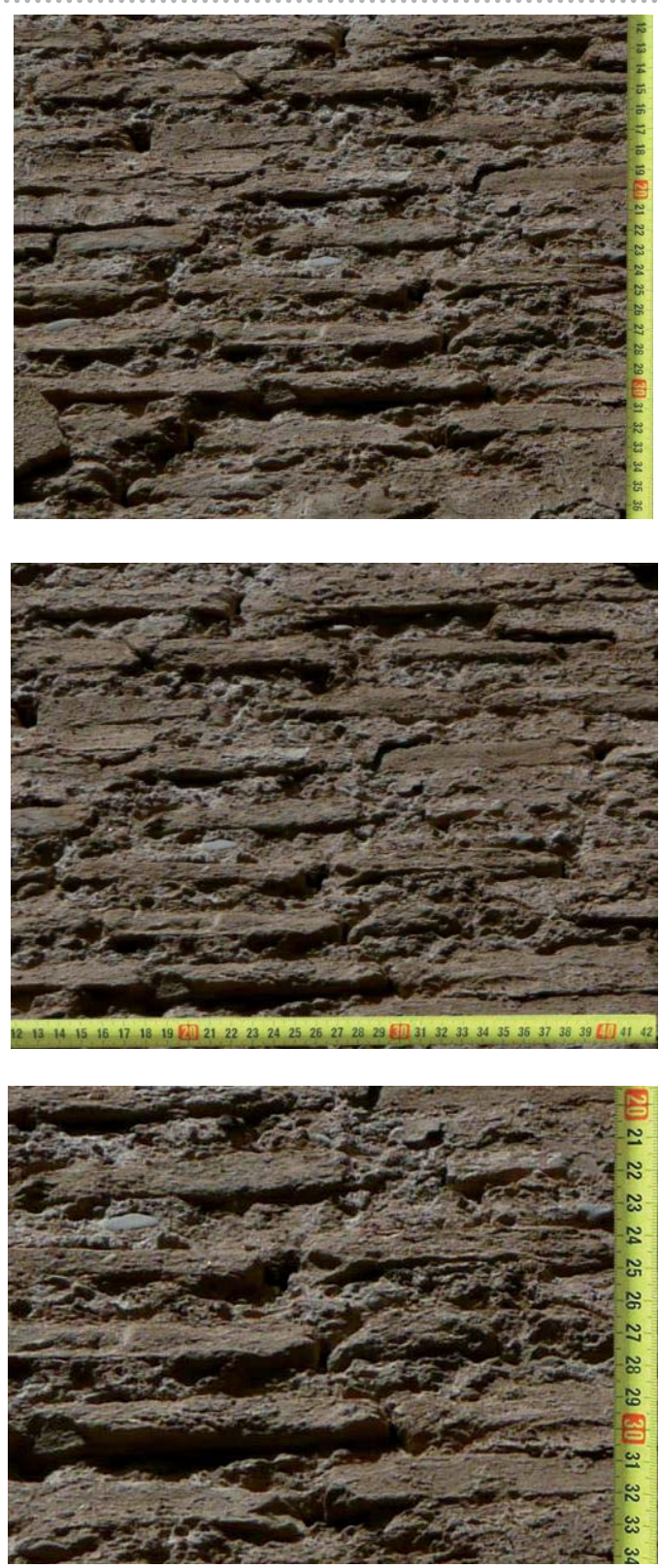

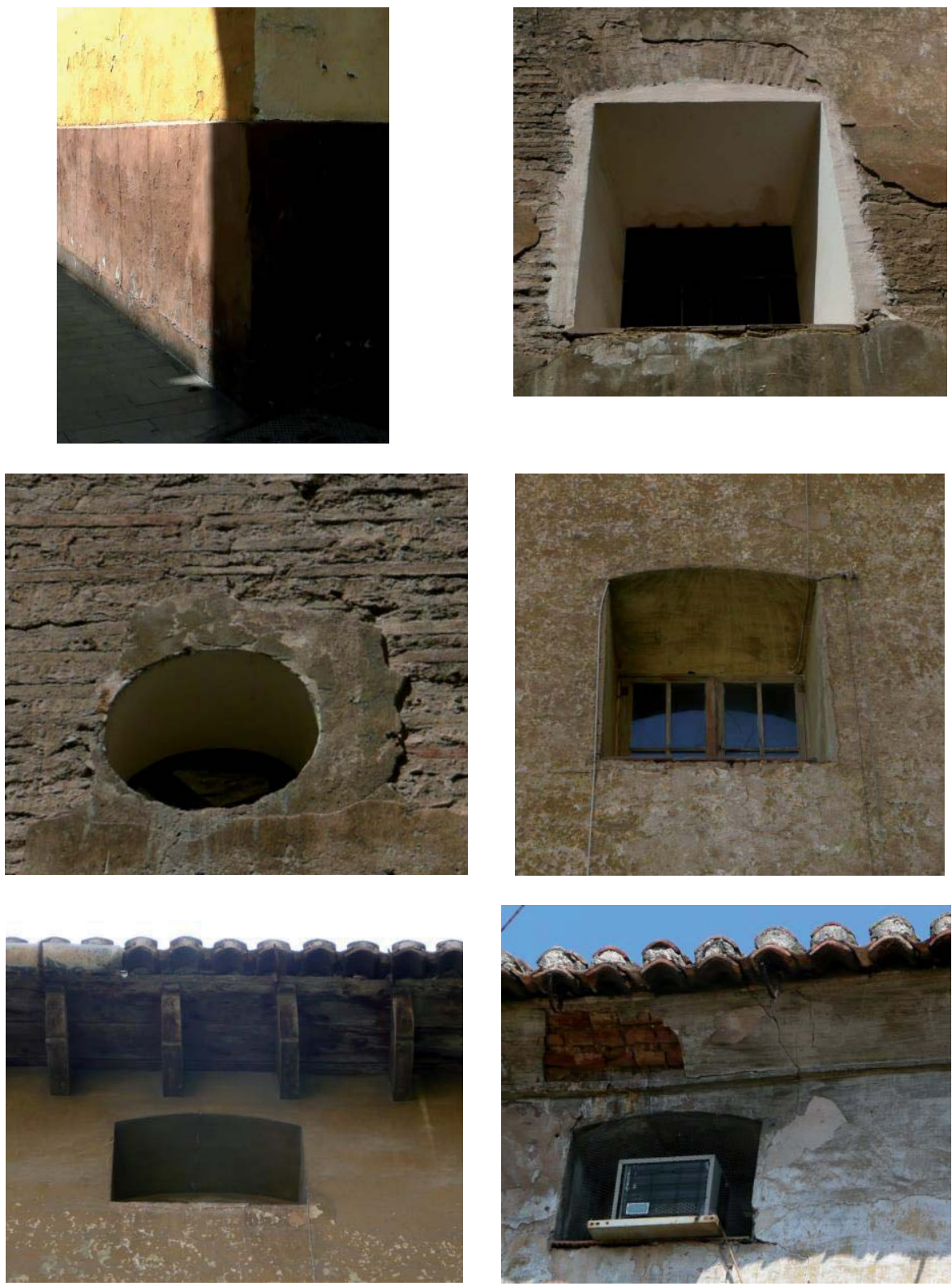
Datos generales

\begin{tabular}{|c|c|c|c|c|c|}
\hline Barrio & Carmen & La Seu-Xerea & Velluters & Mercat & S.Francesc \\
\hline Dirección & C/ dels Hor & $n^{\circ} 1-2$ & & & \\
\hline Tipo de edificio & residencial & palaciego & religioso & militar & \\
\hline $\mathbf{G}^{\circ}$ de protección & 0 & 1 & 2 & 3 & \\
\hline Fechas claves & / & & & & \\
\hline
\end{tabular}
El apartado "fechas claves" se ha extraído de AA.V. ., Guía de Arquitectura de Valencia, Icaro CTAV Ed., Valencia, 2007

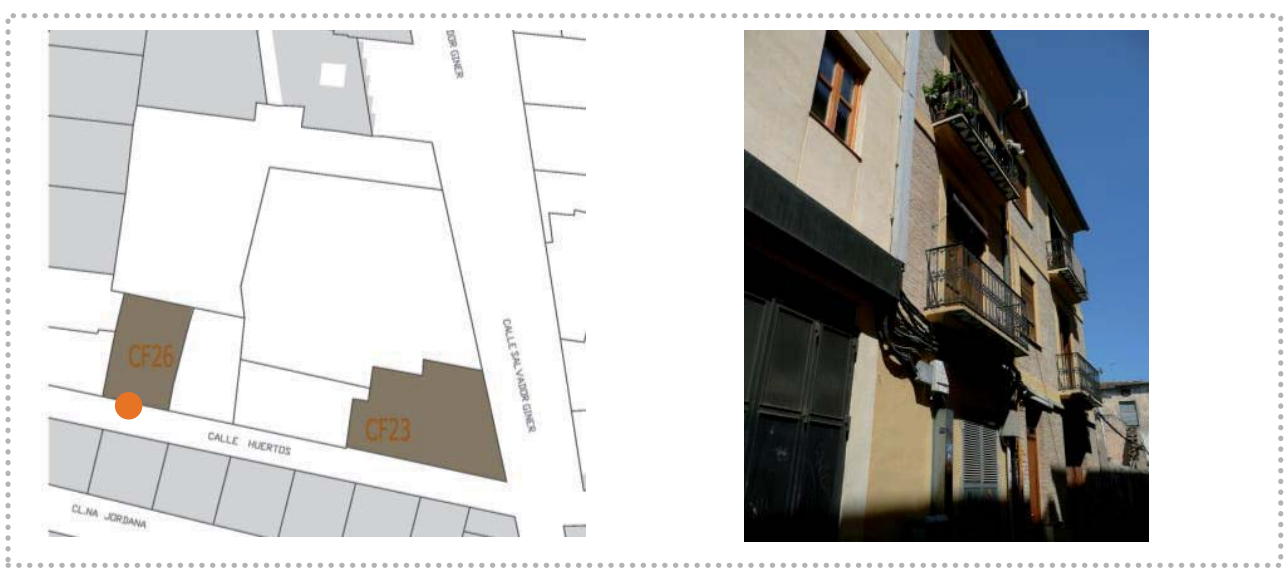

\section{Fachada}

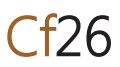

\section{Pisos \\ Composición fachada \\ Zócalo \\ Fábrica \\ Vano/dintel \\ Entrada/dintel \\ Alero \\ Cubierta}

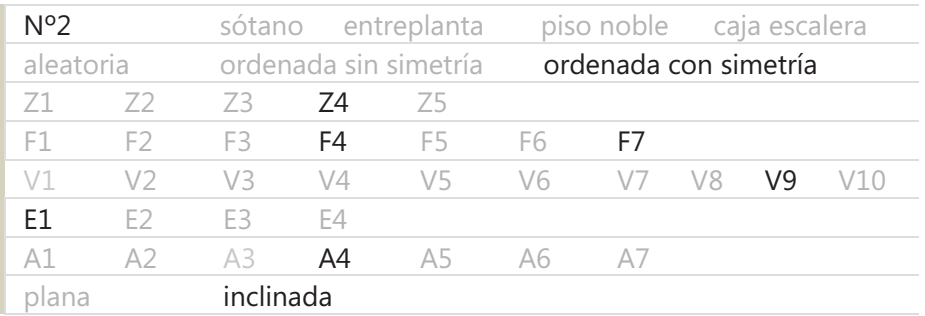

\section{Fábrica}

Cf26

\section{Aparejo \\ Hiladas \\ Superficie \\ Sección (hipótesis) \\ Elementos destacados}

\begin{tabular}{lll} 
soga-tizón & soga & \multicolumn{1}{c}{ tizón } \\
irregulares & pseudo horizontales & horizontales \\
\hline sin planeidad & pseudo planeidad & planeidad perfecta \\
\hline uniforme & hojas y núcleo & abocinada (vano) \\
aplantillado & cortado terracota & \\
\hline
\end{tabular}




$\begin{array}{llll}\begin{array}{l}\text { No elementos medidos } \\ \text { Longitud }(\mathbf{c m})\end{array} & 15 & & \\ \text { Anchura }(\mathbf{c m}) & 27.5 & & \\ \text { Espesor }(\mathbf{c m}) & 12.3 & & \\ \text { Volumen }\left(\mathbf{c m}^{\mathbf{3}}\right) & 3.5 & \text { heterogéneo } & \text { re-empleo } \\ \text { Tipo } & 1183.8 & \text { heterogéneo globular } & \text { heterogéneo marmolado } \\ \text { Color } & \text { homogéneo } & \text { síno } & \text { código } \\ \text { Recogida de muestra } & \text { no } & \text { micro fisuración } & \text { grietas } \\ \text { Patologías } & \text { eflorescencias } & \text { disgregación } & \text { descamación } \\ & \text { erosión } & \text { dióneo } & \end{array}$

1 Datos obtenidos en base al cálculo del desvío estándar (respecto al valor medio de la muestras analizadas) y del gráfico de frecuencia de las muestras analizadas, identificado por una curva gaussiana

\section{Juntas}

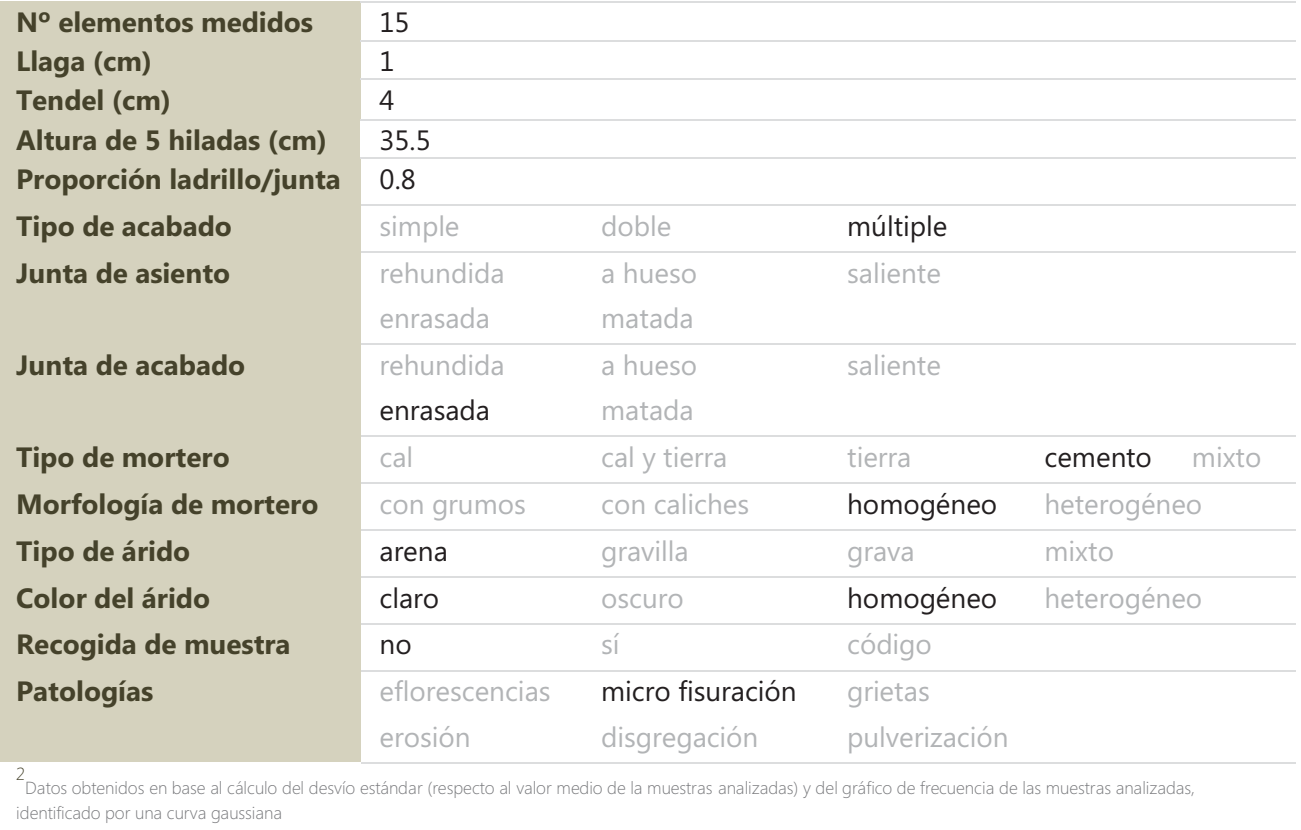


Imágenes
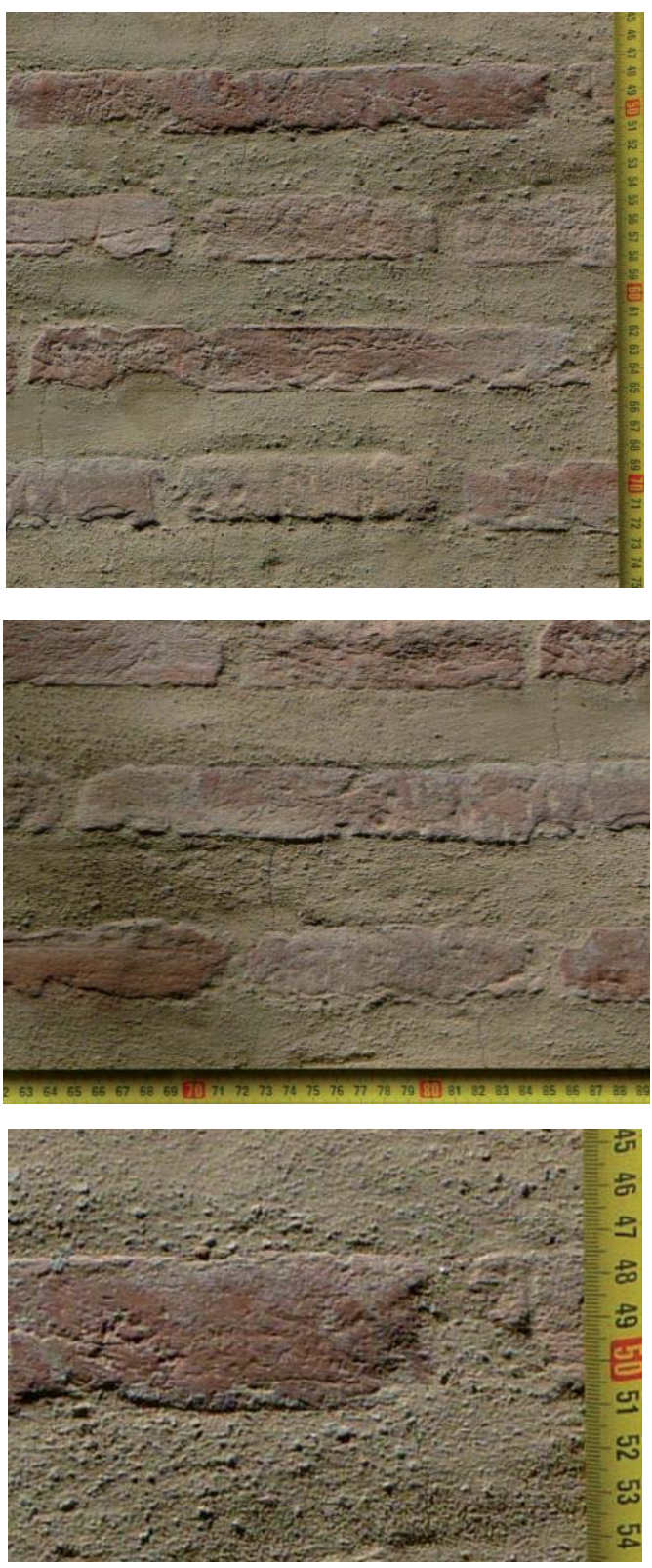

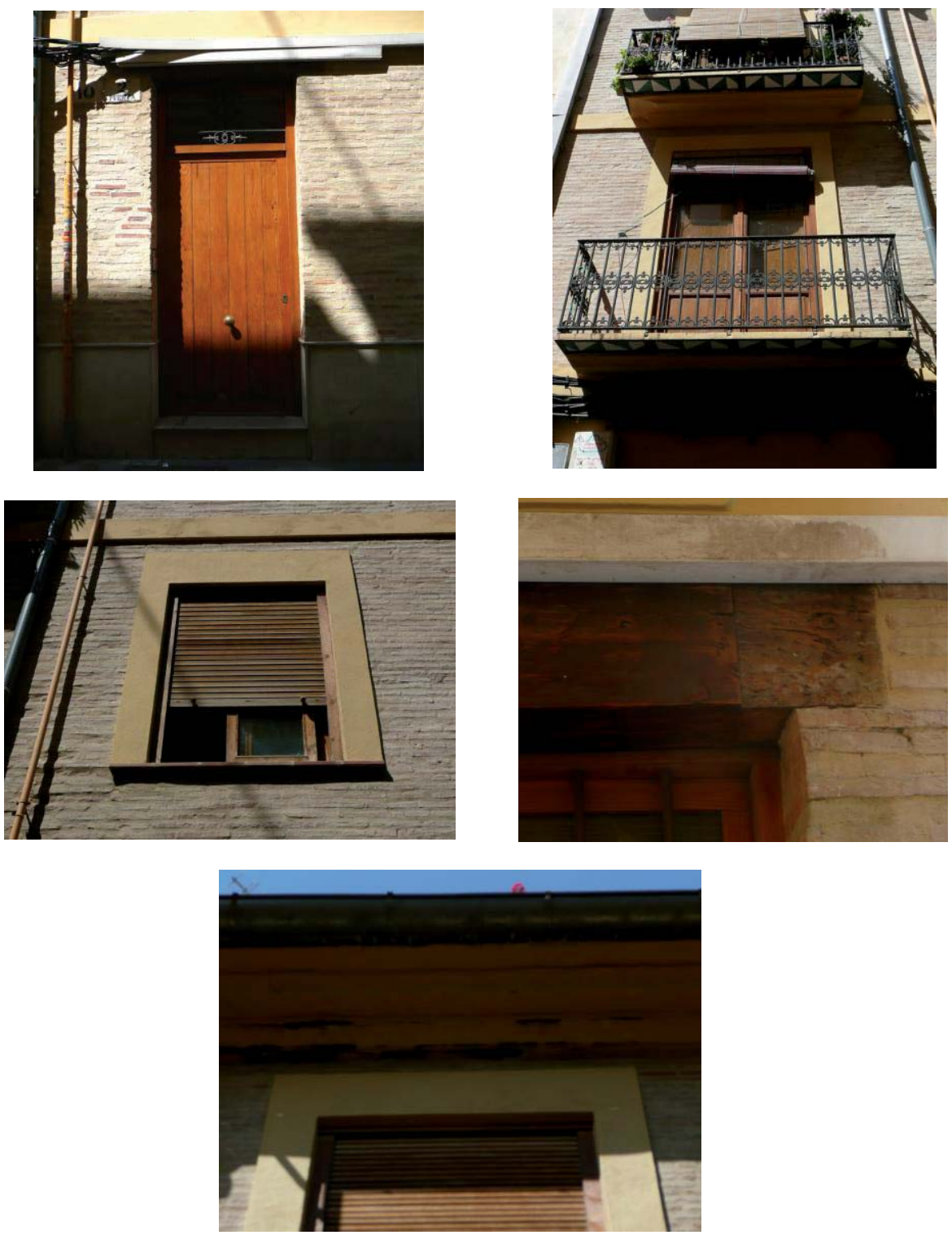
Datos generales

\begin{tabular}{|c|c|c|c|c|c|}
\hline Barrio & Carmen & La Seu-Xerea & Velluters & Mercat & S.Francesc \\
\hline Dirección & C/Gutembe & $s / n$ & & & \\
\hline Tipo de edificio & residencial & palaciego & religioso & militar & \\
\hline $\mathbf{G}^{\circ}$ de protección & 0 & 1 & 2 & 3 & \\
\hline Fechas claves & / & & & & \\
\hline
\end{tabular}
El apartado "fechas claves" se ha extraído de AA.V. ., Guía de Arquitectura de Valencia, Icaro CTAV Ed., Valencia, 2007
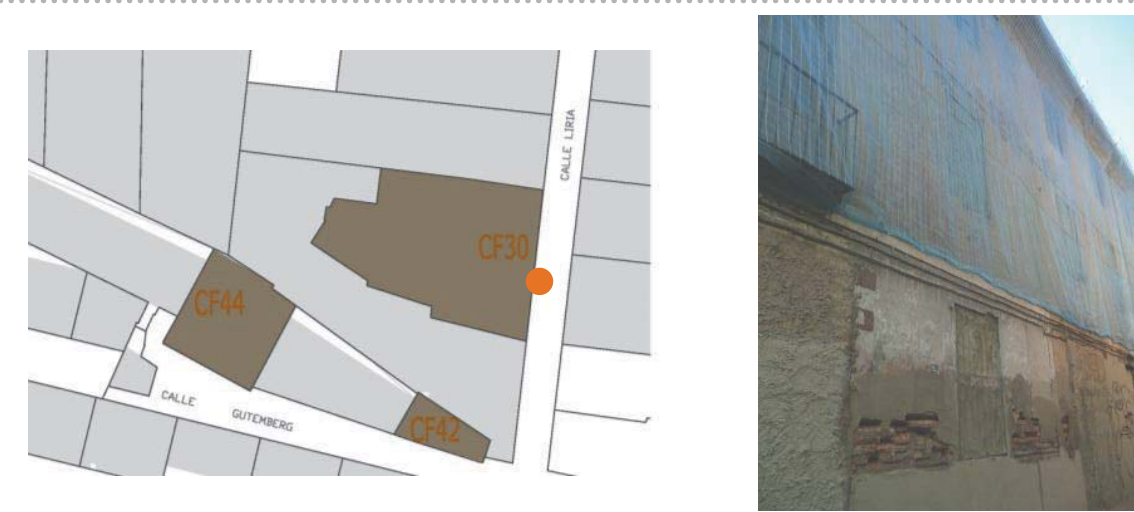

Fachada

$\mathrm{Cf30}$

\begin{tabular}{|c|c|c|c|c|c|c|c|c|c|}
\hline \multirow{3}{*}{$\begin{array}{l}\text { Pisos } \\
\text { Composición fachada } \\
\text { Zócalo }\end{array}$} & \multicolumn{2}{|c|}{$\mathrm{N}^{0} 2$} & sótano & \multicolumn{2}{|c|}{ entreplanta } & \multicolumn{4}{|c|}{ piso noble caja escalera } \\
\hline & \multicolumn{2}{|c|}{ aleatoria } & \multicolumn{3}{|c|}{ ordenada sin simetría } & \multicolumn{4}{|c|}{ ordenada con simetría } \\
\hline & $\mathrm{Z1}$ & $\mathrm{Z2}$ & $\mathrm{Z3}$ & Z4 & $\mathrm{Z} 5$ & & & & \\
\hline Fábrica & F1 & F2 & F3 & F4 & F5 & F6 & & & \\
\hline Vano/dintel & V1 & V2 & V3 & V4 & V5 & V6 & V8 & V9 & V10 \\
\hline Entrada/dintel & E1 & E2 & E3 & E4 & & & & & \\
\hline Alero & A1 & $A 2$ & $\mathrm{~A} 3$ & A4 & A5 & A6 & & & \\
\hline Cubierta & pla & & inclina & & & & & & \\
\hline
\end{tabular}

\section{Fábrica}

$\mathrm{Cf30}$

\section{Aparejo \\ Hiladas \\ Superficie \\ Sección (hipótesis) \\ Elementos destacados}

\begin{tabular}{lll} 
soga-tizón & soga & \multicolumn{1}{c}{ tizón } \\
irregulares & pseudo horizontales & horizontales \\
sin planeidad & pseudo planeidad & planeidad perfecta \\
\hline uniforme & hojas y núcleo & abocinada (vano) \\
aplantillado & cortado terracota & \\
\hline
\end{tabular}




\begin{tabular}{|c|c|c|c|}
\hline \multirow{2}{*}{$\begin{array}{l}\mathrm{N}^{\circ} \text { elementos medidos } \\
\text { Longitud }(\mathrm{cm})\end{array}$} & \multicolumn{3}{|l|}{15} \\
\hline & \multicolumn{3}{|l|}{28} \\
\hline Anchura (cm) & \multicolumn{3}{|l|}{12.5} \\
\hline Espesor (cm) & \multicolumn{3}{|l|}{3.5} \\
\hline Volumen $\left(\mathrm{cm}^{3}\right)$ & \multicolumn{3}{|l|}{1225} \\
\hline Tipo & homogéneo & heterogéneo & re-empleo \\
\hline \multirow{4}{*}{$\begin{array}{l}\text { Color } \\
\text { Recogida de muestra } \\
\text { Patologías }\end{array}$} & homogéneo & heterogéneo globular & heterogéneo marmolado \\
\hline & no & sí & código Cf 30/1 \\
\hline & eflorescencias & micro fisuración & grietas \\
\hline & erosión & disgregación & descamación \\
\hline
\end{tabular}

${ }^{1}$ Datos obtenidos en base al cálculo del desvío estándar (respecto al valor medio de la muestras analizadas) y del gráfico de frecuencia de las muestras analizadas, identificado por una curva gaussiana

\section{untas 2}

\begin{tabular}{|c|c|c|c|c|}
\hline \multirow{2}{*}{$\begin{array}{l}N^{\circ} \text { elementos medidos } \\
\text { Llaga }(\mathrm{cm})\end{array}$} & \multicolumn{4}{|l|}{15} \\
\hline & \multicolumn{4}{|l|}{0.3} \\
\hline Tendel (cm) & \multicolumn{4}{|l|}{4} \\
\hline Altura de 5 hiladas $(\mathrm{cm})$ & \multicolumn{4}{|l|}{35.5} \\
\hline Proporción ladrillo/junta & \multicolumn{4}{|l|}{0.8} \\
\hline Tipo de acabado & simple & doble & múltiple & \\
\hline \multirow[t]{2}{*}{ Junta de asiento } & rehundida & a hueso & saliente & \\
\hline & enrasada & matada & & \\
\hline \multirow{2}{*}{ Junta de acabado } & rehundida & a hueso & saliente & \\
\hline & enrasada & matada & & \\
\hline \multirow{2}{*}{$\begin{array}{l}\text { Tipo de mortero } \\
\text { Morfología de mortero }\end{array}$} & cal & cal y tierra & tierra & cemento mixto \\
\hline & con grumos & con caliches & homogéneo & heterogéneo \\
\hline Tipo de árido & arena & gravilla & grava & mixto \\
\hline \multirow{4}{*}{$\begin{array}{l}\text { Color del árido } \\
\text { Recogida de muestra } \\
\text { Patologías }\end{array}$} & claro & oscuro & homogéneo & heterogéneo \\
\hline & no & sí & \multicolumn{2}{|l|}{ Código Cf30/2 } \\
\hline & eflorescencias & micro fisuración & \multicolumn{2}{|l|}{ grietas } \\
\hline & erosión & disgregación & \multicolumn{2}{|l|}{ pulverización } \\
\hline
\end{tabular}


Imágenes
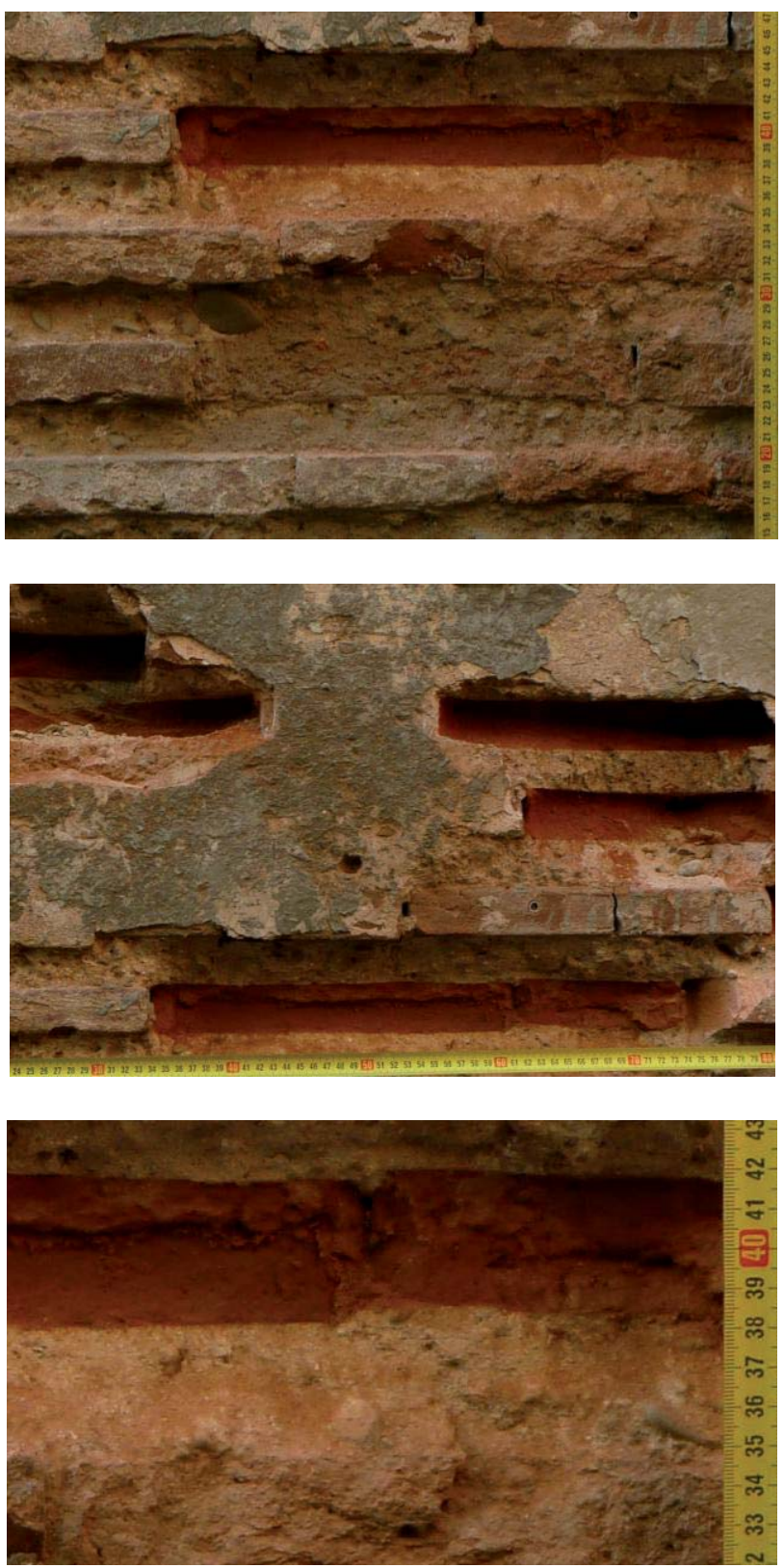

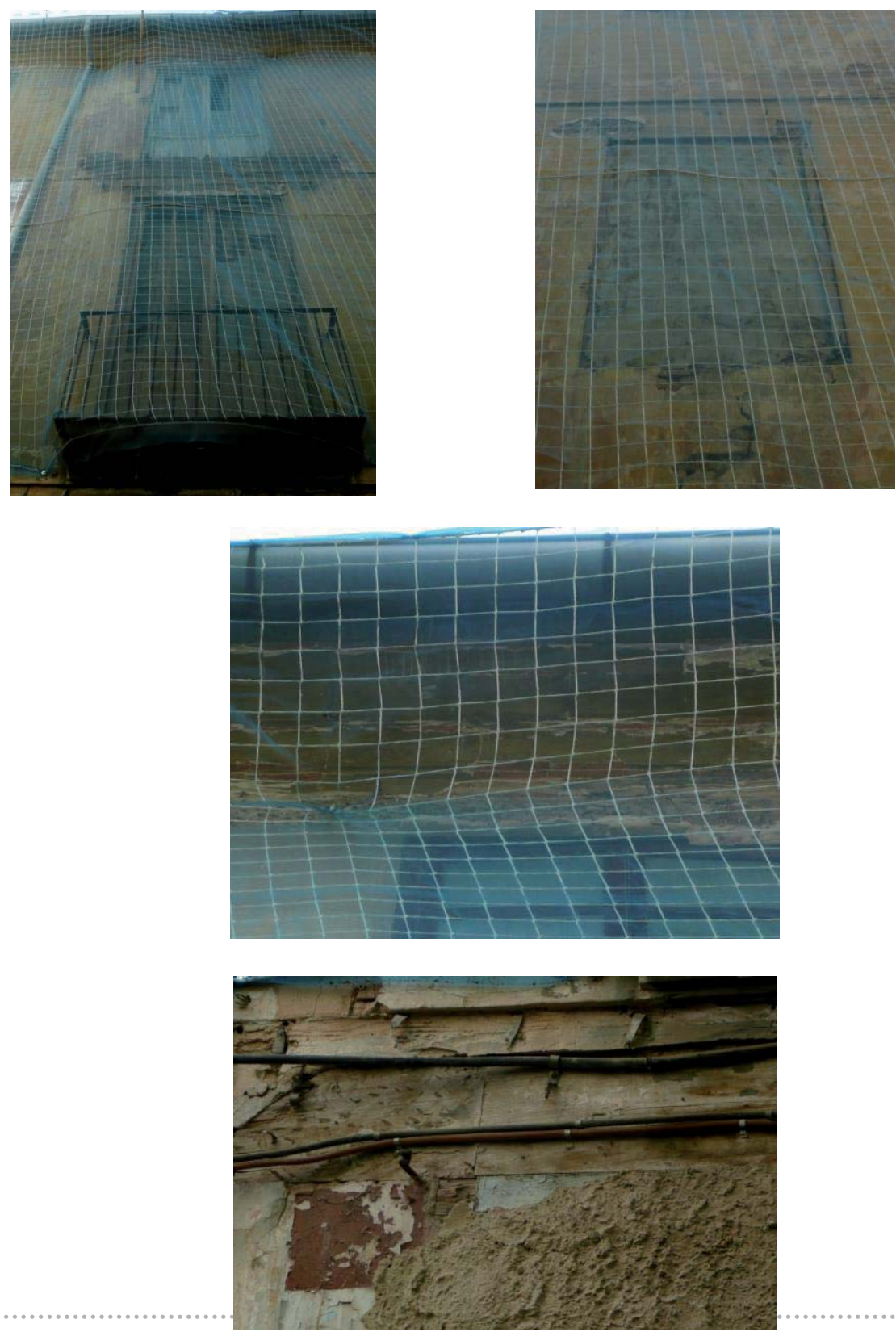


\begin{tabular}{|c|c|c|c|c|c|}
\hline Barrio & Carmen & La Seu-Xerea & Velluters & Mercat & S.Francesc \\
\hline Dirección & C/Gutembe & $s / n$; esquina & ria $s / n$ & & \\
\hline Tipo de edificio & residencial & palaciego & religioso & militar & \\
\hline $\mathbf{G}^{\circ}$ de protección & 0 & 1 & 2 & 3 & \\
\hline Fechas claves & / & & & & \\
\hline
\end{tabular}
El apartado "fechas claves" se ha extraído de AA.V., Guía de Arquitectura de Valencia, Icaro CTAV Ed., Valencia, 2007
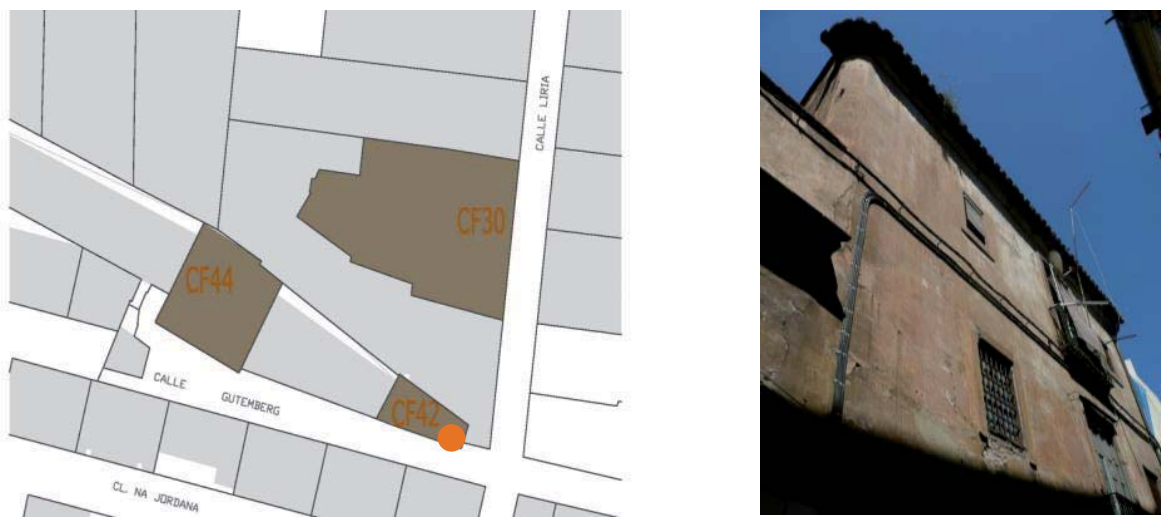

Fachada

\section{Pisos \\ Composición fachada \\ Zócalo \\ Fábrica \\ Vano/dintel \\ Entrada/dintel \\ Alero \\ Cubierta}

\begin{tabular}{|c|c|c|c|c|c|c|c|c|}
\hline \multicolumn{2}{|c|}{$\mathrm{N}^{\circ} 2$} & sótano & & planta & \multicolumn{4}{|c|}{ piso noble caja escalera } \\
\hline \multicolumn{2}{|c|}{ aleatoria } & \multicolumn{3}{|c|}{ ordenada sin simetría } & \multicolumn{4}{|c|}{ ordenada con simetría } \\
\hline Z1 & $\mathrm{Z} 2$ & Z3 & Z4 & $\mathrm{Z} 5$ & & & & \\
\hline $\mathrm{F} 1$ & $\mathrm{~F} 2$ & F3 & F4 & F5 & F6 & & & \\
\hline V1 & V2 & V3 & V4 & V5 & V7 & V8 & V9 & V10 \\
\hline E1 & E2 & E3 & E4 & & & & & \\
\hline A1 & $\mathrm{A} 2$ & $\mathrm{~A} 3$ & A4 & A5 & A7 & & & \\
\hline plar & & inclin & & & & & & \\
\hline
\end{tabular}

\section{Fábrica}

\begin{tabular}{|c|c|c|c|}
\hline Aparejo & soga-tizón & tizón & \\
\hline Hiladas & irregulares & pseudo horizontales & horizontales \\
\hline Superficie & sin planeidad & pseudo planeidad & planeidad perfecta \\
\hline Sección (hipótesis) & uniforme & hojas y núcleo & abocinada (vano) \\
\hline Elementos destacados & aplantillado & terracota & \\
\hline
\end{tabular}




\begin{tabular}{l|lll}
$\begin{array}{l}\text { No elementos medidos } \\
\text { Longitud }(\mathbf{c m})\end{array}$ & 15 & & \\
Anchura $(\mathbf{c m})$ & 28.2 & & \\
Espesor $(\mathbf{c m})$ & 12.5 & & \\
Volumen $\left(\mathbf{c m}^{\mathbf{3}}\right)$ & 3.5 & heterogéneo & re-empleo \\
Tipo & 1233.75 & heterogéneo globular & heterogéneo marmolado \\
Color & homogéneo & si & código Cf 42/1 \\
Recogida de muestra & nomogéneo & micro fisuración & grietas \\
Patologías & eflorescencias & disgregación & descamación
\end{tabular}

${ }^{1}$ Datos obtenidos en base al cálculo del desvío estándar (respecto al valor medio de la muestras analizadas) y del gráfico de frecuencia de las muestras analizadas, identificado por una curva gaussiana

\section{Juntas}

\begin{tabular}{|c|c|c|c|c|}
\hline \multirow{2}{*}{$\begin{array}{l}N^{0} \text { elementos medidos } \\
\text { Llaga }(\mathrm{cm})\end{array}$} & \multicolumn{4}{|l|}{15} \\
\hline & \multicolumn{4}{|l|}{0.4} \\
\hline Tendel (cm) & \multicolumn{4}{|l|}{3.1} \\
\hline Altura de 5 hiladas $(\mathrm{cm})$ & \multicolumn{4}{|l|}{33} \\
\hline Proporción ladrillo/junta & \multicolumn{4}{|l|}{1.12} \\
\hline Tipo de acabado & simple & doble & \multicolumn{2}{|l|}{ múltiple } \\
\hline \multirow[t]{2}{*}{ Junta de asiento } & rehundida & a hueso & \multirow{2}{*}{\multicolumn{2}{|c|}{ saliente }} \\
\hline & enrasada & matada & & \\
\hline \multirow[t]{2}{*}{ Junta de acabado } & rehundida & a hueso & \multirow{2}{*}{\multicolumn{2}{|c|}{ saliente }} \\
\hline & enrasada & matada & & \\
\hline \multirow{2}{*}{$\begin{array}{l}\text { Tipo de mortero } \\
\text { Morfología de mortero }\end{array}$} & cal & cal y tierra & tierra & cemento mixto \\
\hline & con grumos & con caliches & homogéneo & heterogéneo \\
\hline Tipo de árido & arena & gravilla & grava & mixto \\
\hline Color del árido & claro & oscuro & homogéneo & heterogéneo \\
\hline Recogida de muestra & no & sí & \multicolumn{2}{|l|}{ Código Cf42/2 } \\
\hline \multirow[t]{2}{*}{ Patologías } & eflorescencias & micro fisuración & \multicolumn{2}{|l|}{ grietas } \\
\hline & erosión & disgregación & \multicolumn{2}{|l|}{ pulverización } \\
\hline
\end{tabular}


Imágenes
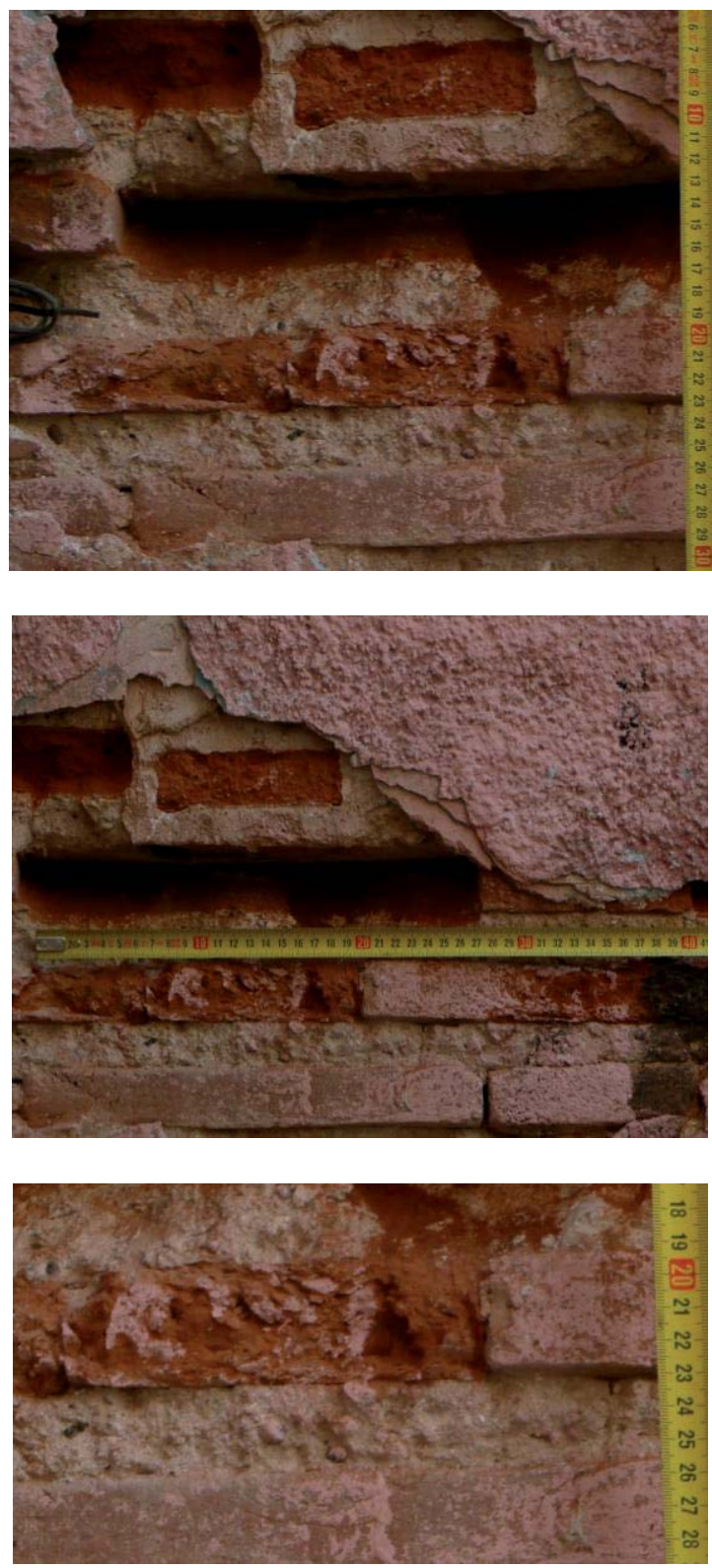
Imágenes

Cf42
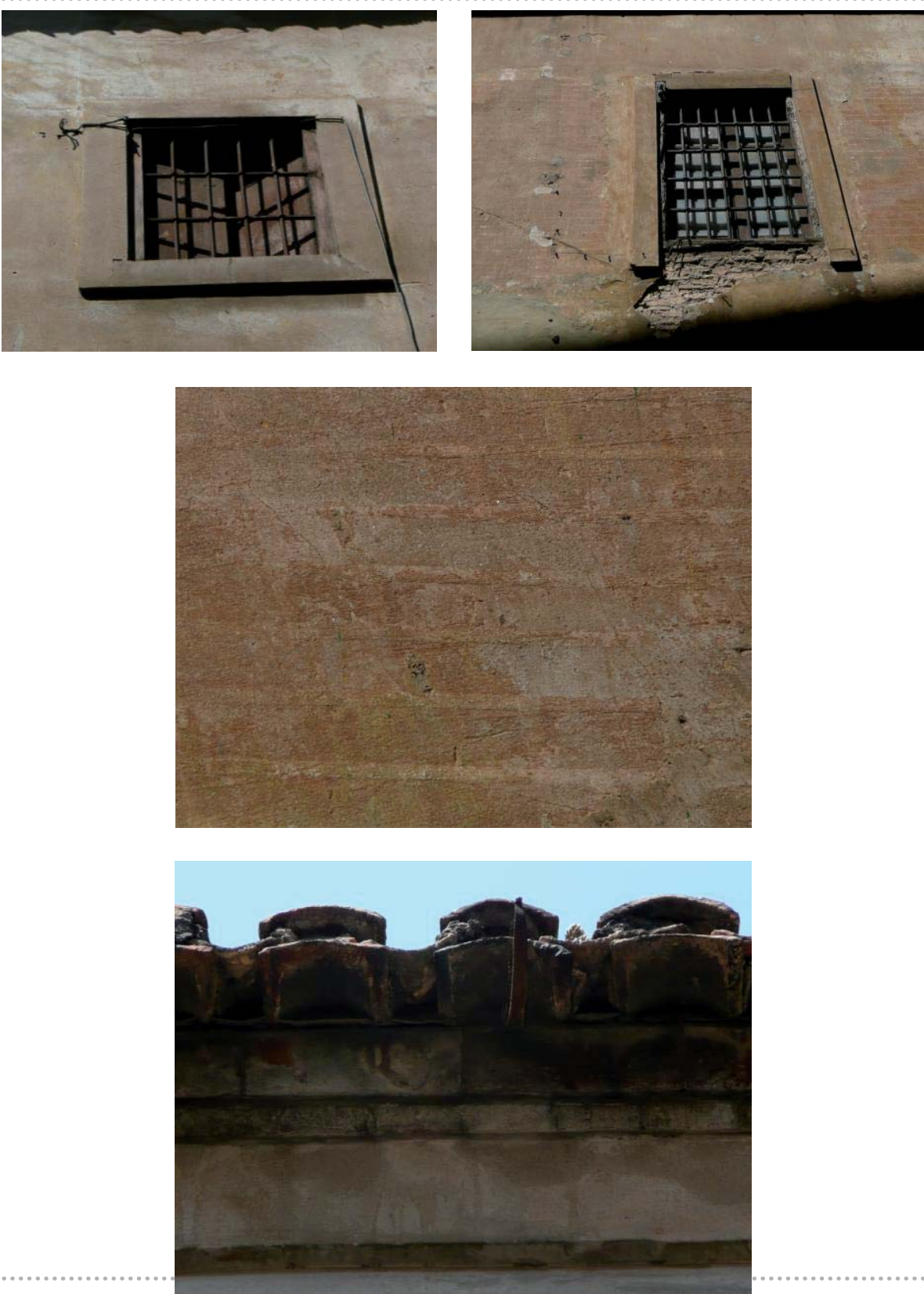
Datos generales

\begin{tabular}{|c|c|c|c|c|c|}
\hline Barrio & Carmen & La Seu-Xerea & Velluters & Mercat & S.Francesc \\
\hline Dirección & C/Gutembe & $n^{\circ} 10$ & & & \\
\hline Tipo de edificio & residencial & palaciego & religioso & militar & \\
\hline $\mathbf{G}^{\circ}$ de protección & 0 & 1 & 2 & 3 & \\
\hline Fechas claves & / & & & & \\
\hline
\end{tabular}
El apartado "fechas claves" se ha extraído de AA.V., Guía de Arquitectura de Valencia, Icaro CTAV Ed., Valencia, 2007

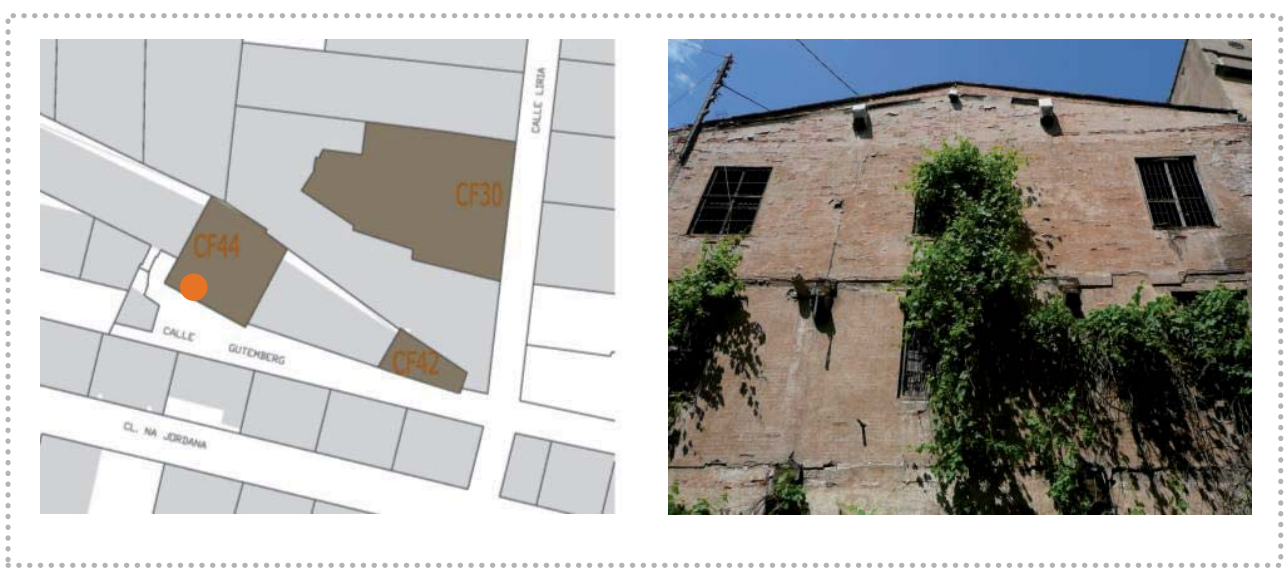

Fachada

Cf44

Pisos
Composición fachada
Zócalo
Fábrica
Vano/dintel
Entrada/dintel
Alero
Cubierta

\begin{tabular}{|c|c|c|c|c|c|c|c|}
\hline \multirow{2}{*}{\multicolumn{2}{|c|}{$\begin{array}{l}\mathrm{N}^{\circ} 2 \\
\text { aleatoria }\end{array}$}} & sótano & entreplanta & piso noble & $\mathrm{ca}$ & ja esca & \\
\hline & & \multicolumn{2}{|c|}{ ordenada sin simetría } & \multicolumn{4}{|c|}{ ordenada con simetría } \\
\hline Z1 & $\mathrm{Z} 2$ & Z3 & $\mathrm{Z} 5$ & & & & \\
\hline F1 & F2 & F3 & F5 & F6 & & & \\
\hline V1 & V2 & V3 & V5 & V6 & V8 & V9 & V10 \\
\hline E1 & E2 & E3 & E4 & & & & \\
\hline A1 & A2 & A3 & A5 & A6 & & & \\
\hline \multicolumn{2}{|c|}{ plana } & \multicolumn{2}{|c|}{ inclinada } & & & & \\
\hline
\end{tabular}

\section{Fábrica}

$\mathrm{Cf} 44$

\begin{tabular}{|c|c|c|c|}
\hline Aparejo & soga-tizón & tizón & \\
\hline Hiladas & irregulares & pseudo horizontales & horizontales \\
\hline Superficie & sin planeidad & pseudo planeidad & planeidad perfecta \\
\hline Sección (hipótesis) & uniforme & hojas y núcleo & abocinada (vano) \\
\hline Elementos destacados & aplantillado & terracota & \\
\hline
\end{tabular}




\begin{tabular}{l|lll}
$\begin{array}{l}\text { No elementos medidos } \\
\text { Longitud }(\mathbf{c m})\end{array}$ & 15 & & \\
Anchura $(\mathbf{c m})$ & 28 & & \\
Espesor $(\mathbf{c m})$ & 12.5 & & \\
Volumen $\left(\mathbf{c m}^{3}\right)$ & 3.5 & heterogéneo & re-empleo \\
Tipo & 1225 & heterogéneo globular & heterogéneo marmolado \\
Color & homogéneo & sínogéneo & código Cf 44/1 \\
Recogida de muestra & no & micro fisuración & grietas \\
Patologías & eflorescencias & disgregación & descamación
\end{tabular}

${ }^{1}$ Datos obtenidos en base al cálculo del desvío estándar (respecto al valor medio de la muestras analizadas) y del gráfico de frecuencia de las muestras analizadas, identificado por una curva gaussiana

\section{Juntas}

\begin{tabular}{|c|c|c|c|c|}
\hline \multirow{2}{*}{$\begin{array}{l}N^{\circ} \text { elementos medidos } \\
\text { Llaga }(\mathrm{cm})\end{array}$} & \multicolumn{4}{|l|}{15} \\
\hline & \multicolumn{4}{|l|}{0.5} \\
\hline Tendel (cm) & \multicolumn{4}{|l|}{2.5} \\
\hline Altura de 5 hiladas $(\mathrm{cm})$ & \multicolumn{4}{|l|}{33} \\
\hline Proporción ladrillo/junta & \multicolumn{4}{|l|}{1.4} \\
\hline Tipo de acabado & simple & doble & múltiple & \\
\hline \multirow[t]{2}{*}{ Junta de asiento } & rehundida & a hueso & \multirow{2}{*}{\multicolumn{2}{|c|}{ saliente }} \\
\hline & enrasada & matada & & \\
\hline \multirow[t]{2}{*}{ Junta de acabado } & rehundida & a hueso & \multirow{2}{*}{\multicolumn{2}{|c|}{ saliente }} \\
\hline & enrasada & matada & & \\
\hline \multirow{2}{*}{$\begin{array}{l}\text { Tipo de mortero } \\
\text { Morfología de mortero }\end{array}$} & cal & cal y tierra & tierra & cemento mixto \\
\hline & con grumos & con caliches & homogéneo & heterogéneo \\
\hline Tipo de árido & arena & gravilla & grava & mixto \\
\hline Color del árido & claro & oscuro & homogéneo & heterogéneo \\
\hline Recogida de muestra & no & sí & \multicolumn{2}{|l|}{ Código Cf 44/2 } \\
\hline \multirow[t]{2}{*}{ Patologías } & eflorescencias & micro fisuración & \multicolumn{2}{|l|}{ grietas } \\
\hline & erosión & disgregación & \multicolumn{2}{|l|}{ pulverización } \\
\hline
\end{tabular}



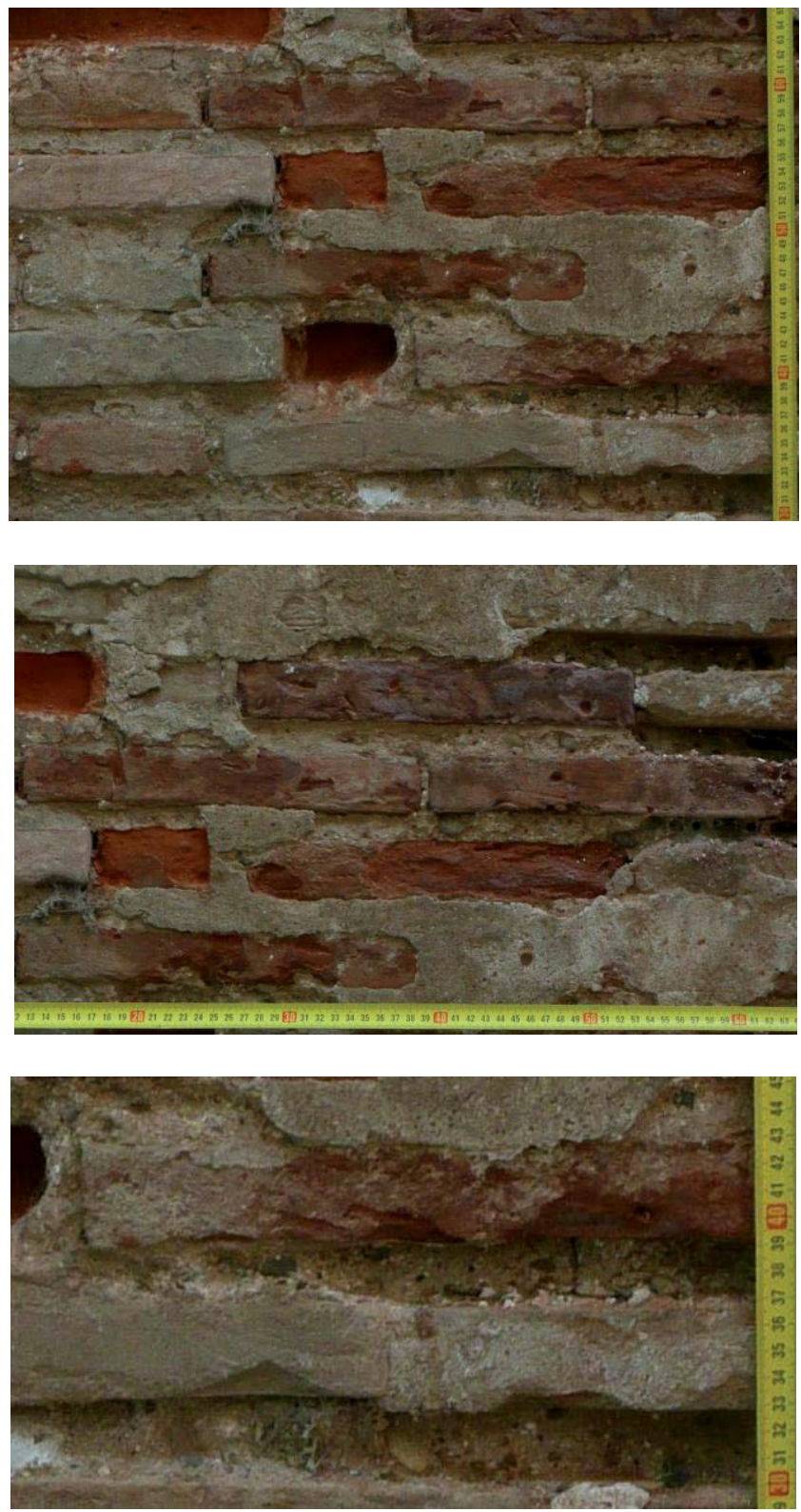

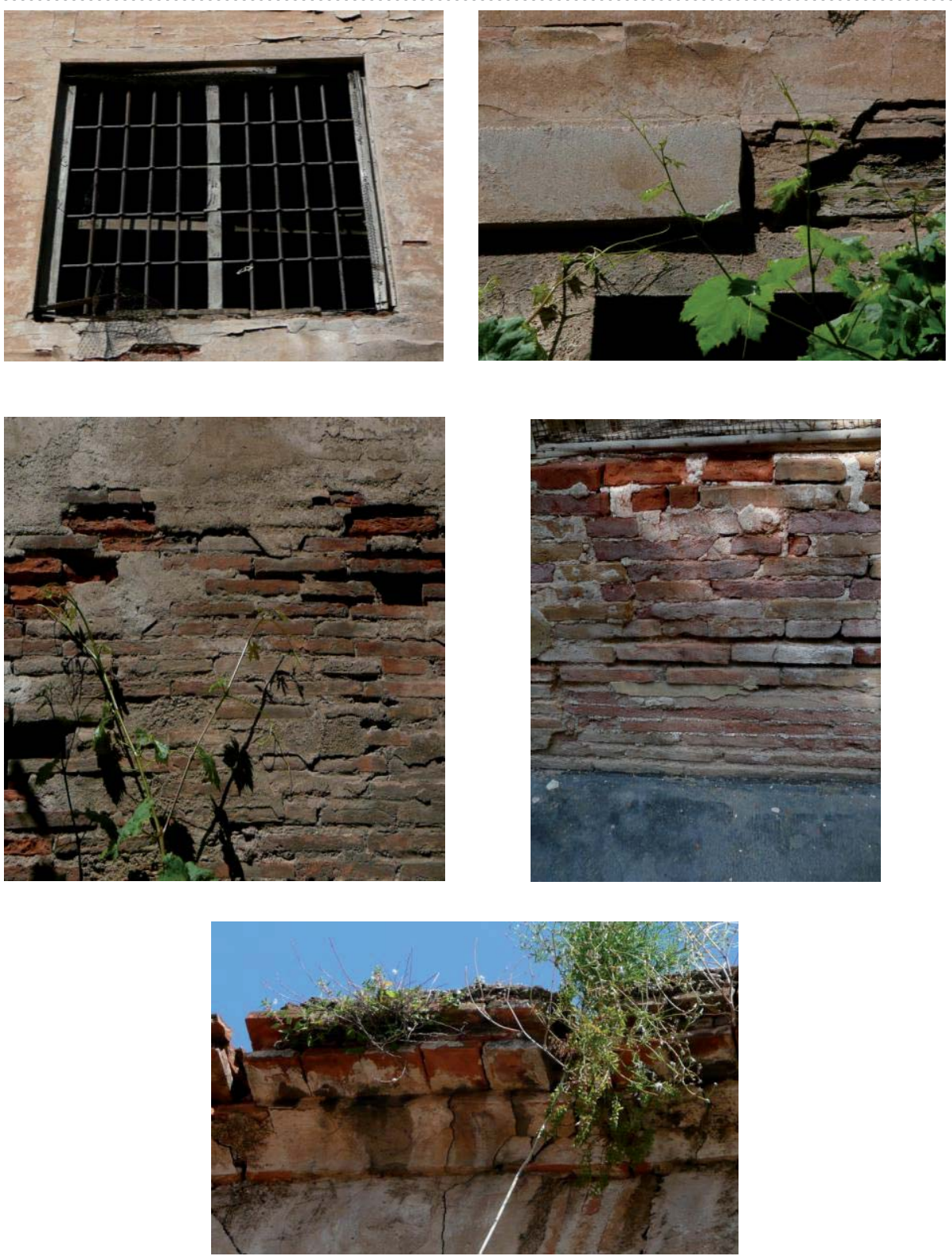


\section{Datos generales}

\section{Cg01a}

Barrio

Dirección

Tipo de edificio

$\mathbf{G}^{\circ}$ de protección

Fechas claves

\begin{tabular}{llll} 
Carmen & La Seu-Xerea & Velluters & Mercat S.Francesc \\
Pza.del Carmen $\mathrm{s} / \mathrm{n}$ & & & \\
residencial palaciego & religioso & militar \\
\hline 0 & 1 & 2 & 3 \\
\hline Ampliación 1555 & &
\end{tabular}

Ampliación 1555

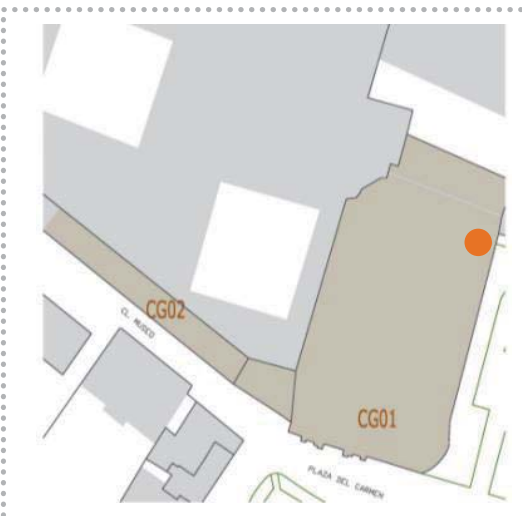

Fachada

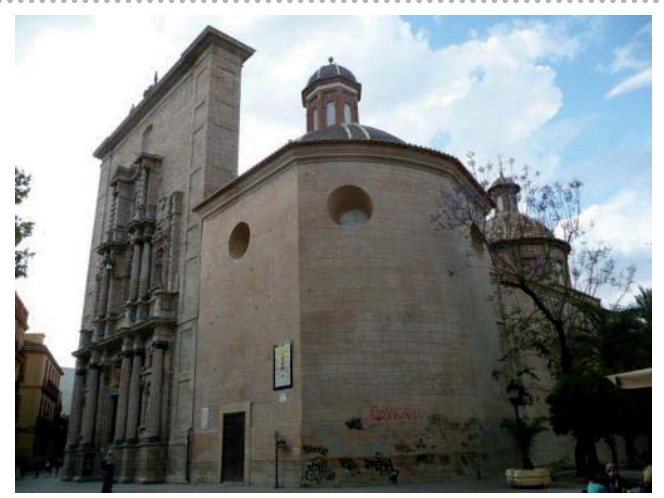

\begin{tabular}{|c|c|c|c|c|c|c|c|c|}
\hline \multirow{2}{*}{\multicolumn{2}{|c|}{$\begin{array}{l}\mathrm{N} \% \\
\text { aleatoria }\end{array}$}} & \multirow{2}{*}{\multicolumn{3}{|c|}{$\begin{array}{l}\text { sotano entreplanta } \\
\text { ordenada sin simetría }\end{array}$}} & \multicolumn{4}{|c|}{ piso noble caja escalera } \\
\hline & & & & & \multicolumn{4}{|c|}{ ordenada con simetría } \\
\hline Z1 & $\mathrm{Z} 2$ & Z3 & Z4 & Z5 & & & & \\
\hline $\mathrm{F} 1$ & $\mathrm{~F} 2$ & F3 & F4 & F5 & F6 & & & \\
\hline V1 & V2 & V3 & V4 & V5 & V6 & V8 & V9 & V10 \\
\hline $\mathrm{E} 1$ & E2 & E3 & E4 & & & & & \\
\hline A1 & A2 & A3 & A4 & A5 & A6 & & & \\
\hline \multicolumn{2}{|c|}{ plana } & \multicolumn{3}{|c|}{ inclinada } & & & & \\
\hline
\end{tabular}

arta

Fábrica

Cg01a

\begin{tabular}{l|lll}
\hline Aparejo & soga-tizón & soga & \multicolumn{2}{c}{ tizón } & \\
\hline Hiladas & irregulares & pseudo horizontales & horizontales \\
\hline Superficie & sin planeidad & pseudo planeidad & planeidad perfecta \\
\hline Sección (hipótesis) & uniforme & hojas y núcleo & abocinada (vano) \\
Elementos destacados & aplantillado & cortado terracota & \\
\hline
\end{tabular}




\begin{tabular}{|c|c|c|c|}
\hline $\mathrm{N}^{\circ}$ elementos medidos & 15 & & \\
\hline Longitud (cm) & 31 & & \\
\hline Anchura (cm) & 13.5 & & \\
\hline Espesor (cm) & 3.8 & & \\
\hline Volumen $\left(\mathrm{cm}^{3}\right)$ & 1590.3 & & \\
\hline Tipo & homogéneo & heterogéneo & re-empleo \\
\hline Color & homogéneo & heterogéneo globular & heterogéneo marmolado \\
\hline Recogida de muestra & no & sí & código Cg01a/1 \\
\hline Patologías & $\begin{array}{l}\text { eflorescencias } \\
\text { erosión }\end{array}$ & $\begin{array}{l}\text { micro fisuración } \\
\text { disgregación }\end{array}$ & $\begin{array}{l}\text { grietas } \\
\text { descamación }\end{array}$ \\
\hline
\end{tabular}

1 Datos obtenidos en base al cálculo del desvio estándar (respecto al valor medio de la muestras analizadas) y del gráfico de frecuencia de las muestras analizadas, identificado por una curva gaussiana

\section{Juntas 2}

\begin{tabular}{|c|c|c|c|c|}
\hline$N^{\circ}$ elementos medidos & 15 & & & \\
\hline Llaga $(\mathrm{cm})$ & 7.5 & & & \\
\hline Tendel (cm) & 5.5 & & & \\
\hline Altura de 5 hiladas $(\mathrm{cm})$ & 42 & & & \\
\hline Proporción ladrillo/junta & 0.6 & & & \\
\hline Tipo de acabado & simple & doble & múltiple & \\
\hline Junta de asiento & rehundida & a hueso & saliente & \\
\hline & enrasada & matada & & \\
\hline Junta de acabado & rehundida & a hueso & saliente & \\
\hline & enrasada & matada & & \\
\hline Tipo de mortero & cal & cal y tierra & tierra & cemento mixto \\
\hline Morfología de mortero & con grumos & con caliches & homogéneo & heterogéneo \\
\hline Tipo de árido & arena & gravilla & grava & mixto \\
\hline Color del árido & claro & oscuro & homogéneo & heterogéneo \\
\hline Recogida de muestra & no & sí & código $\mathrm{Cg01a/2}$ & \\
\hline Patologías & eflorescencias & micro fisuración & grietas & \\
\hline & erosión" & disgregación & pulverización & \\
\hline
\end{tabular}


Imágenes

Cg01a
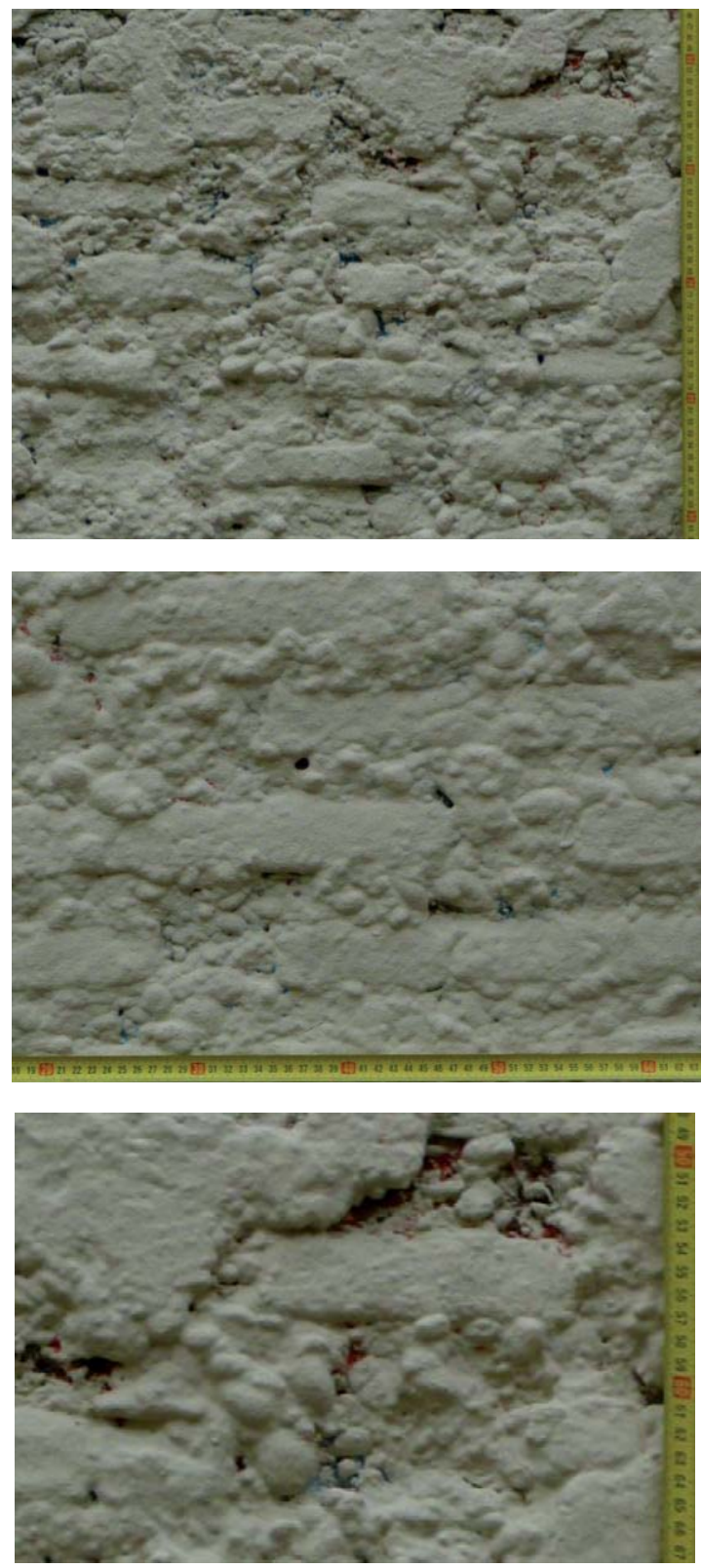

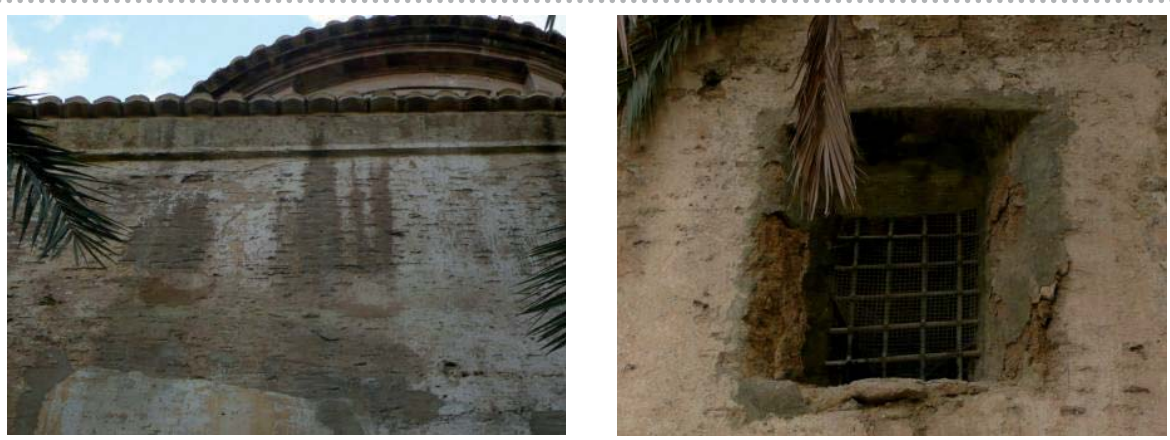

D
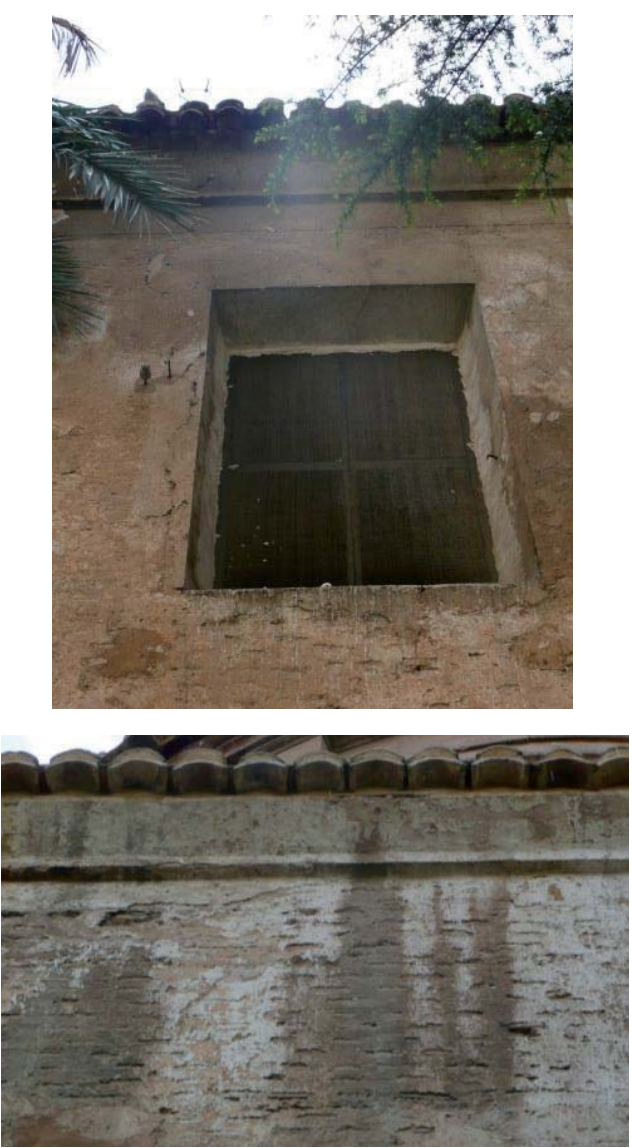


\section{Datos generales}

\section{Cg01b}

\begin{tabular}{|c|c|c|c|c|c|}
\hline Barrio & Carmen & La Seu-Xerea & Velluters & Mercat & S.Francesc \\
\hline Dirección & \multicolumn{5}{|c|}{ Carrer del Museo s/n } \\
\hline Tipo de edificio & residencial & palaciego & religioso & militar & \\
\hline $\mathbf{G}^{\circ}$ de protección & 0 & 1 & 2 & 3 & \\
\hline Fechas claves & \multicolumn{5}{|c|}{ Fundación 1280, Ampliación 1613-44(Fray Gaspar de Sent Martí) } \\
\hline
\end{tabular}

claves

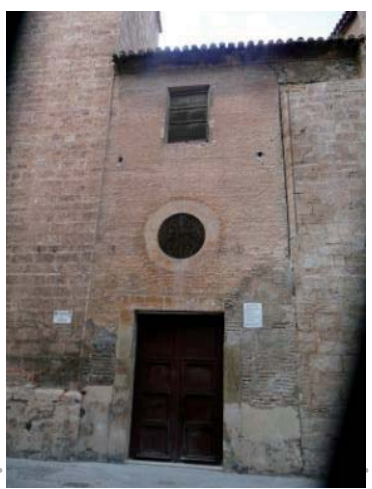

Fachada

Cg01b

Pisos
Composición fachada
Zócalo
Fábrica
Vano/dintel
Entrada/dintel
Alero
Cubierta

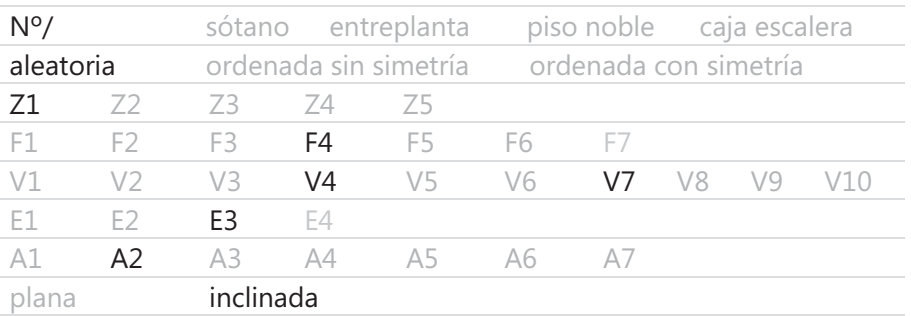

\section{Fábrica}

Cg01b

\begin{tabular}{l|lll} 
Aparejo & soga-tizón & soga & \multicolumn{2}{c}{ tizón } & \\
\hline Hiladas & irregulares & pseudo horizontales & horizontales \\
\hline Superficie & sin planeidad & pseudo planeidad & planeidad perfecta \\
\hline Sección (hipótesis) & uniforme & hojas y núcleo & abocinada (vano) \\
\hline Elementos destacados & aplantillado & cortado terracota & \\
\hline
\end{tabular}




\begin{tabular}{l|lll}
\hline $\begin{array}{l}\text { No elementos medidos } \\
\text { Longitud }(\mathbf{c m})\end{array}$ & 15 & & \\
Anchura $(\mathbf{c m})$ & 30.5 & & \\
Espesor $(\mathbf{c m})$ & 14.4 & & \\
Volumen $\left(\mathbf{c m}^{3}\right)$ & 3.5 & heterogéneo & re-empleo \\
Tipo & 1537.2 & heterogéneo globular & heterogéneo marmolado \\
Color & homogéneo & sínogéneo & código \\
Recogida de muestra & no & micro fisuración & grietas \\
Patologías & eflorescencias & disgregación & descamación
\end{tabular}

${ }^{1}$ Datos obtenidos en base al cálculo del desvío estándar (respecto al valor medio de la muestras analizadas) y del gráfico de frecuencia de las muestras analizadas, identificado por una curva gaussiana

\begin{tabular}{|c|c|c|c|c|}
\hline \multirow{2}{*}{$\begin{array}{l}N^{\circ} \text { elementos medidos } \\
\text { Llaga }(\mathrm{cm})\end{array}$} & \multicolumn{4}{|l|}{15} \\
\hline & \multicolumn{4}{|l|}{1.3} \\
\hline Tendel (cm) & \multicolumn{4}{|l|}{4.2} \\
\hline Altura de 5 hiladas (cm) & \multicolumn{4}{|l|}{38.5} \\
\hline Proporción ladrillo/junta & \multicolumn{4}{|l|}{0.8} \\
\hline Tipo de acabado & simple & doble & \multicolumn{2}{|l|}{ múltiple } \\
\hline \multirow[t]{2}{*}{ Junta de asiento } & rehundida & a hueso & \multirow{2}{*}{\multicolumn{2}{|c|}{ saliente }} \\
\hline & enrasada & matada & & \\
\hline \multirow[t]{2}{*}{ Junta de acabado } & rehundida & a hueso & \multirow{2}{*}{\multicolumn{2}{|c|}{ saliente }} \\
\hline & enrasada & matada & & \\
\hline \multirow{3}{*}{$\begin{array}{l}\text { Tipo de mortero } \\
\text { Morfología de mortero } \\
\text { Tipo de árido }\end{array}$} & cal & cal y tierra & tierra & cemento mixto \\
\hline & con grumos & con caliches & homogéneo & heterogéneo \\
\hline & arena & gravilla & grava & mixto \\
\hline \multirow{4}{*}{$\begin{array}{l}\text { Color del árido } \\
\text { Recogida de muestra } \\
\text { Patologías }\end{array}$} & claro & oscuro & homogéneo & heterogéneo \\
\hline & no & sí & \multicolumn{2}{|l|}{ código } \\
\hline & eflorescencias & micro fisuración & \multicolumn{2}{|l|}{ grietas } \\
\hline & erosión & disgregación & \multicolumn{2}{|l|}{ pulverización } \\
\hline
\end{tabular}


Imágenes
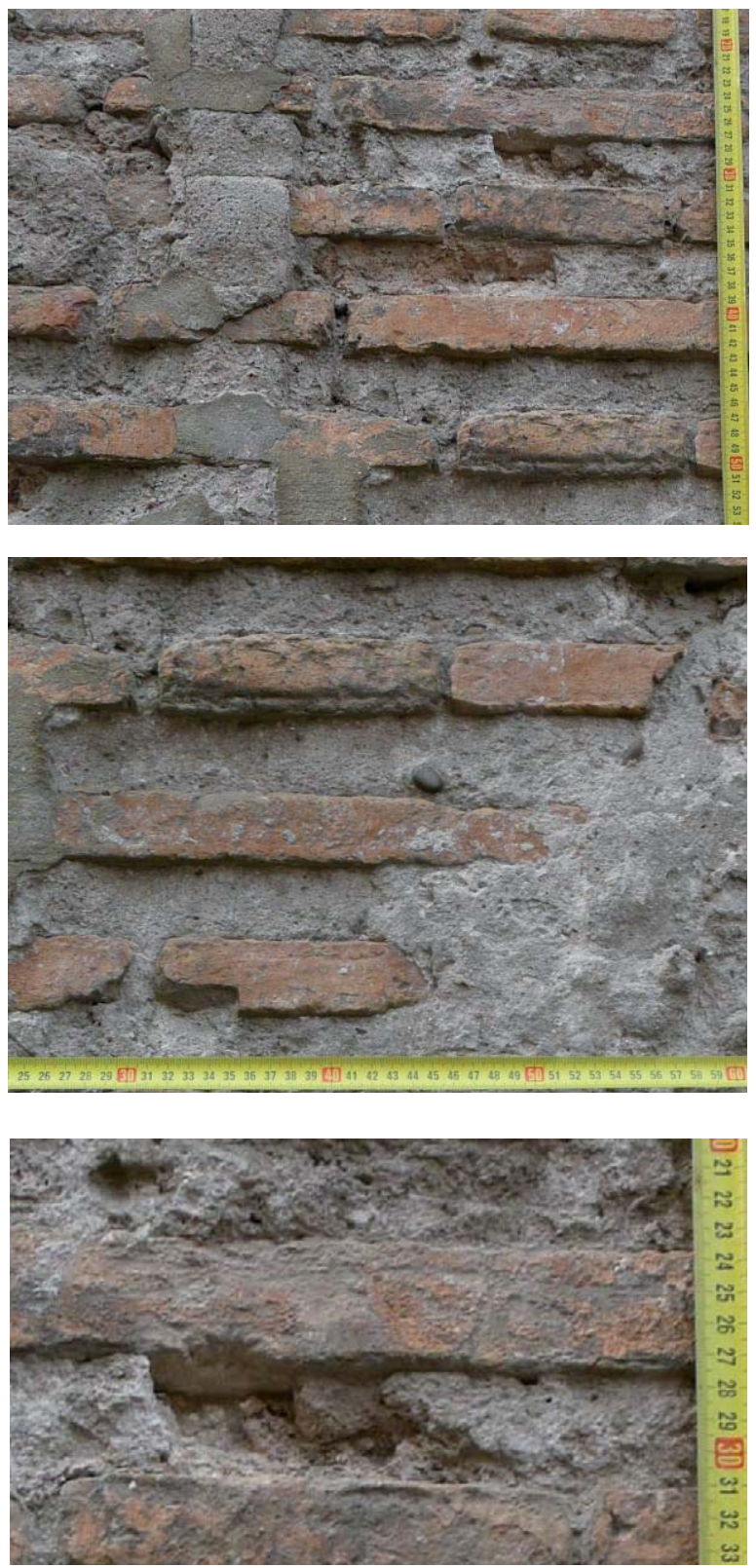

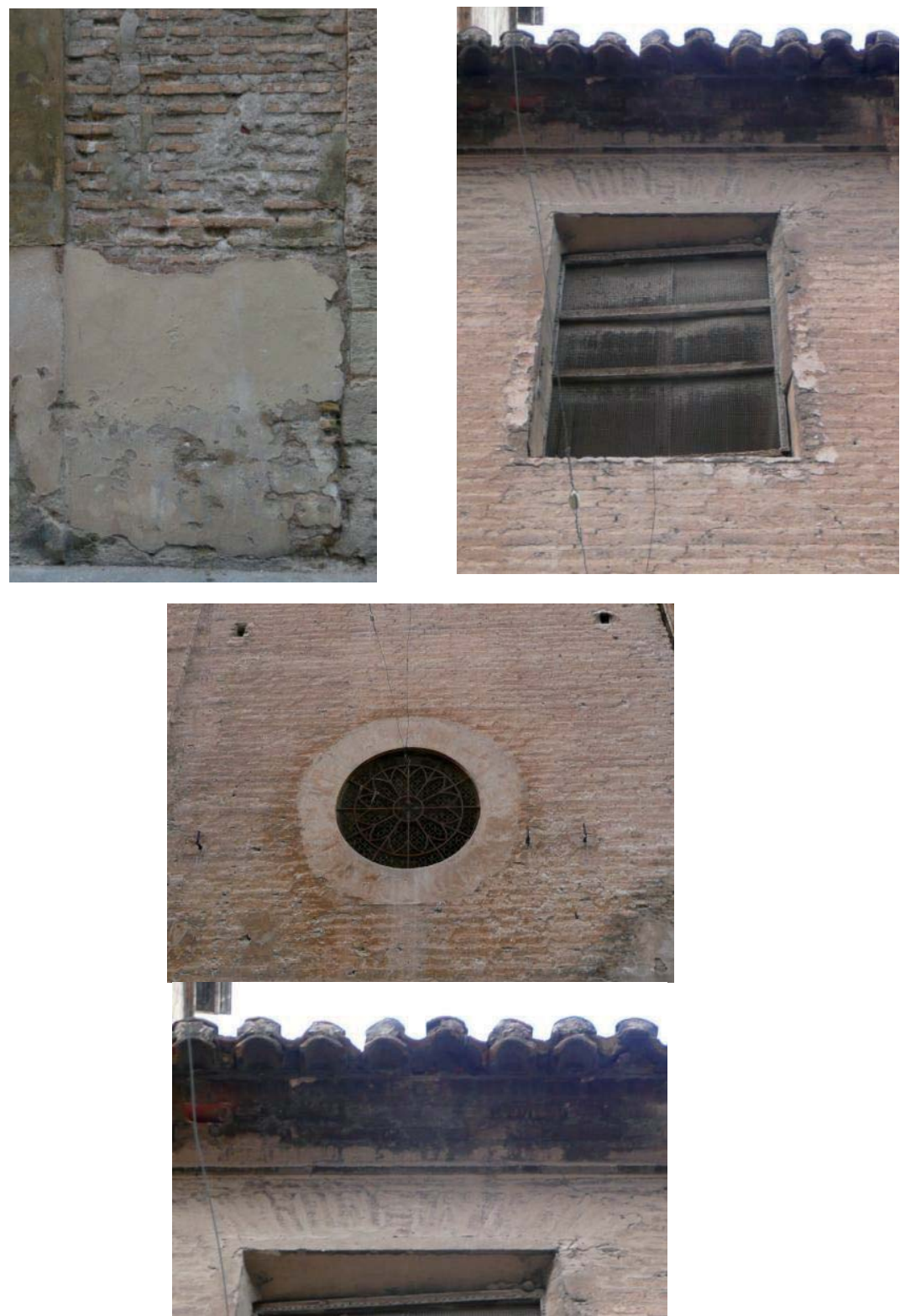
Datos generales

\begin{tabular}{|c|c|c|c|c|}
\hline \multirow{2}{*}{$\begin{array}{l}\text { Barrio } \\
\text { Dirección }\end{array}$} & Carmen & La Seu-Xerea & Velluters & Mercat S.Francesc \\
\hline & \multicolumn{4}{|c|}{ Carrer del Museu n² } \\
\hline Tipo de edificio & residencial & palaciego & religioso & militar \\
\hline $\mathrm{G}^{\circ}$ de protección & 0 & 1 & 2 & 3 \\
\hline Fechas claves & \multicolumn{4}{|c|}{ 1778-90 (José Gascó) Museo (1985-90), Restauración (2009 } \\
\hline
\end{tabular}

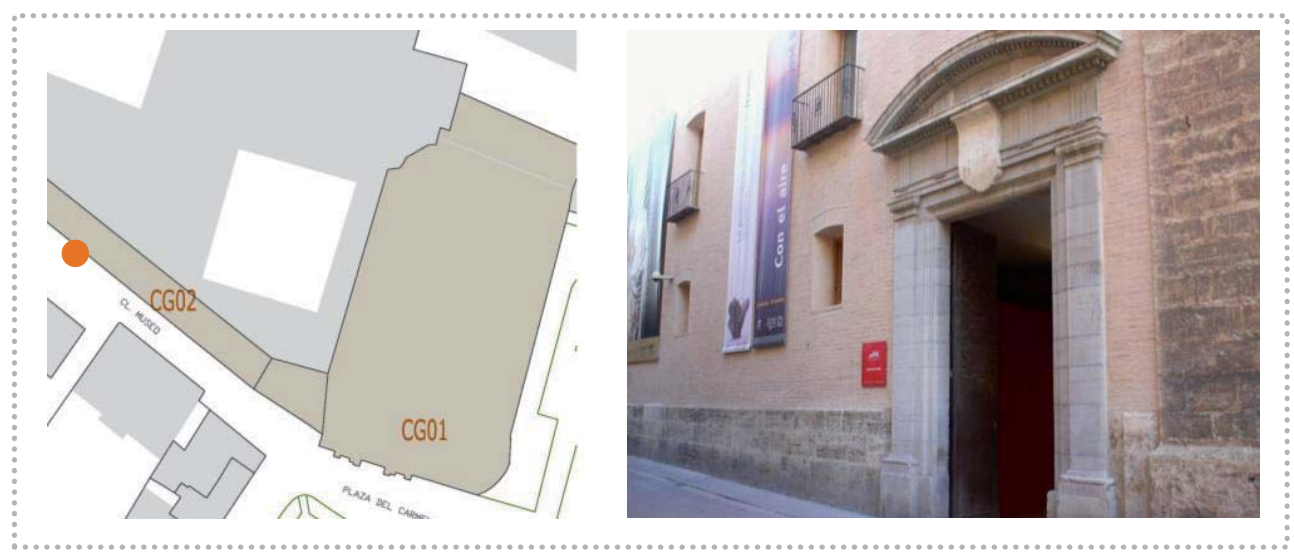

Fachada

Pisos
Composición fachada
Zócalo
Fábrica
Vano/dintel
Entrada/dintel
Alero
Cubierta

\begin{tabular}{|c|c|c|c|c|c|c|c|c|}
\hline \multicolumn{2}{|c|}{$\mathrm{N}^{\circ} 2$} & sótanc & & planta & \multicolumn{4}{|c|}{ piso noble caja escalera } \\
\hline \multicolumn{2}{|c|}{ aleatoria } & \multicolumn{3}{|c|}{ ordenada sin simetría } & \multicolumn{4}{|c|}{ ordenada con simetría } \\
\hline $\mathrm{Z1}$ & $\mathrm{Z2}$ & Z3 & Z4 & $\mathrm{Z5}$ & & & & \\
\hline F1 & F2 & F3 & F4 & F5 & F6 & & & \\
\hline V1 & V2 & V3 & V4 & V5 & V6 & V8 & V9 & V10 \\
\hline E1 & E2 & E3 & E4 & & & & & \\
\hline A1 & A2 & A3 & A4 & A5 & A6 & & & \\
\hline
\end{tabular}

\section{Fábrica}

$\mathrm{CgO2}$

\section{Aparejo \\ Hiladas \\ Superficie \\ Sección (hipótesis) \\ Elementos destacados}

\begin{tabular}{lll} 
soga-tizón & soga & \multicolumn{1}{c}{ tizón } \\
irregulares & pseudo horizontales & horizontales \\
\hline sin planeidad & pseudo planeidad & planeidad perfecta \\
\hline uniforme & hojas y núcleo & abocinada (vano) \\
aplantillado & cortado terracota & \\
\hline
\end{tabular}




$\begin{array}{llll}\begin{array}{l}\text { No elementos medidos } \\ \text { Longitud }(\mathbf{c m})\end{array} & 15 & & \\ \text { Anchura }(\mathbf{c m}) & 29.2 & & \\ \text { Espesor }(\mathbf{c m}) & 14.6 & & \\ \text { Volumen }\left(\mathbf{c m}^{\mathbf{3}}\right) & 4.5 & \text { heterogéneo } & \text { re-empleo } \\ \text { Tipo } & 1918.44 & \text { heterogéneo globular } & \text { heterogéneo marmolado } \\ \text { Color } & \text { homogéneo } & \text { síno } & \text { código } \\ \text { Recogida de muestra } & \text { no } & \text { micro fisuración } & \text { grietas } \\ \text { Patologías } & \text { eflorescencias } & \text { disgregación } & \text { descamación } \\ & \text { erosión } & \text { dióneo } & \end{array}$

${ }^{1}$ Datos obtenidos en base al cálculo del desvío estándar (respecto al valor medio de la muestras analizadas) y del gráfico de frecuencia de las muestras analizadas, identificado por una curva gaussiana

\section{Juntas}

\begin{tabular}{|c|c|c|c|c|}
\hline \multirow{2}{*}{$\begin{array}{l}N^{\circ} \text { elementos medidos } \\
\text { Llaga }(\mathrm{cm})\end{array}$} & \multicolumn{4}{|l|}{15} \\
\hline & \multicolumn{4}{|l|}{2.1} \\
\hline Tendel (cm) & \multicolumn{4}{|l|}{4.9} \\
\hline Altura de 5 hiladas $(\mathrm{cm})$ & \multicolumn{4}{|l|}{47} \\
\hline Proporción ladrillo/junta & \multicolumn{4}{|l|}{0.9} \\
\hline Tipo de acabado & simple & doble & múltiple & \\
\hline \multirow[t]{2}{*}{ Junta de asiento } & rehundida & a hueso & saliente & \\
\hline & enrasada & matada & & \\
\hline \multirow{2}{*}{ Junta de acabado } & rehundida & a hueso & saliente & \\
\hline & enrasada & matada & & \\
\hline \multirow{2}{*}{$\begin{array}{l}\text { Tipo de mortero } \\
\text { Morfología de mortero }\end{array}$} & cal & cal y tierra & tierra & cemento mixto \\
\hline & con grumos & con caliches & homogéneo & heterogéneo \\
\hline Tipo de árido & arena & gravilla & grava & mixto \\
\hline \multirow{4}{*}{$\begin{array}{l}\text { Color del árido } \\
\text { Recogida de muestra } \\
\text { Patologías }\end{array}$} & claro & oscuro & homogéneo & heterogéneo \\
\hline & no & sí & código & \\
\hline & eflorescencias & micro fisuración & grietas & \\
\hline & erosión & disgregación & pulverización & \\
\hline
\end{tabular}


Imágenes

$\mathrm{CgO2}$
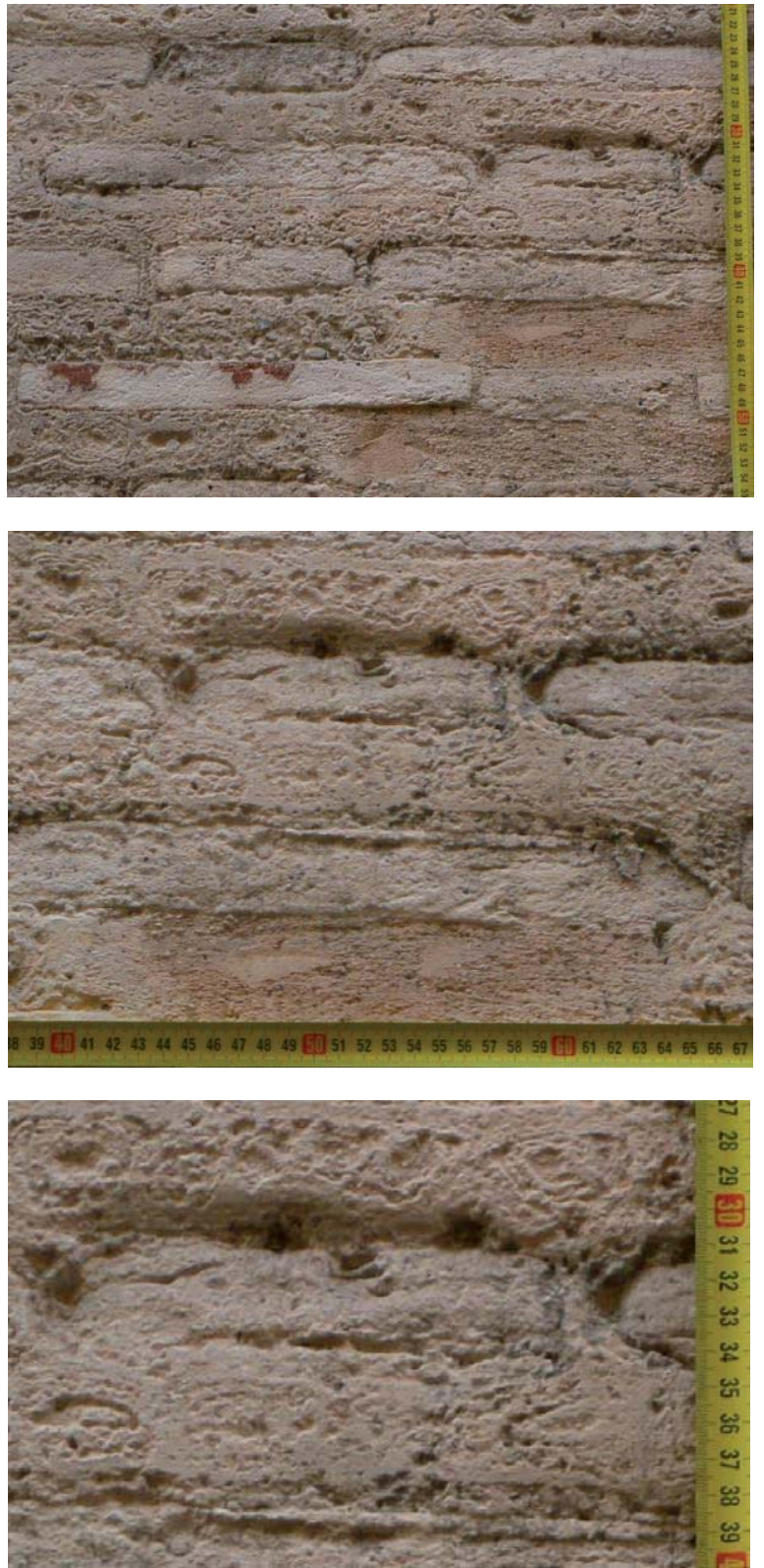
Imágenes

$\mathrm{CgO} 2$
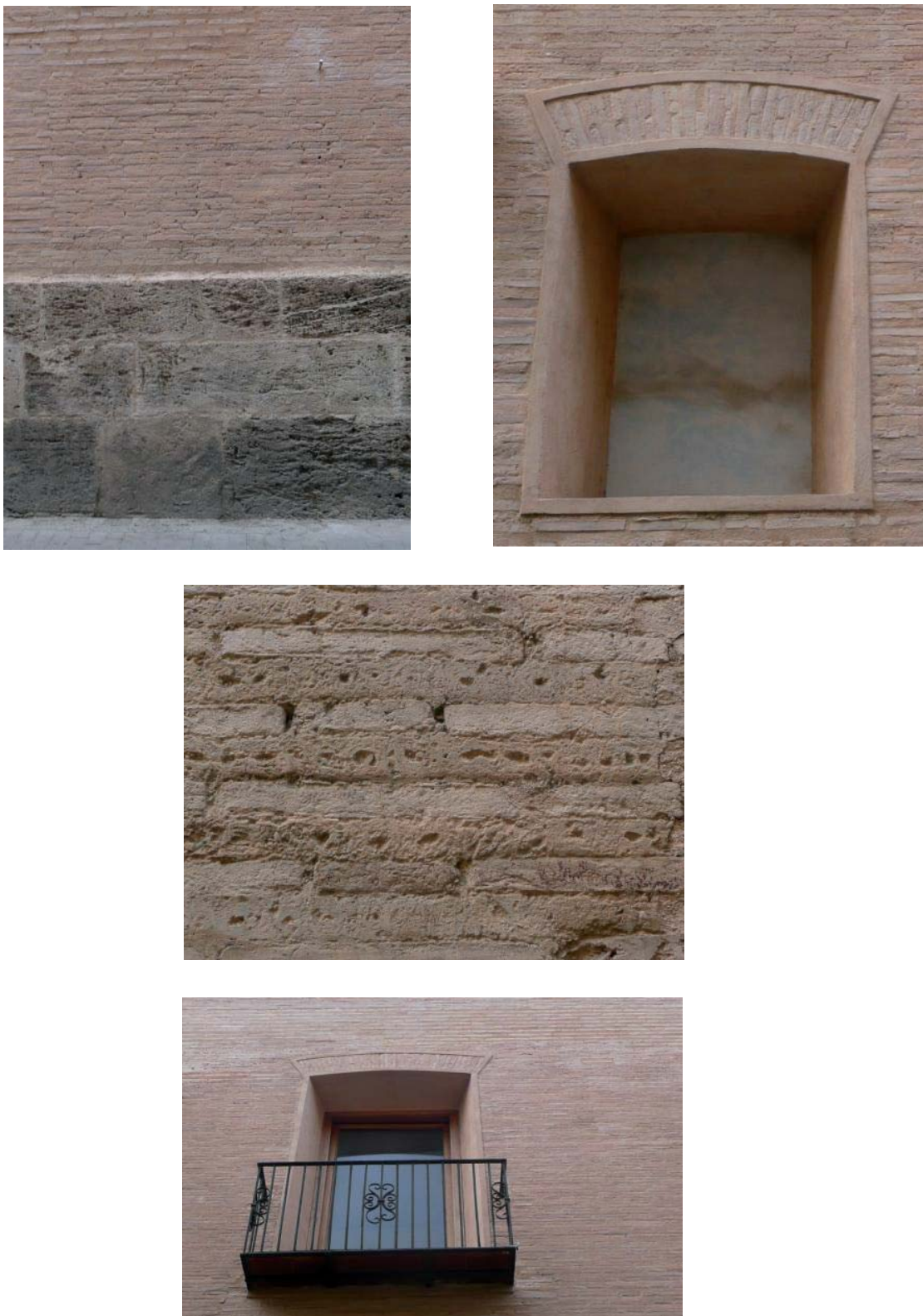
Datos generales

\begin{tabular}{|c|c|c|c|c|c|}
\hline Barrio & Carmen & La Seu-Xerea & Velluters & Mercat & S.Francesc \\
\hline Dirección & \multicolumn{5}{|c|}{ P.za del Portal Nuevo $n^{\circ} 6$} \\
\hline Tipo de edificio & residencial & palaciego & religioso & militar & \\
\hline $\mathbf{G}^{\circ}$ de protección & 0 & 1 & 2 & 3 & \\
\hline Fechas claves & \multicolumn{5}{|c|}{ 1609/intervención 1970 (Luis Gay Ramos) } \\
\hline
\end{tabular}

El apartado "fechas claves" se ha extraído de AA.W.., Guía de Arquitectura de Valencia, Icaro CTAV Ed., Valencia, 2007

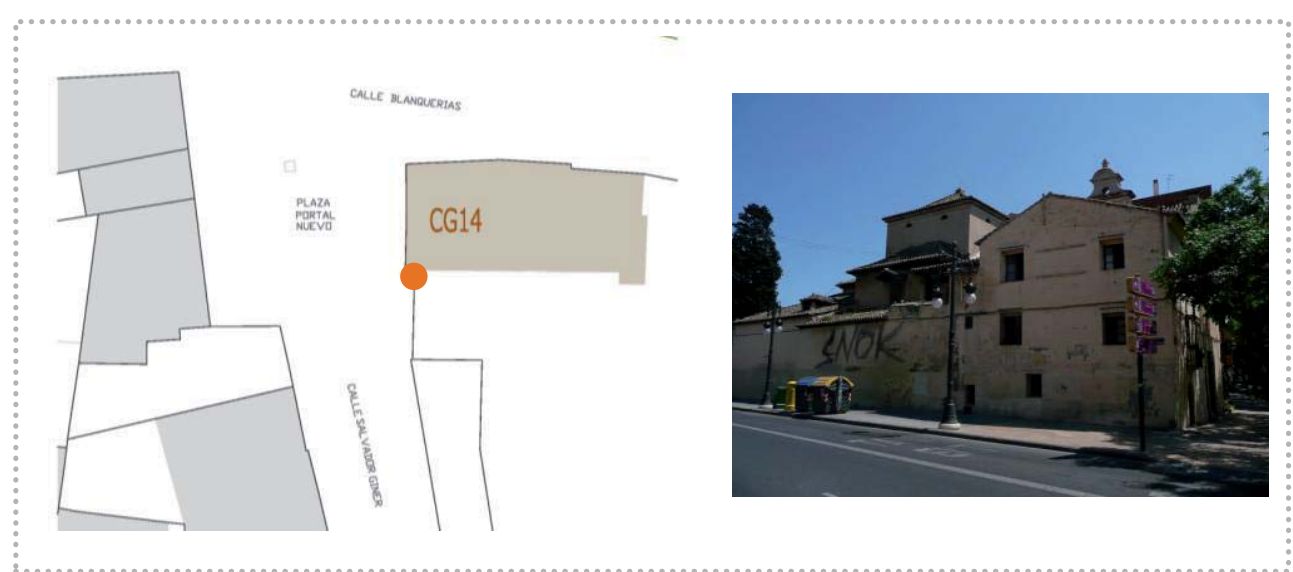

Fachada

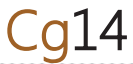

Pisos
Composición fachada
Zócalo
Fábrica
Vano/dintel
Entrada/dintel
Alero
Cubierta

\begin{tabular}{|c|c|c|c|c|c|c|c|c|}
\hline \multirow{3}{*}{\multicolumn{2}{|c|}{$\begin{array}{l}\mathrm{N}^{0} 2 \\
\text { aleatoria }\end{array}$}} & \multirow{2}{*}{\multicolumn{3}{|c|}{$\begin{array}{l}\text { sótano entreplanta } \\
\text { ordenada sin simetría }\end{array}$}} & \multicolumn{4}{|c|}{ piso noble caja escalera } \\
\hline & & & & & \multicolumn{4}{|c|}{ ordenada con simetría } \\
\hline & & Z3 & Z4 & $\mathrm{Z5}$ & & & & \\
\hline F1 & F2 & F3 & F4 & F5 & F6 & & & \\
\hline V1 & V2 & V3 & V4 & V5 & V7 & V8 & V9 & V10 \\
\hline E1 & E2 & E3 & E4 & & & & & \\
\hline A1 & $\mathrm{A} 2$ & A3 & A4 & A5 & A7 & & & \\
\hline \multicolumn{2}{|c|}{ plana } & \multicolumn{3}{|c|}{ inclinada } & & & & \\
\hline
\end{tabular}

\section{Fábrica}

\section{Cg14}

\section{Aparejo \\ Hiladas \\ Superficie \\ Sección (hipótesis) \\ Elementos destacados}

\begin{tabular}{lll} 
soga-tizón & soga & \\
irregulares & tizón & \\
sin planeidad & pseudo planeidad & planeidad perfecta \\
\hline uniforme & hojas y núcleo & abocinada (vano) \\
aplantillado & cortado terracota & \\
\hline
\end{tabular}




\begin{tabular}{|c|c|c|c|}
\hline \multirow{2}{*}{$\begin{array}{l}\mathrm{N}^{\circ} \text { elementos medidos } \\
\text { Longitud }(\mathrm{cm})\end{array}$} & \multicolumn{3}{|l|}{15} \\
\hline & \multicolumn{3}{|l|}{30} \\
\hline Anchura $(\mathrm{cm})$ & \multicolumn{3}{|l|}{ / } \\
\hline Espesor (cm) & \multicolumn{3}{|l|}{3.2} \\
\hline Volumen $\left(\mathrm{cm}^{3}\right)$ & \multicolumn{3}{|l|}{ / } \\
\hline Tipo & homogéneo & heterogéneo & re-empleo \\
\hline Color & homogéneo & heterogéneo globular & heterogéneo marmolado \\
\hline Recogida de muestra & no & sí & código Cg 14/1 \\
\hline Patologías & $\begin{array}{l}\text { eflorescencias } \\
\text { erosión }\end{array}$ & $\begin{array}{l}\text { micro fisuración } \\
\text { disgregación }\end{array}$ & $\begin{array}{l}\text { grietas } \\
\text { descamación }\end{array}$ \\
\hline
\end{tabular}

${ }^{1}$ Datos obtenidos en base al cálculo del desvío estándar (respecto al valor medio de la muestras analizadas) y del gráfico de frecuencia de las muestras analizadas, identificado por una curva gaussiana

\section{untas 2}

\begin{tabular}{|c|c|c|c|c|}
\hline \multirow{2}{*}{$\begin{array}{l}N^{\circ} \text { elementos medidos } \\
\text { Llaga }(\mathrm{cm})\end{array}$} & \multicolumn{4}{|l|}{15} \\
\hline & \multicolumn{4}{|l|}{5.3} \\
\hline Tendel (cm) & \multicolumn{4}{|l|}{5} \\
\hline Altura de 5 hiladas $(\mathrm{cm})$ & \multicolumn{4}{|l|}{40} \\
\hline Proporción ladrillo/junta & \multicolumn{4}{|l|}{0.6} \\
\hline Tipo de acabado & simple & doble & múltiple & \\
\hline \multirow[t]{2}{*}{ Junta de asiento } & rehundida & a hueso & saliente & \\
\hline & enrasada & matada & & \\
\hline \multirow[t]{2}{*}{ Junta de acabado } & rehundida & a hueso & saliente & \\
\hline & enrasada & matada & & \\
\hline \multirow{2}{*}{$\begin{array}{l}\text { Tipo de mortero } \\
\text { Morfología de mortero }\end{array}$} & cal & cal y tierra & tierra & cemento mixto \\
\hline & con grumos & con caliches & homogéneo & heterogéneo \\
\hline Tipo de árido & arena & gravilla & grava & mixto \\
\hline \multirow{4}{*}{$\begin{array}{l}\text { Color del árido } \\
\text { Recogida de muestra } \\
\text { Patologías }\end{array}$} & claro & oscuro & homogéneo & heterogéneo \\
\hline & no & sí & Código Cg14/2 & \\
\hline & eflorescencias & micro fisuración & grietas & \\
\hline & erosión & disgregación & pulverización & \\
\hline
\end{tabular}


Imágenes

Cg14
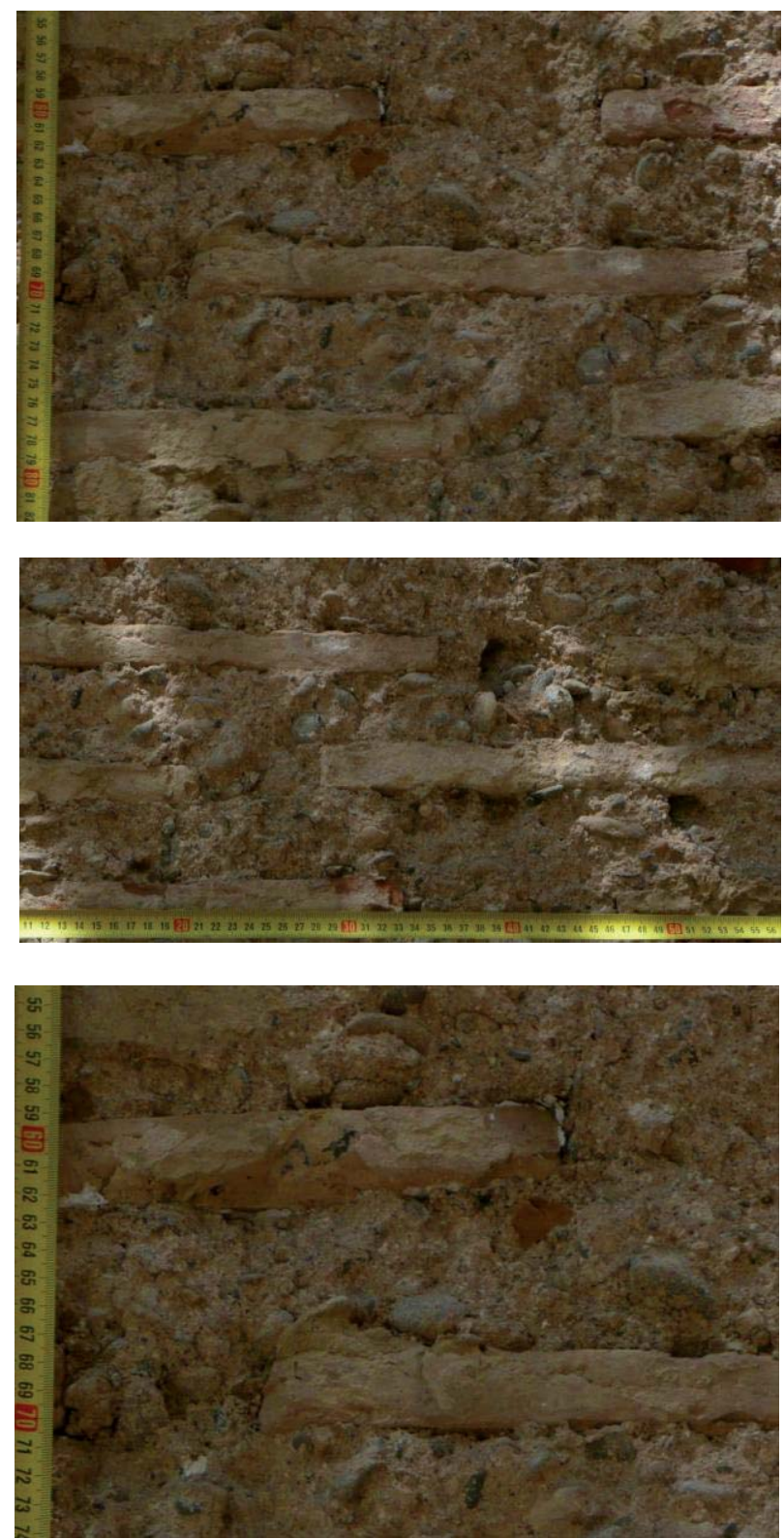

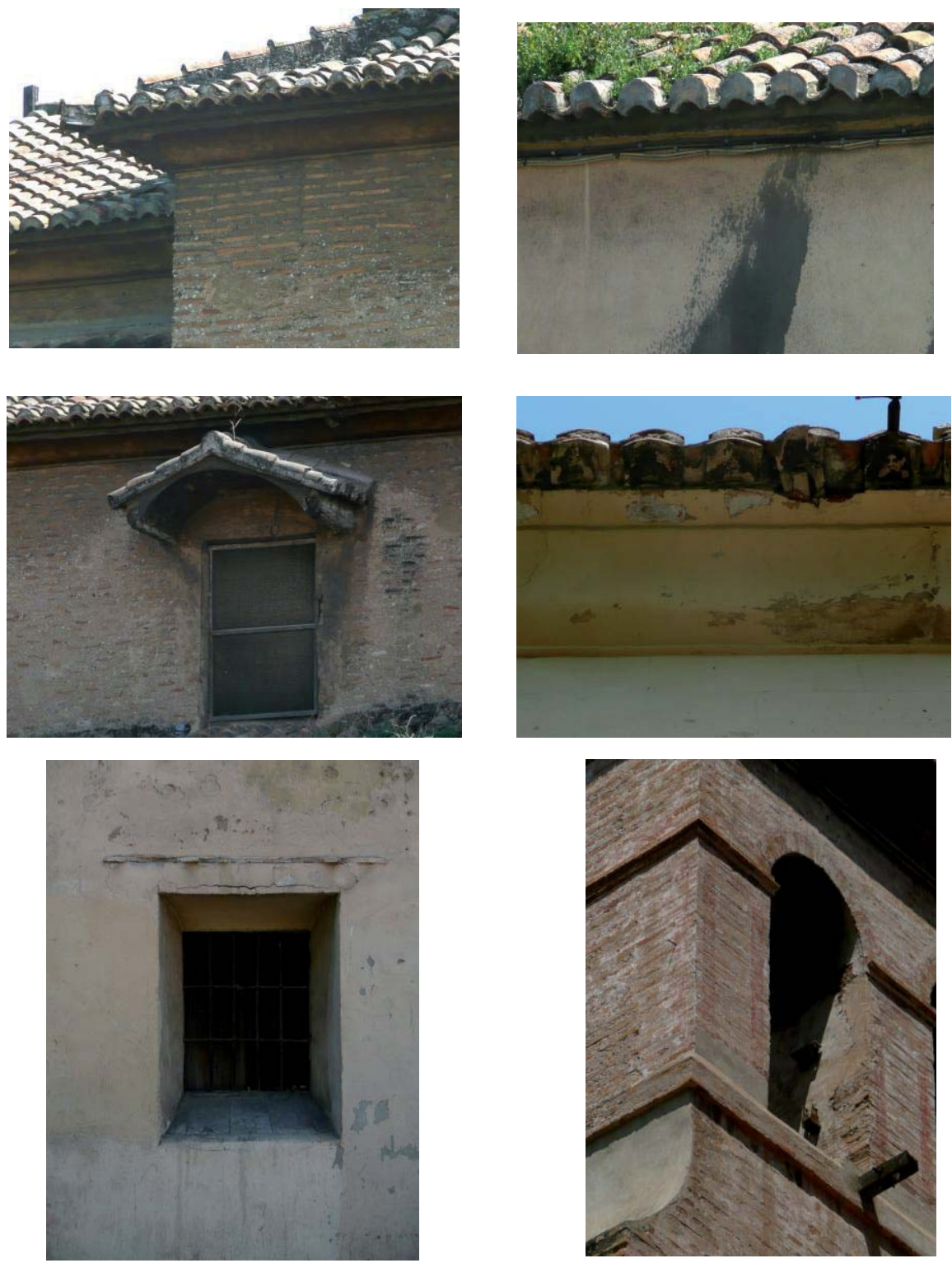
Datos generales

\begin{tabular}{|c|c|c|c|c|c|}
\hline Barrio & Carmen & La Seu-Xerea & Velluters & Mercat & S.Francesc \\
\hline Dirección & Pza. del Aut & $n^{\circ} 12$ & & & \\
\hline Tipo de edificio & residencial & palaciego & religioso & militar & \\
\hline $\mathbf{G}^{\circ}$ de protección & 0 & 1 & 2 & 3 & \\
\hline Fechas claves & / & & & & \\
\hline
\end{tabular}
El apartado "fechas claves" se ha extraído de AA.V. ., Guía de Arquitectura de Valencia, Icaro CTAV Ed., Valencia, 2007
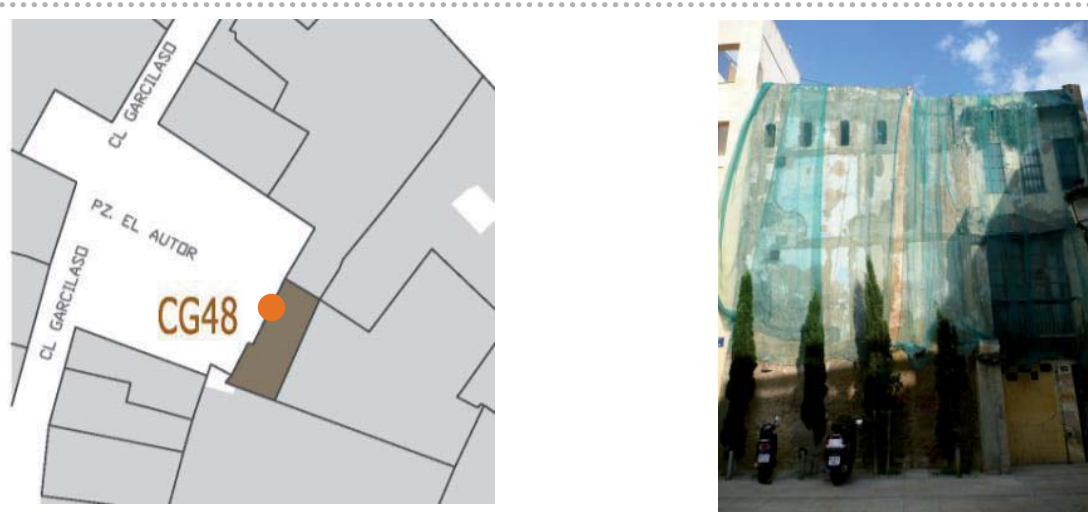

Fachada

Cg48a

Pisos

Composición fachada

Zócalo

Fábrica

Vano/dintel

Entrada/dintel

Alero

Cubierta

\begin{tabular}{|c|c|c|c|c|c|c|c|c|}
\hline \multirow{2}{*}{\multicolumn{2}{|c|}{$\begin{array}{l}\mathrm{N}^{0} 3 \\
\text { aleatoria }\end{array}$}} & sótano & & planta & \multicolumn{4}{|c|}{ piso noble caja escalera } \\
\hline & & \multicolumn{3}{|c|}{ ordenada sin simetría } & \multicolumn{4}{|c|}{ ordenada con simetría } \\
\hline $\mathrm{Z1}$ & $\mathrm{Z} 2$ & $\mathrm{Z3}$ & Z4 & $\mathrm{Z} 5$ & & & & \\
\hline $\mathrm{F} 1$ & $\mathrm{~F} 2$ & F3 & F4 & F5 & F6 & & & \\
\hline V1 & V2 & V3 & V4 & V5 & V6 & V8 & V9 & V10 \\
\hline E1 & E2 & E3 & E4 & & & & & \\
\hline A1 & $\mathrm{A} 2$ & A3 & A4 & A5 & A6 & & & \\
\hline pla & & inclina & & & & & & \\
\hline
\end{tabular}

\section{Fábrica}

Cg48a

Aparejo
Hiladas
Superficie
Sección (hipótesis)
Elementos destacados

soga-tizón

soga

tizón

irregulares

pseudo horizontales

horizontales

sin planeidad

pseudo planeidad

planeidad perfecta

uniforme

hojas y núcleo

abocinada (vano)

aplantillado

cortado

terracota 


\begin{tabular}{|c|c|c|c|}
\hline \multirow{2}{*}{$\begin{array}{l}\mathrm{N}^{\circ} \text { elementos medidos } \\
\text { Longitud }(\mathrm{cm})\end{array}$} & \multicolumn{3}{|l|}{15} \\
\hline & / & & \\
\hline Anchura (cm) & 12.7 & & \\
\hline Espesor (cm) & 3.5 & & \\
\hline Volumen $\left(\mathrm{cm}^{3}\right)$ & / & & \\
\hline Tipo & homogéneo & heterogéneo & re-empleo \\
\hline Color & homogéneo & heterogéneo globular & heterogéneo marmolado \\
\hline Recogida de muestra & no & sí & código Cg 48a/1 \\
\hline Patologías & $\begin{array}{l}\text { eflorescencias } \\
\text { erosión }\end{array}$ & $\begin{array}{l}\text { micro fisuración } \\
\text { disgregación }\end{array}$ & $\begin{array}{l}\text { grietas } \\
\text { descamación }\end{array}$ \\
\hline
\end{tabular}

1 Datos obtenidos en base al cálculo del desvío estándar (respecto al valor medio de la muestras analizadas) y del gráfico de frecuencia de las muestras analizadas, identificado por una curva gaussiana

\section{Juntas}

\begin{tabular}{|c|c|c|c|c|}
\hline \multirow{2}{*}{$\begin{array}{l}N^{0} \text { elementos medidos } \\
\text { Llaga }(\mathrm{cm})\end{array}$} & \multicolumn{4}{|l|}{15} \\
\hline & \multicolumn{4}{|l|}{5.5} \\
\hline Tendel (cm) & \multicolumn{4}{|l|}{6} \\
\hline Altura de 5 hiladas $(\mathrm{cm})$ & \multicolumn{4}{|l|}{64} \\
\hline Proporción ladrillo/junta & \multicolumn{4}{|l|}{0.6} \\
\hline Tipo de acabado & simple & doble & múltiple & \\
\hline Junta de asiento & $\begin{array}{l}\text { rehundida } \\
\text { enrasada }\end{array}$ & $\begin{array}{l}\text { a hueso } \\
\text { matada }\end{array}$ & saliente & \\
\hline Junta de acabado & $\begin{array}{l}\text { rehundida } \\
\text { enrasada }\end{array}$ & $\begin{array}{l}\text { a hueso } \\
\text { matada }\end{array}$ & saliente & \\
\hline Tipo de mortero & cal & cal y tierra & tierra & cemento mixto \\
\hline Morfología de mortero & con grumos & con caliches & homogéneo & heterogéneo \\
\hline Tipo de árido & arena & gravilla & grava & mixto \\
\hline Color del árido & claro & oscuro & homogéneo & heterogéneo \\
\hline Recogida de muestra & no & sí & código Cg 48a/ & \\
\hline Patologías & $\begin{array}{l}\text { eflorescencias } \\
\text { erosión" }\end{array}$ & $\begin{array}{l}\text { micro fisuración } \\
\text { disgregación }\end{array}$ & $\begin{array}{l}\text { grietas } \\
\text { pulverización }\end{array}$ & \\
\hline
\end{tabular}


Imágenes
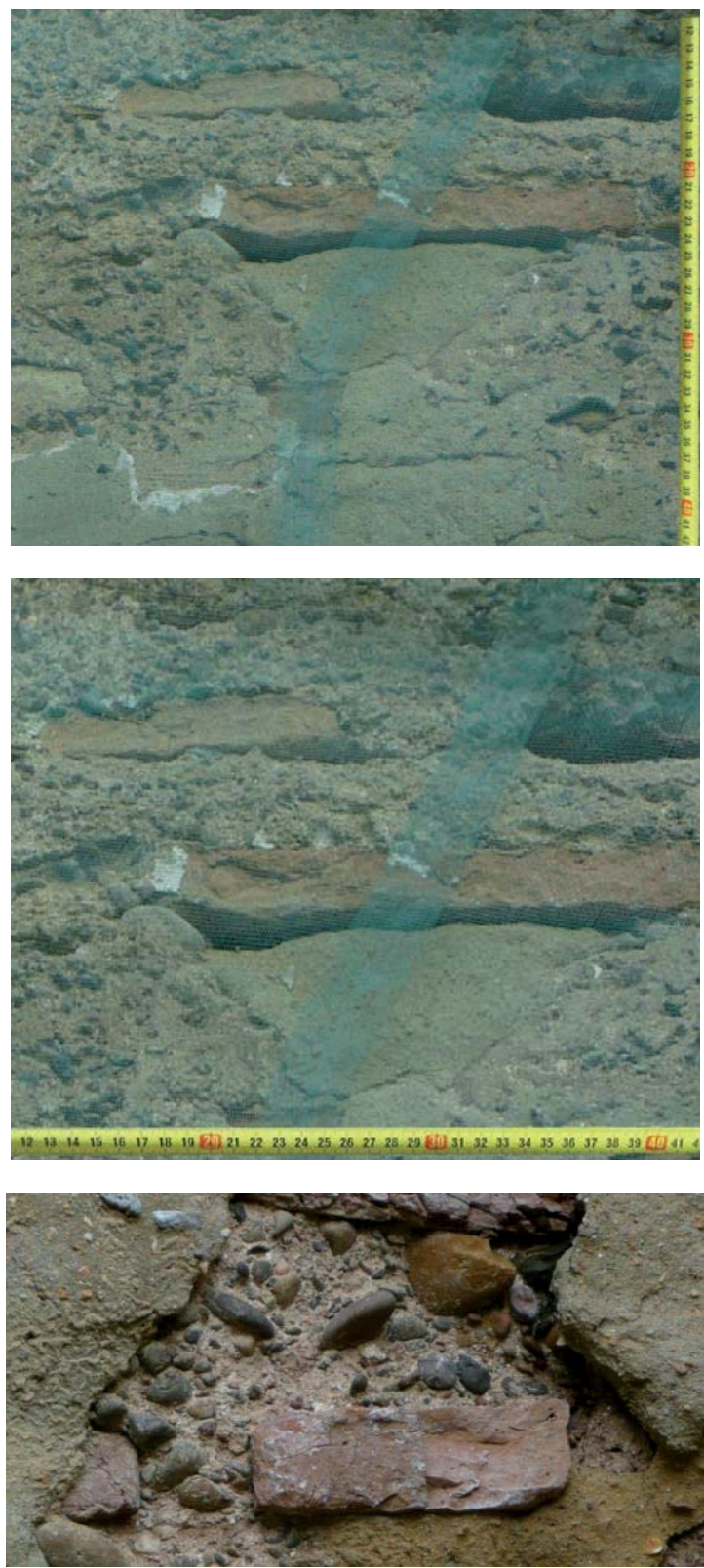


$$
\text { Imágenes }
$$
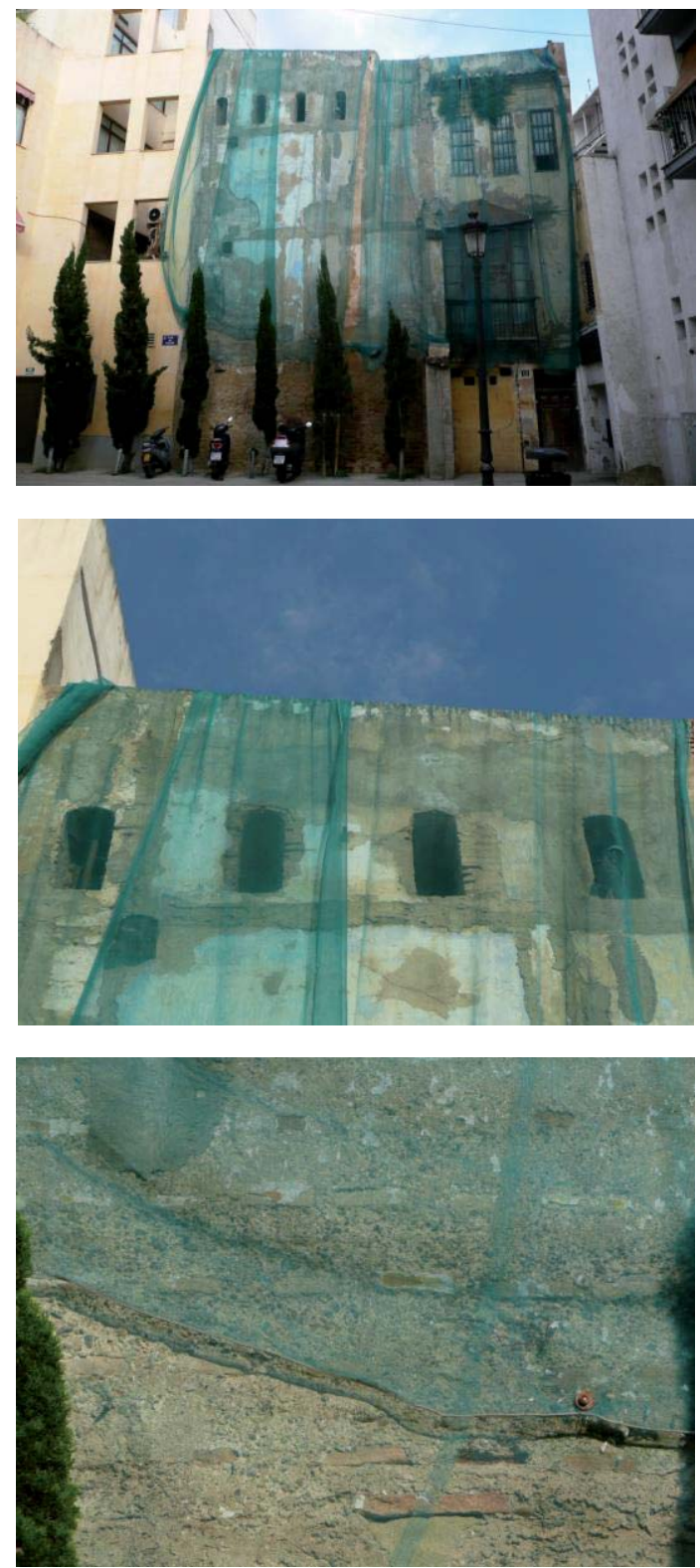
Datos generales

\begin{tabular}{|c|c|c|c|c|c|}
\hline \multirow{2}{*}{$\begin{array}{l}\text { Barrio } \\
\text { Dirección }\end{array}$} & Carmen & La Seu-Xerea & Velluters & Mercat & S.Francesc \\
\hline & \multicolumn{5}{|c|}{ Pza. del Autor n¹2 } \\
\hline Tipo de edificio & residencial & palaciego & religioso & militar & \\
\hline $\mathbf{G}^{\circ}$ de protección & 0 & 1 & 2 & 3 & \\
\hline Fechas claves & / & & & & \\
\hline
\end{tabular}
El apartado "fechas claves" se ha extraído de AA.V., Guía de Arquitectura de Valencia, Icaro CTAV Ed., Valencia, 2007
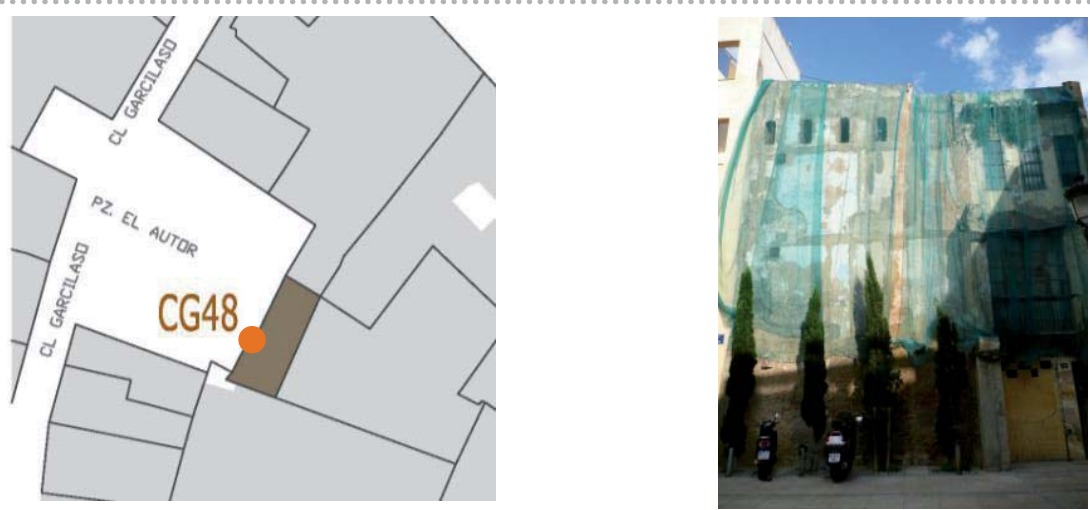

Fachada

Cg48b

Pisos
Composición fachada
Zócalo
Fábrica
Vano/dintel
Entrada/dintel
Alero
Cubierta

\begin{tabular}{|c|c|c|c|c|c|c|c|c|}
\hline \multirow{3}{*}{\multicolumn{2}{|c|}{$\begin{array}{l}\mathrm{N}^{03} \\
\text { aleatoria }\end{array}$}} & \multirow{2}{*}{\multicolumn{3}{|c|}{$\begin{array}{l}\text { sótano entreplanta } \\
\text { ordenada sin simetría }\end{array}$}} & \multicolumn{4}{|c|}{ piso noble caja escalera } \\
\hline & & & & & \multicolumn{4}{|c|}{ ordenada con simetría } \\
\hline & & $\mathrm{Z3}$ & Z4 & Z5 & & & & \\
\hline F1 & F2 & F3 & F4 & F5 & F6 & & & \\
\hline V1 & V2 & V3 & V4 & V5 & V7 & V8 & V9 & V10 \\
\hline E1 & E2 & E3 & E4 & & & & & \\
\hline A1 & $\mathrm{A} 2$ & $\mathrm{~A} 3$ & A4 & A5 & A7 & & & \\
\hline
\end{tabular}

Fábrica

Cg48b

Aparejo
Hiladas
Superficie
Sección
Elementos destacados

soga-tizón

soga

tizón

irregulares

pseudo horizontales

horizontales

sin planeidad

pseudo planeidad

planeidad perfecta

uniforme

hojas y núcleo

abocinada (vano)

aplantillado

cortado

terracota 


\begin{tabular}{l|lll}
$\begin{array}{l}\mathbf{N}^{\circ} \text { elementos medidos } \\
\text { Longitud }(\mathbf{c m})\end{array}$ & 15 & & \\
\hline $\begin{array}{l}\text { Anchura } \mathbf{( c m}) \\
\text { Espesor }(\mathbf{c m})\end{array}$ & 30 & & \\
Volumen $\left(\mathbf{c m}^{3}\right)$ & 3.5 & & \\
\hline $\begin{array}{l}\text { Tipo } \\
\text { Color }\end{array}$ & 1470 & heterogéneo & re-empleo \\
\hline $\begin{array}{l}\text { Recogida de muestra } \\
\text { Patologías }\end{array}$ & homogéneo & heterogéneo globular & heterogéneo marmolado \\
& no & sí & código Cg 48b/1 \\
\hline & erosión & disgregación & grietas \\
\hline
\end{tabular}

${ }^{1}$ Datos obtenidos en base al cálculo del desvío estándar (respecto al valor medio de la muestras analizadas) y del gráfico de frecuencia de las muestras analizadas, identificado por una curva gaussiana

\section{Juntas}

$\mathrm{Cg} 48 \mathrm{~b}$

\begin{tabular}{|c|c|c|c|c|}
\hline \multirow{2}{*}{$\begin{array}{l}N^{0} \text { elementos medidos } \\
\text { Llaga }(\mathrm{cm})\end{array}$} & \multicolumn{4}{|l|}{15} \\
\hline & \multicolumn{4}{|l|}{0.5} \\
\hline Tendel (cm) & \multicolumn{4}{|l|}{2} \\
\hline Altura de 5 hiladas $(\mathrm{cm})$ & \multicolumn{4}{|l|}{29} \\
\hline Proporción ladrillo/junta & \multicolumn{4}{|l|}{1.75} \\
\hline Tipo de acabado & simple & doble & múltiple & \\
\hline Junta de asiento & $\begin{array}{l}\text { rehundida } \\
\text { enrasada }\end{array}$ & $\begin{array}{l}\text { a hueso } \\
\text { matada }\end{array}$ & saliente & \\
\hline Junta de acabado & $\begin{array}{l}\text { rehundida } \\
\text { enrasada }\end{array}$ & $\begin{array}{l}\text { a hueso } \\
\text { matada }\end{array}$ & saliente & \\
\hline Tipo de mortero & cal & cal y tierra & tierra & cemento mixto \\
\hline Morfología de mortero & con grumos & con caliches & homogéneo & heterogéneo \\
\hline Tipo de árido & arena & gravilla & grava & mixto \\
\hline Color del árido & claro & oscuro & homogéneo & heterogéneo \\
\hline Recogida de muestra & no & sí & código Cg 48b/ & \\
\hline Patologías & $\begin{array}{l}\text { eflorescencias } \\
\text { erosión" }\end{array}$ & $\begin{array}{l}\text { micro fisuración } \\
\text { disgregación }\end{array}$ & $\begin{array}{l}\text { grietas } \\
\text { pulverización }\end{array}$ & \\
\hline
\end{tabular}


Imágenes
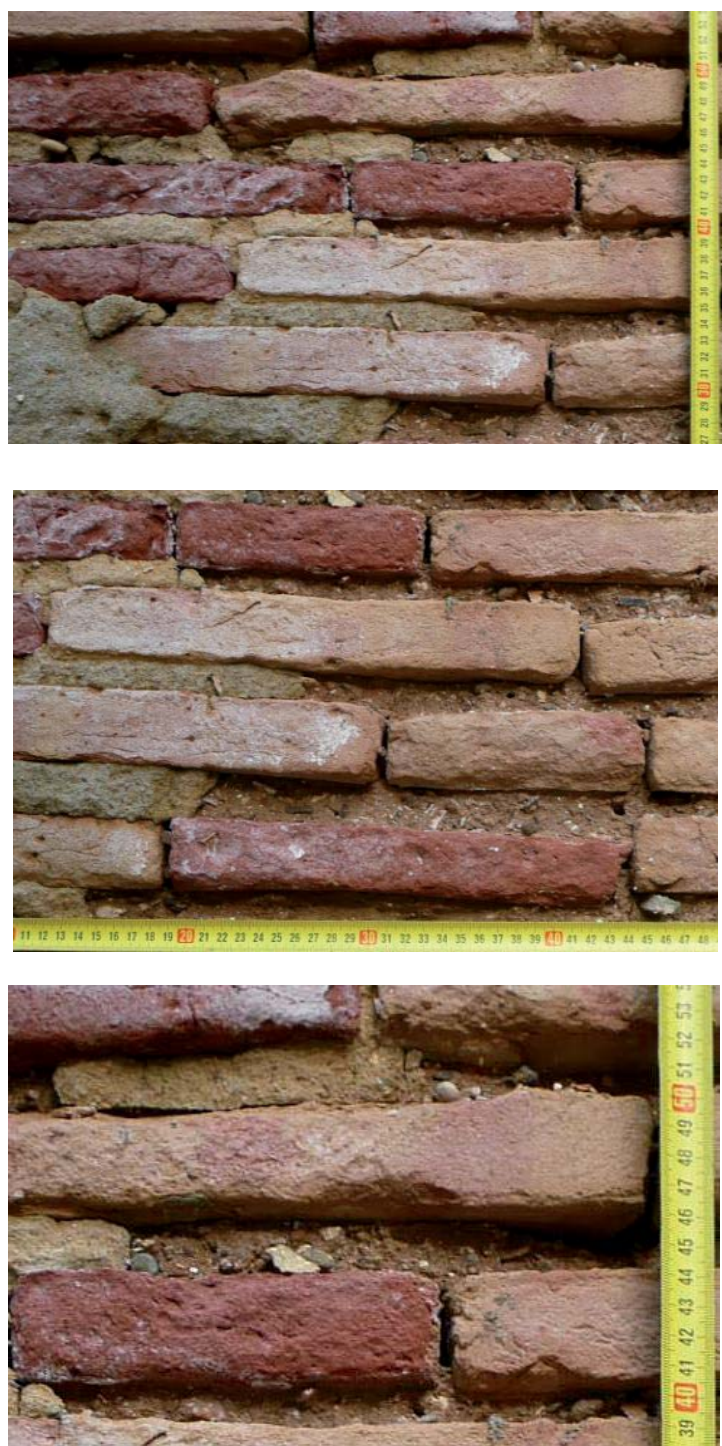

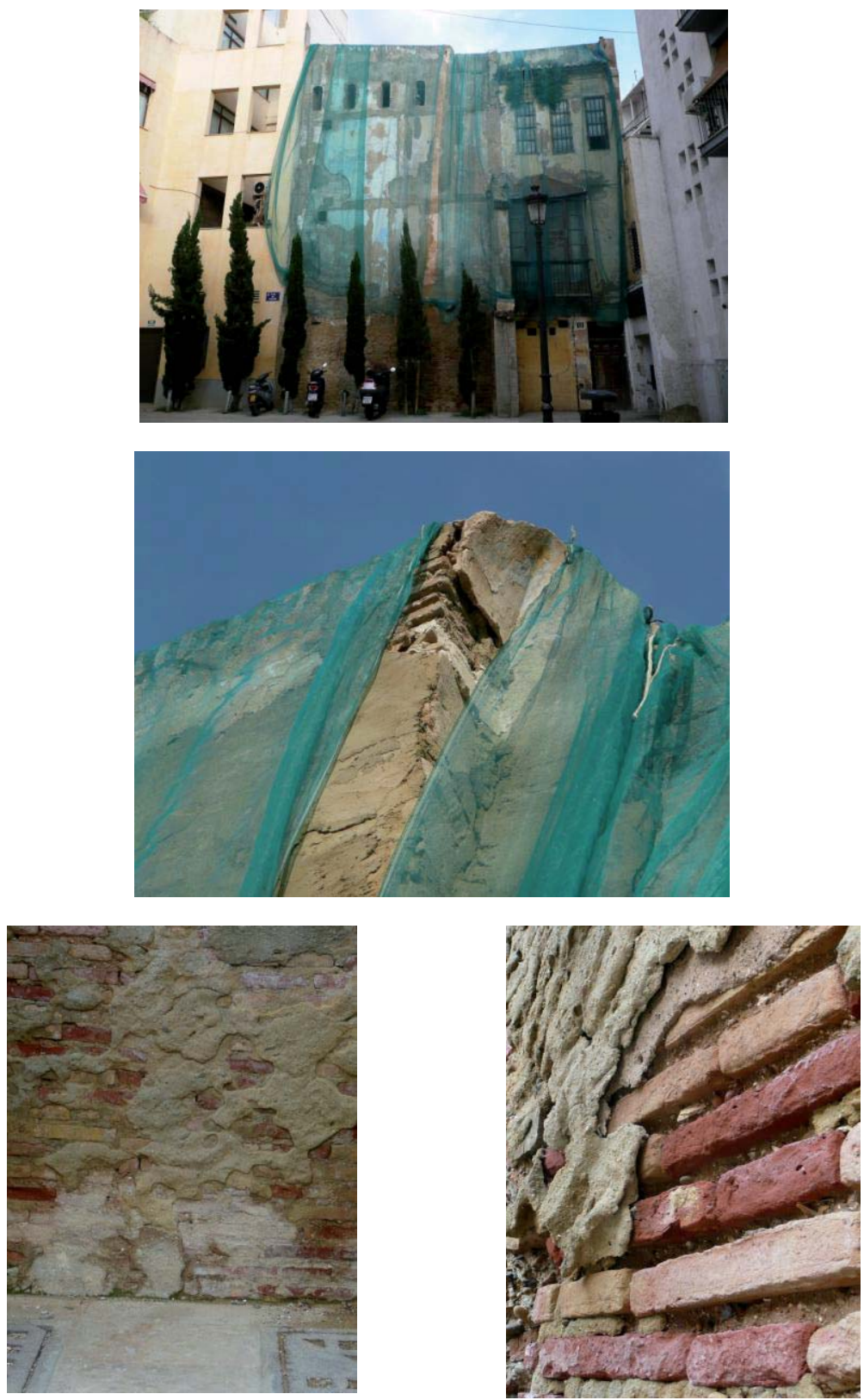
Datos generales

\begin{tabular}{|c|c|c|c|c|c|}
\hline Barrio & Carmen & La Seu-Xerea & Velluters & Mercat & S.Francesc \\
\hline Dirección & C/Garsilaso & & & & \\
\hline Tipo de edificio & residencial & palaciego & religioso & militar & \\
\hline $\mathbf{G}^{\circ}$ de protección & 0 & 1 & 2 & 3 & \\
\hline Fechas claves & / & & & & \\
\hline
\end{tabular}
El apartado "fechas claves" se ha extraído de AA.V.., Guía de Arquitectura de Valencia, Icaro CTAV Ed., Valencia, 2007
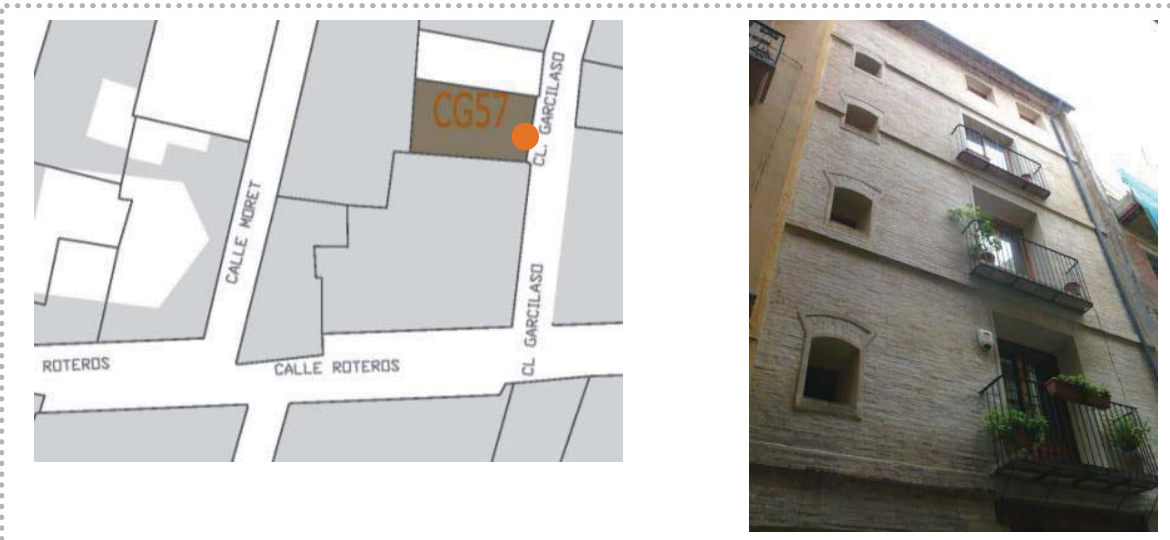

\section{Fachada}

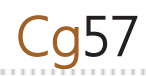

Pisos
Composición fachada
Zócalo
Fábrica
Vano/dintel
Entrada/dintel
Alero
Cubierta

\begin{tabular}{|c|c|c|c|c|c|c|c|c|}
\hline \multirow{3}{*}{\multicolumn{2}{|c|}{$\begin{array}{l}\mathrm{N}^{05} \\
\text { aleatoria } \\
71 \quad 72\end{array}$}} & \multirow{2}{*}{\multicolumn{3}{|c|}{$\begin{array}{l}\text { sótano entreplanta } \\
\text { ordenada sin simetría }\end{array}$}} & \multicolumn{4}{|c|}{ piso noble caja escalera } \\
\hline & & & & & \multicolumn{4}{|c|}{ ordenada con simetría } \\
\hline & $\mathrm{Z} 2$ & Z3 & Z4 & Z5 & & & & \\
\hline F1 & F2 & F3 & F4 & F5 & F7 & & & \\
\hline V1 & V2 & V3 & V4 & V5 & V6 & V8 & V9 & V10 \\
\hline E1 & E2 & E3 & E4 & & & & & \\
\hline A1 & A2 & A3 & A4 & A5 & A7 & & & \\
\hline
\end{tabular}

Fábrica

$\operatorname{Cg} 57$

\section{Aparejo \\ Hiladas \\ Superficie \\ Sección (hipótesis) \\ Elementos destacados}

\begin{tabular}{lll} 
soga-tizón & soga & \multicolumn{1}{c}{ tizón } \\
irregulares & pseudo horizontales & horizontales \\
\hline sin planeidad & pseudo planeidad & planeidad perfecta \\
\hline uniforme & hojas y núcleo & abocinada (vano) \\
aplantillado & cortado terracota & \\
\hline
\end{tabular}




\begin{tabular}{|c|c|c|c|}
\hline \multirow{2}{*}{$\begin{array}{l}\mathrm{N}^{\circ} \text { elementos medidos } \\
\text { Longitud }(\mathrm{cm})\end{array}$} & \multicolumn{3}{|l|}{15} \\
\hline & \multicolumn{3}{|l|}{30.1} \\
\hline Anchura (cm) & \multicolumn{3}{|l|}{14.1} \\
\hline Espesor (cm) & \multicolumn{3}{|l|}{3.2} \\
\hline Volumen $\left(\mathrm{cm}^{3}\right)$ & \multicolumn{3}{|l|}{1358.1} \\
\hline Tipo & homogéneo & heterogéneo & re-empleo \\
\hline \multirow{4}{*}{$\begin{array}{l}\text { Color } \\
\text { Recogida de muestra } \\
\text { Patologías }\end{array}$} & homogéneo & heterogéneo globular & heterogéneo marmolado \\
\hline & no & sí & Código Cg57/1 \\
\hline & eflorescencias & micro fisuración & grietas \\
\hline & erosión & disgregación & descamación \\
\hline
\end{tabular}

${ }^{1}$ Datos obtenidos en base al cálculo del desvío estándar (respecto al valor medio de la muestras analizadas) y del gráfico de frecuencia de las muestras analizadas, identificado por una curva gaussiana

\section{untas 2}

\begin{tabular}{|c|c|c|c|c|}
\hline \multirow{2}{*}{$\begin{array}{l}N^{\circ} \text { elementos medidos } \\
\text { Llaga }(\mathrm{cm})\end{array}$} & \multicolumn{4}{|l|}{15} \\
\hline & \multicolumn{4}{|l|}{1.5} \\
\hline Tendel (cm) & \multicolumn{4}{|l|}{4} \\
\hline Altura de 5 hiladas $(\mathrm{cm})$ & \multicolumn{4}{|l|}{37.5} \\
\hline Proporción ladrillo/junta & \multicolumn{4}{|l|}{0.8} \\
\hline Tipo de acabado & simple & doble & múltiple & \\
\hline \multirow[t]{2}{*}{ Junta de asiento } & rehundida & a hueso & saliente & \\
\hline & enrasada & matada & & \\
\hline \multirow[t]{2}{*}{ Junta de acabado } & rehundida & a hueso & saliente & \\
\hline & enrasada & matada & & \\
\hline \multirow{2}{*}{$\begin{array}{l}\text { Tipo de mortero } \\
\text { Morfología de mortero }\end{array}$} & cal & cal y tierra & tierra & cemento mixto \\
\hline & con grumos & con caliches & homogéneo & heterogéneo \\
\hline Tipo de árido & arena & gravilla & grava & mixto \\
\hline \multirow{4}{*}{$\begin{array}{l}\text { Color del árido } \\
\text { Recogida de muestra } \\
\text { Patologías }\end{array}$} & claro & oscuro & homogéneo & heterogéneo \\
\hline & no & sí & código & \\
\hline & eflorescencias & micro fisuración & grietas & \\
\hline & erosión & disgregación & pulverización & \\
\hline
\end{tabular}


Imágenes
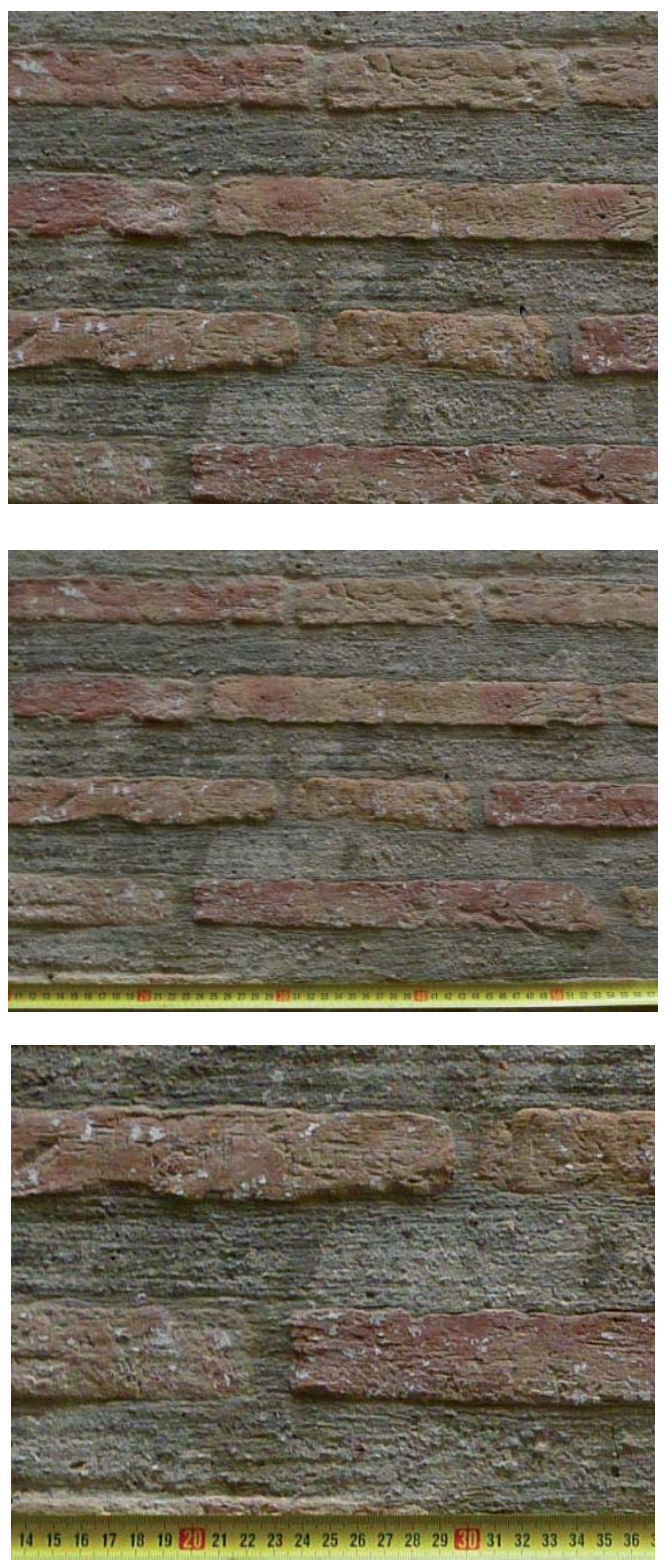

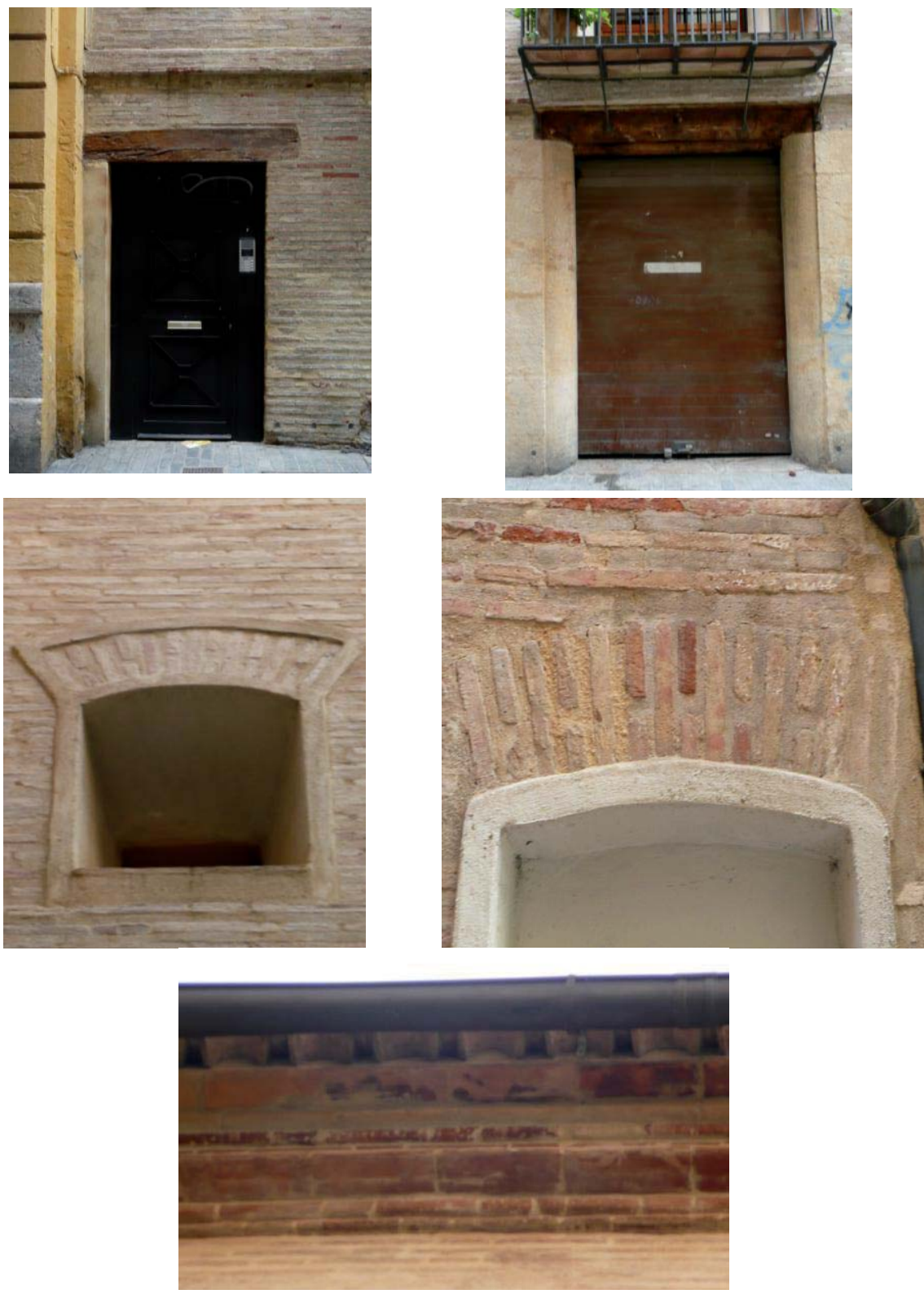


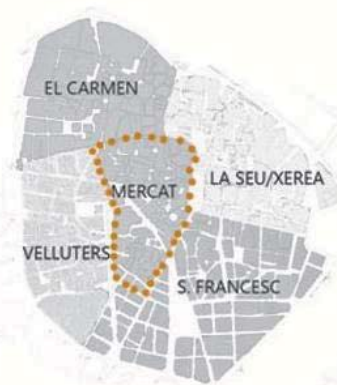

I.2.2. Fábricas históricas: barrio del Mercat 


\begin{tabular}{|c|c|c|}
\hline \multicolumn{3}{|c|}{ Barrio del Mercat: todas las fábricas seleccionadas } \\
\hline Código & Dirección & Edificio \\
\hline Ma28 & C/ Sagrari de la Compañía no 6 & RELIGIOSO \\
\hline Ma31 & C/ Estret Companyia s/n & RELIGIOSO \\
\hline Ma48 & C/ Belén nº 7 & RESIDENCIAL \\
\hline Ma54 & Pza. Horno San Nicolas no 4 & PALACIEGO \\
\hline Ma75 & C/ Marsella esq. Pza. San Nicolas nº 2 & RESIDENCIAL \\
\hline Ma82 & C/ Cadirers no12 & RESIDENCIAL \\
\hline Ma85 & C/ Cadirers n4 & RESIDENCIAL \\
\hline Ma90 & C/ Marsella no 4 acc. & PALACIEGO \\
\hline Ma92 & Pza. Correo Vell n 4 & RELIGIOSO \\
\hline Ma93 & C/ Abadía de S. Nicolás s/n & RELIGIOSO \\
\hline Mb72 & C/ Les Cuines no 1 & PALACIEGO \\
\hline Mb113 & C/ Toledà no 9 & RESIDENCIAL \\
\hline Mb155 & Pza. Mare de Deu no 1 & PALACIEGO \\
\hline Me52 & Pza. del Olmo no 2 & RESIDENCIAL \\
\hline Me172 & C/ Senia no 5 & RESIDENCIAL \\
\hline Me212a & C/ Lucente esq. Pza. Comunión & RELIGIOSO \\
\hline Me212b & C/ Lucente esq. Pza. Comunión & RELIGIOSO \\
\hline
\end{tabular}




\begin{tabular}{|c|c|c|c|}
\hline \multicolumn{4}{|c|}{ Barrio del Mercat: monumentos } \\
\hline Código & Dirección & Edificio & Nombre \\
\hline Ma28 & $\begin{array}{l}\text { C/ Sagrari de la } \\
\text { Compañía no } 6\end{array}$ & RELIGIOSO & $\begin{array}{l}\text { Iglesia Sagrado Corazón } \\
\text { de Jesus }\end{array}$ \\
\hline Ma31 & $\begin{array}{l}\text { C/ Estret Companyia } \\
\text { s/n }\end{array}$ & RELIGIOSO & $\begin{array}{l}\text { Iglesia Sagrado Corazón } \\
\text { de Jesus }\end{array}$ \\
\hline Ma54 & $\begin{array}{l}\text { Pza. Horno San } \\
\text { Nicolas no } 4\end{array}$ & PALACIEGO & $\begin{array}{l}\text { Palacio de los Martinez de } \\
\text { Vallejo }\end{array}$ \\
\hline Ma90 & C/ Marsella no 4 acc. & PALACIEGO & 1 \\
\hline Ma92 & Pza. Correo Vell no 4 & RELIGIOSO & $\begin{array}{l}\text { Sacristía Iglesia de S. } \\
\text { Nicolas }\end{array}$ \\
\hline Ma93 & $\begin{array}{l}\text { C/ Abadía de S. } \\
\text { Nicolás s/n }\end{array}$ & RELIGIOSO & $\begin{array}{l}\text { Capilla de la Comunión } \\
\text { Iglesia de S. nicolas }\end{array}$ \\
\hline Mb72 & C/ Les Cuines no 1 & PALACIEGO & Palacio D'en Bou \\
\hline Mb155 & Pza. Mare de Deu no 1 & PALACIEGO & Casa Vestuario \\
\hline Me212a & $\begin{array}{l}\text { C/ Lucente esq. Pza. } \\
\text { Comunión Stos. Juanes }\end{array}$ & RELIGIOSO & $\begin{array}{l}\text { Capilla Comunión Iglesia } \\
\text { de los Santos Juanes }\end{array}$ \\
\hline Me212b & $\begin{array}{l}\text { C/ Lucente esq. Pza. } \\
\text { Comunión Stos. Juanes }\end{array}$ & RELIGIOSO & $\begin{array}{l}\text { Capilla lateral Iglesia de } \\
\text { los Santos Juanes }\end{array}$ \\
\hline
\end{tabular}




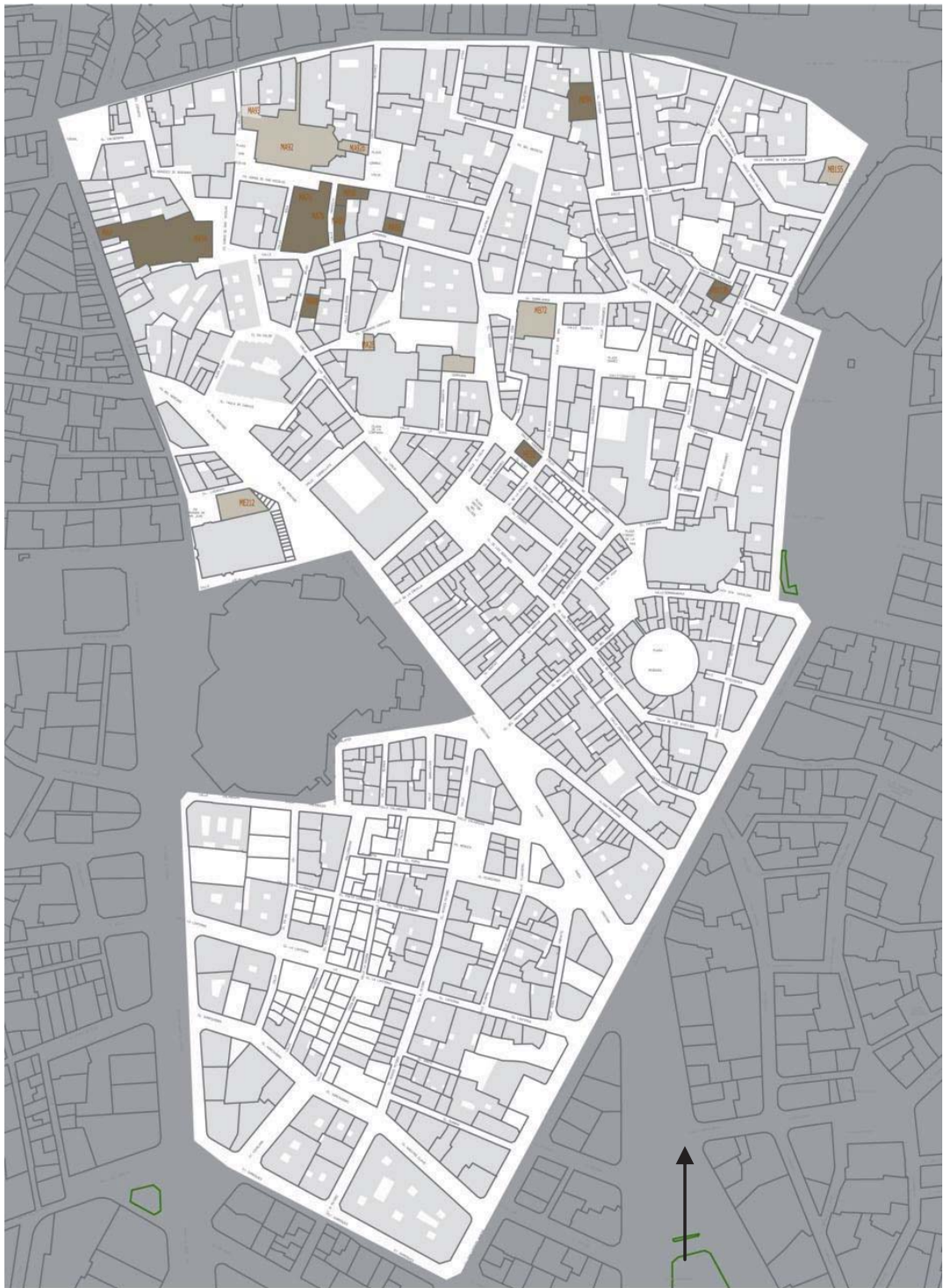

FIG. 5 Mapa de localización de las fichas recopiladas en el barrio del Mercat (CRISTINI) 
Datos generales

Ma28

\begin{tabular}{|c|c|c|c|c|c|}
\hline Barrio & Carmen & La Seu-Xerea & Velluters & Mercat & S.Francesc \\
\hline Dirección & $\mathrm{C} /$ Sagrari $\mathrm{C}$ & npañía n6 & & & \\
\hline Tipo de edificio & residencial & palaciego & religioso & militar & \\
\hline $\mathbf{G}^{\circ}$ de protección & 0 & 1 & 2 & 3 & \\
\hline Fechas claves & 1886 (Belc & oañez) & & & \\
\hline
\end{tabular}
El apartado "fechas claves" se ha extraído de AA.W., Guía de Arquitectura de Valencia, Icaro CTAV Ed., Valencia, 2007

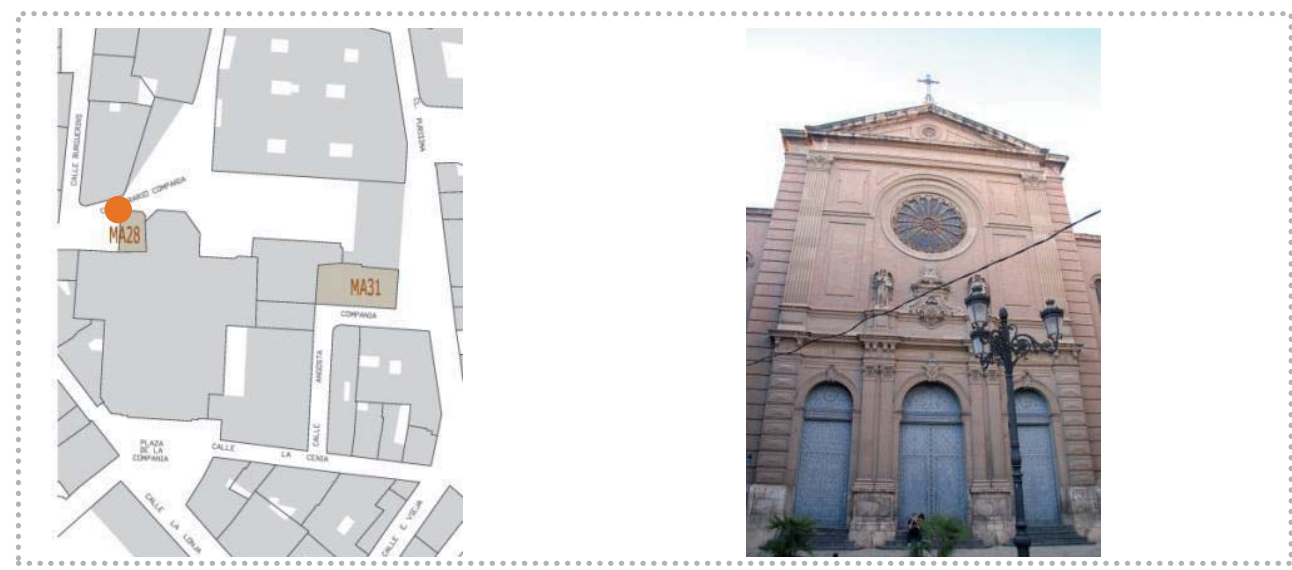

Fachada

Ma28

Pisos
Composición fachada
Zócalo
Fábrica
Vano/dintel
Entrada/dintel
Alero
Cubierta

\begin{tabular}{|c|c|c|c|c|c|c|c|c|}
\hline \multirow{2}{*}{\multicolumn{2}{|c|}{$\begin{array}{l}\mathrm{N} \% \\
\text { aleatoria }\end{array}$}} & \multirow{2}{*}{\multicolumn{3}{|c|}{$\begin{array}{l}\text { sótano entreplanta } \\
\text { ordenada sin simetría }\end{array}$}} & \multicolumn{4}{|c|}{ piso noble caja escalera } \\
\hline & & & & & \multicolumn{4}{|c|}{ ordenada con simetría } \\
\hline Z1 & $\mathrm{Z} 2$ & $\mathrm{Z3}$ & Z4 & Z5 & & & & \\
\hline F1 & $\mathrm{F} 2$ & F3 & F4 & F5 & F6 & & & \\
\hline V1 & V2 & V3 & V4 & V5 & V6 & V8 & V9 & V10 \\
\hline E1 & E2 & E3 & E4 & & & & & \\
\hline A1 & $\mathrm{A} 2$ & A3 & A4 & A5 & A6 & & & \\
\hline
\end{tabular}

Fábrica

Ma28

\section{Aparejo \\ Hiladas \\ Superficie \\ Sección (hipótesis) \\ Elementos destacados}

\begin{tabular}{lll} 
soga-tizón & soga & \\
irregulares & tizón & \\
sin planeidad & pseudo planeidad & planeidad perfecta \\
\hline uniforme & hojas y núcleo & abocinada (vano) \\
aplantillado & cortado terracota & \\
\hline
\end{tabular}




\begin{tabular}{l|lll}
\hline $\begin{array}{l}\text { No elementos medidos } \\
\text { Longitud }(\mathbf{c m})\end{array}$ & 15 & & \\
Anchura $(\mathbf{c m})$ & 26.2 & & \\
Espesor $(\mathbf{c m})$ & 12.1 & & \\
Volumen $\left(\mathbf{c m}^{3}\right)$ & 4.3 & heterogéneo & re-empleo \\
Tipo & 1363.1 & heterogéneo globular & heterogéneo marmolado \\
Color & homogéneo & homogéneo & síno \\
Recogida de muestra & no & micro fisuración & grietas \\
Patologías & eflorescencias & disgregación & descamación
\end{tabular}

${ }^{1}$ Datos obtenidos en base al cálculo del desvío estándar (respecto al valor medio de la muestras analizadas) y del gráfico de frecuencia de las muestras analizadas, identificado por una curva gaussiana

\section{Juntas 2}

Ma28

\begin{tabular}{|c|c|c|c|c|}
\hline \multirow{2}{*}{$\begin{array}{l}N^{\circ} \text { elementos medidos } \\
\text { Llaga }(\mathrm{cm})\end{array}$} & \multicolumn{4}{|l|}{15} \\
\hline & \multicolumn{4}{|l|}{0.7} \\
\hline Tendel (cm) & \multicolumn{4}{|l|}{0.8} \\
\hline Altura de 5 hiladas $(\mathrm{cm})$ & \multicolumn{4}{|l|}{25.5} \\
\hline Proporción ladrillo/junta & \multicolumn{4}{|l|}{5.3} \\
\hline Tipo de acabado & simple & doble & \multicolumn{2}{|l|}{ múltiple } \\
\hline \multirow[t]{2}{*}{ Junta de asiento } & rehundida & a hueso & \multirow{2}{*}{\multicolumn{2}{|c|}{ saliente }} \\
\hline & enrasada & matada & & \\
\hline \multirow[t]{2}{*}{ Junta de acabado } & rehundida & a hueso & \multirow{2}{*}{\multicolumn{2}{|c|}{ saliente }} \\
\hline & enrasada & matada & & \\
\hline \multirow{3}{*}{$\begin{array}{l}\text { Tipo de mortero } \\
\text { Morfología de mortero } \\
\text { Tipo de árido }\end{array}$} & cal & cal y tierra & tierra & cemento mixto \\
\hline & con grumos & con caliches & homogéneo & heterogéneo \\
\hline & arena & gravilla & grava & mixto \\
\hline \multirow{4}{*}{$\begin{array}{l}\text { Color del árido } \\
\text { Recogida de muestra } \\
\text { Patologías }\end{array}$} & claro & oscuro & homogéneo & heterogéneo \\
\hline & no & sí & \multicolumn{2}{|l|}{ código } \\
\hline & eflorescencias & micro fisuración & \multicolumn{2}{|l|}{ grietas } \\
\hline & erosión" & disgregación & \multicolumn{2}{|l|}{ pulverización } \\
\hline
\end{tabular}


Imágenes

Ma28
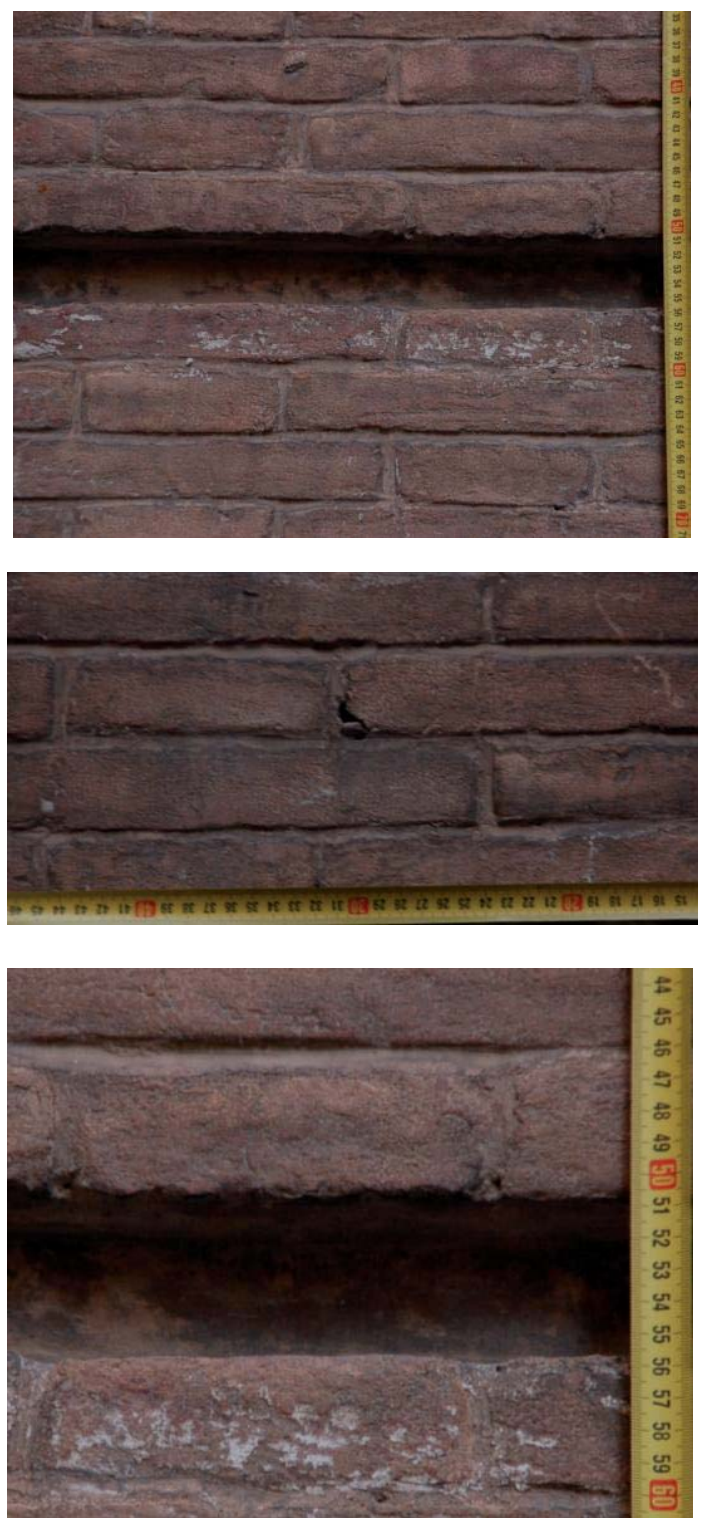

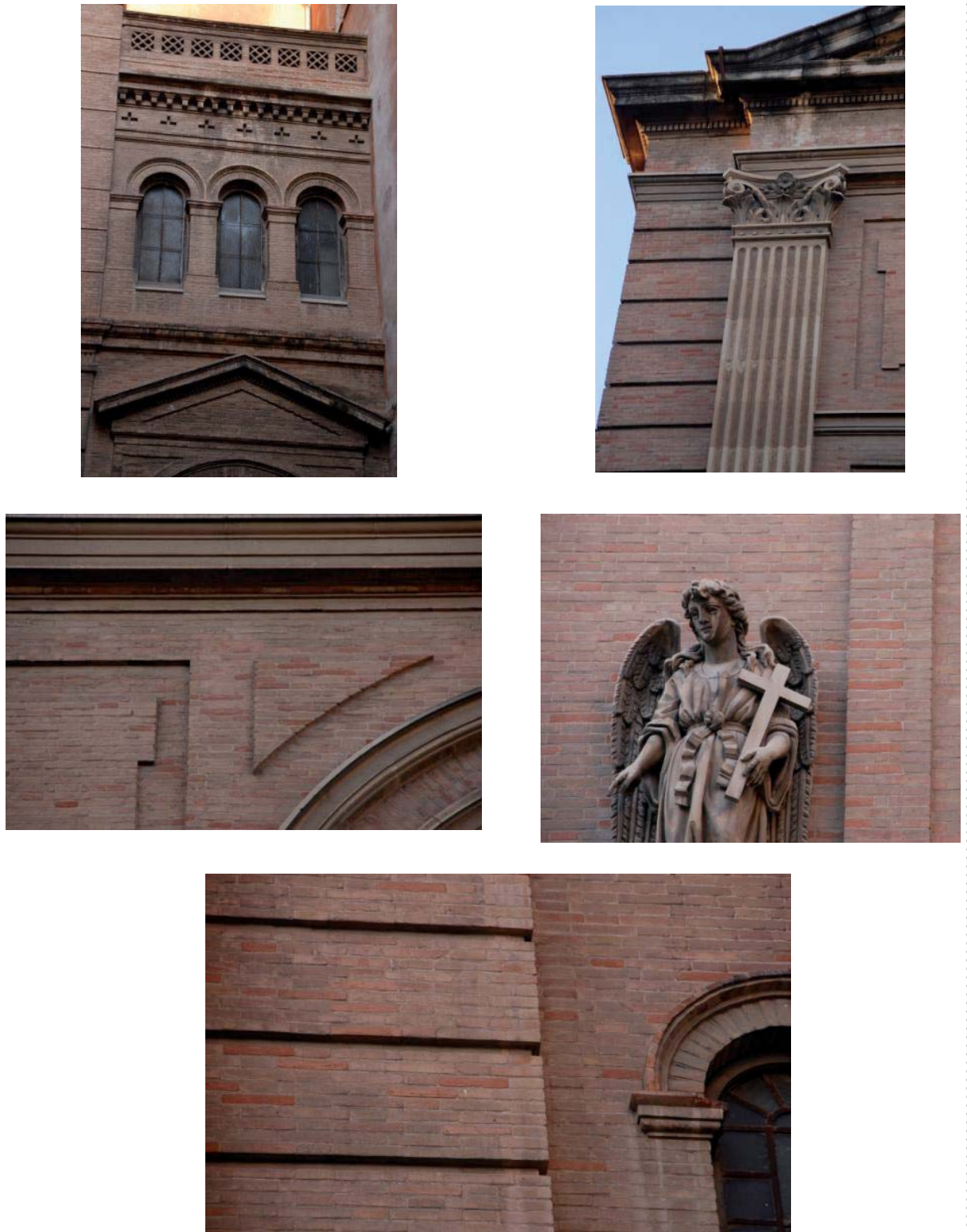


\begin{tabular}{|c|c|c|c|c|c|}
\hline Barrio & Carmen & La Seu-Xerea & Velluters & Mercat & S.Francesc \\
\hline Dirección & \multicolumn{5}{|c|}{ C/Estret Companya s/n } \\
\hline Tipo de edificio & residencial & palaciego & religioso & militar & \\
\hline $\mathbf{G}^{\circ}$ de protección & 0 & 1 & 2 & 3 & \\
\hline Fechas claves & \multicolumn{5}{|c|}{1886 (Belda Ibañez) } \\
\hline
\end{tabular}
El apartado "fechas claves" se ha extraído de AA.V.., Guía de Arquitectura de Valencia, Icaro CTAV Ed., Valencia, 2007
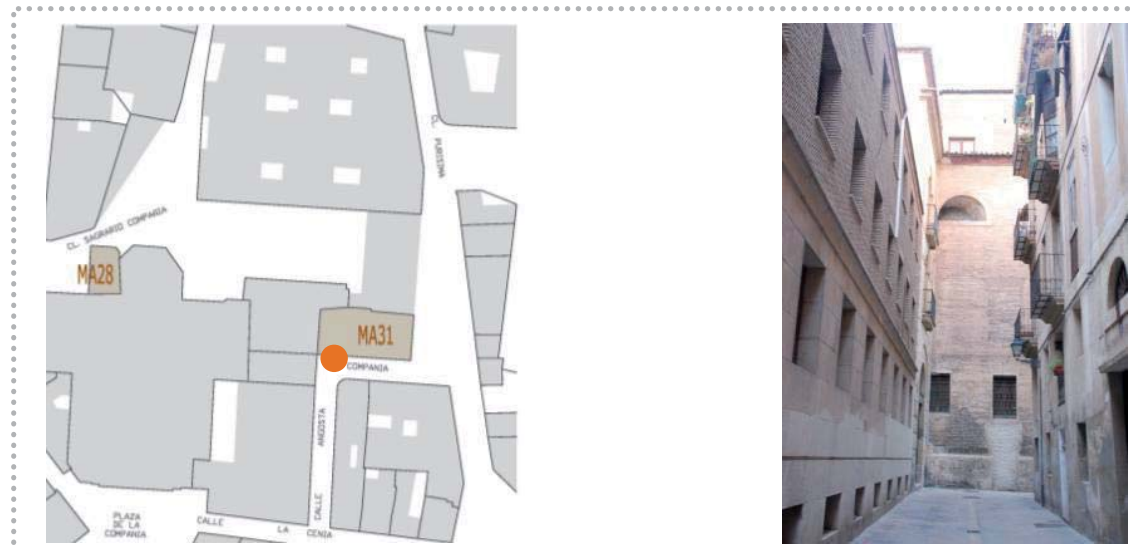

Fachada

Ma31

Pisos
Composición fachada
Zócalo
Fábrica
Vano/dintel
Entrada/dintel
Alero
Cubierta

\begin{tabular}{|c|c|c|c|c|c|c|c|}
\hline \multirow{2}{*}{\multicolumn{2}{|c|}{$\begin{array}{l}\mathrm{N} \% / \\
\text { aleatoria }\end{array}$}} & \multirow{2}{*}{\multicolumn{2}{|c|}{$\begin{array}{l}\text { sótano entreplanta } \\
\text { ordenada sin simetría }\end{array}$}} & \multicolumn{4}{|c|}{ piso noble caja escalera } \\
\hline & & & & \multicolumn{4}{|c|}{ ordenada con simetría } \\
\hline & Z2 & Z3 & Z4 & & & & \\
\hline F1 & F2 & F3 & F4 & F6 & & & \\
\hline V1 & V2 & V3 & V4 & V7 & V8 & V9 & V10 \\
\hline E1 & E2 & E3 & E4 & & & & \\
\hline A1 & $\mathrm{A} 2$ & A3 & A4 & A7 & & & \\
\hline
\end{tabular}

\section{Fábrica}

Ma31

\section{Aparejo \\ Hiladas \\ Superficie \\ Sección (hipótesis) \\ Elementos destacados}

\begin{tabular}{lll} 
soga-tizón & soga & \multicolumn{1}{c}{ tizón } \\
irregulares & pseudo horizontales & horizontales \\
\hline sin planeidad & pseudo planeidad & planeidad perfecta \\
\hline uniforme & hojas y núcleo & abocinada (vano) \\
aplantillado & cortado terracota & \\
\hline
\end{tabular}




\begin{tabular}{l|lll}
$\begin{array}{l}\text { No elementos medidos } \\
\text { Longitud }(\mathbf{c m})\end{array}$ & 15 & & \\
\hline $\begin{array}{l}\text { Anchura } \mathbf{( c m}) \\
\text { Espesor }(\mathbf{c m})\end{array}$ & 26 & & \\
Volumen $\left(\mathbf{c m}^{3}\right)$ & 4.4 & & \\
Tipo & 1795.1 & & \\
Color & homogéneo & heterogéneo & re-empleo \\
\hline Recogida de muestra & homogéneo & heterogéneo globular & heterogéneo marmolado \\
\hline Patologías & no & sí & código \\
\hline & eflorescencias & micro fisuración & grietas \\
& erosión & disgregación & descamación \\
\hline
\end{tabular}

${ }^{1}$ Datos obtenidos en base al cálculo del desvío estándar (respecto al valor medio de la muestras analizadas) y del gráfico de frecuencia de las muestras analizadas, identificado por una curva gaussiana

\section{untas}

\begin{tabular}{|c|c|c|c|c|}
\hline \multirow{2}{*}{$\begin{array}{l}N^{\circ} \text { elementos medidos } \\
\text { Llaga }(\mathrm{cm})\end{array}$} & \multicolumn{4}{|l|}{15} \\
\hline & \multicolumn{4}{|l|}{1.7} \\
\hline Tendel (cm) & \multicolumn{4}{|l|}{4.3} \\
\hline Altura de 5 hiladas $(\mathrm{cm})$ & \multicolumn{4}{|l|}{43.5} \\
\hline Proporción ladrillo/junta & \multicolumn{4}{|l|}{1.02} \\
\hline Tipo de acabado & simple & doble & \multicolumn{2}{|l|}{ múltiple } \\
\hline \multirow[t]{2}{*}{ Junta de asiento } & rehundida & a hueso & \multirow[t]{2}{*}{ saliente } & \\
\hline & enrasada & matada & & \\
\hline \multirow[t]{2}{*}{ Junta de acabado } & rehundida & a hueso & \multirow[t]{2}{*}{ saliente } & \\
\hline & enrasada & matada & & \\
\hline \multirow{2}{*}{$\begin{array}{l}\text { Tipo de mortero } \\
\text { Morfología de mortero }\end{array}$} & cal & cal y tierra & tierra & cemento mixto \\
\hline & con grumos & con caliches & homogéneo & heterogéneo \\
\hline \multirow{5}{*}{$\begin{array}{l}\text { Tipo de árido } \\
\text { Color del árido } \\
\text { Recogida de muestra } \\
\text { Patologías }\end{array}$} & arena & gravilla & grava & mixto \\
\hline & claro & oscuro & homogéneo & heterogéneo \\
\hline & no & sí & \multicolumn{2}{|l|}{ código } \\
\hline & eflorescencias & micro fisuración & \multicolumn{2}{|l|}{ grietas } \\
\hline & erosión" & disgregación & \multicolumn{2}{|l|}{ pulverización } \\
\hline
\end{tabular}


Imágenes
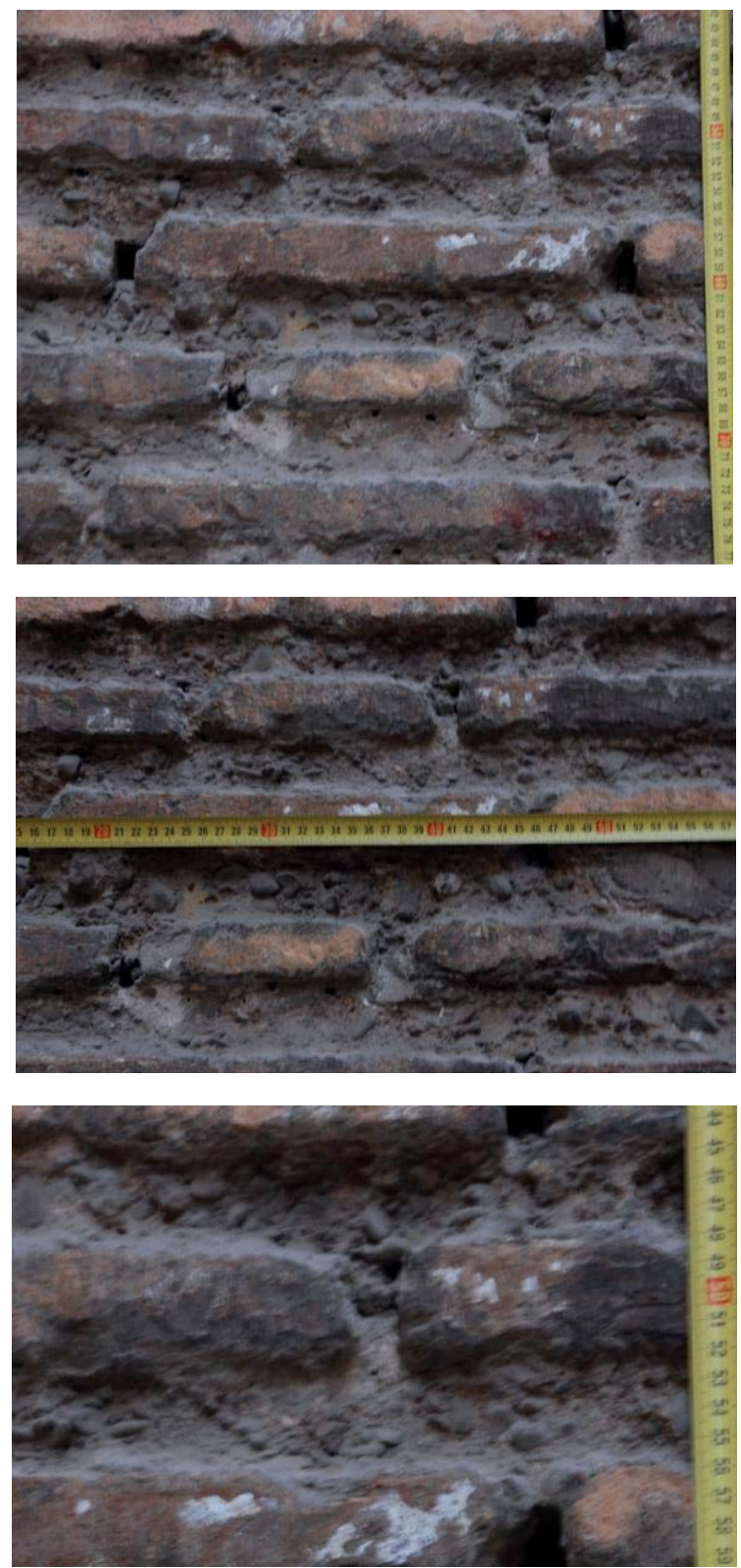

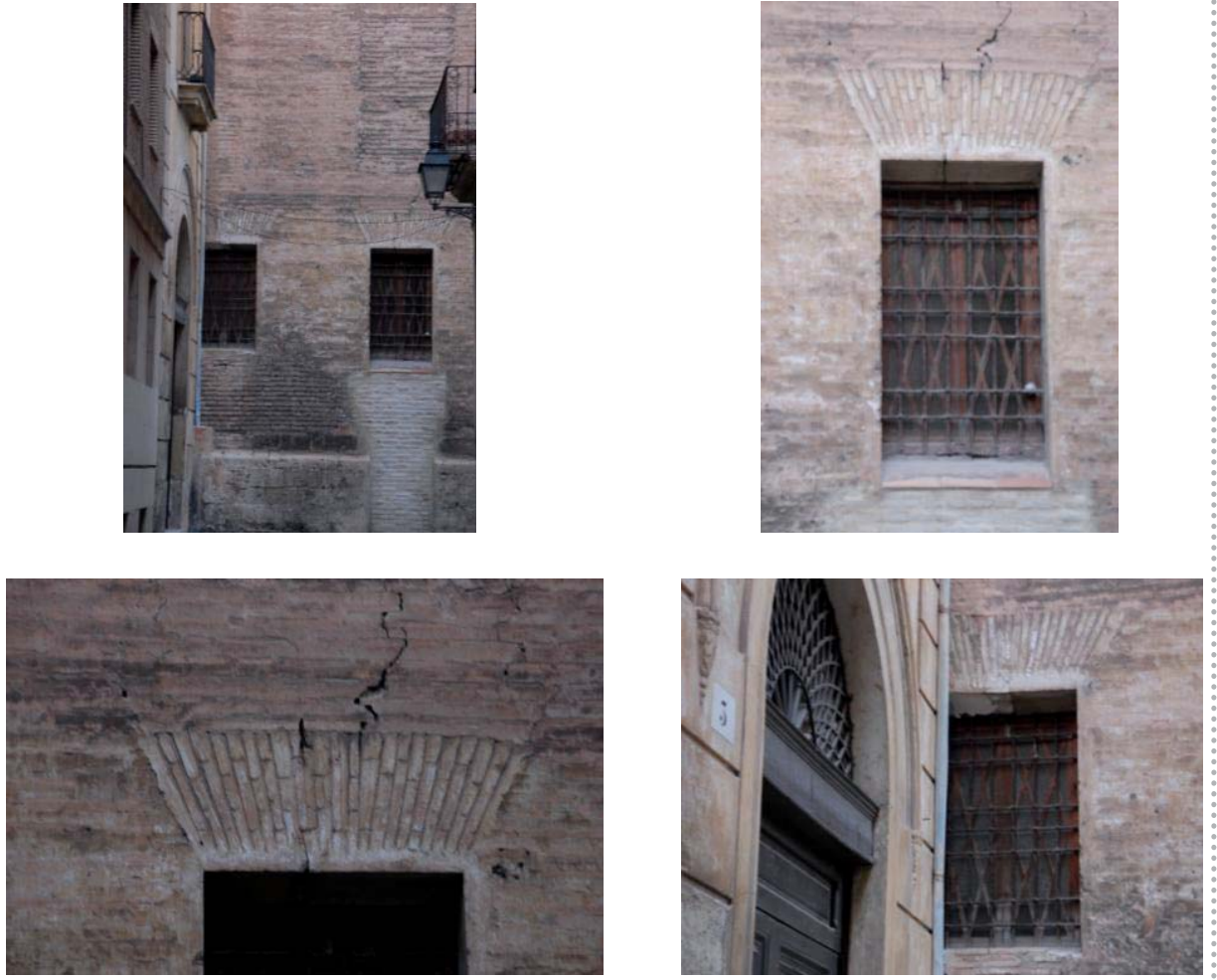

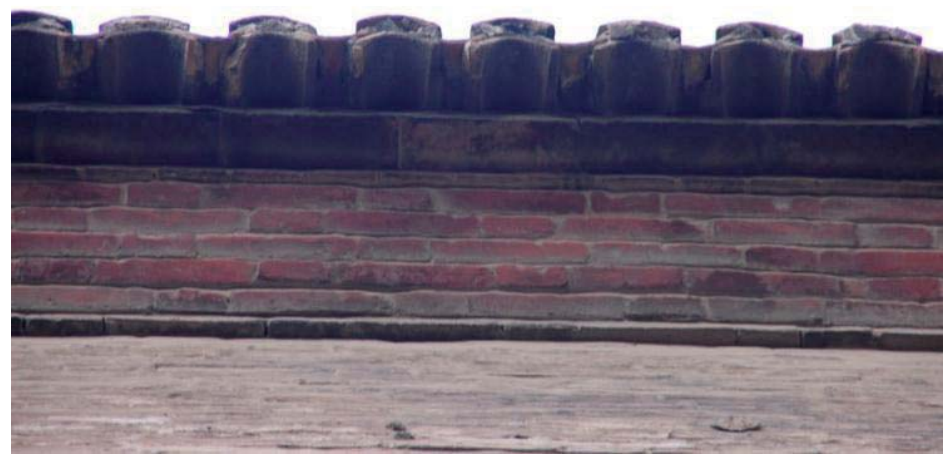




\begin{tabular}{|c|c|c|c|c|c|}
\hline Barrio & Carmen & La Seu-Xerea & Velluters & Mercat & S.Francesc \\
\hline Dirección & C/Belen n'7 & & & & \\
\hline Tipo de edificio & residencial & palaciego & religioso & militar & \\
\hline $\mathbf{G}^{\circ}$ de protección & 0 & 1 & 2 & 3 & \\
\hline Fechas claves & / & & & & \\
\hline
\end{tabular}
El apartado "fechas claves" se ha extraído de AA.V. ., Guía de Arquitectura de Valencia, Icaro CTAV Ed., Valencia, 2007

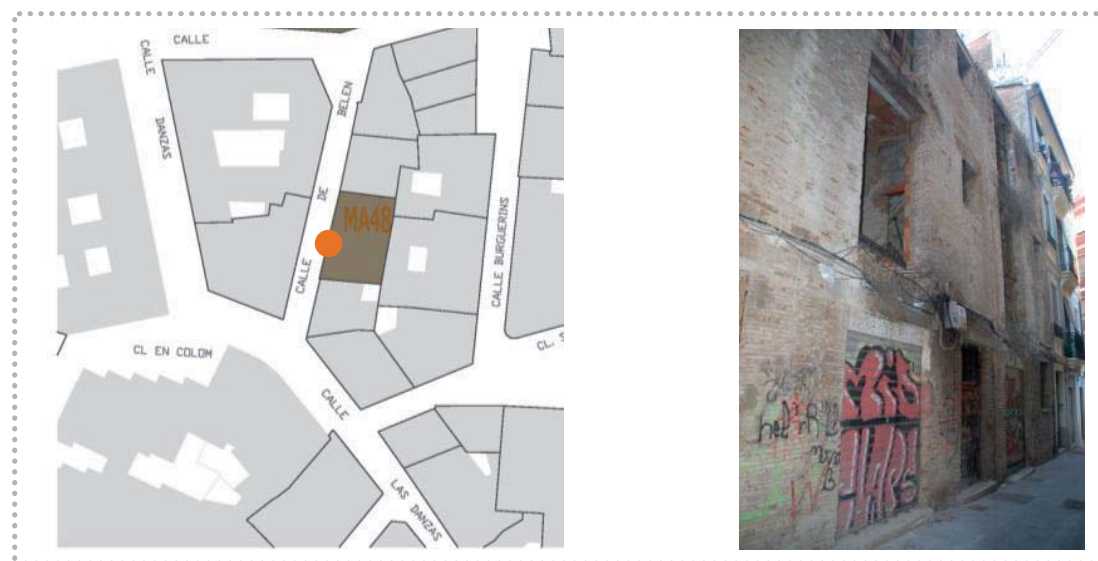

Fachada

Ma48

Pisos
Composición fachada
Zócalo
Fábrica
Vano/dintel
Entrada/dintel
Alero
Cubierta

\begin{tabular}{|c|c|c|c|c|c|c|c|c|c|}
\hline \multicolumn{2}{|c|}{$\mathrm{N} \cdot 2$} & sótano & & planta & \multicolumn{5}{|c|}{ piso noble caja escalera } \\
\hline \multicolumn{2}{|c|}{ aleatoria } & \multicolumn{3}{|c|}{ ordenada sin simetría } & \multicolumn{5}{|c|}{ ordenada con simetría } \\
\hline $\mathrm{Z1}$ & Z2 & $\mathrm{Z3}$ & Z4 & Z5 & & & & & \\
\hline F1 & F2 & F3 & F4 & F5 & F6 & F7 & & & \\
\hline V1 & V2 & V3 & V4 & V5 & V6 & V7 & V8 & V9 & V10 \\
\hline E1 & E2 & E3 & E4 & & & & & & \\
\hline A1 & $\mathrm{A} 2$ & $\mathrm{~A} 3$ & A4 & A5 & A6 & A7 & & & \\
\hline
\end{tabular}

Fábrica

Ma48

Aparejo
Hiladas
Superficie
Sección (hipótesis)
Elementos destacados

\begin{tabular}{|c|c|c|}
\hline soga-tizón & soga & \\
\hline irregulares & pseudo horizontales & horizontales \\
\hline sin planeidad & pseudo planeidad & planeidad perfecta \\
\hline uniforme & hojas y núcleo & abocinada (vano) \\
\hline aplantillado & cortado & \\
\hline
\end{tabular}




\begin{tabular}{|c|c|c|c|}
\hline$N^{\circ}$ elementos medidos & 15 & & \\
\hline Longitud (cm) & 29.1 & & \\
\hline Anchura (cm) & 14.2 & & \\
\hline Espesor (cm) & 2.5 & & \\
\hline Volumen $\left(\mathrm{cm}^{3}\right)$ & 1033.05 & & \\
\hline Tipo & homogéneo & heterogéneo & re-empleo \\
\hline Color & homogéneo & heterogéneo globular & heterogéneo marmolado \\
\hline Recogida de muestra & no & sí & código \\
\hline Patologías & $\begin{array}{l}\text { eflorescencias } \\
\text { erosión }\end{array}$ & $\begin{array}{l}\text { micro fisuración } \\
\text { disgregación }\end{array}$ & $\begin{array}{l}\text { grietas } \\
\text { descamación }\end{array}$ \\
\hline
\end{tabular}

1 Datos obtenidos en base al cálculo del desvio estándar (respecto al valor medio de la muestras analizadas) y del gráfico de frecuencia de las muestras analizadas, identificado por una curva gaussiana

\section{Juntas}

Ma48

\begin{tabular}{|c|c|c|c|c|}
\hline \multirow{2}{*}{$\begin{array}{l}N^{\circ} \text { elementos medidos } \\
\text { Llaga }(\mathrm{cm})\end{array}$} & \multicolumn{4}{|l|}{15} \\
\hline & \multicolumn{4}{|l|}{1.3} \\
\hline Tendel (cm) & \multicolumn{4}{|l|}{1.6} \\
\hline Altura de 5 hiladas $(\mathrm{cm})$ & \multicolumn{4}{|l|}{19.5} \\
\hline Proporción ladrillo/junta & \multicolumn{4}{|l|}{1.5} \\
\hline Tipo de acabado & simple & doble & \multicolumn{2}{|l|}{ múltiple } \\
\hline \multirow[t]{2}{*}{ Junta de asiento } & rehundida & a hueso & \multirow{2}{*}{\multicolumn{2}{|c|}{ saliente }} \\
\hline & enrasada & matada & & \\
\hline \multirow[t]{2}{*}{ Junta de acabado } & rehundida & a hueso & \multirow{2}{*}{\multicolumn{2}{|c|}{ saliente }} \\
\hline & enrasada & matada & & \\
\hline \multirow{2}{*}{ Morfología de mortero } & cal & cal y tierra & tierra & cemento mixto \\
\hline & con grumos & con caliches & homogéneo & heterogéneo \\
\hline \multirow{5}{*}{$\begin{array}{l}\text { Tipo de árido } \\
\text { Color del árido } \\
\text { Recogida de muestra } \\
\text { Patologías }\end{array}$} & arena & gravilla & grava & mixto \\
\hline & claro & oscuro & homogéneo & heterogéneo \\
\hline & no & sí & \multicolumn{2}{|l|}{ código } \\
\hline & eflorescencias & micro fisuración & \multicolumn{2}{|l|}{ grietas } \\
\hline & erosión & disgregación & \multicolumn{2}{|l|}{ pulverización } \\
\hline
\end{tabular}


Imágenes
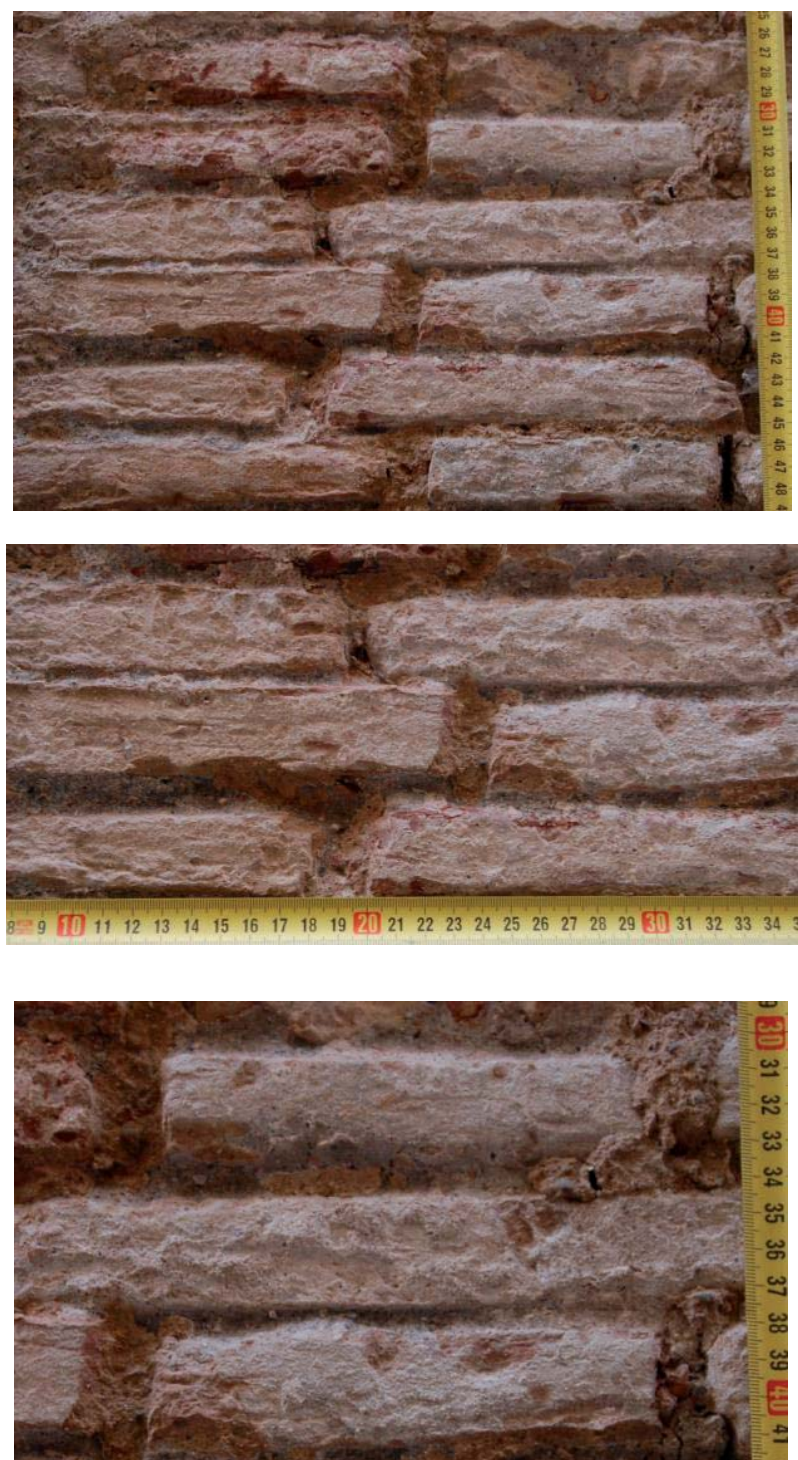
Imágenes

Ma48
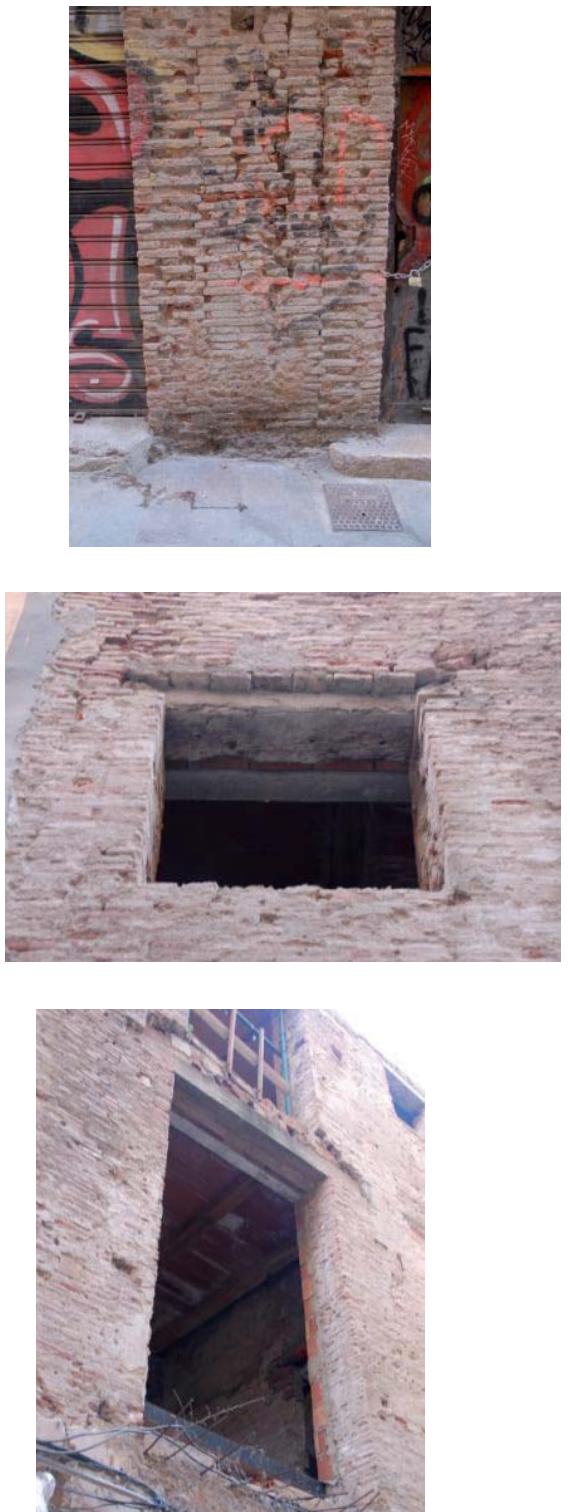
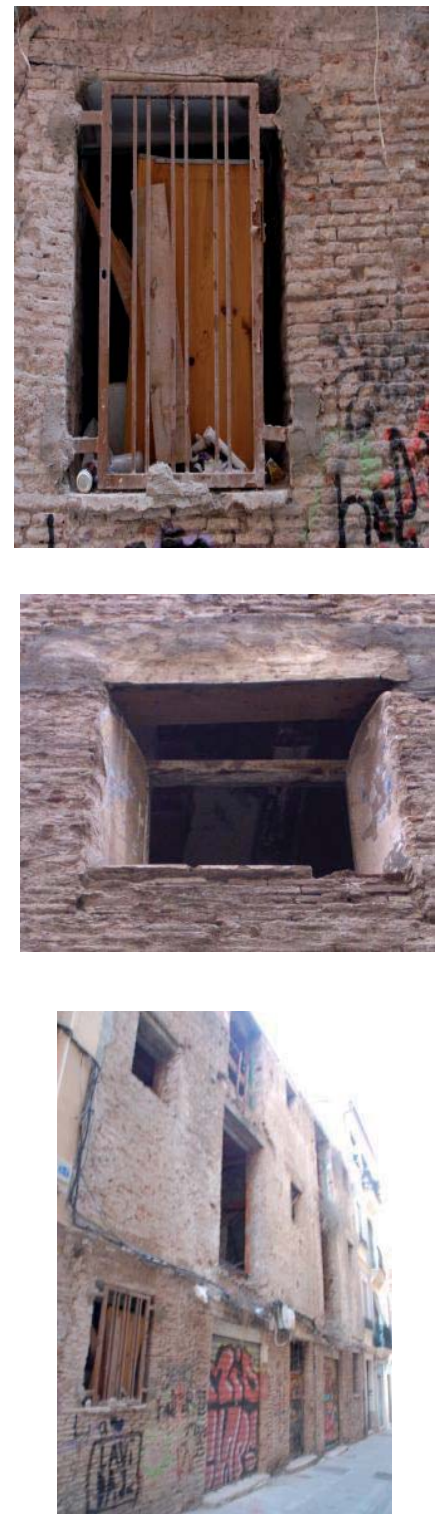


\begin{tabular}{|c|c|c|c|c|c|}
\hline & \multicolumn{2}{|c|}{$\begin{array}{l}\text { Carmen } \quad \text { La Seu-Xerea } \\
\text { Pza. Horno S. Nicolas n4 }\end{array}$} & Velluters & Mercat & S.Francesc \\
\hline & \multicolumn{5}{|c|}{ Pza. Horno S. Nicolas n4 } \\
\hline & residencial & palaciego & religioso & militar & \\
\hline $\begin{array}{l}\text { Barrio } \\
\text { Dirección } \\
\text { Tipo de edificio } \\
\text { G de protección }^{\circ} \text { de }\end{array}$ & 0 & 1 & 2 & 3 & \\
\hline $\begin{array}{l}\mathbf{G}^{\circ} \text { de protección } \\
\text { Fechas claves }\end{array}$ & \multicolumn{5}{|c|}{ S. XVII-XVIII intervención 1994-97 (Vila /Ferrer) } \\
\hline
\end{tabular}
El apartado "fechas claves" se ha extraído de AA.V., Guía de Arquitectura de Valencia, ICaro CTAV Ed., Valencia, 2007

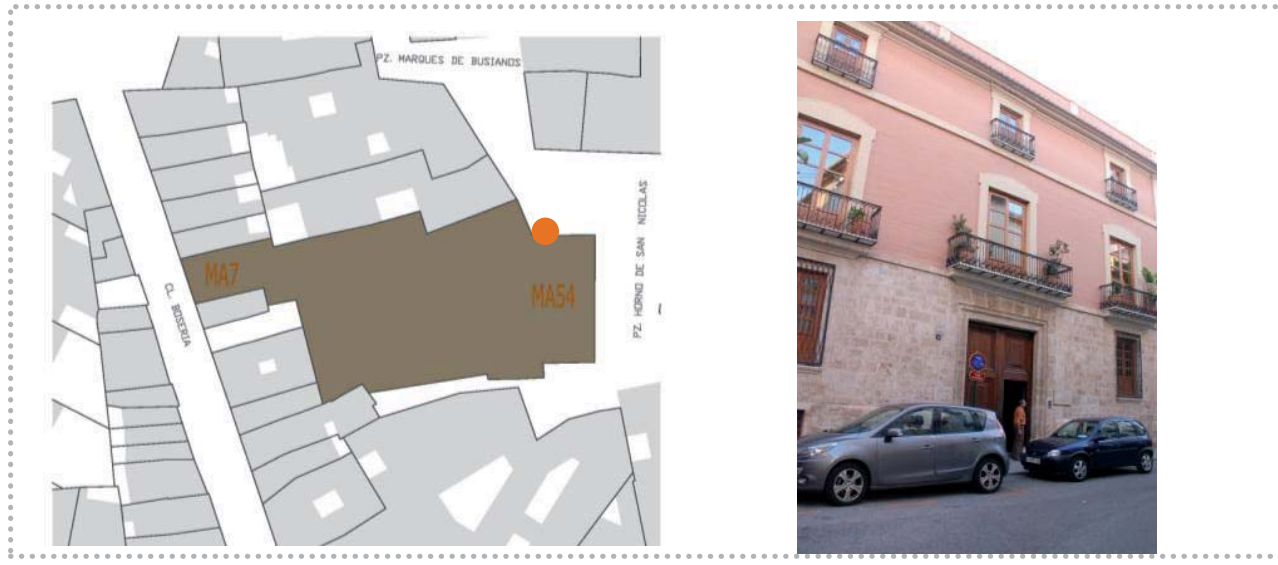

Fachada

Ma54

\begin{tabular}{|c|c|c|c|c|c|c|c|c|c|}
\hline \multirow{3}{*}{$\begin{array}{l}\text { Pisos } \\
\text { Composición fachada } \\
\text { Zócalo }\end{array}$} & \multicolumn{2}{|c|}{$\mathrm{N}^{0} 3$} & sótano & \multicolumn{2}{|c|}{ entreplanta } & \multicolumn{4}{|c|}{ piso noble caja escalera } \\
\hline & \multicolumn{2}{|c|}{ aleatoria } & \multicolumn{3}{|c|}{ ordenada sin simetría } & \multicolumn{4}{|c|}{ ordenada con simetría } \\
\hline & $\mathrm{Z1}$ & $\mathrm{Z} 2$ & Z3 & Z4 & $\mathrm{Z} 5$ & & & & \\
\hline Fábrica & $\mathrm{F} 1$ & $\mathrm{~F} 2$ & F3 & F4 & F5 & F7 & & & \\
\hline Vano/dintel & V1 & V2 & V3 & V4 & V5 & V7 & V8 & V9 & V10 \\
\hline Entrada/dintel & E1 & E2 & E3 & E4 & & & & & \\
\hline Alero & A1 & $\mathrm{A} 2$ & $\mathrm{~A} 3$ & A4 & A5 & A6 & & & \\
\hline Cubierta & pla & & inclinas & & & & & & \\
\hline
\end{tabular}

\section{Fábrica}

Ma54

\section{Aparejo \\ Hiladas \\ Superficie \\ Sección (hipótesis) \\ Elementos destacados}

\begin{tabular}{lll} 
soga-tizón & soga & \\
irregulares & tizón & \\
sin planeidad & pseudo planeidad & planeidad perfecta \\
\hline uniforme & hojas y núcleo & abocinada (vano) \\
aplantillado & cortado terracota & \\
\hline
\end{tabular}




\begin{tabular}{|c|c|c|c|}
\hline \multirow{2}{*}{$\begin{array}{l}\mathrm{N}^{\circ} \text { elementos medidos } \\
\text { Longitud }(\mathrm{cm})\end{array}$} & \multicolumn{3}{|l|}{15} \\
\hline & \multicolumn{3}{|l|}{29.7} \\
\hline Anchura (cm) & \multicolumn{3}{|l|}{14.1} \\
\hline Espesor (cm) & \multicolumn{3}{|l|}{4.1} \\
\hline Volumen $\left(\mathrm{cm}^{3}\right)$ & \multicolumn{3}{|l|}{1716.9} \\
\hline Tipo & homogéneo & heterogéneo & re-empleo \\
\hline Color & homogéneo & heterogéneo globular & heterogéneo marmolado \\
\hline Recogida de muestra & no & sí & código \\
\hline Patologías & $\begin{array}{l}\text { eflorescencias } \\
\text { erosión }\end{array}$ & $\begin{array}{l}\text { micro fisuración } \\
\text { disgregación }\end{array}$ & $\begin{array}{l}\text { grietas } \\
\text { descamación }\end{array}$ \\
\hline
\end{tabular}

1 Datos obtenidos en base al cálculo del desvío estándar (respecto al valor medio de la muestras analizadas) y del gráfico de frecuencia de las muestras analizadas, identificado por una curva gaussiana

\section{untas}

\begin{tabular}{|c|c|c|c|c|}
\hline \multirow{2}{*}{$\begin{array}{l}N^{\circ} \text { elementos medidos } \\
\text { Llaga }(\mathrm{cm})\end{array}$} & \multicolumn{4}{|l|}{15} \\
\hline & \multicolumn{4}{|l|}{1.5} \\
\hline Tendel (cm) & \multicolumn{4}{|l|}{2.5} \\
\hline Altura de 5 hiladas $(\mathrm{cm})$ & \multicolumn{4}{|l|}{28} \\
\hline Proporción ladrillo/junta & \multicolumn{4}{|l|}{2.3} \\
\hline Tipo de acabado & simple & doble & múltiple & \\
\hline \multirow[t]{2}{*}{ Junta de asiento } & rehundida & a hueso & saliente & \\
\hline & enrasada & matada & & \\
\hline \multirow[t]{2}{*}{ Junta de acabado } & rehundida & a hueso & saliente & \\
\hline & enrasada & matada & & \\
\hline \multirow{2}{*}{$\begin{array}{l}\text { Tipo de mortero } \\
\text { Morfología de mortero }\end{array}$} & cal & cal y tierra & tierra & cemento mixto \\
\hline & con grumos & con caliches & homogéneo & heterogéneo \\
\hline Tipo de árido & arena & gravilla & grava & mixto \\
\hline \multirow{4}{*}{$\begin{array}{l}\text { Color del árido } \\
\text { Recogida de muestra } \\
\text { Patologías }\end{array}$} & claro & oscuro & homogéneo & heterogéneo \\
\hline & no & sí & código & \\
\hline & eflorescencias & micro fisuración & grietas & \\
\hline & erosión" & disgregación & pulverización & \\
\hline
\end{tabular}


Imágenes
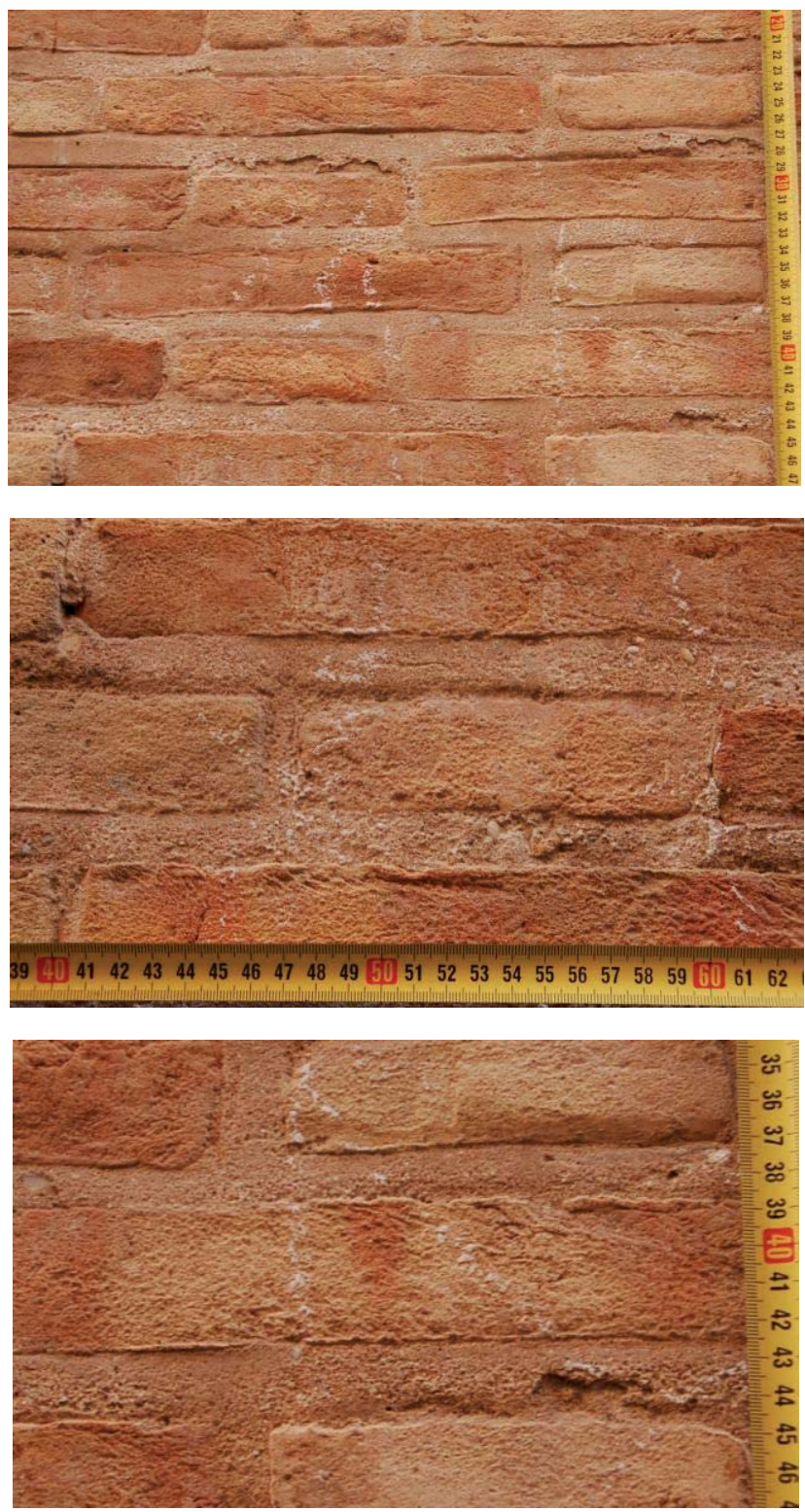

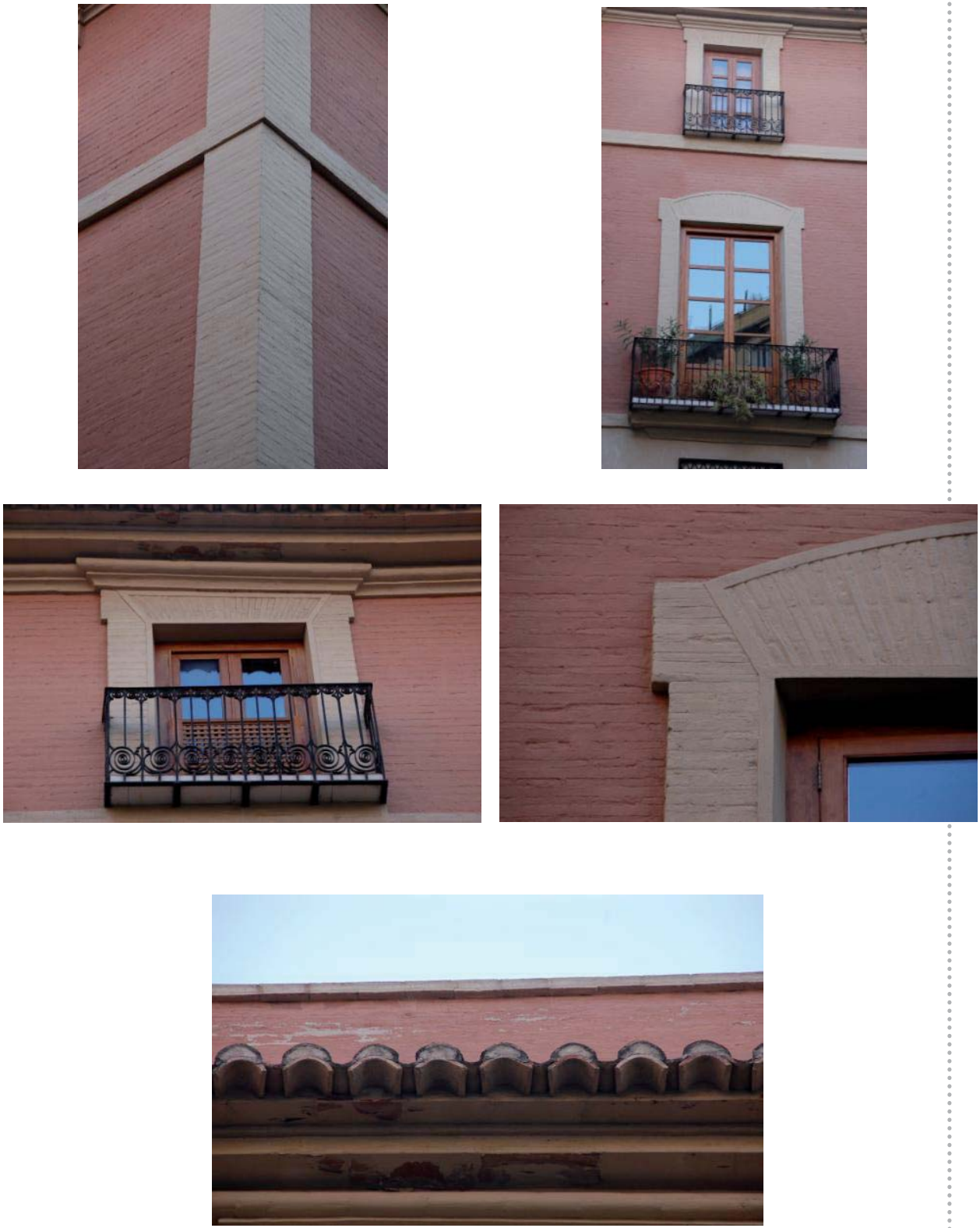
Datos generales

\begin{tabular}{l|lcccc} 
Barrio & Carmen & La Seu-Xerea & Velluters & Mercat & S.Francesc \\
\hline Dirección & C/Marsella esquina P.za S. Nicolas $n^{\circ} 2$ & \\
Tipo de edificio & residencial & palaciego & religioso & militar \\
\hline $\begin{array}{l}\mathbf{G}^{\circ} \text { de protección } \\
\text { Fechas claves }\end{array}$ & 0 & 1 & 2 & 3 \\
\hline
\end{tabular}
El apartado "fechas claves" se ha extraído de AA.W., Guía de Arquitectura de Valencia, Icaro CTAV Ed., Valencia, 2007

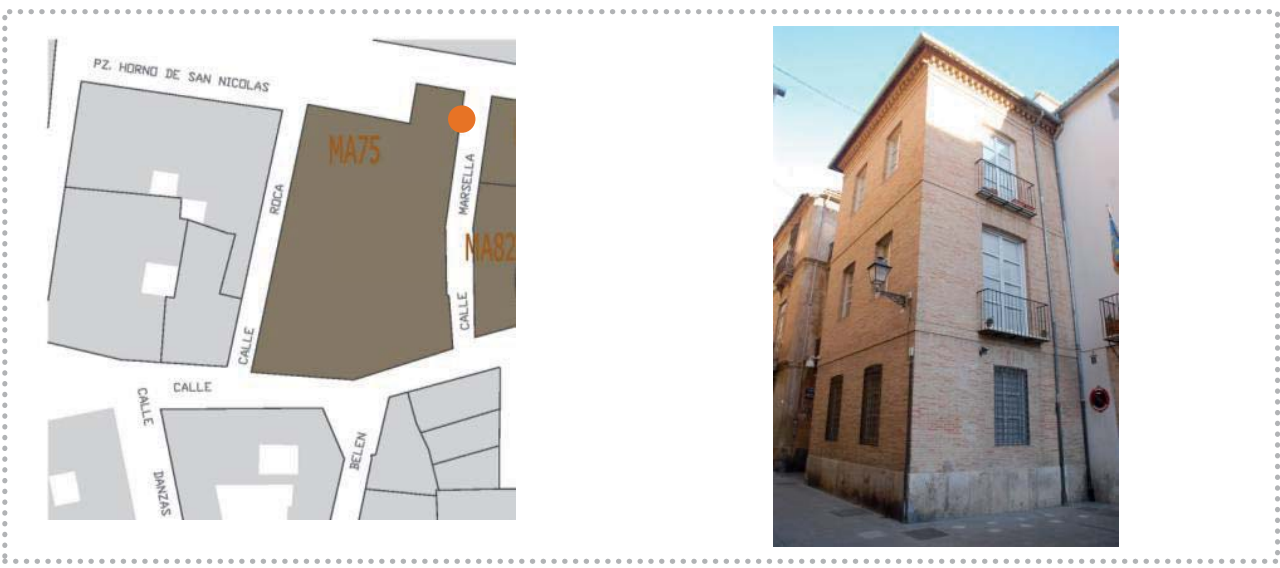

Fachada

Ma75

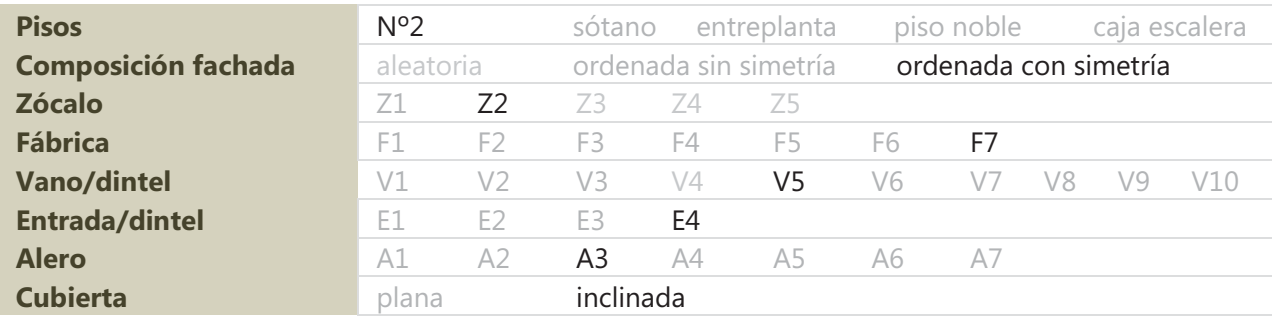

\section{Fábrica}

Ma75

\begin{tabular}{l|lll} 
Aparejo & soga-tizón & soga & \multicolumn{2}{c}{ tizón } & \\
Hiladas & irregulares & pseudo horizontales & horizontales \\
\hline Superficie & sin planeidad & pseudo planeidad & planeidad perfecta \\
Sección (hipótesis) & uniforme & hojas y núcleo & abocinada (vano) \\
Elementos destacados & aplantillado & cortado terracota & \\
\hline
\end{tabular}




\begin{tabular}{|c|c|c|c|}
\hline \multirow{2}{*}{$\begin{array}{l}N^{0} \text { elementos medidos } \\
\text { Longitud }(\mathrm{cm})\end{array}$} & \multicolumn{3}{|l|}{15} \\
\hline & \multicolumn{3}{|l|}{25.5} \\
\hline Anchura (cm) & \multicolumn{3}{|l|}{11.9} \\
\hline Espesor (cm) & \multicolumn{3}{|l|}{3.7} \\
\hline Volumen $\left(\mathrm{cm}^{3}\right)$ & \multicolumn{3}{|l|}{1122.7} \\
\hline Tipo & homogéneo & heterogéneo & re-empleo \\
\hline \multirow{4}{*}{$\begin{array}{l}\text { Color } \\
\text { Recogida de muestra } \\
\text { Patologías }\end{array}$} & homogéneo & heterogéneo globular & heterogéneo marmolado \\
\hline & no & sí & código \\
\hline & eflorescencias & micro fisuración & grietas \\
\hline & erosión & disgregación & descamación \\
\hline
\end{tabular}

${ }^{1}$ Datos obtenidos en base al cálculo del desvío estándar (respecto al valor medio de la muestras analizadas) y del gráfico de frecuencia de las muestras analizadas, identificado por una curva gaussiana

\section{Juntas}

Ma75

\begin{tabular}{|c|c|c|c|c|}
\hline \multirow{2}{*}{$\begin{array}{l}N^{\circ} \text { elementos medidos } \\
\text { Llaga }(\mathrm{cm})\end{array}$} & \multicolumn{4}{|l|}{15} \\
\hline & \multicolumn{4}{|l|}{1} \\
\hline Tendel (cm) & \multicolumn{4}{|l|}{1.5} \\
\hline Altura de 5 hiladas (cm) & \multicolumn{4}{|l|}{27.6} \\
\hline Proporción ladrillo/junta & \multicolumn{4}{|l|}{2.4} \\
\hline Tipo de acabado & simple & doble & \multicolumn{2}{|l|}{ múltiple } \\
\hline \multirow[t]{2}{*}{ Junta de asiento } & rehundida & a hueso & \multirow{2}{*}{\multicolumn{2}{|c|}{ saliente }} \\
\hline & enrasada & matada & & \\
\hline \multirow[t]{2}{*}{ Junta de acabado } & rehundida & a hueso & \multirow{2}{*}{\multicolumn{2}{|c|}{ saliente }} \\
\hline & enrasada & matada & & \\
\hline \multirow{3}{*}{$\begin{array}{l}\text { Tipo de mortero } \\
\text { Morfología de mortero } \\
\text { Tipo de árido }\end{array}$} & cal & cal y tierra & tierra & cemento mixto \\
\hline & con grumos & con caliches & homogéneo & heterogéneo \\
\hline & arena & gravilla & grava & mixto \\
\hline \multirow{4}{*}{$\begin{array}{l}\text { Color del árido } \\
\text { Recogida de muestra } \\
\text { Patologías }\end{array}$} & claro & oscuro & homogéneo & heterogéneo \\
\hline & no & sí & \multicolumn{2}{|l|}{ código } \\
\hline & eflorescencias & micro fisuración & \multicolumn{2}{|l|}{ grietas } \\
\hline & erosión & disgregación & \multicolumn{2}{|l|}{ pulverización } \\
\hline
\end{tabular}


Imágenes
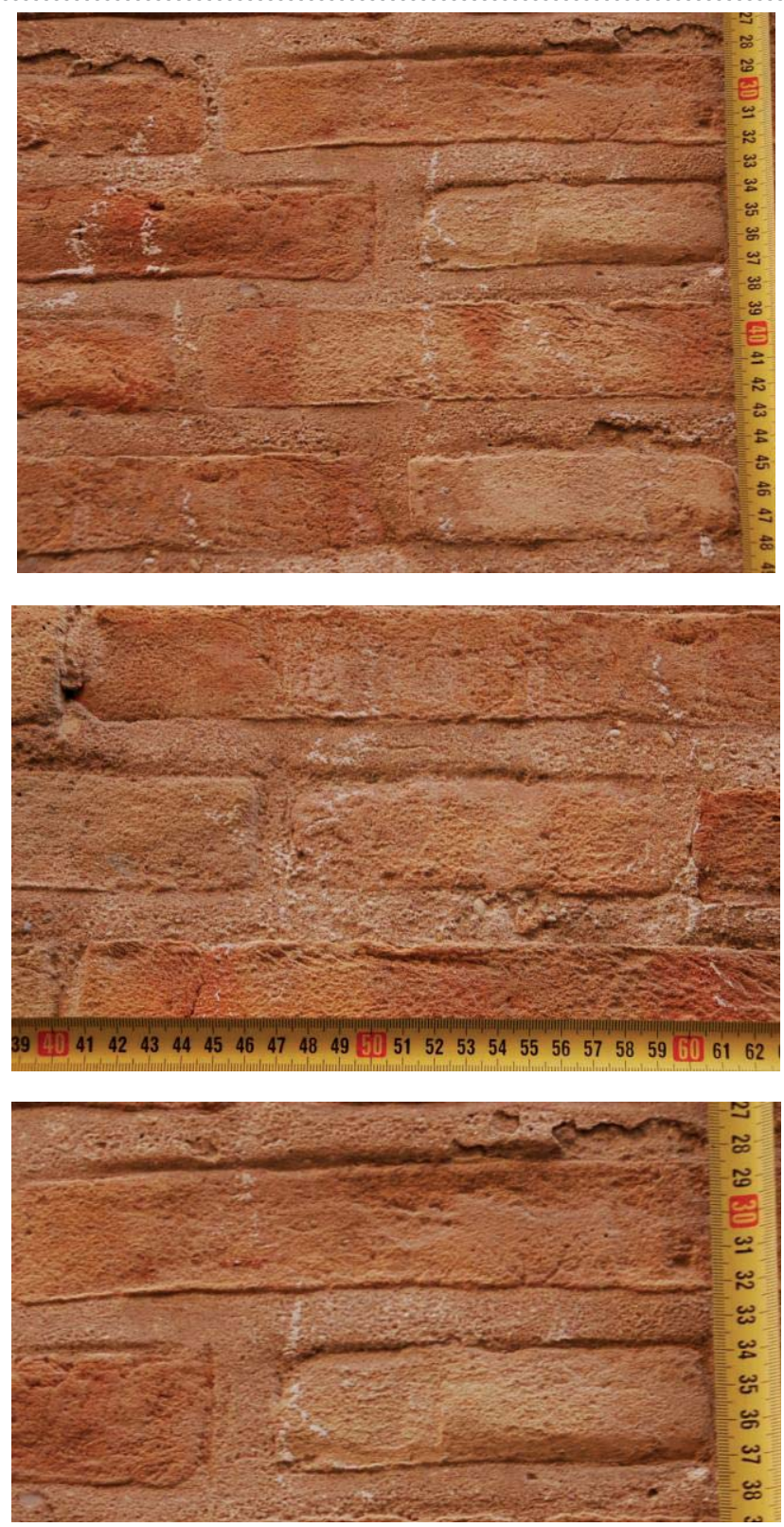

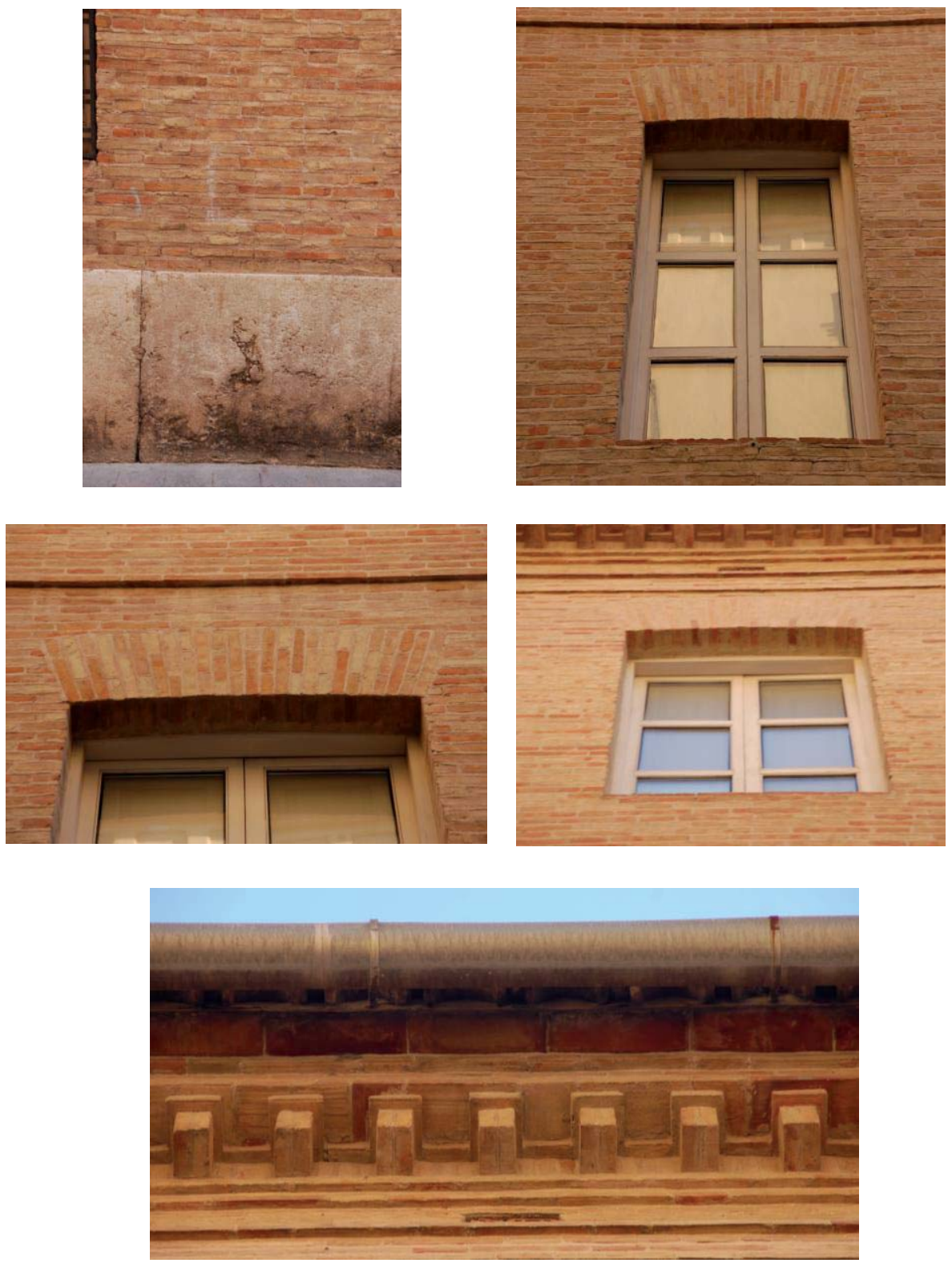


\begin{tabular}{|c|c|c|c|c|c|}
\hline Barrio & Carmen & La Seu-Xerea & Velluters & Mercat & S.Francesc \\
\hline Dirección & C/Cadirers & & & & \\
\hline Tipo de edificio & residencial & palaciego & religioso & militar & \\
\hline G $^{\circ}$ de protección & 0 & 1 & 2 & 3 & \\
\hline
\end{tabular}

El apartado "fechas claves" se ha extraído de AA.V. ., Guía de Arquitectura de Valencia, Icaro CTAV Ed., Valencia, 2007
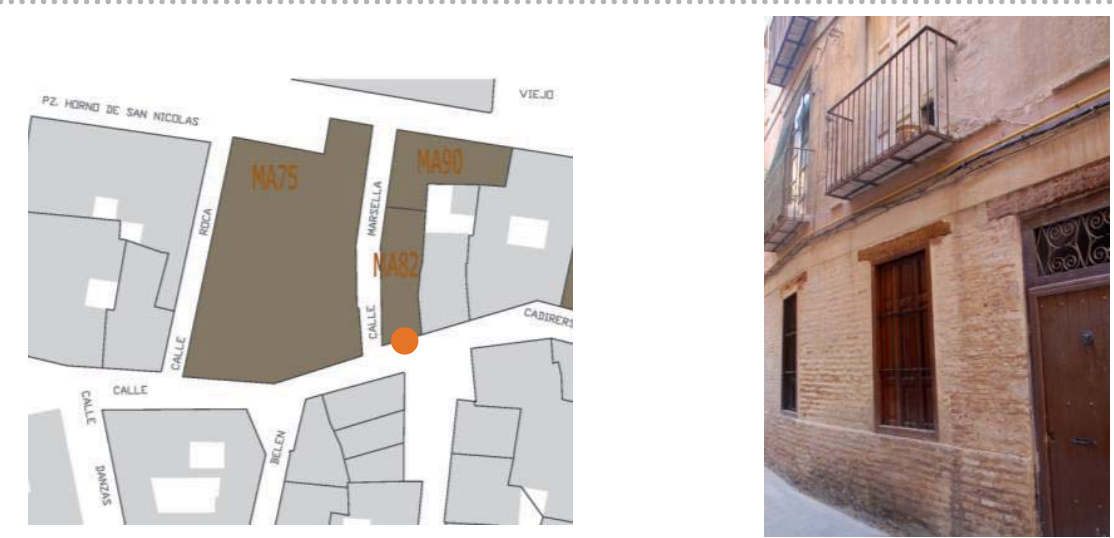

Fachada

Ma82

\begin{tabular}{|c|c|c|c|c|c|c|c|c|c|}
\hline \multirow{3}{*}{$\begin{array}{l}\text { Pisos } \\
\text { Composición fachada } \\
\text { Zócalo }\end{array}$} & \multicolumn{2}{|c|}{$N^{\circ} 2$} & sótano & \multicolumn{2}{|c|}{ entreplanta } & \multicolumn{4}{|c|}{ piso noble caja escalera } \\
\hline & \multicolumn{2}{|c|}{ aleatoria } & \multicolumn{3}{|c|}{ ordenada sin simetría } & \multicolumn{4}{|c|}{ ordenada con simetría } \\
\hline & $\mathrm{Z1}$ & $\mathrm{Z} 2$ & Z3 & Z4 & Z5 & & & & \\
\hline Fábrica & $\mathrm{F} 1$ & $\mathrm{~F} 2$ & F3 & F4 & F5 & F6 & & & \\
\hline Vano/dintel & V1 & V2 & V3 & V4 & V5 & V7 & V8 & V9 & V10 \\
\hline Entrada/dintel & E1 & E2 & E3 & E4 & & & & & \\
\hline Alero & A1 & $\mathrm{A} 2$ & A3 & A4 & A5 & A7 & & & \\
\hline Cubierta & plar & & inclinac & & & & & & \\
\hline
\end{tabular}

\section{Fábrica}

Ma82

Aparejo
Hiladas
Superficie
Sección (hipótesis)
Elementos destacados

soga-tizón

irregulares

sin planeidad

uniforme

aplantillado soga

pseudo horizontales

pseudo planeidad

hojas y núcleo

cortado tizón

horizontales

planeidad perfecta

abocinada (vano)

terracota 


\begin{tabular}{|c|c|c|c|}
\hline$N^{\circ}$ elementos medidos & 15 & & \\
\hline Longitud (cm) & 29.4 & & \\
\hline Anchura (cm) & 13.6 & & \\
\hline Espesor (cm) & 3.7 & & \\
\hline Volumen $\left(\mathrm{cm}^{3}\right)$ & 1479.40 & & \\
\hline Tipo & homogéneo & heterogéneo & re-empleo \\
\hline Color & homogéneo & heterogéneo globular & heterogéneo marmolado \\
\hline Recogida de muestra & no & sí & código \\
\hline Patologías & $\begin{array}{l}\text { eflorescencias } \\
\text { erosión }\end{array}$ & $\begin{array}{l}\text { micro fisuración } \\
\text { disgregación }\end{array}$ & $\begin{array}{l}\text { grietas } \\
\text { descamación }\end{array}$ \\
\hline
\end{tabular}

1 Datos obtenidos en base al cálculo del desvío estándar (respecto al valor medio de la muestras analizadas) y del gráfico de frecuencia de las muestras analizadas, identificado por una curva gaussiana

\section{untas}

\begin{tabular}{|c|c|c|c|c|}
\hline \multirow{2}{*}{$\begin{array}{l}N^{\circ} \text { elementos medidos } \\
\text { Llaga }(\mathrm{cm})\end{array}$} & \multicolumn{4}{|l|}{15} \\
\hline & \multicolumn{4}{|l|}{0.6} \\
\hline Tendel (cm) & \multicolumn{4}{|l|}{3.6} \\
\hline Altura de 5 hiladas $(\mathrm{cm})$ & \multicolumn{4}{|l|}{34.6} \\
\hline Proporción ladrillo/junta & \multicolumn{4}{|l|}{1.02} \\
\hline Tipo de acabado & simple & doble & \multicolumn{2}{|l|}{ múltiple } \\
\hline \multirow[t]{2}{*}{ Junta de asiento } & rehundida & a hueso & \multirow{2}{*}{\multicolumn{2}{|c|}{ saliente }} \\
\hline & enrasada & matada & & \\
\hline \multirow[t]{2}{*}{ Junta de acabado } & rehundida & a hueso & \multirow{2}{*}{\multicolumn{2}{|c|}{ saliente }} \\
\hline & enrasada & matada & & \\
\hline \multirow{3}{*}{$\begin{array}{l}\text { Tipo de mortero } \\
\text { Morfología de mortero } \\
\text { Tipo de árido }\end{array}$} & cal & cal y tierra & tierra & cemento mixto \\
\hline & con grumos & con caliches & homogéneo & heterogéneo \\
\hline & arena & gravilla & grava & mixto \\
\hline \multirow{3}{*}{$\begin{array}{l}\text { Color del árido } \\
\text { Recogida de muestra } \\
\text { Patologías }\end{array}$} & claro & oscuro & homogéneo & heterogéneo \\
\hline & no & sí & \multicolumn{2}{|l|}{ código } \\
\hline & $\begin{array}{l}\text { eflorescencias } \\
\text { erosión }\end{array}$ & $\begin{array}{l}\text { micro fisuración } \\
\text { disgregación }\end{array}$ & \multicolumn{2}{|l|}{$\begin{array}{l}\text { grietas } \\
\text { pulverización }\end{array}$} \\
\hline
\end{tabular}

${ }^{2}$ Datos obtenidos en base al cálculo del desvio estándar (respecto al valor medio de la muestras analizadas) y del gráfico de frecuencia de las muestras analizadas, identificado por una curva gaussiana 
Imágenes
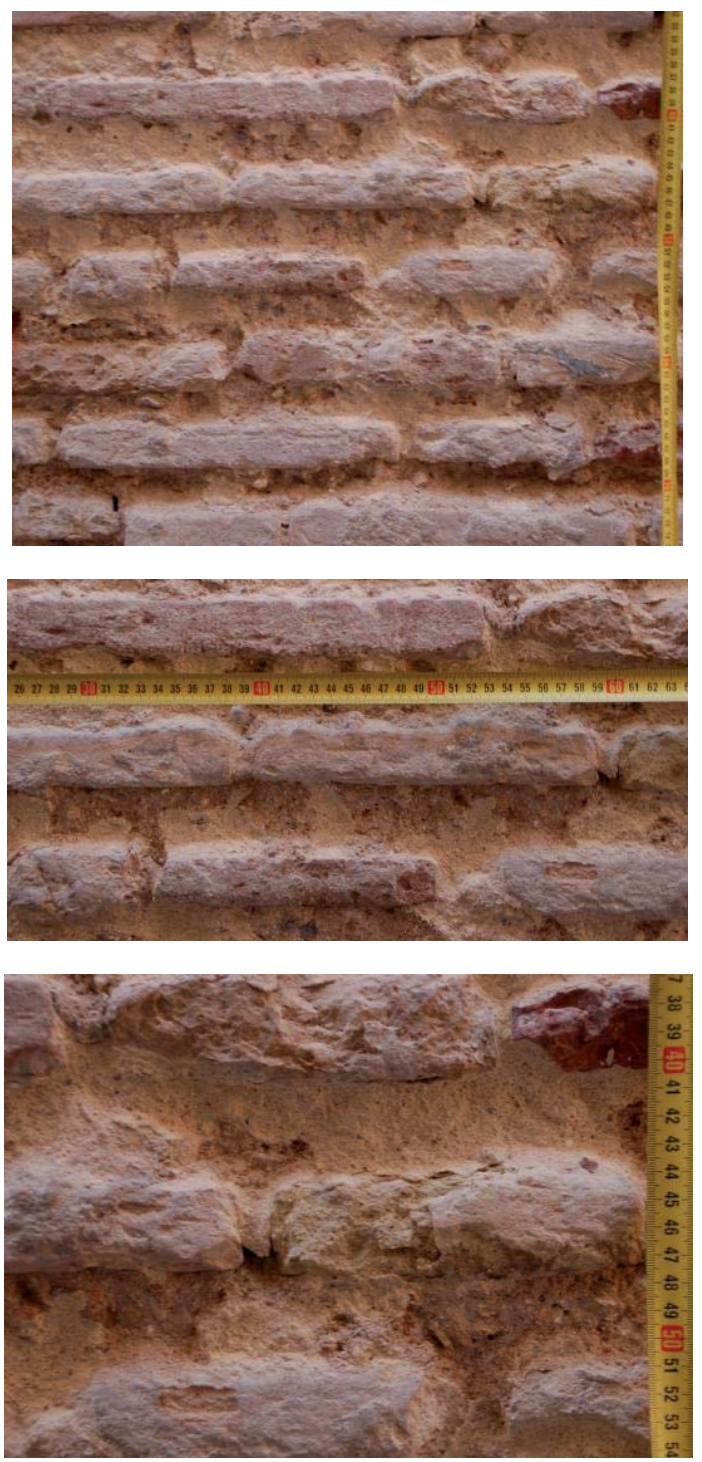
Imágenes

Ma82
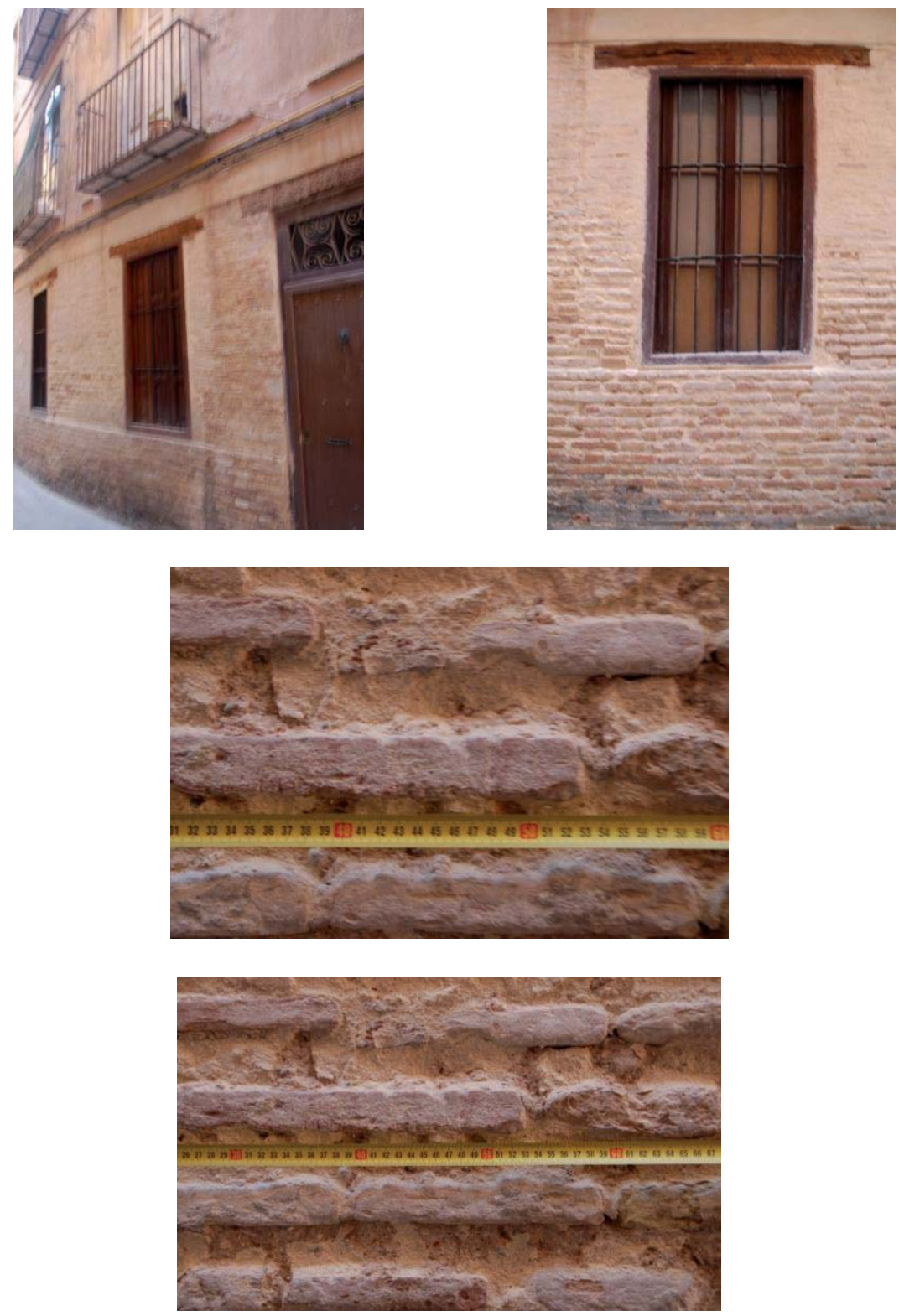


\begin{tabular}{|c|c|c|c|c|c|}
\hline Barrio & Carmen & La Seu-Xerea & Velluters & Mercat & S.Francesc \\
\hline Dirección & C/ Cadirers & & & & \\
\hline Tipo de edificio & residencial & palaciego & religioso & militar & \\
\hline $\mathbf{G}^{\circ}$ de protección & 0 & 1 & 2 & 3 & \\
\hline Fechas claves & / & & & & \\
\hline
\end{tabular}

El apartado "fechas claves" se ha extraído de AA.W., Guía de Arquitectura de Valencia, Icaro CTAV Ed., Valencia, 2007

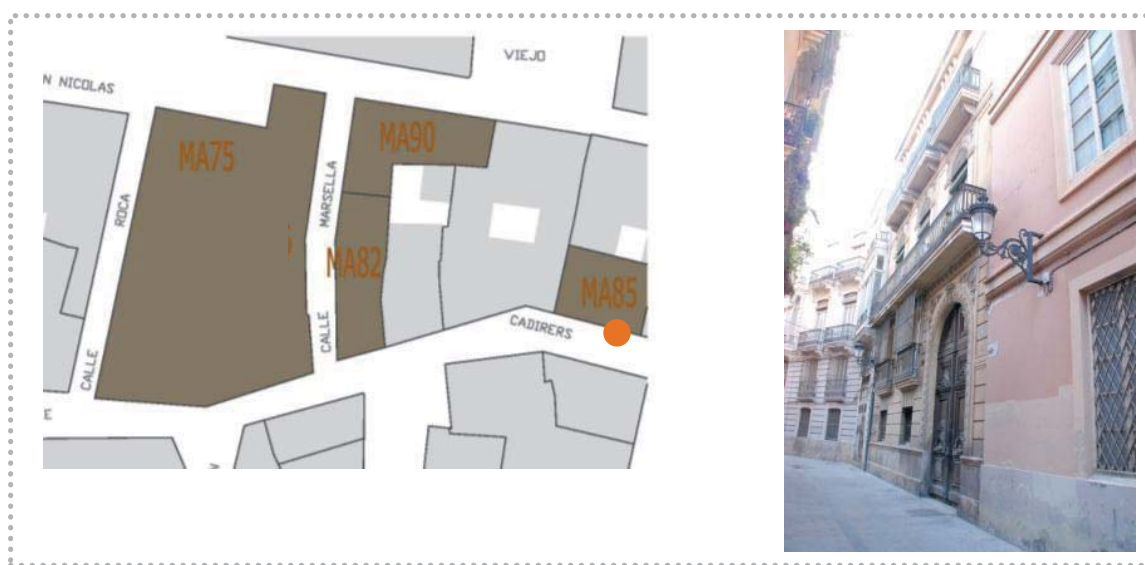

Fachada

Ma85

\begin{tabular}{|c|c|c|c|c|c|c|c|c|c|}
\hline \multirow{3}{*}{$\begin{array}{l}\text { Pisos } \\
\text { Composición fachada } \\
\text { Zócalo }\end{array}$} & \multicolumn{2}{|c|}{$N^{\circ} 3$} & sótano & \multicolumn{2}{|c|}{ entreplanta } & \multicolumn{4}{|c|}{ piso noble caja escalera } \\
\hline & \multicolumn{2}{|c|}{ aleatoria } & \multicolumn{3}{|c|}{ ordenada sin simetría } & \multicolumn{4}{|c|}{ ordenada con simetría } \\
\hline & $\mathrm{Z1}$ & $\mathrm{Z2}$ & Z3 & Z4 & Z5 & & & & \\
\hline Fábrica & $\mathrm{F} 1$ & $\mathrm{~F} 2$ & F3 & F4 & F5 & F6 & & & \\
\hline Vano/dintel & V1 & V2 & V3 & V4 & V5 & V7 & V8 & V9 & V10 \\
\hline Entrada/dintel & E1 & E2 & E3 & E4 & & & & & \\
\hline Alero & A1 & $A 2$ & A3 & A4 & A5 & A7 & & & \\
\hline Cubierta & plar & & inclinac & & & & & & \\
\hline
\end{tabular}

Fábrica

Ma85

\begin{tabular}{l|lll} 
Aparejo & soga-tizón & soga & \multicolumn{2}{c}{ tizón } & \\
Hiladas & irregulares & pseudo horizontales & horizontales \\
\hline Superficie & sin planeidad & pseudo planeidad & planeidad perfecta \\
Sección (hipótesis) & uniforme & hojas y núcleo & abocinada (vano) \\
Elementos destacados & aplantillado & cortado terracota & \\
\hline
\end{tabular}




\begin{tabular}{|c|c|c|c|}
\hline $\mathrm{N}^{\circ}$ elementos medidos & 15 & & \\
\hline Longitud (cm) & 26.5 & & \\
\hline Anchura $(\mathrm{cm})$ & 13 & & \\
\hline Espesor (cm) & 3.3 & & \\
\hline Volumen $\left(\mathrm{cm}^{3}\right)$ & 1136.85 & & \\
\hline Tipo & homogéneo & heterogéneo & re-empleo \\
\hline Color & homogéneo & heterogéneo globular & heterogéneo marmolado \\
\hline Recogida de muestra & no & sí & código \\
\hline Patologías & $\begin{array}{l}\text { eflorescencias } \\
\text { erosión }\end{array}$ & $\begin{array}{l}\text { micro fisuración } \\
\text { disgregación }\end{array}$ & $\begin{array}{l}\text { grietas } \\
\text { descamación }\end{array}$ \\
\hline
\end{tabular}

${ }^{1}$ Datos obtenidos en base al cálculo del desvío estándar (respecto al valor medio de la muestras analizadas) y del gráfico de frecuencia de las muestras analizadas, identificado por una curva gaussiana

\section{untas}

Ma85

\begin{tabular}{|c|c|c|c|c|}
\hline \multirow{2}{*}{$\begin{array}{l}N^{\circ} \text { elementos medidos } \\
\text { Llaga }(\mathrm{cm})\end{array}$} & \multicolumn{4}{|l|}{15} \\
\hline & \multicolumn{4}{|l|}{0.6} \\
\hline Tendel (cm) & \multicolumn{4}{|l|}{1.9} \\
\hline Altura de 5 hiladas $(\mathrm{cm})$ & \multicolumn{4}{|l|}{25.4} \\
\hline Proporción ladrillo/junta & \multicolumn{4}{|l|}{1.7} \\
\hline Tipo de acabado & simple & doble & \multicolumn{2}{|l|}{ múltiple } \\
\hline \multirow[t]{2}{*}{ Junta de asiento } & rehundida & a hueso & \multirow{2}{*}{\multicolumn{2}{|c|}{ saliente }} \\
\hline & enrasada & matada & & \\
\hline \multirow[t]{2}{*}{ Junta de acabado } & rehundida & a hueso & \multirow{2}{*}{\multicolumn{2}{|c|}{ saliente }} \\
\hline & enrasada & matada & & \\
\hline \multirow{3}{*}{$\begin{array}{l}\text { Tipo de mortero } \\
\text { Morfología de mortero } \\
\text { Tipo de árido }\end{array}$} & cal & cal y tierra & tierra & cemento mixto \\
\hline & con grumos & con caliches & homogéneo & heterogéneo \\
\hline & arena & gravilla & grava & mixto \\
\hline \multirow{4}{*}{$\begin{array}{l}\text { Color del árido } \\
\text { Recogida de muestra } \\
\text { Patologías }\end{array}$} & claro & oscuro & homogéneo & heterogéneo \\
\hline & no & sí & \multicolumn{2}{|l|}{ código } \\
\hline & eflorescencias & micro fisuración & \multicolumn{2}{|l|}{ grietas } \\
\hline & erosión & disgregación & \multicolumn{2}{|l|}{ pulverización } \\
\hline
\end{tabular}


Imágenes

Ma85
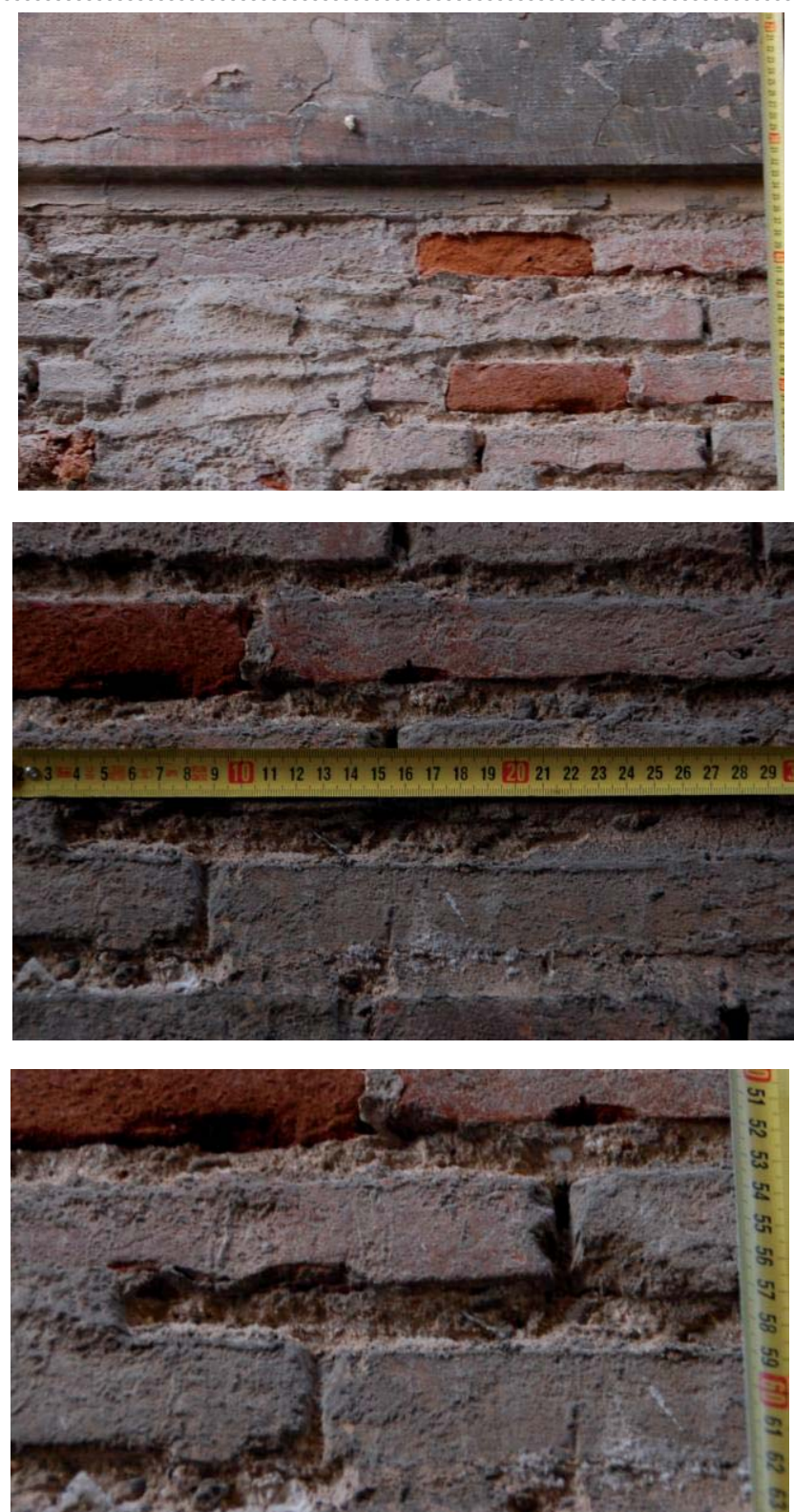
Imágenes

Ma85
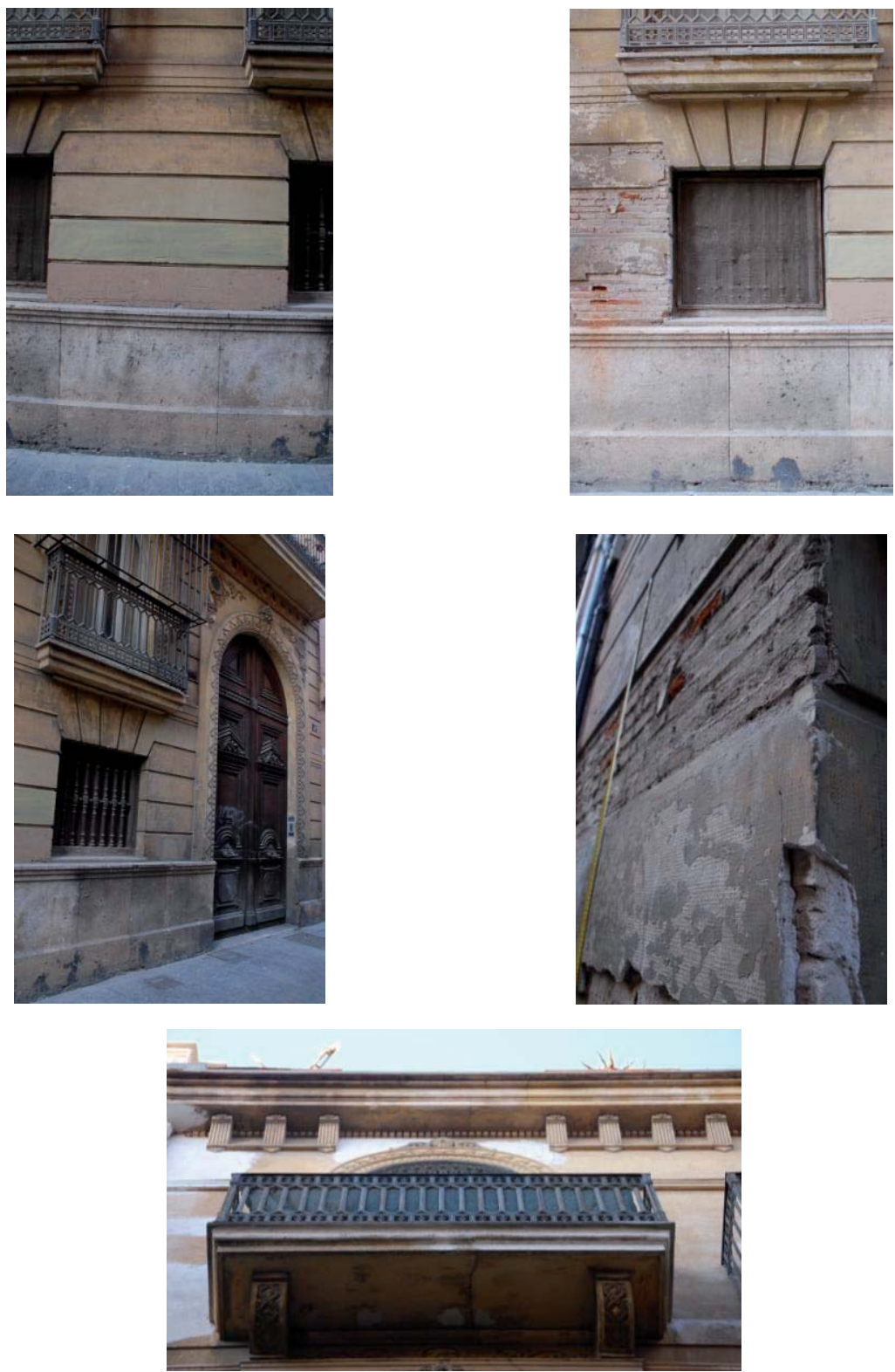
Datos generales

Ma90

\begin{tabular}{|c|c|c|c|c|c|}
\hline Barrio & Carmen & La Seu-Xerea & Velluters & Mercat & S.Francesc \\
\hline Dirección & C/Marsella & 4 accesorio & & & \\
\hline Tipo de edificio & residencial & palaciego & religioso & militar & \\
\hline $\mathbf{G}^{\circ}$ de protección & 0 & 1 & 2 & 3 & \\
\hline Fechas claves & / & & & & \\
\hline
\end{tabular}
El apartado "fechas claves" se ha extraído de AA.V.., Guía de Arquitectura de Valencia, Icaro CTAV Ed., Valencia, 2007

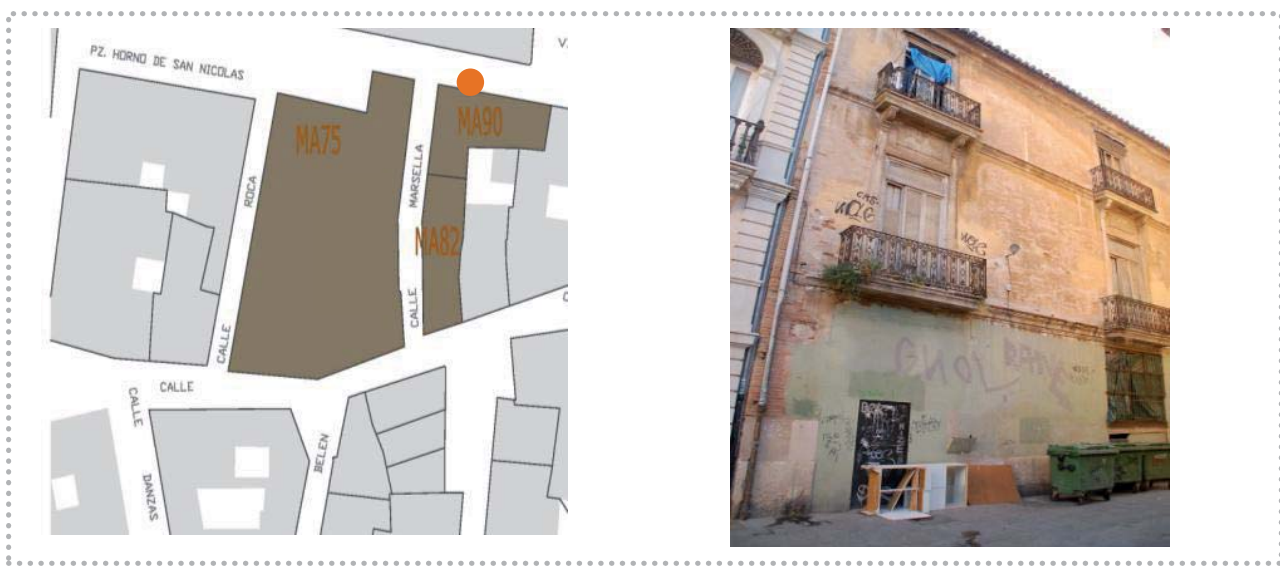

Fachada

Ma90

\begin{tabular}{|c|c|c|c|c|c|c|c|c|c|}
\hline \multirow{3}{*}{$\begin{array}{l}\text { Pisos } \\
\text { Composición fachada } \\
\text { Zócalo }\end{array}$} & \multicolumn{2}{|c|}{$N^{\circ} 2$} & sótano & \multicolumn{2}{|c|}{ entreplanta } & \multicolumn{4}{|c|}{ piso noble caja escalera } \\
\hline & \multicolumn{2}{|c|}{ aleatoria } & \multicolumn{3}{|c|}{ ordenada sin simetría } & \multicolumn{4}{|c|}{ ordenada con simetría } \\
\hline & $\mathrm{Z1}$ & $\mathrm{Z2}$ & Z3 & Z4 & Z5 & & & & \\
\hline Fábrica & $\mathrm{F} 1$ & $\mathrm{~F} 2$ & F3 & F4 & F5 & F6 & & & \\
\hline Vano/dintel & V1 & V2 & V3 & V4 & V5 & V7 & V8 & V9 & V10 \\
\hline Entrada/dintel & E1 & E2 & E3 & E4 & & & & & \\
\hline Alero & A1 & $\mathrm{A} 2$ & A3 & A4 & A5 & A7 & & & \\
\hline Cubierta & plar & & inclinac & & & & & & \\
\hline
\end{tabular}

\section{Fábrica}

Ma90

\begin{tabular}{l|lll} 
Aparejo & soga-tizón & soga & \multicolumn{1}{c}{ tizón } \\
Hiladas & irregulares & pseudo horizontales & horizontales \\
\hline Superficie & sin planeidad & pseudo planeidad & planeidad perfecta \\
\hline Sección (hipótesis) & uniforme & hojas y núcleo & abocinada (vano) \\
Elementos destacados & aplantillado & cortado terracota & \\
\hline
\end{tabular}




\begin{tabular}{|c|c|c|c|}
\hline$N^{\circ}$ elementos medidos & 15 & & \\
\hline Longitud (cm) & 25.5 & & \\
\hline Anchura (cm) & 12.4 & & \\
\hline Espesor (cm) & 3.8 & & \\
\hline Volumen $\left(\mathrm{cm}^{3}\right)$ & 1201.5 & & \\
\hline Tipo & homogéneo & heterogéneo & re-empleo \\
\hline Color & homogéneo & heterogéneo globular & heterogéneo marmolado \\
\hline Recogida de muestra & no & sí & código \\
\hline Patologías & $\begin{array}{l}\text { eflorescencias } \\
\text { erosión }\end{array}$ & $\begin{array}{l}\text { micro fisuración } \\
\text { disgregación }\end{array}$ & $\begin{array}{l}\text { grietas } \\
\text { descamación }\end{array}$ \\
\hline
\end{tabular}

1 Datos obtenidos en base al cálculo del desvío estándar (respecto al valor medio de la muestras analizadas) y del gráfico de frecuencia de las muestras analizadas, identificado por una curva gaussiana

\section{untas}

\begin{tabular}{|c|c|c|c|c|}
\hline \multirow{2}{*}{$\begin{array}{l}N^{\circ} \text { elementos medidos } \\
\text { Llaga }(\mathrm{cm})\end{array}$} & \multicolumn{4}{|l|}{15} \\
\hline & \multicolumn{4}{|l|}{0.5} \\
\hline Tendel (cm) & \multicolumn{4}{|l|}{1.8} \\
\hline Altura de 5 hiladas $(\mathrm{cm})$ & \multicolumn{4}{|l|}{30.5} \\
\hline Proporción ladrillo/junta & \multicolumn{4}{|l|}{2.1} \\
\hline Tipo de acabado & simple & doble & \multicolumn{2}{|l|}{ múltiple } \\
\hline \multirow[t]{2}{*}{ Junta de asiento } & rehundida & a hueso & \multirow[t]{2}{*}{ saliente } & \\
\hline & enrasada & matada & & \\
\hline \multirow[t]{2}{*}{ Junta de acabado } & rehundida & a hueso & \multirow[t]{2}{*}{ saliente } & \\
\hline & enrasada & matada & & \\
\hline \multirow{2}{*}{$\begin{array}{l}\text { Tipo de mortero } \\
\text { Morfología de mortero }\end{array}$} & cal & cal y tierra & tierra & cemento mixto \\
\hline & con grumos & con caliches & homogéneo & heterogéneo \\
\hline \multirow{5}{*}{$\begin{array}{l}\text { Tipo de árido } \\
\text { Color del árido } \\
\text { Recogida de muestra } \\
\text { Patologías }\end{array}$} & arena & gravilla & grava & mixto \\
\hline & claro & oscuro & homogéneo & heterogéneo \\
\hline & no & sí & \multicolumn{2}{|l|}{ código } \\
\hline & eflorescencias & micro fisuración & \multicolumn{2}{|l|}{ grietas } \\
\hline & erosión & disgregación & \multicolumn{2}{|l|}{ pulverización } \\
\hline
\end{tabular}


Imágenes
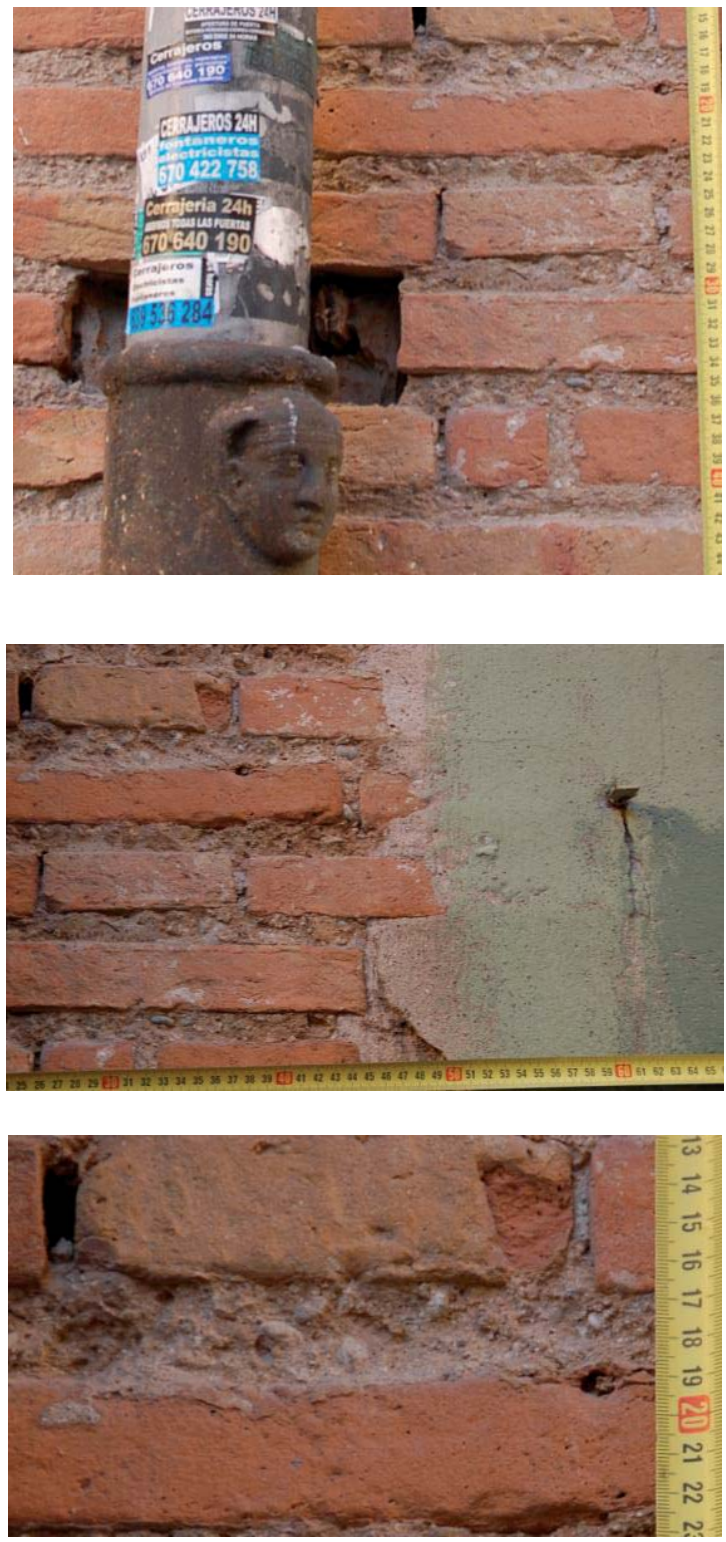
Imágenes

Ma90
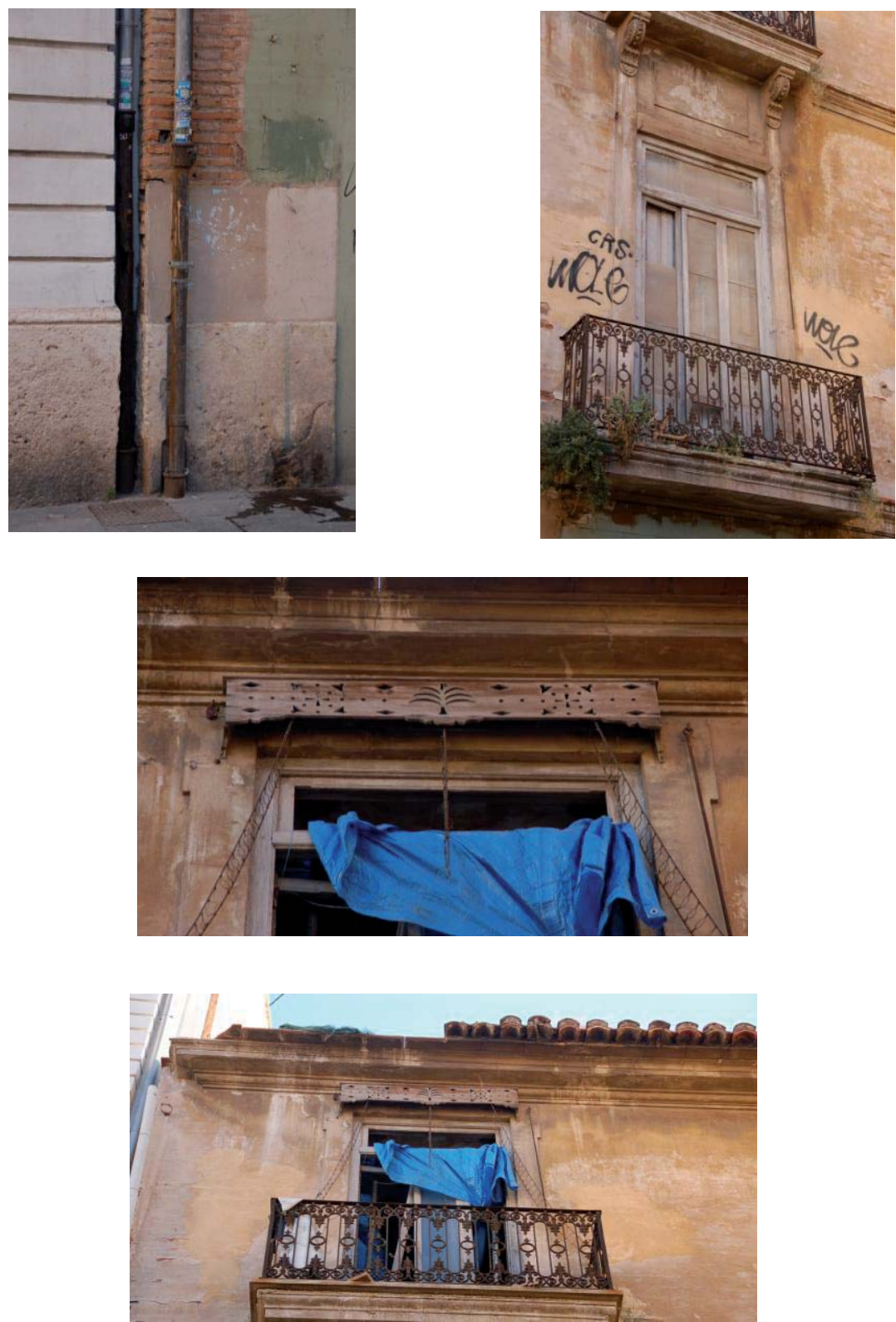


\begin{tabular}{|c|c|c|c|c|c|}
\hline Barrio & Carmen & La Seu-Xerea & Velluters & Mercat & S.Francesc \\
\hline Dirección & \multicolumn{5}{|c|}{ Pza. Correu Vell n4 } \\
\hline Tipo de edificio & residencial & palaciego & religioso & militar & \\
\hline $\mathbf{G}^{\circ}$ de protección & 0 & 1 & 2 & 3 & \\
\hline Fechas claves & \multicolumn{5}{|c|}{ Trasagrario 1664/74 } \\
\hline
\end{tabular}
El apartado "fechas claves" se ha extraído de AA.V., Guía de Arquitectura de Valencia, Icaro CTAV Ed., Valencia, 2007

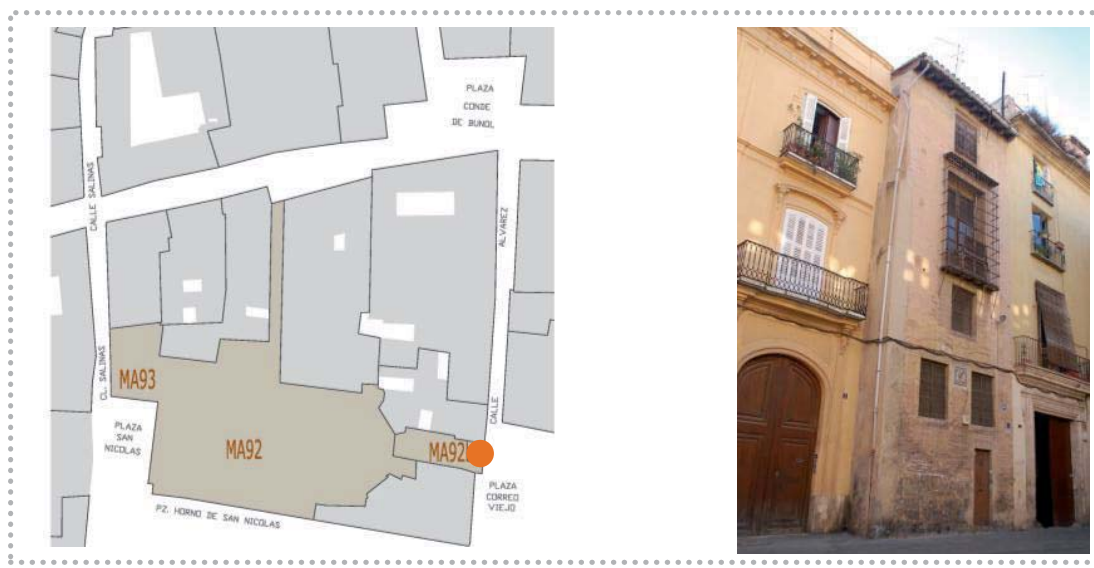

\section{Fachada}

Ma92

\begin{tabular}{|c|c|c|c|c|c|c|c|c|c|}
\hline \multirow{3}{*}{$\begin{array}{l}\text { Pisos } \\
\text { Composición fachada } \\
\text { Zócalo }\end{array}$} & \multicolumn{2}{|c|}{$N^{\circ} 3$} & sótanc & \multicolumn{2}{|c|}{ entreplanta } & \multicolumn{4}{|c|}{ piso noble caja escalera } \\
\hline & \multicolumn{2}{|c|}{ aleatoria } & \multicolumn{3}{|c|}{ ordenada sin simetría } & \multicolumn{4}{|c|}{ ordenada con simetría } \\
\hline & $\mathrm{Z1}$ & $\mathrm{Z} 2$ & $\mathrm{Z3}$ & Z4 & Z5 & & & & \\
\hline Fábrica & $\mathrm{F} 1$ & $\mathrm{~F} 2$ & F3 & $\mathrm{F} 4$ & F5 & F6 & & & \\
\hline Vano/dintel & V1 & V2 & V3 & V4 & V5 & V7 & V8 & V9 & V10 \\
\hline Entrada/dintel & E1 & E2 & E3 & E4 & & & & & \\
\hline Alero & A1 & $\mathrm{A} 2$ & A3 & A4 & A5 & A7 & & & \\
\hline Cubierta & plar & & inclina & & & & & & \\
\hline
\end{tabular}

\section{Fábrica}

Ma92

\begin{tabular}{l|lll}
\hline Aparejo & soga-tizón & soga & \multicolumn{1}{c}{ tizón } \\
Hiladas & irregulares & pseudo horizontales & horizontales \\
\hline Superficie & sin planeidad & pseudo planeidad & planeidad perfecta \\
\hline Sección (hipótesis) & uniforme & hojas y núcleo & abocinada (vano) \\
Elementos destacados & aplantillado & cortado terracota & \\
\hline
\end{tabular}




\begin{tabular}{|c|c|c|c|}
\hline \multirow{2}{*}{$\begin{array}{l}\mathrm{N}^{\circ} \text { elementos medidos } \\
\text { Longitud }(\mathrm{cm})\end{array}$} & \multicolumn{3}{|l|}{15} \\
\hline & \multicolumn{3}{|l|}{29,9} \\
\hline Anchura (cm) & \multicolumn{3}{|l|}{14.4} \\
\hline Espesor (cm) & \multicolumn{3}{|l|}{3.8} \\
\hline Volumen $\left(\mathrm{cm}^{3}\right)$ & \multicolumn{3}{|l|}{1636.12} \\
\hline Tipo & homogéneo & heterogéneo & re-empleo \\
\hline \multirow{4}{*}{$\begin{array}{l}\text { Color } \\
\text { Recogida de muestra } \\
\text { Patologías }\end{array}$} & homogéneo & heterogéneo globular & heterogéneo marmolado \\
\hline & no & sí & código \\
\hline & eflorescencias & micro fisuración & grietas \\
\hline & erosión & disgregación & descamación \\
\hline
\end{tabular}

${ }^{1}$ Datos obtenidos en base al cálculo del desvío estándar (respecto al valor medio de la muestras analizadas) y del gráfico de frecuencia de las muestras analizadas, identificado por una curva gaussiana

\section{untas unt $^{2}$}

Ma92

\begin{tabular}{|c|c|c|c|c|}
\hline \multirow{2}{*}{$\begin{array}{l}N^{\circ} \text { elementos medidos } \\
\text { Llaga }(\mathrm{cm})\end{array}$} & \multicolumn{4}{|l|}{15} \\
\hline & \multicolumn{4}{|l|}{0.8} \\
\hline Tendel (cm) & \multicolumn{4}{|l|}{3.6} \\
\hline Altura de 5 hiladas $(\mathrm{cm})$ & \multicolumn{4}{|l|}{37} \\
\hline Proporción ladrillo/junta & \multicolumn{4}{|l|}{1.05} \\
\hline Tipo de acabado & simple & doble & múltiple & \\
\hline \multirow[t]{2}{*}{ Junta de asiento } & rehundida & a hueso & saliente & \\
\hline & enrasada & matada & & \\
\hline \multirow{2}{*}{ Junta de acabado } & rehundida & a hueso & saliente & \\
\hline & enrasada & matada & & \\
\hline \multirow{2}{*}{$\begin{array}{l}\text { Tipo de mortero } \\
\text { Morfología de mortero }\end{array}$} & cal & cal y tierra & tierra & cemento mixto \\
\hline & con grumos & con caliches & homogéneo & heterogéneo \\
\hline Tipo de árido & arena & gravilla & grava & mixto \\
\hline \multirow{4}{*}{$\begin{array}{l}\text { Color del árido } \\
\text { Recogida de muestra } \\
\text { Patologías }\end{array}$} & claro & oscuro & homogéneo & heterogéneo \\
\hline & no & sí & código & \\
\hline & eflorescencias & micro fisuración & grietas & \\
\hline & erosión" & disgregación & pulverización & \\
\hline
\end{tabular}


Imágenes

Ma92
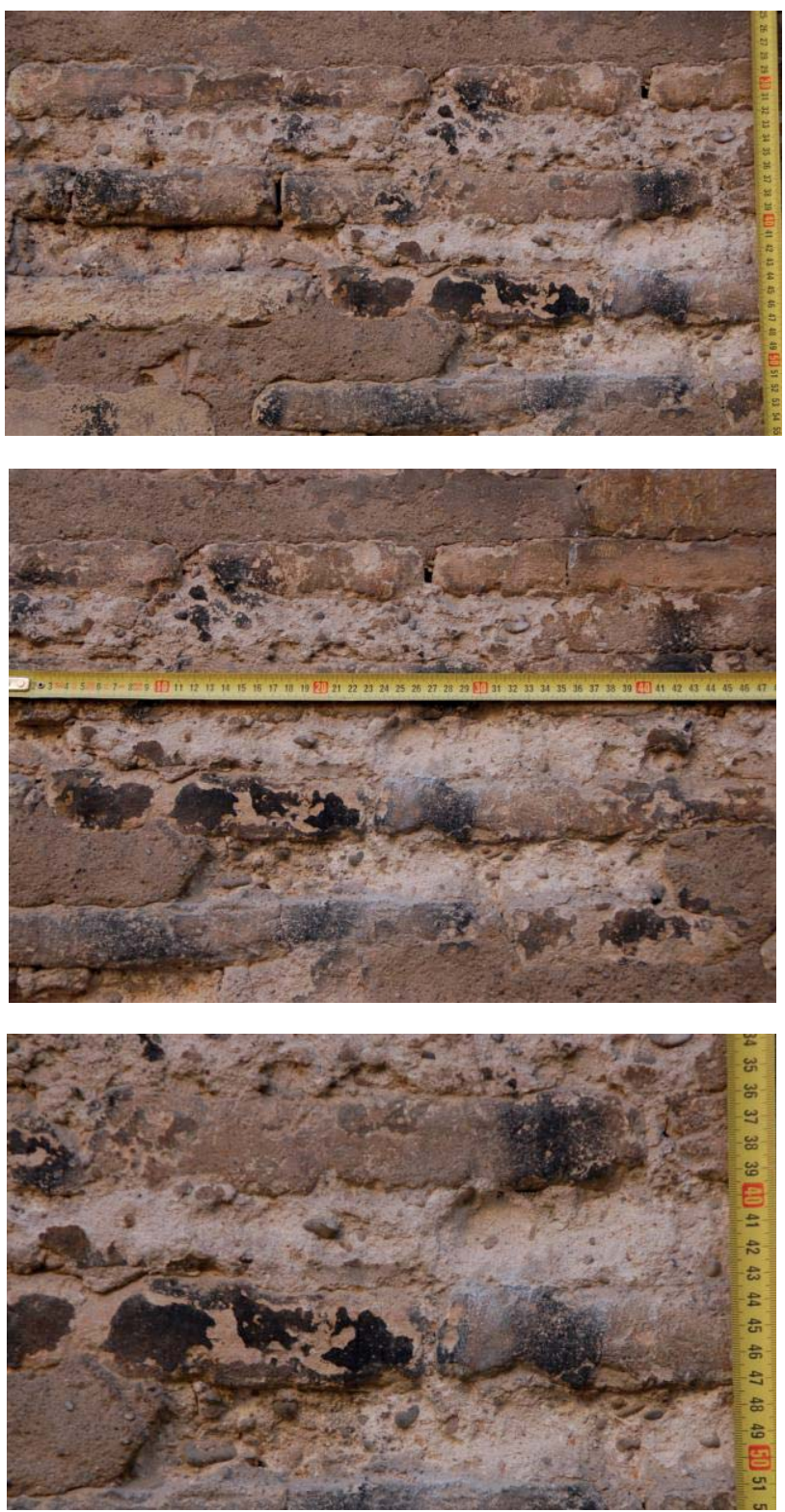

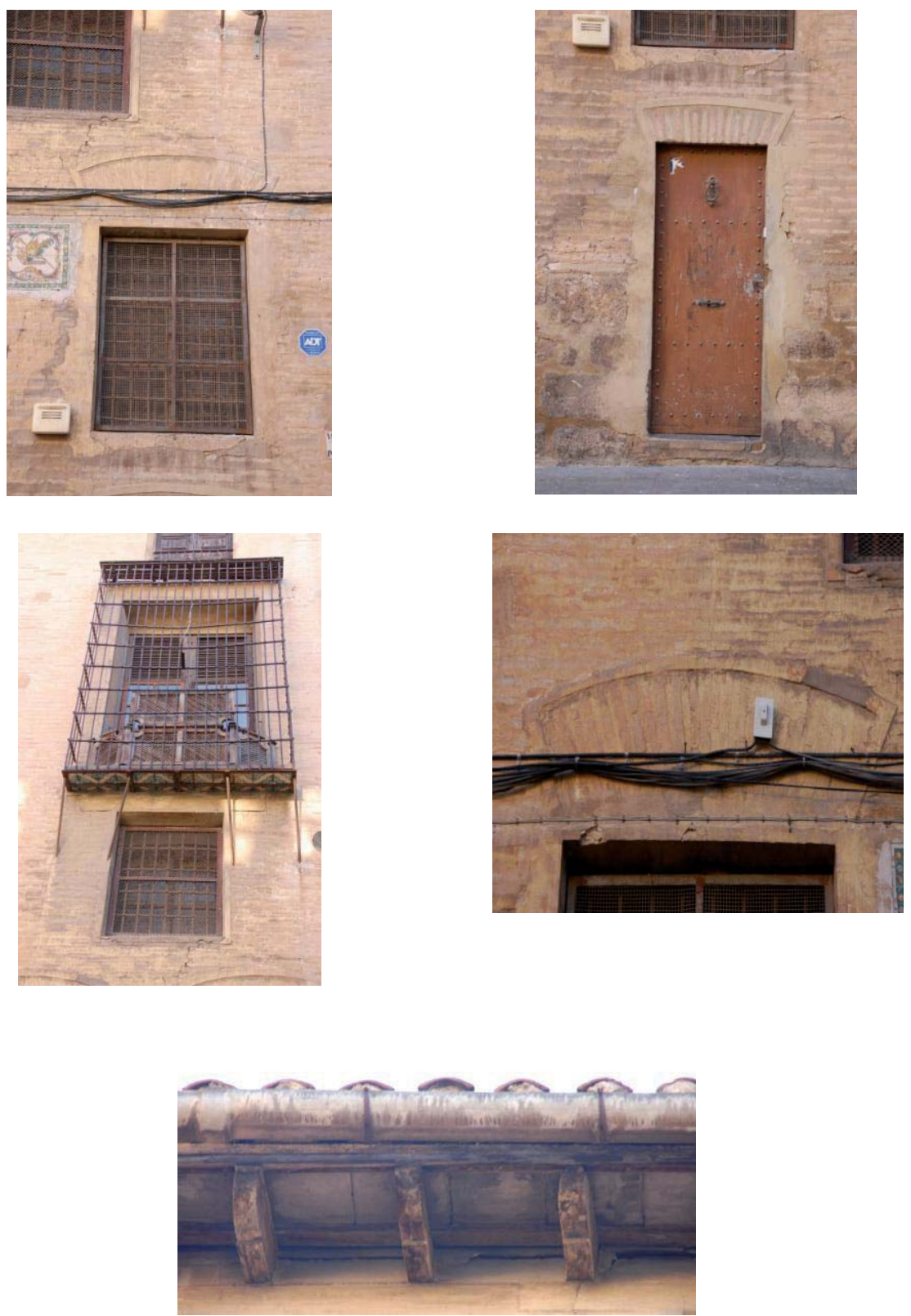


\begin{tabular}{|c|c|c|c|c|c|}
\hline Barrio & Carmen & La Seu-Xerea & Velluters & Mercat & S.Francesc \\
\hline Dirección & \multicolumn{5}{|c|}{ C/Abadia de S. Nicolas s/n } \\
\hline Tipo de edificio & residencial & palaciego & religioso & militar & \\
\hline $\mathbf{G}^{\circ}$ de protección & 0 & 1 & 2 & 3 & \\
\hline Fechas claves & \multicolumn{5}{|c|}{ Capilla de la Comunión 1760} \\
\hline
\end{tabular}
El apartado "fechas claves" se ha extraído de AA.V. ., Guía de Arquitectura de Valencia, Icaro CTAV Ed., Valencia, 2007
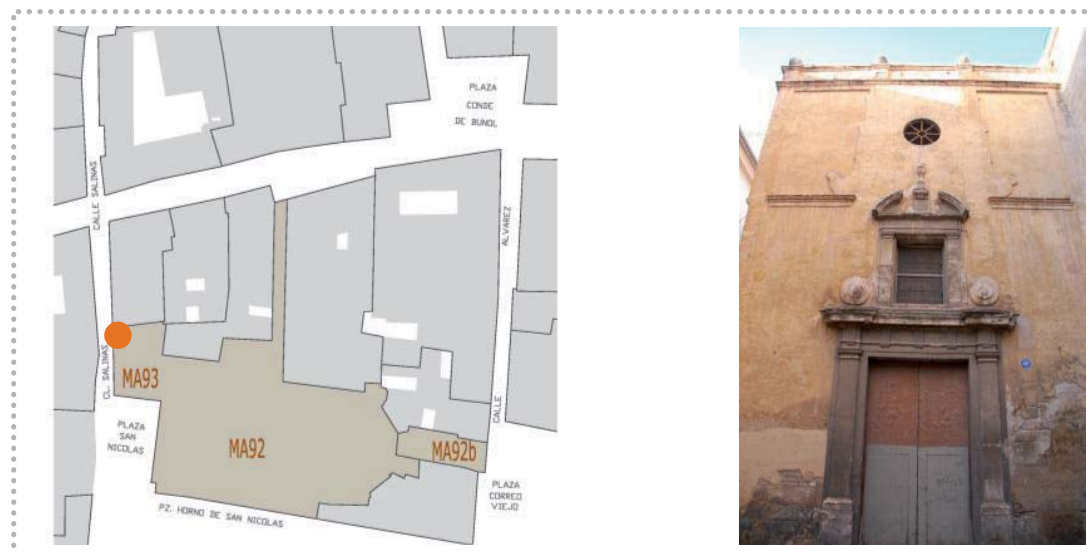

\section{Fachada}

Ma93

\begin{tabular}{|c|c|c|c|c|c|c|c|c|c|}
\hline \multirow{2}{*}{$\begin{array}{l}\text { Pisos } \\
\text { Composición fachada }\end{array}$} & \multicolumn{2}{|c|}{$N^{0} 3$} & sótano & \multicolumn{2}{|c|}{ entreplanta } & \multicolumn{4}{|c|}{ piso noble caja escalera } \\
\hline & \multicolumn{2}{|c|}{ aleatoria } & \multicolumn{3}{|c|}{ ordenada sin simetría } & \multicolumn{4}{|c|}{ ordenada con simetría } \\
\hline Zócalo & $\mathrm{Z1}$ & $\mathrm{Z2}$ & Z3 & Z4 & Z5 & & & & \\
\hline Fábrica & F1 & F2 & F3 & F4 & F5 & F6 & & & \\
\hline Vano/dintel & V1 & V2 & V3 & V4 & V5 & V6 & V8 & V9 & V10 \\
\hline Entrada/dintel & E1 & E2 & E3 & E4 & & & & & \\
\hline Alero & A1 & A2 & A3 & A4 & A5 & A6 & & & \\
\hline Cubierta & pla & & inclinac & & & & & & \\
\hline
\end{tabular}

\section{Fábrica}

Ma93

\section{Aparejo \\ Hiladas \\ Superficie \\ Sección (hipótesis) \\ Elementos destacados}

\begin{tabular}{lll} 
soga-tizón & soga tizón & \\
irregulares & pseudo horizontales & horizontales \\
sin planeidad & pseudo planeidad & planeidad perfecta \\
\hline uniforme & hojas y núcleo & abocinada (vano) \\
aplantillado & cortado terracota & \\
\hline
\end{tabular}




$\begin{array}{llll}\begin{array}{l}\text { No elementos medidos } \\ \text { Longitud }(\mathbf{c m})\end{array} & 15 & & \\ \text { Anchura }(\mathbf{c m}) & 30 & & \\ \text { Espesor }(\mathbf{c m}) & 14.6 & & \\ \text { Volumen }\left(\mathbf{c m}^{\mathbf{3}}\right) & 4.1 & \text { heterogéneo } & \text { re-empleo } \\ \text { Tipo } & 1795.8 & \text { heterogéneo globular } & \text { heterogéneo marmolado } \\ \text { Color } & \text { homogéneo } & \text { síno } & \text { código } \\ \text { Recogida de muestra } & \text { no } & \text { micro fisuración } & \text { grietas } \\ \text { Patologías } & \text { eflorescencias } & \text { disgregación } & \text { descamación } \\ & \text { erosión } & \text { dióneo } & \end{array}$

${ }^{1}$ Datos obtenidos en base al cálculo del desvío estándar (respecto al valor medio de la muestras analizadas) y del gráfico de frecuencia de las muestras analizadas, identificado por una curva gaussiana

\section{Juntas 2}

Ma93

\begin{tabular}{|c|c|c|c|c|}
\hline \multirow{2}{*}{$\begin{array}{l}N^{\circ} \text { elementos medidos } \\
\text { Llaga }(\mathrm{cm})\end{array}$} & \multicolumn{4}{|l|}{15} \\
\hline & \multicolumn{4}{|l|}{1.7} \\
\hline Tendel (cm) & \multicolumn{4}{|l|}{4.4} \\
\hline Altura de 5 hiladas $(\mathrm{cm})$ & \multicolumn{4}{|l|}{42.5} \\
\hline Proporción ladrillo/junta & \multicolumn{4}{|l|}{0.9} \\
\hline Tipo de acabado & simple & doble & \multicolumn{2}{|l|}{ múltiple } \\
\hline \multirow[t]{2}{*}{ Junta de asiento } & rehundida & a hueso & \multirow{2}{*}{\multicolumn{2}{|c|}{ saliente }} \\
\hline & enrasada & matada & & \\
\hline \multirow[t]{2}{*}{ Junta de acabado } & rehundida & a hueso & \multirow{2}{*}{\multicolumn{2}{|c|}{ saliente }} \\
\hline & enrasada & matada & & \\
\hline \multirow{2}{*}{$\begin{array}{l}\text { Tipo de mortero } \\
\text { Morfología de mortero }\end{array}$} & cal & cal y tierra & tierra & cemento mixto \\
\hline & con grumos & con caliches & homogéneo & heterogéneo \\
\hline \multirow{3}{*}{$\begin{array}{l}\text { Tipo de árido } \\
\text { Color del árido } \\
\text { Recogida de muestra }\end{array}$} & arena & gravilla & grava & mixto \\
\hline & claro & oscuro & homogéneo & heterogéneo \\
\hline & no & sí & código & \\
\hline \multirow[t]{2}{*}{ Patologías } & eflorescencias & micro fisuración & grietas & \\
\hline & erosión & disgregación & pulverización & \\
\hline
\end{tabular}


Imágenes

Ma93
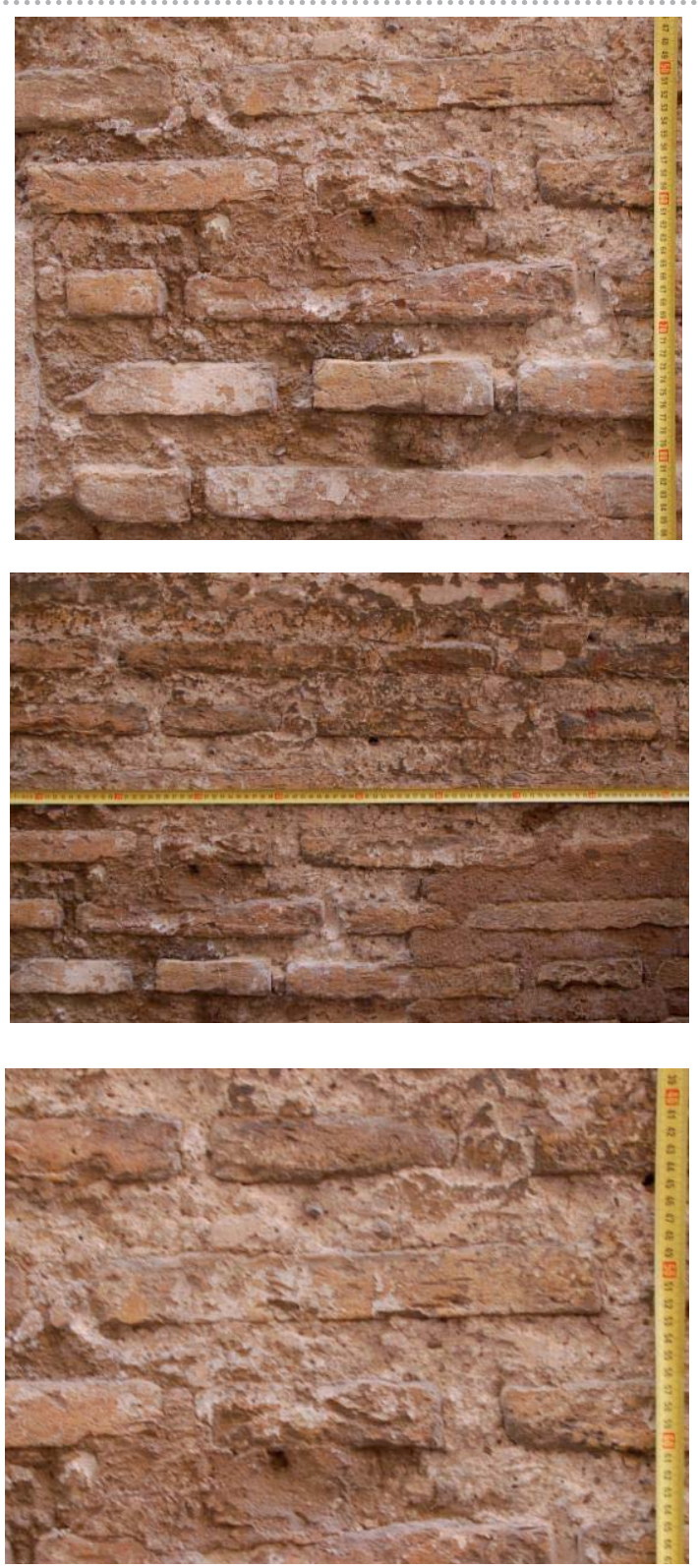
Imágenes

Ma93
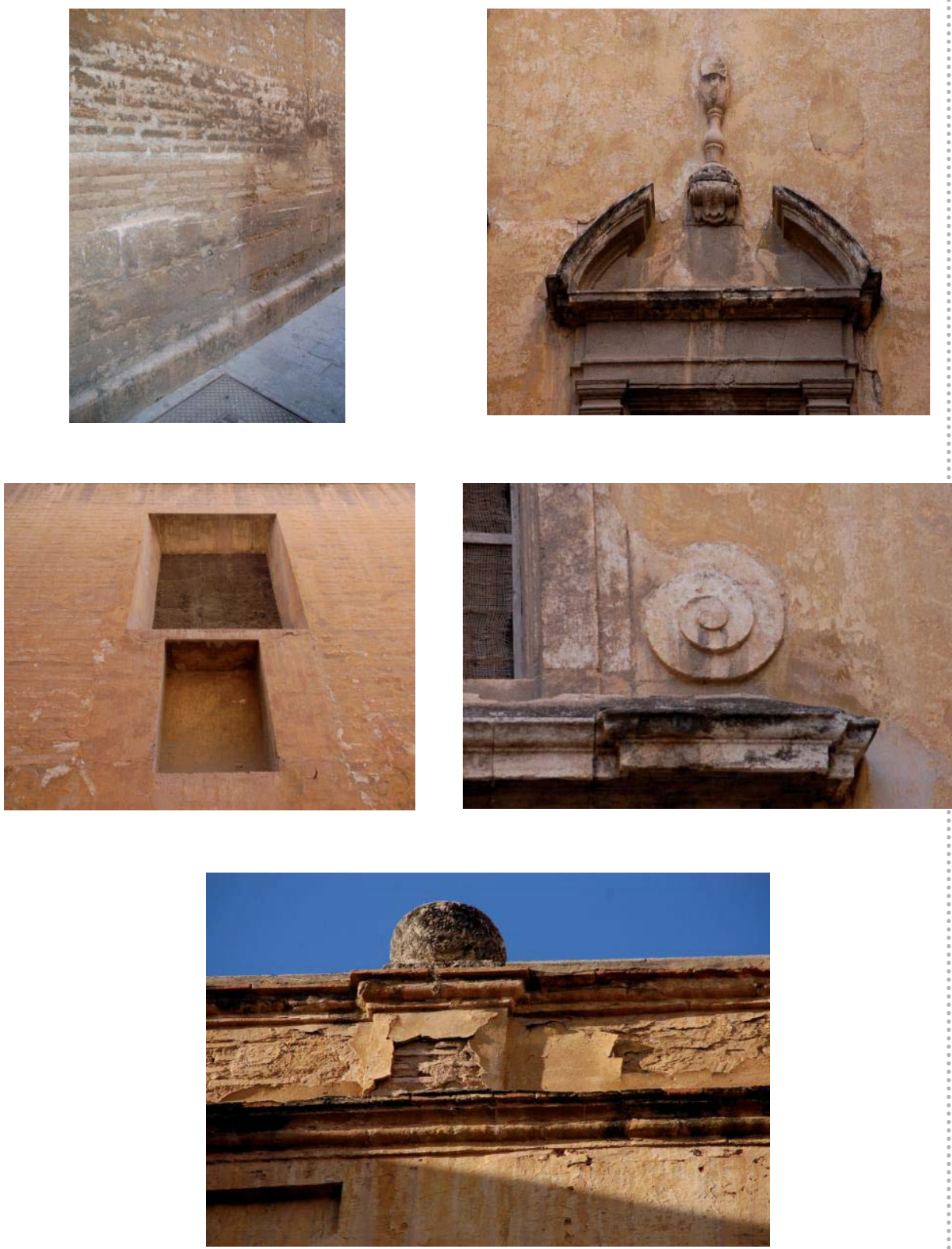
Datos generales

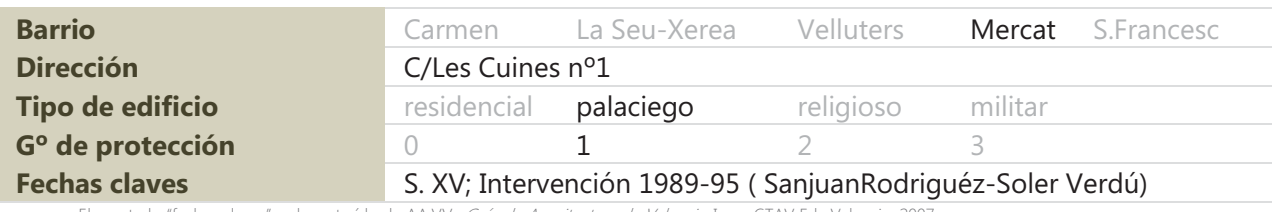
El apartado "fechas claves" se ha extraído de AA.W., Guía de Arquitectura de Valencia, Icaro CTAV Ed., Valencia, 2007
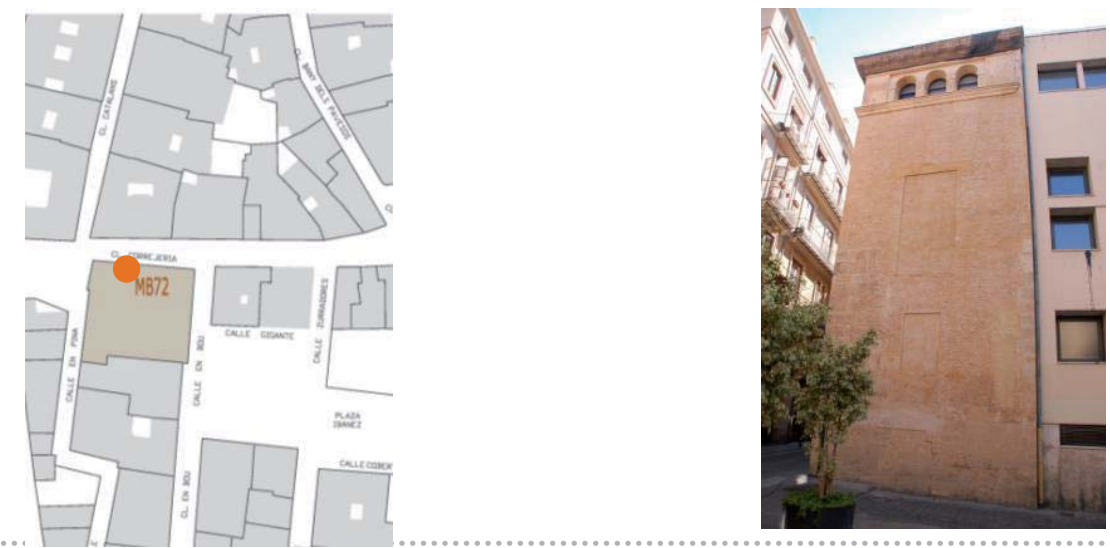

Fachada

Mb72

Pisos
Composición fachada
Zócalo
Fábrica
Vano/dintel
Entrada/dintel
Alero
Cubierta

\begin{tabular}{|c|c|c|c|c|c|c|c|}
\hline $\mathrm{N}^{\circ}$ & & sótano & entreplanta & piso noble & $\mathrm{Ca}$ & ja esca & \\
\hline & & ordenar & la sin simetría & ordenada & on $\mathrm{s}$ & metría & \\
\hline Z1 & Z2 & Z3 & Z5 & & & & \\
\hline F1 & F2 & F3 & F5 & F6 & & & \\
\hline V1 & V2 & V3 & V5 & V6 & V8 & V9 & V10 \\
\hline E1 & E2 & E3 & E4 & & & & \\
\hline A1 & A2 & A3 & A5 & A6 & & & \\
\hline
\end{tabular}

Fábrica

$\mathrm{Mb} 72$

\begin{tabular}{l|lll}
\hline Aparejo & soga-tizón & soga & \multicolumn{2}{c}{ tizón } & \\
Hiladas & irregulares & pseudo horizontales & horizontales \\
\hline Superficie & sin planeidad & pseudo planeidad & planeidad perfecta \\
\hline Sección (hipótesis) & uniforme & hojas y núcleo & abocinada (vano) \\
\hline Elementos destacados & aplantillado & cortado terracota &
\end{tabular}




\begin{tabular}{|c|c|c|c|}
\hline \multirow{2}{*}{$\begin{array}{l}\mathrm{N}^{\circ} \text { elementos medidos } \\
\text { Longitud }(\mathrm{cm})\end{array}$} & \multicolumn{3}{|l|}{15} \\
\hline & \multicolumn{3}{|l|}{28.5} \\
\hline Anchura (cm) & \multicolumn{3}{|l|}{13} \\
\hline Espesor (cm) & \multicolumn{3}{|l|}{4.1} \\
\hline Volumen $\left(\mathrm{cm}^{3}\right)$ & \multicolumn{3}{|l|}{1519,95} \\
\hline Tipo & homogéneo & heterogéneo & re-empleo \\
\hline \multirow{4}{*}{$\begin{array}{l}\text { Color } \\
\text { Recogida de muestra } \\
\text { Patologías }\end{array}$} & homogéneo & heterogéneo globular & heterogéneo marmolado \\
\hline & no & si & código \\
\hline & eflorescencias & micro fisuración & grietas \\
\hline & erosión & disgregación & descamación \\
\hline
\end{tabular}

1 Datos obtenidos en base al cálculo del desvío estándar (respecto al valor medio de la muestras analizadas) y del gráfico de frecuencia de las muestras analizadas, identificado por una curva gaussiana

\section{untas}

\begin{tabular}{|c|c|c|c|c|}
\hline \multirow{2}{*}{$\begin{array}{l}N^{\circ} \text { elementos medidos } \\
\text { Llaga }(\mathrm{cm})\end{array}$} & \multicolumn{4}{|l|}{15} \\
\hline & \multicolumn{4}{|l|}{8.5} \\
\hline Tendel (cm) & \multicolumn{4}{|l|}{8} \\
\hline Altura de 5 hiladas $(\mathrm{cm})$ & \multicolumn{4}{|l|}{57.5} \\
\hline Proporción ladrillo/junta & \multicolumn{4}{|l|}{0.5} \\
\hline Tipo de acabado & simple & doble & múltiple & \\
\hline \multirow[t]{2}{*}{ Junta de asiento } & rehundida & a hueso & saliente & \\
\hline & enrasada & matada & & \\
\hline \multirow{2}{*}{ Junta de acabado } & rehundida & a hueso & saliente & \\
\hline & enrasada & matada & & \\
\hline \multirow{2}{*}{$\begin{array}{l}\text { Tipo de mortero } \\
\text { Morfología de mortero }\end{array}$} & cal & cal y tierra & tierra & cemento mixto \\
\hline & con grumos & con caliches & homogéneo & heterogéneo \\
\hline Tipo de árido & arena & gravilla & grava & mixto \\
\hline \multirow{4}{*}{$\begin{array}{l}\text { Color del árido } \\
\text { Recogida de muestra } \\
\text { Patologías }\end{array}$} & claro & oscuro & homogéneo & heterogéneo \\
\hline & no & sí & código & \\
\hline & eflorescencias & micro fisuración & grietas & \\
\hline & erosión" & disgregación & pulverización & \\
\hline
\end{tabular}


Imágenes

Mb72
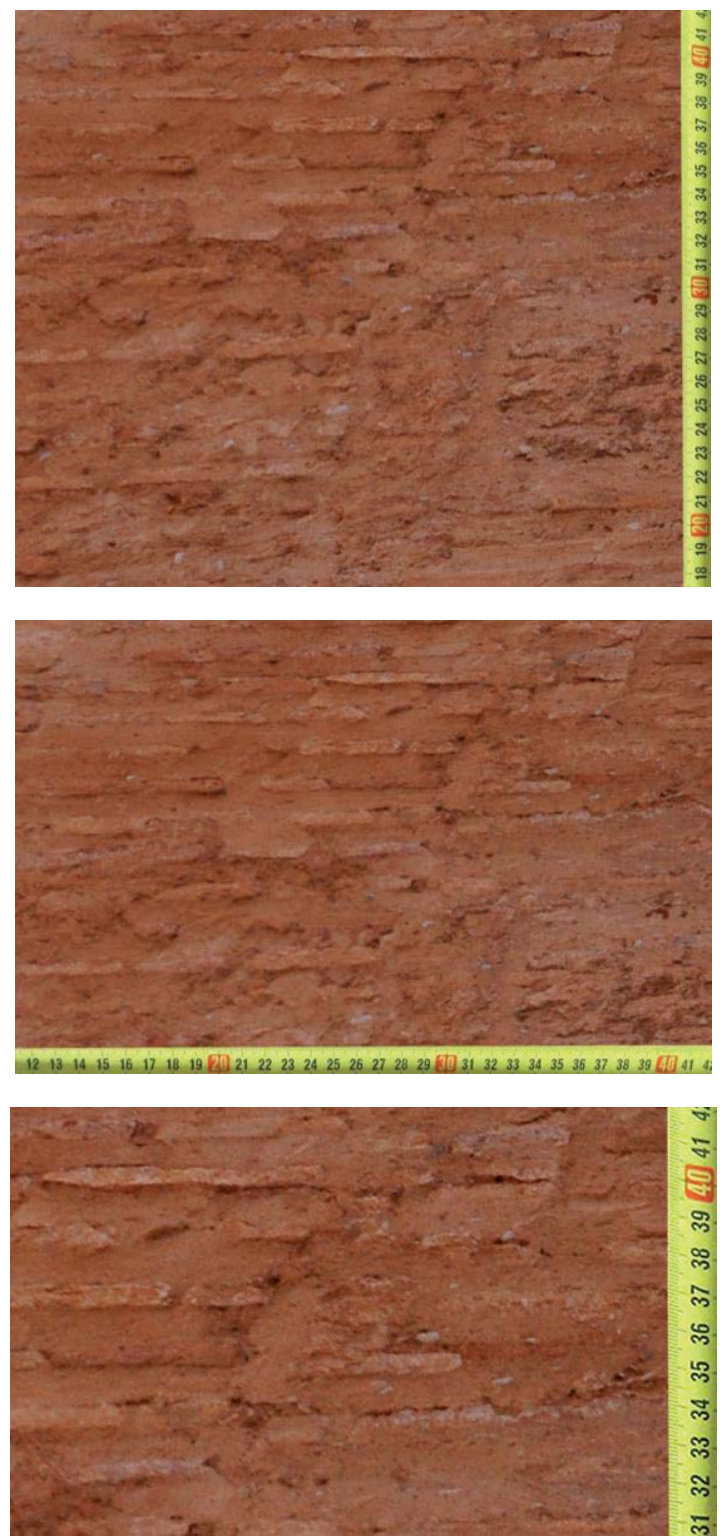

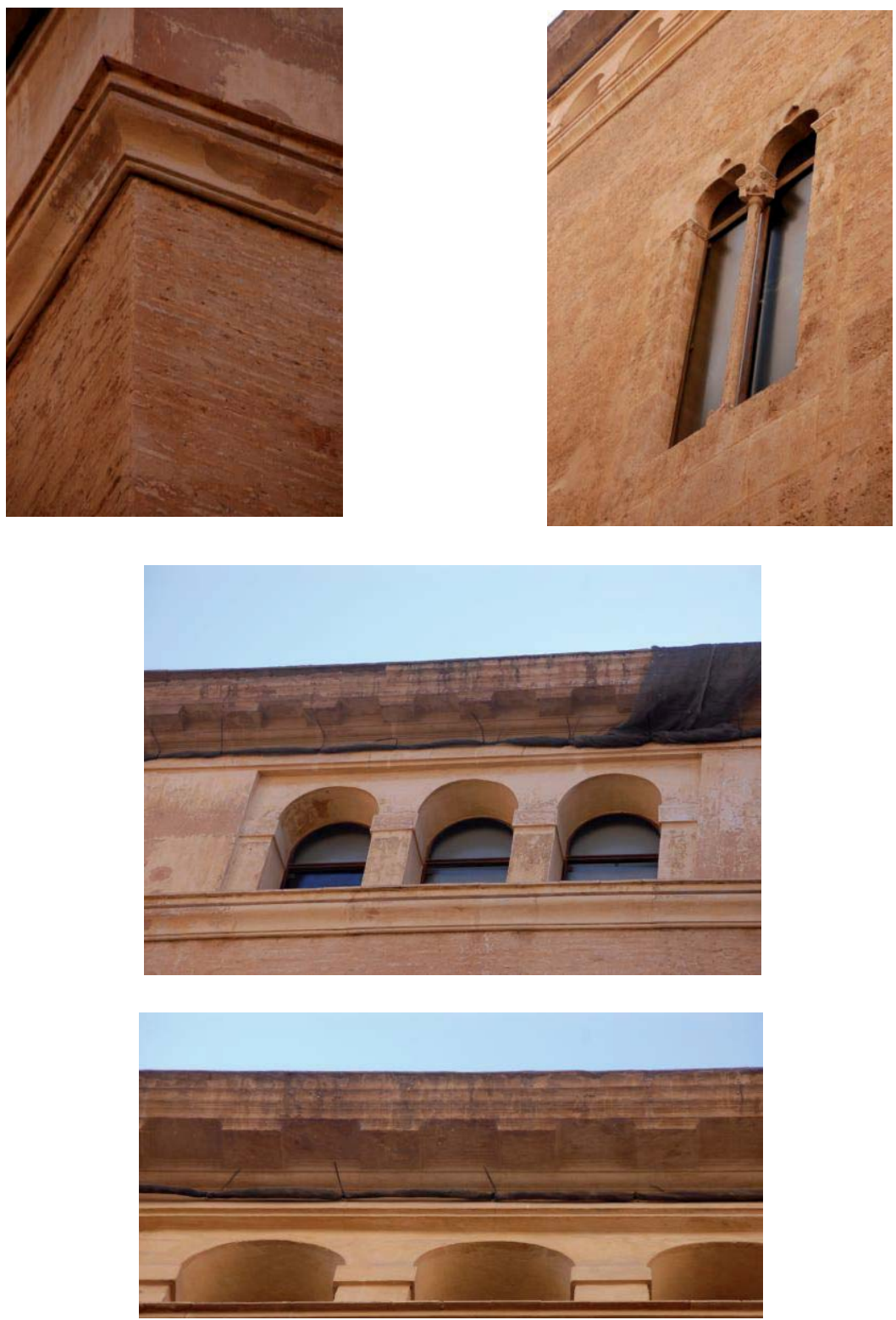
Datos generales

Mb113

\begin{tabular}{|c|c|c|c|c|c|}
\hline Barrio & Carmen & La Seu-Xerea & Velluters & Mercat & S.Francesc \\
\hline Dirección & C/Toledá nº & & & & \\
\hline Tipo de edificio & residencial & palaciego & religioso & militar & \\
\hline $\mathbf{G}^{\circ}$ de protección & 0 & 1 & 2 & 3 & \\
\hline Fechas claves & / & & & & \\
\hline
\end{tabular}

El apartado "fechas claves" se ha extraído de AA.V., Guía de Arquitectura de Valencia, Icaro CTAV Ed., Valencia, 2007

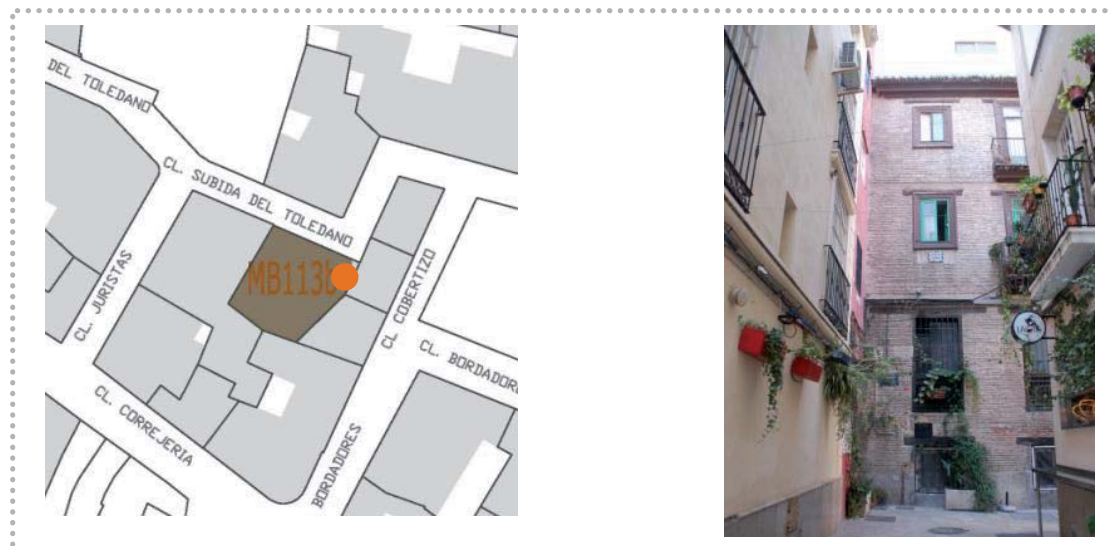

Fachada

Mb113

\begin{tabular}{|c|c|c|c|c|c|c|c|c|c|c|}
\hline \multirow{3}{*}{$\begin{array}{l}\text { Pisos } \\
\text { Composición fachada } \\
\text { Zócalo }\end{array}$} & \multicolumn{2}{|c|}{$N^{\circ} 3$} & sótano & \multicolumn{2}{|c|}{ entreplanta } & \multicolumn{5}{|c|}{ piso noble caja escalera } \\
\hline & \multicolumn{2}{|c|}{ aleatoria } & \multicolumn{3}{|c|}{ ordenada sin simetría } & \multicolumn{5}{|c|}{ ordenada con simetría } \\
\hline & $\mathrm{Z1}$ & $\mathrm{Z} 2$ & $\mathrm{Z3}$ & Z4 & $\mathrm{Z} 5$ & & & & & \\
\hline Fábrica & $\mathrm{F} 1$ & $\mathrm{~F} 2$ & F3 & F4 & F5 & F6 & F7 & & & \\
\hline Vano/dintel & V1 & V2 & V3 & V4 & V5 & V6 & V7 & V8 & V9 & V10 \\
\hline Entrada/dintel & E1 & E2 & E3 & E4 & & & & & & \\
\hline Alero & A1 & $\mathrm{A} 2$ & A3 & A4 & A5 & A6 & A7 & & & \\
\hline Cubierta & plar & & inclinac & & & & & & & \\
\hline
\end{tabular}

Fábrica

Mb113

\begin{tabular}{l|lll} 
Aparejo & soga-tizón & soga & \multicolumn{1}{c}{ tizón } \\
Hiladas & irregulares & pseudo horizontales & horizontales \\
Superficie & sin planeidad & pseudo planeidad & planeidad perfecta \\
\hline Sección (hipótesis) & uniforme & hojas y núcleo & abocinada (vano) \\
Elementos destacados & aplantillado & cortado terracota & \\
\hline
\end{tabular}




\begin{tabular}{|c|c|c|c|}
\hline \multirow{2}{*}{$\begin{array}{l}\mathrm{N}^{\circ} \text { elementos medidos } \\
\text { Longitud }(\mathrm{cm})\end{array}$} & \multicolumn{3}{|l|}{15} \\
\hline & \multicolumn{3}{|l|}{29.6} \\
\hline Anchura (cm) & \multicolumn{3}{|l|}{14.2} \\
\hline Espesor $(\mathrm{cm})$ & \multicolumn{3}{|l|}{3.7} \\
\hline Volumen $\left(\mathrm{cm}^{3}\right)$ & \multicolumn{3}{|l|}{1555.5} \\
\hline Tipo & homogéneo & heterogéneo & re-empleo \\
\hline \multirow{4}{*}{$\begin{array}{l}\text { Color } \\
\text { Recogida de muestra } \\
\text { Patologías }\end{array}$} & homogéneo & heterogéneo globular & heterogéneo marmolado \\
\hline & no & sí & código \\
\hline & eflorescencias & micro fisuración & grietas \\
\hline & erosión & disgregación & descamación \\
\hline
\end{tabular}

${ }^{1}$ Datos obtenidos en base al cálculo del desvío estándar (respecto al valor medio de la muestras analizadas) y del gráfico de frecuencia de las muestras analizadas, identificado por una curva gaussiana

\section{Juntas}

Mb113

\begin{tabular}{|c|c|c|c|c|}
\hline \multirow{2}{*}{$\begin{array}{l}N^{\circ} \text { elementos medidos } \\
\text { Llaga }(\mathrm{cm})\end{array}$} & \multicolumn{4}{|l|}{15} \\
\hline & \multicolumn{4}{|l|}{0.9} \\
\hline Tendel (cm) & \multicolumn{4}{|l|}{2.7} \\
\hline Altura de 5 hiladas $(\mathrm{cm})$ & \multicolumn{4}{|l|}{28.5} \\
\hline Proporción ladrillo/junta & \multicolumn{4}{|l|}{1.3} \\
\hline Tipo de acabado & simple & doble & múltiple & \\
\hline \multirow[t]{2}{*}{ Junta de asiento } & rehundida & a hueso & saliente & \\
\hline & enrasada & matada & & \\
\hline \multirow[t]{2}{*}{ Junta de acabado } & rehundida & a hueso & saliente & \\
\hline & enrasada & matada & & \\
\hline \multirow{2}{*}{$\begin{array}{l}\text { Tipo de mortero } \\
\text { Morfología de mortero }\end{array}$} & cal & cal y tierra & tierra & cemento mixto \\
\hline & con grumos & con caliches & homogéneo & heterogéneo \\
\hline \multirow{4}{*}{$\begin{array}{l}\text { Tipo de árido } \\
\text { Color del árido } \\
\text { Recogida de muestra } \\
\text { Patologías }\end{array}$} & arena & gravilla & grava & mixto \\
\hline & claro & oscuro & homogéneo & heterogéneo \\
\hline & no & sí & código & \\
\hline & $\begin{array}{l}\text { eflorescencias } \\
\text { erosión" }\end{array}$ & $\begin{array}{l}\text { micro fisuración } \\
\text { disgregación }\end{array}$ & $\begin{array}{l}\text { grietas } \\
\text { pulverización }\end{array}$ & \\
\hline
\end{tabular}


Imágenes
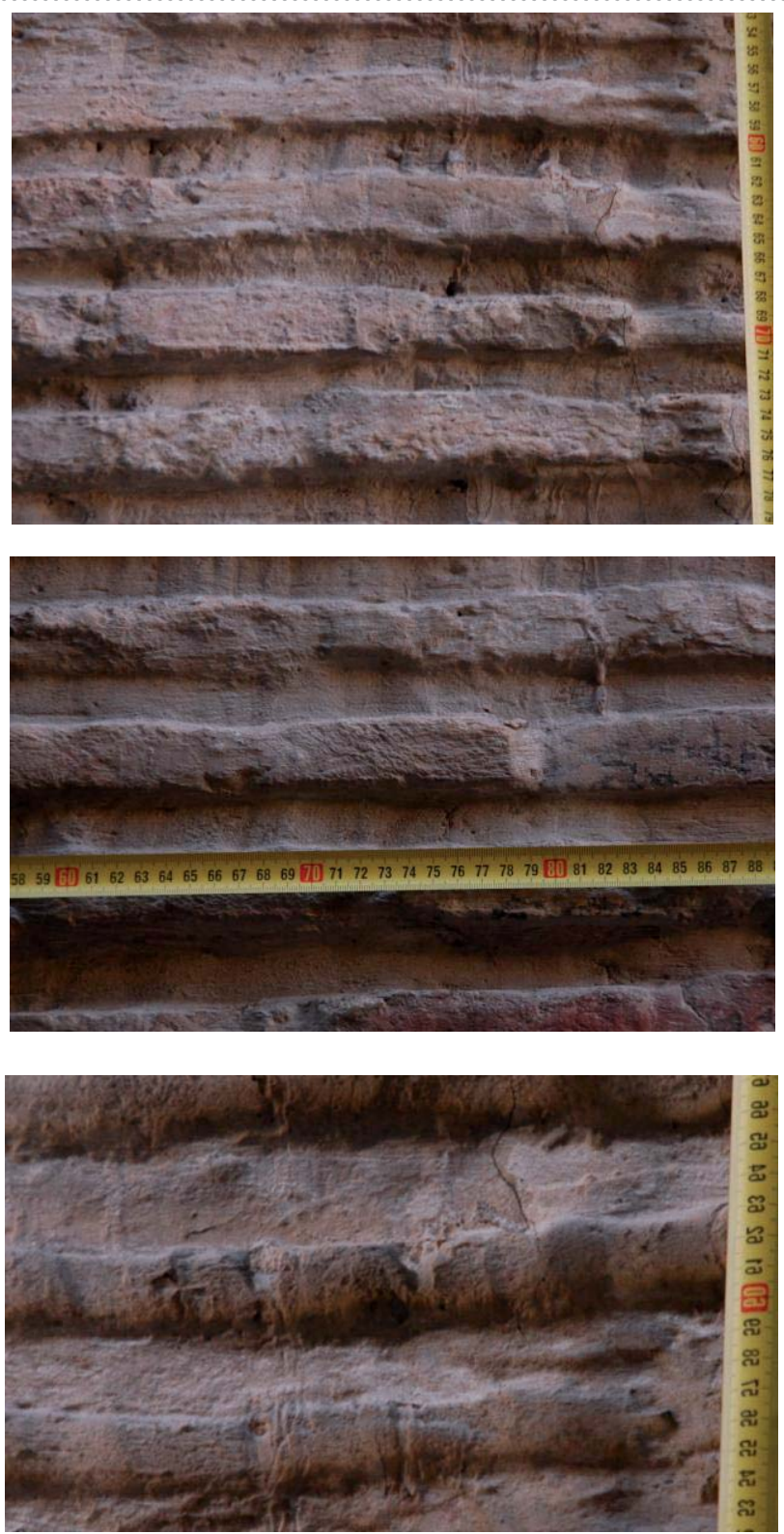
Imágenes

Mb113
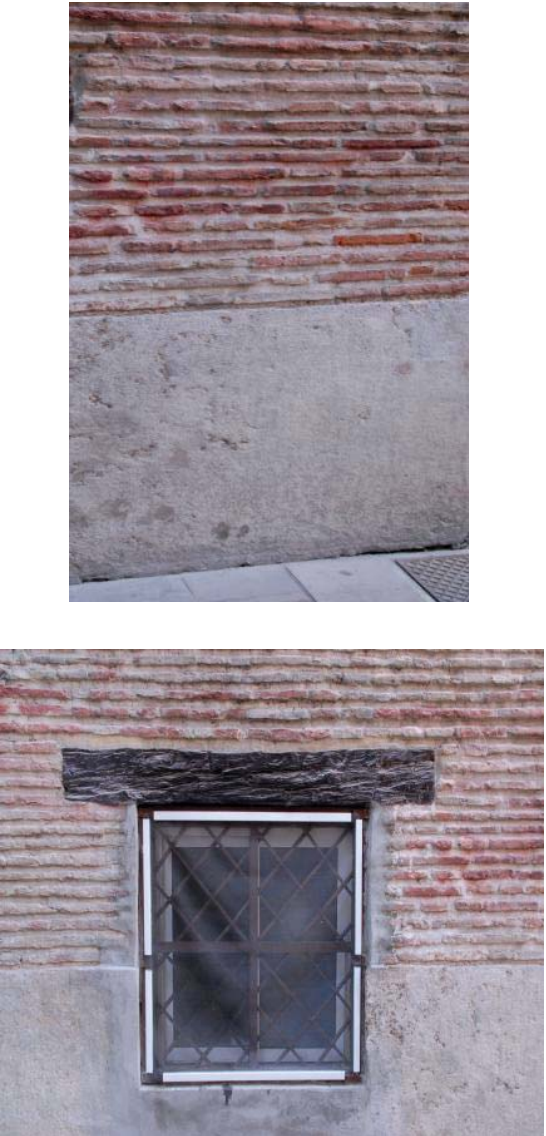
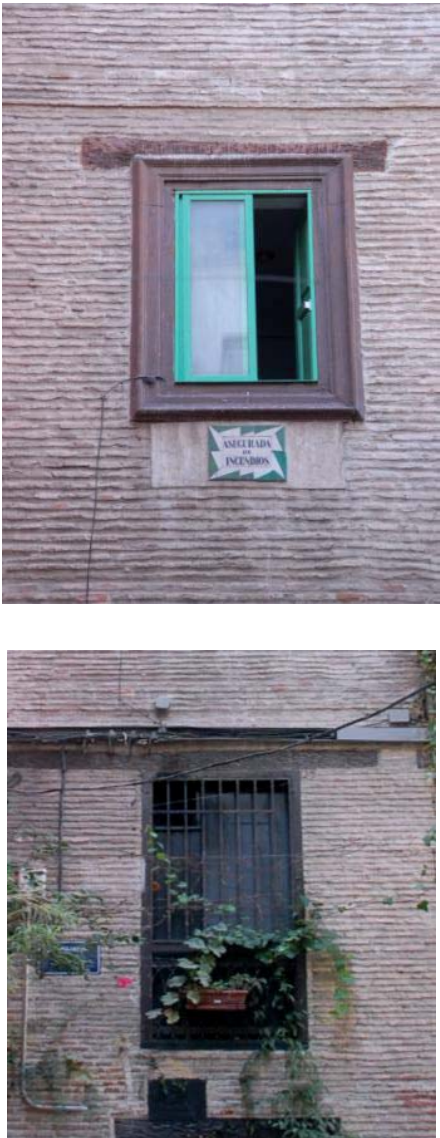

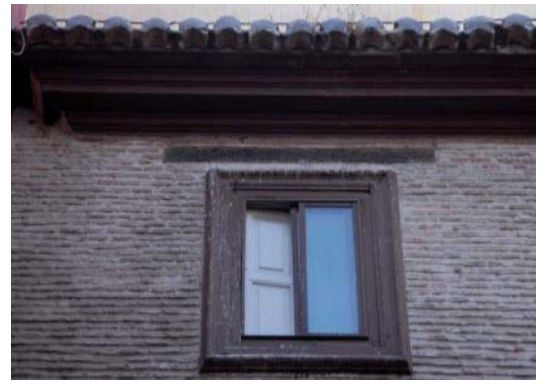


Datos generales

Mb155

\begin{tabular}{|c|c|c|c|c|c|}
\hline Barrio & Carmen & La Seu-Xerea & Velluters & Mercat & S.Francesc \\
\hline Dirección & P.za mare & De un`1 & & & \\
\hline Tipo de edificio & residencial & palaciego & religioso & militar & \\
\hline $\mathbf{G}^{\circ}$ de protección & 0 & 1 & 2 & 3 & \\
\hline Fechas claves & 1800 (José & arcía) & & & \\
\hline
\end{tabular}

El apartado "fechas claves" se ha extraído de AA.V., Guía de Arquitectura de Valencia, Icaro CTAV Ed., Valencia, 2007

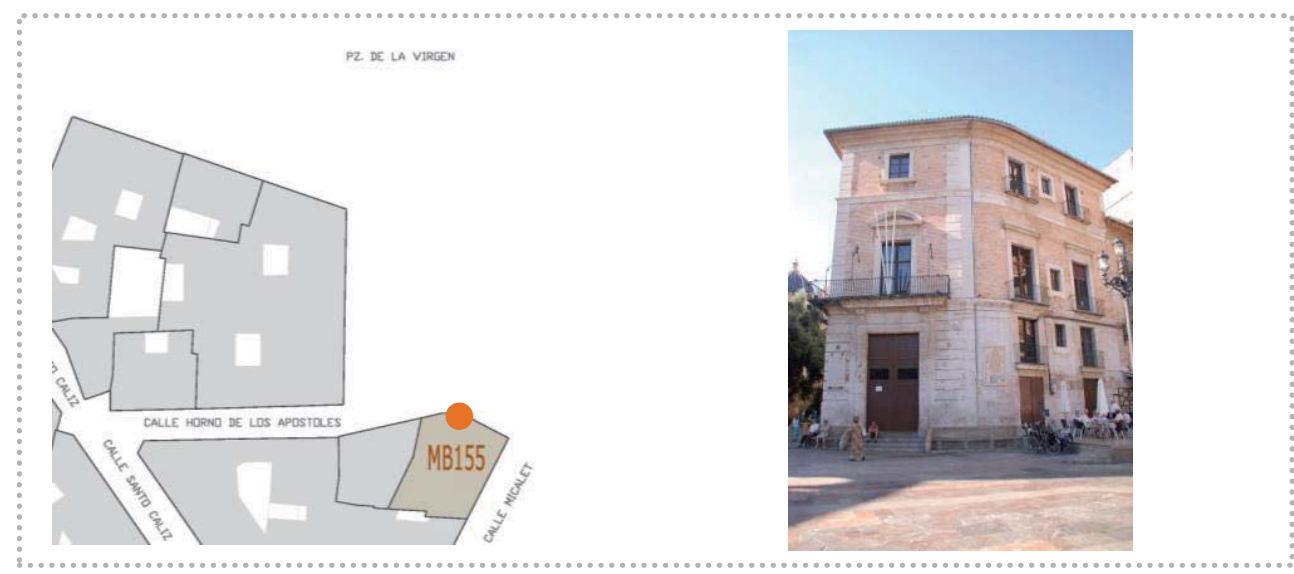

Fachada

Mb155

Pisos
Composición fachada
Zócalo
Fábrica
Vano/dintel
Entrada/dintel
Alero
Cubierta

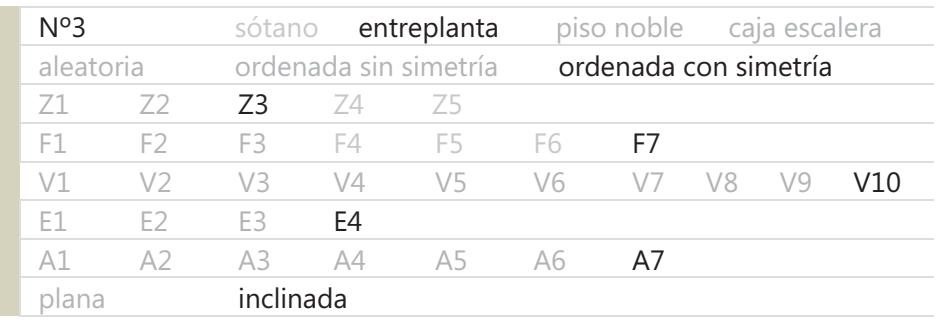

Fábrica

Mb155

\section{Aparejo \\ Hiladas \\ Superficie \\ Sección (hipótesis) \\ Elementos destacados}

\begin{tabular}{lll} 
soga-tizón & soga & \\
irregulares & tizón & \\
sin planeidad horizontales & pseudo planeidad & planeidad perfecta \\
\hline uniforme & hojas y núcleo & abocinada (vano) \\
aplantillado & cortado terracota & \\
\hline
\end{tabular}




\begin{tabular}{l|lll}
\hline $\begin{array}{l}\text { No elementos medidos } \\
\text { Longitud }(\mathbf{c m})\end{array}$ & 15 & & \\
Anchura $(\mathbf{c m})$ & 29.4 & & \\
Espesor $(\mathbf{c m})$ & 14.5 & & \\
Volumen $\left(\mathbf{c m}^{3}\right)$ & 4.7 & heterogéneo & re-empleo \\
Tipo & 2003.6 & heterogéneo globular & heterogéneo marmolado \\
Color & homogéneo & sínogéneo & código \\
Recogida de muestra & no & micro fisuración & grietas \\
Patologías & eflorescencias & disgregación & descamación
\end{tabular}

1 Datos obtenidos en base al cálculo del desvío estándar (respecto al valor medio de la muestras analizadas) y del gráfico de frecuencia de las muestras analizadas, identificado por una curva gaussiana

\section{Juntas}

Mb155

\begin{tabular}{|c|c|c|c|c|}
\hline \multirow{2}{*}{$\begin{array}{l}N^{\circ} \text { elementos medidos } \\
\text { Llaga }(\mathrm{cm})\end{array}$} & \multicolumn{4}{|l|}{15} \\
\hline & \multicolumn{4}{|l|}{1.3} \\
\hline Tendel (cm) & \multicolumn{4}{|l|}{3.1} \\
\hline Altura de 5 hiladas $(\mathrm{cm})$ & \multicolumn{4}{|l|}{39} \\
\hline Proporción ladrillo/junta & \multicolumn{4}{|l|}{1.5} \\
\hline Tipo de acabado & simple & doble & múltiple & \\
\hline Junta de asiento & $\begin{array}{l}\text { rehundida } \\
\text { enrasada }\end{array}$ & $\begin{array}{l}\text { a hueso } \\
\text { matada }\end{array}$ & saliente & \\
\hline Junta de acabado & $\begin{array}{l}\text { rehundida } \\
\text { enrasada }\end{array}$ & $\begin{array}{l}\text { a hueso } \\
\text { matada }\end{array}$ & saliente & \\
\hline Tipo de mortero & cal & cal y tierra & tierra & cemento mixto \\
\hline Morfología de mortero & con grumos & con caliches & homogéneo & heterogéneo \\
\hline Tipo de árido & arena & gravilla & grava & mixto \\
\hline Color del árido & claro & oscuro & homogéneo & heterogéneo \\
\hline Recogida de muestra & no & sí & código & \\
\hline Patologías & $\begin{array}{l}\text { eflorescencias } \\
\text { erosión }\end{array}$ & $\begin{array}{l}\text { micro fisuración } \\
\text { disgregación }\end{array}$ & $\begin{array}{l}\text { grietas } \\
\text { pulverización }\end{array}$ & \\
\hline
\end{tabular}


Imágenes

Mb155
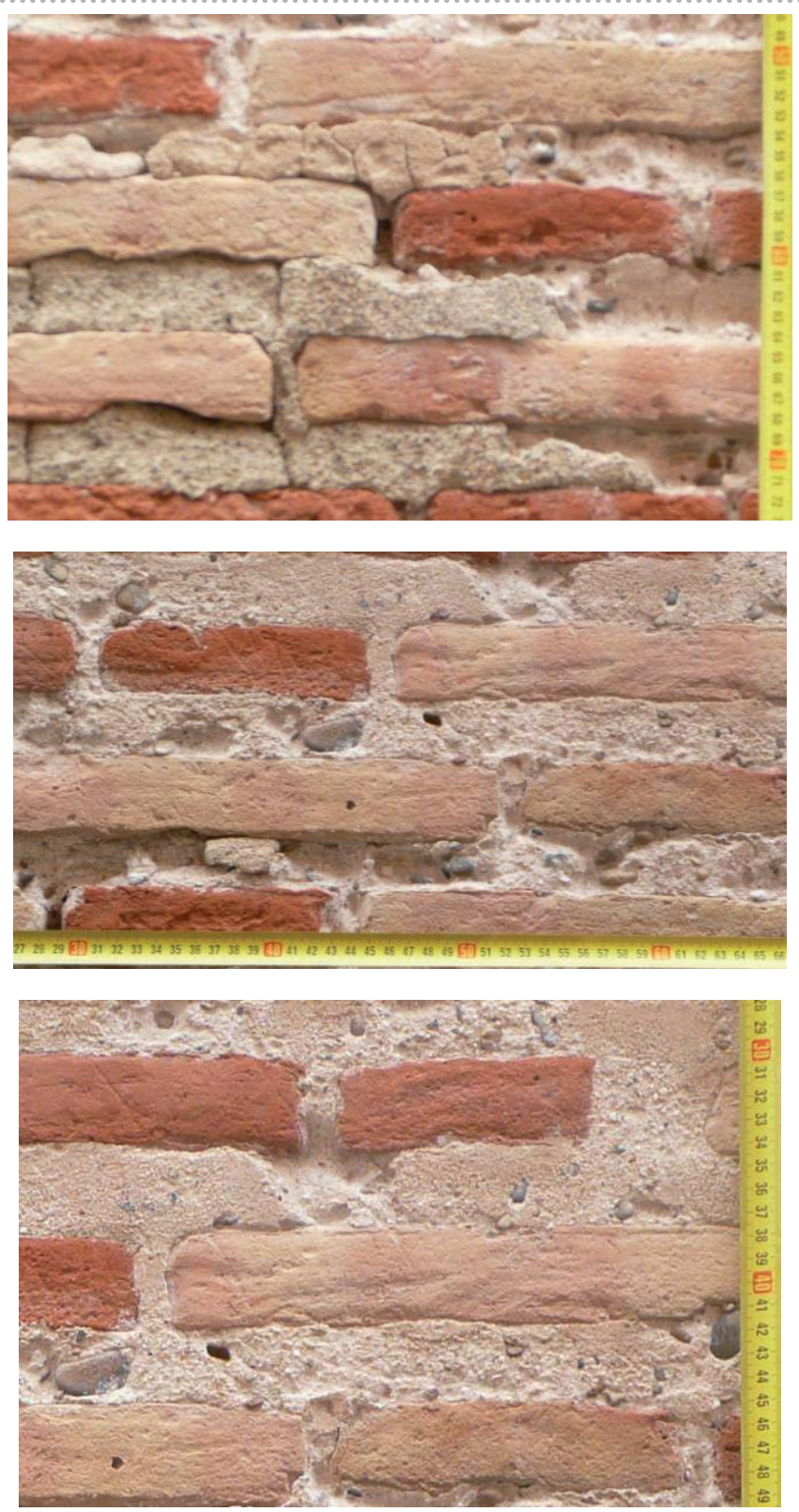

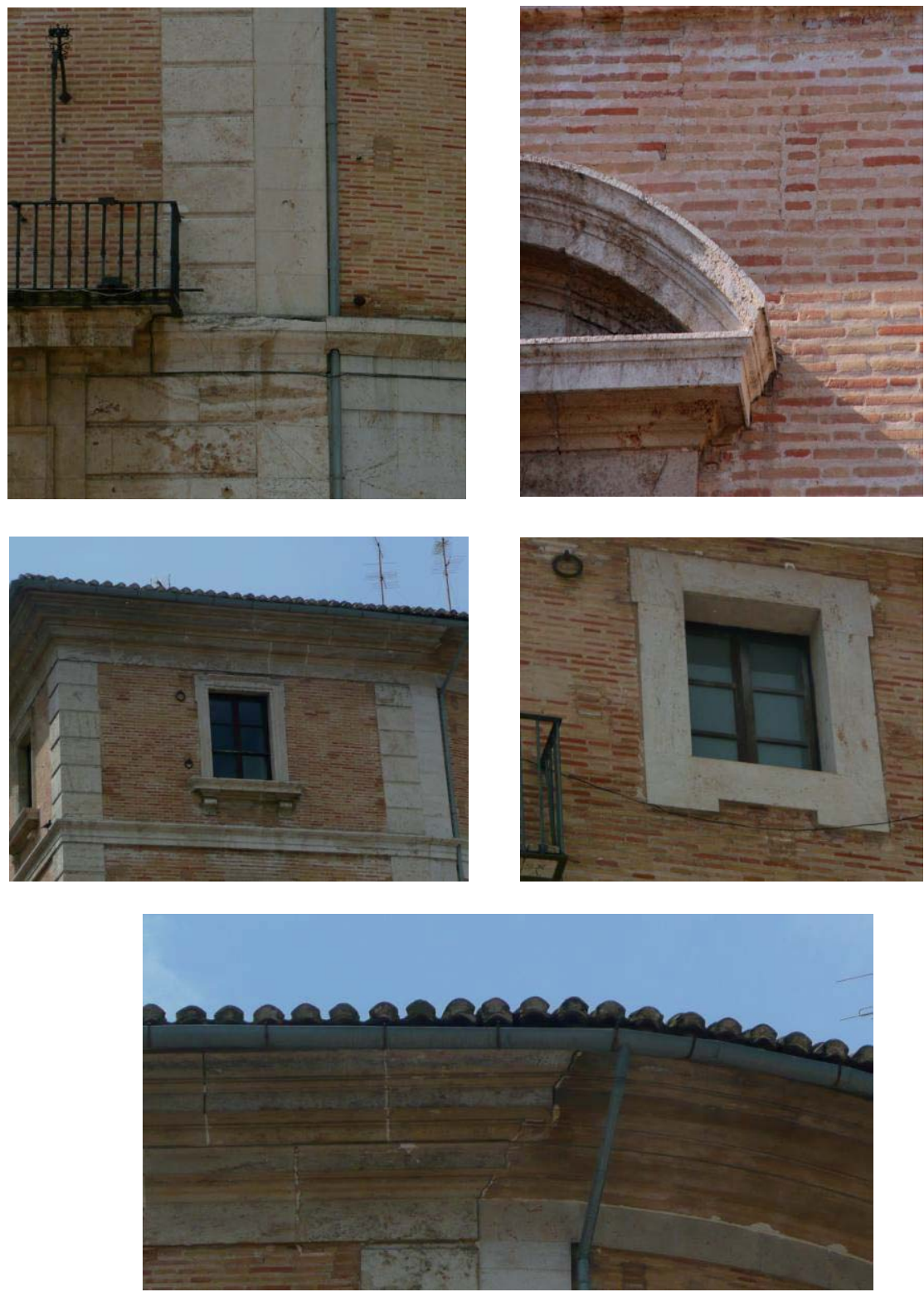
Datos generales

Me172

\begin{tabular}{|c|c|c|c|c|c|}
\hline Barrio & Carmen & La Seu-Xerea & Velluters & Mercat & S.Francesc \\
\hline Dirección & C/Senia $n^{\circ 5}$ & & & & \\
\hline Tipo de edificio & residencial & palaciego & religioso & militar & \\
\hline $\mathbf{G}^{\circ}$ de protección & 0 & 1 & 2 & 3 & \\
\hline Fechas claves & / & & & & \\
\hline
\end{tabular}

El apartado "fechas claves" se ha extraído de AA.V.., Guía de Arquitectura de Valencia, Icaro CTAV Ed., Valencia, 2007

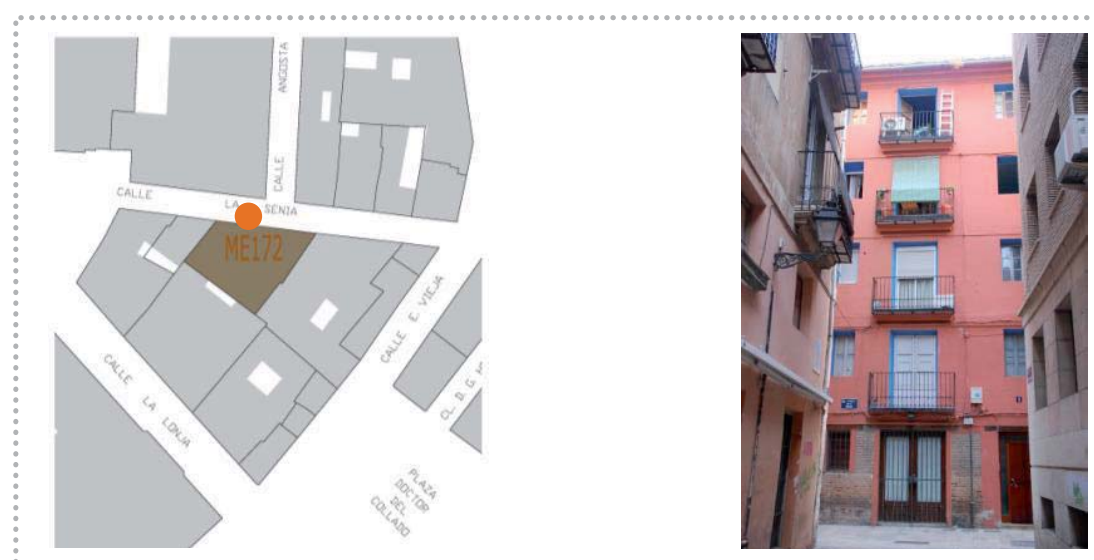

Fachada

Me172

\begin{tabular}{|c|c|c|c|c|c|c|c|c|c|}
\hline \multirow{3}{*}{$\begin{array}{l}\text { Pisos } \\
\text { Composición fachada } \\
\text { Zócalo }\end{array}$} & \multicolumn{2}{|c|}{$N^{0} 4$} & sótano & \multicolumn{2}{|c|}{ entreplanta } & \multicolumn{4}{|c|}{ piso noble caja escalera } \\
\hline & \multicolumn{2}{|c|}{ aleatoria } & \multicolumn{3}{|c|}{ ordenada sin simetría } & \multicolumn{4}{|c|}{ ordenada con simetría } \\
\hline & $\mathrm{Z1}$ & $\mathrm{Z} 2$ & Z3 & Z4 & Z5 & & & & \\
\hline Fábrica & $\mathrm{F} 1$ & $\mathrm{~F} 2$ & F3 & F4 & F5 & F6 & & & \\
\hline Vano/dintel & V1 & V2 & V3 & V4 & V5 & V7 & V8 & V9 & V10 \\
\hline Entrada/dintel & E1 & E2 & E3 & E4 & & & & & \\
\hline Alero & A1 & $\mathrm{A} 2$ & A3 & A4 & A5 & A7 & & & \\
\hline Cubierta & plar & & inclinac & & & & & & \\
\hline
\end{tabular}

Fábrica

Me172

\begin{tabular}{|c|c|c|c|}
\hline Aparejo & soga-tizón & tizón & \\
\hline Hiladas & irregulares & pseudo horizontales & horizontales \\
\hline Superficie & sin planeidad & pseudo planeidad & planeidad perfecta \\
\hline Sección (hipótesis) & uniforme & hojas y núcleo & abocinada (vano) \\
\hline Elementos destacados & aplantillado & terracota & \\
\hline
\end{tabular}




\begin{tabular}{|c|c|c|c|}
\hline \multirow{2}{*}{$\begin{array}{l}\mathrm{N}^{\circ} \text { elementos medidos } \\
\text { Longitud }(\mathrm{cm})\end{array}$} & \multicolumn{3}{|l|}{15} \\
\hline & \multicolumn{3}{|l|}{28.5} \\
\hline Anchura (cm) & \multicolumn{3}{|l|}{13.4} \\
\hline Espesor $(\mathrm{cm})$ & \multicolumn{3}{|l|}{3} \\
\hline Volumen $\left(\mathrm{cm}^{3}\right)$ & \multicolumn{3}{|l|}{1145.7} \\
\hline Tipo & homogéneo & heterogéneo & re-empleo \\
\hline Color & homogéneo & heterogéneo globular & heterogéneo marmolado \\
\hline Recogida de muestra & no & sí & código \\
\hline Patologías & $\begin{array}{l}\text { eflorescencias } \\
\text { erosión }\end{array}$ & $\begin{array}{l}\text { micro fisuración } \\
\text { disgregación }\end{array}$ & $\begin{array}{l}\text { grietas } \\
\text { descamación }\end{array}$ \\
\hline
\end{tabular}

${ }^{1}$ Datos obtenidos en base al cálculo del desvío estándar (respecto al valor medio de la muestras analizadas) y del gráfico de frecuencia de las muestras analizadas, identificado por una curva gaussiana

\section{Juntas}

\begin{tabular}{|c|c|c|c|c|}
\hline \multirow{2}{*}{$\begin{array}{l}N^{\circ} \text { elementos medidos } \\
\text { Llaga }(\mathrm{cm})\end{array}$} & \multicolumn{4}{|l|}{15} \\
\hline & \multicolumn{4}{|l|}{0.4} \\
\hline Tendel (cm) & \multicolumn{4}{|l|}{3.04} \\
\hline Altura de 5 hiladas $(\mathrm{cm})$ & \multicolumn{4}{|l|}{29.4} \\
\hline Proporción ladrillo/junta & \multicolumn{4}{|l|}{0.9} \\
\hline Tipo de acabado & simple & doble & múltiple & \\
\hline \multirow[t]{2}{*}{ Junta de asiento } & rehundida & a hueso & saliente & \\
\hline & enrasada & matada & & \\
\hline \multirow{2}{*}{ Junta de acabado } & rehundida & a hueso & saliente & \\
\hline & enrasada & matada & & \\
\hline \multirow{2}{*}{$\begin{array}{l}\text { Tipo de mortero } \\
\text { Morfología de mortero }\end{array}$} & cal & cal y tierra & tierra & cemento mixto \\
\hline & con grumos & con caliches & homogéneo & heterogéneo \\
\hline Tipo de árido & arena & gravilla & grava & mixto \\
\hline \multirow{4}{*}{$\begin{array}{l}\text { Color del árido } \\
\text { Recogida de muestra } \\
\text { Patologías }\end{array}$} & claro & oscuro & homogéneo & heterogéneo \\
\hline & no & sí & código & \\
\hline & eflorescencias & micro fisuración & grietas & \\
\hline & erosión & disgregación & pulverización & \\
\hline
\end{tabular}


Imágenes
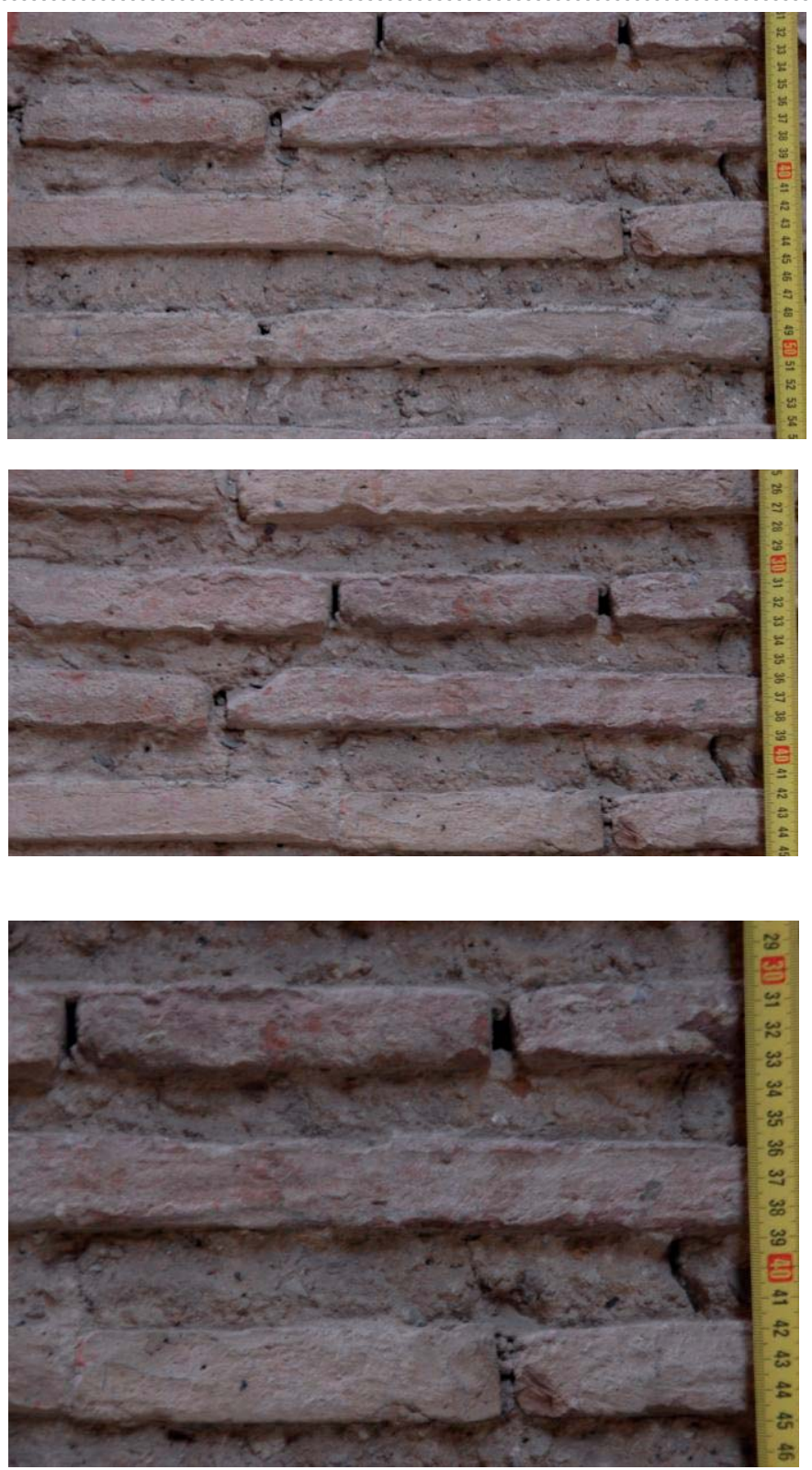

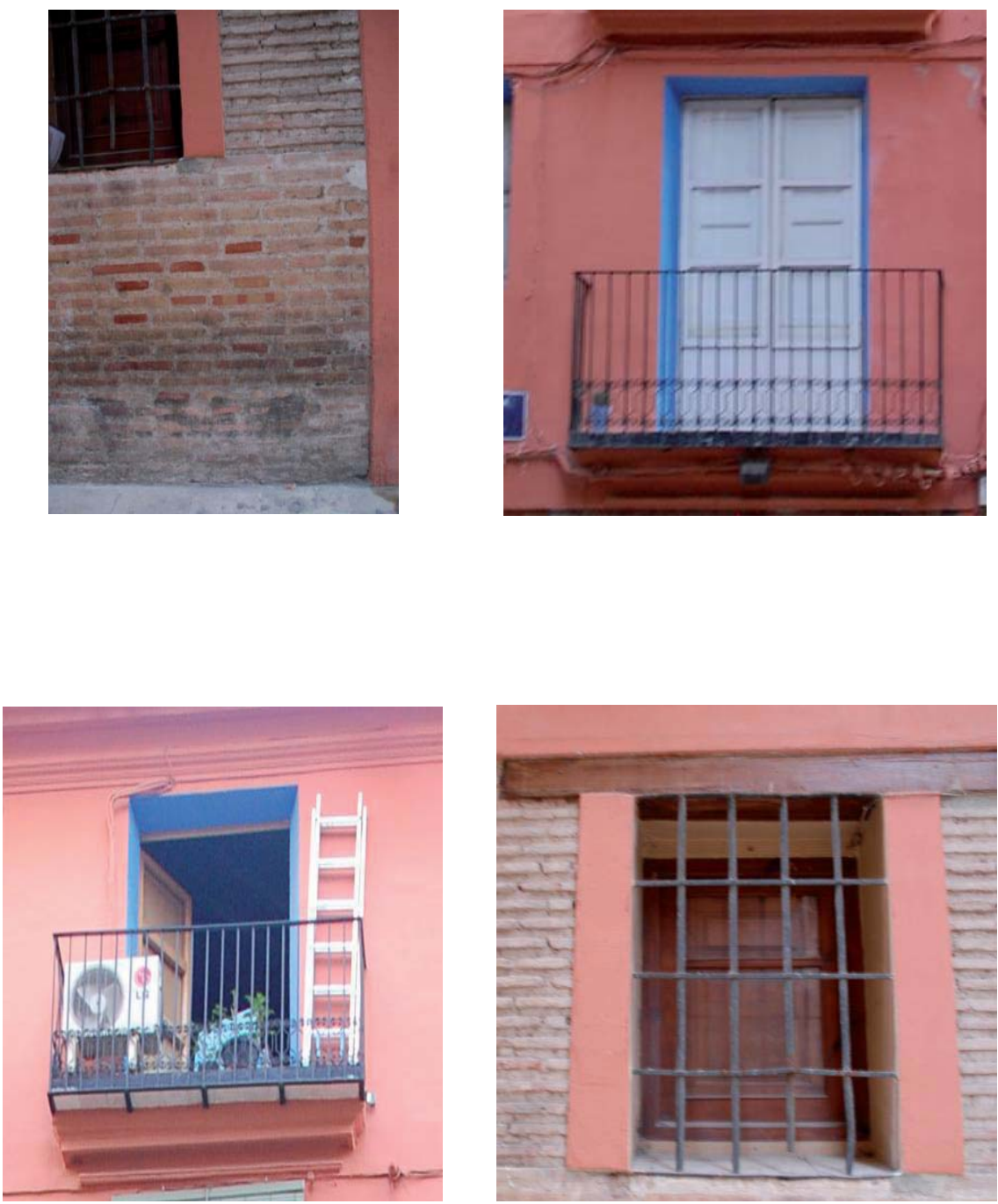


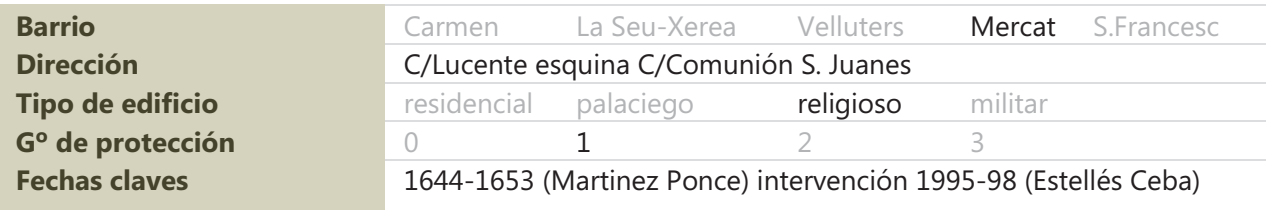
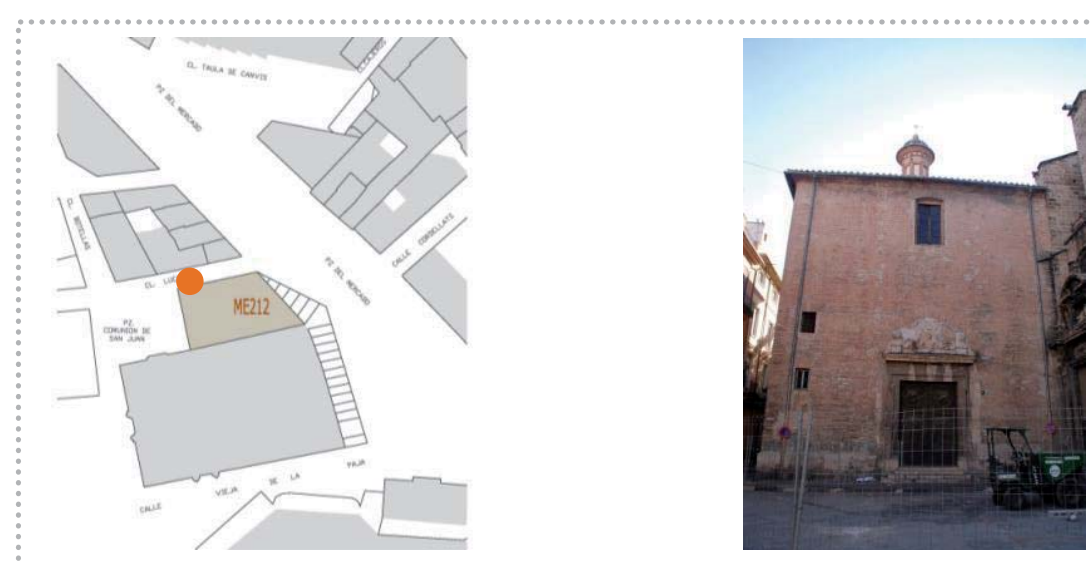

fachada

Me212a

\begin{tabular}{|c|c|c|c|c|c|c|c|c|c|c|}
\hline \multirow{3}{*}{$\begin{array}{l}\text { Pisos } \\
\text { Composición fachada } \\
\text { Zócalo }\end{array}$} & \multicolumn{2}{|c|}{$\mathrm{N} \%$} & sótano & \multicolumn{2}{|c|}{ entreplanta } & \multicolumn{5}{|c|}{ piso noble caja escalera } \\
\hline & \multicolumn{2}{|c|}{ aleatoria } & \multicolumn{3}{|c|}{ ordenada sin simetría } & \multicolumn{5}{|c|}{ ordenada con simetría } \\
\hline & Z1 & $\mathrm{Z2}$ & Z3 & Z4 & $\mathrm{Z} 5$ & & & & & \\
\hline Fábrica & $\mathrm{F} 1$ & $\mathrm{~F} 2$ & F3 & F4 & F5 & F6 & F7 & & & \\
\hline Vano/dintel & V1 & V2 & V3 & V4 & V5 & V6 & V7 & V8 & V9 & V10 \\
\hline Entrada/dintel & E1 & E2 & E3 & E4 & & & & & & \\
\hline Alero & A1 & $\mathrm{A} 2$ & A3 & A4 & A5 & A6 & A7 & & & \\
\hline Cubierta & pla & & inclina & & & & & & & \\
\hline
\end{tabular}
Ver tablas relativas a los códigos indicados, al final de la recopilación de las fichas

\section{Me212a}

Aparejo
Hiladas
Superficie
Sección (hipótesis)
Elementos destacados

soga-tizón

irregulares

sin planeidad

uniforme

aplantillado soga

pseudo horizontales

pseudo planeidad

hojas y núcleo

cortado

\section{tizón}

horizontales

planeidad perfecta

abocinada (vano)

terracota 


\begin{tabular}{|c|c|c|c|}
\hline \multirow{2}{*}{$\begin{array}{l}N^{0} \text { elementos medidos } \\
\text { Longitud }(\mathrm{cm})\end{array}$} & \multicolumn{3}{|l|}{212} \\
\hline & \multicolumn{3}{|l|}{30.2} \\
\hline Anchura (cm) & \multicolumn{3}{|l|}{14.2} \\
\hline Espesor (cm) & \multicolumn{3}{|l|}{4.2} \\
\hline Volumen $\left(\mathrm{cm}^{3}\right)$ & \multicolumn{3}{|l|}{1801.1} \\
\hline Tipo & homogéneo & heterogéneo & re-empleo \\
\hline \multirow{4}{*}{$\begin{array}{l}\text { Color } \\
\text { Recogida de muestra } \\
\text { Patologías }\end{array}$} & homogéneo & heterogéneo globular & heterogéneo marmolado \\
\hline & no & sí & código \\
\hline & eflorescencias & micro fisuración & grietas \\
\hline & erosión & disgregación & descamación \\
\hline
\end{tabular}

1 Datos obtenidos en base al cálculo del desvío estándar (respecto al valor medio de la muestras analizadas) y del gráfico de frecuencia de las muestras analizadas, identificado por una curva gaussiana

\section{untas}

\begin{tabular}{|c|c|c|c|c|}
\hline \multirow{2}{*}{$\begin{array}{l}N^{\circ} \text { elementos medidos } \\
\text { Llaga }(\mathrm{cm})\end{array}$} & \multicolumn{4}{|l|}{15} \\
\hline & \multicolumn{4}{|l|}{1.1} \\
\hline Tendel (cm) & \multicolumn{4}{|l|}{4.1} \\
\hline $\begin{array}{l}\text { Altura de } 5 \text { hiladas } \\
(\mathrm{cm})\end{array}$ & \multicolumn{4}{|l|}{39.9} \\
\hline $\begin{array}{l}\text { Proporción } \\
\text { ladrillo/junta }\end{array}$ & \multicolumn{4}{|l|}{1.02} \\
\hline Tipo de acabado & simple & doble & múltiple & \\
\hline \multirow[t]{2}{*}{ Junta de asiento } & rehundida & a hueso & saliente & \\
\hline & enrasada & matada & & \\
\hline \multirow[t]{2}{*}{ Junta de acabado } & rehundida & a hueso & saliente & \\
\hline & enrasada & matada & & \\
\hline \multirow{3}{*}{$\begin{array}{l}\text { Tipo de mortero } \\
\text { Morfología de mortero } \\
\text { Tipo de árido }\end{array}$} & cal & cal y tierra & tierra & cemento mixto \\
\hline & con grumos & con caliches & homogéneo & heterogéneo \\
\hline & arena & gravilla & grava & mixto \\
\hline \multirow{2}{*}{$\begin{array}{l}\text { Color del árido } \\
\text { Recogida de muestra }\end{array}$} & claro & oscuro & homogéneo & heterogéneo \\
\hline & no & sí & código & \\
\hline \multirow[t]{2}{*}{ Patologías } & eflorescencias & micro fisuración & grietas & \\
\hline & erosión" & disgregación & pulverización & \\
\hline
\end{tabular}

${ }^{2}$ Datos obtenidos en base al cálculo del desvío estándar (respecto al valor medio de la muestras analizadas) y del gráfico de frecuencia de las muestras analizadas, identificado por una curva gaussiana 
Imágenes
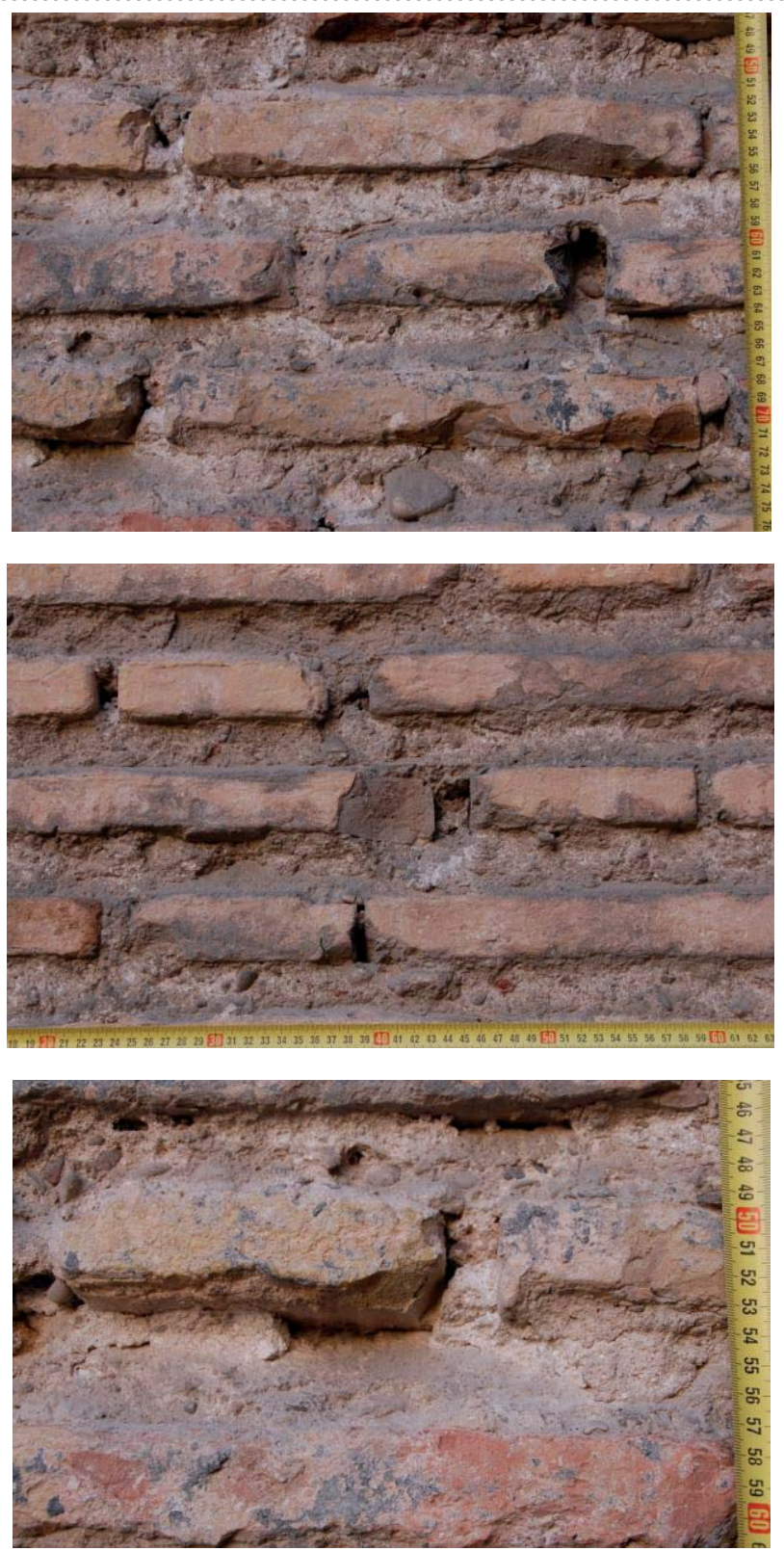

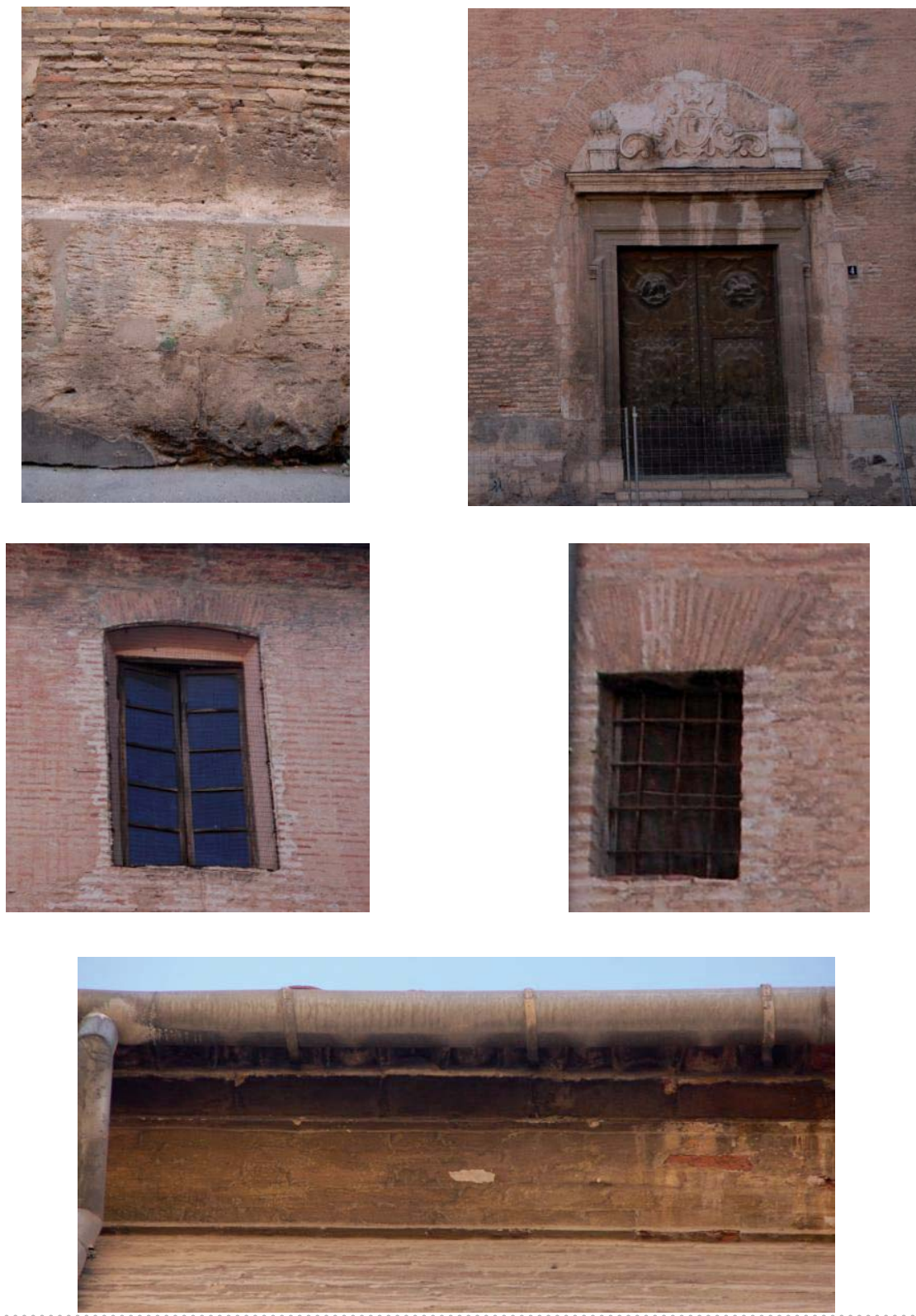


$\begin{array}{llllll}\text { Barrio } & \text { Carmen } & \text { La Seu-Xerea } & \text { Velluters } & \text { Mercat } & \text { S.Francesc } \\ \text { Dirección } & \text { C/Lucente esquina C/Comunión S. Juanes } & & \\ \text { Tipo de edificio } & \text { residencial } & \text { palaciego } & \text { religioso } & \text { militar } \\ \begin{array}{l}\mathbf{G}^{\circ} \text { de protección } \\ \text { Fechas claves }\end{array} & 0 & 1 & 2 & 3 & \\ & \begin{array}{l}\text { Iglesia } \\ \text { intervención }\end{array} & \text { S. XVI-XVIII; } & \text { C. Comunión } & \text { 1644-1653 } & \text { (Martinez Ponce) }\end{array}$

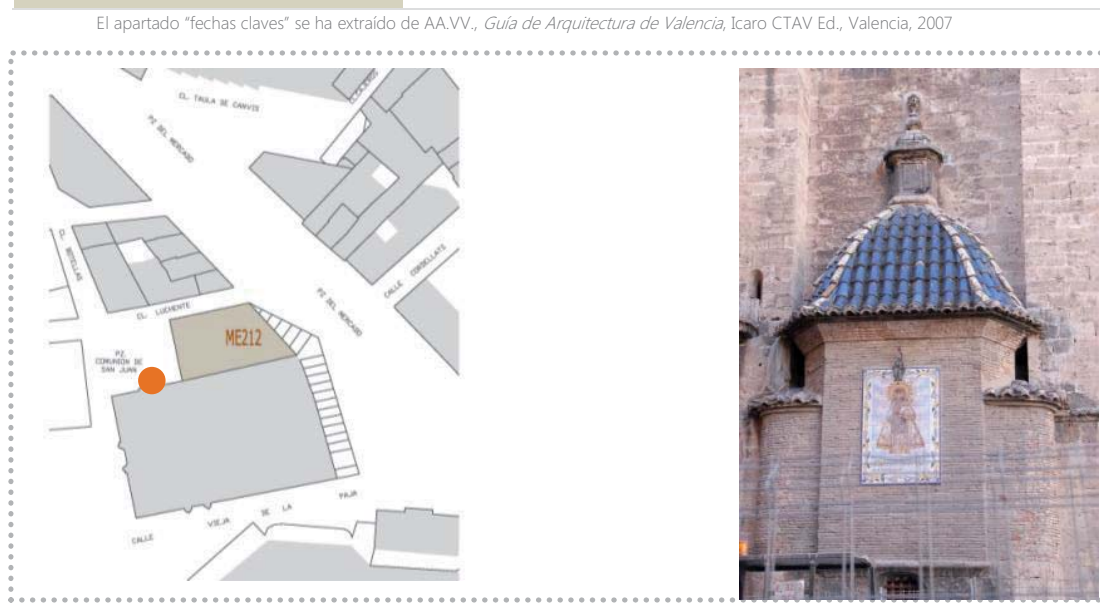

\section{Fachada}

Me212b

\begin{tabular}{|c|c|c|c|c|c|c|c|c|c|c|}
\hline \multirow{3}{*}{$\begin{array}{l}\text { Pisos } \\
\text { Composición fachada } \\
\text { Zócalo }\end{array}$} & \multicolumn{2}{|c|}{ No/ } & \multicolumn{3}{|c|}{ sótano entreplanta } & \multicolumn{5}{|c|}{ piso noble caja escalera } \\
\hline & \multicolumn{2}{|c|}{ aleatoria } & \multicolumn{3}{|c|}{ ordenada sin simetría } & \multicolumn{5}{|c|}{ ordenada con simetría } \\
\hline & Z1 & $\mathrm{Z2}$ & $\mathrm{Z} 3$ & Z4 & $\mathrm{Z5}$ & & & & & \\
\hline Fábrica & $\mathrm{F} 1$ & F2 & F3 & F4 & F5 & F6 & F7 & & & \\
\hline Vano/dintel & V1 & V2 & V3 & V4 & V5 & V6 & V7 & V8 & V9 & V10 \\
\hline Entrada/dintel & E1 & E2 & E3 & E4 & & & & & & \\
\hline Alero & A1 & $\mathrm{A} 2$ & $\mathrm{~A} 3$ & A4 & A5 & A6 & A7 & & & \\
\hline Cubierta & pla & & incli & & & & & & & \\
\hline
\end{tabular}

\section{Fábrica}

Me212b

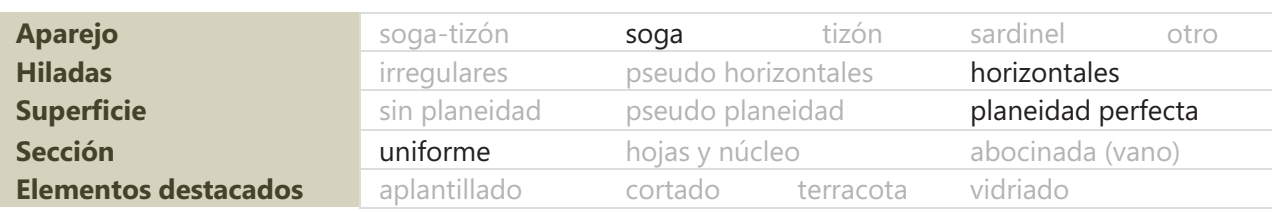




\section{$\mathrm{N}^{\circ}$ elementos medidos}

Longitud $(\mathrm{cm})$

Anchura (cm)

Espesor $(\mathrm{cm})$

Volumen $\left(\mathrm{cm}^{3}\right)$

Tipo

Color

Recogida de muestra

Patologías
212

29.4

11

3.3

1067.22

\begin{tabular}{lll} 
homogéneo & heterogéneo & re-empleo \\
\hline homogéneo & heterogéneo globular & heterogéneo marmolado \\
no & sí & código \\
\hline eflorescencias & $\begin{array}{l}\text { micro fisuración } \\
\text { erosión }\end{array}$ & gisgregactas \\
\hline
\end{tabular}

1 Datos obtenidos en base al cálculo del desvío estándar (respecto al valor medio de la muestras analizadas) y del gráfico de frecuencia de las muestras analizadas, identificado por una curva gaussiana

\section{Juntas 2}

Me212b

\begin{tabular}{|c|c|c|c|c|}
\hline $\mathrm{N}^{\circ}$ elementos medidos & 15 & & & \\
\hline Llaga $(\mathrm{cm})$ & 0.4 & & & \\
\hline Tendel (cm) & 1.2 & & & \\
\hline Altura de 5 hiladas $(\mathrm{cm})$ & 22.7 & & & \\
\hline Proporción ladrillo/junta & 2.7 & & & \\
\hline Tipo de acabado & simple & doble & múltiple & \\
\hline Junta de asiento & $\begin{array}{l}\text { rehundida } \\
\text { enrasada }\end{array}$ & $\begin{array}{l}\text { a hueso } \\
\text { matada }\end{array}$ & saliente & \\
\hline Junta de acabado & $\begin{array}{l}\text { rehundida } \\
\text { enrasada }\end{array}$ & $\begin{array}{l}\text { a hueso } \\
\text { matada }\end{array}$ & saliente & \\
\hline Tipo de mortero & cal & cal y tierra & tierra & cemento mixto \\
\hline Morfología de mortero & con grumos & con caliches & homogéneo & heterogéneo \\
\hline Tipo de árido & arena & gravilla & grava & mixto \\
\hline Color del árido & claro & oscuro & homogéneo & heterogéneo \\
\hline Recogida de muestra & no & sí & código & \\
\hline Patologías & $\begin{array}{l}\text { eflorescencias } \\
\text { erosión" }\end{array}$ & $\begin{array}{l}\text { micro fisuración } \\
\text { disgregación }\end{array}$ & $\begin{array}{l}\text { grietas } \\
\text { pulverización }\end{array}$ & \\
\hline
\end{tabular}


Imágenes

Me212b
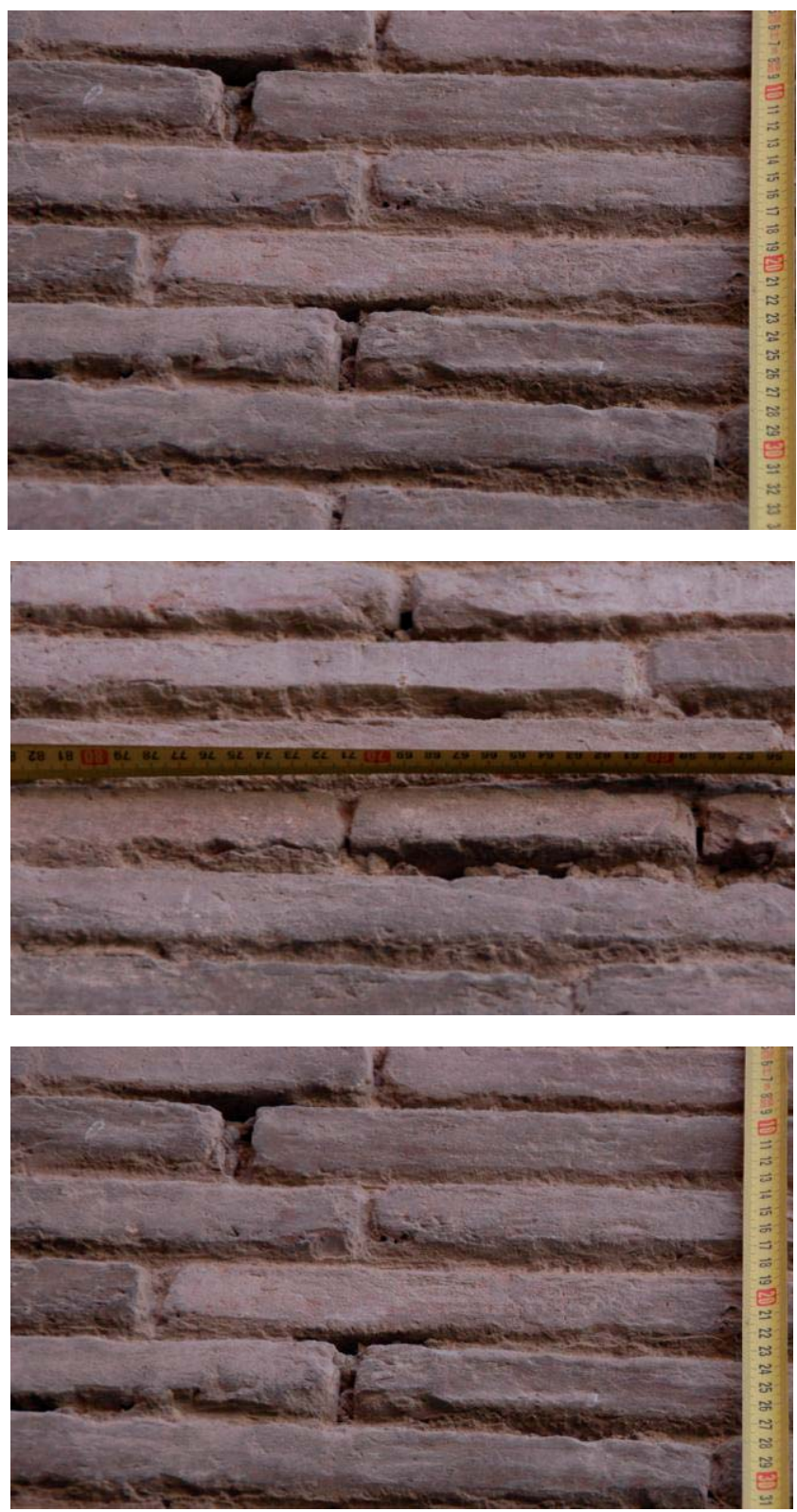

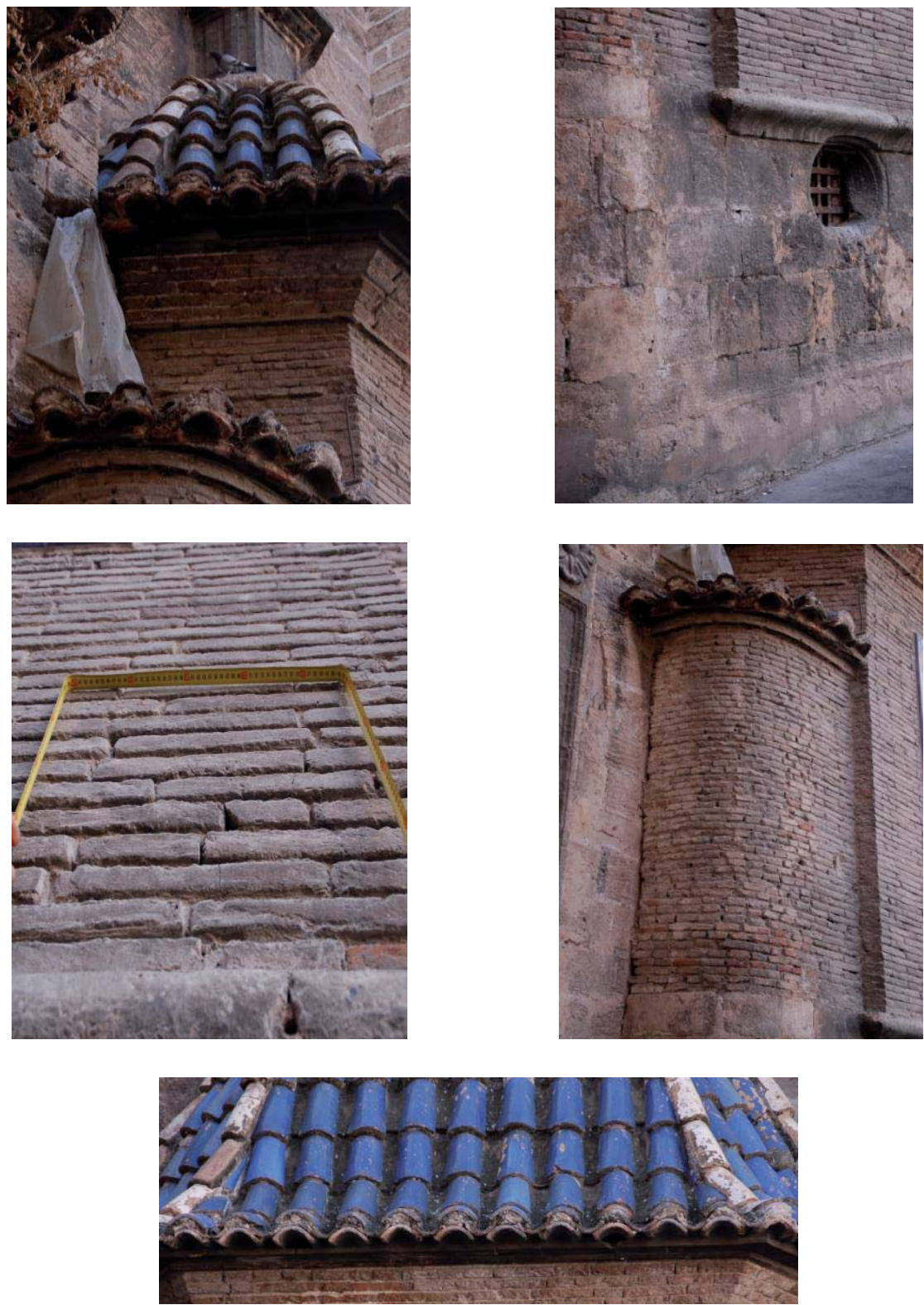


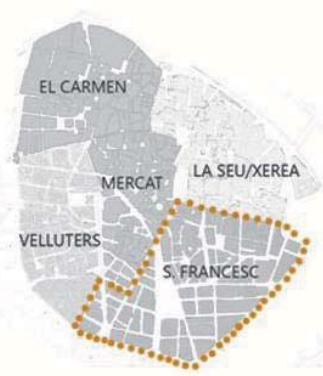

I.2.3. Fábricas históricas: barrio de S. Francesc

Fichas recopiladas 
Barrio de S. Francesc: todas las fábricas seleccionadas

\begin{tabular}{|c|c|c|}
\hline Código & Dirección & Edificio \\
\hline Fa39 & C/ Salvà s/n & RELIGIOSO \\
\hline Fa82 & C/ Cardenal Payà s/n & RELIGIOSO \\
\hline $\mathrm{Fa105}$ & C/ San Vicente Martir $n^{\circ} 2$ & RELIGIOSO \\
\hline $\mathrm{Fa107}$ & Pza. Margarita Valdaura no 1 & RESIDENCIAL \\
\hline Fa153a & C/ San Andrés s/n & RELIGIOSO \\
\hline Fa153b & C/ Procida s/n & RELIGIOSO \\
\hline Fa153c & Pza. Picadero de dos Aguas s/n & RELIGIOSO \\
\hline Fb57 & C/ Verger $n^{\circ} 2$ esq. C/ Bonaire $n^{\circ} 9$ & RESIDENCIAL \\
\hline Fb117 & Pza. Palacio Justicia s/n & PALACIEGO \\
\hline
\end{tabular}




\section{Barrio de S. Francesc: monumentos}

\begin{tabular}{l|l|l|l}
\hline Código & Dirección & Edificio & Nombre \\
\hline Fa39 & C/ Salvà s/n & PALACIEGO & La Nau \\
\hline Fa82 & C/ Cardenal Payà s/n & RELIGIOSO & "El Patriarca" \\
\hline Fa105 & C/ San Vicente Martir n 2 & RELIGIOSO & $\begin{array}{l}\text { Iglesia de } \\
\text { S.Martín }\end{array}$ \\
\hline Fa153a & C/ San Andrés s/n & RELIGIOSO & $\begin{array}{l}\text { Iglesia S. Juan } \\
\text { de la Cruz }\end{array}$ \\
\hline Fa153b & C/ Procida s/n & RELIGIOSO & $\begin{array}{l}\text { Iglesia S. Juan } \\
\text { de la Cruz }\end{array}$ \\
\hline Fa153c & Pza. Picadero de dos Aguas s/n & RELIGIOSO & $\begin{array}{l}\text { Iglesia S. Juan } \\
\text { de la Cruz }\end{array}$ \\
\hline Fb117 & Pza. Palacio Justicia s/n & PALACIEGO & $\begin{array}{l}\text { Palacio de } \\
\text { Justicia }\end{array}$ \\
\hline
\end{tabular}




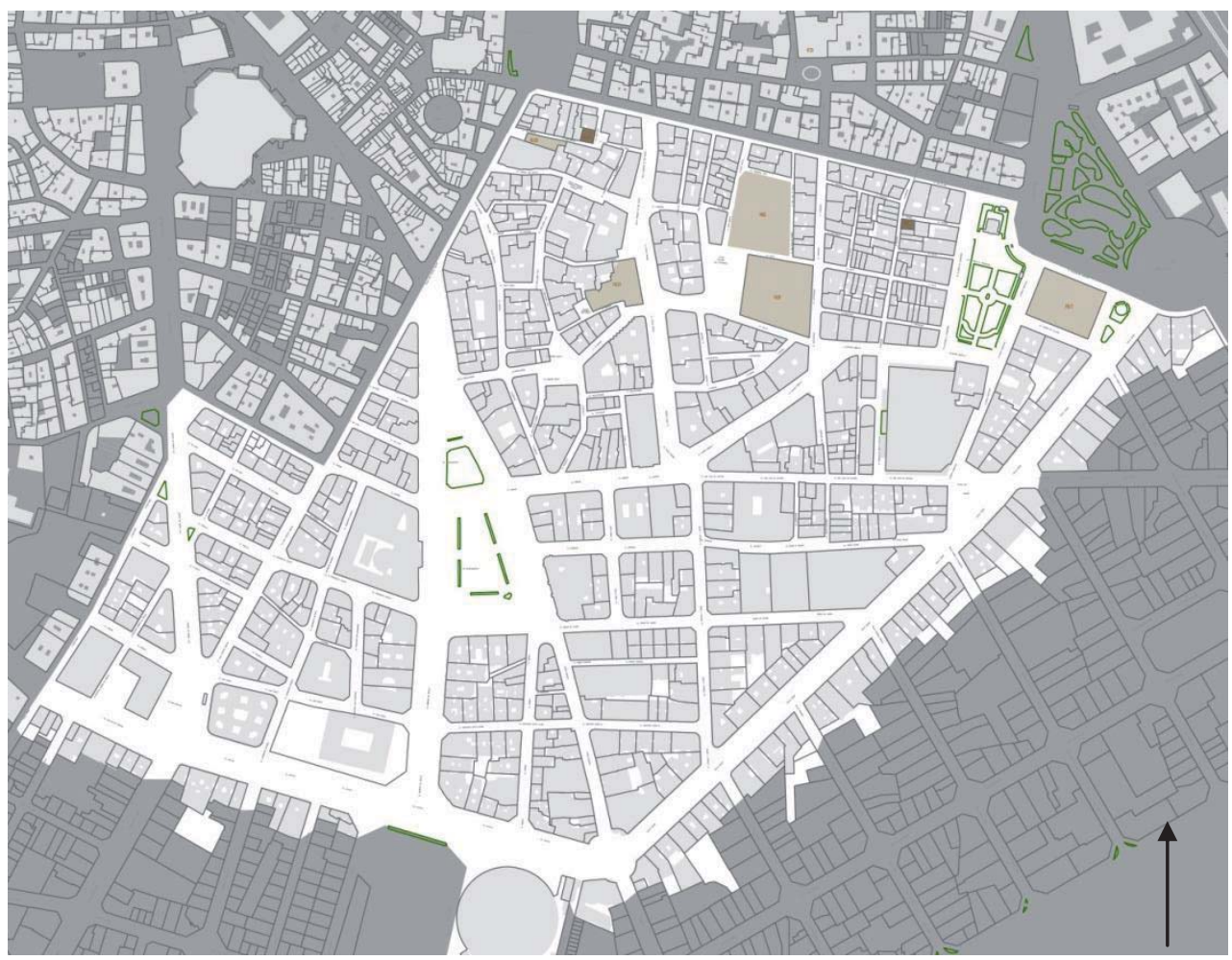

FIG. 6 Mapa de localización de las fichas recopiladas en el barrio de S. Francesc (CRISTINI) 
Datos generales

Fa39

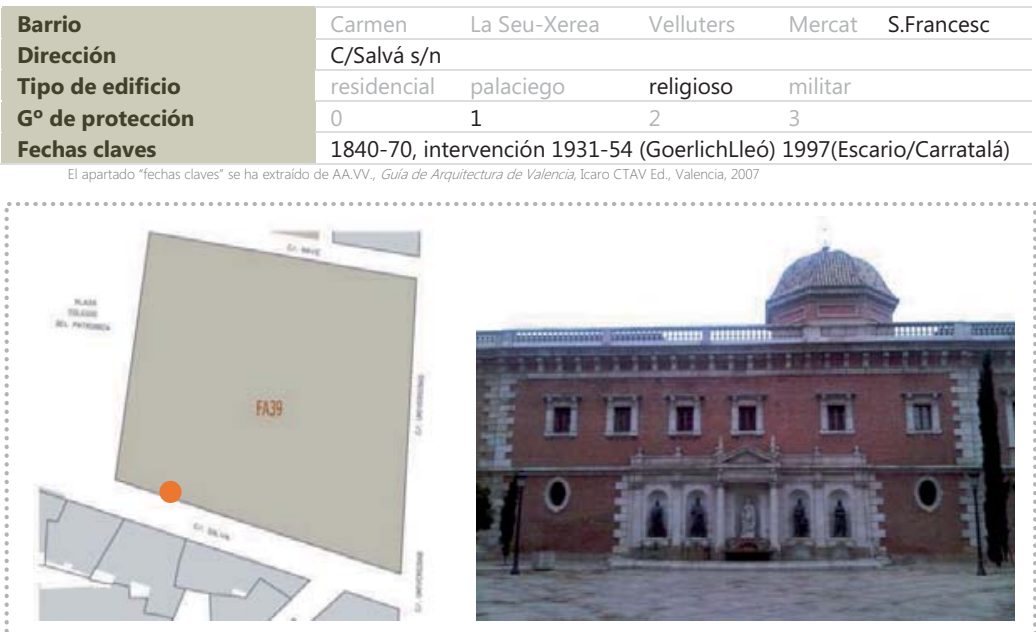

Fachada

Fa39

\begin{tabular}{|c|c|c|c|c|c|c|c|c|c|c|}
\hline \multirow{3}{*}{$\begin{array}{l}\text { Pisos } \\
\text { Composición fachada } \\
\text { Zócalo }\end{array}$} & \multicolumn{2}{|c|}{$N^{\circ} 2$} & \multicolumn{3}{|c|}{ sótano entreplanta } & \multicolumn{5}{|c|}{ piso noble caja escalera } \\
\hline & \multicolumn{2}{|c|}{ aleatoria } & \multicolumn{3}{|c|}{ ordenada sin simetría } & \multicolumn{5}{|c|}{ ordenada con simetría } \\
\hline & $\mathrm{Z1}$ & $\mathrm{Z2}$ & $\mathrm{Z3}$ & Z4 & $\mathrm{Z5}$ & & & & & \\
\hline Fábrica & $\mathrm{F} 1$ & F2 & F3 & F4 & F5 & F6 & F7 & & & \\
\hline Vano/dintel & V1 & V2 & V3 & V4 & V5 & V6 & V7 & V8 & V9 & V10 \\
\hline Entrada/dintel & E1 & E2 & E3 & E4 & & & & & & \\
\hline Alero & $\mathrm{A} 1$ & $\mathrm{~A} 2$ & $\mathrm{~A} 3$ & A4 & A5 & A6 & A7 & & & \\
\hline Cubierta & plar & & inclir & & & & & & & \\
\hline
\end{tabular}

Fábrica

Fa39

\begin{tabular}{l|lll} 
Aparejo & soga-tizón & soga & tizón \\
Hiladas & irregulares & pseudo horizontales & horizontales \\
Superficie & sin planeidad & pseudo planeidad & planeidad perfecta \\
Sección (hipótesis) & uniforme & hojas y núcleo & abocinada (vano) \\
Elementos destacados & aplantillado & cortado terracota &
\end{tabular}


Ladrillos

Fa39

$\mathrm{N}^{\circ}$ elementos medidos

Longitud (cm)

Anchura (cm)

Espesor $(\mathrm{cm})$

Volumen $\left(\mathrm{cm}^{3}\right)$

Tipo

Color

Recogida de muestra

Patologías

\section{5}

24.5

11.5

4.4

1239.7

homogéneo

heterogéneo

re-empleo

homogéneo heterogéneo globular heterogéneo marmolado

no

sí código

erosión disgregación descamación

${ }^{1}$ Datos obtenidos en base al cálculo del desvio estándar (respecto al valor medio de la muestras analizadas) y del gráfico de frecuencia de las muestras analizadas, identificado por una curva gaussiana

Juntas

Fa39

$N^{\circ}$ elementos medidos
Llaga $(\mathrm{cm})$
Tendel $(\mathrm{cm})$
Altura de 5 hiladas $(\mathrm{cm})$
Proporción ladrillo/junta
Tipo de acabado

Junta de asiento

Junta de acabado

Tipo de mortero Morfología de mortero

Tipo de árido

Color del árido

Recogida de muestra

Patologías

15

0.7

1.2

28

3.6

simple

rehundida

doble

múltiple

enrasada matada

saliente

rehundida a hueso saliente

enrasada matada

cal

cal y tierra

tierra

aren

con caliches

homogéneo heterc

gravilla grava mixto

claro oscuro homogéneo heterogéneo

no

eflorescencias micro fisuración

código

erosión" disgregación pulverización

${ }^{2}$ Datos obtenidos en base al cálculo del desvio estándar (respecto al valor medio de la muestras analizadas) y del gráfico de frecuencia de las muestras analizadas.

identificado por una curva gaussiana 

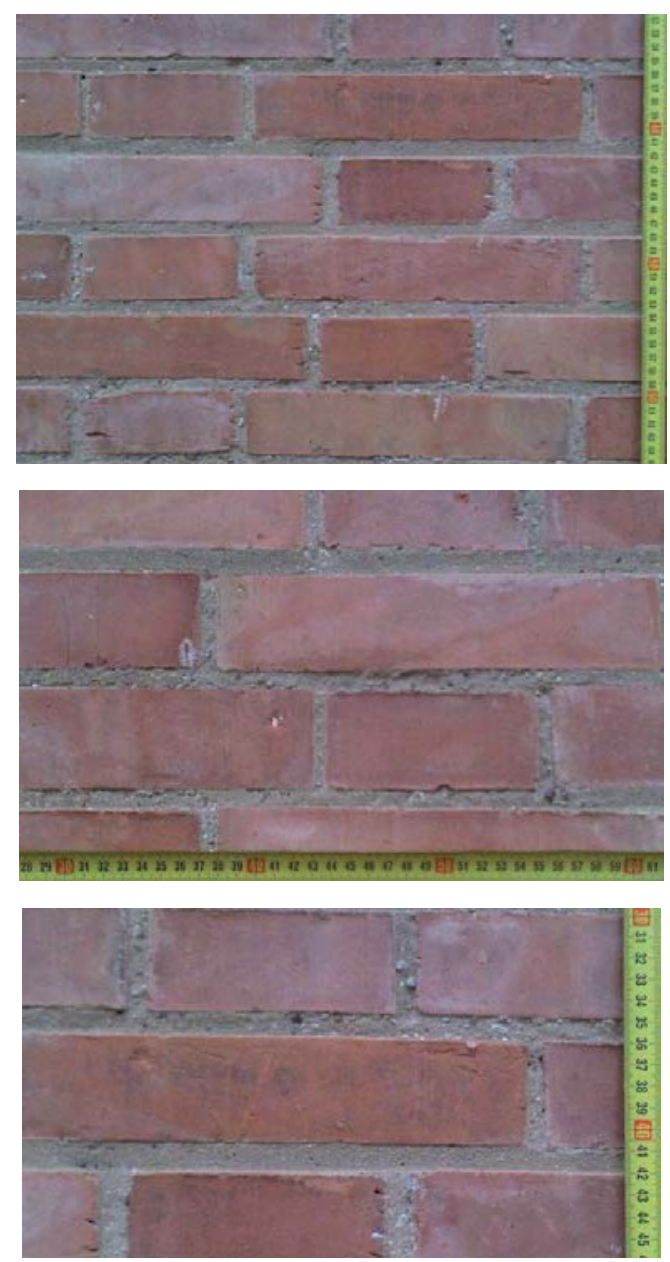

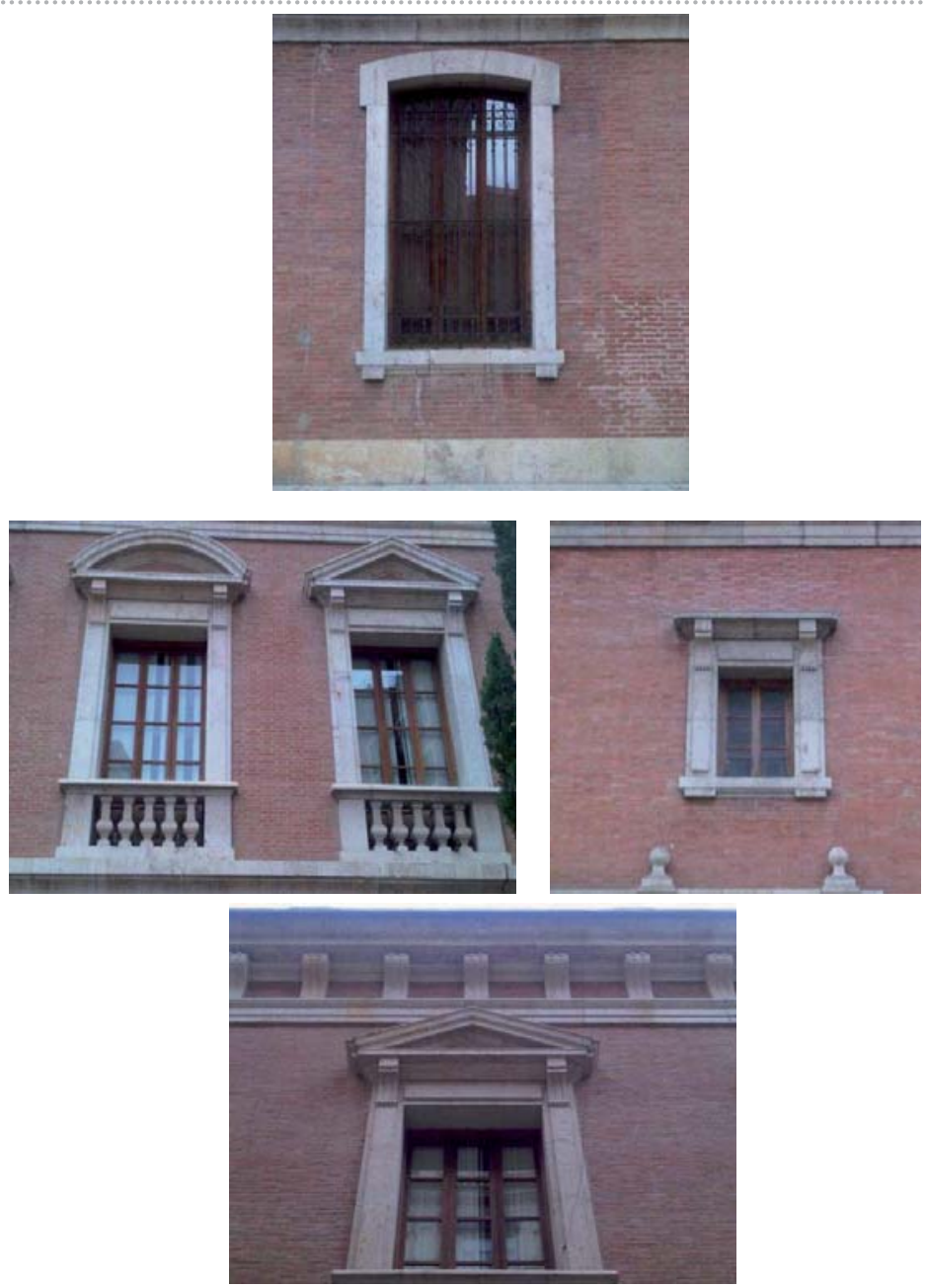
Datos generales

Fa82

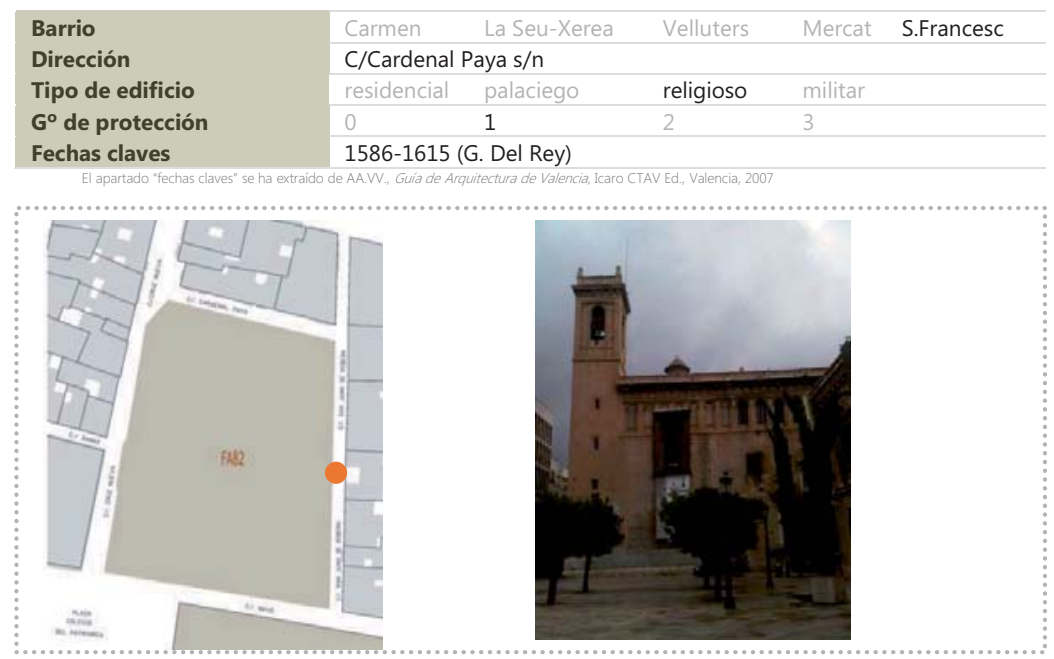

Fachada

Fa82

\begin{tabular}{|c|c|c|c|c|c|c|c|c|c|}
\hline \multirow{3}{*}{$\begin{array}{l}\text { Pisos } \\
\text { Composición fachada } \\
\text { Zócalo }\end{array}$} & \multicolumn{2}{|c|}{$\mathrm{N}^{0} 3$} & \multicolumn{3}{|c|}{ sótano entreplanta } & \multicolumn{4}{|c|}{ piso noble caja escalera } \\
\hline & \multicolumn{2}{|c|}{ aleatoria } & \multicolumn{3}{|c|}{ ordenada sin simetría } & \multicolumn{4}{|c|}{ ordenada con simetría } \\
\hline & Z1 & $\mathrm{Z} 2$ & $\mathrm{Z3}$ & Z4 & Z5 & & & & \\
\hline Fábrica & $\mathrm{F} 1$ & F2 & F3 & F4 & F5 & F6 & & & \\
\hline Vano/dintel & V1 & V2 & V3 & V4 & V5 & V6 & V8 & V9 & V10 \\
\hline Entrada/dintel & E1 & E2 & E3 & E4 & & & & & \\
\hline Alero & A1 & A2 & A3 & A4 & A5 & A7 & & & \\
\hline Cubierta & pla & & incl & & & & & & \\
\hline
\end{tabular}

Ver tablas relativas a los códigos indicados al final de la recopilación de las fichats

Fábrica

Fa82

\begin{tabular}{llll} 
Aparejo & soga-tizón & soga & \multicolumn{1}{c}{ tizón } \\
Hiladas & irregulares & pseudo horizontales & horizontales \\
Superficie & sin planeidad & pseudo planeidad & planeidad perfecta \\
Sección (hipótesis) & uniforme & hojas y núcleo & abocinada (vano) \\
Elementos destacados & aplantillado & cortado terracota &
\end{tabular}


Ladrillos

Fa82

$\mathrm{N}^{\circ}$ elementos medidos

Longitud (cm)

Anchura (cm)

Espesor $(\mathrm{cm})$

Volumen $\left(\mathrm{cm}^{3}\right)$

Tipo

Color

Recogida de muestra

Patologías

\section{5}

31.2

14.2

3.4

1506.33

homog

$\begin{array}{lll}\text { homogéneo } & \text { heterogéneo } & \text { re-empleo } \\ \text { homogéneo } & \text { heterogéneo globular } & \text { heterogéneo marmolado } \\ \text { no } & \text { sí } & \text { código }\end{array}$

eflorescencias micro fisuración grietas

erosión disgregación descamación

${ }^{1}$ Datos obtenidos en base al cálculo del desvio estándar (respecto al valor medio de la muestras analizadas) y del gráfico de frecuencia de las muestras analizadas, identificado por una curva gaussiana

Juntas

Fa82

\begin{tabular}{|c|c|c|c|c|}
\hline$N^{\circ}$ elementos medidos & 15 & & & \\
\hline Llaga $(\mathrm{cm})$ & 8.2 & & & \\
\hline Tendel (cm) & 8 & & & \\
\hline Altura de 5 hiladas $(\mathrm{cm})$ & 40 & & & \\
\hline Proporción ladrillo/junta & 0.4 & & & \\
\hline Tipo de acabado & simple & doble & múltiple & \\
\hline Junta de asiento & rehundida & a hueso & saliente & \\
\hline & enrasada & matada & & \\
\hline Junta de acabado & rehundida & a hueso & saliente & \\
\hline & enrasada & matada & & \\
\hline Tipo de mortero & cal & cal y tierra & tierra & cemento mixto \\
\hline Morfología de mortero & con grumos & con caliches & homogéneo & heterogéneo \\
\hline Tipo de árido & arena & gravilla & grava & mixto \\
\hline Color del árido & claro & oscuro & homogéneo & heterogéneo \\
\hline Recogida de muestra & no & sí & código & \\
\hline Patologías & eflorescencias & micro fisuración & grietas & \\
\hline & erosión & disgregación & pulverización & \\
\hline
\end{tabular}

${ }^{2}$ Datos obtenidos en base al cálculo del desvio estándar (respecto al valor medio de la muestras analizadas) y del gráfico de frecuencia de las muestras analizadas,

identificado por una curva gaussiana 

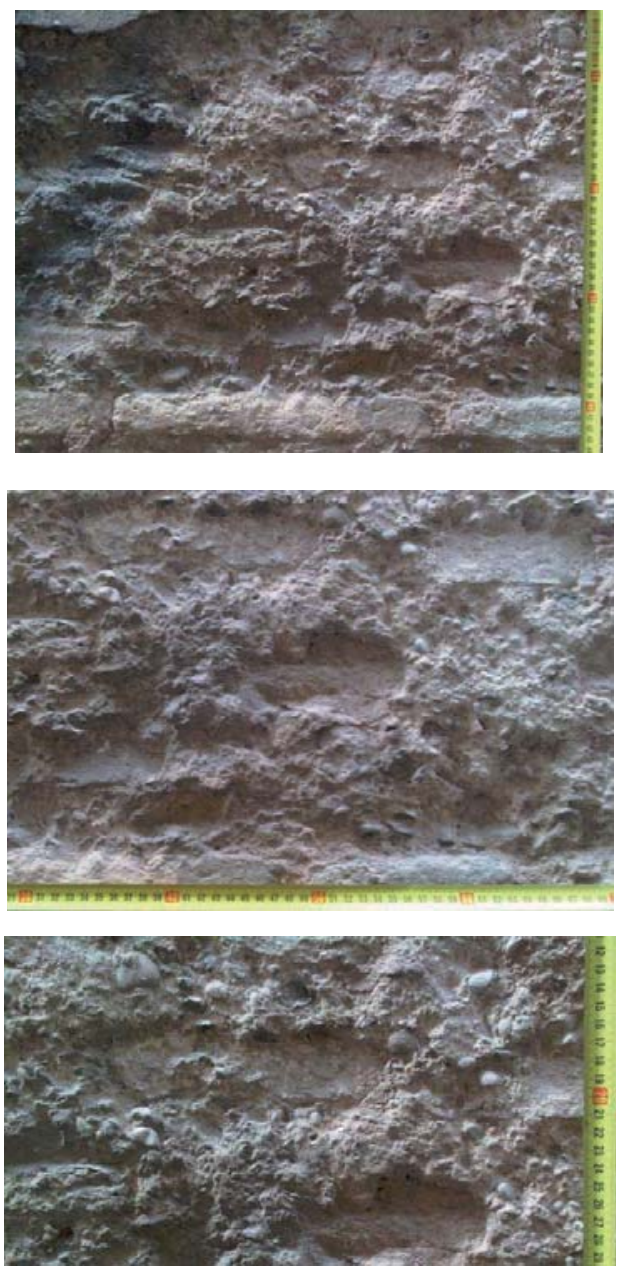

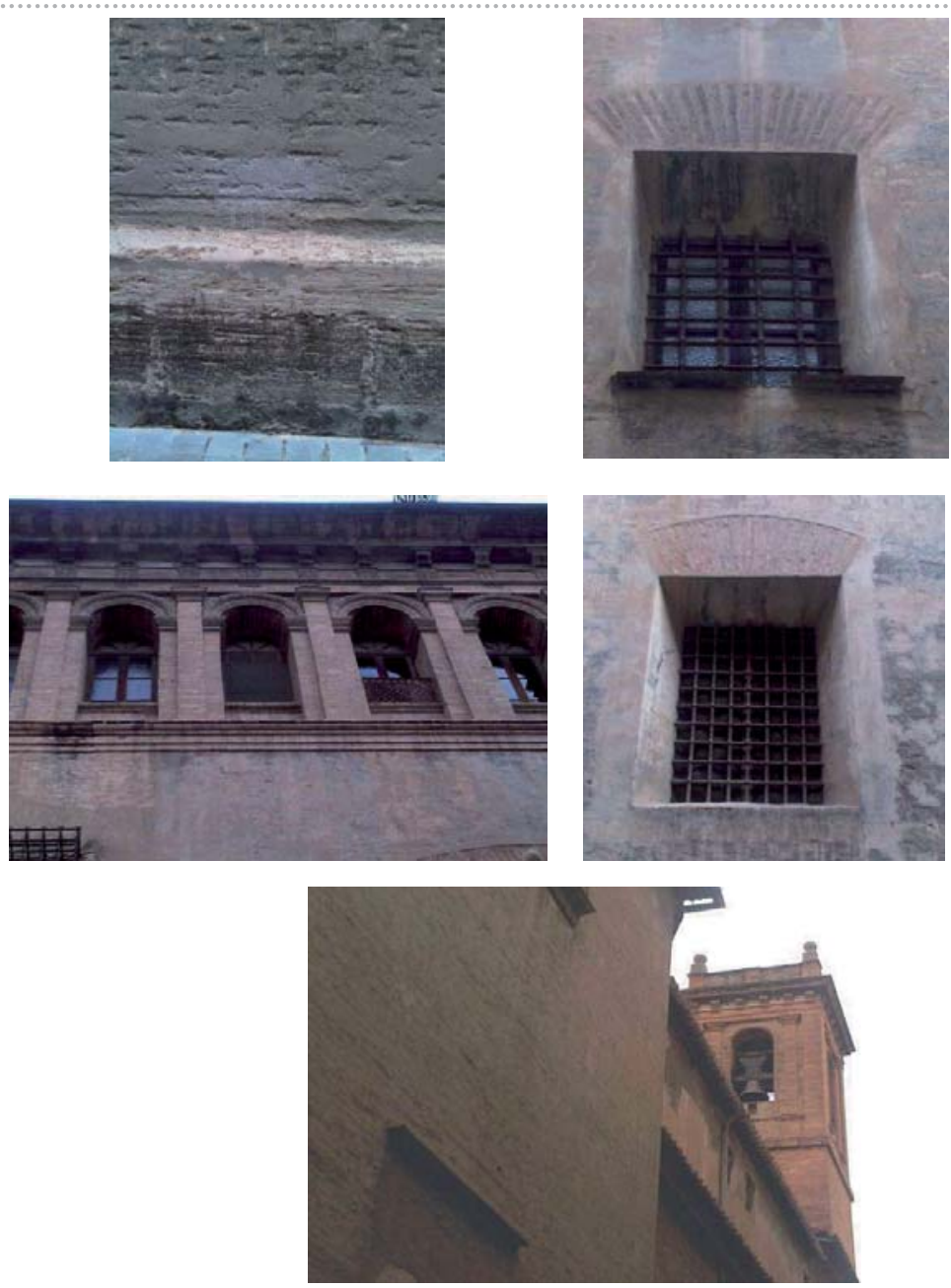
Datos generales

Fa105

\begin{tabular}{|c|c|c|c|c|c|}
\hline \multirow{3}{*}{$\begin{array}{l}\text { Barrio } \\
\text { Dirección } \\
\text { Tipo de edificio }\end{array}$} & Carmen & La Seu-Xerea & Velluters & Mercat & S.Francesc \\
\hline & \multicolumn{5}{|c|}{ C/S. Vicente Mártir n² } \\
\hline & residencial & palaciego & religioso & militar & \\
\hline \multirow{2}{*}{$\begin{array}{l}\mathrm{G}^{\circ} \text { de protección } \\
\text { Fechas claves }\end{array}$} & 0 & 1 & 2 & 3 & \\
\hline & \multicolumn{5}{|c|}{ 1669-74; Intervención 2008-2010 } \\
\hline
\end{tabular}

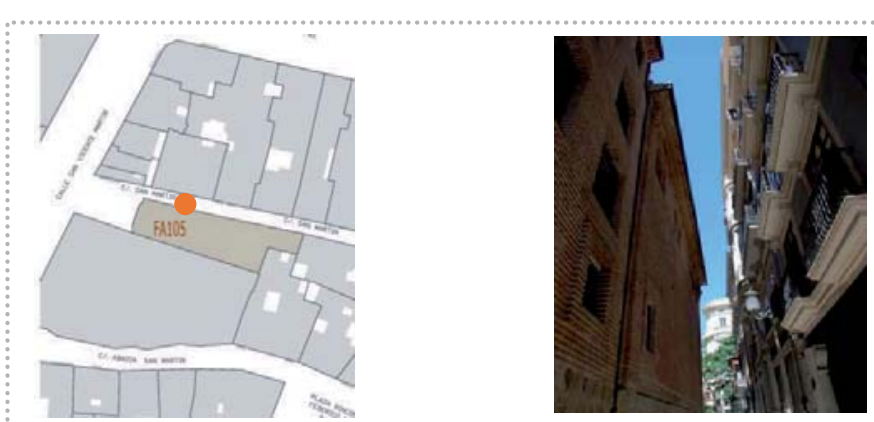

Fachada

Fa105

\begin{tabular}{|c|c|c|c|c|c|c|c|c|c|c|}
\hline Pisos & $\mathrm{N}^{\circ} 3$ & & sótan & & planta & & noble & $\mathrm{ca}$ & a esc & lera \\
\hline Composición fachada & alea & & orden & da si & metría & & nada & con si & netrí & \\
\hline Zócalo & $\mathrm{Z1}$ & $\mathrm{Z2}$ & $\mathrm{Z3}$ & Z4 & $\mathrm{Z} 5$ & & & & & \\
\hline Fábrica & $\mathrm{F} 1$ & F2 & F3 & F4 & F5 & F6 & F7 & & & \\
\hline Vano/dintel & V1 & V2 & V3 & V4 & V5 & V6 & V7 & V8 & V9 & V10 \\
\hline Entrada/dintel & E1 & E2 & E3 & E4 & & & & & & \\
\hline Alero & A1 & $\mathrm{A} 2$ & $\mathrm{~A} 3$ & A4 & A5 & A6 & A7 & & & \\
\hline
\end{tabular}

Fábrica

Fa105

\begin{tabular}{l|lll} 
Aparejo & soga-tizón & soga & \multicolumn{2}{c}{ tizón } & \\
Hiladas & irregulares & pseudo horizontales & horizontales \\
Superficie & sin planeidad & pseudo planeidad & planeidad perfecta \\
Sección (hipótesis) & uniforme & hojas y núcleo & abocinada (vano) \\
Elementos destacados & aplantillado & cortado terracota & \\
\hline
\end{tabular}


Ladrillos

Fa105

$\mathrm{N}^{\circ}$ elementos medidos
Longitud $(\mathrm{cm})$
Anchura $(\mathrm{cm})$
Espesor $(\mathrm{cm})$
Volumen $\left(\mathrm{cm}^{3}\right)$
Tipo
Color
Recogida de muestra
Patologías

\section{5}

30.2

14.6

3.8

1675.49

homogéneo heterogéneo re-empleo

homogéneo heterogéneo globular heterogéneo marmolado

no sí código

eflorescencias micro fisuración grietas

erosión disgregación descamación

${ }^{1}$ Datos obtenidos en base al cálculo del desvio estándar (respecto al valor medio de la muestras analizadas) y del gráfico de frecuencia de las muestras analizadas, identificado por una curva gaussiana

Juntas

Fa105

№ elementos medidos
Llaga $(\mathrm{cm})$
Tendel $(\mathrm{cm})$
Altura de 5 hiladas $(\mathrm{cm})$
Proporción ladrillo/junta
Tipo de acabado

Junta de asiento

Junta de acabado

Tipo de mortero Morfología de mortero

Tipo de árido

Color del árido

Recogida de muestra

Patologías

\begin{tabular}{llll}
15 & & & \\
0.8 & & & \\
3.9 & & & \\
\hline 38.5 & doble & múltiple & \\
\hline 0.9 & a hueso & saliente & \\
simple & matada & & \\
\hline rehundida & a hueso & saliente & \\
enrasada & matada & tierra & cemento mixto \\
\hline rehundida & cal y tierra & homogéneo & heterogéneo \\
enrasada & con caliches & grava & mixto \\
\hline cal & gravilla & homogéneo & heterogéneo \\
con grumos & oscuro & código & \\
\hline arena & sí & grietas & \\
\hline claro & micro fisuración & pulverización & \\
\hline no & disgregación & & \\
\hline eflorescencias & & & \\
erosión & & & \\
\hline
\end{tabular}

${ }^{2}$ Datos obtenidos en base al cálculo del desvio estándar (respecto al valor medio de la muestras analizadas) y del gráfico de frecuencia de las muestras analizadas.

identificado por una curva gaussiana 

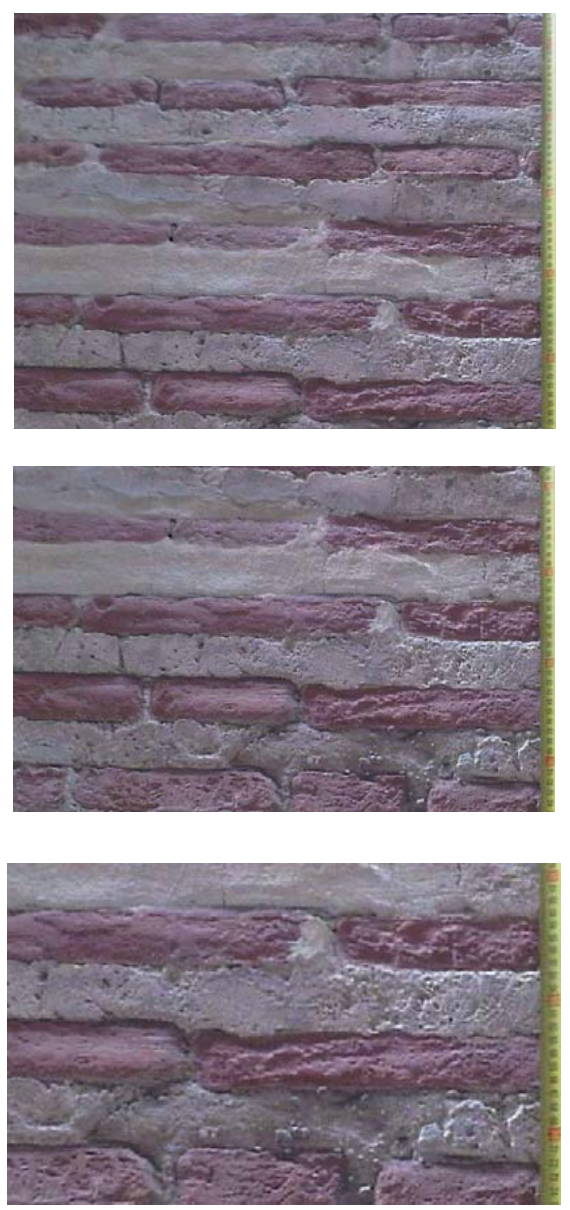

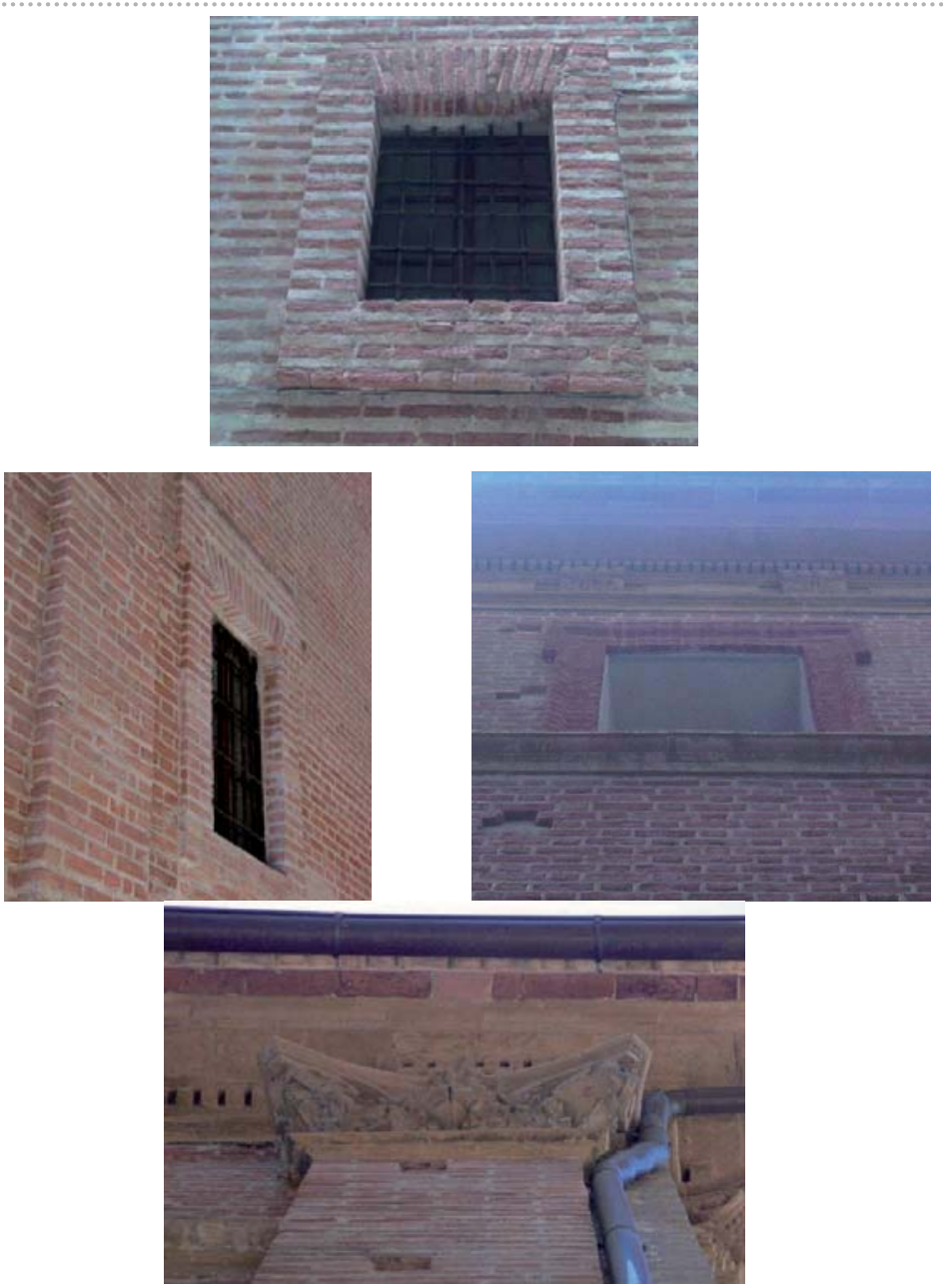
Datos generales

Fa107

\begin{tabular}{|c|c|c|c|c|c|}
\hline Barrio & Carmen & La Seu-Xerea & Velluters & Mercat & S.Francesc \\
\hline Dirección & \multicolumn{5}{|c|}{ Pza. Margarita Valdaura $n^{\circ} 1$} \\
\hline Tipo de edificio & residencial & palaciego & religioso & militar & \\
\hline $\mathrm{G}^{\circ}$ de protección & 0 & 1 & 2 & 3 & \\
\hline Fechas claves & / & & & & \\
\hline
\end{tabular}

El apartado "fechas claves" se ha extraído de AA.V., Guía de Arquitectura de Valencia, Icaro CTAV Ed., Valencia, 2007
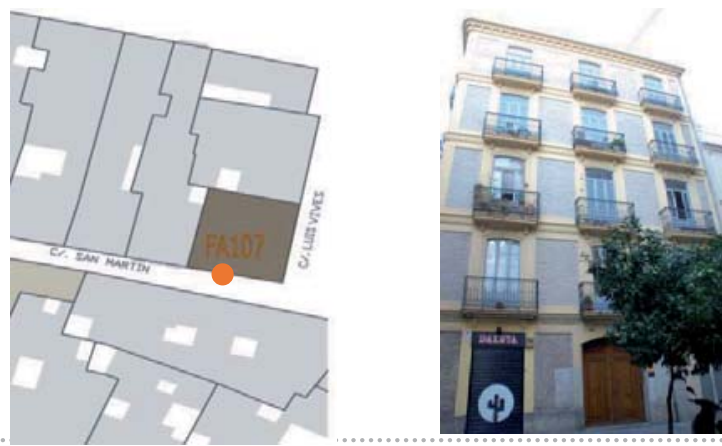

Fachada

Fa107

\begin{tabular}{|c|c|c|c|c|c|c|c|c|c|}
\hline \multirow{3}{*}{$\begin{array}{l}\text { Pisos } \\
\text { Composición fachada } \\
\text { Zócalo }\end{array}$} & \multicolumn{2}{|c|}{$N^{0} 4$} & sótano & \multicolumn{2}{|c|}{ entreplanta } & \multicolumn{4}{|c|}{ piso noble caja escalera } \\
\hline & \multicolumn{2}{|c|}{ aleatoria } & \multicolumn{3}{|c|}{ ordenada sin simetría } & \multicolumn{4}{|c|}{ ordenada con simetría } \\
\hline & $\mathrm{Z1}$ & $\mathrm{Z} 2$ & $\mathrm{Z3}$ & Z4 & $\mathrm{Z5}$ & & & & \\
\hline Fábrica & $\mathrm{F} 1$ & $\mathrm{~F} 2$ & F3 & $\mathrm{F} 4$ & F5 & F6 & & & \\
\hline Vano/dintel & V1 & V2 & V3 & V4 & V5 & V6 & V8 & V9 & V10 \\
\hline Entrada/dintel & E1 & E2 & E3 & E4 & & & & & \\
\hline \multirow{2}{*}{$\begin{array}{l}\text { Alero } \\
\text { Cubierta }\end{array}$} & A1 & $\mathrm{A} 2$ & A3 & A4 & A5 & A6 & & & \\
\hline & \multicolumn{2}{|c|}{ plana } & \multicolumn{3}{|c|}{ inclinada } & & & & \\
\hline
\end{tabular}

plana

inclinada

Fábrica

Fa107

\begin{tabular}{l|lll} 
Aparejo & soga-tizón & soga & \multicolumn{1}{c}{ tizón } \\
Hiladas & irregulares & pseudo horizontales & horizontales \\
Superficie & sin planeidad & pseudo planeidad & planeidad perfecta \\
Sección (hipótesis) & uniforme & hojas y núcleo & abocinada (vano) \\
Elementos destacados & aplantillado & cortado terracota & \\
\hline
\end{tabular}


Ladrillos

Fa107

$N^{\circ}$ elementos medidos
Longitud $(\mathrm{cm})$
Anchura $(\mathrm{cm})$
Espesor $(\mathrm{cm})$
Volumen $\left(\mathrm{cm}^{3}\right)$
Tipo
Color
Recogida de muestra
Patologías

\section{5}

30.5

14.2

3.4

1472.5

homogéneo heterogéneo re-empleo

homogéneo heterogéneo globular heterogéneo marmolado

no si código

eflorescencias micro fisuración grietas

erosión disgregación descamación

${ }^{1}$ Datos obtenidos en base al cálculo del desvio estándar (respecto al valor medio de la muestras analizadas) y del gráfico de frecuencia de las muestras analizadas, identificado por una curva gaussiana

Juntas

Fa107

\begin{tabular}{|c|c|c|c|c|}
\hline $\mathrm{N}^{\circ}$ elementos medidos & 15 & & & \\
\hline Llaga $(\mathrm{cm})$ & 0.7 & & & \\
\hline Tendel (cm) & 2.5 & & & \\
\hline Altura de 5 hiladas $(\mathrm{cm})$ & 30 & & & \\
\hline Proporción ladrillo/junta & 1.4 & & & \\
\hline Tipo de acabado & simple & doble & múltiple & \\
\hline Junta de asiento & rehundida & a hueso & saliente & \\
\hline & enrasada & matada & & \\
\hline Junta de acabado & rehundida & a hueso & saliente & \\
\hline & enrasada & matada & & \\
\hline Tipo de mortero & cal & cal y tierra & tierra & cemento mixto \\
\hline Morfología de mortero & con grumos & con caliches & homogéneo & heterogéneo \\
\hline Tipo de árido & arena & gravilla & grava & mixto \\
\hline Color del árido & claro & oscuro & homogéneo & heterogéneo \\
\hline Recogida de muestra & no & sí & código & \\
\hline Patologías & eflorescencias & micro fisuración & grietas & \\
\hline & erosión & disgregación & pulverización & \\
\hline
\end{tabular}

${ }^{2}$ Datos obtenidos en base al cálculo del desvio estándar (respecto al valor medio de la muestras analizadas) y del gráfico de frecuencia de las muestras analizadas. identificado por una curva gaussiana 

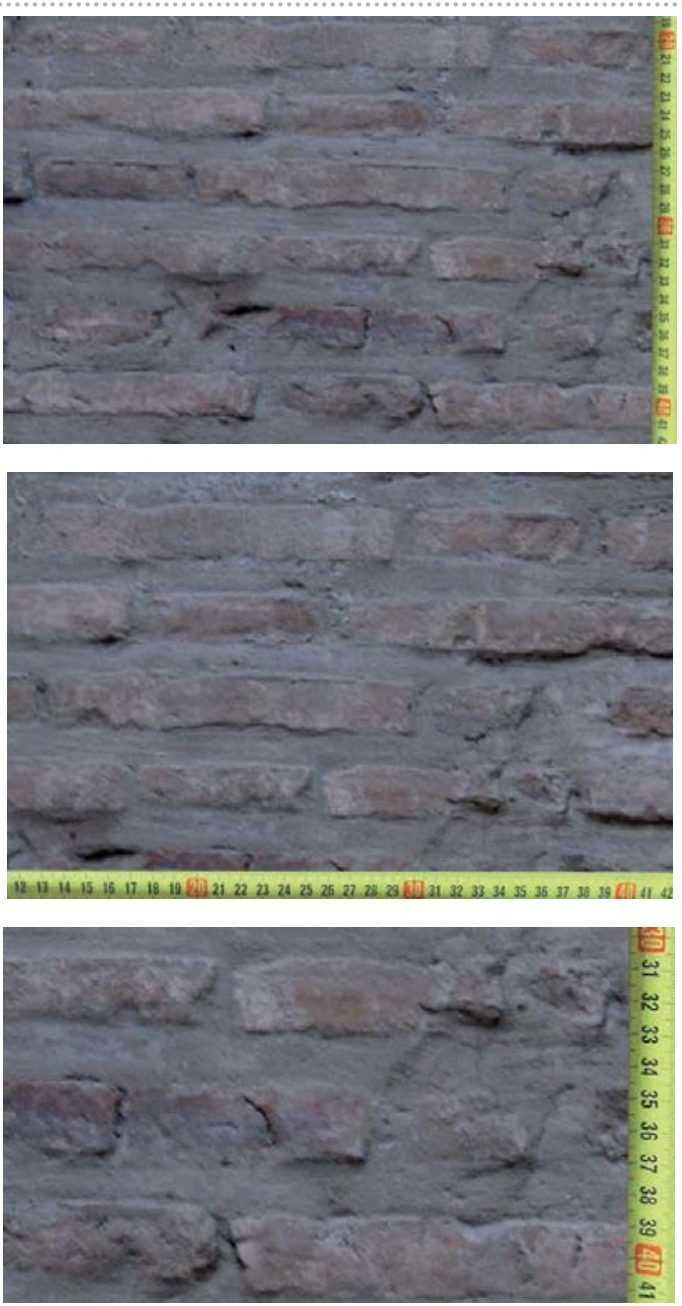


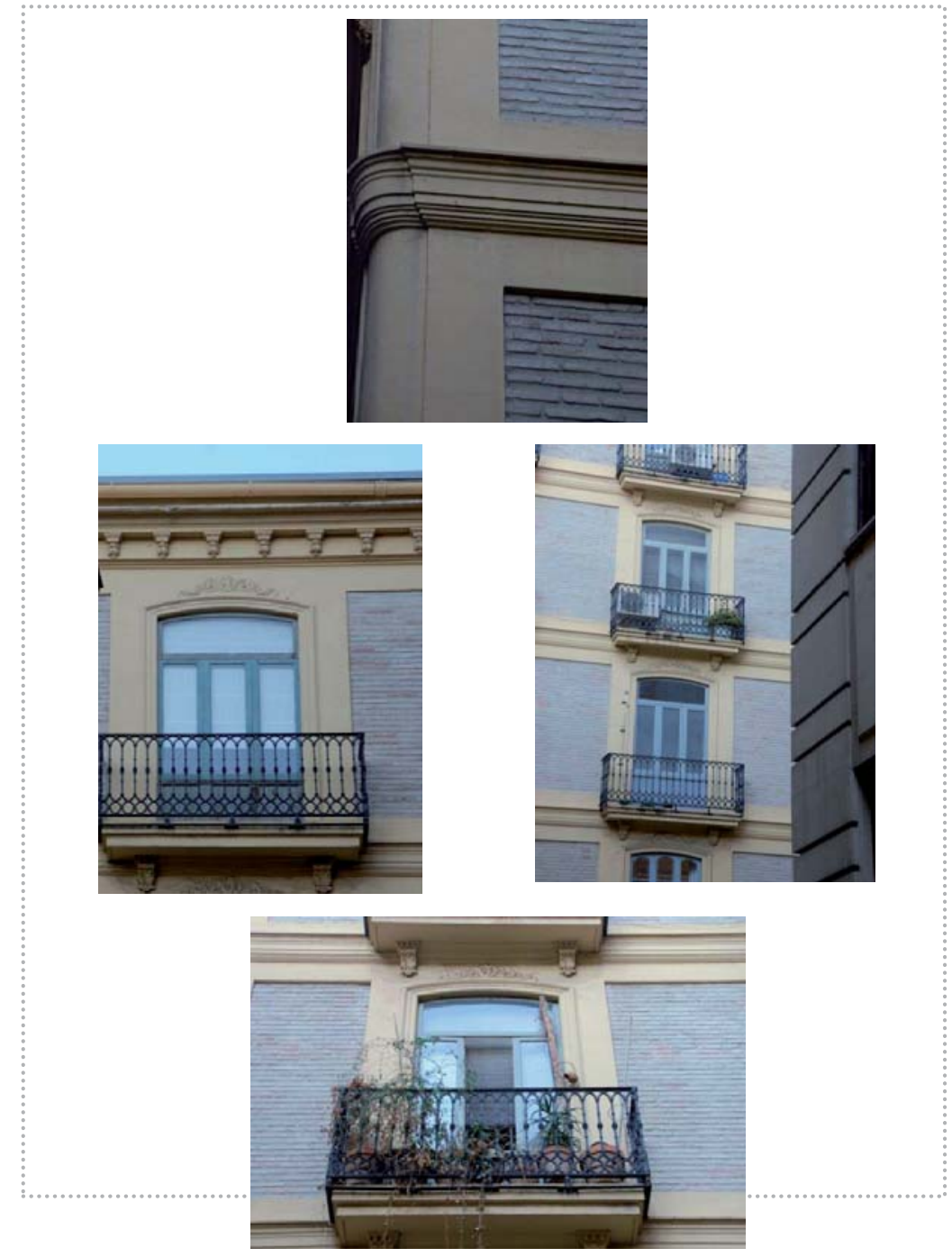


Datos generales

Fa153a

\begin{tabular}{|c|c|c|c|c|}
\hline \multirow{2}{*}{$\begin{array}{l}\text { Barrio } \\
\text { Dirección }\end{array}$} & Carmen & La Seu-Xerea & Velluters & Mercat S.Francesc \\
\hline & \multicolumn{4}{|c|}{$\mathrm{C} /$ Sto. Andres s/n } \\
\hline Tipo de edificio & residencial & palaciego & religioso & militar \\
\hline \multirow{2}{*}{$\begin{array}{l}\mathrm{G}^{\circ} \text { de protección } \\
\text { Fechas claves }\end{array}$} & 0 & 1 & 2 & 3 \\
\hline & \multicolumn{4}{|c|}{ Capilla Comunión (1736-41) intervención 2005 (Soler Verdú) } \\
\hline
\end{tabular}

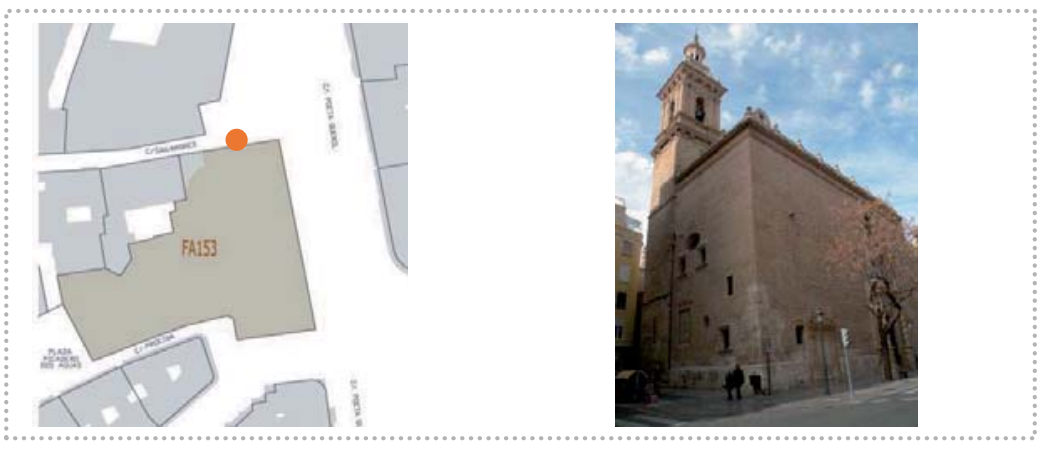

Fachada

Fa153a

\begin{tabular}{|c|c|c|c|c|c|c|c|c|c|c|}
\hline \multirow{3}{*}{$\begin{array}{l}\text { Pisos } \\
\text { Composición fachada } \\
\text { Zócalo }\end{array}$} & \multicolumn{2}{|l|}{ No\% } & sótar & \multicolumn{2}{|c|}{ entreplanta } & \multicolumn{5}{|c|}{ piso noble caja escalera } \\
\hline & \multicolumn{2}{|c|}{ aleatoria } & \multicolumn{3}{|c|}{ ordenada sin simetría } & \multicolumn{5}{|c|}{ ordenada con simetría } \\
\hline & $\mathrm{Z1}$ & $\mathrm{ZZ}$ & Z3 & Z4 & Z5 & & & & & \\
\hline Fábrica & F1 & F2 & F3 & $\mathrm{F} 4$ & F5 & F6 & F7 & & & \\
\hline Vano/dintel & V1 & V2 & V3 & V4 & V5 & V6 & V7 & V8 & V9 & V10 \\
\hline Entrada/dintel & E1 & E2 & E3 & E4 & & & & & & \\
\hline \multirow{2}{*}{$\begin{array}{l}\text { Alero } \\
\text { Cubierta }\end{array}$} & $\mathrm{A} 1$ & $\mathrm{~A} 2$ & $\mathrm{~A} 3$ & A4 & A5 & A6 & A7 & & & \\
\hline & \multicolumn{2}{|c|}{ plana } & \multicolumn{3}{|c|}{ inclinada } & & & & & \\
\hline
\end{tabular}

Ver tablas relativas a los códigos indicados al final de la recopilación de las fichas

Fábrica

Fa153a

Aparejo

Hiladas

Superficie

Sección (hipótesis)

Elementos destacados

\begin{tabular}{lll}
\hline soga-tizón & soga tizón & \\
irregulares & pseudo horizontales & horizontales \\
\hline sin planeidad & pseudo planeidad & planeidad perfecta \\
\hline uniforme & hojas y núcleo & abocinada (vano) \\
\hline aplantillado & cortado terracota & \\
\hline
\end{tabular}


Ladrillos

Fa153a

No elementos medidos
Longitud $(\mathrm{cm})$
Anchura $(\mathrm{cm})$
Espesor $(\mathrm{cm})$
Volumen $\left(\mathrm{cm}^{3}\right)$
Tipo
Color
Recogida de muestra
Patologías

\section{5}

30.7

14.2

4.1

1787.3

\begin{tabular}{lll} 
homogéneo & heterogéneo & re-empleo \\
homogéneo & heterogéneo globular & heterogéneo marmolado \\
\hline no & sí & código \\
eflorescencias & micro fisuración & grietas \\
erosión & disgregación & descamación
\end{tabular}

${ }^{1}$ Datos obtenidos en base al cálculo del desvio estándar (respecto al valor medio de la muestras analizadas) y del gráfico de frecuencia de las muestras analizadas, identificado por una curva gaussiana

Juntas

Fa153a

No elementos medidos
Llaga $(\mathrm{cm})$
Tendel $(\mathrm{cm})$
Altura de 5 hiladas $(\mathrm{cm})$
Proporción ladrillo/junta
Tipo de acabado

Junta de asiento

Junta de acabado

Tipo de mortero Morfología de mortero

Tipo de árido

Color del árido

Recogida de muestra

Patologías

\section{5}

1.2

3.8

39

0.9

$\begin{array}{lll}\text { simple } & \text { doble } & \text { múltiple } \\ \text { rehundida } & \text { a hueso } & \text { saliente }\end{array}$

enrasada matada

rehundida a hueso saliente

enrasada matada

$\begin{array}{llll}\text { cal } & \text { cal y tierra } & \text { tierra } & \text { cemento mixto } \\ \text { con grumos } & \text { concaliches } & \text { homogéneo } & \text { heterogéneo } \\ \text { arena } & \text { gravilla } & \text { grava } & \text { mixto } \\ \text { claro } & \text { oscuro } & \text { homogéneo } & \text { heterogéneo } \\ \text { no } & \text { sí } & \text { código } & \\ \text { eflorescencias } & \text { micro fisuración } & \text { grietas } & \\ \text { erosión } & \text { disgregación } & \text { pulverización } & \end{array}$

${ }^{2}$ Datos obtenidos en base al cálculo del desvio estándar (respecto al valor medio de la muestras analizadas) y del gráfico de frecuencia de las muestras analizadas,

identificado por una curva gaussiana 

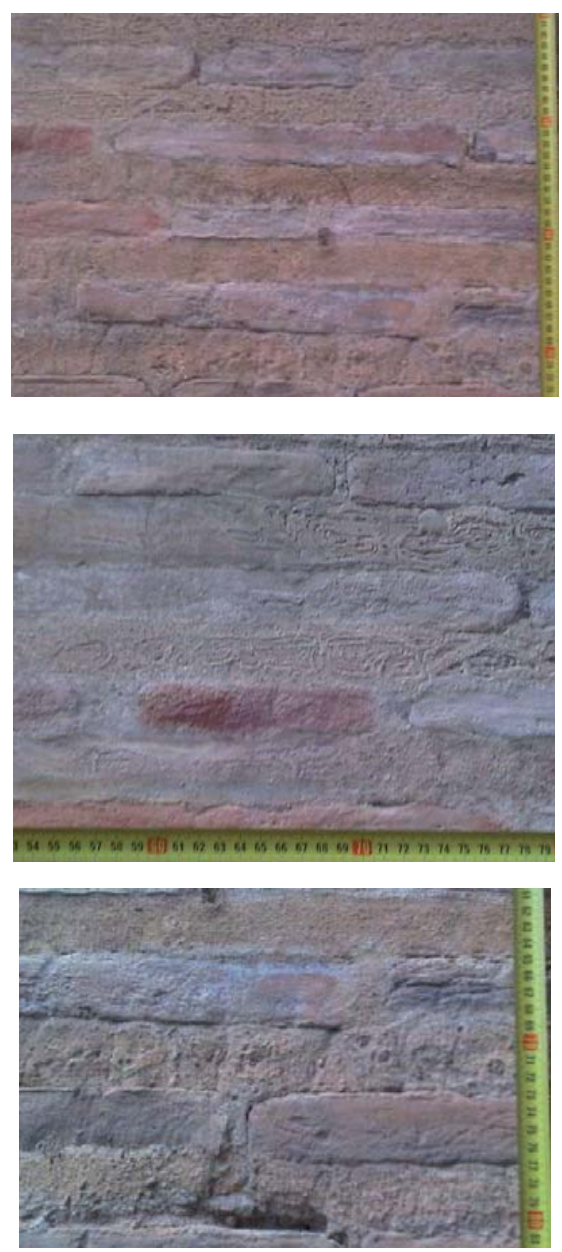

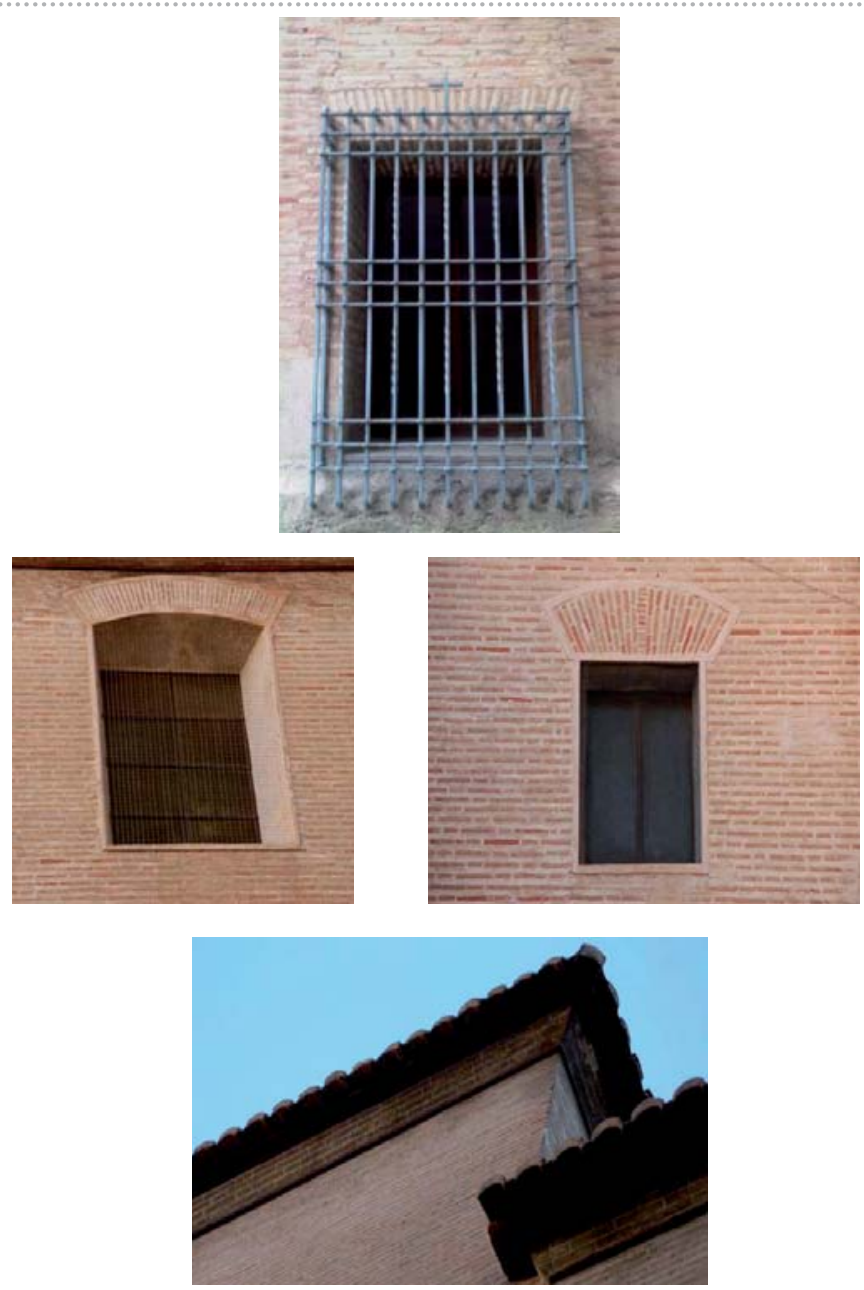
Datos generales

Fa153b

\begin{tabular}{|c|c|c|c|c|c|}
\hline Barrio & Carmen & La Seu-Xerea & Velluters & Mercat & S.Francesc \\
\hline Dirección & \multicolumn{5}{|c|}{ C/ Procida s/n } \\
\hline Tipo de edificio & residencial & palaciego & religioso & militar & \\
\hline \multirow{2}{*}{$\begin{array}{l}\mathbf{G}^{\circ} \text { de protección } \\
\text { Fechas claves }\end{array}$} & 0 & 1 & 2 & 3 & \\
\hline & \multicolumn{5}{|c|}{ Construcción 1608-1620 (AlonsoOrts) } \\
\hline
\end{tabular}

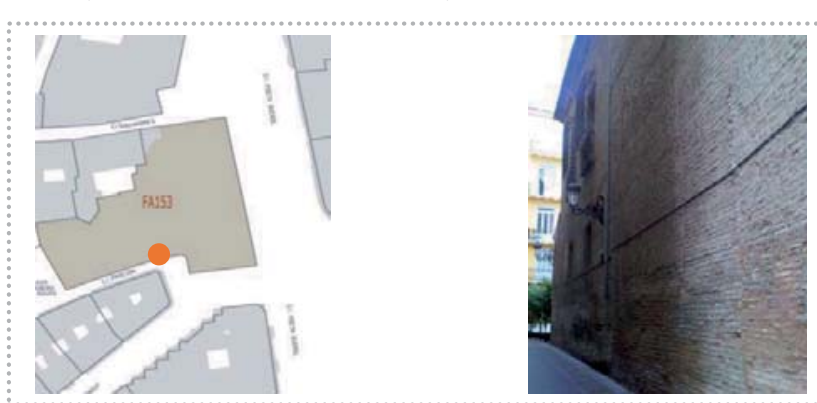

Fachada

Fa153b

\begin{tabular}{|c|c|c|c|c|c|c|c|c|c|c|}
\hline \multirow{3}{*}{$\begin{array}{l}\text { Pisos } \\
\text { Composición fachada }\end{array}$} & \multicolumn{2}{|c|}{ No\% } & sóta & \multicolumn{2}{|c|}{ entreplanta } & \multicolumn{5}{|c|}{ piso noble caja escalera } \\
\hline & \multicolumn{2}{|c|}{ aleatoria } & \multicolumn{3}{|c|}{ ordenada sin simetría } & \multicolumn{5}{|c|}{ ordenada con simetría } \\
\hline & $\mathrm{Z1}$ & $\mathrm{Z} 2$ & $\mathrm{Z3}$ & Z4 & $\mathrm{Z} 5$ & & & & & \\
\hline Fábrica & F1 & F2 & F3 & F4 & F5 & F6 & F7 & & & \\
\hline Vano/dintel & V1 & V2 & V3 & V4 & V5 & V6 & V7 & V8 & V9 & V10 \\
\hline Entrada/dintel & E1 & E2 & E3 & E4 & & & & & & \\
\hline Alero & $\mathrm{A} 1$ & $\mathrm{~A} 2$ & $\mathrm{~A} 3$ & A4 & A5 & A6 & A7 & & & \\
\hline Cubierta & plar & & incli & & & & & & & \\
\hline
\end{tabular}

Fábrica

Fa153b

Aparejo
Hiladas
Superficie
Sección (hipótesis)
Elementos destacados

soga-tizón

irregulares

sin planeidad

uniforme

aplantillado

soga

soga tizón

pseudo horizontales

pseudo planeidad

horizontales

hojas y núcleo

planeidad perfecta

cortado

terracota

abocinada (vano)

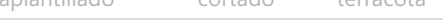


Ladrillos

Fa153b

No elementos medidos
Longitud $(\mathrm{cm})$
Anchura $(\mathrm{cm})$
Espesor $(\mathrm{cm})$
Volumen $\left(\mathrm{cm}^{3}\right)$
Tipo
Color
Recogida de muestra
Patologías

15

/

14.5

3.2

/

homogéneo heterogéneo re-empleo

homogéneo heterogéneo globular heterogéneo marmolado

no sí código

eflorescencias micro fisuración grietas

erosión disgregación descamación

${ }^{1}$ Datos obtenidos en base al cálculo del desvio estándar (respecto al valor medio de la muestras analizadas) y del gráfico de frecuencia de las muestras analizadas, identificado por una curva gaussiana

untas 2

Fa153b

№ elementos medidos
Llaga $(\mathrm{cm})$
Tendel $(\mathrm{cm})$
Altura de 5 hiladas $(\mathrm{cm})$
Proporción ladrillo/junta
Tipo de acabado

Junta de asiento

Junta de acabado

Tipo de mortero Morfología de mortero

Tipo de árido

Color del árido

Recogida de muestra

Patologías

\begin{tabular}{|c|c|c|c|}
\hline 15 & & & \\
\hline 8.7 & & & \\
\hline 8.5 & & & \\
\hline 41.2 & & & \\
\hline 0.3 & & & \\
\hline simple & doble & múltiple & \\
\hline rehundida & a hueso & saliente & \\
\hline enrasada & matada & & \\
\hline rehundida & a hueso & saliente & \\
\hline enrasada & matada & & \\
\hline cal & cal y tierra & tierra & cemento mixto \\
\hline con grumos & con caliches & homogéneo & heterogéneo \\
\hline arena & gravilla & grava & mixto \\
\hline claro & oscuro & homogéneo & heterogéneo \\
\hline no & sí & código & \\
\hline eflorescencias & micro fisuración & grietas & \\
\hline erosión" & disgregación & pulverización & \\
\hline
\end{tabular}

${ }^{2}$ Datos obtenidos en base al cálculo del desvio estándar (respecto al valor medio de la muestras analizadas) y del gráfico de frecuencia de las muestras analizadas.

identificado por una curva gaussiana 

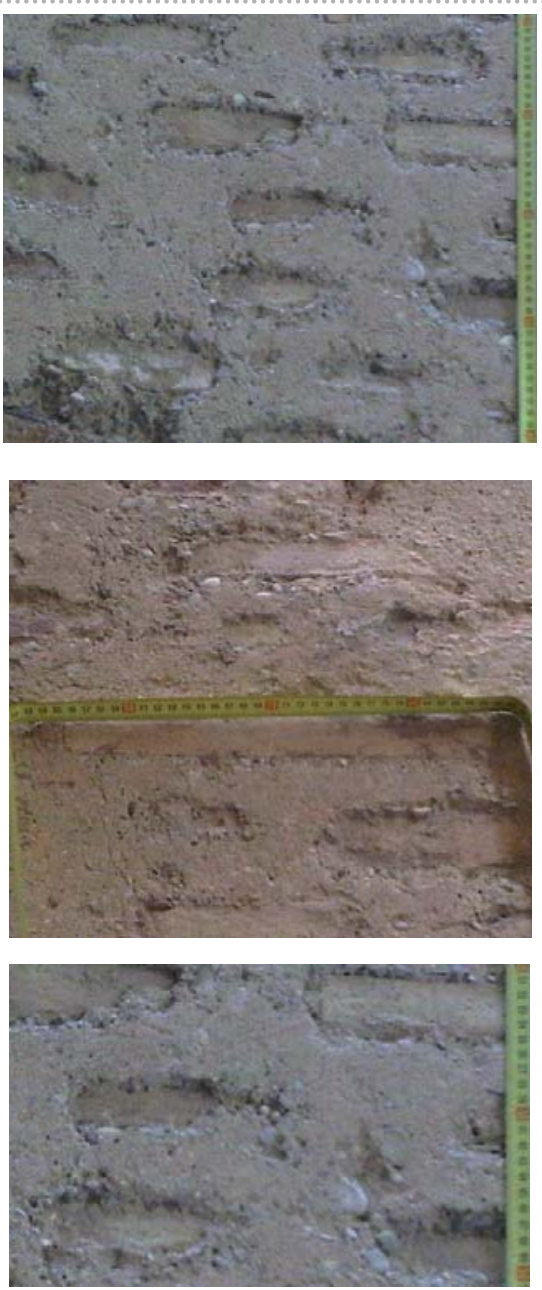

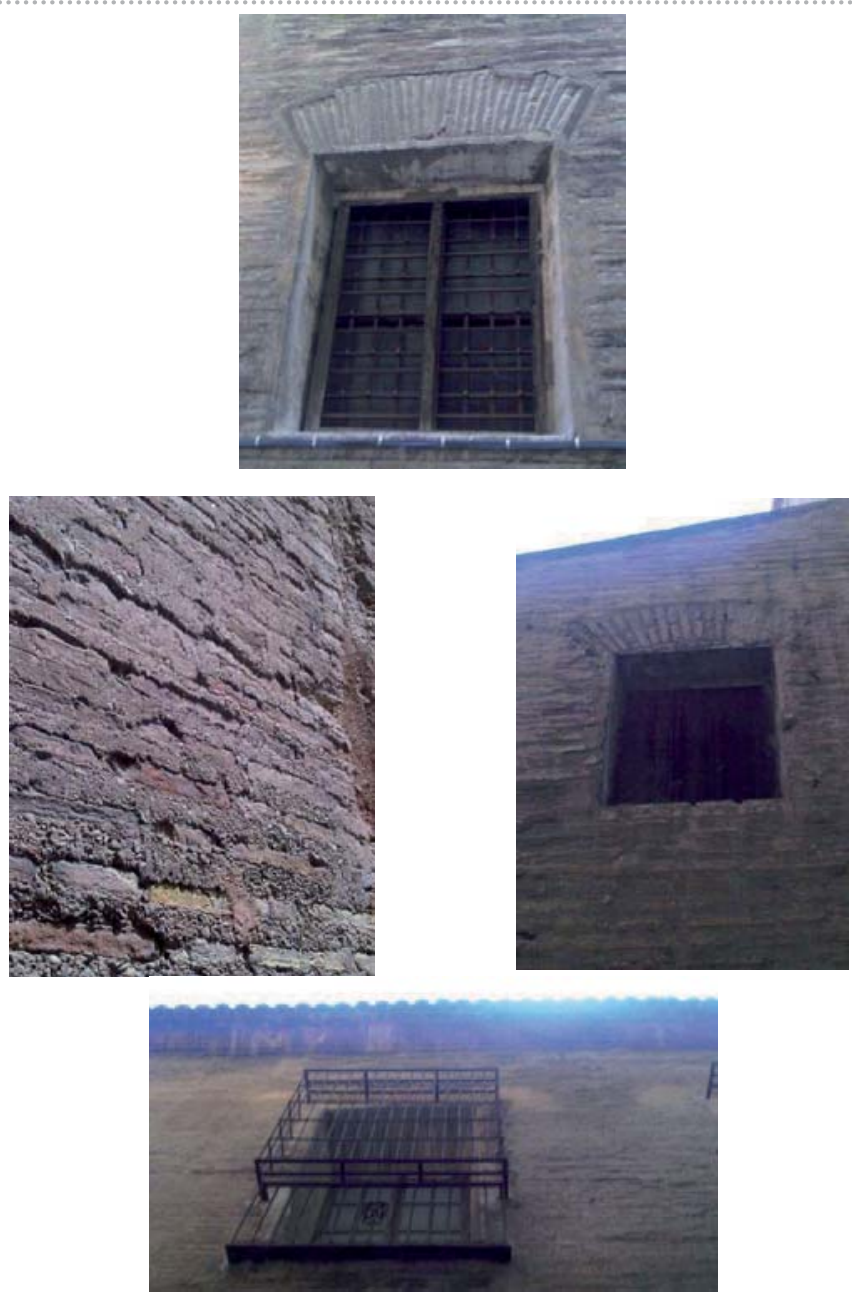
Datos generales

\section{Fa153c}

\begin{tabular}{|c|c|c|c|c|c|}
\hline \multirow{3}{*}{$\begin{array}{l}\text { Barrio } \\
\text { Dirección } \\
\text { Tipo de edificio }\end{array}$} & Carmen & La Seu-Xerea & Velluters & Mercat & S.Francesc \\
\hline & \multicolumn{5}{|c|}{ Pza. Picadero de dos Agua s/n } \\
\hline & residencial & palaciego & religioso & militar & \\
\hline \multirow{2}{*}{$\begin{array}{l}\text { G }^{\circ} \text { de protección } \\
\text { Fechas claves }\end{array}$} & 0 & 1 & 2 & 3 & \\
\hline & \multicolumn{5}{|c|}{ Construcción 1608-1620 (AlonsoOrts) } \\
\hline
\end{tabular}

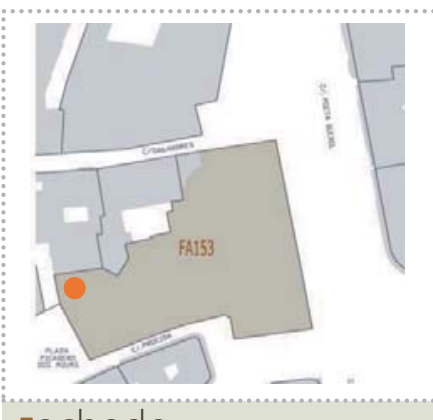

Fachada

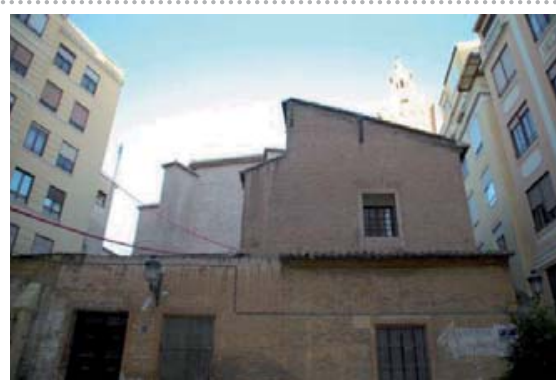

Pisos
Composición fachada
Zócalo
Vanorica
Entradintel
Alero
Cubierta

\begin{tabular}{|c|c|c|c|c|c|c|c|c|c|}
\hline \multirow{2}{*}{\multicolumn{2}{|c|}{$\begin{array}{l}\mathrm{N}^{\circ} 2 \\
\text { aleatoria }\end{array}$}} & \multirow{2}{*}{\multicolumn{3}{|c|}{$\begin{array}{l}\text { sotano entreplanta } \\
\text { ordenada sin simetría }\end{array}$}} & \multicolumn{5}{|c|}{ piso noble caja escalera } \\
\hline & & & & & \multicolumn{5}{|c|}{ ordenada con simetría } \\
\hline $\mathrm{Z1}$ & $\mathrm{Z} 2$ & Z3 & Z4 & Z5 & & & & & \\
\hline F1 & F2 & F3 & F4 & F5 & F6 & F7 & & & \\
\hline V1 & V2 & V3 & V4 & V5 & V6 & V7 & V8 & V9 & V10 \\
\hline E1 & E2 & E3 & E4 & & & & & & \\
\hline $\mathrm{A} 1$ & $\mathrm{~A} 2$ & $\mathrm{~A} 3$ & A4 & A5 & A6 & A7 & & & \\
\hline
\end{tabular}

Fábrica

Fa153c

Aparejo
Hiladas
Superficie
Sección (hipótesis)
Elementos destacados

soga-tizón

irregulares pseudo horizontales

sin planeidad pseudo planeidad

uniforme hojas y núcleo

aplantillado

cortado terracota

Fa153c 
Ladrillos

Fa153c

$\mathrm{N}^{\circ}$ elementos medidos
Longitud $(\mathrm{cm})$
Anchura $(\mathrm{cm})$
Espesor $(\mathrm{cm})$
Volumen $\left(\mathrm{cm}^{3}\right)$
Tipo
Color
Recogida de muestra
Patologías

\section{5}

30.5

14.1

3.2

1476.16

homogéneo

re-empleo

homogéneo heterogéneo globular heterogéneo marmolado

no sí código Fa153c/1

eflorescencias micro fisuración grietas

erosión disgregación descamación

${ }^{1}$ Datos obtenidos en base al cálculo del desvio estándar (respecto al valor medio de la muestras analizadas) y del gráfico de frecuencia de las muestras analizadas. identificado por una curva gaussiana

Juntas

Fa153c

No elementos medidos
Llaga $(\mathrm{cm})$
Tendel $(\mathrm{cm})$
Altura de 5 hiladas $(\mathrm{cm})$
Proporción ladrillo/junta
Tipo de acabado

Junta de asiento

Junta de acabado

Tipo de mortero Morfología de mortero

Tipo de árido

Color del árido

Recogida de muestra

Patologías

\begin{tabular}{|c|c|c|c|}
\hline \multicolumn{4}{|l|}{15} \\
\hline \multicolumn{4}{|l|}{1.5} \\
\hline \multicolumn{4}{|l|}{4.1} \\
\hline \multicolumn{4}{|l|}{31.5} \\
\hline \multicolumn{4}{|l|}{0.78} \\
\hline simple & doble & múltiple & \\
\hline rehundida & a hueso & saliente & \\
\hline enrasada & matada & & \\
\hline rehundida & a hueso & saliente & \\
\hline enrasada & matada & & \\
\hline cal & cal y tierra & tierra & cemento mixto \\
\hline con grumos & con caliches & homogéneo & heterogéneo \\
\hline arena & gravilla & grava & mixto \\
\hline claro & oscuro & homogéneo & heterogéneo \\
\hline no & sí & código Fa153 & $/ 2 a / 2 b$ \\
\hline eflorescencias & micro fisuración & grietas & \\
\hline erosión & disgregación & pulverización & \\
\hline
\end{tabular}

${ }^{2}$ Datos obtenidos en base al cálculo del desvio estándar (respecto al valor medio de la muestras analizadas) y del gráfico de frecuencia de las muestras analizadas,

identificado por una curva gaussiana 

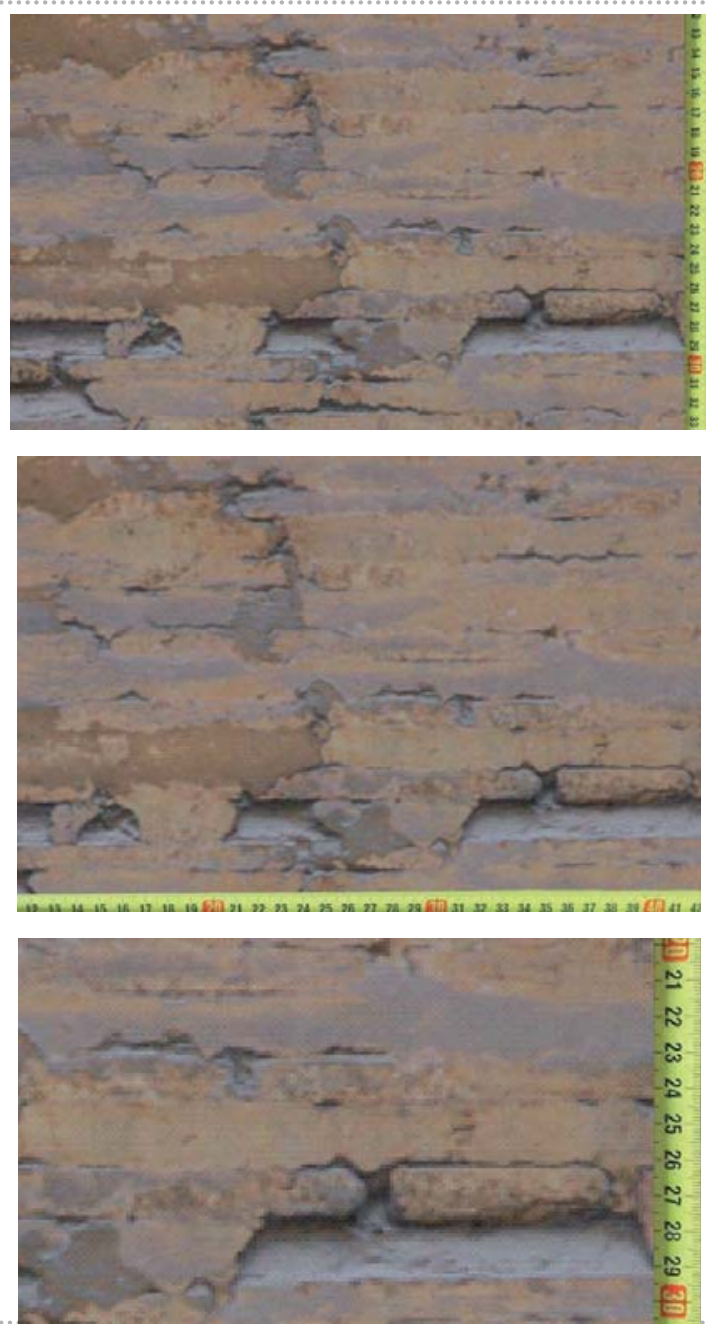

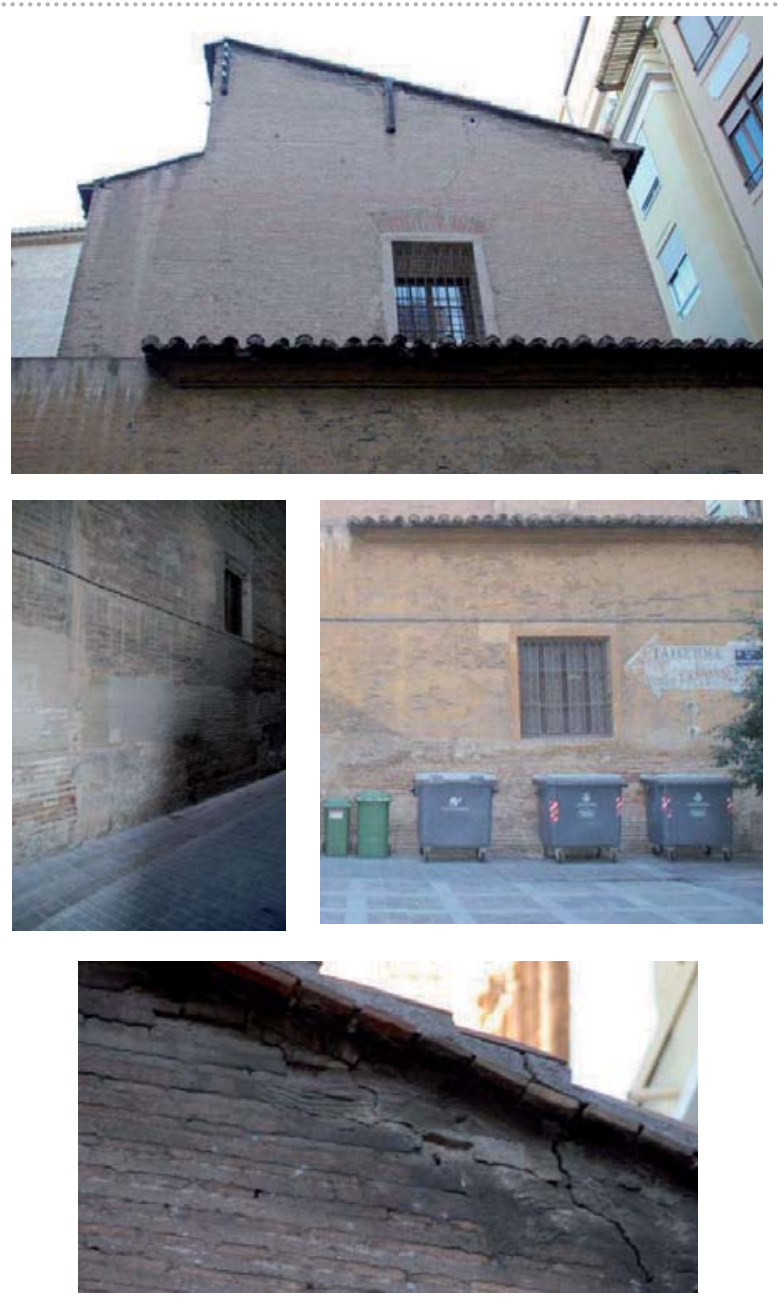


\section{Datos generales}

\section{Fb57}

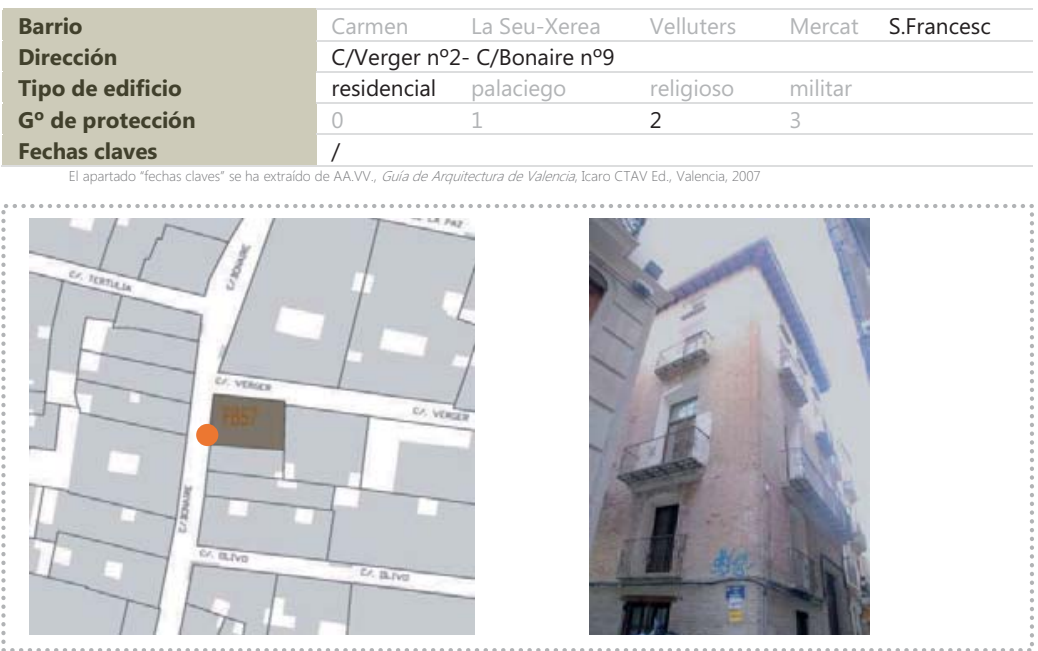

Fachada

Fb57

\begin{tabular}{|c|c|c|c|c|c|c|c|c|c|c|}
\hline \multirow{3}{*}{$\begin{array}{l}\text { Pisos } \\
\text { Composición fachada } \\
\text { Zócalo }\end{array}$} & \multicolumn{2}{|c|}{$N^{0} 3$} & sóta & \multicolumn{2}{|c|}{ entreplanta } & \multicolumn{5}{|c|}{ piso noble caja escalera } \\
\hline & \multicolumn{2}{|c|}{ aleatoria } & \multicolumn{3}{|c|}{ ordenada sin simetría } & \multicolumn{5}{|c|}{ ordenada con simetría } \\
\hline & Z1 & $\mathrm{Z} 2$ & Z3 & Z4 & Z5 & & & & & \\
\hline Fábrica & F1 & F2 & F3 & F4 & F5 & F6 & F7 & & & \\
\hline Vano/dintel & V1 & V2 & V3 & V4 & V5 & V6 & V7 & V8 & V9 & V10 \\
\hline Entrada/dintel & E1 & E2 & E3 & E4 & & & & & & \\
\hline Alero & A1 & A2 & A3 & A4 & A5 & A6 & A7 & & & \\
\hline Cubierta & pla & & inclit & & & & & & & \\
\hline
\end{tabular}

plana inclinada

\begin{tabular}{l|lll} 
Aparejo & soga-tizón & soga & \multicolumn{1}{c}{ tizón } \\
Hiladas & irregulares & pseudo horizontales & horizontales \\
Superficie & sin planeidad & pseudo planeidad & planeidad perfecta \\
Sección (hipótesis) & uniforme & hojas y núcleo & abocinada (vano) \\
Elementos destacados & aplantillado & cortado terracota &
\end{tabular}




\title{
$\begin{array}{ll}\text { Ladrillos }^{1} & \text { Fb57 }\end{array}$
}

No elementos medidos
Longitud $(\mathrm{cm})$
Anchura $(\mathrm{cm})$
Espesor $(\mathrm{cm})$
Volumen $\left(\mathrm{cm}^{3}\right)$
Tipo
Color
Recogida de muestra
Patologías

\author{
15
}

29.5

14

4.2

1734.6

homogéneo heterogéneo re-empleo

homogéneo heterogéneo globular heterogéneo marmolado

no sí código

eflorescencias micro fisuración grietas

erosión disgregación descamación

1 Datos obtenidos en base al cálculo del desvio estándar (respecto al valor medio de la muestras analizadas) y del gráfico de frecuencia de las muestras analizadas, identificado por una curva gaussiana

Juntas

Fb57

\begin{tabular}{|c|c|c|c|c|}
\hline \multirow{2}{*}{$\begin{array}{l}\mathrm{N}^{\circ} \text { elementos medidos } \\
\text { Llaga }(\mathrm{cm})\end{array}$} & \multicolumn{4}{|l|}{15} \\
\hline & \multicolumn{4}{|l|}{1.2} \\
\hline Tendel (cm) & \multicolumn{4}{|l|}{4} \\
\hline Altura de 5 hiladas $(\mathrm{cm})$ & \multicolumn{4}{|l|}{38.7} \\
\hline Proporción ladrillo/junta & \multicolumn{4}{|l|}{1.05} \\
\hline \multirow{3}{*}{$\begin{array}{l}\text { Tipo de acabado } \\
\text { Junta de asiento }\end{array}$} & simple & doble & \multicolumn{2}{|l|}{ múltiple } \\
\hline & rehundida & a hueso & \multicolumn{2}{|l|}{ saliente } \\
\hline & enrasada & matada & & \\
\hline \multirow[t]{2}{*}{ Junta de acabado } & rehundida & a hueso & \multicolumn{2}{|l|}{ saliente } \\
\hline & enrasada & matada & & \\
\hline \multirow{3}{*}{$\begin{array}{l}\text { Tipo de mortero } \\
\text { Morfología de mortero } \\
\text { Tipo de árido }\end{array}$} & cal & cal y tierra & tierra & cemento mixto \\
\hline & con grumos & con caliches & homogéneo & heterogéneo \\
\hline & arena & gravilla & grava & mixto \\
\hline \multirow{4}{*}{$\begin{array}{l}\text { Color del árido } \\
\text { Recogida de muestra } \\
\text { Patologías }\end{array}$} & claro & oscuro & homogéneo & heterogéneo \\
\hline & no & sí & \multicolumn{2}{|l|}{ código } \\
\hline & eflorescencias & micro fisuración & \multicolumn{2}{|l|}{ grietas } \\
\hline & erosión & disgregación & \multicolumn{2}{|l|}{ pulverización } \\
\hline
\end{tabular}

${ }^{2}$ Datos obtenidos en base al cálculo del desvio estándar (respecto al valor medio de la muestras analizadas) y del gráfico de frecuencia de las muestras analizadas,

identificado por una curva gaussiana 

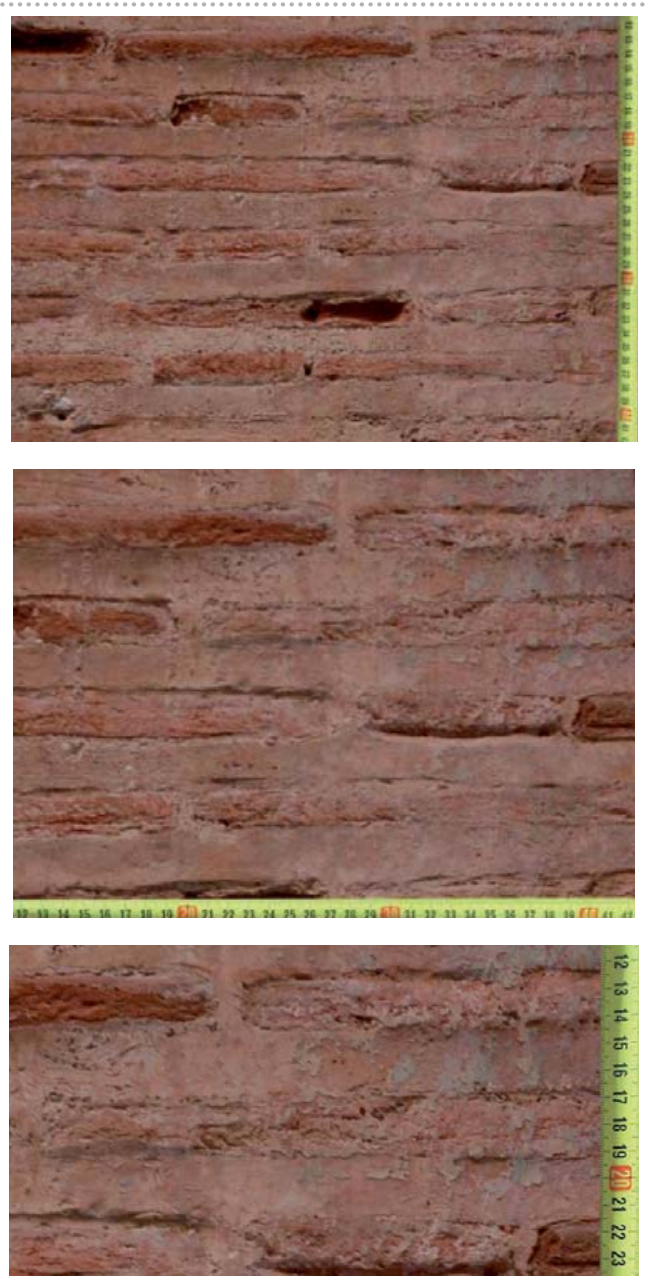

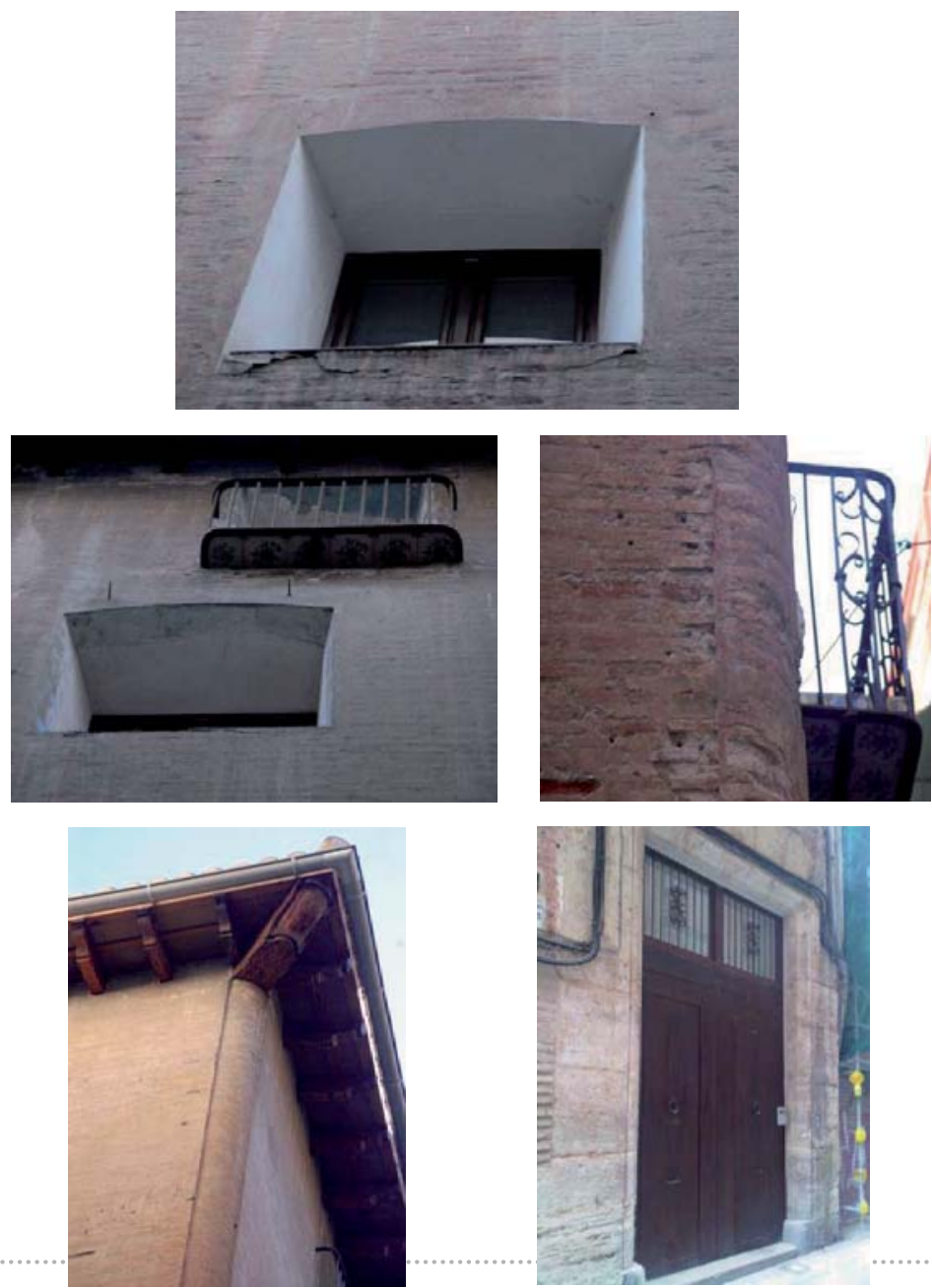
Datos generales

Fb117

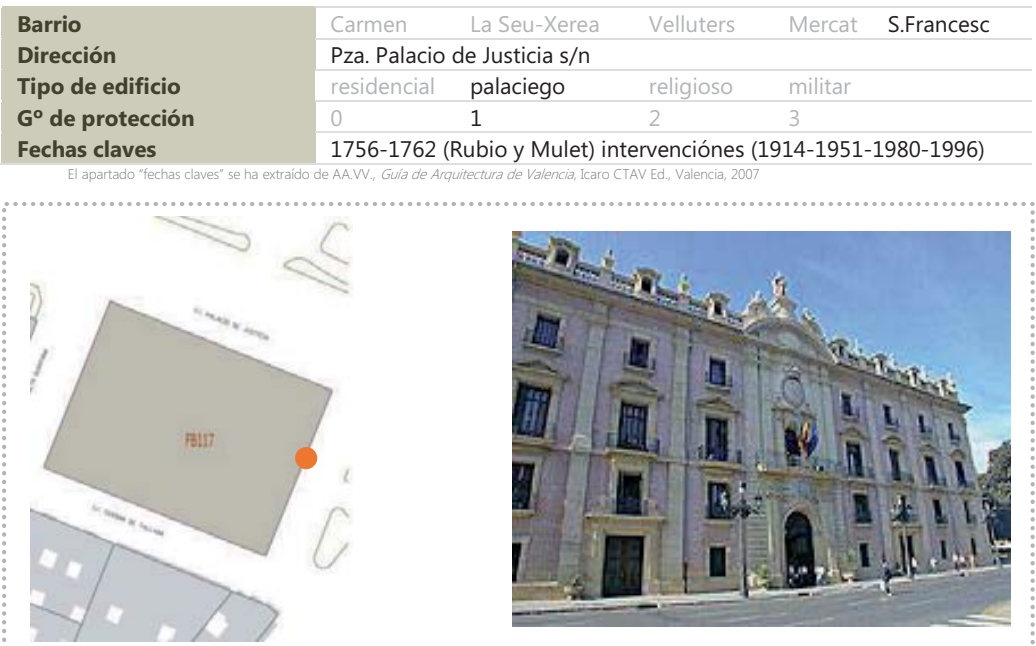

Fachada

Fb117

\begin{tabular}{|c|c|c|c|c|c|c|c|c|c|c|}
\hline \multirow{3}{*}{$\begin{array}{l}\text { Pisos } \\
\text { Composición fachada } \\
\text { Zócalo }\end{array}$} & \multicolumn{2}{|c|}{$N^{0} 3$} & \multicolumn{3}{|c|}{ sótano entreplanta } & \multicolumn{5}{|c|}{ piso noble caja escalera } \\
\hline & \multicolumn{2}{|c|}{ aleatoria } & \multicolumn{3}{|c|}{ ordenada sin simetría } & \multicolumn{5}{|c|}{ ordenada con simetría } \\
\hline & $\mathrm{Z1}$ & $\mathrm{Z2}$ & $\mathrm{Z3}$ & Z4 & $\mathrm{Z5}$ & & & & & \\
\hline Fábrica & $\mathrm{F} 1$ & F2 & F3 & F4 & F5 & F6 & F7 & & & \\
\hline Vano/dintel & V1 & V2 & V3 & V4 & V5 & V6 & V7 & V8 & V9 & V10 \\
\hline Entrada/dintel & E1 & E2 & E3 & E4 & & & & & & \\
\hline Alero & $\mathrm{A} 1$ & $\mathrm{~A} 2$ & $\mathrm{~A} 3$ & A4 & A5 & $\mathrm{A} 6$ & A7 & & & \\
\hline Cubierta & plar & & incli & & & & & & & \\
\hline
\end{tabular}

Fábrica

Fb117

\begin{tabular}{l|lll} 
Aparejo & soga-tizón & soga & tizón \\
Hiladas & irregulares & pseudo horizontales & horizontales \\
Superficie & sin planeidad & pseudo planeidad & planeidad perfecta \\
Sección (hipótesis) & uniforme & hojas y núcleo & abocinada (vano) \\
Elementos destacados & aplantillado & cortado terracota &
\end{tabular}


Ladrillos

Fb117

$N^{\circ}$ elementos medidos
Longitud $(\mathrm{cm})$
Anchura $(\mathrm{cm})$
Espesor $(\mathrm{cm})$
Volumen $\left(\mathrm{cm}^{3}\right)$
Tipo
Color
Recogida de muestra
Patologías

\begin{tabular}{lll}
15 & & \\
32 & & \\
15 & & \\
4.5 & & \\
1856.4 & heterogéneo & re-empleo \\
\hline homogéneo & heterogéneo globular & heterogéneo marmolado \\
\hline homogéneo & sí & código \\
\hline no & micro fisuración & grietas \\
\hline eflorescencias & disgregación & descamación \\
erosión & &
\end{tabular}

${ }^{1}$ Datos obtenidos en base al cálculo del desvio estándar (respecto al valor medio de la muestras analizadas) y del gráfico de frecuencia de las muestras analizadas, identificado por una curva gaussiana

Juntas

Fb117

No elementos medidos
Llaga $(\mathrm{cm})$
Tendel $(\mathrm{cm})$
Altura de 5 hiladas $(\mathrm{cm})$
Proporción ladrillo/junta
Tipo de acabado
Junta de asiento
Junta de acabado
Tipo de mortero
Morfología de mortero
Tipo de árido
Color del árido
Recogida de muestra
Patologías

15

1

3.5

40

1.2

simple doble múltiple

rehundida a hueso saliente

enrasada matada

rehundida a hueso saliente

enrasada matada

cal caly tierra tierra cemento mixto

congrumos concaliches homogéneo heterogéneo

arena gravilla grava mixto

claro oscuro homogéneo heterogéneo

no sí código

eflorescencias micro fisuración grietas

erosión" disgregación pulverización

2 Datos obtenidos en base al cálculo del desvio estándar (respecto al valor medio de la muestras analizadas) y del gráfico de frecuencia de las muestras analizadas identificado por una curva gaussiana 

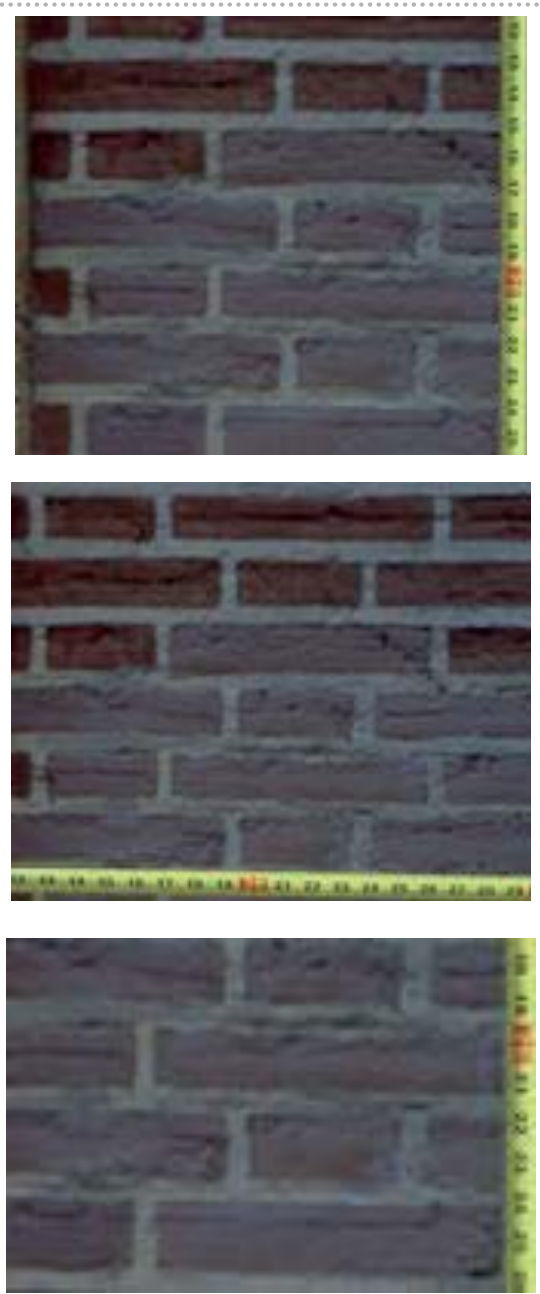

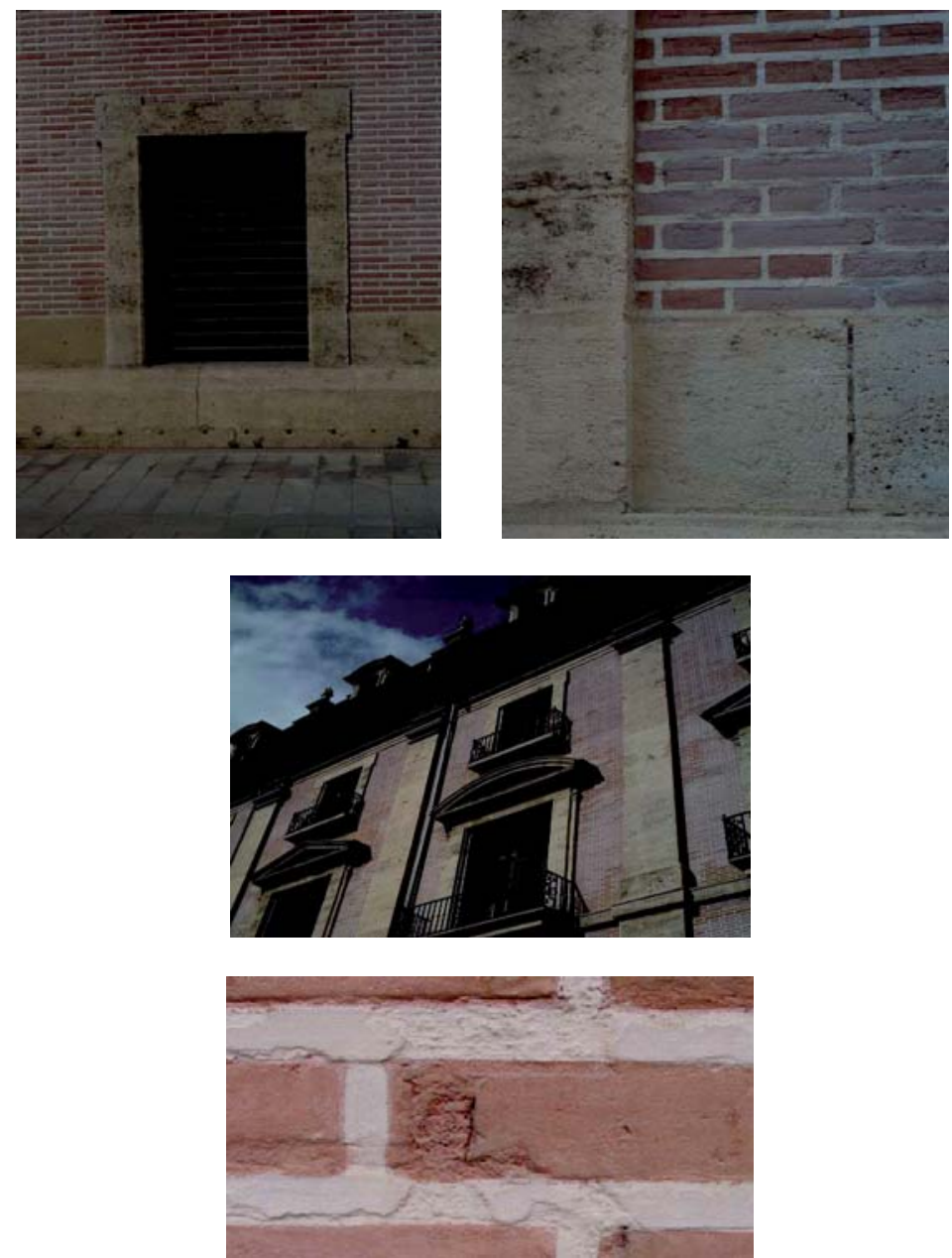


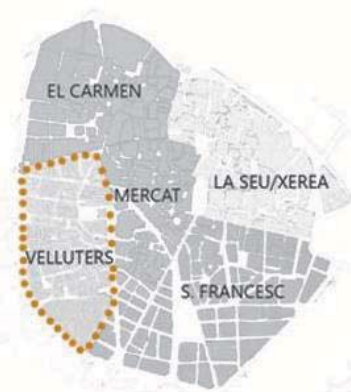

I.2.4 Fábricas históricas: barrio de Velluters

Fichas recopiladas 


\begin{tabular}{|c|c|c|}
\hline \multicolumn{3}{|c|}{ Barrio de Velluters: todas las fábricas seleccionadas } \\
\hline Código & Dirección & Edificio \\
\hline Va34 & C/Balmes no 29 & PALACIEGO \\
\hline Va81a & C/ Exarchs no 5 & RESIDENCIAL \\
\hline Va81b & C/ Exarchs n० 7 & RESIDENCIAL \\
\hline Va82 & C/ Exarchs no 3 & RESIDENCIAL \\
\hline Va101 & C/ Villena no 13 & RESIDENCIAL \\
\hline Va103a & C/ Carniceros s/n & RELIGIOSO \\
\hline Va103b & C/ Carniceros no 6 & RELIGIOSO \\
\hline Va104 & C/ Carniceros no 8 & RESIDENCIAL \\
\hline Va112 & C/ Carniceros no 22 & RESIDENCIAL \\
\hline Va119 & C/ Lopez de Rueda s/n & RESIDENCIAL \\
\hline Vb22 & C/ Roger de Flor n 39 & RESIDENCIAL \\
\hline Vb45 & C/ Roger de Flor nº 13 & RESIDENCIAL \\
\hline Vb62 & C/ San Antoni no 8 & RESIDENCIAL \\
\hline Vb67 & Pza. Pilar s/n & RELIGIOSO \\
\hline Vb68 & C/ Quevedo n² & RELIGIOSO \\
\hline Vb69 & C/ Quevedo s/n & RELIGIOSO \\
\hline
\end{tabular}




\begin{tabular}{|c|c|c|c|}
\hline \multicolumn{4}{|c|}{ Barrio de Velluters: monumentos } \\
\hline Código & Dirección & Edificio & mbre \\
\hline Va34 & C/Balmes n² 29 & PALACIEGO & $\begin{array}{ll}\text { Gremio de los } \\
\text { Maestros } \\
\text { Carpinteros }\end{array}$ \\
\hline Va103a & C/ Carniceros s/n & RELIGIOSO & $\begin{array}{l}\text { Iglesia de las } \\
\text { Escuelas Pías }\end{array}$ \\
\hline Va103b & C/ Carniceros nº 6 & RELIGIOSO & $\begin{array}{l}\text { Colegio de las } \\
\text { Escuelas Pías }\end{array}$ \\
\hline Vb67 & Pza. Pilar s/n & RELIGIOSO & $\begin{array}{l}\text { Convento del } \\
\text { Pilar }\end{array}$ \\
\hline Vb68 & C/ Quevedo n०2 & RELIGIOSO & $\begin{array}{l}\text { Iglesia de San } \\
\text { Carlos Borromeo }\end{array}$ \\
\hline Vb69 & C/ Quevedo s/n & RELIGIOSO & $\begin{array}{l}\text { Convento de San } \\
\text { Carlos Borromeo }\end{array}$ \\
\hline
\end{tabular}




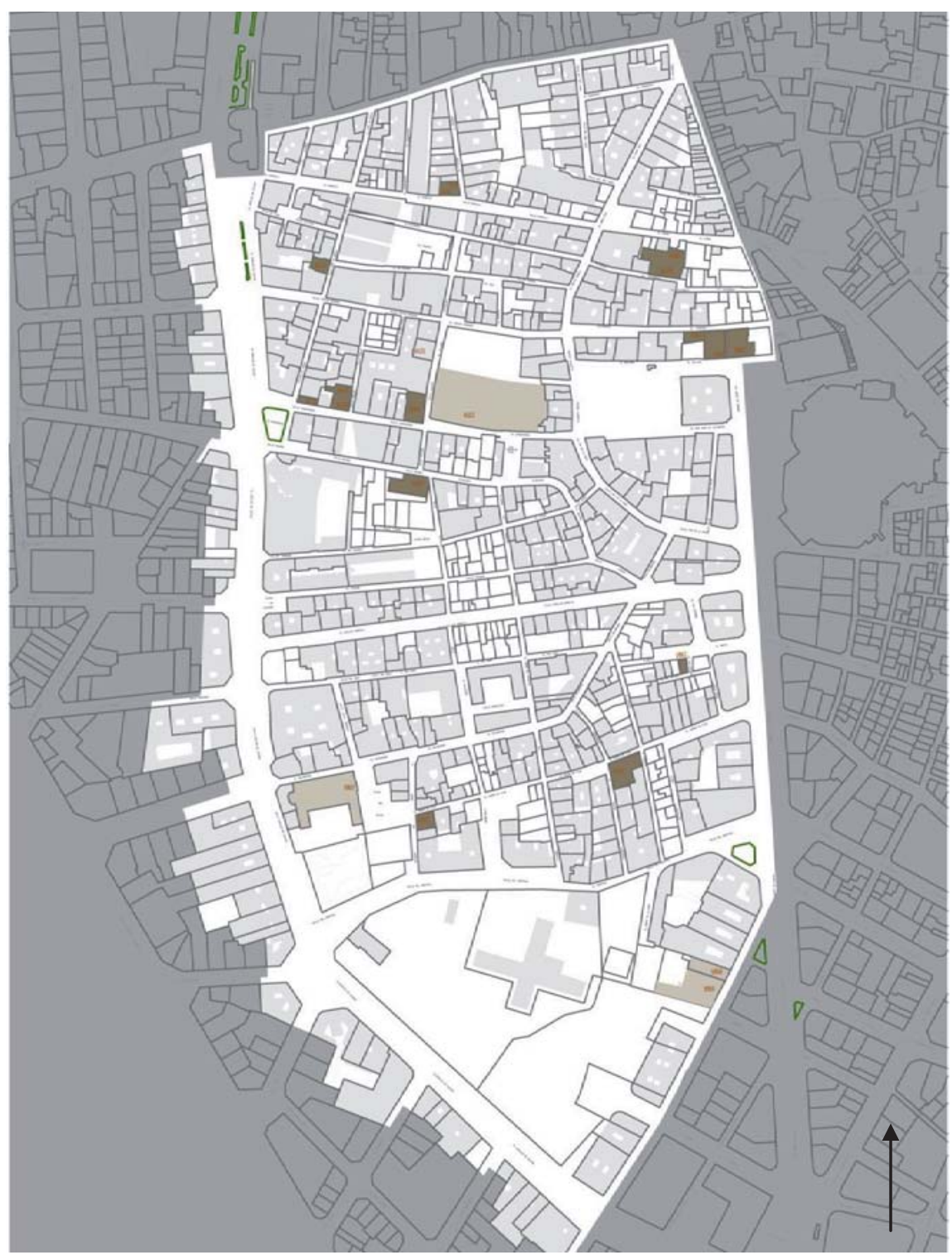

FIG. 7 Mapa de localización de las fichas recopiladas en el barrio de Velluters (CRISTINI) 
Datos generales

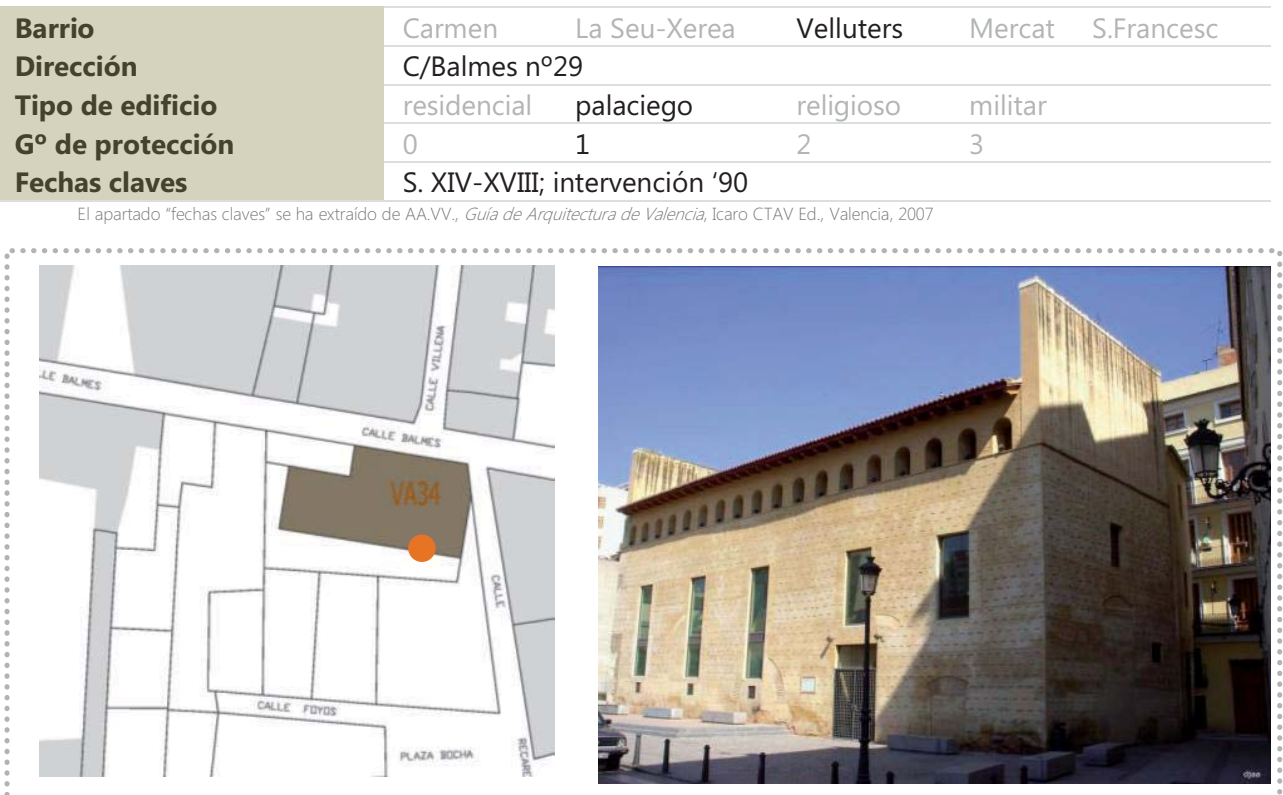

\section{Pisos \\ Composición fachada \\ Zócalo \\ Fábrica \\ Vano/dintel \\ Entrada/dintel \\ Alero \\ Cubierta}

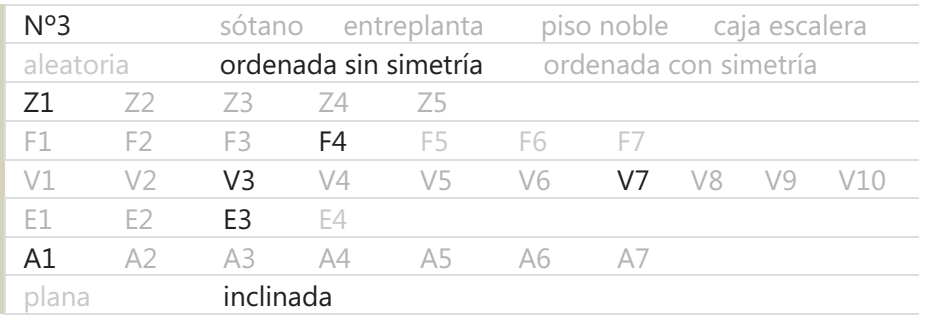

\section{Fábrica}

\section{Va34}

\section{Aparejo \\ Hiladas \\ Superficie \\ Sección (hipótesis) \\ Elementos destacados}

\begin{tabular}{lll} 
soga-tizón & soga tizón & \\
irregulares & pseudo horizontales & horizontales \\
\hline sin planeidad & pseudo planeidad & planeidad perfecta \\
\hline uniforme & hojas y núcleo & abocinada (vano) \\
aplantillado & cortado terracota & \\
\hline
\end{tabular}




\begin{tabular}{|c|c|c|c|}
\hline \multirow{3}{*}{$\begin{array}{l}\mathrm{N}^{\circ} \text { elementos medidos } \\
\text { Longitud }(\mathrm{cm}) \\
\text { Anchura }(\mathrm{cm})\end{array}$} & \multicolumn{3}{|l|}{15} \\
\hline & \multicolumn{3}{|l|}{28.2} \\
\hline & \multicolumn{3}{|l|}{13.1} \\
\hline Espesor (cm) & \multicolumn{3}{|l|}{4.1} \\
\hline Volumen $\left(\mathrm{cm}^{3}\right)$ & \multicolumn{3}{|l|}{1514.6} \\
\hline Tipo & homogéneo & heterogéneo & re-empleo \\
\hline Color & homogéneo & heterogéneo globular & heterogéneo marmolado \\
\hline Recogida de muestra & no & sí & código Va34/1 \\
\hline Patologías & $\begin{array}{l}\text { eflorescencias } \\
\text { erosión }\end{array}$ & $\begin{array}{l}\text { micro fisuración } \\
\text { disgregación }\end{array}$ & $\begin{array}{l}\text { grietas } \\
\text { descamación }\end{array}$ \\
\hline
\end{tabular}

${ }^{1}$ Datos obtenidos en base al cálculo del desvío estándar (respecto al valor medio de la muestras analizadas) y del gráfico de frecuencia de las muestras analizadas, identificado por una curva gaussiana

\section{Juntas}

\begin{tabular}{|c|c|c|c|c|}
\hline \multirow{2}{*}{$\begin{array}{l}N^{\circ} \text { elementos medidos } \\
\text { Llaga }(\mathrm{cm})\end{array}$} & \multicolumn{4}{|l|}{15} \\
\hline & \multicolumn{4}{|l|}{1} \\
\hline Tendel (cm) & \multicolumn{4}{|l|}{2.9} \\
\hline Altura de 5 hiladas $(\mathrm{cm})$ & \multicolumn{4}{|l|}{28} \\
\hline Proporción ladrillo/junta & \multicolumn{4}{|l|}{1.41} \\
\hline Tipo de acabado & simple & doble & \multicolumn{2}{|l|}{ múltiple } \\
\hline \multirow[t]{2}{*}{ Junta de asiento } & rehundida & a hueso & \multirow{2}{*}{\multicolumn{2}{|c|}{ saliente }} \\
\hline & enrasada & matada & & \\
\hline \multirow[t]{2}{*}{ Junta de acabado } & rehundida & a hueso & \multirow{2}{*}{\multicolumn{2}{|c|}{ saliente }} \\
\hline & enrasada & matada & & \\
\hline \multirow{3}{*}{$\begin{array}{l}\text { Tipo de mortero } \\
\text { Morfología de mortero } \\
\text { Tipo de árido }\end{array}$} & cal & cal y tierra & tierra & cemento mixto \\
\hline & con grumos & con caliches & homogéneo & heterogéneo \\
\hline & arena & gravilla & grava & mixto \\
\hline \multirow{4}{*}{$\begin{array}{l}\text { Color del árido } \\
\text { Recogida de muestra } \\
\text { Patologías }\end{array}$} & claro & oscuro & homogéneo & heterogéneo \\
\hline & no & sí & \multicolumn{2}{|l|}{ código Va34/2 } \\
\hline & eflorescencias & micro fisuración & \multirow{2}{*}{\multicolumn{2}{|c|}{$\begin{array}{l}\text { grietas } \\
\text { pulverización }\end{array}$}} \\
\hline & erosión" & disgregación & & \\
\hline
\end{tabular}


Imágenes

Va34
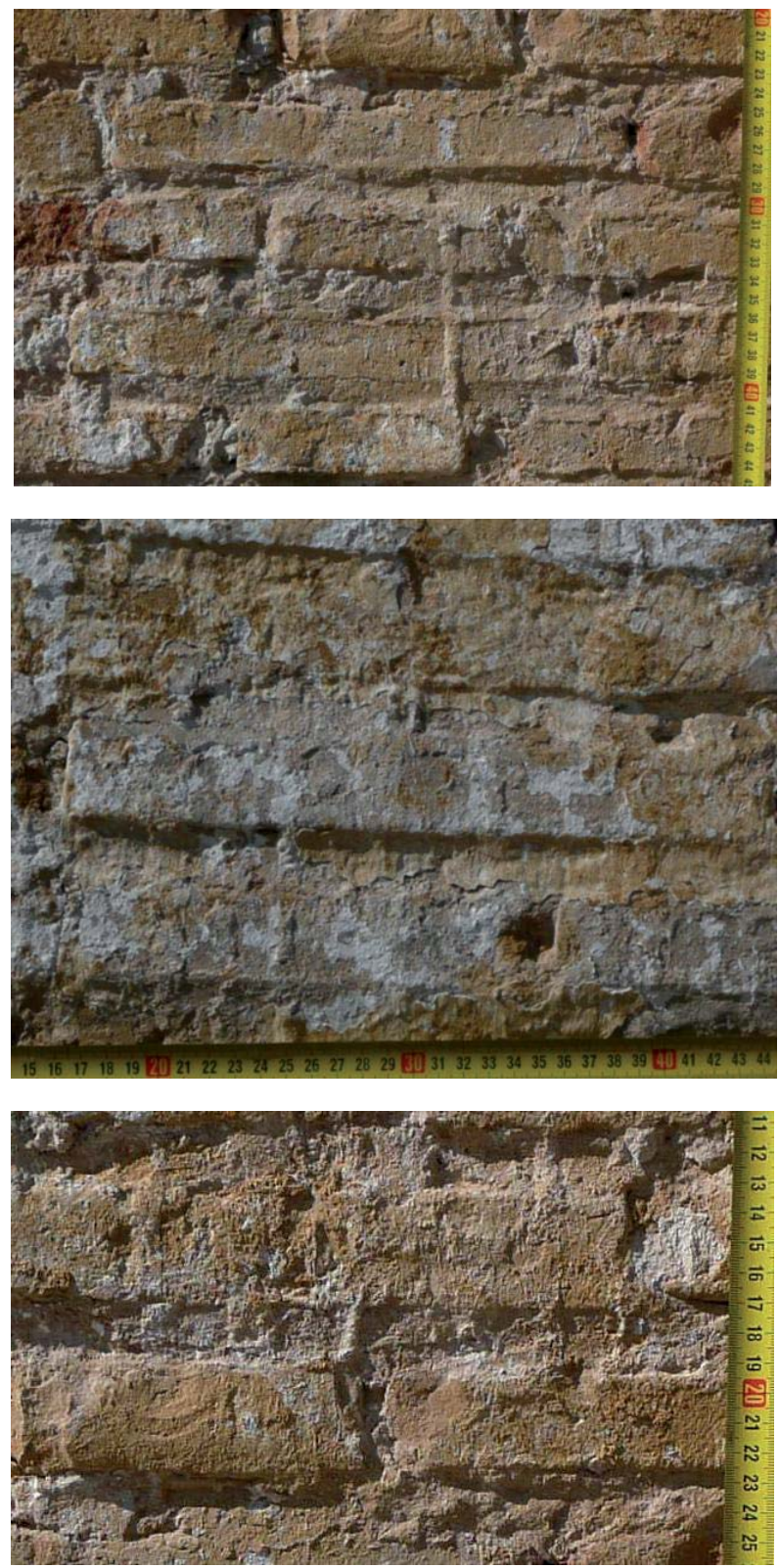

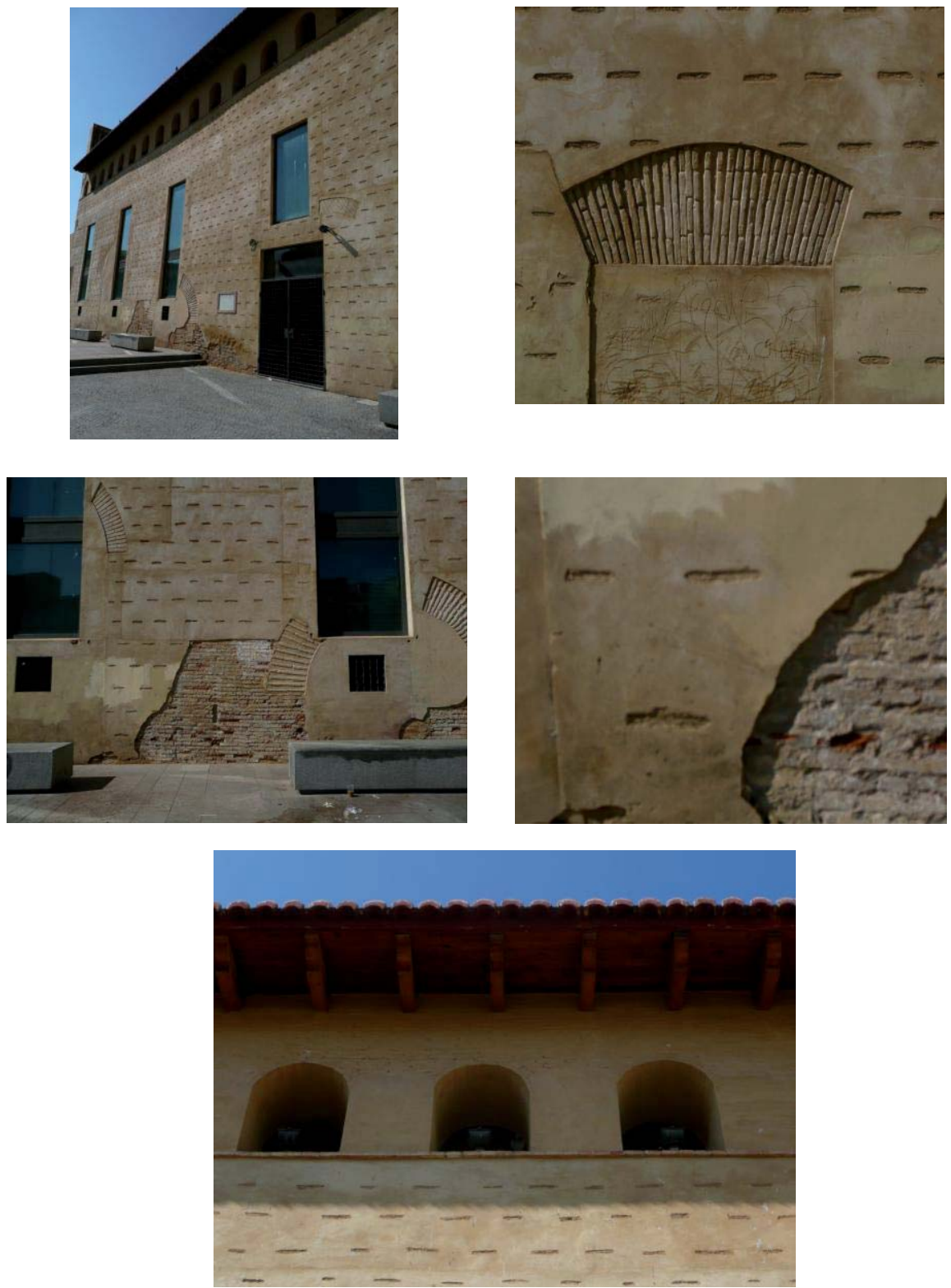


\begin{tabular}{|c|c|c|c|c|c|}
\hline Barrio & Carmen & La Seu-Xerea & Velluters & Mercat & S.Francesc \\
\hline Dirección & C/ Exarchs & & & & \\
\hline Tipo de edificio & residencial & palaciego & religioso & militar & \\
\hline $\mathbf{G}^{\circ}$ de protección & 0 & 1 & 2 & 3 & \\
\hline Fechas claves & (Posible S. & III) & & & \\
\hline
\end{tabular}

El apartado "fechas claves" se ha extraído de AA.W., Guía de Arquitectura de Valencia, Icaro CTAV Ed., Valencia, 2007
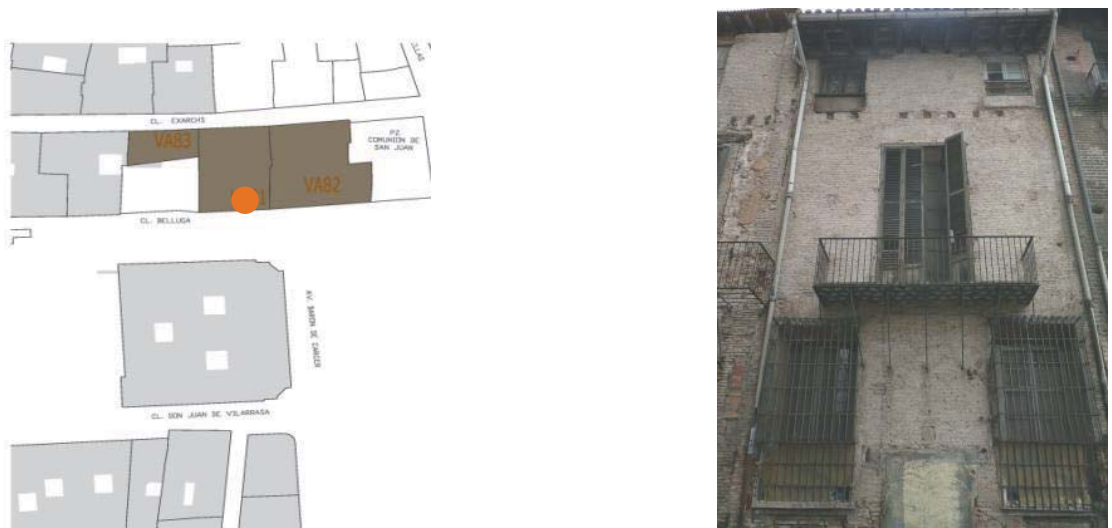

Fachada

Va81a

Pisos

Composición fachada

Zócalo

Fábrica

Vano/dintel

Entrada/dintel

Alero

Cubierta

\begin{tabular}{|c|c|c|c|c|c|c|c|c|}
\hline \multicolumn{2}{|c|}{$N^{\circ} 3$} & sótano & & planta & \multicolumn{4}{|c|}{ piso noble caja escalera } \\
\hline \multicolumn{2}{|c|}{ aleatoria } & \multicolumn{3}{|c|}{ ordenada sin simetría } & \multicolumn{4}{|c|}{ ordenada con simetría } \\
\hline Z1 & $\mathrm{Z2}$ & $\mathrm{Z3}$ & Z4 & $\mathrm{Z5}$ & & & & \\
\hline F1 & $\mathrm{F} 2$ & F3 & $\mathrm{F} 4$ & F5 & F6 & & & \\
\hline V1 & V2 & V3 & V4 & V5 & V7 & V8 & V9 & V10 \\
\hline E1 & E2 & E3 & E4 & & & & & \\
\hline A1 & $A 2$ & A3 & A4 & A5 & A6 & & & \\
\hline plar & & inclina & & & & & & \\
\hline
\end{tabular}

Fábrica

Va81a

\section{Aparejo \\ Hiladas \\ Superficie \\ Sección (hipótesis) \\ Elementos destacados}

\begin{tabular}{lll} 
soga-tizón & soga & \multicolumn{1}{c}{ tizón } \\
irregulares & pseudo horizontales & horizontales \\
\hline sin planeidad & pseudo planeidad & planeidad perfecta \\
\hline uniforme & hojas y núcleo & abocinada (vano) \\
aplantillado & cortado terracota & \\
\hline
\end{tabular}




\begin{tabular}{|c|c|c|c|}
\hline \multirow{2}{*}{$\begin{array}{l}\mathrm{N}^{\circ} \text { elementos medidos } \\
\text { Longitud }(\mathrm{cm})\end{array}$} & \multicolumn{3}{|l|}{15} \\
\hline & \multicolumn{3}{|l|}{32.1} \\
\hline Anchura (cm) & \multicolumn{3}{|l|}{14.4} \\
\hline Espesor (cm) & \multicolumn{3}{|l|}{4.1} \\
\hline Volumen $\left(\mathrm{cm}^{3}\right)$ & \multicolumn{3}{|l|}{1901} \\
\hline Tipo & homogéneo & heterogéneo & re-empleo \\
\hline Color & homogéneo & heterogéneo globular & heterogéneo marmolado \\
\hline Recogida de muestra & no & sí & Código \\
\hline Patologías & $\begin{array}{l}\text { eflorescencias } \\
\text { erosión }\end{array}$ & $\begin{array}{l}\text { micro fisuración } \\
\text { disgregación }\end{array}$ & $\begin{array}{l}\text { grietas } \\
\text { descamación }\end{array}$ \\
\hline
\end{tabular}

1 Datos obtenidos en base al cálculo del desvío estándar (respecto al valor medio de la muestras analizadas) y del gráfico de frecuencia de las muestras analizadas, identificado por una curva gaussiana

\section{Juntas}

Va81a

\begin{tabular}{|c|c|c|c|c|}
\hline \multirow{2}{*}{$\begin{array}{l}N^{\circ} \text { elementos medidos } \\
\text { Llaga }(\mathrm{cm})\end{array}$} & \multicolumn{4}{|l|}{15} \\
\hline & \multicolumn{4}{|l|}{0.8} \\
\hline \multirow{4}{*}{$\begin{array}{l}\text { Tendel }(\mathrm{cm}) \\
\text { Altura de } 5 \text { hiladas (cm) } \\
\text { Proporción ladrillo/junta } \\
\text { Tipo de acabado }\end{array}$} & \multicolumn{4}{|l|}{3} \\
\hline & \multicolumn{4}{|l|}{35} \\
\hline & \multicolumn{4}{|l|}{1.19} \\
\hline & simple & doble & múltiple & \\
\hline \multirow[t]{2}{*}{ Junta de asiento } & rehundida & a hueso & saliente & \\
\hline & enrasada & matada & & \\
\hline \multirow[t]{2}{*}{ Junta de acabado } & rehundida & a hueso & saliente & \\
\hline & enrasada & matada & & \\
\hline \multirow{2}{*}{$\begin{array}{l}\text { Tipo de mortero } \\
\text { Morfología de mortero }\end{array}$} & cal & cal y tierra & tierra & cemento mixto \\
\hline & con grumos & con caliches & homogéneo & heterogéne \\
\hline \multirow{5}{*}{$\begin{array}{l}\text { Tipo de árido } \\
\text { Color del árido } \\
\text { Recogida de muestra } \\
\text { Patologías }\end{array}$} & arena & gravilla & grava & mixto \\
\hline & claro & oscuro & homogéneo & heterogéneo \\
\hline & no & sí & Código & \\
\hline & eflorescencias & micro fisuración & grietas & \\
\hline & erosión & disgregación & pulverización & \\
\hline
\end{tabular}


Imágenes

Va81a
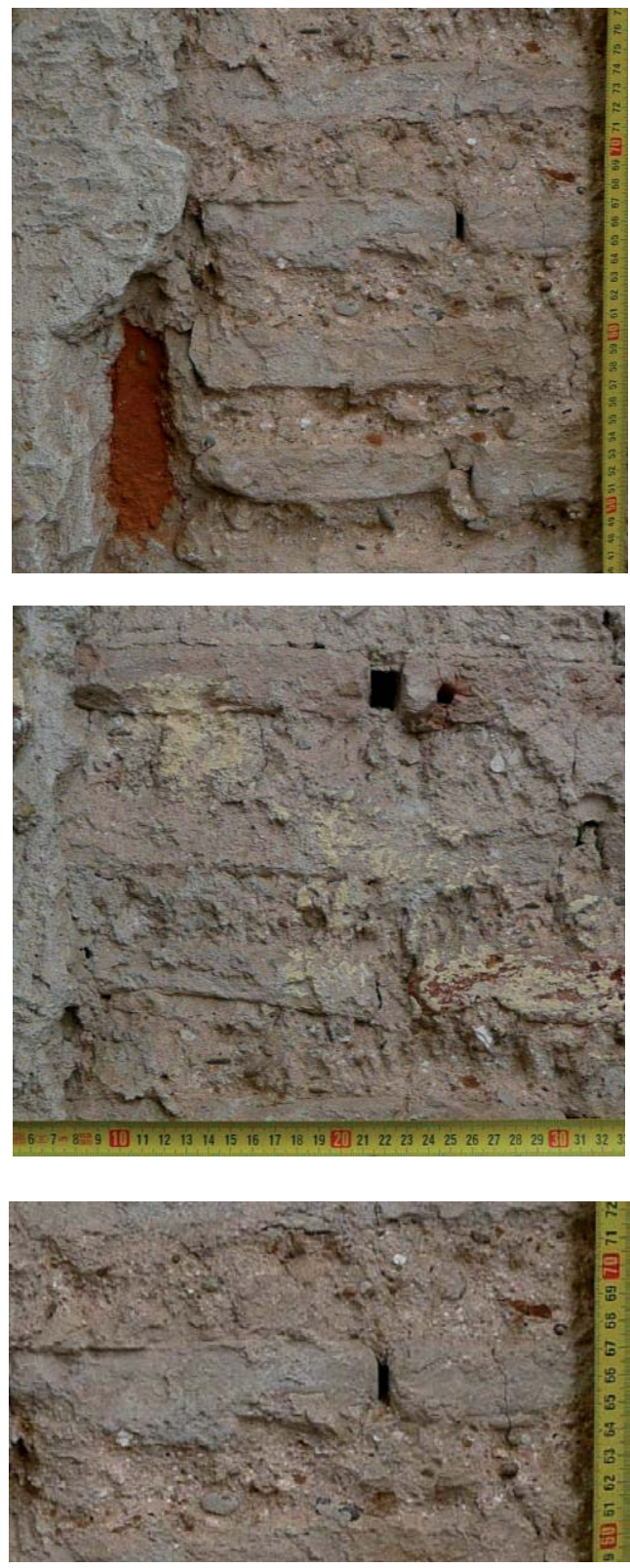
Imágenes

Va81a
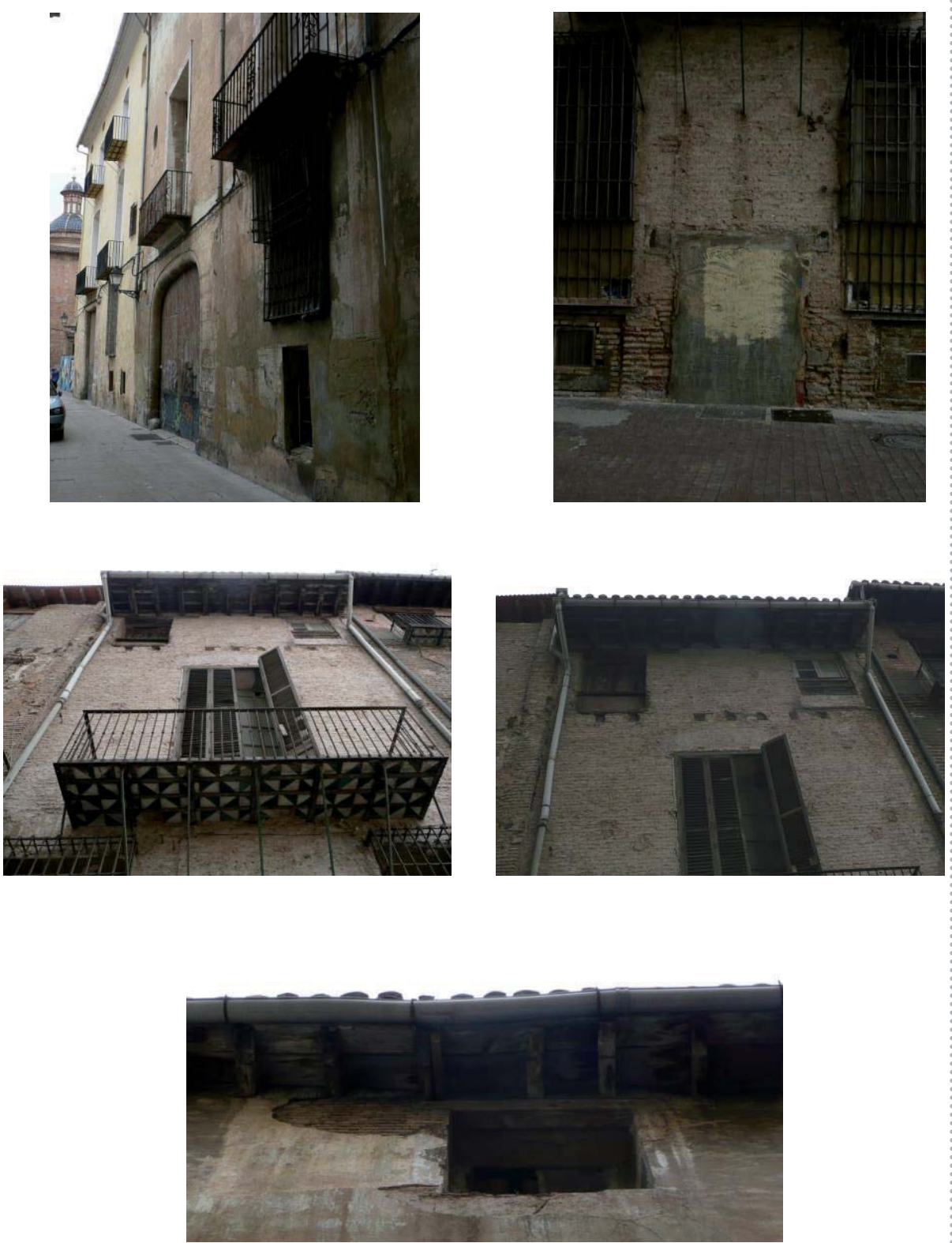
Datos generales

\section{Va81b}

\begin{tabular}{|c|c|c|c|c|c|}
\hline \multirow{2}{*}{$\begin{array}{l}\text { Barrio } \\
\text { Dirección }\end{array}$} & Carmen & La Seu-Xerea & Velluters & Mercat & S.Francesc \\
\hline & \multicolumn{5}{|c|}{ C/ Exarchs n ${ }^{07}$} \\
\hline Tipo de edificio & residencial & palaciego & religioso & militar & \\
\hline $\mathbf{G}^{\circ}$ de protección & 0 & 1 & 2 & 3 & \\
\hline Fechas claves & \multicolumn{5}{|c|}{ Posible S. XIV } \\
\hline
\end{tabular}

El apartado "fechas claves" se ha extraído de AA.W., Guía de Arquitectura de Valencia, Icaro CTAV Ed., Valencia, 2007
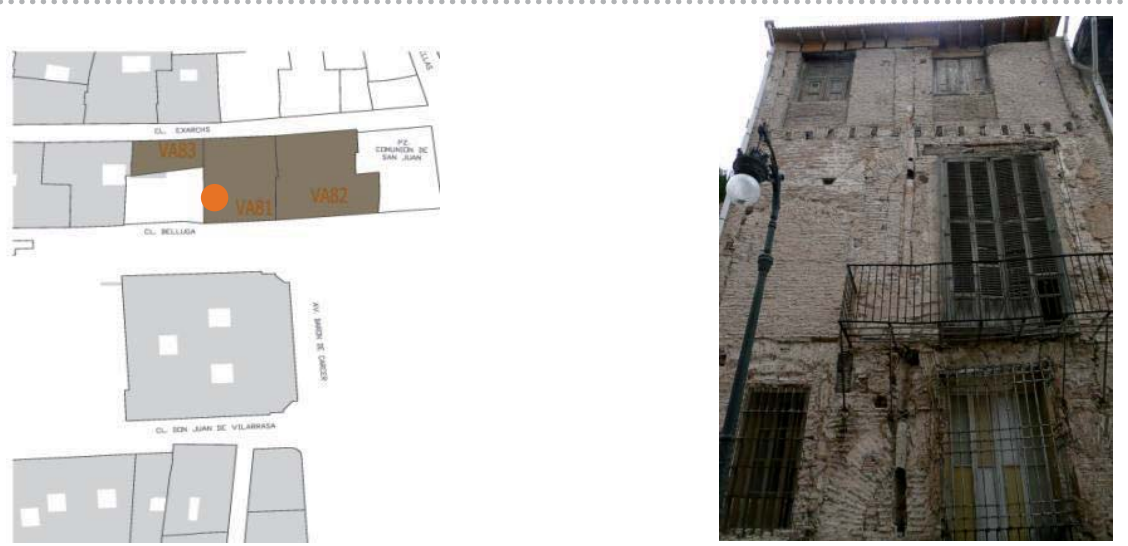

Fachada

\section{Va81b}

Pisos

Composición fachada

Zócalo

Fábrica

Vano/dintel

Entrada/dintel

Alero

Cubierta

\begin{tabular}{|c|c|c|c|c|c|c|c|}
\hline \multicolumn{2}{|c|}{$\mathrm{N}^{0} 3$} & sótano & entreplanta & \multicolumn{4}{|c|}{ piso noble caja escalera } \\
\hline \multicolumn{2}{|c|}{ aleatoria } & \multicolumn{2}{|c|}{ ordenada sin simetría } & \multicolumn{4}{|c|}{ ordenada con simetría } \\
\hline Z1 & $\mathrm{Z} 2$ & $\mathrm{Z3}$ & $\mathrm{Z} 5$ & & & & \\
\hline F1 & $\mathrm{F} 2$ & F3 & F5 & F6 & & & \\
\hline V1 & V2 & V3 & V5 & V6 & V8 & V9 & V10 \\
\hline E1 & E2 & E3 & E4 & & & & \\
\hline A1 & $\mathrm{A} 2$ & A3 & A5 & A6 & & & \\
\hline
\end{tabular}

Va81b

\begin{tabular}{lll} 
soga-tizón & soga & \\
irregulares & tizón & \\
sin planeidad & pseudo planeidad & planeidad perfecta \\
\hline uniforme & hojas y núcleo & abocinada (vano) \\
aplantillado & cortado terracota & \\
\hline
\end{tabular}




\begin{tabular}{|c|c|c|c|}
\hline \multirow{2}{*}{$\begin{array}{l}\mathrm{N}^{\circ} \text { elementos medidos } \\
\text { Longitud }(\mathrm{cm})\end{array}$} & \multicolumn{3}{|l|}{15} \\
\hline & \multicolumn{3}{|l|}{29.5} \\
\hline Anchura (cm) & \multicolumn{3}{|l|}{13.6} \\
\hline Espesor (cm) & \multicolumn{3}{|l|}{4.1} \\
\hline Volumen $\left(\mathrm{cm}^{3}\right)$ & \multicolumn{3}{|l|}{1644.9} \\
\hline Tipo & homogéneo & heterogéneo & re-empleo \\
\hline Color & homogéneo & heterogéneo globular & heterogéneo marmolado \\
\hline Recogida de muestra & no & sí & Código \\
\hline Patologías & $\begin{array}{l}\text { eflorescencias } \\
\text { erosión }\end{array}$ & $\begin{array}{l}\text { micro fisuración } \\
\text { disgregación }\end{array}$ & $\begin{array}{l}\text { grietas } \\
\text { descamación }\end{array}$ \\
\hline
\end{tabular}

1 Datos obtenidos en base al cálculo del desvío estándar (respecto al valor medio de la muestras analizadas) y del gráfico de frecuencia de las muestras analizadas, identificado por una curva gaussiana

\begin{tabular}{|c|c|c|c|c|}
\hline \multirow{2}{*}{$\begin{array}{l}N^{\circ} \text { elementos medidos } \\
\text { Llaga }(\mathrm{cm})\end{array}$} & \multicolumn{4}{|l|}{15} \\
\hline & \multicolumn{4}{|l|}{0.7} \\
\hline Tendel (cm) & \multicolumn{4}{|l|}{1.9} \\
\hline Altura de 5 hiladas $(\mathrm{cm})$ & \multicolumn{4}{|l|}{30} \\
\hline Proporción ladrillo/junta & \multicolumn{4}{|l|}{2.1} \\
\hline Tipo de acabado & simple & doble & \multicolumn{2}{|l|}{ múltiple } \\
\hline \multirow[t]{2}{*}{ Junta de asiento } & rehundida & a hueso & \multirow{2}{*}{\multicolumn{2}{|c|}{ saliente }} \\
\hline & enrasada & matada & & \\
\hline \multirow[t]{2}{*}{ Junta de acabado } & rehundida & a hueso & \multirow{2}{*}{\multicolumn{2}{|c|}{ saliente }} \\
\hline & enrasada & matada & & \\
\hline \multirow{3}{*}{$\begin{array}{l}\text { Tipo de mortero } \\
\text { Morfología de mortero } \\
\text { Tipo de árido }\end{array}$} & cal & cal y tierra & tierra & cemento mixto \\
\hline & con grumos & con caliches & homogéneo & heterogéneo \\
\hline & arena & gravilla & grava & mixto \\
\hline \multirow{4}{*}{$\begin{array}{l}\text { Color del árido } \\
\text { Recogida de muestra } \\
\text { Patologías }\end{array}$} & claro & oscuro & homogéneo & heterogéneo \\
\hline & no & si & \multicolumn{2}{|l|}{ Código } \\
\hline & eflorescencias & micro fisuración & \multicolumn{2}{|l|}{ grietas } \\
\hline & erosión & disgregación & \multicolumn{2}{|l|}{ pulverización } \\
\hline
\end{tabular}


Imágenes

Va81b
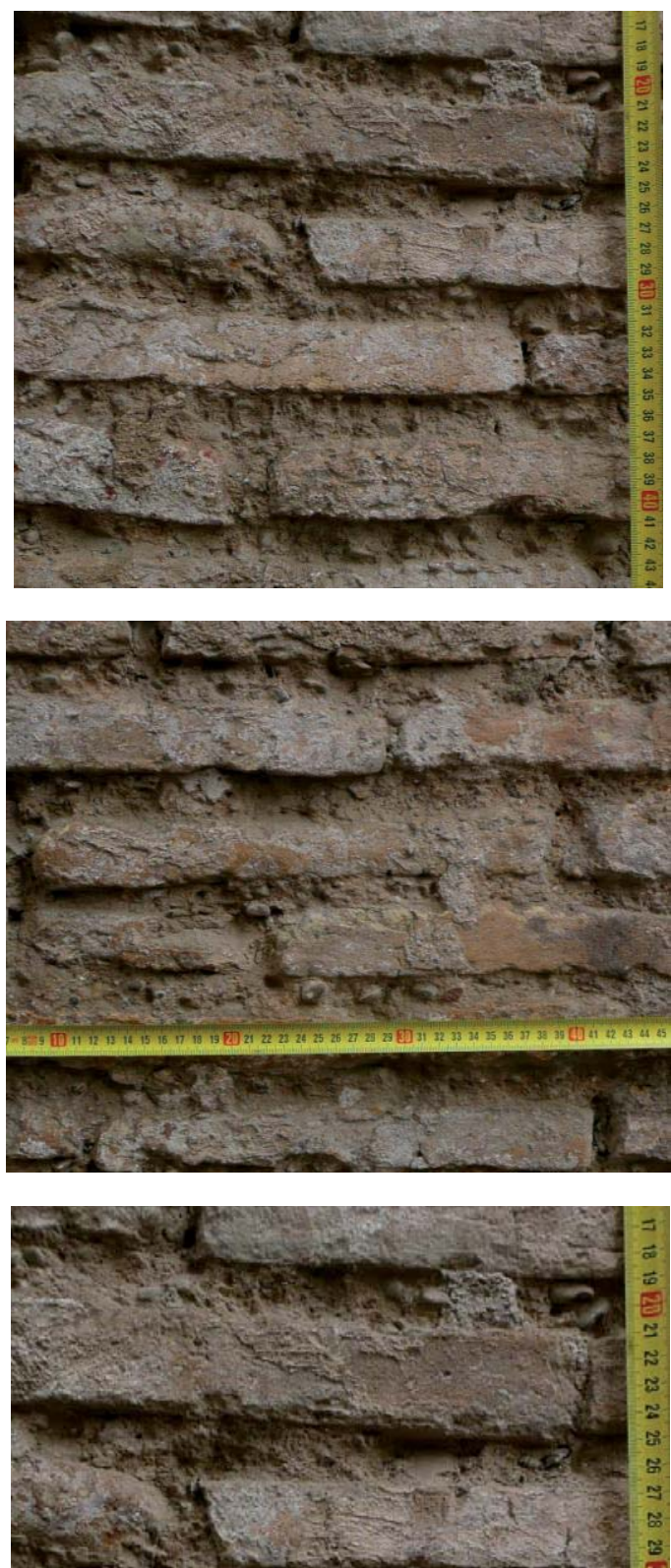

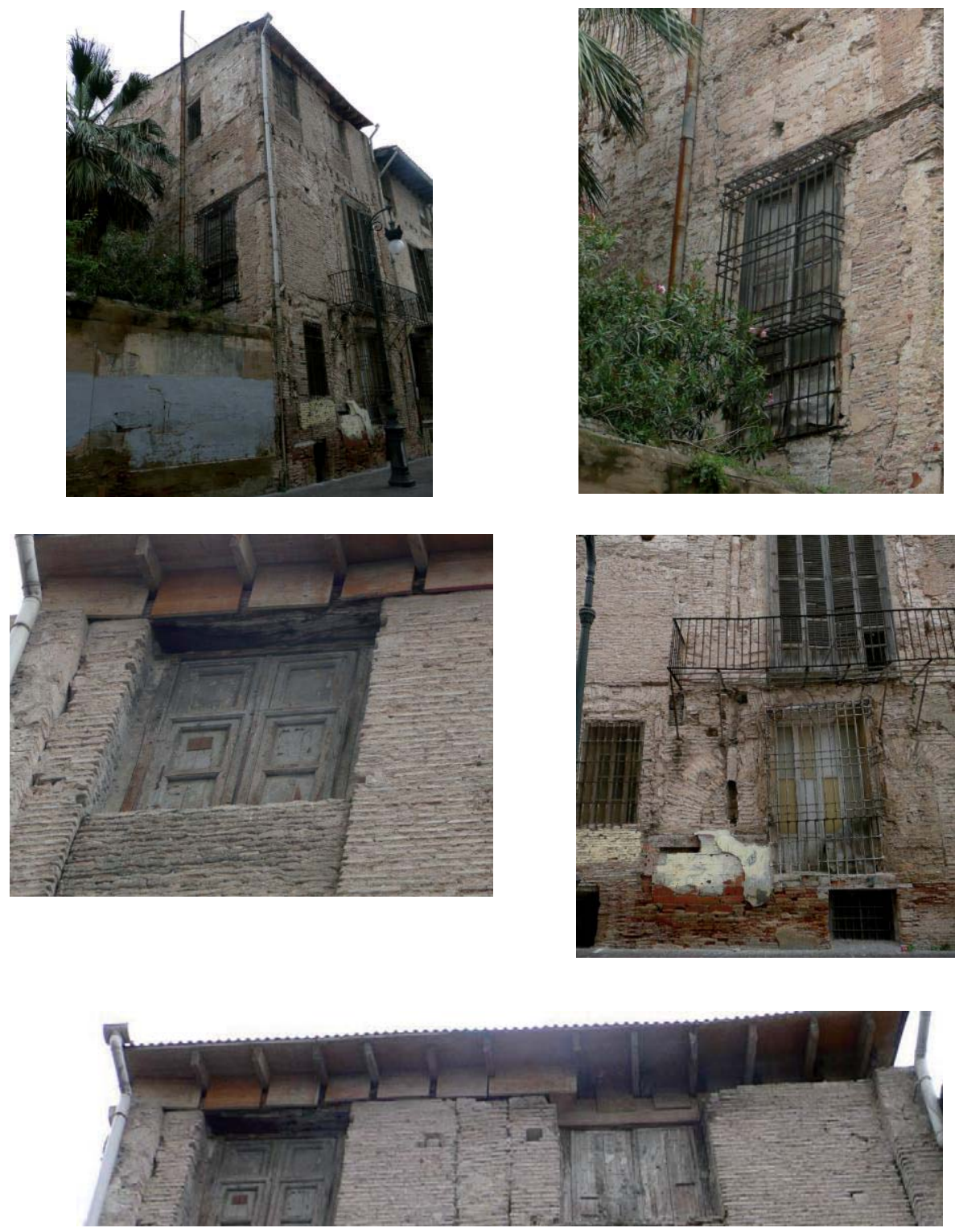


\section{Datos generales}

\begin{tabular}{|c|c|c|c|c|c|}
\hline Barrio & Carmen & La Seu-Xerea & Velluters & Mercat & S.Francesc \\
\hline Dirección & C/ Exarchs & & & & \\
\hline Tipo de edificio & residencial & palaciego & religioso & militar & \\
\hline $\mathbf{G}^{\circ}$ de protección & 0 & 1 & 2 & 3 & \\
\hline Fechas claves & (Posible S & & & & \\
\hline
\end{tabular}
El apartado "fechas claves" se ha extraído de AA.W., Guía de Arquitectura de Valencia, Icaro CTAV Ed., Valencia, 2007
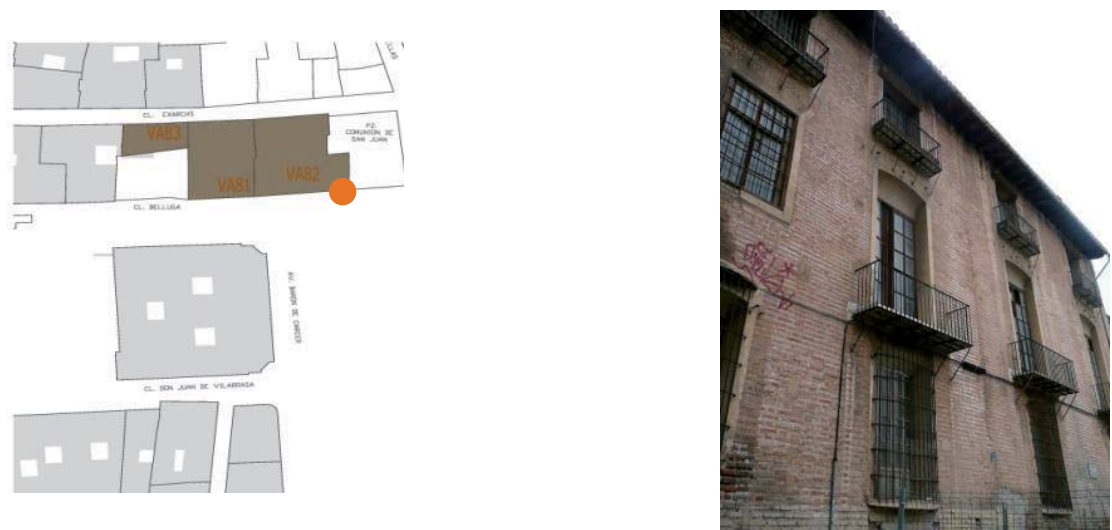

Fachada

Va82

\begin{tabular}{|c|c|c|c|c|c|c|c|c|c|}
\hline \multirow{3}{*}{$\begin{array}{l}\text { Pisos } \\
\text { Composición fachada } \\
\text { Zócalo }\end{array}$} & \multicolumn{2}{|c|}{$\mathrm{N}^{0} 3$} & sótano & \multicolumn{2}{|c|}{ entreplanta } & \multicolumn{4}{|c|}{ piso noble caja escalera } \\
\hline & \multicolumn{2}{|c|}{ aleatoria } & \multicolumn{3}{|c|}{ ordenada sin simetría } & \multicolumn{4}{|c|}{ ordenada con simetría } \\
\hline & $\mathrm{Z1}$ & $\mathrm{Z2}$ & $\mathrm{Z3}$ & Z4 & Z5 & & & & \\
\hline Fábrica & F1 & F2 & F3 & F4 & F5 & F6 & & & \\
\hline Vano/dintel & V1 & V2 & V3 & V4 & V5 & V6 & V8 & V9 & V10 \\
\hline Entrada/dintel & E1 & E2 & E3 & E4 & & & & & \\
\hline Alero & A1 & $A 2$ & $\mathrm{~A} 3$ & A4 & A5 & A6 & & & \\
\hline Cubierta & pla & & inclina & & & & & & \\
\hline
\end{tabular}

\section{Fábrica}

Va82

\section{Aparejo \\ Hiladas \\ Superficie \\ Sección (hipótesis) \\ Elementos destacados}

\begin{tabular}{lll} 
soga-tizón & soga & \multicolumn{1}{c}{ tizón } \\
irregulares & pseudo horizontales & horizontales \\
\hline sin planeidad & pseudo planeidad & planeidad perfecta \\
\hline uniforme & hojas y núcleo & abocinada (vano) \\
aplantillado & cortado terracota & \\
\hline
\end{tabular}




\begin{tabular}{|c|c|c|c|}
\hline \multirow{2}{*}{$\begin{array}{l}\mathrm{N}^{\circ} \text { elementos medidos } \\
\text { Longitud }(\mathrm{cm})\end{array}$} & \multicolumn{3}{|l|}{15} \\
\hline & \multicolumn{3}{|l|}{31.1} \\
\hline Anchura $(\mathrm{cm})$ & \multicolumn{3}{|l|}{15.1} \\
\hline Espesor (cm) & \multicolumn{3}{|l|}{4.6} \\
\hline Volumen $\left(\mathrm{cm}^{3}\right)$ & \multicolumn{3}{|l|}{2160.2} \\
\hline Tipo & homogéneo & heterogéneo & re-empleo \\
\hline \multirow{4}{*}{$\begin{array}{l}\text { Color } \\
\text { Recogida de muestra } \\
\text { Patologías }\end{array}$} & homogéneo & heterogéneo globular & heterogéneo marmolado \\
\hline & no & sí & Código Va82/1 \\
\hline & eflorescencias & micro fisuración & grietas \\
\hline & erosión & disgregación & descamación \\
\hline
\end{tabular}

${ }^{1}$ Datos obtenidos en base al cálculo del desvío estándar (respecto al valor medio de la muestras analizadas) y del gráfico de frecuencia de las muestras analizadas, identificado por una curva gaussiana

\section{untas}

\begin{tabular}{|c|c|c|c|c|}
\hline \multirow{2}{*}{$\begin{array}{l}N^{\circ} \text { elementos medidos } \\
\text { Llaga }(\mathrm{cm})\end{array}$} & \multicolumn{4}{|l|}{15} \\
\hline & \multicolumn{4}{|l|}{1.3} \\
\hline Tendel (cm) & \multicolumn{4}{|l|}{4.2} \\
\hline Altura de 5 hiladas $(\mathrm{cm})$ & \multicolumn{4}{|l|}{44} \\
\hline Proporción ladrillo/junta & \multicolumn{4}{|l|}{1.09} \\
\hline Tipo de acabado & simple & doble & \multicolumn{2}{|l|}{ múltiple } \\
\hline \multirow[t]{2}{*}{ Junta de asiento } & rehundida & a hueso & \multirow{2}{*}{\multicolumn{2}{|c|}{ saliente }} \\
\hline & enrasada & matada & & \\
\hline \multirow[t]{2}{*}{ Junta de acabado } & rehundida & a hueso & \multirow{2}{*}{\multicolumn{2}{|c|}{ saliente }} \\
\hline & enrasada & matada & & \\
\hline \multirow{2}{*}{$\begin{array}{l}\text { Tipo de mortero } \\
\text { Morfología de mortero }\end{array}$} & cal & cal y tierra & tierra & cemento mixto \\
\hline & con grumos & con caliches & homogéneo & heterogéneo \\
\hline Tipo de árido & arena & gravilla & grava & mixto \\
\hline Color del árido & claro & oscuro & homogéneo & heterogéneo \\
\hline Recogida de muestra & no & sí & \multicolumn{2}{|c|}{ Código va82/2a_Va82//2b } \\
\hline \multirow[t]{2}{*}{ Patologías } & eflorescencias & micro fisuración & \multicolumn{2}{|l|}{ grietas } \\
\hline & erosión & disgregación & \multicolumn{2}{|l|}{ pulverización } \\
\hline
\end{tabular}


Imágenes

Va82
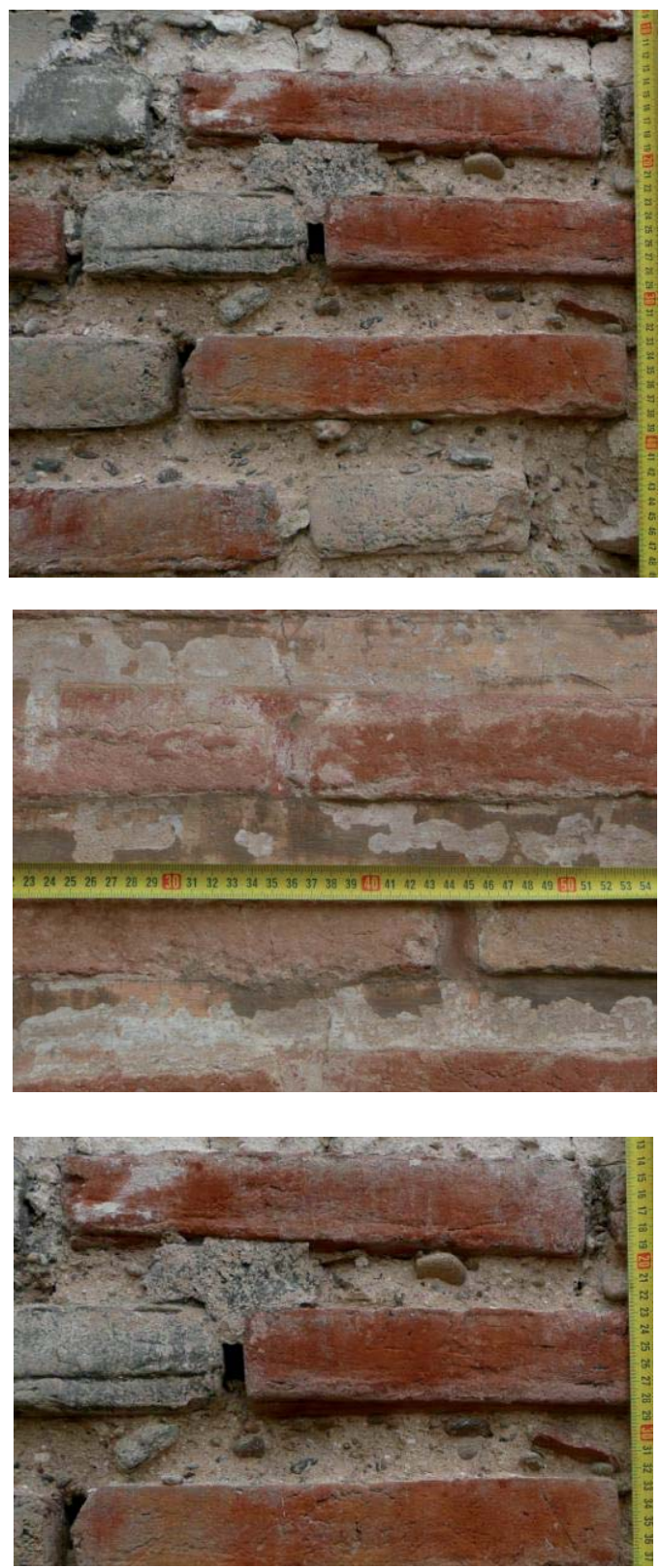

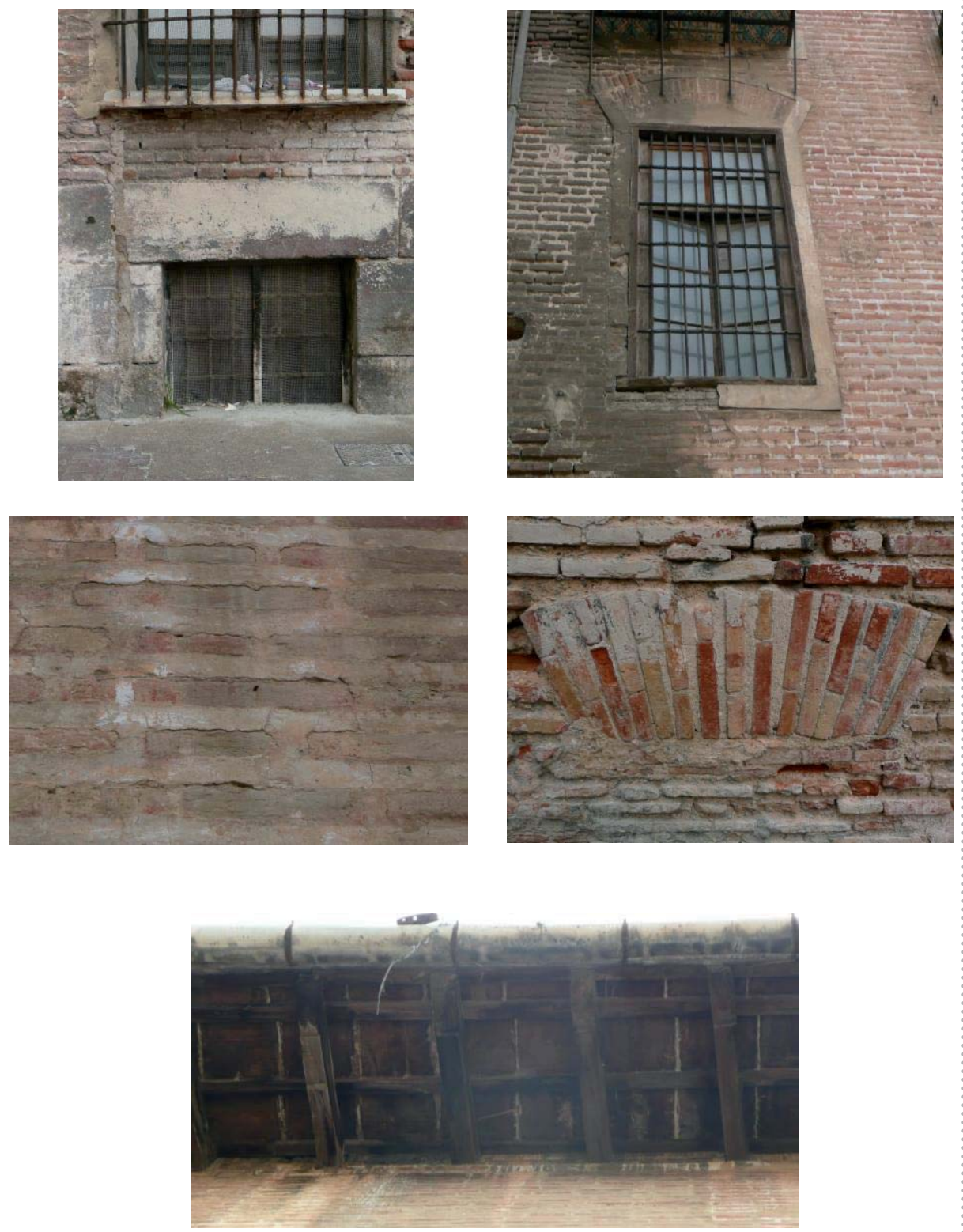
Datos generales

\begin{tabular}{|c|c|c|c|c|c|}
\hline Barrio & Carmen & La Seu-Xerea & Velluters & Mercat & S.Francesc \\
\hline Dirección & \multicolumn{5}{|c|}{ Carrer de Villena $\mathrm{n}^{\circ} 13$} \\
\hline Tipo de edificio & residencial & palaciego & religioso & militar & \\
\hline $\mathbf{G}^{\circ}$ de protección & 0 & 1 & 2 & 3 & \\
\hline Fechas claves & / & & & & \\
\hline
\end{tabular}
El apartado "fechas claves" se ha extraído de AA.V. ., Guía de Arquitectura de Valencia, Icaro CTAV Ed., Valencia, 2007

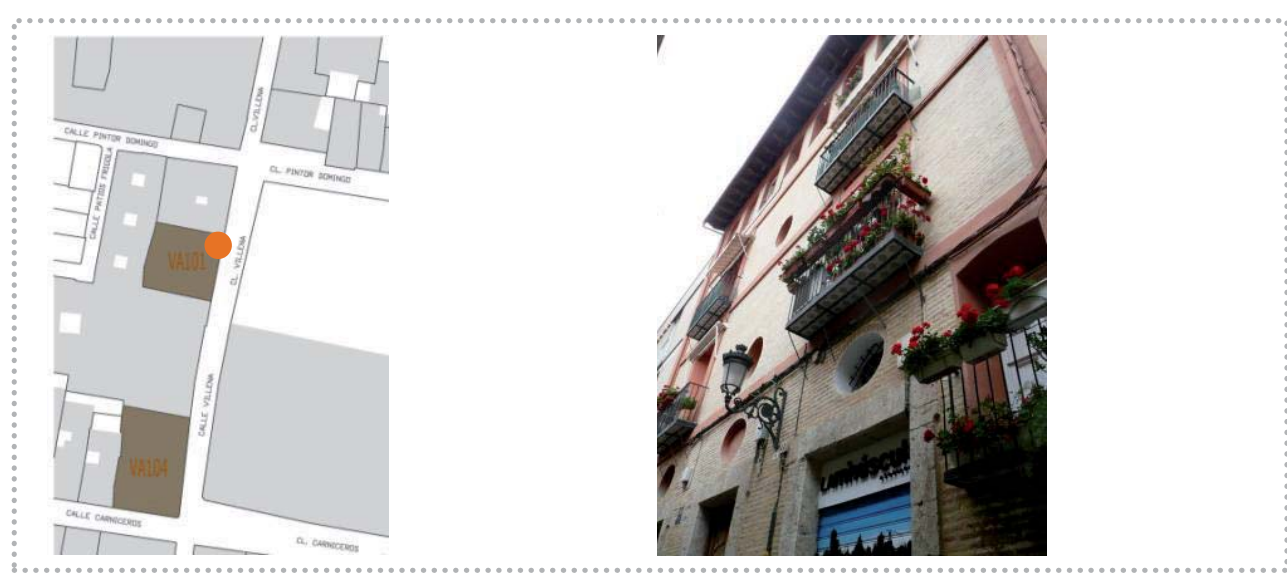

\section{Fachada}

Va101

Pisos

Composición fachada

Zócalo

Fábrica

Vano/dintel

Entrada/dintel

Alero

Cubierta

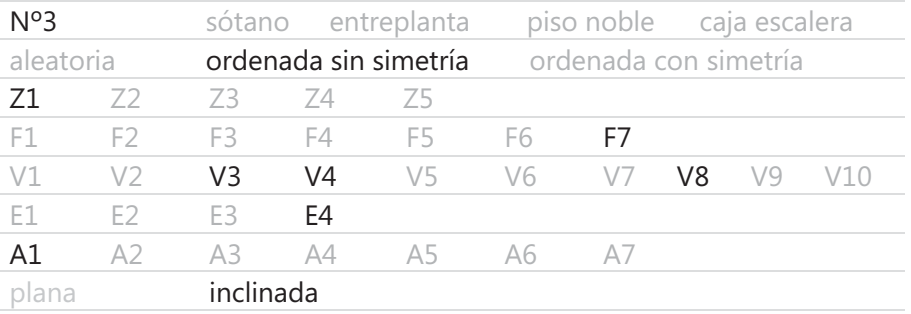

Va101

Aparejo
Hiladas
Superficie
Sección (hipótesis)
Elementos destacados

\begin{tabular}{lll} 
soga-tizón & soga & \multicolumn{1}{c}{ tizón } \\
irregulares & pseudo horizontales & horizontales \\
\hline sin planeidad & pseudo planeidad & planeidad perfecta \\
\hline uniforme & hojas y núcleo & abocinada (vano) \\
aplantillado & cortado terracota & $\mathrm{v}$ \\
\hline
\end{tabular}




\begin{tabular}{|c|c|c|c|}
\hline \multirow{2}{*}{$\begin{array}{l}\mathrm{N}^{\circ} \text { elementos medidos } \\
\text { Longitud }(\mathrm{cm})\end{array}$} & \multicolumn{3}{|l|}{15} \\
\hline & \multicolumn{3}{|l|}{30.1} \\
\hline Anchura (cm) & \multicolumn{3}{|l|}{13.5} \\
\hline Espesor (cm) & \multicolumn{3}{|l|}{3.5} \\
\hline Volumen $\left(\mathrm{cm}^{3}\right)$ & \multicolumn{3}{|l|}{1422.2} \\
\hline Tipo & homogéneo & heterogéneo & re-empleo \\
\hline \multirow{4}{*}{$\begin{array}{l}\text { Color } \\
\text { Recogida de muestra } \\
\text { Patologías }\end{array}$} & homogéneo & heterogéneo globular & heterogéneo marmolado \\
\hline & no & sí & código \\
\hline & eflorescencias & micro fisuración & grietas \\
\hline & erosión & disgregación & descamación \\
\hline
\end{tabular}

1 Datos obtenidos en base al cálculo del desvío estándar (respecto al valor medio de la muestras analizadas) y del gráfico de frecuencia de las muestras analizadas, identificado por una curva gaussiana

Juntas 2

Va101

\begin{tabular}{|c|c|c|c|c|}
\hline \multirow{2}{*}{$\begin{array}{l}N^{\circ} \text { elementos medidos } \\
\text { Llaga }(\mathrm{cm})\end{array}$} & \multicolumn{4}{|l|}{15} \\
\hline & \multicolumn{4}{|l|}{1.1} \\
\hline \multirow{4}{*}{$\begin{array}{l}\text { Tendel }(\mathrm{cm}) \\
\text { Altura de } 5 \text { hiladas (cm) } \\
\text { Proporción ladrillo/junta } \\
\text { Tipo de acabado }\end{array}$} & \multicolumn{4}{|l|}{3.3} \\
\hline & \multicolumn{4}{|l|}{34} \\
\hline & \multicolumn{4}{|l|}{1.06} \\
\hline & simple & doble & múltiple & \\
\hline \multirow[t]{2}{*}{ Junta de asiento } & rehundida & a hueso & saliente & \\
\hline & enrasada & matada & & \\
\hline \multirow[t]{2}{*}{ Junta de acabado } & rehundida & a hueso & saliente & \\
\hline & enrasada & matada & & \\
\hline \multirow{3}{*}{$\begin{array}{l}\text { Tipo de mortero } \\
\text { Morfología de mortero } \\
\text { Tipo de árido }\end{array}$} & cal & cal y tierra & tierra & cemento mixto \\
\hline & con grumos & con caliches & homogéneo & heterogéneo \\
\hline & arena & gravilla & grava & mixto \\
\hline \multirow{4}{*}{$\begin{array}{l}\text { Color del árido } \\
\text { Recogida de muestra } \\
\text { Patologías }\end{array}$} & claro & oscuro & homogéneo & heterogéneo \\
\hline & no & sí & código & \\
\hline & eflorescencias & micro fisuración & grietas & \\
\hline & & & pulverización & \\
\hline
\end{tabular}




\section{Imágenes}

Va101
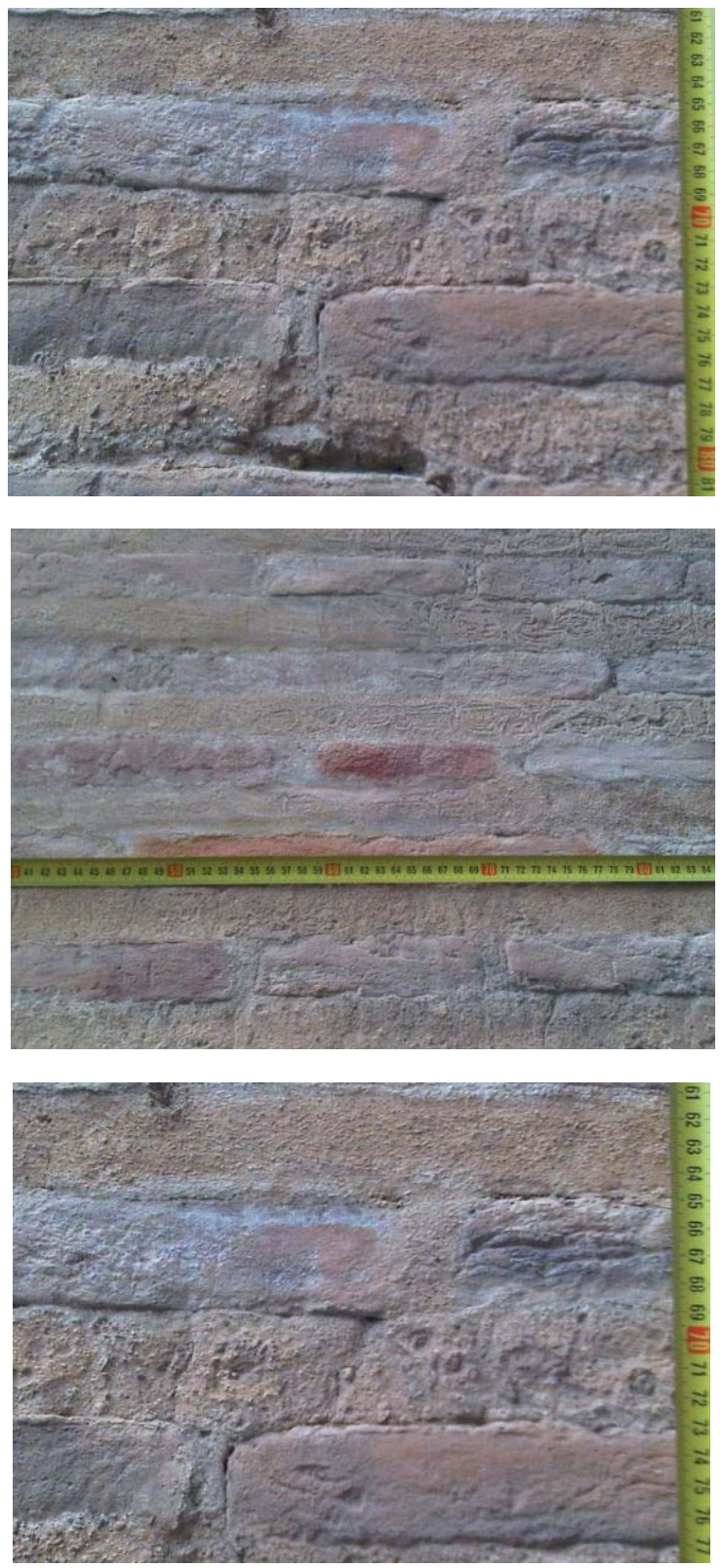

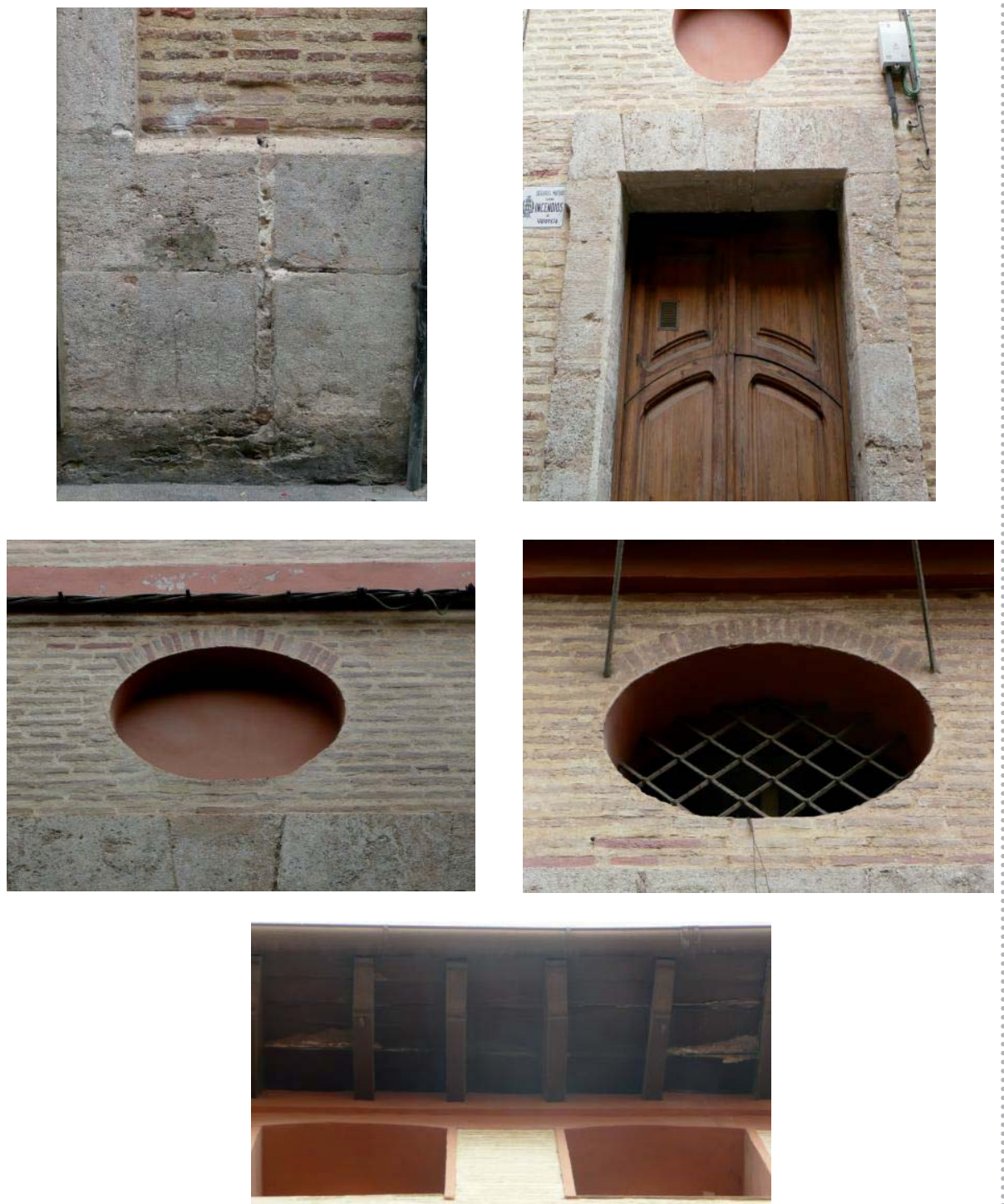


\section{Va103a}

\begin{tabular}{|c|c|c|c|c|c|}
\hline Barrio & Carmen & La Seu-Xerea & Velluters & Mercat & S.Francesc \\
\hline Dirección & C/Carnicer & $s / n$ & & & \\
\hline Tipo de edificio & residencial & palaciego & religioso & militar & \\
\hline $\mathbf{G}^{\circ}$ de protección & 0 & 1 & 2 & 3 & \\
\hline Fechas claves & $1739-1773$ & ás-Gilabert-Puc & intervenci & 995-99（ & oler Verdú) \\
\hline
\end{tabular}
El apartado "fechas claves" se ha extraído de AA.W.., Guía de Arquitectura de Valencia, Icaro CTAV Ed., Valencia, 2007
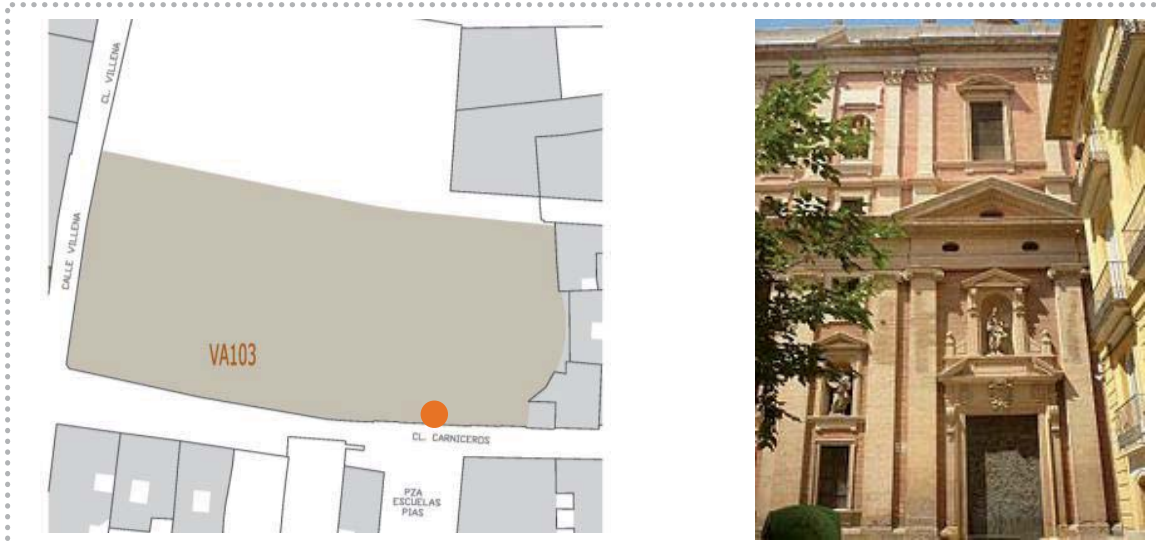

\section{Fachada}

\section{Va103a}

Pisos

Composición fachada

Zócalo

Fábrica

Vano/dintel

Entrada/dintel

Alero

Cubierta

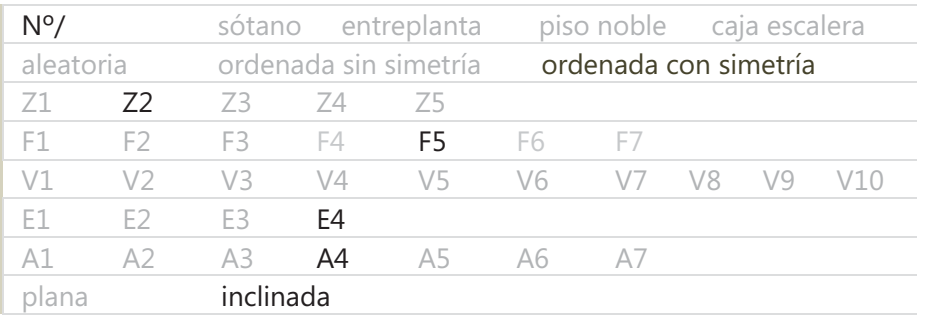

\section{Fábrica}

\section{Va103a}

Aparejo
Hiladas
Superficie
Sección (hipótesis)
Elementos destacados

soga-tizón

irregulares

sin planeidad

uniforme

aplantillado

\section{soga}

pseudo horizontales

horizontales

pseudo planeidad

planeidad perfecta

hojas y núcleo

cortado

terracota 


\begin{tabular}{|c|c|c|c|}
\hline \multirow{2}{*}{$\begin{array}{l}N^{0} \text { elementos medidos } \\
\text { Longitud }(\mathrm{cm})\end{array}$} & \multicolumn{3}{|l|}{15} \\
\hline & \multicolumn{3}{|l|}{31.1} \\
\hline Anchura (cm) & \multicolumn{3}{|l|}{14.6} \\
\hline Espesor (cm) & \multicolumn{3}{|l|}{4.2} \\
\hline Volumen $\left(\mathrm{cm}^{3}\right)$ & \multicolumn{3}{|l|}{1907} \\
\hline Tipo & homogéneo & heterogéneo & re-empleo \\
\hline \multirow{4}{*}{$\begin{array}{l}\text { Color } \\
\text { Recogida de muestra } \\
\text { Patologías }\end{array}$} & homogéneo & heterogéneo globular & heterogéneo marmolado \\
\hline & no & sí & código \\
\hline & eflorescencias & micro fisuración & grietas \\
\hline & erosión & disgregación & descamación \\
\hline
\end{tabular}

${ }^{1}$ Datos obtenidos en base al cálculo del desvío estándar (respecto al valor medio de la muestras analizadas) y del gráfico de frecuencia de las muestras analizadas, identificado por una curva gaussiana

\section{untas unt $^{2}$}

Va103a

\begin{tabular}{|c|c|c|c|c|}
\hline \multirow{2}{*}{$\begin{array}{l}N^{\circ} \text { elementos medidos } \\
\text { Llaga }(\mathrm{cm})\end{array}$} & \multicolumn{4}{|l|}{15} \\
\hline & \multicolumn{4}{|l|}{1.2} \\
\hline \multirow{4}{*}{$\begin{array}{l}\text { Tendel }(\mathrm{cm}) \\
\text { Altura de } 5 \text { hiladas (cm) } \\
\text { Proporción ladrillo/junta } \\
\text { Tipo de acabado }\end{array}$} & \multicolumn{4}{|l|}{4} \\
\hline & \multicolumn{4}{|l|}{39} \\
\hline & \multicolumn{4}{|l|}{1.07} \\
\hline & simple & doble & múltiple & \\
\hline \multirow[t]{2}{*}{ Junta de asiento } & rehundida & a hueso & saliente & \\
\hline & enrasada & matada & & \\
\hline \multirow[t]{2}{*}{ Junta de acabado } & rehundida & a hueso & saliente & \\
\hline & enrasada & matada & & \\
\hline \multirow{3}{*}{$\begin{array}{l}\text { Tipo de mortero } \\
\text { Morfología de mortero } \\
\text { Tipo de árido }\end{array}$} & cal & cal y tierra & tierra & cemento mixto \\
\hline & con grumos & con caliches & homogéneo & heterogéneo \\
\hline & arena & gravilla & grava & mixto \\
\hline \multirow{4}{*}{$\begin{array}{l}\text { Color del árido } \\
\text { Recogida de muestra } \\
\text { Patologías }\end{array}$} & claro & oscuro & homogéneo & heterogéneo \\
\hline & no & sí & código & \\
\hline & eflorescencias & micro fisuración & grietas & \\
\hline & & & pulverización & \\
\hline
\end{tabular}


Imágenes

Va103a
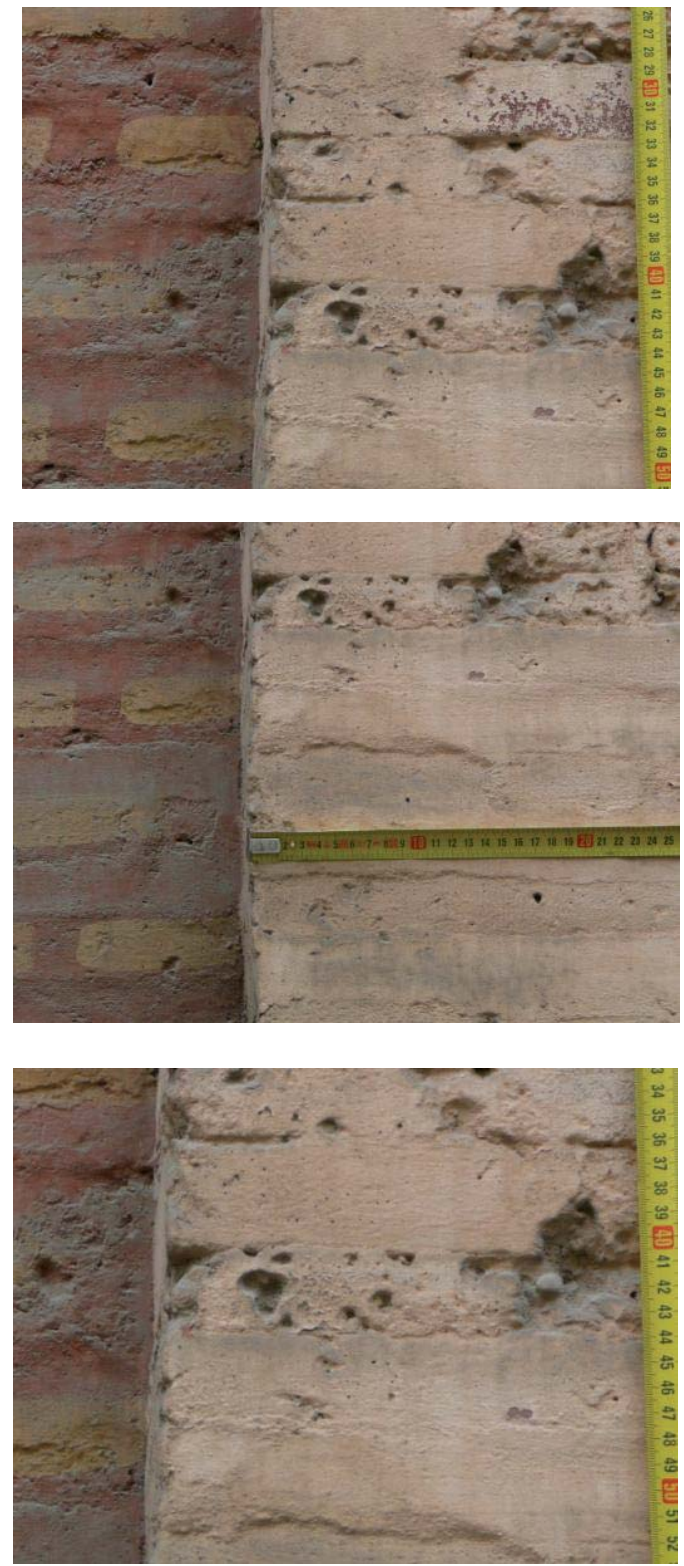

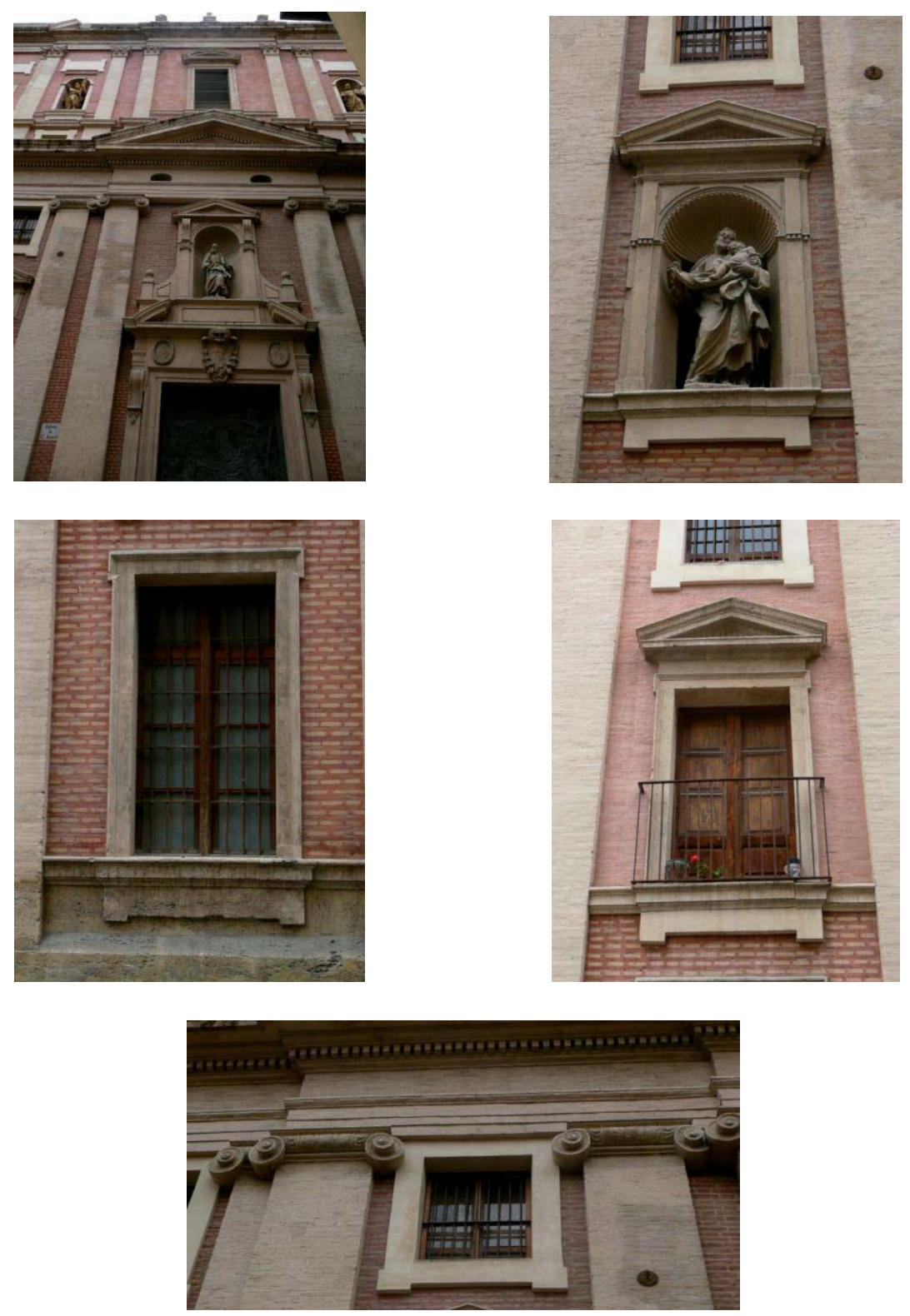


\begin{tabular}{|c|c|c|c|c|c|}
\hline Barrio & Carmen & La Seu-Xerea & Velluters & Mercat & S.Francesc \\
\hline Dirección & C/Carnicer & $n^{\circ} 6$ & & & \\
\hline Tipo de edificio & residencial & palaciego & religioso & militar & \\
\hline$G^{\circ}$ de protección & 0 & 1 & 2 & 3 & \\
\hline Fechas claves & $1739-1773$ & ás-Gilabert-Puç & intervenci & 995-99 ( & oler Verdú) \\
\hline
\end{tabular}
El apartado "fechas claves" se ha extraído de AA.V. ., Guía de Arquitectura de Valencia, Icaro CTAV Ed, Valencia, 2007

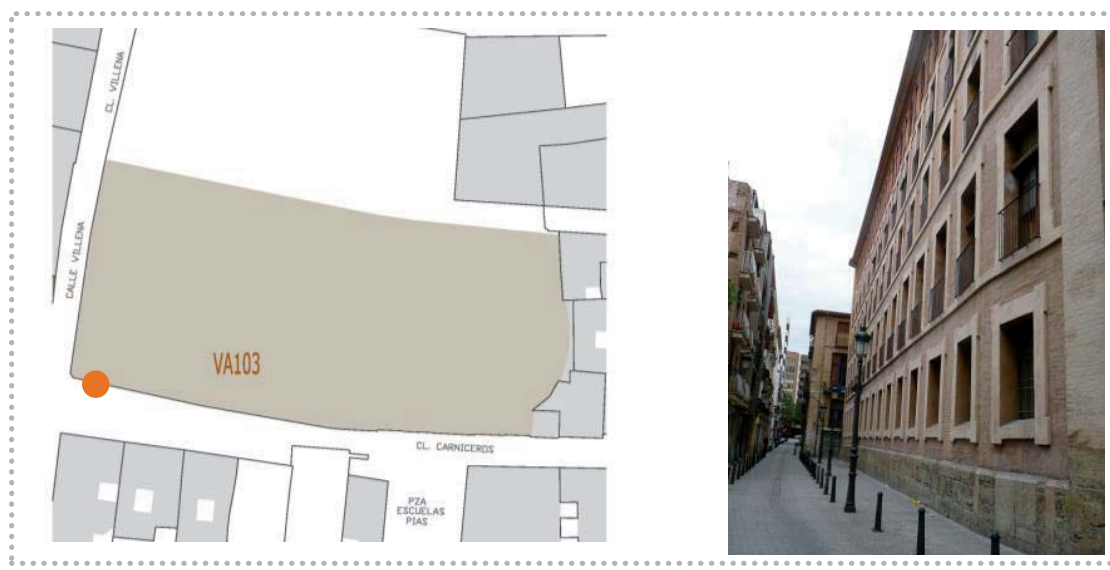

\section{Fachada}

Va103b

Pisos
Composición fachada
Zócalo
Fábrica
Vano/dintel
Entrada/dintel
Alero
Cubierta

\begin{tabular}{|c|c|c|c|c|c|c|c|}
\hline \multirow{3}{*}{\multicolumn{2}{|c|}{$\begin{array}{l}\mathrm{N}^{0} 4 \\
\text { aleatoria }\end{array}$}} & sótano & entreplanta & \multicolumn{4}{|c|}{ piso noble caja escalera } \\
\hline & & \multicolumn{2}{|c|}{ ordenada sin simetría } & \multicolumn{4}{|c|}{ ordenada con simetría } \\
\hline & & Z3 & Z5 & & & & \\
\hline F1 & F2 & F3 & F5 & F6 & & & \\
\hline V1 & V2 & V3 & V5 & V6 & V8 & V9 & V10 \\
\hline E1 & E2 & E3 & E4 & & & & \\
\hline A1 & A2 & A3 & A5 & A6 & & & \\
\hline \multicolumn{2}{|c|}{ plana } & \multicolumn{2}{|c|}{ inclinada } & & & & \\
\hline
\end{tabular}

\section{Fábrica}

Va103b

Aparejo
Hiladas
Superficie
Sección (hipótesis)
Elementos destacados

\begin{tabular}{|lll}
\hline soga-tizón & soga & \\
irregulares & pseudo horizontales & horizontales \\
\hline sin planeidad & pseudo planeidad & planeidad perfecta \\
\hline uniforme & hojas y núcleo & abocinada (vano) \\
\hline aplantillado & cortado terracota & \\
\hline
\end{tabular}




\begin{tabular}{|c|c|c|c|}
\hline \multirow{2}{*}{$\begin{array}{l}\mathrm{N}^{\circ} \text { elementos medidos } \\
\text { Longitud }(\mathrm{cm})\end{array}$} & \multicolumn{3}{|l|}{15} \\
\hline & \multicolumn{3}{|l|}{32} \\
\hline Anchura (cm) & \multicolumn{3}{|l|}{15} \\
\hline Espesor (cm) & \multicolumn{3}{|l|}{4.5} \\
\hline Volumen $\left(\mathrm{cm}^{3}\right)$ & \multicolumn{3}{|l|}{1856.4} \\
\hline Tipo & homogéneo & heterogéneo & re-empleo \\
\hline \multirow{4}{*}{$\begin{array}{l}\text { Color } \\
\text { Recogida de muestra } \\
\text { Patologías }\end{array}$} & homogéneo & heterogéneo globular & heterogéneo marmolado \\
\hline & no & sí & código \\
\hline & eflorescencias & micro fisuración & grietas \\
\hline & erosión & disgregación & descamación \\
\hline
\end{tabular}

${ }^{1}$ Datos obtenidos en base al cálculo del desvío estándar (respecto al valor medio de la muestras analizadas) y del gráfico de frecuencia de las muestras analizadas, identificado por una curva gaussiana

\section{Juntas}

Va103b

\begin{tabular}{|c|c|c|c|c|}
\hline \multirow{2}{*}{$\begin{array}{l}N^{\circ} \text { elementos medidos } \\
\text { Llaga }(\mathrm{cm})\end{array}$} & \multicolumn{4}{|l|}{15} \\
\hline & \multicolumn{4}{|l|}{1} \\
\hline \multirow{4}{*}{$\begin{array}{l}\text { Tendel (cm) } \\
\text { Altura de } 5 \text { hiladas (cm) } \\
\text { Proporción ladrillo/junta } \\
\text { Tipo de acabado }\end{array}$} & \multicolumn{4}{|l|}{3.5} \\
\hline & \multicolumn{4}{|l|}{40} \\
\hline & \multicolumn{4}{|l|}{1.2} \\
\hline & simple & doble & múltiple & \\
\hline \multirow[t]{2}{*}{ Junta de asiento } & rehundida & a hueso & saliente & \\
\hline & enrasada & matada & & \\
\hline \multirow[t]{2}{*}{ Junta de acabado } & rehundida & a hueso & saliente & \\
\hline & enrasada & matada & & \\
\hline \multirow{2}{*}{$\begin{array}{l}\text { Tipo de mortero } \\
\text { Morfología de mortero }\end{array}$} & cal & cal y tierra & tierra & cemento mixto \\
\hline & con grumos & con caliches & homogéneo & heterogéneo \\
\hline \multirow{3}{*}{$\begin{array}{l}\text { Tipo de árido } \\
\text { Color del árido } \\
\text { Recogida de muestra }\end{array}$} & arena & gravilla & grava & mixto \\
\hline & claro & oscuro & homogéneo & heterogéneo \\
\hline & no & sí & código & \\
\hline \multirow[t]{2}{*}{ Patologías } & eflorescencias & micro fisuración & grietas & \\
\hline & erosión" & disgregación & pulverización & \\
\hline
\end{tabular}


Imágenes

Va103b
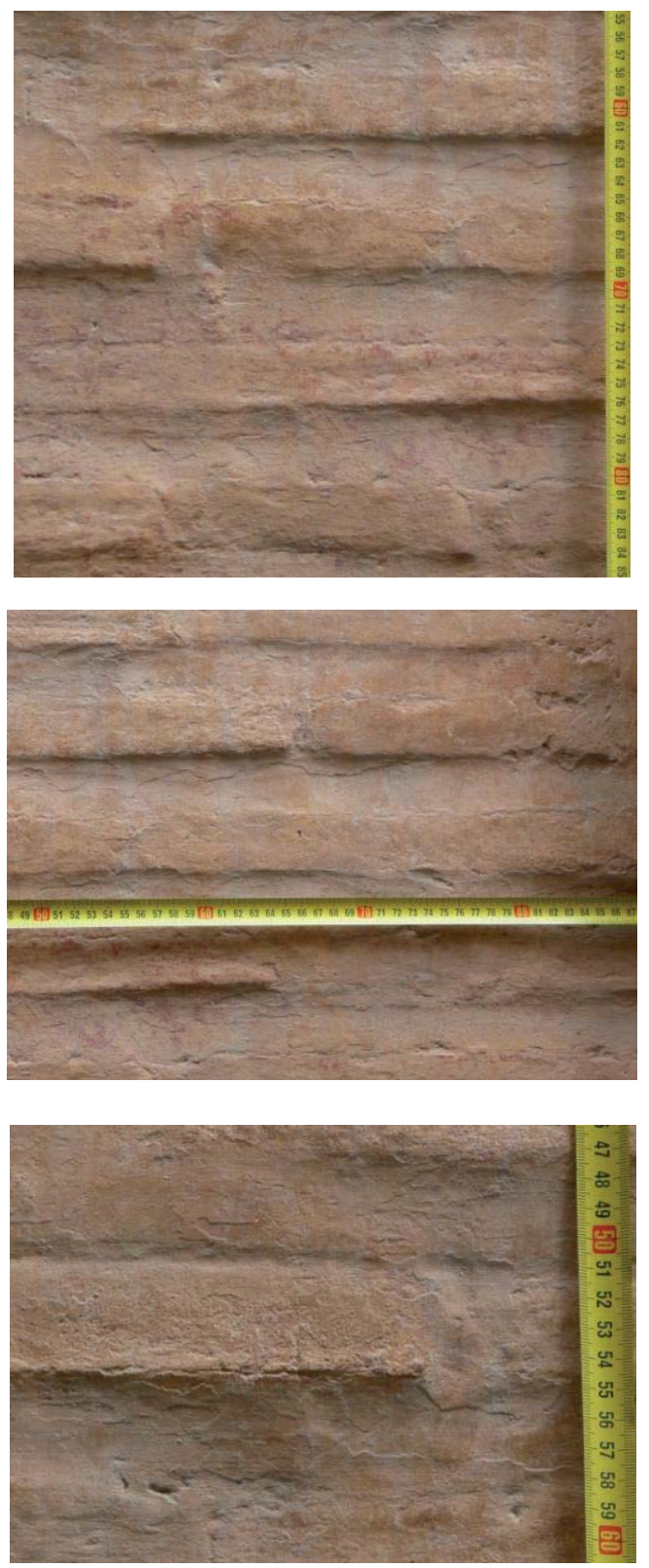

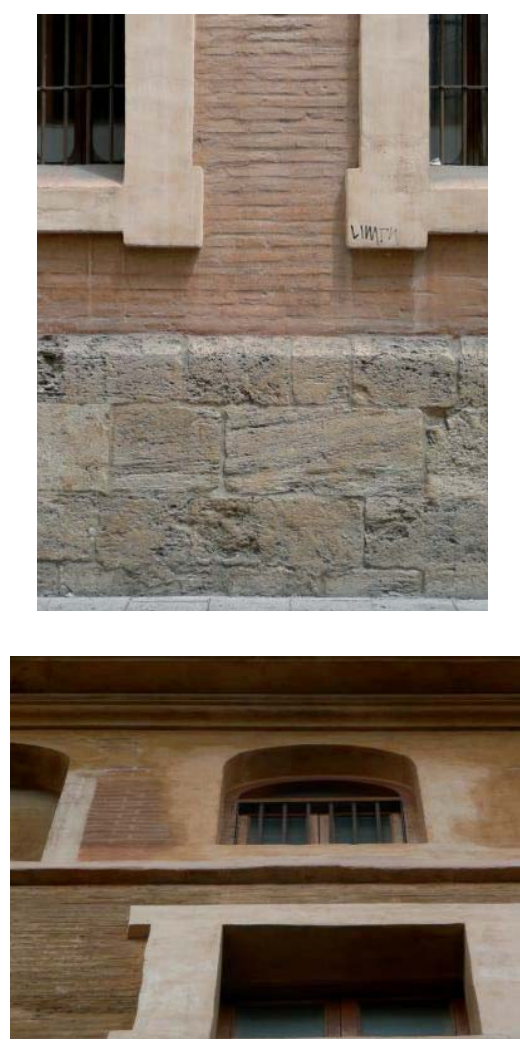
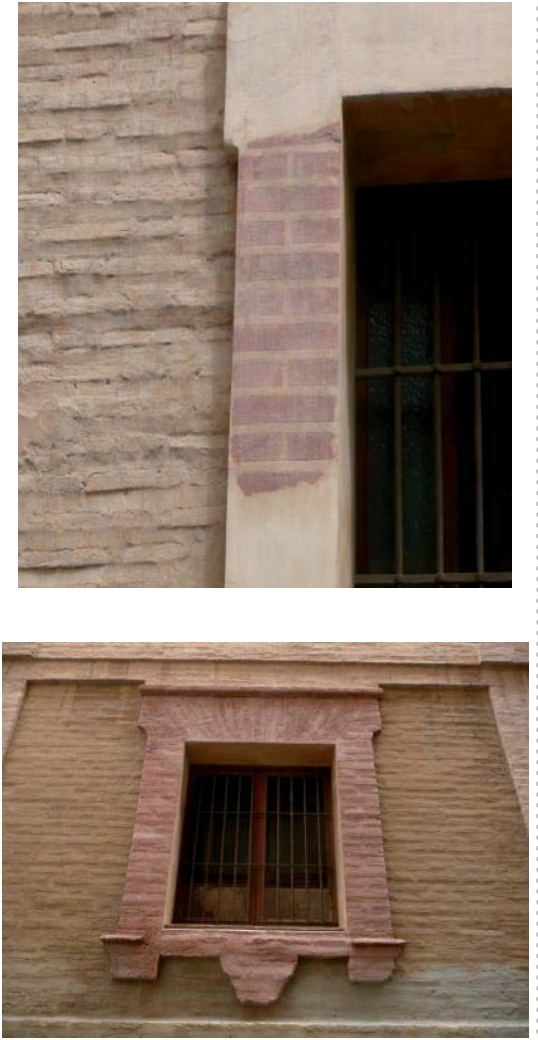


\section{Datos generales}

\section{Va104}

\begin{tabular}{|c|c|c|c|c|c|}
\hline Barrio & Carmen & La Seu-Xerea & Velluters & Mercat & S.Francesc \\
\hline Dirección & C/Carnicero & $n \circ 8$ & & & \\
\hline Tipo de edificio & residencial & palaciego & religioso & militar & \\
\hline $\mathbf{G}^{\circ}$ de protección & 0 & 1 & 2 & 3 & \\
\hline Fechas claves & / & & & & \\
\hline
\end{tabular}

El apartado "fechas claves" se ha extraído de AA.V.., Guía de Arquitectura de Valencia, Icaro CTAV Ed., Valencia, 2007

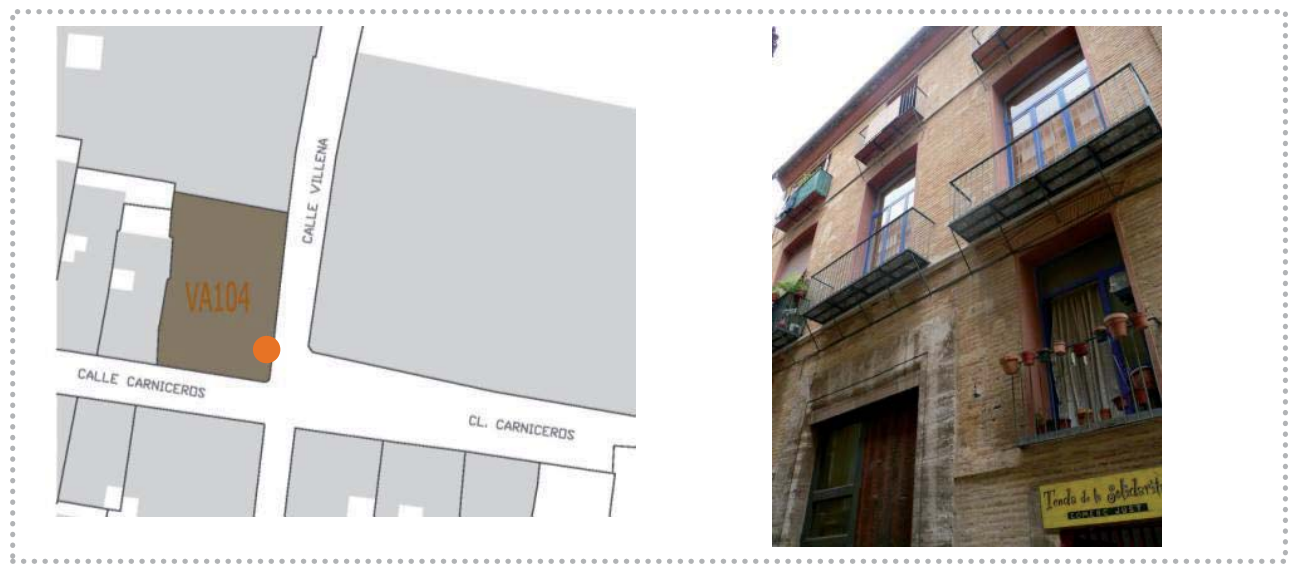

Fachada

Va104

\begin{tabular}{|c|c|c|c|c|c|c|c|c|c|c|}
\hline \multirow{3}{*}{$\begin{array}{l}\text { Pisos } \\
\text { Composición fachada } \\
\text { Zócalo }\end{array}$} & \multicolumn{2}{|c|}{$N^{\circ} 3$} & sót & \multicolumn{2}{|c|}{ entreplanta } & \multicolumn{5}{|c|}{ piso noble caja escalera } \\
\hline & \multicolumn{2}{|c|}{ aleatoria } & \multicolumn{3}{|c|}{ ordenada sin simetría } & \multicolumn{5}{|c|}{ ordenada con simetría } \\
\hline & Z1 & $\mathrm{Z} 2$ & Z3 & Z4 & Z5 & & & & & \\
\hline Fábrica & $\mathrm{F} 1$ & $\mathrm{~F} 2$ & F3 & $\mathrm{F} 4$ & F5 & F6 & F7 & & & \\
\hline Vano/dintel & V1 & V2 & V3 & V4 & V5 & V6 & V7 & V8 & V9 & V10 \\
\hline Entrada/dintel & E1 & E2 & E3 & E4 & & & & & & \\
\hline Alero & A1 & $\mathrm{A} 2$ & A3 & A4 & A5 & A6 & A7 & & & \\
\hline Cubierta & pla & & inc & & & & & & & \\
\hline
\end{tabular}

\section{Fábrica}

\section{Va104}

\section{Aparejo \\ Hiladas \\ Superficie \\ Sección (hipótesis) \\ Elementos destacados}

\begin{tabular}{lll} 
soga-tizón & soga tizón & \\
irregulares & pseudo horizontales & horizontales \\
\hline sin planeidad & pseudo planeidad & planeidad perfecta \\
\hline uniforme & hojas y núcleo & abocinada (vano) \\
aplantillado & cortado terracota & \\
\hline
\end{tabular}




\begin{tabular}{|c|c|c|c|}
\hline$N^{\circ}$ elementos medidos & 15 & & \\
\hline Longitud (cm) & 27 & & \\
\hline Anchura (cm) & 12.1 & & \\
\hline Espesor (cm) & 3.5 & & \\
\hline Volumen $\left(\mathrm{cm}^{3}\right)$ & 1143.45 & & \\
\hline Tipo & homogéneo & heterogéneo & re-empleo \\
\hline Color & homogéneo & heterogéneo globular & heterogéneo marmolado \\
\hline Recogida de muestra & no & sí & código \\
\hline Patologías & $\begin{array}{l}\text { eflorescencias } \\
\text { erosión }\end{array}$ & $\begin{array}{l}\text { micro fisuración } \\
\text { disgregación }\end{array}$ & $\begin{array}{l}\text { grietas } \\
\text { descamación }\end{array}$ \\
\hline
\end{tabular}

${ }^{1}$ Datos obtenidos en base al cálculo del desvío estándar (respecto al valor medio de la muestras analizadas) y del gráfico de frecuencia de las muestras analizadas, identificado por una curva gaussiana

\section{untas}

\begin{tabular}{|c|c|c|c|c|}
\hline \multirow{2}{*}{$\begin{array}{l}N^{\circ} \text { elementos medidos } \\
\text { Llaga }(\mathrm{cm})\end{array}$} & \multicolumn{4}{|l|}{15} \\
\hline & \multicolumn{4}{|l|}{2.1} \\
\hline Tendel (cm) & \multicolumn{4}{|l|}{4.1} \\
\hline Altura de 5 hiladas $(\mathrm{cm})$ & \multicolumn{4}{|l|}{38.3} \\
\hline Proporción ladrillo/junta & \multicolumn{4}{|l|}{0.8} \\
\hline Tipo de acabado & simple & doble & \multicolumn{2}{|l|}{ múltiple } \\
\hline \multirow[t]{2}{*}{ Junta de asiento } & rehundida & a hueso & \multirow{2}{*}{\multicolumn{2}{|c|}{ saliente }} \\
\hline & enrasada & matada & & \\
\hline \multirow[t]{2}{*}{ Junta de acabado } & rehundida & a hueso & \multirow{2}{*}{\multicolumn{2}{|c|}{ saliente }} \\
\hline & enrasada & matada & & \\
\hline \multirow{3}{*}{$\begin{array}{l}\text { Tipo de mortero } \\
\text { Morfología de mortero } \\
\text { Tipo de árido }\end{array}$} & cal & cal y tierra & tierra & cemento mixto \\
\hline & con grumos & con caliches & homogéneo & heterogéneo \\
\hline & arena & gravilla & grava & mixto \\
\hline \multirow{4}{*}{$\begin{array}{l}\text { Color del árido } \\
\text { Recogida de muestra } \\
\text { Patologías }\end{array}$} & claro & oscuro & homogéneo & heterogéneo \\
\hline & no & sí & \multicolumn{2}{|l|}{ código } \\
\hline & eflorescencias & micro fisuración & \multicolumn{2}{|l|}{ grietas } \\
\hline & erosión & disgregación & \multicolumn{2}{|l|}{ pulverización } \\
\hline
\end{tabular}


Imágenes

Va104
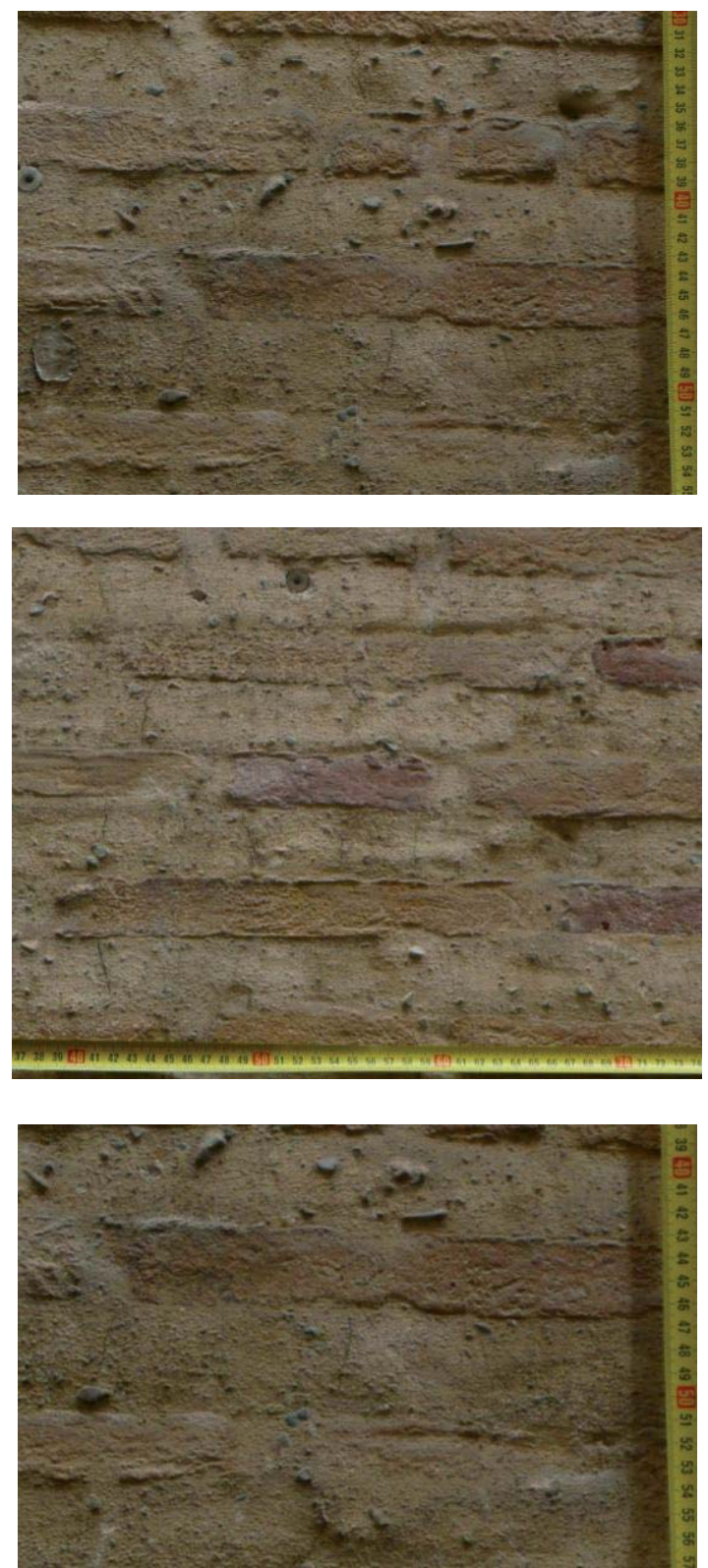

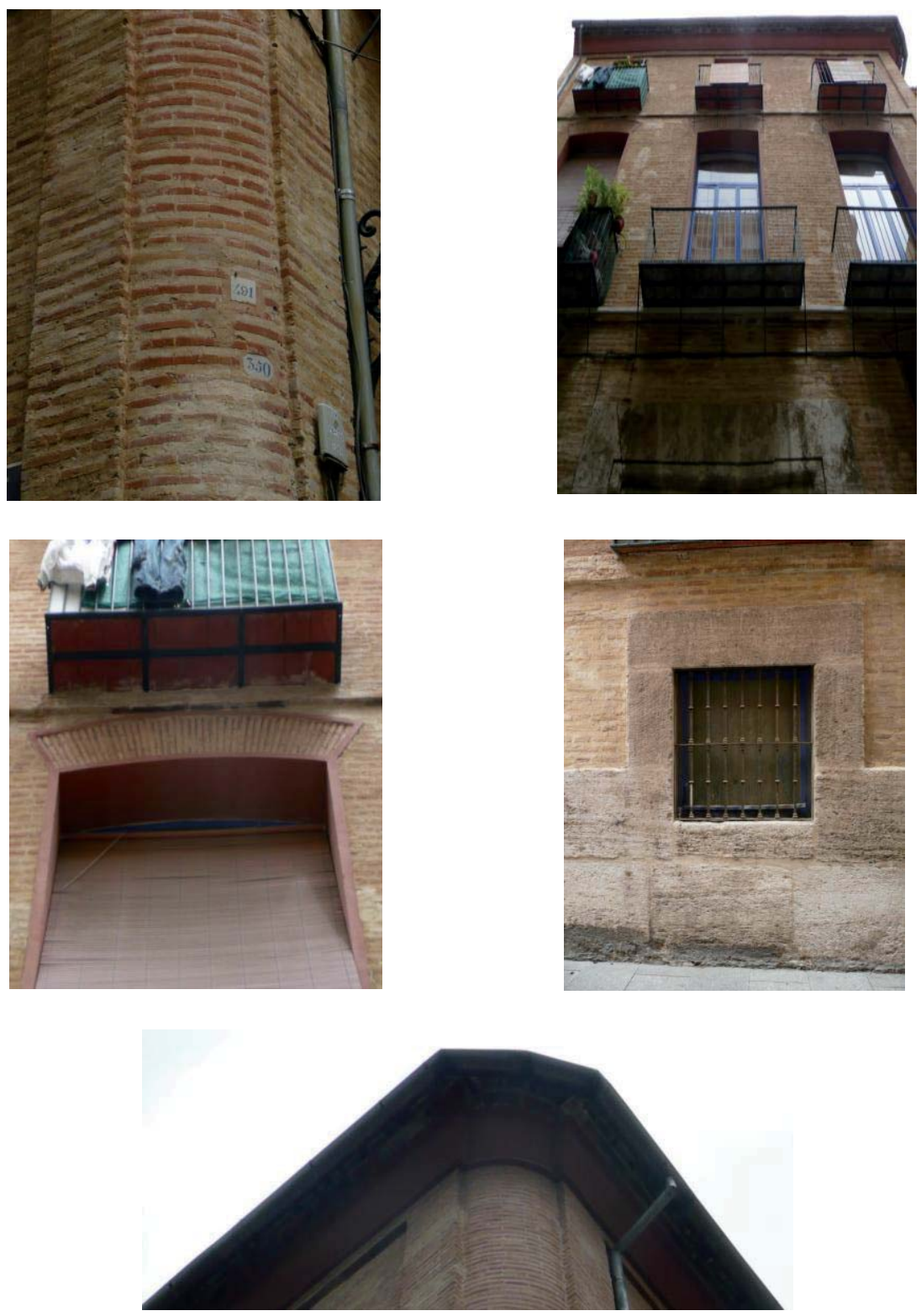
Datos generales

\begin{tabular}{|c|c|c|c|c|c|}
\hline Barrio & Carmen & La Seu-Xerea & Velluters & Mercat & S.Francesc \\
\hline Dirección & C/Carnicero & $n^{\circ} 22$ & & & \\
\hline Tipo de edificio & residencial & palaciego & religioso & militar & \\
\hline $\mathbf{G}^{\circ}$ de protección & 0 & 1 & 2 & 3 & \\
\hline Fechas claves & / & & & & \\
\hline
\end{tabular}

El apartado "fechas claves" se ha extraído de AA.W., Guía de Arquitectura de Valencia, Icaro CTAV Ed., Valencia, 2007

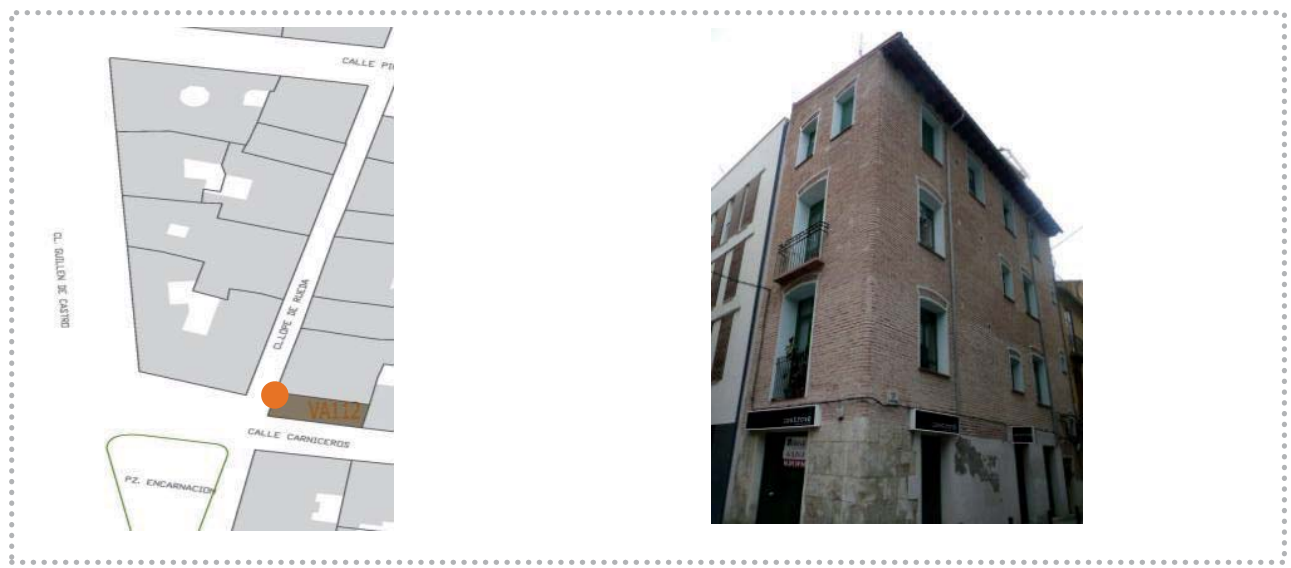

\section{Fachada}

\section{Va112}

Pisos

Composición fachada

Zócalo

Fábrica

Vano/dintel

Entrada/dintel

Alero

Cubierta

\begin{tabular}{|c|c|c|c|c|c|c|c|c|}
\hline \multirow{2}{*}{\multicolumn{2}{|c|}{$\begin{array}{l}\mathrm{N}^{03} \\
\text { aleatoria }\end{array}$}} & sótano & & planta & \multicolumn{4}{|c|}{ piso noble caja escalera } \\
\hline & & \multicolumn{3}{|c|}{ ordenada sin simetría } & \multicolumn{4}{|c|}{ ordenada con simetría } \\
\hline $\mathrm{Z1}$ & $\mathrm{Z} 2$ & Z3 & Z4 & $\mathrm{Z} 5$ & & & & \\
\hline $\mathrm{F} 1$ & $\mathrm{~F} 2$ & F3 & F4 & F5 & F6 & & & \\
\hline V1 & V2 & V3 & V4 & V5 & V6 & V8 & V9 & V10 \\
\hline E1 & E2 & E3 & E4 & & & & & \\
\hline A1 & $\mathrm{A} 2$ & A3 & A4 & A5 & A6 & & & \\
\hline
\end{tabular}

Va112

\begin{tabular}{lll} 
soga-tizón & soga & \multicolumn{1}{c}{ tizón } \\
irregulares & pseudo horizontales & horizontales \\
\hline sin planeidad & pseudo planeidad & planeidad perfecta \\
\hline uniforme & hojas y núcleo & abocinada (vano) \\
aplantillado & cortado terracota & \\
\hline
\end{tabular}




$N^{\circ}$ elementos medidos
Longitud $(\mathrm{cm})$
Anchura $(\mathrm{cm})$
Espesor $(\mathrm{cm})$
Volumen $\left(\mathrm{cm}^{3}\right)$

Tipo

Color

Recogida de muestra

Patologías

\section{5}

30.1

14.1

4.5

1909.8

\begin{tabular}{lll} 
homogéneo & heterogéneo & re-empleo \\
\hline homogéneo & heterogéneo globular & heterogéneo marmolado \\
\hline no & sí & código \\
\hline eflorescencias & micro fisuración & grietas \\
erosión & disgregación & descamación
\end{tabular}

${ }^{1}$ Datos obtenidos en base al cálculo del desvio estándar (respecto al valor medio de la muestras analizadas) y del gráfico de frecuencia de las muestras analizadas, identificado por una curva gaussiana

\section{untas}

Va112

\begin{tabular}{|c|c|c|c|c|}
\hline \multirow{2}{*}{$\begin{array}{l}N^{\circ} \text { elementos medidos } \\
\text { Llaga }(\mathrm{cm})\end{array}$} & \multicolumn{4}{|l|}{15} \\
\hline & \multicolumn{4}{|l|}{1} \\
\hline Tendel (cm) & \multicolumn{4}{|l|}{4.1} \\
\hline Altura de 5 hiladas $(\mathrm{cm})$ & \multicolumn{4}{|l|}{40.5} \\
\hline Proporción ladrillo/junta & \multicolumn{4}{|l|}{1} \\
\hline Tipo de acabado & simple & doble & múltiple & \\
\hline \multirow[t]{2}{*}{ Junta de asiento } & rehundida & a hueso & saliente & \\
\hline & enrasada & matada & & \\
\hline \multirow[t]{2}{*}{ Junta de acabado } & rehundida & a hueso & saliente & \\
\hline & enrasada & matada & & \\
\hline \multirow{2}{*}{$\begin{array}{l}\text { Tipo de mortero } \\
\text { Morfología de mortero }\end{array}$} & cal & cal y tierra & tierra & cemento mixto \\
\hline & con grumos & con caliches & homogéneo & heterogéneo \\
\hline Tipo de árido & arena & gravilla & grava & mixto \\
\hline \multirow{2}{*}{$\begin{array}{l}\text { Color del árido } \\
\text { Recogida de muestra }\end{array}$} & claro & oscuro & homogéneo & heterogéneo \\
\hline & no & sí & código & \\
\hline \multirow[t]{2}{*}{ Patologías } & eflorescencias & micro fisuración & grietas & \\
\hline & erosión & disgregación & pulverización & \\
\hline
\end{tabular}


Imágenes
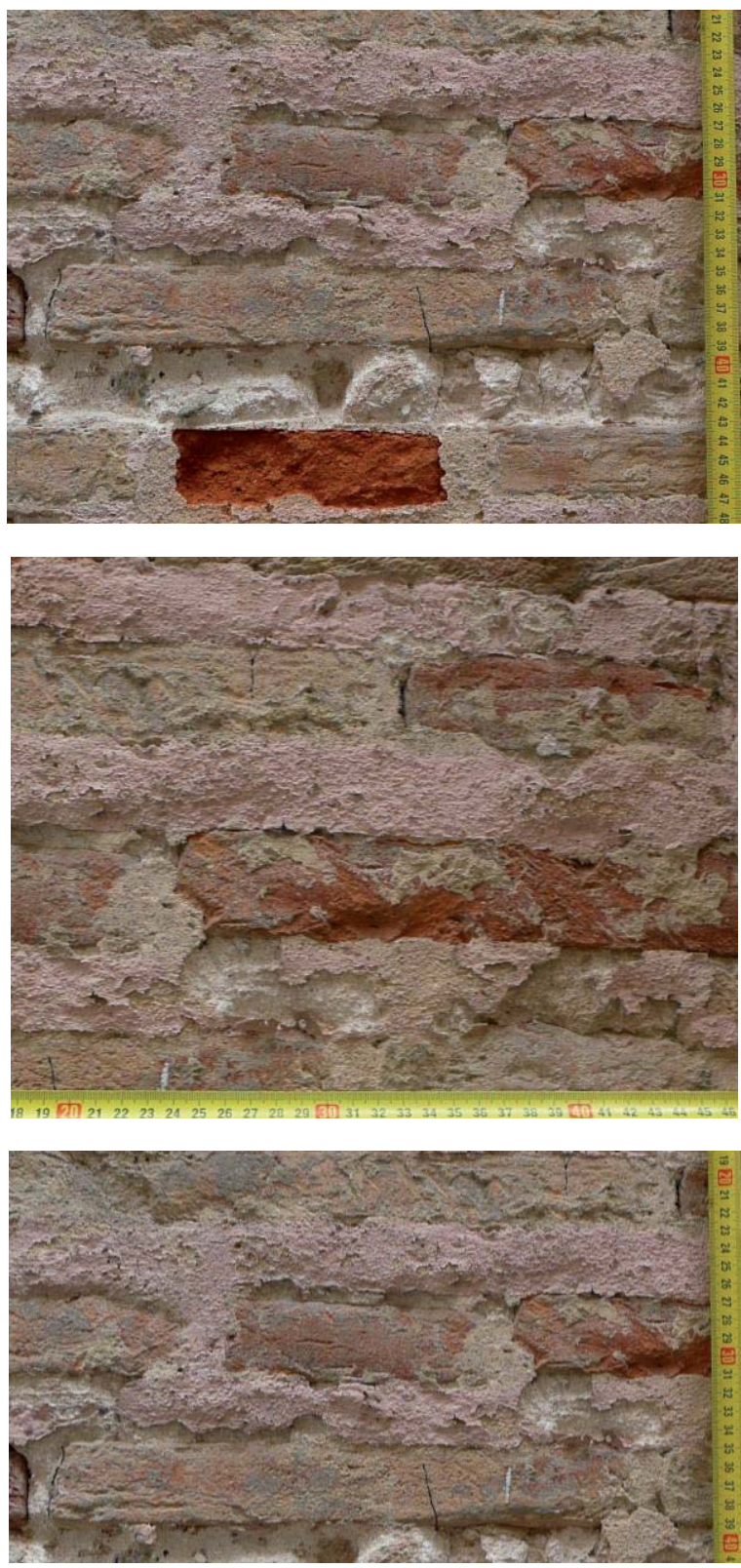

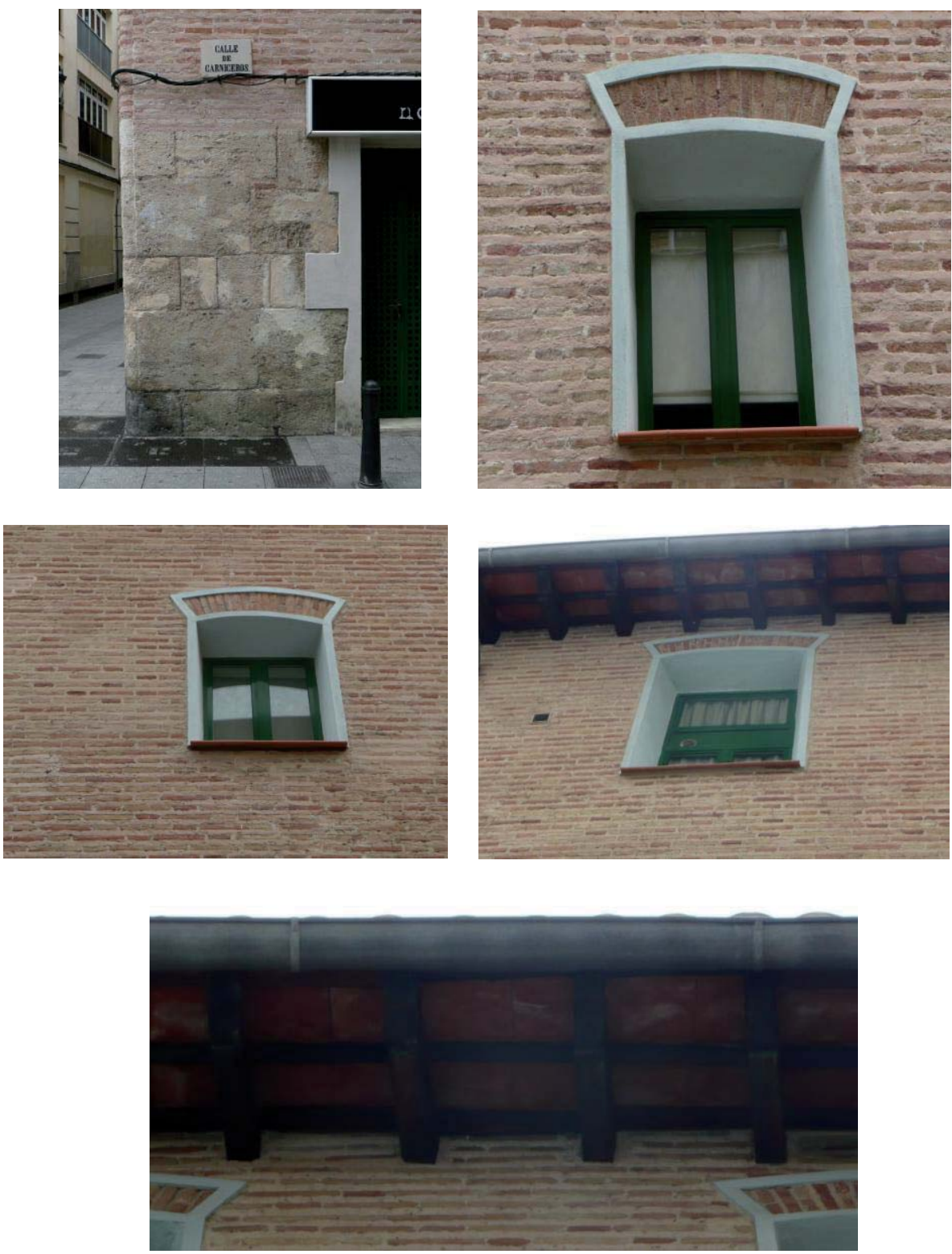
Datos generales

\section{Va119}

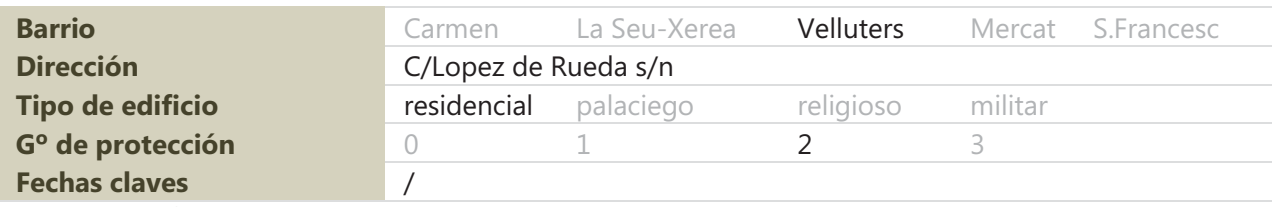

El apartado "fechas claves" se ha extraído de AA.V., Guía de Arquitectura de Valencia, Icaro CTAV Ed., Valencia, 2007

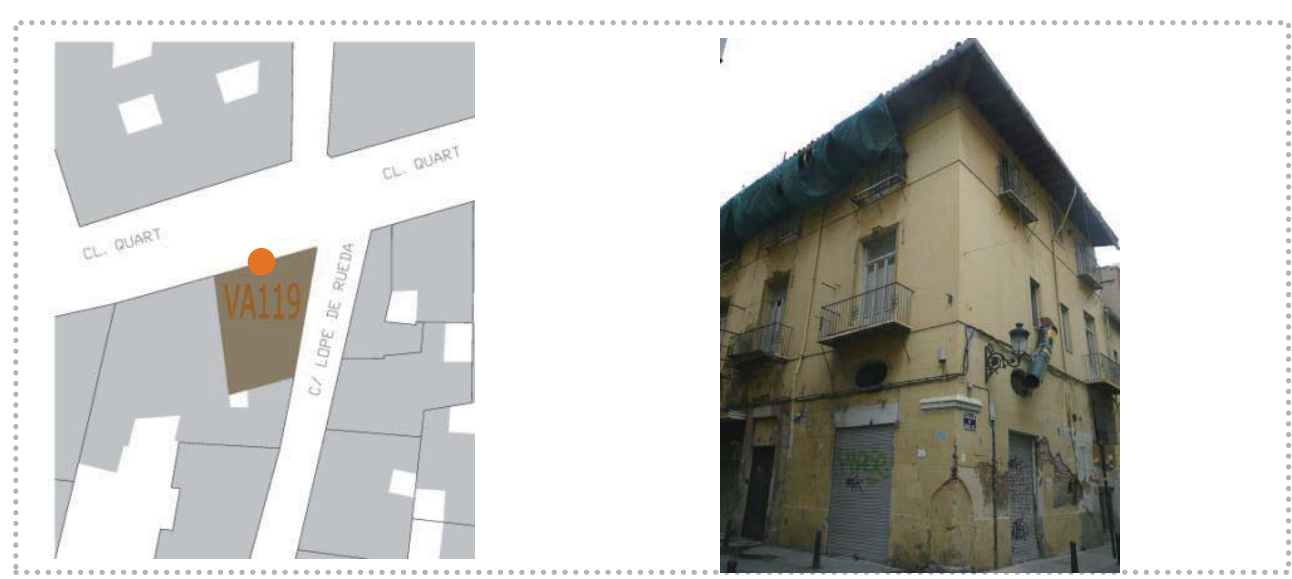

Fachada

Va119

Pisos
Composición fachada
Zócalo
Fábrica
Vano/dintel
Entrada/dintel
Alero
Cubierta

\begin{tabular}{|c|c|c|c|c|c|c|c|}
\hline \multirow{2}{*}{\multicolumn{2}{|c|}{$\begin{array}{l}\mathrm{N}^{0} 2 \\
\text { aleatoria }\end{array}$}} & sótano & entreplanta & \multicolumn{4}{|c|}{ piso noble caja escalera } \\
\hline & & \multicolumn{2}{|c|}{ ordenada sin simetría } & \multicolumn{4}{|c|}{ ordenada con simetría } \\
\hline Z1 & $\mathrm{Z} 2$ & Z3 & $\mathrm{Z} 5$ & & & & \\
\hline F1 & F2 & F3 & F4 & F6 & & & \\
\hline V1 & V2 & V3 & V4 & V6 & V8 & V9 & V10 \\
\hline E1 & E2 & E3 & E4 & & & & \\
\hline A1 & A2 & A3 & A5 & A6 & & & \\
\hline plar & & inclina & & & & & \\
\hline
\end{tabular}

Fábrica

Va119

\section{Aparejo \\ Hiladas \\ Superficie \\ Sección (hipótesis) \\ Elementos destacados}

\begin{tabular}{lll} 
soga-tizón & soga & \\
irregulares & pseudo horizontales & horizontales \\
\hline sin planeidad & pseudo planeidad & planeidad perfecta \\
\hline uniforme & hojas y núcleo & abocinada (vano) \\
aplantillado & cortado terracota & \\
\hline
\end{tabular}




\begin{tabular}{|c|c|c|c|}
\hline$N^{\circ}$ elementos medidos & 15 & & \\
\hline Longitud (cm) & 30.5 & & \\
\hline Anchura $(\mathrm{cm})$ & 14.2 & & \\
\hline Espesor (cm) & 3.1 & & \\
\hline Volumen $\left(\mathrm{cm}^{3}\right)$ & 1342.6 & & \\
\hline Tipo & homogéneo & heterogéneo & re-empleo \\
\hline Color & homogéneo & heterogéneo globular & heterogéneo marmolado \\
\hline Recogida de muestra & no & sí & código Va119/1 \\
\hline Patologías & $\begin{array}{l}\text { eflorescencias } \\
\text { erosión }\end{array}$ & $\begin{array}{l}\text { micro fisuración } \\
\text { disgregación }\end{array}$ & $\begin{array}{l}\text { grietas } \\
\text { descamación }\end{array}$ \\
\hline
\end{tabular}

1 Datos obtenidos en base al cálculo del desvío estándar (respecto al valor medio de la muestras analizadas) y del gráfico de frecuencia de las muestras analizadas, identificado por una curva gaussiana

\begin{tabular}{|c|c|c|c|c|}
\hline \multirow{2}{*}{$\begin{array}{l}N^{\circ} \text { elementos medidos } \\
\text { Llaga }(\mathrm{cm})\end{array}$} & \multicolumn{4}{|l|}{15} \\
\hline & \multicolumn{4}{|l|}{0.5} \\
\hline Tendel (cm) & \multicolumn{4}{|l|}{3.5} \\
\hline Altura de 5 hiladas (cm) & \multicolumn{4}{|l|}{42} \\
\hline Proporción ladrillo/junta & \multicolumn{4}{|l|}{0.8} \\
\hline Tipo de acabado & simple & doble & \multicolumn{2}{|l|}{ múltiple } \\
\hline \multirow[t]{2}{*}{ Junta de asiento } & rehundida & a hueso & \multirow{2}{*}{\multicolumn{2}{|c|}{ saliente }} \\
\hline & enrasada & matada & & \\
\hline \multirow[t]{2}{*}{ Junta de acabado } & rehundida & a hueso & \multirow{2}{*}{\multicolumn{2}{|c|}{ saliente }} \\
\hline & enrasada & matada & & \\
\hline \multirow{3}{*}{$\begin{array}{l}\text { Tipo de mortero } \\
\text { Morfología de mortero } \\
\text { Tipo de árido }\end{array}$} & cal & cal y tierra & tierra & cemento mixto \\
\hline & con grumos & con caliches & homogéneo & heterogéneo \\
\hline & arena & gravilla & grava & mixto \\
\hline Color del árido & claro & oscuro & homogéneo & heterogéneo \\
\hline Recogida de muestra & no & sí & \multicolumn{2}{|c|}{ código Va119/1 } \\
\hline Patologías & $\begin{array}{l}\text { eflorescencias } \\
\text { erosión" }\end{array}$ & $\begin{array}{l}\text { micro fisuración } \\
\text { disgregación }\end{array}$ & $\begin{array}{l}\text { grietas } \\
\text { pulverización }\end{array}$ & \\
\hline
\end{tabular}

2 Datos obtenidos en base al cálculo del desvio estándar (respecto al valor medio de la muestras analizadas) y del gráfico de frecuencia de las muestras analizadas, identificado por una curva gaussiana 
Imágenes

Va119
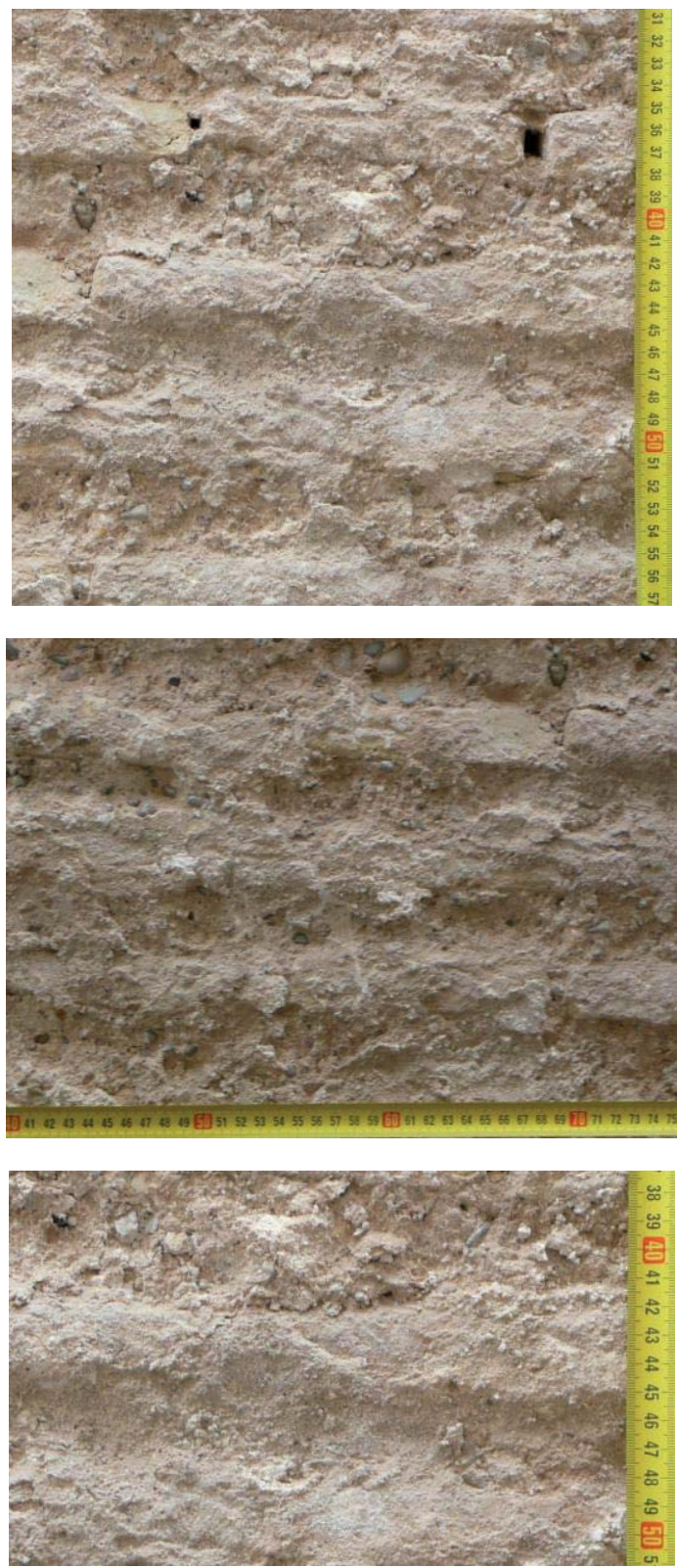

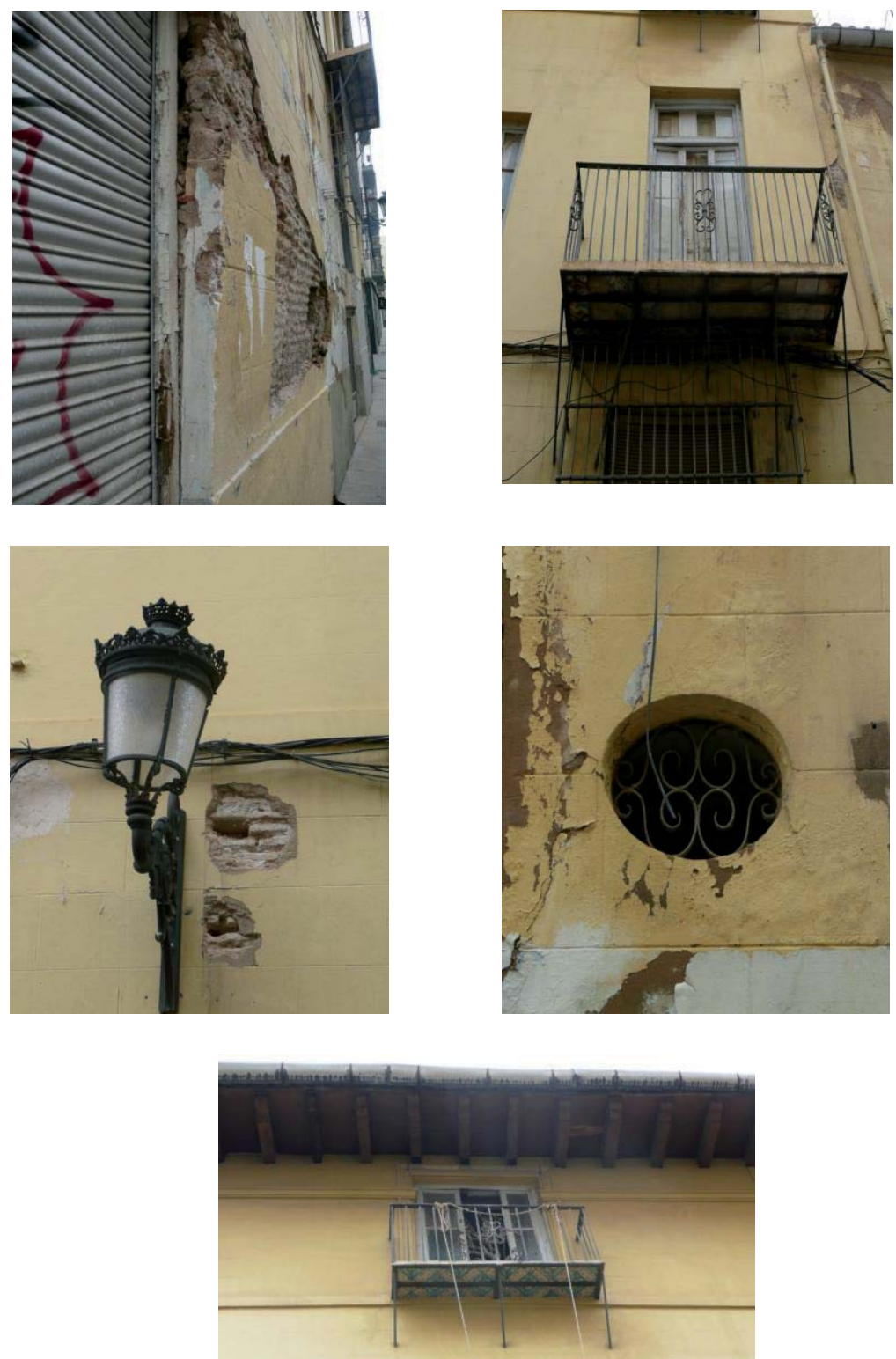
Datos generales

Vb22

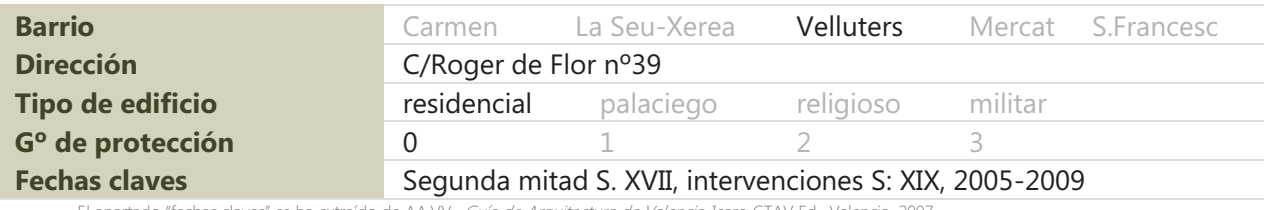

El apartado "fechas claves" se ha extraído de AA.V., Guía de Arquitectura de Valencia, Icaro CTAV Ed., Valencia, 2007
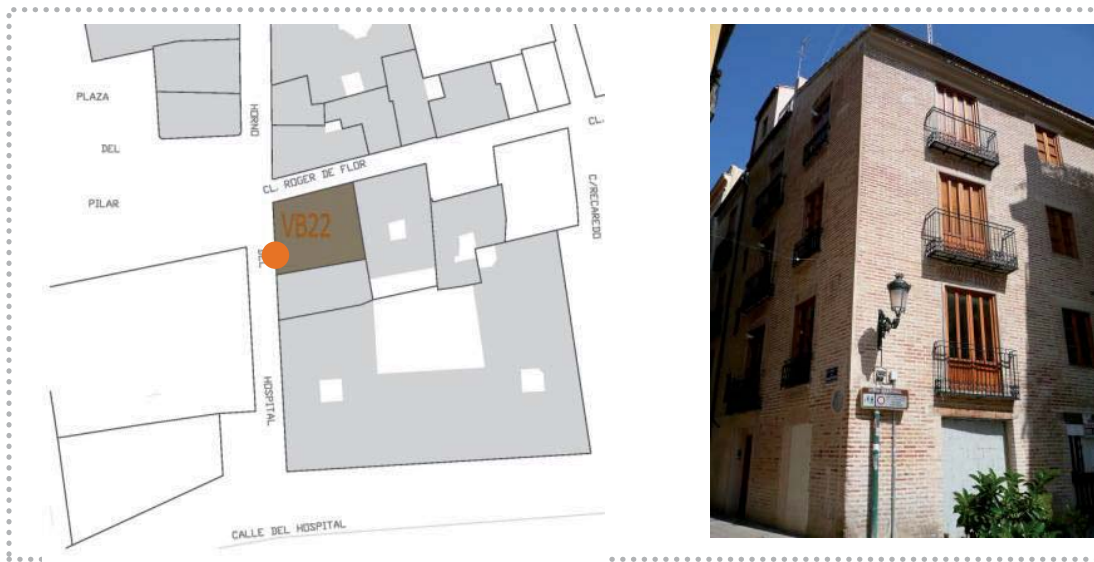

Fachada

Vb22

Pisos

Composición fachada

Zócalo

Fábrica

Vano/dintel

Entrada/dintel

Alero

Cubierta

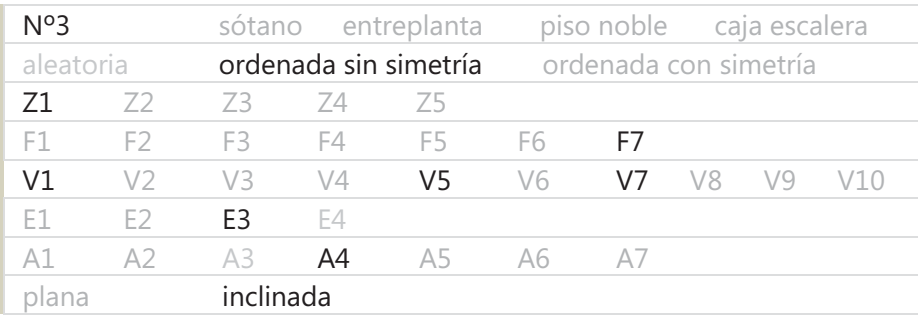

Fábrica

Vb22

Aparejo
Hiladas
Superficie
Sección (hipótesis)
Elementos destacados

soga-tizón

irregulares

sin planeidad

uniforme

aplantillado soga

pseudo horizontales

pseudo planeidad

horizontales

hojas y núcleo

cortado

terracota 


\begin{tabular}{|c|c|c|c|}
\hline \multirow{2}{*}{$\begin{array}{l}\mathrm{N}^{\circ} \text { elementos medidos } \\
\text { Longitud }(\mathrm{cm})\end{array}$} & \multicolumn{3}{|l|}{15} \\
\hline & \multicolumn{3}{|l|}{29.5} \\
\hline Anchura (cm) & \multicolumn{3}{|l|}{13.5} \\
\hline Espesor (cm) & \multicolumn{3}{|l|}{4.1} \\
\hline Volumen $\left(\mathrm{cm}^{3}\right)$ & \multicolumn{3}{|l|}{1632.8} \\
\hline Tipo & homogéneo & heterogéneo & re-empleo \\
\hline \multirow{4}{*}{$\begin{array}{l}\text { Color } \\
\text { Recogida de muestra } \\
\text { Patologías }\end{array}$} & homogéneo & heterogéneo globular & heterogéneo marmolado \\
\hline & no & sí & código \\
\hline & eflorescencias & micro fisuración & grietas \\
\hline & erosión & disgregación & descamación \\
\hline
\end{tabular}

${ }^{1}$ Datos obtenidos en base al cálculo del desvío estándar (respecto al valor medio de la muestras analizadas) y del gráfico de frecuencia de las muestras analizadas, identificado por una curva gaussiana

\section{Juntas}

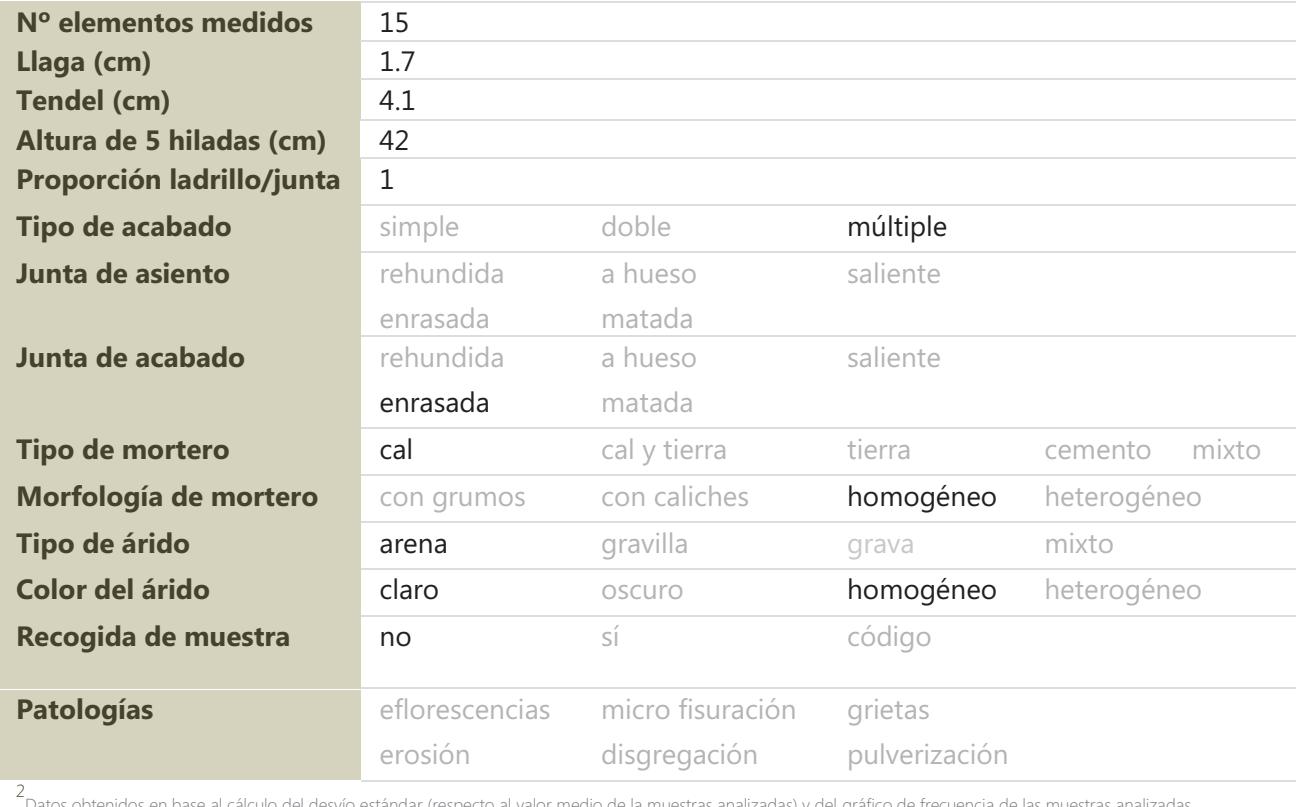

en base al cálculo del desvío estándar (respecto al valor medio de la muestras analizadas) y del gráfico de frecuencia de las muestras analizadas. identificado por una curva gaussiana 
Imágenes

Vb22
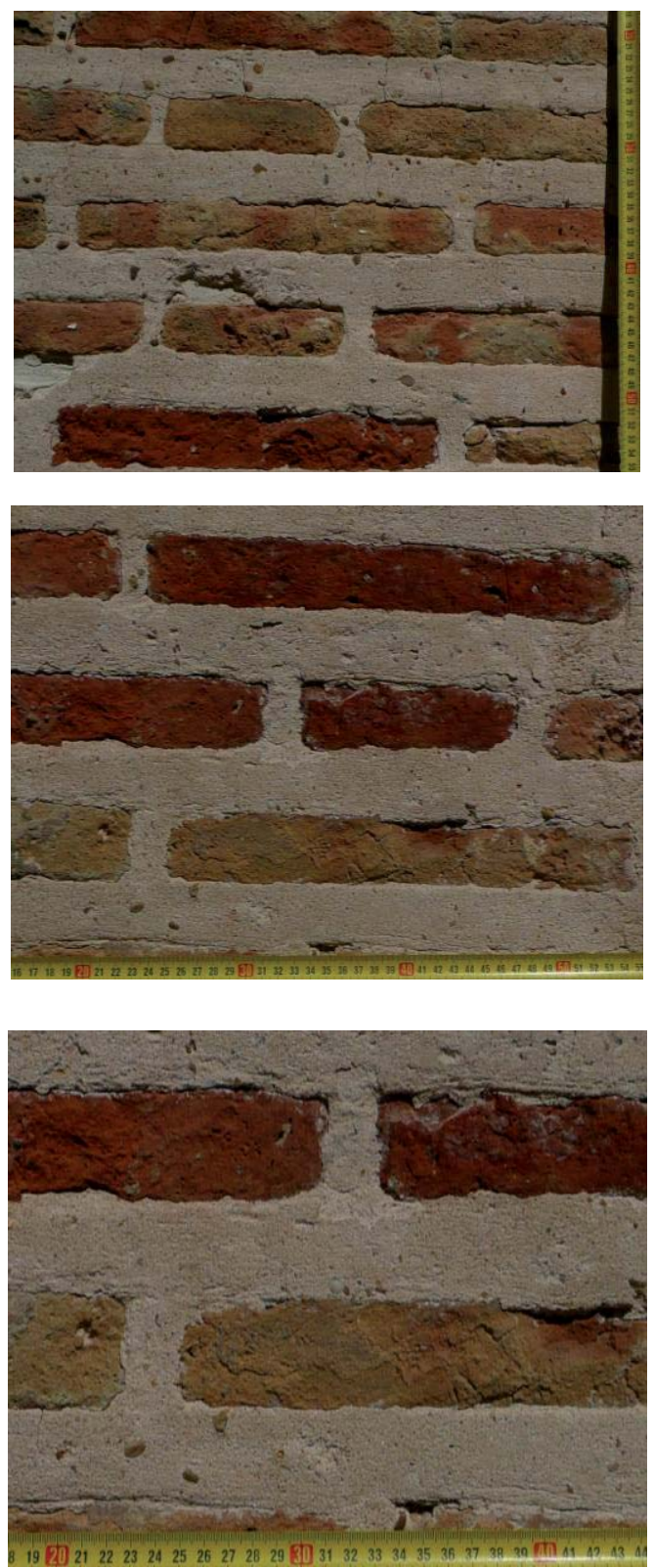
Imágenes

Vb22
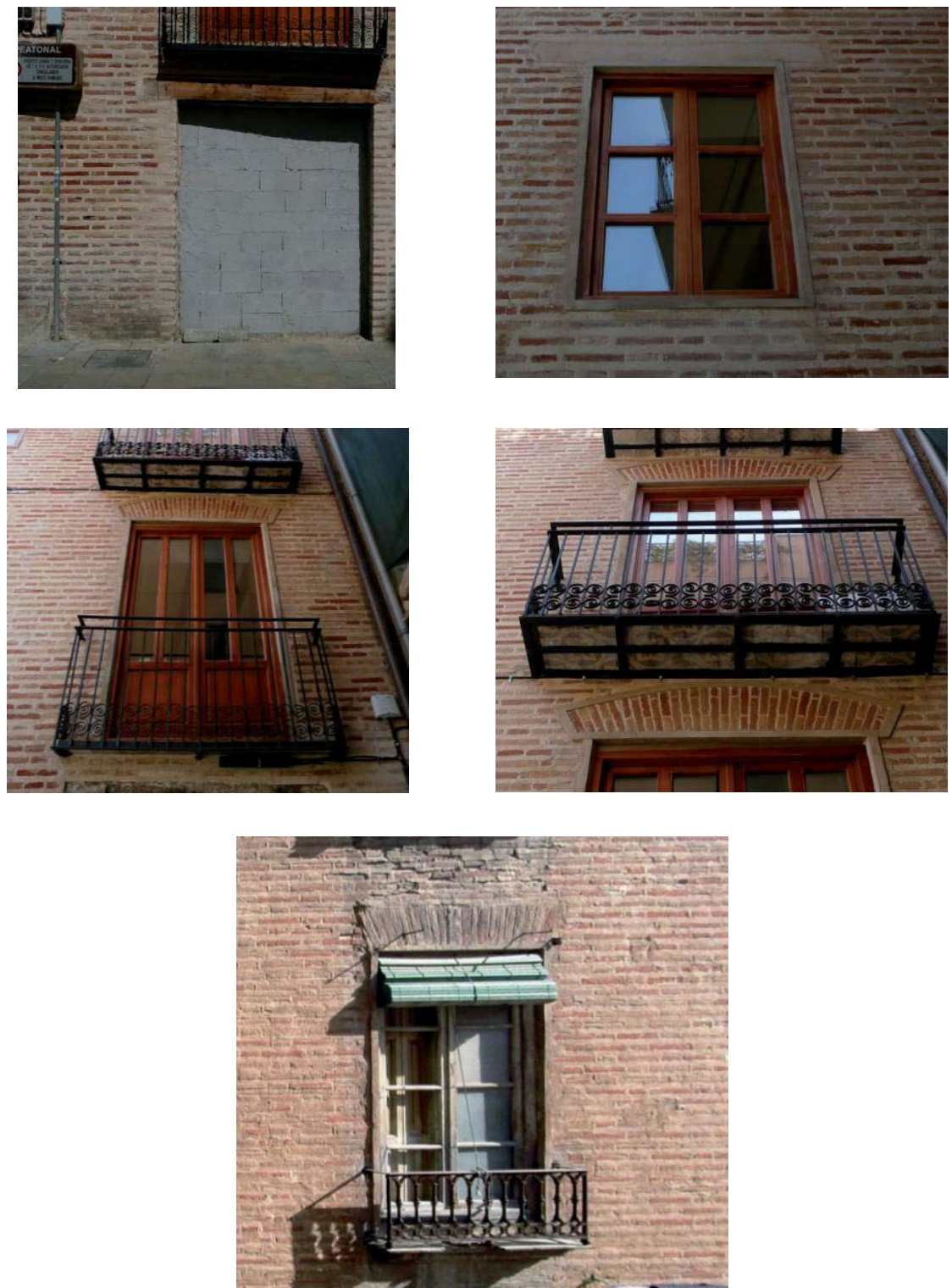
Datos generales

\begin{tabular}{|c|c|c|c|c|c|}
\hline Barrio & Carmen & La Seu-Xerea & Velluters & Mercat & S.Francesc \\
\hline Dirección & C/Roger de & lor no13 & & & \\
\hline Tipo de edificio & residencial & palaciego & religioso & militar & \\
\hline $\mathbf{G}^{\circ}$ de protección & 0 & 1 & 2 & 3 & \\
\hline Fechas claves & / & & & & \\
\hline
\end{tabular}
El apartado "fechas claves" se ha extraído de AA.W., Guía de Arquitectura de Valencia, Icaro CTAV Ed., Valencia, 2007

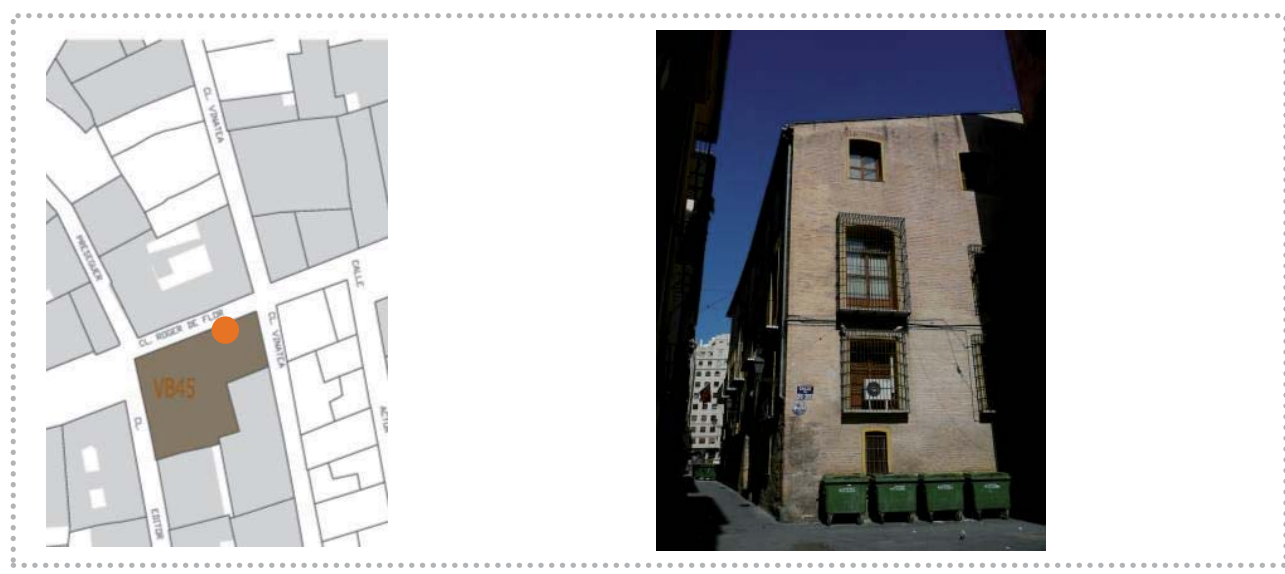

Fachada

Vb45

\begin{tabular}{|c|c|c|c|c|c|c|c|c|c|}
\hline \multirow{3}{*}{$\begin{array}{l}\text { Pisos } \\
\text { Composición fachada } \\
\text { Zócalo }\end{array}$} & \multicolumn{2}{|c|}{$N^{\circ} 3$} & sótano & \multicolumn{2}{|c|}{ entreplanta } & \multicolumn{4}{|c|}{ piso noble caja escalera } \\
\hline & \multicolumn{2}{|c|}{ aleatoria } & \multicolumn{3}{|c|}{ ordenada sin simetría } & \multicolumn{4}{|c|}{ ordenada con simetría } \\
\hline & $\mathrm{Z1}$ & $\mathrm{Z} 2$ & Z3 & Z4 & Z5 & & & & \\
\hline Fábrica & $\mathrm{F} 1$ & $\mathrm{~F} 2$ & F3 & $\mathrm{F} 4$ & F5 & F6 & & & \\
\hline Vano/dintel & V1 & V2 & V3 & V4 & V5 & V7 & V8 & V9 & V10 \\
\hline Entrada/dintel & E1 & E2 & E3 & E4 & & & & & \\
\hline Alero & A1 & $\mathrm{A} 2$ & A3 & A4 & A5 & A7 & & & \\
\hline Cubierta & plar & & inclinac & & & & & & \\
\hline
\end{tabular}

\section{Fábrica}

Vb45

Aparejo
Hiladas
Superficie
Sección
Elementos destacados

\begin{tabular}{lll}
\hline $\begin{array}{l}\text { soga-tizón } \\
\text { irregulares }\end{array}$ & soga tizón & \\
\hline sin planeidad & pseudo horizontales & horizontales \\
\hline uniforme & hojas y núcleo & planeidad perfecta \\
\hline aplantillado & cortado terracota & \\
\hline
\end{tabular}




\begin{tabular}{|c|c|c|c|}
\hline \multirow{2}{*}{$\begin{array}{l}N^{0} \text { elementos medidos } \\
\text { Longitud }(\mathrm{cm})\end{array}$} & \multicolumn{3}{|l|}{15} \\
\hline & \multicolumn{3}{|l|}{30.1} \\
\hline Anchura (cm) & \multicolumn{3}{|l|}{13.5} \\
\hline Espesor (cm) & \multicolumn{3}{|l|}{3.1} \\
\hline Volumen $\left(\mathrm{cm}^{3}\right)$ & \multicolumn{3}{|l|}{1259.6} \\
\hline Tipo & homogéneo & heterogéneo & re-empleo \\
\hline \multirow{4}{*}{$\begin{array}{l}\text { Color } \\
\text { Recogida de muestra } \\
\text { Patologías }\end{array}$} & homogéneo & heterogéneo globular & heterogéneo marmolado \\
\hline & no & sí & código \\
\hline & eflorescencias & micro fisuración & grietas \\
\hline & erosión & disgregación & descamación \\
\hline
\end{tabular}

1 Datos obtenidos en base al cálculo del desvío estándar (respecto al valor medio de la muestras analizadas) y del gráfico de frecuencia de las muestras analizadas, identificado por una curva gaussiana

\section{untas}

\begin{tabular}{|c|c|c|c|c|}
\hline \multirow{2}{*}{$\begin{array}{l}N^{\circ} \text { elementos medidos } \\
\text { Llaga }(\mathrm{cm})\end{array}$} & \multicolumn{4}{|l|}{15} \\
\hline & \multicolumn{4}{|l|}{1} \\
\hline \multirow{4}{*}{$\begin{array}{l}\text { Tendel (cm) } \\
\text { Altura de } 5 \text { hiladas (cm) } \\
\text { Proporción ladrillo/junta } \\
\text { Tipo de acabado }\end{array}$} & \multicolumn{4}{|l|}{4.1} \\
\hline & \multicolumn{4}{|l|}{38} \\
\hline & \multicolumn{4}{|l|}{0.7} \\
\hline & simple & doble & múltiple & \\
\hline \multirow[t]{2}{*}{ Junta de asiento } & rehundida & a hueso & saliente & \\
\hline & enrasada & matada & & \\
\hline \multirow[t]{2}{*}{ Junta de acabado } & rehundida & a hueso & saliente & \\
\hline & enrasada & matada & & \\
\hline \multirow{2}{*}{$\begin{array}{l}\text { Tipo de mortero } \\
\text { Morfología de mortero }\end{array}$} & cal & cal y tierra & tierra & cemento mixto \\
\hline & con grumos & con caliches & homogéneo & heterogéneo \\
\hline Tipo de árido & arena & gravilla & grava & mixto \\
\hline Color del árido & claro & oscuro & homogéneo & heterogéneo \\
\hline Recogida de muestra & no & sí & código & \\
\hline Patologías & $\begin{array}{l}\text { eflorescencias } \\
\text { erosión }\end{array}$ & $\begin{array}{l}\text { micro fisuración } \\
\text { disgregación }\end{array}$ & $\begin{array}{l}\text { grietas } \\
\text { pulverización }\end{array}$ & \\
\hline
\end{tabular}

2 Datos obtenidos en base al cálculo del desvio estándar (respecto al valor medio de la muestras analizadas) y del gráfico de frecuencia de las muestras analizadas, identificado por una curva gaussiana 
Imágenes

Vb45
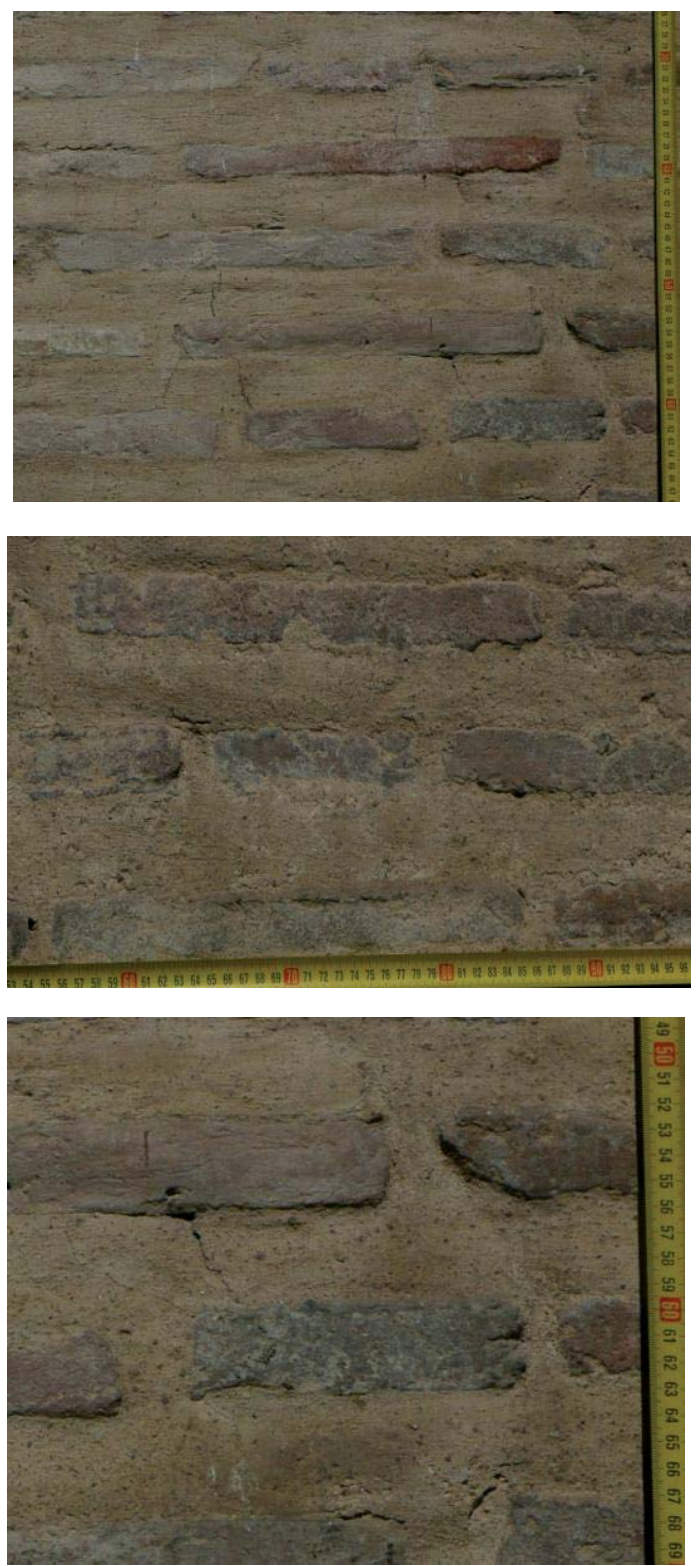

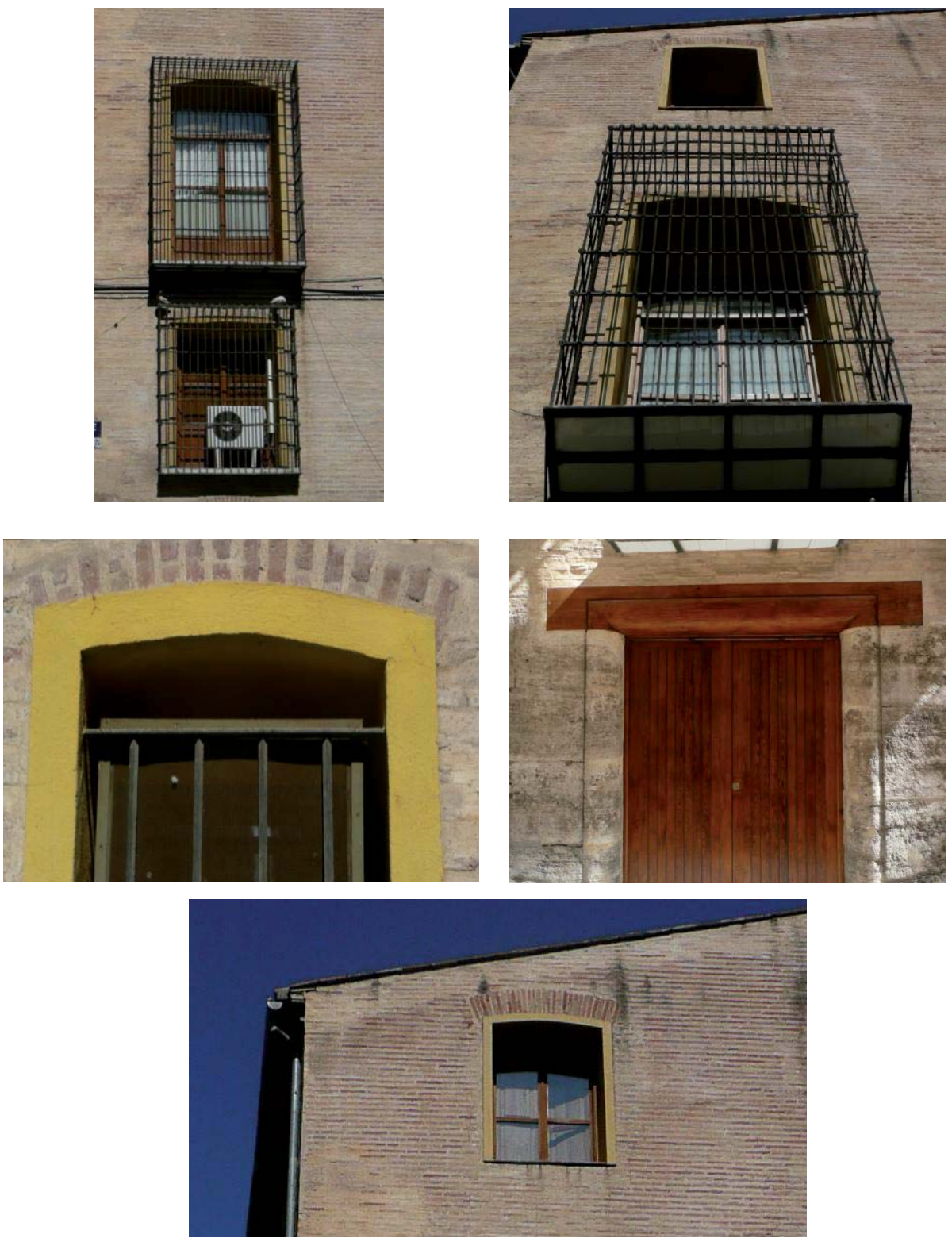
Datos generales

\begin{tabular}{|c|c|c|c|c|c|}
\hline Barrio & Carmen & La Seu-Xerea & Velluters & Mercat & S.Francesc \\
\hline Dirección & C/S. Antoni & 18 & & & \\
\hline Tipo de edificio & residencial & palaciego & religioso & militar & \\
\hline$G^{\circ}$ de protección & 0 & 1 & 2 & 3 & \\
\hline Fechas claves & / & & & & \\
\hline
\end{tabular}

El apartado "fechas claves" se ha extraído de AA.W., Guía de Arquitectura de Valencia, Icaro CTAV Ed., Valencia, 2007
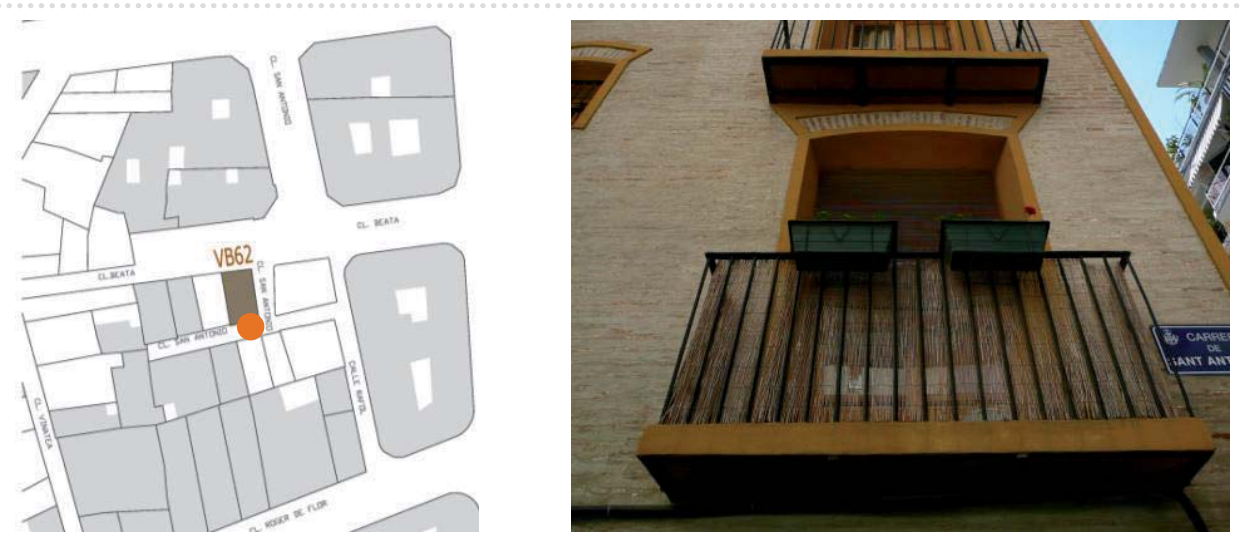

\section{Fachada}

\section{Pisos \\ Composición fachada \\ Zócalo \\ Fábrica \\ Vano/dintel \\ Entrada/dintel \\ Alero \\ Cubierta}

\begin{tabular}{|c|c|c|c|c|c|c|c|c|c|}
\hline \multicolumn{2}{|c|}{$\mathrm{N}^{\circ} 3$} & sótano & & planta & \multicolumn{2}{|c|}{ piso noble } & $\mathrm{Ca}$ & esc & era \\
\hline \multicolumn{2}{|c|}{ aleatoria } & \multicolumn{3}{|c|}{ ordenada sin simetría } & \multicolumn{5}{|c|}{ ordenada con simetría } \\
\hline $\mathrm{Z1}$ & $\mathrm{Z} 2$ & Z3 & Z4 & Z5 & & & & & \\
\hline F1 & $\mathrm{F} 2$ & F3 & F4 & $\mathrm{F} 5$ & F6 & F7 & & & \\
\hline V1 & V2 & V3 & V4 & V5 & V6 & V7 & V8 & V9 & V10 \\
\hline E1 & E2 & E3 & E4 & & & & & & \\
\hline A1 & $\mathrm{A} 2$ & A3 & A4 & A5 & A6 & A7 & & & \\
\hline
\end{tabular}

\section{Fábrica}

Aparejo
Hiladas
Superficie
Sección (hipótesis)
Elementos destacados

\begin{tabular}{|lll}
\hline soga-tizón & soga & \\
\hline irregulares & pseudo horizontales & horizontales \\
\hline sin planeidad & pseudo planeidad & planeidad perfecta \\
\hline uniforme & hojas y núcleo & abocinada (vano) \\
\hline aplantillado & cortado terracota & \\
\hline
\end{tabular}




\begin{tabular}{|c|c|c|c|}
\hline \multirow{2}{*}{$\begin{array}{l}N^{0} \text { elementos medidos } \\
\text { Longitud }(\mathrm{cm})\end{array}$} & \multicolumn{3}{|l|}{15} \\
\hline & \multicolumn{3}{|l|}{30.1} \\
\hline Anchura (cm) & \multicolumn{3}{|l|}{14.1} \\
\hline Espesor (cm) & \multicolumn{3}{|l|}{3.1} \\
\hline Volumen $\left(\mathrm{cm}^{3}\right)$ & \multicolumn{3}{|l|}{1315.6} \\
\hline Tipo & homogéneo & heterogéneo & re-empleo \\
\hline \multirow{4}{*}{$\begin{array}{l}\text { Color } \\
\text { Recogida de muestra } \\
\text { Patologías }\end{array}$} & homogéneo & heterogéneo globular & heterogéneo marmolado \\
\hline & no & sí & código \\
\hline & eflorescencias & micro fisuración & grietas \\
\hline & erosión & disgregación & descamación \\
\hline
\end{tabular}

${ }^{1}$ Datos obtenidos en base al cálculo del desvío estándar (respecto al valor medio de la muestras analizadas) y del gráfico de frecuencia de las muestras analizadas, identificado por una curva gaussiana

\section{Juntas}

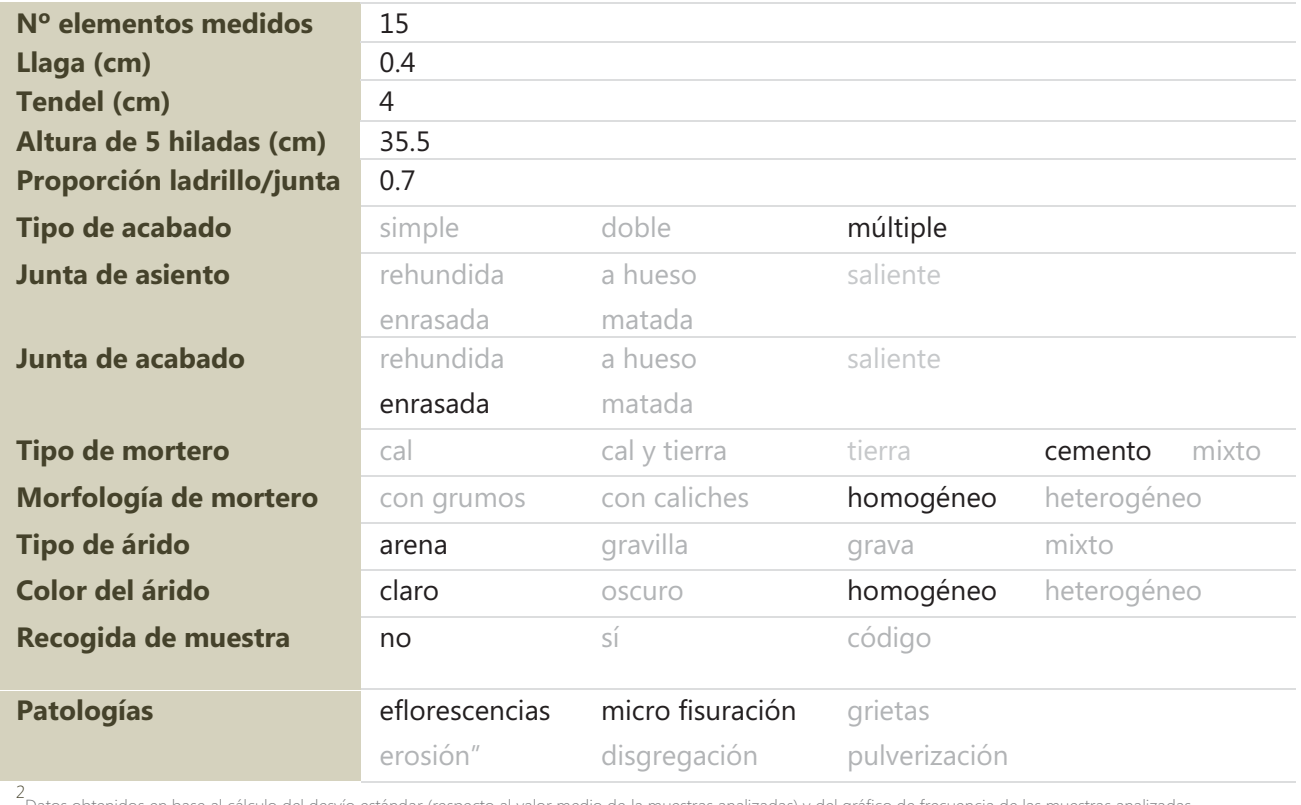

${ }^{2}$ Datos obtenidos en base al cálculo del desvio estándar (respecto al valor medio de la muestras analizadas) y del gráfico de frecuencia de las muestras analizadas, identificado por una curva gaussiana 

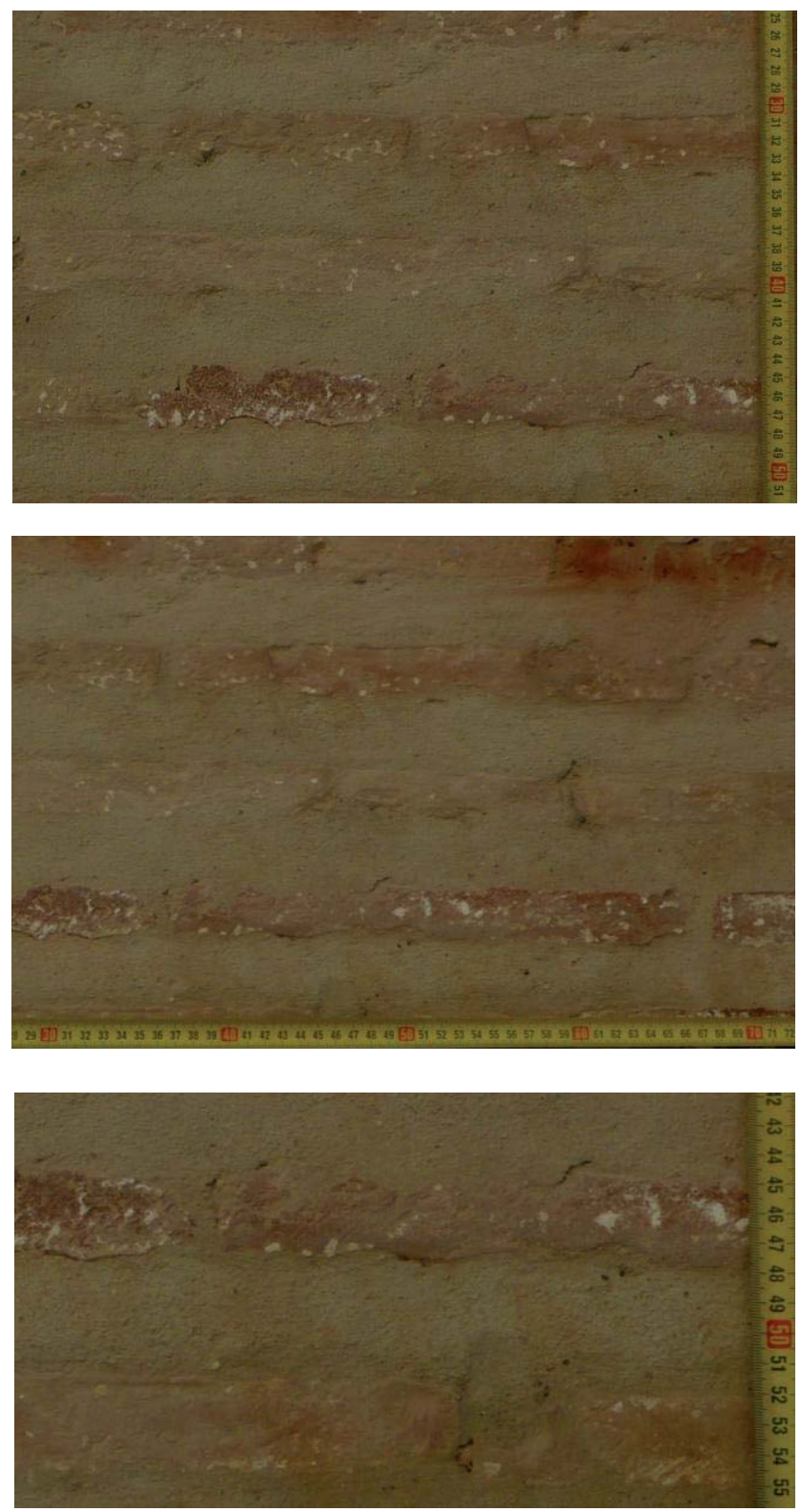

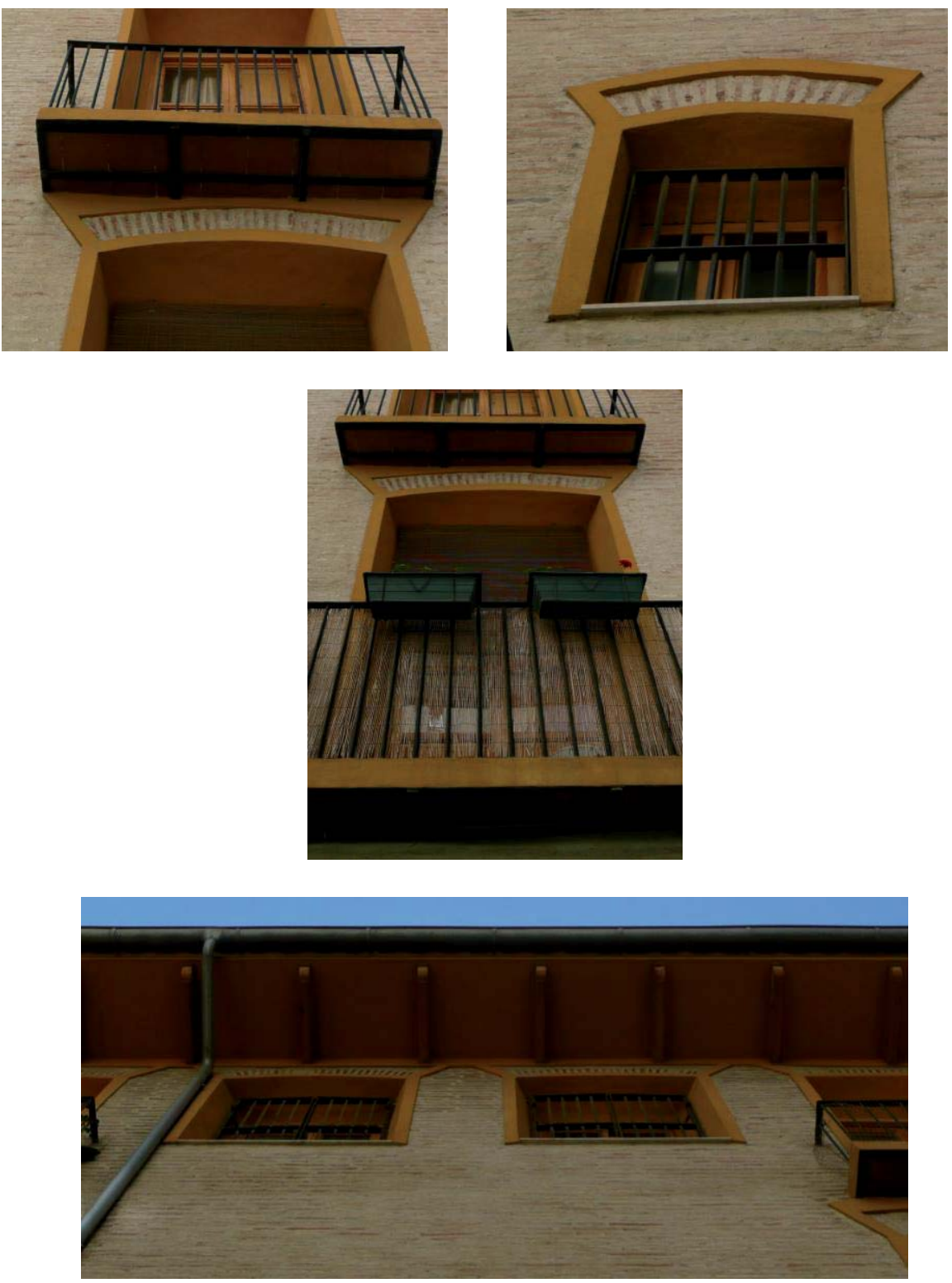
Datos generales

Vb67

\begin{tabular}{|c|c|c|c|c|c|}
\hline Barrio & Carmen & La Seu-Xerea & Velluters & Mercat & S.Francesc \\
\hline Dirección & P.za Pilar s/ & & & & \\
\hline Tipo de edificio & residencial & palaciego & religioso & militar & \\
\hline $\mathbf{G}^{\circ}$ de protección & 0 & 1 & 2 & 3 & \\
\hline Fechas claves & 1659 (Leon & t-Do); portada & 0 ; interve & n 2009 & \\
\hline
\end{tabular}

El apartado "fechas claves" se ha extraído de AA.V., Guía de Arquitectura de Valencia, Icaro CTAV Ed., Valencia, 2007

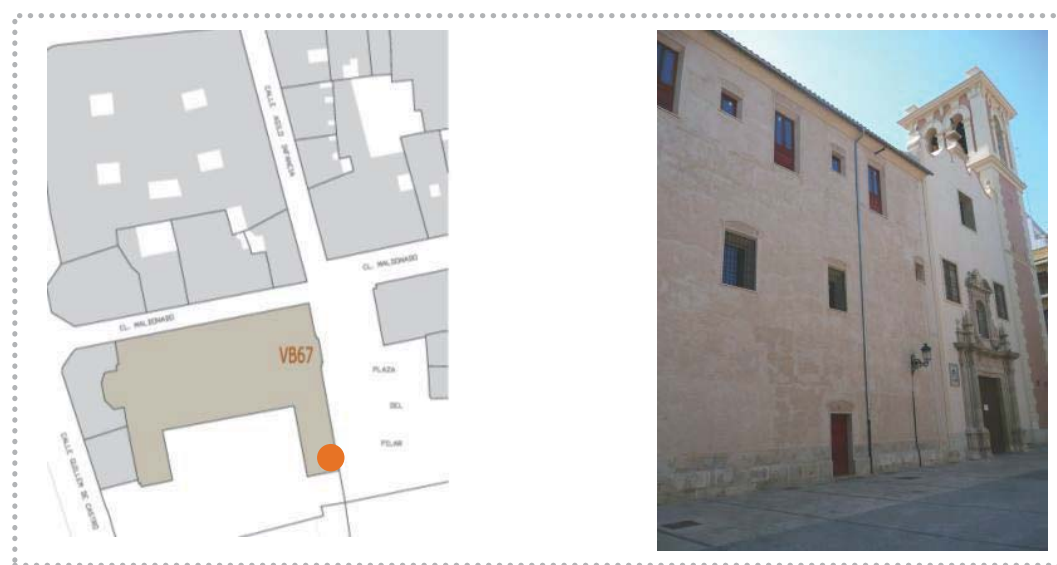

Fachada

Vb67

Pisos
Composición fachada
Zócalo
Fábrica
Vano/dintel
Entrada/dintel
Alero
Cubierta

\begin{tabular}{|c|c|c|c|c|c|c|c|c|}
\hline \multirow{3}{*}{\multicolumn{2}{|c|}{$\begin{array}{l}\mathrm{N}^{03} \\
\text { aleatoria }\end{array}$}} & \multirow{2}{*}{\multicolumn{3}{|c|}{$\begin{array}{l}\text { sótano entreplanta } \\
\text { ordenada sin simetría }\end{array}$}} & \multicolumn{4}{|c|}{ piso noble caja escalera } \\
\hline & & & & & \multicolumn{4}{|c|}{ ordenada con simetría } \\
\hline & $\mathrm{Z2}$ & Z3 & Z4 & Z5 & & & & \\
\hline F1 & F2 & F3 & F4 & F5 & F6 & & & \\
\hline V1 & V2 & V3 & V4 & V5 & V6 & V8 & V9 & V10 \\
\hline E1 & E2 & E3 & E4 & & & & & \\
\hline A1 & A2 & A3 & A4 & A5 & A6 & & & \\
\hline
\end{tabular}

Fábrica

Vb67

\begin{tabular}{l|lll} 
Aparejo & soga-tizón & soga & \multicolumn{2}{c}{ tizón } & \\
Hiladas & irregulares & pseudo horizontales & horizontales \\
Superficie & sin planeidad & pseudo planeidad & planeidad perfecta \\
Sección (hipótesis) & uniforme & hojas y núcleo & abocinada (vano) \\
Elementos destacados & aplantillado & cortado terracota & \\
\hline
\end{tabular}




\begin{tabular}{|c|c|c|c|}
\hline \multirow{2}{*}{$\begin{array}{l}\mathrm{N}^{\circ} \text { elementos medidos } \\
\text { Longitud }(\mathrm{cm})\end{array}$} & \multicolumn{3}{|l|}{15} \\
\hline & / & & \\
\hline Anchura (cm) & 14.5 & & \\
\hline Espesor (cm) & 3.9 & & \\
\hline Volumen $\left(\mathrm{cm}^{3}\right)$ & / & & \\
\hline Tipo & homogéneo & heterogéneo & re-empleo \\
\hline Color & homogéneo & heterogéneo globular & heterogéneo marmolado \\
\hline Recogida de muestra & no & si & código \\
\hline Patologías & $\begin{array}{l}\text { eflorescencias } \\
\text { erosión }\end{array}$ & $\begin{array}{l}\text { micro-fisuración } \\
\text { disgregación }\end{array}$ & $\begin{array}{l}\text { grietas } \\
\text { descamación }\end{array}$ \\
\hline
\end{tabular}

1 Datos obtenidos en base al cálculo del desvio estándar (respecto al valor medio de la muestras analizadas) y del gráfico de frecuencia de las muestras analizadas, identificado por una curva gaussiana

\section{untas}

Vb67

\begin{tabular}{|c|c|c|c|c|}
\hline \multirow{2}{*}{$\begin{array}{l}N^{\circ} \text { elementos medidos } \\
\text { Llaga }(\mathrm{cm})\end{array}$} & \multicolumn{4}{|l|}{15} \\
\hline & \multicolumn{4}{|l|}{13.1} \\
\hline Tendel (cm) & \multicolumn{4}{|l|}{10.2} \\
\hline Altura de 5 hiladas $(\mathrm{cm})$ & \multicolumn{4}{|l|}{70.5} \\
\hline Proporción ladrillo/junta & \multicolumn{4}{|l|}{0.3} \\
\hline Tipo de acabado & simple & doble & \multicolumn{2}{|l|}{ múltiple } \\
\hline \multirow[t]{2}{*}{ Junta de asiento } & rehundida & a hueso & \multirow{2}{*}{\multicolumn{2}{|c|}{ saliente }} \\
\hline & enrasada & matada & & \\
\hline \multirow[t]{2}{*}{ Junta de acabado } & rehundida & a hueso & \multirow{2}{*}{\multicolumn{2}{|c|}{ saliente }} \\
\hline & enrasada & matada & & \\
\hline \multirow{2}{*}{$\begin{array}{l}\text { Tipo de mortero } \\
\text { Morfología de mortero }\end{array}$} & cal & cal y tierra & tierra & cemento mixto \\
\hline & con grumos & con caliches & homogéneo & heterogéneo \\
\hline Tipo de árido & arena & gravilla & grava & mixto \\
\hline Color del árido & claro & oscuro & homogéneo & heterogéneo \\
\hline Recogida de muestra & no & si & código & \\
\hline Patologías & $\begin{array}{l}\text { eflorescencias } \\
\text { erosión" }\end{array}$ & $\begin{array}{l}\text { micro-fisuración } \\
\text { disgregación }\end{array}$ & $\begin{array}{l}\text { grietas } \\
\text { pulverización }\end{array}$ & \\
\hline
\end{tabular}

2 Datos obtenidos en base al cálculo del desvio estándar (respecto al valor medio de la muestras analizadas) y del gráfico de frecuencia de las muestras analizadas, identificado por una curva gaussiana 
Imágenes
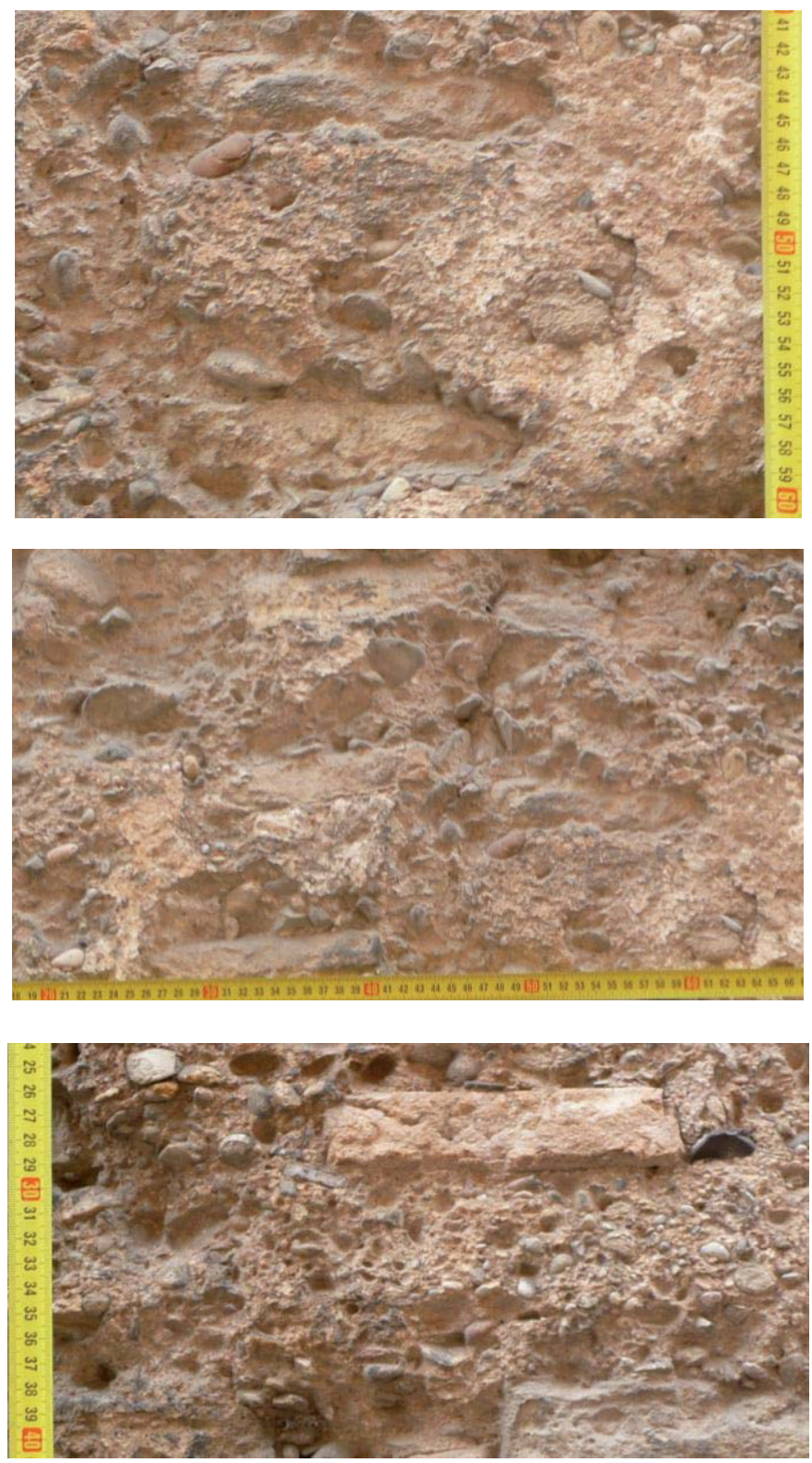

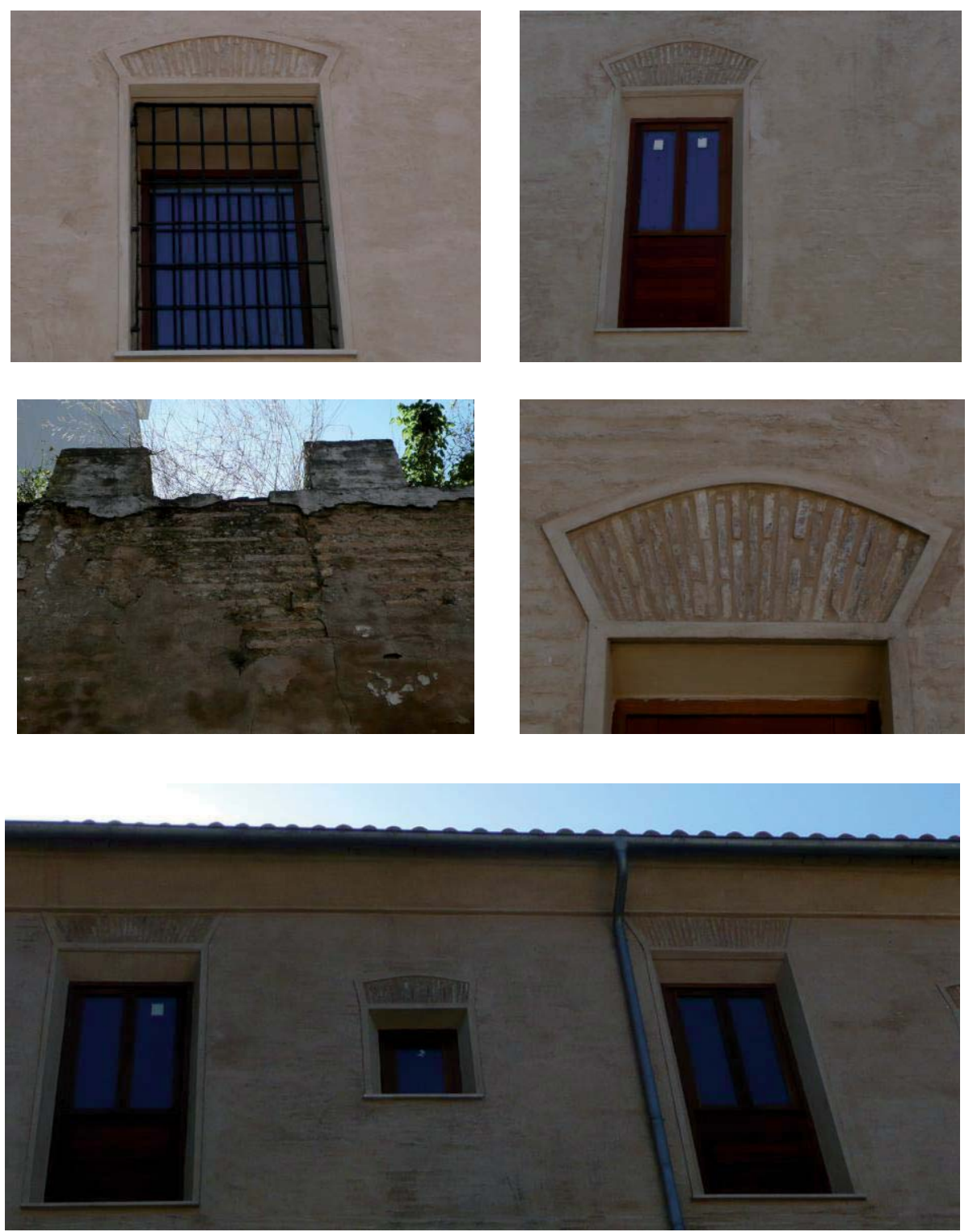
Datos generales

Vb68

\begin{tabular}{|c|c|c|c|c|c|}
\hline Barrio & Carmen & La Seu-Xerea & Velluters & Mercat & S.Francesc \\
\hline Dirección & C/Quevedo & 12 & & & \\
\hline Tipo de edificio & residencial & palaciego & religioso & militar & \\
\hline $\mathbf{G}^{\circ}$ de protección & 0 & 1 & 2 & 3 & \\
\hline Fechas claves & 1760 , interv & nción 2008 & & & \\
\hline
\end{tabular}

El apartado "fechas claves" se ha extraído de AA.V., Guía de Arquitectura de Valencia, Icaro CTAV Ed., Valencia, 2007

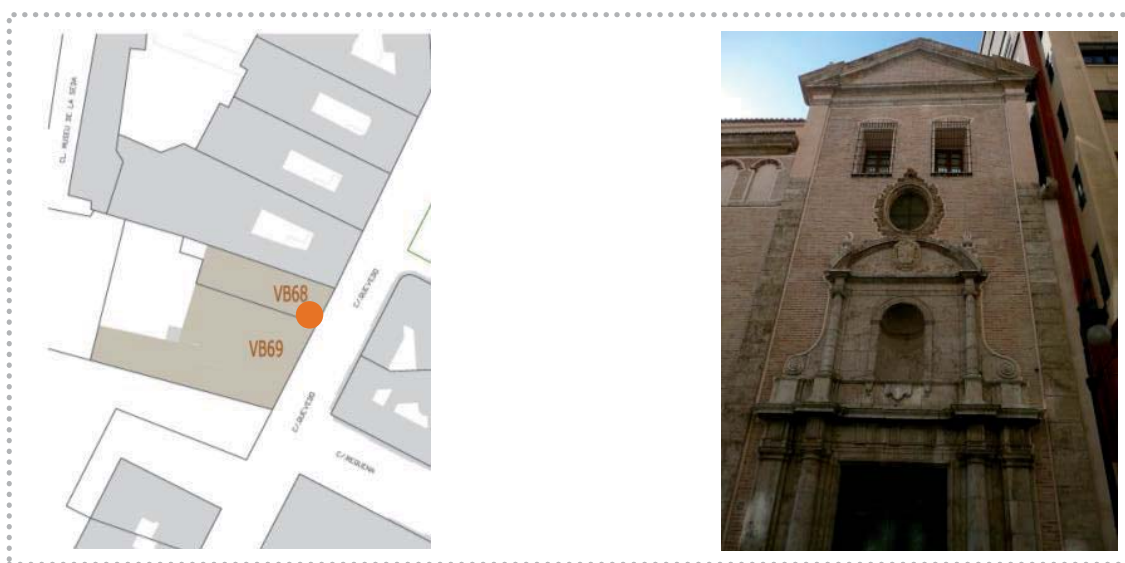

Fachada

Vb68

\begin{tabular}{|c|c|c|c|c|c|c|c|c|c|}
\hline \multirow{3}{*}{$\begin{array}{l}\text { Pisos } \\
\text { Composición fachada } \\
\text { Zócalo }\end{array}$} & \multicolumn{2}{|c|}{ No/ } & sótano & \multicolumn{2}{|c|}{ entreplanta } & \multicolumn{4}{|c|}{ piso noble caja escalera } \\
\hline & \multicolumn{2}{|c|}{ aleatoria } & \multicolumn{3}{|c|}{ ordenada sin simetría } & \multicolumn{4}{|c|}{ ordenada con simetría } \\
\hline & Z1 & $\mathrm{Z} 2$ & Z3 & Z4 & Z5 & & & & \\
\hline Fábrica & $\mathrm{F} 1$ & $\mathrm{~F} 2$ & F3 & $\mathrm{F} 4$ & F5 & F7 & & & \\
\hline Vano/dintel & V1 & V2 & V3 & V4 & V5 & V7 & V8 & V9 & V10 \\
\hline Entrada/dintel & E1 & E2 & E3 & E4 & & & & & \\
\hline Alero & A1 & $\mathrm{A} 2$ & $\mathrm{~A} 3$ & A4 & A5 & A6 & & & \\
\hline Cubierta & pla & & inclin & & & & & & \\
\hline
\end{tabular}

Ver tablas relativas a los códigos indicados, al final de la recopilación de las fichas

\section{Fábrica}

Vb68

\section{Aparejo \\ Hiladas \\ Superficie \\ Sección (hipótesis) \\ Elementos destacados}

\begin{tabular}{lll} 
soga-tizón & soga & \multicolumn{1}{c}{ tizón } \\
irregulares & pseudo horizontales & horizontales \\
\hline sin planeidad & pseudo planeidad & planeidad perfecta \\
\hline uniforme & hojas y núcleo & abocinada (vano) \\
aplantillado & cortado terracota & \\
\hline
\end{tabular}




\begin{tabular}{l|lll}
\hline $\begin{array}{l}\text { No elementos medidos } \\
\text { Longitud }(\mathbf{c m})\end{array}$ & 15 & & \\
Anchura $(\mathbf{c m})$ & 26.2 & & \\
Espesor $(\mathbf{c m})$ & 14.5 & & \\
Volumen $\left(\mathbf{c m}^{3}\right)$ & 4 & heterogéneo & re-empleo \\
Tipo & 1693.6 & heterogéneo globular & heterogéneo marmolado \\
Color & homogéneo & homogéneo & síno \\
Recogida de muestra & no & micro fisuración & grietas \\
Patologías & eflorescencias & disgregación & descamación
\end{tabular}

${ }^{1}$ Datos obtenidos en base al cálculo del desvío estándar (respecto al valor medio de la muestras analizadas) y del gráfico de frecuencia de las muestras analizadas, identificado por una curva gaussiana

\section{untas}

Vb68

\begin{tabular}{|c|c|c|c|c|}
\hline \multirow{2}{*}{$\begin{array}{l}N^{0} \text { elementos medidos } \\
\text { Llaga }(\mathrm{cm})\end{array}$} & \multicolumn{4}{|l|}{15} \\
\hline & \multicolumn{4}{|l|}{1.5} \\
\hline \multirow{4}{*}{$\begin{array}{l}\text { Tendel (cm) } \\
\text { Altura de } 5 \text { hiladas (cm) } \\
\text { Proporción ladrillo/junta } \\
\text { Tipo de acabado }\end{array}$} & \multicolumn{4}{|l|}{4.3} \\
\hline & \multicolumn{4}{|l|}{41.5} \\
\hline & \multicolumn{4}{|l|}{0.9} \\
\hline & simple & doble & múltiple & \\
\hline \multirow[t]{2}{*}{ Junta de asiento } & rehundida & a hueso & saliente & \\
\hline & enrasada & matada & & \\
\hline \multirow[t]{2}{*}{ Junta de acabado } & rehundida & a hueso & saliente & \\
\hline & enrasada & matada & & \\
\hline \multirow{3}{*}{$\begin{array}{l}\text { Tipo de mortero } \\
\text { Morfología de mortero } \\
\text { Tipo de árido }\end{array}$} & cal & cal y tierra & tierra & cemento mixto \\
\hline & con grumos & con caliches & homogéneo & heterogéneo \\
\hline & arena & gravilla & grava & mixto \\
\hline \multirow{2}{*}{$\begin{array}{l}\text { Color del árido } \\
\text { Recogida de muestra }\end{array}$} & claro & oscuro & homogéneo & heterogéneo \\
\hline & no & sí & código & \\
\hline Patologías & $\begin{array}{l}\text { eflorescencias } \\
\text { erosión }\end{array}$ & $\begin{array}{l}\text { micro fisuración } \\
\text { disgregación }\end{array}$ & $\begin{array}{l}\text { grietas } \\
\text { pulverización }\end{array}$ & \\
\hline
\end{tabular}

2 Datos obtenidos en base al cálculo del desvio estándar (respecto al valor medio de la muestras analizadas) y del gráfico de frecuencia de las muestras analizadas, identificado por una curva gaussiana 
Imágenes
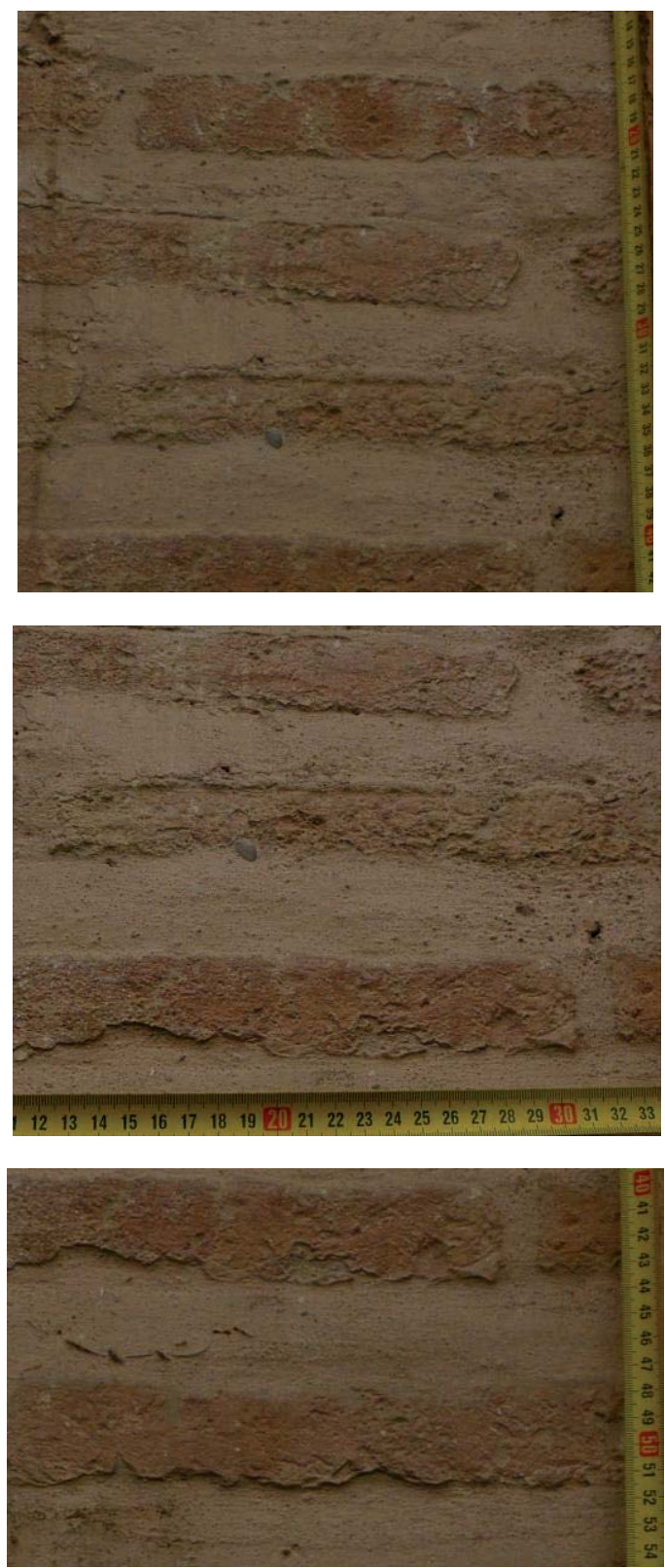

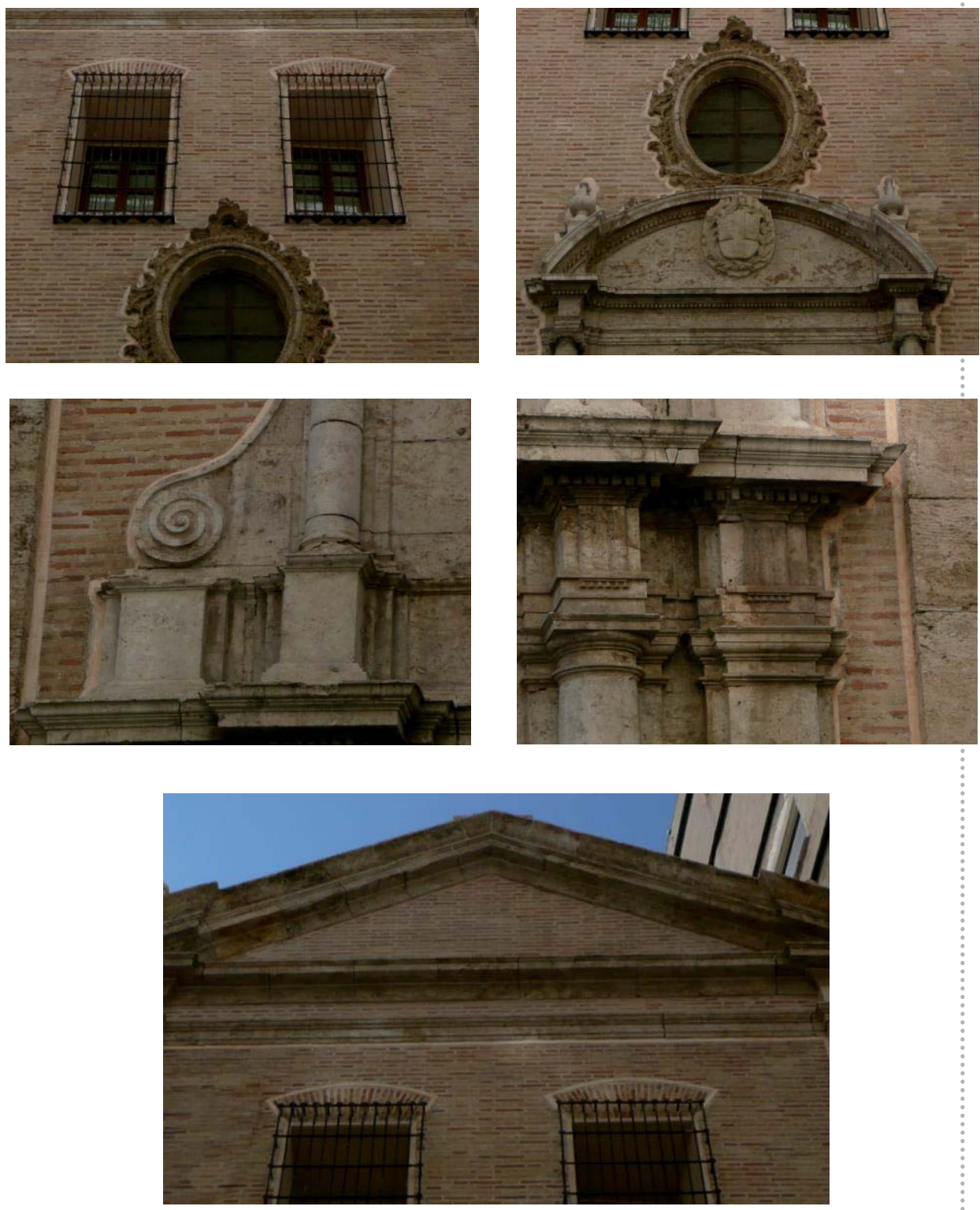
Datos generales

Vb69

\begin{tabular}{|c|c|c|c|c|c|}
\hline Barrio & Carmen & La Seu-Xerea & Velluters & Mercat & S.Francesc \\
\hline Dirección & \multicolumn{5}{|c|}{ C/Quevedo s/n } \\
\hline Tipo de edificio & residencial & palaciego & religioso & militar & \\
\hline $\mathbf{G}^{\circ}$ de protección & 0 & 1 & 2 & 3 & \\
\hline Fechas claves & \multicolumn{5}{|c|}{ 1760, intervención 2008} \\
\hline
\end{tabular}
El apartado "fechas claves" se ha extraído de AA.V.., Guía de Arquitectura de Valencia, Icaro CTAV Ed, Valencia, 2007

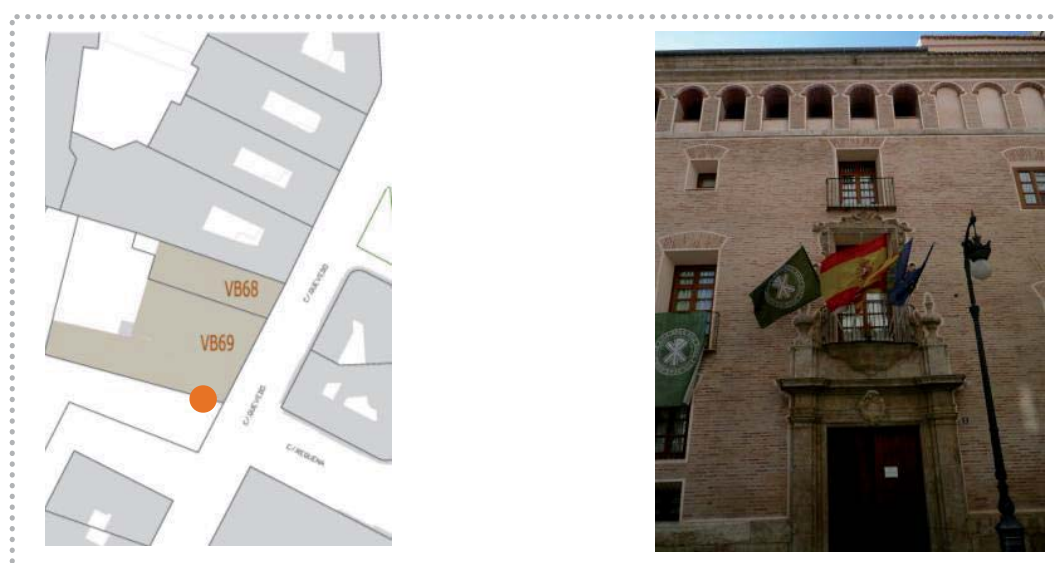

Fachada

Vb69

\begin{tabular}{|c|c|c|c|c|c|c|c|c|c|}
\hline \multirow{3}{*}{$\begin{array}{l}\text { Pisos } \\
\text { Composición fachada } \\
\text { Zócalo }\end{array}$} & \multicolumn{2}{|c|}{$N^{\circ} 3$} & sótano & \multicolumn{2}{|c|}{ entreplanta } & \multicolumn{4}{|c|}{ piso noble caja escalera } \\
\hline & \multicolumn{2}{|c|}{ aleatoria } & \multicolumn{3}{|c|}{ ordenada sin simetría } & \multicolumn{4}{|c|}{ ordenada con simetría } \\
\hline & $\mathrm{Z1}$ & $\mathrm{Z2}$ & Z3 & Z4 & Z5 & & & & \\
\hline Fábrica & $\mathrm{F} 1$ & $\mathrm{~F} 2$ & F3 & $\mathrm{F} 4$ & F5 & F6 & & & \\
\hline Vano/dintel & V1 & V2 & V3 & V4 & V5 & V7 & V8 & V9 & V10 \\
\hline Entrada/dintel & E1 & E2 & E3 & E4 & & & & & \\
\hline Alero & A1 & $\mathrm{A} 2$ & A3 & A4 & A5 & A7 & & & \\
\hline Cubierta & plar & & inclinac & & & & & & \\
\hline
\end{tabular}

\section{Fábrica}

Vb69

Aparejo
Hiladas
Superficie
Sección (hipótesis)
Elementos destacados

\begin{tabular}{|lll}
\hline soga-tizón & soga & \multicolumn{1}{c}{ tizón } \\
\hline irregulares & pseudo horizontales & horizontales \\
\hline sin planeidad & pseudo planeidad & planeidad perfecta \\
\hline uniforme & hojas y núcleo & abocinada (vano) \\
\hline aplantillado & cortado terracota & \\
\hline
\end{tabular}




\begin{tabular}{|c|c|c|c|}
\hline \multirow{2}{*}{$\begin{array}{l}\mathrm{N}^{\circ} \text { elementos medidos } \\
\text { Longitud }(\mathrm{cm})\end{array}$} & \multicolumn{3}{|l|}{15} \\
\hline & \multicolumn{3}{|l|}{30.1} \\
\hline Anchura (cm) & \multicolumn{3}{|l|}{14.1} \\
\hline Espesor (cm) & \multicolumn{3}{|l|}{4} \\
\hline Volumen $\left(\mathrm{cm}^{3}\right)$ & \multicolumn{3}{|l|}{1697.6} \\
\hline Tipo & homogéneo & heterogéneo & re-empleo \\
\hline \multirow{4}{*}{$\begin{array}{l}\text { Color } \\
\text { Recogida de muestra } \\
\text { Patologías }\end{array}$} & homogéneo & heterogéneo globular & heterogéneo marmolado \\
\hline & no & sí & código \\
\hline & eflorescencias & micro fisuración & grietas \\
\hline & erosión & disgregación & descamación \\
\hline
\end{tabular}

1 Datos obtenidos en base al cálculo del desvío estándar (respecto al valor medio de la muestras analizadas) y del gráfico de frecuencia de las muestras analizadas, identificado por una curva gaussiana

\section{untas}

Vb69

\begin{tabular}{|c|c|c|c|c|}
\hline \multirow{2}{*}{$\begin{array}{l}N^{\circ} \text { elementos medidos } \\
\text { Llaga }(\mathrm{cm})\end{array}$} & \multicolumn{4}{|l|}{15} \\
\hline & \multicolumn{4}{|l|}{1.3} \\
\hline \multirow{4}{*}{$\begin{array}{l}\text { Tendel (cm) } \\
\text { Altura de } 5 \text { hiladas (cm) } \\
\text { Proporción ladrillo/junta } \\
\text { Tipo de acabado }\end{array}$} & \multicolumn{4}{|l|}{3.5} \\
\hline & \multicolumn{4}{|l|}{37.5} \\
\hline & \multicolumn{4}{|l|}{1.1} \\
\hline & simple & doble & múltiple & \\
\hline \multirow[t]{2}{*}{ Junta de asiento } & rehundida & a hueso & saliente & \\
\hline & enrasada & matada & & \\
\hline \multirow[t]{2}{*}{ Junta de acabado } & rehundida & a hueso & saliente & \\
\hline & enrasada & matada & & \\
\hline \multirow{3}{*}{$\begin{array}{l}\text { Tipo de mortero } \\
\text { Morfología de mortero } \\
\text { Tipo de árido }\end{array}$} & cal & cal y tierra & tierra & cemento mixto \\
\hline & con grumos & con caliches & homogéneo & heterogéneo \\
\hline & arena & gravilla & grava & mixto \\
\hline \multirow{2}{*}{$\begin{array}{l}\text { Color del árido } \\
\text { Recogida de muestra }\end{array}$} & claro & oscuro & homogéneo & heterogéneo \\
\hline & no & sí & código & \\
\hline Patologías & $\begin{array}{l}\text { eflorescencias } \\
\text { erosión }\end{array}$ & $\begin{array}{l}\text { micro fisuración } \\
\text { disgregación }\end{array}$ & $\begin{array}{l}\text { grietas } \\
\text { pulverización }\end{array}$ & \\
\hline
\end{tabular}

2 Datos obtenidos en base al cálculo del desvio estándar (respecto al valor medio de la muestras analizadas) y del gráfico de frecuencia de las muestras analizadas, identificado por una curva gaussiana 
Imágenes

Vb69
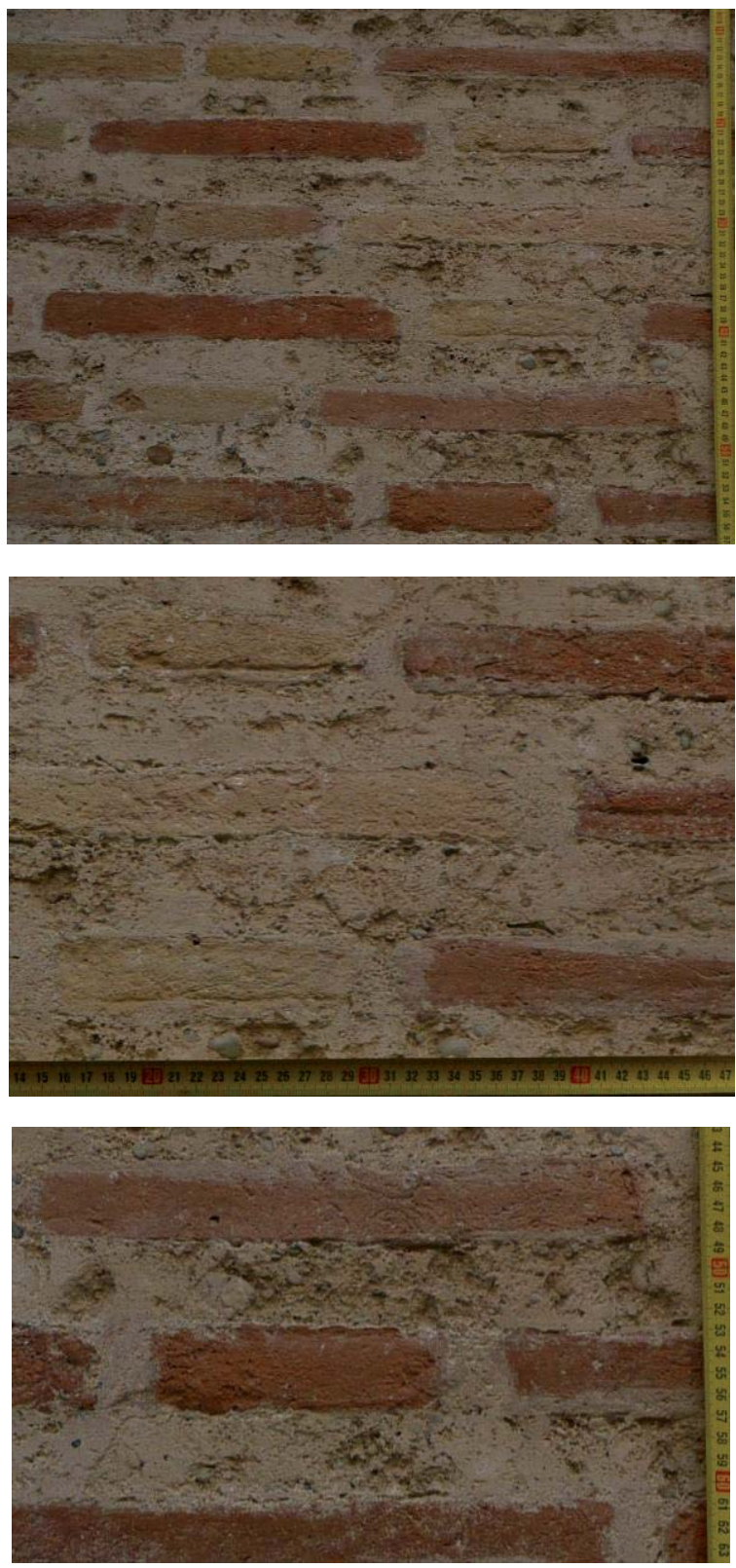

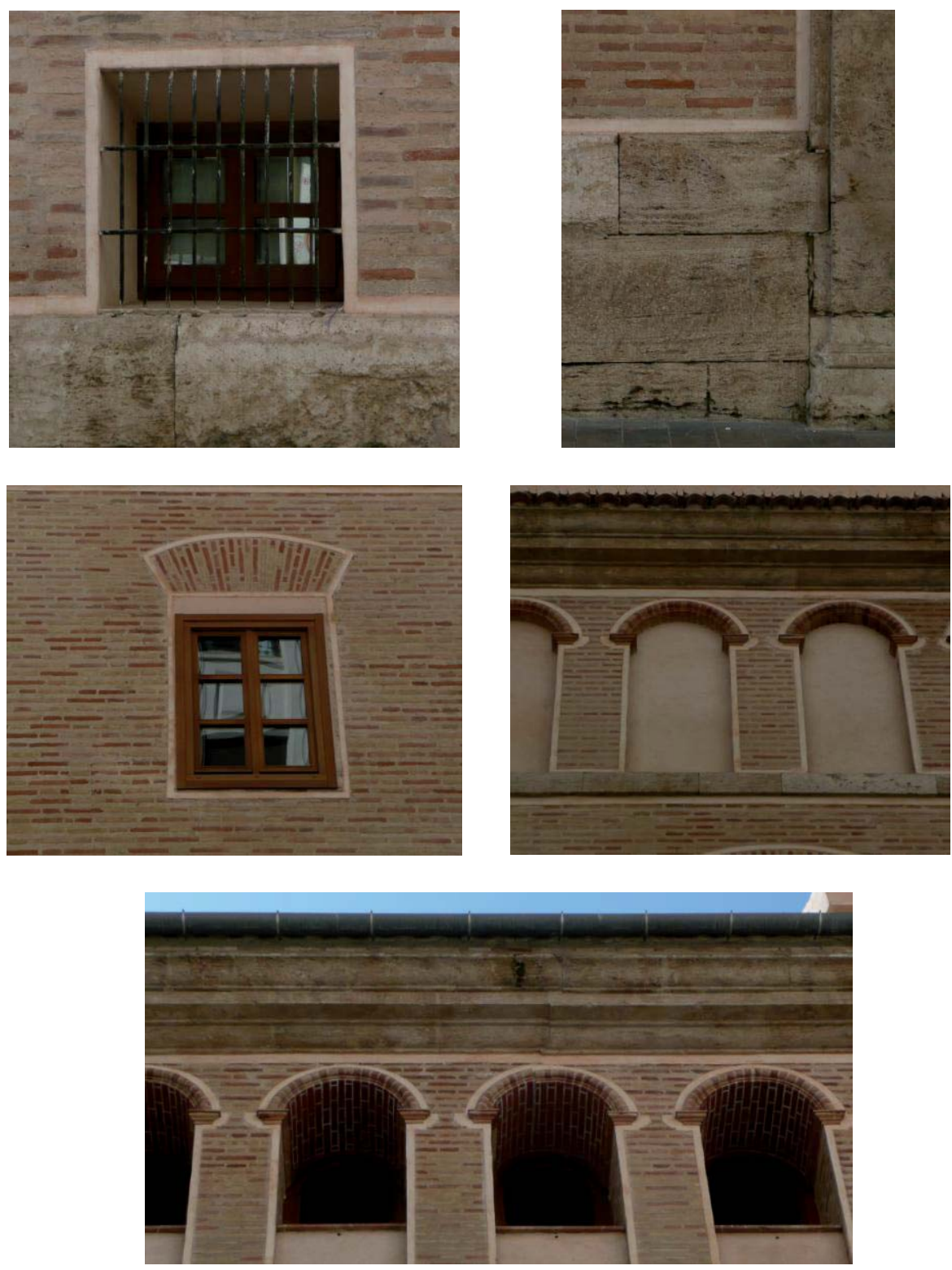


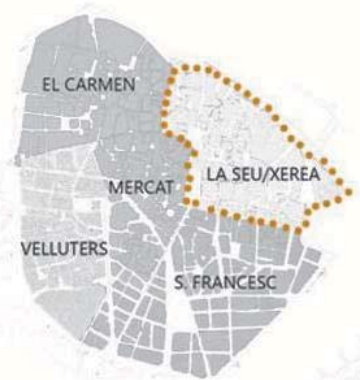

I.2.5 Fábricas históricas: barrio de la Seu-Xerea Fichas recopiladas 


\begin{tabular}{|c|c|c|}
\hline \multicolumn{3}{|c|}{ Barrio de la Seu-Xerea: todas las fábricas seleccionadas } \\
\hline Código & Dirección & Edificio \\
\hline Xa46 & Pza. Nules no 2 & PALACIEGO \\
\hline $\mathrm{Xa74}$ & C/ Serrano no 18 & RESIDENCIAL \\
\hline Xc16a & Pza. Conde de Carlet no 4 & RELIGIOSO \\
\hline Xc16b & C/ Trinitarios no 5 & RELIGIOSO \\
\hline Xc16c & C/ Trinitarios no 5 acc & RELIGIOSO \\
\hline Xc66 & C/ Mestres n०3 & RESIDENCIAL \\
\hline Xc72 & C/ Escoles del Temple no 3 & RESIDENCIAL \\
\hline Xc78 & Pza. Conde del Real n³ & RESIDENCIAL \\
\hline Xc94 & c/ Entenza s/n & RESIDENCIAL \\
\hline Xc96a & Pza. San Luis Beltrán no 1 & PALACIEGO \\
\hline Xc96b & Pza. San Luis Beltrán no 1 & PALACIEGO \\
\hline $\mathrm{Xd11}$ & C/ Venerable No4 & RESIDENCIAL \\
\hline $\mathrm{xd13}$ & C/ Venerable s/n & RELIGIOSO \\
\hline$x d 54 a$ & C/ Lleña no 7 & RELIGIOSO \\
\hline$x d 54 b$ & C/ Miguelete s/n & RELIGIOSO \\
\hline$x d 65$ & Pza. Decimo Julio Bruto s/n & RELIGIOSO \\
\hline $\mathrm{Xe14}$ & C/Avellanas no5 & RESIDENCIAL \\
\hline$\overline{X e 66}$ & c/ Trin de Caballeros no 5 & RELIGIOSO \\
\hline$x f 25$ & C/ Mestres no $2-4$ & RELIGIOSO \\
\hline$x f 26$ & $\begin{array}{l}\text { Pza. Congregación C/ } \\
\text { Trinquete de Caballeros s/n }\end{array}$ & RELIGIOSO \\
\hline $\mathrm{Xg74}$ & C/Engordo n'2 & RESIDENCIAL \\
\hline
\end{tabular}




\begin{tabular}{|c|c|c|c|}
\hline \\
\hline \multicolumn{3}{|c|}{$\begin{array}{l}\text { Barrio de la Seu- Xerea: monumentos } \\
\text { Código }\end{array}$} & \\
\hline Xa46 & Pza. Nules no 2 & PALACIEGO & $\begin{array}{l}\text { Palacio de los } \\
\text { Catalá de } \\
\text { Valeriola }\end{array}$ \\
\hline Xc16a & $\begin{array}{l}\text { Pza. Conde de } \\
\text { Carlet } n^{\circ} 4\end{array}$ & RELIGIOSO & $\begin{array}{l}\text { Antiguo } \\
\text { Seminario } \\
\text { Conciliar }\end{array}$ \\
\hline Xc16b & C/ Trinitarios no 5 & RELIGIOSO & $\begin{array}{l}\text { Antiguo } \\
\text { Seminario } \\
\text { Conciliar }\end{array}$ \\
\hline Xc16c & $\begin{array}{l}\text { C/ Trinitarios no } 5 \\
\text { acc }\end{array}$ & RELIGIOSO & $\begin{array}{l}\text { Antiguo } \\
\text { Seminario } \\
\text { Conciliar } \\
\end{array}$ \\
\hline Xc96a & $\begin{array}{l}\text { Pza. San Luis } \\
\text { Beltrán } n^{0} 1\end{array}$ & PALACIEGO & Almudín \\
\hline Xc96b & $\begin{array}{l}\text { Pza. San Luis } \\
\text { Beltrán n } 1\end{array}$ & PALACIEGO & Almudín \\
\hline$x d 13$ & c/Venerable s/n & RELIGIOSO & $\begin{array}{l}\text { Sacristía Iglesia S } \\
\text { Esteban }\end{array}$ \\
\hline$x d 54 a$ & c/ Lleña no 7 & RELIGIOSO & $\begin{array}{l}\text { Catedral } \\
\text { metropolitana }\end{array}$ \\
\hline$x d 54 b$ & C/ Miguelete s/n & RELIGIOSO & $\begin{array}{l}\text { Catedral } \\
\text { metropolitana }\end{array}$ \\
\hline $\mathrm{xd} 65$ & $\begin{array}{l}\text { Pza. Decimo Julio } \\
\text { Bruto s/n } \\
\end{array}$ & RELIGIOSO & $\begin{array}{l}\text { Real Baślica V. } \\
\text { Desamparados }\end{array}$ \\
\hline Xe66 & $\begin{array}{l}\text { C/ Trinquete de } \\
\text { Caballeros } n^{0} 5 \\
\end{array}$ & RELIGIOSO & $\begin{array}{l}\text { Iglesia San Juan } \\
\text { del Hospital }\end{array}$ \\
\hline$x f 25$ & C/ Mestres no 2/4 & RELIGIOSO & El Temple \\
\hline$x+26$ & $\begin{array}{l}\text { Pza. } \\
\text { Congregación s/n }\end{array}$ & RELIGIOSO & $\begin{array}{l}\text { Iglesia de la } \\
\text { Congregación }\end{array}$ \\
\hline
\end{tabular}




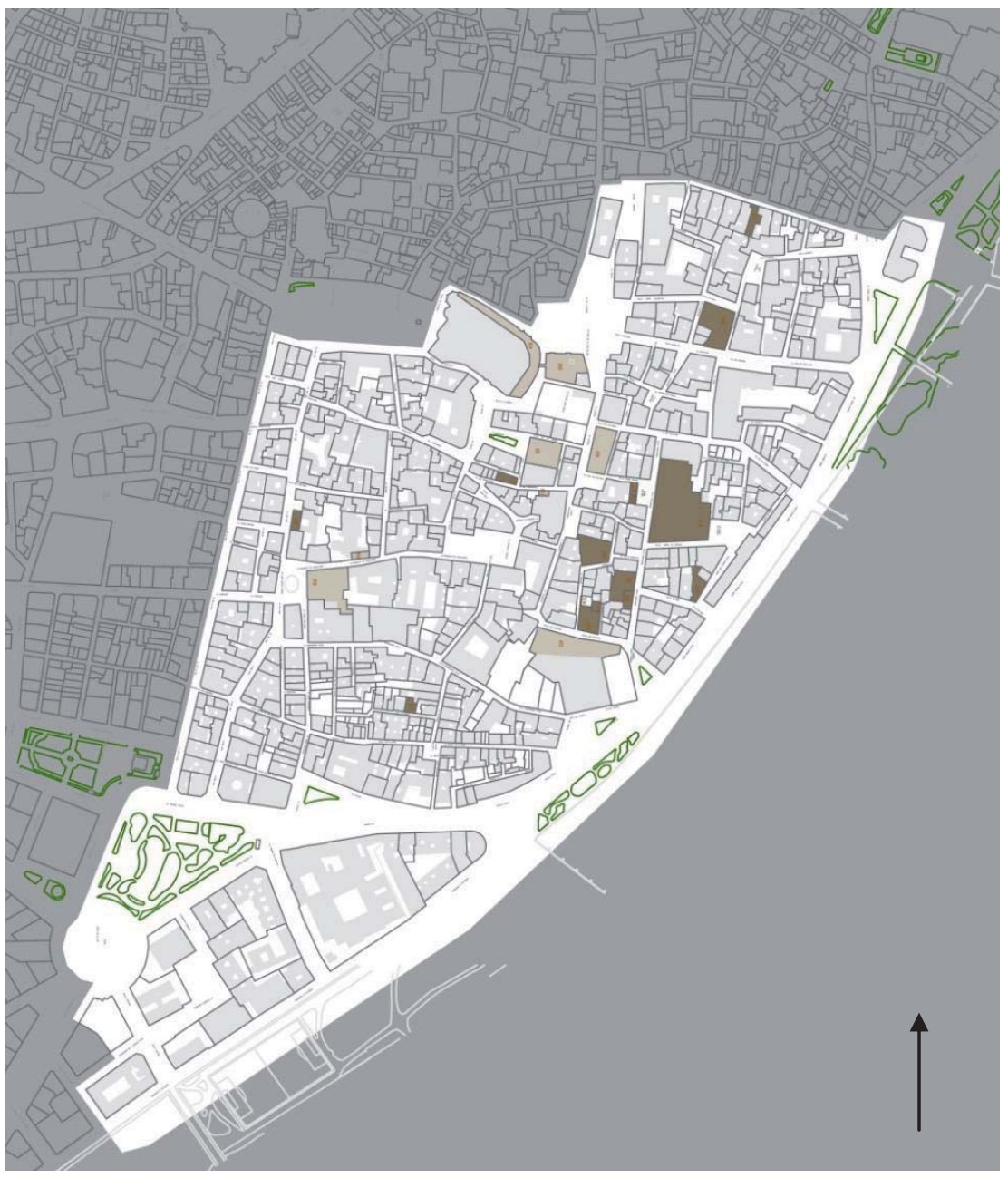

FIG. 8 Mapa de localización de las fichas recopiladas en el barrio de la Seu-Xerea (CRISTINI) 
Datos generales

\begin{tabular}{|c|c|c|c|c|c|}
\hline Barrio & Carmen & La Seu-Xerea & Velluters & Mercat & S.Francesc \\
\hline Dirección & \multicolumn{5}{|c|}{ Pza. Nules n² } \\
\hline Tipo de edificio & residencial & palaciego & religioso & militar & \\
\hline $\mathbf{G}^{\circ}$ de protección & 0 & 1 & 2 & 3 & \\
\hline Fechas claves & \multicolumn{5}{|c|}{ S.XV, intervención 2006(Leyva Sánchez) } \\
\hline
\end{tabular}

El apartado "fechas claves" se ha extraído de AA.V.., Guía de Arquitectura de Valencia, Icaro CTAV Ed., Valencia, 2007

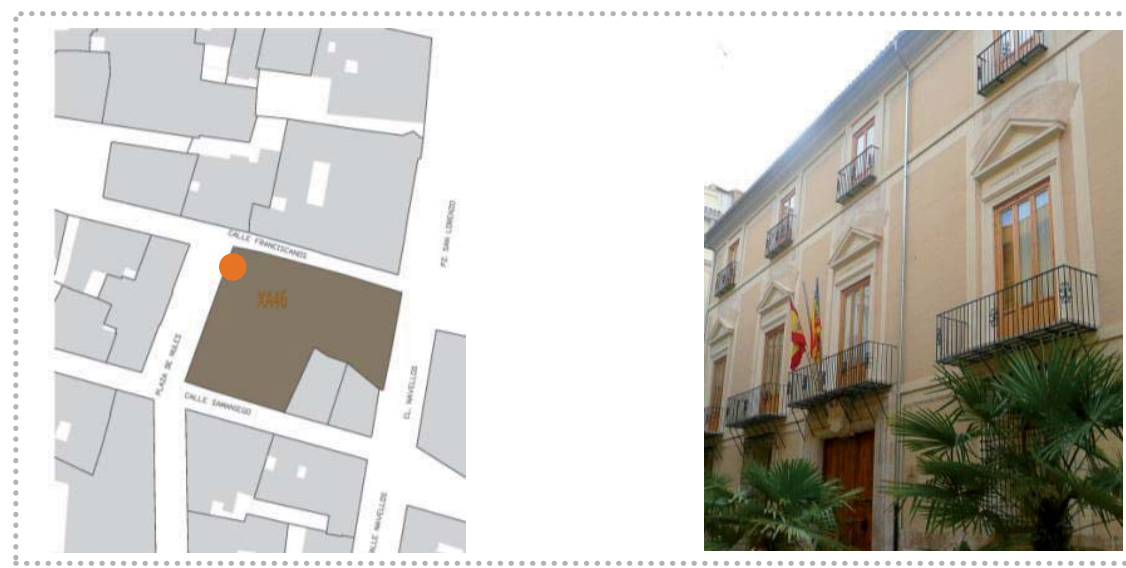

Fachada

Xa46

Pisos
Composición fachada
Zócalo
Fábrica
Vano/dintel
Entrada/dintel
Alero
Cubierta

\begin{tabular}{|c|c|c|c|c|c|c|c|}
\hline \multirow{2}{*}{\multicolumn{2}{|c|}{$\begin{array}{l}\mathrm{N}^{\circ} 2 \\
\text { aleatoria }\end{array}$}} & sótano & entreplanta & piso noble & $\mathrm{ca}$ & ja esca & lera \\
\hline & & \multicolumn{2}{|c|}{ ordenada sin simetría } & \multicolumn{4}{|c|}{ ordenada con simetría } \\
\hline Z1 & Z2 & Z3 & Z4 & & & & \\
\hline $\mathrm{F} 1$ & F2 & F3 & F5 & F6 & & & \\
\hline V1 & V2 & V3 & V4 & V6 & V8 & V9 & V10 \\
\hline E1 & E2 & E3 & E4 & & & & \\
\hline A1 & $\mathrm{A} 2$ & $\mathrm{~A} 3$ & A5 & A6 & & & \\
\hline \multicolumn{2}{|c|}{ plana } & \multicolumn{2}{|c|}{ inclinada } & & & & \\
\hline
\end{tabular}

Fábrica

Xa46

\begin{tabular}{l|lll} 
Aparejo & soga-tizón & soga tizón & \\
Hiladas & irregulares & pseudo horizontales & horizontales \\
Superficie & sin planeidad & pseudo planeidad & planeidad perfecta \\
\hline Sección (hipótesis) & uniforme & hojas y núcleo & abocinada (vano) \\
\hline Elementos destacados & aplantillado & cortado terracota & \\
\hline
\end{tabular}




\begin{tabular}{|c|c|c|c|}
\hline$N^{\circ}$ elementos medidos & 15 & & \\
\hline Longitud (cm) & 29.5 & & \\
\hline Anchura (cm) & 13.5 & & \\
\hline Espesor (cm) & 4.3 & & \\
\hline Volumen $\left(\mathrm{cm}^{3}\right)$ & 1712.4 & & \\
\hline Tipo & homogéneo & heterogéneo & re-empleo \\
\hline Color & homogéneo & heterogéneo globular & heterogéneo marmolado \\
\hline Recogida de muestra & no & sí & código \\
\hline Patologías & $\begin{array}{l}\text { eflorescencias } \\
\text { erosión }\end{array}$ & $\begin{array}{l}\text { micro fisuración } \\
\text { disgregación }\end{array}$ & $\begin{array}{l}\text { grietas } \\
\text { descamación }\end{array}$ \\
\hline
\end{tabular}

1 Datos obtenidos en base al cálculo del desvío estándar (respecto al valor medio de la muestras analizadas) y del gráfico de frecuencia de las muestras analizadas, identificado por una curva gaussiana

\section{untas}

\begin{tabular}{|c|c|c|c|c|}
\hline \multirow{2}{*}{$\begin{array}{l}N^{\circ} \text { elementos medidos } \\
\text { Llaga }(\mathrm{cm})\end{array}$} & \multicolumn{4}{|l|}{15} \\
\hline & \multicolumn{4}{|l|}{1.2} \\
\hline Tendel (cm) & \multicolumn{4}{|l|}{3.5} \\
\hline Altura de 5 hiladas $(\mathrm{cm})$ & \multicolumn{4}{|l|}{39} \\
\hline Proporción ladrillo/junta & \multicolumn{4}{|l|}{1.14} \\
\hline Tipo de acabado & simple & doble & \multicolumn{2}{|l|}{ múltiple } \\
\hline \multirow[t]{2}{*}{ Junta de asiento } & rehundida & a hueso & \multirow{2}{*}{\multicolumn{2}{|c|}{ saliente }} \\
\hline & enrasada & matada & & \\
\hline \multirow[t]{2}{*}{ Junta de acabado } & rehundida & a hueso & \multirow{2}{*}{\multicolumn{2}{|c|}{ saliente }} \\
\hline & enrasada & matada & & \\
\hline \multirow{3}{*}{$\begin{array}{l}\text { Tipo de mortero } \\
\text { Morfología de mortero } \\
\text { Tipo de árido }\end{array}$} & cal & cal y tierra & tierra & cemento mixto \\
\hline & con grumos & con caliches & homogéneo & heterogéneo \\
\hline & arena & gravilla & grava & mixto \\
\hline \multirow{4}{*}{$\begin{array}{l}\text { Color del árido } \\
\text { Recogida de muestra } \\
\text { Patologías }\end{array}$} & claro & oscuro & homogéneo & heterogéneo \\
\hline & no & sí & \multicolumn{2}{|l|}{ código } \\
\hline & eflorescencias & micro fisuración & \multicolumn{2}{|l|}{ grietas } \\
\hline & erosión & disgregación & \multicolumn{2}{|l|}{ pulverización } \\
\hline
\end{tabular}


Imágenes

Xa46
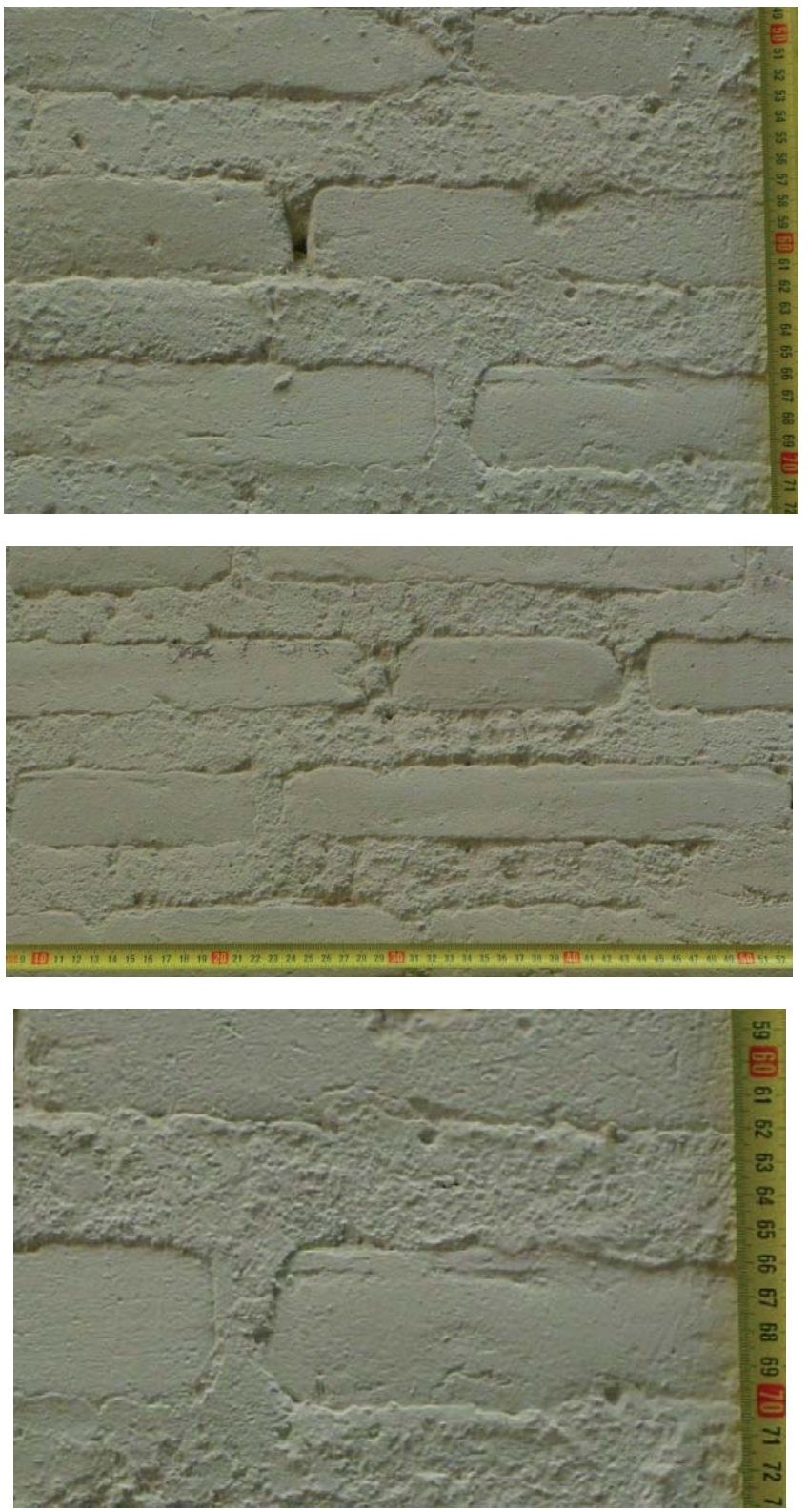

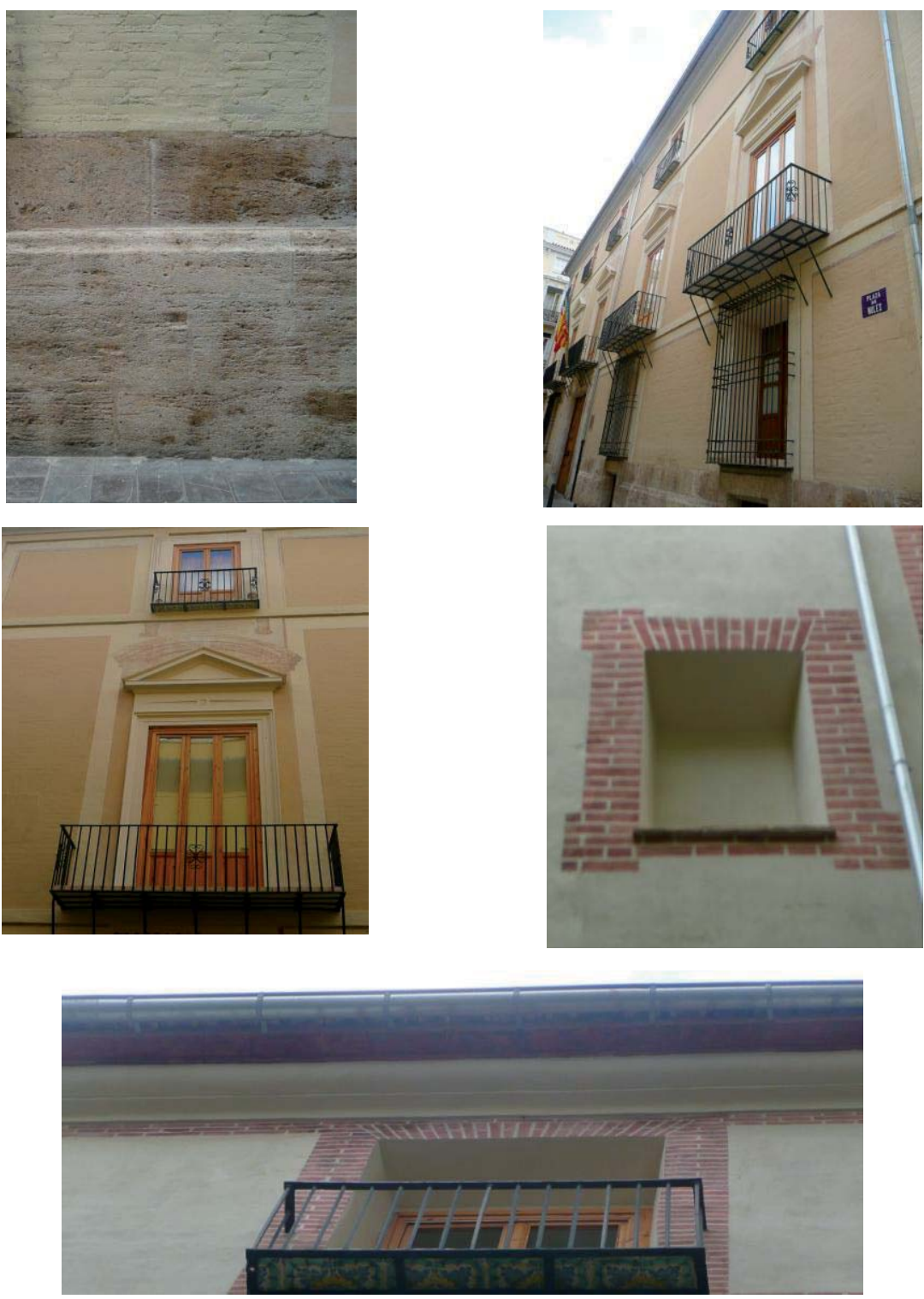
Datos generales

\begin{tabular}{|c|c|c|c|c|c|}
\hline \multirow{2}{*}{$\begin{array}{l}\text { Barrio } \\
\text { Dirección }\end{array}$} & Carmen & La Seu-Xerea & Velluters & Mercat & S.Francesc \\
\hline & \multicolumn{5}{|c|}{ C/Serranos nº18 } \\
\hline Tipo de edificio & residencial & palaciego & religioso & militar & \\
\hline $\mathbf{G}^{\circ}$ de protección & 0 & 1 & 2 & 3 & \\
\hline Fechas claves & / & & & & \\
\hline
\end{tabular}
El apartado "fechas claves" se ha extraído de AA.V. ., Guía de Arquitectura de Valencia, Icaro CTAV Ed., Valencia, 2007
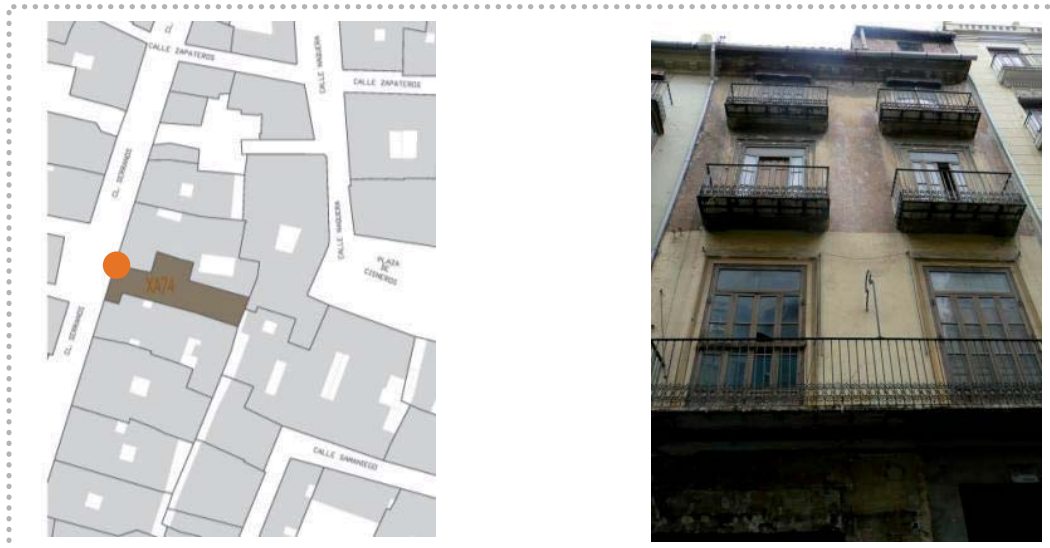

Fachada

Xa74

Pisos
Composición fachada
Zócalo
Fábrica
Vano/dintel
Entrada/dintel
Alero
Cubierta

\begin{tabular}{|c|c|c|c|c|c|c|c|}
\hline \multirow{2}{*}{\multicolumn{2}{|c|}{$\begin{array}{l}\mathrm{N}^{\circ 3} \\
\text { aleatoria }\end{array}$}} & \multirow{2}{*}{\multicolumn{2}{|c|}{$\begin{array}{l}\text { sótano entreplanta } \\
\text { ordenada sin simetría }\end{array}$}} & \multicolumn{4}{|c|}{ piso noble caja escalera } \\
\hline & & & & \multicolumn{4}{|c|}{ ordenada con simetría } \\
\hline $\mathrm{Z1}$ & Z2 & $\mathrm{Z3}$ & Z4 & & & & \\
\hline F1 & F2 & F3 & F5 & F6 & & & \\
\hline V1 & V2 & V3 & V5 & V6 & V8 & V9 & V10 \\
\hline E1 & E2 & E3 & E4 & & & & \\
\hline A1 & $\mathrm{A} 2$ & $\mathrm{~A} 3$ & A5 & A6 & & & \\
\hline \multicolumn{2}{|c|}{ plana } & \multicolumn{2}{|c|}{ inclinada } & & & & \\
\hline
\end{tabular}

Fábrica

Xa74

\section{Aparejo \\ Hiladas \\ Superficie \\ Sección (hipótesis) \\ Elementos destacados}

\begin{tabular}{lll} 
soga-tizón & soga & \multicolumn{1}{c}{ tizón } \\
irregulares & pseudo horizontales & horizontales \\
\hline sin planeidad & pseudo planeidad & planeidad perfecta \\
\hline uniforme & hojas y núcleo & abocinada (vano) \\
aplantillado & cortado terracota & \\
\hline
\end{tabular}




\begin{tabular}{|c|c|c|c|}
\hline \multirow{3}{*}{$\begin{array}{l}\mathrm{N}^{\circ} \text { elementos medidos } \\
\text { Longitud }(\mathrm{cm}) \\
\text { Anchura }(\mathrm{cm})\end{array}$} & \multicolumn{3}{|l|}{15} \\
\hline & \multicolumn{3}{|l|}{30.05} \\
\hline & \multicolumn{3}{|l|}{12.0} \\
\hline Espesor (cm) & \multicolumn{3}{|l|}{3.5} \\
\hline Volumen $\left(\mathrm{cm}^{3}\right)$ & \multicolumn{3}{|l|}{1262.1} \\
\hline Tipo & homogéneo & heterogéneo & re-empleo \\
\hline Color & homogéneo & heterogéneo globular & heterogéneo marmolado \\
\hline Recogida de muestra & no & sí & código Xa74/2 \\
\hline Patologías & $\begin{array}{l}\text { eflorescencias } \\
\text { erosión }\end{array}$ & $\begin{array}{l}\text { micro fisuración } \\
\text { disgregación }\end{array}$ & $\begin{array}{l}\text { grietas } \\
\text { descamación }\end{array}$ \\
\hline
\end{tabular}

${ }^{1}$ Datos obtenidos en base al cálculo del desvío estándar (respecto al valor medio de la muestras analizadas) y del gráfico de frecuencia de las muestras analizadas, identificado por una curva gaussiana

\section{untas}

\begin{tabular}{|c|c|c|c|c|}
\hline \multirow{2}{*}{$\begin{array}{l}N^{\circ} \text { elementos medidos } \\
\text { Llaga }(\mathrm{cm})\end{array}$} & \multicolumn{4}{|l|}{15} \\
\hline & \multicolumn{4}{|l|}{0.7} \\
\hline Tendel (cm) & \multicolumn{4}{|l|}{3.1} \\
\hline Altura de 5 hiladas $(\mathrm{cm})$ & \multicolumn{4}{|l|}{32} \\
\hline Proporción ladrillo/junta & \multicolumn{4}{|l|}{1.12} \\
\hline Tipo de acabado & simple & doble & \multicolumn{2}{|l|}{ múltiple } \\
\hline \multirow[t]{2}{*}{ Junta de asiento } & rehundida & a hueso & \multirow{2}{*}{\multicolumn{2}{|c|}{ saliente }} \\
\hline & enrasada & matada & & \\
\hline \multirow[t]{2}{*}{ Junta de acabado } & rehundida & a hueso & \multirow{2}{*}{\multicolumn{2}{|c|}{ saliente }} \\
\hline & enrasada & matada & & \\
\hline \multirow{3}{*}{$\begin{array}{l}\text { Tipo de mortero } \\
\text { Morfología de mortero } \\
\text { Tipo de árido }\end{array}$} & cal & cal y tierra & tierra & cemento mixto \\
\hline & con grumos & con caliches & homogéneo & heterogéneo \\
\hline & arena & gravilla & grava & mixto \\
\hline \multirow{4}{*}{$\begin{array}{l}\text { Color del árido } \\
\text { Recogida de muestra } \\
\text { Patologías }\end{array}$} & claro & oscuro & homogéneo & heterogéneo \\
\hline & no & sí & \multicolumn{2}{|l|}{ código Xa74/1 } \\
\hline & eflorescencias & micro fisuración & \multirow{2}{*}{\multicolumn{2}{|c|}{ grietas }} \\
\hline & erosión" & disgregación & & pulverización \\
\hline
\end{tabular}




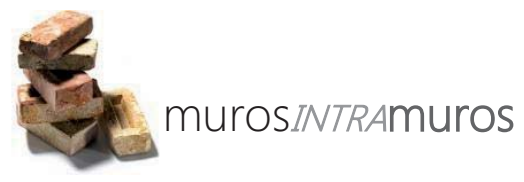

Imágenes $\quad$ Xa74
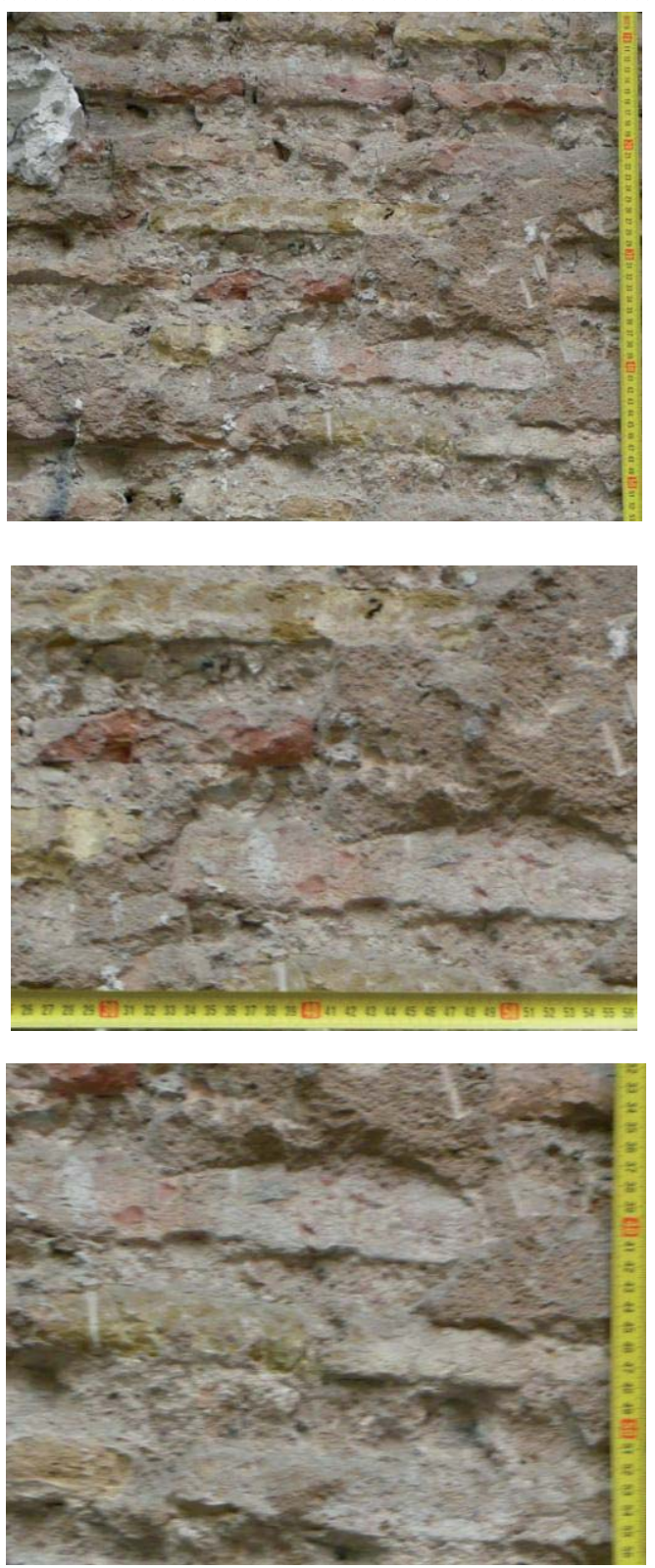

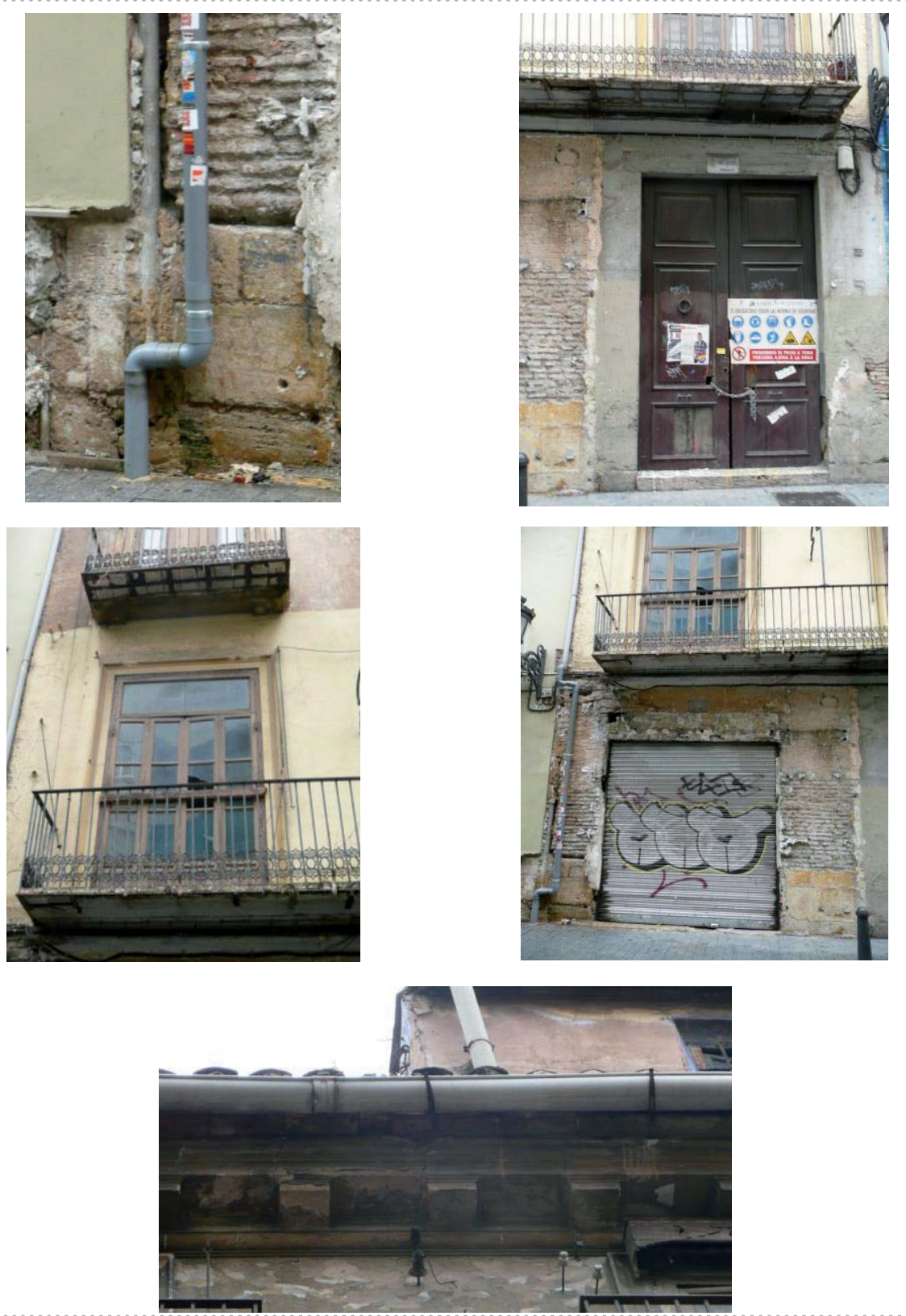
Datos generales

\begin{tabular}{|c|c|c|c|c|c|}
\hline Barrio & Carmen & La Seu-Xerea & Velluters & Mercat & S.Francesc \\
\hline Dirección & Pza. Conde & Carlet $n^{\circ} 4$ & & & \\
\hline Tipo de edificio & residencial & palaciego & religioso & militar & \\
\hline $\mathbf{G}^{\circ}$ de protección & 0 & 1 & 2 & 3 & \\
\hline Fechas claves & 1853 (Calvo & arra) & & & \\
\hline
\end{tabular}

El apartado "fechas claves" se ha extraído de AA.W., Guía de Arquitectura de Valencia, Icaro CTAV Ed., Valencia, 2007

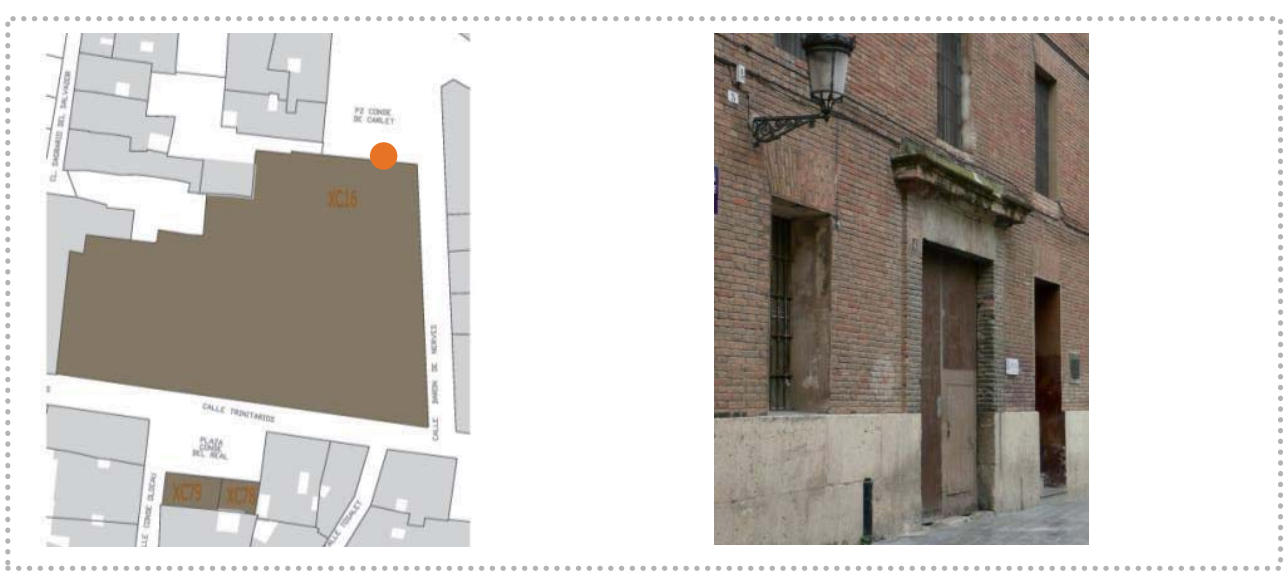

Fachada

Xc16a

\begin{tabular}{|c|c|c|c|c|c|c|c|c|c|}
\hline \multirow{3}{*}{$\begin{array}{l}\text { Pisos } \\
\text { Composición fachada } \\
\text { Zócalo }\end{array}$} & \multicolumn{2}{|c|}{$N^{0} 5$} & sótano & \multicolumn{2}{|c|}{ entreplanta } & \multicolumn{4}{|c|}{ piso noble caja escalera } \\
\hline & \multicolumn{2}{|c|}{ aleatoria } & \multicolumn{3}{|c|}{ ordenada sin simetría } & \multicolumn{4}{|c|}{ ordenada con simetría } \\
\hline & Z1 & $\mathrm{Z2}$ & $\mathrm{Z3}$ & Z4 & Z5 & & & & \\
\hline Fábrica & $\mathrm{F} 1$ & $\mathrm{~F} 2$ & F3 & $\mathrm{F} 4$ & F5 & F6 & & & \\
\hline Vano/dintel & V1 & V2 & V3 & V4 & V5 & V6 & V8 & V9 & V10 \\
\hline Entrada/dintel & E1 & E2 & E3 & E4 & & & & & \\
\hline Alero & A1 & $\mathrm{A} 2$ & A3 & A4 & A5 & A6 & & & \\
\hline Cubierta & plar & & inclin & & & & & & \\
\hline
\end{tabular}

\section{Fábrica}

Xc16a

Aparejo
Hiladas
Superficie
Sección (hipótesis)
Elementos destacados

\begin{tabular}{lll} 
soga-tizón & soga & \multicolumn{1}{c}{ tizón } \\
irregulares & pseudo horizontales & horizontales \\
\hline sin planeidad & pseudo planeidad & planeidad perfecta \\
\hline uniforme & hojas y núcleo & abocinada (vano) \\
aplantillado & cortado terracota & \\
\hline
\end{tabular}




\begin{tabular}{|c|c|c|c|}
\hline \multirow{2}{*}{$\begin{array}{l}\mathrm{N}^{\circ} \text { elementos medidos } \\
\text { Longitud }(\mathrm{cm})\end{array}$} & \multicolumn{3}{|l|}{15} \\
\hline & \multicolumn{3}{|l|}{28} \\
\hline Anchura (cm) & \multicolumn{3}{|l|}{13.5} \\
\hline Espesor (cm) & \multicolumn{3}{|l|}{5} \\
\hline Volumen $\left(\mathrm{cm}^{3}\right)$ & \multicolumn{3}{|l|}{1890} \\
\hline Tipo & homogéneo & heterogéneo & re-empleo \\
\hline \multirow{4}{*}{$\begin{array}{l}\text { Color } \\
\text { Recogida de muestra } \\
\text { Patologías }\end{array}$} & homogéneo & heterogéneo globular & heterogéneo marmolado \\
\hline & no & sí & código \\
\hline & eflorescencias & micro fisuración & grietas \\
\hline & erosión & disgregación & descamación \\
\hline
\end{tabular}

1 Datos obtenidos en base al cálculo del desvío estándar (respecto al valor medio de la muestras analizadas) y del gráfico de frecuencia de las muestras analizadas, identificado por una curva gaussiana

\begin{tabular}{|c|c|c|c|c|}
\hline \multirow{2}{*}{$\begin{array}{l}N^{\circ} \text { elementos medidos } \\
\text { Llaga }(\mathrm{cm})\end{array}$} & \multicolumn{4}{|l|}{15} \\
\hline & \multicolumn{4}{|l|}{0.8} \\
\hline Tendel (cm) & \multicolumn{4}{|l|}{1.3} \\
\hline Altura de 5 hiladas $(\mathrm{cm})$ & \multicolumn{4}{|l|}{31} \\
\hline Proporción ladrillo/junta & \multicolumn{4}{|l|}{3.8} \\
\hline Tipo de acabado & simple & doble & \multicolumn{2}{|l|}{ múltiple } \\
\hline \multirow[t]{2}{*}{ Junta de asiento } & rehundida & a hueso & \multirow[t]{2}{*}{ saliente } & \\
\hline & enrasada & matada & & \\
\hline \multirow[t]{2}{*}{ Junta de acabado } & rehundida & a hueso & \multirow[t]{2}{*}{ saliente } & \\
\hline & enrasada & matada & & \\
\hline \multirow{2}{*}{$\begin{array}{l}\text { Tipo de mortero } \\
\text { Morfología de mortero }\end{array}$} & cal & cal y tierra & tierra & cemento mixto \\
\hline & con grumos & con caliches & homogéneo & heterogéneo \\
\hline \multirow{5}{*}{$\begin{array}{l}\text { Tipo de árido } \\
\text { Color del árido } \\
\text { Recogida de muestra } \\
\text { Patologías }\end{array}$} & arena & gravilla & grava & mixto \\
\hline & claro & oscuro & homogéneo & heterogéneo \\
\hline & no & sí & \multicolumn{2}{|l|}{ código } \\
\hline & eflorescencias & micro fisuración & \multicolumn{2}{|l|}{ grietas } \\
\hline & erosión & disgregación & \multicolumn{2}{|l|}{ pulverización } \\
\hline
\end{tabular}


Imágenes
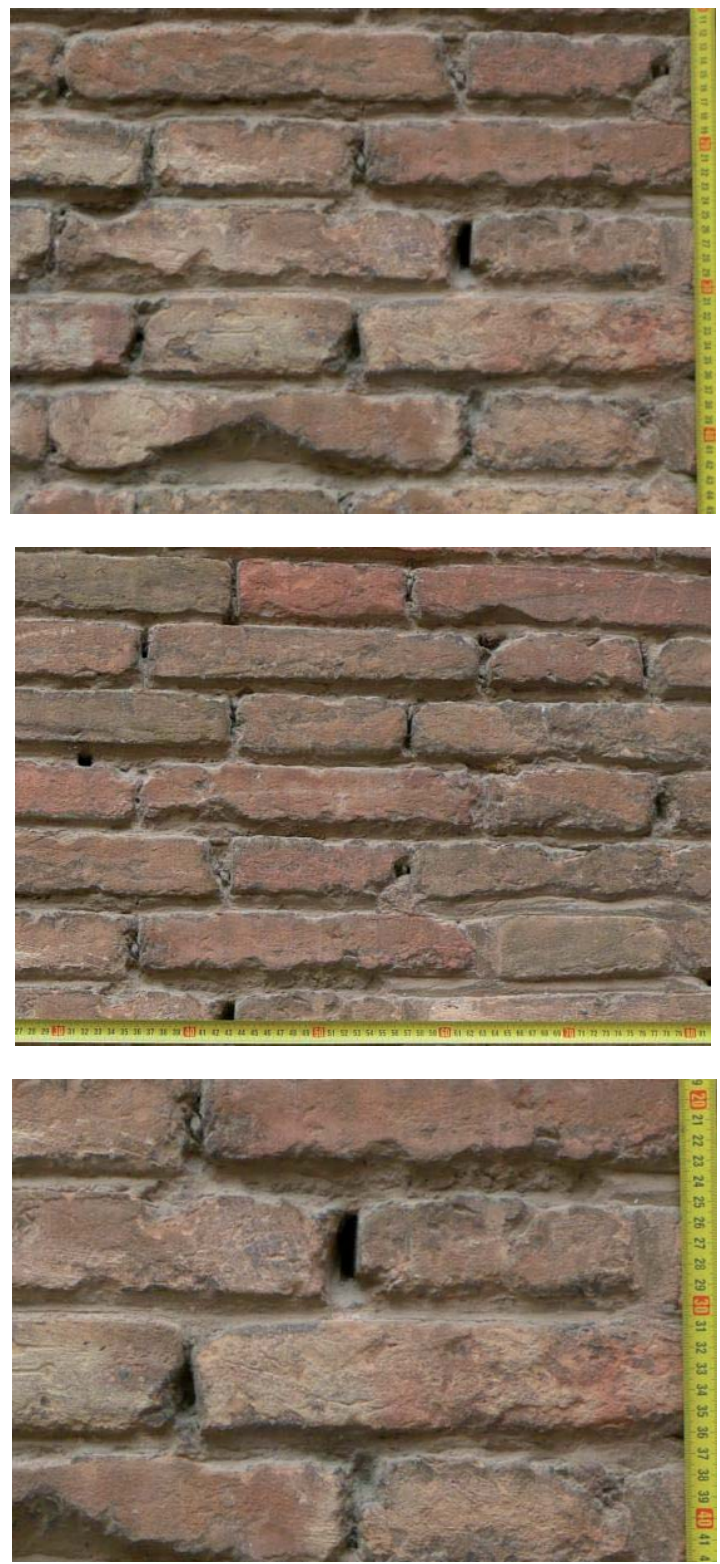

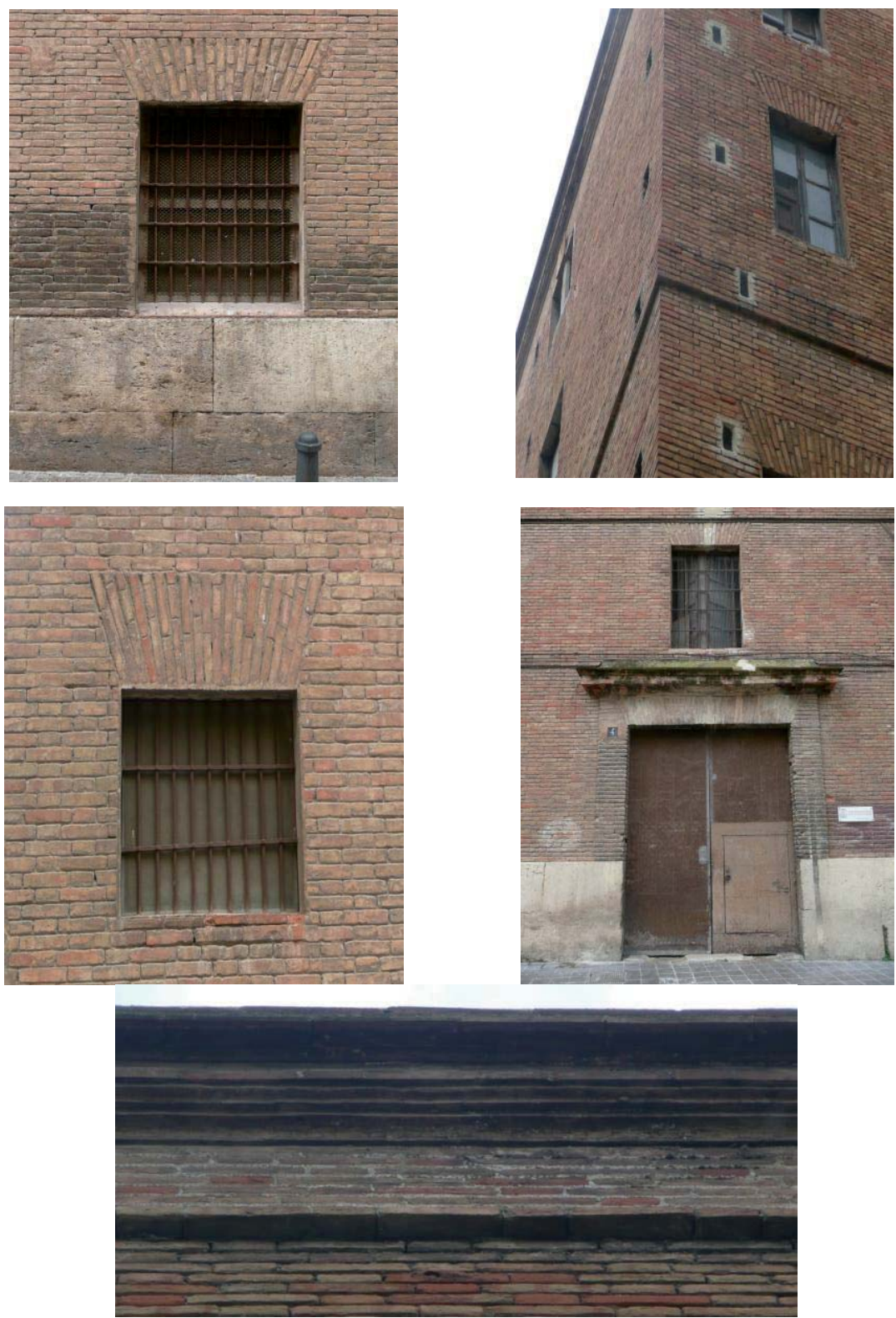
Datos generales

\section{$\mathrm{Xc16b}$}

\begin{tabular}{|c|c|c|c|c|c|}
\hline Barrio & Carmen & La Seu-Xerea & Velluters & Mercat & S.Francesc \\
\hline Dirección & \multicolumn{5}{|c|}{ C/Trinitarios $n^{\circ} 5$} \\
\hline Tipo de edificio & residencial & palaciego & religioso & militar & \\
\hline $\mathbf{G}^{\circ}$ de protección & 0 & 1 & 2 & 3 & \\
\hline Fechas claves & \multicolumn{5}{|c|}{1853 (Calvo Ibarra) } \\
\hline
\end{tabular}

El apartado "fechas claves" se ha extraído de AA.W., Guía de Arquitectura de Valencia, Icaro CTAV Ed., Valencia, 2007
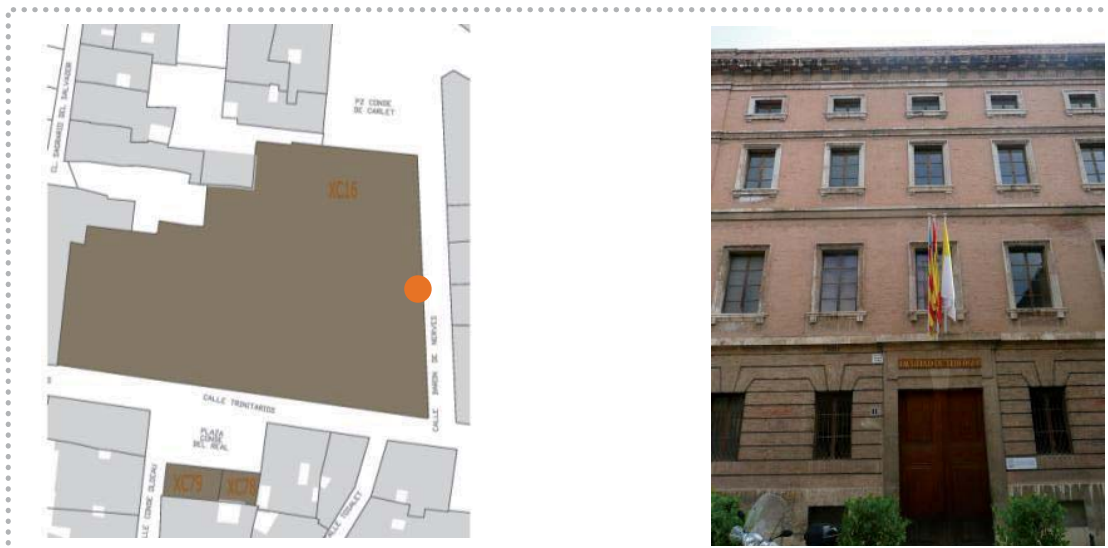

Fachada

Xc16b

Pisos
Composición fachada
Zócalo
Fábrica
Vano/dintel
Entrada/dintel
Alero
Cubierta

\begin{tabular}{|c|c|c|c|c|c|c|c|c|c|}
\hline \multirow{2}{*}{\multicolumn{2}{|c|}{$\begin{array}{l}\mathrm{N}^{\circ} 4 \\
\text { aleatoria }\end{array}$}} & sótano & & planta & \multicolumn{5}{|c|}{ piso noble caja escalera } \\
\hline & & \multicolumn{3}{|c|}{ ordenada sin simetría } & \multicolumn{5}{|c|}{ ordenada con simetría } \\
\hline Z1 & $\mathrm{Z} 2$ & Z3 & Z4 & $\mathrm{Z} 5$ & & & & & \\
\hline F1 & F2 & F3 & F4 & F5 & F6 & F7 & & & \\
\hline V1 & V2 & V3 & V4 & V5 & V6 & V7 & V8 & V9 & V10 \\
\hline $\mathrm{E} 1$ & E2 & E3 & E4 & & & & & & \\
\hline A1 & A2 & A3 & A4 & A5 & A6 & A7 & & & \\
\hline \multicolumn{2}{|c|}{ plana } & \multicolumn{3}{|c|}{ inclinada } & & & & & \\
\hline
\end{tabular}

Fábrica

Xc16b

\section{Aparejo \\ Hiladas \\ Superficie \\ Sección (hipótesis) \\ Elementos destacados}

\begin{tabular}{lll} 
soga-tizón & soga & \multicolumn{1}{c}{ tizón } \\
irregulares & pseudo horizontales & horizontales \\
\hline sin planeidad & pseudo planeidad & planeidad perfecta \\
\hline uniforme & hojas y núcleo & abocinada (vano) \\
aplantillado & cortado terracota & \\
\hline
\end{tabular}




\begin{tabular}{l|lll}
\hline $\begin{array}{l}\text { No elementos medidos } \\
\text { Longitud }(\mathbf{c m})\end{array}$ & 15 & & \\
Anchura $(\mathbf{c m})$ & 29 & & \\
Espesor $(\mathbf{c m})$ & 14 & & \\
Volumen $\left(\mathbf{c m}^{3}\right)$ & 2030 & heterogéneo & re-empleo \\
Tipo & homogéneo & heterogéneo globular & heterogéneo marmolado \\
Color & homogéneo & sí & código \\
Recogida de muestra & no & micro fisuración & grietas \\
Patologías & eflorescencias & disgregación & descamación \\
& erosión & &
\end{tabular}

${ }^{1}$ Datos obtenidos en base al cálculo del desvío estándar (respecto al valor medio de la muestras analizadas) y del gráfico de frecuencia de las muestras analizadas, identificado por una curva gaussiana

Juntas 2

Xc16b

\begin{tabular}{|c|c|c|c|c|}
\hline \multirow{2}{*}{$\begin{array}{l}N^{0} \text { elementos medidos } \\
\text { Llaga }(\mathrm{cm})\end{array}$} & \multicolumn{4}{|l|}{15} \\
\hline & \multicolumn{4}{|l|}{1.5} \\
\hline Tendel (cm) & \multicolumn{4}{|l|}{1.6} \\
\hline Altura de 5 hiladas $(\mathrm{cm})$ & \multicolumn{4}{|l|}{33} \\
\hline Proporción ladrillo/junta & \multicolumn{4}{|l|}{3.1} \\
\hline Tipo de acabado & simple & doble & múltiple & \\
\hline Junta de asiento & $\begin{array}{l}\text { rehundida } \\
\text { enrasada }\end{array}$ & $\begin{array}{l}\text { a hueso } \\
\text { matada }\end{array}$ & saliente & \\
\hline Junta de acabado & $\begin{array}{l}\text { rehundida } \\
\text { enrasada }\end{array}$ & $\begin{array}{l}\text { a hueso } \\
\text { matada }\end{array}$ & saliente & \\
\hline Tipo de mortero & cal & cal y tierra & tierra & cemento mixto \\
\hline Morfología de mortero & con grumos & con caliches & homogéneo & heterogéneo \\
\hline Tipo de árido & arena & gravilla & grava & mixto \\
\hline Color del árido & claro & oscuro & homogéneo & heterogéneo \\
\hline Recogida de muestra & no & sí & código & \\
\hline Patologías & $\begin{array}{l}\text { eflorescencias } \\
\text { erosión" }\end{array}$ & $\begin{array}{l}\text { micro fisuración } \\
\text { disgregación }\end{array}$ & $\begin{array}{l}\text { grietas } \\
\text { pulverización }\end{array}$ & \\
\hline
\end{tabular}


Imágenes
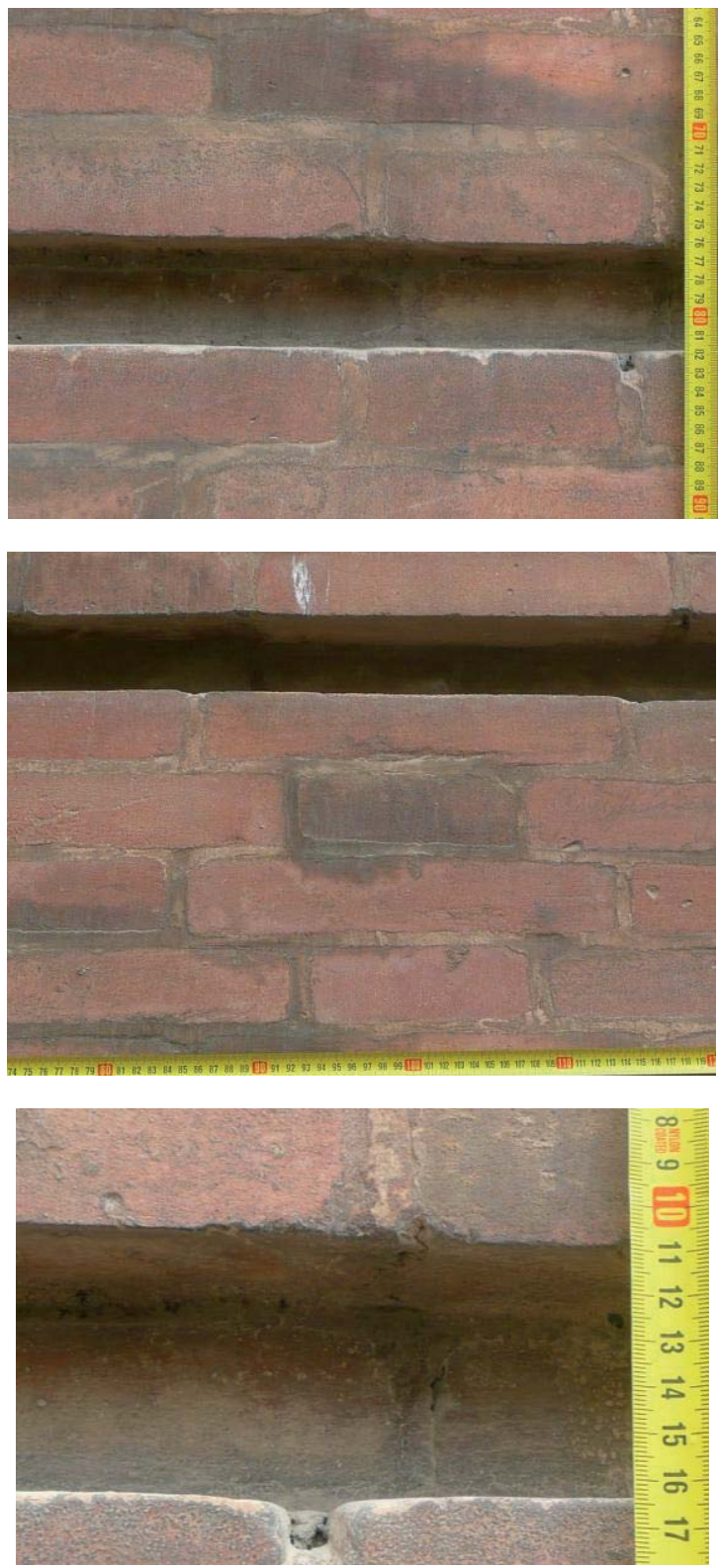

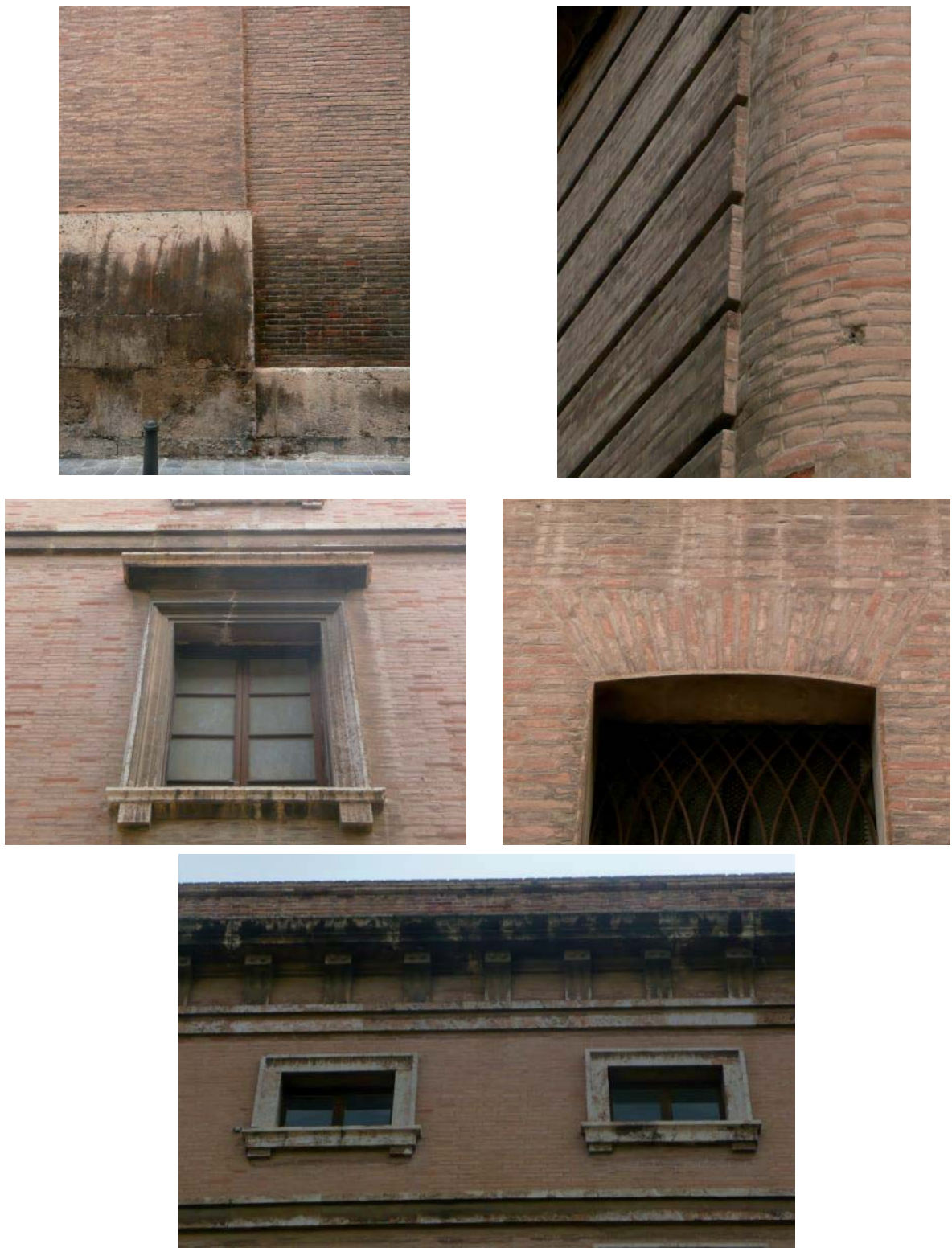
Datos generales

\begin{tabular}{|c|c|c|c|c|c|}
\hline Barrio & Carmen & La Seu-Xerea & Velluters & Mercat & S.Francesc \\
\hline Dirección & C/Trinitarios & n5/acc. & & & \\
\hline Tipo de edificio & residencial & palaciego & religioso & militar & \\
\hline$G^{\circ}$ de protección & 0 & 1 & 2 & 3 & \\
\hline Fechas claves & 1853 (Calvo & borra) & & & \\
\hline
\end{tabular}

El apartado "fechas claves" se ha extraído de AA.W., Guía de Arquitectura de Valencia, Icaro CTAV Ed., Valencia, 2007

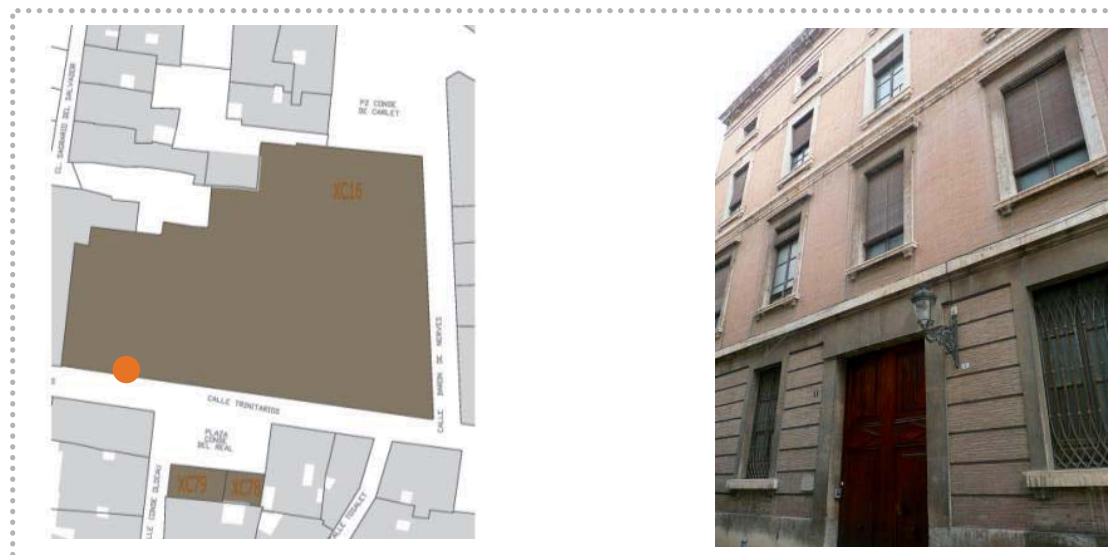

Fachada

Xc16c

Pisos

Composición fachada

Zócalo

Fábrica

Vano/dintel

Entrada/dintel

Alero

Cubierta

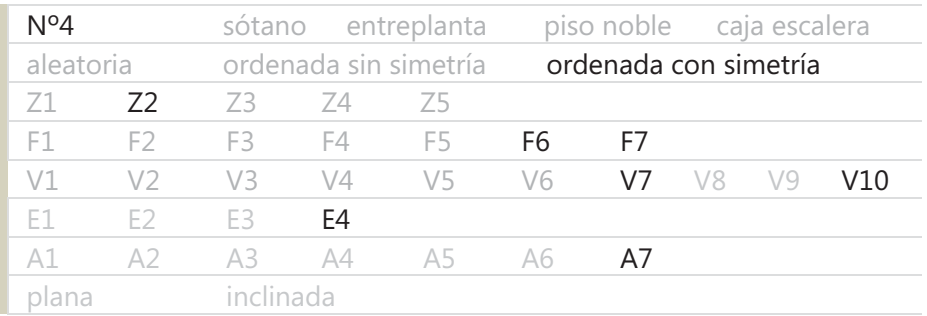

\section{Fábrica}

\section{Xc16c}

\section{Aparejo \\ Hiladas \\ Superficie \\ Sección (hipótesis) \\ Elementos destacados}

\begin{tabular}{lll} 
soga-tizón & soga & \\
irregulares & tizón & \\
sin planeidad & pseudo planeidad & planeidad perfecta \\
\hline uniforme & hojas y núcleo & abocinada (vano) \\
aplantillado & cortado terracota & \\
\hline
\end{tabular}




\begin{tabular}{|c|c|c|c|}
\hline \multirow{2}{*}{$\begin{array}{l}\mathrm{N}^{\circ} \text { elementos medidos } \\
\text { Longitud }(\mathrm{cm})\end{array}$} & \multicolumn{3}{|l|}{15} \\
\hline & \multicolumn{3}{|l|}{27.8} \\
\hline Anchura (cm) & \multicolumn{3}{|l|}{13.5} \\
\hline Espesor (cm) & \multicolumn{3}{|l|}{4.6} \\
\hline Volumen $\left(\mathrm{cm}^{3}\right)$ & \multicolumn{3}{|l|}{1726.38} \\
\hline Tipo & homogéneo & heterogéneo & re-empleo \\
\hline \multirow{4}{*}{$\begin{array}{l}\text { Color } \\
\text { Recogida de muestra } \\
\text { Patologías }\end{array}$} & homogéneo & heterogéneo globular & heterogéneo marmolado \\
\hline & no & sí & código \\
\hline & eflorescencias & micro fisuración & grietas \\
\hline & erosión & disgregación & descamación \\
\hline
\end{tabular}

1 Datos obtenidos en base al cálculo del desvío estándar (respecto al valor medio de la muestras analizadas) y del gráfico de frecuencia de las muestras analizadas, identificado por una curva gaussiana

\section{untas}

\begin{tabular}{|c|c|c|c|c|}
\hline \multirow{2}{*}{$\begin{array}{l}N^{\circ} \text { elementos medidos } \\
\text { Llaga }(\mathrm{cm})\end{array}$} & \multicolumn{4}{|l|}{15} \\
\hline & \multicolumn{4}{|l|}{0.8} \\
\hline \multirow{4}{*}{$\begin{array}{l}\text { Tendel (cm) } \\
\text { Altura de } 5 \text { hiladas (cm) } \\
\text { Proporción ladrillo/junta } \\
\text { Tipo de acabado }\end{array}$} & \multicolumn{4}{|l|}{1} \\
\hline & \multicolumn{4}{|l|}{28} \\
\hline & \multicolumn{4}{|l|}{1} \\
\hline & simple & doble & múltiple & \\
\hline \multirow[t]{2}{*}{ Junta de asiento } & rehundida & a hueso & saliente & \\
\hline & enrasada & matada & & \\
\hline \multirow[t]{2}{*}{ Junta de acabado } & rehundida & a hueso & saliente & \\
\hline & enrasada & matada & & \\
\hline \multirow{2}{*}{$\begin{array}{l}\text { Tipo de mortero } \\
\text { Morfología de mortero }\end{array}$} & cal & cal y tierra & tierra & cemento mixto \\
\hline & con grumos & con caliches & homogéneo & heterogéneo \\
\hline Tipo de árido & arena & gravilla & grava & mixto \\
\hline \multirow{4}{*}{$\begin{array}{l}\text { Color del árido } \\
\text { Recogida de muestra } \\
\text { Patologías }\end{array}$} & claro & oscuro & homogéneo & heterogéneo \\
\hline & no & sí & código & \\
\hline & eflorescencias & micro fisuración & grietas & \\
\hline & erosión & disgregación & pulverización & \\
\hline
\end{tabular}


Imágenes
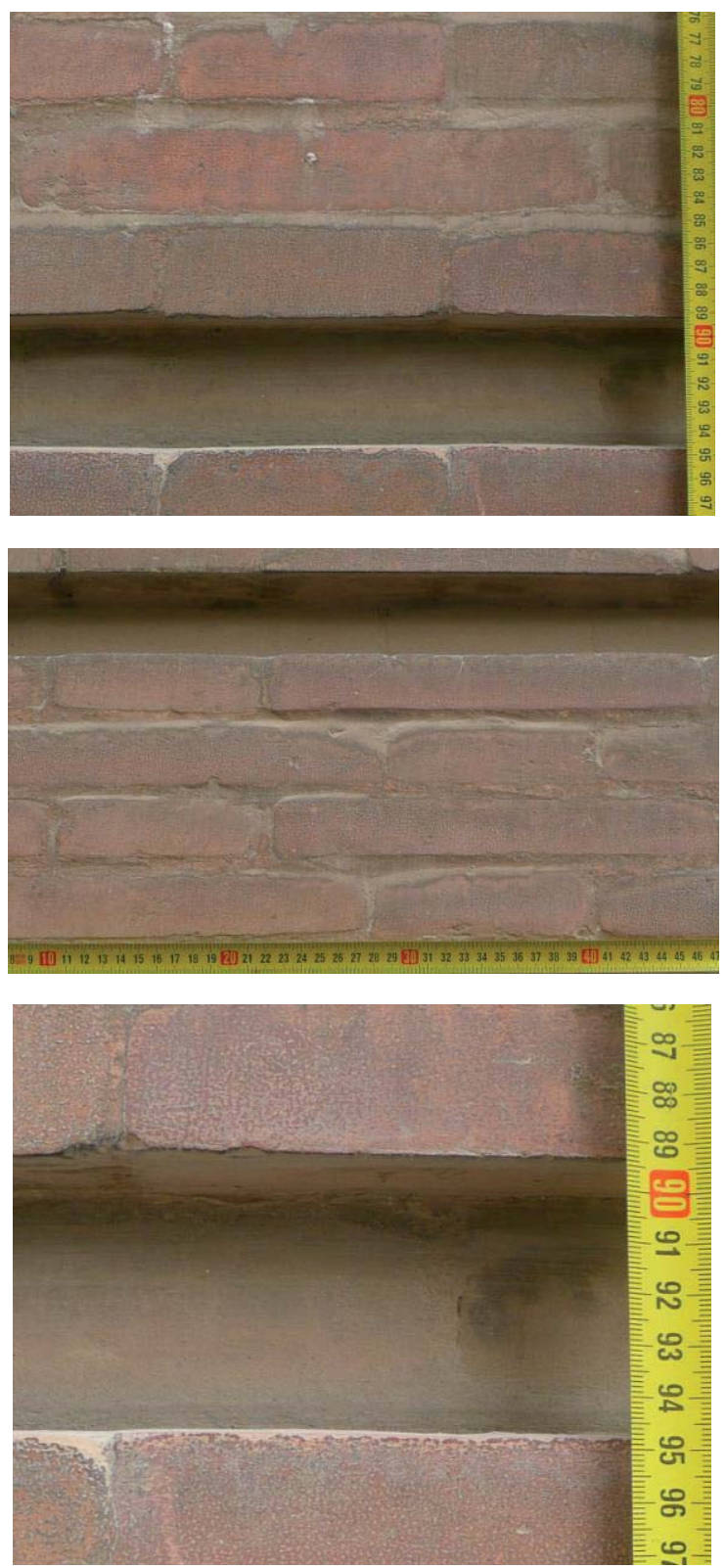
Imágenes

Xc16c
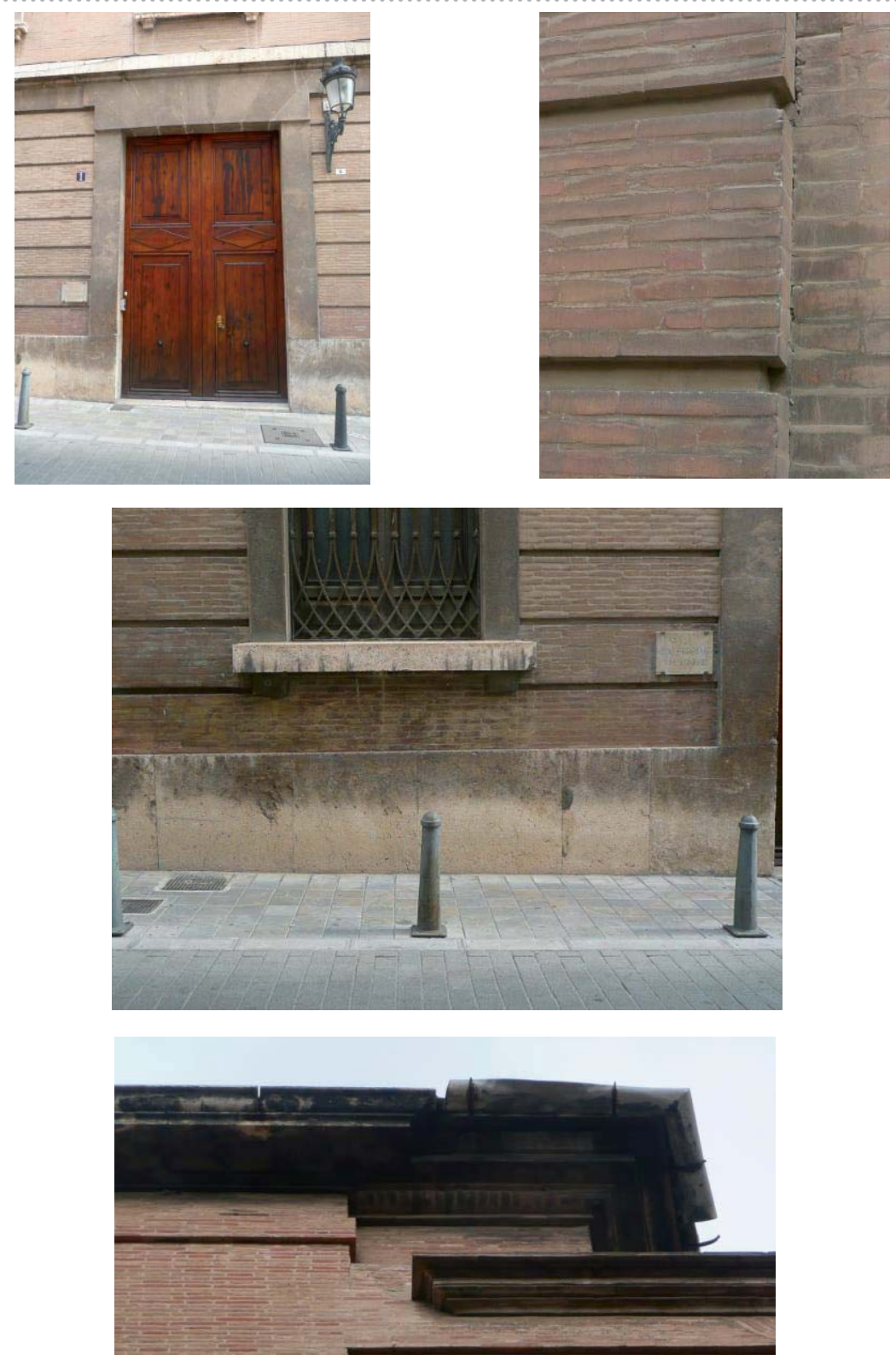
Datos generales

\begin{tabular}{|c|c|c|c|c|c|}
\hline \multirow{2}{*}{$\begin{array}{l}\text { Barrio } \\
\text { Dirección }\end{array}$} & Carmen & La Seu-Xerea & Velluters & Mercat & S.Francesc \\
\hline & \multicolumn{5}{|c|}{ C/Mestres n³ } \\
\hline Tipo de edificio & residencial & palaciego & religioso & militar & \\
\hline $\mathbf{G}^{\circ}$ de protección & 0 & 1 & 2 & 3 & \\
\hline Fechas claves & / & & & & \\
\hline
\end{tabular}
El apartado "fechas claves" se ha extraído de AA.V.., Guía de Arquitectura de Valencia, Icaro CTAV Ed., Valencia, 2007

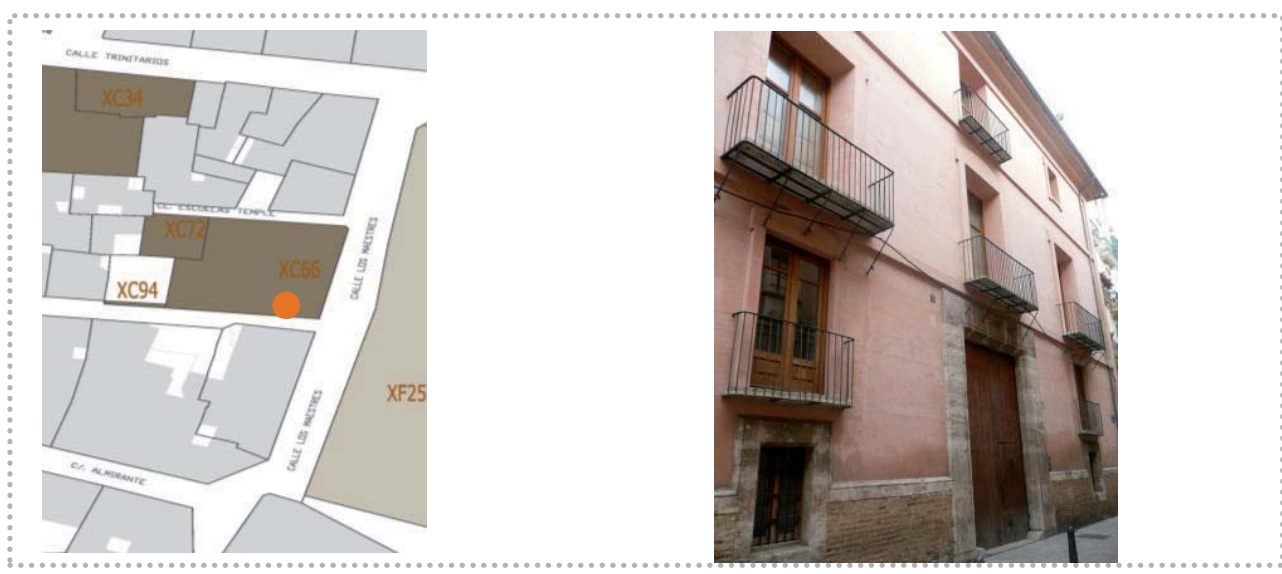

Fachada

Xc66

\begin{tabular}{|c|c|c|c|c|c|c|c|c|c|c|}
\hline \multirow{3}{*}{$\begin{array}{l}\text { Pisos } \\
\text { Composición fachada } \\
\text { Zócalo }\end{array}$} & \multicolumn{2}{|c|}{$\mathrm{N}^{0} 3$} & sótano & \multicolumn{2}{|c|}{ entreplanta } & \multicolumn{2}{|c|}{ piso noble } & \multicolumn{3}{|c|}{ caja escalera } \\
\hline & \multicolumn{2}{|c|}{ aleatoria } & \multicolumn{3}{|c|}{ ordenada sin simetría } & \multicolumn{5}{|c|}{ ordenada con simetría } \\
\hline & $\mathrm{Z1}$ & $\mathrm{Z2}$ & Z3 & Z4 & Z5 & & & & & \\
\hline Fábrica & F1 & F2 & F3 & $\mathrm{F} 4$ & F5 & F6 & F7 & & & \\
\hline Vano/dintel & V1 & V2 & V3 & V4 & V5 & V6 & V7 & V8 & V9 & V10 \\
\hline Entrada/dintel & E1 & E2 & E3 & E4 & & & & & & \\
\hline Alero & A1 & $A 2$ & $\mathrm{~A} 3$ & A4 & A5 & A6 & A7 & & & \\
\hline Cubierta & pla & & inclina & & & & & & & \\
\hline
\end{tabular}

\section{Fábrica}

Xc66

\begin{tabular}{|c|c|c|c|}
\hline Aparejo & soga-tizón & tizón & \\
\hline Hiladas & irregulares & pseudo horizontales & horizontales \\
\hline Superficie & sin planeidad & pseudo planeidad & planeidad perfecta \\
\hline Sección (hipótesis) & uniforme & hojas y núcleo & abocinada (vano) \\
\hline Elementos destacados & aplantillado & terracota & \\
\hline
\end{tabular}




\begin{tabular}{|c|c|c|c|}
\hline \multirow{2}{*}{$\begin{array}{l}N^{0} \text { elementos medidos } \\
\text { Longitud }(\mathrm{cm})\end{array}$} & \multicolumn{3}{|l|}{15} \\
\hline & \multicolumn{3}{|l|}{29.7} \\
\hline Anchura (cm) & \multicolumn{3}{|l|}{14.7} \\
\hline Espesor (cm) & \multicolumn{3}{|l|}{3.8} \\
\hline Volumen $\left(\mathrm{cm}^{3}\right)$ & \multicolumn{3}{|l|}{1659.0} \\
\hline Tipo & homogéneo & heterogéneo & re-empleo \\
\hline Color & homogéneo & heterogéneo globular & heterogéneo marmolado \\
\hline Recogida de muestra & no & sí & código \\
\hline \multirow[t]{2}{*}{ Patologías } & eflorescencias & micro fisuración & grietas \\
\hline & erosión & disgregación & descamación \\
\hline
\end{tabular}

1 Datos obtenidos en base al cálculo del desvío estándar (respecto al valor medio de la muestras analizadas) y del gráfico de frecuencia de las muestras analizadas, identificado por una curva gaussiana

\section{untas 2}

\begin{tabular}{|c|c|c|c|c|}
\hline \multirow{2}{*}{$\begin{array}{l}N^{0} \text { elementos medidos } \\
\text { Llaga }(\mathrm{cm})\end{array}$} & \multicolumn{4}{|l|}{15} \\
\hline & \multicolumn{4}{|l|}{1} \\
\hline Tendel (cm) & \multicolumn{4}{|l|}{3} \\
\hline Altura de 5 hiladas $(\mathrm{cm})$ & \multicolumn{4}{|l|}{33} \\
\hline Proporción ladrillo/junta & \multicolumn{4}{|l|}{1.2} \\
\hline Tipo de acabado & simple & doble & múltiple & \\
\hline Junta de asiento & $\begin{array}{l}\text { rehundida } \\
\text { enrasada }\end{array}$ & $\begin{array}{l}\text { a hueso } \\
\text { matada }\end{array}$ & saliente & \\
\hline Junta de acabado & $\begin{array}{l}\text { rehundida } \\
\text { enrasada }\end{array}$ & $\begin{array}{l}\text { a hueso } \\
\text { matada }\end{array}$ & saliente & \\
\hline Tipo de mortero & cal & cal y tierra & tierra & cemento mixto \\
\hline Morfología de mortero & con grumos & con caliches & homogéneo & heterogéneo \\
\hline Tipo de árido & arena & gravilla & grava & mixto \\
\hline Color del árido & claro & oscuro & homogéneo & heterogéneo \\
\hline Recogida de muestra & no & sí & código Xc 66/2 & \\
\hline Patologías & $\begin{array}{l}\text { eflorescencias } \\
\text { erosión }\end{array}$ & $\begin{array}{l}\text { micro fisuración } \\
\text { disgregación }\end{array}$ & $\begin{array}{l}\text { grietas } \\
\text { pulverización }\end{array}$ & \\
\hline
\end{tabular}


Imágenes
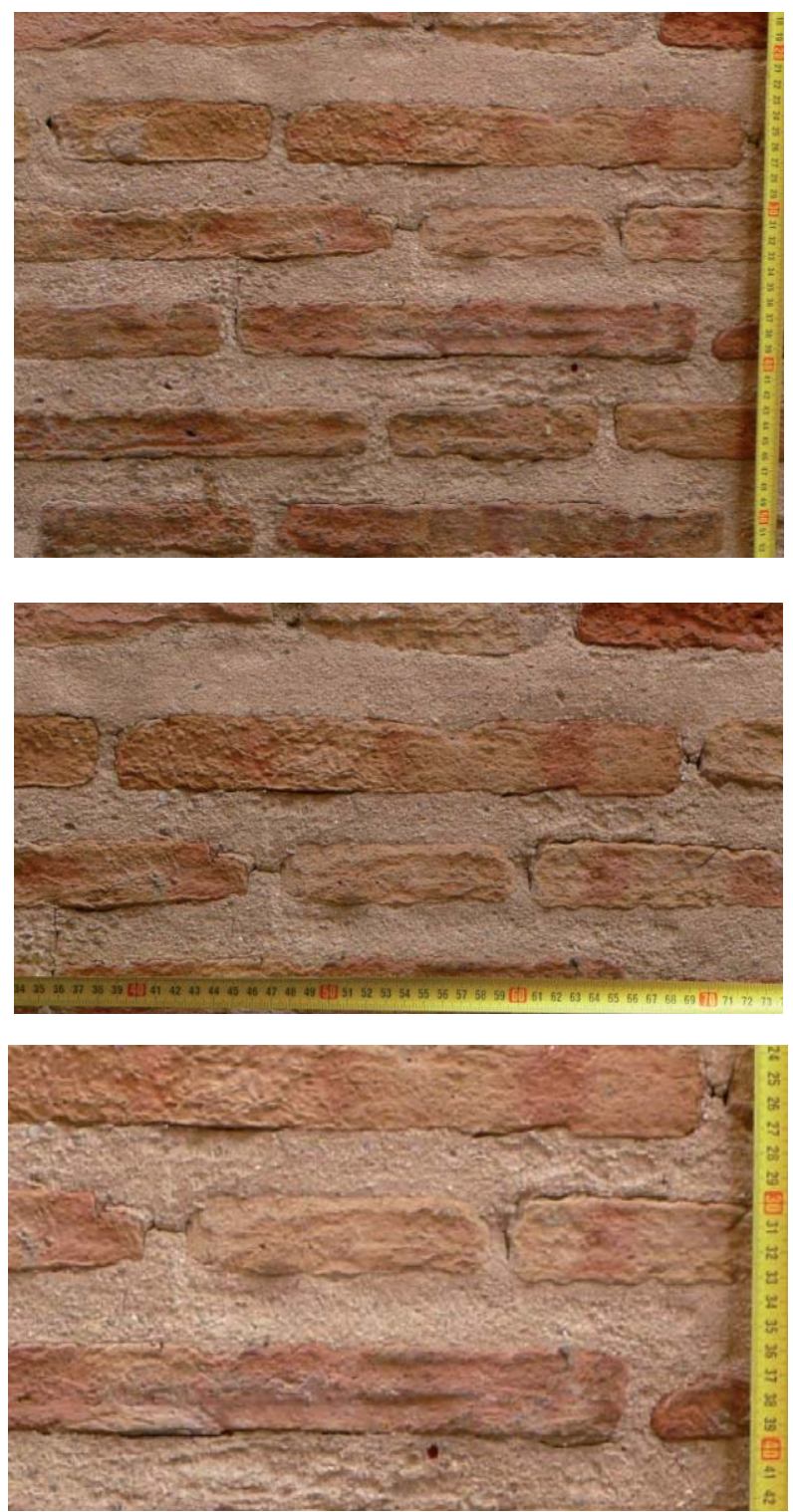

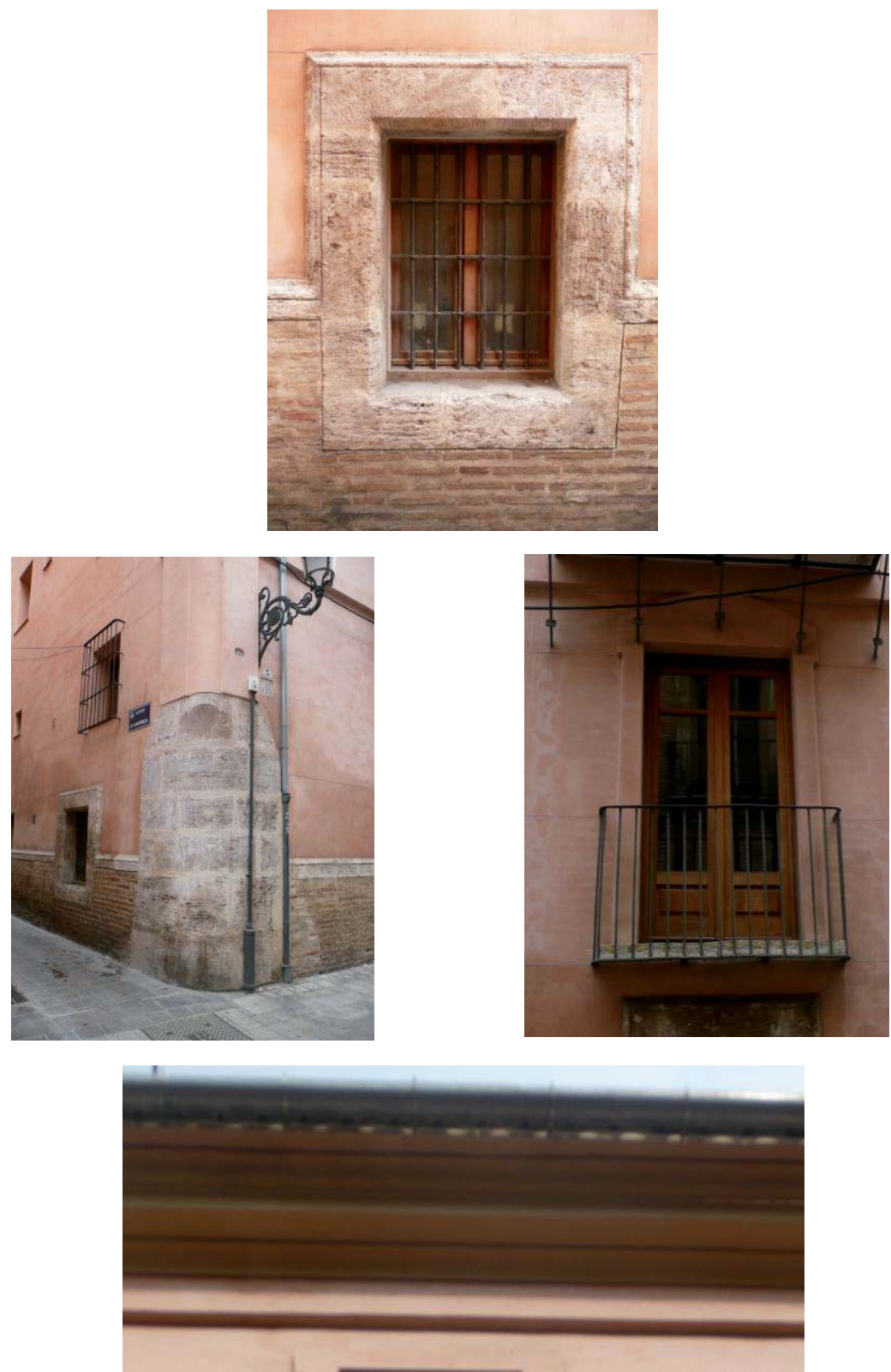
Datos generales

\begin{tabular}{|c|c|c|c|c|c|}
\hline Barrio & Carmen & La Seu-Xerea & Velluters & Mercat & S.Francesc \\
\hline Dirección & C/Escoles d & Temple $\mathrm{n}^{\circ 3}$ & & & \\
\hline Tipo de edificio & residencial & palaciego & religioso & militar & \\
\hline $\mathbf{G}^{\circ}$ de protección & 0 & 1 & 2 & 3 & \\
\hline Fechas claves & / & & & & \\
\hline
\end{tabular}

El apartado "fechas claves" se ha extraído de AA.W., Guía de Arquitectura de Valencia, Icaro CTAV Ed., Valencia, 2007
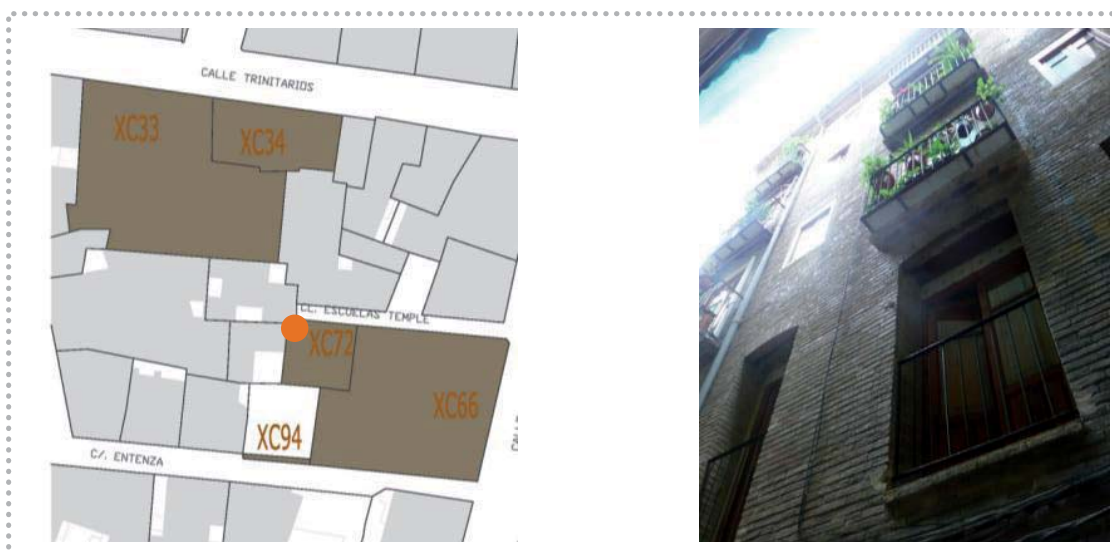

Fachada

\section{Pisos \\ Composición fachada \\ Zócalo \\ Fábrica \\ Vano/dintel \\ Entrada/dintel \\ Alero \\ Cubierta}

\begin{tabular}{|c|c|c|c|c|c|c|c|c|}
\hline \multirow{2}{*}{\multicolumn{2}{|c|}{$\begin{array}{l}\mathrm{N}^{\circ} 3 \\
\text { aleatoria }\end{array}$}} & \multirow{2}{*}{\multicolumn{3}{|c|}{$\begin{array}{l}\text { sótano entreplanta } \\
\text { ordenada sin simetría }\end{array}$}} & \multicolumn{4}{|c|}{ piso noble caja escalera } \\
\hline & & & & & \multicolumn{4}{|c|}{ ordenada con simetría } \\
\hline $\mathrm{Z1}$ & $\mathrm{Z} 2$ & Z3 & Z4 & $\mathrm{Z} 5$ & & & & \\
\hline F1 & $\mathrm{F} 2$ & F3 & F4 & F5 & F6 & & & \\
\hline V1 & V2 & V3 & V4 & V5 & V6 & V8 & V9 & V10 \\
\hline E1 & E2 & E3 & E4 & & & & & \\
\hline A1 & $\mathrm{A} 2$ & A3 & A4 & A5 & A6 & & & \\
\hline \multicolumn{2}{|c|}{ plana } & \multicolumn{3}{|c|}{ inclinada } & & & & \\
\hline
\end{tabular}

\section{Fábrica}

Xc72

\section{Aparejo \\ Hiladas \\ Superficie \\ Sección (hipótesis) \\ Elementos destacados}

\begin{tabular}{lll} 
soga-tizón & soga & \multicolumn{1}{c}{ tizón } \\
irregulares & pseudo horizontales & horizontales \\
\hline sin planeidad & pseudo planeidad & planeidad perfecta \\
\hline uniforme & hojas y núcleo & abocinada (vano) \\
aplantillado & cortado terracota & \\
\hline
\end{tabular}




\begin{tabular}{|c|c|c|c|}
\hline \multirow{2}{*}{$\begin{array}{l}\mathrm{N}^{\circ} \text { elementos medidos } \\
\text { Longitud }(\mathrm{cm})\end{array}$} & \multicolumn{3}{|l|}{15} \\
\hline & \multicolumn{3}{|l|}{24.5} \\
\hline Anchura (cm) & \multicolumn{3}{|l|}{12} \\
\hline Espesor (cm) & \multicolumn{3}{|l|}{4.5} \\
\hline Volumen $\left(\mathrm{cm}^{3}\right)$ & \multicolumn{3}{|l|}{1323} \\
\hline Tipo & homogéneo & heterogéneo & re-empleo \\
\hline Color & homogéneo & heterogéneo globular & heterogéneo marmolado \\
\hline Recogida de muestra & no & sí & código \\
\hline Patologías & $\begin{array}{l}\text { eflorescencias } \\
\text { erosión }\end{array}$ & $\begin{array}{l}\text { micro fisuración } \\
\text { disgregación }\end{array}$ & $\begin{array}{l}\text { grietas } \\
\text { descamación }\end{array}$ \\
\hline
\end{tabular}

1 Datos obtenidos en base al cálculo del desvío estándar (respecto al valor medio de la muestras analizadas) y del gráfico de frecuencia de las muestras analizadas, identificado por una curva gaussiana

\section{untas}

\begin{tabular}{|c|c|c|c|c|}
\hline \multirow{2}{*}{$\begin{array}{l}N^{\circ} \text { elementos medidos } \\
\text { Llaga }(\mathrm{cm})\end{array}$} & \multicolumn{4}{|l|}{15} \\
\hline & \multicolumn{4}{|l|}{0.4} \\
\hline Tendel (cm) & \multicolumn{4}{|l|}{1.7} \\
\hline Altura de 5 hiladas $(\mathrm{cm})$ & \multicolumn{4}{|l|}{30} \\
\hline Proporción ladrillo/junta & \multicolumn{4}{|l|}{2.6} \\
\hline Tipo de acabado & simple & doble & múltiple & \\
\hline \multirow[t]{2}{*}{ Junta de asiento } & rehundida & a hueso & saliente & \\
\hline & enrasada & matada & & \\
\hline \multirow{2}{*}{ Junta de acabado } & rehundida & a hueso & saliente & \\
\hline & enrasada & matada & & \\
\hline \multirow{2}{*}{$\begin{array}{l}\text { Tipo de mortero } \\
\text { Morfología de mortero }\end{array}$} & cal & cal y tierra & tierra & cemento mixto \\
\hline & con grumos & con caliches & homogéneo & heterogéneo \\
\hline Tipo de árido & arena & gravilla & grava & mixto \\
\hline \multirow{4}{*}{$\begin{array}{l}\text { Color del árido } \\
\text { Recogida de muestra } \\
\text { Patologías }\end{array}$} & claro & oscuro & homogéneo & heterogéneo \\
\hline & no & sí & código & \\
\hline & eflorescencias & micro fisuración & grietas & \\
\hline & erosión & disgregación & pulverización & \\
\hline
\end{tabular}


Imágenes
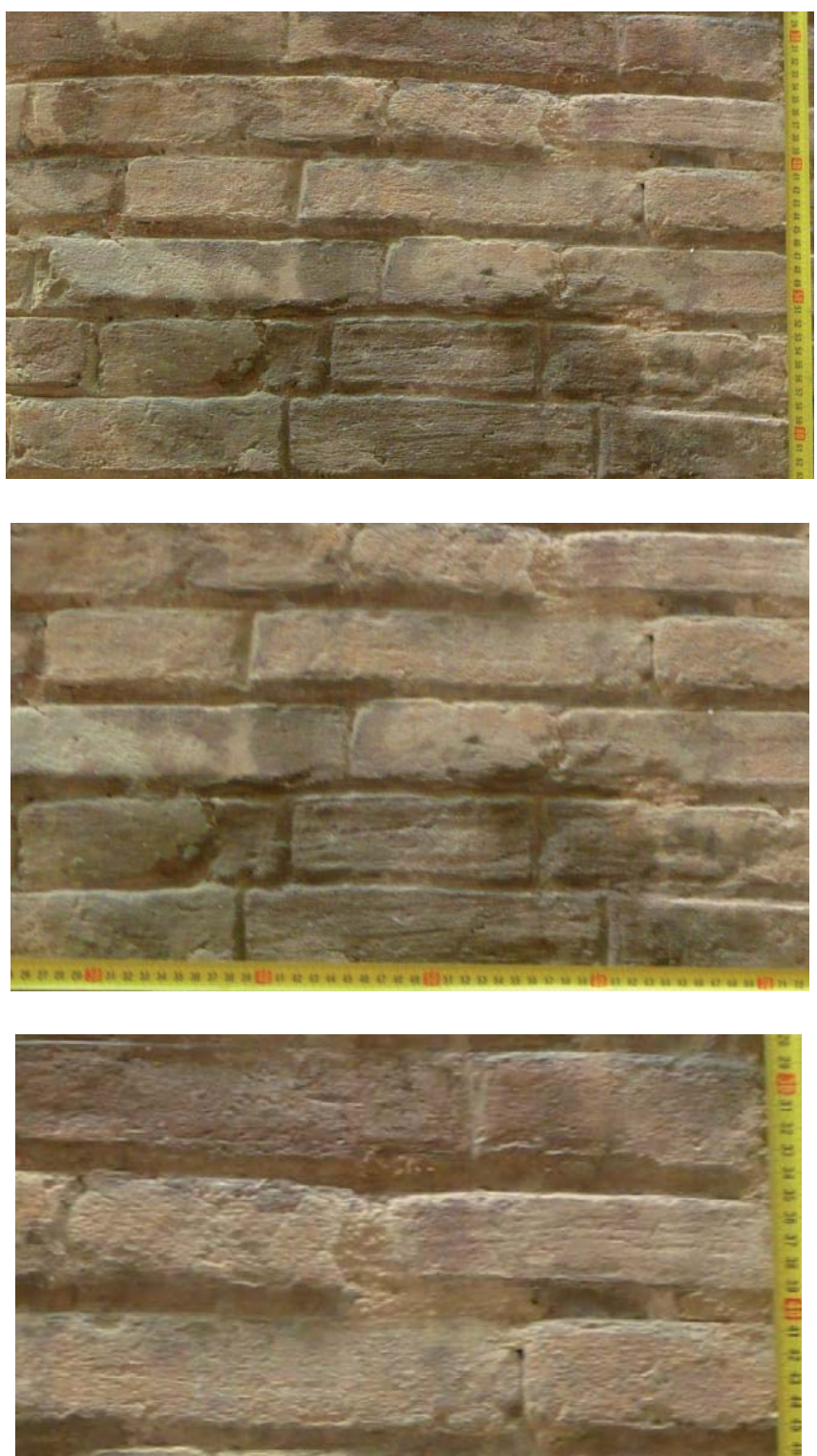

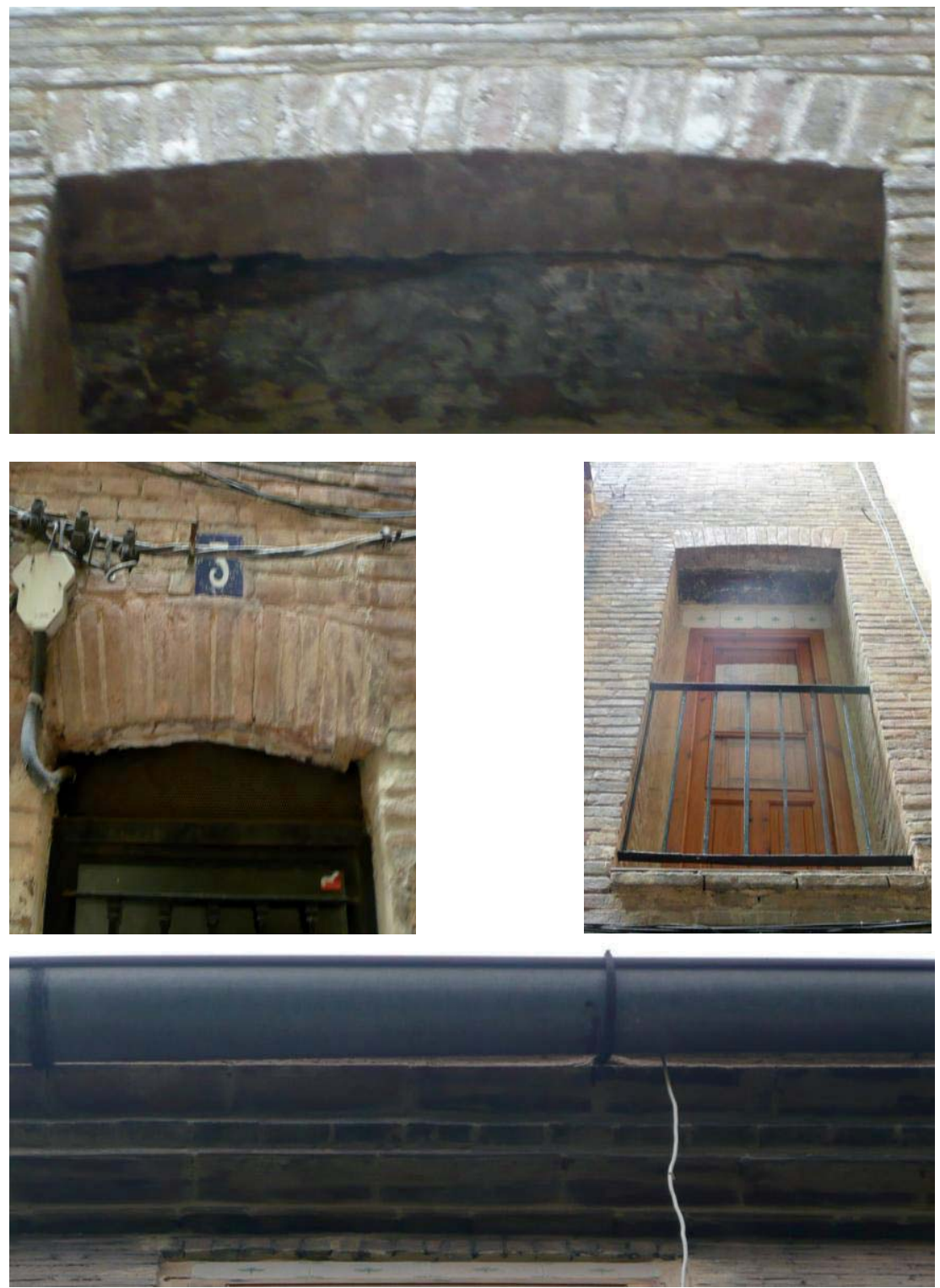
Datos generales

\begin{tabular}{|c|c|c|c|c|c|}
\hline Barrio & Carmen & La Seu-Xerea & Velluters & Mercat & S.Francesc \\
\hline Dirección & Pza. Conde & el Real n³ & & & \\
\hline Tipo de edificio & residencial & palaciego & religioso & militar & \\
\hline $\mathbf{G}^{\circ}$ de protección & 0 & 1 & 2 & 3 & \\
\hline Fechas claves & / & & & & \\
\hline
\end{tabular}

El apartado "fechas claves" se ha extraído de AA.W., Guía de Arquitectura de Valencia, Icaro CTAV Ed., Valencia, 2007

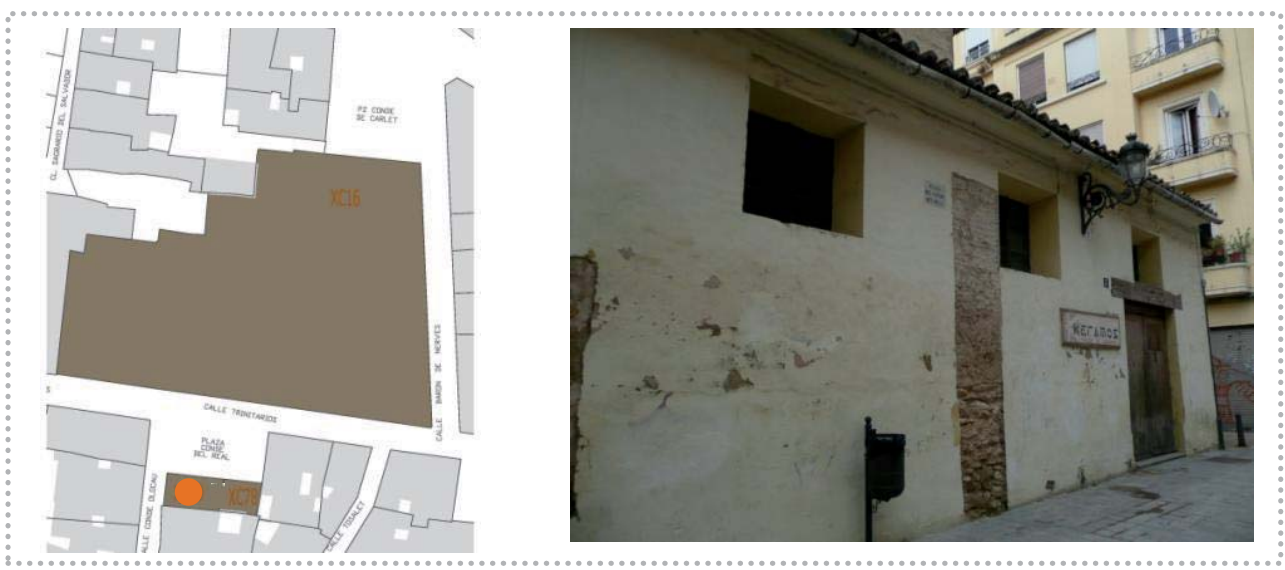

Fachada

Xc78

Pisos
Composición fachada
Zócalo
Fábrica
Vano/dintel
Entrada/dintel
Alero
Cubierta

\begin{tabular}{|c|c|c|c|c|c|c|c|c|c|}
\hline \multirow{2}{*}{\multicolumn{2}{|c|}{$\begin{array}{l}\mathrm{N}^{\circ} 1 \\
\text { aleatoria }\end{array}$}} & sótano & & planta & \multicolumn{5}{|c|}{ piso noble caja escalera } \\
\hline & & \multicolumn{3}{|c|}{ ordenada sin simetría } & \multicolumn{5}{|c|}{ ordenada con simetría } \\
\hline $\mathrm{Z1}$ & $\mathrm{Z} 2$ & Z3 & Z4 & Z5 & & & & & \\
\hline F1 & F2 & F3 & F4 & F5 & F6 & F7 & & & \\
\hline V1 & V2 & V3 & V4 & V5 & V6 & V7 & V8 & V9 & V10 \\
\hline E1 & E2 & E3 & E4 & & & & & & \\
\hline A1 & A2 & A3 & A4 & A5 & A6 & A7 & & & \\
\hline \multicolumn{2}{|c|}{ plana } & \multicolumn{3}{|l|}{ inclina } & & & & & \\
\hline
\end{tabular}

\section{Fábrica}

\section{Xc78}

Aparejo
Hiladas
Superficie
Sección (hipótesis)
Elementos destacados

\begin{tabular}{lll}
\hline soga-tizón & soga tizón & \\
\hline irregulares & pseudo horizontales & horizontales \\
\hline sin planeidad & pseudo planeidad & planeidad perfecta \\
\hline uniforme & hojas y núcleo & abocinada (vano) \\
\hline aplantillado & cortado terracota & \\
\hline
\end{tabular}




\begin{tabular}{|c|c|c|c|}
\hline $\mathrm{N}^{\circ}$ elementos medidos & 15 & & \\
\hline Longitud (cm) & 30.5 & & \\
\hline Anchura $(\mathrm{cm})$ & 14.5 & & \\
\hline Espesor (cm) & 3.2 & & \\
\hline Volumen $\left(\mathrm{cm}^{3}\right)$ & 1415.2 & & \\
\hline Tipo & homogéneo & heterogéneo & re-empleo \\
\hline Color & homogéneo & heterogéneo globular & heterogéneo marmolado \\
\hline Recogida de muestra & no & sí & código Xc78/ 1 \\
\hline Patologías & $\begin{array}{l}\text { eflorescencias } \\
\text { erosión }\end{array}$ & $\begin{array}{l}\text { micro fisuración } \\
\text { disgregación }\end{array}$ & $\begin{array}{l}\text { grietas } \\
\text { descamación }\end{array}$ \\
\hline
\end{tabular}

${ }^{1}$ Datos obtenidos en base al cálculo del desvío estándar (respecto al valor medio de la muestras analizadas) y del gráfico de frecuencia de las muestras analizadas, identificado por una curva gaussiana

\section{untas 2}

\begin{tabular}{|c|c|c|c|c|}
\hline \multirow{2}{*}{$\begin{array}{l}N^{\circ} \text { elementos medidos } \\
\text { Llaga }(\mathrm{cm})\end{array}$} & \multicolumn{4}{|l|}{15} \\
\hline & \multicolumn{4}{|l|}{0.4} \\
\hline Tendel (cm) & \multicolumn{4}{|l|}{2.8} \\
\hline Altura de 5 hiladas $(\mathrm{cm})$ & \multicolumn{4}{|l|}{32} \\
\hline Proporción ladrillo/junta & \multicolumn{4}{|l|}{1.1} \\
\hline Tipo de acabado & simple & doble & \multicolumn{2}{|l|}{ múltiple } \\
\hline \multirow[t]{2}{*}{ Junta de asiento } & rehundida & a hueso & \multirow[t]{2}{*}{ saliente } & \\
\hline & enrasada & matada & & \\
\hline \multirow[t]{2}{*}{ Junta de acabado } & rehundida & a hueso & \multirow[t]{2}{*}{ saliente } & \\
\hline & enrasada & matada & & \\
\hline \multirow{3}{*}{$\begin{array}{l}\text { Tipo de mortero } \\
\text { Morfología de mortero } \\
\text { Tipo de árido }\end{array}$} & cal & cal y tierra & tierra & cemento mixto \\
\hline & con grumos & con caliches & homogéneo & heterogéneo \\
\hline & arena & gravilla & grava & mixto \\
\hline \multirow{4}{*}{$\begin{array}{l}\text { Color del árido } \\
\text { Recogida de muestra } \\
\text { Patologías }\end{array}$} & claro & oscuro & homogéneo & heterogéneo \\
\hline & no & sí & \multicolumn{2}{|l|}{ código } \\
\hline & eflorescencias & micro fisuración & \multicolumn{2}{|l|}{ grietas } \\
\hline & erosión & disgregación & \multicolumn{2}{|l|}{ pulverización } \\
\hline
\end{tabular}


Imágenes
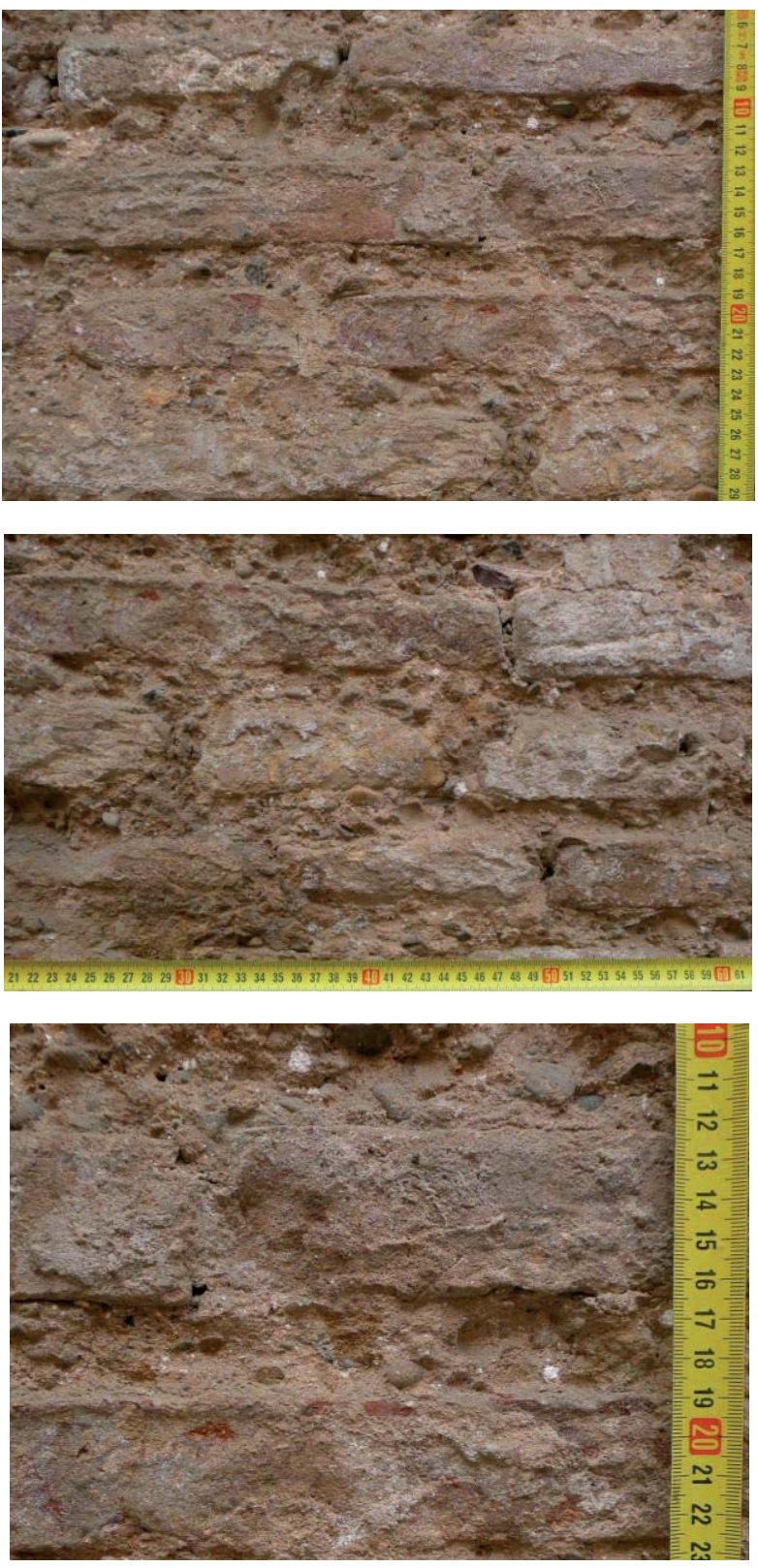

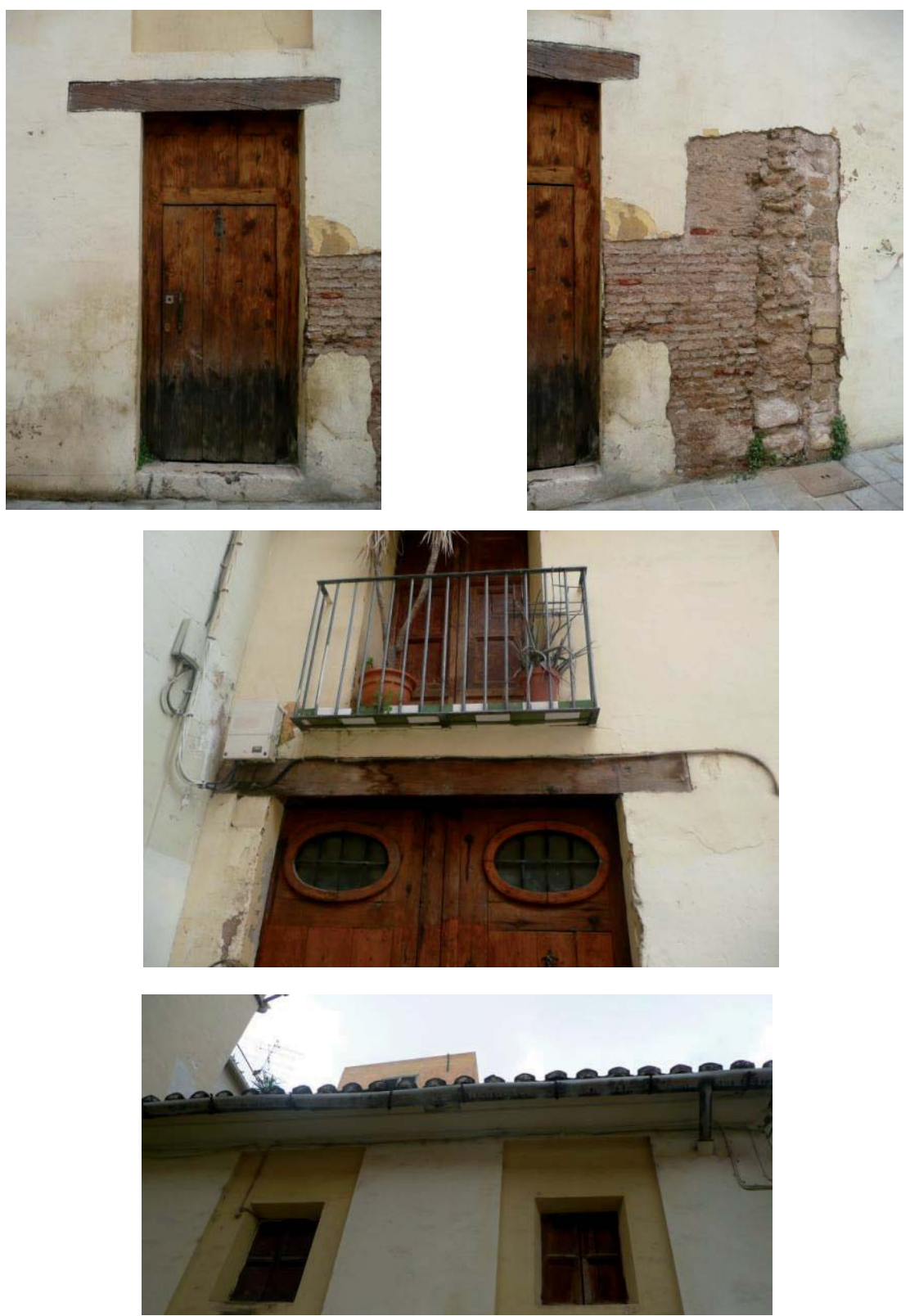
Datos generales

\begin{tabular}{|c|c|c|c|c|c|}
\hline Barrio & Carmen & La Seu-Xerea & Velluters & Mercat & S.Francesc \\
\hline Dirección & C/Entenza & & & & \\
\hline Tipo de edificio & residencial & palaciego & religioso & militar & \\
\hline $\mathbf{G}^{\circ}$ de protección & 0 & 1 & 2 & 3 & \\
\hline Fechas claves & / & & & & \\
\hline
\end{tabular}
El apartado "fechas claves" se ha extraído de AA.V., Guía de Arquitectura de Valencia, Icaro CTAV Ed., Valencia, 2007

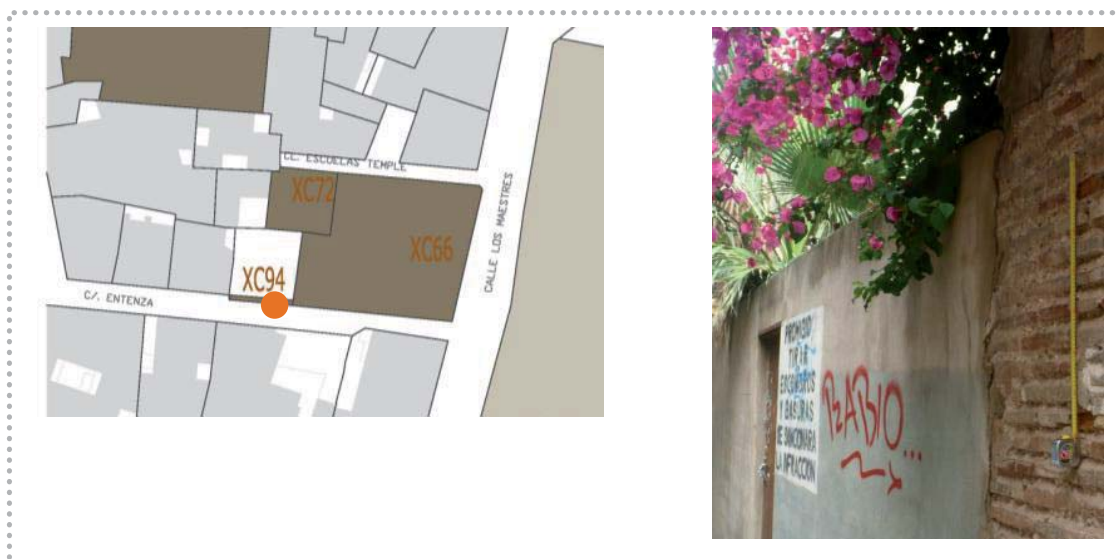

Fachada

Xc94

Pisos
Composición fachada
Zócalo
Fábrica
Vano/dintel
Entrada/dintel
Alero
Cubierta

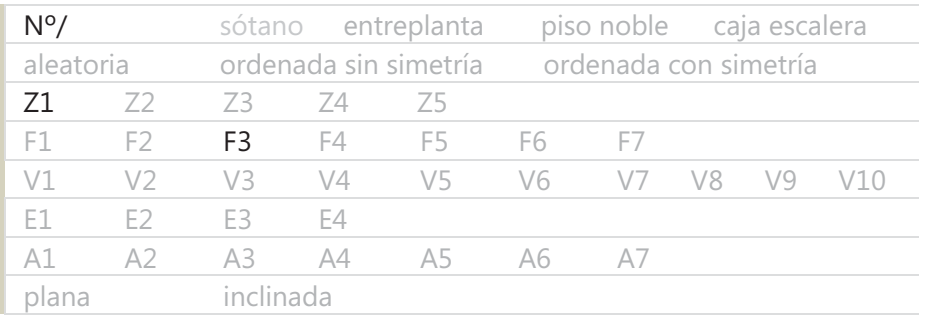

Fábrica

Xc94

\begin{tabular}{l|lll} 
Aparejo & soga-tizón & soga tizón & \\
Hiladas & irregulares & pseudo horizontales & horizontales \\
\hline Superficie & sin planeidad & pseudo planeidad & planeidad perfecta \\
\hline Sección (hipótesis) & uniforme & hojas y núcleo & abocinada (vano) \\
Elementos destacados & aplantillado & cortado terracota & \\
\hline
\end{tabular}




\begin{tabular}{|c|c|c|c|}
\hline \multirow{2}{*}{$\begin{array}{l}\mathrm{N}^{\circ} \text { elementos medidos } \\
\text { Longitud }(\mathrm{cm})\end{array}$} & \multicolumn{3}{|l|}{15} \\
\hline & 29.5 & & \\
\hline Anchura (cm) & 14.2 & & \\
\hline Espesor $(\mathrm{cm})$ & 4 & & \\
\hline Volumen $\left(\mathrm{cm}^{3}\right)$ & 1675.6 & & \\
\hline Tipo & homogéneo & heterogéneo & re-empleo \\
\hline Color & homogéneo & heterogéneo globular & heterogéneo marmolado \\
\hline Recogida de muestra & no & sí & código \\
\hline Patologías & $\begin{array}{l}\text { eflorescencias } \\
\text { erosión }\end{array}$ & $\begin{array}{l}\text { micro fisuración } \\
\text { disgregación }\end{array}$ & $\begin{array}{l}\text { grietas } \\
\text { descamación }\end{array}$ \\
\hline
\end{tabular}

1 Datos obtenidos en base al cálculo del desvío estándar (respecto al valor medio de la muestras analizadas) y del gráfico de frecuencia de las muestras analizadas, identificado por una curva gaussiana

\section{Juntas}

\begin{tabular}{|c|c|c|c|c|}
\hline \multirow{2}{*}{$\begin{array}{l}N^{\circ} \text { elementos medidos } \\
\text { Llaga }(\mathrm{cm})\end{array}$} & \multicolumn{4}{|l|}{15} \\
\hline & \multicolumn{4}{|l|}{0.7} \\
\hline Tendel (cm) & \multicolumn{4}{|l|}{3.5} \\
\hline Altura de 5 hiladas (cm) & \multicolumn{4}{|l|}{37.5} \\
\hline Proporción ladrillo/junta & \multicolumn{4}{|l|}{1} \\
\hline Tipo de acabado & simple & doble & \multicolumn{2}{|l|}{ múltiple } \\
\hline \multirow[t]{2}{*}{ Junta de asiento } & rehundida & a hueso & saliente & \\
\hline & enrasada & matada & & \\
\hline \multirow[t]{2}{*}{ Junta de acabado } & rehundida & a hueso & \multirow{2}{*}{\multicolumn{2}{|c|}{ saliente }} \\
\hline & enrasada & matada & & \\
\hline \multirow{3}{*}{$\begin{array}{l}\text { Tipo de mortero } \\
\text { Morfología de mortero } \\
\text { Tipo de árido }\end{array}$} & $\mathrm{cal}$ & cal y tierra & tierra & cemento mixto \\
\hline & con grumos & con caliches & homogéneo & heterogéneo \\
\hline & arena & gravilla & grava & mixto \\
\hline \multirow{4}{*}{$\begin{array}{l}\text { Color del árido } \\
\text { Recogida de muestra } \\
\text { Patologías }\end{array}$} & claro & oscuro & homogéneo & heterogéneo \\
\hline & no & sí & \multicolumn{2}{|l|}{ código } \\
\hline & eflorescencias & micro fisuración & \multicolumn{2}{|l|}{ grietas } \\
\hline & erosión & disgregación & \multicolumn{2}{|l|}{ pulverización } \\
\hline
\end{tabular}


Imágenes

Xc94
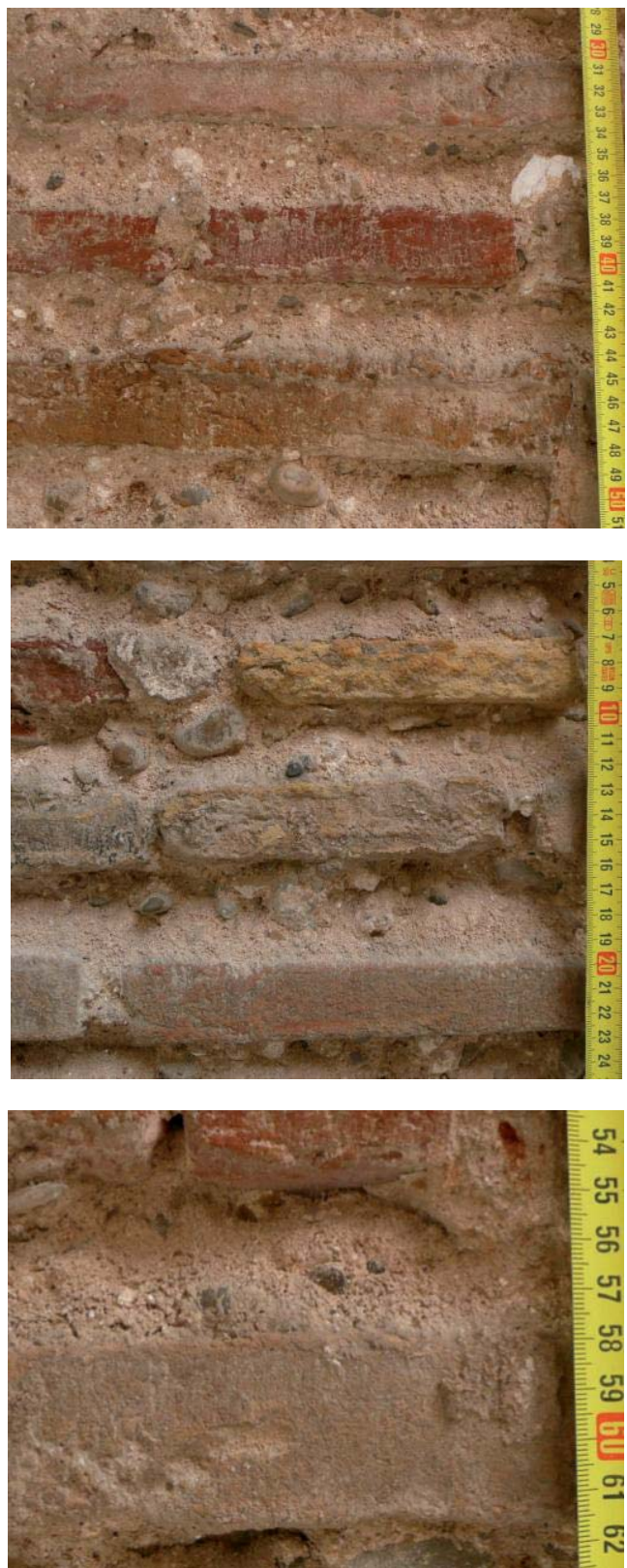
Imágenes

Xc94
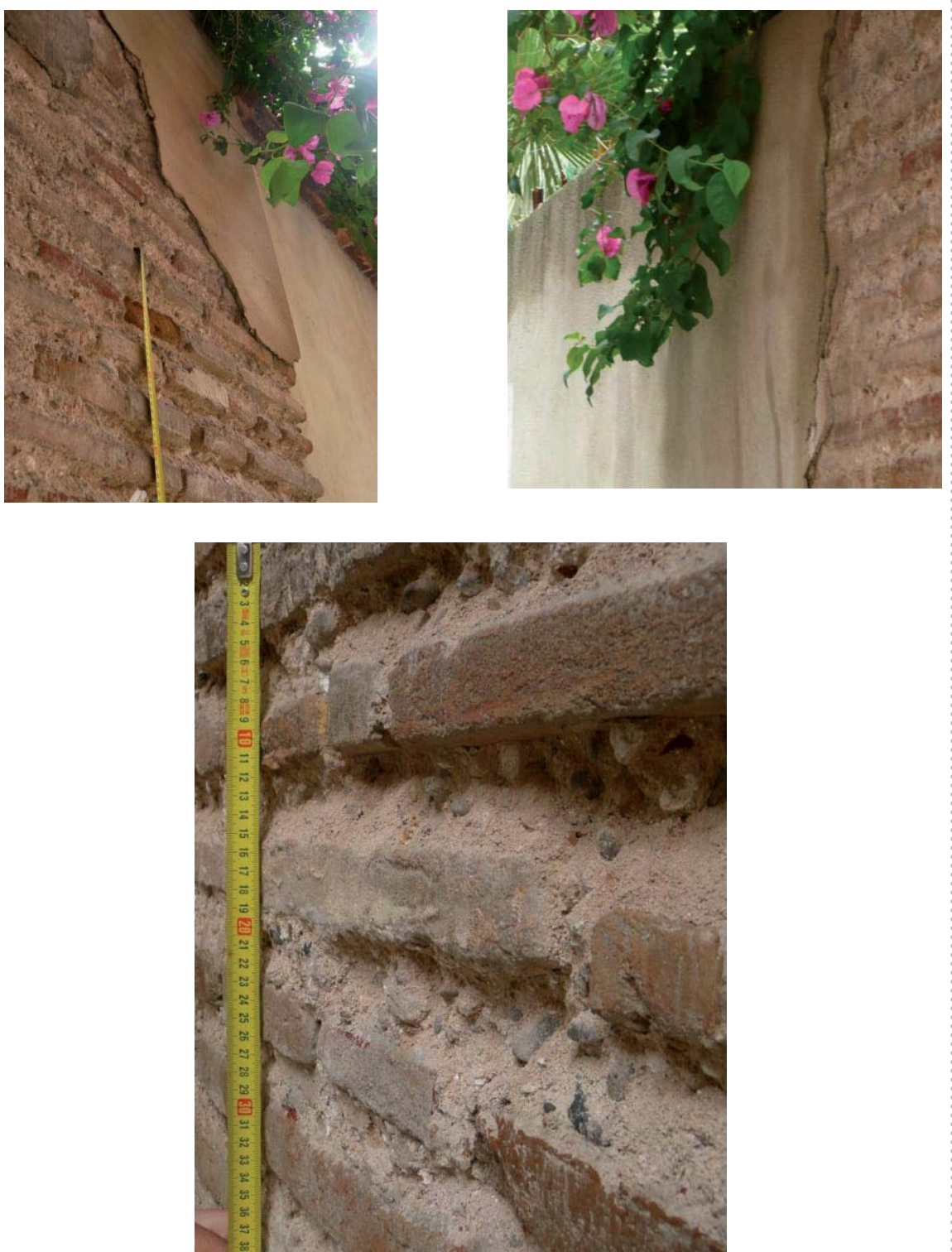
Datos generales

\section{Xc96b}

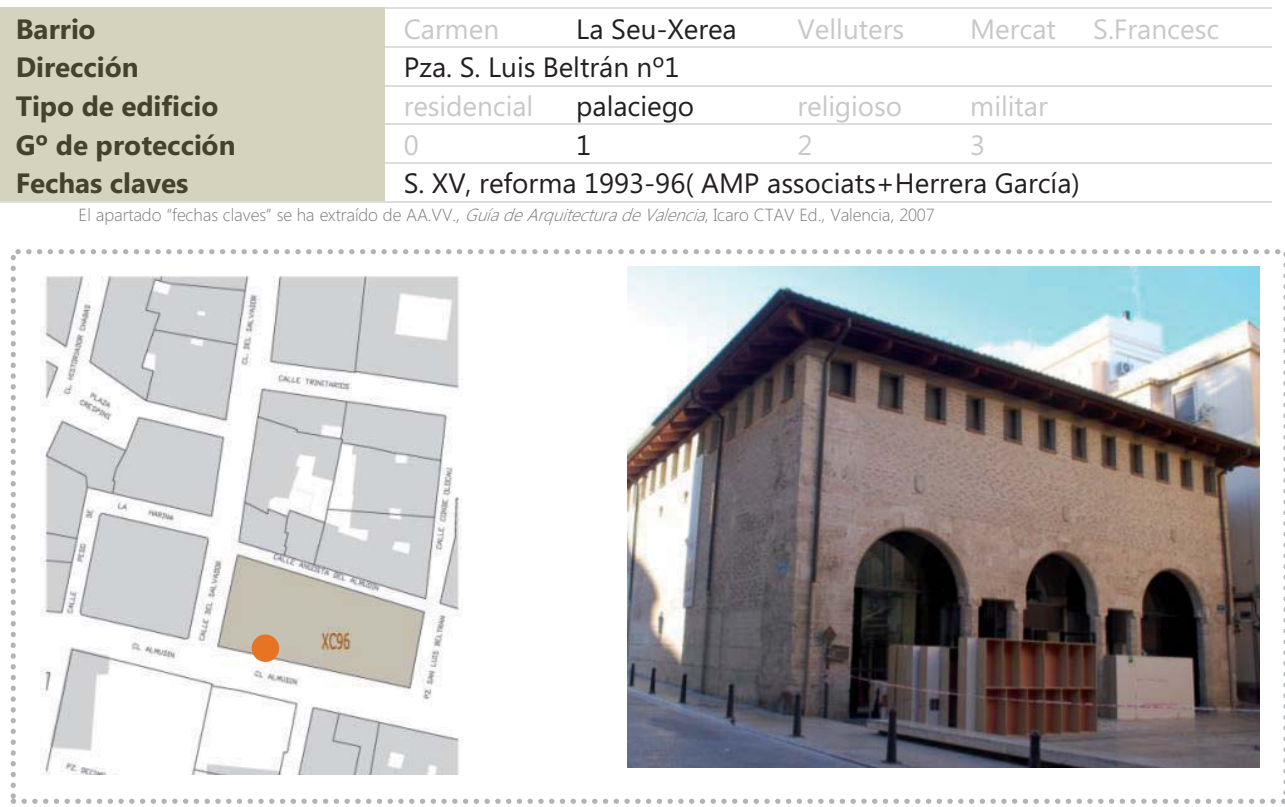

Fachada

Xc96b

Pisos
Composición fachada
Zócalo
Fábrica
Vano/dintel
Entrada/dintel
Alero
Cubierta

\begin{tabular}{|c|c|c|c|c|c|c|c|}
\hline \multirow{2}{*}{\multicolumn{2}{|c|}{$\begin{array}{l}\mathrm{N}^{\circ} 2 \\
\text { aleatoria }\end{array}$}} & sótano & entreplanta & piso noble & ca & esca & \\
\hline & & \multicolumn{2}{|c|}{ ordenada sin simetría } & \multicolumn{4}{|c|}{ ordenada con simetría } \\
\hline Z1 & Z2 & Z3 & Z5 & & & & \\
\hline F1 & F2 & F3 & F5 & F6 & & & \\
\hline V1 & V2 & V3 & V5 & V6 & V8 & V9 & V10 \\
\hline E1 & E2 & E3 & E4 & & & & \\
\hline A1 & A2 & A3 & A5 & A6 & & & \\
\hline \multicolumn{2}{|c|}{ plana } & \multicolumn{2}{|c|}{ inclinada } & & & & \\
\hline
\end{tabular}

Fábrica

Xc96b

\begin{tabular}{|c|c|c|c|}
\hline Aparejo & soga-tizón & tizón & \\
\hline Hiladas & irregulares & pseudo horizontales & horizontales \\
\hline Superficie & sin planeidad & pseudo planeidad & planeidad perfecta \\
\hline Sección (hipótesis) & uniforme & hojas y núcleo & abocinada (vano) \\
\hline Elementos destacados & aplantillado & terracota & \\
\hline
\end{tabular}




\begin{tabular}{|l|l|}
\hline$N^{\circ}$ elementos medidos & 15 \\
\hline Longitud $(\mathrm{cm})$ & $/$ \\
\hline Anchura $(\mathrm{cm})$ & $/$ \\
\hline Espesor $(\mathrm{cm})$ & 4.3 \\
Volumen $\left(\mathrm{cm}^{3}\right)$ & $/$
\end{tabular}

Tipo

Color

Recogida de muestra

Patologías

15

/

4.

/

\begin{tabular}{lll}
\hline homogéneo & heterogéneo & re-empleo \\
\hline homogéneo & heterogéneo globular & heterogéneo marmolado \\
\hline no & sí & código \\
\hline eflorescencias & micro fisuración & grietas \\
erosión & disgregación & descamación \\
\hline
\end{tabular}

${ }^{1}$ Datos obtenidos en base al cálculo del desvío estándar (respecto al valor medio de la muestras analizadas) y del gráfico de frecuencia de las muestras analizadas, identificado por una curva gaussiana

\section{untas 2}

Xc96b

\begin{tabular}{|c|c|c|c|c|}
\hline \multirow{2}{*}{$\begin{array}{l}N^{\circ} \text { elementos medidos } \\
\text { Llaga }(\mathrm{cm})\end{array}$} & \multicolumn{4}{|l|}{15} \\
\hline & \multicolumn{4}{|l|}{13} \\
\hline Tendel (cm) & \multicolumn{4}{|l|}{7} \\
\hline Altura de 5 hiladas $(\mathrm{cm})$ & \multicolumn{4}{|l|}{50,2} \\
\hline Proporción ladrillo/junta & \multicolumn{4}{|l|}{0.6} \\
\hline Tipo de acabado & simple & doble & múltiple & \\
\hline \multirow[t]{2}{*}{ Junta de asiento } & rehundida & a hueso & saliente & \\
\hline & enrasada & matada & & \\
\hline \multirow[t]{2}{*}{ Junta de acabado } & rehundida & a hueso & saliente & \\
\hline & enrasada & matada & & \\
\hline \multirow{2}{*}{$\begin{array}{l}\text { Tipo de mortero } \\
\text { Morfología de mortero }\end{array}$} & cal & cal y tierra & tierra & cemento mixto \\
\hline & con grumos & con caliches & homogéneo & heterogéneo \\
\hline Tipo de árido & arena & gravilla & grava & mixto \\
\hline \multirow{4}{*}{$\begin{array}{l}\text { Color del árido } \\
\text { Recogida de muestra } \\
\text { Patologías }\end{array}$} & claro & oscuro & homogéneo & heterogéneo \\
\hline & no & sí & código & \\
\hline & eflorescencias & micro fisuración & grietas & \\
\hline & erosión" & disgregación & pulverización & \\
\hline
\end{tabular}


Imágenes
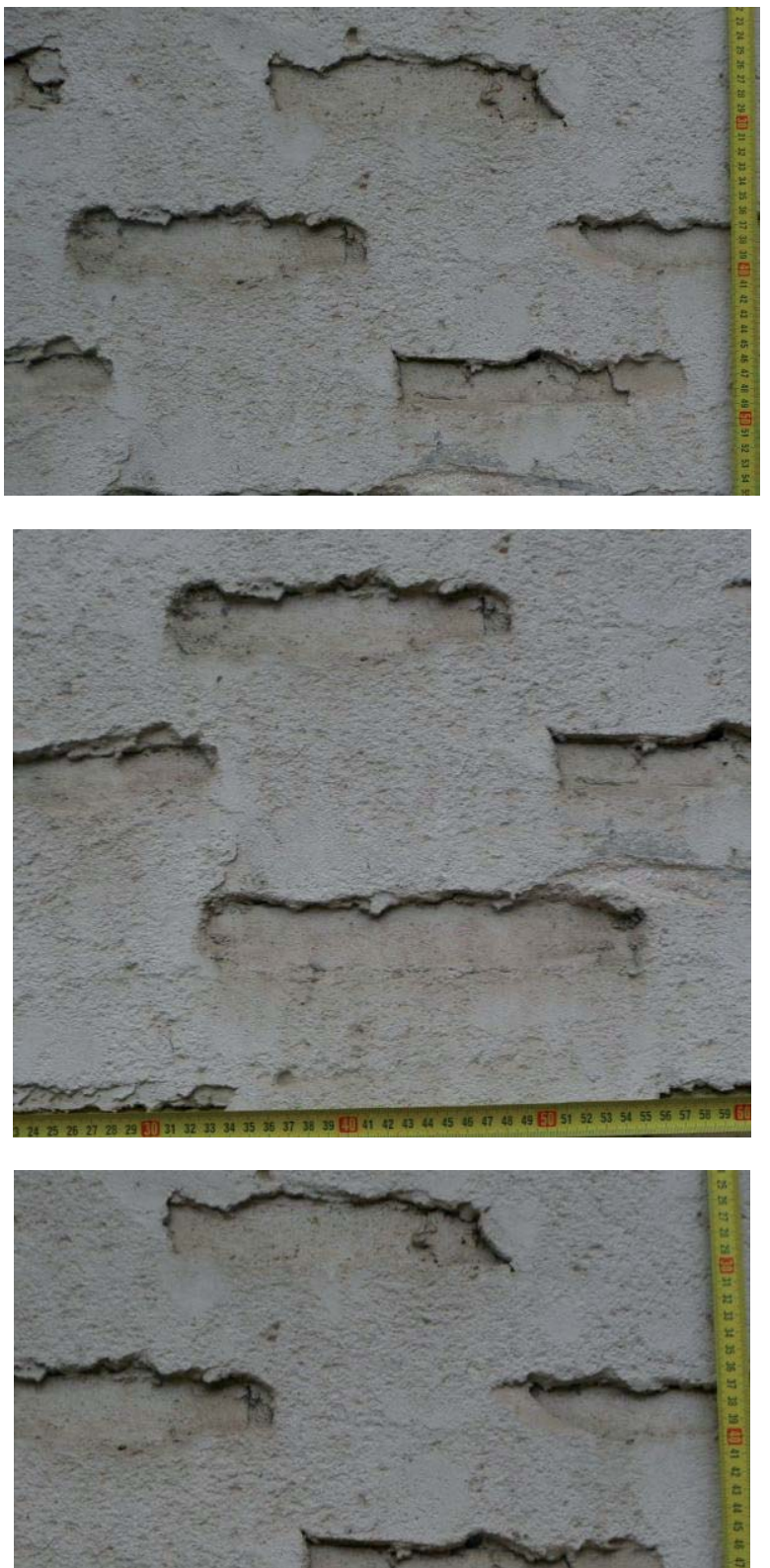
Imágenes
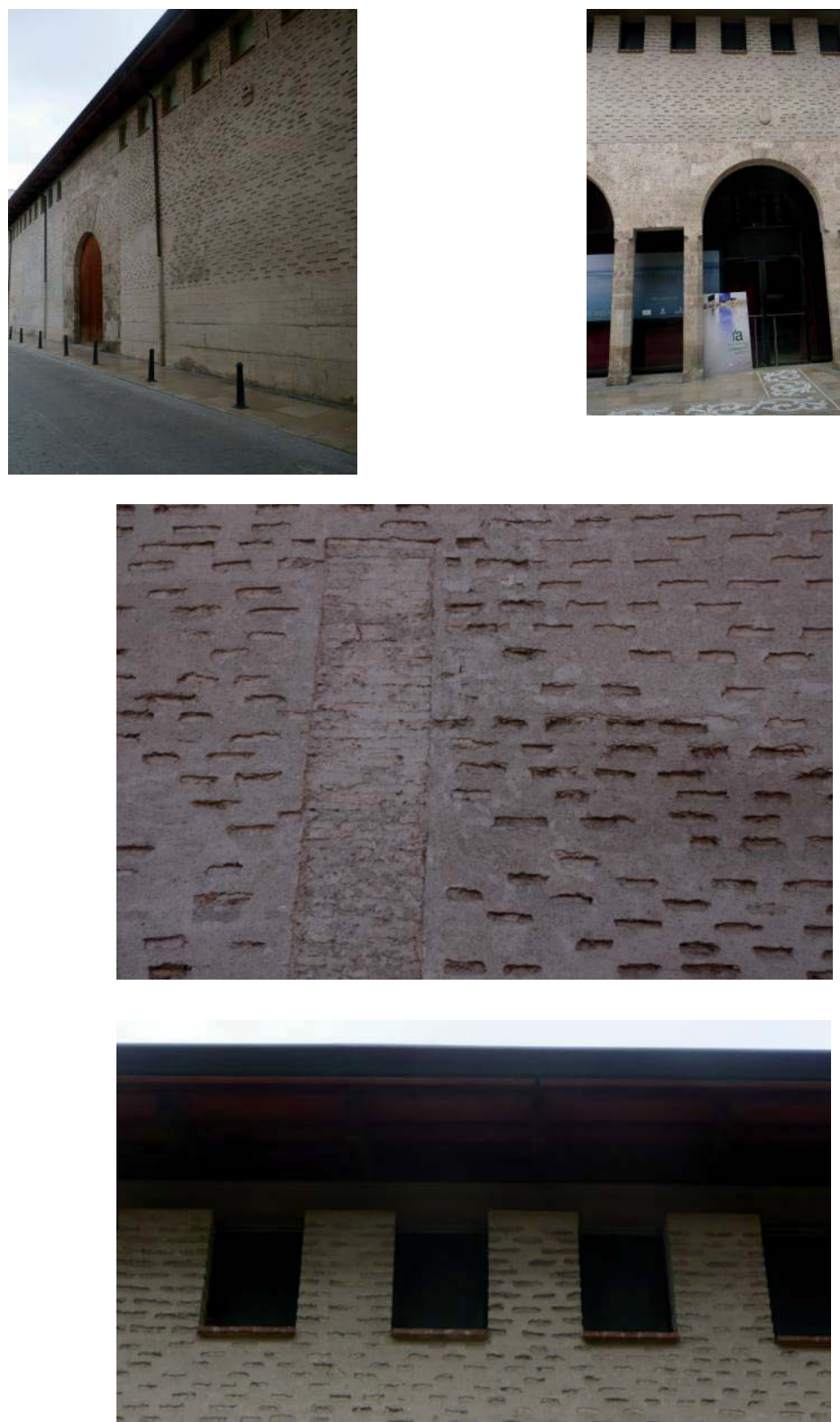

Xc96b

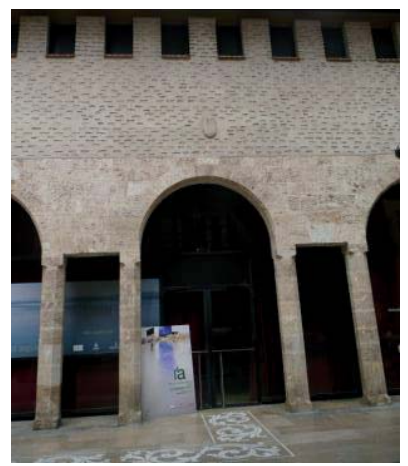

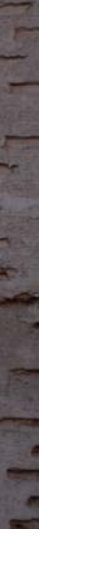

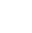




\begin{tabular}{|c|c|c|c|c|c|}
\hline Barrio & Carmen & La Seu-Xerea & Velluters & Mercat & S.Francesc \\
\hline Dirección & C/ Venerabl & s s/n & & & \\
\hline Tipo de edificio & residencial & palaciego & religioso & militar & \\
\hline $\mathbf{G}^{\circ}$ de protección & 0 & 1 & 2 & 3 & \\
\hline Fechas claves & / & & & & \\
\hline
\end{tabular}
El apartado "fechas claves" se ha extraído de AA.V.., Guía de Arquitectura de Valencia, Icaro CTAV Ed., Valencia, 2007

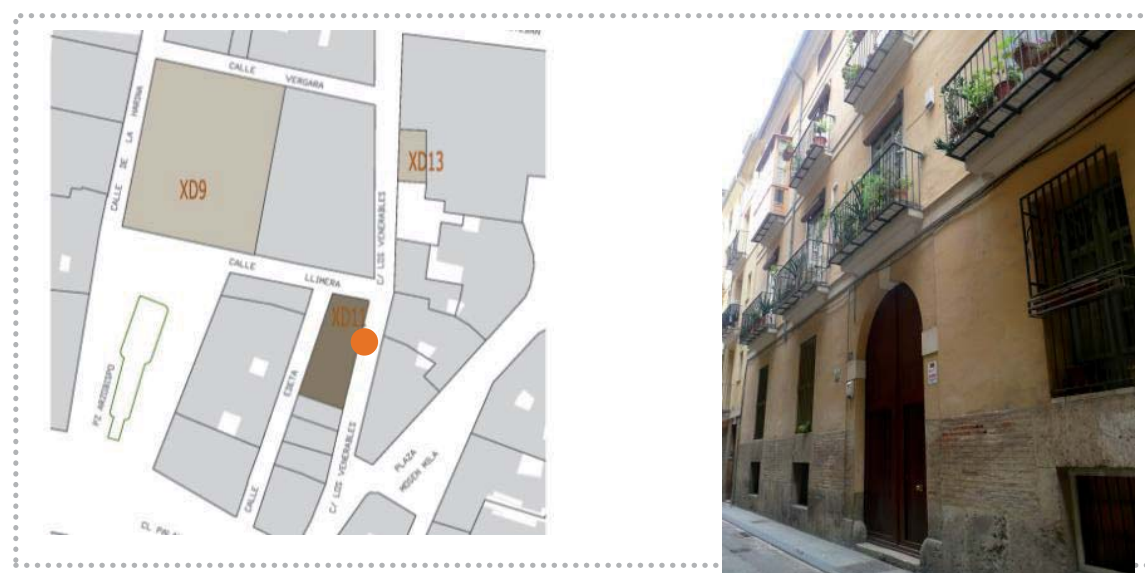

Fachada

$\mathrm{Xd11}$

\begin{tabular}{|c|c|c|c|c|c|c|c|c|c|}
\hline \multirow{3}{*}{$\begin{array}{l}\text { Pisos } \\
\text { Composición fachada } \\
\text { Zócalo }\end{array}$} & \multicolumn{2}{|c|}{$\mathrm{N}^{0} 3$} & sótano & \multicolumn{2}{|c|}{ entreplanta } & \multicolumn{4}{|c|}{ piso noble caja escalera } \\
\hline & \multicolumn{2}{|c|}{ aleatoria } & \multicolumn{3}{|c|}{ ordenada sin simetría } & \multicolumn{4}{|c|}{ ordenada con simetría } \\
\hline & $\mathrm{Z1}$ & $\mathrm{Z} 2$ & $\mathrm{Z3}$ & Z4 & Z5 & & & & \\
\hline Fábrica & $\mathrm{F} 1$ & $\mathrm{~F} 2$ & F3 & F4 & $\mathrm{F} 5$ & F7 & & & \\
\hline Vano/dintel & V1 & V2 & V3 & V4 & V5 & V7 & V8 & V9 & V10 \\
\hline Entrada/dintel & E1 & E2 & E3 & E4 & & & & & \\
\hline Alero & A1 & $\mathrm{A} 2$ & A3 & A4 & A5 & A7 & & & \\
\hline Cubierta & pla & & inclina & & & & & & \\
\hline
\end{tabular}

Aparejo
Hiladas
Superficie
Sección (hipótesis)
Elementos destacados

\begin{tabular}{lll} 
soga-tizón & soga tizón & \\
irregulares & pseudo horizontales & horizontales \\
\hline sin planeidad & pseudo planeidad & planeidad perfecta \\
\hline uniforme & hojas y núcleo & abocinada (vano) \\
aplantillado & cortado terracota & \\
\hline
\end{tabular}




\begin{tabular}{|c|c|c|c|}
\hline \multirow{2}{*}{$\begin{array}{l}\mathrm{N}^{\circ} \text { elementos medidos } \\
\text { Longitud }(\mathrm{cm})\end{array}$} & \multicolumn{3}{|l|}{15} \\
\hline & \multicolumn{3}{|l|}{30} \\
\hline Anchura (cm) & \multicolumn{3}{|l|}{13.5} \\
\hline Espesor (cm) & \multicolumn{3}{|l|}{3.3} \\
\hline Volumen $\left(\mathrm{cm}^{3}\right)$ & \multicolumn{3}{|l|}{1336.3} \\
\hline Tipo & homogéneo & heterogéneo & re-empleo \\
\hline \multirow{4}{*}{$\begin{array}{l}\text { Color } \\
\text { Recogida de muestra } \\
\text { Patologías }\end{array}$} & homogéneo & heterogéneo globular & heterogéneo marmolado \\
\hline & no & sí & código \\
\hline & eflorescencias & micro fisuración & grietas \\
\hline & erosión & disgregación & descamación \\
\hline
\end{tabular}

1 Datos obtenidos en base al cálculo del desvío estándar (respecto al valor medio de la muestras analizadas) y del gráfico de frecuencia de las muestras analizadas, identificado por una curva gaussiana

\section{untas}

\begin{tabular}{|c|c|c|c|c|}
\hline \multirow{2}{*}{$\begin{array}{l}N^{\circ} \text { elementos medidos } \\
\text { Llaga }(\mathrm{cm})\end{array}$} & \multicolumn{4}{|l|}{15} \\
\hline & \multicolumn{4}{|l|}{1.2} \\
\hline Tendel (cm) & \multicolumn{4}{|l|}{4.6} \\
\hline Altura de 5 hiladas $(\mathrm{cm})$ & \multicolumn{4}{|l|}{41} \\
\hline Proporción ladrillo/junta & \multicolumn{4}{|l|}{1} \\
\hline Tipo de acabado & simple & doble & múltiple & \\
\hline \multirow[t]{2}{*}{ Junta de asiento } & rehundida & a hueso & saliente & \\
\hline & enrasada & matada & & \\
\hline \multirow[t]{2}{*}{ Junta de acabado } & rehundida & a hueso & saliente & \\
\hline & enrasada & matada & & \\
\hline \multirow{2}{*}{$\begin{array}{l}\text { Tipo de mortero } \\
\text { Morfología de mortero }\end{array}$} & cal & cal y tierra & tierra & cemento mixto \\
\hline & con grumos & con caliches & homogéneo & heterogéneo \\
\hline Tipo de árido & arena & gravilla & grava & mixto \\
\hline \multirow{4}{*}{$\begin{array}{l}\text { Color del árido } \\
\text { Recogida de muestra } \\
\text { Patologías }\end{array}$} & claro & oscuro & homogéneo & heterogéneo \\
\hline & no & sí & código & \\
\hline & eflorescencias & micro fisuración & grietas & \\
\hline & erosión & disgregación & pulverización & \\
\hline
\end{tabular}


Imágenes

Xd11
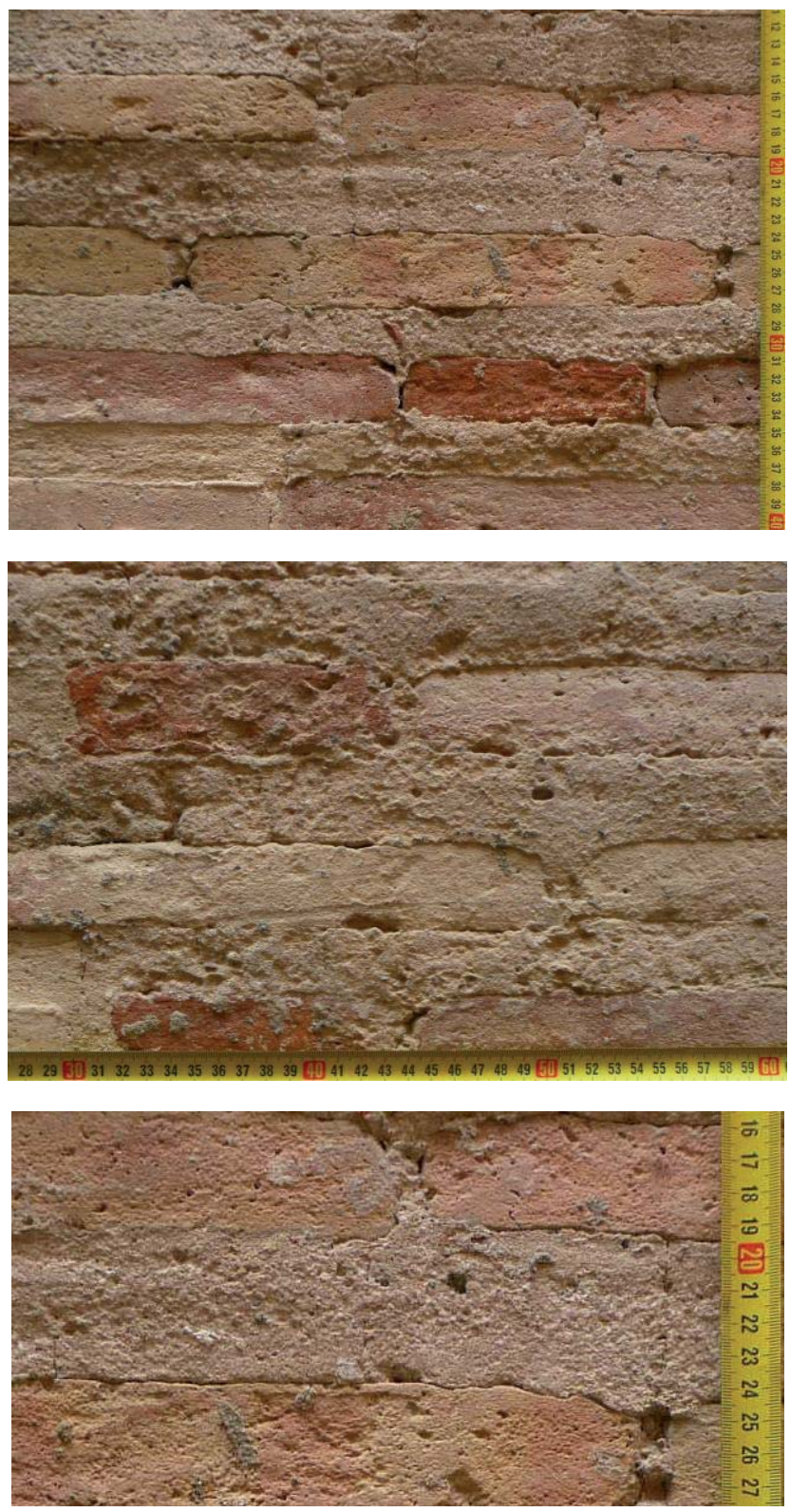
Imágenes

Xd11
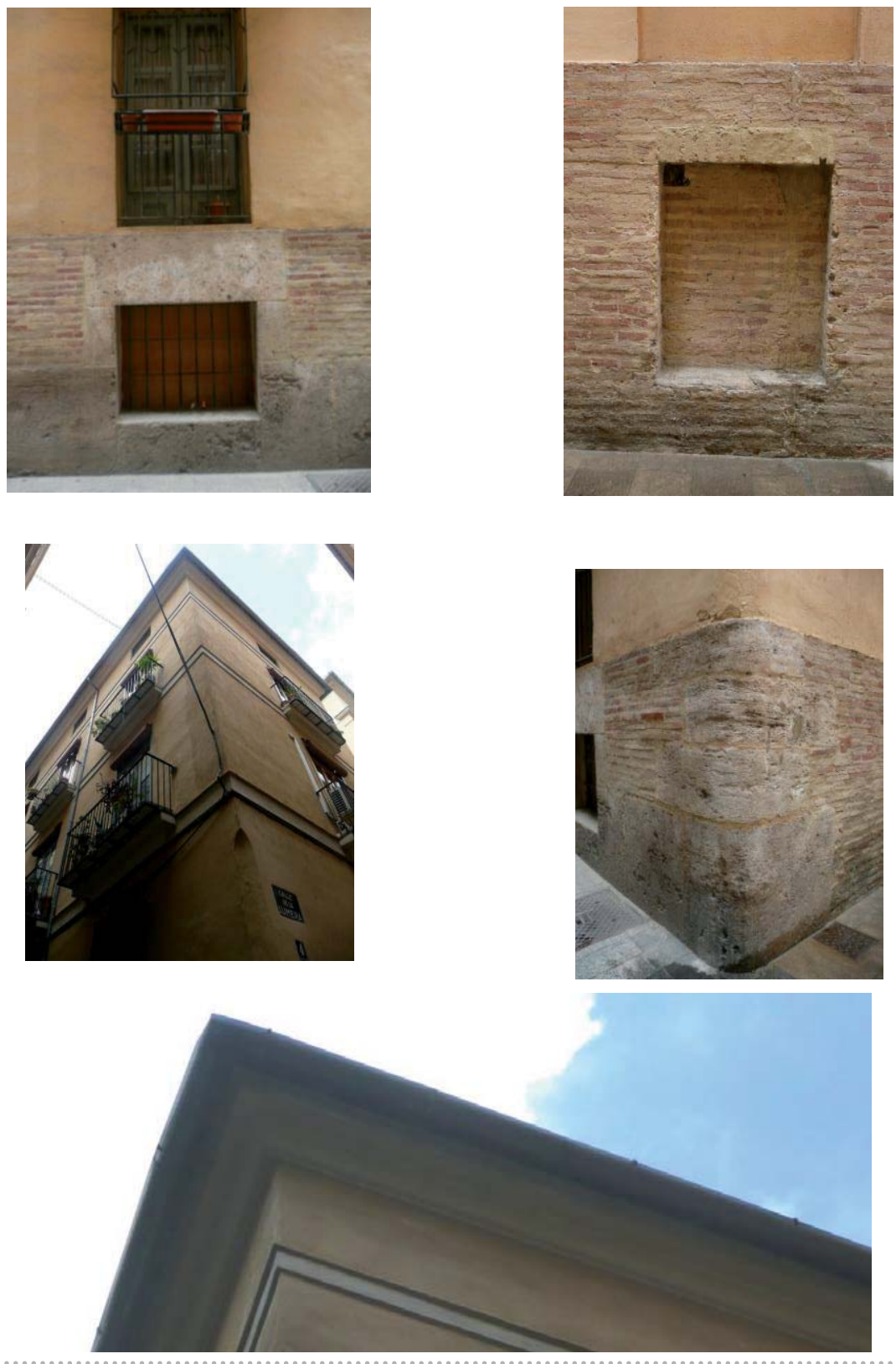
Datos generales

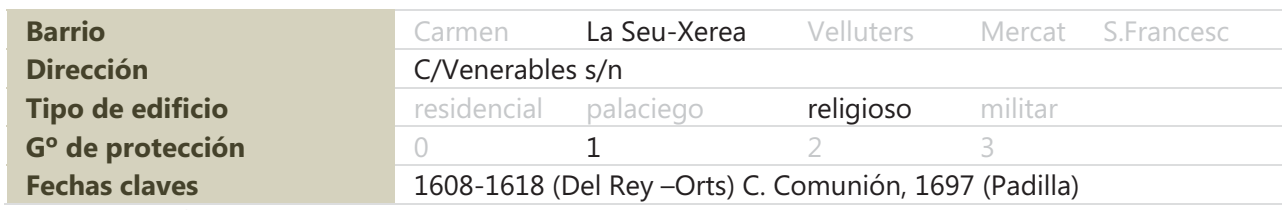
El apartado "fechas claves" se ha extraído de AA.W.., Guía de Arquitectura de Valencia, Icaro CTAV Ed., Valencia, 2007
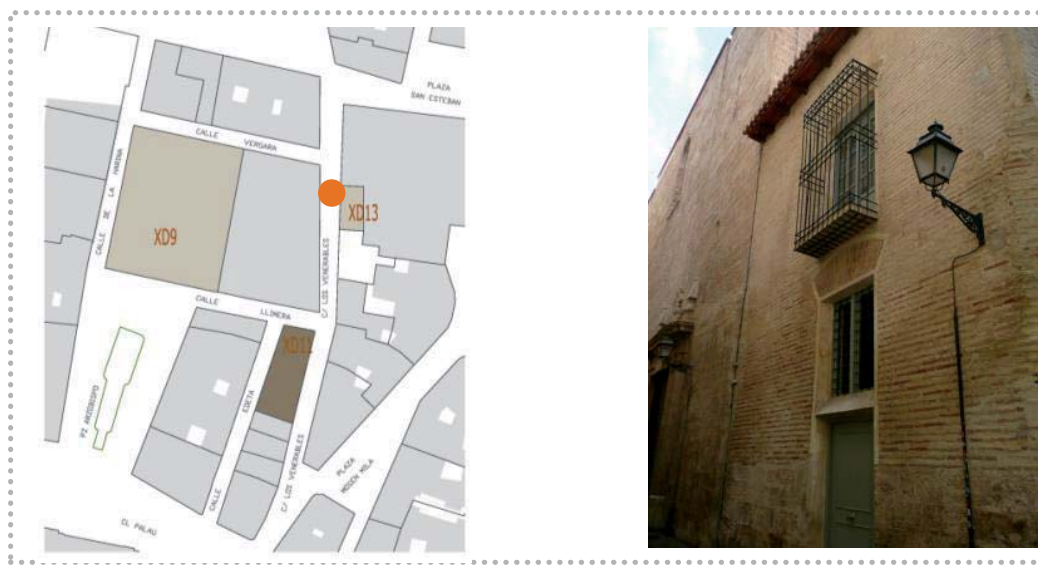

Fachada

Xd13

Pisos
Composición fachada
Zócalo
Fábrica
Vano/dintel
Entrada/dintel
Alero
Cubierta

\begin{tabular}{|c|c|c|c|c|c|c|c|c|c|}
\hline \multicolumn{2}{|c|}{$N^{\circ} 2$} & sótano & & planta & \multicolumn{2}{|c|}{ piso noble } & $\mathrm{Ca}$ & a esc & era \\
\hline \multicolumn{2}{|c|}{ aleatoria } & \multicolumn{3}{|c|}{ ordenada sin simetría } & \multicolumn{5}{|c|}{ ordenada con simetría } \\
\hline Z1 & $\mathrm{Z} 2$ & $\mathrm{Z3}$ & Z4 & $\mathrm{Z} 5$ & & & & & \\
\hline F1 & $\mathrm{F} 2$ & F3 & F4 & F5 & F6 & F7 & & & \\
\hline V1 & V2 & V3 & V4 & V5 & V6 & V7 & V8 & V9 & V10 \\
\hline E1 & E2 & E3 & E4 & & & & & & \\
\hline A1 & $\mathrm{A} 2$ & $\mathrm{~A} 3$ & A4 & A5 & A6 & A7 & & & \\
\hline pla & & inclina & & & & & & & \\
\hline
\end{tabular}

\section{Fábrica}

$\mathrm{Xd13}$

\section{Aparejo \\ Hiladas \\ Superficie \\ Sección (hipótesis) \\ Elementos destacados}

\begin{tabular}{lll} 
soga-tizón & soga & \multicolumn{1}{c}{ tizón } \\
irregulares & pseudo horizontales & horizontales \\
\hline sin planeidad & pseudo planeidad & planeidad perfecta \\
\hline uniforme & hojas y núcleo & abocinada (vano) \\
aplantillado & cortado terracota & \\
\hline
\end{tabular}




\begin{tabular}{|c|c|c|c|}
\hline \multirow{2}{*}{$\begin{array}{l}\mathrm{N}^{\circ} \text { elementos medidos } \\
\text { Longitud }(\mathrm{cm})\end{array}$} & \multicolumn{3}{|l|}{15} \\
\hline & \multicolumn{3}{|l|}{30} \\
\hline Anchura (cm) & \multicolumn{3}{|l|}{13.9} \\
\hline Espesor (cm) & \multicolumn{3}{|l|}{3.3} \\
\hline Volumen $\left(\mathrm{cm}^{3}\right)$ & \multicolumn{3}{|l|}{1376.1} \\
\hline Tipo & homogéneo & heterogéneo & re-empleo \\
\hline \multirow{4}{*}{$\begin{array}{l}\text { Color } \\
\text { Recogida de muestra } \\
\text { Patologías }\end{array}$} & homogéneo & heterogéneo globular & heterogéneo marmolado \\
\hline & no & sí & código \\
\hline & eflorescencias & micro fisuración & grietas \\
\hline & erosión & disgregación & descamación \\
\hline
\end{tabular}

${ }^{1}$ Datos obtenidos en base al cálculo del desvío estándar (respecto al valor medio de la muestras analizadas) y del gráfico de frecuencia de las muestras analizadas, identificado por una curva gaussiana

\section{Juntas}

\begin{tabular}{|c|c|c|c|c|}
\hline \multirow{2}{*}{$\begin{array}{l}N^{\circ} \text { elementos medidos } \\
\text { Llaga }(\mathrm{cm})\end{array}$} & \multicolumn{4}{|l|}{15} \\
\hline & \multicolumn{4}{|l|}{1.2} \\
\hline Tendel (cm) & \multicolumn{4}{|l|}{4.6} \\
\hline Altura de 5 hiladas $(\mathrm{cm})$ & \multicolumn{4}{|l|}{4.1} \\
\hline Proporción ladrillo/junta & \multicolumn{4}{|l|}{0.19} \\
\hline Tipo de acabado & simple & doble & \multicolumn{2}{|l|}{ múltiple } \\
\hline \multirow[t]{2}{*}{ Junta de asiento } & rehundida & a hueso & \multirow[t]{2}{*}{ saliente } & \\
\hline & enrasada & matada & & \\
\hline \multirow[t]{2}{*}{ Junta de acabado } & rehundida & a hueso & \multirow[t]{2}{*}{ saliente } & \\
\hline & enrasada & matada & & \\
\hline \multirow{2}{*}{$\begin{array}{l}\text { Tipo de mortero } \\
\text { Morfología de mortero }\end{array}$} & cal & cal y tierra & tierra & cemento mixto \\
\hline & con grumos & con caliches & homogéneo & heterogéneo \\
\hline \multirow{5}{*}{$\begin{array}{l}\text { Tipo de árido } \\
\text { Color del árido } \\
\text { Recogida de muestra } \\
\text { Patologías }\end{array}$} & arena & gravilla & grava & mixto \\
\hline & claro & oscuro & homogéneo & heterogéneo \\
\hline & no & sí & \multicolumn{2}{|l|}{ código } \\
\hline & eflorescencias & micro fisuración & \multicolumn{2}{|l|}{ grietas } \\
\hline & erosión & disgregación & \multicolumn{2}{|l|}{ pulverización } \\
\hline
\end{tabular}



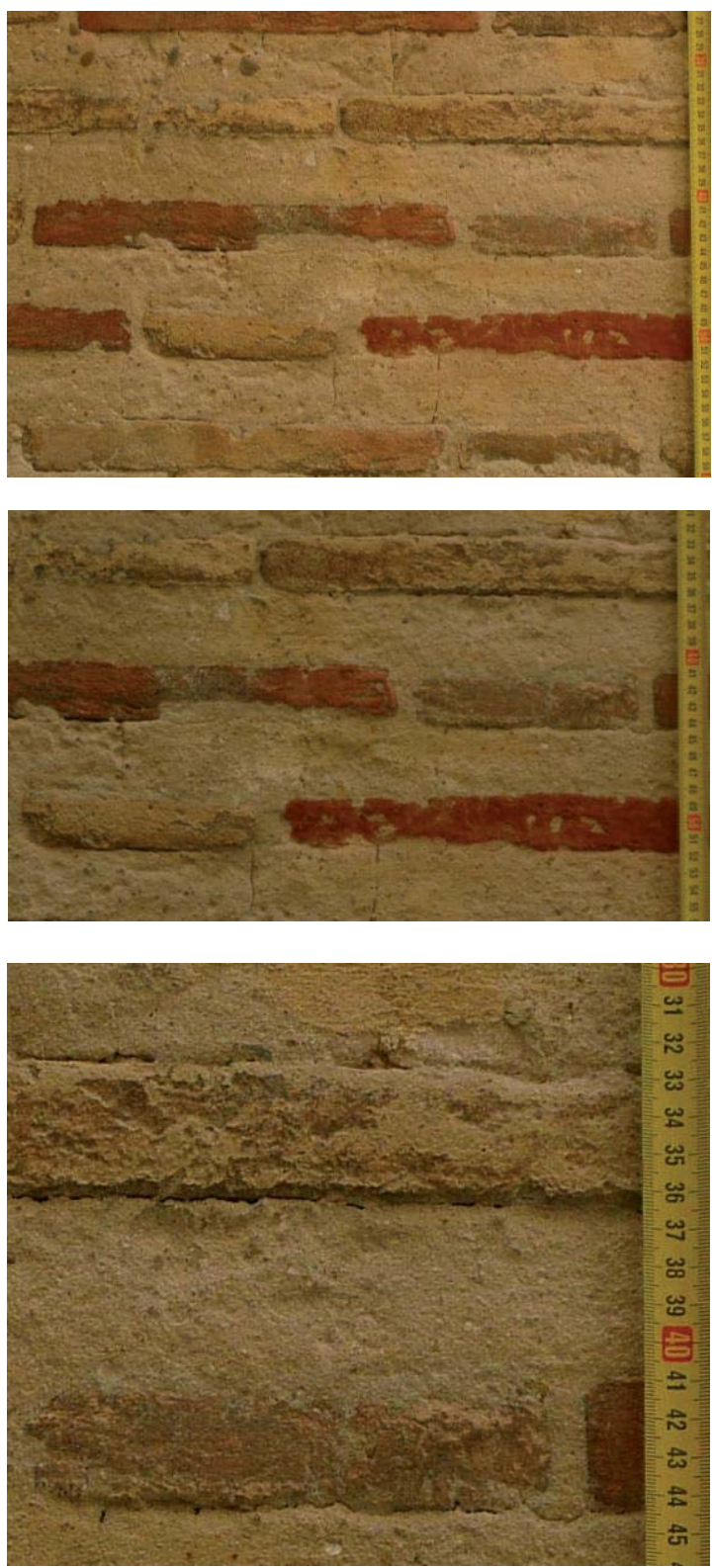

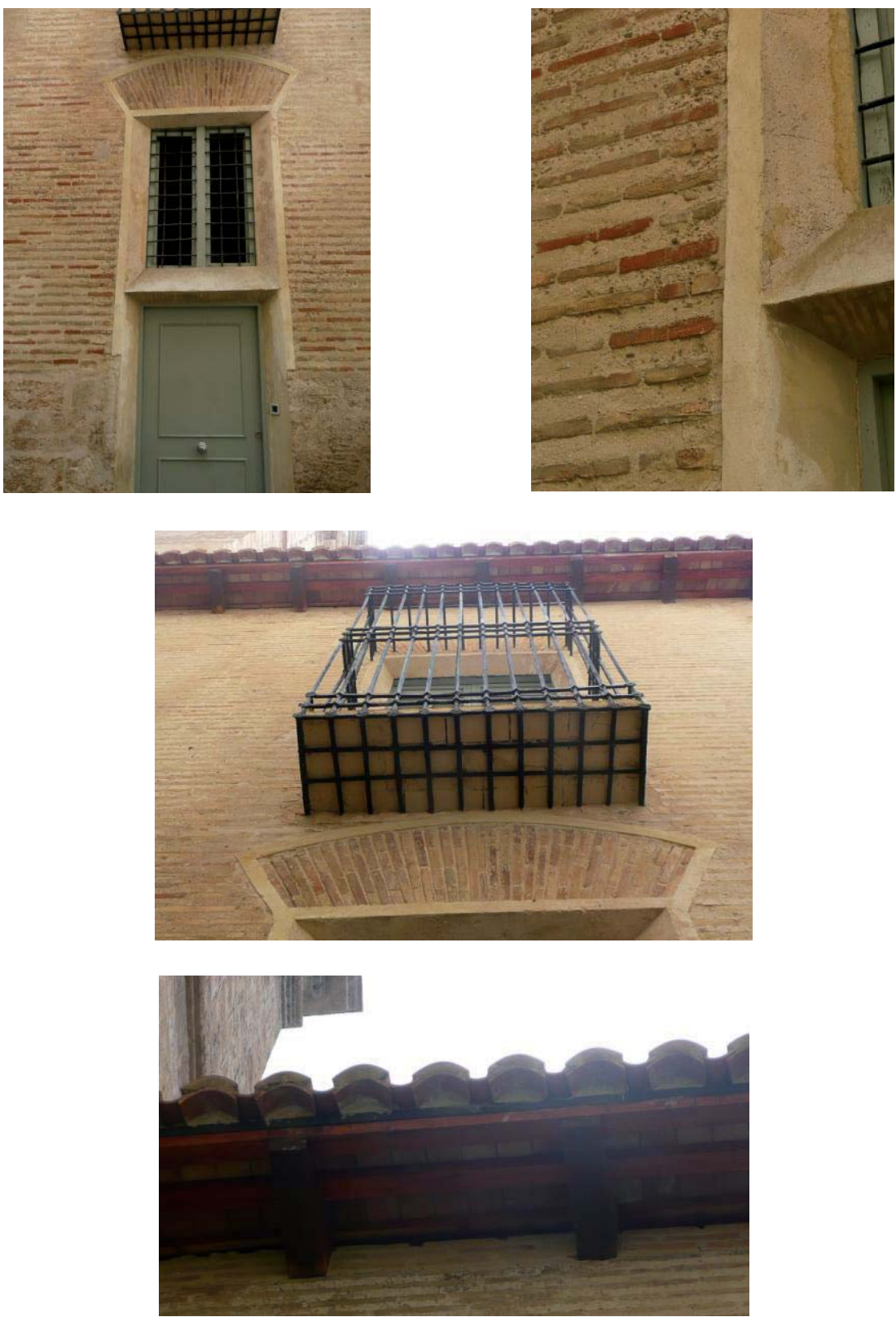
Datos generales

\section{$\mathrm{Xd54a}$}

\begin{tabular}{|c|c|c|c|c|c|}
\hline Barrio & Carmen & La Seu-Xerea & Velluters & Mercat & S.Francesc \\
\hline Dirección & C/Lleña n7 & & & & \\
\hline Tipo de edificio & residencial & palaciego & religioso & militar & \\
\hline $\mathbf{G}^{\circ}$ de protección & 0 & 1 & 2 & 3 & \\
\hline Fechas claves & Ampliación & forma 1774 (C & el)) & & \\
\hline
\end{tabular}
El apartado "fechas claves" se ha extraído de AA.W., Guía de Arquitectura de Valencia, Icaro CTAV Ed., Valencia, 2007.

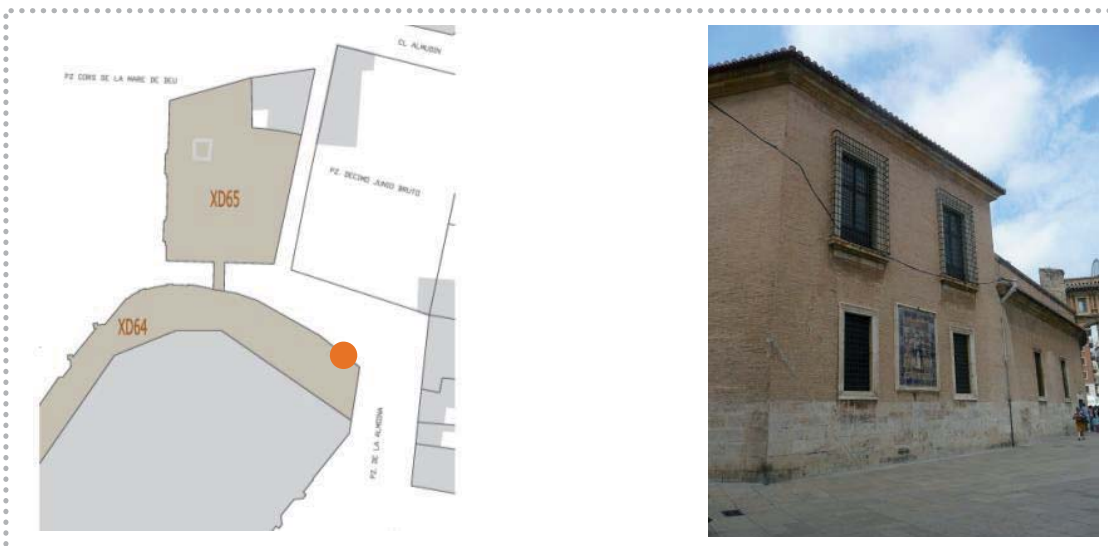

Fachada

$\mathrm{Xd54a}$

\begin{tabular}{|c|c|c|c|c|c|c|c|c|c|c|}
\hline \multirow{3}{*}{$\begin{array}{l}\text { Pisos } \\
\text { Composición fachada } \\
\text { Zócalo }\end{array}$} & \multicolumn{2}{|c|}{$\mathrm{N}^{\circ} 2$} & sót & \multicolumn{2}{|c|}{ entreplanta } & \multicolumn{2}{|c|}{ piso noble } & \multicolumn{3}{|c|}{ caja escalera } \\
\hline & \multicolumn{2}{|c|}{ aleatoria } & \multicolumn{3}{|c|}{ ordenada sin simetría } & \multicolumn{5}{|c|}{ ordenada con simetría } \\
\hline & Z1 & Z2 & $\mathrm{Z3}$ & Z4 & $\mathrm{Z} 5$ & & & & & \\
\hline Fábrica & $\mathrm{F} 1$ & F2 & F3 & F4 & F5 & F6 & F7 & & & \\
\hline Vano/dintel & V1 & V2 & V3 & V4 & V5 & V6 & V7 & V8 & V9 & V10 \\
\hline Entrada/dintel & E1 & E2 & E3 & E4 & & & & & & \\
\hline Alero & A1 & A2 & A3 & A4 & A5 & A6 & A7 & & & \\
\hline Cubierta & plai & & incl & & & & & & & \\
\hline
\end{tabular}

Fábrica

Xd54a

\section{Aparejo \\ Hiladas \\ Superficie \\ Sección (hipótesis) \\ Elementos destacados}

\begin{tabular}{lll} 
soga-tizón & soga & \multicolumn{1}{c}{ tizón } \\
irregulares & pseudo horizontales & horizontales \\
\hline sin planeidad & pseudo planeidad & planeidad perfecta \\
\hline uniforme & hojas y núcleo & abocinada (vano) \\
aplantillado & cortado terracota & \\
\hline
\end{tabular}




\begin{tabular}{l|lll}
\hline $\begin{array}{l}\text { No elementos medidos } \\
\text { Longitud }(\mathbf{c m})\end{array}$ & 15 & & \\
Anchura $(\mathbf{c m})$ & 29.5 & & \\
Espesor $(\mathbf{c m})$ & 14.4 & & \\
Volumen $\left(\mathbf{c m}^{3}\right)$ & 4.1 & heterogéneo & re-empleo \\
Tipo & 1741.68 & heterogéneo globular & heterogéneo marmolado \\
Color & homogéneo & homogéneo & síno \\
Recogida de muestra & no & micro fisuración & grietas \\
Patologías & eflorescencias & disgregación & descamación
\end{tabular}

${ }^{1}$ Datos obtenidos en base al cálculo del desvío estándar (respecto al valor medio de la muestras analizadas) y del gráfico de frecuencia de las muestras analizadas, identificado por una curva gaussiana

\section{Juntas}

$X d 54 a$

\begin{tabular}{|c|c|c|c|c|}
\hline $\mathrm{N}^{\circ}$ elementos medidos & \multicolumn{4}{|l|}{15} \\
\hline \multirow{2}{*}{$\begin{array}{l}\text { Llaga }(\mathrm{cm}) \\
\text { Tendel }(\mathrm{cm})\end{array}$} & \multicolumn{4}{|l|}{1.7} \\
\hline & \multicolumn{4}{|l|}{3.5} \\
\hline Altura de 5 hiladas $(\mathrm{cm})$ & \multicolumn{4}{|l|}{34} \\
\hline Proporción ladrillo/junta & \multicolumn{4}{|l|}{1.5} \\
\hline \multirow{3}{*}{$\begin{array}{l}\text { Tipo de acabado } \\
\text { Junta de asiento }\end{array}$} & simple & doble & \multicolumn{2}{|l|}{ múltiple } \\
\hline & rehundida & a hueso & \multicolumn{2}{|l|}{ saliente } \\
\hline & enrasada & matada & & \\
\hline \multirow[t]{2}{*}{ Junta de acabado } & rehundida & a hueso & \multirow{2}{*}{\multicolumn{2}{|c|}{ saliente }} \\
\hline & enrasada & matada & & \\
\hline \multirow{3}{*}{$\begin{array}{l}\text { Tipo de mortero } \\
\text { Morfología de mortero } \\
\text { Tipo de árido }\end{array}$} & cal & cal y tierra & tierra & cemento mixto \\
\hline & con grumos & con caliches & homogéneo & heterogéneo \\
\hline & arena & gravilla & grava & mixto \\
\hline \multirow{2}{*}{$\begin{array}{l}\text { Color del árido } \\
\text { Recogida de muestra }\end{array}$} & claro & oscuro & homogéneo & heterogéneo \\
\hline & no & sí & \multicolumn{2}{|l|}{ código } \\
\hline \multirow[t]{2}{*}{ Patologías } & eflorescencias & micro fisuración & \multicolumn{2}{|l|}{ grietas } \\
\hline & erosión" & disgregación & \multicolumn{2}{|l|}{ pulverización } \\
\hline
\end{tabular}


Imágenes
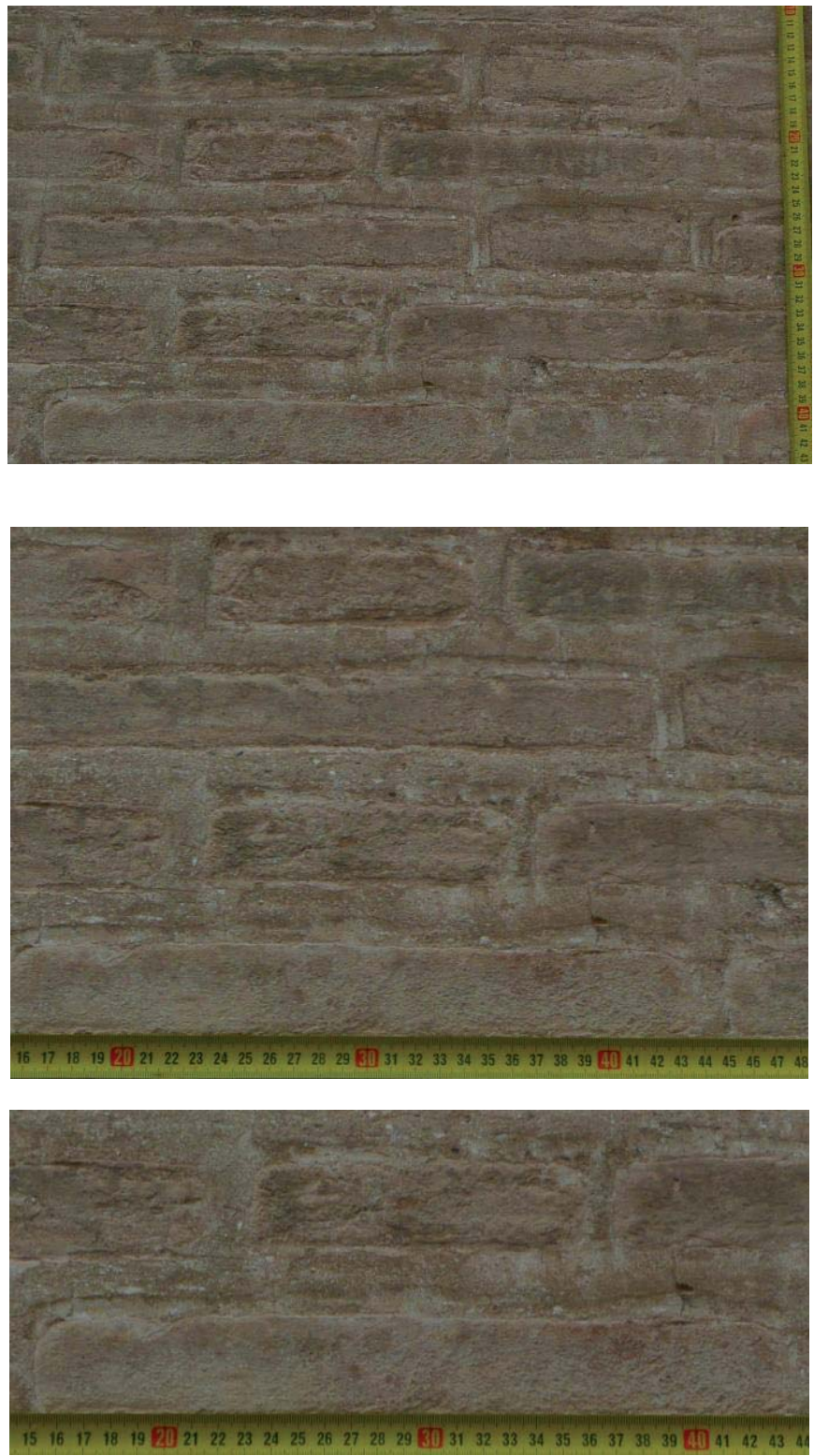


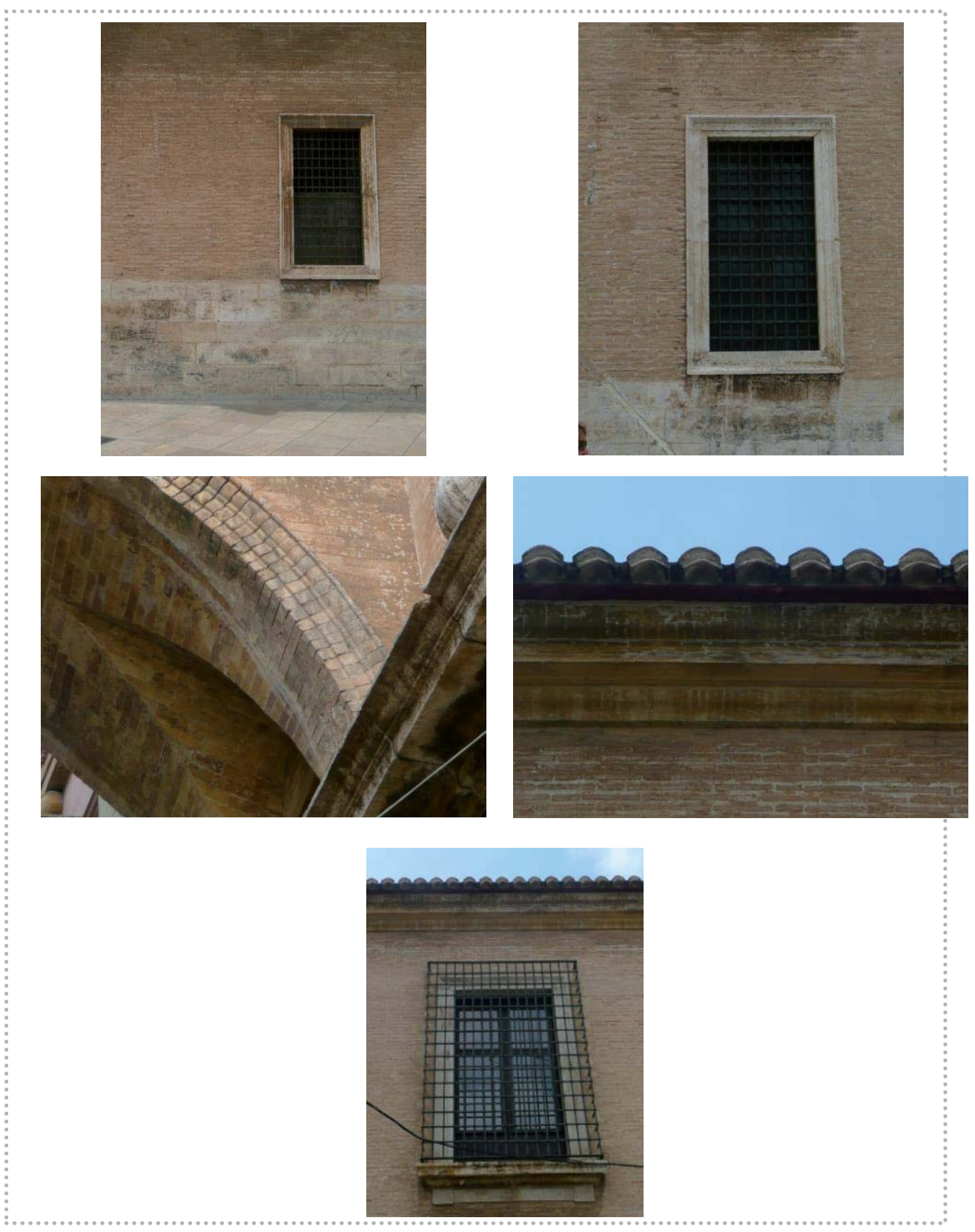




\begin{tabular}{|c|c|c|c|c|c|}
\hline Barrio & Carmen & La Seu-Xerea & Velluters & Mercat & S.Francesc \\
\hline Dirección & \multicolumn{5}{|c|}{ C/Miguelete s/n } \\
\hline Tipo de edificio & residencial & palaciego & religioso & militar & \\
\hline $\mathbf{G}^{\circ}$ de protección & 0 & 1 & 2 & 3 & \\
\hline Fechas claves & \multicolumn{5}{|c|}{ Ampliación reforma 1774 (Castiel)) } \\
\hline
\end{tabular}
El apartado "fechas claves" se ha extraído de AA.V.., Guía de Arquitectura de Valencia, Icaro CTAV Ed., Valencia, 2007

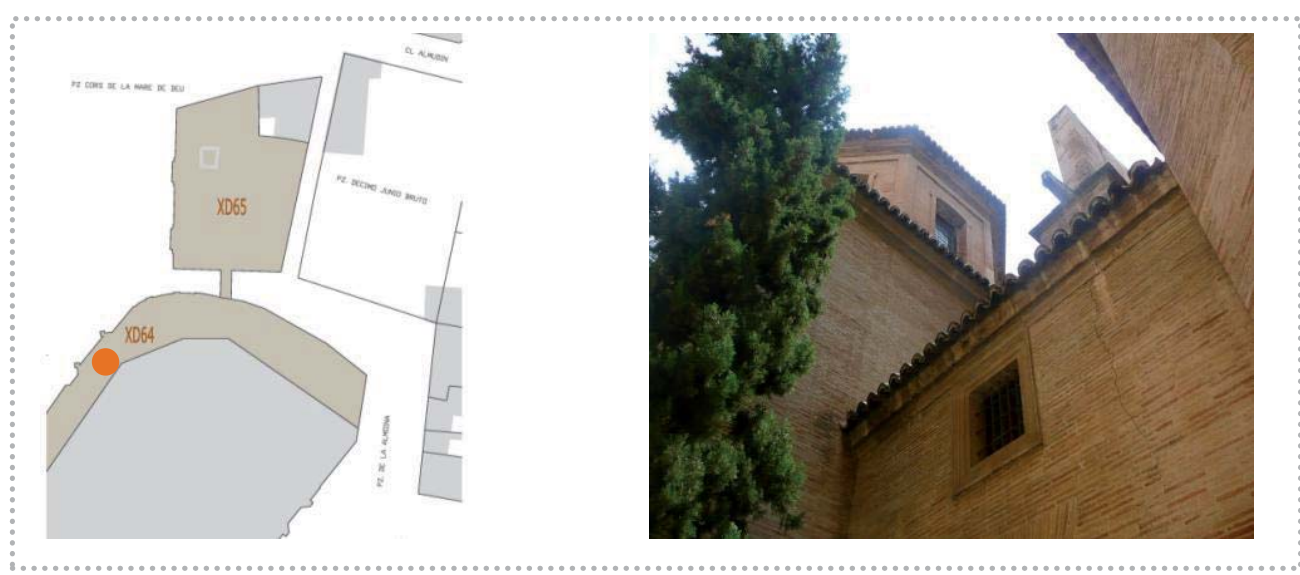

Fachada

$X d 54 b$

Pisos
Composición fachada
Zócalo
Fábrica
Vano/dintel
Entrada/dintel
Alero
Cubierta

\begin{tabular}{|c|c|c|c|c|c|c|c|c|c|}
\hline \multirow{2}{*}{\multicolumn{2}{|c|}{$\begin{array}{l}\mathrm{N}^{\circ} 2 \\
\text { aleatoria }\end{array}$}} & \multirow{2}{*}{\multicolumn{3}{|c|}{$\begin{array}{l}\text { sótano entreplanta } \\
\text { ordenada sin simetría }\end{array}$}} & \multicolumn{5}{|c|}{ piso noble caja escalera } \\
\hline & & & & & \multicolumn{5}{|c|}{ ordenada con simetría } \\
\hline Z1 & Z2 & Z3 & Z4 & Z5 & & & & & \\
\hline F1 & F2 & F3 & F4 & F5 & F6 & F7 & & & \\
\hline V1 & V2 & V3 & V4 & V5 & V6 & V7 & V8 & V9 & V10 \\
\hline E1 & E2 & E3 & E4 & & & & & & \\
\hline A1 & $\mathrm{A} 2$ & $\mathrm{~A} 3$ & A4 & A5 & A6 & A7 & & & \\
\hline \multicolumn{2}{|c|}{ plana } & \multicolumn{3}{|c|}{ inclinada } & & & & & \\
\hline
\end{tabular}

\section{Fábrica}

\section{$\mathrm{Xd54b}$}

\section{Aparejo \\ Hiladas \\ Superficie \\ Sección (hipótesis) \\ Elementos destacados}

\begin{tabular}{lll} 
soga-tizón & soga & \\
irregulares & pseudo horizontales & horizontales \\
\hline sin planeidad & pseudo planeidad & planeidad perfecta \\
\hline uniforme & hojas y núcleo & abocinada (vano) \\
aplantillado & cortado terracota & \\
\hline
\end{tabular}




\begin{tabular}{|c|c|c|c|}
\hline \multirow{2}{*}{$\begin{array}{l}\mathrm{N}^{\circ} \text { elementos medidos } \\
\text { Longitud }(\mathrm{cm})\end{array}$} & \multicolumn{3}{|l|}{15} \\
\hline & \multicolumn{3}{|l|}{28.8} \\
\hline Anchura (cm) & \multicolumn{3}{|l|}{14.7} \\
\hline Espesor (cm) & \multicolumn{3}{|l|}{4.1} \\
\hline Volumen $\left(\mathrm{cm}^{3}\right)$ & \multicolumn{3}{|l|}{1735.7} \\
\hline Tipo & homogéneo & heterogéneo & re-empleo \\
\hline \multirow{4}{*}{$\begin{array}{l}\text { Color } \\
\text { Recogida de muestra } \\
\text { Patologías }\end{array}$} & homogéneo & heterogéneo globular & heterogéneo marmolado \\
\hline & no & sí & código \\
\hline & eflorescencias & micro fisuración & grietas \\
\hline & erosión & disgregación & descamación \\
\hline
\end{tabular}

${ }^{1}$ Datos obtenidos en base al cálculo del desvío estándar (respecto al valor medio de la muestras analizadas) y del gráfico de frecuencia de las muestras analizadas, identificado por una curva gaussiana

\section{Juntas}

$X d 54 b$

\begin{tabular}{|c|c|c|c|c|}
\hline $\mathrm{N}^{\circ}$ elementos medidos & \multicolumn{4}{|l|}{15} \\
\hline \multirow{2}{*}{$\begin{array}{l}\text { Llaga }(\mathrm{cm}) \\
\text { Tendel }(\mathrm{cm})\end{array}$} & \multicolumn{4}{|l|}{2.7} \\
\hline & \multicolumn{4}{|l|}{3.6} \\
\hline Altura de 5 hiladas $(\mathrm{cm})$ & \multicolumn{4}{|l|}{39.5} \\
\hline Proporción ladrillo/junta & \multicolumn{4}{|l|}{1.13} \\
\hline \multirow{3}{*}{$\begin{array}{l}\text { Tipo de acabado } \\
\text { Junta de asiento }\end{array}$} & simple & doble & \multicolumn{2}{|l|}{ múltiple } \\
\hline & rehundida & a hueso & \multicolumn{2}{|l|}{ saliente } \\
\hline & enrasada & matada & & \\
\hline \multirow[t]{2}{*}{ Junta de acabado } & rehundida & a hueso & \multicolumn{2}{|l|}{ saliente } \\
\hline & enrasada & matada & & \\
\hline \multirow{2}{*}{$\begin{array}{l}\text { Tipo de mortero } \\
\text { Morfología de mortero }\end{array}$} & cal & cal y tierra & tierra & cemento mixto \\
\hline & con grumos & con caliches & homogéneo & heterogéneo \\
\hline Tipo de árido & arena & gravilla & grava & mixto \\
\hline \multirow{2}{*}{$\begin{array}{l}\text { Color del árido } \\
\text { Recogida de muestra }\end{array}$} & claro & oscuro & homogéneo & heterogéneo \\
\hline & no & sí & código & \\
\hline \multirow[t]{2}{*}{ Patologías } & eflorescencias & micro fisuración & grietas & \\
\hline & erosión & disgregación & pulverización & \\
\hline
\end{tabular}


Imágenes
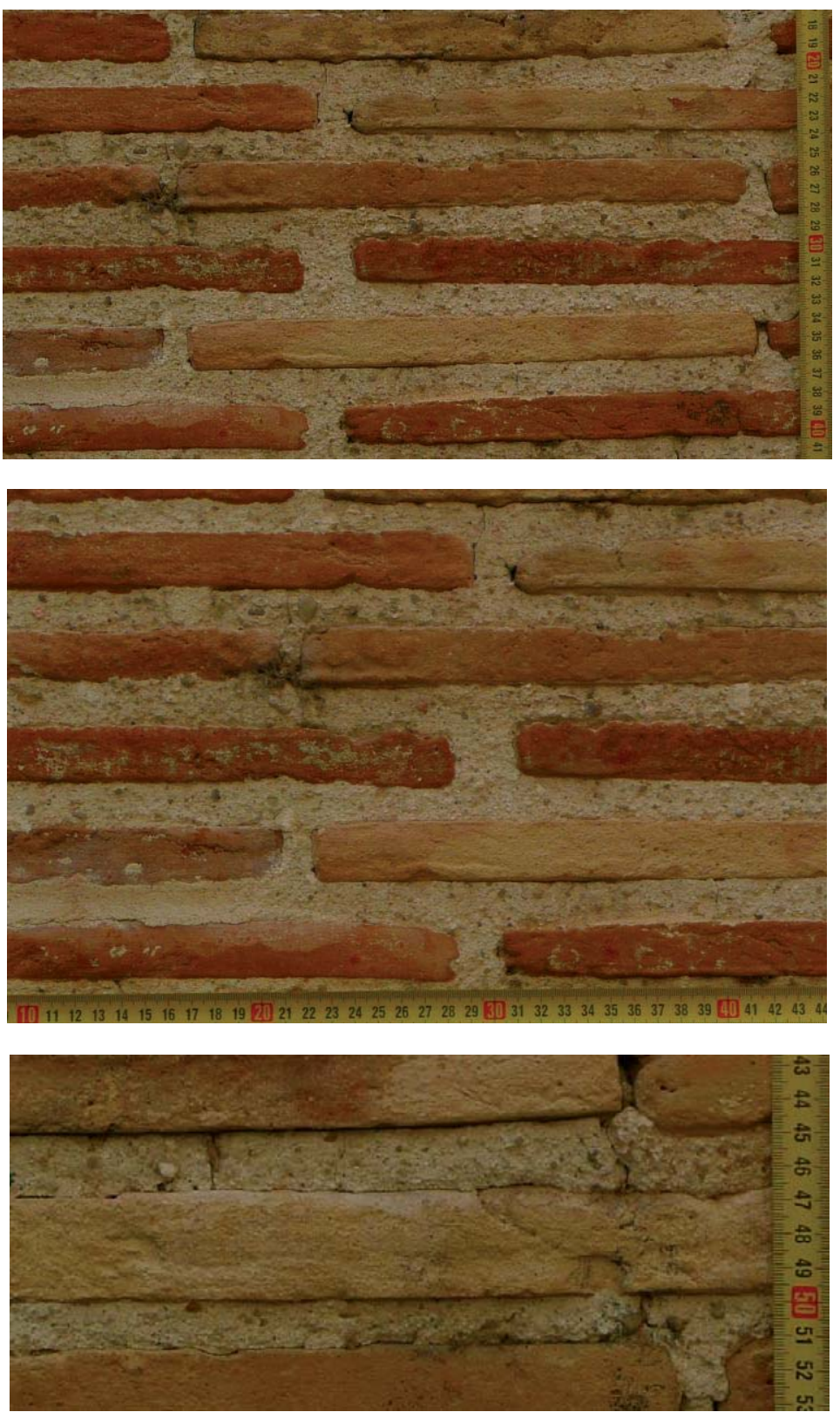

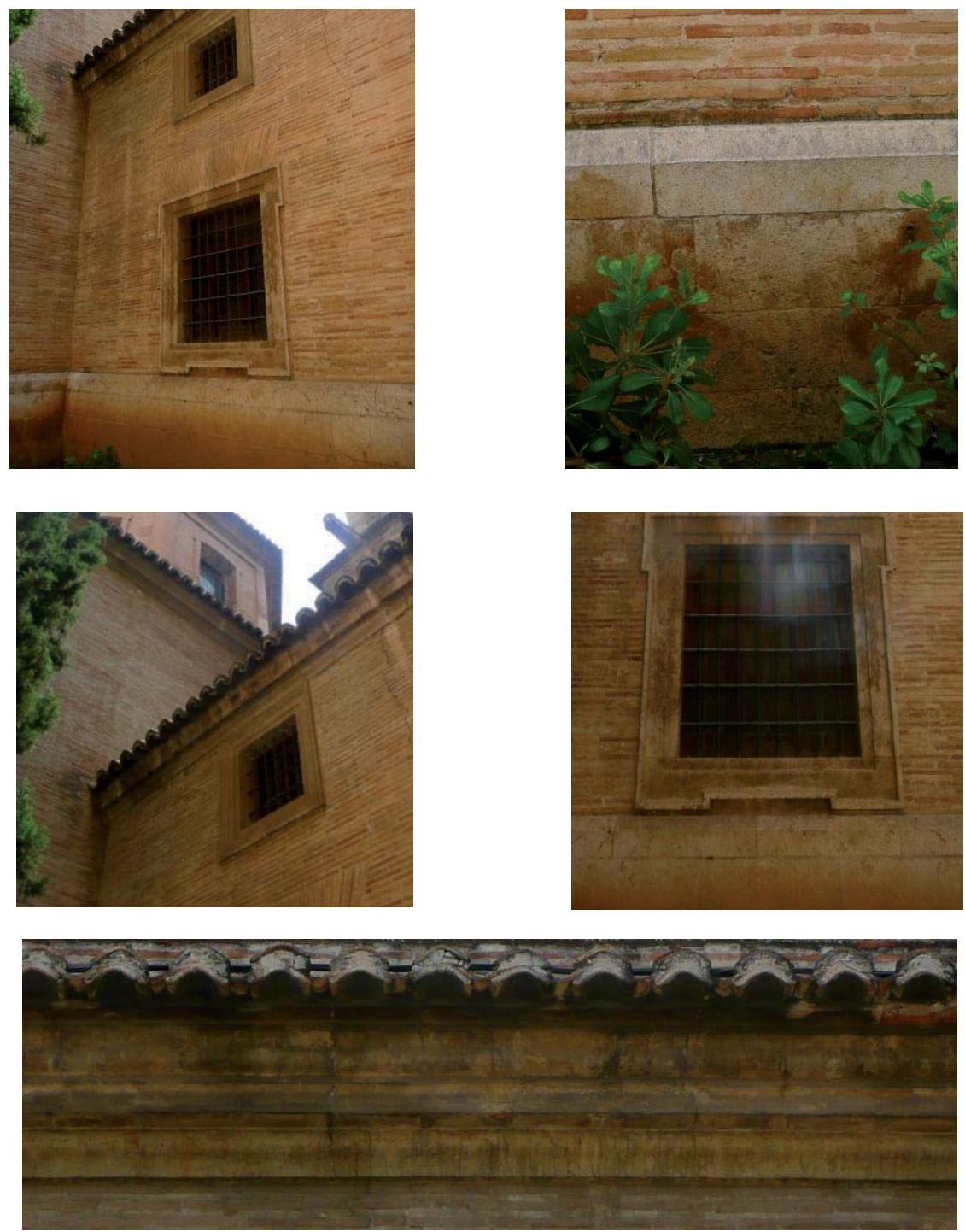
Datos generales

\section{Xd65}

\begin{tabular}{|c|c|c|c|c|}
\hline Barrio & Carmen & La Seu-Xerea & Velluters & S.Francesc \\
\hline Dirección & \multicolumn{4}{|c|}{ Pza. Decimo Julio Bruto s/n } \\
\hline Tipo de edificio & residencial & palaciego & religioso & militar \\
\hline $\mathbf{G}^{\circ}$ de protección & 0 & 1 & 2 & 3 \\
\hline Fechas claves & \multicolumn{4}{|c|}{1653 (Martinez Ponce de Urrana)restauración 2005-2010 ( Bosch) } \\
\hline
\end{tabular}

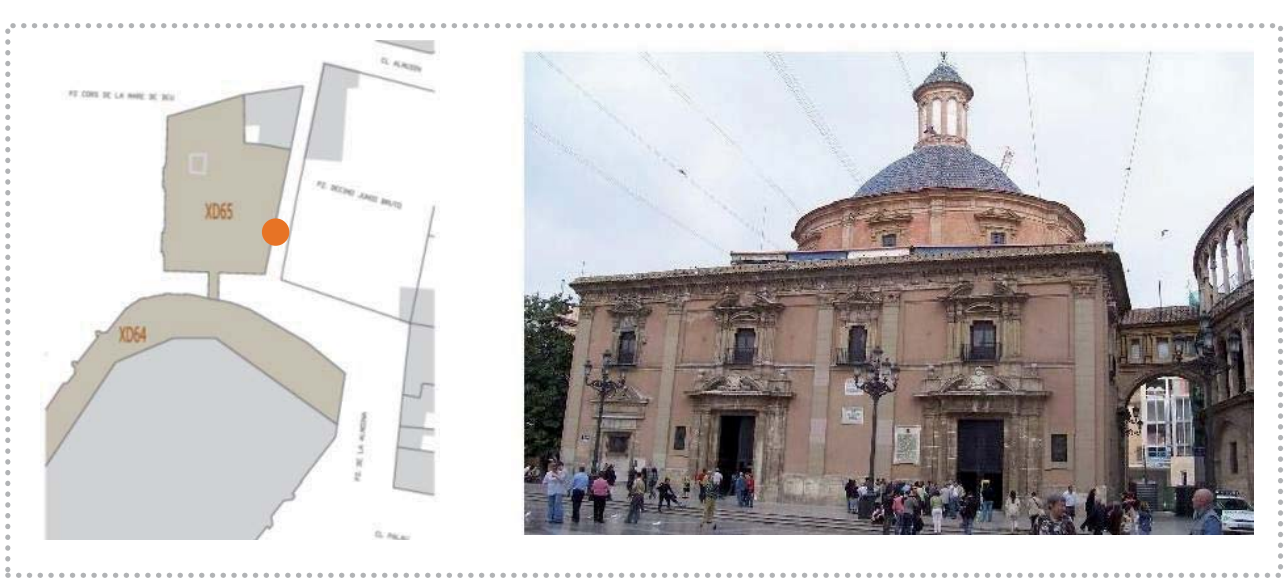

Fachada

Xd65

Pisos
Composición fachada
Zócalo
Fábrica
Vano/dintel
Entrada/dintel
Alero
Cubierta

\begin{tabular}{|c|c|c|c|c|c|c|c|c|c|}
\hline \multirow{2}{*}{\multicolumn{2}{|c|}{$\begin{array}{l}\mathrm{N}^{\circ} 2 \\
\text { aleatoria }\end{array}$}} & sótano & & planta & \multicolumn{5}{|c|}{ piso noble caja escalera } \\
\hline & & \multicolumn{3}{|c|}{ ordenada sin simetría } & \multicolumn{5}{|c|}{ ordenada con simetría } \\
\hline Z1 & $\mathrm{Z} 2$ & Z3 & Z4 & $\mathrm{Z} 5$ & & & & & \\
\hline F1 & F2 & F3 & F4 & F5 & F6 & F7 & & & \\
\hline V1 & V2 & V3 & V4 & V5 & V6 & V7 & V8 & V9 & V10 \\
\hline E1 & E2 & E3 & E4 & & & & & & \\
\hline A1 & A2 & A3 & A4 & A5 & A6 & A7 & & & \\
\hline \multicolumn{2}{|c|}{ plana } & \multicolumn{3}{|l|}{ inc } & & & & & \\
\hline
\end{tabular}

\section{Fábrica}

Xd65

Aparejo
Hiladas
Superficie
Sección (hipótesis)
Elementos destacados

\begin{tabular}{|lll}
\hline soga-tizón & soga & \\
\hline irregulares & pseudo horizontales & horizontales \\
\hline sin planeidad & pseudo planeidad & planeidad perfecta \\
\hline uniforme & hojas y núcleo & abocinada (vano) \\
\hline aplantillado & cortado terracota & \\
\hline
\end{tabular}




\section{Xd65}

\begin{tabular}{l|lll}
$\begin{array}{l}\text { No elementos medidos } \\
\text { Longitud }(\mathbf{c m})\end{array}$ & 15 & & \\
Anchura $(\mathbf{c m})$ & 30.5 & & \\
Espesor $(\mathbf{c m})$ & 14 & & \\
Volumen $\left(\mathbf{c m}^{3}\right)$ & 4 & heterogéneo & re-empleo \\
Tipo & 1708 & heterogéneo globular & heterogéneo marmolado \\
Color & homogéneo & sínogéneo & código Xd $65 / 1$ \\
Recogida de muestra & no & micro fisuración & grietas \\
Patologías & eflorescencias & disgregación & descamación
\end{tabular}

${ }^{1}$ Datos obtenidos en base al cálculo del desvío estándar (respecto al valor medio de la muestras analizadas) y del gráfico de frecuencia de las muestras analizadas, identificado por una curva gaussiana

\section{untas}

$X d 65$

\begin{tabular}{|c|c|c|c|c|}
\hline \multirow{2}{*}{$\begin{array}{l}N^{\circ} \text { elementos medidos } \\
\text { Llaga }(\mathrm{cm})\end{array}$} & \multicolumn{4}{|l|}{15} \\
\hline & \multicolumn{4}{|l|}{0.5} \\
\hline Tendel (cm) & \multicolumn{4}{|l|}{2.8} \\
\hline Altura de 5 hiladas $(\mathrm{cm})$ & \multicolumn{4}{|l|}{33.4} \\
\hline Proporción ladrillo/junta & \multicolumn{4}{|l|}{1.4} \\
\hline Tipo de acabado & simple & doble & \multicolumn{2}{|l|}{ múltiple } \\
\hline Junta de asiento & $\begin{array}{l}\text { rehundida } \\
\text { enrasada }\end{array}$ & $\begin{array}{l}\text { a hueso } \\
\text { matada }\end{array}$ & \multicolumn{2}{|l|}{ saliente } \\
\hline Junta de acabado & $\begin{array}{l}\text { rehundida } \\
\text { enrasada }\end{array}$ & $\begin{array}{l}\text { a hueso } \\
\text { matada }\end{array}$ & \multicolumn{2}{|l|}{ saliente } \\
\hline \multirow{3}{*}{$\begin{array}{l}\text { Tipo de mortero } \\
\text { Morfología de mortero } \\
\text { Tipo de árido }\end{array}$} & cal & cal y tierra & tierra & cemento mixto \\
\hline & con grumos & con caliches & homogéneo & heterogéneo \\
\hline & arena & gravilla & grava & mixto \\
\hline Color del árido & claro & oscuro & homogéneo & heterogéneo \\
\hline Recogida de muestra & no & sí & \multicolumn{2}{|l|}{ Código Xd65/2 } \\
\hline Patologías & $\begin{array}{l}\text { eflorescencias } \\
\text { erosión }\end{array}$ & $\begin{array}{l}\text { micro fisuración } \\
\text { disgregación }\end{array}$ & \multicolumn{2}{|l|}{$\begin{array}{l}\text { grietas } \\
\text { pulverización }\end{array}$} \\
\hline
\end{tabular}


Imágenes

Xd65
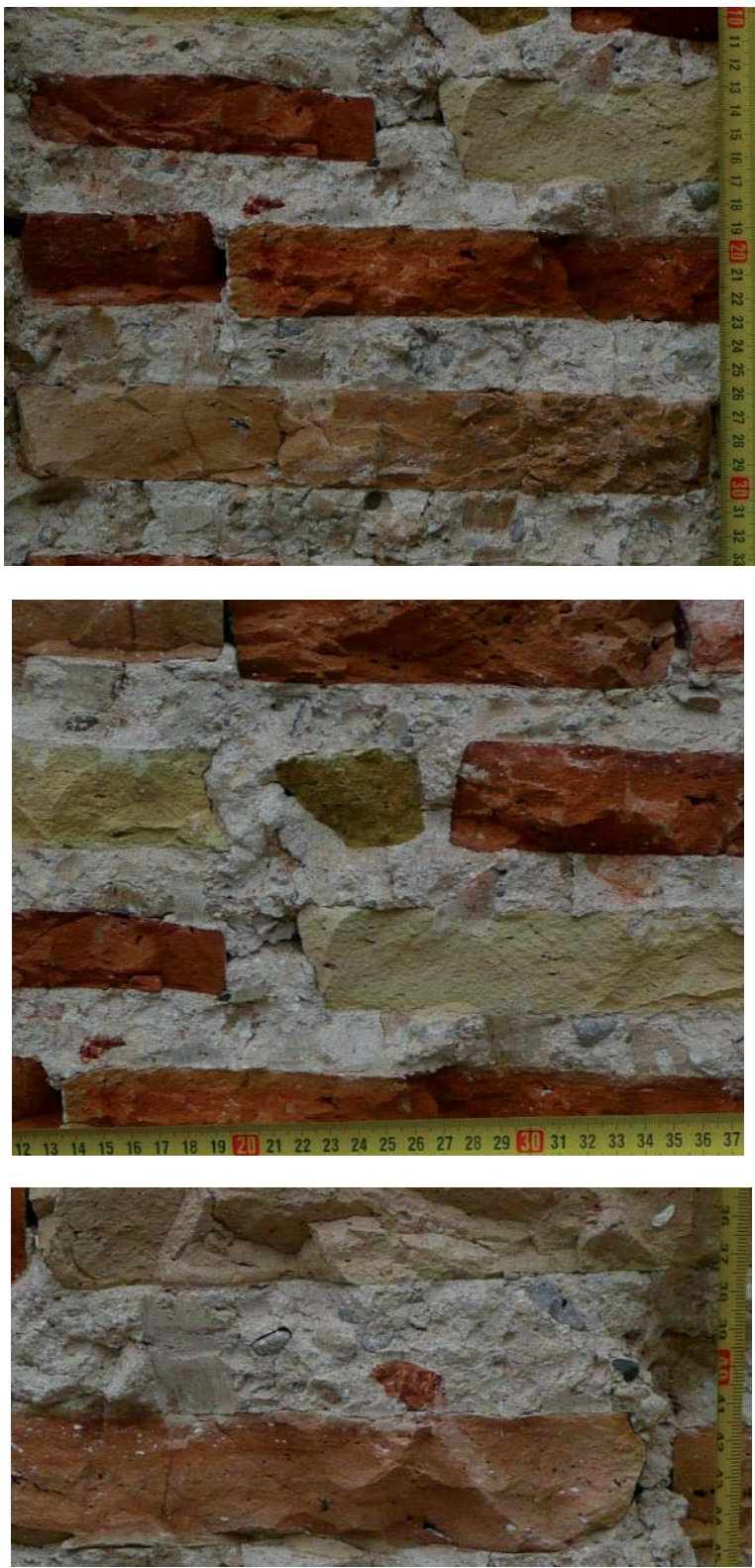

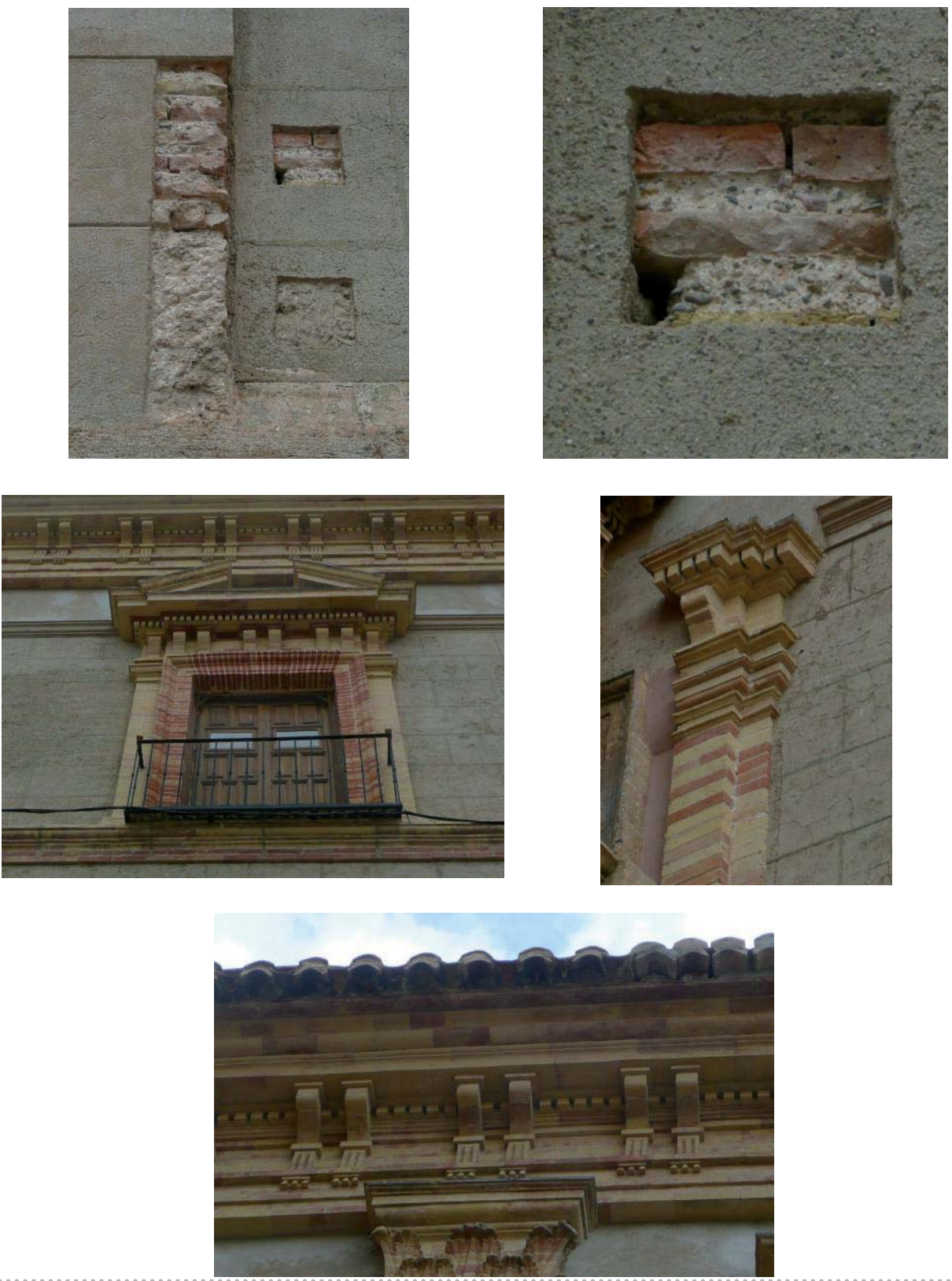
Datos generales

\begin{tabular}{|c|c|c|c|c|c|}
\hline \multirow{2}{*}{$\begin{array}{l}\text { Barrio } \\
\text { Dirección }\end{array}$} & Carmen & La Seu-Xerea & Velluters & Mercat & S.Francesc \\
\hline & \multicolumn{5}{|c|}{ C/Avellanas n5 } \\
\hline Tipo de edificio & residencial & palaciego & religioso & militar & \\
\hline $\mathbf{G}^{\circ}$ de protección & 0 & 1 & 2 & 3 & \\
\hline Fechas claves & / & & & & \\
\hline
\end{tabular}

El apartado "fechas claves" se ha extraído de AA.V. ., Guía de Arquitectura de Valencia, Icaro CTAV Ed., Valencia, 2007

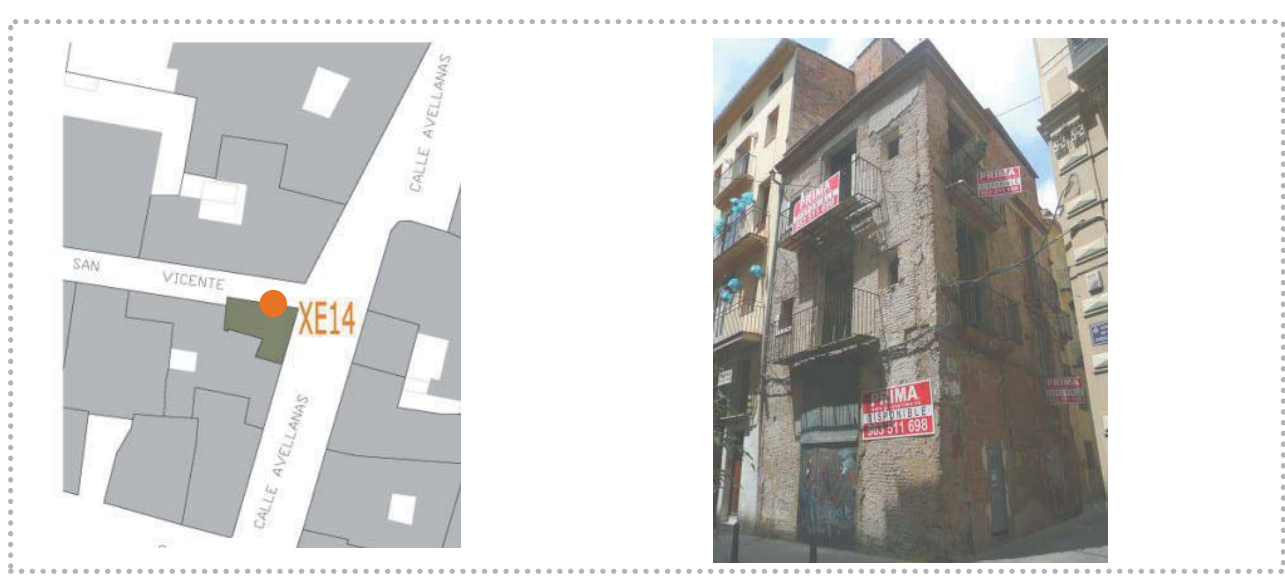

Fachada

Xe14

\begin{tabular}{|c|c|c|c|c|c|c|c|c|c|}
\hline \multirow{3}{*}{$\begin{array}{l}\text { Pisos } \\
\text { Composición fachada } \\
\text { Zócalo }\end{array}$} & \multicolumn{2}{|c|}{$N^{\circ} 3$} & sótano & \multicolumn{2}{|c|}{ entreplanta } & \multicolumn{4}{|c|}{ piso noble caja escalera } \\
\hline & \multicolumn{2}{|c|}{ aleatoria } & \multicolumn{3}{|c|}{ ordenada sin simetría } & \multicolumn{4}{|c|}{ ordenada con simetría } \\
\hline & $\mathrm{Z1}$ & $\mathrm{Z} 2$ & Z3 & Z4 & Z5 & & & & \\
\hline Fábrica & $\mathrm{F} 1$ & $\mathrm{~F} 2$ & F3 & F4 & F5 & F6 & & & \\
\hline Vano/dintel & V1 & V2 & V3 & V4 & V5 & V7 & V8 & V9 & V10 \\
\hline Entrada/dintel & E1 & E2 & E3 & E4 & & & & & \\
\hline Alero & A1 & $\mathrm{A} 2$ & $\mathrm{~A} 3$ & A4 & A5 & A7 & & & \\
\hline Cubierta & plar & & inclinac & & & & & & \\
\hline
\end{tabular}

Ver tablas relativas a los códigos indicados, al final de la recopilación de las fichas

Fábrica

Xe14

\begin{tabular}{l|lll}
\hline Aparejo & soga-tizón & soga & \multicolumn{2}{c}{ tizón } & \\
\hline Hiladas & irregulares & pseudo horizontales & horizontales \\
\hline Superficie & sin planeidad & pseudo planeidad & planeidad perfecta \\
\hline $\begin{array}{l}\text { Sección (hipótesis) } \\
\text { Elementos destacados }\end{array}$ & uniforme & hojas y núcleo & abocinada (vano) \\
\hline
\end{tabular}




\begin{tabular}{|c|c|c|c|}
\hline$N^{\circ}$ elementos medidos & 15 & & \\
\hline Longitud (cm) & 28 & & \\
\hline Anchura (cm) & 14.2 & & \\
\hline Espesor (cm) & 3.6 & & \\
\hline Volumen $\left(\mathrm{cm}^{3}\right)$ & 1431.36 & & \\
\hline Tipo & homogéneo & heterogéneo & re-empleo \\
\hline Color & homogéneo & heterogéneo globular & heterogéneo marmolado \\
\hline Recogida de muestra & no & sí & código Xe 14/1 \\
\hline Patologías & $\begin{array}{l}\text { eflorescencias } \\
\text { erosión }\end{array}$ & $\begin{array}{l}\text { micro fisuración } \\
\text { disgregación }\end{array}$ & $\begin{array}{l}\text { grietas } \\
\text { descamación }\end{array}$ \\
\hline
\end{tabular}

${ }^{1}$ Datos obtenidos en base al cálculo del desvío estándar (respecto al valor medio de la muestras analizadas) y del gráfico de frecuencia de las muestras analizadas, identificado por una curva gaussiana

\section{untas}

\begin{tabular}{|c|c|c|c|c|}
\hline \multirow{2}{*}{$\begin{array}{l}N^{\circ} \text { elementos medidos } \\
\text { Llaga }(\mathrm{cm})\end{array}$} & \multicolumn{4}{|l|}{15} \\
\hline & \multicolumn{4}{|l|}{0.7} \\
\hline Tendel (cm) & \multicolumn{4}{|l|}{3.5} \\
\hline Altura de 5 hiladas $(\mathrm{cm})$ & \multicolumn{4}{|l|}{35.5} \\
\hline Proporción ladrillo/junta & \multicolumn{4}{|l|}{1.02} \\
\hline Tipo de acabado & simple & doble & \multicolumn{2}{|l|}{ múltiple } \\
\hline \multirow[t]{2}{*}{ Junta de asiento } & rehundida & a hueso & \multirow{2}{*}{\multicolumn{2}{|c|}{ saliente }} \\
\hline & enrasada & matada & & \\
\hline \multirow[t]{2}{*}{ Junta de acabado } & rehundida & a hueso & \multirow{2}{*}{\multicolumn{2}{|c|}{ saliente }} \\
\hline & enrasada & matada & & \\
\hline \multirow{3}{*}{$\begin{array}{l}\text { Tipo de mortero } \\
\text { Morfología de mortero } \\
\text { Tipo de árido }\end{array}$} & $\mathrm{cal}$ & cal y tierra & tierra & cemento mixto \\
\hline & con grumos & con caliches & homogéneo & heterogéneo \\
\hline & arena & gravilla & grava & mixto \\
\hline \multirow{4}{*}{$\begin{array}{l}\text { Color del árido } \\
\text { Recogida de muestra } \\
\text { Patologías }\end{array}$} & claro & oscuro & homogéneo & heterogéneo \\
\hline & no & sí & \multicolumn{2}{|l|}{ código Xe14/2 } \\
\hline & eflorescencias & micro fisuración & \multicolumn{2}{|l|}{ grietas } \\
\hline & erosión & disgregación & \multicolumn{2}{|l|}{ pulverización } \\
\hline
\end{tabular}


Imágenes
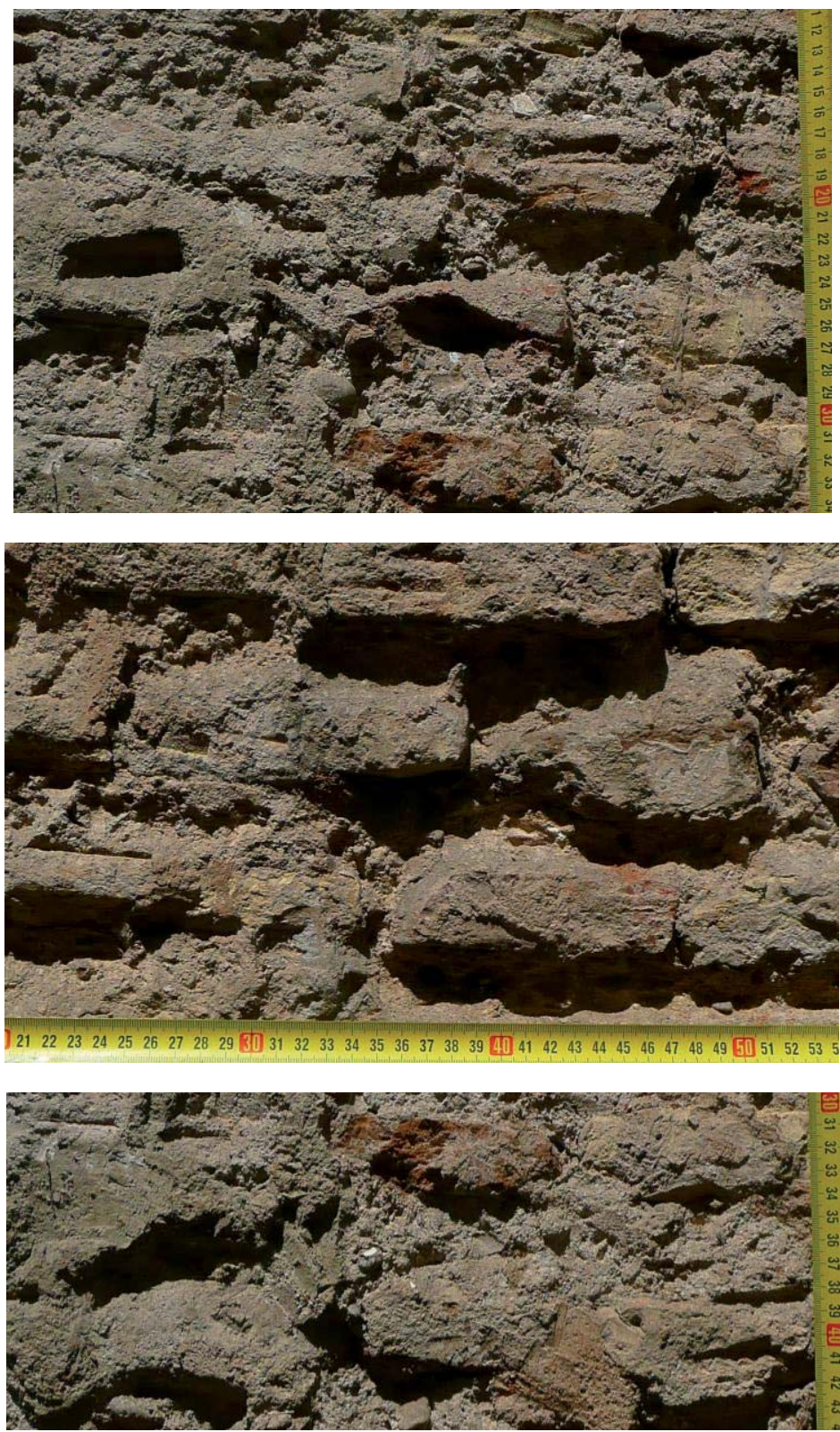
Imágenes

Xe14
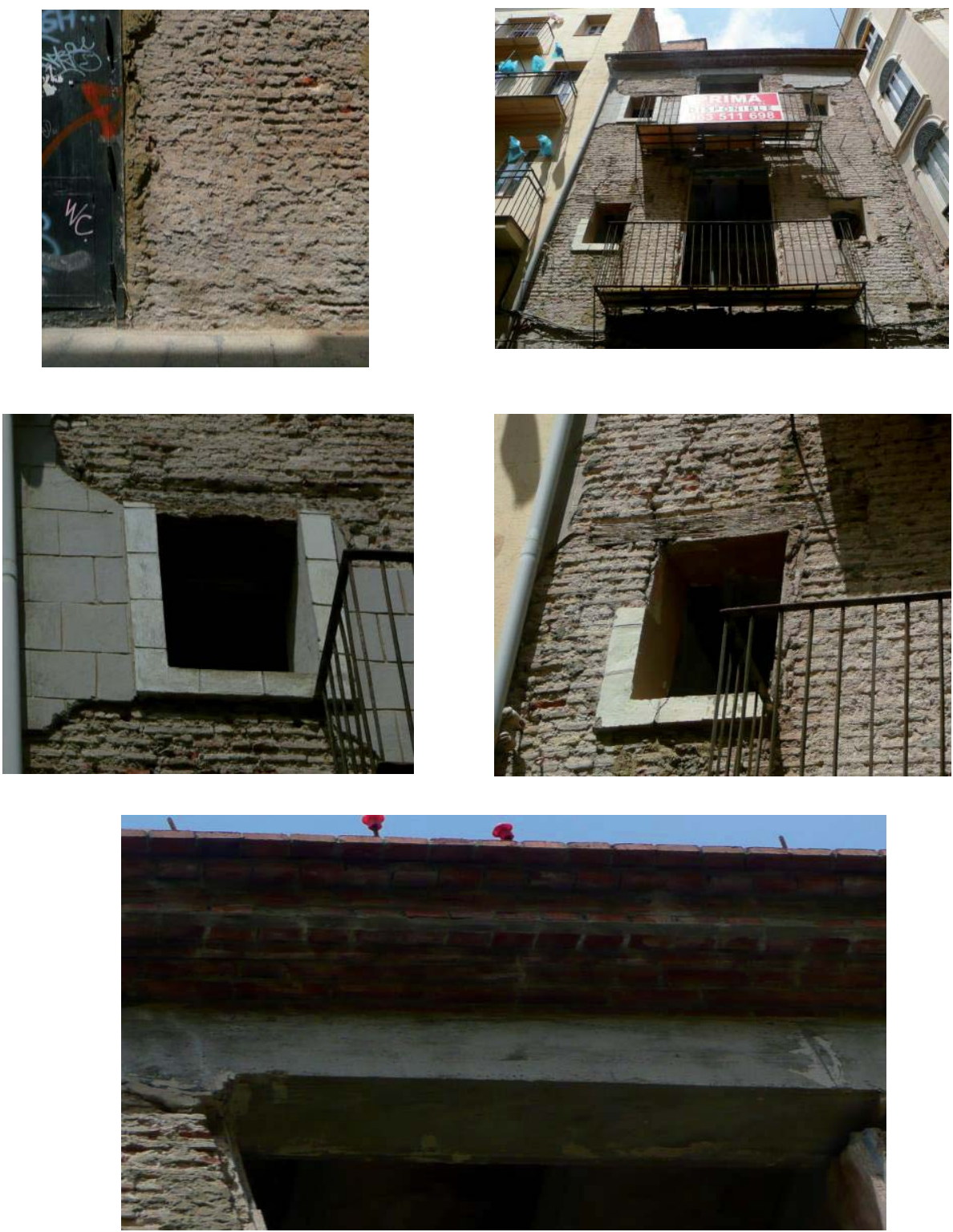
Datos generales

Xe66

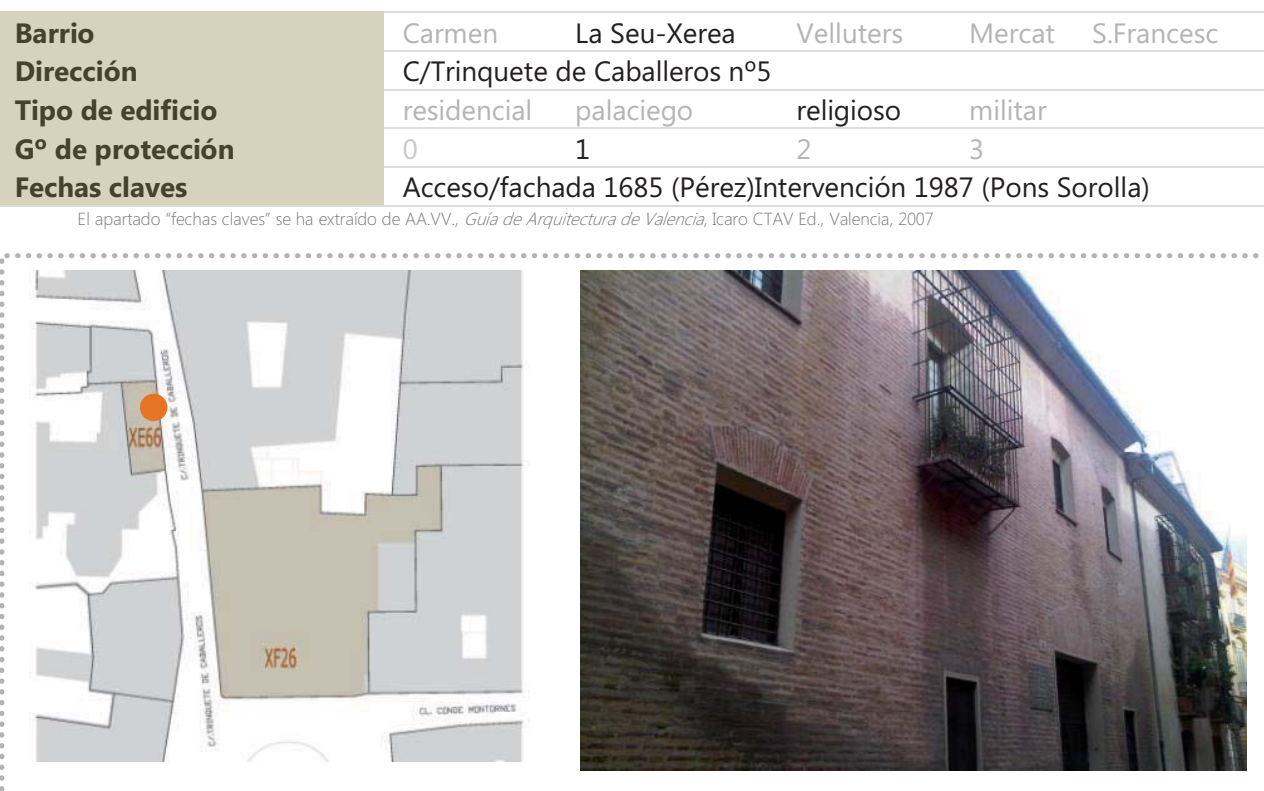

Fachada

Xe66

Pisos
Composición fachada
Zócalo
Fábrica
Vano/dintel
Entrada/dintel
Alero
Cubierta

\begin{tabular}{|c|c|c|c|c|c|c|c|c|c|}
\hline \multirow{2}{*}{\multicolumn{2}{|c|}{$\begin{array}{l}\mathrm{N}^{0} 2 \\
\text { aleatoria }\end{array}$}} & \multirow{2}{*}{\multicolumn{3}{|c|}{$\begin{array}{l}\text { sótano entreplanta } \\
\text { ordenada sin simetría }\end{array}$}} & \multicolumn{5}{|c|}{ piso noble caja escalera } \\
\hline & & & & & \multicolumn{5}{|c|}{ ordenada con simetría } \\
\hline Z1 & $\mathrm{Z2}$ & $\mathrm{Z3}$ & Z4 & $\mathrm{Z5}$ & & & & & \\
\hline F1 & F2 & F3 & F4 & F5 & F6 & F7 & & & \\
\hline V1 & V2 & V3 & V4 & V5 & V6 & V7 & V8 & V9 & V10 \\
\hline E1 & E2 & E3 & E4 & & & & & & \\
\hline A1 & $\mathrm{A} 2$ & $\mathrm{~A} 3$ & A4 & A5 & A6 & A7 & & & \\
\hline \multicolumn{2}{|c|}{ plana } & \multicolumn{3}{|c|}{ inclinada } & & & & & \\
\hline
\end{tabular}

\section{Fábrica}

Xe66

\section{Aparejo \\ Hiladas \\ Superficie \\ Sección (hipótesis) \\ Elementos destacados}

\begin{tabular}{lll} 
soga-tizón & soga & \multicolumn{1}{c}{ tizón } \\
irregulares & pseudo horizontales & horizontales \\
\hline sin planeidad & pseudo planeidad & planeidad perfecta \\
\hline uniforme & hojas y núcleo & abocinada (vano) \\
aplantillado & cortado terracota & \\
\hline
\end{tabular}




$N^{\circ}$ elementos medidos
Longitud $(\mathrm{cm})$
Anchura $(\mathrm{cm})$
Espesor $(\mathrm{cm})$
1370.5

Tipo

Color

Recogida de muestra

Patologías

\section{5}

30.2

14.4

3.8

1625.5

homogéneo heterogéneo re-empleo

homogéneo heterogéneo globular heterogéneo marmolado

no sí código

eflorescencias micro fisuración grietas

erosión disgregación descamación

1 Datos obtenidos en base al cálculo del desvío estándar (respecto al valor medio de la muestras analizadas) y del gráfico de frecuencia de las muestras analizadas, identificado por una curva gaussiana

\section{Juntas}

Xe66

\begin{tabular}{|c|c|c|c|c|}
\hline \multirow{2}{*}{$\begin{array}{l}N^{\circ} \text { elementos medidos } \\
\text { Llaga }(\mathrm{cm})\end{array}$} & \multicolumn{4}{|l|}{15} \\
\hline & \multicolumn{4}{|l|}{0.9} \\
\hline \multirow{4}{*}{$\begin{array}{l}\text { Tendel (cm) } \\
\text { Altura de } 5 \text { hiladas (cm) } \\
\text { Proporción ladrillo/junta } \\
\text { Tipo de acabado }\end{array}$} & \multicolumn{4}{|l|}{4} \\
\hline & \multicolumn{4}{|l|}{39} \\
\hline & \multicolumn{4}{|l|}{0.9} \\
\hline & simple & doble & múltiple & \\
\hline \multirow[t]{2}{*}{ Junta de asiento } & rehundida & a hueso & saliente & \\
\hline & enrasada & matada & & \\
\hline \multirow{2}{*}{ Junta de acabado } & rehundida & a hueso & saliente & \\
\hline & enrasada & matada & & \\
\hline \multirow{2}{*}{$\begin{array}{l}\text { Tipo de mortero } \\
\text { Morfología de mortero }\end{array}$} & cal & cal y tierra & tierra & cemento mixto \\
\hline & con grumos & con caliches & homogéneo & heterogéneo \\
\hline \multirow{5}{*}{$\begin{array}{l}\text { Tipo de árido } \\
\text { Color del árido } \\
\text { Recogida de muestra } \\
\text { Patologías }\end{array}$} & arena & gravilla & grava & mixto \\
\hline & claro & oscuro & homogéneo & heterogéneo \\
\hline & no & si & código & \\
\hline & eflorescencias & micro fisuración & grietas & \\
\hline & erosión" & disgregación & pulverización & \\
\hline
\end{tabular}


Imágenes

Xe66
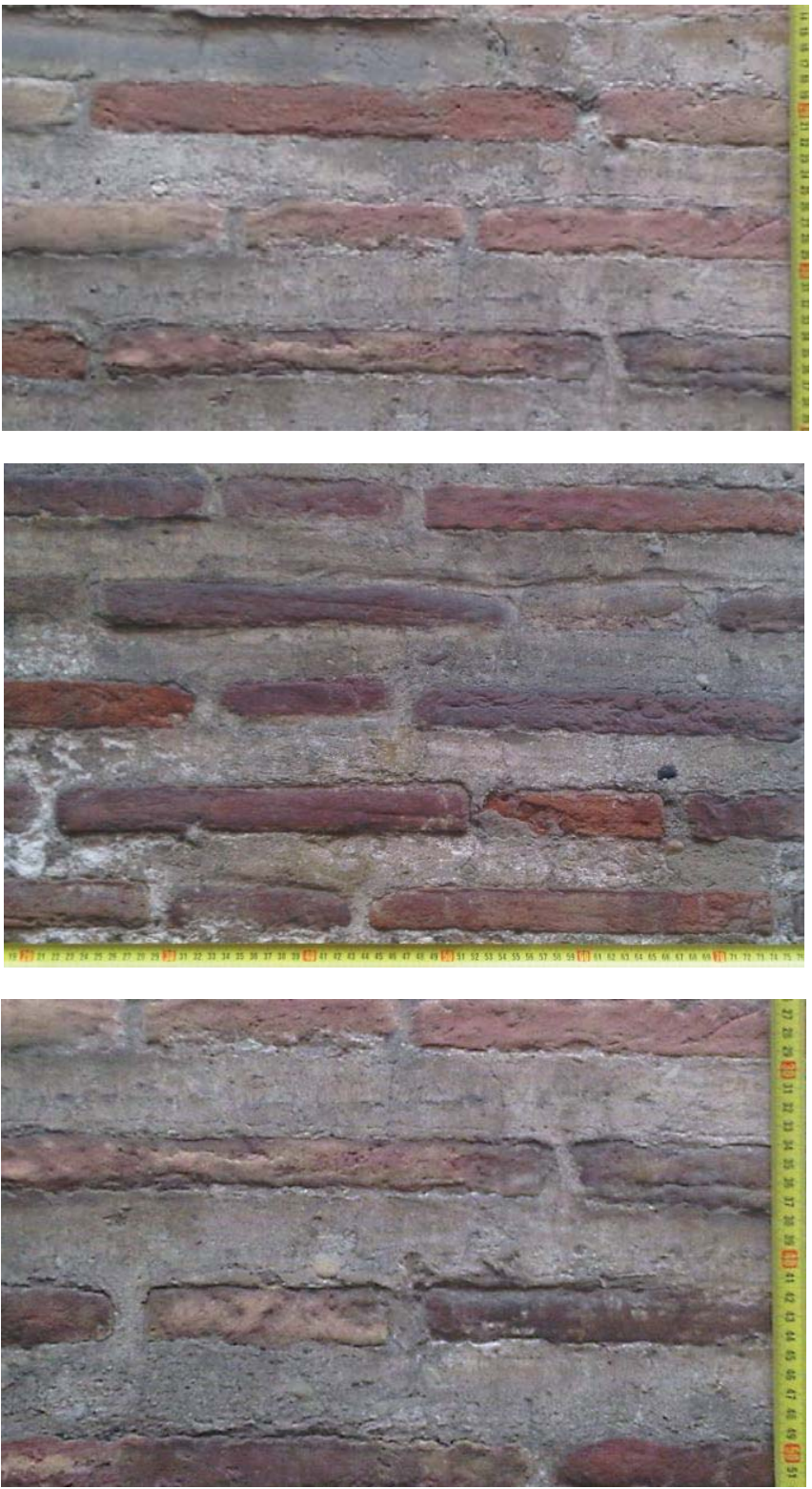

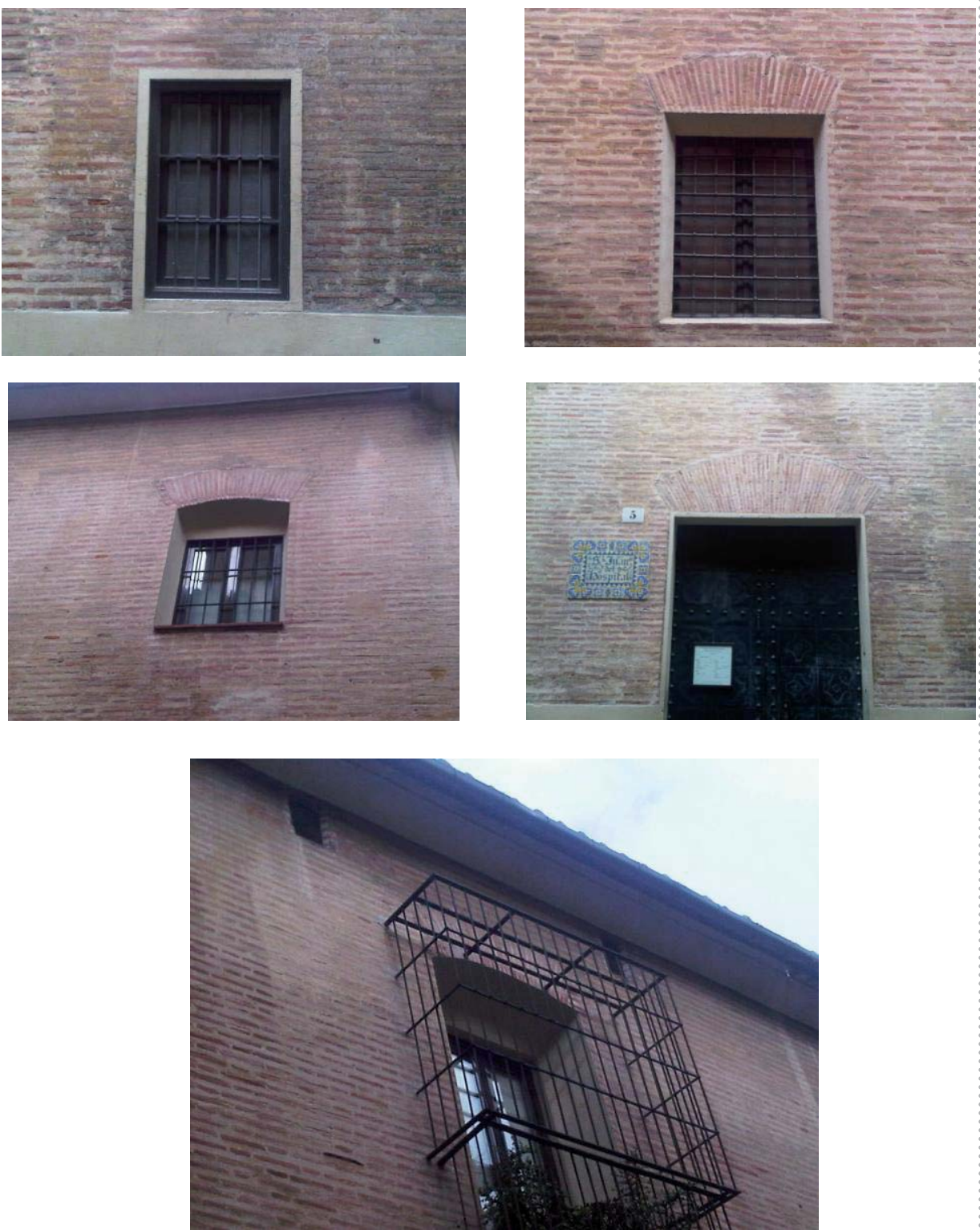
Datos generales

\begin{tabular}{|c|c|c|c|c|c|}
\hline Barrio & Carmen & La Seu-Xerea & Velluters & Mercat & S.Francesc \\
\hline Dirección & C/Mestres I & $2 / 4$ & & & \\
\hline Tipo de edificio & residencial & palaciego & religioso & militar & \\
\hline $\mathbf{G}^{\circ}$ de protección & 0 & 1 & 2 & 3 & \\
\hline Fechas claves & $1761-70$ & andéz) & & & \\
\hline
\end{tabular}
El apartado "fechas claves" se ha extraído de AA.V.., Guía de Arquitectura de Valencia, Icaro CTAV Ed., Valencia, 2007.

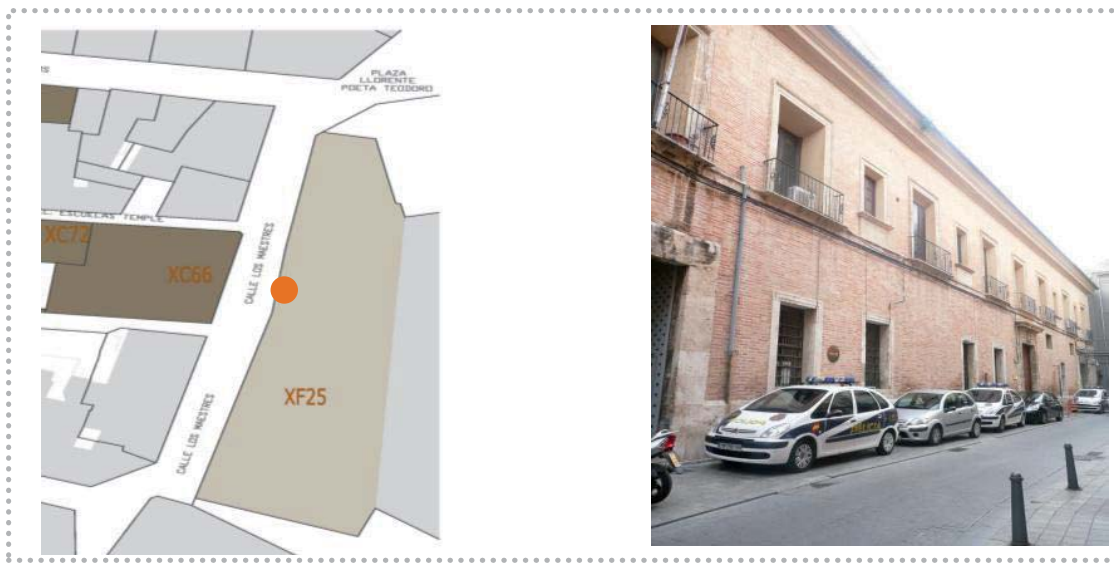

Fachada

$\mathrm{xf25}$

\begin{tabular}{|c|c|c|c|c|c|c|c|c|c|c|}
\hline \multirow{3}{*}{$\begin{array}{l}\text { Pisos } \\
\text { Composición fachada } \\
\text { Zócalo }\end{array}$} & \multicolumn{2}{|c|}{$N^{\circ} 2$} & sótano & \multicolumn{2}{|c|}{ entreplanta } & \multicolumn{5}{|c|}{ piso noble caja escalera } \\
\hline & \multicolumn{2}{|c|}{ aleatoria } & \multicolumn{3}{|c|}{ ordenada sin simetría } & \multicolumn{5}{|c|}{ ordenada con simetría } \\
\hline & $\mathrm{Z1}$ & $\mathrm{Z2}$ & Z3 & Z4 & Z5 & & & & & \\
\hline Fábrica & $\mathrm{F} 1$ & $\mathrm{~F} 2$ & F3 & $\mathrm{F} 4$ & F5 & F6 & F7 & & & \\
\hline Vano/dintel & V1 & V2 & V3 & V4 & V5 & V6 & V7 & V8 & V9 & V10 \\
\hline Entrada/dintel & E1 & E2 & E3 & E4 & & & & & & \\
\hline Alero & A1 & $\mathrm{A} 2$ & A3 & A4 & A5 & A6 & A7 & & & \\
\hline Cubierta & plar & & inclinac & & & & & & & \\
\hline
\end{tabular}

Fábrica

$\mathrm{Xf25}$

\section{Aparejo \\ Hiladas \\ Superficie \\ Sección (hipótesis) \\ Elementos destacados}

\begin{tabular}{lll} 
soga-tizón & soga & \multicolumn{1}{c}{ tizón } \\
irregulares & pseudo horizontales & horizontales \\
\hline sin planeidad & pseudo planeidad & planeidad perfecta \\
\hline uniforme & hojas y núcleo & abocinada (vano) \\
aplantillado & cortado terracota & \\
\hline
\end{tabular}




\section{$N^{\circ}$ elementos medidos}

Longitud $(\mathrm{cm})$

Anchura (cm)

Espesor $(\mathrm{cm})$

Volumen $\left(\mathrm{cm}^{3}\right)$

Tipo

Color

Recogida de muestra

Patologías

\section{5}

29.5

14.5

4

1711

homogéneo heterogéneo re-empleo

homogéneo heterogéneo globular heterogéneo marmolado

no sí código

eflorescencias micro fisuración grietas

erosión disgregación descamación

${ }^{1}$ Datos obtenidos en base al cálculo del desvío estándar (respecto al valor medio de la muestras analizadas) y del gráfico de frecuencia de las muestras analizadas, identificado por una curva gaussiana

\section{Juntas}

$X f 25$

\begin{tabular}{|c|c|c|c|c|}
\hline \multirow{2}{*}{$\begin{array}{l}N^{\circ} \text { elementos medidos } \\
\text { Llaga }(\mathrm{cm})\end{array}$} & \multicolumn{4}{|l|}{15} \\
\hline & \multicolumn{4}{|l|}{1.4} \\
\hline Tendel (cm) & \multicolumn{4}{|l|}{3.1} \\
\hline Altura de 5 hiladas $(\mathrm{cm})$ & \multicolumn{4}{|l|}{36.9} \\
\hline Proporción ladrillo/junta & \multicolumn{4}{|l|}{1.2} \\
\hline Tipo de acabado & simple & doble & múltiple & \\
\hline Junta de asiento & $\begin{array}{l}\text { rehundida } \\
\text { enrasada }\end{array}$ & $\begin{array}{l}\text { a hueso } \\
\text { matada }\end{array}$ & saliente & \\
\hline Junta de acabado & $\begin{array}{l}\text { rehundida } \\
\text { enrasada }\end{array}$ & $\begin{array}{l}\text { a hueso } \\
\text { matada }\end{array}$ & saliente & \\
\hline Tipo de mortero & cal & cal y tierra & tierra & cemento mixto \\
\hline Morfología de mortero & con grumos & con caliches & homogéneo & heterogéneo \\
\hline Tipo de árido & arena & gravilla & grava & mixto \\
\hline Color del árido & claro & oscuro & homogéneo & heterogéneo \\
\hline Recogida de muestra & no & sí & código & \\
\hline Patologías & $\begin{array}{l}\text { eflorescencias } \\
\text { erosión }\end{array}$ & $\begin{array}{l}\text { micro fisuración } \\
\text { disgregación }\end{array}$ & $\begin{array}{l}\text { grietas } \\
\text { pulverización }\end{array}$ & \\
\hline
\end{tabular}


Imágenes
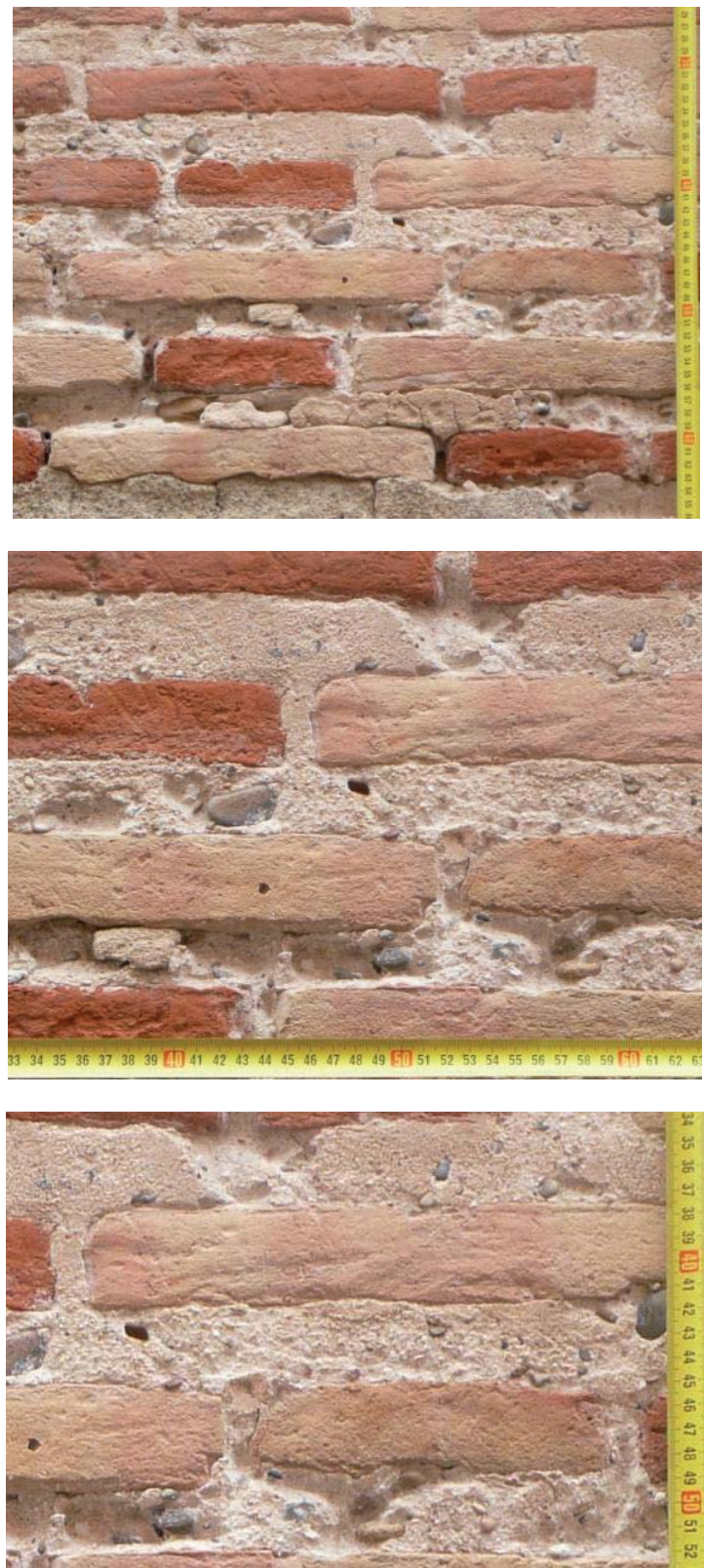
Imágenes

$X f 25$
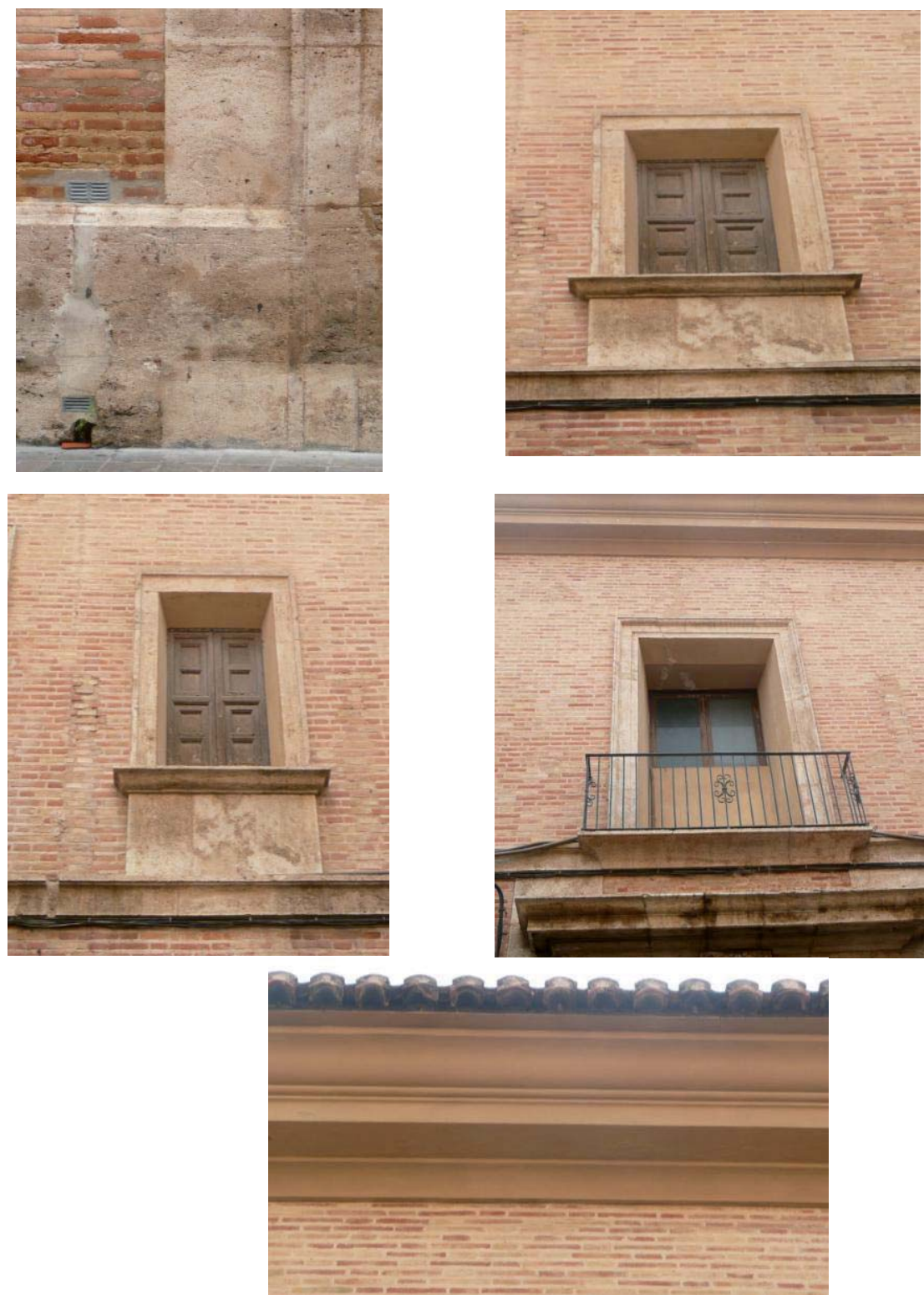
Datos generales

\begin{tabular}{|c|c|c|c|c|c|}
\hline Barrio & Carmen & La Seu-Xerea & Velluters & Mercat & S.Francesc \\
\hline Dirección & \multicolumn{5}{|c|}{ Pza. Congregación ; C/Trinquete de Caballeros s/n } \\
\hline Tipo de edificio & residencial & palaciego & religioso & militar & \\
\hline $\mathbf{G}^{\circ}$ de protección & 0 & 1 & 2 & 3 & \\
\hline Fechas claves & \multicolumn{5}{|c|}{ 1725-36 (Padre Tosca/Martí /Padilla) fachada '80 (Soler Verdú) } \\
\hline
\end{tabular}
El apartado "fechas claves" se ha extraído de AA.W., Guía de Arquitectura de Valencia, Icaro CTAV Ed., Valencia, 2007
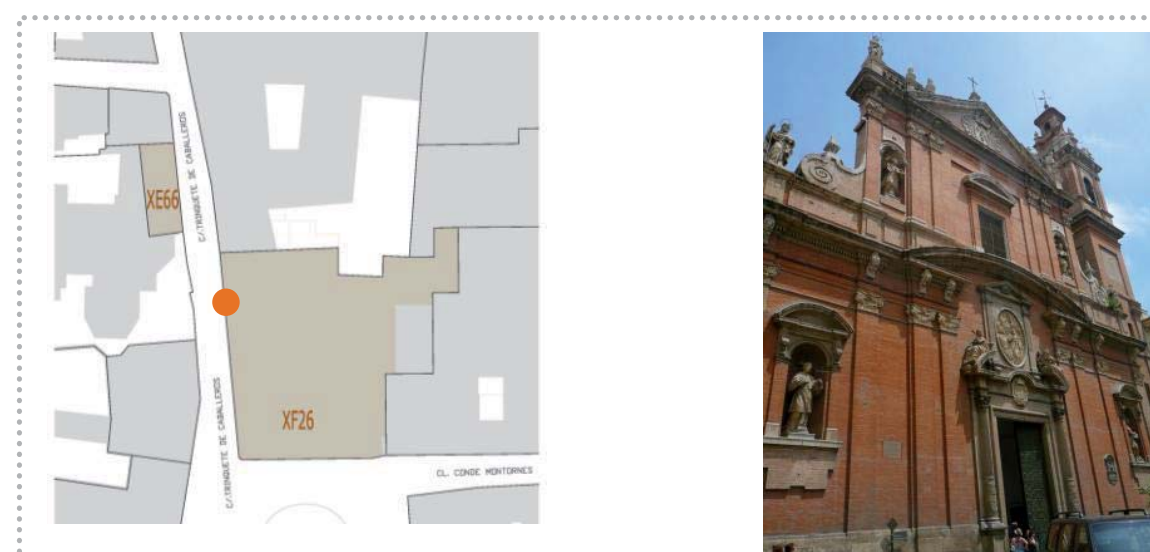

Fachada

$\mathrm{Xf26}$

Pisos

Composición fachada

Zócalo

Fábrica

Vano/dintel

Entrada/dintel

Alero

Cubierta

\begin{tabular}{|c|c|c|c|c|c|c|c|c|c|}
\hline \multirow{2}{*}{\multicolumn{2}{|c|}{$\begin{array}{l}\mathrm{N}^{\circ} 2 \\
\text { aleatoria }\end{array}$}} & sótano & & planta & \multicolumn{5}{|c|}{ piso noble caja escalera } \\
\hline & & \multicolumn{3}{|c|}{ ordenada sin simetría } & \multicolumn{5}{|c|}{ ordenada con simetría } \\
\hline $\mathrm{Z1}$ & $\mathrm{Z} 2$ & Z3 & Z4 & Z5 & & & & & \\
\hline $\mathrm{F} 1$ & F2 & F3 & F4 & F5 & F6 & F7 & & & \\
\hline V1 & V2 & V3 & V4 & V5 & V6 & V7 & V8 & V9 & V10 \\
\hline E1 & E2 & E3 & E4 & & & & & & \\
\hline A1 & A2 & $\mathrm{A} 3$ & A4 & A5 & A6 & A7 & & & \\
\hline \multicolumn{2}{|c|}{ plana } & \multicolumn{3}{|c|}{ inclinada } & & & & & \\
\hline
\end{tabular}

\section{Fábrica}

$X f 26$

\section{Aparejo \\ Hiladas \\ Superficie \\ Sección (hipótesis) \\ Elementos destacados}

\begin{tabular}{lll} 
soga-tizón & soga & \multicolumn{1}{c}{ tizón } \\
irregulares & pseudo horizontales & horizontales \\
\hline sin planeidad & pseudo planeidad & planeidad perfecta \\
\hline uniforme & hojas y núcleo & abocinada (vano) \\
aplantillado & cortado terracota & \\
\hline
\end{tabular}




\begin{tabular}{|c|c|c|c|}
\hline \multirow{2}{*}{$\begin{array}{l}\mathrm{N}^{\circ} \text { elementos medidos } \\
\text { Longitud }(\mathrm{cm})\end{array}$} & \multicolumn{3}{|l|}{15} \\
\hline & \multicolumn{3}{|l|}{30.5} \\
\hline Anchura (cm) & \multicolumn{3}{|l|}{14.5} \\
\hline Espesor (cm) & \multicolumn{3}{|l|}{4.1} \\
\hline Volumen $\left(\mathrm{cm}^{3}\right)$ & \multicolumn{3}{|l|}{1813.22} \\
\hline Tipo & homogéneo & heterogéneo & re-empleo \\
\hline \multirow{4}{*}{$\begin{array}{l}\text { Color } \\
\text { Recogida de muestra } \\
\text { Patologías }\end{array}$} & homogéneo & heterogéneo globular & heterogéneo marmolado \\
\hline & no & si & código \\
\hline & eflorescencias & micro fisuración & grietas \\
\hline & erosión & disgregación & descamación \\
\hline
\end{tabular}

1 Datos obtenidos en base al cálculo del desvío estándar (respecto al valor medio de la muestras analizadas) y del gráfico de frecuencia de las muestras analizadas, identificado por una curva gaussiana

\section{Juntas}

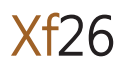

\begin{tabular}{|c|c|c|c|c|}
\hline \multirow{2}{*}{$\begin{array}{l}N^{\circ} \text { elementos medidos } \\
\text { Llaga }(\mathrm{cm})\end{array}$} & \multicolumn{4}{|l|}{15} \\
\hline & \multicolumn{4}{|l|}{1.2} \\
\hline Tendel (cm) & \multicolumn{4}{|l|}{3.8} \\
\hline Altura de 5 hiladas $(\mathrm{cm})$ & \multicolumn{4}{|l|}{40.5} \\
\hline Proporción ladrillo/junta & \multicolumn{4}{|l|}{1.7} \\
\hline Tipo de acabado & simple & doble & múltiple & \\
\hline Junta de asiento & $\begin{array}{l}\text { rehundida } \\
\text { enrasada }\end{array}$ & $\begin{array}{l}\text { a hueso } \\
\text { matada }\end{array}$ & saliente & \\
\hline Junta de acabado & $\begin{array}{l}\text { rehundida } \\
\text { enrasada }\end{array}$ & $\begin{array}{l}\text { a hueso } \\
\text { matada }\end{array}$ & saliente & \\
\hline Tipo de mortero & cal & cal y tierra & tierra & cemento mixto \\
\hline Morfología de mortero & con grumos & con caliches & homogéneo & heterogéneo \\
\hline Tipo de árido & arena & gravilla & grava & mixto \\
\hline Color del árido & claro & oscuro & homogéneo & heterogéneo \\
\hline Recogida de muestra & no & sí & código & \\
\hline Patologías & $\begin{array}{l}\text { eflorescencias } \\
\text { erosión }\end{array}$ & $\begin{array}{l}\text { micro fisuración } \\
\text { disgregación }\end{array}$ & $\begin{array}{l}\text { grietas } \\
\text { pulverización }\end{array}$ & \\
\hline
\end{tabular}


Imágenes
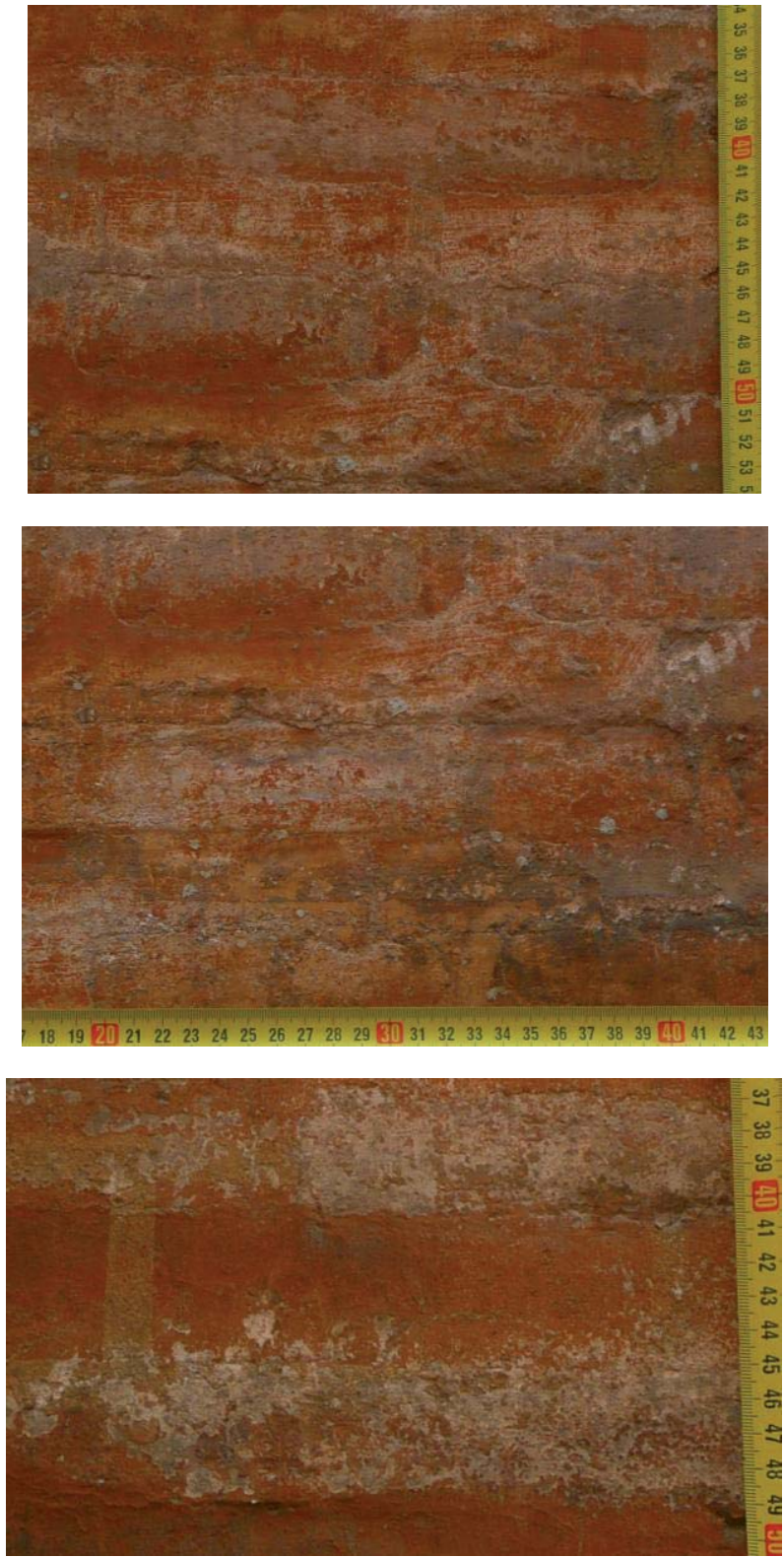

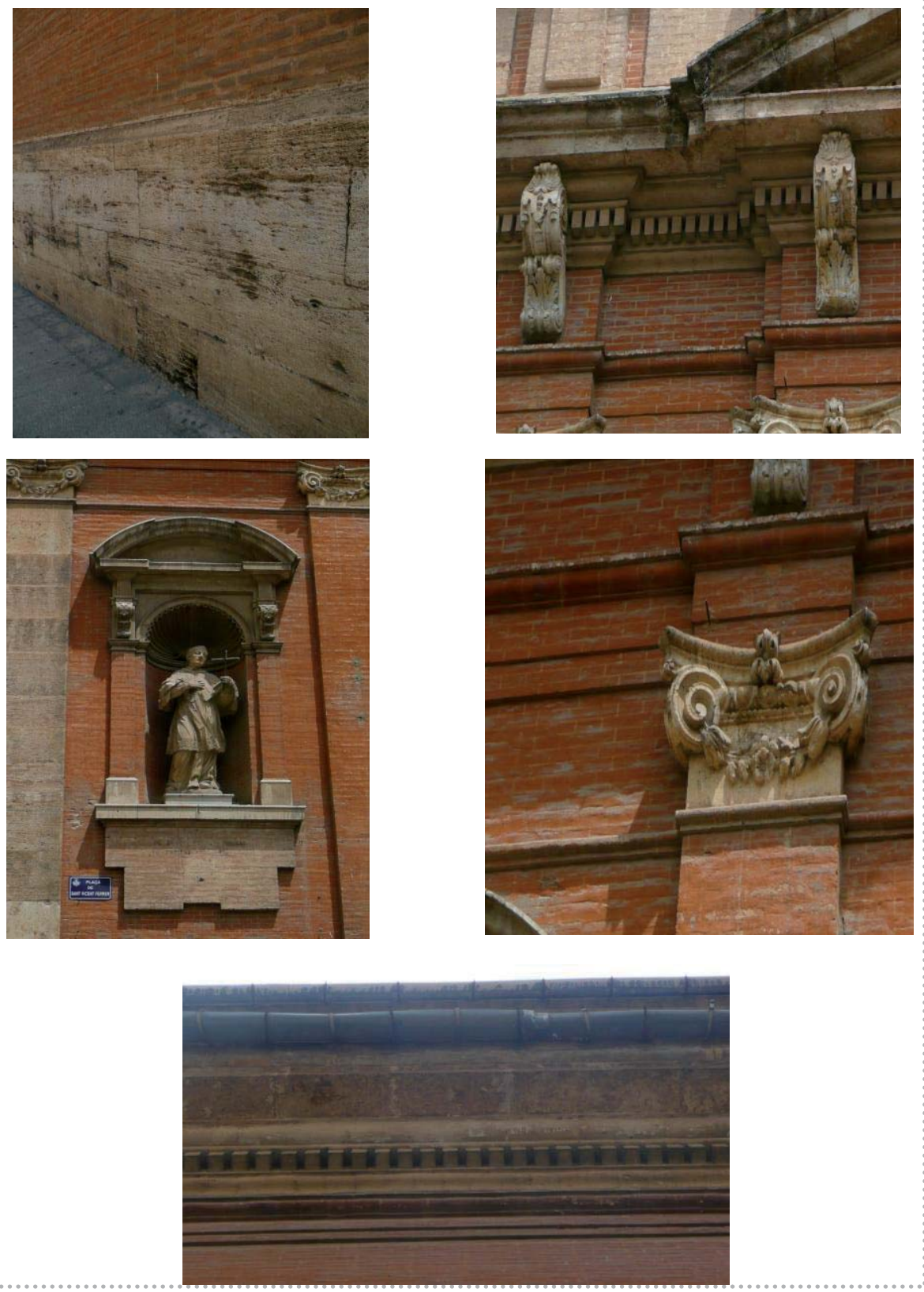


\begin{tabular}{|c|c|c|c|c|c|}
\hline Barrio & Carmen & La Seu-Xerea & Velluters & Mercat & S.Francesc \\
\hline Dirección & C/Engordo & 25 & & & \\
\hline Tipo de edificio & residencial & palaciego & religioso & militar & \\
\hline $\mathbf{G}^{\circ}$ de protección & 0 & 1 & 2 & 3 & \\
\hline Fechas claves & / & & & & \\
\hline
\end{tabular}
El apartado "fechas claves" se ha extraído de AA.V. ., Guía de Arquitectura de Valencia, Icaro CTAV Ed, Valencia, 2007

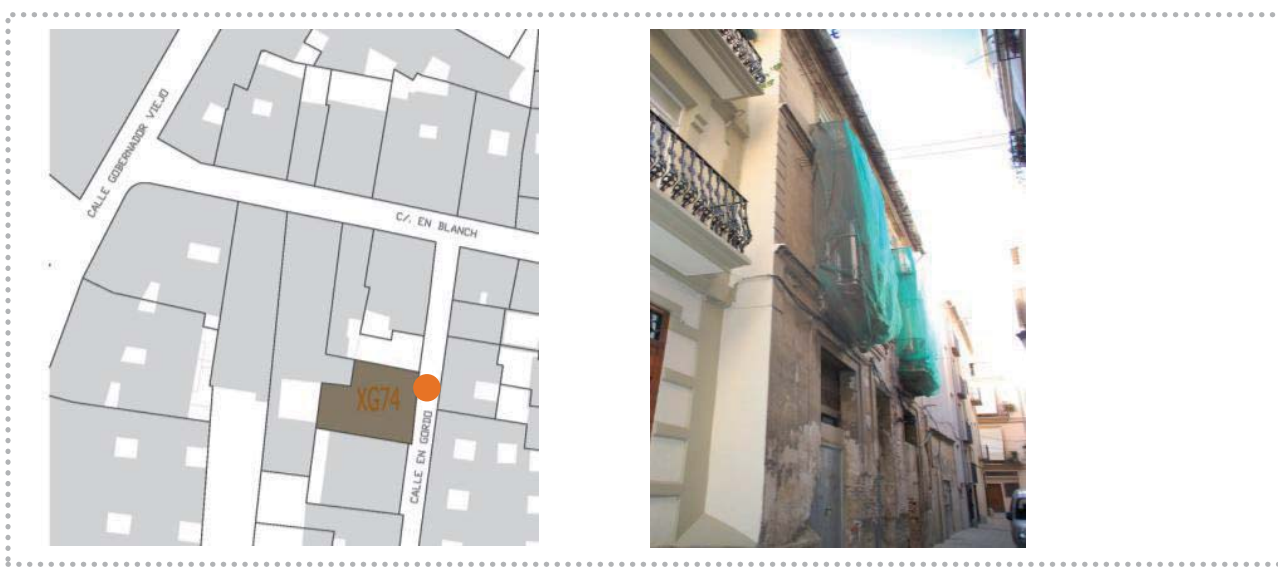

Fachada

Pisos

Composición fachada

Zócalo

Fábrica

Entrada/dintel

Alero

Cubierta
Vano/dintel

\begin{tabular}{|c|c|c|c|c|c|c|c|c|}
\hline \multicolumn{2}{|c|}{$\mathrm{N}^{0} 2$} & sótano & & planta & \multicolumn{4}{|c|}{ piso noble caja escalera } \\
\hline \multicolumn{2}{|c|}{ aleatoria } & \multicolumn{3}{|c|}{ ordenada sin simetría } & \multicolumn{4}{|c|}{ ordenada con simetría } \\
\hline Z1 & $\mathrm{Z} 2$ & $\mathrm{Z3}$ & Z4 & Z5 & & & & \\
\hline F1 & $\mathrm{F} 2$ & F3 & F4 & F5 & F7 & & & \\
\hline V1 & V2 & V3 & V4 & V5 & V6 & V8 & V9 & V10 \\
\hline E1 & E2 & E3 & E4 & & & & & \\
\hline A1 & $\mathrm{A} 2$ & A3 & A4 & A5 & A6 & & & \\
\hline
\end{tabular}

Xg74

\begin{tabular}{|c|c|c|c|}
\hline Aparejo & soga-tizón & tizón & \\
\hline Hiladas & irregulares & pseudo horizontales & horizontales \\
\hline Superficie & sin planeidad & pseudo planeidad & planeidad perfecta \\
\hline Sección (hipótesis) & uniforme & hojas y núcleo & abocinada (vano) \\
\hline Elementos destacados & aplantillado & terracota & \\
\hline
\end{tabular}




\begin{tabular}{|c|c|c|c|}
\hline $\mathrm{N}^{\circ}$ elementos medidos & 15 & & \\
\hline Longitud (cm) & 32 & & \\
\hline Anchura $(\mathrm{cm})$ & 14.1 & & \\
\hline Espesor (cm) & 2.8 & & \\
\hline Volumen $\left(\mathrm{cm}^{3}\right)$ & 1263.36 & & \\
\hline Tipo & homogéneo & heterogéneo & re-empleo \\
\hline Color & homogéneo & heterogéneo globular & heterogéneo marmolado \\
\hline Recogida de muestra & no & sí & código Xg74/1 \\
\hline Patologías & $\begin{array}{l}\text { eflorescencias } \\
\text { erosión }\end{array}$ & $\begin{array}{l}\text { micro fisuración } \\
\text { disgregación }\end{array}$ & $\begin{array}{l}\text { grietas } \\
\text { descamación }\end{array}$ \\
\hline
\end{tabular}

${ }^{1}$ Datos obtenidos en base al cálculo del desvío estándar (respecto al valor medio de la muestras analizadas) y del gráfico de frecuencia de las muestras analizadas, identificado por una curva gaussiana

\section{Juntas}

\begin{tabular}{|c|c|c|c|c|}
\hline \multirow{2}{*}{$\begin{array}{l}N^{\circ} \text { elementos medidos } \\
\text { Llaga }(\mathrm{cm})\end{array}$} & \multicolumn{4}{|l|}{15} \\
\hline & \multicolumn{4}{|l|}{0.6} \\
\hline Tendel (cm) & \multicolumn{4}{|l|}{3.6} \\
\hline Altura de 5 hiladas (cm) & \multicolumn{4}{|l|}{36} \\
\hline Proporción ladrillo/junta & \multicolumn{4}{|l|}{0.7} \\
\hline Tipo de acabado & simple & doble & \multicolumn{2}{|l|}{ múltiple } \\
\hline \multirow[t]{2}{*}{ Junta de asiento } & rehundida & a hueso & \multicolumn{2}{|l|}{ saliente } \\
\hline & enrasada & matada & & \\
\hline \multirow[t]{2}{*}{ Junta de acabado } & rehundida & a hueso & \multicolumn{2}{|l|}{ saliente } \\
\hline & enrasada & matada & & \\
\hline \multirow{2}{*}{$\begin{array}{l}\text { Tipo de mortero } \\
\text { Morfología de mortero }\end{array}$} & cal & cal y tierra & tierra & cemento mixto \\
\hline & con grumos & con caliches & homogéneo & heterogéneo \\
\hline Tipo de árido & arena & gravilla & grava & mixto \\
\hline Color del árido & claro & oscuro & homogéneo & heterogéneo \\
\hline Recogida de muestra & no & sí & \multicolumn{2}{|l|}{ Código Xg74/2 } \\
\hline \multirow[t]{2}{*}{ Patologías } & eflorescencias & micro fisuración & \multicolumn{2}{|l|}{ grietas } \\
\hline & erosión & disgregación & \multicolumn{2}{|l|}{ pulverización } \\
\hline
\end{tabular}


Imágenes
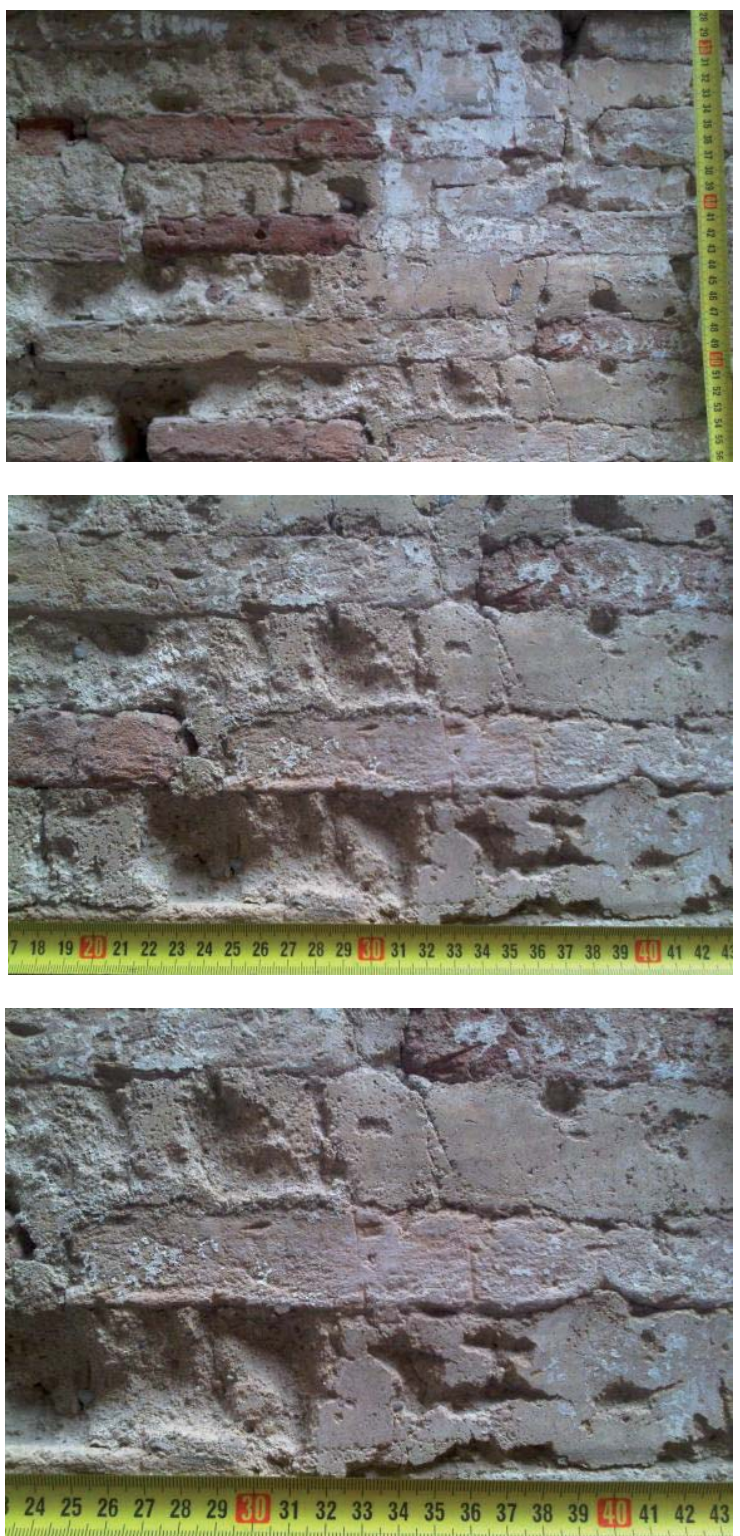
Imágenes

Xg74
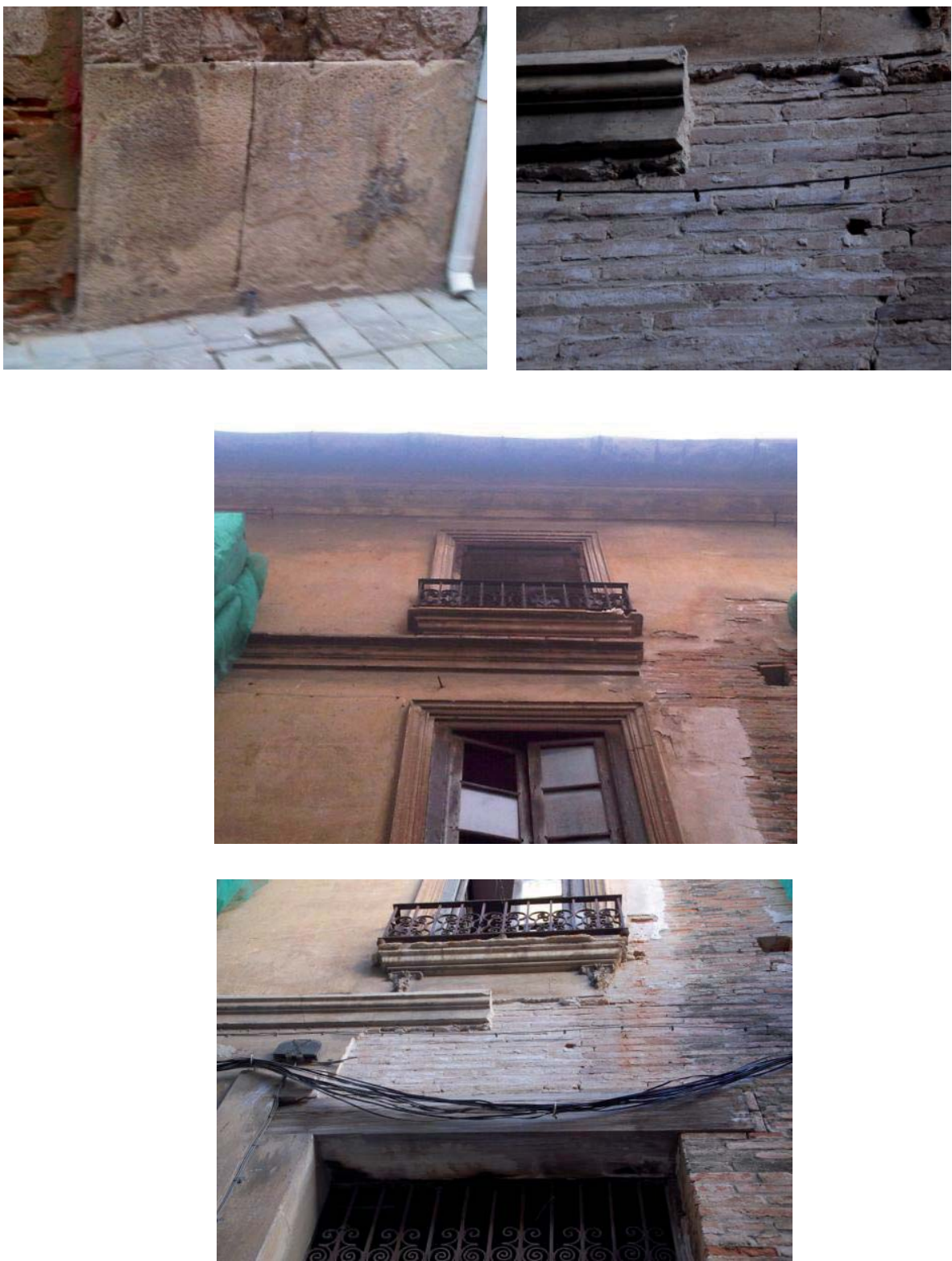


\section{I.3 Abaco de detalles de fábricas históricas de ladrillo}

El registro de fichas, realizado en el tomo II/anejo I, prevé la descripción de diferentes elementos característicos de las fachadas analizadas. Datos arquitectónicos y constructivos constituyen este ábaco de posibles combinaciones técnicas. Por lo tanto, se consideran en detalle soluciones específicas para "zócalo", "fábrica", "relación vano/dintel", "relación entrada/dintel", "alero". La búsqueda de estos elementos, a pesar de revivals, modas e intervenciones es una ayuda determinante para establecer posibles cronologías de las fábricas analizadas.

\section{Zócalo}

\begin{tabular}{|l|l|}
\hline$Z 1$ & Descripción \\
\hline &
\end{tabular}



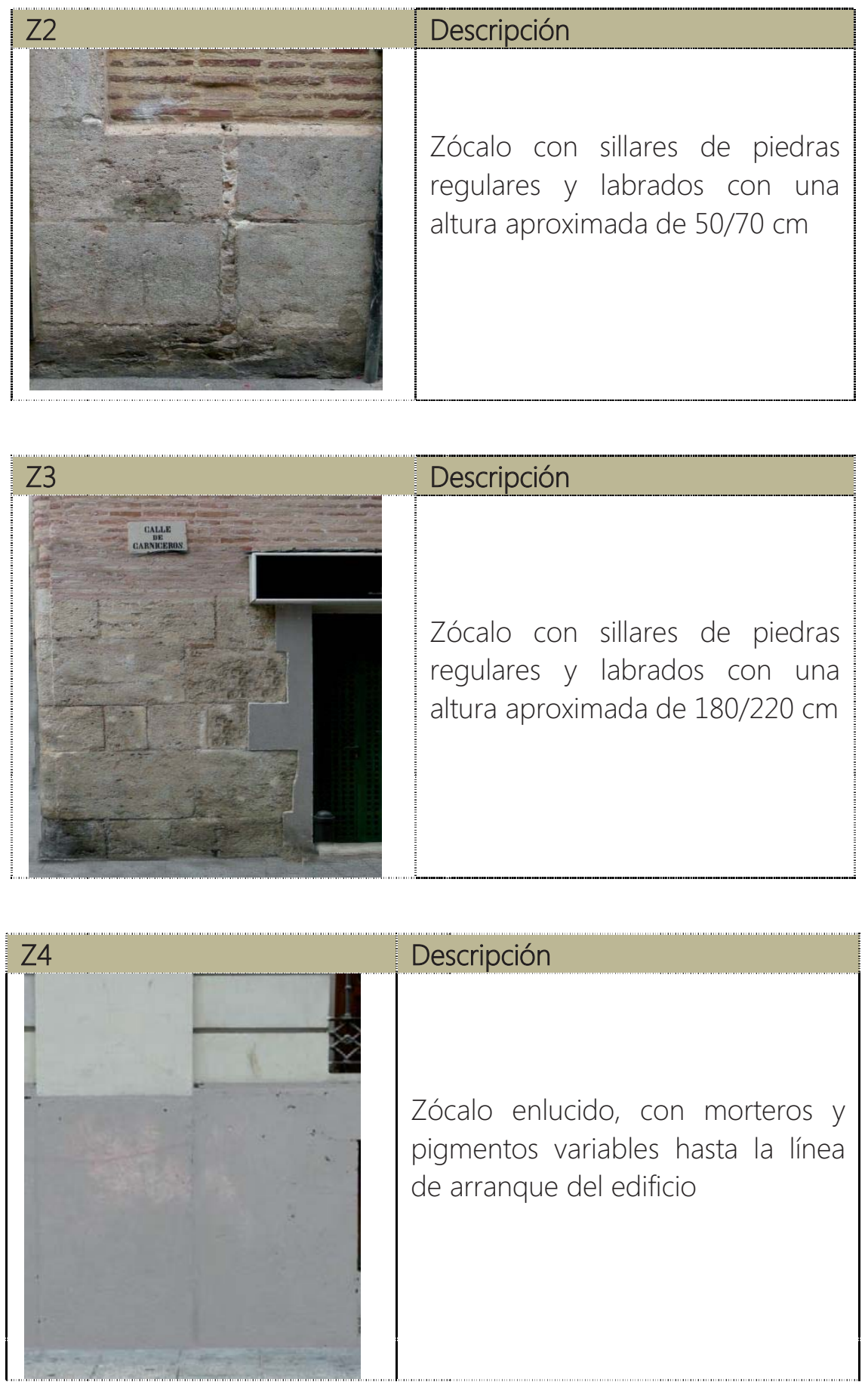


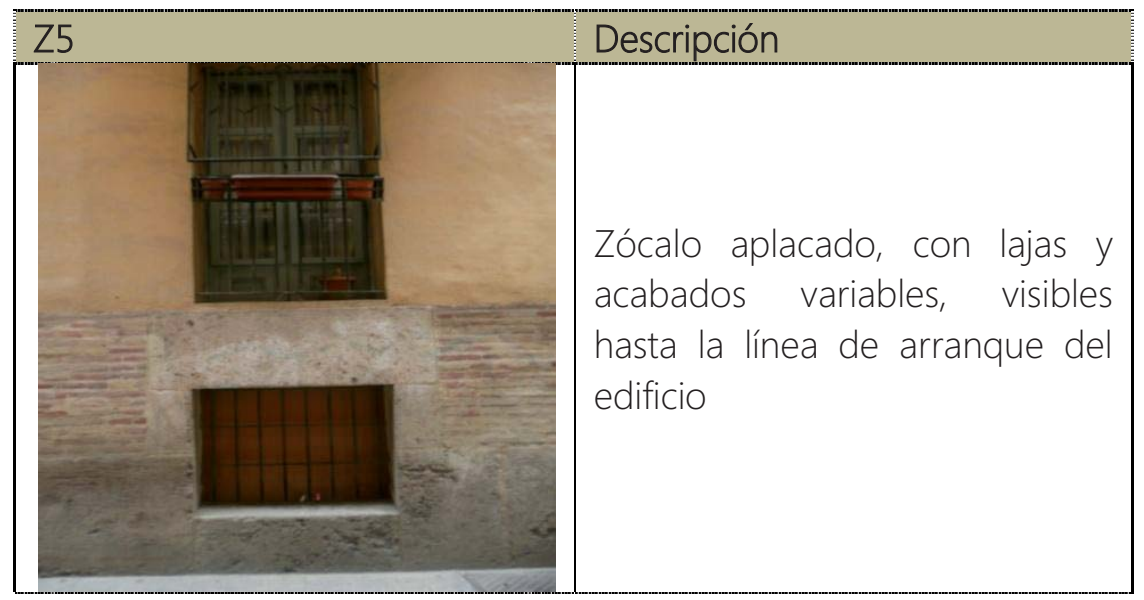

Fábrica

\begin{tabular}{|c|c|}
\hline $\mathrm{F} 1$ & Descripción \\
\hline & $\begin{array}{l}\text { Fábrica de tapia valenciana, } \\
\text { aparejada a tizón, con costra de } \\
\text { cal y núcleo de argamasa } \\
\text { (realizada con cal, cascotes, } \\
\text { gravilla y tierra) }\end{array}$ \\
\hline
\end{tabular}

\begin{tabular}{|l|l|}
\hline D2 & Descripción \\
\hline & \\
\hline
\end{tabular}



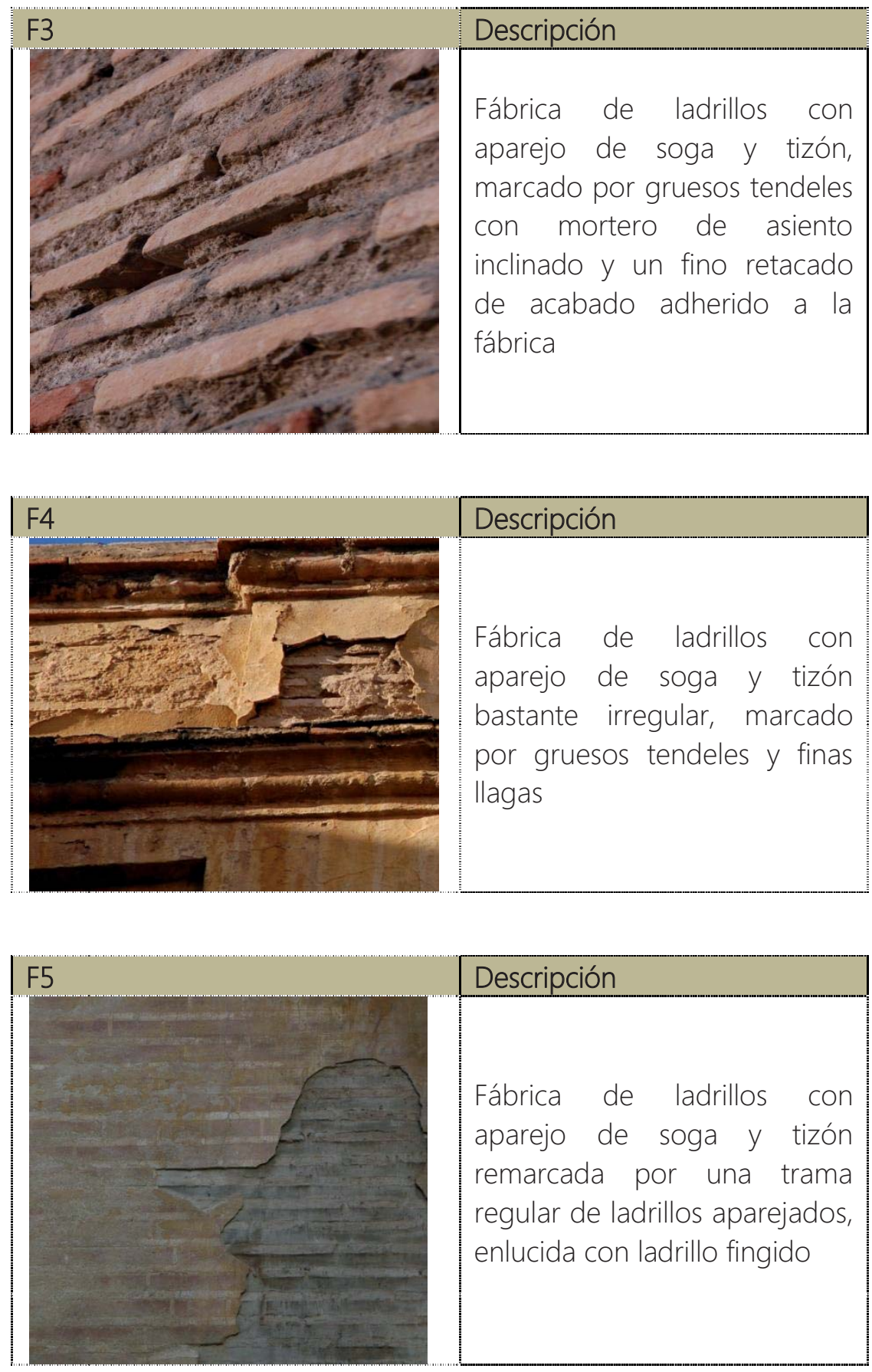

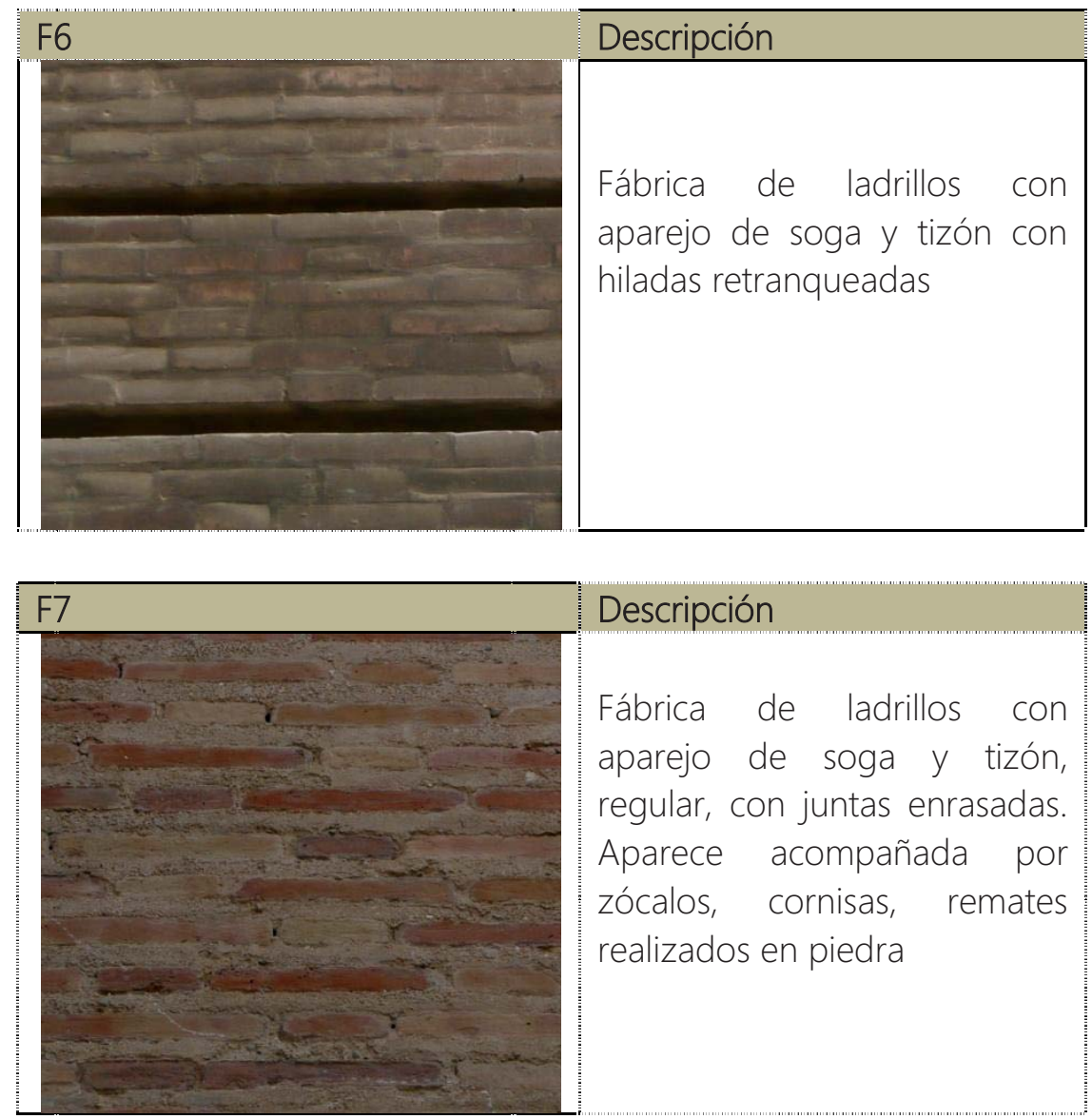

Vano/dintel

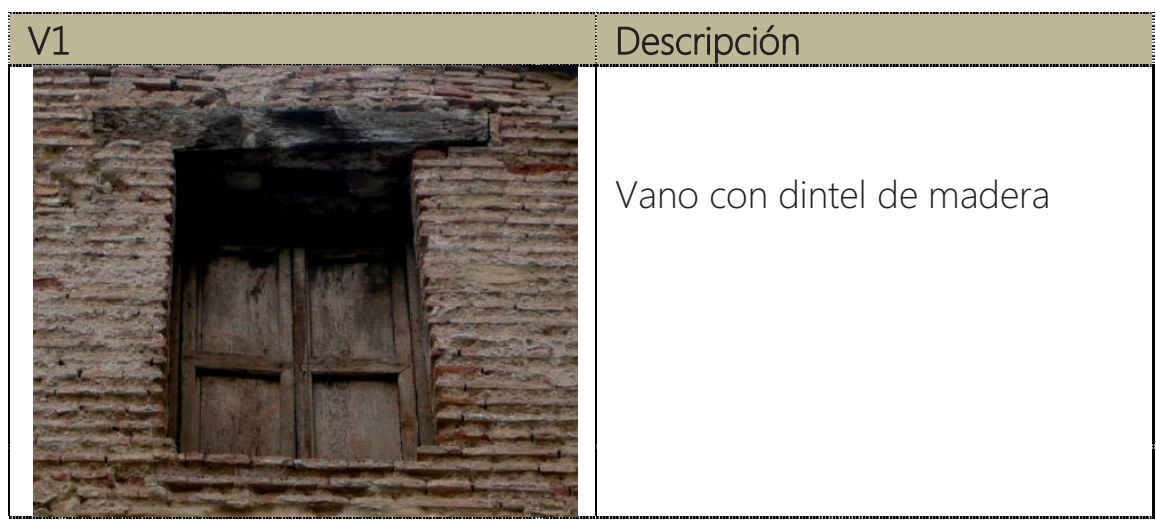



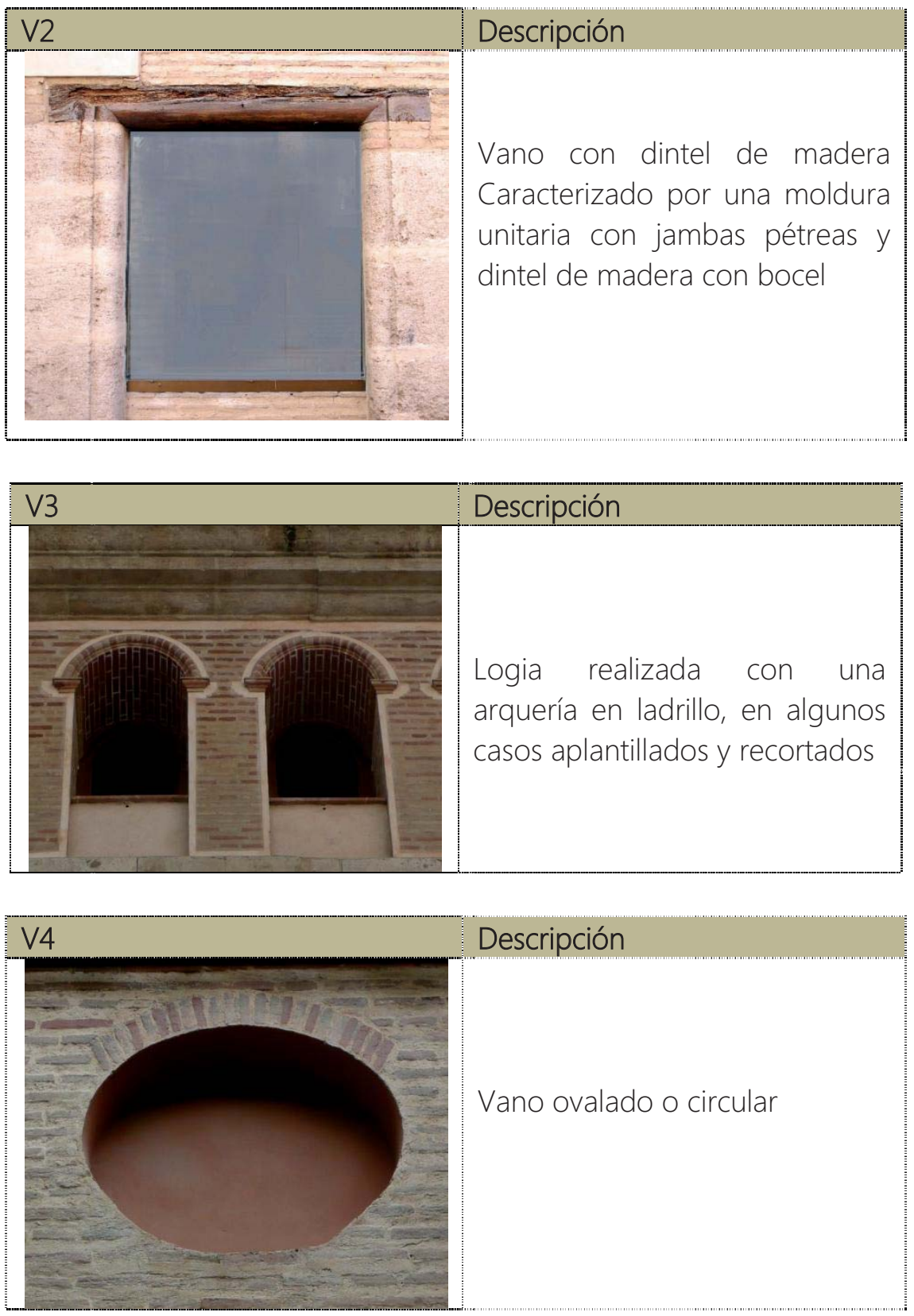

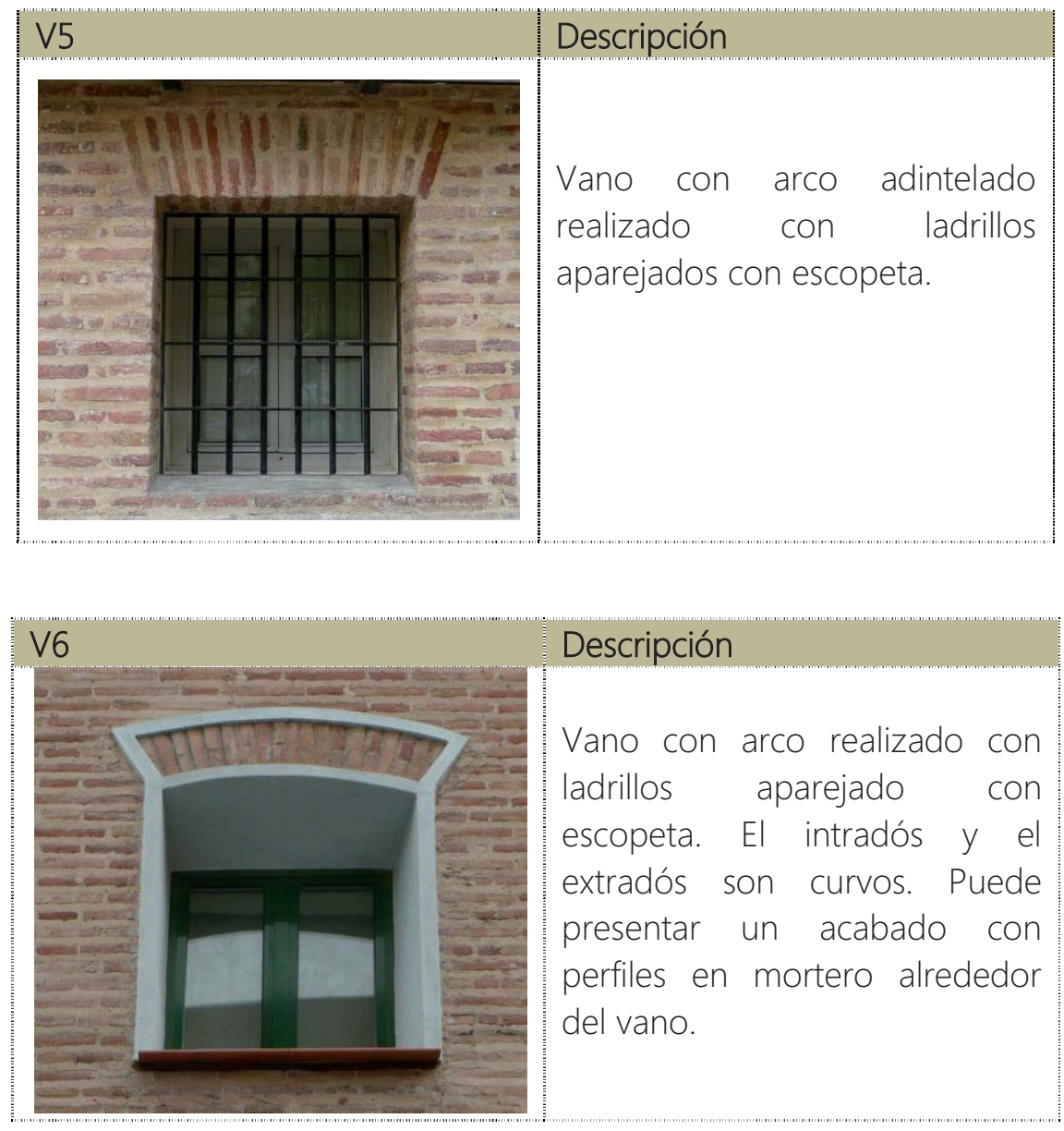

\begin{tabular}{|l|l|}
\hline V7 & $\begin{array}{l}\text { Descripción } \\
\text { Vano con arco realizado con } \\
\text { ladrillos aparejados con escopeta. } \\
\text { El intradós es plano y el extradós } \\
\text { es curvo. Puede presentar un } \\
\text { acabado con perfiles en mortero } \\
\text { alrededor del vano. }\end{array}$ \\
\hline
\end{tabular}



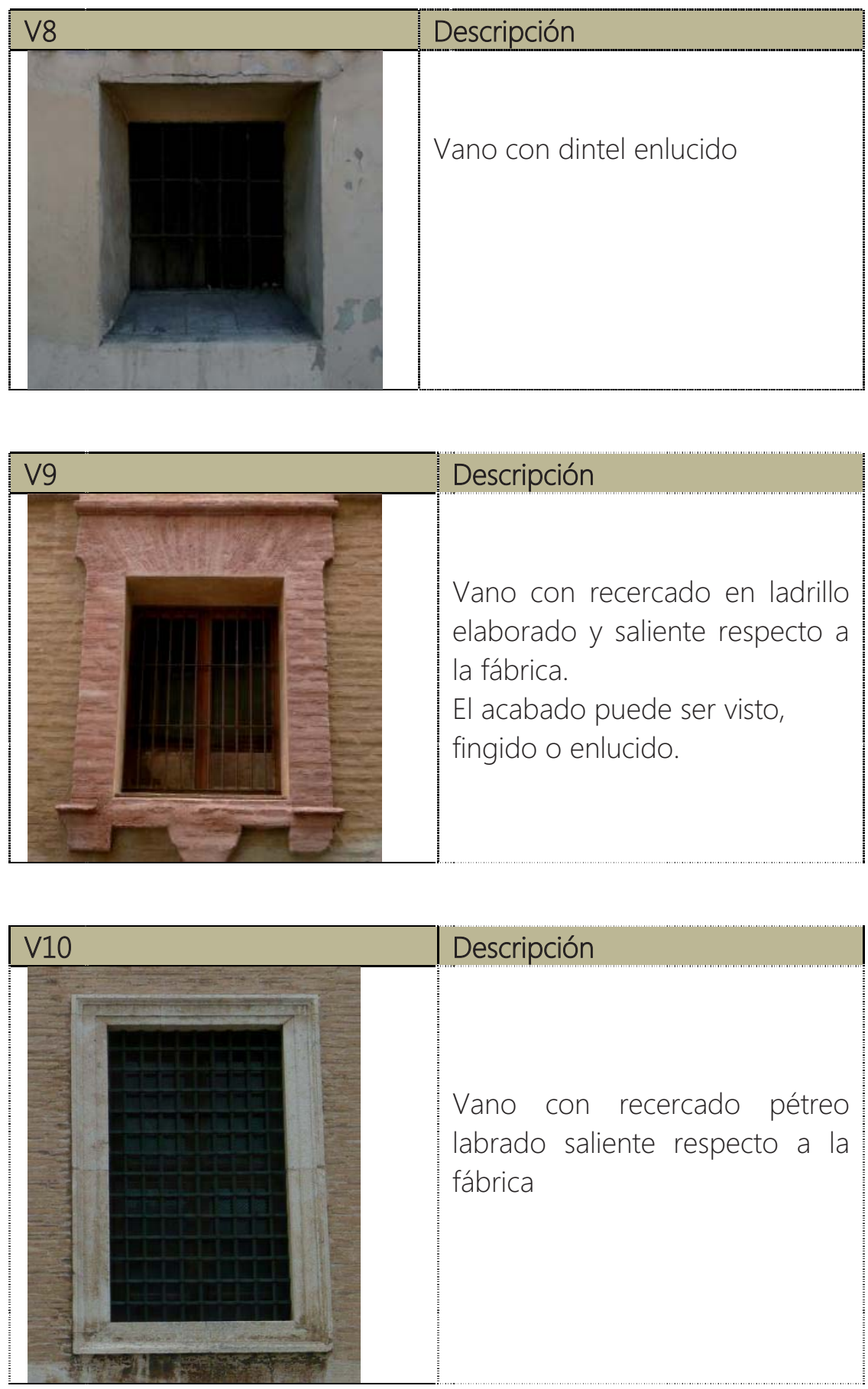


\section{Entrada/dintel}

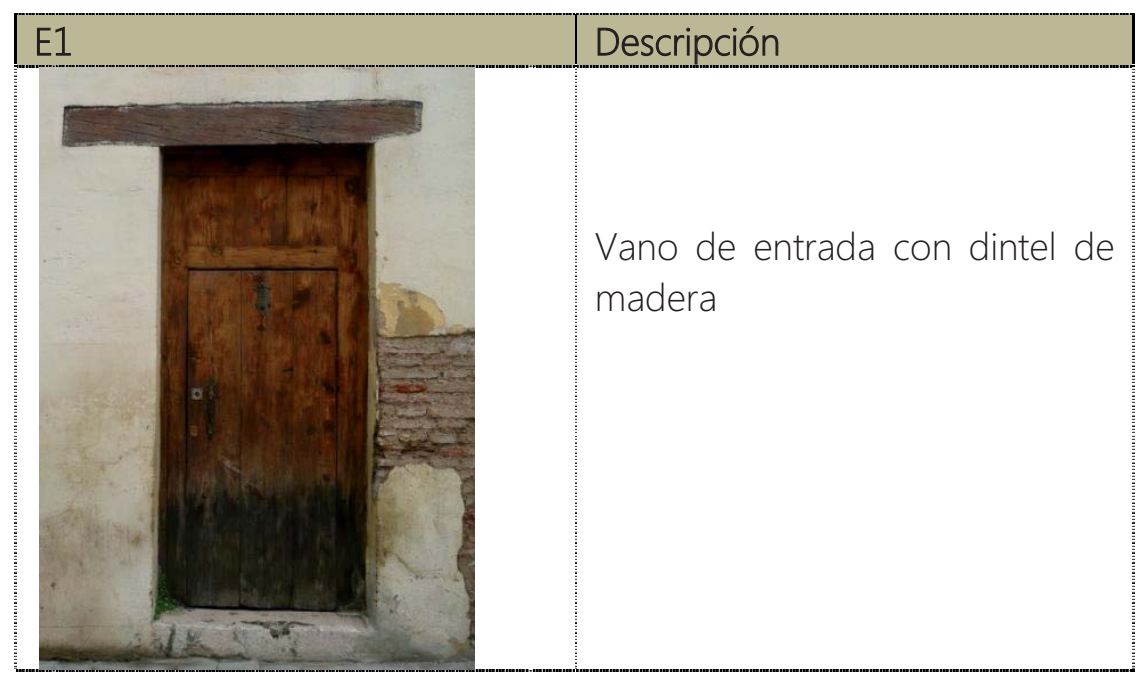

\begin{tabular}{|l|l|} 
Descripción \\
Vano de entrada con dintel de \\
madera. Caracterizado por una \\
moldura unitaria con jambas \\
pétreas y dintel de madera con \\
bocel.
\end{tabular}



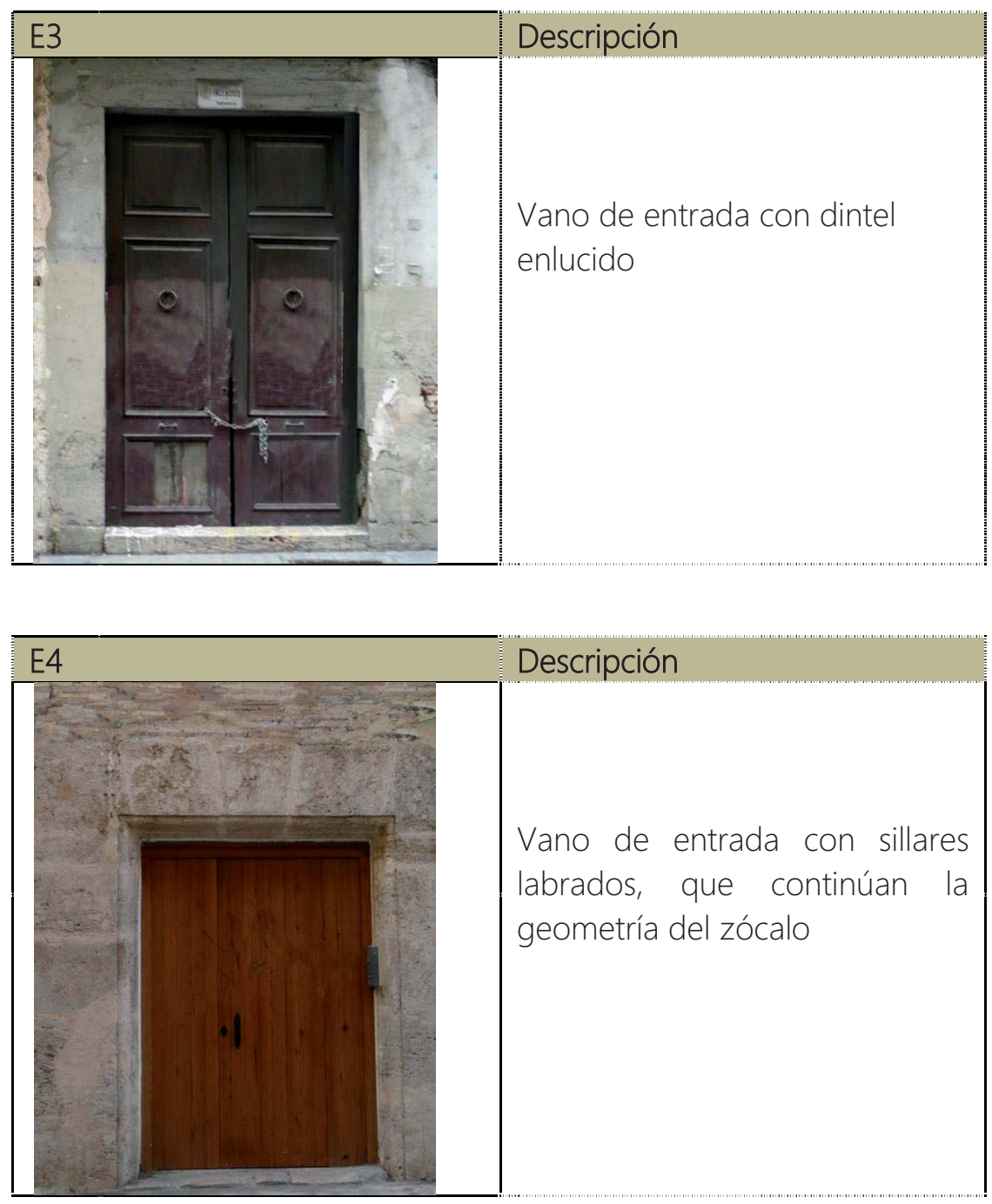


\section{Alero}
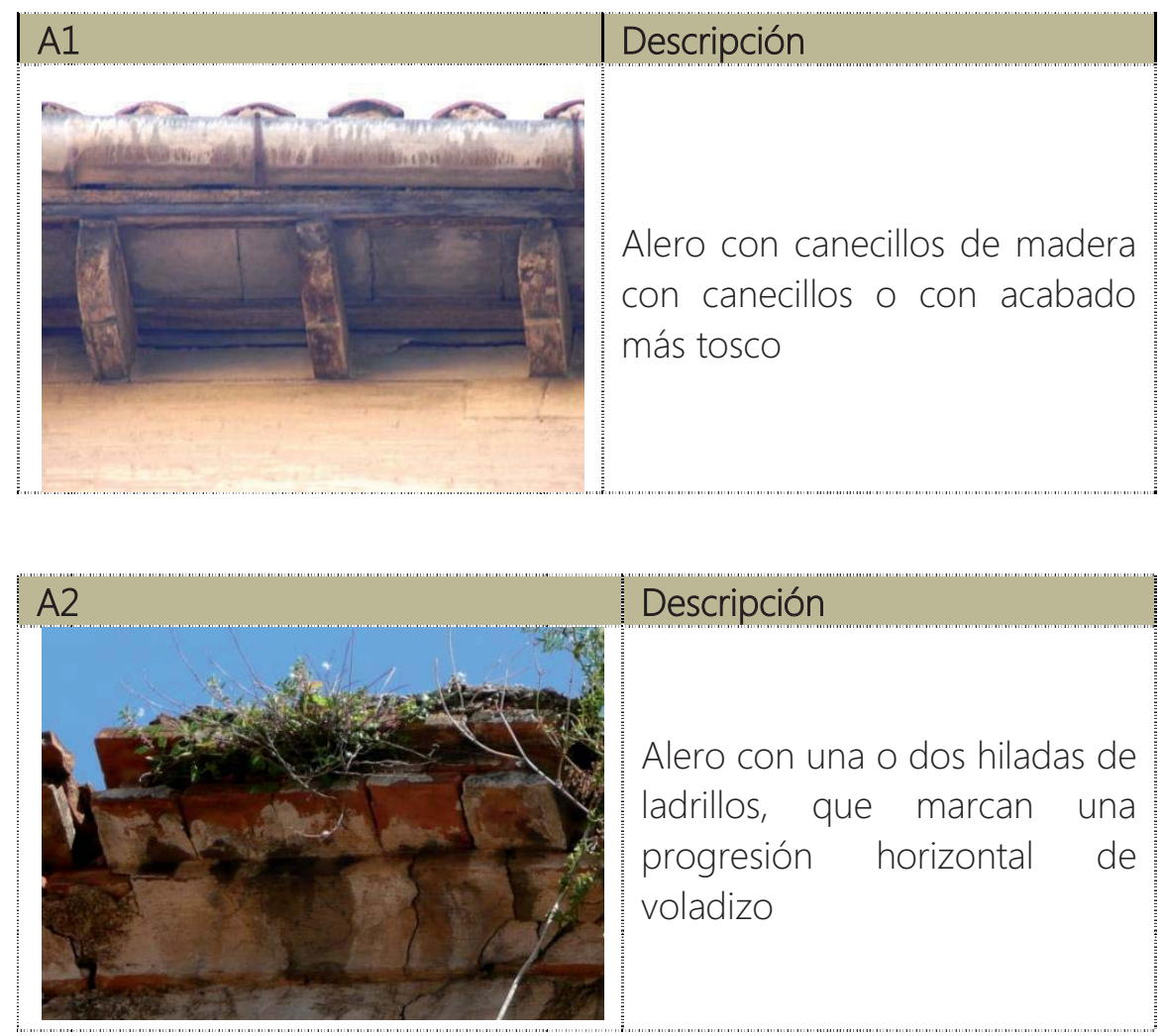

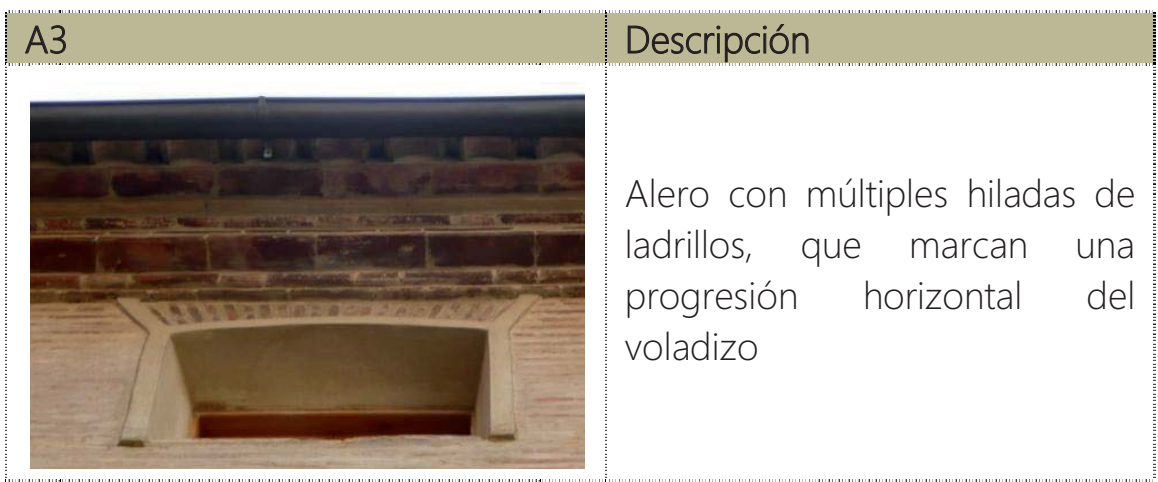




\begin{tabular}{|c|c|}
\hline A4 & Descripción \\
\hline $209 \Rightarrow$ and & $\begin{array}{l}\text { Alero enlucido con presencia } \\
\text { variable de molduras } \\
\text { decorativas }\end{array}$ \\
\hline
\end{tabular}

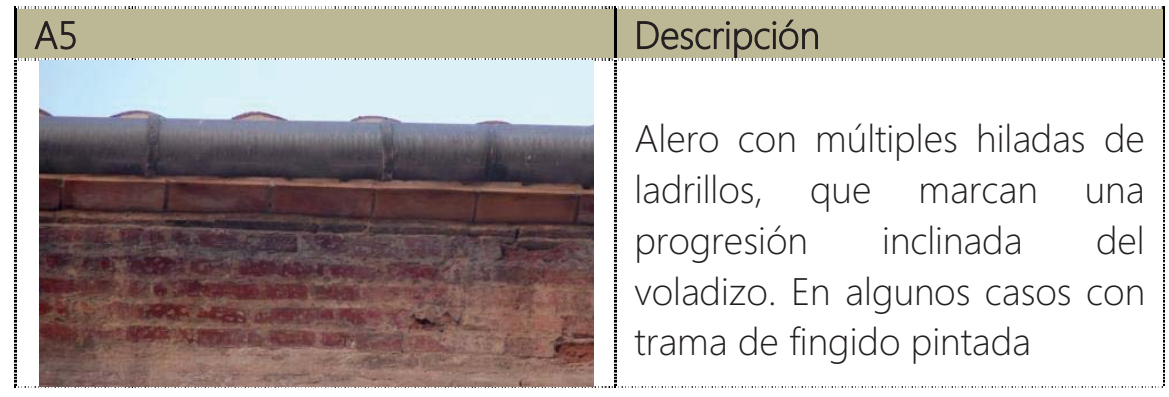

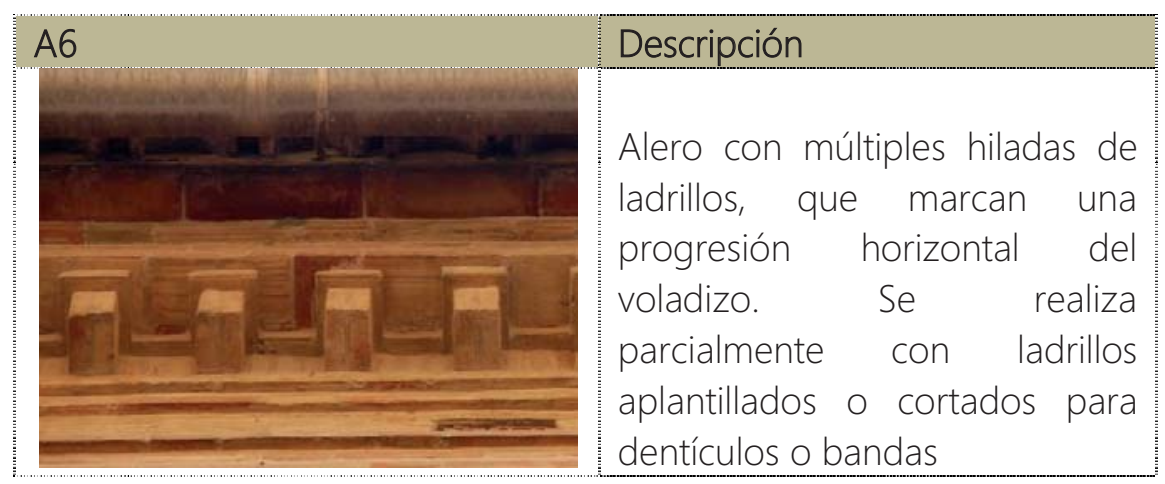

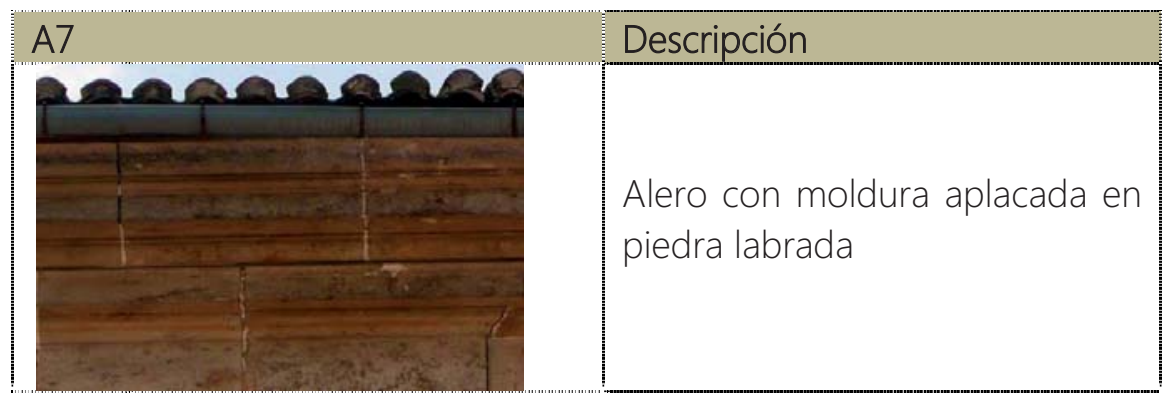


murOSINTRAMUIOS

ANEJO II.

Recopilación de datos arqueológicos 



\section{II.1 Criterios para la recopilación de datos arqueológicos}

Con el fin de abordar un análisis sobre las posibles huellas arqueológicas de la ciudad, se ha realizado un vaciado del depósito del SIAM (Servicio de Investigación Arqueológico Municipal de la ciudad de Valencia), donde se han localizados 19 ladrillos (romanos, bajomedievales, altomedievales).

Estos ladrillos, almacenados y catalogados en los $2.300 \mathrm{~m}^{2}$ del depósito del SIAM, en el Polígono de Vara de Quart (Valencia), pertenecen a 10 excavaciones arqueológicas, que recogen muestras de piezas enteras de ladrillos, clasificados en las diversas unidades estratigráficas.

Desafortunadamente, no hay abundancia de ladrillos almacenados y catalogados, debido al hecho que estos elementos constructivos no se consideran como "elementos claves" para una excavación arqueológica, y su documentación correcta sólo se debe a la sensibilidad y al cuidado puntual de arqueólogos y técnicos responsables de la redacción de los informes y del registro del material arqueológico.

Para realizar este análisis se ha procedido con dos vaciados. Por un lado se han consultado todos los informes arqueológicos archivados en el SIAM, vinculados a talleres urbanos cerámicos (no decorativos); por otro lado, se han seleccionado entre las cajas del almacén de material arqueológico ladrillos (enteros, sin fragmentos), para procesar su toma de datos y análisis.

Consecuentemente, se ha procedido a la redacción de un extracto de los informes arqueológicos y, al mismo tiempo, a la redacción de unas fichas de registro de mediciones efectuadas en los ladrillos. 


\section{II.1.1.Extractos de informes arqueológicos}

*ROSSELLÓ MESQUiDA M., BURRIEL ALBERICH J.M "Informe final de los trabajos arqueológicos de la C/Guillem de Castro 10-16/ Quevedo, de Valencia, Futuro Museo de la Ilustración "(15.12.97/30.4.98)1GUIQUE

"De finales del siglo XIII se han encontrado hornos de planta cuadrada, que conservan parrilla y cámara de acceso, Las evidencias apuntan que se trata de unos hornos para la fabricación de tejas y ladrillos. Están excavados en el subsuelo y aparecen amortizados a medianos del siglo XIV, momento que coincide con la urbanización de la zona, explicitada en la parcelación del terreno y la construcción de los diversos huertos/jardines." Se han depositado en el almacén del Siam algunos ladrillos procedentes de U.E.2141 (ficha S1)

*SALAVERT J.V., BURRIEL ALBERICH J.M., SERRANO FAJARDO M., "Informe preliminar estudio arqueológico previo desarrollo en los jardines del Antiguo Hospital General de Valencia" (9.12.04/9.2.05) 2GUIQUE

"XV-XVI. Se han encontrado huellas de la muralla construida en la segunda mitad del siglo XIV; se trata de tapia de tierra reforzada con tongada de mortero pobre, tierra y refuerzo de ladrillo; el zócalo es un potente zócalo de mortero de cal y piedra, encofrado, de aprox. $2.5 \mathrm{~m}$ de grosor. Se conservan unos $80 \mathrm{~cm}$ de alzado del muro de tapia. Concretamente este tramo estaba comprendido entre el Portal de Torrent y el Portal de San Vicent. También se han encontrado huellas del camino de ronda. Siempre de esta época son los pavimentos, realizados con ladrillos macizos, trabados con pobre mortero de cal, dispuestos a "falsa espiga", de reutilización, que contribuyen a la parcelización de los huertos. También de ladrillo es el cajero de la acequia de Favara, cubierta por grandes losas de piedra."

Se han depositado en el almacén del Siam algunos ladrillos procedentes de U.E. 2147(ficha S2) 
*ALGARRA PARDO V.M., BERROCAL RUIZ P., "Informe preliminar de la intervención arqueológica en el solar de la Avda Constitución 154, 156,158, y C/ Sagunto 195/97, Valencia" (15.11.06/29.12.06) 1SAG195

"Etapa Islámica, siglo XI. Hay restos de un horno de producción cerámica, con grande cámara de cocción y otra segundaria, precedidas de un prefurnium. Junto una fosa circular que cumple con la función de probable silo, en forma de saca. El horno presenta una planta tendente al óvalo, con una orientación noroeste/sudeste, con boca a noreste. La parte superior conservada señala un incipiente cierre o curvatura hacia el interior del horno, que se interpreta como el arranque de una bóveda de cierre.

Las dimensiones de las cámaras son de $2.7 \mathrm{~m}$ de longitud máxima en la parte superior conservada y $2.29 \mathrm{~m}$ en la base por anchuras variables comprendidas entre $1.60 \mathrm{~m}$ en la parte central, $1.40 \mathrm{~m}$ en el extremo noroeste, $1.08 \mathrm{~m}$ en el sudeste. Su altura máxima es de $1.2 \mathrm{~m}$. Las paredes del horno formaban una camisa o carchata de arcilla refractaria altamente rubefactada.

El sistema de sustentación de la bóveda y parrilla de la cámara superior de cocción se fundamenta en 2 pilastras y columna central. El horno presenta una cámara de combustión segundaria, que formaba un apéndice mucho más pequeño, de $0.94 \mathrm{~m}$ por $0.36 \mathrm{~m}$, sección en " $\mathrm{V}$ " e revestido por una carchata de $10 \mathrm{~cm}$ de grosor. Se supone pudiera servir para vidriar o para la cocción de piezas singulares. Por otro lado el acceso al pre-furnium es a través de una fosa e "u", de planta irregular. El relleno del horno, con abundantes huellas de tejas, coincide con su desmontaje e sucesiva transformación en balsa, con una función que no se relaciona a la técnica cerámica.

El horno coincide con un gran núcleo alfarero del antiguo Camino a Sagunto, en torno al cruce del Camino con Moncada."

Se han depositado en el almacén del Siam algunos ladrillos procedentes de U.E. 1624 (Ficha S3) 
*ROCA FERNÁNDEZ L., "Informe arqueológico final, excavación C/Lauria 2, Valencia (28.09.05/27/12.05)'1LAURI2

"Cerca de la plaza Ayto. la acequia de Rovella cruza el solar de oeste a este, encauzada con paredes de ladrillos y abovedada. Se trata de un encauzamiento medieval de una pre-existente acequia islámica. (TORRÓGUINOT). Excavado en la tierra estéril se ha encontrado una estructura cuadrangular, de un área de aprox. 9m2, identificada como restos de un horno, en concreto cámara de fuego, con tres arcos que sustentan la parrilla y parte de la misma.

Una amplia fosa de acceso da el paso a la puerta de la cámara de fuego, con arco de medio punto construido con ladrillos. En esta boca de acceso además de haberse encontrado ladrillos del posible derrumbe del laboratorio o cámara de carga, se encontraron muchísimas tejas de lo que se ha deducido que era la producción del horno. El material cerámico que satura la fosa se ha clasificado como del siglo XIII-cristiano. Hay dos interpretaciones: por un lado un horno que ha estado funcionando en los últimos años de ciudad islámica, destruido por los reconquistadores o realizado en los primeros años de la ciudad cristiana, destruido por la urbanización."

No se han depositado en el almacén del SIAM muestras de ladrillos procedentes de esta excavación.

*GUERÍN P.," Informe de la intervención arqueológica en la CMesón de Morella, Valencia"(26.10.96/21.1.97), IMEMOR3

"El solar se encuentra en un entorno peri-fluvial, que se refleja en la topografía paleo-geográfica del solar. La transición a la época bajomedieval se documenta gracias al espectacular hallazgo de un horno dedicado a la producción de material constructivo de cerámica, como indican los desechos de cocción tanto de tejas, como de ladrillos. Es un horno de cámara rectangular, equipado con 6 conductos de aire lateral y una boca excavada en el sedimento natural, en forma de conducto tubular, orientado hacia el Este. Los restos indican una zona de producción alfarera en los siglos XIII-XIV, si que se pueda precisar si esta estructura 
perdura durante la baja edad media. El su totalidad el horno ocupa un área de unos $5 \mathrm{~m}$ de eje longitudinal por $3 \mathrm{~m}$ de eje transversal. Se compone de una cámara rectangular de $3 \mathrm{~m}$ por $1.5 \mathrm{~m}$ prolongada hacia el E por un conducto tubular de $1 \mathrm{~m}$ de largo por $0.8 \mathrm{~m}$ de ancho, al final, del cual se abre la boca.

A cada lado de la cámara, 6 pilares de ladrillo delimitan 6 conductos de chimenea que conducían el aire caliente desde la cámara de fuego hasta el laboratorio. La parrilla no se ha conservado. Es una estructura mista, en parte construida en ladrillo. La construcción empezó por la excavación de un plano inclinado desde el suelo hasta profundidad de $1 \mathrm{~m}$, en cuya pared se excavó "en cueva" la boca del horno y la cámara de fuego. Más tarde se construyeron de ladrillo los 6 pilares y la pared del fondo de la cámara de cocción sobre los cuales descansaba la parrilla. La altura de la cámara de cocción es de unos $1.55 \mathrm{~m}$. Es probable que el taller fuera de ladrillos. En el sector de la boca, una hilera de tejas dispuestas de canto refuerza la estructura, ofreciendo sin duda una protección refractaria....

...El paralelo más exacto es con el horno del circo romano de Toledo, de dimensiones parecidas, aunque reducidas. En dicho horno habían también 6 pilares que en este caso configuraban 3 arcos. En este caso la cronología apunta a época califal."

No se han depositado en el almacén del SIAM muestras de ladrillos procedentes de esta excavación.

*GARCÍA VILLANUEVA I., RUIZ VAL E., "Informe de la intervención arqueológica realizada en los solares de la C/Sagunt 127-130, Valencia" (13.06.94/17.09.94) 1SAG127

"En los siglos V-IV el solar era una suave vertiente sedimentaria cercana a la ribera izquierda del Río Turia, justo al norte del codo que hacia el sur hacía la difluencia principal existente entonces. El registro arqueológico vuelve a proporcionar datos para la época islámica. Durante el periodo comprendido entre el siglo XI y el primer tercio del XIII, este lugar fue ocupado por sucesivos talleres alfareros. La localización de esta zona es en 


\section{murOSINTRAMUIOS}

un área bajo la influencia de distintos aparatos fluviales que ha proporcionado la parcialidad misma del registro estratigráfico. Se trata realmente de una de las zonas con más riesgo de inundación ( Campanar, Marxalenes_Camí de Morvedre) con frecuente erosión de tierra y escasa edificación, debido a los efectos del Barranc d'En Dolça y el paleocanal de I'Almara. El lugar se vio afectado por decapitación de una serie de niveles antrópicos. Sobre todo en 1088, según las fuentes históricas, hubo una gran inundación que marca en muchos casos las remodelaciones urbanísticas (SORIANO-PASCUAL). Esto en muchos casos descartas el arrasamiento de las estructuras debido al asedio de la ciudad por parte de las tropas del CID.

La localización de la zona se encuentra cerca de materias primas y vías de comunicaciones importantes hacia la Via Heraklea. También podemos considerar el barrio alfarero de Denia, situado fuera de la Madina, porque considerado en parte insalubre y contaminante para la ciudad. En la excavación se han localizados 7 hornos diferentes pero no se localizaron estructuras de hábitat. Los vecinos se solían quejar de la presencia de humos y contaminantes (TDR (Tribunal del Repeso), Caja C5, "Mariano Cabanes solicitó al Tribunal el permiso para construir una fábrica de alfarería en la C/Murviedo, denegado por molestia de humo".)

HORNO $1=$ El horno arrasado por niveles posteriores, es colmatado por un relleno de adobes, atifles, barras. Las dimensiones máximas: $2.20 \mathrm{~m}$ de longitud, 1.14 m de anchura, con un lazado máximo de 1.03 m; La planta presenta cámara de cocción y cámara baja de combustión (sagén), como los hornos 4 y 5 . Es el primer horno de tipo "moruno" documentado en valencia, por primera vez, en época islámica....desarrollado luego en el testar de Paterna. La cámara de combustión es de planta oval, con paredes cocidas reducidas por la presencia de la cámara baja de cocción. Abajo el revestimiento hay una estructura de sustentación de adobe.

HORNO 2 = El horno solo conserva parte de la cámara de combustión, mide unos $1.5 \mathrm{mx} 1$, con un alto de $73 \mathrm{~cm}$. Fue usado como testar tras su 
abandono. Este también es de planta ovalada. Queda el arranque del arco de sustentación de la cámara tallado en la tierra.

HORNO 3= El estado de conservación es deficiente...sólo quedan unos $0.8 \mathrm{~m} \times 0.67 \mathrm{~m}$ e una altura de $0.47 \mathrm{~cm}$. Quedan 4 concavidades, toberas, que comunicaban la cámara de fuego y la cámara de combustión a través de la parrilla.

HORNO 4= Este horno también tiene sagén, quedan unos $1.7 \times 1 \times 0.29 \mathrm{~m}$. Encima se construyó un horno más corto y más alto que el original. HORNO 5= Este horno como en el horno 1 y 4 en este también la cámara de fuego se reduce por ensanchar el sagén. Pasa de $1.8 \mathrm{~m}$ a $1.3 \mathrm{~m}$ También en este caso el sagén es circular, de $0.6 \mathrm{~m} \times 1.4 \mathrm{~m}$.

HORNO $6=$ Este horno tienen una excavación muy parcial e limitada. Es también excavado en el terreno natural, con un acceso facilitado, a través de un escalón de tierra; hay una reparación, también realizada a posteriori, que enmascara la estructura original.

HORNO 7 = Se trata de un horno muy reparado, hasta se realiza una pared con trozos de ollas. Es también en el subsuelo con paredes amarillentas por el fuego.

Fragmentos de tejas, tierra cocida, ladrillos adobe...cenizas y carbones marcadas como finales del siglo XII primer tercio el siglo XIII marcan la desamortización del taller."

No se han depositado en el almacén del SIAM muestras de ladrillos procedentes de esta excavación.

*MIQUEL ROSELLÓ MESQuidA, "Intervención arqueológica en la CNIRGEN DE LA Misericordia 4"; (14/05/1992. 10/05/1993).1MIS004

"Las primeras evidencias de ocupación del espacio se concretan en la instalación de un área cementerial que abarca cronológicamente desde principios de siglo I a.C. hasta finales del S. III d.C. o principios del S. IV d.C. (en estos años empieza a funcionar la necrópolis de la Boatella). Se trata de la necrópolis romana que mejor se ha estudiado en la ciudad. Es un solar con un pequeño desnivel, apenas perceptible aún hoy en día. Es interesante en este marco destacar la presencia de diferentes tipologías de 
tumbas, tanto para incineración (minoritaria, de todas formas, es la documentación más antigua encontrada), así como de inhumación."

"Hay tumbas variadas:

a) Fosa cubierta de tierra (tipo más numeroso)

b) Inhumación en contenedor cerámico (sólo 1 caso, para inhumación infantil)

c) Fosa con cubierta de tégulas, de tégulas a doble vertiente, de losas cerámicas

d) Fosa enlucida de argamasa y cubierta de tégula a doble vertiente (sólo hay 1 ejemplo)

e) Cista de tégulas (sólo hay 1 ejemplo)

semi-cista de tegulas y cubierta por un tumular de opus cementicium

g) Fósa de ladrillo, con cubierta de tégula con doble vertiente, con segunda cubierta de opus caementicum

h) Fosa de opus caementitium en planta con cámara abovedada

En general la cubierta plana se halla como más antigua que la cubierta cerámica con tegulae. El tipo d) es una variante más compleja del tipo c).Los tipos f) g) y h) son tumbas de proyección vertical y su aparición en la necrópolis es más tardía".

Se han depositado en el almacén del Siam algunos ladrillos procedentes de UE 1753 (ficha S4) y UE 1388(ficha S5) y UE 1774 (ficha S6).

*MIQUEL ROSSELÓ MESQUIDA "Informe de los trabajos arqueológicos en la C/Conde de Montores 1-3-5y C/Gobernador Viejo 3,5,7, Valencia" (24/05/1995) 2MONGOV

"El solar se encuentra fuera de la ciudad romana pero muy próximo a ella, próxima al edificio del circo; zona que en época islámica se trasforma en la puerta de la Xerea; hace referencia a Milagros Cárcel y José Trenchs, "Consell de Valencia, disposiciones urbanísticas (Siglo XIV)", n¹07/diciembre 1372, el Conse// da licencia para que se puedan vender o enajenar las partidas de los muros, torres, barbacanas y patios antiguos de la ciudad que ya no tienen ninguna utilidad". 
En esta zona se edificará la iglesia y convento de S. Tomás y Felipe Neri, que, después de la desamortización se reducirá solo a Iglesia (Enajenación del convento y exclaustración). La excavación se realiza en el solar del convento, en 5 área de intervención, tratándose de un solar muy grande, en el que se re-edificaron muchas viviendas".

Algunos ladrillos con marcas medieval UE 5111 (ficha S7) y UE 1028 (ficha S8), se encuentran en un nivel de relleno documentado a finales del siglo XIV, pero no presentan una descripción exhaustiva.

*CARMEN MARÍN JORDÁ, REMEDIOS MARTíNEZ GARCÍA, "Intervenciones arqueológicas C/Paz 28/ esq. C/Juan de Ribera, Valencia" (1/02/1995. 07/04/1997).1PAZRIB

"El solar excavado se encuentra en la cabecera del circo romano, cuyos potentes muros de opus caementitium encofrado, se reutilizan tanto en época romana cómo islámica (ej. para construir viviendas y la noria de un molino)."

Se han depositado en el almacén del Siam algunos ladrillos procedentes de:

UE 1105= muro de ladrillo con restos de enlucido de cal, Bajomedievalhasta siglo XIV. (ficha S9)

UE 1113 = estructura del patio con andén y rotonda Islámica, primer tercio del siglo XIII. (ficha S10)

UE 1100 (ficha S11), UE 1121 (ficha S11), UE1137(ficha S12), estructuras más tardías, posible S: XVI

*MARISA SERRANO MARCOS "Memoria de las excavaciones arqueológicas realizadas en el solar recayente a la Plaza de Cisneros 6 y C/Zapateros 9 de Valencia"( 29/05/1998. 30711/1998)2SABCIS

"En el solar se encontraron restos de la primera ocupación humana de la zona caracterizada por empleo de adobe (UE 3067). Los muros de estas primeras edificaciones eran de tapia de tierra y adobe. Se trata de grandes edificios de planta rectangular, compartimentada, con una serie de habitaciones alargadas, indiferenciadas. Las estructuras eran reforzadas en las esquinas por piedras y enlucida con cal. Se trata de una serie de barracones, realizados por los soldados licenciados, que se insediaron 
como colonos, que levantaron estas estructuras para sus familias. La guerra civil entre el partido senatorial de Sula y el popular de Mario y Sertorio seña el fin de la ciudad. Las fuentes indican que Valentia se decantó por estos últimos, motivo que provocó la destrucción de la ciudad por Pompeyo en el año 75 a C. A este periodo bélico se debió el arrasamiento de las primeras edificaciones así como la presencia en las excavaciones de estratos de carbones y cenizas con fragmentos óseos humanos."

Se han depositado en el almacén del SIAM algunos ladrillos procedentes de las UE 2458 (ficha S14), UE 2628 (ficha S15), UE 2819 (ficha S16), UE 2894 (ficha S17), UE 2974 (ficha S.18) UE3071 (ficha S.19). 


\section{II.2Base de datos}

Para realizar este trabajo se ha confeccionado una FICHA DE ESTUDIO DE LOS LADRILLOS compuesta por dos apartados principales, tanto de catalogación expeditiva así como descriptiva. La estructura de la ficha sigue estas pautas de enfoque progresivo, desde la localización general de la excavación hasta la definición en detalle del ladrillo.

\section{Datos generales}

\section{Ladrillos}

Los códigos alfanuméricos identificativos de cada ficha se han establecido en base a la progresión de la toma de datos

\begin{tabular}{|l|l|}
\hline Ladrillo de procedencia arqueológica & Código clasificación \\
\hline Siam & $1,2,3 \ldots$ etc. \\
\hline
\end{tabular}

Cada uno de los apartados de las fichas indican una serie de datos que se pueden resumir a continuación:

\section{Datos generales}

código

\section{Excavación \\ Código SIAM \\ Dirección \\ Fechas Claves \\ Procedencia}

funeraria

residencial hornos 
Este apartado, crucial para cada ficha, sirve para identificar la excavación y definir pautas generales relativas a su localización espacio/temporal. La clasificación resume datos generales del informe arqueológico consultado. Por lo tanto, en esta tabla se resumen: el título de la excavación, su código de referencia para el archivo del SIAM, la dirección de la excavación, unas posibles fechas claves recopiladas en el informe y la procedencia de los ladrillos analizados (funeraria, residencial, monumental o artesanal).

Estos datos se completan también con una foto, con metro, de un ladrillo medido in situ.

\section{Ladrillos (U.E.)}

código

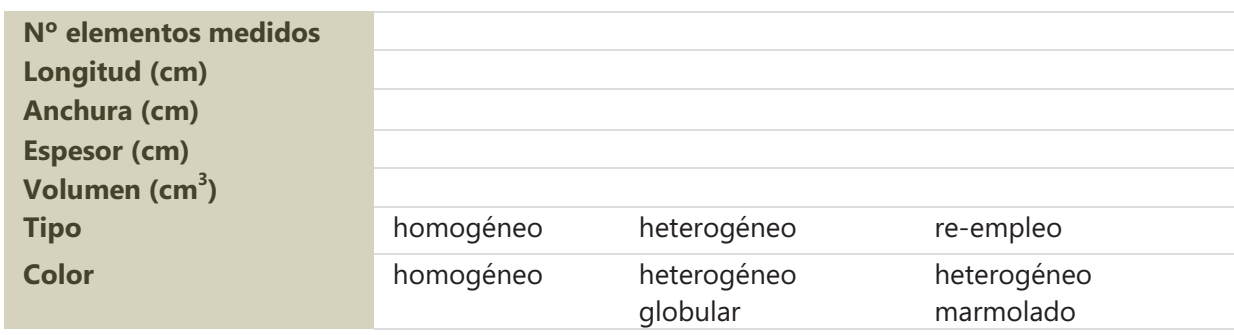

Este apartado es específico para el análisis detallado de los ladrillos localizados en una unidad estratigráfica específica a analizar. Se trata de una parte de la ficha que se estructura fundamentalmente a partir de parámetros métricos, propios de la mensiocronología ("No de elementos medidos", "Longitud", "Anchura", "Espesor", "Volumen")‥ Por otro lado se codifican indicadores del análisis visual como "Tipo" o "Color".

\footnotetext{
${ }^{1}$ Así como se indica en el Cap2.2.2 la mensiocronología emplea datos obtenidos en base al cálculo del desvío estándar (respecto al valor medio de la muestras analizadas) y del gráfico de frecuencia de las muestras analizadas, identificado por una curva gaussiana
} 



\begin{tabular}{l|l} 
Excavación & $\begin{array}{l}\text { "Informe final de los trabajos arqueológicos de la C/Guillem de } \\
\text { Castro 10-16, de Valencia, Futuro Museo de la Ilustración " }\end{array}$ \\
\hline $\begin{array}{l}\text { Código SIAM } \\
\text { Dirección }\end{array}$ & CGUIQUE \\
Fechas Claves & C/Guillem de Castro 10-16 \\
Procedencia & Ladrillo bajomedieval- S. XIV (U.E. 2141) \\
\hline & funerariar residencial monumental hornos \\
\hline
\end{tabular}

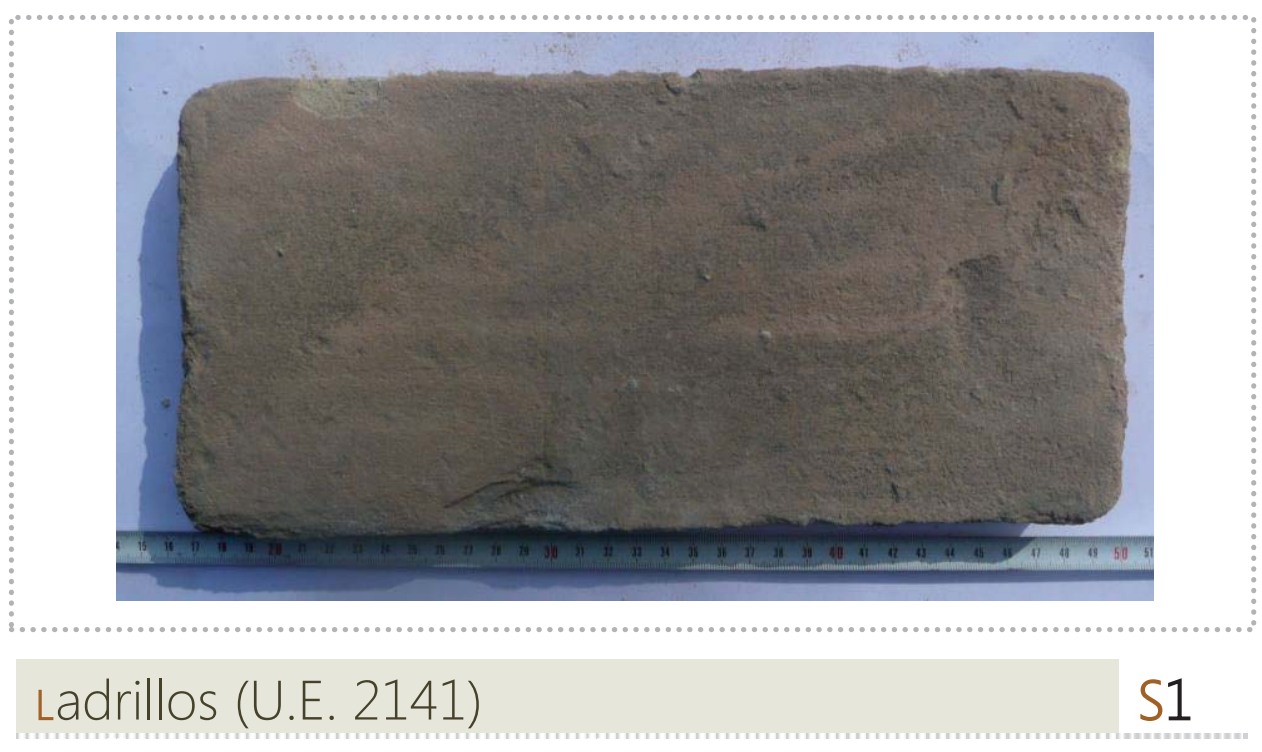

\begin{tabular}{|c|c|c|c|}
\hline $\mathbf{N}^{\circ}$ elementos medidos & 6 & & \\
\hline Longitud (cm) & 30.5 & & \\
\hline Anchura (cm) & 15 & & \\
\hline Espesor $(\mathrm{cm})$ & 3 & & \\
\hline Volumen $\left(\mathrm{cm}^{3}\right)$ & 1601.2 & & \\
\hline Tipo & homogéneo & heterogéneo & re-empleo \\
\hline Color & homogéneo & $\begin{array}{l}\text { heterogéneo } \\
\text { globular }\end{array}$ & $\begin{array}{l}\text { heterogéneo } \\
\text { marmolado }\end{array}$ \\
\hline
\end{tabular}




\section{Datos generales}

\section{Excavación \\ Código SIAM \\ Dirección \\ Fechas Claves \\ Procedencia}

"Informe preliminar estudio arqueológico previo desarrollo en los jardines del Antiguo Hospital General de Valencia" 2GUIQUE

jardines del Antiguo Hospital General de Valencia Ladrillo bajomedieval- S. XIV-para pavimentos (U.E. 2147)

funeraria residencial monumental hornos

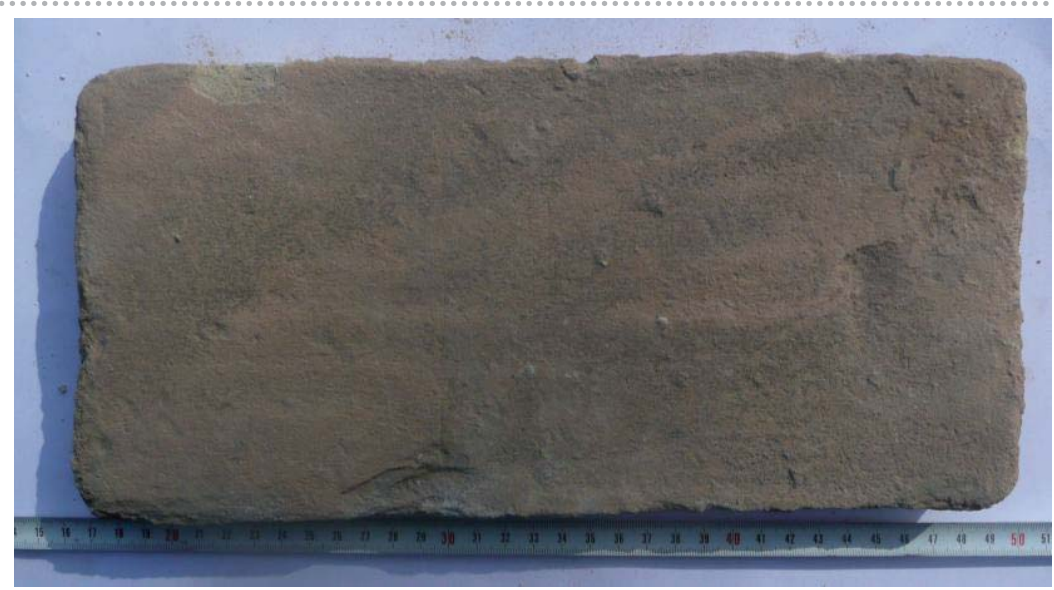

Ladrillos (U.E. 2147)

S2

$\mathbf{N}^{\circ}$ elementos medidos
Longitud $(\mathrm{cm})$
Anchura $(\mathrm{cm})$
Espesor $(\mathrm{cm})$
Volumen $\left(\mathrm{cm}^{3}\right)$
Tipo
Color

\section{6} 30.5 14.5

2.5

1105.6

homogéneo

homogéneo heterogéneo

heterogéneo

globular re-empleo

heterogéneo marmolado 
Datos generales

\section{Excavación \\ Código SIAM \\ Dirección \\ Fechas Claves \\ Procedencia}

"Informe preliminar de la intervención arqueológica en el solar de la Avda Constitución 154, 156,158, y C/ Sagunto 195/97, Valencia" 1SAG195

Avda Constitución 154, 156,158, y C/ Sagunto 195/97

S. XI (U.E. 1624.6)

funeraria residencial monumental hornos

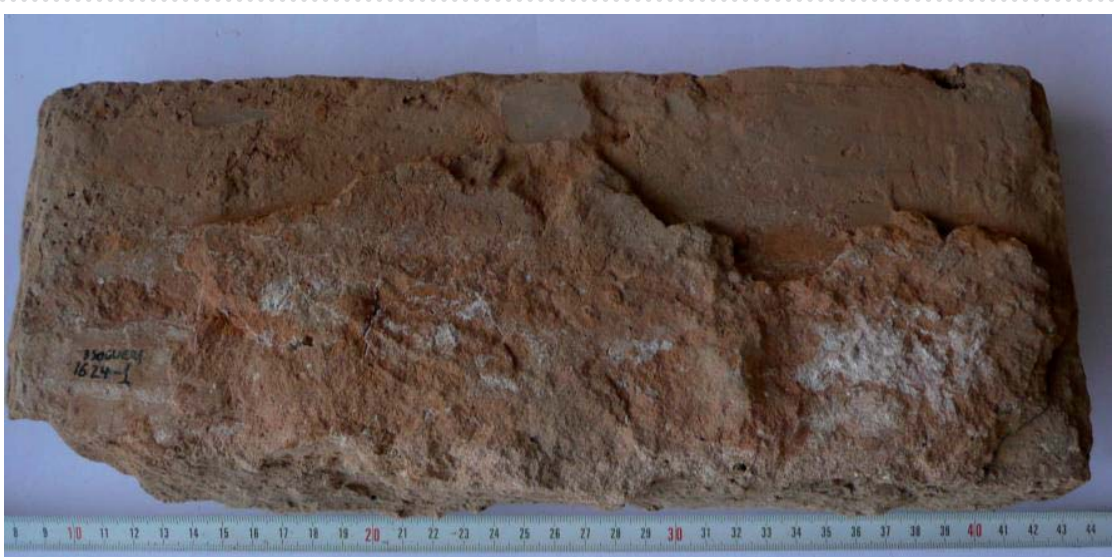

Ladrillos (U.E. 1624)

S3

No elementos medidos
Longitud $(\mathrm{cm})$
Anchura $(\mathrm{cm})$
Espesor $(\mathrm{cm})$
Volumen $\left(\mathrm{cm}^{3}\right)$
Tipo
Color

\section{3}

31

15

4

1860

homogéneo

homogéneo re-empleo

heterogéneo

marmolado 
Datos generales

\section{Excavación \\ Código SIAM \\ Dirección \\ Fechas Claves \\ Procedencia}

"Intervención arqueológica en la C/Virgen de la Misericordia 4" $1 \mathrm{MISO04}$

C/Virgen de la Misericordia 4

S. I-IV d.C.(época romana)

funeraria monumental hornos

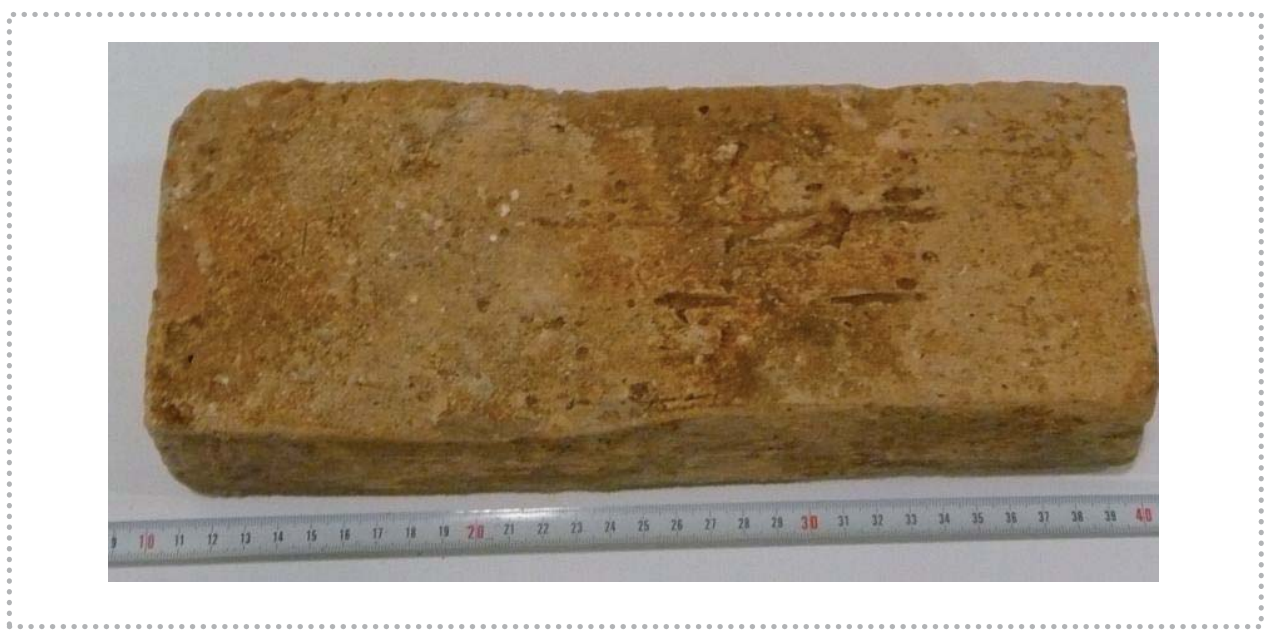

\section{Ladrillos (U.E. 1753)}

$N^{\circ}$ elementos medidos
Longitud $(\mathrm{cm})$
Anchura $(\mathrm{cm})$
Espesor $(\mathrm{cm})$
Volumen $\left(\mathrm{cm}^{3}\right)$
Tipo
Color

13

30

10

6.3

1890

$\begin{array}{lll}\text { homogéneo } & \text { heterogéneo } & \text { re-empleo } \\ \text { homogéneo } & \text { heterogéneo } & \text { heterogéneo } \\ & \text { globular } & \text { marmolado }\end{array}$


Datos generales

\section{Excavación \\ Código SIAM \\ Dirección \\ Fechas Claves \\ Procedencia}

"Intervención arqueológica en la C/Virgen de la Misericordia 4"; $1 \mathrm{MIS} 004$

C/Virgen de la Misericordia 4

S. I-IV d.C.(época romana)

funeraria

residencial

monumental

hornos

Ladrillos (U.E. 1573)

\section{S5}

№ elementos medidos
Longitud $(\mathrm{cm})$
Anchura $(\mathrm{cm})$
Espesor $(\mathrm{cm})$
Volumen $\left(\mathrm{cm}^{3}\right)$
Tipo
Color

6

29.2

10

6.3

1790

homogéneo

heterogéneo

re-empleo

heterogéneo heterogéneo

globular 


\section{Datos generales}

\section{Excavación \\ Código SIAM \\ Dirección \\ Fechas Claves \\ Procedencia}

"Intervención arqueológica en la CNirgen de la Misericordia 4"; $1 \mathrm{MIS} 004$

C/Virgen de la Misericordia 4

S. I-IV d.C.(época romana)

funeraria

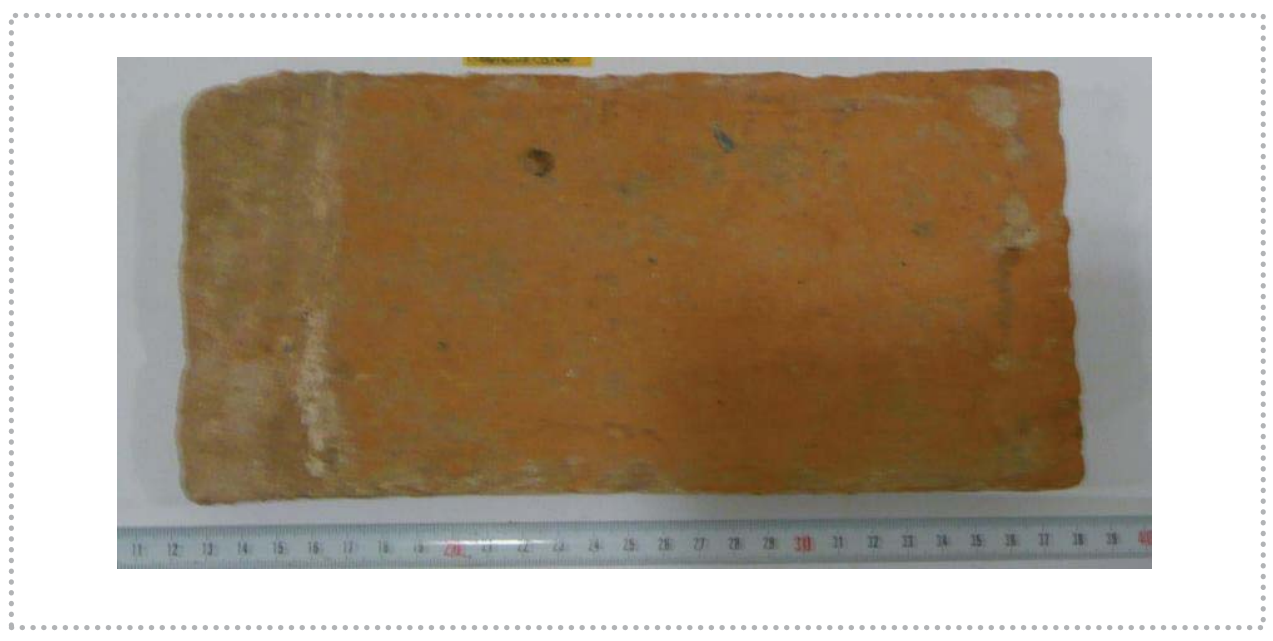

\section{Ladrillos (U.E. 1015)}

$N^{\circ}$ elementos medidos
Longitud $(\mathrm{cm})$
Anchura $(\mathrm{cm})$
Espesor $(\mathrm{cm})$
Volumen $\left(\mathrm{cm}^{3}\right)$
Tipo
Color

3

25

12

2.5

1790

$\begin{array}{lll}\text { homogéneo } & \text { heterogéneo } & \text { re-empleo } \\ \text { homogéneo } & \text { heterogéneo } & \text { heterogéneo } \\ & \text { globular } & \text { marmolado }\end{array}$


Datos generales

\section{Excavación \\ Código SIAM \\ Dirección \\ Fechas Claves \\ Procedencia}

"Informe de los trabajos arqueológicos en la C/Conde de Montores 1-3-5y C/Gobernador Viejo 3,5,7, Valencia" 2MONGOV

C/Conde de Montores 1-3-5C/Gobernador Viejo 3,5,7 Posible S. XIV

funeraria residencial monumental hornos

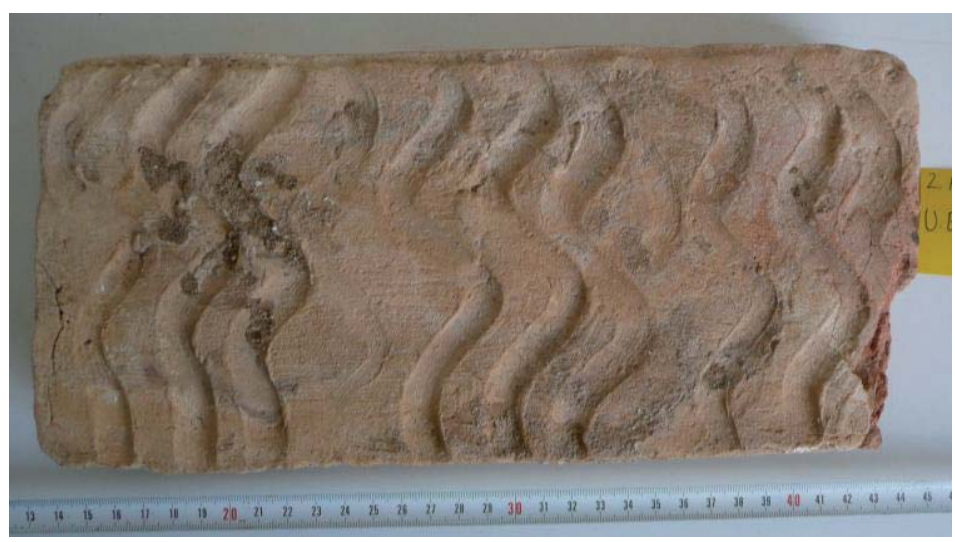

Ladrillos (U.E.5111)

$N^{\circ}$ elementos medidos
Longitud $(\mathrm{cm})$
Anchura $(\mathrm{cm})$
Espesor $(\mathrm{cm})$
Volumen $\left(\mathrm{cm}^{3}\right)$
Tipo
Color

1 31

15

4

1860

\begin{tabular}{cll} 
homogéneo & heterogéneo & re-empleo \\
homogéneo & $\begin{array}{l}\text { heterogéneo } \\
\text { globular }\end{array}$ & $\begin{array}{l}\text { heterogéneo } \\
\text { marmolado }\end{array}$ \\
\hline
\end{tabular}




\section{Datos generales}

\section{Excavación \\ Código SIAM \\ Dirección \\ Fechas Claves \\ Procedencia}

"Informe de los trabajos arqueológicos en la $\mathrm{C} /$ Conde de Montores 1-3-5y C/Gobernador Viejo 3,5,7, Valencia" 2MONGOV

C/Conde de Montores 1-3-5C/Gobernador Viejo 3,5,7, Posible S. XIV

funeraria residencial

monumental

hornos

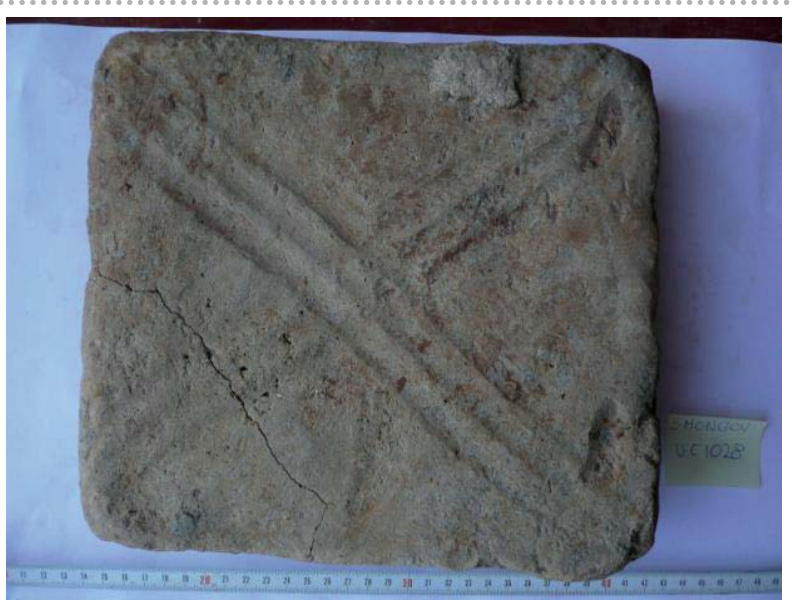

$N^{\circ}$ elementos medidos
Longitud $(\mathrm{cm})$
Anchura $(\mathrm{cm})$
Espesor $(\mathrm{cm})$
Volumen $\left(\mathrm{cm}^{3}\right)$
Tipo
Color

\section{1}

25

23

5 2875

$\begin{array}{lll}\text { homogéneo } & \text { heterogéneo } & \text { re-empleo } \\ \text { homogéneo } & \begin{array}{l}\text { heterogéneo } \\ \text { globular }\end{array} & \begin{array}{l}\text { heterogéneo } \\ \text { marmolado }\end{array}\end{array}$


Datos generales

\section{Excavación \\ Código SIAM \\ Dirección \\ Fechas Claves \\ Procedencia}

"Intervención arqueológicas C/Paz 28 esq. C/Juan de Ribera, Valencia"

PAZ RIB95

C/ Paz 28 esq. C/Juan de Ribera

S. XIV monumental

hornos

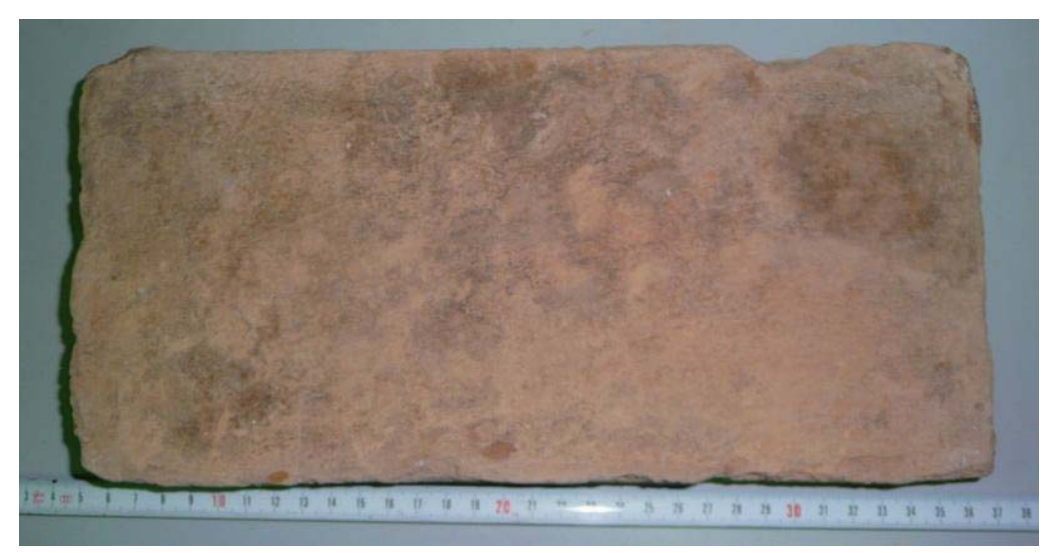

Ladrillos (U.E.1105)

№ elementos medidos
Longitud $(\mathrm{cm})$
Anchura $(\mathrm{cm})$
Espesor $(\mathrm{cm})$
Volumen $\left(\mathrm{cm}^{3}\right)$
Tipo
Color

2 29.5

14

3.5

1445.5

\begin{tabular}{cll} 
homogéneo & heterogéneo & re-empleo \\
homogéneo & $\begin{array}{l}\text { heterogéneo } \\
\text { globular }\end{array}$ & $\begin{array}{l}\text { heterogéneo } \\
\text { marmolado }\end{array}$ \\
\hline
\end{tabular}


Datos generales

\section{Excavación \\ Código SIAM \\ Dirección \\ Fechas Claves \\ Procedencia}

"Intervención arqueológicas C/Paz 28 esq. C/Juan de Ribera, Valencia"

PAZ RIB95

C/ Paz 28 esq. C/Juan de Ribera

S. XIII

funeraria residencial monumental hornos

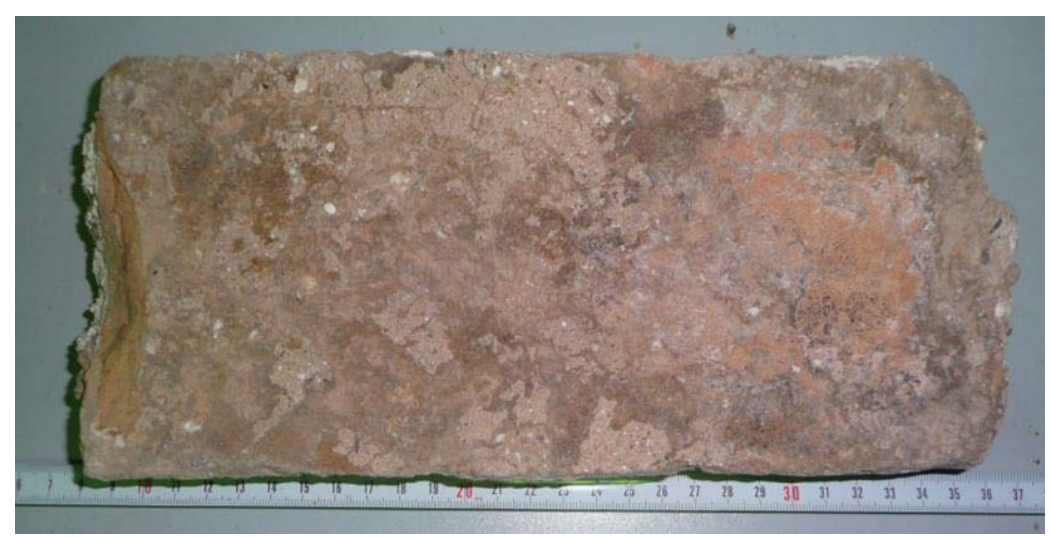

Ladrillos (U.E.1113)

$N^{\circ}$ elementos medidos
Longitud $(\mathrm{cm})$
Anchura $(\mathrm{cm})$
Espesor $(\mathrm{cm})$
Volumen $\left(\mathrm{cm}^{3}\right)$
Tipo
Color

3

23

12

3.1

855.6

$\begin{array}{lll}\text { homogéneo } & \text { heterogéneo } & \text { re-empleo } \\ \text { homogéneo } & \text { heterogéneo } & \text { heterogéneo } \\ & \text { globular } & \text { marmolado }\end{array}$


Datos generales

\section{Excavación \\ Código SIAM \\ Dirección \\ Fechas Claves \\ Procedencia}

"Intervención arqueológicas C/Paz 28 esq. C/Juan de Ribera, Valencia"

PAZ RIB95

C/ Paz 28 esq. C/Juan de Ribera

S. XVI (posible)

funeraria residencial monumental hornos

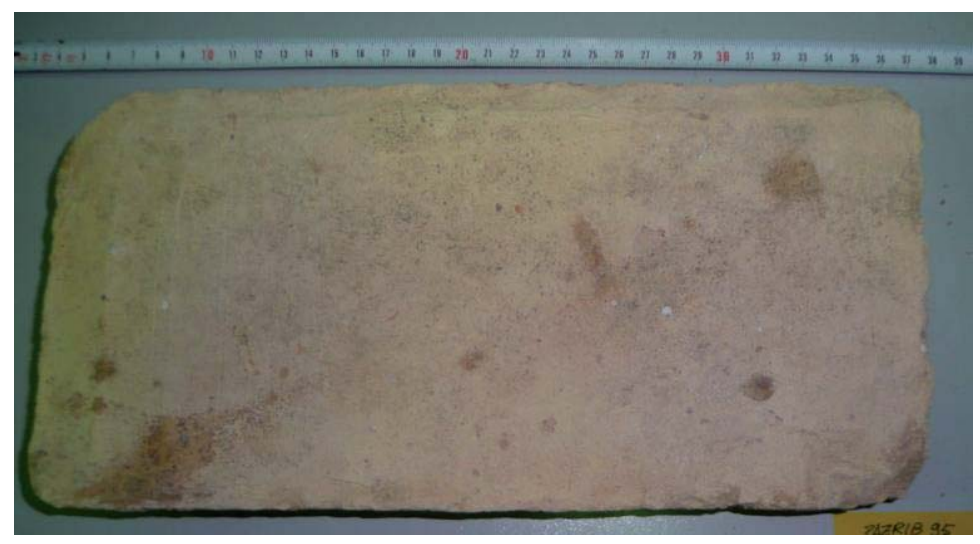

Ladrillos (U.E.1100)

S11

No elementos medidos
Longitud $(\mathrm{cm})$
Anchura $(\mathrm{cm})$
Espesor $(\mathrm{cm})$
Volumen $\left(\mathrm{cm}^{3}\right)$
Tipo
Color

$N^{\circ}$ elementos medidos 3 30 14.5

3.7

1609.5

homogéneo

homogéneo re-empleo

heterogéneo marmolado 
Datos generales

\section{Excavación \\ Código SIAM \\ Dirección \\ Fechas Claves \\ Procedencia}

"Intervención arqueológicas C/Paz 28 esq. C/Juan de Ribera, Valencia"

PAZ RIB95

C/ Paz 28 esq. C/Juan de Ribera

S. XVI (posible)

funeraria residencial

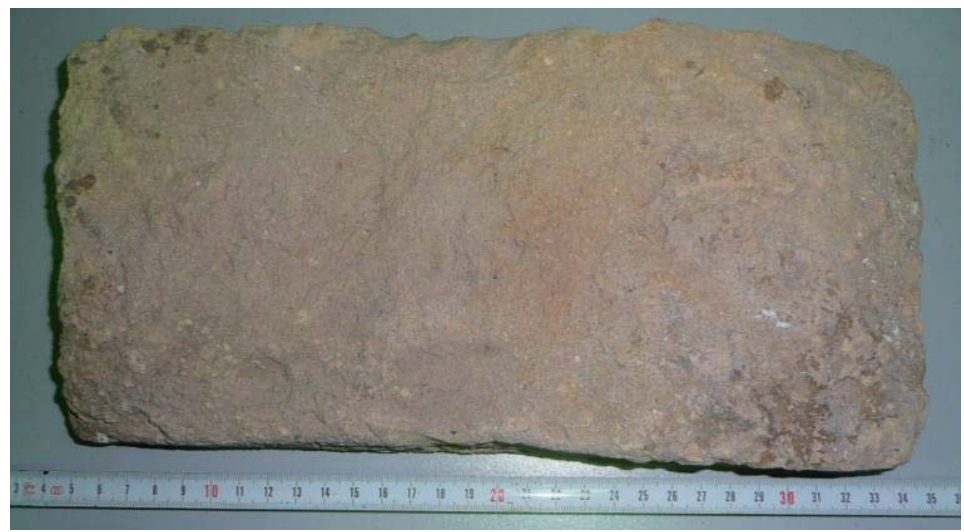

$\mathbf{N}^{\circ}$ elementos medidos
Longitud $(\mathrm{cm})$
Anchura $(\mathrm{cm})$
Espesor $(\mathrm{cm})$
Volumen $\left(\mathrm{cm}^{3}\right)$
Tipo
Color

2

28

13.5

4

1512

\begin{tabular}{lll} 
homogéneo & heterogéneo & re-empleo \\
homogéneo & $\begin{array}{l}\text { heterogéneo } \\
\text { globular }\end{array}$ & $\begin{array}{l}\text { heterogéneo } \\
\text { marmolado }\end{array}$ \\
\hline
\end{tabular}


Datos generales

\section{Excavación \\ Código SIAM \\ Dirección \\ Fechas Claves \\ Procedencia}

"Intervención arqueológicas C/Paz 28 esq. C/Juan de Ribera, Valencia"

PAZ RIB95

C/ Paz 28 esq. C/Juan de Ribera

S. XVI (posible)

funeraria residencial monumental hornos

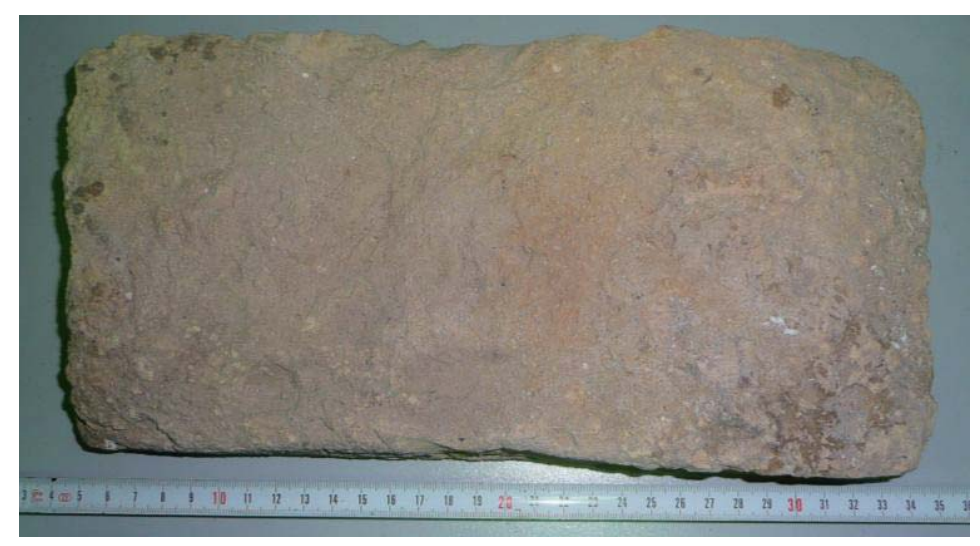

Ladrillos (U.E.1137)

No elementos medidos
Longitud $(\mathrm{cm})$
Anchura $(\mathrm{cm})$
Espesor $(\mathrm{cm})$
Volumen $\left(\mathrm{cm}^{3}\right)$
Tipo
Color

1 28 13.5 4.2 1587.6

\begin{tabular}{lll} 
homogéneo & heterogéneo & re-empleo \\
homogéneo & $\begin{array}{l}\text { heterogéneo } \\
\text { globular }\end{array}$ & $\begin{array}{l}\text { heterogéneo } \\
\text { marmolado }\end{array}$ \\
\hline
\end{tabular}


Datos generales

Excavación
Código SIAM
Dirección
Fechas Claves
Procedencia

"Memoria de las excavaciones arqueológicas realizadas en el solar recayente a la Plaza de Cisneros 6 y C/Zapateros 9 de Valencia" 2SABCIS

Plaza de Cisneros 6 y C/Zapateros 9

S. III

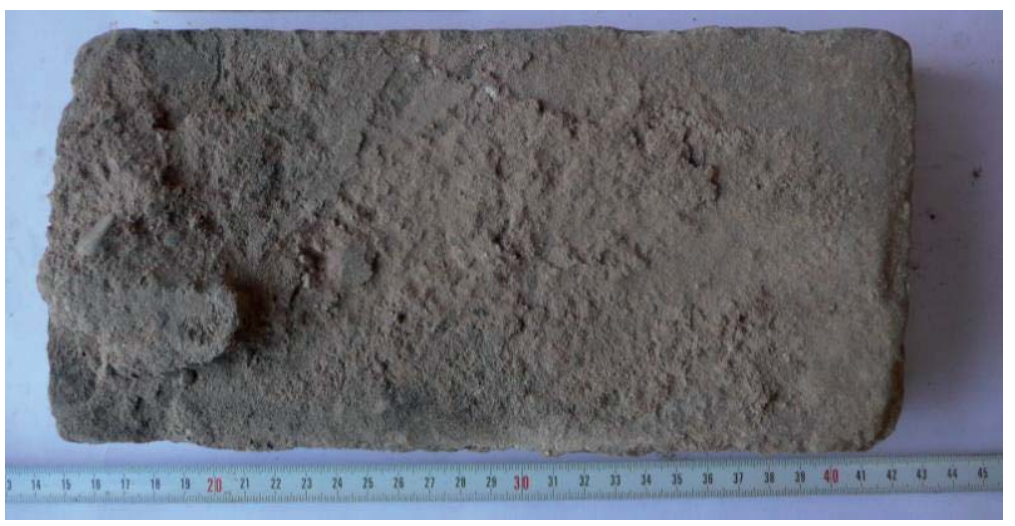

$N^{\circ}$ elementos medidos
Longitud $(\mathrm{cm})$
Anchura $(\mathrm{cm})$
Espesor $(\mathrm{cm})$
Volumen $\left(\mathrm{cm}^{3}\right)$
Tipo
Color

\section{1} 26.5 13 3.5 1205.75

\begin{tabular}{lll} 
homogéneo & heterogéneo & re-empleo \\
homogéneo & $\begin{array}{l}\text { heterogéneo } \\
\text { globular }\end{array}$ & $\begin{array}{l}\text { heterogéneo } \\
\text { marmolado }\end{array}$ \\
\hline
\end{tabular}


Datos generales

\section{Excavación}

Código SIAM

Dirección

Fechas Claves

Procedencia
"Memoria de las excavaciones arqueológicas realizadas en el solar recayente a la Plaza de Cisneros 6 y C/Zapateros 9 de Valencia" 2SABCIS

Plaza de Cisneros 6 y C/Zapateros 9

S. III

funeraria residencial monumental hornos

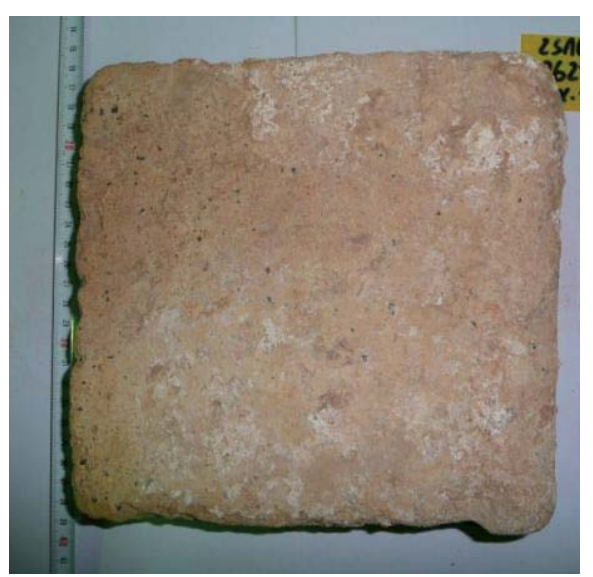

Ladrillos (U.E.2628)

$N^{\circ}$ elementos medidos
Longitud $(\mathrm{cm})$
Anchura $(\mathrm{cm})$
Espesor $(\mathrm{cm})$
Volumen $\left(\mathrm{cm}^{3}\right)$
Tipo
Color

1 20.5

20.5

5.5

2311.3

homogéned

heterogéneo

re-empleo

homogéneo

heterogéneo

heterogéneo marmolado 


\section{Datos generales}

\section{Excavación \\ Código SIAM \\ Dirección \\ Fechas Claves \\ Procedencia}

"Memoria de las excavaciones arqueológicas realizadas en el solar recayente a la Plaza de Cisneros 6 y C/Zapateros 9 de Valencia" 2SABCIS

Plaza de Cisneros 6 y C/Zapateros 9

S. III

funeraria residencial monumental hornos

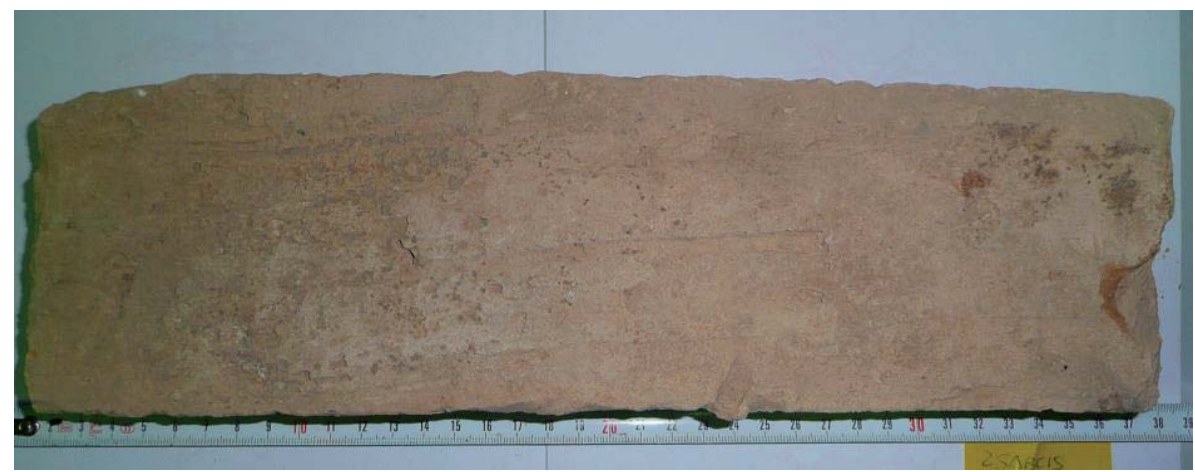

Ladrillos (U.E.2819)

No elementos medidos
Longitud $(\mathrm{cm})$
Anchura $(\mathrm{cm})$
Grueso $(\mathrm{cm})$
Volumen $\left(\mathrm{cm}^{3}\right)$
Tipo
Color

1 33

9.5

3.2

950.4

homogéneo

heterogéneo

re-empleo

homogéneo

heterogéneo

globular heterogéneo

marmolado 


\section{Datos generales}

\section{Excavación \\ Código SIAM \\ Dirección \\ Fechas Claves \\ Procedencia}

"Memoria de las excavaciones arqueológicas realizadas en el solar recayente a la Plaza de Cisneros 6 y C/Zapateros 9 de Valencia" 2SABCIS

Plaza de Cisneros 6 y C/Zapateros 9

S. III

funeraria residencial monumental hornos

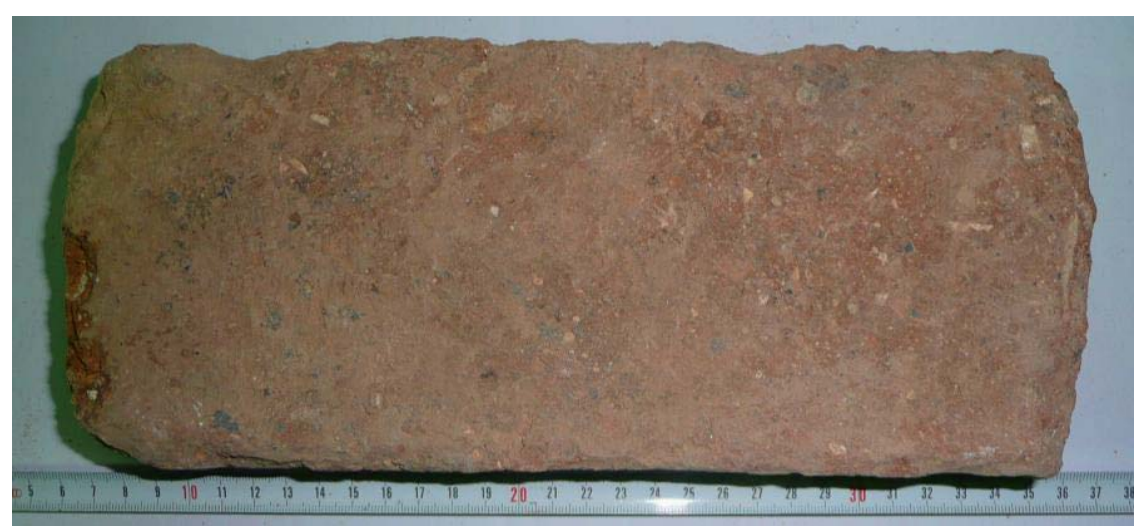

Ladrillos (U.E.2894)

$N^{\circ}$ elementos medidos
Longitud $(\mathrm{cm})$
Anchura $(\mathrm{cm})$
Espesor $(\mathrm{cm})$
Volumen $\left(\mathrm{cm}^{3}\right)$
Tipo
Color

2 26

11

5.5

1573

\begin{tabular}{lll} 
homogéneo & heterogéneo & re-empleo \\
\hline homogéneo & heterogéneo & heterogéneo \\
& globular & marmolado
\end{tabular}


Datos generales

\section{Excavación \\ Código SIAM \\ Dirección \\ Fechas Claves \\ Procedencia}

"Memoria de las excavaciones arqueológicas realizadas en el solar recayente a la Plaza de Cisneros 6 y C/Zapateros 9 de Valencia" 2SABCIS

Plaza de Cisneros 6 y C/Zapateros 9

S. III

funeraria residencial monumental hornos

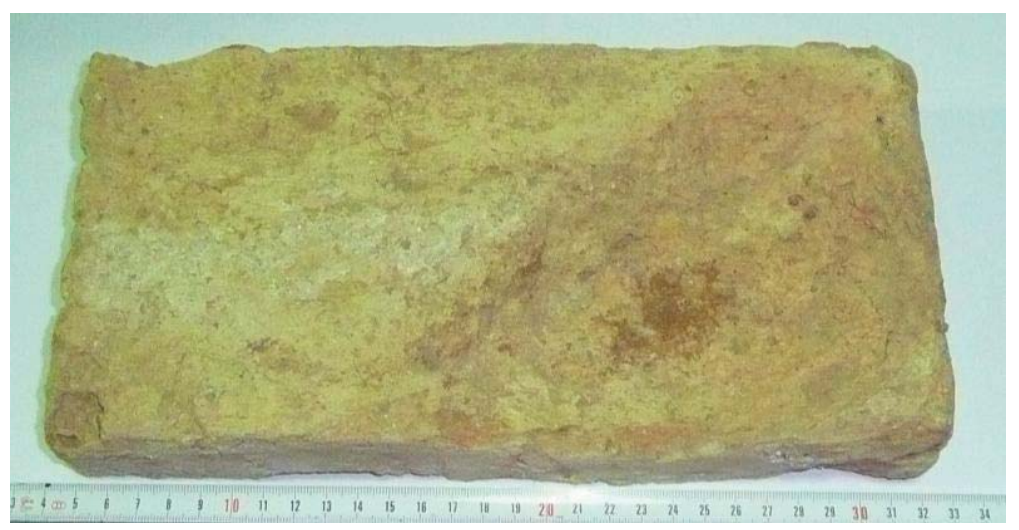

Ladrillos (U.E.2974)

No elementos medidos
Longitud $(\mathrm{cm})$
Anchura $(\mathrm{cm})$
Espesor $(\mathrm{cm})$
Volumen $\left(\mathrm{cm}^{3}\right)$
Tipo
Color

\section{1}

28

13.5

4.7

1776.6

homogéneo

heterogéneo

re-empleo

homogéneo 


\section{Datos generales}

\section{Excavación \\ Código SIAM \\ Dirección \\ Fechas Claves \\ Procedencia}

"Memoria de las excavaciones arqueológicas realizadas en el solar recayente a la Plaza de Cisneros 6 y C/Zapateros 9 de Valencia" 2SABCIS

Plaza de Cisneros 6 y C/Zapateros 9

S. III

funeraria residencial monumental hornos

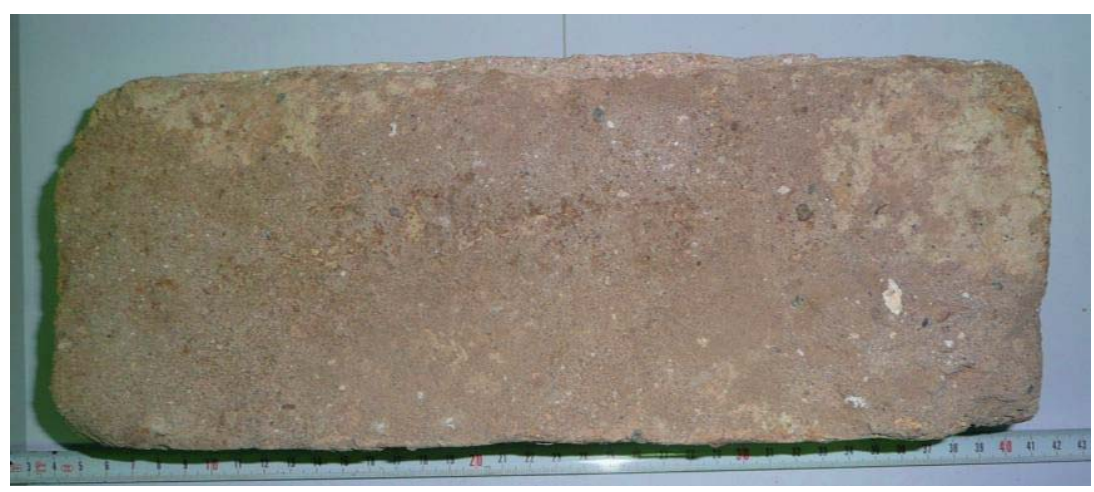

Ladrillos (U.E.3071)

$N^{\circ}$ elementos medidos
Longitud $(\mathrm{cm})$
Anchura $(\mathrm{cm})$
Espesor $(\mathrm{cm})$
Volumen $\left(\mathrm{cm}^{3}\right)$
Tipo
Color

1 31

12.5

8

3100

homogéned

homogéneo heterogéneo

heterogéneo

globular re-empleo

heterogéneo marmolado 

murOSINTRAMUIOS

ANEJO III.

Caracterización y análisis de las fábricas 



\section{III.1. Propiedades químicas, físicas, mecánicas de los ladrillos históricos}

Tanto la tapia valenciana como los ladrillos presentan un denominador común, en su composición, y es su materia prima, la arcilla. Sin embargo, aunque se considere este aspecto, es necesario tener presente el tipo de mortero o, en el caso de la tapia, el tipo de argamasa, cuya unión con el ladrillo es necesaria para garantizar la estabilidad y durabilidad del conjunto. Con estas consideraciones en este apartado se pretenden analizar las características fundamentales de los ladrillos históricos, bien en las fábricas, bien en forma de refuerzo en la tapia.
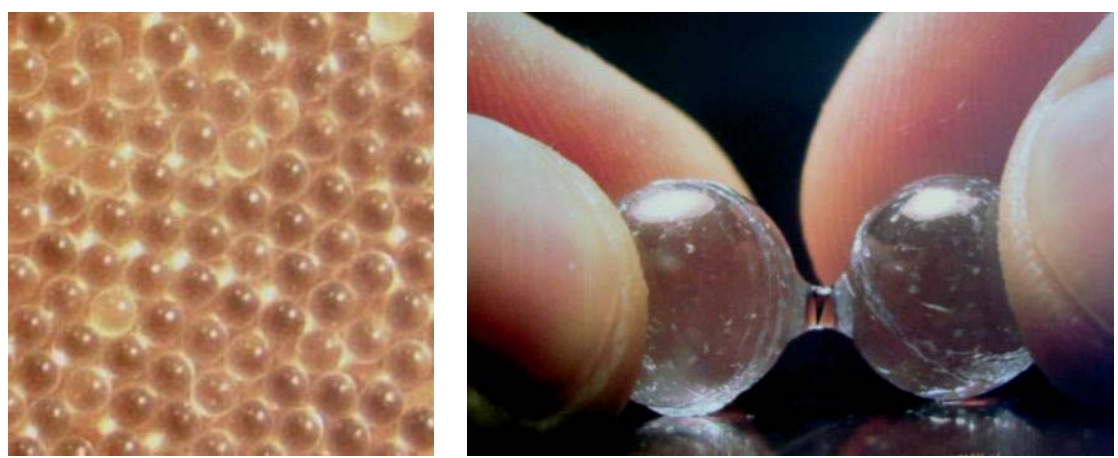

FIG. 9 Ejemplo de los contactos y las relaciones físicas que se establecen entre las partículas de arcilla en fase de hidratación (CRATERRE)

A continuación se van a analizar las propiedades más importantes que caracterizan y definen los ladrillos históricos, analizados en la labor de análisis del centro histórico de Valencia, y que son aspectos 
fundamentales para comprender y prevenir el deterioro de las fábricas.

\section{CARACTERISTICAS MINERALÓGICAS}

PROPIEDADES FÍSICAS

PROPIEDADES HÍDRICAS

PROPIEDADES MECÁNICAS

PROPIEDADES TÉRMICAS

PROPIEDADES DE DURABILIDAD

\section{III.1.1.Características mineralógicas}

Los materiales cerámicos o productos de arcilla cocida presentan bastante variedad en el centro histórico de Valencia, a pesar de su "homogeneidad"de medidas. Aspectos interesantes que se pueden considerar a la hora de proporcionar datos sobre las características de los ladrillos son:
A) La extensión de la vitrificación
B) La homogeneidad en el mezclado de la pasta (enriquecida o empobrecida de algunas partes)
C) La temperatura de cocción (el tipo de reacción entre la matriz de la pasta y los granos minerales)
D) La existencia o no de desengrasantes (mediante el análisis de la morfología y el tamaño de los granos)
E) El grado de selección de la materia prima

Igualmente la existencia o no de una orientación textural o mineralógica microscópica, puede revelar alguna información acerca del método de moldeo (manual cuando se observan orientaciones muy puntuales que corresponden a las huellas de dedos, y de extrusión cuando se observa una clara orientación en toda la pieza). 
Las fases mineralógicas que se pueden encontrar en un material cerámico, en función de la cocción son básicamente de minerales residuales o relictos, y compuestos neo formados. A su vez, dentro de estos últimos se pueden distinguir las denominadas fases de progrado y fases retrógradas o secundarias. Las fases residuales y las de progrado son las que se conocen como el estudio de las paragénesis minerales o conjunto de minerales en equilibrio.
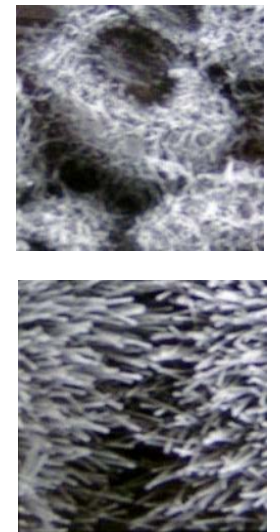
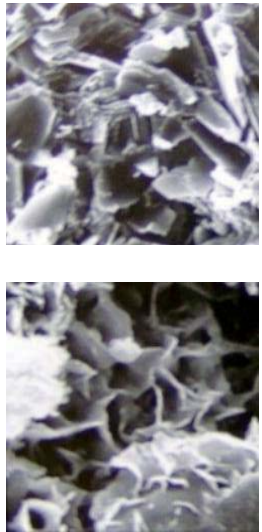
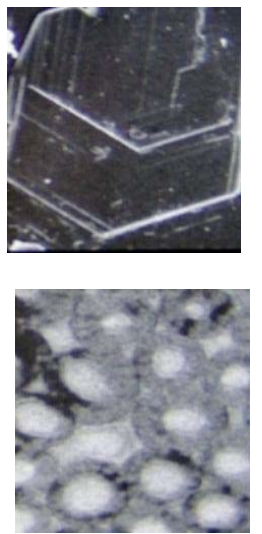

FIG. 10 Ejemplo de mineralogía microscópica de diferentes tipos de arcillas (HOUBENGUILLAUD)

Además de la estimación de la temperatura de cocción mediante estudios mineralógicos, también se podría obtener información mediante la determinación del grado de sintetización o vitrificación, es decir cantidad de vidrio existente que a su vez depende de la mineralogía de la arcilla de partida y de la cocción.

El grado de uniformidad de la cocción se analiza mediante el estudio comparativo en una misma pieza de la mineralogía y textura, en partes superficiales o externas y en las partes centrales o corazón de la misma.

En este sentido, la determinación de la composición química sirve para poner manifiesto la presencia de compuestos que, aún en cantidades pequeñas, por ser fácilmente alterables, pueden afectar a la durabilidad del material en su fase de utilización. 


\section{III.1.2. Propiedades físicas}

El color es la propiedad física que define la "apariencia" estética del ladrillo. La determinación de color se realiza, en primer lugar, para su correcta caracterización, en segundo lugar, para determinar las variaciones de color en estudio de patologías (por ejemplo debidas al ennegrecimiento por efecto de la contaminación atmosférica), y, por último, cuando se realiza una intervención (limpieza, aplicación de productos conservantes, etc.
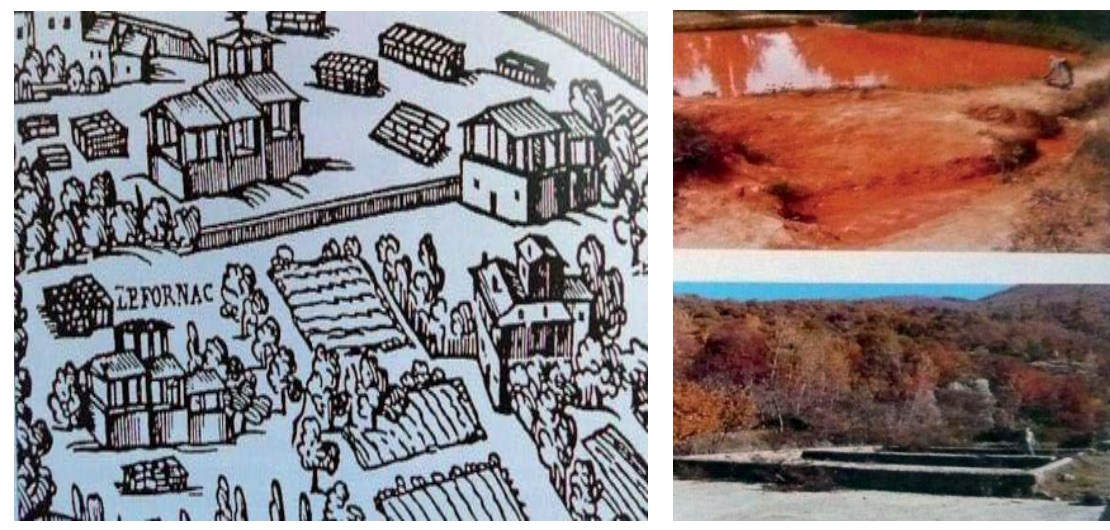

FIG. 11 Fases de extracción, decantación, secado de las arcillas (CARBONARA)

El color de los materiales cerámicos es una propiedad que depende fundamentalmente de la composición química, de la intensidad de la cocción y de las condiciones atmosféricas existentes en el horno decocción.

La determinación del color se puede llevar a cabo mediante cartas o atlas de color (Tablas de Munsell) o bien mediante empleo de espectro colorímetros.

Los colores de los ladrillos oscilan desde el amarillo claro hasta el rojo pardo, según la naturaleza de las arcillas y de la cantidad de impurezas presentes, del contenido de óxidos e hidróxidos de hierro, del contenido en hierro combinado en los silicatos, de la proporción 
de alúmina y del oxido cálcico. En general se puede afirmar que el análisis visual demuestra:

A) Los ladrillos fabricados con arcillas pobres en compuestos de de hierro tienen colores blancuzcos-amarillentos, mientras que las ricas en dichos compuestos, proporcionan colores rojos violetas

B) Las arcillas con hierro y carbonato cálcico producen ladrillos de color anaranjado

C) Las ricas en carbonato cálcico dan tonos amarillentos

D) Si hay materia orgánica los colores serán negruzcos

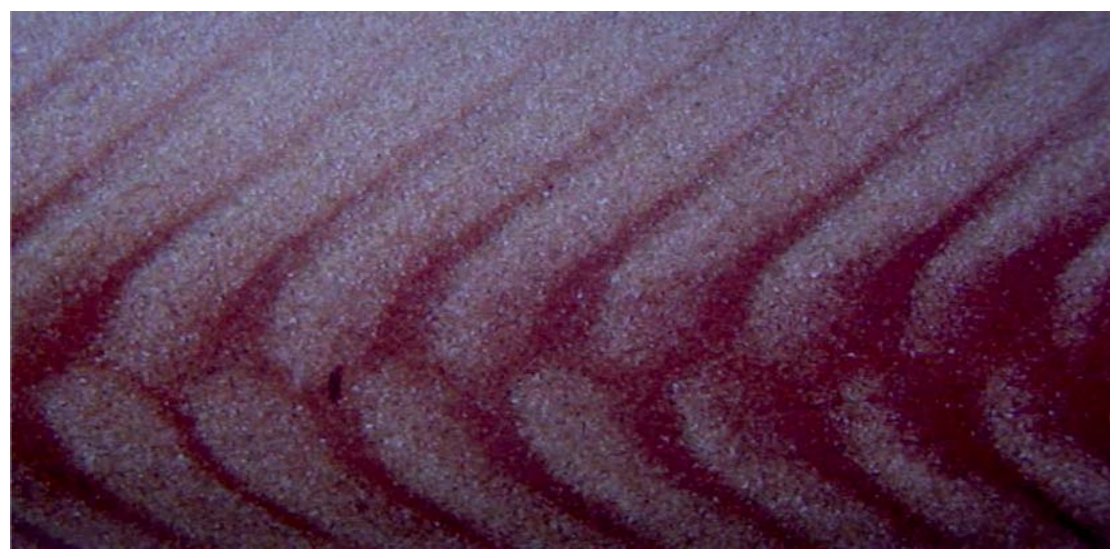

FIG. 12 Arcillas con carbonato cálcico y hierro, factores responsables del color anaranjado de los ladrillos (CRISTINI)

El principal agente colorante en los ladrillos suele ser el óxido férrico, responsable de su característico color rojo intenso. Otros óxidos metálicos que contribuyen a variar el color en las piezas suelen ser:
A) Óxido de manganeso (color marrón pardo)
B) Óxido de cromo (color rosa)
C) Óxido de cobalto y manganeso (color negro)
D) Óxido de antimonio y óxido de titanio (color naranja-amarillo)
E) Óxido de cobre (color verdoso)
F) Óxido de cobalto (color azulado) 
Realmente es importante constatar que la temperatura y las condiciones de cocción en el horno son factores que influyen en las características cromáticas. En general atmósferas oxidantes proporcionan colores claros y atmósferas reductoras, oscuros. La mayoría de los ladrillos adquieren un color rojo en atmósferas oxidantes a 900-1.000 C, temperatura por encima de la cual pueden volverse púrpuras, y a 1.200 C, marrones o grises. En atmosferas reductoras, se obtienen ladrillos violáceos o azules, a menudo con manchas negras.

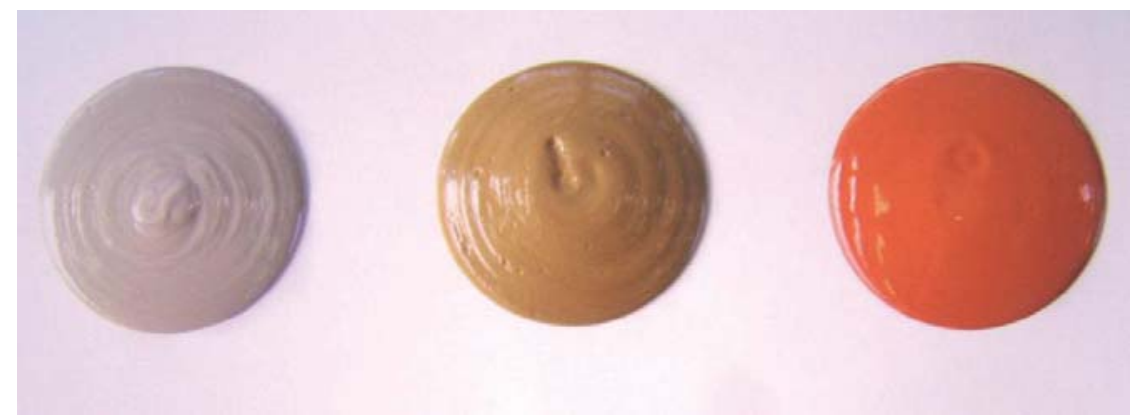

FIG. 13 Ejemplos de pigmentos que determinan el color de las arcillas, como el óxidos de antimonio, manganeso y titanio (CRATERRE)

\section{Densidad aparente y densidad real}

Existen factores diversos que condicionan los valores de densidad: composición de la pasta, método de moldeo, temperatura de cocción, porosidad, entre otros.

Para ladrillos antiguos, el valor de densidad aparente oscila como máximo entre $1.750 \mathrm{~kg} / \mathrm{m}_{3}-1.800 \mathrm{~kg} / \mathrm{m}_{3}$ para el caso concreto de ladrillos macizos valencianos.

\section{Porosidad}

Los ladrillos históricos se caracterizan por ser cuerpos con una porosidad elevada, entre 30 y $40 \%$. Realmente estos valores de porosidad hoy en día son bastante más reducidos en las producciones industriales, gracias a la fase de selección de las 
materias primas y al control de la temperatura de cocción. La porosidad de los ladrillos es, fundamentalmente, función de los constituyentes y del proceso de fabricación. Con respecto a los primeros, cuanto mayor es el tamaño de las partículas de arcilla, mayor es la porosidad, ya que partículas grandes tienden a crear grandes poros.

Igualmente se puede observar que los ladrillos históricos suelen tener una mayor proporción de calcita, lo que genera mayor porosidad (debido a su disociación y liberación de $\mathrm{CO}_{2}$ ) disminuyendo la porosidad a medida que aumenta la proporción de filosilicatos.

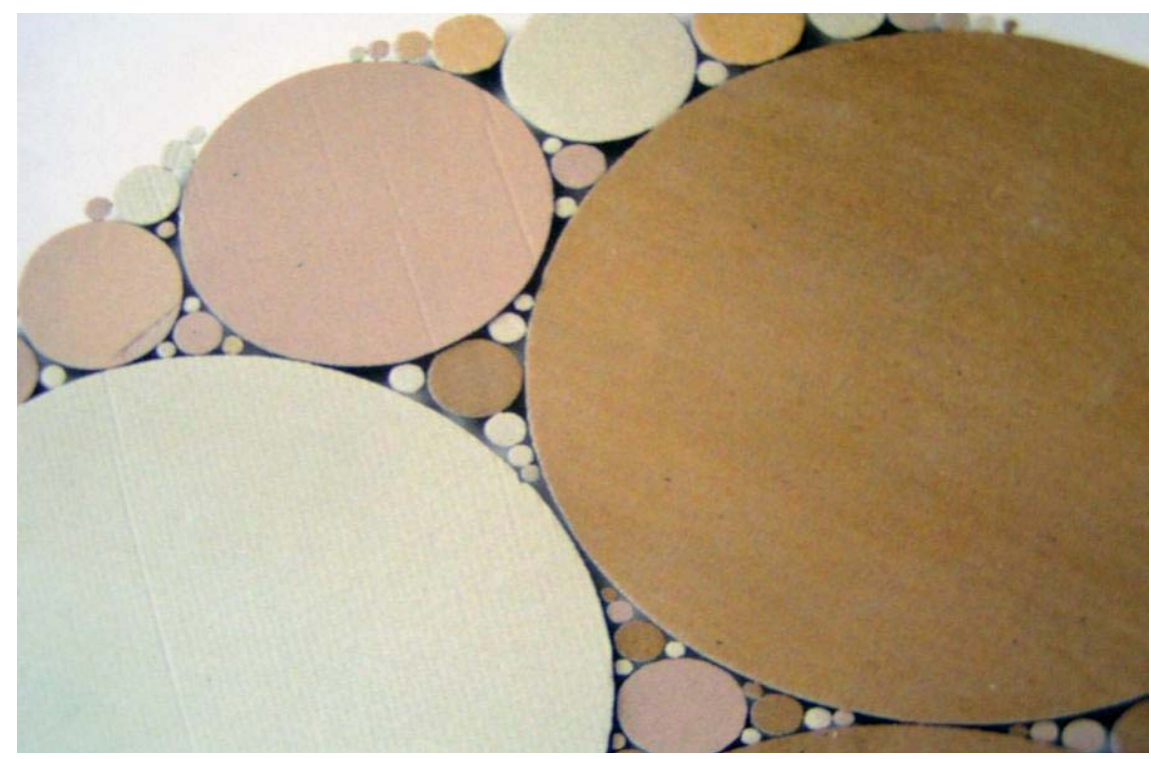

FIG. 14 Visualización de la variabilidad y aleatoriedad de las partículas de arcilla en su distribución granulométrica (CRATERRE)

No se debe olvidar tampoco la influencia, siempre hablando de ladrillos históricos, de la granulometría del desengrasante utilizado en producciones pre-industriales. Una distribución granulométrica adecuada favorece el empaquetamiento de las partículas, proporcionando una mayor compacidad al material. 
Por último la existencia de materia orgánica puede originar huecos en el proceso de su combustión, dando lugar a una porosidad función de la proporción existente y del tamaño de la partícula.

Además de conocer el porcentaje de poros, existen otras series de parámetros de interés como el modelo de sistema poroso, tipo de porosidad, distribución del tamaño de poro, forma del poro, etc.

\section{Influencia del moldeo de la arcilla y la temperatura de cocción}

En el ladrillo histórico el tamaño y la distribución de los poros están condicionados, principalmente por dos factores del proceso de fabricación: el moldeo de la arcilla y la temperatura de cocción. El moldeo manual origina piezas cerámicas de mayor porosidad que aquellas moldeadas por prensado y extrusión.

El aumento de temperatura, origina una mayor proporción de poros grandes y una disminución de poros finos (estableciendo la separación entre tamaños de poros en 0.25 micrón de diámetro).

\section{III.1.3. Propiedades hídricas}

Existen una serie de propiedades que establecen las relaciones existentes entre el material y el agua, tanto en estado líquido como gaseoso, que se denominan propiedades hídricas. A continuación se comentan las propiedades hídricas más interesantes:

\section{Absorción/Desorción de agua}

Además del estudio de la porosidad, que como hemos dicho en los ladrillos históricos es bastante considerable, es importante considerar la proporción de poros susceptibles de saturarse de agua, así como la velocidad a la que el fenómeno se puede producir.

Para cuerpos muy porosos, como los ladrillos que se encuentran en los edificios del centro histórico de Valencia, es frecuente que la mayor parte del agua sea absorbida en los primeros minutos de contacto sólido-agua. Esto se debe a que el agua inicialmente rellena los poros más grandes, causando un rápido incremento en su absorción. Este último parámetro es indicativo de la porosidad de la 
pieza, en función de la composición de la materia prima y del grado de cocción de la misma.

En general, al elevar la temperatura de cocción, se forma una mayor proporción de fase vítrea, disminuyendo la porosidad, y por lo tanto, la absorción; no obstante, cada tipo de arcilla presenta una temperatura máxima de cocción para una absorción determinada. Los valores de absorción de agua oscilan entre 4, 5-30\%; los ladrillos de producción pre-industrial.

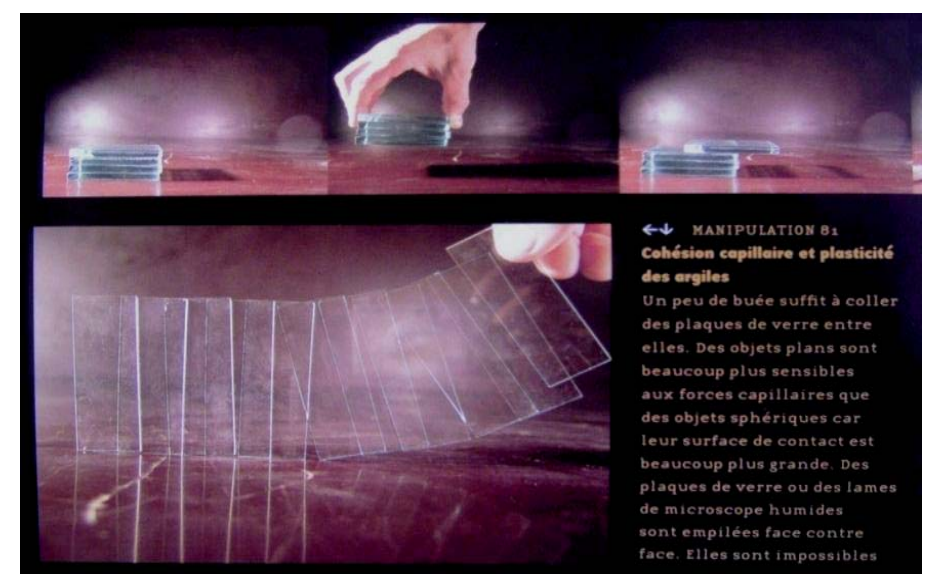

FIG. 15 Ejemplo de cohesión capilar y de plasticidad entre las partículas de arcilla (HOUBEN-GUILLAUD)

Tan importante es que el agua no se introduzca en el material o que si lo hace que sea tan lentamente, como que la eliminación del agua absorbida se realice de forma rápida. El ensayo de desorción, muy útil hablando de ladrillos históricos, permite determinar la capacidad que tiene un material de perder agua por evaporación una vez que se hayan alcanzado sus condiciones de saturación;

\section{Absorción bajo lámina de agua, capilaridad o succión capilar}

En el contexto específico de fábricas de ladrillos históricos es interesante evaluar el valor de grado inicial de absorción o succión capilar; o porque se puede averiguar con precisión uno de los valores que más influyen en la adherencia entre el ladrillo y el mortero. Valores altos de capilaridad aumentan la capacidad del 
ladrillo de absorber el agua del mortero antes de completar el fraguado, reduciendo la adherencia entre ambos materiales, y por lo tanto, disminuyendo la resistencia de la fábrica.

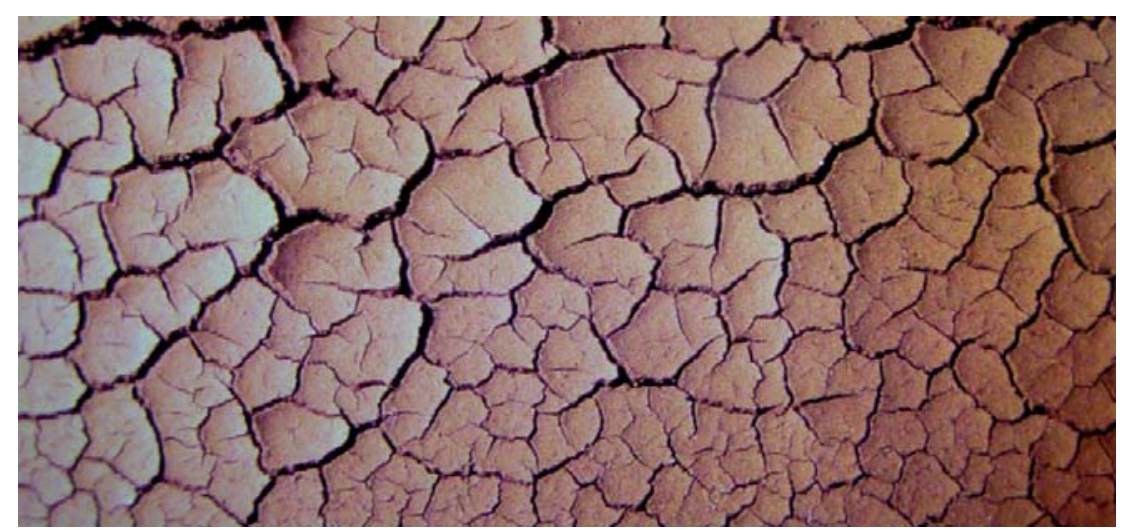

FIG. 16 Variación de las partículas de arcilla en contacto con el agua, durante y después la fase de secado (HOUBEN-GUILLAUD)

Existe una relación directa entre la succión capilar y la porosidad; los ladrillos de baja porosidad son los de capilaridad también más baja y viceversa. Además, el tamaño de los capilares condiciona la velocidad y altura que alcanza el agua: así, que cuanto más finos son, mayor es la presión capilar, más lenta es la absorción capilar, pero mayor la altura alcanzada por el agua.

La capilaridad depende, además, del volumen de los poros comunicados entre sí y de distribución de sus radios de acceso. Por tanto, para un mismo valor de porosidad, la cantidad de agua absorbida por capilaridad será mayor en los ladrillos que presenten un mayor porcentaje de poros finos. Hablando en especifico de valores propios de ladrillos antiguos, los valores de succión capilar, se sitúan entre 0.05 y $0.35 \mathrm{~g} / \mathrm{cm} 2$ x min, y la altura alcanzada por el agua alrededor de 15-20 mm en el primer minuto de exposición ${ }^{1}$. En

\footnotetext{
${ }^{1}$ V.AA. Patologías, técnica de intervención y limpieza de Fábricas de ladrillo, Intemac Ed., Madrid, 2003.p.52
} 
esto sentido siempre sería aconsejable humedecer los ladrillos antiguos, de recolocación en una fábrica, para contrastar los altos parámetros de succión.

1. Liquid

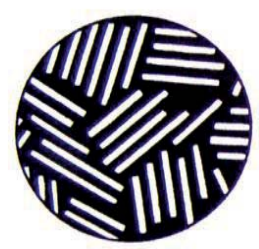

2. Plastic

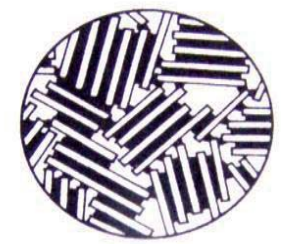

3. Solid

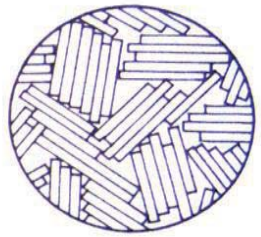

FIG. 17 Variación de las partículas de arcilla en contacto con el agua, durante y después la fase de secado (HOUBEN-GUILLAUD)

\section{Permeabilidad al agua}

Los ensayos de permeabilidad al agua líquida se realizan principalmente en tejas; todavía no estaría mal realizar los mismos ensayos en casos de ladrillos antiguos; en estos casos los valores oscilan entre 160 y $180 \mathrm{~g} / \mathrm{m} 2$, en una exposición de aprox. 24 horas $^{2}$.

\section{Expansión por humedad}

La expansión por humedad o dilatación hídrica de los materiales cerámicos antiguos se debe principalmente al contenido de ciertos materiales arcillosos (cómo el grupo de las esmecitas) o a la presencia de nódulos de cal.

La total o parcial reversibilidad de las dilataciones de humedadsequedad son más significativas en los casos de ladrillos silíceocalcáreos, en cuyas fábricas las juntas de dilatación deberían colocarse en intervalos de $7 / 9 \mathrm{~m}$. En el caso de ladrillos antiguos con contenido alto en arcilla, sería mejor dejar una separación entre 12$18 \mathrm{~m}^{3}$, tanto para la expansión hídrica, como para expansiones de otro tipo.

\footnotetext{
2 ÁlVAREZ DEL BUERGO M., GONZÁLEZ LIMÓN T., Manual de diagnosis y tratamiento de materiales pétreos y cerámicos, COAAT, Barcelona, 1997, p.121
} 


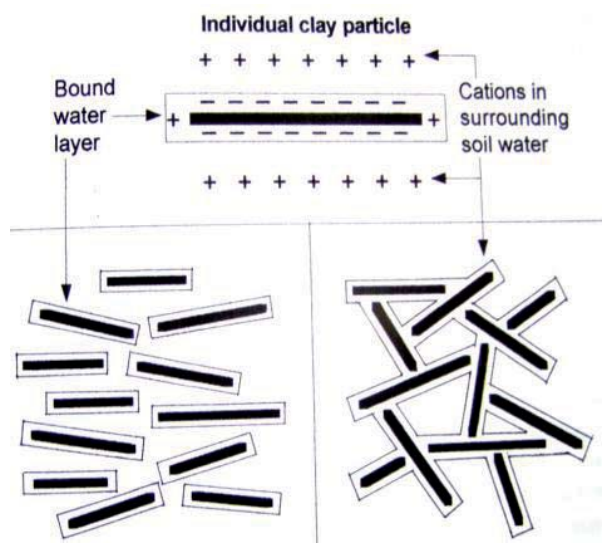

FIG. 18 Diferencia entre partículas de arcilla, antes y después del proceso de mezcla con agua y cocción (HOUBEN-GUILLAUD)

\section{III.1.4. Propiedades mecánicas}

La resistencia mecánica es una de las propiedades más características de los ladrillos y, por tanto, es la propiedad que se determina con más frecuencia. Los materiales frágiles, entre los cuales se encuentra el ladrillo, resisten mejor los esfuerzos a compresión que a tracción. A igual que para los materiales pétreos, se cumple que cuanto menor es el tamaño de grano del material cerámico, mayor es su resistencia mecánica, y, por el contrario, ésta disminuye con el aumento de porosidad y de contenido de agua.

Por el otro lado, se observa que los ladrillos con elevada resistencia mecánica y baja porosidad, pero con un diámetro de poro medio inferior a 1-2 micrón, son menos durables que aquellos con baja resistencia mecánica y mayor porosidad, debido a que presentan un tamaño de poros superior a 1-2 micrón ${ }^{4}$.

\section{Resistencia a compresión}

Los ladrillos se emplean normalmente para trabajar a compresión y como consecuencia, éste es el ensayo que se realiza con mayor frecuencia en ladrillos históricos y la propiedad más requerida por

\footnotetext{
${ }^{3}$ Op. Cit. AMOROSO G. (2002), p.114

${ }^{4}$ Op. Cit. ÁlVAREZ DEL BUERGO M., GONZÁLEZ LiMÓN T. (1997), p.112
} 
sus empleos estructurales. Las tensiones admisibles oscilan de $1 / 6$ a $1 / 4$ de las tensiones de rotura, que alcanzan valores de 5 a 300 $\mathrm{Kp} / \mathrm{cm} 2$. Los valores de resistencia a compresión, en el caso concreto de edificios históricos oscilan entre $15-300 \mathrm{Kp} / \mathrm{cm}^{5}$.

\section{Resistencia a tracción}

En cuanto a resistencia a tracción, esta función, tanto de la resistencia de los granos minerales y de la matriz que los une, como del área interfacial entre los minerales. El esfuerzo a tracción de los materiales de construcción porosos (aire, agua, resina, etc...).

El ladrillo no es un material diseñado para soportar esfuerzo a tracción. Cuando se somete un elemento constructivo, un muro de fábrica, a una compresión uniforme, generalmente se desarrollan grietas paralelas al eje de carga, resultado de los esfuerzos de tracción perpendiculares a la compresión principal. La resistencia a tracción y esfuerzo cortante del ladrillo es alrededor de 1/2 o 1/3 de la resistencia a compresión. ${ }^{6}$

\section{Resistencia a flexión}

Cuando un ladrillo histórico está sometido a flexión es necesario su correcto dimensionamiento para evitar los esfuerzos de tracción que se producirán en algunas zonas. Los valores de resistencia a flexión de los ladrillos antiguos oscilan entre 30/80 Kp/cm2 ${ }^{7}$.

\section{Módulo de Resistencia o Módulo de Young}

Es un índice de rigidez relacionado con la resistencia a compresión. El módulo de elasticidad de los ladrillos es normalmente superior a 20X10 elevado a la cuarta potencia por $\mathrm{cm}^{8}$.

\section{Coeficiente o Módulo de Poissón}

Es la relación entre las deformaciones unitarias (trasversal y longitudinal) es adimensional; en el caso de una fábrica de ladrillos

\footnotetext{
${ }^{5}$ Op. Cit. PEDEMONTE- FORNARI (2003) p.124

${ }^{6}$ Op. Cit. ACCARDO- VIGILIANO (1999) p.87

${ }^{7}$ Op. Cit. PEDEMONTE- FORNARI (2003) p.132

${ }^{8}$ Op. Cit. ALESSANDRINI-FABBRI (2000) p.119
} 
pre-industriales de buena calidad es de aproximadamente $0.25^{9}$, teniendo en cuenta un módulo de elasticidad transversal $G=0.4 E_{1}$ siendo E el módulo de elasticidad citado.

\section{Dureza superficial}

La dureza del ladrillo depende de la dureza de cada una de los minerales que constituyen el producto cerámico y de cohesión entre ellos. Existen varios métodos para la determinación de la dureza superficial de un material; dureza por rayado, dureza por abrasión, dureza por rebote y dureza por penetración o micro dureza Knoop ${ }^{10}$.

\section{Propiedades térmicas}

Todos los materiales de construcción son susceptibles de dilatarse con variaciones de temperatura. Esta propiedad, en los productos de arcilla, depende de la materia de origen, y del incremento de Temp ${ }^{11}$.

\section{III.1.5. Propiedades de durabilidad}
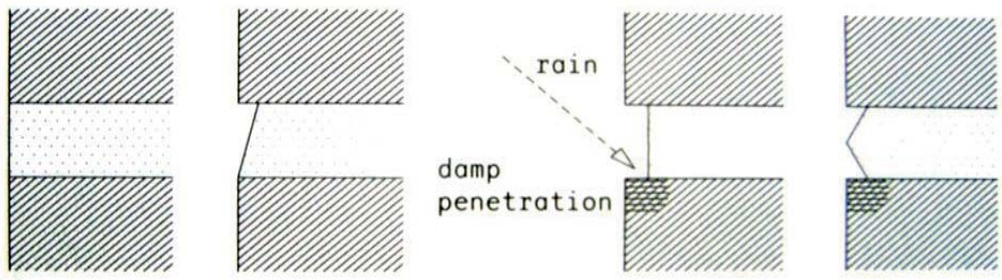

FIG. 19 Juntas correctas (izquierda) o incorrectas (derecha) que favorecen una posible penetración de agua en la fábrica (DESPLAZES)

Los materiales cerámicos, como otros materiales de construcción, se encuentran sometidos a la acción de los factores medioambientales; por ello, es importante conocer la alterabilidad de estos productos, mediante ensayos de cristalización de sales, humedad, sequedad, etc. ${ }^{12}$.

\footnotetext{
9 DESPLAZES A., Constructing Architecture: Materials, Processes, Structures, Birkauser Verlag, Berlin, 2006, p.234

${ }^{10}$ Op. Cit. FRANCESCHI-GERMANI (2007) p.45-52

${ }^{11}$ Op. Cit. ACCARDO- VIGILIANO (1999) p.83

12 Op. Cit. ALESSANDRINI- FABBRI (2000) p.123-26
} 


\section{III.2. Criterios para el estudio de ladrillos y morteros}

Para examinar con detalle las fábricas históricas de la zona intramuros de la ciudad de Valencia se ha considerado necesario realizar una caracterización general de materiales, tras un muestreo significativo de edificios, analizados en el marco de la tesis.

La selección de estas muestras ha sido un proceso complejo, debido a diferentes factores inhibidores. De hecho se debe considerar que la extracción de fragmentos, tanto de mortero cómo de ladrillo, es un proceso delicado que implica una pérdida de estratos y materialidad de las fábricas aunque ésta sea mínima. Esta circunstancia complica la selección de partes de fábricas y recogida de las mismas en edificios emblemáticos y monumentales ${ }^{1}$.

Por otro lado, las diferentes intervenciones, reparaciones, rejuntados y modificaciones que han sufrido las fábricas del centro histórico de la ciudad de Valencia no facilitan la selección de materias primas auténticas y ejemplificativas de las construcciones históricas.

Así dada la imposibilidad de extraer muestras en conjuntos monumentales o protegidos y la dificultad en seleccionar y distinguir partes que pertenecen a estratos primigenios del construido, se ha limitado la toma de muestras al listado de edificios enumerado a continuación.

\footnotetext{
${ }^{1}$ En el caso de conjuntos monumentales, como por ejemplo en el caso de la extracción de la muestra Xd65 (Iglesia de la Virgen de los Desamparados) se han seleccionado zonas que ya habían sido empeladas para catas en fase de obras o en inspecciones.
} 


\begin{tabular}{|c|c|}
\hline \multicolumn{2}{|c|}{ Barrio del Carmen } \\
\hline Ca 30 & Pza. Navarro no 2-7 \\
\hline Ca 32 & C/ Mare Vella no 12 \\
\hline Ca 82 & C/ Adoberies n055 \\
\hline Ca 85 & Pza. Navarro no 1 \\
\hline $\mathrm{Cb} 55$ & C/ Quart no 16 \\
\hline $\mathrm{Cb} 63$ & C/ Quart nº $16-$ C/ Rei en Jaume \\
\hline $\mathrm{Cb} 65$ & C/ Guillén de Castillo s/n \\
\hline $\mathrm{Cd} 118$ & C/ Na Jordana no 15 \\
\hline Ce 24 & C/ d'Alt n² 24 \\
\hline Ce 62 & C/ Sto. Tomás no 10 \\
\hline Ce 93 & C/ D'En Borras no 8 \\
\hline Ce 101 & Pza. de la Cruz s/n \\
\hline Cf 30 & C/ Gutemberg s/n \\
\hline Cf 42 & C/ Gutemberg s/n esq. C/ Lliria s/n \\
\hline Cf 44 & C/ Gutemberg no 10 \\
\hline $\mathrm{Cg} \mathrm{01a}$ & Pza. Carmen s/n \\
\hline $\mathrm{Cg} 14$ & Pza. Portal Nuevo no 6 \\
\hline $\mathrm{Cg} 48 \mathrm{a}$ & Pza. Autor no 12 \\
\hline $\mathrm{Cg} 48 \mathrm{~b}$ & Pza. Autor no 12 \\
\hline \multicolumn{2}{|c|}{ Barrio de S. Francesc } \\
\hline Fa $153 \mathrm{C}$ & Pza. Picadero de dos Aguas $\mathrm{s} / \mathrm{n}$ \\
\hline \multicolumn{2}{|c|}{ Barrio de Velluters } \\
\hline Va 34a & C/Balmes no 29 \\
\hline Va 34b & C/Balmes no 29 \\
\hline Va 82 & C/ Exarchs no 3 \\
\hline Va 119 & C/ Lopez de Rueda s/n \\
\hline \multicolumn{2}{|c|}{ Barrio de La Xeu/Serea } \\
\hline $\mathrm{Xa} 74$ & C/ Serrano no 18 \\
\hline Xc 78 & Pza. Conde del Real n³ \\
\hline $\mathrm{xd} 65$ & Pza. Decimo Julio Bruto s/n \\
\hline $\mathrm{Xe} 14$ & C/ Avellanas no 5 \\
\hline $\mathrm{Xg} 74$ & C/ Engordo no 25 \\
\hline
\end{tabular}


En los diferentes casos de estudio analizados se ha procedido a la selección de muestras ${ }^{2}$, numerando las mismas procedentes de los ladrillos con código (1) y las procedentes de mortero con código (2). Por lo tanto se han podido extraer y clasificar:

\section{Muestras de ladrillos}

Barrio del Carmen: Ca 30/1, Ca 32/1, Ca 82/1, Ca 85/1, Cb 55/1, Cb 63/1, Cb 65/1, Cd 118/1, Ce 24/1, Ce 62/1, Ce 93/1, Ce 101/1, Cf 30/1, Cf 42/1, Cf 44/1, Cg 01a/1, Cg 14/1, Cg 48a/1, Cg 48b/1 Barrio del S. Francesc: Fa 153c/1

Barrio de Velluters: Va 34a/1, Va 34b/1, Va 82/1, Va 119/1 Barrio de la Xeu/Serea: Xa 74/1, Xc 78/1, Xd 65/1, Xe 14/1, Xg 74/1

\section{Muestras de morteros}

Barrio del Carmen: Ca 30/2, Ca 32/2, Ca 82/2, Ca 85/2, Cb 55/2, Cb 63/2, Cd 118/2, Ce 62/2, Ce 93/2, Cf 30/2, Cf 42/2, Cf 44/2, Cg 01a/2, Cg 14/2, Cg 48a/2, Cg 48b/2

Barrio de S. Francesc: Fa 153 C/2a, Fa 153C/2b

Barrio de Velluters: Va 34a/2, Va 34b/2, Va 82/2, Va 119/2

Barrio de la Xeu/Serea: Xa 74/2, Xc 78/2, Xd65/2, Xe 14/2, Xg 74/2

El objeto de la selección in situ de estos fragmentos/muestras es caracterizar los materiales, con el fin de aportar datos útiles sobre el estado actual de los mismos y establecer comparaciones entre los

Los criterios empleados para la selección de las muestras han surgido cruzando el análisis documental (comprobación de la falta de documentación explícita sobre reparaciones e intervenciones) junto con una escrupulosa inspección visual. Para ello se ha comprobado in situ la integridad del mortero, la profundidad de la junta de asiento, la compacidad y unidad de la fábrica, la falta de rejuntados adheridos y de parcheados de ladrillos. 
distintos tipos de morteros y arcillas, sean de viviendas como de entornos monumentales, y obtener datos relativos a los procesos de cocción/preparación de diferentes materias primas y acabados. Tras la selección de las muestras se ha procedido a su catalogación, análisis y agrupación según semejanzas principalmente constitutivas y visuales. De esta manera se han podido establecer 6 grandes agrupaciones según el análisis cromático y visual de las muestras:

\begin{tabular}{|c|c|}
\hline \multicolumn{2}{|c|}{ Análisis visual de muestras de ladrillo } \\
\hline $\begin{array}{l}\text { Ladrillos amarillentos } \\
\text { (Munsell } 8 / 5 \mathrm{Y} / 3^{3} \text { ) }\end{array}$ & $\begin{array}{l}\text { Ce93/1, Ce101/1, Cf42/1, Cg01a/1, } \\
\text { Fa153c/1, Xd65/1，Xa74/1, Xg74/1, } \\
\text { Va34b/1 }\end{array}$ \\
\hline $\begin{array}{l}\text { Ladrillos anaranjados } \\
\text { (Munsell 5/5YR/6) }\end{array}$ & $\begin{array}{l}\text { Ca82/1, Cb55/1, Cb63/1, Ce62/1, } \\
\text { Cf30/1, Cg14/1, Xc78/1, Va34a/1 }\end{array}$ \\
\hline $\begin{array}{l}\text { Ladrillos pardos } \\
\text { (Munsell 5/2.5YR/8) }\end{array}$ & $\begin{array}{l}\text { Ca 30/1, Ca 32/1, Ca85/1, Cb6571, } \\
\text { Cd118/1, Ce2471, Cg48a/1;Cg48b/1, } \\
\text { Xe14/1, Va82/1, Va119/1, Cf 44/1 }\end{array}$ \\
\hline
\end{tabular}
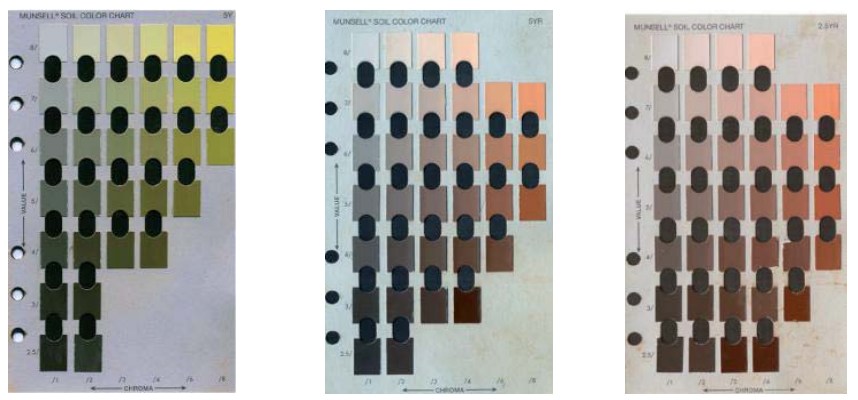

FIG. 20 Atlas of the Munsell Color System, identificación de ladrillos amarillentos (Munsell 8/5Y/3), ladrillos anaranjados (Munsell 5/5YR/6), ladrillos pardos (Munsell 5/2.5YR/8) (CRISTINI)

\footnotetext{
${ }^{3}$ El Sistema de Color de Munsell fue elaborado por el pintor y profesor de arte Albert Henry Munsell en su libro Atlas of the Munsell Color System (Atlas del sistema de color Munsell) en el año 1915. Se basa en una disposición ordenada en sólido tridimensional formado por tres ejes correspondientes a TRES códigos: tono (la longitud de onda dominante del color y la cualidad que lo distingue de los demás), al valor (claridad u oscuridad) y a la saturación (intensidad o pureza). (traducido de la página web de" Munsell Color Science Laboratory " www.mcsl.com)
} 


\begin{tabular}{|c|c|}
\hline \multicolumn{2}{|c|}{ Análisis visual de muestras de mortero } \\
\hline $\begin{array}{l}\text { Morteros oscuros } \\
\text { (Munsell 4/10YR/6) }\end{array}$ & $\mathrm{Cb} 63 / 2, \mathrm{Cd} 118 / 2, \mathrm{Cg} 48 \mathrm{~b} / 2$ \\
\hline $\begin{array}{l}\text { Morteros grisáceos } \\
\text { (Munsell 6/10YR/4) }\end{array}$ & 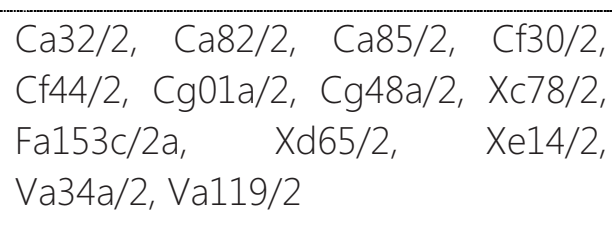 \\
\hline $\begin{array}{l}\text { Morteros claros } \\
\text { (Munsell 8/10YR/2) }\end{array}$ & $\begin{array}{l}\text { Ca30/2, Cb55/2, Ce62/2, Ce93/2, } \\
\text { Cf42/2, Cg14/2, Fa153c/2b, Xa74/2, } \\
\text { Xg74/2, Va34b/2, Va82/2 }\end{array}$ \\
\hline
\end{tabular}
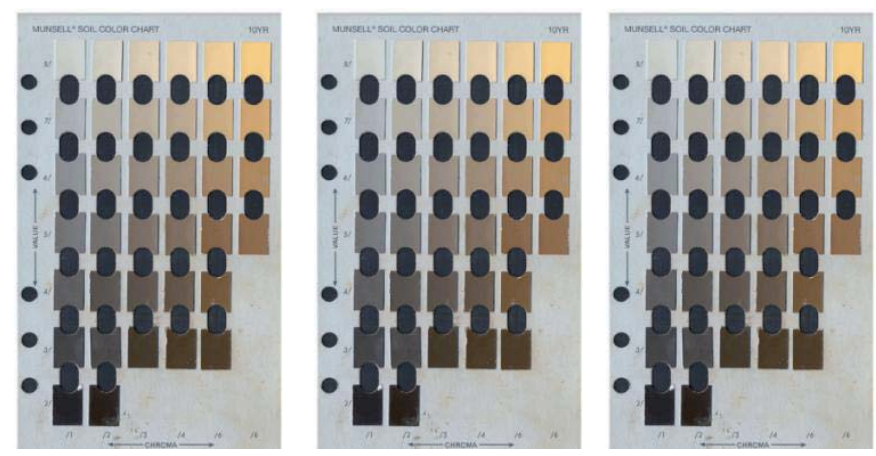

FIG. 21 Atlas of the Munsell Color System, identificación de morteros oscuros (Munsell 4/10YR/6), morteros grisáceos (Munsell 6/10YR/4), morteros claros (Munsell 8/10YR/2)

Tras la agrupación se han seleccionado 1 muestra por familia, para proceder al análisis mediante Espectrofotómetro Infrarrojo por Transformada de Fourier (FT-IR), microscopía electrónica de barrido/ microanálisis de rayos $X$ (SEM/EDX) y microscopía óptica (ver anexos correspondientes) de 6 muestras. 


\begin{tabular}{l|l}
\hline \begin{tabular}{l} 
Análisis de muestras de ladrillo \\
\hline $\begin{array}{l}\text { Ladrillos amarillentos } \\
\text { (Munsell 8/5Y/3) }\end{array}$
\end{tabular} & Cg01a/1, \\
\hline $\begin{array}{l}\text { Ladrillos anaranjados } \\
\text { (Munsell 5/5YR/6) }\end{array}$ & Cf30/1 \\
\hline $\begin{array}{l}\text { Ladrillos pardos } \\
\text { (Munsell 5/2.5YR/8) }\end{array}$ & Va119/1 \\
\hline
\end{tabular}

\begin{tabular}{l|l|}
\hline \begin{tabular}{l} 
Análisis de muestras de mortero \\
\hline $\begin{array}{l}\text { Morteros oscuros } \\
\text { (Munsell 4/10YR/6) }\end{array}$
\end{tabular} & Cg48b/2 \\
\hline $\begin{array}{l}\text { Morteros grisáceos } \\
\text { (Munsell 6/10YR/4) }\end{array}$ & Va82 \\
\hline $\begin{array}{l}\text { Morteros claros } \\
\text { (Munsell 8/10YR/2) }\end{array}$ & Fa153c/2b \\
\hline
\end{tabular}

El Espectrofotómetro Infrarrojo por Transformada de Fourier (FT-IR), permite conocer aspectos ligados a la vibración de moléculas y a la vibración infraroja de determinados elementos químicos. Por otro lado, la microscopía electrónica de barrido/ microanálisis de rayos $X$ (SEM/EDX) permite investigar la estructura de la materia cristalina mediante la difracción de rayos $X$.

La técnica consistente en hacer pasar un haz de rayos $X$ a través de un cristal de la muestra sujeta a estudio. El haz se expande en varias direcciones debido a la simetría de la agrupación de átomos y, por difracción, dando lugar a un patrón de intensidades que puede interpretarse según la ubicación de los átomos en el cristal. Se considera como una de las técnicas que goza de mayor prestigio entre la comunidad científica para dilucidar estructuras cristalinas, debido a su precisión. 


\section{Análisis visual de muestras de ladrillos amarillentos}

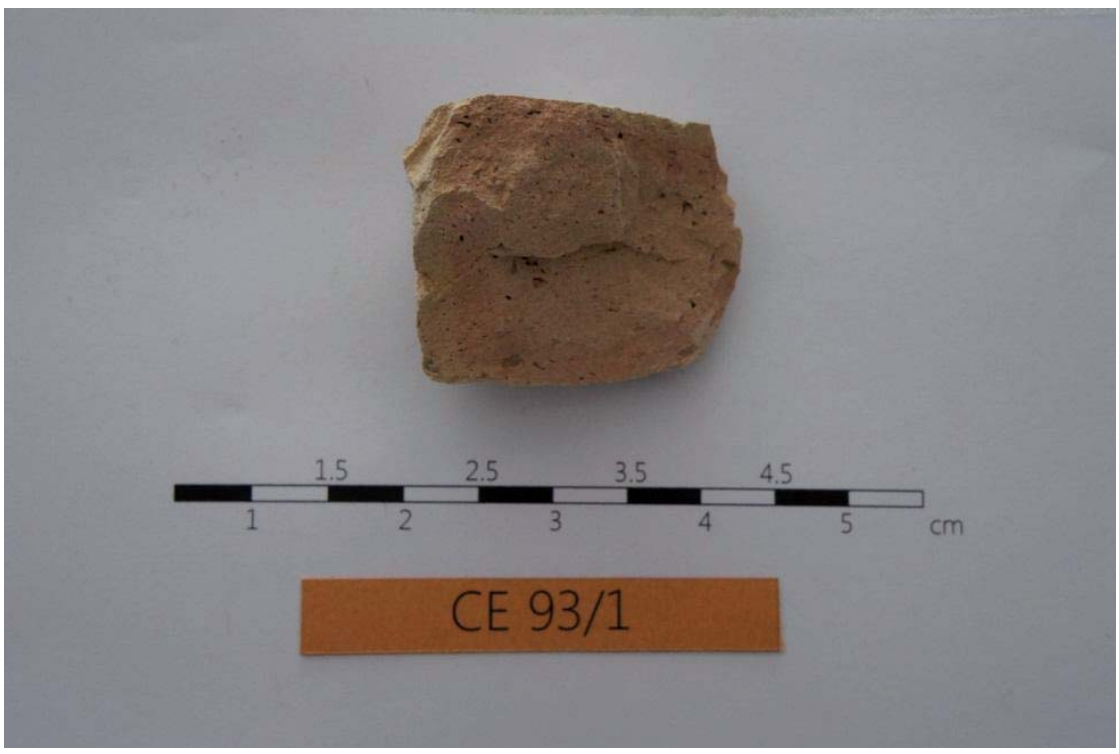

FIG. 22 Clasificación muestra CE93/1 (CRISTINI)

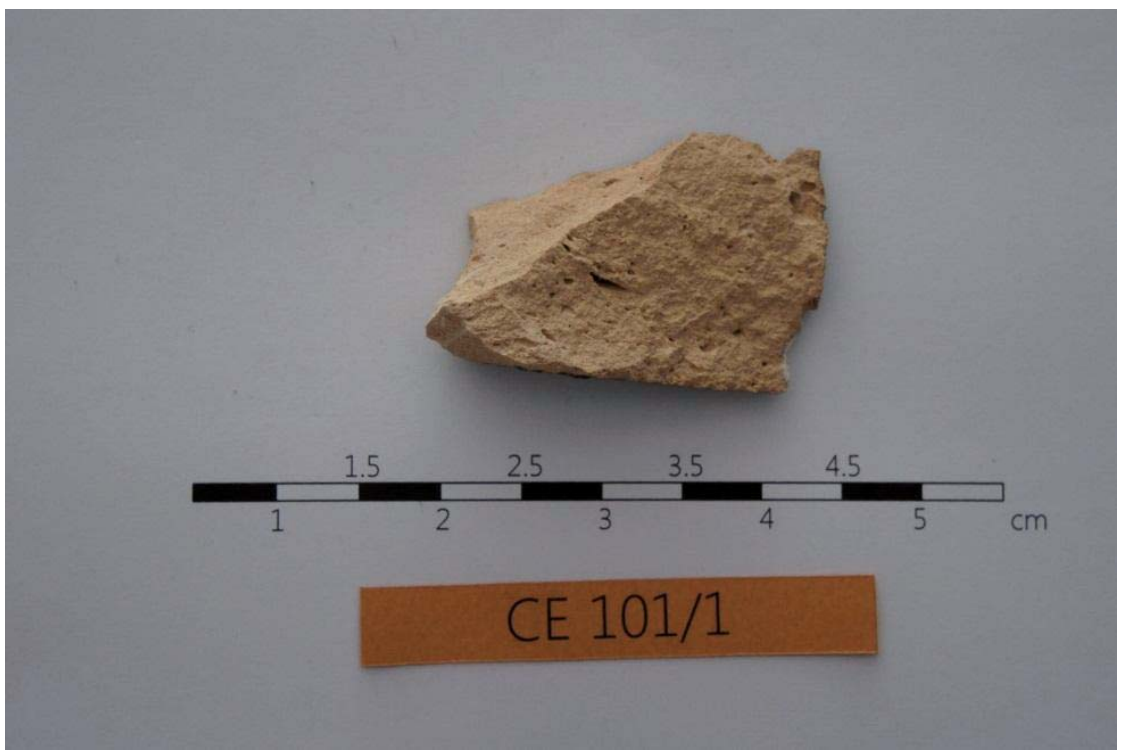

FIG. 23 Clasificación muestra CE101/1 (CRISTINI) 


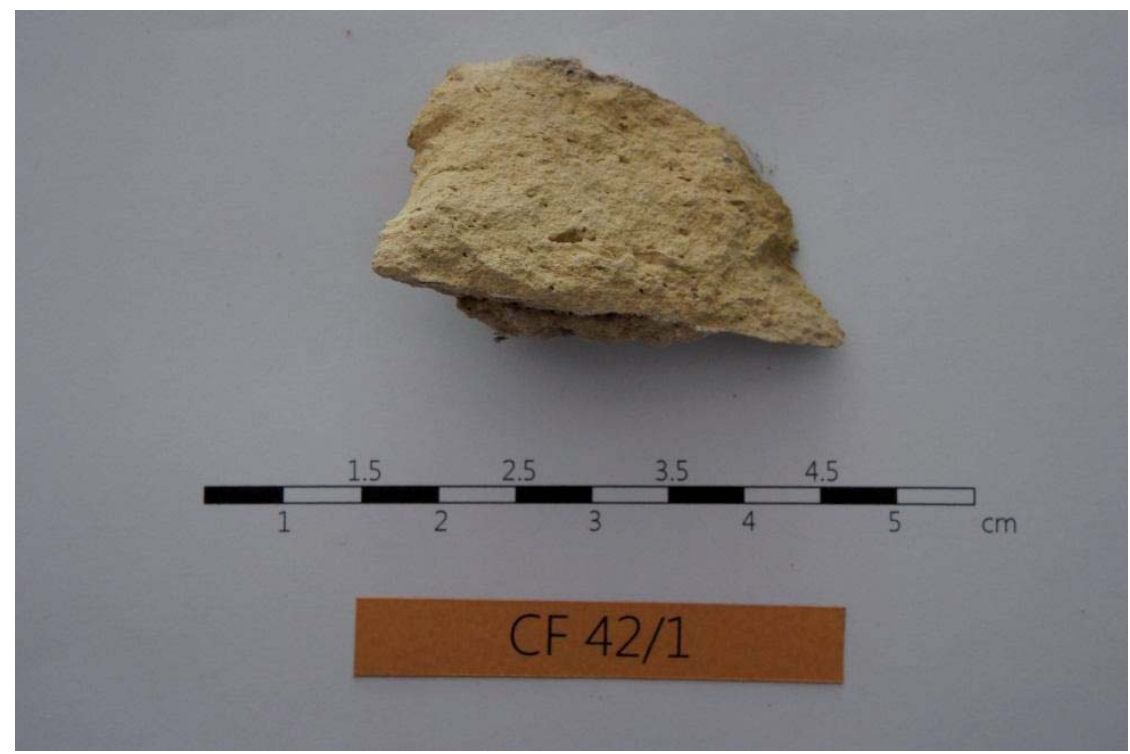

FIG. 24 Clasificación muestra CF 42/1 (CRISTINI)

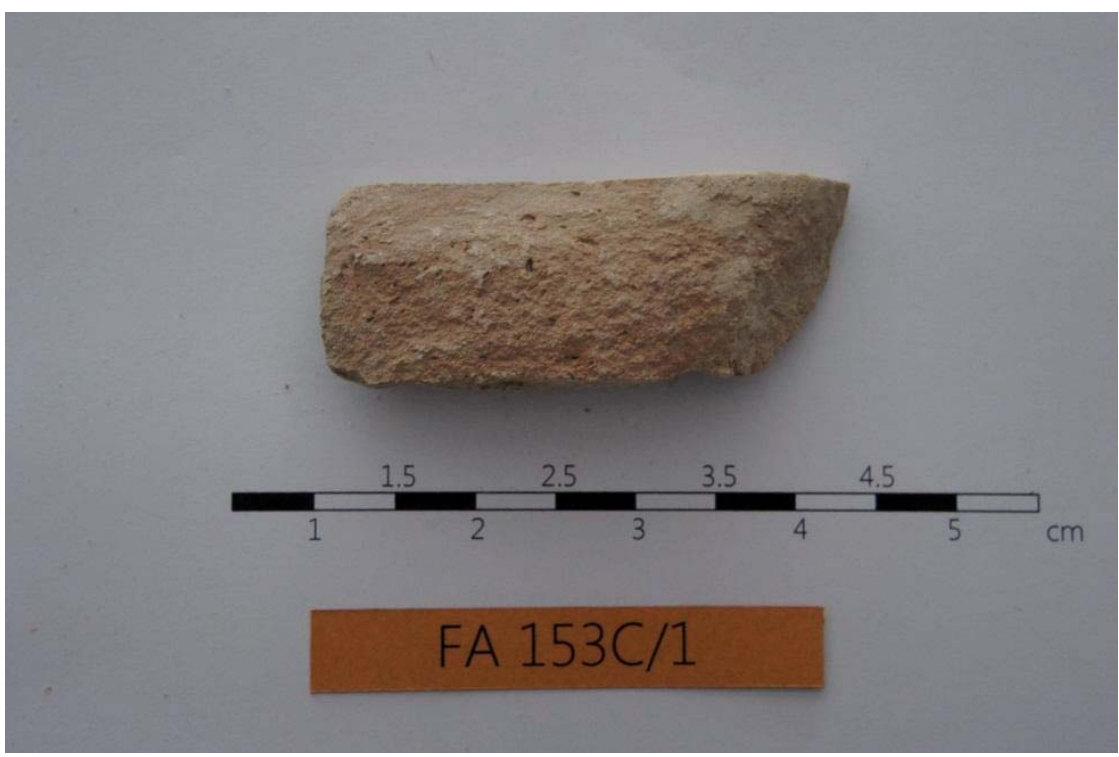

FIG. 25 Clasificación muestra FA 153C/1 (CRISTINI) 


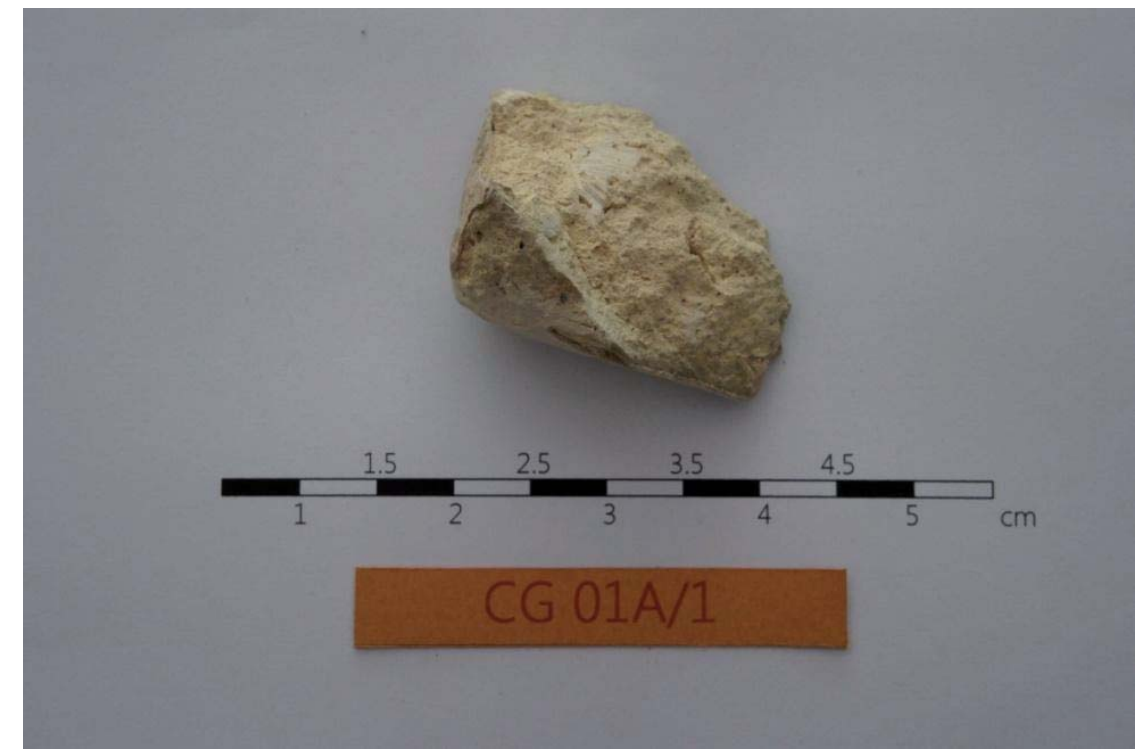

FIG. 26 Clasificación muestra CG 01A/1 (CRISTINI)

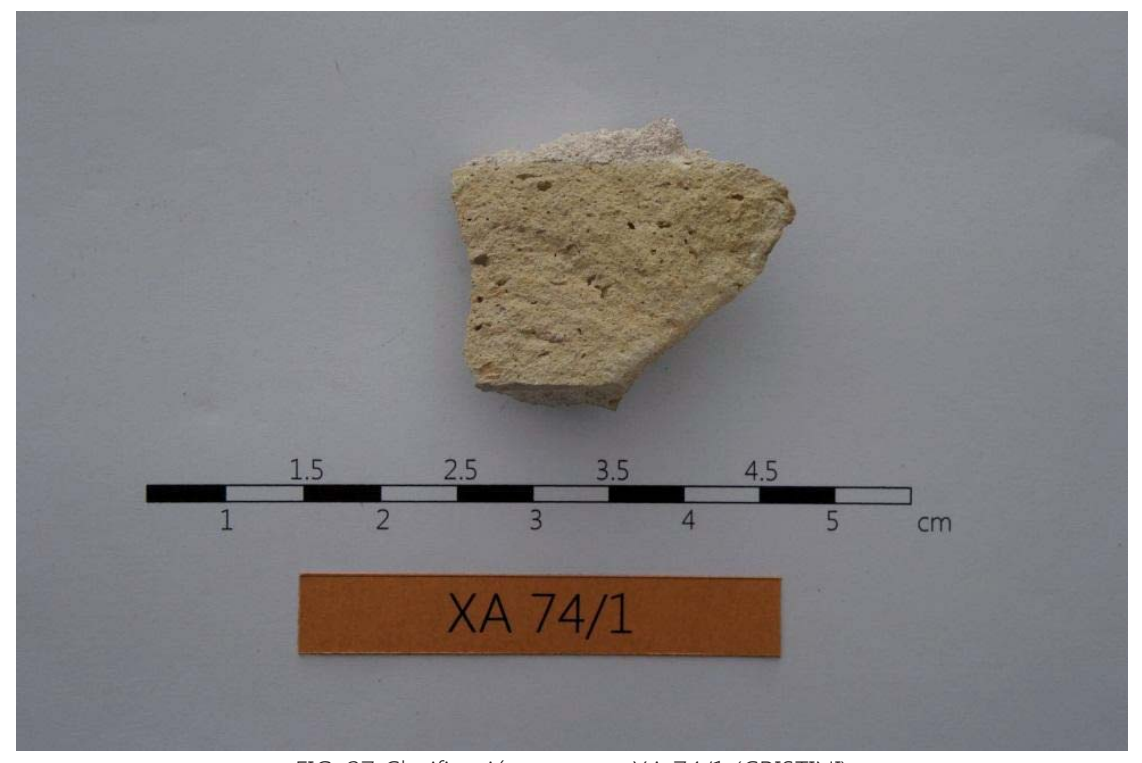

FIG. 27 Clasificación muestra XA 74/1 (CRISTINI) 


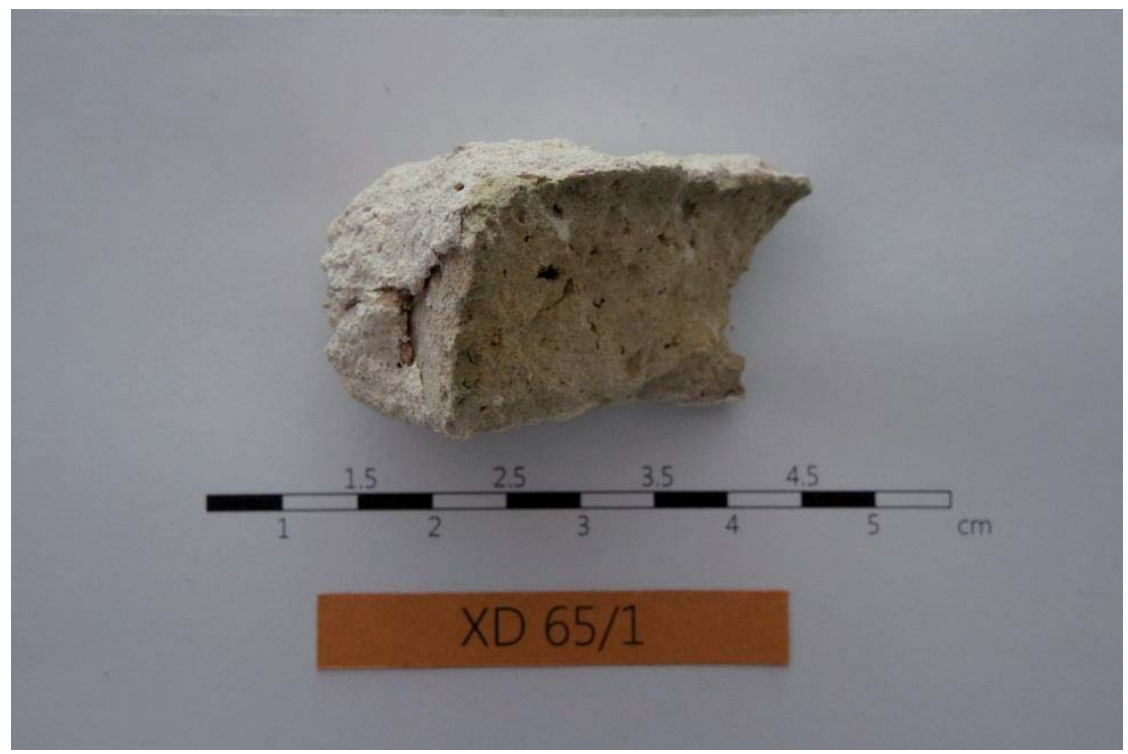

FIG. 28 Clasificación muestra XD 65/1 (CRISTINI)

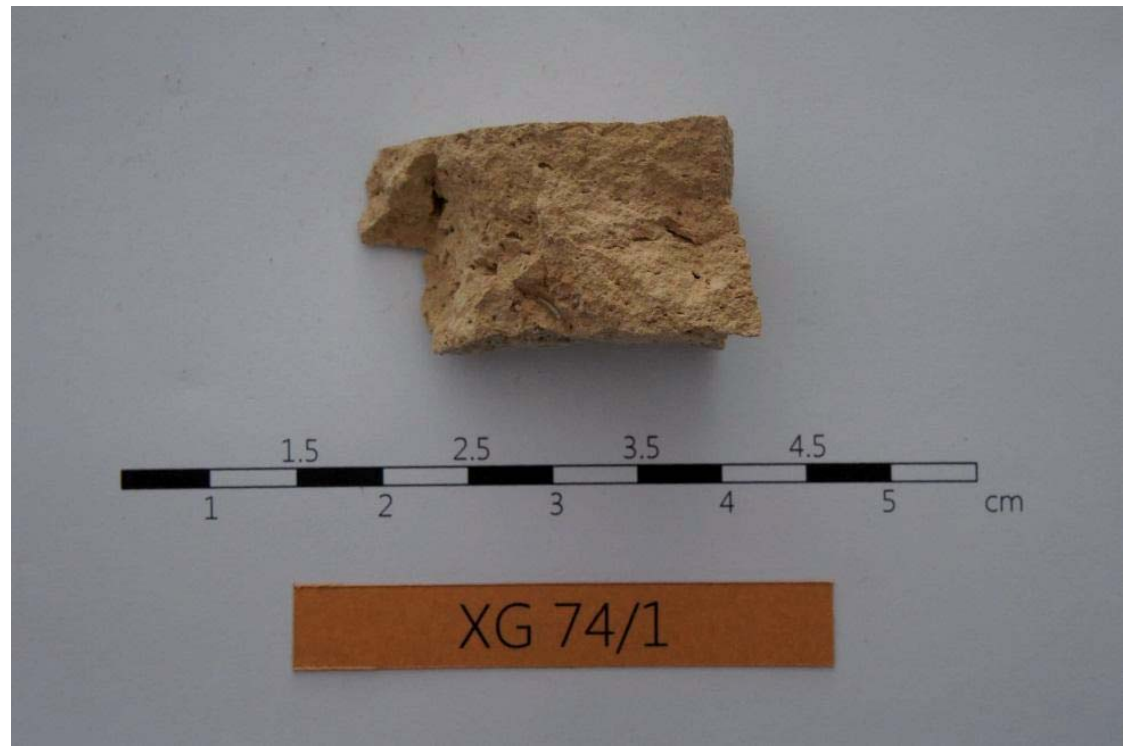

FIG. 29 Clasificación muestra XG 74/1 (CRISTINI) 


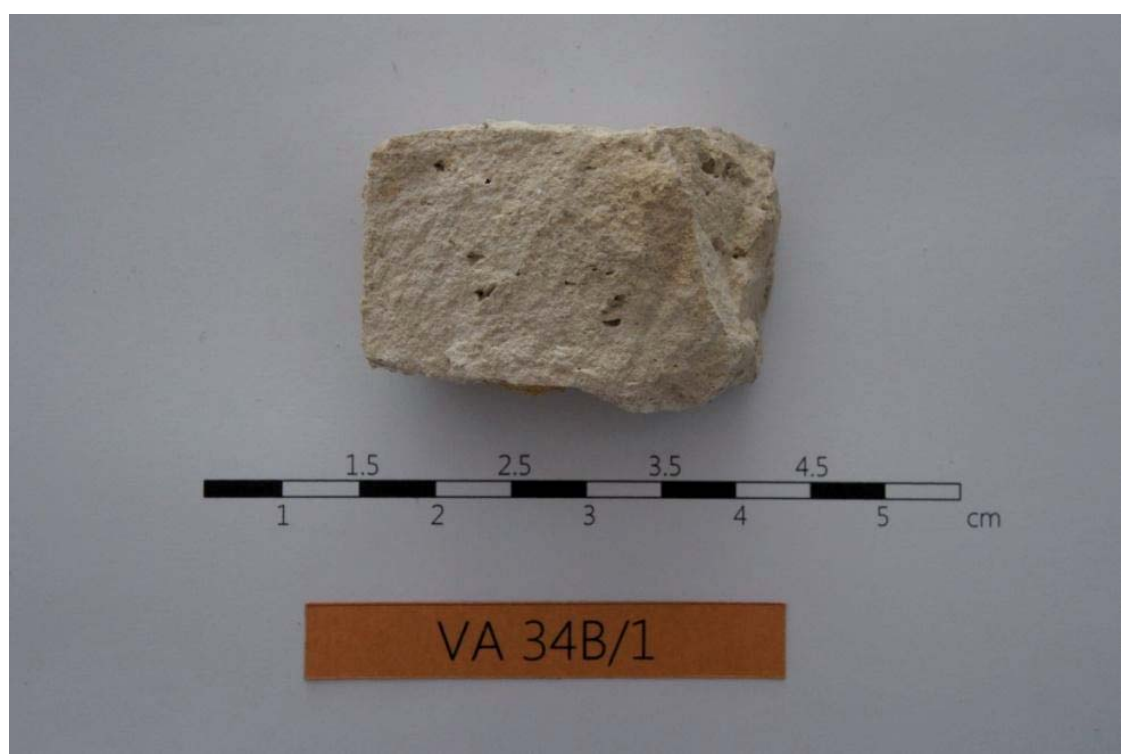

FIG. 30 Clasificación muestra VA 34B/1 (CRISTINI)
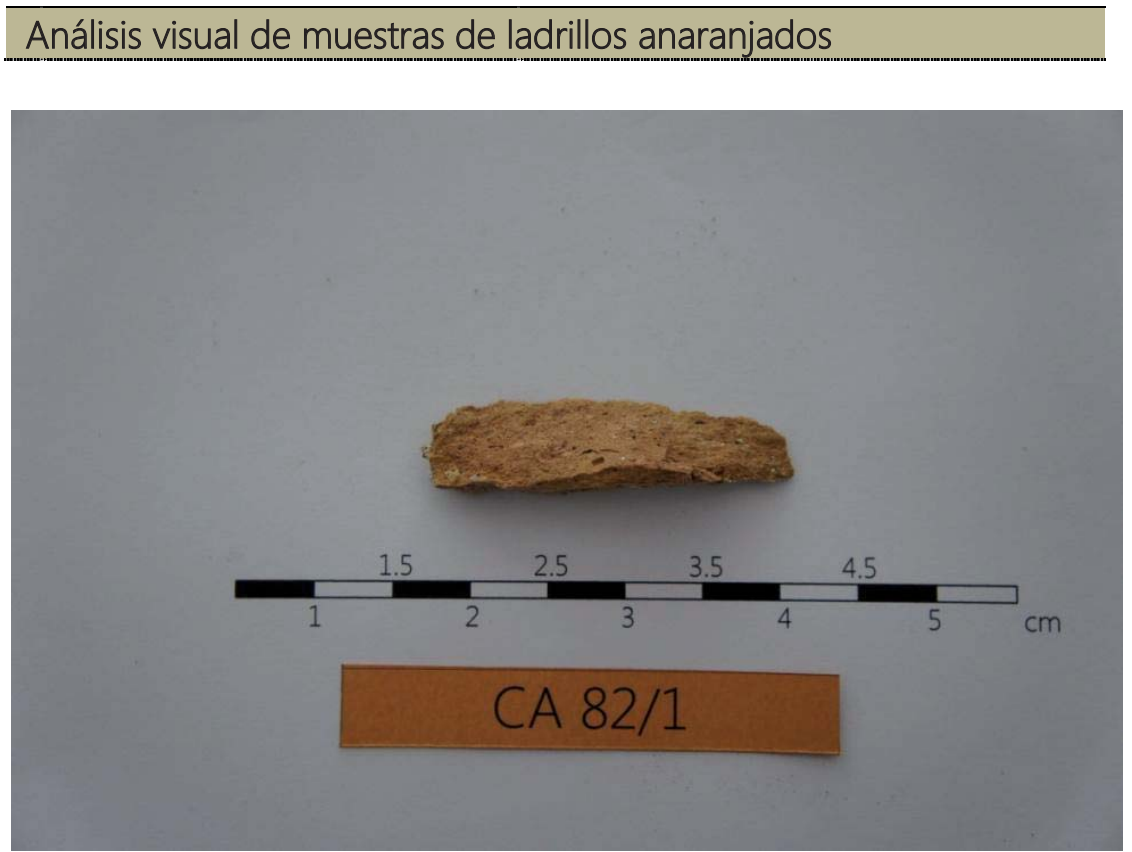

FIG. 31 Clasificación muestra CA 82/1 (CRISTINI) 


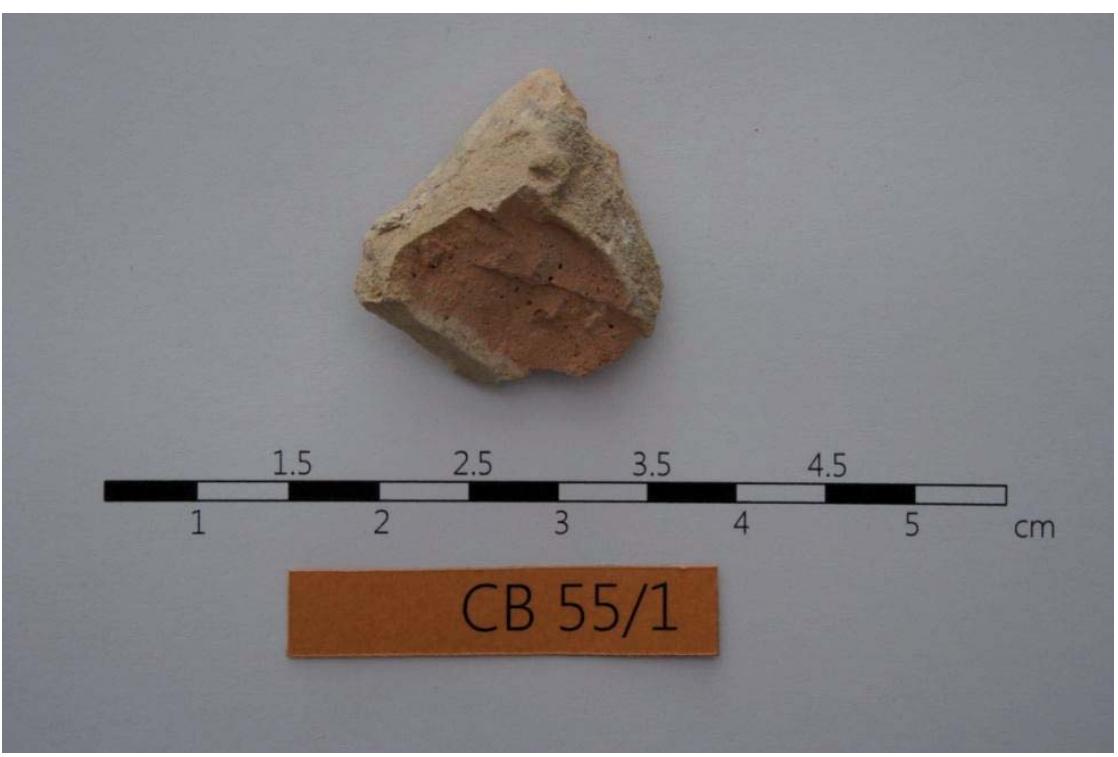

FIG. 32 Clasificación muestra CB 55/1 (CRISTINI)

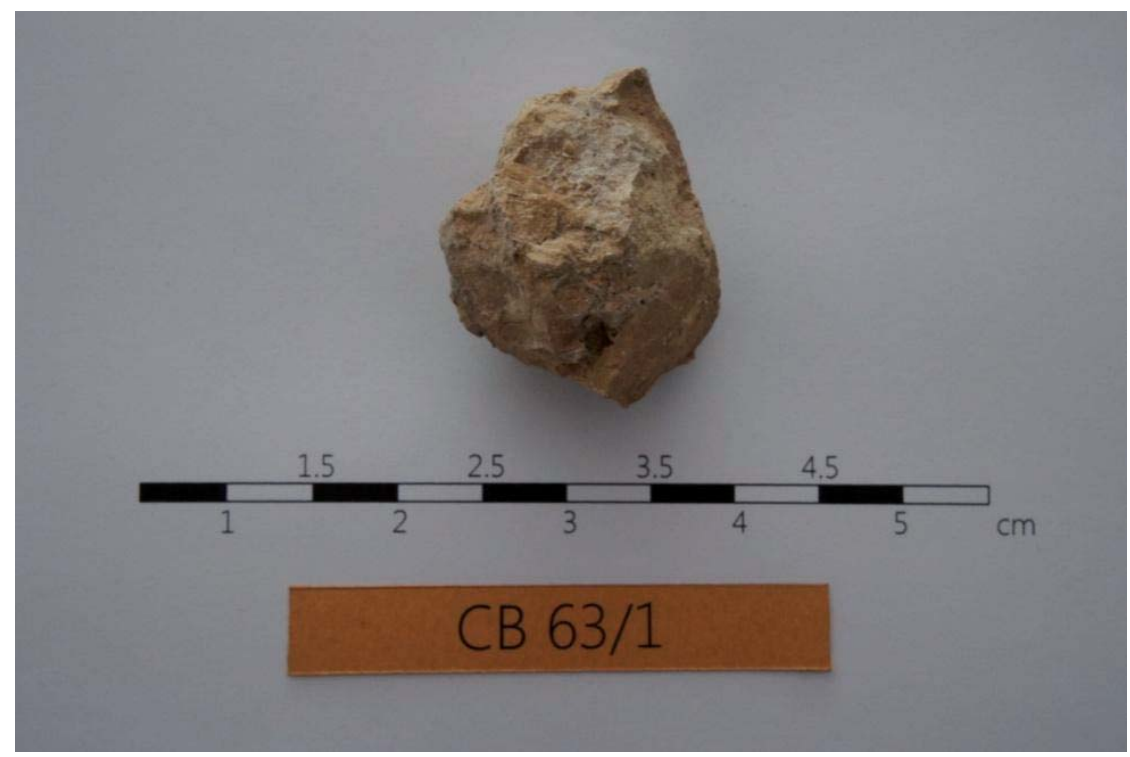

FIG. 33 Clasificación muestra CB 63/1 (CRISTINI) 


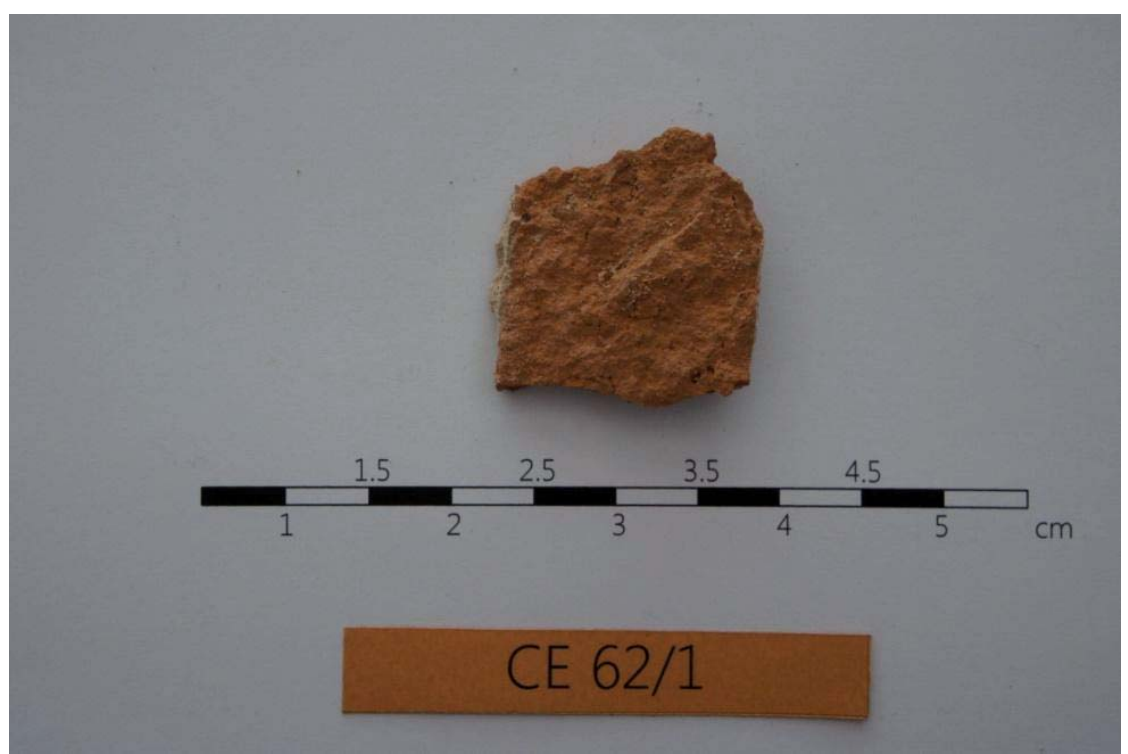

FIG. 34 Clasificación muestra CE 62/1 (CRISTINI)

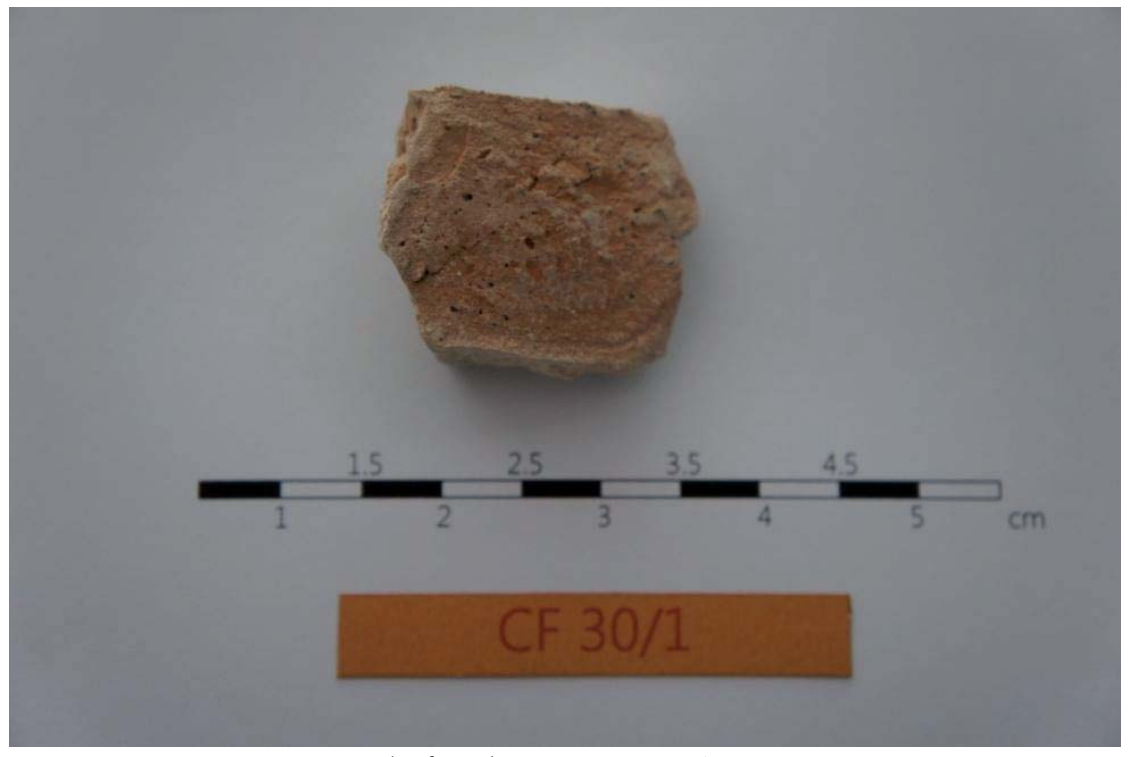

FIG. 35 Clasificación muestra CF 30/1 (CRISTINI) 


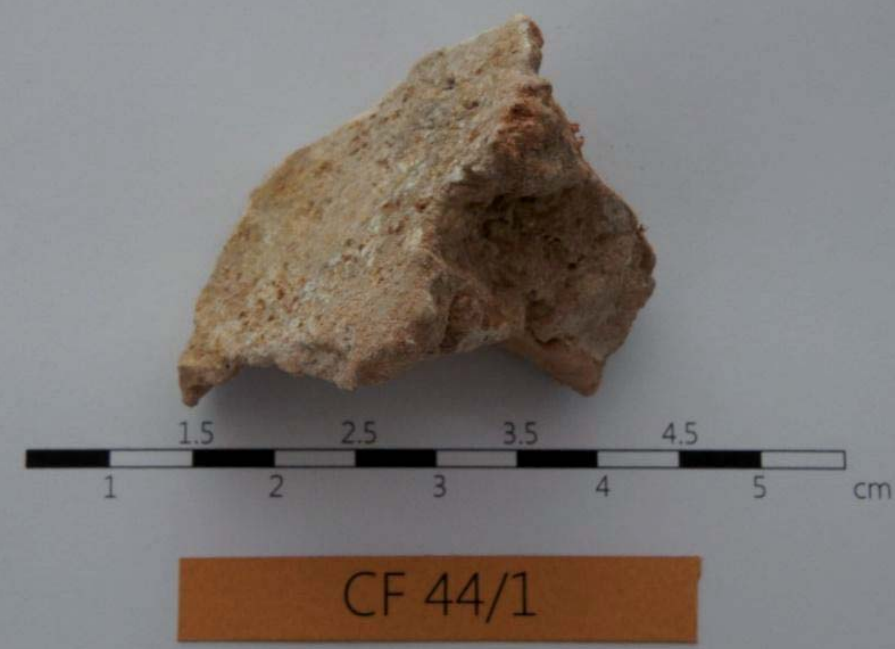

FIG. 36 Clasificación muestra CF 44/1 (CRISTINI)

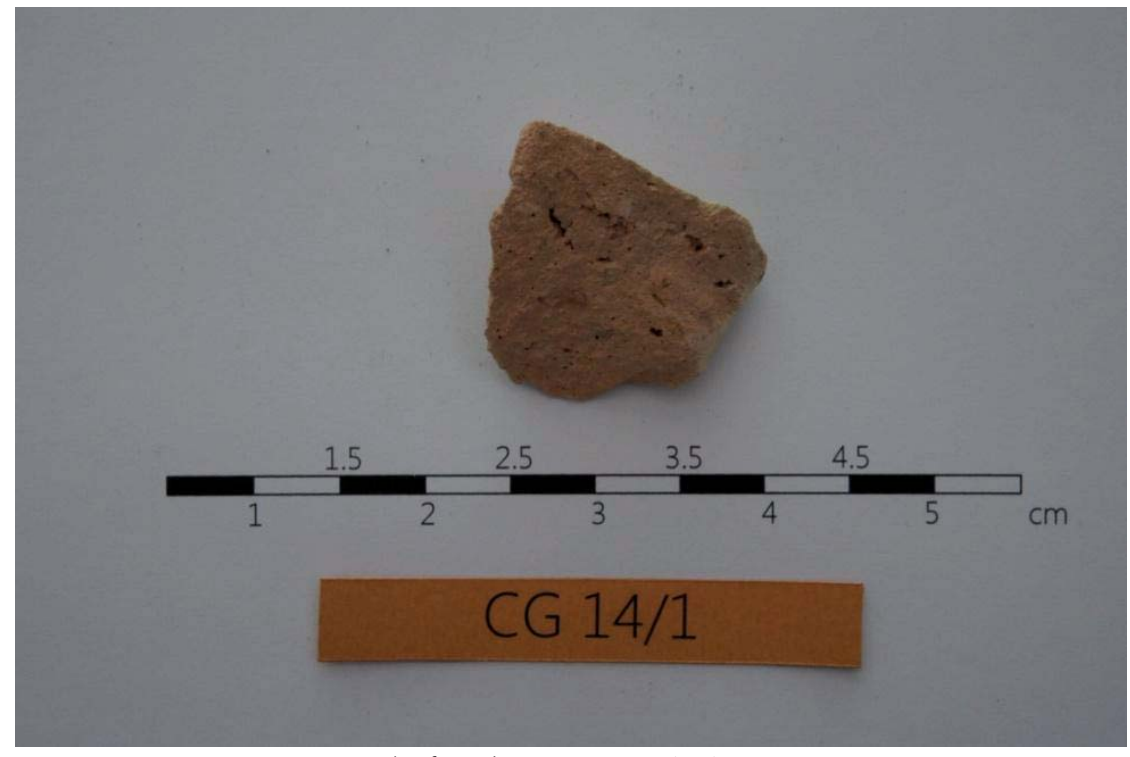

FIG. 37 Clasificación muestra CG 14/1 (CRISTINI) 


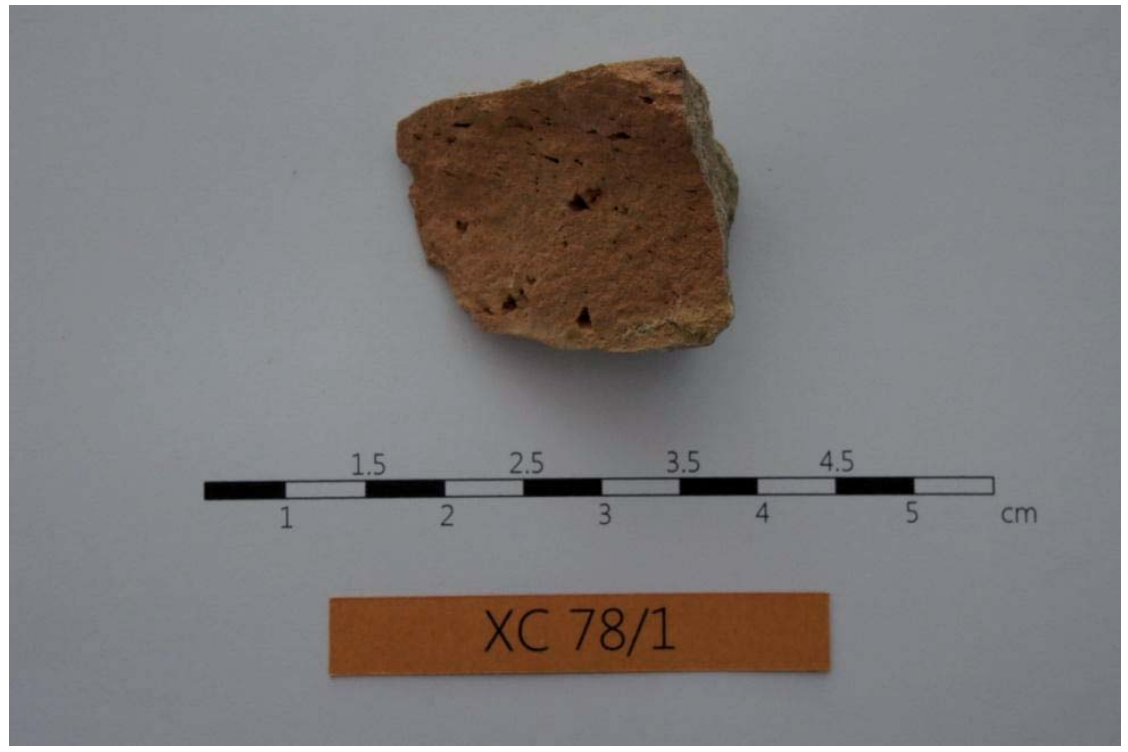

FIG. 38 Clasificación muestra XC 78/1 (CRISTINI)

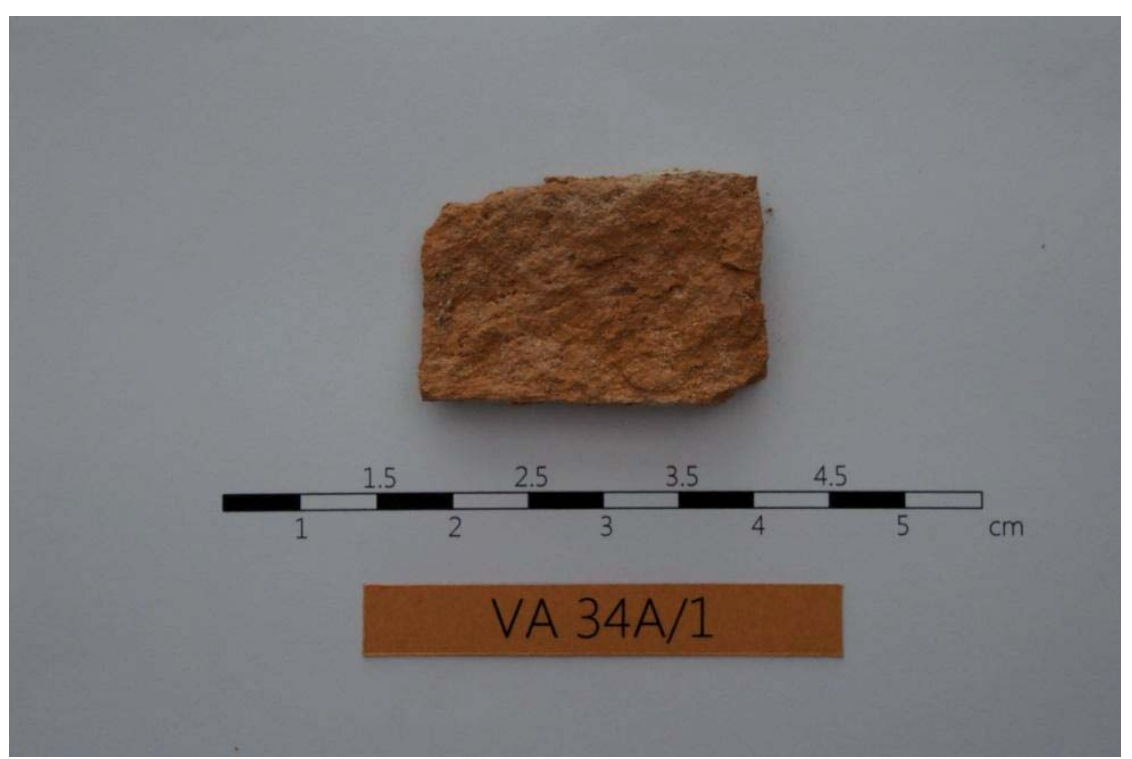

FIG. 39 Clasificación muestra VA 3AA/1 (CRISTINI) 


\section{Análisis visual de muestras de ladrillos pardos}

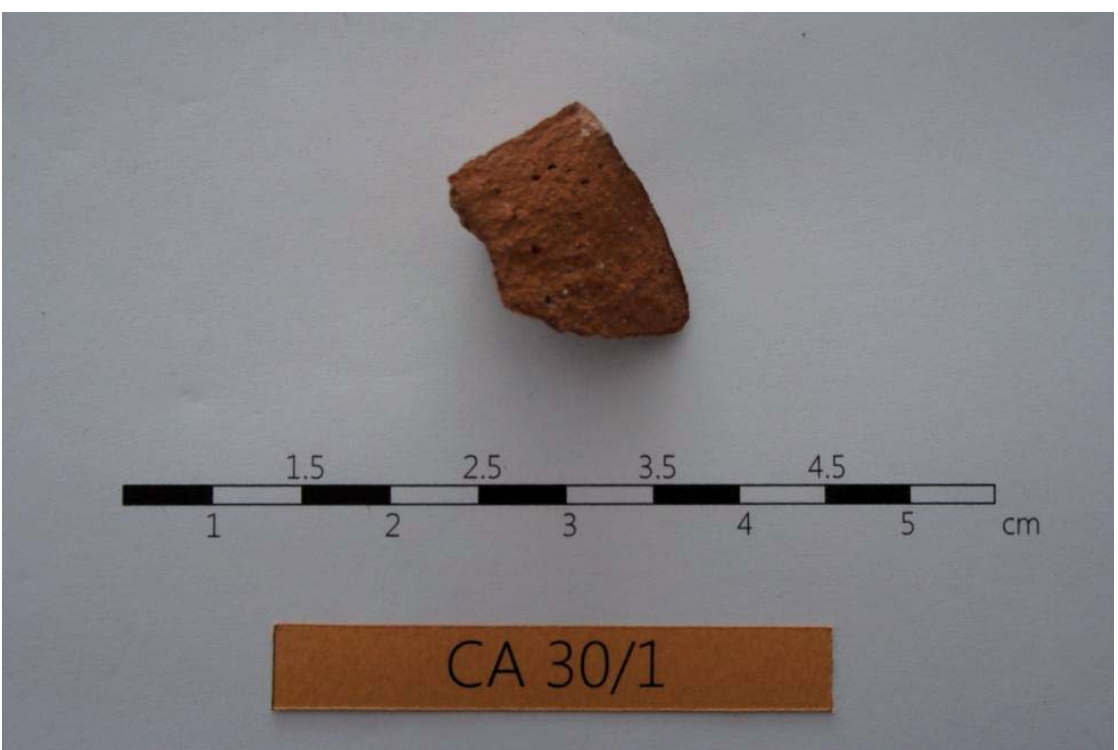

FIG. 40 Clasificación muestra CA 30/1 (CRISTINI)

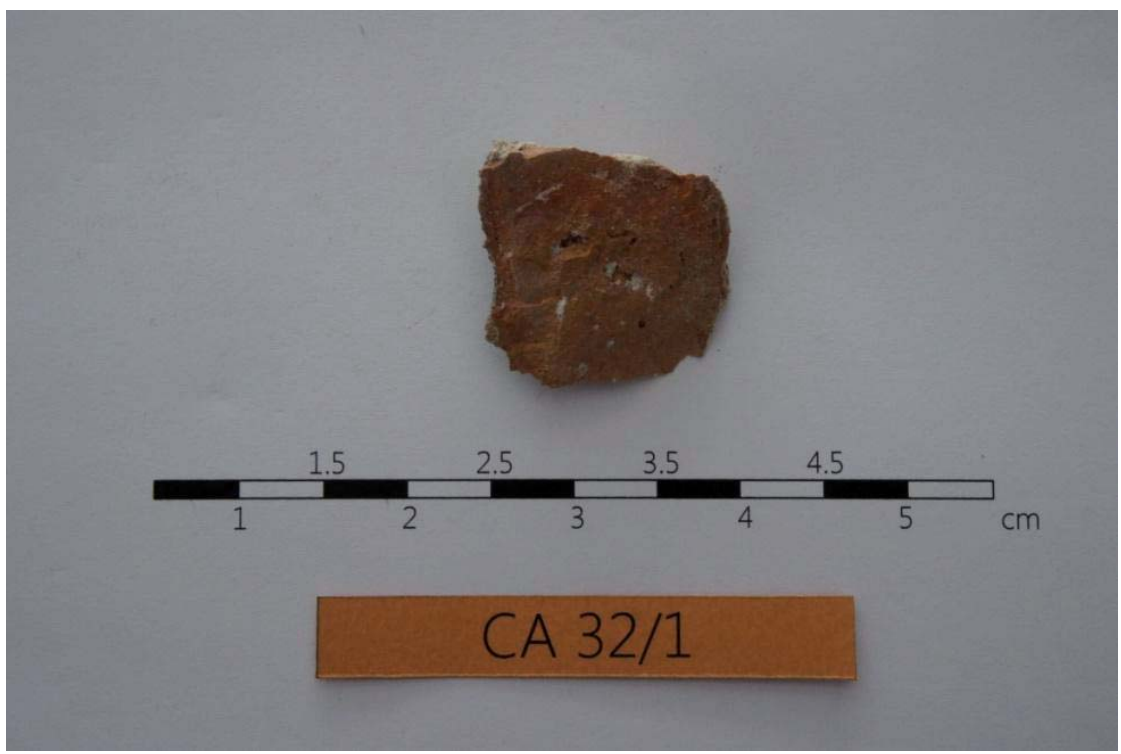

FIG. 41 Clasificación muestra CA 32/1 (CRISTINI) 


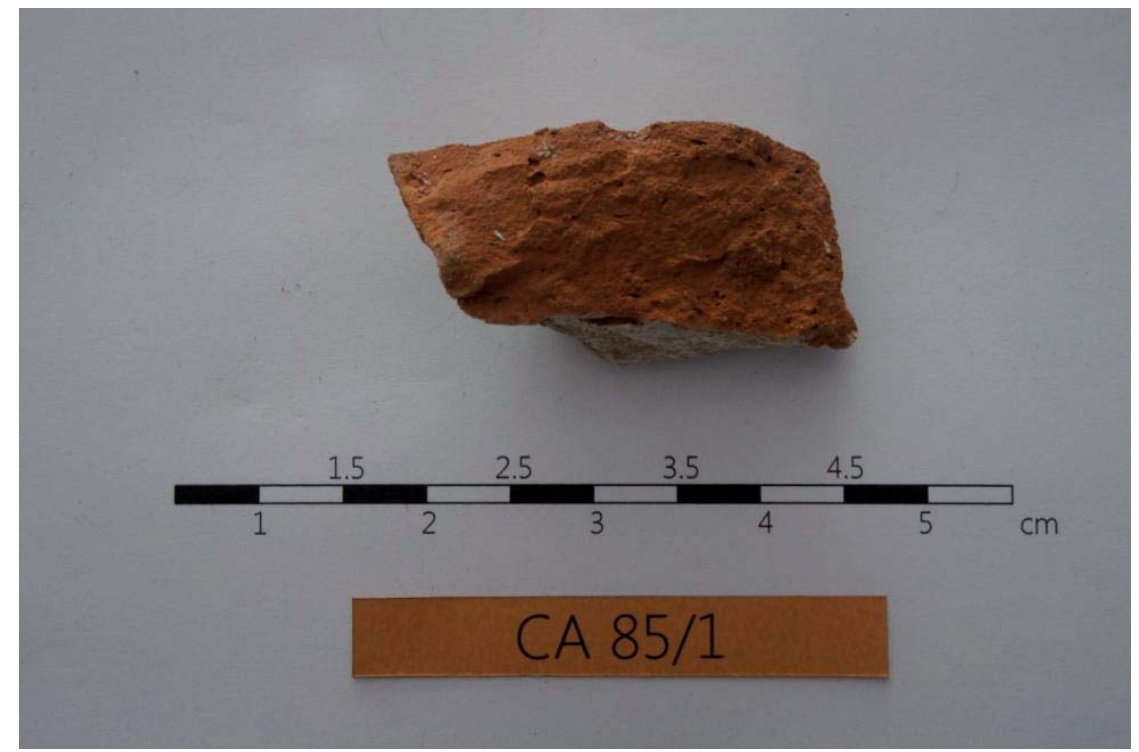

FIG. 42 Clasificación muestra CA 85/1 (CRISTINI)

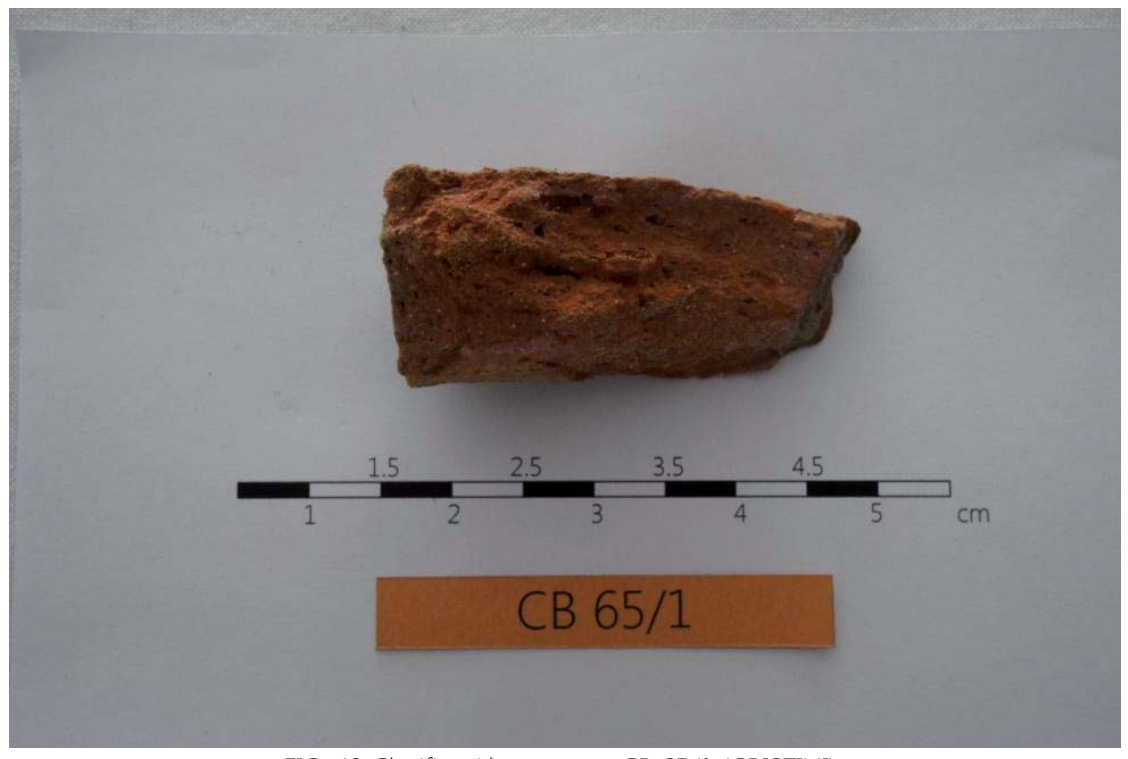

FIG. 43 Clasificación muestra CB 65/1 (CRISTINI) 


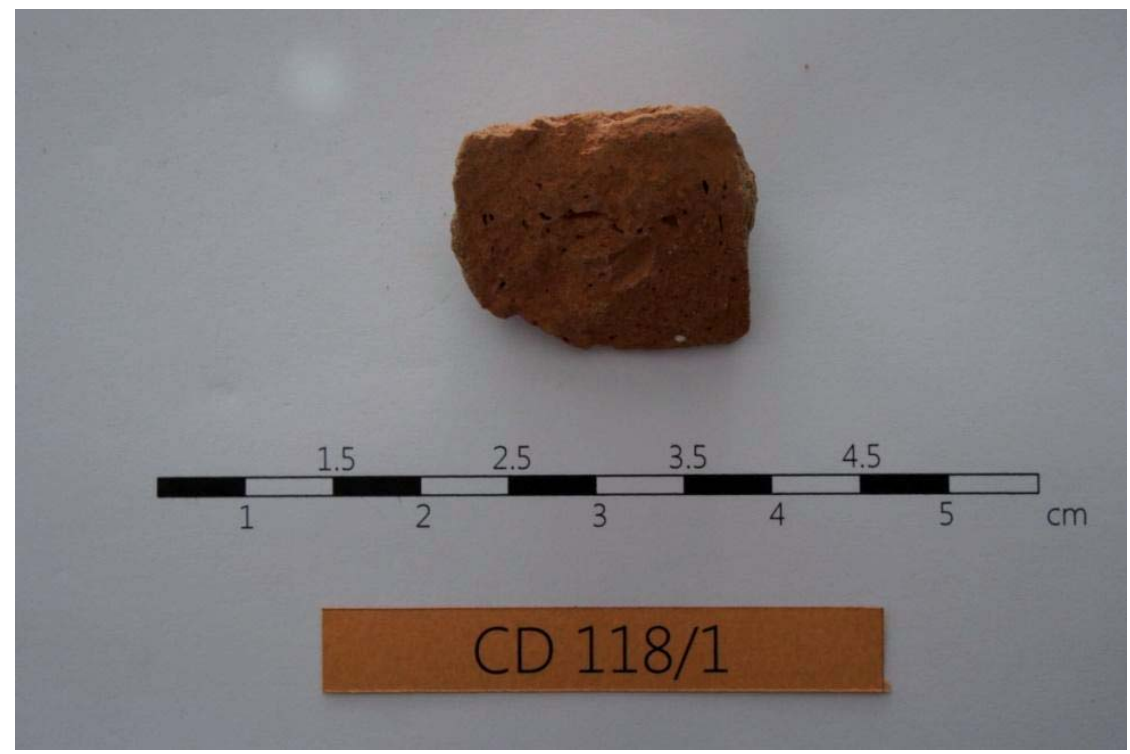

FIG. 44 Clasificación muestra CD 118/1 (CRISTINI)

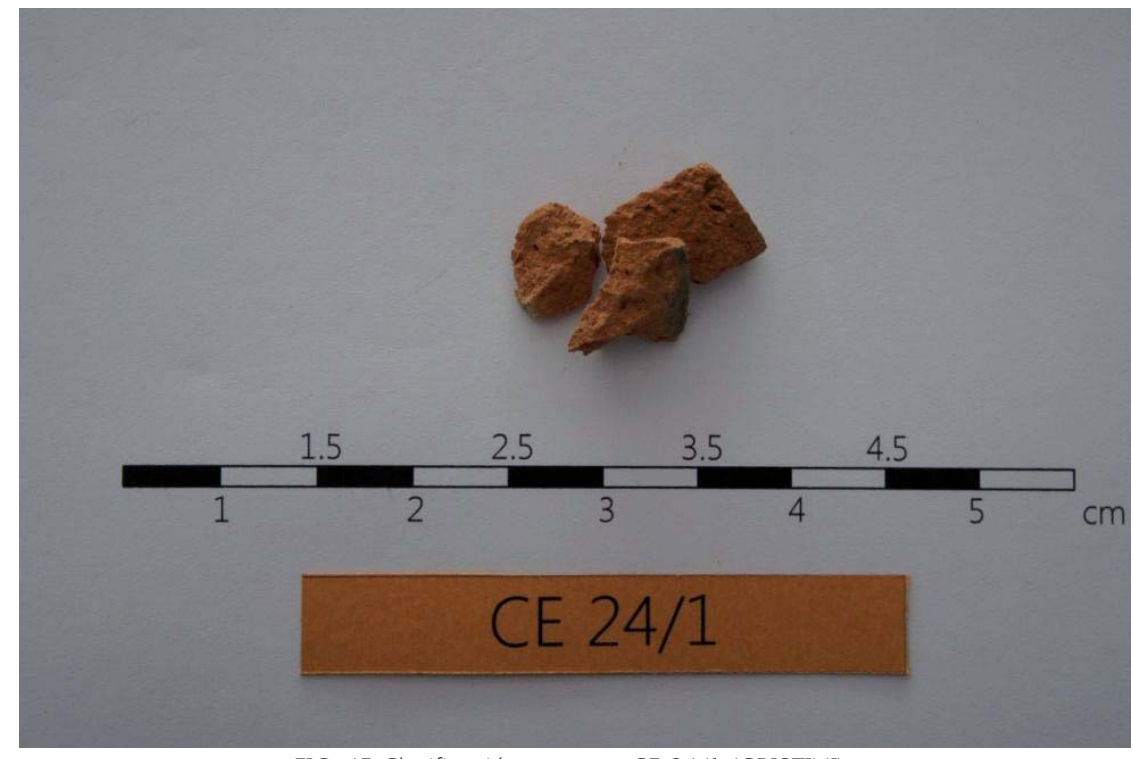

FIG. 45 Clasificación muestra CE 24/1 (CRISTINI) 


\section{MUROSINTRAMUIOS}

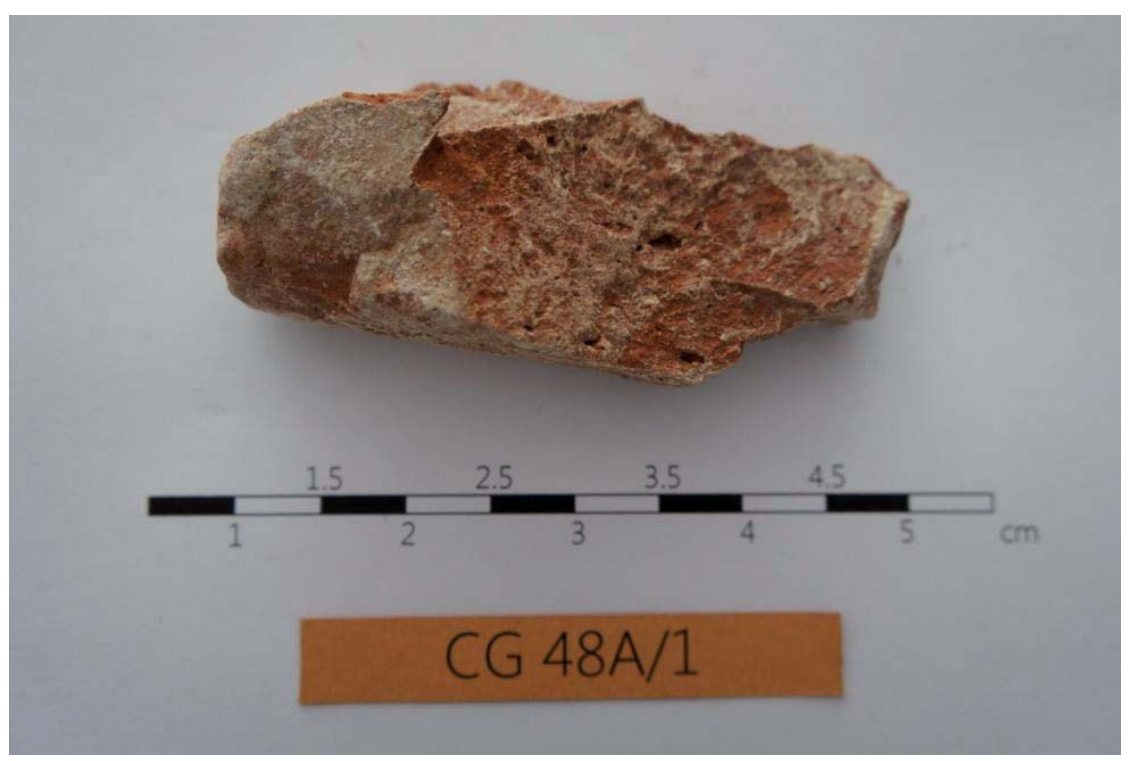

FIG. 46 Clasificación muestra CG 48A/1 (CRISTINI)

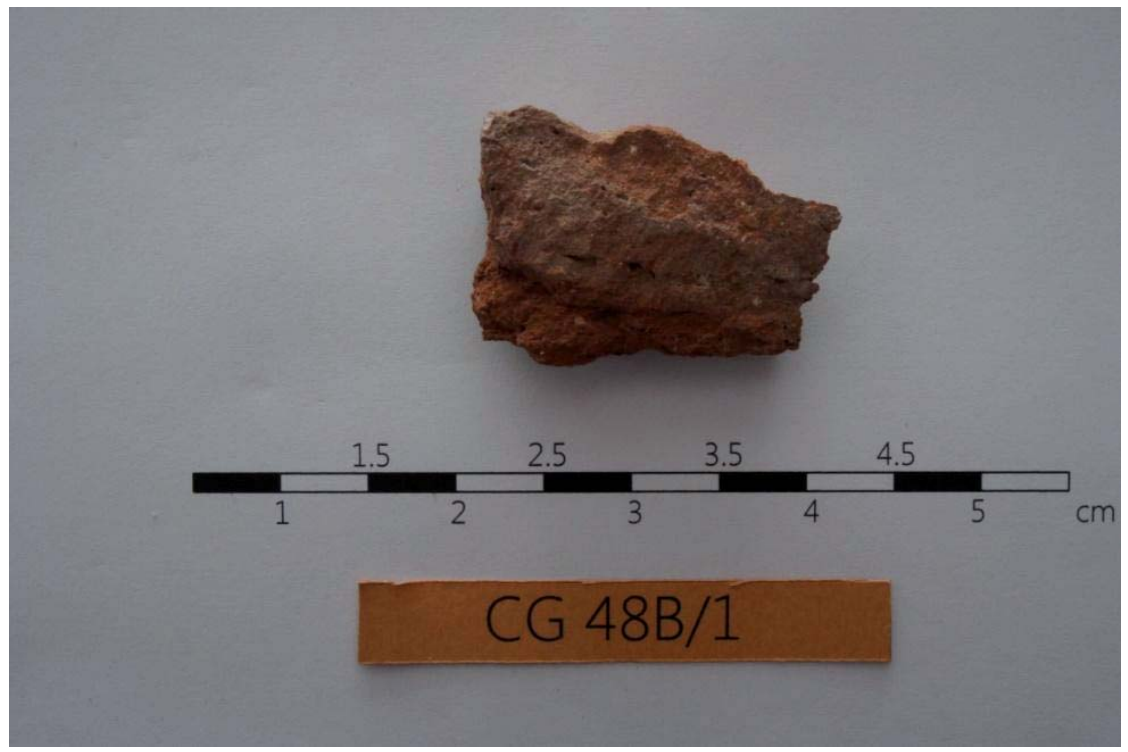

FIG. 47 Clasificación muestra CG 48B/1 (CRISTINI) 


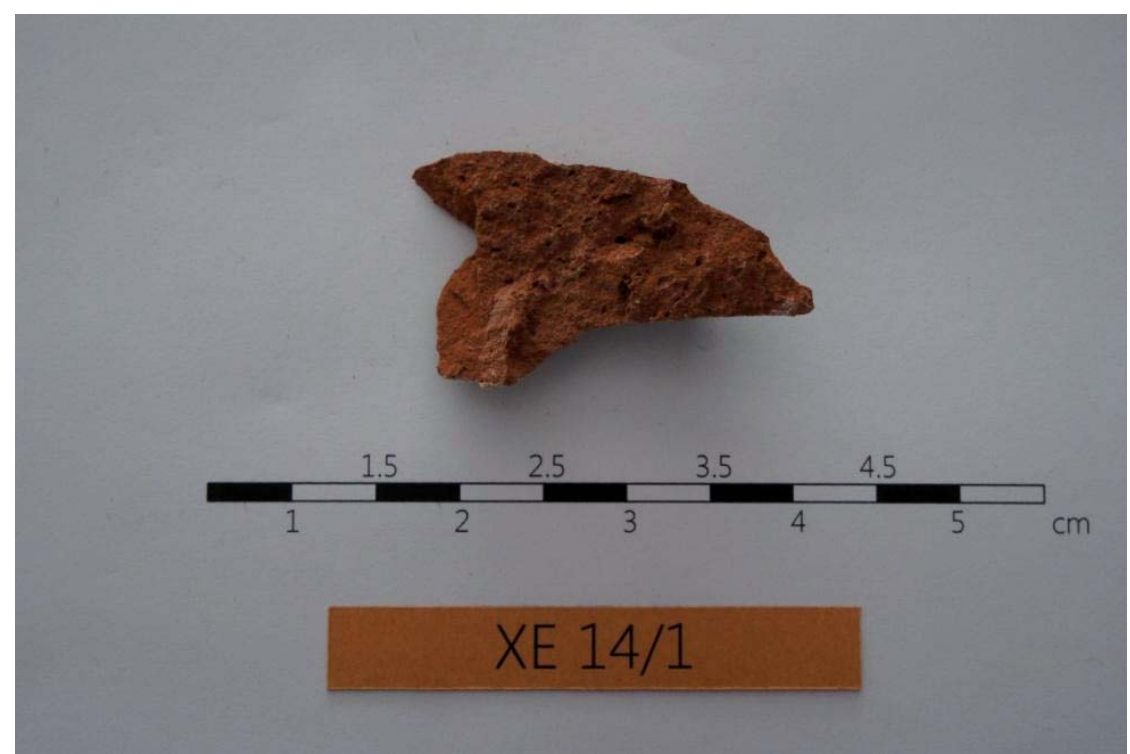

FIG. 48 Clasificación muestra XE 14/1 (CRISTINI)

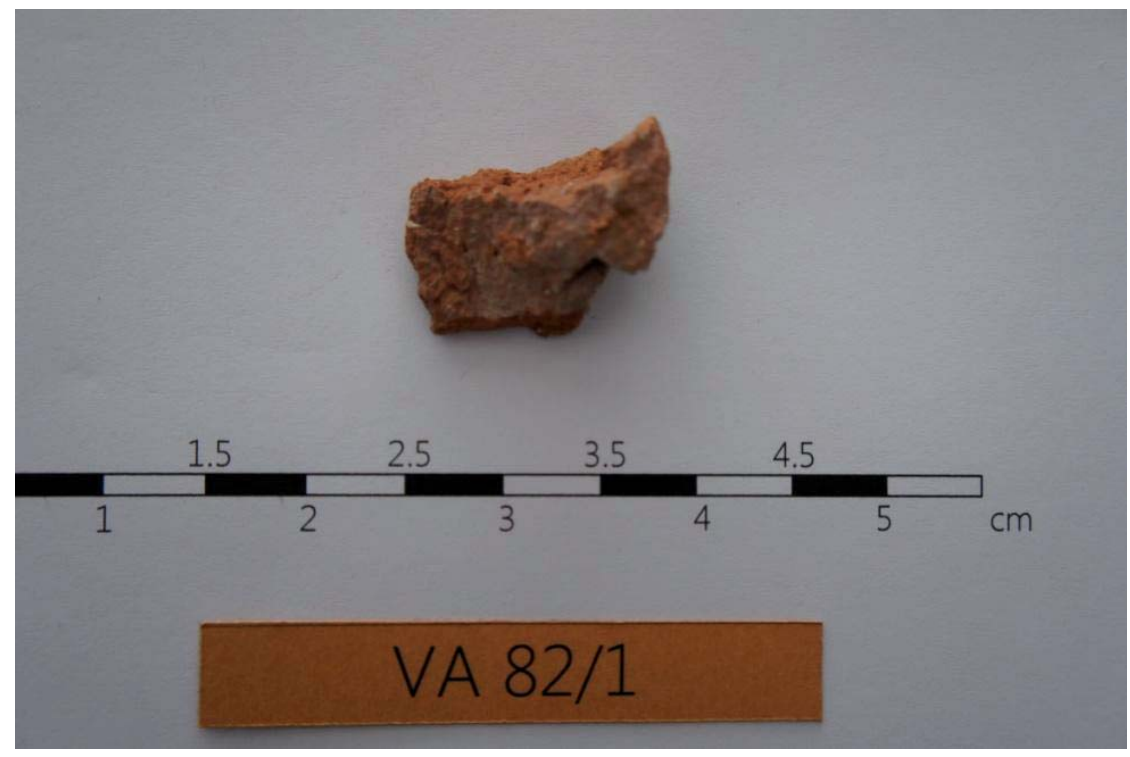

FIG. 49 Clasificación muestra VA 82/1 (CRISTINI) 


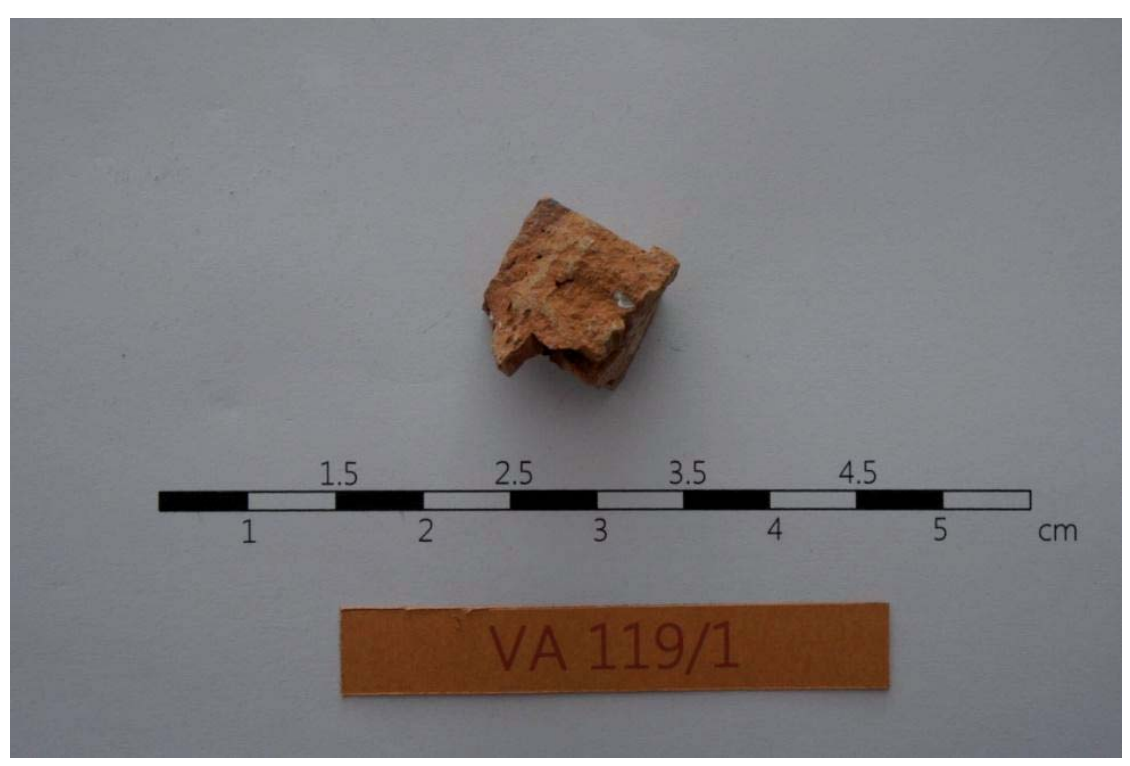

FIG. 50 Clasificación muestra VA 119/1 (CRISTINI)

\section{Análisis visual de muestras de morteros oscuros}

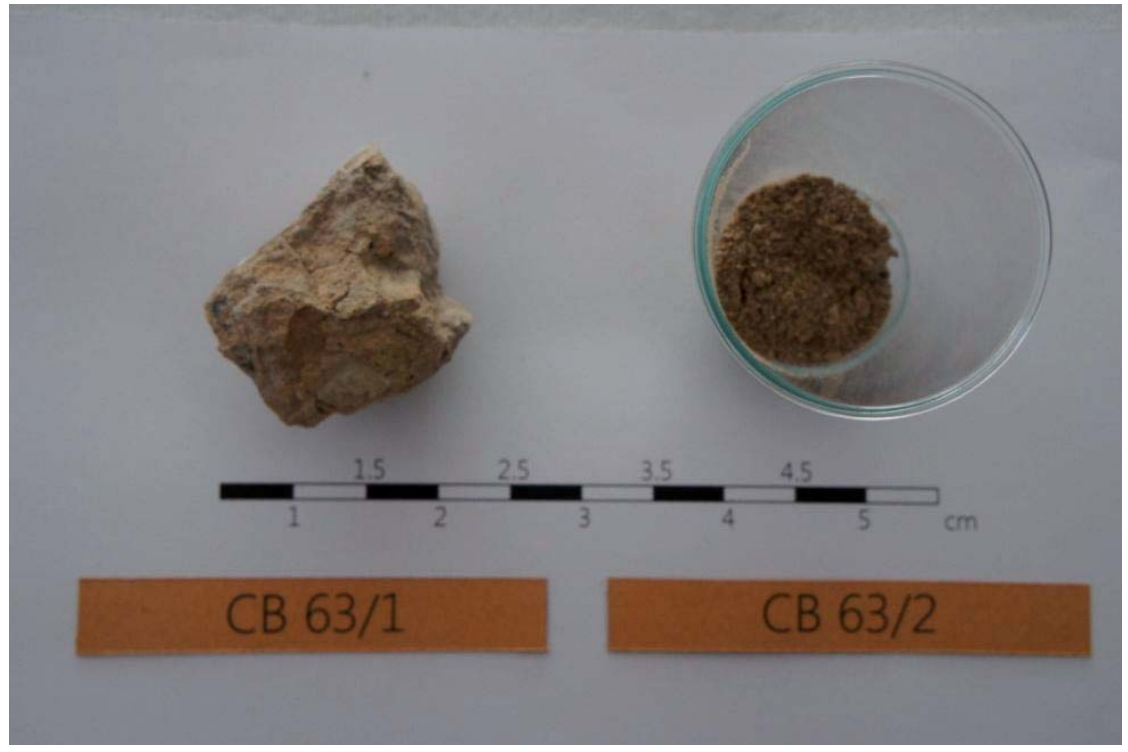

FIG. 51 Clasificación muestras CB 63/1 y CB 63/2(CRISTINI) 


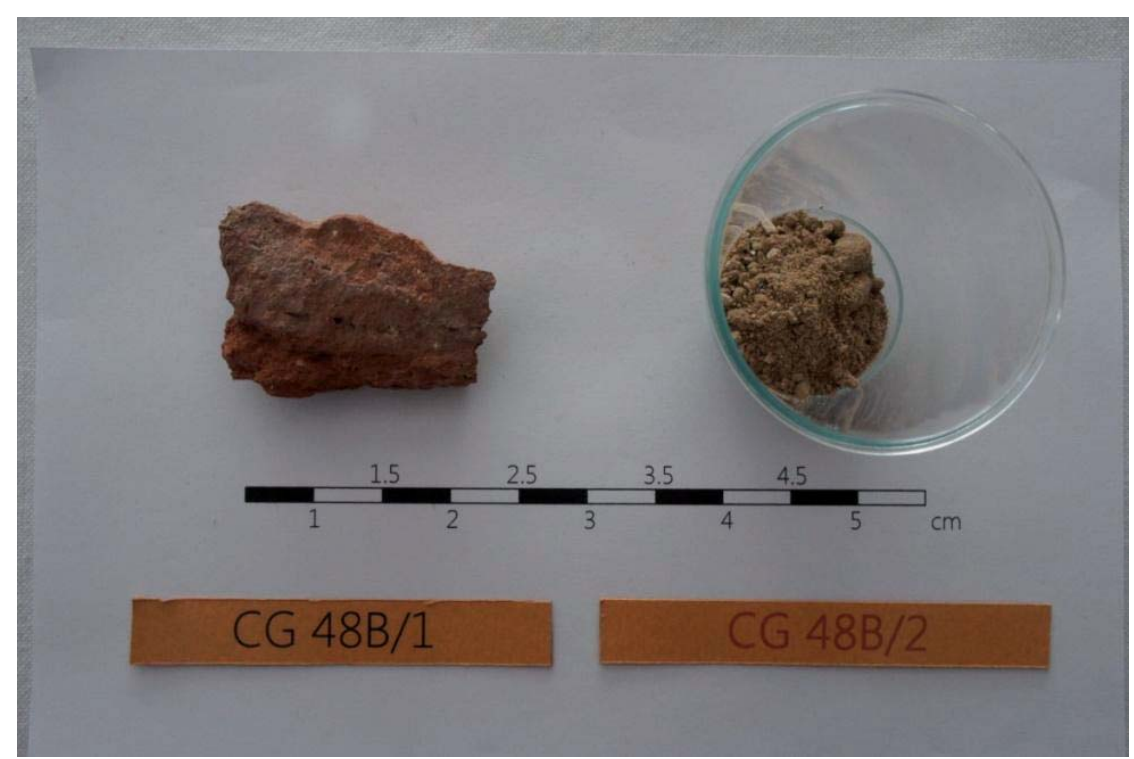

FIG. 52 Clasificación muestras CB 48B/1 y CG 48B/2 (CRISTINI)

\section{Análisis visual de muestras de morteros grisáceos}

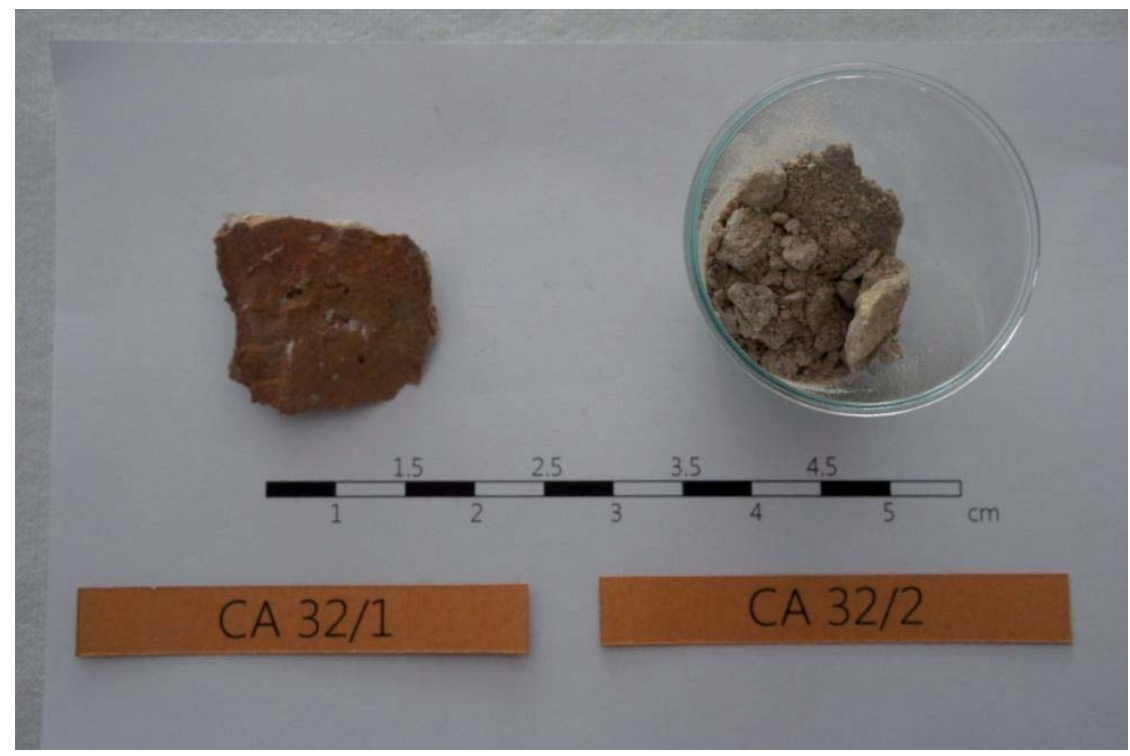

FIG. 53 Clasificación muestras CA 32/1 y CA 32/2 (CRISTINI) 


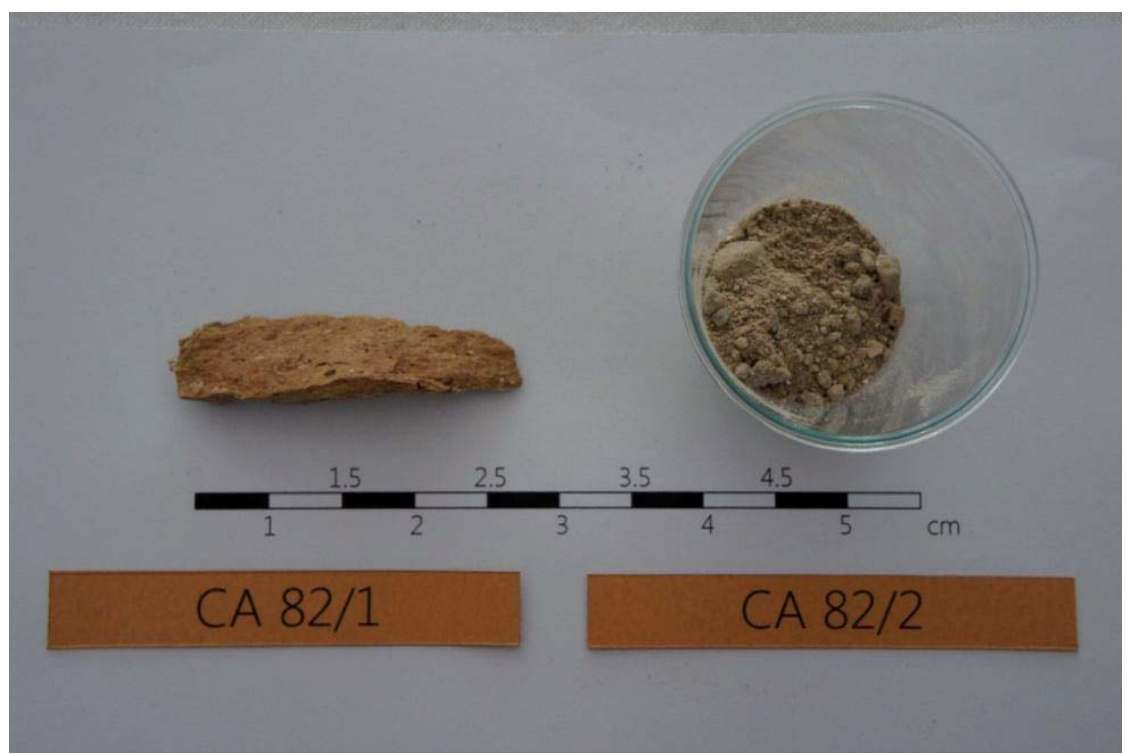

FIG. 54 Clasificación muestras CA 82/1 y CA 82/2 (CRISTINI)

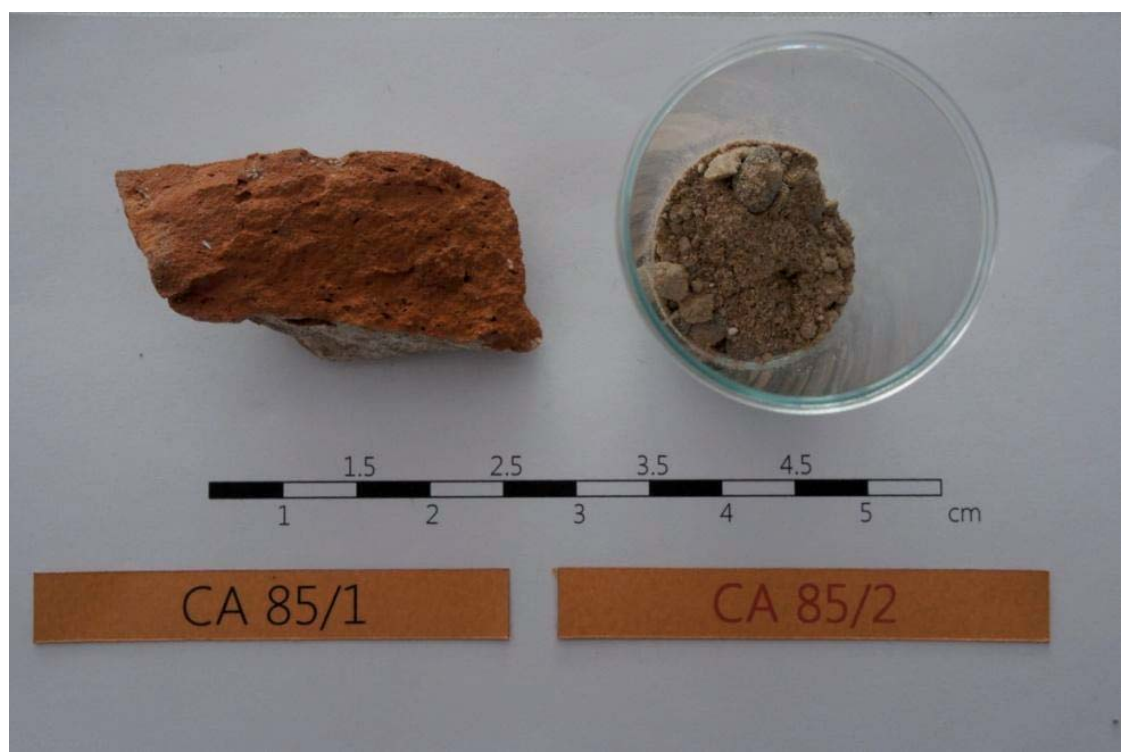

FIG. 55 Clasificación muestras CA 85/1 y CA 85/2 (CRISTINI) 


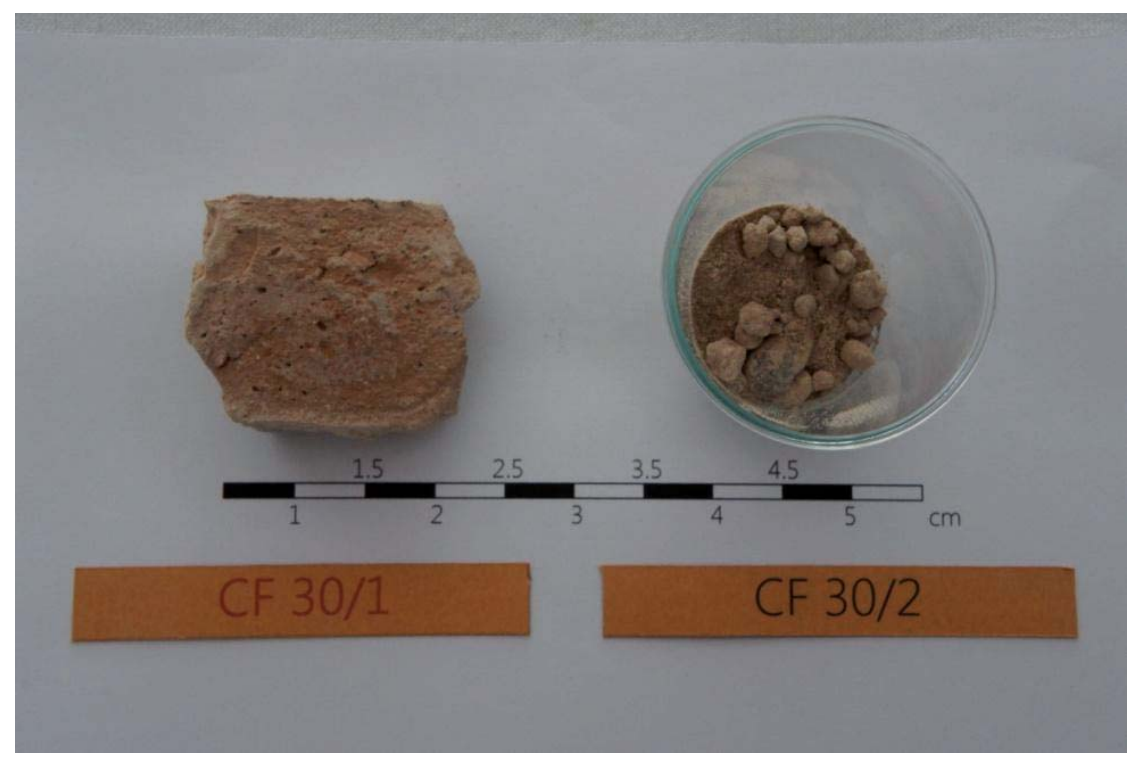

FIG. 56 Clasificación muestras CF 30/1 y CF 30/2 (CRISTINI)

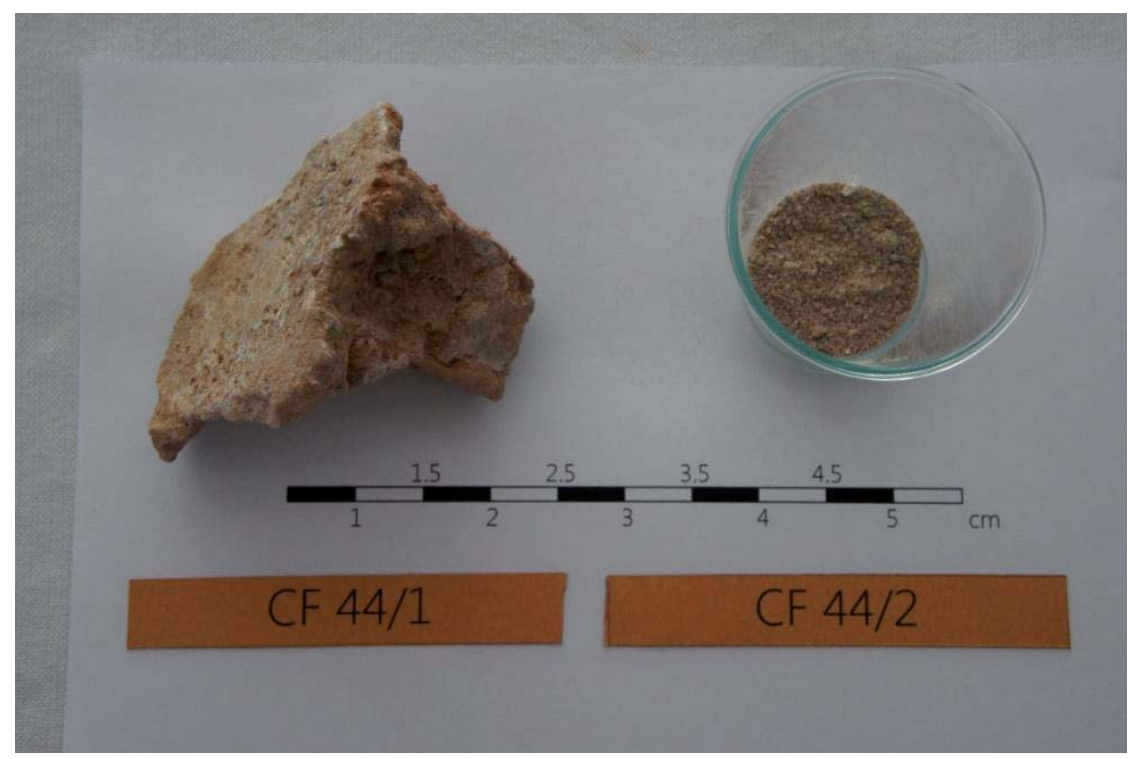

FIG. 57 Clasificación muestras CF 44/1 y CF 44/2 (CRISTINI) 


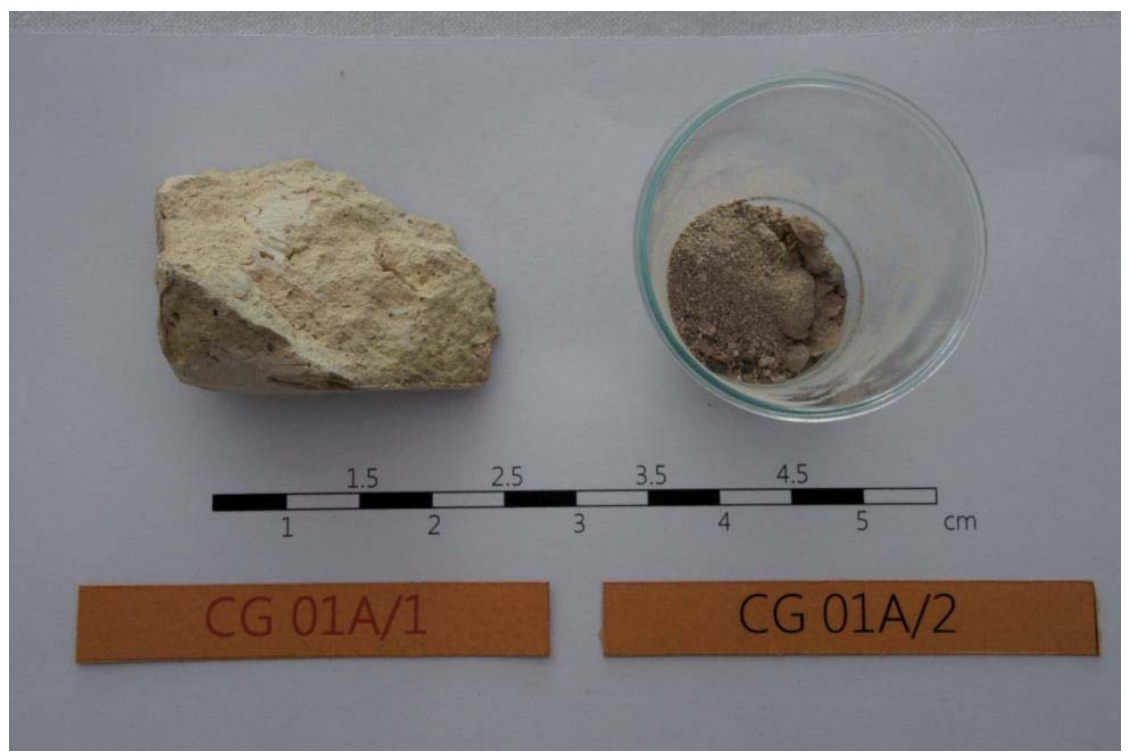

FIG. 58 Clasificación muestras CG O1A/1 y CG 01A/2 (CRISTINI)

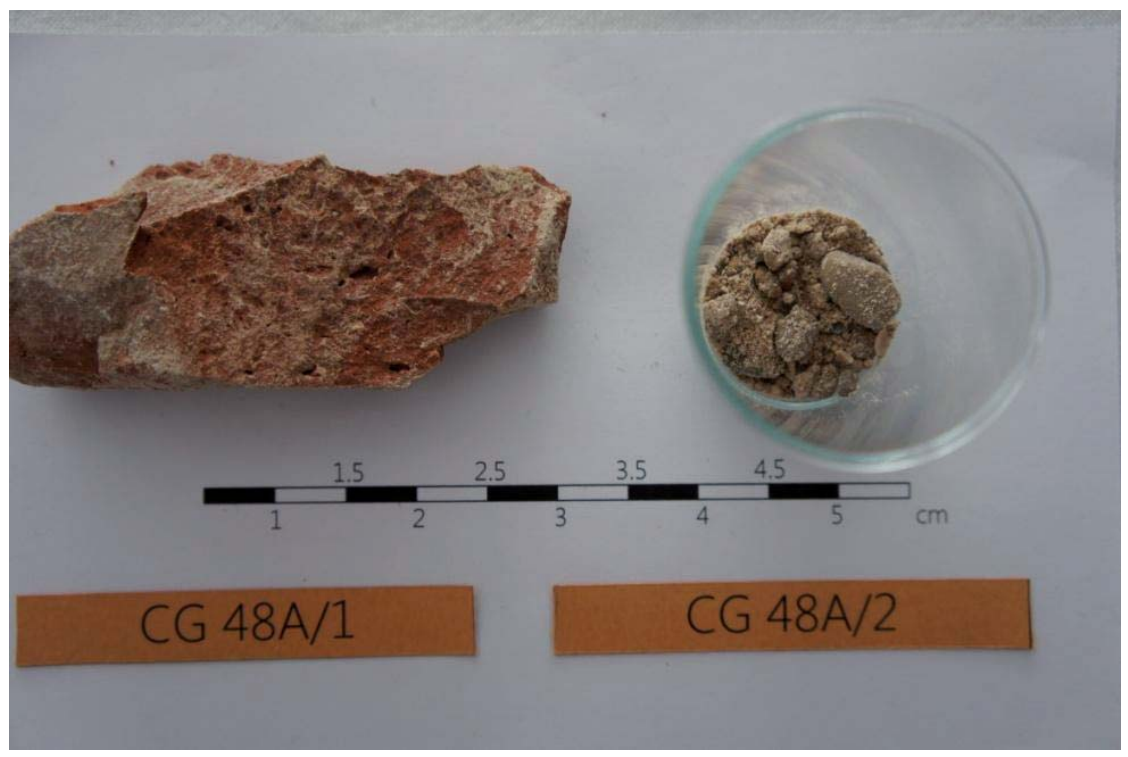

FIG. 59 Clasificación muestras CG 48A/1 y CG 48A/2 (CRISTINI) 


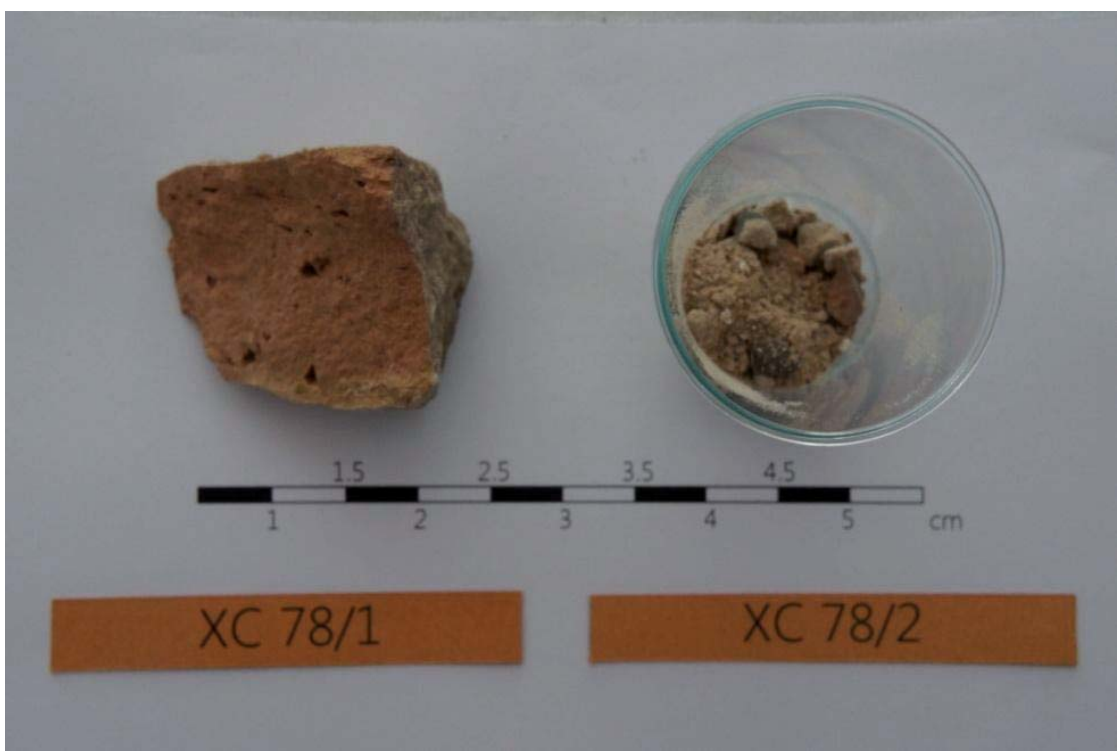

FIG. 60 Clasificación muestras XC 78/1 y XC 78/2 (CRISTINI)

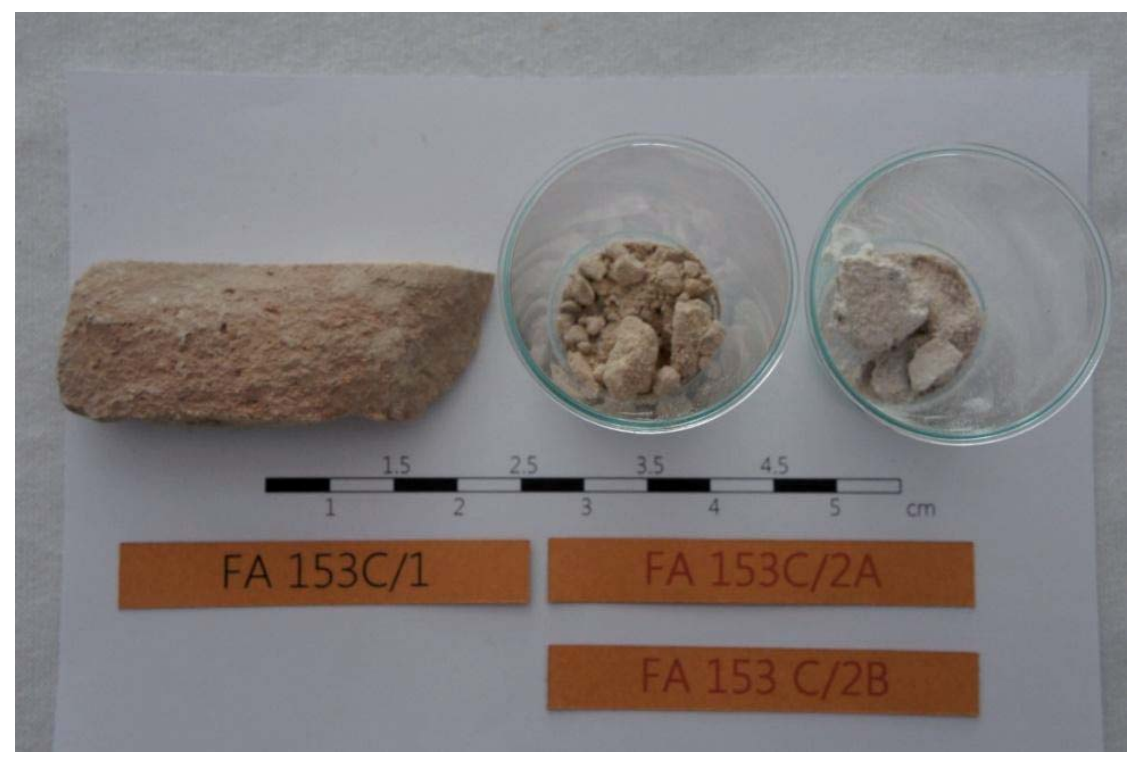

FIG. 61 Clasificación muestras FA 153C/1 FA 153C/2A y FA 153C/2B (CRISTINI) 


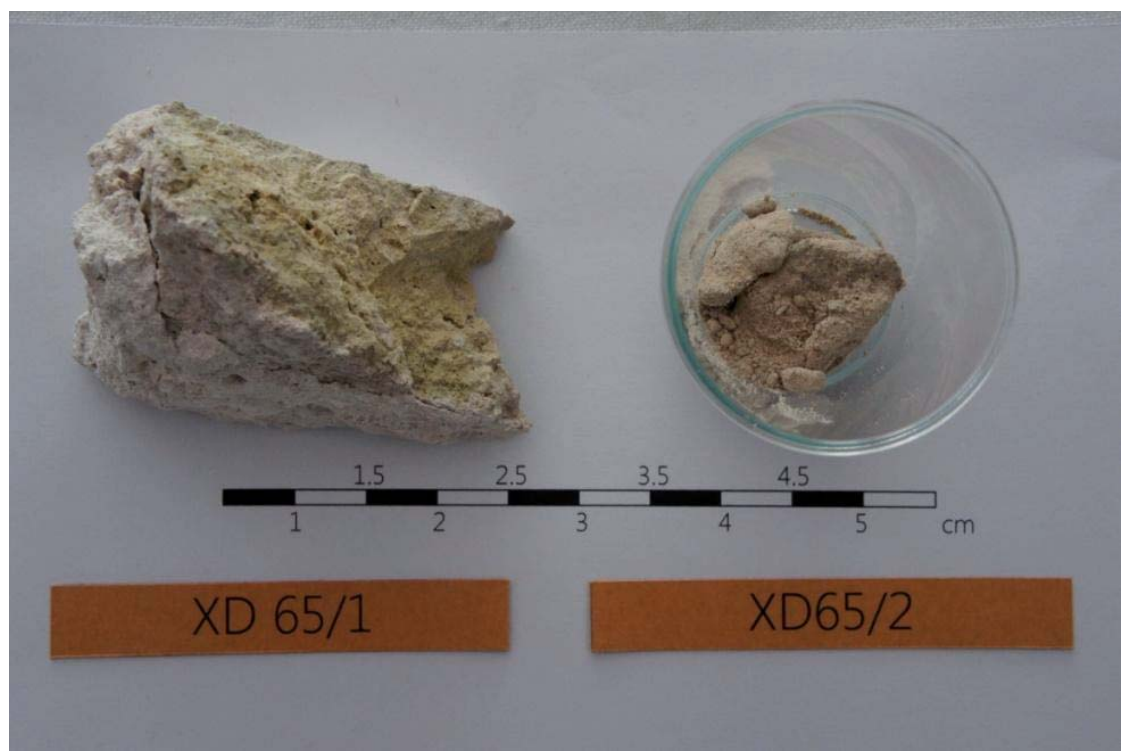

FIG. 62 Clasificación muestras XD 65/1 y XD 65/2 (CRISTINI)

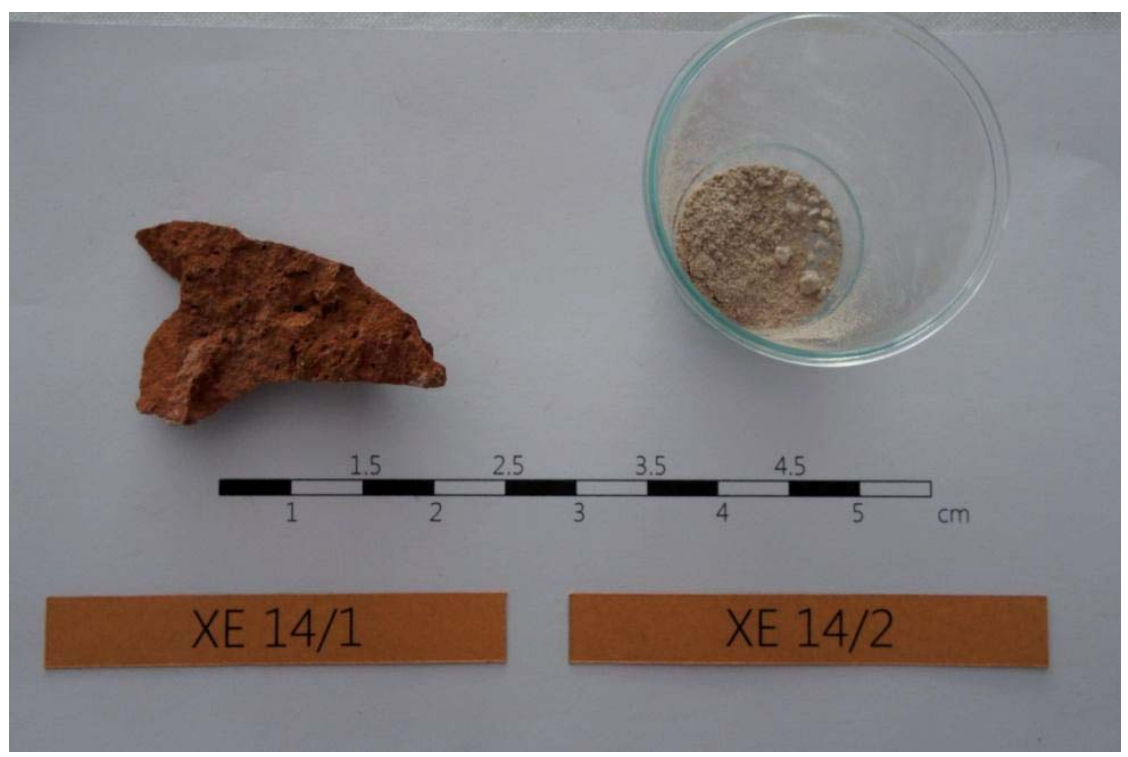

FIG. 63 Clasificación muestras XE 14/1 y XE 14/2 (CRISTINI) 


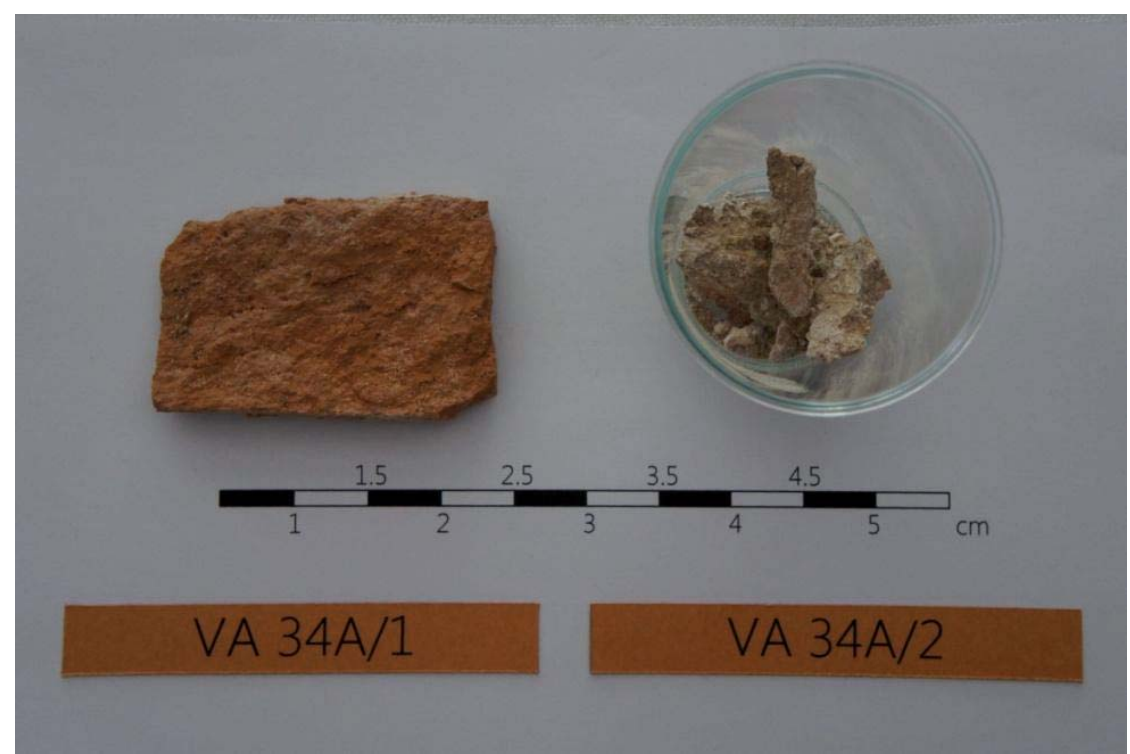

FIG. 64 Clasificación muestras VA 34A/1 y VA 34A/2 (CRISTINI)

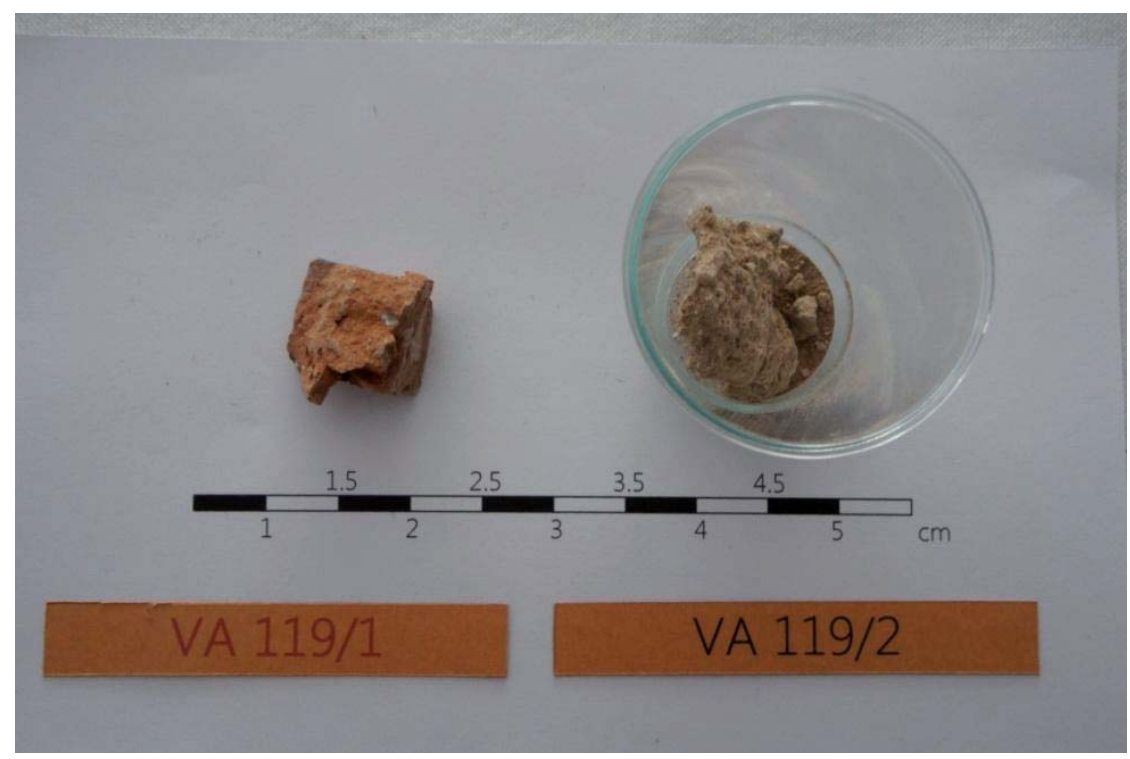

FIG. 65 Clasificación muestras VA 119/1 y VA 119/2 (CRISTINI) 


\section{Análisis visual de muestras de morteros claros}

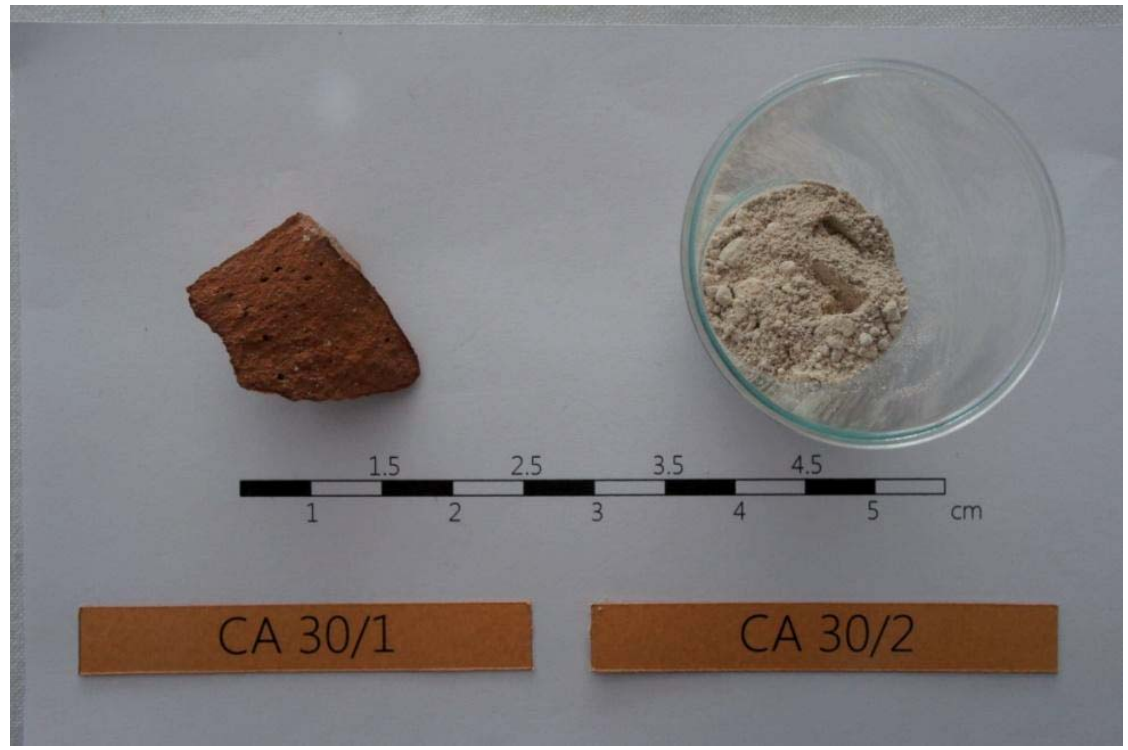

FIG. 66 Clasificación muestras CA 30/1 y CA 30/2 (CRISTINI)

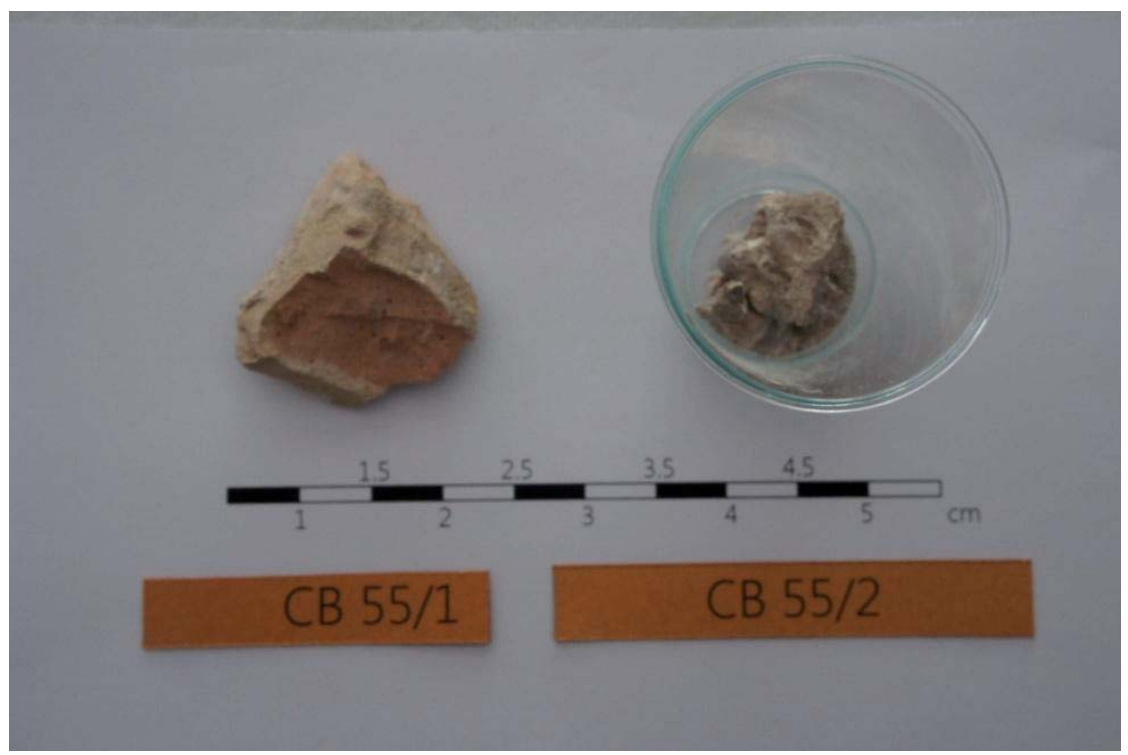

FIG. 67 Clasificación muestras CB 55/1 y CB 55/2 (CRISTINI) 


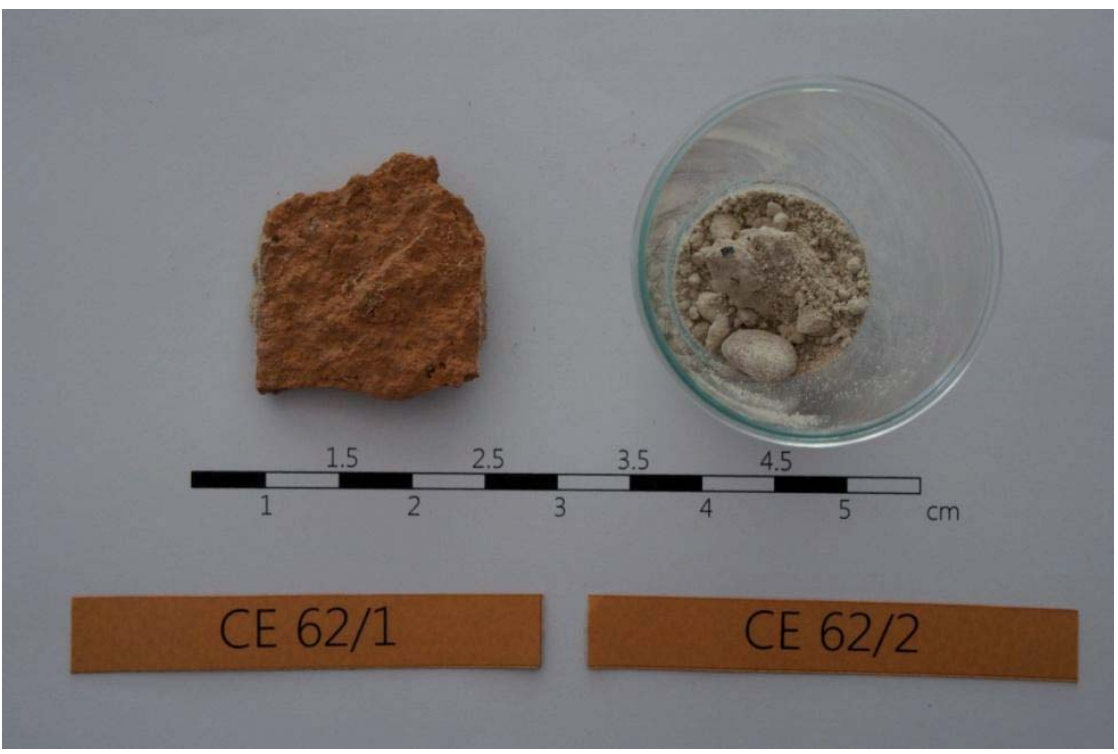

FIG. 68 Clasificación muestras CE 62/1 y CE 62/2 (CRISTINI)

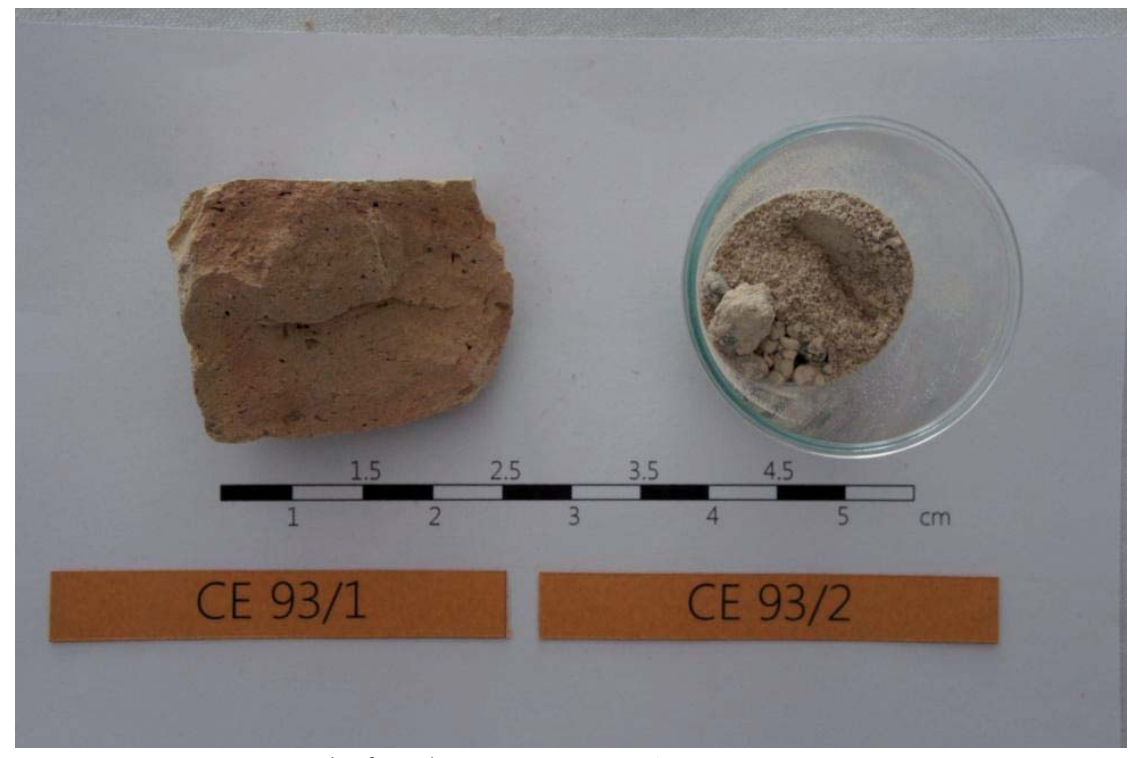

FIG. 69 Clasificación muestras CE 93/1 y CE 93/2 (CRISTINI) 


\section{MUROSINTRAMUIOS}

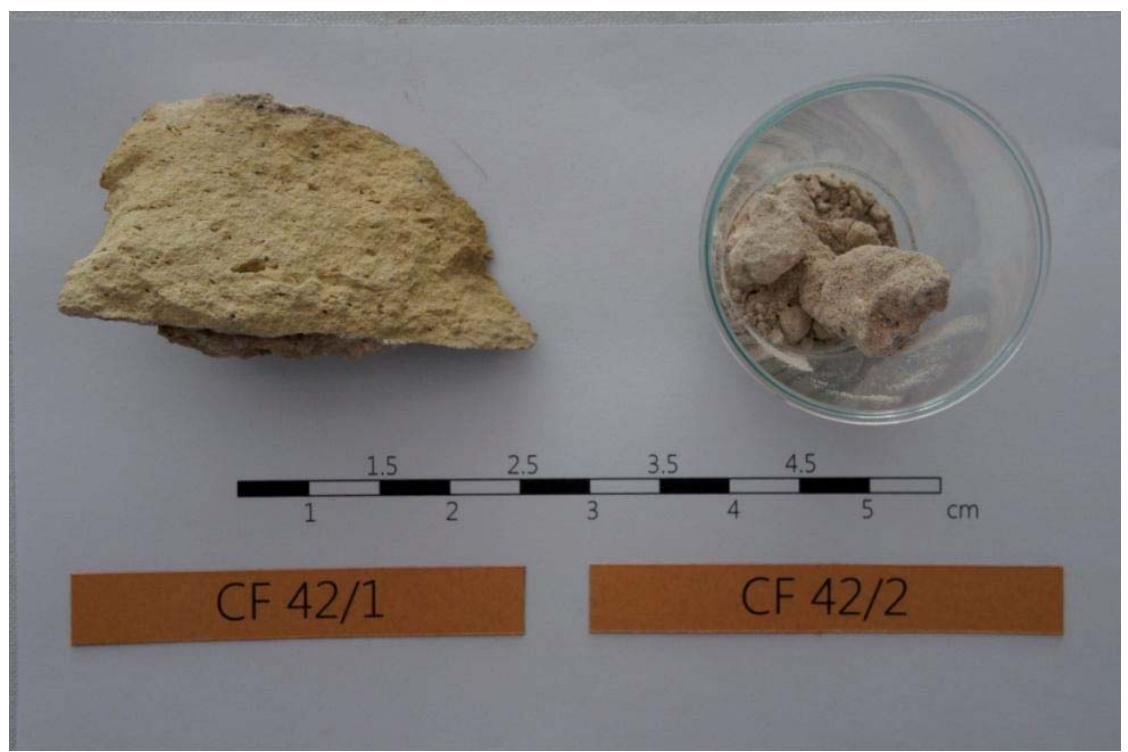

FIG. 70 Clasificación muestras CF 42/1 y CF 42/2 (CRISTINI)

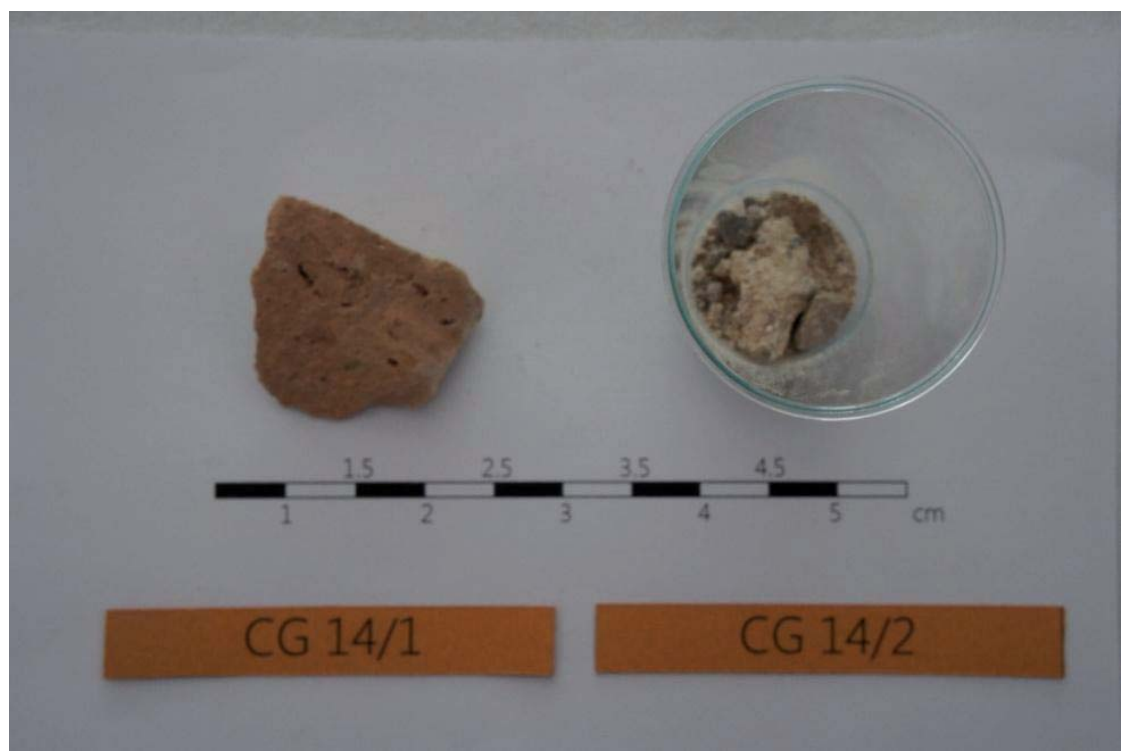

FIG. 71 Clasificación muestras CG 14/1 y CG 14/2(CRISTINI) 


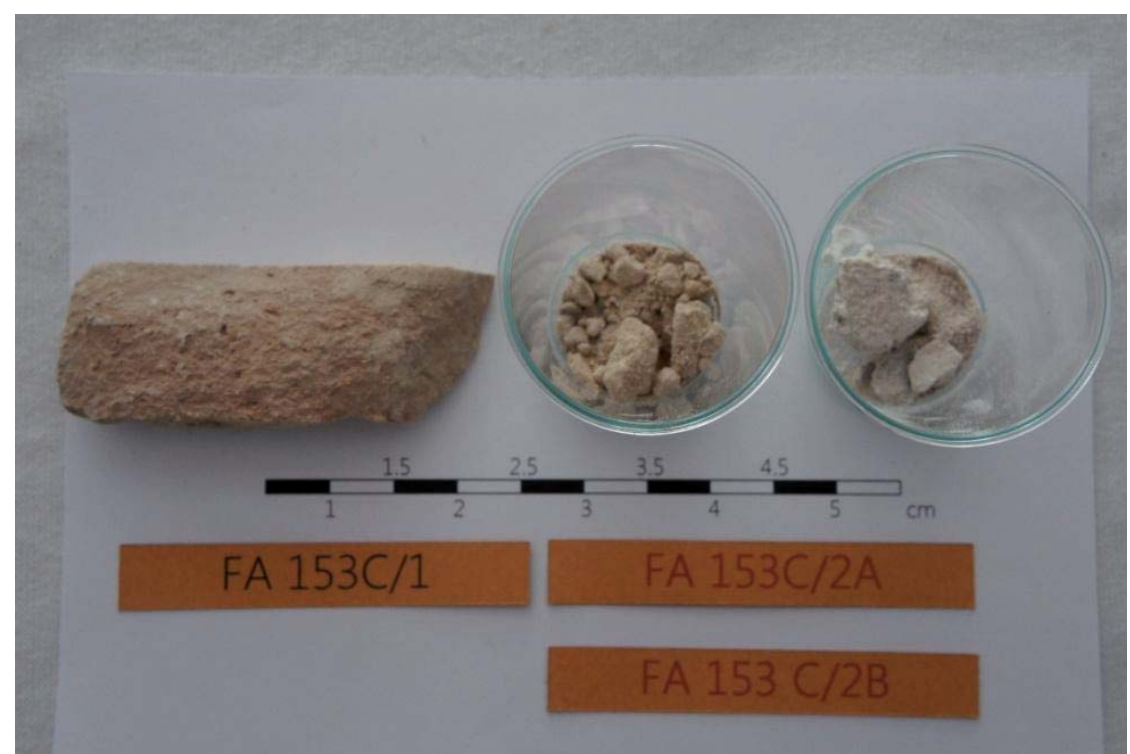

FIG. 72 Clasificación muestras FA 153C/1, FA 153C/2A y FA 153C/2A (CRISTINI)

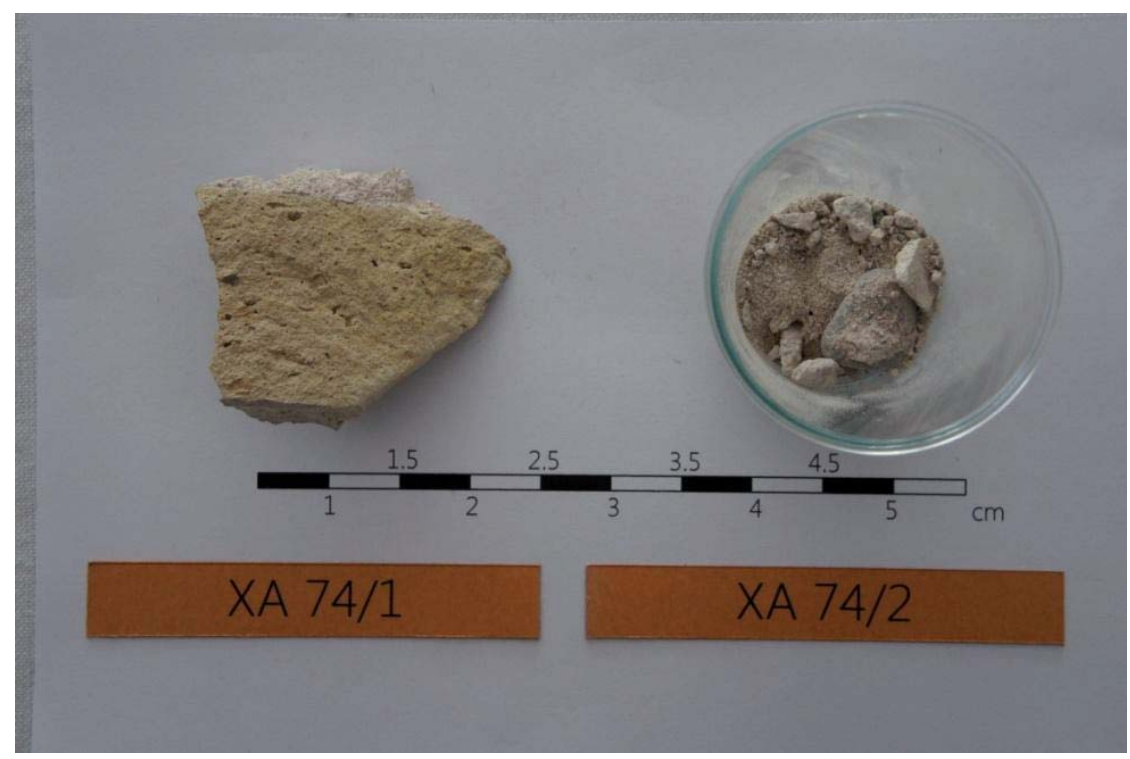

FIG. 73 Clasificación muestras XA 74/1 y XA 74/2 (CRISTINI) 


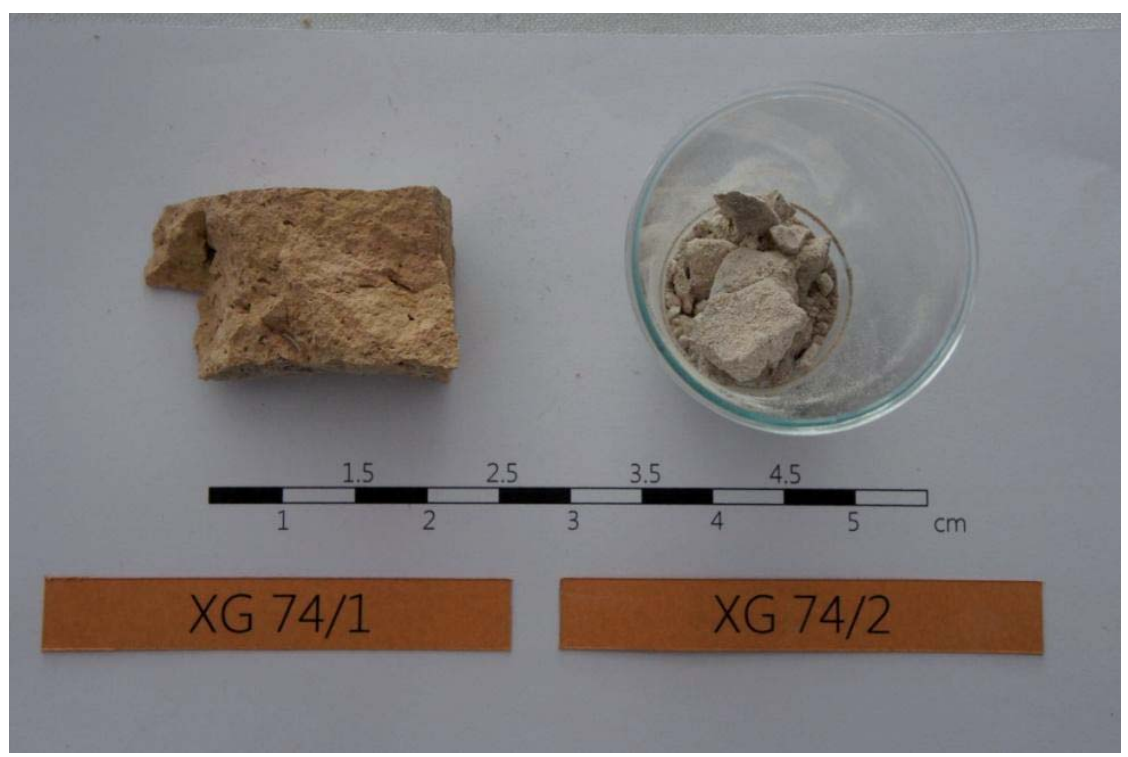

FIG. 74 Clasificación muestras XG 74/1 y XG 74/2 (CRISTINI)

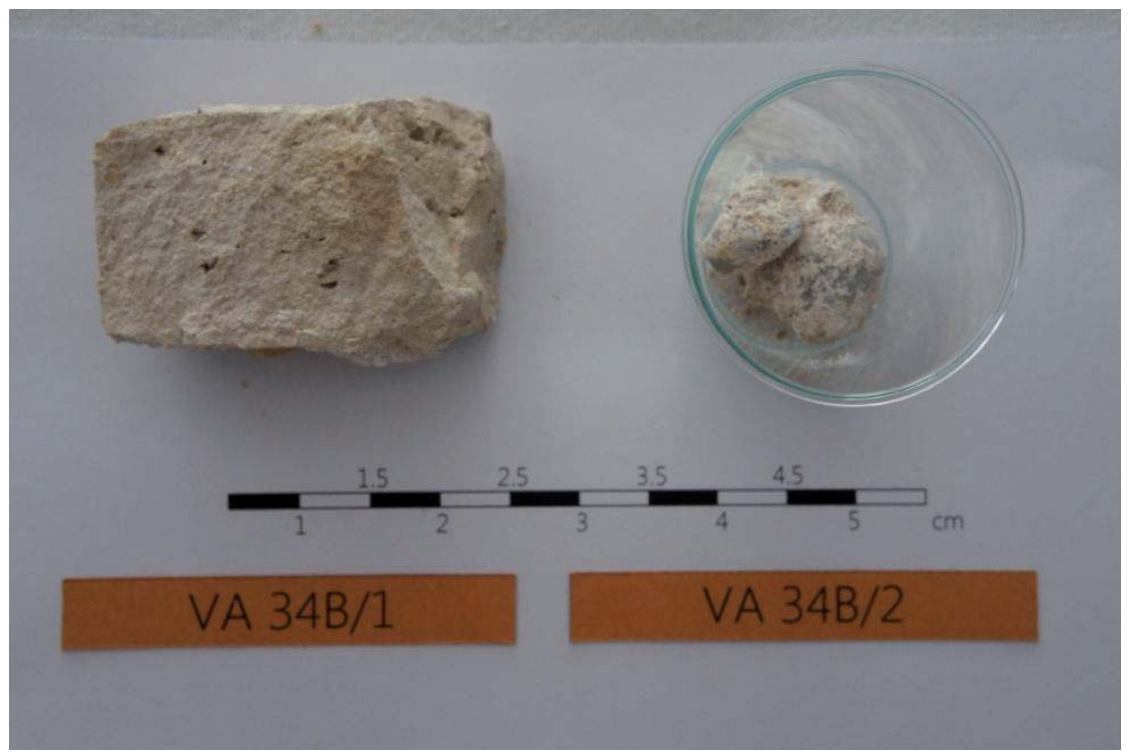

FIG. 75 Clasificación muestras VA 34B/1 y VA 34B/2 (CRISTINI) 


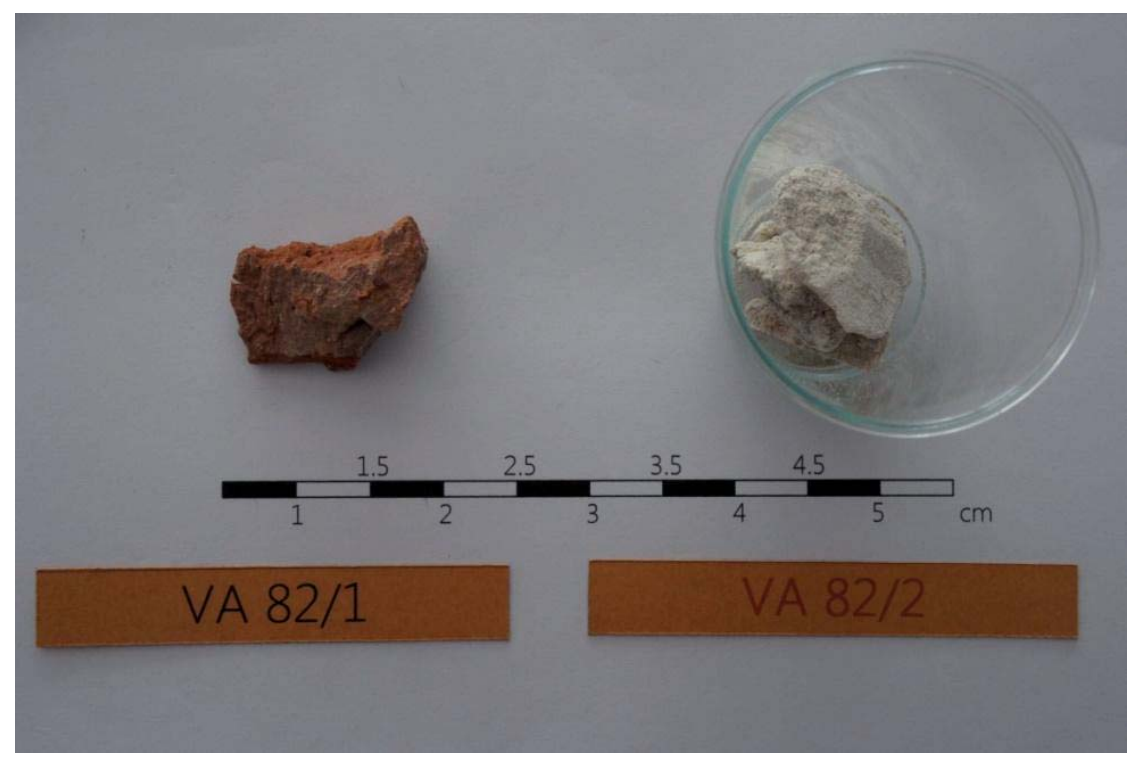

FIG. 76 Clasificación muestras VA 82/1 y VA 82/2 (CRISTINI)

\section{Análisis visual general de muestras de ladrillos amarillentos}

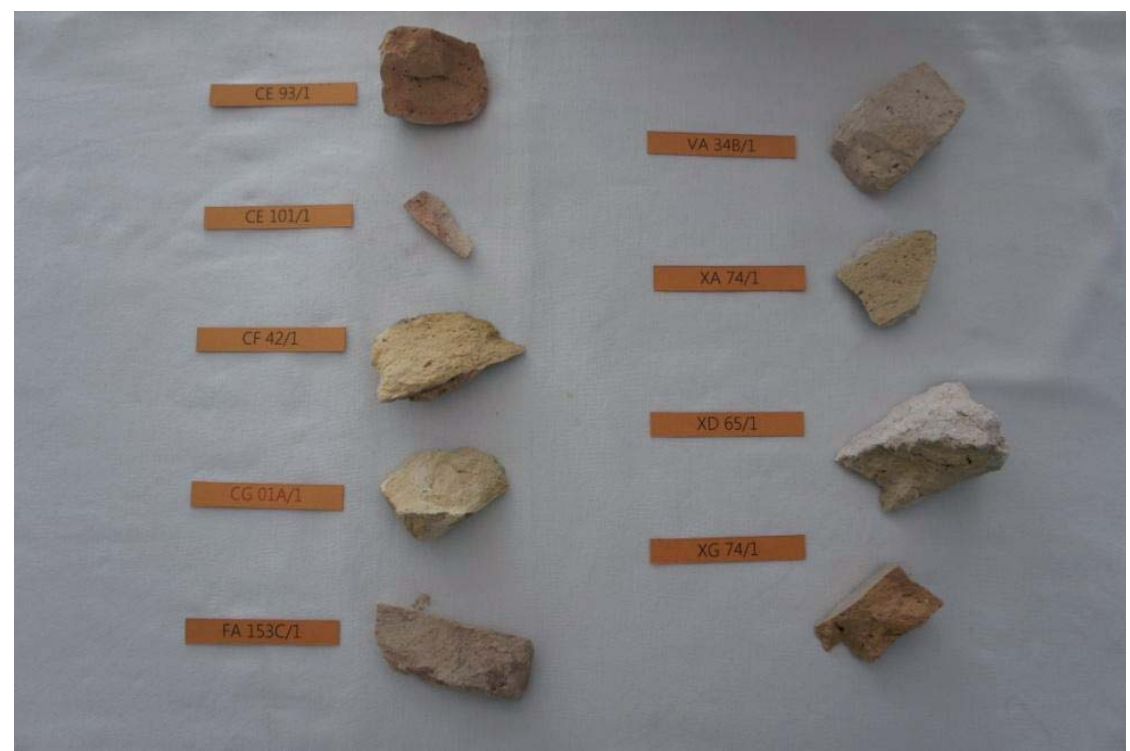

FIG. 77 Clasificación muestras ladrillos amarillentos: Ce93/1, Ce101/1, Cf42/1, Cg01a/1, Fa153c/1, Xd65/1, Xa74/1, Xg74/1, Va34b/1 (CRISTINI) 
murOSINTRAMUIOS

Resumen de análisis visual de muestras 


\section{Análisis visual de muestras de ladrillos anaranjados}

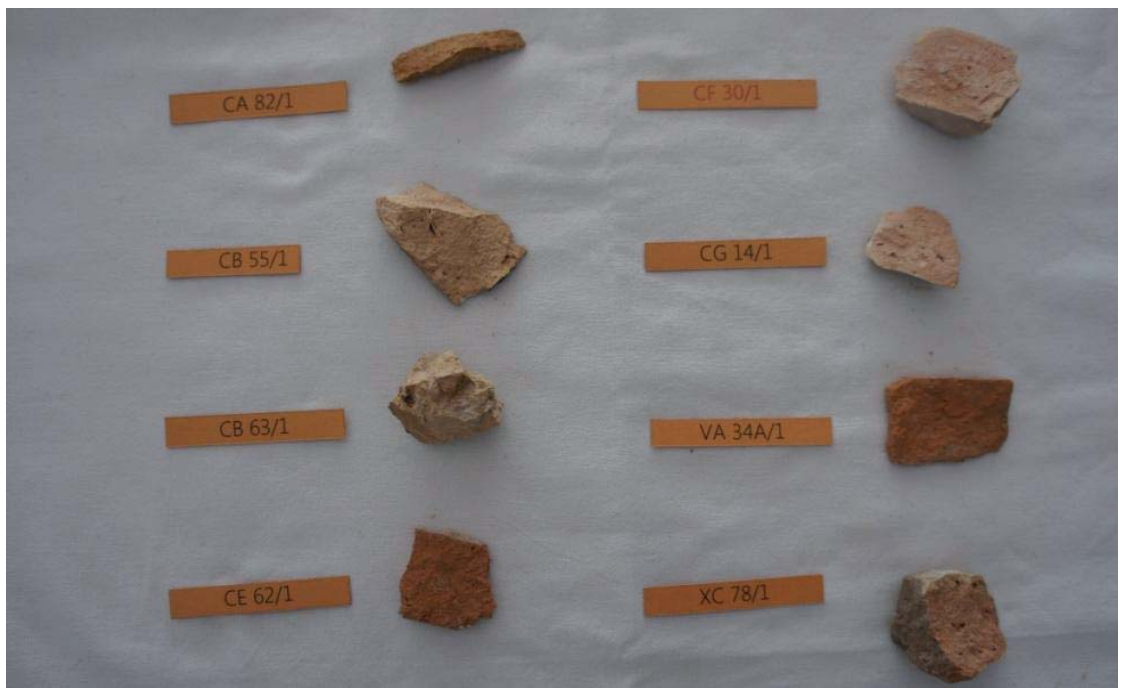

FIG. 78 Clasificación muestras ladrillos anaranjados Ca82/1, Cb55/1, Cb63/1, Ce62/1, Cf30/1, Cg14/1, Xc78/1, Va34a/1 (CRISTINI)

\section{Análisis visual general de muestras de ladrillos pardos}

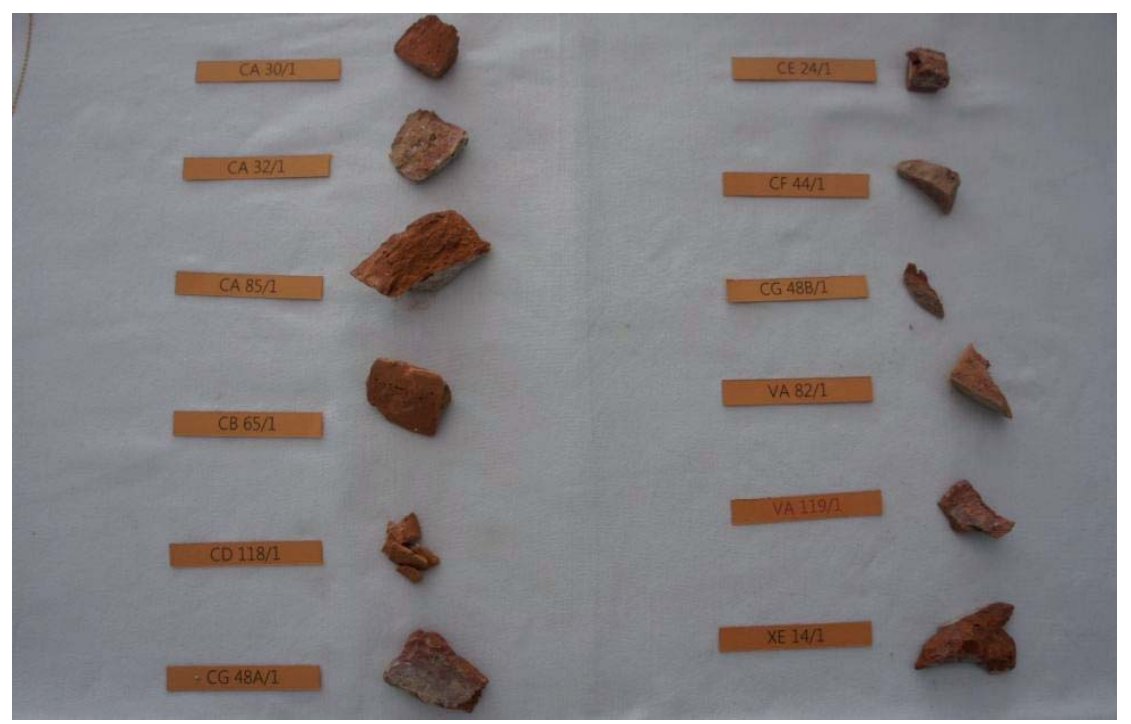

FIG. 79 Clasificación muestras ladrillos pardos Ca 30/1, Ca 32/1, Ca85/1, Cb6571, Cd118/1, Ce2471, Cg48a/1;Cg48b/1, Xe14/1, Va82/1, Va119/1, Cf 44/1 (CRISTINI) 


\section{Análisis visual general de muestras de morteros oscuros}

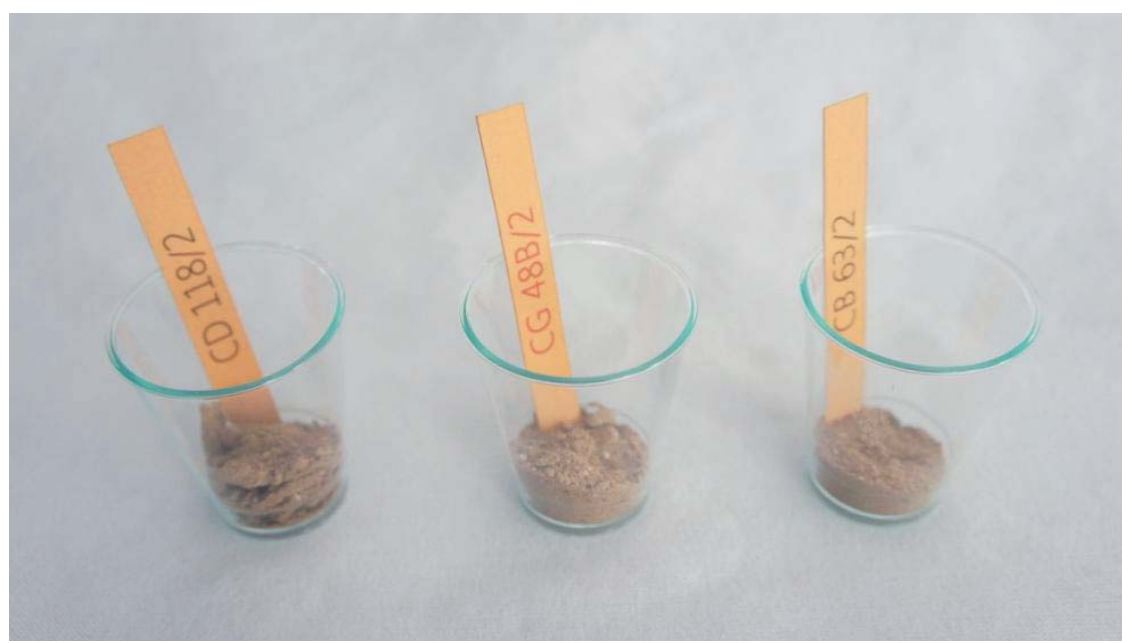

FIG. 80 Clasificación muestras de morteros oscuros CD 118/2, CG 48B/2 Y CB 63/2 (CRISTINI)

\section{Análisis visual general de muestras de morteros grisáceos}

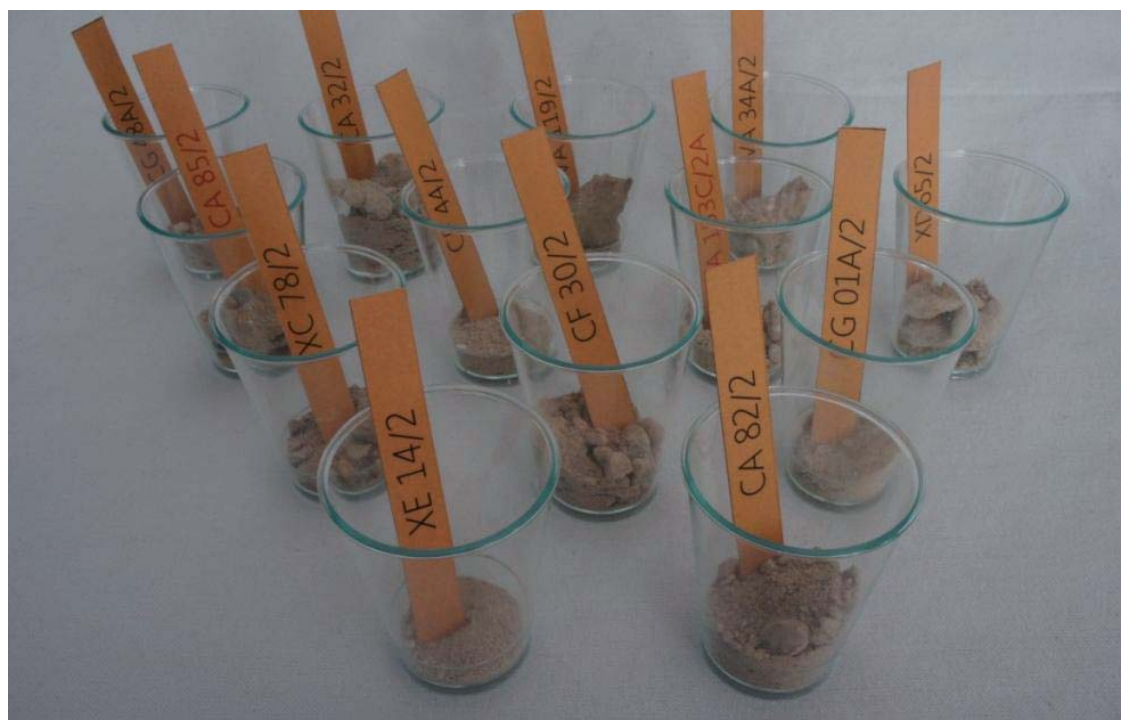

FIG. 81 Clasificación muestras de morteros grisáceos Ca32/2, Ca82/2, Ca85/2, Cf30/2, Cf44/2, Cg01a/2, Cg48a/2, Xc78/2, Fa153c/2a, Xd65/2, Xe14/2, Va34a/2, Va119/2 (CRISTINI) 


\section{Análisis visual general de muestras de morteros claros}

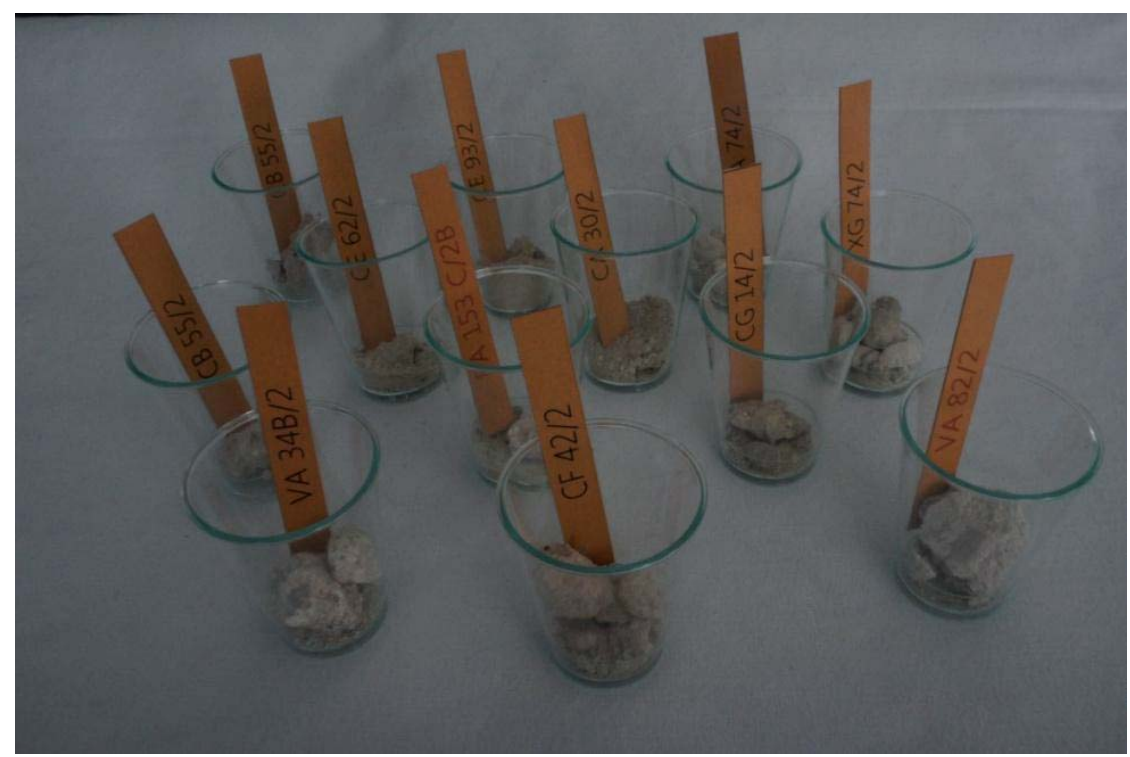

FIG. 82 Clasificación muestras de morteros claros Ca30/2, Cb55/2, Ce62/2, Ce93/2, Cf42/2, Cg14/2, Fa153c/2b, Xa74/2, Xg74/2, Va34b/2, Va82/2 (CRISTINI) 


\section{III.3 Informe analítico}

Selección de muestras de ladrillos y morteros (FT-IR)

Informe realizado por:

Dr. Stephan Kröner

Dra. María Teresa Doménech Carbó

INFORME ANALÍTICO LAC 1147 INSTITUTO UNIVERSITARIO DE RESTAURACIÓN DEL PATRIMONIO, Universitat Politécnica de Valencia, Valencia

Valencia, 14 de noviembre de 2011.

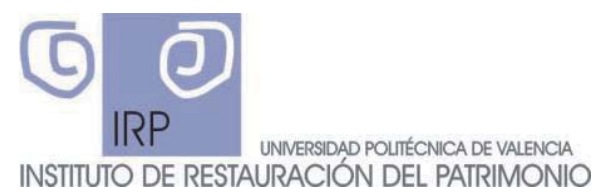



murOSINTRAMUIOS

Índice

FICHA TÉCNICA

1. INTERPRETACIÓN GLOBAL DE LOS RESULTADOS OBTENIDOS

2. ESPECTROFOTÓMETRO INFRARROJO POR TRANSFORMADA DE FOURIER (FT-IR)

2.1. COMPARACIÓN VISUAL DE LAS CUATRO MUESTRAS

2.2. PREPARACión DE LAS MUESTRAS

2.3. DESCRIPCIÓN DE LA MUESTRA FA 153C/2A

2.4. ESPECTROSCOPÍA FT-IR

2.5. DESCRIPCIÓN DE LA MUESTRA FA 153C/2B

2.6. ESPECTROSCOPÍA FT-IR

2.7. DESCRIPCIÓN DE LA MUESTRA CA 85/2

2.8. ESPECTROSCOPÍA FT-IR

2.7. DESCRIPCIÓN DE LA MUESTRA CG 48B/2

2.8. ESPECTROSCOPÍA FT-IR 


\section{FICHA TÉCNICA}

TÍTULO: $\quad$ CARACTERIZACIÓN DE MORTEROS

SOLICITANTE:

EXTRACCIÓN DE MUESTRAS:
Valentina Cristini

Muestras extraídas por el equipo de investigación del Instituto Universitario de Restauración de Patrimonio.

Muestra FA 153c/2a acabado: Mortero de tonalidad beige-claro

Muestra FA 153c/2b acabado: Mortero de tonalidad beige

Muestra CA 85/2: $\quad$ Mortero de tonalidad beige-marrón

Muestra CG 48b/2: $\quad$ Mortero de tonalidad marrón

TÉCNICAS INSTRUMENTALES UTILIZADAS:

- Espectrofotómetro Infrarrojo por Transformada de Fourier (FT-IR) 


\section{INTERPRETACIÓN GLOBAL DE LOS RESULTADOS OBTENIDOS}

Las cuatro muestras analizadas mediante Espectroscopia infrarroja (FT-IR) revelan como ligante principal de los morteros carbonato de calcio $\left(\mathrm{CaCO}_{3}\right)$. El examen visu indica la posible incorporación de silicatos como cuarzos en el árido de las muestras FA 153c/2a, CA 85/2y CG 48b/2El color de estas últimas tres muestras y la subida de las bandas de absorción del espectro FT-IR son característicos de minerales de óxido de hierro. En las tres muestras se identifica sulfato de calcio (yeso $\mathrm{CaSO}_{4} \cdot 2 \mathrm{H}_{2} \mathrm{O}$ ) como productos de alteración, siempre en una menor proporción. Asimismo se identifica, en las tres muestras, arcillas en diferente proporción.

\begin{tabular}{|c|c|c|c|}
\hline \multicolumn{4}{|c|}{ Arcillas } \\
\hline FA 153c/2a & FA $153 c / 2 b$ & CA 85/2 & $\mathrm{CG} 48 \mathrm{~b} / 2$ \\
\hline 0 & + & ++ & ++ \\
\hline \multicolumn{4}{|c|}{ Sulfatos } \\
\hline FA $153 c / 2 b$ & FA 153c/2a & $\mathrm{CG} 48 \mathrm{~b} / 2$ & CA 85/2 \\
\hline 0 & + & + & + \\
\hline
\end{tabular}

$(-)$ ausente, (o) presente, $(+)$ moderado, $(++)$ considerable, $(+++)$ abundante 
2. FTR

\subsection{COMPARACIÓN VISUAL DE LAS 4 MUESTRAS}
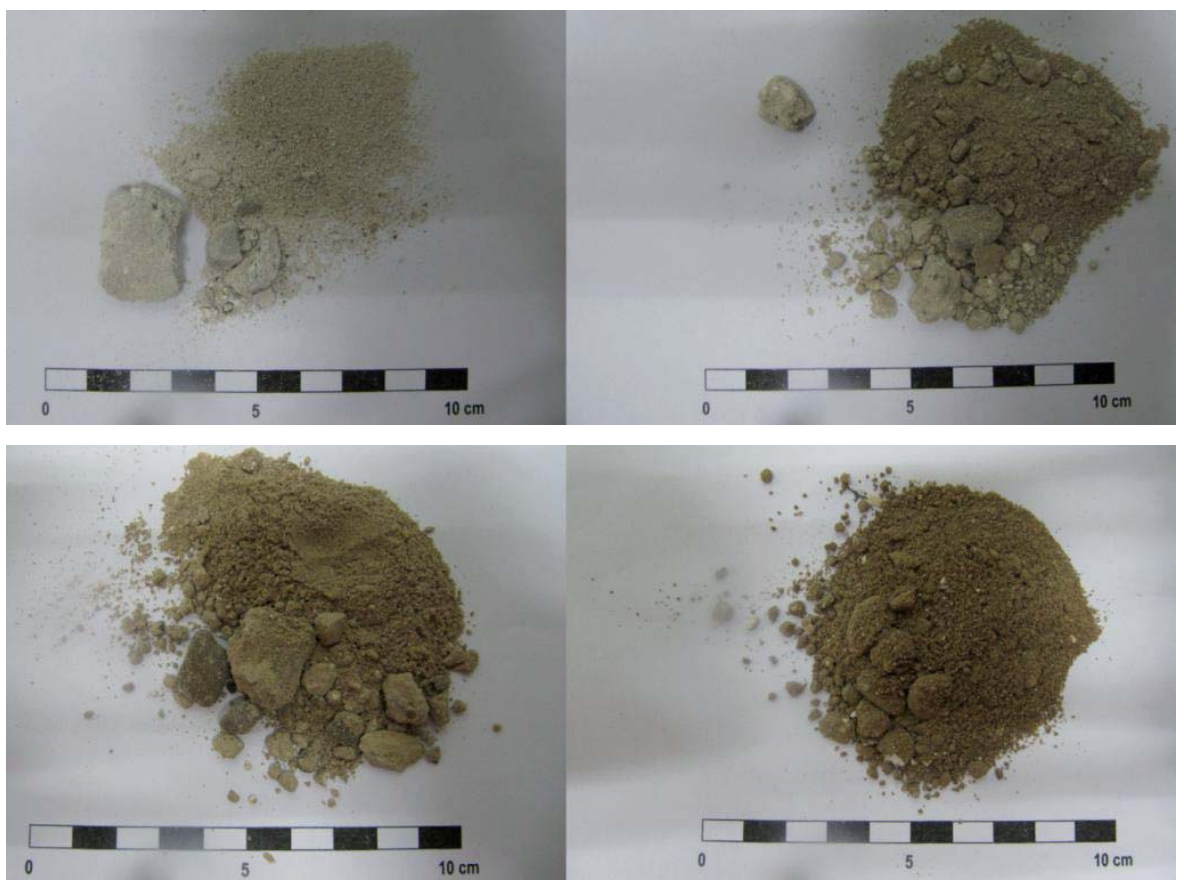

FIG.83 desde arriba a la izquierda, Fa153c/2a, Fa153153c/2b, Ca85/2, Cg48b/2

Las muestras proporcionadas se distinguen por el tamaño del árido y el color. La muestra FA 153C/2a tiene el tono más claro y una distribución granulométrica más homogénea. En cambio el mortero FA 153c/2b, de la misma edificación, tiene un árido más heterogéneo y un tono más oscuro, sugiriendo una incorporación de arcillas. Las muestras CA 85/2y CG 48b/2 tienen una tonalidad más oscuro virando a marrón indicando una participación de arcillas en la elaboración de los morteros. 


\subsection{PREPARACIÓN DE LAS MUESTRAS}

Con el fin de determinar el ligante y la posible presencia de arcillas se disgrega una pequeña parte del mortero para pasarlo por un tamiz con luz de malla de 0,063mm. Se analizan los granos inferiores a 0,063 mediante el FT-IR. 
2.3. DESCRIPCIÓN DE LA MUESTRA FA 153c/2a

Mortero de tonalidad beige-claro con Ref. 1147-FA153c/2a

\subsection{ESPECTROSCOPIA FTIR}

MUESTRA REF. : $\quad$ 1147-FA153c/2a

TIPO DE PREPARACIÓN : Pulverización

DESCRIPCIÓN :

FA $153 c / 2 a,<0,063 \mathrm{~mm}$

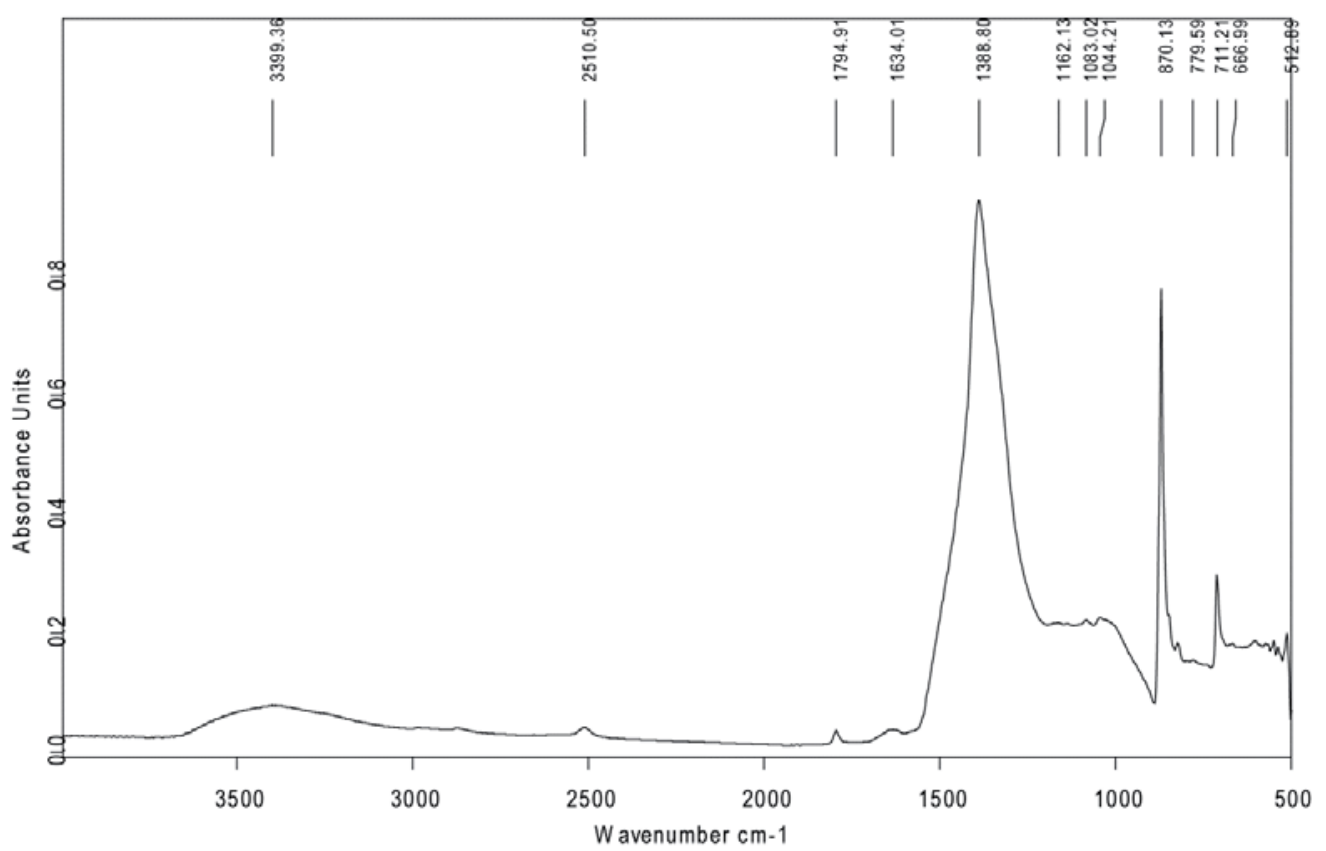




\begin{tabular}{|c|c|}
\hline Muestra & Interpretación de resultados FTIR \\
\hline $\begin{array}{l}\text { FA 153c/2a, } \\
<0,063 \mathrm{~mm}\end{array}$ & $\begin{array}{l}\text { Elementos mayoritarios: } \\
\text { Calcita: } 2511,1795,1389,870 \text { y } 711 \mathrm{~cm}^{-1} \\
\text { Elementos minoritarios: } \\
\text { Arcillas: } 3399,1634,1162-1100 \text { y } 513 \mathrm{~cm}^{-1} \\
\text { Yeso: } 3399,1634,1083 \text { y } 667 \mathrm{~cm}^{-1} \\
\text { Cuarzo: } 780 \mathrm{~cm}^{-1}\end{array}$ \\
\hline
\end{tabular}


2.5. DESCRIPCIÓN DE LA MUESTRA FA 153c/2b

Mortero de tonalidad beige con Ref. 1147- FA153c/2b

\subsection{ESPECTROSCOPÍA FTIR}

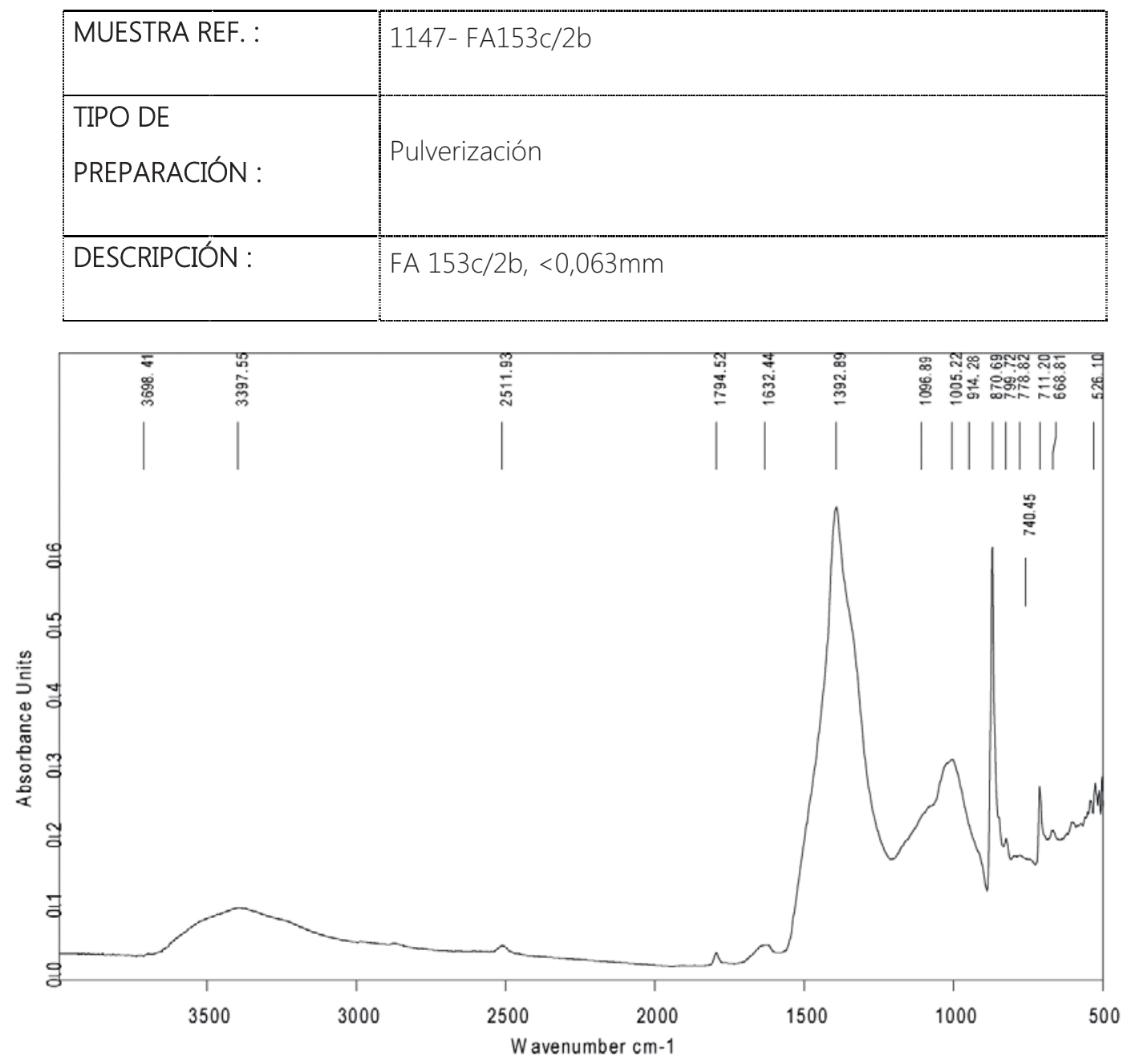




\begin{tabular}{|l|l|}
\hline \multicolumn{1}{|c|}{ Muestra } & \multicolumn{1}{c}{ Interpretación de resultados FTIR: } \\
\hline Elementos mayoritarios: \\
Calcita: $2512,1795,1393,871$ y $711 \mathrm{~cm}^{-1}$ \\
$<0,063 \mathrm{~mm}$
\end{tabular} \mid $\begin{aligned} & \text { Elementos minoritarios: } \\
& \text { Arcillas: } 3698,3397,1632,1200-914,740 \text { y } 526 \mathrm{~cm}^{-1} \\
& \text { Yeso: } 3397,1632,1095 \text { y } 669 \mathrm{~cm}^{-1} \\
& \text { Cuarzo: } 800 \text { y } 779 \mathrm{~cm}^{-1} \text { (Qtz-doblete) } \\
& \end{aligned}$




\subsection{DESCRIPCIÓN DE LA MUESTRA CA 85/2}

Mortero de tonalidad beige-marrón con Ref. 1147- CA 85/2

\subsection{ESPECTROSCOPÍA FTIR}

\begin{tabular}{|l|l|}
\hline MUESTRA REF. : & $1147-$ CA $85 / 2$ \\
\hline TIPO DE PREPARACIÓN : & Pulverización \\
\hline DESCRIPCIÓN : & CA $85 / 2,<0,063 \mathrm{~mm}$ \\
\end{tabular}

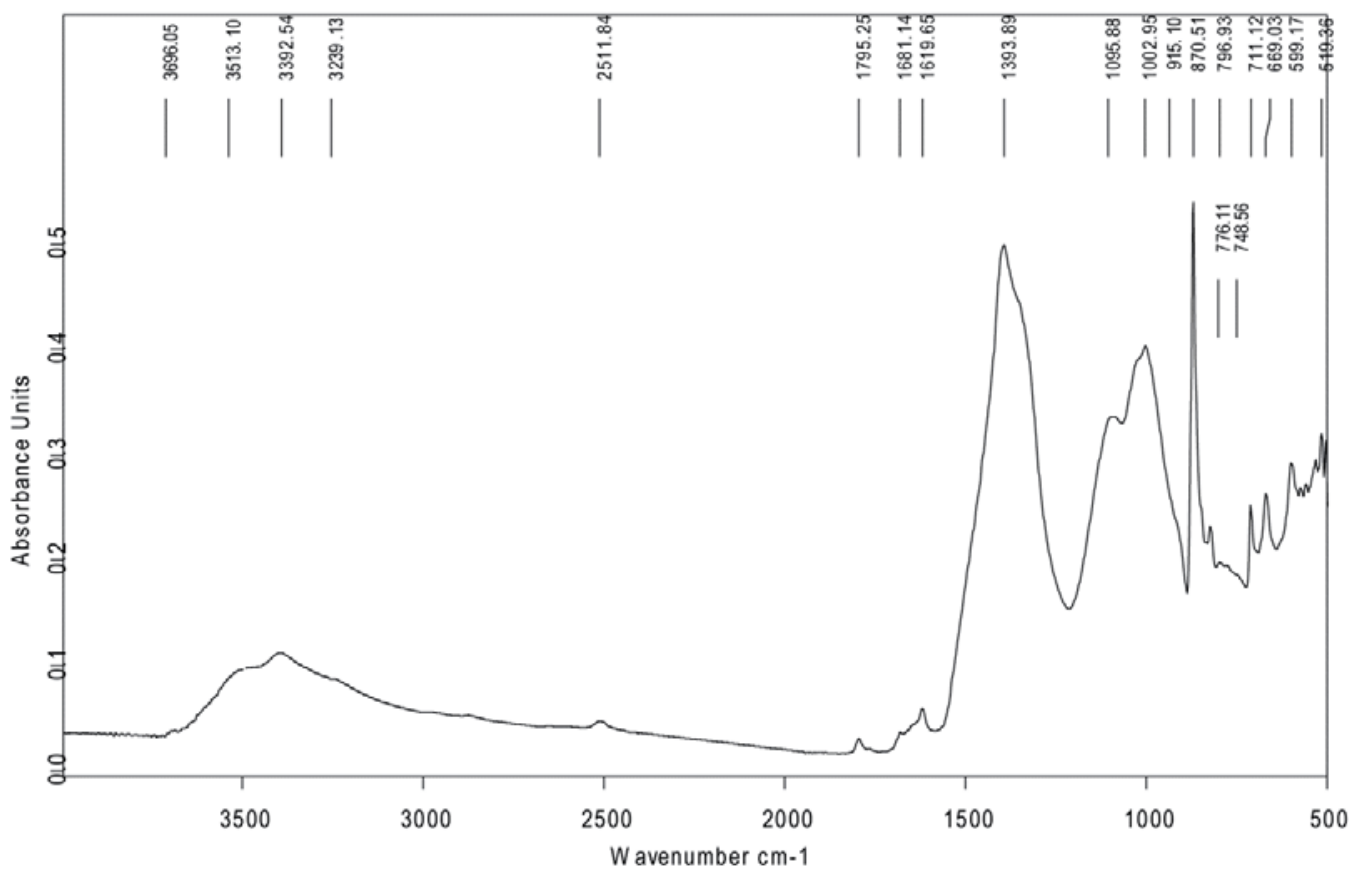




\begin{tabular}{|l|l|}
\hline \multicolumn{1}{|c|}{ Muestra } & \multicolumn{1}{c|}{$\begin{array}{c}\text { Interpretación de resultados FTIR: } \\
\text { Elementos mayoritarios: } \\
\text { Calcita: 2512, 1795, 1394, 871 y } 711 \mathrm{~cm}^{-1}\end{array}$} \\
$<0,063 \mathrm{~mm}$ & $\begin{array}{l}\text { Elementos minoritarios: } \\
\text { Arcillas: } 3696,3513,3393,1620,1200-915,748 \text { y } 519 \\
\mathrm{~cm}^{-1} \\
\text { Yeso: } 3513,3393,3239,1681,1620,1096,669 \text { y } 599 \\
\text { cm }{ }^{-1} \\
\text { Cuarzo: } 797 \text { y } 776 \mathrm{~cm}^{-1} \text { (Qtz-doblete) }\end{array}$ \\
\hline
\end{tabular}


2.7. Descripción de la muestra CG 48b/2

Mortero de tonalidad marrón con Ref. 1147- CG 48b /2

\subsection{ESPECTROSCOPÍA FTIR}

\begin{tabular}{|l|l|}
\hline MUESTRA REF. : & $1147-$ CG 48b/2 \\
\hline TIPO DE & Pulverización \\
\hline PREPARACIÓN : & \\
\hline DESCRIPCIÓN : & CG 48b/2<0,063mm \\
\hline
\end{tabular}

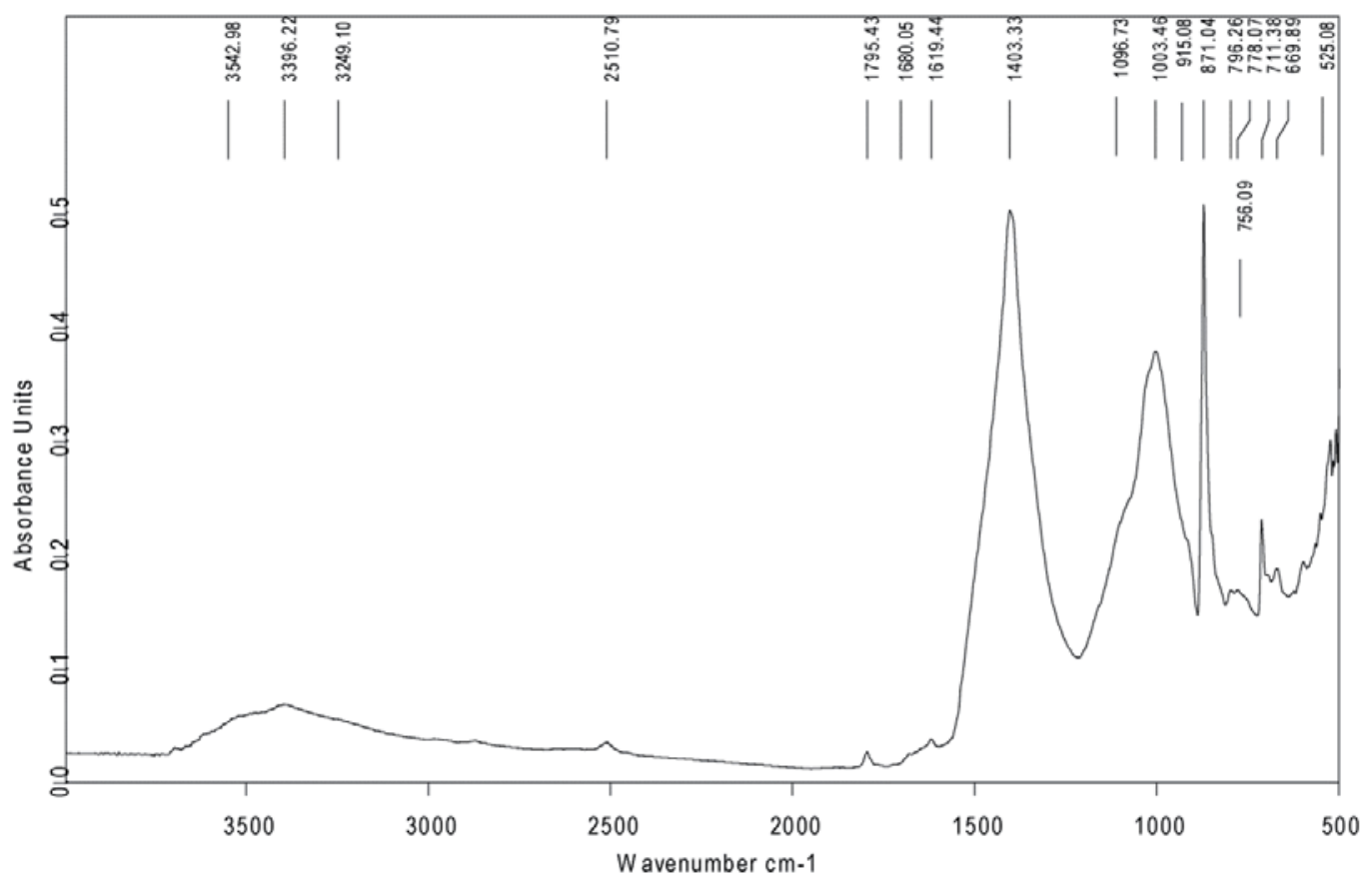




\begin{tabular}{|c|l|}
\hline \multicolumn{1}{|c|}{ Muestra } & \multicolumn{1}{c}{$\begin{array}{c}\text { Interpretación de resultados FTIR: } \\
\text { Elementos mayoritarios: } \\
\text { Calcita: } 2511,1795,1403,871 \text { y } 711 \mathrm{~cm}^{-1}\end{array}$} \\
CG 48b/2<0,063mm & $\begin{array}{l}\text { Arcillas: } 3696,3543,3396,1619,1200-915,756 \text { y } \\
525 \mathrm{~cm}^{-1} \\
\text { Yeso: } 3543,3396,3249,1680,1619,1097 \text { y } 670 \mathrm{~cm}^{-} \\
1 \\
\text { Cuarzo: } 796 \text { y } 778 \mathrm{~cm}^{-1} \text { (Qtz-doblete) }\end{array}$ \\
\hline
\end{tabular}





\section{III.4 Informe analítico}

Selección de muestras de ladrillos y morteros (SEM/EDX/MO)

Informe realizado por:

Dr. Stephan Kröner

Dra. María Teresa Doménech Carbó

INFORME ANALÍTICO LAC 1147 INSTITUTO UNIVERSITARIO DE RESTAURACIÓN DEL PATRIMONIO, Universitat Politécnica de Valencia, Valencia

Valencia, 14 de noviembre de 2011.

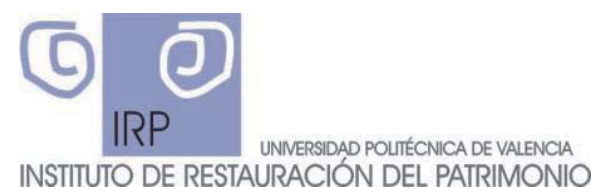



murOSINTRAMUROS

Índice

FICHA TÉCNICA

1. INTERPRETACIÓN GLOBAL DE LOS RESULTADOS OBTENIDOS

2. CARACTERIZACIÓN QUÍMICA-MINERALÓGICA DE LOS LADRILLOS

2.1. MUESTRA VA 119/1

2.1.1. DESCRIPCIÓN DE LA MUESTRA

2.1.2. $\mathrm{MO}$

2.1.3. SEM/EDX

2.2. MuestRa CF 30/1

2.2.1. DESCRIPCIÓN DE LA MUESTRA

2.2.2. $\mathrm{MO}$

2.2.3. SEM/EDX

2.3. MUESTRA CG $01 / 1$

2.3.1. DESCRIPCIÓN DE LA MUESTRA

2.3.2. $\mathrm{MO}$

2.3.3. SEM/EDX

3. CARACTERIZACIÓN MINERALÓGICA MORTERO/ CAPA PICTÓRICA

3.1. MUESTRA VA $82 / 2$

3.1.1. DESCRIPCIÓN DE LA MUESTRA

3.1.2. $\mathrm{MO}$

3.1.3. SEM/EDX 


\section{FICHA TÉCNICA}

TÍTULO: CARACTERIZACIÓN DE LADRILLOS Y MORTEROS

SOLICITANTE:

EXTRACCIÓN DE MUESTRAS:
Valentina Cristini

Muestras extraídas por el equipo de investigación del Instituto Universitario de Restauración de Patrimonio.

Ladrillo de tonalidad roja Ladrillo de tonalidad rojiza Ladrillo de tonalidad amarillenta Mortero de tonalidad claro-gris

Muestra VA 82 /2:

con capa pictórica

\section{TÉCNICAS INSTRUMENTALES UTILIZADAS:}

- MICROSCOPÍA ELECTRÓNICA DE BARRIDO/ MICROANÁLISIS DE RAYOS X (SEM/EDX)

- MICROSCOPÍA ÓPTICA (MO) 


\section{INTERPRETACIÓN GLOBAL DE LOS RESULTADOS OBTENIDOS}

\section{A. Comparación de los resultados obtenidos en los ladrillos analizados.}

En términos geológicos, las pastas cerámicas cocidas, que conforman los ladrillos, se podrían describir como rocas (artificiales) que han experimentado un metamorfismo bajo las condiciones de temperatura y presión adquiridas a lo largo su cocción artificial. Sin embargo, el tiempo de calentamiento y enfriamiento en ladrillos (unas horas) es mucho menor que en rocas metamórficas 'normales'. Posteriormente la exposición externa en el edificio provocará inestabilidad de los ladrillos provocando cambios micro-estructurales y mineralógicos (alteración y deterioro), debido a las condiciones (sub-)aéreas.

Por consiguiente, se utiliza el análisis mediante la Microscopía Óptica (MO) y la Microscopía Electrónica de Barrido/ Microanálisis de Rayos X (SEM/EDX) para describir los ladrillos.

En todas las muestras se detecta la presencia de los minerales cuarzo, calcita, ortoclasa y arcillas. Asimismo se detectaron en todos los ladrillos cloruros y sulfatos. Una tonalidad rojiza se atribuye a una combinación de núcleos ferríferos de óxidos de hierro (Fe) y focos de neoformación en entornos Ca-Fe así como restos de arcillas precursoras. Sin embargo en las muestras CF 30/1 y CG 01/1se detectan también (alumino-) silicatos de calcio, muy probablemente gehlenita $\mathrm{Ca}_{2} \mathrm{Al}\left[\mathrm{AlSiO}_{7}\right]$ y/o wollastonita $\mathrm{CaSiO}_{3}$ que se interpretan como minerales de neoformación debido a las temperaturas de cocción. Además en la muestra CG 01 (1) se sospecha la aparición de diópsido $\mathrm{CaMgSi}_{2} \mathrm{O}_{6}$ por el alto contenido del elemento magnesio en algunos aluminosilicatos.

En general, las fases de neoformación ayudan a hacer una estimación de la temperatura de cocción. La presencia de una cantidad de calcita primaria considerable sugiere una temperatura $<800^{\circ} \mathrm{C}$, ya que la calcita (carbonato cálcico) empieza a descomponerse a partir de $800^{\circ} \mathrm{C}$. La aparición de gehlenita supone una temperatura $>800^{\circ} \mathrm{C}$ y la coexistencia de gehlenita + diópsido (alumino silicatos) una temperatura mayor a $900^{\circ} \mathrm{C}$. Sin embargo 
estas temperaturas son sólo orientativas y se necesitaría otra técnica analítica complementaria para confirmar los minerales de neoformación. Al referirnos a tiempos geológicos, la fabricación de los ladrillos (tanto calentamiento como enfriamiento) tarda muy poco, y estas fases sólo se encuentran a escala micro-cristalina que se podrían identificar con más certeza mediante la difracción de Rayos X (DRX).

\begin{tabular}{|c|c|c|c|}
\hline & VA $119 / 1$ & CF 30/1 & CG 0/1 \\
\hline Color & rojo & rojizo & amarillento \\
\hline \multicolumn{4}{|l|}{ Minerales } \\
\hline Cuarzo & ++ & ++ & ++ \\
\hline Calcita & ++ & ++ & + \\
\hline Ortoclasa & + & + & + \\
\hline Arcillas & ++ & + & + \\
\hline $\begin{array}{l}\text { (Alumino-)silicatos de } \\
\text { calcio }\end{array}$ & - & O & + \\
\hline \multicolumn{4}{|l|}{ Sales } \\
\hline $\mathrm{Cl}^{-}$ & + & 0 & 0 \\
\hline $\mathrm{SO}_{4}^{2-}$ & 0 & 0 & 0 \\
\hline
\end{tabular}

ausente, (o) presente, $(+)$ moderado, $(++)$ considerable, $(+++)$ abundante

B. Mortero de tonalidad gris claro con capa pictórica

El mortero está mayoritariamente compuesto por granos de cuarzo y calcita. El ligante está constituido principalmente por calcita. El análisis del SEM/EDX revela en el 'mapping' y 'line scan' una concentración de los sulfatos en la transición mortero-capa pictórica y un nivel más elevado de cloruros en el mortero que en la capa pictórica. En la capa pictórica se detecta la presencia de arcillas y óxidos de hierro, dándole el color rojo característico. 
murOSINTRAMUIOS

II. CARACTERIZACIÓN QUIMICO/MINERALÓGICA DE LOS LADRILLOS 


\subsection{MUESTRA VA $119 / 1$}

\subsubsection{DESCRIPCIÓN DE LA MUESTRA}

Ladrillo de tonalidad roja con Ref. 1148-VA 119/1

\subsection{2. $\mathrm{MO}$}

\section{MICROSCOPIA OPTICA (MO)}

Microfotografia 1 : Luz incidente, $\times 10$

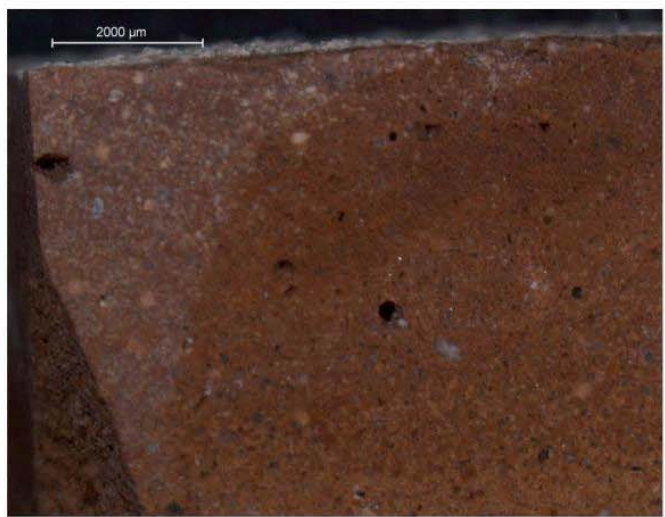

Figura 1. Ladrillo compacto de color rojo 


\section{ESPECTRO 3}

Project: Project 1

Owner: Administrador

Site: Site of Interest 1, 20x

Spectrum processing :

No peaks omitted

Processing option : All elements analyzed Number of iterations $=4$

Standard :

O SiO2 1-jun-1999 12:00 AM

Na Albite 1-jun-1999 12:00 AM

Al Al2O3 1-jun-1999 12:00 AM

$\mathrm{Si} \mathrm{SiO} 2$ 1-jun-1999 12:00 AM

K MAD-10 Feldspar 1-jun-1999 12:00 AM

\begin{tabular}{l|ll}
\hline Element & Weight\% & Atomic\% \\
& & \\
OK & 16.86 & 55.16 \\
$\mathrm{Na} \mathrm{K}$ & 0.29 & 0.67 \\
$\mathrm{Al} \mathrm{K}$ & 4.38 & 8.49 \\
$\mathrm{Si} \mathrm{K}$ & 14.50 & 27.02 \\
$\mathrm{~K} \mathrm{~K}$ & 6.47 & 8.66 \\
& & \\
Totals & 42.51 & \\
\hline
\end{tabular}

Sample: Ladrillo de tonalidad roja

ID: 1148-VA 119/1

Análisis puntual: Ortoclasa

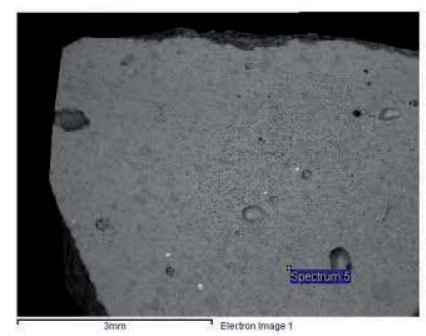

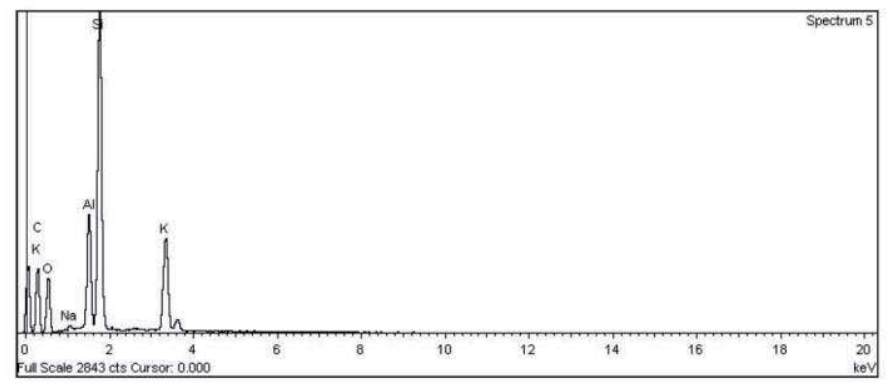




\section{ESPECTRO 4}

Project: Project 1

Owner: Administrador

Site: Site of Interest $1,20 \mathrm{x}$

Spectrum processing

No peaks omitted

Processing option : All elements analyzed Number of iterations $=3$

Standard :

O $\mathrm{SiO} 2$ 1-jun-1999 12:00 AM

Na Albite 1-jun-1999 12:00 AM

Al Al2O3 1-jun-1999 12:00 AM

$\begin{array}{lll}\text { Al } & \mathrm{Al} 2 \mathrm{O} 3 & 1 \text {-jun-1999 12:00 AM } \\ \mathrm{Si} & \mathrm{SiO} 2 \text { 1-jun-1999 12:00 AM }\end{array}$

$\begin{array}{llll}\mathrm{Si} & \mathrm{SiO} 2 & 1 \text {-jun-1999 12:00 AM } \\ \mathrm{Cl} & \mathrm{KCl} & 1 \text {-jun-1999 12:00 AM }\end{array}$

$\begin{array}{llll}\mathrm{Cl} & \mathrm{KCl} & \text { 1-jun-1999 12:00 AM } \\ \mathrm{K} & \mathrm{MAD}-10 \text { Feldspar 1-jun-1999 12:00 AM }\end{array}$

$\mathrm{Ca}$ Wollastonite 1-jun-1999 12:00 AM

\begin{tabular}{l|ll}
\hline Element & Weight\% & Atomic\% \\
& & \\
$\mathrm{OK}$ & 16.58 & 67.62 \\
$\mathrm{Na} \mathrm{K}$ & 0.21 & 0.59 \\
$\mathrm{Al} \mathrm{K}$ & 0.16 & 0.40 \\
$\mathrm{Si} \mathrm{K}$ & 0.46 & 1.08 \\
$\mathrm{Cl} \mathrm{K}$ & 0.18 & 0.33 \\
$\mathrm{~K} \mathrm{~K}$ & 0.14 & 0.24 \\
$\mathrm{CaK}$ & 18.27 & 29.75 \\
& & \\
Totals & 36.00 & \\
\hline
\end{tabular}

Sample: Ladrillo de tonalidad roja

ID: 1148-VA 119/1

Análisis puntual: Calcita y arcillas

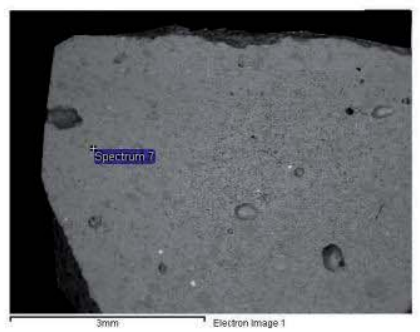

thelton image 1

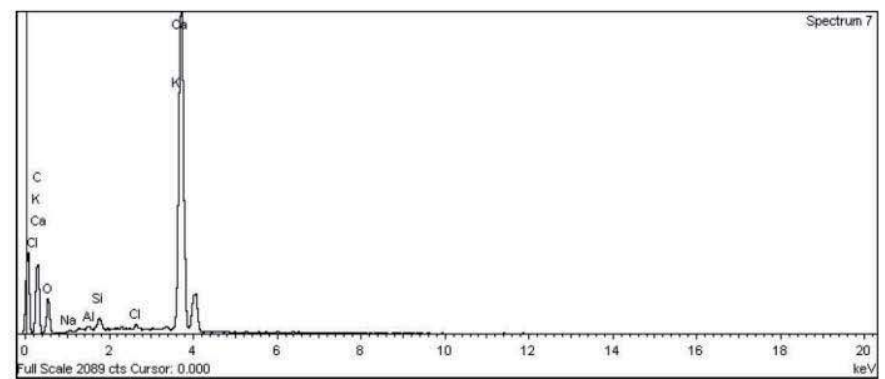




\section{ESPECTRO 5}

Project: Project 1

Owner: Administrador

Site: Site of Interest 1, 20x

Sample: Ladrillo de tonalidad roja

ID: 1148-VA 119/1

Análisis puntual: Calcita y arcillas

Spectrum processing :

No peaks omitted

Processing option : All elements analyzed

Number of iterations $=5$

Standard :

O $\mathrm{SiO2}$ 1-jun-1999 12:00 AM

$\begin{array}{lcc}\mathrm{Mg} & \mathrm{MgO} & 1 \text {-jun-1999 12:00 AM } \\ \mathrm{Al} & \mathrm{Al} 2 \mathrm{O} 3 & 1 \text {-jun-1999 12:00 AM }\end{array}$

$\mathrm{Si} \mathrm{SiO}_{2}$ 1-jun-1999 12:00 AM

$\mathrm{Ca}$ Wollastonite 1-jun-1999 12:00 AM

\begin{tabular}{l|ll}
\hline Element & Weight\% & Atomic\% \\
O K & 50.28 & 77.69 \\
$\mathrm{Mg} \mathrm{K}$ & 0.38 & 0.39 \\
$\mathrm{Al} \mathrm{K}$ & 0.23 & 0.21 \\
$\mathrm{Si} \mathrm{K}$ & 0.76 & 0.67 \\
$\mathrm{Ca} \mathrm{K}$ & 34.13 & 21.05 \\
& & \\
Totals & 85.78 & \\
\hline
\end{tabular}

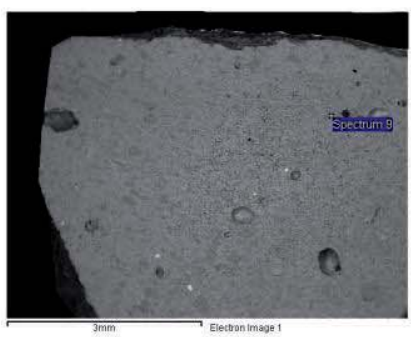

Al K

$\begin{array}{lll}\mathrm{CaK} & 34.13 & 21.05\end{array}$

Totals 85.78

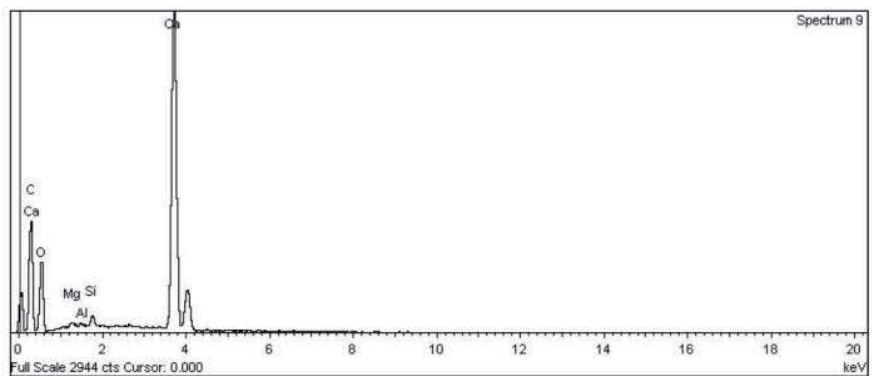


Distribución puntual de elementos/Mapping 1. ID: 1148-VA 119/1

\section{Interpretación de los resultados:}

A 200 aumentos se detecta una cantidad considerable de cuarzo $\mathrm{SiO}_{2}$ (elemento SI), junto con calcita $\mathrm{CaCO}_{3}$ (matriz y algunos granos de tamaño medio, elemento $\mathrm{Ca}$ ). Asimismo se identifica ortodasa $\mathrm{KALSi}_{3} \mathrm{O}_{3}$ por acumulación de los elementos potasio y aluminio Se detecta también una distribución homogénea dispersa del elemento $\mathrm{Fe}$ asociado con Si, Al y K que se atriburye a la presencia de arcillas En zonas puntuales de alta concentración de Fe se identífican óxidos de hierro como hematita $\mathrm{Fe}_{2} \mathrm{O}_{3}$. Destacar una concentración moderada de cloruros y en menor cantidad de sulfatos
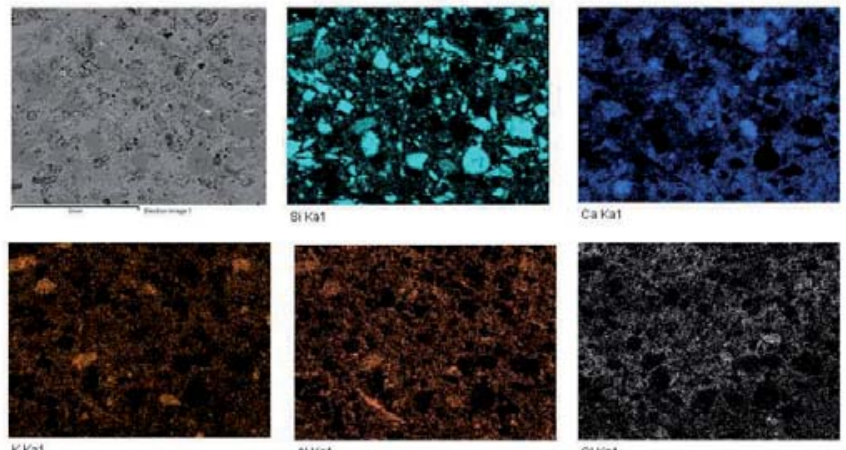

gera1

cakat
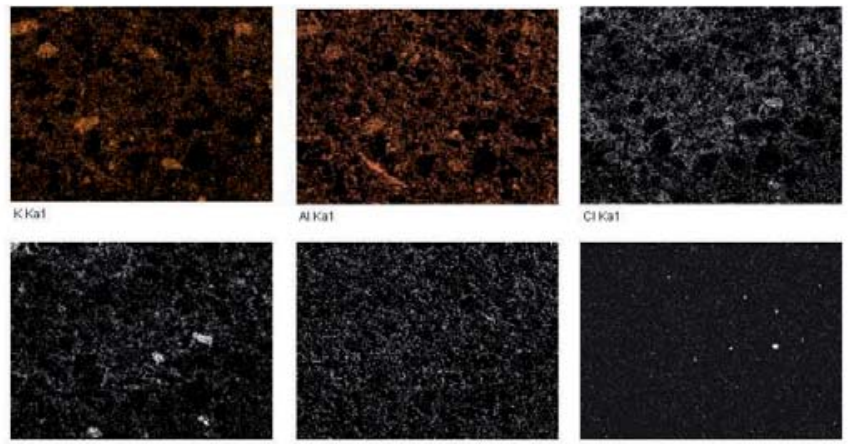

caka1

Mgkat_2

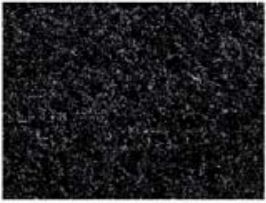

Nakal _
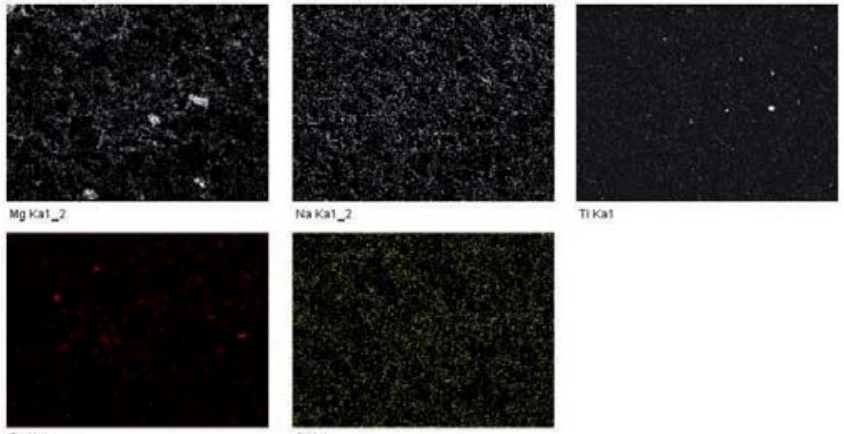

Tikat 


\section{ESPECTRO 6}

Project: Project 1

Owner: Administrador

Site: Site of Interest 1, 200x

Spectrum processing

Peak possibly omitted : $1.045 \mathrm{keV}$

Processing option : All elements analyzed Number of iterations $=4$

Standard :

O $\mathrm{SiO} 2$ 1-jun-1999 12:00 AM

Al Al2O3 1-jun-1999 12:00 AM

Al Al2O3 1-jun-1999 12:00 AM

$\begin{array}{lll}\mathrm{Si} & \mathrm{SiO} 2 & 1 \text {-jun-1999 12:00 AM } \\ \mathrm{S} & \mathrm{FeS} 2 & \text { 1-jun-1999 12:00 AM }\end{array}$

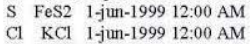

K MAD-10 Feldspar 1-jun-1999 12:00 AM

Ca Wollastonite 1-jun-1999 12:00 AM

\begin{tabular}{l|ll}
\hline Element & Weight $\%$ & Atomic\% \\
& & \\
OK & 33.37 & 73.52 \\
Al K & 0.29 & 0.38 \\
Si K & 0.77 & 0.96 \\
S K & 0.32 & 0.36 \\
C K & 0.23 & 0.23 \\
K K & 0.27 & 0.24 \\
Ca K & 27.65 & 24.31 \\
& & \\
Totals & 62.90 & \\
\hline
\end{tabular}

Sample: Ladrillo de tonalidad roja

ID: 1148-VA $119 / 1$

Análisis puntual: Calcita, sulfatos, cloruros y

arcillas

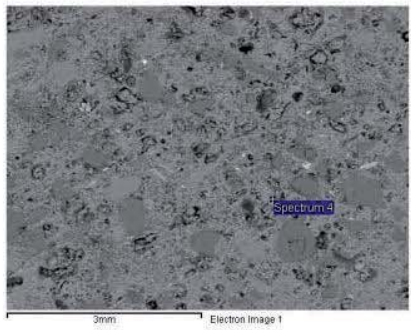

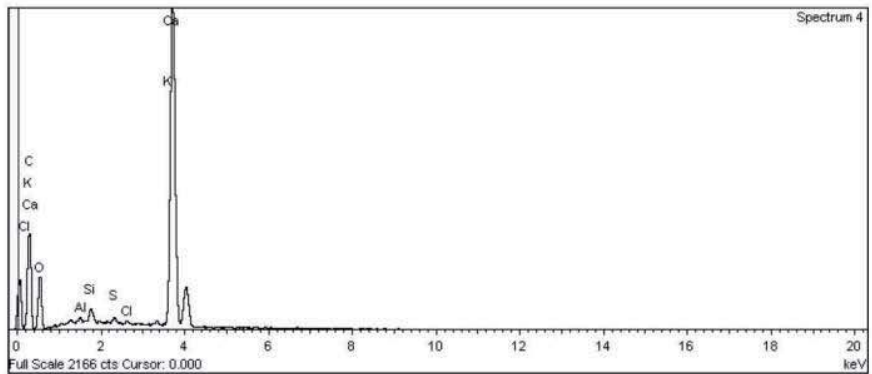




\section{ESPECTRO 7}

Project: Project 1

Owner: Administrador

Site: Site of Interest 1, 200x

Spectrum processing :

Peak possibly omitted : $1.031 \mathrm{keV}$

Processing option : All elements analyzed

Number of iterations $=4$

Standard :

O $\mathrm{SiO} 2$ 1-jun-1999 12:00 AM

Al Al2O3 1-jun-1999 12:00 AM

$\begin{array}{llll}\text { Al } & \mathrm{Al} 2 \mathrm{O} 3 & 1 \text {-jun-1999 12:00 AM } \\ \mathrm{Si} & \mathrm{SiO} 2 & 1-\text { jun-1999 12:00 AM }\end{array}$

$\begin{array}{llll}\mathrm{Si} & \mathrm{SiO} 2 & \text { 1-jun-1999 12:00 AM } \\ \mathrm{K} & \mathrm{MAD}-10 \text { Feldspar } & \text { 1-jun-1999 12:00 AM }\end{array}$

\begin{tabular}{l|ll}
\hline Element & Weight\% & Atomic\% \\
O K & 30.19 & 58.84 \\
Al K & 6.76 & 7.82 \\
Si K & 22.96 & 25.49 \\
K K & 9.85 & 7.85 \\
Totals & 69.76 & \\
\hline
\end{tabular}

Sample: Ladrillo de tonalidad roja

ID: 1148-VA 119/1

Análisis puntual: Ortoclasa

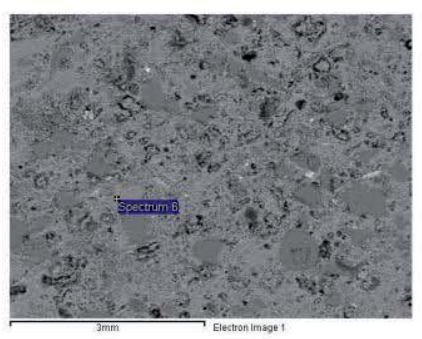

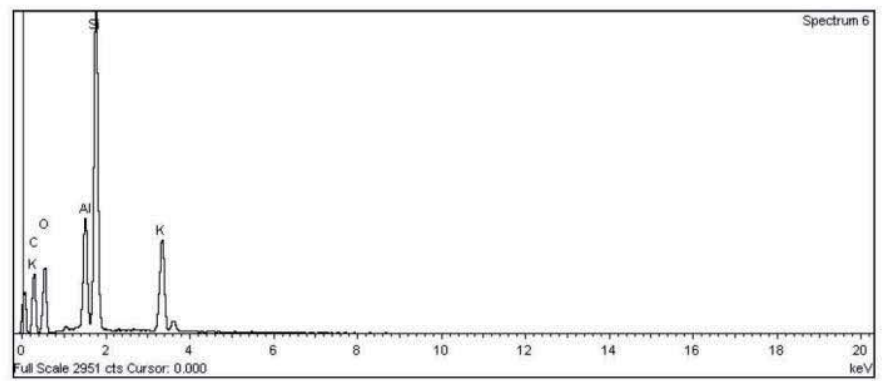




\section{ESPECTRO 8}

Project: Project 1

Owner: Administrador

Site: Site of Interest $1,200 \mathrm{x}$
Sample: Ladrillo de tonalidad roja

ID: 1148-VA 119/1

Análisis puntual: Arcillas, calcita, cloruros y sulfatos

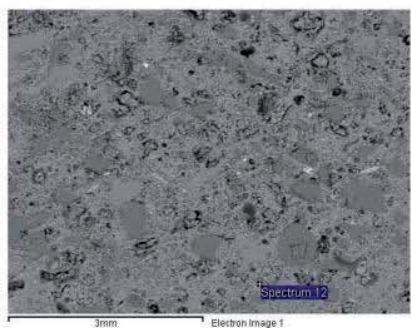

Electron imsae 1

Spectrum processing

No peaks omitted

Processing option : All elements analyzed Number of iterations $=4$

Standard :

- $\mathrm{SiO} 2$ 1-jun-1999 12:00 AM

Na Albite 1-jun-1999 12:00 AM

$\mathrm{Na}$ Albite 1 -jun-1999 12:00 AM

$\begin{array}{llll}\mathrm{Mg} & \mathrm{MgO} & 1 \text {-jun-1999 12:00 AM } \\ \mathrm{Al} & \mathrm{Al} 2 \mathrm{O} 3 & 1 \text {-jun-1999 12:00 AM }\end{array}$

$\begin{array}{llll}\text { Al } & \mathrm{Al} 2 \mathrm{O} 3 & 1 \text {-jun-1999 12:00 AM } \\ \mathrm{Si} & \mathrm{SiO} 2 & 1 \text {-jun-1999 12:00 AM }\end{array}$

$S$ FeS2 1-jun-1999 12:00 AM

Cl KCl 1-jun-1999 12:00 AM

K MAD-10 Feldspar 1-jun-1999 12:00 AM

Ca Wollastonite 1-jun-1999 12:00 AM

$\mathrm{Ca}$ Wollastonite 1-jun-1999

\begin{tabular}{l|ll}
\hline Element & Weight \% & Atomic\% \\
& & \\
$\mathrm{OK}$ & 48.75 & 67.82 \\
$\mathrm{Na} \mathrm{K}$ & 0.43 & 0.42 \\
$\mathrm{Mg} \mathrm{K}$ & 0.64 & 0.58 \\
$\mathrm{Al} \mathrm{K}$ & 7.30 & 6.02 \\
$\mathrm{Si} \mathrm{K}$ & 21.23 & 16.82 \\
$\mathrm{~S} \mathrm{~K}$ & 0.17 & 0.12 \\
$\mathrm{Cl} \mathrm{K}$ & 0.66 & 0.42 \\
$\mathrm{~K} \mathrm{~K}$ & 7.83 & 4.45 \\
$\mathrm{Ca} \mathrm{K}$ & 5.64 & 3.13 \\
$\mathrm{Fe} \mathrm{K}$ & 0.55 & 0.22 \\
& & \\
Totals & 93.20 & \\
\hline
\end{tabular}

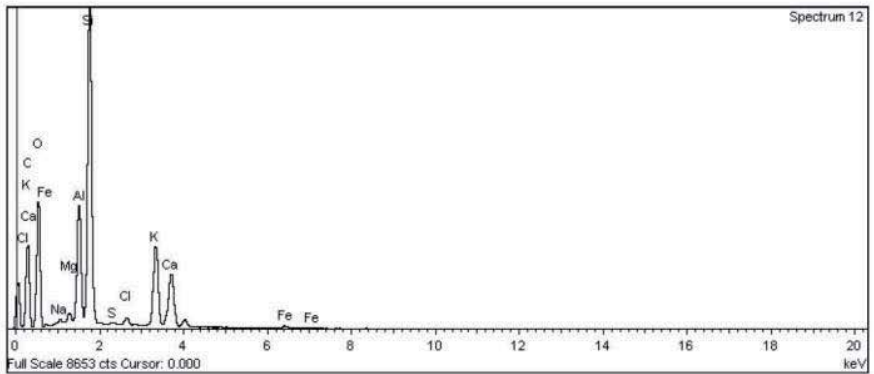




\section{ESPECTRO 9}

Project: Project 1

Owner: Administrador

Site: Site of Interest 1, 200x

Sample: Ladrillo de tonalidad roja

ID: 1148-VA 119/1

Análisis puntual: Arcillas, cloruros, calcita y óxidos de hierro

\section{Spectrum processing \\ No peaks omitted}

Processing option : All elements analyzed

Number of iterations $=4$

Standard :

O SiO2 1-jun-1999 12:00 AM

$\mathrm{Na}$ Albite 1-jun-1999 12:00 AM

$\mathrm{Mg} \mathrm{MgO}$ 1-jun-1999 12:00 AM

Al Al2O3 1-jun-1999 12:00 AM

Si $\quad \mathrm{SiO} 2$ 1-jun-1999 12:00 AM

Cl KCl 1-jun-1999 12:00 AM

K MAD-10 Feldspar 1-jun-1999 12:00 AM

$\mathrm{Ca}$ Wollastonite 1-jun-1999 12:00 AM

$\mathrm{Fe} \quad \mathrm{Fe}$ 1-jun-1999 12:00 AM

\begin{tabular}{l|ll}
\hline Element & Weight\% & Atomic\% \\
& & \\
$\mathrm{OK}$ & 40.23 & 63.14 \\
$\mathrm{Na} \mathrm{K}$ & 1.70 & 1.86 \\
$\mathrm{Mg} \mathrm{K}$ & 5.78 & 5.97 \\
$\mathrm{Al} \mathrm{K}$ & 5.88 & 5.47 \\
$\mathrm{Si} \mathrm{K}$ & 13.37 & 11.95 \\
$\mathrm{Cl} \mathrm{K}$ & 6.51 & 4.61 \\
$\mathrm{~K} \mathrm{~K}$ & 3.96 & 2.54 \\
$\mathrm{Ca} \mathrm{K}$ & 5.73 & 3.59 \\
$\mathrm{Fe} \mathrm{K}$ & 1.94 & 0.87 \\
& & \\
Totals & 85.10 & \\
\hline
\end{tabular}
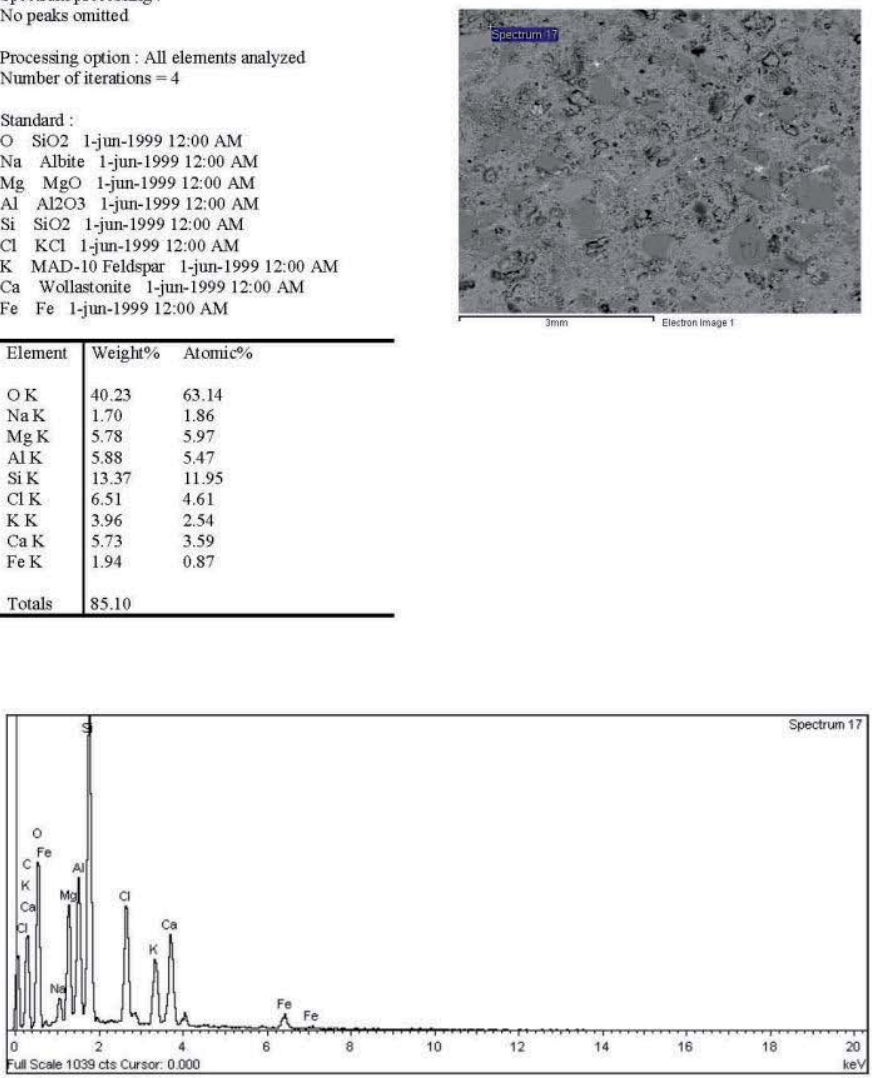


\section{ESPECTRO 10}

Project: Project 1

Owner: Administrador

Site: Site of Interest 1, 200x

Sample: Ladrillo de tonalidad roja

ID: 1148-VA 119/1

Análisis puntual: Rutilo

Spectrum processing

No peaks omitted

Processing option : All elements analyzed

Number of iterations $=4$

Standard

O SiO2 1-jun-1999 12:00 AM

$\mathrm{Mg} \mathrm{MgO}$ 1-jun-1999 12:00 AM

Al Al2O3 1-jun-1999 12:00 AM

Si $\mathrm{SiO} 2$ 1-jun-1999 12:00 AM

Ca Wollastonite 1-jun-1999 12:00 AM

Ti Ti 1-jun-1999 12:00 AM

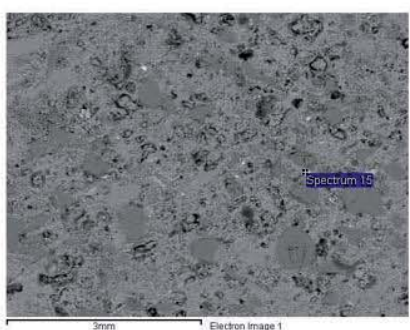

\begin{tabular}{l|ll}
\hline Element & Weight\% & Atomic\% \\
& & \\
$\mathrm{OK}$ & 44.89 & 74.89 \\
$\mathrm{Mg} \mathrm{K}$ & 0.36 & 0.39 \\
$\mathrm{Al} \mathrm{K}$ & 0.49 & 0.48 \\
$\mathrm{Si} \mathrm{K}$ & 0.49 & 0.47 \\
$\mathrm{Ca} \mathrm{K}$ & 0.66 & 0.44 \\
Ti K & 41.85 & 23.32 \\
& & \\
Totals & 88.74 & \\
\hline
\end{tabular}

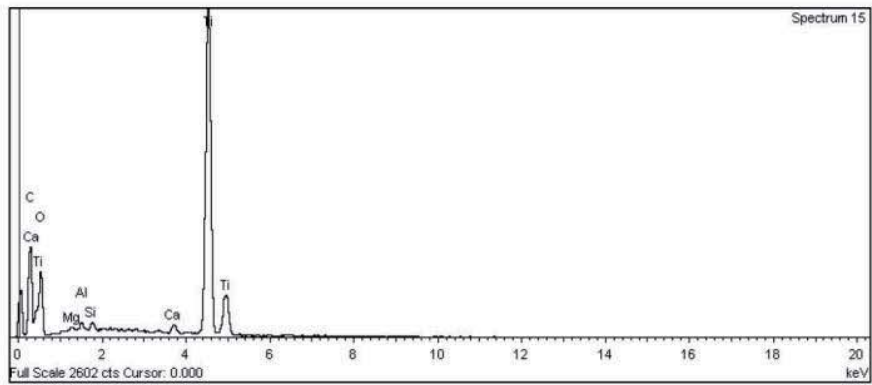




\subsection{MUESTRA CF $30 / 1$}

\subsubsection{DESCRIPCIÓN DE LA MUESTRA}

Ladrillo de tonalidad rojiza con Ref. 1148- CF 30/1

\subsubsection{MO}

MICROSCOPIA OPTICA (MO)

Microfotografia 2: Luz incidente, $\times 10$

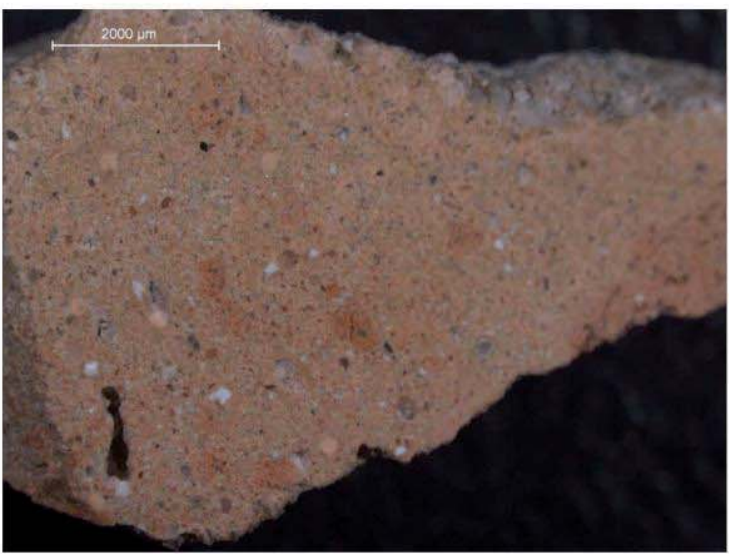

Figura 2. Ladrillo compacto de color rojizo. 


\subsubsection{SEM/EDX}

\section{ESPECTRO 11}

Project: Project 1

Owner: Administrador

Site: Site of Interest 1, 20x

Spectrum processing :

No peaks omitted

Processing option : All elements analyzed

Number of iterations $=5$

Standard :

O $\mathrm{SiO} 2$ 1-jun-1999 12:00 AM

Na Albite 1-jun-1999 12:00 AM

$\mathrm{Mg}$ MgO 1-jun-1999 12:00 AM

Al Al2O3 1-jun-1999 12:00 AM

$\mathrm{Si} \mathrm{SiO} 2$ 1-jun-1999 12.00 AM

S FeS2 1-jun-1999 12:00 AM

Cl $\mathrm{KCl}$ 1-jun-1999 12:00 AM

$\begin{array}{lll}\text { Cl } & \mathrm{KCl} \text { 1-jun-1999 12:00 AM } \\ \mathrm{K} & \mathrm{MAD}-10 \text { Feldspar 1-jun-1999 12:00 AM }\end{array}$

Ca Wollastonite 1-jun-1999 12:00 AM

Ti Ti 1-jun-1999 12:00 AM

$\mathrm{Fe} \mathrm{Fe}$ 1-jun-1999 12:00 AM

\begin{tabular}{l|ll}
\hline Element & Weight\% & Atomic\% \\
$\mathrm{OK}$ & 47.31 & 71.84 \\
$\mathrm{Na} \mathrm{K}$ & 0.73 & 0.77 \\
$\mathrm{Mg} \mathrm{K}$ & 1.97 & 1.97 \\
$\mathrm{Al} \mathrm{K}$ & 3.42 & 3.08 \\
$\mathrm{Si} \mathrm{K}$ & 13.59 & 11.76 \\
$\mathrm{~S} \mathrm{~K}$ & 0.30 & 0.22 \\
$\mathrm{CI} \mathrm{K}$ & 0.67 & 0.46 \\
$\mathrm{~K} \mathrm{~K}$ & 2.04 & 1.27 \\
$\mathrm{Ca} \mathrm{K}$ & 12.82 & 7.77 \\
$\mathrm{Ti} \mathrm{K}$ & 0.21 & 0.10 \\
Fe K & 1.78 & 0.77 \\
& & \\
Totals & 84.83 & \\
\hline
\end{tabular}

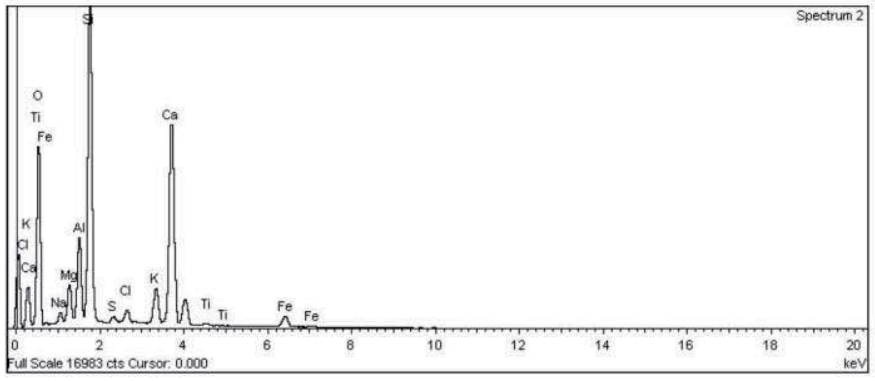

Sample: Ladrillo de tonalidad rojiza

ID: 1148 - CF $30 / 1$

Análisis de área: Cuarzo, calcita, (alumino-)

silicatos de calcio, arcillas, cloruros y

sulfatos

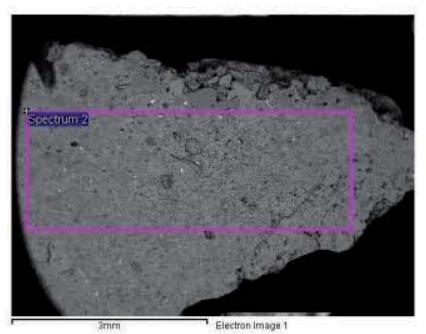

10 


\section{ESPECTRO 12}

Project: Project 1
Owner: Administrador
Site: Site of Interest 1, 20x

Spectrum processing

No peaks omitted

Processing option : All elements analyzed Number of iterations $=4$

Standard :

O $\mathrm{SiO} 2$ 1-jun-1999 12:00 AM

Si $\quad \mathrm{SiO} 2$ 1-jun-1999 12:00 AM

\begin{tabular}{l|ll}
\hline Element & Weight\% & Atomic\% \\
OK & 68.88 & 70.28 \\
Si K & 51.14 & 29.72 \\
Totals & 120.02 & \\
\hline
\end{tabular}

Sample: Ladrillo de tonalidad rojiza

ID: $1148-$ CF $30 / 1$

Análisis puntual: Cuarzo

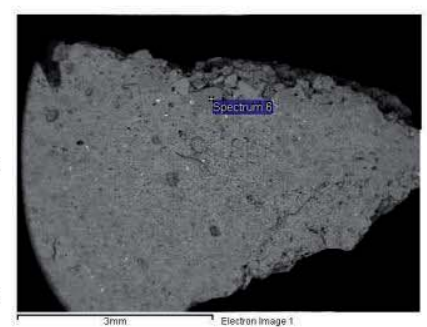

7 Electron Imase 1

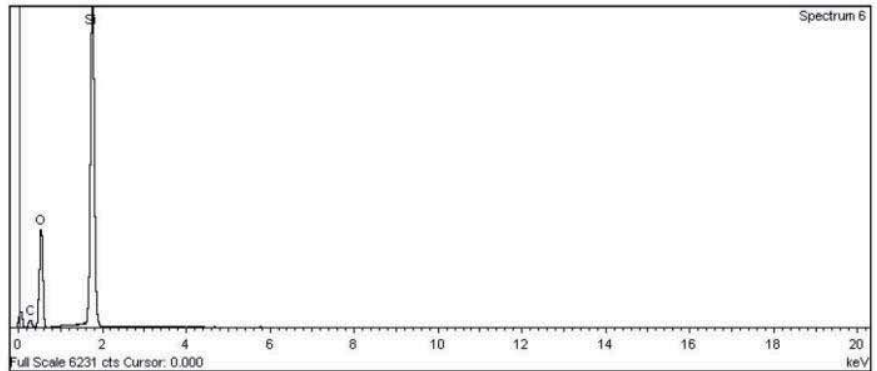




\section{ESPECTRO 13}

Project: Project 1

Owner: Administrador

Site: Site of Interest 1, 20x

Sample: Ladrillo de tonalidad rojiza

ID: $1148-$ CF $30 / 1$

Análisis puntual: ortoclasa

Spectrum processing

No peaks omitted

Processing option : All elements analyzed

Number of iterations $=4$

Standard :

O $\mathrm{SiO} 2$ 1-jun-1999 12:00 AM

Al A12O3 1-jun-1999 12:00 AM

$\mathrm{Si} \mathrm{SiO2}$ 1-jun-1999 12:00 AM

$\begin{array}{llll}\mathrm{Si} & \mathrm{SiO} 2 & 1-j u n-1999 & 12: 00 \mathrm{AM} \\ \mathrm{K} & \mathrm{MAD}-10 \text { Feldspar 1-jun-1999 12:00 AM }\end{array}$

\begin{tabular}{l|ll}
\hline Element & Weight $\%$ & Atomic\% \\
& & \\
OK & 70.56 & 68.48 \\
Al K & 10.81 & 6.22 \\
Si K & 35.65 & 19.71 \\
K K & 14.10 & 5.60 \\
Totals & 131.12 & \\
\hline
\end{tabular}

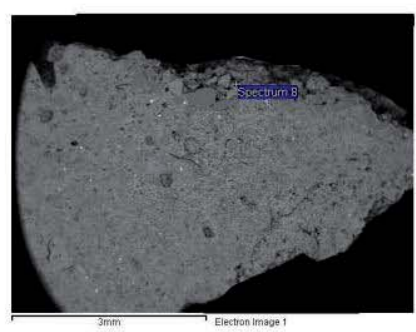

\begin{tabular}{l|l} 
Totals & 131.12 \\
\hline
\end{tabular}

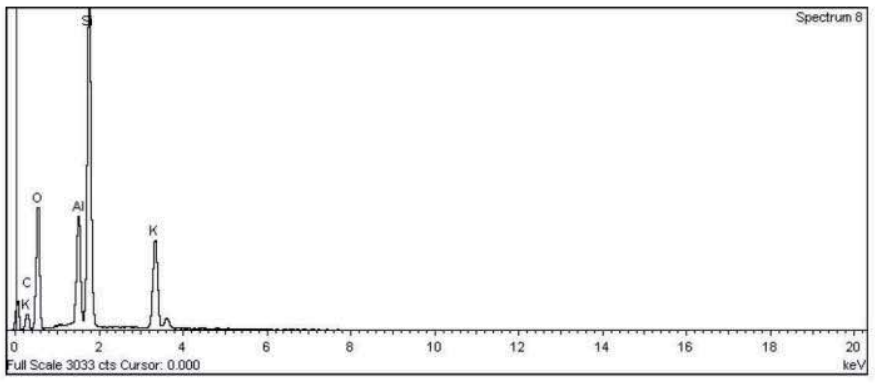




\section{ESPECTRO 14}

Project: Project 1

Owner: Administrador

Site: Site of Interest 1, 20x

Spectrum processing

No peaks omitted

Processing option : All elements analyzed

Number of iterations $=5$

Standard:

O $\mathrm{SiO} 2$ 1-jun-1999 12:00 AM

Na Albite 1-jun-1999 12:00 AM

$\mathrm{Mg} \mathrm{MgO}$ 1-jun-1999 12:00 AM

Al Al2O3 1-jun-1999 12:00 AM

$\mathrm{Si} \quad \mathrm{SiO} 2$ 1-jun-1999 12:00 AM

$\mathrm{S}$ FeS2 1-jun-1999 12:00 AM

$\begin{array}{lrlll}\mathrm{S} & \mathrm{FeS} 2 & 1-\mathrm{jun}-1999 & 12: 00 \mathrm{AM} \\ \mathrm{Cl} & \mathrm{KCl} & 1-\mathrm{jun}-1999 & \text { 12:00 AM }\end{array}$

$\begin{array}{llll}\mathrm{Cl} & \mathrm{KCl} & 1-\mathrm{jun}-1999 & 12: 00 \mathrm{AM} \\ \mathrm{K} & \mathrm{MAD}-10 \mathrm{Feldspar} & \text { 1-jun-1999 12:00 AM }\end{array}$

$\mathrm{Ca}$ Wollastonite 1-jun-1999 12:00 AM

$\mathrm{Fe} \mathrm{Fe}$ 1-jun-1999 12:00 AM

\begin{tabular}{l|ll}
\hline Element & Weight\% & Atomic\% \\
& & \\
$\mathrm{OK}$ & 64.09 & 75.26 \\
$\mathrm{Na} \mathrm{K}$ & 1.53 & 1.25 \\
$\mathrm{Mg} \mathrm{K}$ & 5.44 & 4.21 \\
$\mathrm{Al} \mathrm{K}$ & 0.25 & 0.17 \\
$\mathrm{Si} \mathrm{K}$ & 6.38 & 4.27 \\
$\mathrm{~S} \mathrm{~K}$ & 1.61 & 0.94 \\
$\mathrm{Cl} \mathrm{K}$ & 1.25 & 0.66 \\
$\mathrm{~K} \mathrm{~K}$ & 1.72 & 0.83 \\
$\mathrm{Ca} \mathrm{K}$ & 25.95 & 12.16 \\
Fe K & 0.73 & 0.24 \\
& & \\
Totals & 108.95 & \\
\hline
\end{tabular}

\section{Sample: Ladrillo de tonalidad rojiza}

ID: 1148 - CF $30 / 1$

Análisis puntual: Silicatos de calcio y

magnesio, sulfatos y cloruros.
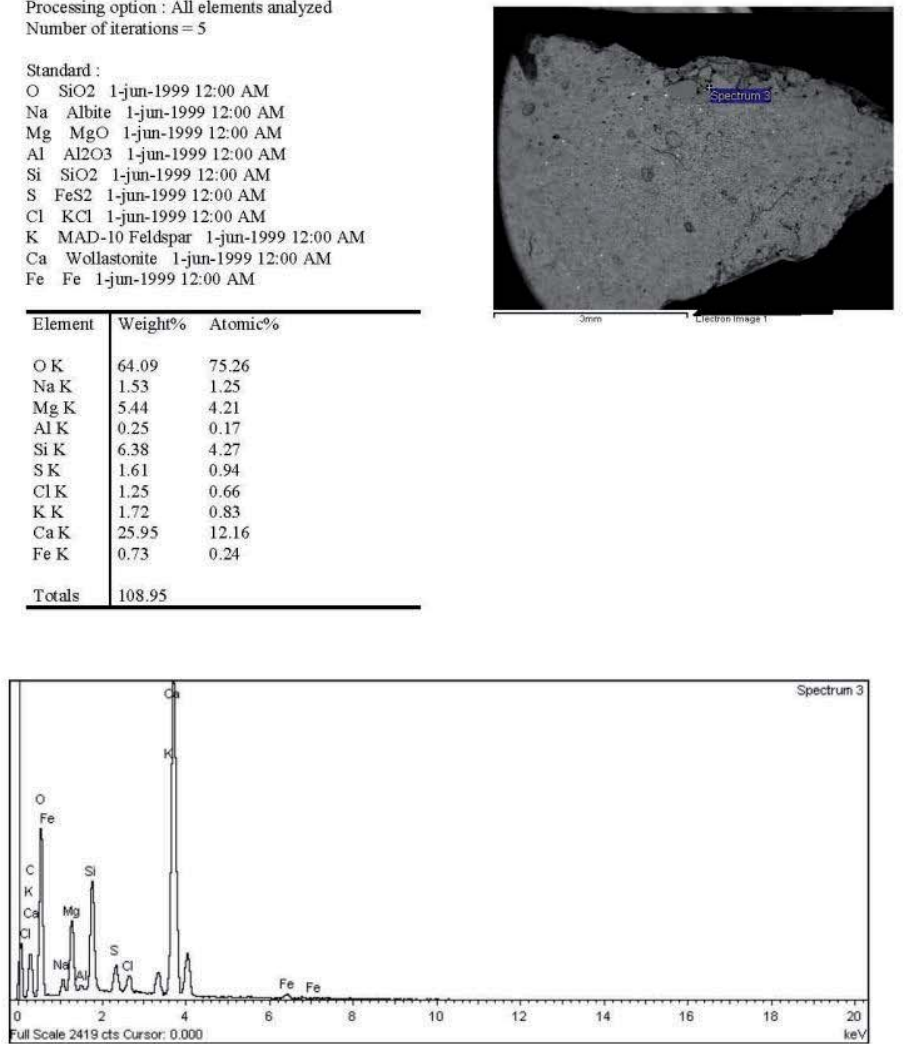


\section{ESPECTRO 18}

Project: Project 1

Owner: Administrador

Site: Site of Interest $1,250 \mathrm{x}$

Spectrum processing :

No peaks omitted

Processing option : All elements analyzed

Number of iterations $=6$

\section{Standard :}

O SiO2 1-jun-1999 12:00 AM

Na Albite 1-jun-1999 12:00 AM

$\mathrm{Mg} \mathrm{MgO}$ 1-jun-1999 12:00 AM

Si SiO2 1-jun-1999 12:00 AM

S FeS2 1-jun-1999 12:00 AM

Cl KCl 1-jun-1999 12.00 AM

K MAD-10 Feldspar 1-jun-1999 12:00 AM

$\mathrm{Ca}$ Wollastonite 1-jun-1999 12:00 AM

\begin{tabular}{l|ll}
\hline Element & Weight $\%$ & Atomic\% \\
& & \\
$\mathrm{OK}$ & 62.63 & 82.04 \\
$\mathrm{Na} \mathrm{K}$ & 0.38 & 0.35 \\
$\mathrm{Mg} \mathrm{K}$ & 0.78 & 0.67 \\
$\mathrm{Si} \mathrm{K}$ & 1.61 & 1.20 \\
$\mathrm{~S} \mathrm{~K}$ & 0.38 & 0.25 \\
$\mathrm{Cl} \mathrm{K}$ & 0.26 & 0.15 \\
$\mathrm{~K} \mathrm{~K}$ & 0.33 & 0.18 \\
$\mathrm{Ca} \mathrm{K}$ & 29.02 & 15.17 \\
& & \\
Totals & 95.37 & \\
\hline
\end{tabular}

Sample: Ladrillo de tonalidad rojiza

ID: 1148-CF 30/1

Análisis puntual: Calcita, cuarzo, sulfatos y

cloruros

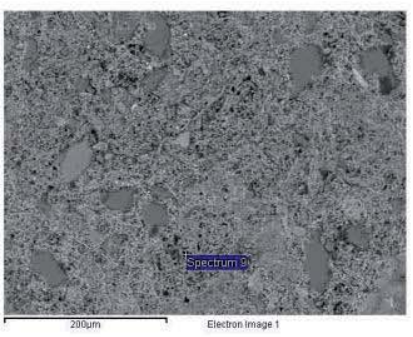

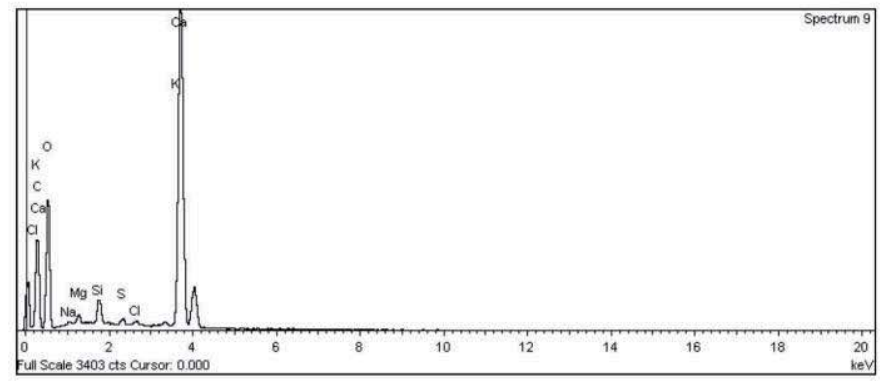


Distribución puntual de elementos/Mapping 2. ID: 1148- CF 30/1

\section{Interpretación de los resultados: 200x}

Se identifican cuarzo $\mathrm{SiO}_{2}$, cristales de calcita (en menor cantidad que la muestra VA 119/1 ortodasa $\mathrm{KAISI}_{3} \mathrm{O}_{8}$ y rutilo $\mathrm{TiO}_{2}$ (elemento $\mathrm{TI}$ ). Se detecta también una distribución homogénea dispersa de los elementos Fe, Al y K Se observa la presencia de sales (cloruros y sulfatos), pero en

menor cantidad que en la muestra anterior.
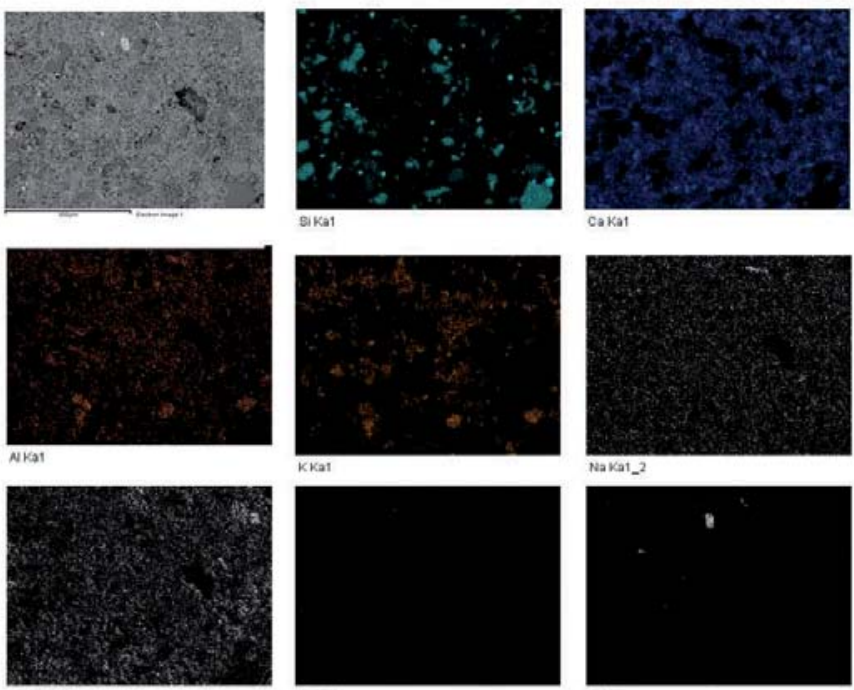
KKa1
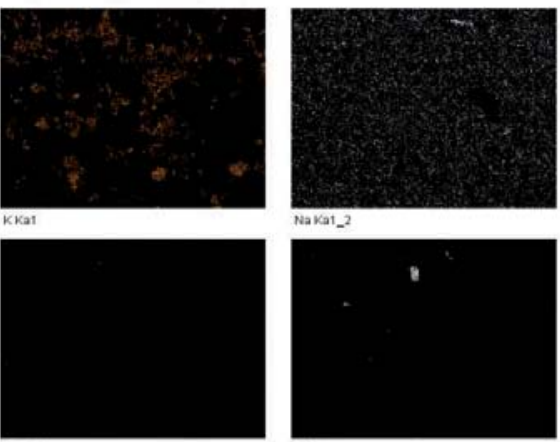

Mo Ka1_2

Fekat

TiKa1
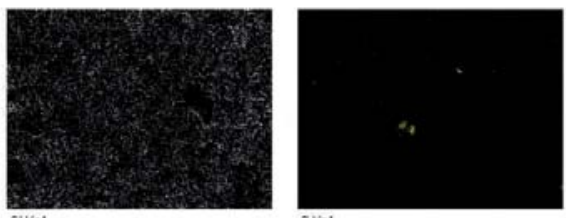

cikal

ska1 


\section{ESPECTRO 15}

Project: Project 1

Owner: Administrador

Site: Site of Interest 1, 200x

Sample: Ladrillo de tonalidad rojiza

ID: $1148-$ CF $30 / 1$

Análisis puntual: rutilo

Spectrum processing :

Peaks possibly omitted : $2.165,2.778,6.405,7.030,7.665,9.040$

$\mathrm{keV}$

Processing option : All elements analyzed

Number of iterations $=5$

Standard :

O $\mathrm{SiO} 2$ 1-jun-1999 12:00 AM

$\mathrm{Si} \mathrm{SiO} 2$ 1-jun-1999 12:00 AM

$\mathrm{Cl}$ Wollastonite 1-jun-1999 12:00 AM

Ca Wollastonite 1-jun-1999
Ti Ti 1-jun-1999 12:00 AM

\begin{tabular}{l|ll}
\hline Element & Weight\% & Atomic\% \\
OK & 71.40 & 78.00 \\
$\mathrm{Si} \mathrm{K}$ & 0.31 & 0.20 \\
$\mathrm{CaK}$ & 0.85 & 0.37 \\
Ti K & 58.74 & 21.43 \\
& & \\
Totals & 131.31 & \\
\hline
\end{tabular}

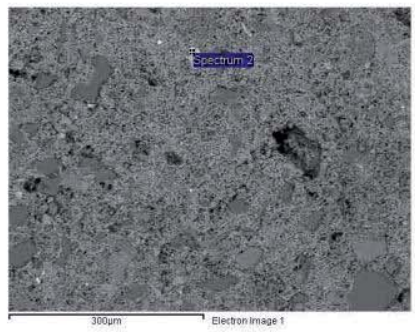

Totals 131.31

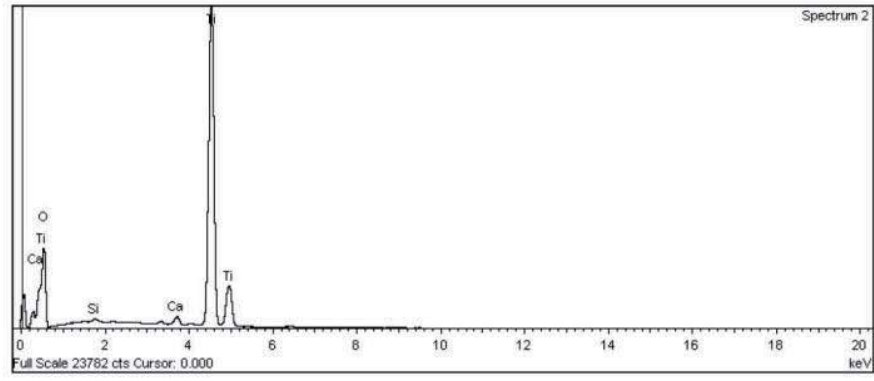




\section{ESPECTRO 16}

Project: Project 1

Owner: Administrador

Site: Site of Interest 1, 200x

Spectrum processing :
Peak possibly omitted : $4.519 \mathrm{keV}$

Processing option : All elements analyzed

Number of iterations $=4$

\section{Standard:}

O $\mathrm{SiO2}$ 1-jun-1999 12:00 AM

$\mathrm{Na}$ Albite 1-jun-1999 12:00 AM

$\mathrm{Mg} \mathrm{MgO}$ 1-jun-1999 12:00 AM

$\mathrm{Al} \mathrm{Al} 2 \mathrm{O} 3$ 1-jun-1999 12:00 AM

$\mathrm{Si} \quad \mathrm{SiO} 2$ 1-jun-1999 12:00 AM

S FeS2 1-jun-1999 12:00 AM

Cl $\mathrm{KCl}$ 1-jun-1999 12:00 AM

K MAD-10 Feldspar 1-jun-1999 12:00 AM

Ca Wollastonite 1-jun-1999 12:00 AM

$\mathrm{Fe} \mathrm{Fe}$ 1-jun-1999 12:00 AM

\begin{tabular}{l|ll}
\hline Element & Weight\% & Atomic\% \\
& & \\
$\mathrm{OK}$ & 40.24 & 63.60 \\
$\mathrm{Na} \mathrm{K}$ & 1.04 & 1.14 \\
$\mathrm{Mg} \mathrm{K}$ & 2.41 & 2.51 \\
$\mathrm{Al} \mathrm{K}$ & 5.14 & 4.81 \\
$\mathrm{Si} \mathrm{K}$ & 11.47 & 10.33 \\
$\mathrm{~S} \mathrm{~K}$ & 1.19 & 0.94 \\
$\mathrm{Cl} \mathrm{K}$ & 0.88 & 0.63 \\
$\mathrm{~K} \mathrm{~K}$ & 1.68 & 1.08 \\
$\mathrm{Ca} \mathrm{K}$ & 21.43 & 13.52 \\
$\mathrm{Fe} \mathrm{K}$ & 3.17 & 1.44 \\
& & \\
Totals & 88.65 & \\
\hline
\end{tabular}

Sample: Ladrillo de tonalidad rojiza

ID: $1148-$ CF $30 / 1$

Análisis puntual: Aluminosilicatos de calcio,

arcillas, sulfatos y cloruros
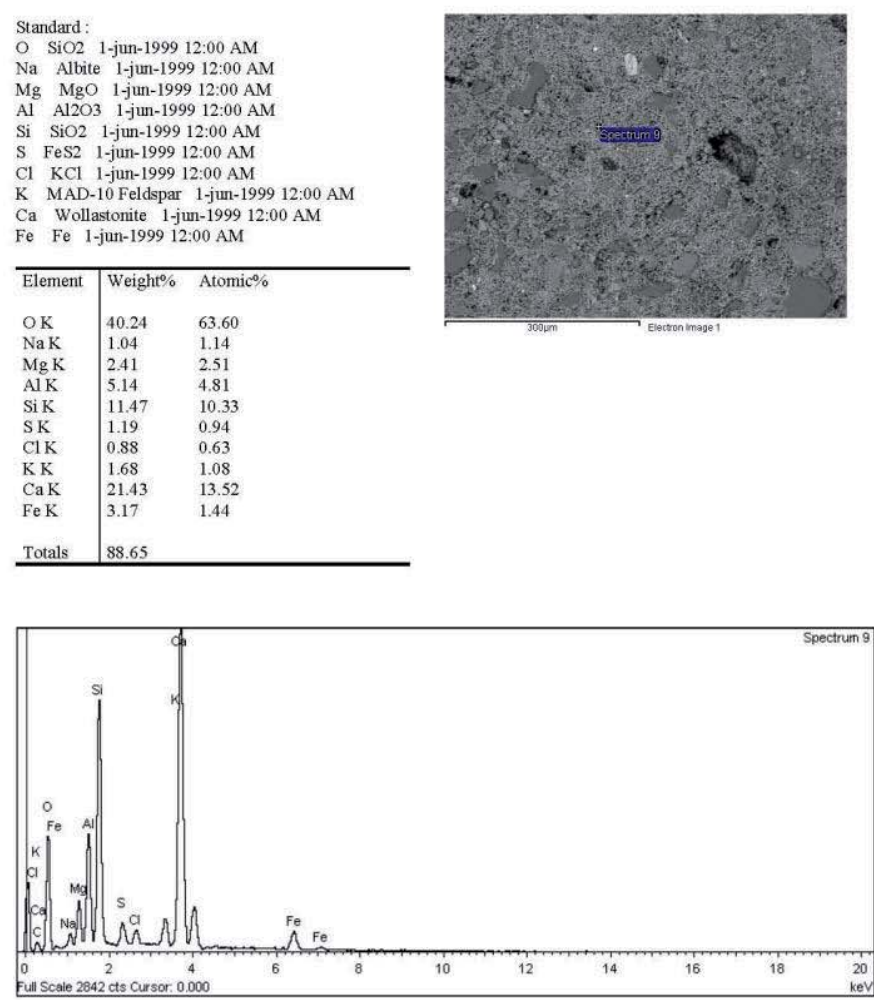


\section{ESPECTRO 17}

Project: Project 1

Owner: Administrador

Site: Site of Interest 1, 200x

\section{Spectrum processing :}

No peaks omitted

Processing option : All elements analyzed

Number of iterations $=3$

Standard :

O SiO2 1-jun-1999 12:00 AM

$\mathrm{Mg} \mathrm{MgO}$ 1-jun-1999 12:00 AM

Al Al2O3 1-jun-1999 12:00 AM

Si SiO2 1-jun-1999 12:00 AM

Cl $\mathrm{KCl}$ 1-jun-1999 12:00 AM

K MAD-10 Feldspar 1-jun-1999 12:00 AM

$\mathrm{Ca}$ Wollastonite 1-jun-1999 12:00 AM

$\mathrm{Fe}$ Fe 1-jun-1999 12:00 AM

\begin{tabular}{l|ll}
\hline Element & Weight\% & Atomic\% \\
& & \\
$\mathrm{OK}$ & 3.54 & 31.90 \\
$\mathrm{Mg} \mathrm{K}$ & 0.13 & 0.77 \\
$\mathrm{Al} \mathrm{K}$ & 0.59 & 3.13 \\
$\mathrm{Si} \mathrm{K}$ & 2.26 & 11.60 \\
$\mathrm{Cl} \mathrm{K}$ & 0.13 & 0.52 \\
$\mathrm{~K} \mathrm{~K}$ & 1.86 & 6.87 \\
$\mathrm{Ca} \mathrm{K}$ & 11.14 & 40.06 \\
$\mathrm{Fe} \mathrm{K}$ & 2.00 & 5.16 \\
& & \\
Totals & 21.64 & \\
\hline
\end{tabular}

Sample: Ladrillo de tonalidad rojiza

ID: $1148-$ CF $30 / 1$

Análisis puntual: (Alumino-)silicatos de

calcio y hierro y arcillas
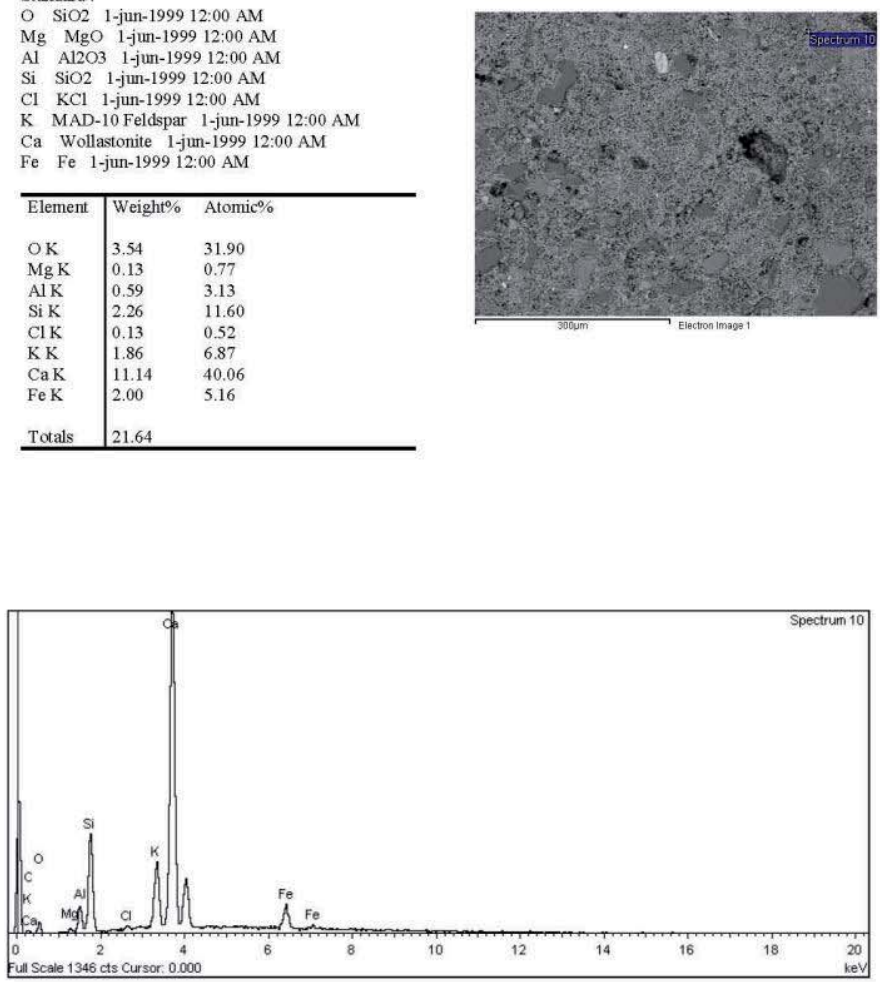


\section{ESPECTRO 18}

Project: Project 1

Owner: Administrador

Site: Site of Interest 1, 250x

Spectrum processing

No peaks omitted

Processing option: All elements analyzed

Number of iterations $=6$

Standard:

O SiO2 1-jun-1999 12:00 AM

Na Albite 1-jun-1999 12:00 AM

$\mathrm{Mg} \mathrm{MgO}$ 1-jun-1999 12:00 AM

$\mathrm{Si} \mathrm{SiO} 2$ 1-jun-1999 12:00 AM

S FeS2 1-jun-1999 12:00 AM

$\mathrm{Cl} \mathrm{KCl} \mathrm{1-jun-1999} \mathrm{12:00} \mathrm{AM}$

K MAD-10 Feldspar 1-jun-1999 12:00 AM

$\mathrm{Ca}$ Wollastonite 1-jun-1999 12:00 AM

\begin{tabular}{l|ll}
\hline Element & Weight\% & Atomic\% \\
$\mathrm{OK}$ & 62.63 & 82.04 \\
$\mathrm{Na} \mathrm{K}$ & 0.38 & 0.35 \\
$\mathrm{Mg} \mathrm{K}$ & 0.78 & 0.67 \\
$\mathrm{Si} \mathrm{K}$ & 1.61 & 1.20 \\
$\mathrm{~S} \mathrm{~K}$ & 0.38 & 0.25 \\
$\mathrm{Cl} \mathrm{K}$ & 0.26 & 0.15 \\
$\mathrm{~K} \mathrm{~K}$ & 0.33 & 0.18 \\
$\mathrm{Ca} \mathrm{K}$ & 29.02 & 15.17 \\
& & \\
Totals & 95.37 & \\
\hline
\end{tabular}

Sample: Ladrillo de tonalidad rojiza

ID: 1148 - CF 30/1

Análisis puntual: Calcita, cuarzo, sulfatos y cloruros

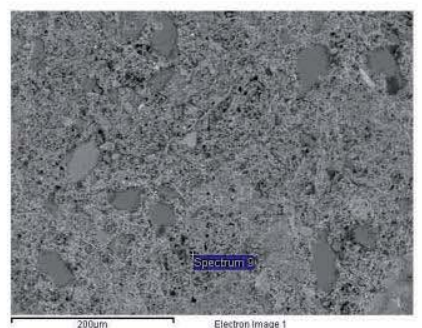

Electron image 1

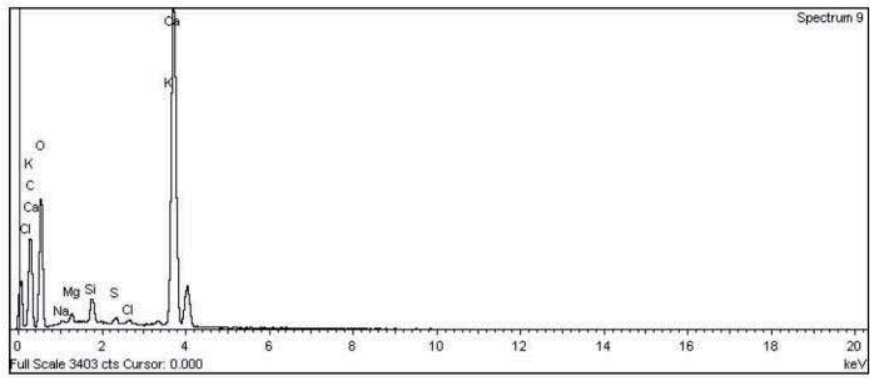




\subsection{MUESTRA CG $01 / 1$}

\subsubsection{DESCRIPCIÓN DE LA MUESTRA}

Ladrillo de tonalidad amarillenta con Ref. 1148- CG 01/1

2.3.2. $\mathrm{MO}$

MICROSCOPIA OPTICA (MO)

Microfotografia 3 : Luz incidente, $\mathrm{x} 10$

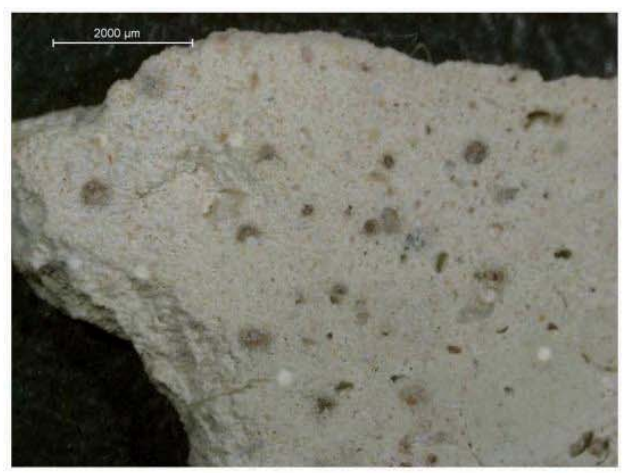

Figura 3. Ladrillo compacto de color amarillento 


\subsubsection{SEM/EDX}

\section{ESPECTRO 19}

Project: Project 1

Owner: Administrador

Site: Site of Interest 1, $20 \mathrm{X}$

Sample: Ladrillo de tonalidad amarillenta

ID: 1148 - CG 01/1

Análisis de área: Cuarzo, calcita, (alumino-)

silicato de calcio, arcillas, sulfatos y clonuros

Spectrum processing

Peak possibly omitted : $8.075 \mathrm{keV}$

Processing option : All elements analyzed

Number of iterations $=5$

Standard :

O $\mathrm{SiO} 2$ 1-jun-1999 12:00 AM

$\mathrm{Na}$ Albite 1-jun-1999 12:00 AM

$\mathrm{Mg} \mathrm{MgO}$ 1-jun-1999 12:00 AM

Al Al2O3 1-jun-1999 12:00 AM

Si SiO2 1-jun-1999 12:00 AM

S FeS2 1-jun-1999 12:00 AM

Cl KCl 1-jun-1999 12.00 AM

K MAD-10 Feldspar 1-jun-1999 12:00 AM

$\mathrm{Ca}$ Wollastonite 1-jun-1999 12:00 AM

Ca Wollastonite 1-jun-1999
Ti Ti 1-jun-1999 12:00 AM

Mn Mn 1-jun-1999 12:00 AM

$\mathrm{Fe} \mathrm{Fe}$ 1-jun-1999 12:00 AM

\begin{tabular}{l|ll}
\hline Element & Weight $\%$ & Atomic\% \\
OK & 37.71 & 71.72 \\
$\mathrm{Na} \mathrm{K}$ & 0.71 & 0.94 \\
$\mathrm{Mg} \mathrm{K}$ & 0.84 & 1.05 \\
$\mathrm{Al} \mathrm{K}$ & 3.56 & 4.02 \\
$\mathrm{Si} \mathrm{K}$ & 11.26 & 12.19 \\
$\mathrm{SK}$ & 0.22 & 0.21 \\
$\mathrm{Cl} \mathrm{K}$ & 0.11 & 0.09 \\
$\mathrm{~K} \mathrm{~K}$ & 0.64 & 0.50 \\
$\mathrm{Ca} \mathrm{K}$ & 10.51 & 7.98 \\
Ti K & 0.18 & 0.11 \\
Mn K & 0.07 & 0.04 \\
Fe K & 2.11 & 1.15 \\
& & \\
Totals & 67.91 & \\
\hline
\end{tabular}
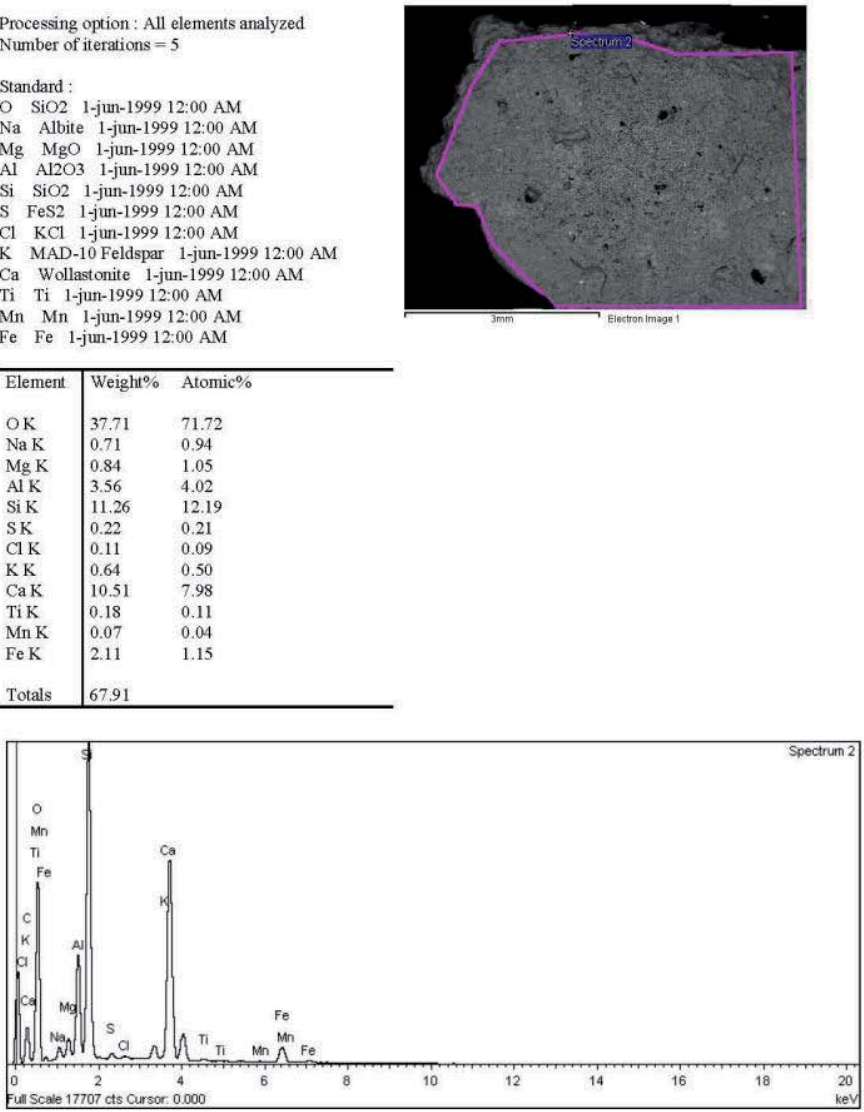


\section{ESPECTRO 20}

Project: Project 1

Owner: Administrador

Site: Site of Interest 1, $20 \mathrm{X}$

\section{Spectrum processing}

Peaks possibly omitted : $2.620,11.725 \mathrm{keV}$

Processing option : All elements analyzed Number of iterations $=3$

Standard :

O $\quad \mathrm{SiO} 2$ 1-jun-1999 12:00 AM

Mg MgO 1-jun-1999 12:00 AM

Al Al2O3 1-jun-1999 12:00 AM

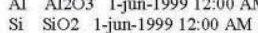

$\begin{array}{lll}\mathrm{Si} & \mathrm{SiO} 2 & \text { 1-jun-1999 12:00 AM } \\ \mathrm{P} & \mathrm{GaP} \text { 1-jun-1999 12:00 AM }\end{array}$

$\begin{array}{llll}\text { P } & \text { GaP 1-jun-1999 12:00 AM } \\ \text { K } & \text { MAD-10 Feldspar 1-jun-1999 12:00 AM }\end{array}$

Ca Wollastonite 1-jun-1999 12:00 AM

Ti Ti 1-jun-1999 12:00 AM

Fe Fe 1-jun-1999 12.00 AM

\begin{tabular}{l|ll}
\hline Element & Weight\% & Atomic\% \\
& & \\
$\mathrm{OK}$ & 5.90 & 35.16 \\
$\mathrm{Mg} \mathrm{K}$ & 0.43 & 1.69 \\
$\mathrm{Al} \mathrm{K}$ & 1.46 & 5.15 \\
$\mathrm{Si} \mathrm{K}$ & 4.60 & 15.62 \\
$\mathrm{P} \mathrm{K}$ & 0.19 & 0.57 \\
$\mathrm{~K} \mathrm{~K}$ & 0.18 & 0.43 \\
$\mathrm{Ca} \mathrm{K}$ & 15.17 & 36.09 \\
Ti K & 0.58 & 1.15 \\
Fe K & 2.43 & 4.16 \\
& & \\
Totals & 30.93 & \\
\hline
\end{tabular}

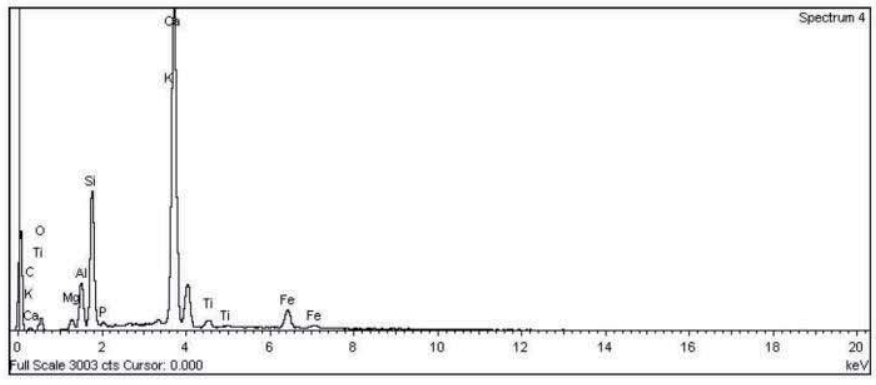

Sample: Ladrillo de tonalidad amarillenta

ID: 1148-CG 01/1

Análisis puntual: (Alumino-) silicatos de

calcio, óxidos de hierro

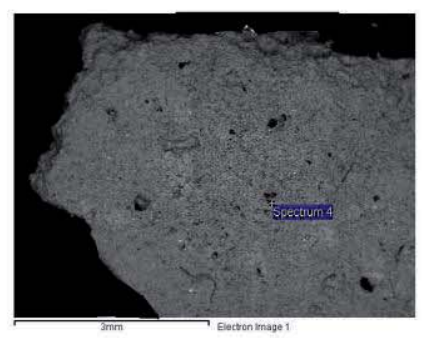


Distribución puntual de elementos/Mapping 3. ID: 1148- CG 01/1

\section{Interpretación de los resultados:}

Como en las muestras anteriores se identifica la presencia de dos minerales principales a 200 aumentos: cuarzo $\mathrm{SiO}_{2}$ y calcita $\mathrm{CaCO}_{3}$. Sin embargo, el tamaño de los granos es menor que en la muestra 1148-YA 119-1 (compárense las imágenes de Si en mapping 1) También se observan altas concentraciones de los elementos Al y Fe, pero muy dispersas. Se confirma también la presencia de cloruros y sulfatos.
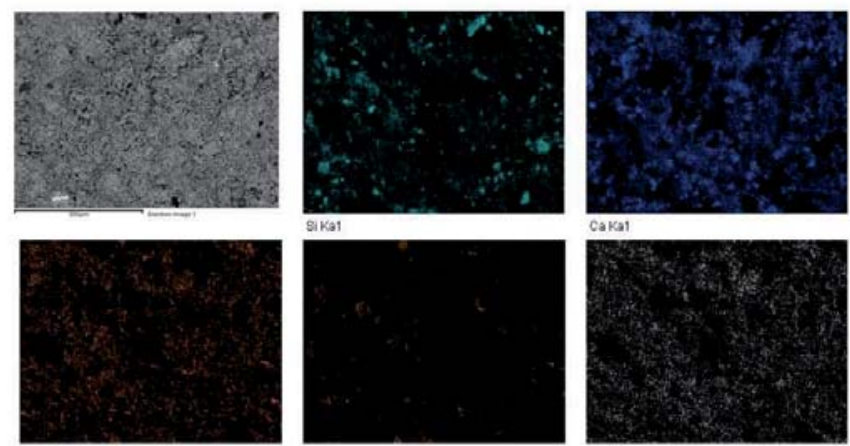
Cakal
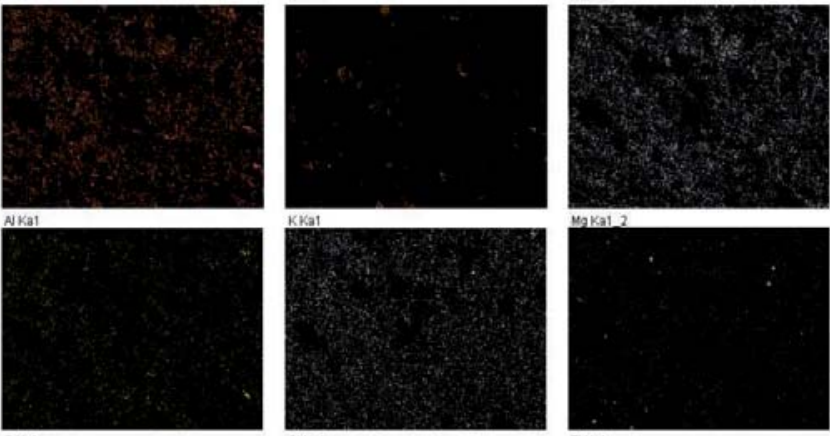

vaka12

ClKa1
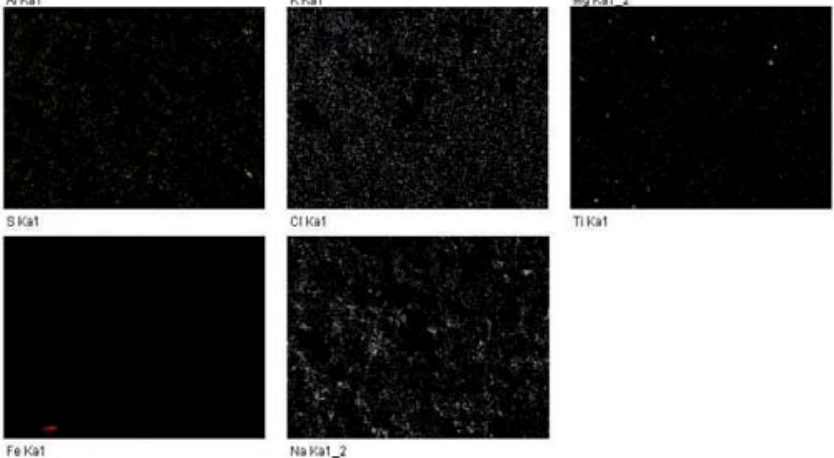

Tikat 


\section{ESPECTRO 21}

Project: Project 1

Owner: Administrador

Site: Site of Interest 1, 200x

Sample: Ladrillo de tonalidad amarillenta

ID: 1148 - CG $01 / 1$

Análisis puntual: Cuarzo

Spectrum processing

No peaks omitted

Processing option : All elements analyzed

Number of iterations $=4$

Standard :

O $\mathrm{SiO} 2$ 1-jun-1999 12:00 AM

$\mathrm{Si} \quad \mathrm{SiO} 2$ 1-jun-1999 12:00 AM

\begin{tabular}{l|ll}
\hline Element & Weight \% & Atomic\% \\
OK & 66.89 & 67.91 \\
Si K & 55.49 & 32.09 \\
Totals & 122.38 & \\
\hline
\end{tabular}
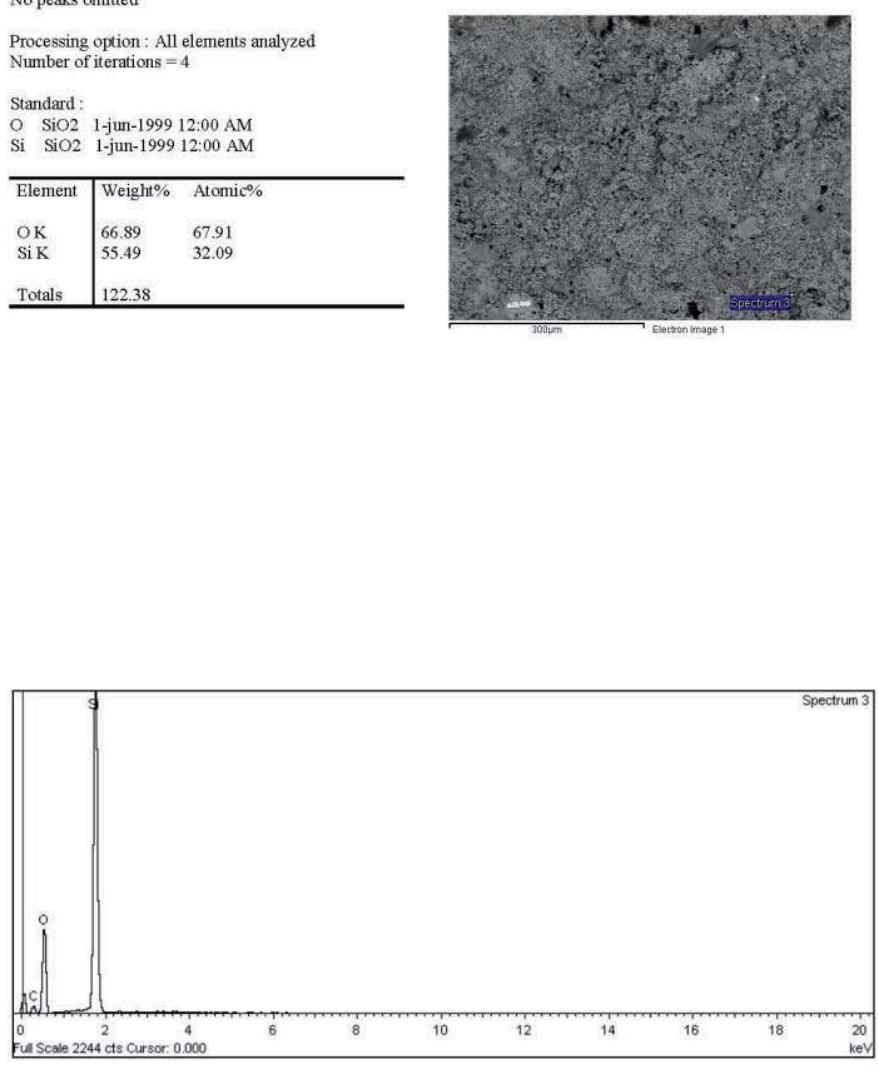


\section{ESPECTRO 22}

Project: Project 1

Owner: Administrador

Site: Site of Interest $1,200 \mathrm{x}$

No peaks omitted

Processing option : All elements analyzed

Number of iterations $=3$

Standard :

O $\mathrm{SiO2}$ 1-jun-1999 12:00 AM

Al $\mathrm{Al} 2 \mathrm{O} 3$ 1-jun-1999 12:00 AM

$\mathrm{Si} \quad \mathrm{SiO} 2$ 1-jun-1999 12:00 AM

K MAD-10 Feldspar 1-jun-1999 12:00 AM

Ca Wollastonite 1-jun-1999 12:00 AM

$\mathrm{Fe} F e$ 1-jun-1999 12:00 AM

\begin{tabular}{l|ll}
\hline Element & Weight\% & Atomic\% \\
& & \\
O K & 3.62 & 73.24 \\
Al K & 0.20 & 2.35 \\
Si K & 0.68 & 7.85 \\
K K & 0.09 & 0.71 \\
Ca K & 1.12 & 9.05 \\
Fe K & 1.17 & 6.81 \\
Totals & 6.88 & \\
\hline
\end{tabular}

Sample: Ladrillo de tonalidad amarillenta ID: 1148 - CG 01/1

Análisis de área: (Alumino-) silicatos de

calcio y hierro

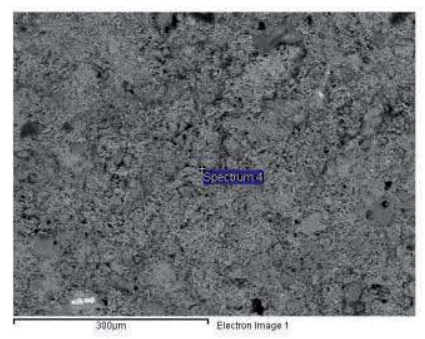

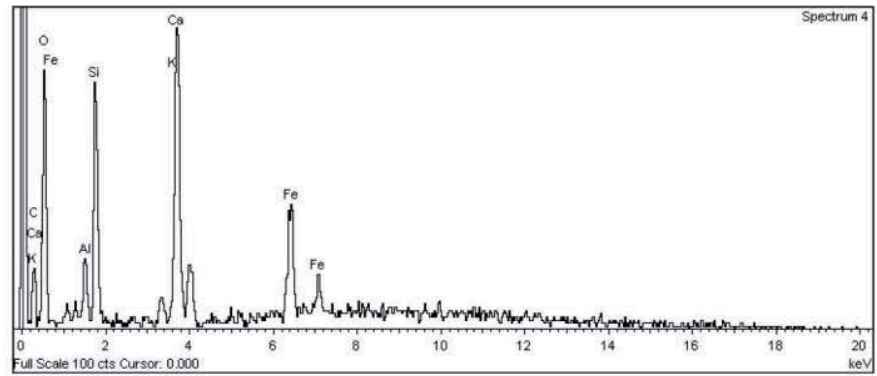




\section{ESPECTRO 23}

Project: Project 1

Owner: Administrador

Site: Site of Interest $1,200 \mathrm{x}$

Spectrum processing :

No peaks omitted

Processing option : All elements analyzed Number of iterations $=5$

\section{Standard:}

O $\mathrm{SiO} 2$ 1-jun-1999 12:00 AM

$\mathrm{Mg} \mathrm{MgO}$ 1-jun-1999 12:00 AM

Al $\mathrm{Al} 2 \mathrm{O} 3$ 1-jun-1999 12:00 AM

$\mathrm{Si} \mathrm{SiO} 2$ 1-jun-1999 12:00 AM

S FeS2 1-jun-1999 12:00 AM

K MAD-10 Feldspar 1-jun-1999 12:00 AM

Ca Wollastonite 1-jun-1999 12:00 AM

$\mathrm{Fe} \mathrm{Fe}$ 1-jun-1999 12:00 AM

\begin{tabular}{l|ll}
\hline Element & Weight\% & Atomic\% \\
& & \\
$\mathrm{OK}$ & 66.45 & 75.57 \\
$\mathrm{Mg} \mathrm{K}$ & 0.78 & 0.58 \\
$\mathrm{Al} \mathrm{K}$ & 4.55 & 3.07 \\
$\mathrm{Si} \mathrm{K}$ & 7.08 & 4.59 \\
$\mathrm{~S} \mathrm{~K}$ & 0.79 & 0.45 \\
$\mathrm{~K} \mathrm{~K}$ & 0.21 & 0.10 \\
$\mathrm{Ca} \mathrm{K}$ & 33.86 & 15.37 \\
$\mathrm{Fe} \mathrm{K}$ & 0.82 & 0.27 \\
& & \\
Totals & 114.54 & \\
\hline
\end{tabular}

Sample: Ladrillo de tonalidad amarillenta ID: $1148-$ CG $01 / 1$

Análisis de área: Aluminosilicatos de calcio y sulfatos

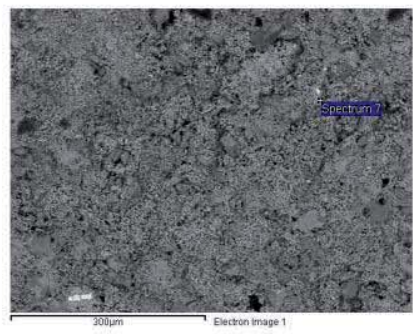

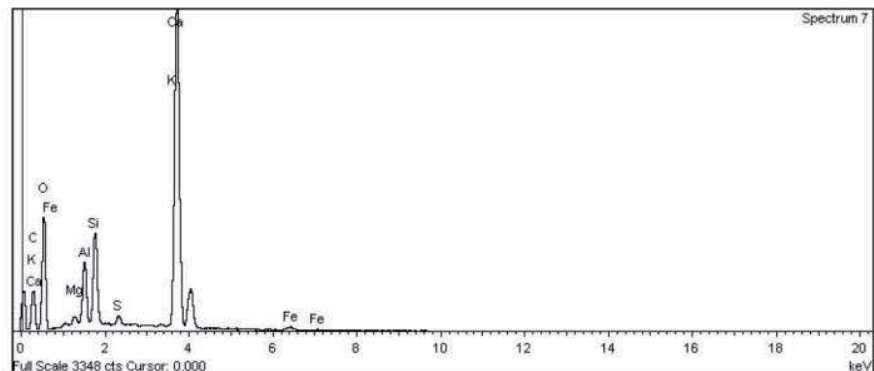




\section{ESPECTRO 24}

Project: Project 1

Owner. Administrador

Site: Site of Interest 1, 200x

Spectrum processing

Peak possibly omitted : $8.450 \mathrm{keV}$

Processing option : All elements analyzed Number of iterations $=3$

Standard :

O $\mathrm{SiO} 2$ 1-jun-1999 12:00 AM

Al Al2O3 1-jun-1999 12:00 AM

$\mathrm{Si} \quad \mathrm{SiO} 2$ 1-jun-1999 12:00 AM

S FeS2 1-jun-1999 12:00 AM

Ca Wollastonite 1-jun-1999 12:00 AM

\begin{tabular}{l|ll}
\hline Element & Weight\% & Atomic\% \\
OK K & 11.86 & 50.66 \\
Al K & 0.23 & 0.59 \\
Si K & 0.53 & 1.29 \\
S K & 0.20 & 0.42 \\
Ca K & 27.59 & 47.04 \\
& & \\
Totals & 40.41 & \\
\hline
\end{tabular}

Sample: Ladrillo de tonalidad amarillenta ID: 1148 - CG 01/1

Análisis puntual: Calcita

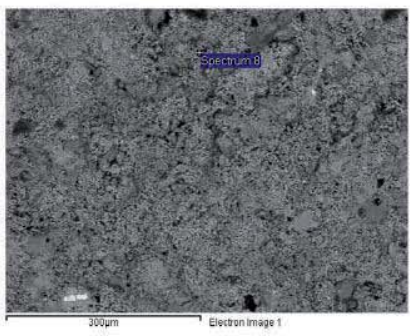

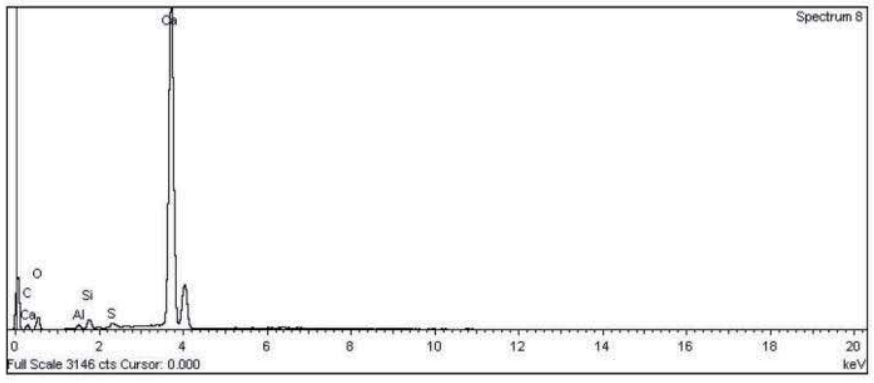




\section{ESPECTRO 25}

Project: Project 1

Owner. Administrador

Site: Site of Interest 1, 200x

ample: Ladrillo de tonalidad amarillenta

D: $1148-$ CG 01/1

Análisis puntual: Calcita, sulfatos y cloruros

\section{Spectrum processing :}

Peak possibly omitted : $7.385 \mathrm{keV}$

Processing option : All elements analyzed Number of iterations $=3$

Standard :

O $\mathrm{SiO} 2$ 1-jun-1999 12:00 AM

Na Albite 1-jun-1999 12:00 AM

$\mathrm{Si} \quad \mathrm{SiO} 2$ 1-jun-1999 12:00 AM

S FeS2 1-jun-1999 12:00 AM

$\begin{array}{lrl}\mathrm{S} & \mathrm{FeS} 2 & 1 \text {-jun-1999 12:00 AM } \\ \mathrm{Cl} & \mathrm{KCl} & 1 \text {-jun-1999 12:00 AM }\end{array}$

$\begin{array}{lll}\mathrm{Cl} & \mathrm{KCl} \text { 1-jun-1999 12:00 AM } \\ \mathrm{K} & \mathrm{MAD}-10 \mathrm{Feldspar} \text { 1-jun-1999 12:00 AM }\end{array}$

$\mathrm{K}$ MAD-10 Feldspar 1-jun-1999 12:00 AM
$\mathrm{Ca}$ Wollastonite 1-jun-1999 12:00 AM

\begin{tabular}{l|ll}
\hline Element & Weight\% & Atomic\% \\
$\mathrm{OK}$ & 30.75 & 67.67 \\
$\mathrm{NaK}$ & 0.24 & 0.37 \\
$\mathrm{Si} \mathrm{K}$ & 0.36 & 0.45 \\
$\mathrm{~S} \mathrm{~K}$ & 0.77 & 0.84 \\
$\mathrm{Cl} \mathrm{K}$ & 0.44 & 0.43 \\
$\mathrm{~K} \mathrm{~K}$ & 0.28 & 0.25 \\
$\mathrm{Ca} \mathrm{K}$ & 34.14 & 29.99 \\
& \\
Totals & 66.97 & \\
\hline
\end{tabular}
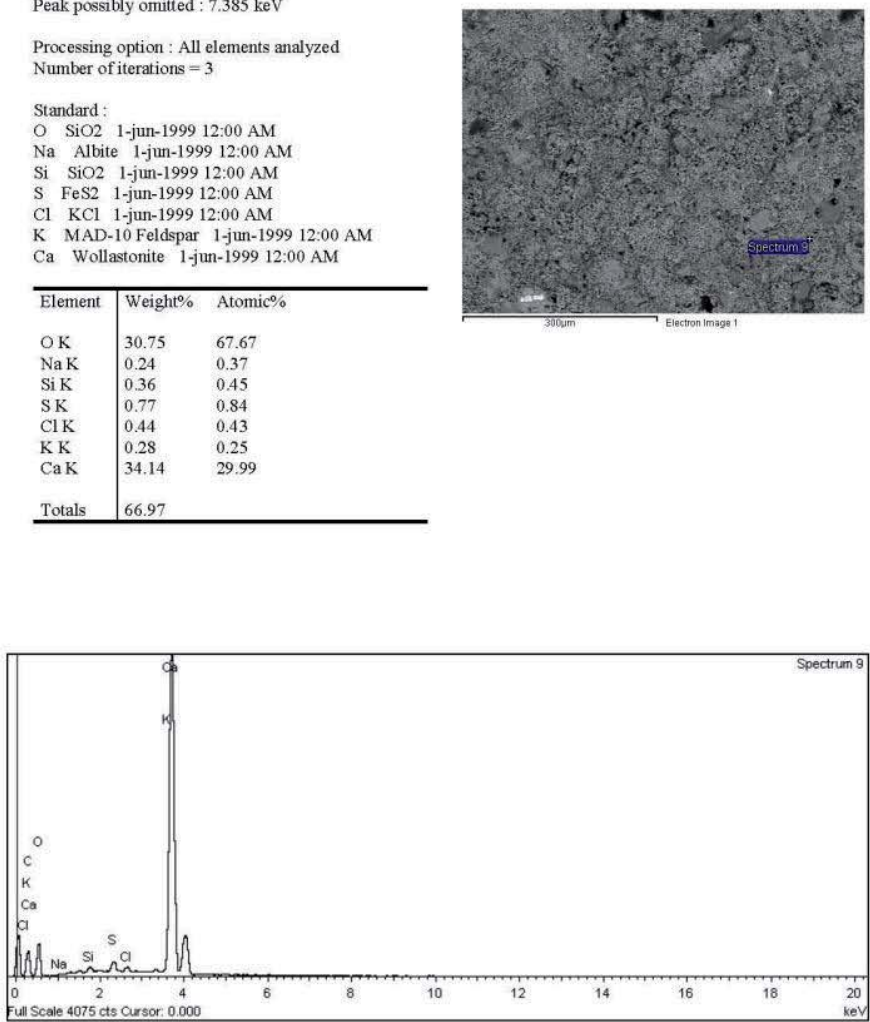


\section{ESPECTRO 26}

Project: Project 1

Owner: Administrador

Site: Site of Interest 1, 250x

Sample: Ladrillo de tonalidad amarillenta

ID: $1148-$ CG 01/1

Análisis puntual: Cuarzo

Spectrum processing

Peak possibly omitted : $3.470 \mathrm{keV}$

Processing option : All elements analyzed

Number of iterations $=4$

Standard :

O $\quad \mathrm{SiO} 2$ 1-jun-1999 12:00 AM

$\mathrm{Si} \quad \mathrm{SiO} 2$ 1-jun-1999 12:00 AM

\begin{tabular}{l|ll}
\hline Element & Weight\% & Atomic\% \\
OK & 54.75 & 66.51 \\
Si K & 48.39 & 33.49 \\
& & \\
Totals & 103.14 & \\
\hline
\end{tabular}

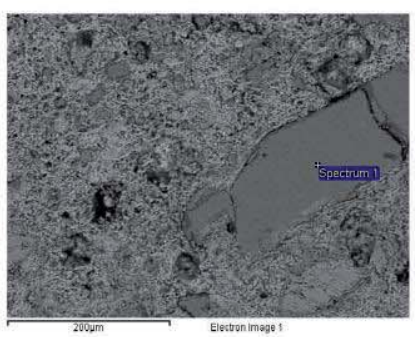

Elestron image !

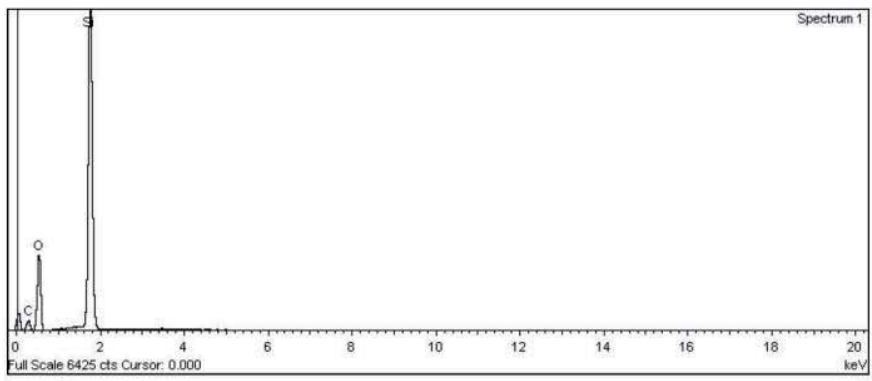




\section{ESPECTRO 27}

Project: Project 1

Owner: Administrador

Site: Site of Interest 1, 250x

Spectrum processing

No peaks omitted

Processing option : All elements analyzed

Number of iterations $=4$

Standard:

O $\mathrm{SiO} 2$ 1-jun-1999 12:00 AM

Na Albite 1-jun-1999 12:00 AM

$\mathrm{Mg} \mathrm{MgO}$ 1-jun-1999 12:00 AM

Al Al2O3 1-jun-1999 12:00 AM

$\mathrm{Si} \quad \mathrm{SiO} 2$ 1-jun-1999 12:00 AM

S FeS2 1-jun-1999 12:00 AM

K MAD-10 Feldspar 1-jun-1999 12.00 AM

$\mathrm{Ca}$ Wollastonite 1-jun-1999 12:00 AM

$\mathrm{Ca}$ Wollastonite 1-jun-1999

$\begin{array}{lll}\text { Ti } & \text { Ti } & \text { 1-jun-1999 12:00 AM } \\ \text { Fe } & \text { Fe 1-jun-1999 12:00 AM }\end{array}$

\begin{tabular}{l|ll}
\hline Element & Weight\% & Atomic\% \\
$\mathrm{OK}$ & 54.34 & 66.19 \\
$\mathrm{Na} \mathrm{K}$ & 0.41 & 0.34 \\
$\mathrm{Mg} \mathrm{K}$ & 2.75 & 2.20 \\
$\mathrm{Al} \mathrm{K}$ & 8.96 & 6.47 \\
$\mathrm{Si} \mathrm{K}$ & 14.87 & 10.32 \\
$\mathrm{SK}$ & 0.31 & 0.19 \\
$\mathrm{~K} \mathrm{~K}$ & 0.38 & 0.19 \\
$\mathrm{Ca} \mathrm{K}$ & 21.20 & 10.31 \\
Ti K & 0.86 & 0.35 \\
Fe K & 9.89 & 3.45 \\
& & \\
Totals & 113.96 & \\
\hline
\end{tabular}

Sample: Ladrillo de tonalidad amarillenta ID: 1148 - CG 01/1

Análisis de área: Aluminosilicatos de calcio y hierro

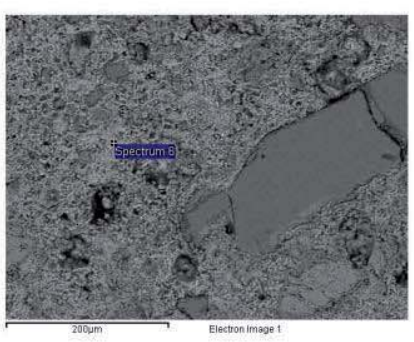

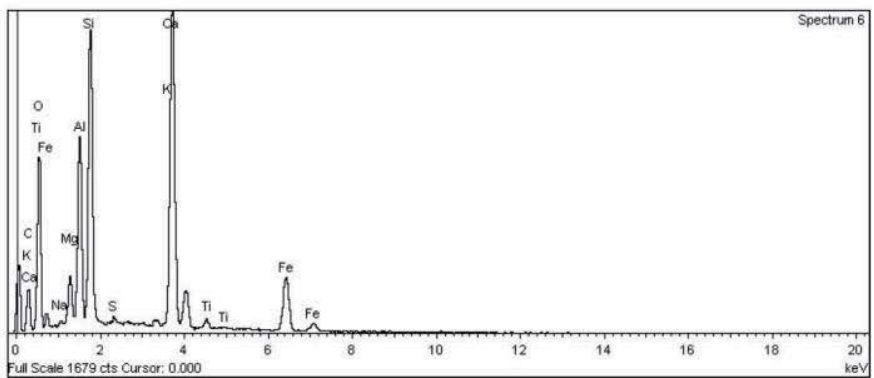


III. CARACTERIZACIÓN QUIMICO/MINERALÓGICA MORTERO CON CAPA PICTÓRICA 


\subsection{MUESTRA VA $82 / 2$}

\subsubsection{DESCRIPCIÓN DE LA MUESTRA}

Mortero de tonalidad gris claro con capa pictórica con Ref. 1148- VA 82/2

\subsubsection{MO}

\section{MICROSCOPIA OPTICA (MO)}

Microfotografias 4 : Luz incidente, $x 20$

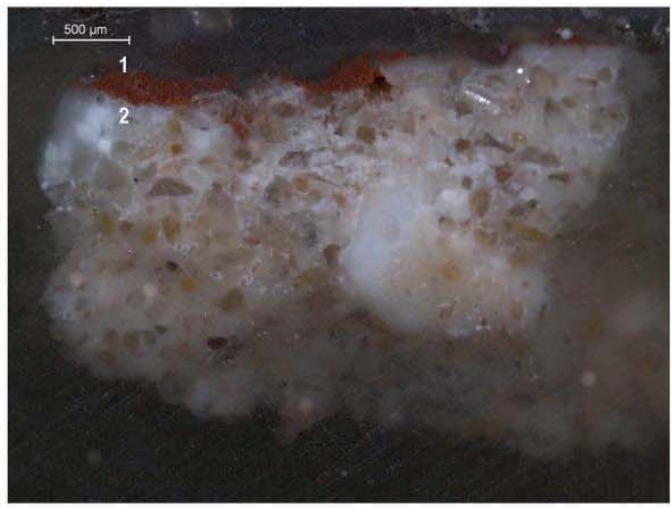

Figura 4. Mortero (2) con una capa pictórica roja (1) de aproximadamente 0,3 mm de grosor máximo. 


\subsubsection{SEMVEDX}

Distribución puntual de elementos/Mapping 4. ID: 1148-VA 82/2

Interpretación de los resultados (30 X):

Granos de arido siliceo, cuarzo y en menor proporción feldespato potásico KAISi $\mathrm{O}_{i}$ (véase altas concentraciones de los elementos K y Al) junto con granos aislado de naturaleza carbonática (calcita y en menor cantidad dolomita). El ligante está constituido principalmente por calcita. La capa pictórica se identifica por los elementos Fe y AL. Esto se atribuye a la presencia de óxidos de hierro y arcillas, dándole el color. Destacar la presencia de cloruros en toda la muestra y de sulfatos en la transición mortero-capa pictórica (véase tambiên mapping 5).
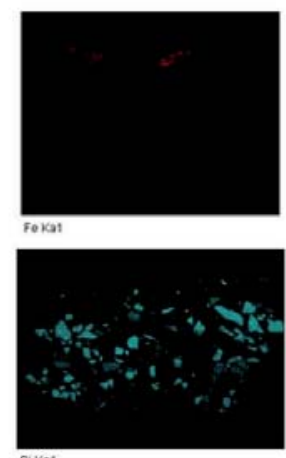

Sika1

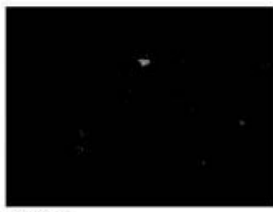

MgKa1_2
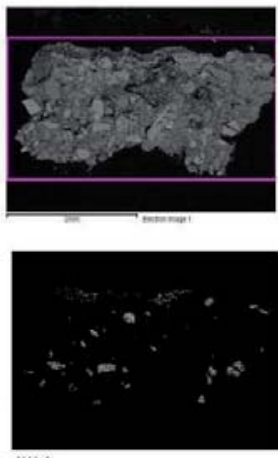

NKaI

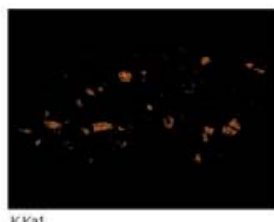

KKaI

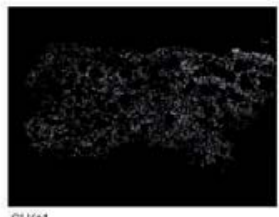

CI Ka1

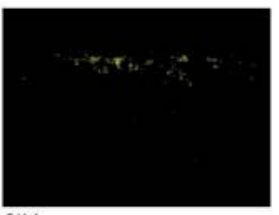

$5 \mathrm{KaI}$
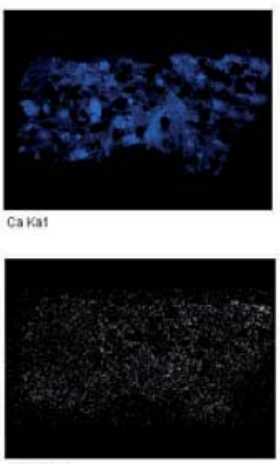

NuKa1_2 
Distribución puntual de elementos/Mapping 5. ID:1148- VA 82/2

\section{Interpretación de los resultados (180 X):}

Granos de árido siliceo (cuarzo) y junto con granos de calcita en la capa 2 (mortero). El ligante está constituido principalmente por calcita. La capa pictórica (1) destaca por la alta concentración de los elementos Fe y Al. Se observa una concentración de los sulfatos en la transición mortero-capa pictórica y un nivel más elevado de cloruros en el mortero que en la capa pictórica (véase también
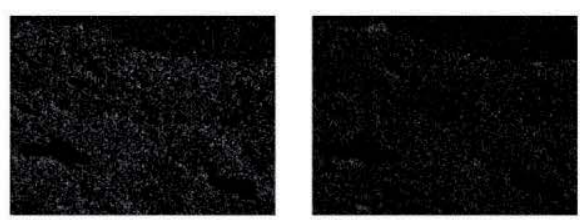

Mg Ka1_2
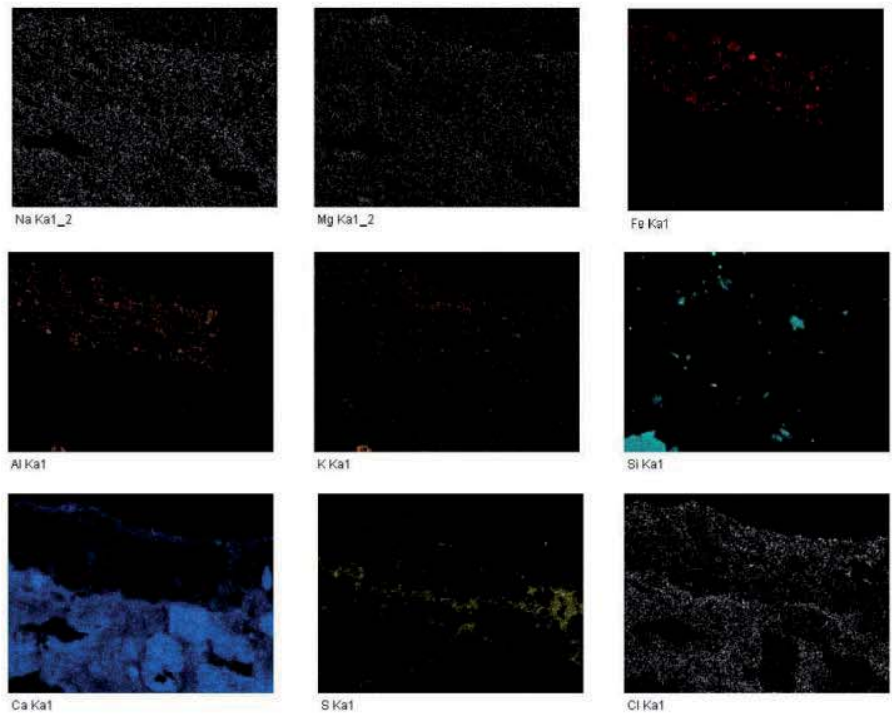
Distribución puntual de elementos/Line scan 1. ID: 1148- VA 82/2

Interpretación de los resultados (180 X):

Concentración de los elementos Fe (rosa) y Al (verde claro) en la capa pictórica. Obsérvense el aumento del elemento $\mathrm{Cl}$ (morado) en el mortero

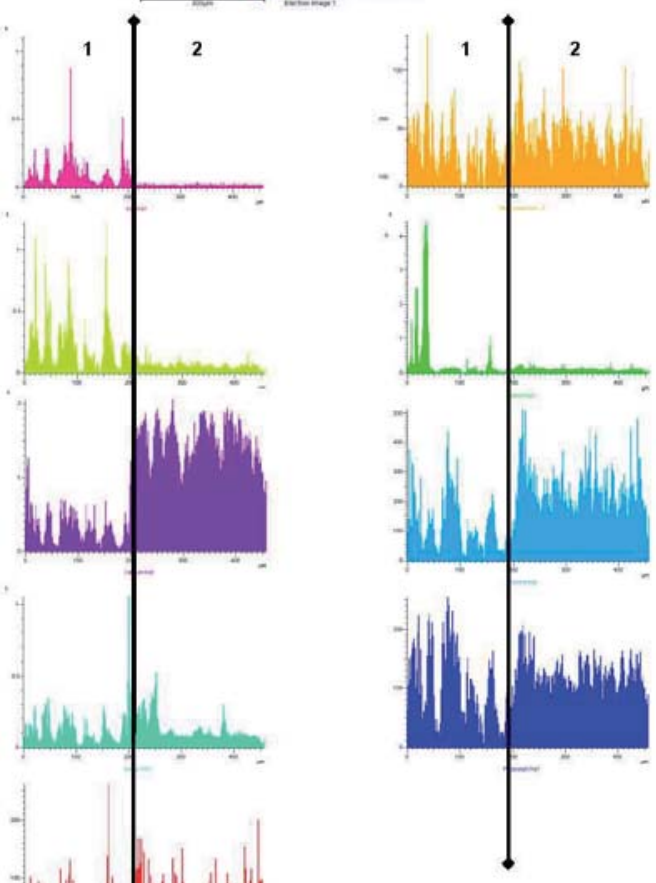




\section{ESPECTRO 28}

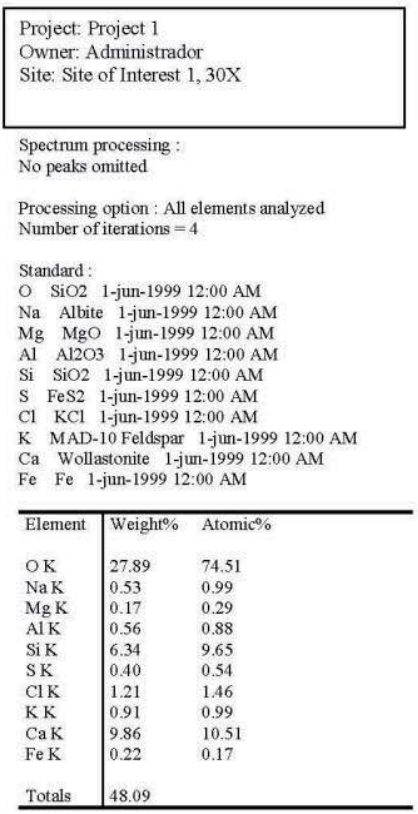

\section{Sample: Mortero con capa pictórica}

ID: 1148 - VA $82 / 2$

Análisis de área: Calcita, cuarzo, arcillas, cloruros y sulfatos

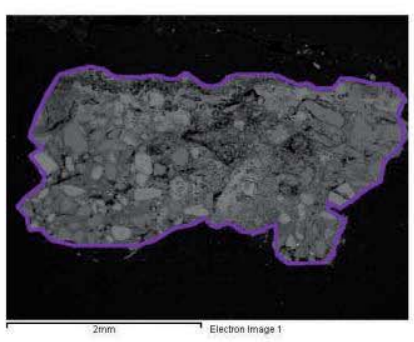




\section{ESPECTRO 29}

Project: Project 1

Owner: Administrador

Site: Site of Interest 1,30X

Spectrum processing :

Peaks possibly omitted : $3.481,9.380 \mathrm{keV}$

Processing option : All elements analyzed

Number of iterations $=4$

Standard :

O $\mathrm{SiO} 2$ 1-jun-1999 12:00 AM

$\mathrm{Si} \quad \mathrm{SiO} 2$ 1-jun-1999 12:00 AM

\begin{tabular}{l|ll}
\hline Element & Weight $\%$ & Atomic\% \\
OK & 41.05 & 64.49 \\
Si K & 39.68 & 35.51 \\
Totals & 80.73 & \\
\hline
\end{tabular}

Sample: Mortero con capa pictórica

ID: 1148 - VA $82 / 2$

Análisis puntual: cuarzo

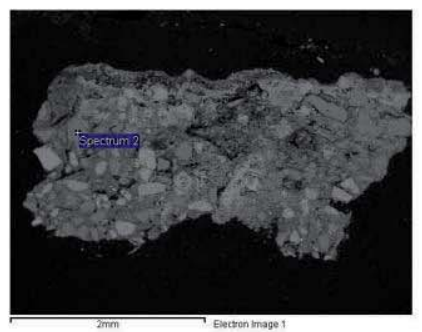

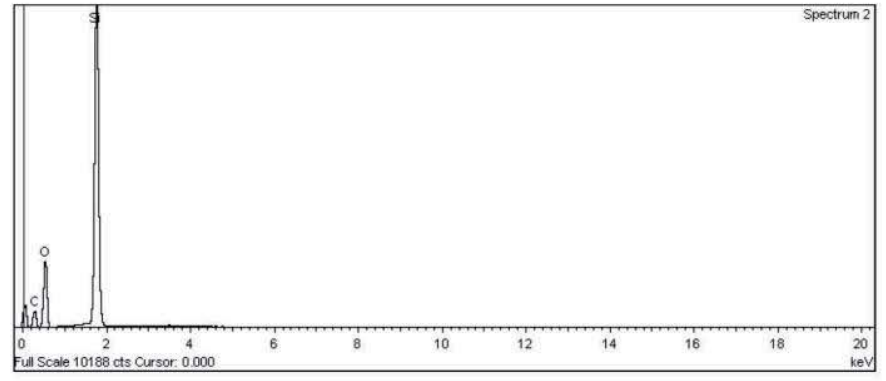




\section{ESPECTRO 30}

Project: Project 1

Owner: Administrador

Site: Site of Interest 1, 30X

Spectrum processing :

Peaks possibly omitted : $3.481,9.380 \mathrm{keV}$

Processing option : All elements analyzed

Number of iterations $=4$

Standard:

O SiO2 1-jun-1999 12:00 AM

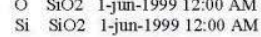

\begin{tabular}{l|ll}
\hline Element & Weight\% & Atomic\% \\
O K & 41.05 & 64.49 \\
Si K & 39.68 & 35.51 \\
& & \\
Totals & 80.73 & \\
\hline
\end{tabular}

Sample: Mortero con capa pictórica

ID: 1148 - VA $82 / 2$

Análisis puntual: cuarzo

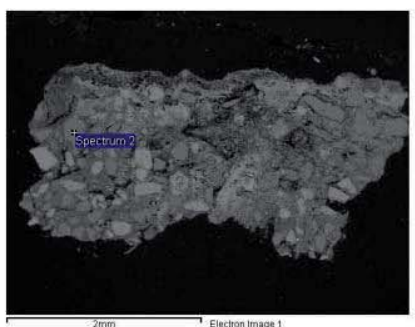

2 Electron Image 1

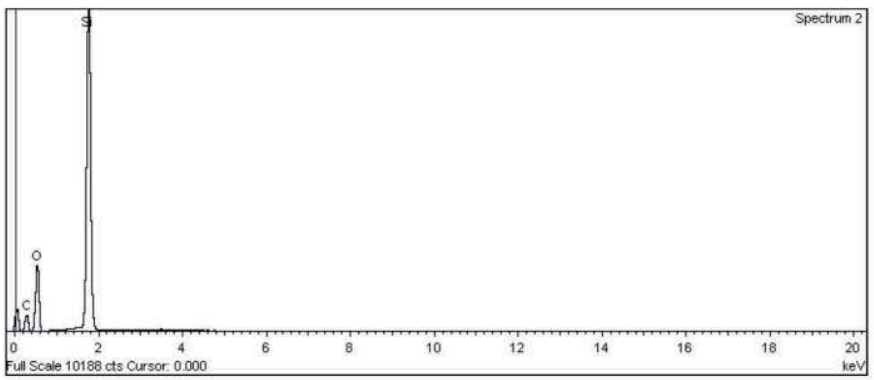




\section{ESPECTRO 31}

Project: Project 1

Owner: Administrador

Site: Site of Interest $1,30 \mathrm{X}$

Spectrum processing

Peak possibly omitted : $6.435 \mathrm{keV}$

Processing option : All elements analyzed

Number of iterations $=5$

Standard :

O $\mathrm{SiO} 2$ 1-jun-1999 12:00 AM

Cl KCl 1-jun-1999 12:00 AM

Ca Wollastonite 1-jun-1999 12:00 AM

\begin{tabular}{l|ll}
\hline Element & Weight $\%$ & Atomic\% \\
OK & 54.08 & 78.05 \\
Cl K & 0.32 & 0.21 \\
Ca K & 37.73 & 21.74 \\
& & \\
Totals & 92.13 & \\
\hline
\end{tabular}

Sample: Mortero con capa pictórica

ID: 1148 - VA $82 / 2$

Análisis puntual: calcita y cloruros
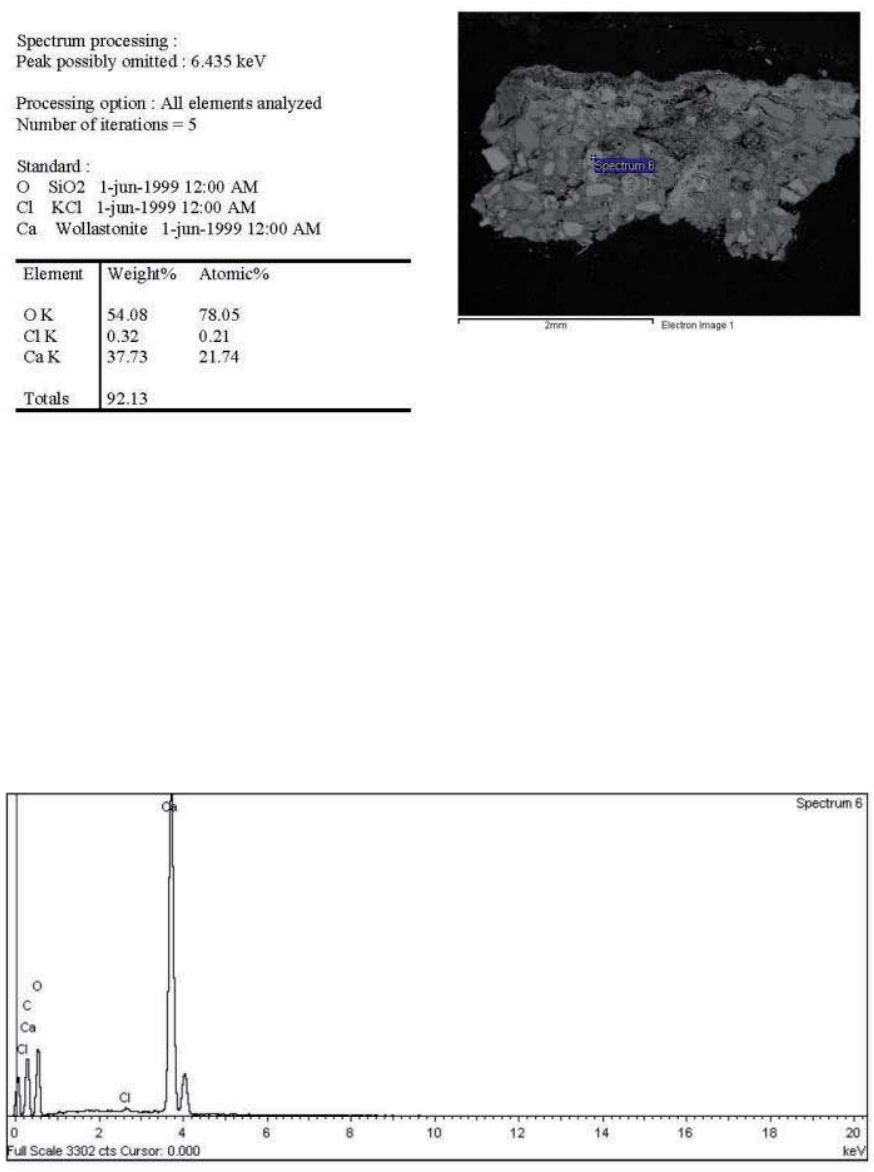


\section{ESPECTRO 32}

\section{Project: Project 1}

Owner: Administrador

Site: Site of Interest 1, 30X

Spectrum processing :

No peaks omitted

Processing option : All elements analyzed

Number of iterations $=$

Standard :

O SiO2 1-jun-1999 12:00 AM

$\mathrm{Mg} \mathrm{MgO} \mathrm{1-jun-1999} \mathrm{12:00} \mathrm{AM}$

$\mathrm{Ca}$ Wollastonite 1-jun-1999 12:00 AM

$\mathrm{Fe} \mathrm{Fe}$ 1-jun-1999 12:00 AM

\begin{tabular}{l|ll}
\hline Element & Weight\% & Atomic\% \\
$\mathrm{OK}$ & 47.28 & 72.88 \\
$\mathrm{Mg} \mathrm{K}$ & 13.89 & 14.09 \\
$\mathrm{Ca} \mathrm{K}$ & 20.98 & 12.91 \\
$\mathrm{Fe} \mathrm{K}$ & 0.28 & 0.12 \\
& & \\
Totals & 82.43 & \\
\hline
\end{tabular}

Sample: Mortero con capa pictórica

ID: 1148 - VA $82 / 2$

Análisis puntual: dolomita
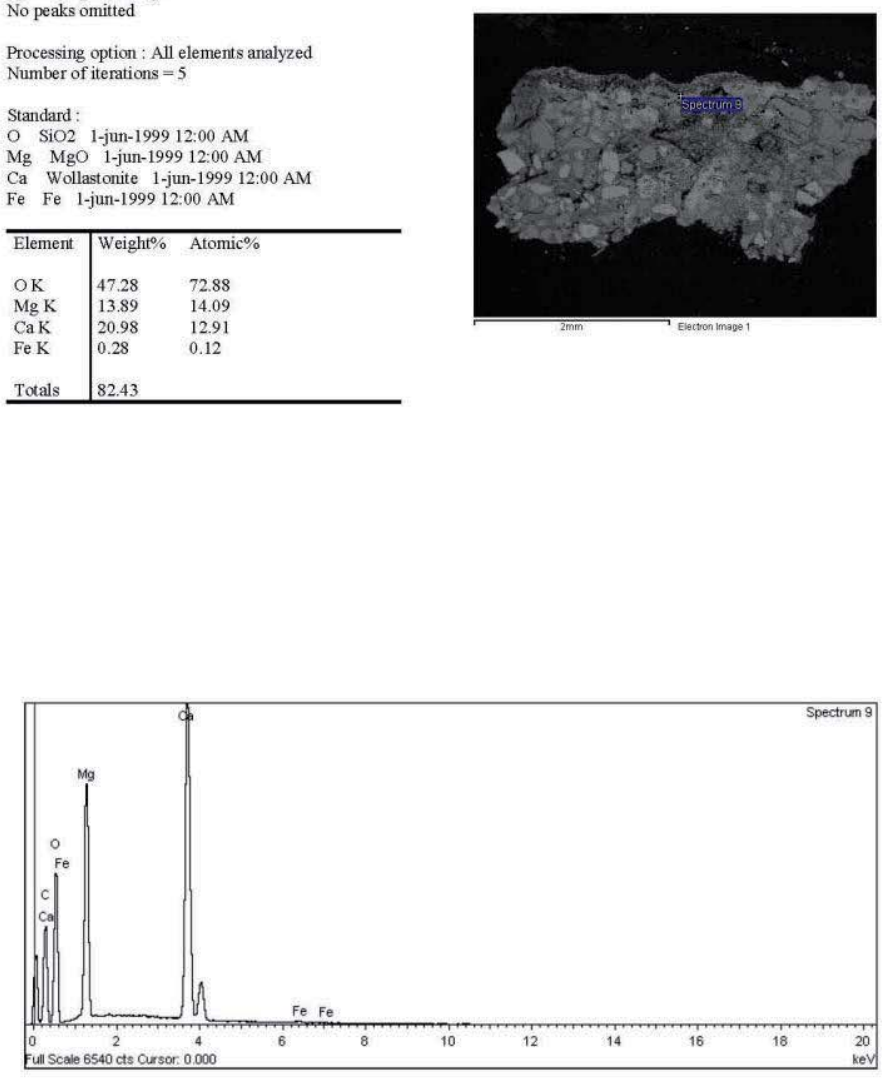



\section{Glosario $^{1}$}

ABOCINADO (cas.) adjetivo que se aplica ad un arco cuyas dos frentes son semejantes, pero de mayor diámetro una que otra, con las jambas colocadas oblicuamente respecto a la planta

ACICALAR (cas.) dar a la pared el último pulimento por fuera. Para esto, si la pared es de sillería, se rehúnden y rematan las juntas; si es de mampostería, se revoca. Si es de ladrillo, se da una mano de almazarrón, recorriendo y señalando con una lechada de cal a las llagas y tendeles ${ }^{2}$

$A D O B E$ (ár.) ladrillo sin cocer, que se gasta después de estar muy $\mathrm{seco}^{3}$.El termino deriva del arabo "at tub", terrón

\footnotetext{
${ }^{1}$ Se presenta una global identificación de términos técnicos empleados por la autora en el texto. Las abreviaciones respetan los siguientes criterios: cas./ castellano; val./ valenciano, ing./inglés, it./ italiano, lat./latín, ár./ árabe;

ALVAR EZQUERIA M., El vox mayor: diccionario general ilustrado de la lengua española, Zanichelli, Bologna, 1989.

CASSINELLO F., El ladrillo y su fábricas, Eva Ed., Valencia, IV ed., 1971

CHING F., Diccionario visual de arquitectura, G. Gili Ed., Barcelona, 1995

COROMINAS-PASCUAL, Diccionario Crítico Etimológico Castellano y Hispano, Ed.Grados, Madrid, 1992

GÓMEZ FERRER M., Siglos XV-XVIII, Vocabulario de arquitectura valenciana, Ayto Valencia Ed., Valencia, 2002

MARTÍNEZ AMADOR E., Diccionario Italiano-Español, Ramon Sopena Editore, Barcellona, 1997 PLAZA ESCUDERO L., Diccionario visual de términos arquitectónicos, Cátedra Ed., Madrid, 2008 REJÓN DE SILVA D.A., Diccionario de la noble arte, Ed. Consejería de Cultura y Educación, Murcia, 1985, (Antonio Espinosa Imprenta, Segovia, 1788)

www.rae.es

${ }^{2}$ BAILS B.. Diccionario de Arquitectura Civil. Obra Póstuma de Don Benito Bails. Madrid:

Imprenta de la viuda de Ibarra, 1802.

${ }^{3}$ BAILS B., Op. Cit.
} 
ADOBERA (ár.) molde para hacer adobes.=Obra hecha de adobes ${ }^{4}$

AGRAMILADO (cas.) arreglar los ladrillos de que se ha de componer un edificio, pared a un mismo ancho y grueso raspándolos y cortándolos con el aciche; con lo cual se llama Obra de Agramilado asentados los ladrillos en la fábrica se frota la superficie exterior de ésta con otro ladrillo, á fin de que quede perfectamente igual ${ }^{5}$

AGUJA (cas.) barra de hierro o de madera, con agujeros y pasadores, que sirve para mantener paralelos los tableros de un tapial

ALMAGRE (cas.) óxido rojo de hierro, más o menos arcilloso, abundante en la naturaleza, y que suele emplearse en la pintura para fingir fábricas de ladrillos

ALMAZARRÓN (cas.) tierra colorada que sirve para teñir ${ }^{6}$

ALMOHADILLADO (cas.) aparejo con las líneas de unión entre los ladrillos hundidas, resaltando así el paramento en su parte central. Al tratarse de una forma decorativa, el almohadillado se presta a muchas variaciones como la de en chaflán (que es la más corriente), la de en punta de diamante, el almohadillado rústico, el vermiculado, etc.

ALUMBRE (cas.) sulfato doble de alúmina y potasa, tradicionalmente añadido a los morteros para facilitar el fraguado

AMASADORA (cas.) aparato utilizado para la correcta mezcla y dosificación de la arcilla. Se remontan al siglo XVIII y suele funcionar inicialmente por tracción animal y mecánica a partir del siglo XVIII

\footnotetext{
${ }^{4}$ MATALLANA M., Vocabulario de Arquitectura Civil. Madrid: Imprenta de Don Francisco Rodríguez, 1848

${ }^{5}$ BAILS B., Op. Cit.

${ }^{6}$ BAILS B., Op. Cit.
} 
ANATHIROSIS (lat.) técnica de acabado de las juntas de ladrillos y elementos pétreos para mejorar la adherencia de los módulos y dar menor visibilidad a las juntas

APAREJO (cas.) modo de ordenar los ladrillos unos sobre otros, para que, solapados tanto en un sentido vertical como horizontal, puedan formar una fábrica

APLANTILLADO (cas.) ladrillo hecho con un molde que se emplea en la construcción de muros curvos, arcos, bóvedas, etc.; caracterizado por que una de sus esquinas es redondeada y se coloca con su cara menor a la vista. También llamado ladrillo moldeado

ARCILLA (cas.) tierra finamente dividida, constituida por agregados de silicatos de aluminio hidratados, que procede de la descomposición de minerales de aluminio, blanca cuando es pura y con coloraciones diversas según las impurezas que contiene ${ }^{7}$

ARCICHE/ACHICE (cas.) instrumento de hierro que tiene dos bocas cortantes en una misma dirección, y sirve para cortar y arreglar los ladrillos que se han de poner en obra

BAILO (val.) aprendiz o ayudante de los ladrillares pre-industriales

BALADA DE SECADO (cas.) ladrillos apilados, recién moldeados, que se disponen de esta forma para facilitar el secado antes de la fase de cocción

BASSER (val.) trabajador que mezclan la tierra con el agua en los ladrillares

BESSALIS (lat.) tipo de ladrillo romano, que equivale a dos tercios (bes) de un pié romano, (unidad de medida). Es un ladrillo cuadrado, 
el más pequeño los formatos entonces disponibles de 19.7x19.7x $4.5 \mathrm{~cm}$

BIPEDALES (lat.) tipo de ladrillo romano, que equivale a dos pies romanos, (unidad de medida). Es un ladrillo cuadrado, el más grande los formatos entonces disponibles de 590-750x590-750x6.5 cm

BOFETÓN (A) (cas.) ladrillo colocado a restregón sobre el paramento de otro elemento de fábrica aparejado

BOSCATER (val.) peón que se ocupan de la búsqueda de combustible para los ladrillares pre-industriales

CABEZA (cas.) ladrillo cortado trasversalmente por la mitad, también llamado media asta

CABEZAL (cas.) ladrillo cortado especialmente para terminar una hilada o completar el aparejo en una esquina de un muro

CANTO (cas.) cara media de un ladrillo (soga x grueso)

CAJÓN (cas.) espacio que hay entre dos machos de ladrillo en las paredes de esta clase de construcción y que se suelen atar de trecho en trecho con verdugadas cuyo espacio se rellena con tierra ${ }^{8}$

CARCHATA (cas.) camisa de arcilla refractaria altamente rubefactada dentro de las paredes de un horno cerámico

CÁRREGA (val.) unidad de medida de matorral que equivale aproximadamente a 3 manojos, de unos $1.5 \mathrm{~m}$ de largo y $50 \mathrm{~cm}$ de diámetro, para alimentar hornos pre-industriales de ladrillos

\footnotetext{
${ }^{8}$ MATALLANA M, Op. Cit.
} 
CARROS DE TRABUC (O D'ESCALA) (val.) medio de transporte tradicional para trasportar manojos utilizados como elementos de combustión en los hornos pre-industriales de ladrillos

CINTREL (cas.) cuerda o regla que se ponen el centro de un arco o bóveda para la debida colocación de las hiladas de ladrillo al tiempo de construir uno u otra ${ }^{9}$

CIGARRET I BEGUDA (val.) termino que indica el descanso que se iba a repetir en el taller de ladrilleros a lo largo del día laboral

CITARA (cas.) pared delgada que no tiene más grueso que el ancho del ladrillo común ${ }^{10}$

CHAMOTA (cas.) arcilla cocida y molida, utilizada como agregado de morteros y mezclas

COCCIÓN POR REDUCCIÓN (cas.) cocción de los ladrillos en una cámara de combustión, con reducción de oxígeno, suele reconocerse por dejar a los ladrillos un color verdoso

CORNISA (cas.) termino general para cualquier moldura, que corona un edificio o que marca una específica parte o paño del mismo

COUADOR (val.) artesano que se encarga del mantenimiento del fuego en el ladrillar

DIÁTONO (it.) tipo de fábrica que se realiza con una sola hoja

DEGOLLADA (cas.) sinónimo que indica una junta de mortero (llaga) matada

\footnotetext{
${ }^{9}$ MATALLANA M, Op. Cit.

${ }^{10}$ MATALLANA M, Op. Cit.
} 
DIMENSIÓN NOMINAL (cas.) dimensión imaginaria de un ladrillo resultante de sumar a su dimensión real el espesor de una junta ideal de mortero (que suele ser de $10 \mathrm{~mm}$ )

ENFORNADOR (val.), artesano que coloca las piezas cerámicas en el horno

ENLADRILLAR (cas.) formar un pavimento con ladrillos

ENREIXAT (val.) área regular, con piezas uniformes dispuestas de canto, para garantizar la correcta separación de los elementos cerámicos, la justa ventilación, y un secado apropiado ( también llamada RÍMA)

ENRASADA (cas.) tipo de junta de mortero que llena totalmente el espacio existente entre los ladrillos, dejando al ras las caras exteriores de las piezas de la pared

ESCOPETA (cas.) diferencia de espesor de los tendeles, entre el intrados y el trasdós, de un arco realizado en ladrillo

ESBRAVADOR (val.) especialista que se ocupa de perfilar bien los prismas de arcilla y de ordenar los ladrillo en los ladrillares preindustriales

ESMOLADO (val.) ladrillo escafilado

ESTILO/ESTILETE (cas.) herramienta, puntiaguda, parecida a una estaca que permite marcar la junta de las fábricas de ladrillo

FIGLINAE (lat.) espacios y establecimientos para la producción de tajas y ladrillos en la Antigua Roma y en Hispania

FIGULUS (FIGLINUS O FIGULINUS) (lat.) artesano que trabaja la arcilla 
FORCAT (val.) horca de diferente tamaño que alimenta el fuego de la cámara de combustión del horno pre-industrial de ladrillos

GAUGED (ing.) adjetivo que define el ladrillo aplantillado o cortado

GAVELLA (val.) materia prima, de proveniencia de los matorrales, para encender el fuego en los hornos de ladrillos pre-industriales

GRAMIL (cas.) instrumento que sirve para trazar paralelas al borde de una pieza escuadrada

GRAVILLA (cas.) molde para fabricar ladrillo ${ }^{11}$

GREDA (cas.) tierra blanca y pegajosa, que entre otras propiedades tiene la de atajar el agua ${ }^{12}$

GREMIO (cas.) corporación formada por los maestros, oficiales y aprendices de una misma profesión u oficio, regida por ordenanzas o estatutos especiales

HILADA (cas.) serie horizontal de ladrillos aparejados en una fábrica

HILADA DE HOJA (cas.) aparejo en el que los ladrillos muestran la cara mayor aparejada perpendicular al suelo y la menor rejuntada

HILADA DE ROSCA (cas.) aparejo en el que los ladrillos muestran la cara menor perpendicular al suelo y la mayor rejuntada

HILADA DE SARDINEL (cas.) aparejo en el que los ladrillos muestran la cara mediana perpendicular al suelo y la mayor rejuntada

\footnotetext{
${ }^{11}$ MATALLANA M, Op. Cit.

12 BAILS B., Op. Cit.
} 
HILADA DE SOGA (cas.) aparejo de ladrillos en el que la cara mediana es perpendicular al suelo y la cara menor es rejuntada

HILADA DE TIZÓN (cas.) aparejo de ladrillos en el que la cara menor es perpendicular I suelo mientras la cara mediana es rejuntada

HILADA TRISCADA (cas.) tipo de aparejo (de soga o de tizón) que presenta un aparejo relativo a la fachada

HILADA A PANDERETE (cas.) aparejo con ladrillo colocado horizontalmente sobre su canto en un muro

HORNERA (cas.) horno de producción domésticas de ladrillos y tejas sin tecnologías especializadas para la producción

HORNOS DE LADERA (cas.) horno de producción pre-industrial con cámaras de combustión para ladrillos dispuestas en una ladera. Los hornos se suelen excavar de forma escalonada, para realizar un punto de cocción específico

HORNOS DE SUSTENTACIÓN (cas.) horno de producción preindustrial con sistema de bóveda plana, sostenida directamente sobre los muros o machones salientes. Puede ser de sustentación alveolar, arcos o de columnas, según el nivel de especialización detectado

HUESO (cas.) tipo de aparejo en el que se emplean ladrillos con una sección especial, en cuyo interior solo puede colocar una mínima llaga de mortero

JOINT (ing.) junta de fábricas de ladrillo

GRUESO (cas.) arista menor de un ladrillo

LADRILLAR (cas.) taller pre-industrial donde se producían ladrillos y tejas de forma artesanal 
LADRILLERO (cas.) artesano que se dedica a la producción de ladrillos

LATER (lat.) diminutivo de later/is, ladrillo de pequeño formato

LATERCULO (lat.) diminutivo de later/is, ladrillo de pequeño formato

LLAGA (cas.) junta entre dos ladrillos de una misma hilada

LLAGUERO (cas.) herramienta tradicional de albañilería para rematar y acabar las juntas de las fábricas de ladrillo

MATADA (cas.) junta inclinada, hasta una profundidad que no suele superar los $20 \mathrm{~mm}$. Puede presentar un corte superior o inferior (denominándose así como junta matada superior o inferior). El primer caso favorece el desagüe, el segundo no tiene que confundirse con una pérdida de mortero

MEDIA ASTA (cas.) ladrillo cortado trasversalmente por la mitad, también llamado CABEZA

MOLDE (cas.) instrumento que sirve para dar forma a los ladrillos. abierto, cuando tiene una caja de cuatro lados, pero sin fondo ni tapa. caja de moldeo, cuando tiene un molde con cuatro lados y un fondo, pero sin tapa

MODANO (cas.) plantilla que a escala natural reproduce las dimensiones, perfil y el tamaño de los cerámicos. Puede ser en piedra o en madera, recortada de forma tal que se corresponde al lleno o al vacío de los cerámicos producidos

MUESCA (cas.) tipo de junta que, en sección vertical, presenta un estrato de acabado de mortero cóncavo o semi-circular 
MUNYDORA (val.) capazo lleno de agua, que se utiliza en los ladrillares pre-industriales, para calibrar y afinar así la cantidad de agua presente en la mezcla de arcilla

MURO "A SACCO" (it.) fábrica realizada con un núcleo de argamasa dishomogénea y dos hojas exteriores que se quedan como encofrado perdido (realizadas con ladrillos, mampuestos, sillares, etc.). El resultado es un muro "multicapa" que se constituye por una unidad estructural muy marcada, llamado en castellano muro a la romana

OBRA CRUA (val.), producto recién moldeado en los ladrillares

OBRA VERDA (val.) producción madura de los ladrillos en los ladrillares, antes de su final cocción

OCULTA (cas.) tipo de junta que, en sección vertical, no destaca por su presencia en la fábrica (también conocida como junta a hueso)

OPUS DOLIARE (lat.) producción de ánforas de gran tamaño

OPUS LATERICIUM (lat.) fábrica realizada con lateres, o sea ladrillos sin cocer

OPUS SPICATUM (lat.) aparejo en forma de espina de pez. Las piezas están oblicuas y encajan unas con otras en ángulo recto alternando su inclinación a derecha e izquierda

ORTOSTATO (it.) ladrillo aparejado según el largo de una fábrica

PASTER (val.) experto que se ocupaba de la dosificación de las materias primas en los ladrillares pre-industriales

PEDALIS (lat.) tipo de ladrillo romano, que equivale a un pie romano, (unidad de medida). Es un ladrillo cuadrado, de $29.5 \times 29.5 \times 4.5 \mathrm{~cm}$. 
PLANTILLA (cas.) tabla o plancha cortada con los mismos ángulos, figuras y tamaños que ha de tener la superficie de una pieza, y que puesta sobre ella, sirve en varios oficios de regla para cortarla y labrarla

PORTILLO (cas.) martillo con que los albañiles dan golpes á la piedra ó ladrillo que asientan, para ponerla en obra ${ }^{13}$

RAFA (cas.) machos de cascotes y yeso que se ponen entre cajón y cajón de tierra en una tapia, cortados en figura curvilínea o recta por los lados ${ }^{14}$

RAJOLA (val.) ladrillo de arcilla cocida que se utiliza en construcción

RAJOLER (val.) artesano que se dedica a la producción de ladrillos y tejas

RAJOLAR (val.) espacio taller donde se realizan ladrillos y tejas

RASERO (cas.) listón o regla, que aplicada de canto sobre el marco de la gradilla, elimina la arcilla sobrante, a la hora de realizar un ladrillo

RASILLA (cas.) ladrillo delgado (unos $20 \mathrm{~mm}$ de grueso) que se emplea para solar o techar

RASQUETA (cas.) herramienta en forma de plancha metálica con cantos afilados. Tiene una estructura y función similar a una espátula con la diferencia de tener la base de la cuchilla más ancha

\footnotetext{
${ }^{13}$ BAILS B., Op. Cit.

13 BAILS B., Op. Cit.

${ }^{14}$ BAILS B., Op. Cit.
} 
REBLAR (cas.) rellenar con rebles o ripios una pared

REBLE (cas.) un cascajo o fragmento de ladrillos y de otros materiales que sirve como relleno en muros y fábricas

RECOCHA (cas.) testa de ladrillo que tiene diferente color al del resto de los ladrillos que se emplean en una obra de albañilería

REDONDEADO (cas.) tipo de junta que sobresale del aparejo de la fábrica

REHUNDIDO (cas.) tipo de junta que, en sección vertical, no llena completamente el espacio entre los ladrillos

RESTREGÓN (A) (cas.) puesta en obra de ladrillos sobre la "torta" de mortero hasta que este rebose por llagas y tendeles

REJUNTADO (cas.) aplicación esmerada de diferentes capas de mortero sobre una junta previamente con el fin de obtener una junta de un particular perfil (ver diferentes definiciones)

RIMA (val.) área regular, con piezas uniformes dispuestas de canto, para garantizar la correcta separación de los elementos cerámicos, la justa ventilación, y un secado apropiado (también llamada ENREIXAT)

RIPIO (cas.) material con que se rellena el hueco que queda detrás del paramento de un muro de sillería labrado a soga y tizón; cuyo relleno se hace, según los casos, de ripio, mampostería, o ladrillo

SAGÉN (cas.) cámara baja de combustión de los hornos cerámicos morunos

SALIENTE (cas.) tipo de junta cuyo acabado sobresale del aparejo, cubriendo parte del mismo 
SECADERO (cas.) espacio del ladrillar dispuesto para secar natural o artificialmente las piezas cerámicas moldeadas

SELLO (cas.) marca estampada en los ladrillos romanos, que indicaba productores así como zonas de venta y comercio de ladrillos

SOGA (cas.) lado mayor del prisma regular que constituye un ladrillo

TABIQUE (cas.) pared de escaso grosor realizada con ladrillos o planchas de yeso

TABLA (cas.) cara mayor de un ladrillo (soga x tizón)

TAPIA (cas.) porción determinada de pared hecha de tierra apisonada con regularidad dentro de una horma ${ }^{15}$

TAPIAL (cas.) molde $u$ horma hecha de dos tablas puestas de cuchillo, gracias al cual se obtienen muros de tapia. También se llama tapial cada una de las tablas con que se hace esta horma, y en sentido más amplio la técnica de realizar muros de tierra ${ }^{16}$

TENDEL (cas.) capa de mortero que se extiende sobre cada hilada de ladrillos al construir un muro, para sentar la siguiente. Cuerda que se tiende horizontalmente entre dos reglones verticales, para sentar con igualdad las hiladas de ladrillo o piedra

TEJAR (cas.) lugar donde se fabrican tejas o ladrillos ${ }^{17}$

TERRAJA (cas.) perfil de hierro o madera para perfilar las molduras y a la vez utilizado en retirar exceso de barro en la parte superior del molde de un ladrillo

\footnotetext{
${ }^{15}$ BAILS B., Op. Cit.

${ }^{16}$ BAILS B., Op. Cit.

${ }^{17}$ MATALLANA M, Op. Cit.
} 
TERRAIRE (val.) peón que extrae la tierra y la trasporta hasta la balsa de trabajo de los ladrillares pre-industriales

TESTA (cas.) cara menor de un ladrillo (tizón x grueso)

TESTAR (lat.) lugar del taller de ladrillos pre-industrial, destinado a desechos de la producción

IIZÓN (cas.) ladrillo aparejado con visible la cara más corta

TRABAZÓN (cas.) hilada continua de tizones o adarajas que enlaza dos o más hojas de fábricas

UVE (cas.) tipo de junta que, en sección vertical, presenta un acabado de mortero en forma de" $V^{\prime \prime}$, que con un efecto óptico confiere a la junta una significativa reducción de su grosor

VIDRIADO (cas.) ladrillo rico en cal y óxido férrico, de alta densidad, que ha sido cocido hasta su vitrificación

VELADURA (cas.) técnica que permite, a través de una ligera capa de enlucido, proteger y acabar una fábrica vista

VERDUGONERDUGUILLO (cas.) toda hilada de ladrillo tirada horizontalmente en una fábrica de mampostería ó tierra

VERDUGADA (cas.), tramo de pared realizada con verdugo

ZABOYADO (cas.) operación llevada a cabo por el albañil a la hora de realizar un acabado de juntas de fábricas de ladrillos 


\section{Bibliografía}

AA.VV., Actas del Congreso Internacional sobre restauración del ladrillo, IEA Ed., León, 1999

AA.VV. Expert system for the evaluation of the deterioration of ancient brick structures, Research Report no8, Vol.1, project EV5V-CT92-0182, Official Publications of The European Communities Ed., Bruxelles, 1992

AA.VV., Historia de la Ciudad: recorrido histórico por la arquitectura y el urbanismo de la ciudad de Valencia, Ícaro-CTAV Ed., Valencia, 2000

AA. VV., Guía de Arquitectura de Valencia, Ícaro Ed., Valencia, 2007

AA. VV., Guía del Centro arqueológico de l'Almoina, Ayto. Valencia Ed., 2010

AA.VV., L'arqueologia fa ciutat: les excavacions de la plaça de Cisneros, Ayto. Ed., Valencia, 2000

AA. VV. Patología, Técnicas de intervención y limpieza de fábricas de ladrillo, Intemac Ed., Madrid, 2003

AA.VV., Recuperando el Centro Histórico: urbanizaciones y actuaciones en plazas, calles e edificios, Ayto. Valencia Ed., Valencia, 2006

AA.VV., Rilievo e analisi morfologico descrittivo dei paramenti murari, Ministero della ricerca scientifica e tecnologica, Kappa, Roma, 2003

ACCARDO G., VIGILIANO G., Strumenti e materiali del restauro, metodi di analisi misura e control/o, Kappa Ed., Roma, 1998 


\section{murOSINTRAMUROS}

ADAM J., La construcción romana, materiales y técnicas, Los Oficios Ed., León, 1996

ALBAREDA D., Revestimientos continuos en la arquitectura tradicional española, Ministerio de Obras Públicas y Transportes Ed., Madrid, 1998

ALBIACH R., Informe de la intervenciò arqueológica en la excavaciò del solar situat a la Plaça del Pilar, SIAM., Valencia, 1997

ALESSANDRINI G., FABBRI B., Laterizi e terracotte, la conoscenza per la conservazione, University Press, Bologna, 2000

ALMAGRO GORBEA A., "El color en la Arquitectura Nazarí,, en Francisco Javier Gallego Roca, Revestimiento en la arquitectura, Conservación y Restauración, Servicio Publicaciones Universidad de Granada, Granada 1996

ALMELA Y VIVES F., Llibre del Mustaçaf de la ciutat de València, Ayto. Ed., Valencia, 2003

ALTARRIBA, M., GUILLÉN, R., GUZMÁN, R., ROJO, N., MARTÍ, J., "Una propuesta de curva mensiocronológica latericia para la ciudad de Valencia", in S.A., Actas del V Congreso de Arqueología Medieval Española, Junta de Castilla y León, Valladolid 2001

AMIGUES F. (entre otros), "Curva de variación del campo magnético terrestre en la Península Ibérica y datación de los hornos alfareros medievales" en Actas de IV Congreso de Arqueología medieval Española Vol. III, Asociación Española de Arqueología Medieval, Alicante, 1994

AMELA F., Las riadas del Turia-1321-1949, Exmo. Ayto. Ed., Valencia, 1957

AMOROSO G.G., Trattato di scienza della costruzione dei monumenti, Alinea Ed., Firenze, 2002

AÑADÓN, ALCALÁ, "Morphological taphonomic transformations in continental environments, and repercussions on their chemical composition" en Archaeometry, n 44, Fribourg, 1995 
ANTHOINE A., MAGENES G., MAGONETTE G., Shear compression testing and analysis of bricks masonry walls, en actas de "10th Europ. Conf. on Earthquake Engng ", Vienna, 1999

ASHURST N., Brick, terracotta and earth, Gower Technical Press, London, 1988

ASHURST N., Cleaning Historic Buildings, Donhead Ed., Londres, 1994

AZUAR RUIZ R., "La técnicas constructivas en al-Ándalus: el origen de la sillería y el hormigón de tapial" en Actas de V semana de estudios medievales, IER Ed., 1995

BAILS B., Diccionario de Arquitectura Civil. Obra Póstuma de Don Benito Bails. Imprenta Viuda de Ibarra, Madrid, 1802

BAIXAULI JUAN I.A., Els artesans de la Válencia del segle XVII. Capítols dels oficis i col legis, Universitat de Valencia Ed., Valencia, 2001

BAZZANA A., "III. La cerámica hispano-musulmana: problemas técnicos", en La cerámica islámica de la ciudad de Valencia, Ayto. Ed., Valencia, 1990

BELLINI A., I/ restauro architettonico, Italia Nostra Ed., Milano, 1979

BENDALA GALÁN M., RICO C., ROLDÁN GÓMEZ L., El ladrillo y su derivados en la época romana, Serie Mònografías de Arquitectura Romana, n.4, Madrid, 1999

BÉRCHEZ J., Arquitectura y academicismo en el siglo XVIII valenciano, Alfons el Magnànim Ed., Valencia, 1987

BÉRCHEZ J., Arquitectura barroca valenciana, Bancaja Ed.,Valencia, 1993

BÉRCHEZ J., Monumentos de la Comunidad Valenciana, Generalitat Valenciana Ed., Valencia, 1995

BIANCHI G., FRANCOVICH R., "L'archeologia dell'architettura come archeologia", en Arqueología de la Arquitectura, n.1, Universidad del País Vasco Ed., Vitoria Gasteiz, 2002 
BINDA L., TEDESCHI C., BARONIO G., Mechanical behavior at different ages of masonry prisms with thick mortar joints reproducing a byzantine masonry, Politecnico di Milano, 1999

BISCONTIN G., L'intonaco, storia cultura e tecnologia, (Atti del Congresso di Bressanone 1985) Libreria Progetto Ed., Padova, 1985

BLAT LLORENS, J.V., Presencia del ladrillo cara vista en el primer Ensanche de la ciudad de Valencia, Tesis doctoral dirigida por Lecuona López, Espí Cerdá, Valencia, 1996

BOUCHERON BROISE, THÉBERT, La brique Antique et médiévale. Production et commercialisation d'un matérieu, Ed. École Francaise e Rome, Rome, 2000

BRAVO DEL FRESNO I., SÁNCHEZ TORO J., "La tapia valenciana en la ciudad de Guadix, Granada" en Séptimo Congreso Nacional de Historia de la Construcción, Instituto Juan de Herrera Ed., Madrid, 2011

BREYMANN G.A., Muri, costruzioni in mattoni ed in pietre artificiali e naturali, Dedalo Ed., Roma, 1995. (edición del original-1885)

BROGIOLO G.P., Archeologia dell'edilizia storica, New Press Ed., Como, 1988

BROGIOLO G.P., DE MARCHI P.M., DELLA TORRE S., I metodi dell'archeologia e il progetto di architettura, New Press Ed., Como, 1996

BROGIOLO G.P., GELICHI S., 1996, Le ceramiche altomedievali (fineVI-X secolo) in Italia settentrionale: produzione e commerci, Padua, 1996

BROGIOLO G.P.., GELICHI S., La città nell'altomedioevo. Archeologia e storia, Roma-Bari, 1998

BURN, R.S., Masonry, Bricklaying and Plastering (1871 Ed.), Donhead Ed., Shaftesbury, 2001 


\section{murOSINTRAMUROS}

CABALLERO ZOREDA L., ESCRIBANO VELASCO C., Arqueología de la arquitectura. El método arqueológico aplicado al proceso de estudio y de intervención en los edificios históricos, Junta de Castilla y León Ed., 1996

CALVO A., Geomorfología, climatología de laderas y montañas del País Valenciano, IVEI Ed., Valencia, 1987

CAMPELL J., PRICE W., Brick. A world history, Thames \&Hudson Ed., London, 2003

CANEVA G., NUGARI M.P., SALVATORI O., Il controllo del degrado biológico. I biocidi nel restauro dei materiali lapidei e intonaci, Nardini Ed., Firenze 1996, pp.134

CARCER ORTI V., Historia de la Iglesia en Valencia, Vol.I, Del Cenia Al Segura Ed., Valencia, 1986

CARRERA PUJAL J., Historia de la Economía Española, Bosh Ed., Barcelona, 1943-47

CARMONA P., "El Medio natural", en La Ciudad de Valencia, Geografía y Arte, vol.II, Ayto. Ed., Valencia, 2009

CARMONA P., Las terrazas del bajo Río Turia, Tesis doctoral, UV, Facultat de Geografía, Valencia, 1982

CARMONA P. "Geomorfología de la llanura de Valencia; el Río Turia y la Ciudad" en Historia de la ciudad II, Territorio, Sociedad y patrimonio, ICARO, Valencia, 2002

CASOLO GINELLI L., BINDA P., Mensiocronologia dei laterizi. Un metodo di datazione assoluta in ambito regionale, Politecnico di Milano, tutóres G. CRUCIALI FABBOZZI G-DELLA TORRE S., Milano, 1997

CASSINELLO F., El ladrillo y su fábricas, Eva Ed., Valencia, IV Ed., 1971

CATALÁ GORGES M., Catalogo Monumental de la ciudad de Valencia, Encuentos Ed., Valencia, 1983 
CHALMETA P., "El almotacén a través de los llibre del Mustaçaf" en Aragón en la Edad Media, n²2, Univ. De Zaragoza Ed., Zaragoza, 2008

CHENNAOUI, Y., "Algérie: la construction ancienne à Cherchell: un autre type d'architecture en terre" en Bulletin d'information Craterre, no17-19, EAG. Ed., Grenoble, 1997

CHINER GIMENO J., GALIANA CHACÓN J., Libre del Mustaçaf, edición del manuscrito del archivo municipal de Valencia de1549, Graficas Ronda, Valencia, 2003

CHING F., Diccionario visual de arquitectura, G. Gili Ed., Barcelona, 1995

CLARKE D., Arqueología analitica, Ediciones Bellaterra, Barcelona, 1983

COSCOLLÁ SANZ V., La Valencia musulmana, Carena ed., Valencia, 2003

COLL CONESA J., Cerámica valenciana, Apuntes para una síntesis, AVEC Ed., Valencia, 2009

COLL CONESA J., PASCUAL J., MARTí J., Cerámica y cambio cultural, el tránsito de la Valencia Islamica a la cristiana, Dir. Gral. De Bellas Artes y Archivos, Madrid, 1989

CORBíN FERRER J.L., Barrio del Pilar, Antiguo de Velluters, Domenech Ed., Valencia, 1991

CORNELLAS P., CRUZ P., L'ofici de rajoler, Editorial Alpina, Granollers, 2010

COROMINAS J., PASCUAL J.A., Diccionario crítico etimológico castellano e hispánico, Gredos Ed., Madrid, 1954

CORSI R., "Forma, dimensioni e caratteristiche del mattone senese", en Fornaci e mattoni a Siena, dal XIII secolo all'azienda Ciafi, Siena, 1991

CRISTINI V., Valencia, ciudad vella, ladrillos cara a vista, agramilados, fingidos $y$ enlucidos. Analisi delle murature in laterizio: prassi costruttiva ed evoluzione archeometrica, PFC, Tutores: Bellini A., Mileto C., Pertot G., Politecnico di Milano, diciembre 2005 (inédito) 
CRISTINI V., "Valencia, ciutat vella. ladrillos cara a vista, agramilados, fingidos y enlucidos. Analisi delle murature in laterizio: prassi costruttiva ed evoluzione archeometrica", en Loggia, arquitectura y restauración, n¹9, UPV Ed., Valencia, 2006

CRISTINI V., "El centro histórico de Valencia. Análisis de las fábricas de ladrillo. Técnicas constructivas y evolución arqueométrica", en Asimetrías, Colección de textos de arquitectura, n9, Valencia, UPV Ed., 2006

CRISTINI V., "Valencia, ciudad vella: Huellas de artesanía constructiva en fábricas tradicionales de ladrillo", en Actas de APT San Juan 2007, Congress of International Association for Preservation Technology, San Juan de Puerto Rico, APT Ed., 2007

CRISTINI V., "Estudio de fabricas de ladrillos en Valencia: Análisis mensiocronológico y técnicas de acabado", en Arqueología de la Arquitectura, n5, CSIC, Madrid, 2008

CRISTINI V., Técnicas constructivas en arcilla: tapia valenciana y ladrillos en el centro histórico de Valencia, hacia el conocimiento y conservación de fábricas tradicionales. Trabajo de investigación, Programa de Doctorado: Patrimonio Arquitectónico: história, conservación, estudios gráficos, Universidad Politécnica de Valencia, noviembre 2008 (inédito)

CRISTINI V., "Hacia la conservación de fabricas históricas de ladrillos en Valencia: estrategias y conocimiento para preservar ejemplos de edilicia residencial", en Actas de IV Seminario Internacional de Conservación de Patrimonio, Universidad Autónoma de Yucatán, UADY Ed., Mérida, México, 2008

CRISTINI V., RUIZ CHECA JR., "A traditional reinforced rammed lime \& earth technique: the case of study of tapia valenciana", en Actas de Concrete 2009, Technological development of concret: tradition, actualities, prospects, Luciano Ed., Termoli, 2009

CRISTINI V., RUIZ CHECA JR., "Tapia valenciana, caratteristiche di muri in terra cruda rinforzati con mattoni" en Actas de Mediterra, $1^{\text {th }}$ mediterranean conference on earth architecture, Cagliari, 2009 
CRISTINI V., RUIZ CHECA JR, "A historical Spanish traditional masonry technique: some features about tapia valenciana as a reinforced rammed earth wall", en Actas de $11^{\text {th }}$ Canadian Masonry Symposium, Toronto, Canada, 2009

CRISTINI V., "Rajoles valencianes. Características de fábricas tradicionales en ladrillo", en Huerta S., Marín R., Soler R., Zaragozá A., en Actas de Sexto Congreso Nacional de Historia de la construcción, Instituto Juan de Herrera, Madrid, 2009

CRISTINI V., RUIZ CHECA JR, "Carved ceramic: gauged brickwork in Valencia city centre", en Structural studies, repairs and maintenance of heritage architecture, WIT, Wessex Institute of Technology Press, 2011

CRUILLES M., Guía urbana de Valencia antigua y moderna, Imprenta Domenech Ed., Valencia, 1876

DAVEY N., Historia de la Construcción, Editorial Jano, Barcelona, 1964

DEL BUFALO A., Conservazione edilizia e tecnologia del restauro, Kappa Ed., Roma, 1992

DELLA TORRE S., Storia delle tecniche murarie e tutela del costruito. Esperienze e questioni di metodo, Brescia, 1996

DIODATO M., Analisi e classificazione dei solai storici della città di Valencia = Análisis y clasificación de los forjados históricos de la ciudad de Valencia, PFC, tutores, Pratali Maffei S., Mileto C., Università degli Studi di Trieste, 2006 (inédito)

ECO U., Cómo se hace una tesis, Gedisa Ed., Barcelona, 2001

EMILIANI G.P., CORBARA F., Tecnología cerámica. Le lavorazioni vol.2, Faenza Ed.,Faenza, 1999

ESCOLANO G., Década primera y segunda parte de la historia de la insigne y coronada ciudad y Reino de Valencia, 1610-1611, Terraza, Aliena y Compañía Ed., 1878-1880 
ESQUIEU y., "L'arqueología du batir en France", en Archeologia dell'architettura, nII, Ed. All'Insegna del Giglio, Firenze, 1997

FEIFFER C., La conservazione delle superfici intonacate, Skira Ed., Milano, 1997

FERRANDO CABONA I, CRUSI E., "costruzioni rurali in Lunigiana: elementi tipo ed evoluzione delle strutture insediative" en Arqueología medieval, n. VII, All'Insegna del Giglio ED., Firenze, 1980

FERRANDO CABONA I, GARDINI E., MANNONI T., "Zignano I: gli insediamenti e il territorio" en Arqueología medieval, n. V, All'Insegna del Giglio ED., Firenze, 1978

FERRANDO CABONA I, MANNONI T., PAGELLA R., "Cronotipología" en Arqueología medieval, n. XVI, All'Insegna del Giglio ED., Firenze, 1989

FIORANI D., ESPOSITO D., Tecniche costruttive dell'edilizia storica, conoscere per conservare, Viella Ed., Roma, 2005

FRANCOVICH R., PARENTI R., Archeologia e restauro dei monumento, All'Insegna del Giglio Ed., Firenze, 1988

FRITZ MAYER J., La química de los materiale: colorantes naturales, Aguilar Ed., Madrid, 1950

FONT F., HIDALGO P., Arquitecturas de tapia, COAT, Castellón, 2009

FOSSATI S., "Possibilitá di datare complessi di mattoni", en Archeologia Medievale, n’XI, All'Insegna del Giglio Ed., Firenze, 1984

GABRIELLI R.,"Prime analisi mensiocronologiche della città di Bologna", en Archeologia dell'Architettura, n.IV, All'Insegna del Giglio Ed., Firenze, 1999

GALLONE A., Analisi fisiche e conservazione, Franco Angeli Ed., Milano, 1988

GALARZA TORTAJADA, "La Tapia Valenciana: una técnica construida poco conocida", en Actas del Primer Congreso Nacional de Historia de la 


\section{MUROSINTRAMUIOS}

Construcción, Madrid, 16-21 septiembre 1996, Instituto Juan de Herrera Ed., Madrid, 1996

GÁRATE RIOJAS I., Artes de la Cal, MRRP; Universidad de Alcalá, Madrid, 2000

GALLEGO F. J., El color en la arquitectura nazarí, Universidad de Granada Ed., Granada, 1996

GALLEGO ROCA F.J., Granada: Guía artística y Histórica de la Ciudad, Comares Ed., Granada, 1996

GALLEGO ROCA F.J., Revestimiento en la arquitectura, Conservación y Restauración, Servicio Publicaciones Universidad de Granada, Granada, 1996

GARCÍA DE MIGUEL J.M., Tratamiento y conservación de la piedra, el ladrillo y los morteros: en monumentos y construcciones, Consejo General de la Arquitectura Técnica de España, Madrid, 2009

GARCÍA OLIVER F., Libre de establimenti e ordenacions de la ciutat de Valencia, I, 1296-1345, UV. Ediciones, Valencia, 2007. (Fax-simil del libre de Claveria, 1401_folio 405)

GARCÍA VILLANUEVA I., RUIZ VAL E., Informe de la intervención arqueológica realizada en los solares de la C/Sagunt 127-130, SIAM, Valencia, 1994

GARÍN ORTIZ DE TARANCO F.M., Catálogo monumental de la provincia de Valencia, Conselleria de Cultura Ed.,Valencia, 1986

GASPAROLI P., Le superfici esterne degli edifici. Degradi, criteri di progetto e tecniche di manutenzione, Alinea Ed., Firenze, 2002

GELICHI S., NOVARA P.,I laterizi nell'Alto Medioevo Italiano, Società degli Studi Ravennati Ed., Ravenna, 2000

GHISLANZONI P., PITTALUGA D., "Un metodo di datazione del patrimonio edilizio: la curva mensiocronologica dei mattoni in Liguria", in, Archeologia dell'architettura, n.XVI, All'Insegna del Giglio Ed.,Firenze, 1989 
GIACALONE P., LANER F., PALA A., Murature faccia a vista patologie e rimedi, Franco Angeli Ed., Milano, 1997

GIMENO ROSSELLÓ MJ., Las germanias en Paterna, el tejido artesanal alfarero 1520-1521, Ayto. Paterna Ed.1995

GIUSTINI L., Fornaci e laterizi a Roma dal XV al XIX secolo, Kappa Ed., Roma, 1997

GOERLICH BENITO D., La arquitectura del eclecticismo en Valencia, vertiente de la arquitectura valenciana entre el sec.XIX, Vincent Garcia Ed., 1992

GÓMEZ FERRER M., Siglos XV-XVIII, Vocabulario de arquitectura valenciana, Ayto. Valencia Ed., Valencia, 2002

GÓMEZ FERRER M., "Las murallas de Mascarell", en Boletín de la sociedad Castellonense de cultura, Castellón, Soc. Castellonense de Cultura Ed., 2002

GÓMEZ SERRANO I., PRIMITIU SERRANO, "La muralla valenciana que conquistaron el Cid y Jaime I" en Feriario, 9, 1945

GÓMEZ URDÁÑEZ JL y CADARSO L. (entre otros), Historia de Castilla, La esfera de los libros Ed., Madrid, 2008

GONZÁLEZ MARTí, Cerámica del Levante español, siglos medievales, tomo II. Alicatados y azulejos, Barcelona, Ed. Labor, 1952

GUERIN P., Informe arqueológico de la intervención arqueológica en la Calle Mesón de Morella de Valencia, SIAM, Valencia, 1997

GUERRIERO L., RONDINELLA, L., 2008, "The mensiochronology of traditional building elements as way to safe the authenticity of monuments and urban environments" en Actas de Finding the spirit of place between the tangible and the intangible, ICOMOS Ed., Quebec, Canada,2008

GUICHARD P., VAN STAEVEL JP., "La casa andalusí: ensayo de lectura antropológica" en Casa y Palacios de Al-Andalusí, Barcelona, 2003 
HAYWARD R., The brick book, Batsford Press, London, 1978

HAMILTON E.J., Money, prices, and wages in Valencia, Aragon, and Navarre, 1351-1500, Harvard University Press, 1936, vol.51

HOUBEN H. \& GUILLAUD H., Earth Construction. A comprehensive guide, Earth construction series, CraTerre-EAG, Intermediate Technology Publications, London, 1984

HOUBEN H. \& GUILLAUD H., Traité de Construction en Terre, CraTerre-EAG, Editions Parenthèses, Marseille, 1989

HOUSTON J. M., Geografia urbana de Valencia, E.G.Ed., Madrid, 1957

JUANELO TURRIANO (FUNDACIÓN), LOS Veintiún Libros de los Ingenios y Máquinas, (Autor Anónimo), Doce Calles Ed., Madrid, 1996

KLEJN L.S., Archaeology Typology, British Archaeology Reports, International Series 153, Oxford, 1982

KUMMER N.,Masonry construction, Birkáuser Ed., basel, 2007

LYNCH, G., Brickwork, history, technology and practice, Donhead Ed., London, Vol. I+II, 1994

LYNCH, G., Gauged Brickwork, a technical handbook, Donhead Ed., Shaftesbury, 2006

LOP. J., De la Institució, govern, politich... de la Fabrica vella dita de Murs i Valls e Nova dita del Riii, Ayto. Valencia Ed., Valencia, 1999

LÓPEZ ELUM P., Los orígenes de los Furs de València y de las cortes en el siglo XIII, Conselleria de Cultura Ed., Valencia, 2001

LÓPEZ GONZÁLEZ C. y GARCÍA VALLDECABRES J., "La instauración del sistema metrológico valenciano y Jaime I en la tradición medieval: los sistemas de unidades, las prácticas de control y los usos ", ETSIG, Valencia, 1999 
LÓPEZ MARTINEZ F.J., "Tapias y Tapiales", en Loggia, Arquitectura \& restauración, n.8, Universidad Politécnica de Valencia Ed., Valencia, 1999

LÓPEZ MARTINEZ F.J., Tapiería en fortificaciones medievales, Región de Murcia, Tesis doctoral, dirigida por Noguera Giménez, UPV, Valencia, 2003

LORUSSO S., MARABELLI M., VIVIANO G., La contaminazione ambientale ed il degrado dei materiali di interesse storico-artistico, Pitagora Ed., Bologna, 2006 (II Ed.)

LUGLI G., La tecnica edilizia romana con particolare riferimento a Roma e Lazio, Roma, 1957

MALPICA CUELLO A., "Las técnicas constructivas en Al-Andalus. Una deuda entre la arqueología y la arquitectura", en Técnicas agrícolas, industrial y constructivas en la edad media, Vigo, 1989

MANGO C., Byzantine architecture, Electa, 1978

MANNONI T., "Metodi di datazione dell'edilizia storica" en Archeologia Medievale n’XI, All'Insegna del Giglio ED., Firenze, 1984

MANNONI T., Liguria. Architettura tra storia e archeologia, Genova, ISCUM Ed., 1988

MANNONI T., Archeologia delle tecniche produttive, Sagep Ed., Genova, 1994

MANNONI T., Caratteri costruttivi dell'edilizia storica, Sagep Ed., Genova, 1994

MANNONI T., SFRECOLA S., "Esercizi di microscopia dei reperti ceramici" en Scienze in Archeologia, All'Insegna del Giglio Ed., Firenze, 1990

MARCOS Y BAUSÁ, Manual del Albañil, Madrid, 1887

MARCONI P., "El color en la arquitectura italiana", en Francisco Javier Gallego Roca, Revestimiento en la arquitectura, Conservación y Restauración, Servicio Publicaciones Universidad de Granada, Granada 1996 


\section{MUROSINTRAMUIOS}

MARQUÉS DE CRUILLES, Guía urbana de Valencia Antigua y Moderna, Valencia, 1876

MARTA R., Tecnica Constructiva Romana, Kappa Ed., Roma, 1986

MARTÍ J., PASCUAL J. "Arqueología y proyecto urbano. Nuevas aportaciones para el conocimiento de la ciudad de Valencia", en Boletín de Arqueología Medieval, n.9, SIAM Ed., Valencia, 1995

MARTÍ J., ROCA L.,"Obra pública y espacio doméstico en la urbanización del sector meridional de Mâdinat Balansiya" en Historia de la ciudad, IV Memoria urbana, ÍCARO Ed., 2005

MARTÍN JORDÁ C. y RIBERA i LACOMBA A., Las termas de la época romana republicana de l'Almoina (Valencia), Quaderns de difusió arqueológica, nº7, Ayto. Valencia Ed. ,2010

MARTÍNEZ AMADOR E., Diccionario Italiano-Español, Ramón Sopena Ed., Barcelona, 1997

MATALLANA M., Vocabulario de Arquitectura Civil, Madrid: Imprenta de Don Francisco Rodríguez, 1848

MC-WHIRR A., Roman brick and tile. Studies in manifacture distribution and use in western empire, Bar Ed., London, 1978

MELIÓ URIBE V., "La fábrica de Murs y Valls, estudio de una institución municipal de la Valencia del antiguo régimen, tesis doctoral inedita dirigida por Salvador Esteban E., Universdiad De Valencia, 1990

MENICALI U., I materiali dell'edilizia storica. Tecnologie e impiego di materiali tradizionali, Nis Ed., Roma, 1992

MESQUIDA GARCÍA M., Socarrats y pavimentos medievales, Ay.to de Paterna Ed., 2001

MEZZINA M., UVA G:, Modellazione costitutiva per dannaggiamento per I'analisi della risposta della muratura storica di Hagia Sofia, Politecnico di Bari, 1999 
MILETO C. (investigador principal entre otros) proyecto de investigación: Caracteres constructivos del centro histórico de Valencia; Análisis, caracterización y conservación; Generalitat Valenciana (ref: GVPRE/2008/240)

MILETO C., VEGAS F., CRISTINI C., "Knowledge of Traditional Building Methods to Safeguard and Preserve Them. Evolution of Masonry Techniques in Valencia City", en Actas de The tenth north American masonry conference" Sant Luis, Missouri, 2007

MOLINA de L., "Las dos versiones de la geografía de Al-Udri", en AlQantara, vol. 3, CSIC, Madrid, 1982

MOLERA J., "Presentación del proyecto: el estudio arqueométrico de la cerámica islámica y mudéjar" en XXXVII Congreso nacional de cerámica y vidrio. Faenza Ibérica Ed., Vila Real, 1997

MONESMA E., Los ladrilleros, las tejas, teja, ladrillo y baldosa, el cañicero, el cielo raso, Huesca Pirynee Ed., Huesca, 2004 (DVD)

MONTAGNI C., Materiali per il restauro e la manutenzione, Utet Ed., Torino, 2000

MUSSO F.S., Architettura, segni, misura. Repertorio di tecniche analitiche, Esculapio Ed., Bologna, 1995

MUSSO F.S., Recupero e restauro di edifici storici. Guida pratica al rilievo e alla diagnostica, EPC Ed., Roma, 2004

NOGUERA GIMÉNEZ J.F., "Ciudad conventual, fabricas renacentistas y barrocas" en AA.VV., Historia de la ciudad, COAV Ed., Valencia 2000

OFFESTEIN F., Compatibilitá dei materiali. come associare i materiali da costruzione, Utet Ed., Torino, 1995

ORELLANA M.A., Valencia antigua y moderna, Acciòn Bibliogràfica Valenciana Ed., Valencia 1924 
OUSTERHOUT R., Master builders of Bizantyum, Princeton University Press, 1999, cap.VI

PARENTI R., "Fonti materiali e lettura stratigrafica di un centro urbano: i risultati di una sperimentazione non tradizionale", en Archeologia medievale, n. XIX, All'Insegna del Giglio Ed., Firenze, 1992

PEDEMONTE E, FORNARI G., Chimica e restauro, la scienza dei materiali per I'architettura, Marsilio Ed., Venezia, 2003

PÉREZ DE LOS COBOS F., Palacios y casas nobles, Ars Longa Ed., Valencia, 1998

PÉREZ GULLÉN I.V., Las reales fábricas de azulejos de Valencia, Faenza Ibérica Ed., Vila Real, 1990

PEIRS G., La brique: fabrication et traditions constructives, Eyrolles, 2004

PINGARRÓN F., Arquitectura religiosa del siglo XVII en la ciudad de Valencia, Marí Montanana Ed., Valencia, 1998

PITTALUGA D. GHISLAZONI P.," Informazioni Storiche e tecniche leggibili sulle superfici in laterizio", en Scienze e beni culturali VIII: la superficie dell'architettura: il cotto. Caratterizzazione e trattamenti, Padova, 1992

PITTALUGA D., Consolidare le cortine murarie e gli apparati decorativi in laterizio, Arcadia ed., Venezia 2007

PITTALUGA D. La mensiocronologia dei mattoni. Per datare, per conoscere e per comprendere le strutture storiche, ECIG Ed., Genova, 2009

PLAZA ESCUDERO L., Diccionario visual de términos arquitectónicos, Cátedra Ed., Madrid, 2008

PONS A., Llibre del Mostassaf de Mallorca, Palma de Mallorca, 1949

PONS SOROLLA F., El ladrillo en la historia de la construcción, Patronato Juan de la Cierva de Investigación Técnica Ed., Madrid, 1952 
PRIVITERA P., Asómate a la calle, estudio histórico constructivo y formal de los balcones tradicionales de la Valencia intramuros, TFM, tutores Vegas F., Mileto C., UPV, Valencia, 2011 (inédito)

QUIRÓS CASTILLO J.A., "Cronología di portali nell'alta Valdinievole: la montagna Pesciatina (PTT)" en Archeologia medievale, n. XVIII, All'Insegna del Giglio Ed., Firenze,1992

QUIRÓS CASTILLO J.A., Indicadores cronológicos de ámbito local: cronotipología y mensiocronología, Junta de Castilla y León Ed., Burgos, 1996

QUIRÓS CASTILLO J.A., "La mensiocronologia dei laterizi della Toscana: problematiche e prospettive di ricerca", en Archeologia dell'Architettura, n.2, All'Insegna del Giglio Ed., Firenze, 1997

QUIRÓS CASTILLO J.A., "Arqueología de la Arquitectura en España", en Arqueología de la Arquitectura, n¹, Universidad del País Vasco Ed., Vitoria Gasteiz, 2002

REJÓN DE SILVA D.A., Diccionario de la noble arte, Ed. Consejería de Cultura y Educación, Murcia, 1985, (Antonio Espinosa Imprenta, Segovia, 1788)

REVERTÉ P., La industria ladrillera: moldeo manual y mecánico de los ladrillos, secaderos y hornos modernos. Normas para el empleo de los ladrillos en las obras, Buenos Aires, 1979

RIDHA T. (entre otros), El legado Andalusí, Monografía de la Junta de Andalucía Ed., n6, Granada 2009

RIBERA A.,"Les origines de la ciudad", en Catalogo de: Valencia romana, Consellería de Cultura Ed., Valencia, 1984

ROBRES LLUCH R., San Juan de Ribera, patriarca de Antioquia, Arzobispo y Virrey de Valencia, un obispo segun el ideal de Trento, Imprenta Olvar, Barcelona, 1960 
ROSSELLÓ V.M., "Los Rìos Yucar y Turia en el gènesis de la Albufera de Valencia", en, Cuaderno de Geografia, n.11, Universidad de Valencia Ed., Valencia, 1972

ROSELLÓ MESQUIDA M., Intervención arqueológica en la C/Virgen de la Misericordia 4, SIAM, Valencia, 1993

ROSELLÓ MESQUIDA M., Informe de los trabajos arqueológicos en la C/Conde de Montores 1-3-5y C/Gobernador Viejo 3,5,7, SIAM, Valencia, 1995

ROSELLÓ MESQUIDA M., Informe final de los trabajos arquelogicos de la Calle Guillem de Castro 10-16/ Quevedo, SIAM, Valencia, 1998

ROTA P., SARTORI L.,"Analisi mensiocronologiche delle strutture antiche di Parma: i setti murari". Tratto da: Dal sito archeologico all'archeologia del costruito: conoscenza e conservazione, Actas del encuentro de Padova 1996 e Bressanone 1997

SANCHIS GUARNER M., La ciudad de Valencia, sintesis de historia y geografía urbana; Consell de Valencià de Cultura Ed., Valencia, 1999

SANCHIS SIVERA J., Vida intíma de los valencianos en época foral, Aitana ed., Valencia, 1992

SÁNCHEZ-OSTIZ GUTIÉRREZ A., El ladrillo cerámico en la construcción arquitectónica, Dossat Ed, Madrid, 2009

SAJUAME E., Las costas valencianas. Sedimentología y morfología, Universidad de Valencia Ed., Sección de Geografía, Valencia, 1985

SCARZELLA P., ZERBINATTI M., Recupero e conservazione dell'edilizia storica, Alinea, Firenze, 2009

SERRA A., "Ingeniería y construcción en las murallas de Valencia en el siglo XIV" en Actas del Quinto Congreso Nacional de Historia de la Construcción, Burgos, 2007 
SERRA A.,"La belleza de la ciudad, el urbanismo en Valencia, 1350, 1410" en Ars Longa: Cuadernos de Arte, UV Ed.,Valencia, 1990

SERRANO M.L., Informe de la actuación arqueológica realizada en los n.9 y 11 de la Calle Corona de Valencia, SIAM Ed., Valencia, 1995

SEVILLANO COLOM, De la Institución del mustaçaf de Barcelona, de Mallorca y de Valencia., Madrid, 1952

SIMÓ T., Valencia centro historico. Guía urbana y de arquitectura, Istituciò Alfons el Magnànim Ed., Valencia, 1983

SOLER FERRER M.P., "Valencia", en Mediterraneum, Cerámica medieval en España e Italia, Faul Ed., Viterbo, 1992

TABALES RODRÍGUEZ M.A., "Aportaciones de la arqueología medieval al conocimiento de las técnicas constructivas" en La técnica de la arquitectura medieval, GRACIANI A., Universidad de Sevilla Ed., 2000

TARAZONA P.J., Institucions dels Furs, y Privilegis del Regne, 1580

TARRADEL M., Valencia: ciudad romana, estado actual de los problemas, Serie: Papeles del laboratorio de Arqueologia, n.1, Universidad de Valencia Ed., Valencia, 1962

TEIXIDOR DE OTTO, Valéncia la construcción de un ciutat, UV Ed., Valencia, 1982

TORMO ESTEVE, S \& CORTÉS MESEGUER, L. "La organización de la intervención", en Patrimonio monumental 2: intervenciones recientes, Valencia: Ícaro Ed., 2008

TORRES BARCHINO A., "Color y técnicas tradicionales en la arquitectura religiosa del siglo XVIII en Valencia", en Investigando los bienes arquitectónicos, Dep. de Expresión Grafica Arquitectónica, UPV, 2005

TORREÑO CALATAYUDA M., Arquitectura y urbanismo en Valencia, Carena Ed., Valencia, 2005 


\section{MUROSINTRAMUIOS}

TORSELLO P.B., La materia del restauro. Tecniche e teorie analitiche, Marsilio Ed., Venezia, 1988

TORSELLO P.B., MUSSO S.F, Tecniche di Restauro Architettonico, Utet, Torino, 2002

TRAMOYERES BLASCO L., Instituciones gremiales, su origen y organización en Valencia, Imprenta Vives Mora Ed., Valencia, 1889

TRECCANI G.P., Archeologie, restauro, conservazione. Mentalità e pratiche dell'archeologia nell'intervento del costruito, Milano, 2000

VALLDECABRES GÓMEZ R., Análisis formal de veinte Iglesias del casco antiguo de Valencia, Imprenta R. Gómez Ed., Valencia, 1993

VIAPLANA, Memoria sobre la alfarería, o arte de petrificar, Biblioteca de Hispano América, Barcelona, 1887, pp.35-67

VILLANUEVA J., Arte de la Albañilería, Madrid, 1827, Cap. X

JIMÉNEZ SALVADOR, J. L. y RIBERA i LACOMBA, A., Urbanismo y arquitectura de la Valencia romana y visigoda. Historia de la ciudad. Recorrido histórico por la arquitectura y el urbanismo de la ciudad de Valencia, COACV ed., Valencia, 2000

VARAGNOLI C., Muri parlanti, prospettive e conservazione per l'analisi dell'edilizia storica, Alinea, Firenze, 2008

VAROSIO F., "Mensiocronologia dei laterizi a Venezia: ricerche, verifiche di applicabilita', stesura di una prima curva", en Archeologia dell'Architettura n.VI, All'Insegna del Giglio Ed., Firenze, 2001

VEGAS F., MILETO C., CALABUIG J.L., Proyecto de ejecución de rehabilitación de un edificio de seis viviendas en la calle Roger de Flor 39 esquina con la plaza del Pilar, Valencia., Valencia, noviembre 2006 (inédito)

VEGAS F., MILETO C., CRISTINI V., DIODATO M., "Constructive Features of the Historic Architecture at Valencia City", en Arché, Publicación del Instituto de Restauración del Patrimonio, n¹, UPV Ed., Valencia, 2006 
VEGAS F., MiLeto C., GUimARAENS G., Homo faber, Arquitectura preindustrial del Rincón de Ademuz, Prames, 2008

VEGAS F., MILETO C., CRISTINI C. (entre otros), Terra Incognita. Decouvrir une Europe des architectures de terre / Terra Incognita. Discovering European Earthen Architecture, Argumentum Ed., Lisboa, 2008

VEGAS F., MILETO C., CRISTINI C. (entre otros), Terra Incognita. Preserver une Europe des architectures de terre / Terra Incognita. Preserving European Earten Architecture, Argumentum Ed., Lisboa, 2008

VEGAS F., MILETO C., CRISTINI C. (entre otros) Earthen Domes and Habitats, ETS, Pisa, 2009

VEGAS F., MILETO C., LA SPINA V., "Is gypsum external rendering possible? The use of gypsum mortar for rendering historic façades of Valencia's city centre", en Advanced Materials Research, Vols. 250-253, Trans Tech Publications, Switzerland, 2011

VEGAS F., MILETO C., CRISTINI V. (entre otros), Terra Europae. Earthen Architecture in European Union, ETS, Pisa, 2011

VEGAS F., MILETO C., Aprendiendo a restaurar, Valencia, COACV, Valencia, 2011

VITRUVIO POLIÓN, M.. Los Diez Libros de Arquitectura de M. Vitruvio Polión. Traducidos del latín, y comentados por Don Joseph Ortíz y Sanz. Madrid: Imprenta Real, 1787, Libro II, Cap. III.pp.31-34

WARD PERKINS J.B., "Notes on the structure and buildings methods of early byzantine architecture" in Studies in Roman and Early Christian Architecture, The Pindar Press, London, 1994

WARREN J., Conservation of brick, Butterworth-Heinemann Ed., Oxford, 1999

ZANARINI G., Le murature dalla $A$ alla $Z$, termini sui laterizi, il loro significato e glossario in cinque lingue, Alveolater Ed., Bologna, 1993 
ZARAGOZÁ A.; IBORRA F, "Otros góticos: Bóvedas de crucería con nervios de ladrillo aplantillado y de yeso, nervios curvos, claves de bayoneta, plementerías tabicadas, cubiertas planas y cubiertas inclinadas", Historia de la ciudad IV. Memoria urbana, Ícaro Ed., Valencia 2005

ZARAGOZÁ A.; IBORRA F, "Fábricas de ladrillo aplantillado en Valencia durante la Edad Moderna", en Actas del Séptimo Congreso nacional de Historia de la Construcción, Instituto Juan de Herrera Ed., Madrid, 2011, Vol. II 


\section{Abreviaciones}

AHMV/ Archivo Histórico Municipal de Valencia

AHMB/ Archivo Histórico Municipal de Barcelona

IB./ Ibidem

OP. CIT/"Opere Citato"

RAE/ Real Academia Española de la Lengua

SIAM/ Servicio de Investigación Arqueológico Municipal 


\section{Índice de imágenes TOMO I/II}

FIG.1 Làmina realizada por la autora en el marco de su proyecto de PFC, exponiendo los resultados iniciales de su estudio sobre fábricas de ladrillo en Valencia, 2005 (CRISTINI)

FIG. 2 Detalles del trabajo de investigación/DEA, realizado por la autora, centrado en las fábricas de ladrillo, en el barrio de Velluters, Valencia, 2008 (CRISTINI)

FIG. 3 Ejemplos de fichas de estudio de fábricas de ladrillo histórico, perfeccionadas a lo largo de los trabajos de investigación, 2005-2008 (CRISTINI)

FIG.4 Detalle de las tablas de comparación entre distintas fábricas de ladrillo histórico, definidas en el trabajo de investigación/DEA, realizado por la autora (CRISTINI)

FIG. 5 Algunas de las conclusiones del trabajo de investigación/DEA, realizado por la autora, donde se definen las principales características de fábricas de ladrillos históricos del barrio de Velluters, Valencia (CRISTINI)

FIG. 6 Grabado de la ciudad de la Valencia intramuros por BREUER, portada de "Primera Parte de la Crónica General de toda España y especialmente del Reino de Valencia", 1546 (ÍCARO Pub. )

FIG. 7 Perímetro de Valencia intramuros, marcado en el plano más antiguo de la ciudad, grabado por Mançeli A., 1608 (AHMV)

FIG. 8 Vista de la Valencia intramuros según Wijngaerde 1563 (ÍCARO PUB.)

FIG. 9 Ejemplo de algunos de los primeros talleres de ladrillos documentados, en manuscritos de la Librería Vaticana (Ms gr 476-fol.61r y Ms gr 747-fol 78v-OUSTERHOUT)

FIG. 10 Estructura tipo de un horno Hoffman musealizado hoy en día, en el Rajolar de Paiporta, Valencia (Principio S. XX) (CRISTINI-CAMPBELL PRICE)

FIG. 11 Detalle del informe presentado tras la estancia en la University of Lincoln, UK (CRISTINI)

FIG. 12 Detalle del informe presentado tras la estancia en el Politecnico de Milán, Italia (CRISTINI) 


\section{murOSINTRAMUIOS}

FIG. 13 Detalle del informe presentado tras la estancia en la PUCP, Lima, Perú (CRISTINI)

FIG. 14 Portadas de las publicaciones del programa Culture 2000/ Convetion 2006-2344 en las que la doctoranda ha participado como autora con estudios de fábricas mixtas, tapia y adobe

FIG. 15 Portadas de las publicaciones en las que la doctoranda ha participado como autora. Contribuciones al estudio de arquitectura en tierra en Siria y en países de la Comunidad Europea (CRISTINI)

FIG. 16 Estudios mensiocronológicos, ISCUM (PITTALUGA) y plantilla con las indicaciones 1:1 para ladrilleros en Asissi-Italia (CAGNANA)

FIG. 17 Primera curva mensiocronológica para la ciudad de Valencia, longitud, anchura y espesor de ladrillos desde 1200 hasta 1960 (ALTARRIBA, GUILLÉN, GUZMÁN, ROJO, MARTÍ).

FIG. 18 Diferentes tipos de molde para ladrillos, simple y múltiple (MARTÍ y LINCH)

FIG. 19 Talleres medievales de ladrillos. Ilustración de Hartmanuss Shopperus's en Panopilia, Frankfurt- 1568 y Nederlandische Bijebel, Utrecht- 1425 (CAMBELL PRICE)

FIG. 20 Extracto de "Aleluya de los Oficios", impresa en valencia, por Miquel Borrás, en 1578, según Gayano Lluch la más antigua de España (SANCHIS GUARNER)

FIG. 21 Esquema de las principales causas que pueden afectar a fábricas de ladrillos diferentes problemas de humedad (LANER, GIACALONE, PALA)

FIG. 22 Geomorfología de la llanura de Valencia; en naranja se evidencian las terrazas con depósitos de arcilla de mayor calidad y concentración (CARMONA-RUIZ)

FIG. 23 Unidades litológicas estériles del ambiente fluviodeltaico, con ausencia de depósitos de arcilla en zonas próximas a la costa (CARMONA RUIZ)

FIG. 24 Áreas con concentración de sedimentos de inundación a base de arcillas (CARMONA)

FIG .25 Estructura molecular de dos diferentes arcillas, más calcárea (izquierda) o con más hierro (derecha). Esta última caracteriza una sección litológica efectuada en Alfara del Patriarca (Valencia) (CAGNANA- CRISTINI)

FIG. 26 Zonas de detritos del abanico de Pleistoceno ricas en arcillas, aunque de menor calidad de la zona de Pla de Quart (en este caso con arcillas ricas en óxido de hierro) (CARMONA)

FIG. 27 Detalles de la presencia de adobe en el yacimiento arqueológico de la Almoina y en la toponimia de la ciudad (barrio del Carmen) (CRISTINI-AA.VV. 2010)

FIG. 28 Empleo de losas y tejas cerámicas en el cementerio romano de C/Virgen de la Misericordia (ROSELLÓ MESQUIDA) 


\section{MUROSINTRAMUIOS}

FIG. 29 Croquis de la muralla árabe (SANCHIS GUARNER) visible hoy en día en la calle Del Ángel y sus alrededores (PALACIOS)

FIG. 30 Valencia, fases de construcción de la muralla cristiana, donde se aprecian los encofrados de tapia; por BREUER, portada de "Primera Parte de la Crónica General de toda España y especialmente del Reino de Valencia" 1546 (SERRA DESFILIS)

Fig. 31 Embarco de moriscos en el Grao de Valencia, por Oromig Pere 1613 (FUN. BANCAJA)

FIG. 32 Manuscrito, "Advertencias para los edificios y fábricas de Templos" por Isidoro Aliaga, 1631. Se considera el texto que impulsó a nivel constructivo los principios de la contrarreforma y el empleo del ladrillo en Valencia para estas soluciones constructivas (PINGARRÓN)

FIG. 33 Imagen de la plenitud constructiva tras la contrarreforma cristiana. Vista septentrional de la ciudad de Valencia, desde el Puente de la Trinidad hasta las Torres de Serrano, por Palomino J.F. 1784. Marcan el skyline los campanarios de la ciudad conventual (NOGUERA)

FIG. 34 La fundación de la fábrica Cerámica de l'Alcora 1727(Castellón) y de la Real Academia de Nobles y Bellas Artes de San Carlos, Valencia (1768) son momentos claves para comprender el cambio de gusto que viven las artes y la arquitectura vinculadas a la cerámica a lo largo del Siglo XVIII (COLL CONESA)

FIG. 35 Derribo de la Muralla Cristiana, junto a la Pta. del Real, 1865 (SANCHIS GUARNER)

FIG. 36 Ipogeo di Trebio Augusto, Via latina, Roma; aparejo con opus latericum (RIVORIA)

FIG. 37 Manufactura y puesta en obra de ladrillos en la Edad Media en Plymouth, UK (LYNCH)

FIG. 38 Selección y criba de arcilla en un taller de ladrillos pre-industrial (LYNCH)

FIG. 39 Hornos cerámicos romanos y restos de talleres en la C/Guillem de Castro, (siglo XII), ejemplos que marcan la continuidad en el know-how técnico (ROSSELÓ MESQUIDA (AMPBELL)

FIG. 40 Empleo de ladrillos romanos en estructuras hidráulicas: el prefurnium y del hypocaustum de las termas de la Almoína, Valencia (MARTíN JORDÁ-RIBERA LACOMBA)

FIG. 41 Hallazgos de talleres cerámicos en excavaciones arqueológicas de la C/ Sagunto, Valencia (finales S.XII- principios S.XIII) (GARCÍA VILLANUEVA-RUIZ VAL)

FIG. 42 Hallazgos de talleres cerámicos en excavaciones arqueológicas del centro histórico de Valencia; hornos de la C/Mesón de Morella (S. XIII-XIV) y de la C/Corona, Valencia (S. XVII-XVIII) (GUERÍN-SERRANO)

FIG. 43 Producción cerámica artesanal y sus huellas. Ladrillos catalogados en la excavación arqueológica de la C/Gobernador Viejo esquina con C/Conde de Montores (ROSSELLÓ MESQUIDA-JUANELO TURRIANO FUND.-CRISTINI) 


\section{MUROSINTRAMUIOS}

FIG. 44 Primeras patentes que emplean la fuerza animal para mezcla de arcilla y extrusionadoras de ladrillos, 1845, Sheffield, UK (CAMBELL-PRICE)

FIG. 45 Dos distintos modelos experimentales de extrusionadoras a vapor, patente inglesa Whitehead, 1860 (CAMBELL-PRICE)

FIG. 46 Terraires y bassers moldeando ladrillos, en un rajolar de Granollers (CORNELLAS)

FIG. 47 Rajoleres y bailos moldeando ladrillos, en un rajolar de Granollers (CORNELLAS)

FIG. 48 Munydora y carrega, herramientas básicas del rajolar de Granelles (CORNELLAS)

FIG. 49 Detalle (caja contenedora por PALOMAR M.) de la primera edición de los Privilegi de la ciutat de Valencia, donde se recopilan las actuaciones el Mustaçafjunto con los fueros 1372, A la derecha la portada del pionero texto de SEVILLANO COLOM, De la Institución del Mustaçaf de Barcelona, de Mallorca y de Valencia, Madrid, 1952 (AYTO. VALENCIA)

FIG. 50 Detalle (portada por PORTA M..J.) de la actualización de las instituciones forales del Mustaçaf, 1568 (ALMELA Y VIVES). A la derecha ejemplo de las páginas del Llibre del Mustaçaf conservado en el archivo del Ayto. de Catí, Castellón (CHALMETA)

FIG. 51 San Miguel, como símbolo del Mustaçaf, prohombre responsable de pesos y medidas (en el caso de los ladrillos, la unidad de medida eran los palmos $1 \mathrm{p}=23 \mathrm{~cm}$, y los dedos $1 \mathrm{~d}=2 \mathrm{~cm}$ ) (MUSEO DE LA CIUDAD VALENCIA)

FIG. 52 Azulejos con el emblema del Gremio de los ladrilleros, Manises, Valencia posiblemente 1415. La casa gremial era identificada por un muro de ladrillos sobre el que se superponía un gallo, símbolo del santo protector de la misma, S. Pedro. (MUSEO NACIONAL DE CERÁMICA)

FIG. 53 Partición de ladrillos cuadrados romanos de medidas corrientes. A la derecha estampillas de las principales figlinae romane. Hasta ahora no se han encontrado en Valencia restos de ladrillos con estas marcas de productores, ni en las formas más arcaicas rectangulares, ni en las más recientes a media luna (ADAM)

FIG. 54 Distintas formas y tamaño de ladrillos antiguos por CESARIANO 1521 y a la derecha por RUSCONI 1590 (TROGU ROHRICH)

FIG. 55 Muro "a sacco" o a la romana, realizado con ladrillos triangulares (ALBERTI 1485, BARTOLI 1565) (TROGU ROHRICH)

FIG. 66 Antiguas fábricas de ladrillo por FRA GIOCONDO 1511 y CESARIANO 1521 (TROGU $\mathrm{ROHRICH)}$

FIG. 67 Distintas distribuciones a Emplecton, RUSCONI 1590 (TROGU ROHRICH)

FIG. 68 Ejemplos de fábricas de ladrillos antiguos BARBARO 1556 (TROGU ROHRICH)

FIG. 69 Aparejo de fábrica de ladrillos (Lam.VI-VILLANUEVA 1827) 


\section{MUROSINTRAMUIOS}

FIG. 70 Soluciones para dinteles de fábricas de ladrillo (Lam.VII-VILLANUEVA 1827)

FIG. 71 Producción de adobe, visible en la pintura mural de la Tumba de Reck-Mi-Re, a Tebas, Luxor, Egipto, 1450 a.C. (CAMBELL-PRICE)

FIG. 72 Preparación, secado y transporte de ladrillo en Túnez, S. XIX (ADAM)

FIG. 73 Tapia valenciana, equilibrio híbrido entre fábricas encofradas y de ladrillos, C/Prócida, Valencia (Fa153) (CRISTINI)

FIG. 74 Ejemplos de fábricas de tapia valenciana visibles en Valencia, tras intervenciones u olvido. El Almudín (Xc96), el Convento de la Trinidad. Abajo el cercado junto a de S. Miguel de los Reyes, las Viviendas en Plaza del Autor (Cg48), en el Barrio del Carmen (CRISTINI)

FIG. 75 Tapia valenciana: maquetas, ensayos y toma de datos (CRISTINI-RUIZ CHECA)

FIG. 76 Arquitectura bizantina y caracteres constructivos: detalles de muros con hiladas retranqueadas y gruesas juntas. ¿Posibles antecedentes de fábricas valencianas? (OUSTERHOUT)

FIG. 77 Tapia valenciana. Detalles de refuerzo con ladrillos en la muralla cristiana de la ciudad de Valencia (Cb65) (CRISTINI)

FIG. 78 Tapia valenciana en algunos edificios religiosos/monumentales intramuros; (a la izquierda) alzado de la Iglesia de San José (Cg14), muralla junto a las Torres de Quart (Cb65), cerca del Monasterio del Carmen (Cgolb), alzado del Convento del Pilar (Vb67) (CRISTINI)

FIG. 79 Huellas de fábricas de tapia valenciana, oculta y transformada en los siglos. Palacio de los Valeriolas, C/ del Mar (CRISTINI)

FIG. 80 Imágenes de fábricas en tejido residencial de la ciudad de Cherchell (Argelia), S. XVII (por cortesía de Prof. Chenouy-Universidad de Argel-Argelia)

FIG. 81 Diferencias entre tongadas de tapia de argamasa y tapia valenciana (CRISTINI)

FIG. 82 Fábrica de ladrillo agramilado, en hilo entre un muro cara vista y uno enlucido; vivienda en la C/Bonaire (Fb57), Valencia (CRISTINI)

FIG. 83 Muro con doble sellado de tendeles, de asiento y de acabado; vivienda en la C/ San Ramón (Cd15), Valencia (CRISTINI)

FIG. 84 Tendel con gruesa capa de mortero de asiento, inclinado de aprox. $30^{\circ}$, luego rejuntado y alisado; vivienda en la C/Quart (Cb55) (CRISTINI)

FIG. 85 Muros con ladrillos visto yuxtapuesto con piedra (en zócalos o columnas adosadas...); conjunto del Seminario (Xc16), complejo de la Nau (Fa39), sacristía de la Iglesia de la Congregación (Xf26) (CRISTINI) 
FIG. 86 Expedientes del Archivo Histórico de Valencia que registran los "cambios de gusto" de finales del siglo XVIII; columnas adosadas, zócalos, cornisas... reflejo de criterios académicos en la maquetación de fachadas (AHMV)

FIG. 87 Almohadillado en un alzado; viviendas en la C/Cadirers (Ma82) en Valencia (CRISTINI)

FIG. 88 Posibles soluciones de "ladrillos para almohadillados" en viviendas del Barrio de San Francesc y de la Seu-Xerea, Valencia (CRISTINI)

FIG. 89 Fachadas con ladrillos vidriado y pigmentado; viviendas en C/ de la Pau, Valencia (CRISTINI)

FIG. 90 Soluciones con ladrillos aplantillados para aleros y esquinas, Palacio Pineda (Ce71) en Valencia (CRISTINI)

FIG. 91 Corte de ladrillos en un taller artesanal gracias a la guía de una caja de madera con plantillas (CAMBELL-PRICE). Soluciones con ladrillos aplantillados y escafilados para aleros y esquinas, vivienda de la C/ Carniceros (Va104) en Valencia (CRISTINI)

FIG. 92 Ladrillos aplantillados en el Palacio del Marqués de Campo, y en la fachada trasera de la Iglesia de la virgen de los Desamparados (Xd65), Valencia (CRISTINI)

FIG. 93 Ladrillos aplantillados en el Palacio de los Condes de Alpuente (Ca 113) y en la fachada Iglesia de S. Úrsula (Cb64), Valencia (CRISTINI)

FIG. 94 Detalles de ladrillos escafilados en la Capilla de la Iglesia de S. Martín (Fa105) y en la fachada trasera de la Iglesia de la Virgen de los Desamparados (Xd65) (CRISTINI)

FIG. 95 Arquería con ladrillo aplantillado en el conjunto del "El Patriarca" (Fa82) y en el Convento de S. Carlos Borromeo (Vb69) (CRISTINI)

FIG. 96 Empleo de ladrillos aplantillados en los campanarios de la Iglesia de S. Esteban, Conjunto de "El Patriarca" (Fa82), Basílica de la Virgen de los Desamparados (Xd65) y Convento de San José (Cg14) (CRISTINI)

FIG. 97 Fábrica de ladrillo enlucido, C/Subida del Toledano, Valencia (CRISTINI)

FIG. 98 Muros con ladrillo enlucido en el barrio del Carmen, Valencia (CRISTINI)

FIG. 99 Palacio de la Calle Eixarcs (Va81/82), alzado con acabado de ladrillos fingidos (CRISTINI)

FIG. 100 Detalle del fingido trompe l'oeil, Palacio Catalá de Valeriola (Xa46), Valencia (CRISTINI)

FIG. 101 Acabados con ladrillos fingidos en edificios de la P.za de la Cruz (Ce101), C/

Gutemberg (Cf42) en Valencia (CRISTINI) 


\section{MUROSINTRAMUIOS}

FIG. 102 Alzados estudiados por la autora, C/Roger de Flor 39, Valencia, ficha Vb22 (CRISTINI)

FIG. 103 Edificio C/Roger de Flor 39, Valencia, (VEGAS, MILETO, CALABUIG)

FIG. 104 Gráficos: presencia de patologías en ladrillos y clasificación (CRISTINI)

FIG. 105 Detalles de eflorescencias en ladrillos, fichas Cg48 y Ca82 (CRISTINI)

FIG. 106 Detalles de erosiones en ladrillos, fichas Cf39 y Cf42 (CRISTINI)

FIG. 107 Detalles de microfisuración en ladrillos, fichas Ma91 y Cg01/b (CRISTINI)

FIG. 108 Detalles de disgregación en ladrillos, fichas Ca55 y Cf23 (CRISTINI)

FIG. 109 Detalles de descamación en ladrillos, fichas Xc78 y Ma82 (CRISTINI)

FIG. 110 Gráficos: presencia de patologías en morteros y clasificación (CRISTINI)

FIG. 111 Detalles de microfisuración de las juntas, fichas Ce71 y Me52 (CRISTINI)

FIG. 112 Detalles de pulverización y disgregación de las juntas, fichas Cg02 y Xc94 (CRISTINI)

FIG. 113 Ejemplos de diferentes tipos de limpieza a base de agua, con distintos métodos de proyección (CRISTINI)

FIG: 114 Detalles de dispositivos de presión de chorreados y aplicación en fábricas históricas (LYNCH- FEIFFER)

FIG. 115 Ejemplos de herramientas que se pueden emplear para la proyección de fachadas (ASHRUST)

FIG. 116 Estudio de patologías, alzado principal C/R. de Flor n³9, Valencia, (Vb 22) (CRISTINI)

FIG. 117 Estudio de patologías, alzado lateral C/R. de Flor n³9, Valencia, (Vb22) (CRISTINI)

FIG. 118 Detalle de limpieza con método mecánico, proyección abrasiva en seco con cáscaras de almendras en las viviendas de C/Roger de Flor n³9, Valencia (VEGAS-MILETO)

FIG. 119 Detalle de limpieza, varias intensidad de proyección con cáscaras de almendras, viviendas de C/Roger de Flor n³9, Valencia (CRISTINI)

FIG. 120 Detalle de limpieza, zonas con excesiva proyección mecánica, viviendas de C/Roger de Flor n³9, Valencia (CRISTINI) 
FIG. 121 Diferentes tipos de arenas para micro-arenado y aparato para la proyección (SABIX)

FIG. 122 Moléculas de acido clorhídrico y fluorhídrico (CRISTINI)

FIG. 123 Limpieza con compuestos a base de celulosa en fábricas previamente limpiada (FEIFFER)

FIG. 125 Protección y consolidación de ladrillos, viviendas de C/Roger de Flor n³9, Valencia (CRISTINI)

FIG. 126 Complementación de piezas, viviendas C/Roger de Flor n³9, Valencia (CRISTINI)

FIG. 127 Sustitución de piezas en viviendas de C/Roger de Flor n³9, Valencia (VEGAS-MILETO)

FIG. 128 Reparación de juntas, viviendas de C/Roger de Flor n³9, Valencia (CRISTINI)

FIG. 129 Pruebas de entonado de morteros, viviendas C/Roger de Flor n³9, Valencia (CRISTINI)

FIG. 130 Reparación de fisuras y perfiles de juntas históricas, viviendas de C/Roger de Flor n³9, Valencia (CRISTINI)

FIG. 131 Consolidación con agua de cal de micro fisuras, viviendas de C/Roger de Flor n³9, Valencia (CRISTINI)

FIG. 132 Ejemplo de dos enemigos"históricos" de fábricas: aves y plantas trepadoras (CRISTINI)

FIG. 133 Detalle de reconstrucción de fábricas de tapia valenciana, Mascarell, Castellón (CRISTINI)

FIG. 134 Tapial, encofrado en el que se apisonan argamasa de tierra, cal y grava en estratos regulares (ADAM-CRISTINI)

FIG. 135 Esquema de apisonado en con estratos de argamasa y refuerzo de ladrillos (CRISTINI)

FIG. 136 Detalles de distintos tipos de costras en fábricas de tapia valenciana (CRISTINI)

FIG. 137 Detalles de tapia valenciana restaurada, Almudín, Valencia, ficha Xc 96 (CRISTINI)

FIG. 138 Simulación de tapia valenciana, Gremio de Carpinteros, Valencia, ficha Va34 (CRISTINI)

FIG. 139 Costras de tapia valenciana con acabados históricos, Iglesia de S. Jaume Fadrell, Castillo de Vilavella y Alqueria Carmona, Castellón (CRISTINI)

FIG. 140 Tapia valenciana restaurada, Castillo de Alaquàs, Valencia (CRISTINI) 


\section{MUROSINTRAMUIOS}

FIG. 141 Rol de los conectores dentro del sistema "tapia valenciana". Su correcta posición absorbe esfuerzos rasantes, aspecto importante a considerar en las intervenciones (CRISTINI)

FIG. 142 Secuencia de juntas estructurales y de acabado, Capilla de la Iglesia de S. Juanes, ficha Me212a y Vivienda C/Quart n¹6, ficha Cb55 (CRISTINI)

FIG. 143 Efecto "scraping", muy común en edificios de viviendas sin alto grado de protección. Edificio en la C/Avellanas n5, ficha Xe 14 y viviendas C/Belén n7, ficha Ma48 (CRISTINI)

FIG. 144 Fábricas de ladrillos en el barrio del Carmen, principio S. XIX (VIDAL)

FIG. 146 Curva mensiocronológica relativa a la longitud de ladrillos analizados (CRISTINI)

FIG. 147 Curva mensiocronológica relativa a la anchura de ladrillos analizados (CRISTINI)

FIG. 148 Curva mensiocronológica relativa al grosor de ladrillos analizados (CRISTINI)

FIG. 149 Curva mensiocronológica (resumen con periodización) de ladrillos analizados

FIG. 150 Curva mensiocronológica (resumen) de los ladrillos analizados (CRISTINI)

FIG. 151 Ejemplo de hoja generada en la base de datos (CRISTINI)

FIG. 152 Gráficos de estudio. Tipo de edificios y grado de protección (CRISTINI)

FIG. 153 Gráficos de estudio. Distribución de las fábricas y No de pisos de los edificios (CRISTINI)

FIG. 154 Gráficos de estudio. Composición de las fachadas (CRISTINI)

FIG. 155 Ejemplo de fachada: aleatoria, ordenada con simetría, ordenada sin simetría, Expedientes Policía Urbana (AHMV)

FIG. 156 Gráficos de estudio. Estudio de zócalos y de fábricas (CRISTINI)

FIG. 157 Gráficos de estudio. Definición de vanos/dintel y entrada/dintel (CRISTINI)

FIG. 158 Solución de vano más simple, con dintel de madera, frecuente hasta pleno S. XIX (tipo V1) y más compleja (tipo V3) con ladrillos aplantillados, del S. XVIII (CRISTINI)

FIG. 159 Solución frecuente desde finales de S: XVI hasta mitad del S. XVIII con arco de extradós curvo, intradós plano (tipo V7). Las soluciones primigenias son más peraltadas, las tardías más abombadas; en la imagen un detalle de la ficha Xe66. (CRISTINI) 
FIG. 160 Solución frecuente a lo largo de S. XVIII con arco de extradós e intradós curvo (tipo v6) en un detalle de la ficha Cg57 (CRISTINI)

FIG. 161 Solución de vano académico, con recercado pétreo (tipo V10), común en arquitectura monumental en un detalle de la ficha Xd 54 (CRISTINI)

FIG. 162 Solución de vano académico, con recercado con ladrillos (tipo V9), frecuente en arquitectura residencial y religiosa en un detalle de la ficha Vb103 (CRISTINI)

FIG. 163 Gráficos de estudio. Análisis de aleros y cubiertas (CRISTINI)

FIG. 164 Gráficos de estudio. Análisis de aparejos e hiladas (CRISTINI)

FIG. 165 Gráficos de estudio. Análisis de superficies e hipótesis de sección (CRISTINI)

FIG. 166 Gráficos de estudio. Análisis de vanos y elementos destacados (CRISTINI)

FIG. 167 Gráficos de estudio. Características de los ladrillos y estudio del color (CRISTINI)

FIG. 168 Gráficos de estudio. Tipo de acabado y análisis de juntas de asiento (CRISTINI)

FIG. 169 Gráficos de estudio. Análisis de junta de acabado y tipo de mortero (CRISTINI)

FIG. 170 Gráficos de estudio. Análisis de la morfología de mortero (CRISTINI)

FIG. 171 Gráficos de estudio. Análisis del color de mortero (CRISTINI)

FIG. 172 Tejas romanas, depósito SIAM, tejas puestas en obra, cerámica arquitectónica en el Patio del Museo Nacional de Cerámica, Valencia (CRISTINI)

FIG. 173 Detalle de fábricas de tapia valenciana en la costa norte de Argelia, en la ciudad de Cherchell (imágenes cortesía de Alliche Samira)

FIG. 174 Escena de la llegada de los moriscos a Oran (Argelia), por Mestre V., 1613 (BANCAJA); fábricas de ladrillo agramilado en el barrio de Der Timija, Marrakech, Marruecos (CRISTINI)

FIG. 175 Fábricas de ladrillos de Turquía. Detalle de la fachada de Panagia Chalkeon, con "recessed bricks", nártex de la Iglesia de Christ Pantepoptes en Estambul (HOSTEROUT) 


\section{Índice de imágenes TOMO II/II}

FIG. 1 Cuadrante de estudio del centro histórico de la ciudad intramuros (MILETO)

FIG. 2 Localización de los barrios históricos de Valencia intramuros (MILETO)

FIG. 3 Localización de los edificios estudiados. Edilicia monumental (beige) y edilicia residencial (marrón) (CRISTINI)

FIG. 4 Mapa de localización de las fichas recopiladas en el barrio del Carmen (CRISTINI)

Ficha Ca15 Pza. Navarro nº4 -Pza. Ángel n²

Ficha Ca30 Pza. Navarro n²/7

Ficha Ca32 C/ Mare Vella no 12

Ficha Ca82 C/ Adoberies no55

Ficha Ca85 Pza. Navarro n 1

Ficha Ca113 C/ Caballeros no 28

Ficha Ca118 C/ Caballeros $n^{\circ} 40$

Ficha Cb55 C/ Quart no 16

Ficha Cb63 C/ Quart no $16-$ C/ Rei en Jaume s/n

Ficha Cb64 Pza. Sta. Úrsula s/n

Ficha Cb65 C/ Guillén de Castillo s/n

Ficha Cd10 C/ Corona n ${ }^{\circ} 6$

Ficha Cd15 C/ San Ramón nº 5

Ficha Cd75 C/ Ripalda no 3

Ficha Cd118 C/ Na Jordana $n^{\circ} 15$

Ficha Ce24 C/ d'Alt no 24

Ficha Ce62 C/ Sto. Tomás no 10

Ficha Ce71 Pza. Carmen $n^{\circ} 4$

Ficha Ce93 C/ D'En Borras no 8

Ficha Ce101 Pza. de la Cruz s/n esq. C/ Pintor Filloll

Ficha Cf23C/ dels Horts C/ S. Giner no 1

Ficha Cf26C/ dels Horts $n^{\circ} 1-2$

Ficha Cf30C/ Gutemberg s/n

Ficha Cf42C/ Gutemberg s/n esq. C/ Lliria s/n

Ficha Cf44C/ Gutemberg n 10

Ficha Cg01a Pza. Carmen s/n

Ficha Cg01b C/ del Museo s/n

Ficha Cg02 C/ del Museo $\mathrm{n}^{\circ} 2$ 


$\begin{array}{ll}\text { Ficha Cg14 } & \text { Pza. Portal Nuevo n }{ }^{\circ} 6 \\ \text { Ficha Cg48a } & \text { Pza. Autor } n^{\circ} 12 \\ \text { Ficha Cg48b } & \text { Pza. Autor } n^{\circ} 12 \\ \text { Ficha Cg57 } & \text { C/ Garcilaso } n^{\circ} 3\end{array}$

FIG. 5 Mapa de localización de las fichas recopiladas en el barrio del Mercat (CRISTINI)

\begin{tabular}{|c|c|}
\hline Ficha Ma28 & C/ Sagrari de la Compañía no 6 \\
\hline Ficha Ma31 & C/ Estret Companyia s/n \\
\hline Ficha Ma48 & C/ Belén n 7 \\
\hline Ficha Ma54 & Pza. Horno San Nicolas no 4 \\
\hline Ficha Ma75 & C/ Marsella esq. Pza. San Nicolas n 2 \\
\hline Ficha Ma82 & C/ Cadirers no 12 \\
\hline Ficha Ma85 & C/ Cadirers n4 \\
\hline Ficha Ma90 & C/ Marsella n 4 acc. \\
\hline Ficha Ma92 & Pza. Correo Vell no 4 \\
\hline Ficha Ma93 & C/ Abadía de S. Nicolás s/n \\
\hline Ficha Mb72 & $C /$ Les Cuines $n^{\circ} 1$ \\
\hline Ficha Mb113 & C/ Toledà no 9 \\
\hline Ficha Mb155 & Pza. Mare de Deu n 1 \\
\hline Ficha Me52 & Pza. del Olmo n² \\
\hline Ficha Me172 & C/ Senia no 5 \\
\hline Ficha Me212a & C/ Lucente esq. Pza. Comunión \\
\hline Ficha Me212b & C/ Lucente esq. Pza. Comunión \\
\hline
\end{tabular}

FIG. 6 Mapa de localización de las fichas recopiladas en el barrio de S. Francesc (CRISTINI)

Ficha Fa39C/ Salvà s/n

Ficha Fa82C/ Cardenal Payà s/n

Ficha Fa105 C/ San Vicente Martir n 2

Ficha Fa107 Pza. Margarita Valdaura $n^{\circ} 1$

Ficha Fa153a $\quad$ C/ San Andrés s/n

Ficha Fa153b C/ Procida s/n

Ficha Fa153c Pza. Picadero de dos Aguas $s / n$

Ficha Fb57 C/ Verger no 2 esq. C/ Bonaire no 9

Ficha Fb117 Pza. Palacio Justicia s/n

FIG. 7 Mapa de localización de las fichas recopiladas en el barrio de Velluters (CRISTINI)

$\begin{array}{ll}\text { Ficha Va34 } & \text { C/Balmes } n^{\circ} 29 \\ \text { Ficha Va81a } & \text { C/ Exarchs } n^{\circ} 5 \\ \text { Ficha Va81b } & \text { C/ Exarchs } n^{\circ} 7 \\ \text { Ficha Va82 } & \text { C/ Exarchs } n^{\circ} 3 \\ \text { Ficha Va101 } & \text { C/ Villena } n^{\circ} 13 \\ \text { Ficha Va103a } & \text { C/ Carniceros } s / n \\ \text { Ficha Va103b } & \text { C/ Carniceros } n^{\circ} 6 \\ \text { Ficha Va104 } & \text { C/ Carniceros } n^{\circ} 8 \\ \text { Ficha Va112 } & \text { C/ Carniceros } n^{\circ} 22\end{array}$




\section{murOSINTRAMUIOS}

$\begin{array}{ll}\text { Ficha Va119 } & \text { C/ Lopez de Rueda s/n } \\ \text { Ficha Vb22 } & \text { C/ Roger de Flor } n^{\circ} 39 \\ \text { Ficha Vb45 } & \text { C/ Roger de Flor } n^{\circ} 13 \\ \text { Ficha Vb62 } & \text { C/ San Antoni } n^{\circ} 8 \\ \text { Ficha Vb67 } & \text { Pza. Pilar s/n } \\ \text { Ficha Vb68 } & \text { C/ Quevedo } n^{\circ} 2 \\ \text { Ficha Vb69 } & \text { C/ Quevedo } / \mathrm{n}\end{array}$

FIG. 8 Mapa de localización de las fichas recopiladas en el barrio de la Seu-Xerea (CRISTINI)

\begin{tabular}{|c|c|}
\hline Ficha Xa46 & Pza. Nules $n^{\circ} 2$ \\
\hline Ficha Xa74 & C/ Serrano $n^{\circ} 18$ \\
\hline Ficha Xc16a & Pza. Conde de Carlet no 4 \\
\hline Ficha Xc16b & C/ Trinitarios $n^{\circ} 5$ \\
\hline Ficha Xc16c & C/ Trinitarios $n^{\circ} 5$ acc \\
\hline Ficha Xc66 & C/ Mestres no 3 \\
\hline Ficha $X_{c} 72$ & C/ Escoles del Temple n 3 \\
\hline Ficha Xc78 & Pza. Conde del Real n³ \\
\hline Ficha Xc94 & C/ Entenza s/n \\
\hline Ficha Xc96a & Pza. San Luis Beltrán nº 1 \\
\hline Ficha Xc96b & Pza. San Luis Beltrán n 1 \\
\hline Ficha Xd11 & $\mathrm{C} /$ Venerable No4 \\
\hline Ficha Xd13 & $\mathrm{C} /$ Venerable $\mathrm{s} / \mathrm{n}$ \\
\hline Ficha Xd54a & C/ Lleña no 7 \\
\hline Ficha Xd54b & C/ Miguelete $s / n$ \\
\hline Ficha Xd65 & Pza. Decimo Julio Bruto s/n \\
\hline Ficha Xe14 & C/Avellanas n5 \\
\hline Ficha Xe66 & C/ Trin. de Caballeros $n^{\circ} 5$ \\
\hline
\end{tabular}

Ficha Xf25C/ Mestres $n^{\circ} 2-4$

Ficha Xf26 Pza. Congregación C/ Trinquete de Caballeros s/n

Ficha Xg74 C/Engordo n²

Ficha S1

Ficha S2

Ficha S3

Ficha S4

Ficha S5

Ficha 56

Ficha 57

Ficha S8

Ficha S9

Ficha S10

Ficha S11

Ficha S12

Ficha S13

Ficha S14

Ficha S15

Ficha S16 
Ficha S17

Ficha S18

Ficha S19

FIG. 9 Ejemplo de los contactos y las relaciones físicas que se establecen entre las partículas de arcilla en fase de hidratación (CRATERRE)

FIG. 10 Ejemplo de mineralogía microscópica de diferentes tipos de arcillas (HOUBENGUILLAUD)

FIG. 11 Fases de extracción, decantación, secado de las arcillas (CARBONARA)

FIG. 12 Arcillas con carbonato cálcico y hierro, factores responsables del color anaranjado de los ladrillos (CRISTINI)

FIG. 13 Ejemplos de pigmentos que determinan el color de las arcillas, como el óxidos de antimonio, manganeso y titanio (CRATERRE)

FIG. 14 Visualización de la variabilidad y aleatoriedad de las partículas de arcilla en su distribución granulométrica (CRATERRE)

FIG. 15 Ejemplo de cohesión capilar y de plasticidad entre las partículas de arcilla (HOUBENGUILLAUD)

FIG. 16 Variación de las partículas de arcilla en contacto con el agua, durante y después la fase de secado (HOUBEN-GUILLAUD)

FIG. 17 Variación de las partículas de arcilla en contacto con el agua, durante y después la fase de secado (HOUBEN-GUILLAUD

FIG. 18 Diferencia entre partículas de arcilla, antes y después del proceso de mezcla con agua y cocción (HOUBEN-GUILLAUD)

FIG. 19 Juntas correctas (izquierda) o incorrectas (derecha) que favorecen una posible penetración de agua en la fábrica (DESPLAZES)

FIG. 20 Atlas of the Munsell Color System, identificación de ladrillos amarillentos (Munsell 8/5Y/3), ladrillos anaranjados (Munsell 5/5YR/6), ladrillos pardos (Munsell 5/2.5YR/8) (CRISTINI)

FIG. 21 Atlas of the Munsell Color System, identificación de morteros oscuros (Munsell 4/10YR/6), morteros grisáceos (Munsell 6/10YR/4), morteros claros (Munsell 8/10YR/2) (CRISTINI)

FIG. 22 Clasificación muestra CE93/1 (CRISTINI)

FIG. 23 Clasificación muestra CE101/1 (CRISTINI)

FIG. 24 Clasificación muestra CF 42/1 (CRISTINI) 
FIG. 25 Clasificación muestra FA 153C/1 (CRISTINI)

FIG. 26 Clasificación muestra CG 01A/1 (CRISTINI)

FIG. 27 Clasificación muestra XA 74/1 (CRISTINI)

FIG. 28 Clasificación muestra XD 65/1 (CRISTINI)

FIG. 29 Clasificación muestra XG 74/1 (CRISTINI)

FIG. 30 Clasificación muestra VA 34B/1 (CRISTINI)

FIG. 31 Clasificación muestra CA 82/1 (CRISTINI)

FIG. 32 Clasificación muestra CB 55/1 (CRISTINI)

FIG. 33 Clasificación muestra CB 63/1 (CRISTINI)

FIG. 34 Clasificación muestra CE 62/1 (CRISTINI)

FIG. 35 Clasificación muestra CF 30/1 (CRISTINI)

FIG. 36 Clasificación muestra CF 44/1 (CRISTINI)

FIG. 37 Clasificación muestra CG 14/1 (CRISTINI)

FIG. 38 Clasificación muestra XC 78/1 (CRISTINI)

FIG. 39 Clasificación muestra VA 3AA/1 (CRISTINI)

FIG. 40 Clasificación muestra CA 30/1 (CRISTINI)

FIG. 41 Clasificación muestra CA 32/1 (CRISTINI)

FIG. 42 Clasificación muestra CA 85/1 (CRISTINI)

FIG. 43 Clasificación muestra CB 65/1 (CRISTINI)

FIG. 44 Clasificación muestra CD 118/1 (CRISTINI)

FIG. 45 Clasificación muestra CE 24/1 (CRISTINI)

FIG. 46 Clasificación muestra CG 48A/1 (CRISTINI)

FIG. 47 Clasificación muestra CG 48B/1 (CRISTINI)

FIG. 48 Clasificación muestra XE 14/1 (CRISTINI) 


\section{murOSINTRAMUIOS}

FIG. 49 Clasificación muestra VA 82/1 (CRISTINI)

FIG. 50 Clasificación muestra VA 119/1 (CRISTINI)

FIG. 51 Clasificación muestras CB 63/1 y CB 63/2(CRISTINI)

FIG. 52 Clasificación muestras CB 48B/1 y CG 48B/2 (CRISTINI)

FIG. 53 Clasificación muestras CA 32/1 y CA 32/2 (CRISTINI)

FIG. 54 Clasificación muestras CA 82/1 y CA 82/2 (CRISTINI)

FIG. 55 Clasificación muestras CA 85/1 y CA 85/2 (CRISTINI)

FIG. 56 Clasificación muestras CF 30/1 y CF 30/2 (CRISTINI)

FIG. 57 Clasificación muestras CF 44/1 y CF 44/2 (CRISTINI)

FIG. 58 Clasificación muestras CG O1A/1 y CG 01A/2 (CRISTINI)

FIG. 59 Clasificación muestras CG 48A/1 y CG 48A/2 (CRISTINI)

FIG. 60 Clasificación muestras XC 78/1 y XC 78/2 (CRISTINI)

FIG. 61 Clasificación muestras FA 153C/1 FA 153C/2A y FA 153C/2B (CRISTINI)

FIG. 62 Clasificación muestras XD 65/1 y XD 65/2 (CRISTINI)

FIG. 63 Clasificación muestras XE 14/1 y XE 14/2 (CRISTINI)

FIG. 64 Clasificación muestras VA 34A/1 y VA 34A/2 (CRISTINI)

FIG. 65 Clasificación muestras VA 119/1 y VA 119/2 (CRISTINI)

FIG. 66 Clasificación muestras CA 30/1 y CA 30/2 (CRISTINI)

FIG. 67 Clasificación muestras CB 55/1 y CB 55/2 (CRISTINI)

FIG. 68 Clasificación muestras CE 62/1 y CE 62/2 (CRISTINI)

FIG. 69 Clasificación muestras CE 93/1 y CE 93/2 (CRISTINI)

FIG. 70 Clasificación muestras CF 42/1 y CF 42/2 (CRISTINI)

FIG. 71 Clasificación muestras CG 14/1 y CG 14/2(CRISTINI)

FIG. 72 Clasificación muestras FA 153C/1, FA 153C/2A y FA 153C/2A (CRISTINI) 


\section{murOSINTRAMUROS}

FIG. 73 Clasificación muestras XA 74/1 y XA 74/2 (CRISTINI)

FIG. 74 Clasificación muestras XG 74/1 y XG 74/2 (CRISTINI)

FIG. 75 Clasificación muestras VA 34B/1 y VA 34B/2 (CRISTINI)

FIG. 76 Clasificación muestras VA 82/1 y VA 82/2 (CRISTINI)

FIG. 77 Clasificación muestras ladrillos amarillentos: Ce93/1, Ce101/1, Cf42/1, Cg01a/1, Fa153c/1, Xd65/1, Xa74/1, Xg74/1, Va34b/1 (CRISTINI)

FIG. 78 Clasificación muestras ladrillos anaranjados Ca82/1, Cb55/1, Cb63/1, Ce62/1, Cf30/1, Cg14/1, Xc78/1, Va34a/1 (CRISTINI)

FIG. 79 Clasificación muestras ladrillos pardos Ca 30/1, Ca 32/1, Ca85/1, Cb6571, Cd118/1, Ce2471, Cg48a/1;Cg48b/1, Xe14/1, Va82/1, Va119/1, Cf 44/1 (CRISTINI)

FIG. 80 Clasificación muestras de morteros oscuros CD 118/2, CG 48B/2 Y CB 63/2 (CRISTINI)

FIG. 81 Clasificación muestras de morteros grisáceos Ca32/2, Ca82/2, Ca85/2, Cf30/2, Cf44/2, Cg01a/2, Cg48a/2, Xc78/2, Fa153c/2a, Xd65/2, Xe14/2, Va34a/2, Va119/2 (CRISTINI)

FIG. 82 Clasificación muestras de morteros claros Ca30/2, Cb55/2, Ce62/2, Ce93/2, Cf42/2, Cg14/2, Fa153c/2b, Xa74/2, Xg74/2, Va34b/2, Va82/2 (CRISTINI)

Fig. 83 desde arriba a la izquierda, Fa153c/2a, Fa153153c/2b, Ca85/2, Cg48b/2 


\section{GRACIAS a...}

MIS padres por su APOYO INCONDICIONAL constante J.R. por compartir esta labor SIEMPRE, a mi LADO, en el DÍA A DÍA Camilla y Fernando por su ejemplo, guía y cercanía SIAM, Servicio de Investigación Arqueológica Municipal Jaume Coll Conesa, Pilar Carmona, Amadeo Serra, Pepa Pascual por sU ATENCIÓN Y DISPONIBIIIDAD EN FACILITAR INFORMACIón a lo largo de la investigación John Warren, Belinda Colston, Amedeo Bellini y Julio Vargas por su ayuda a lo largo de las varias estancias de investigación QUIEN ME HA APOYADO SINCERAMENTE, DE FORMA DIRECTA o INDIRECTA, ESTOS AÑOS. 
Créditos maquetación textos y portadas: Valentina Cristini

Foto de portada: ladrillos macizos en venta en un almacén de derribos,

Pobla de Farnals, Valencia (Cristini) 